UNIVERSIDADE DE SÃO PAULO

FACULDADE DE ECONOMIA, ADMINISTRAÇÃO E CONTABILIDADE DEPARTAMENTO DE ADMINISTRAÇÃO PROGRAMA DE PÓS-GRADUAÇÃO EM ADMINISTRAÇÃo

OPÇÃO DE INVESTIMENTO EM INSTITUIÇÃO DE LONGA PERMANÊNCIA SITUADA EM SÃO PAULO

Eduardo Braga

Orientador: Prof. Dr. Almir Ferreira de Sousa

SÃO PAULO 
Profa. Dra. Suely Vilela

Reitora da Universidade de São Paulo

Prof. Dr. Carlos Roberto Azzoni

Diretor da Faculdade de Economia, Administração e Contabilidade

Prof. Dr. Isak Kruglianskas

Chefe do Departamento de Administração

Prof. Dr. Lindolfo Galvão de Albuquerque

Coordenador do Programa de Pós-Graduação em Administração 
EDUARDO BRAGA

\section{OPÇÃO DE INVESTIMENTO EM INSTITUIÇÃO DE LONGA PERMANÊNCIA SITUADA EM SÃO PAULO}

Tese apresentada ao Departamento de Administração da Faculdade de Economia, Administração e Contabilidade da Universidade de São Paulo como requisito para a obtenção do título de Doutor em Administração.

Orientador: Prof. Dr. Almir Ferreira de Sousa

\section{SÃO PAULO}


Tese defendida e aprovada no Departamento de Administração da Faculdade de Economia, Administração e Contabilidade da Universidade de São Paulo - Programa de Pós-Graduação em Administração, pela seguinte banca examinadora:

Braga, Eduardo

Opção de investimento em instituição de longa permanência situada em São Paulo / Eduardo Braga. - São Paulo, 2009.

$378 \mathrm{p}$.

Tese (Doutorado) - Universidade de São Paulo, 2009

Bibliografia.

1. Administração de investimentos 2. Instituições sociais 3. Aposentadoria (Planejamento) 4. Deficientes I. Universidade de São Paulo. Faculdade de Economia, Administração e Contabilidade. II. Título.

CDD - 658.152 
À minha amada esposa, por todo estímulo $\mathrm{e}$ paciência ao longo dessa etapa. 
Em primeiro lugar agradeço a Deus pela saúde que tem me proporcionado ao longo de toda minha vida.

Agradeço ao meu orientador, Prof. Almir, pela dedicação na orientação desta tese, desde conselhos, leituras até visitas em instituições de longa permanência.

Agradeço à educação dada pelos meus pais, que sempre valorizaram a honestidade, a bondade, o trabalho e os estudos.

Agradeço o apoio, a ajuda e a compreensão da Sônia, do Wilson e do Vinícius.

Agradeço o apoio e a amizade da Silvia e do Marcelo, colegas do doutorado que sempre estiveram prontos a me auxiliar a qualquer dia e hora. 
"Senhor, dai-me a serenidade para aceitar o que não pode ser mudado; a coragem para mudar o que pode ser mudado; e a sabedoria para distinguir uma coisa da outra." 


\section{RESUMO}

O objetivo deste trabalho foi identificar uma opção de investimento em ambientes residenciais especiais, mais conhecidos no Brasil como instituições de longa permanência, com um formato jurídico e uma estrutura de governança corporativa que assegure perenidade institucional, além de um formato econômico-financeiro flexível que priorize qualidade de vida para os residentes. Três aspectos subsidiaram o propósito deste estudo e puderam ser comprovados ao final: uma parcela representativa da população pesquisada não acredita que os rendimentos a serem recebidos da previdência social ao se aposentarem sejam suficientes para sustentá-la; as pessoas não confiam nas organizações atuais no que tange aos cuidados oferecidos aos seus residentes e ambientes residenciais especiais que ofereçam garantias de qualidade de vida são opções de investimentos a futuros usufrutuários. Um fator intimamente ligado ao assunto é a mudança da pirâmide etária, caracterizada pelo aumento da população com faixa etária superior aos 60 anos de idade. Enquanto a população com menos de 40 anos deve diminuir $2 \%$ de 2008 a 2050, o grupo com 60 anos ou mais deve aumentar $256 \%$. Outro aspecto determinante são os portadores de necessidades especiais, que precisarão de organizações confiáveis para quando os familiares não puderem oferecer-lhes cuidados adequados. Instituições nacionais e internacionais com formatos diferenciados foram analisadas e mais de 1500 pessoas foram pesquisadas na região metropolitana de São Paulo e arredores. Os resultados culminaram com a definição do perfil de investidores potenciais. Este trabalho pode gerar alguns desdobramentos, tais como estudos que evidenciem a necessidade de educação e de cultura financeira objetivando propiciar aposentadoria com rendimentos que proporcionem condições sociais de qualidade, outros modelos jurídicos, pesquisas em outras cidades, refinamentos das informações geradas na primeira pesquisa e possíveis variações em relação ao perfil do investidor potencial. 


\begin{abstract}
The objective of this work was to identify an investment option in special residential environments, better known in Brazil as institutions of long permanence, with legal format and corporate governance, which assures institutional perenniality and also a flexible financial-economic format that gives priority to the residents' quality of life. The purpose of this study was subventioned by three aspects, which were proved at the end: a significant part of the population researched does not believe that the social security income will be enough for a living when they retire; people do not trust the current organizations concerning the offered care to its residents and special residential environments that guarantee quality of life are investment options to future beneficial owners. One factor closely related to the subject is the population pyramid change, characterized by an increase in population over 60 years of age. While the population below 40 years old must decrease $2 \%$ from 2008 to 2050, the group over 60 years old must increase 256\%. Another determining aspect is the handicapped, who will need trustworthy organizations to when their family is not able to offer them appropriate care. National and international institutions with exclusive formats were analyzed and more than 1500 people were researched in São Paulo metropolitan area and surroundings. The results have culminated with the definition of the potential investor profile. This work can create some unfolding, such as studies that enhance the need of education and financial culture with the objective of providing retirement with interest that provide high-quality social conditions, other legal models, researches in other cities, refinement of the information generated on the first research and possible variations concerning the potential investor profile.
\end{abstract}




\section{SUMÁRIO}

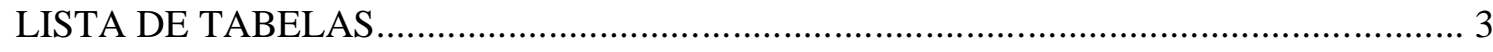

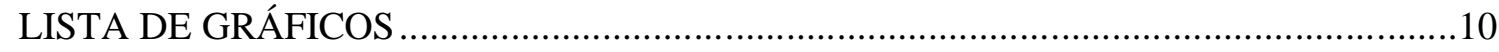

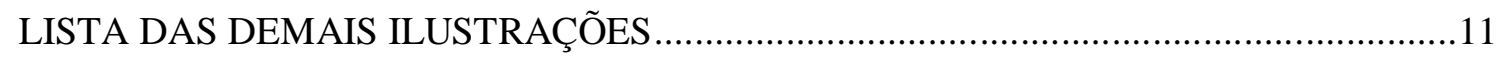

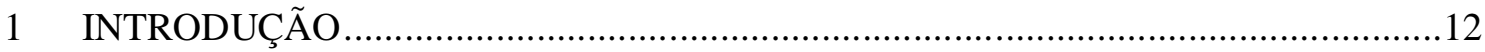

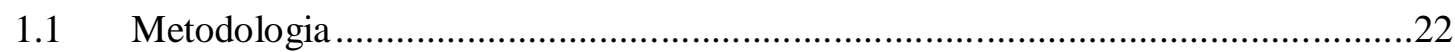

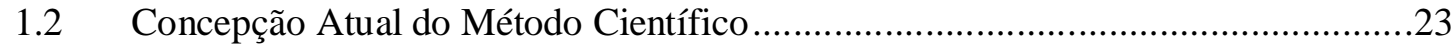

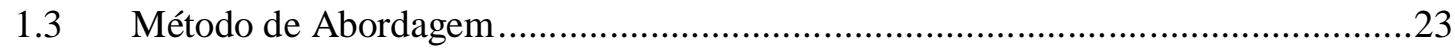

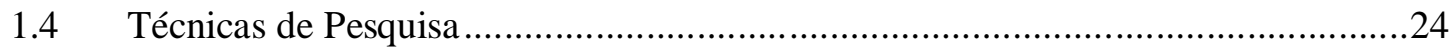

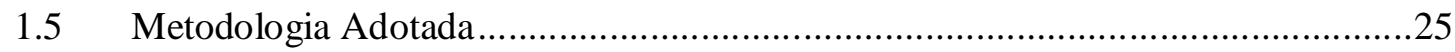

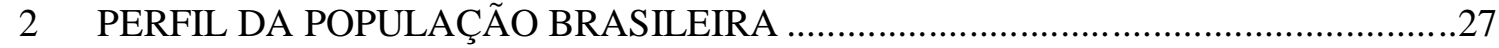

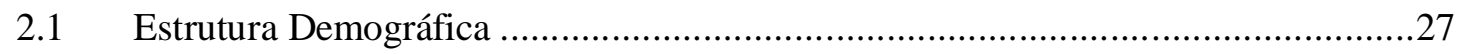

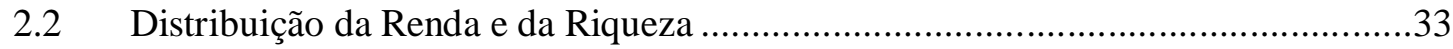

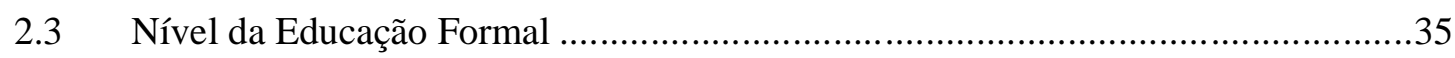

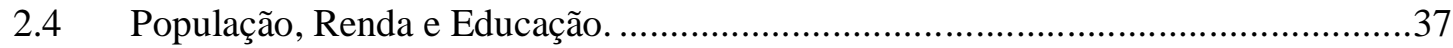

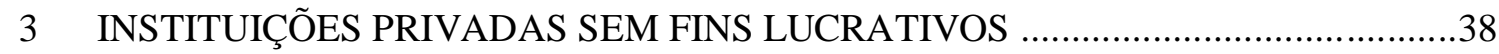

3.1 Peculiaridades Conceituais e Formais da Legislação Brasileira ..............................38

3.2 O que Existe no Brasil a Respeito, suas Finalidades e Respectivos Modelos

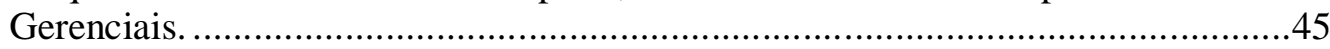

3.3 Modelos Diferenciados no Brasil e no Mundo ......................................................

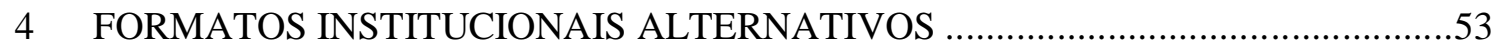

4.1 Pressupostos Fundamentais com Relação aos Objetivos e ao Perfil dos Investidores

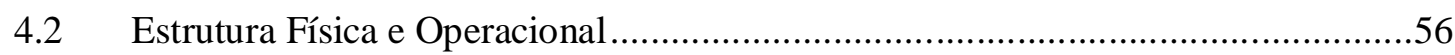

4.3 Formato Jurídico-Institucional e suas Vantagens ...............................................56

4.4 Estrutura Organizacional e os Aspectos de Governança Corporativa ......................59

5 SUSTENTABILIDADE ECONÔMICO-FINANCEIRA ......................................63

5.1 Pressupostos para sustentabilidade e para seu desenvolvimento ............................63

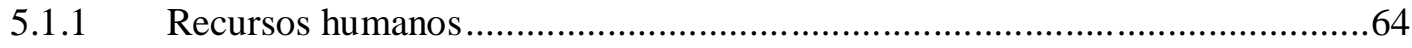

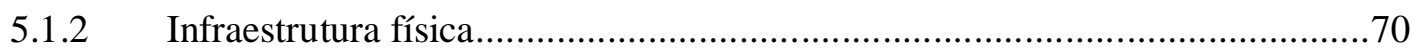

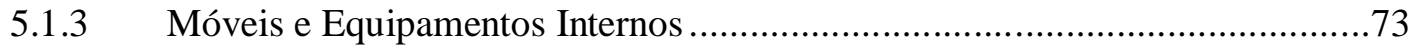

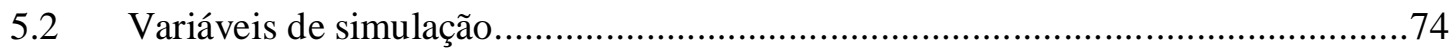

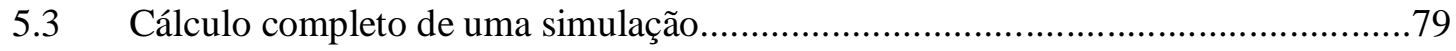

5.4 Simulações do modelo ............................................................................... 81

5.4.1 $1^{\mathrm{a}}$ série de simulações - investimentos em função do nível de utilização da

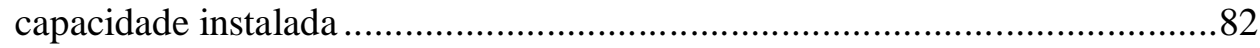

5.4.2 2a série de simulações - investimentos em função do número de habitações acessíveis a pessoas que utilizam cadeira de rodas .......................................86

5.4.3 $\quad 3^{\mathrm{a}}$ série de simulações - investimentos em função da variação de áreas comuns 
5.4.4 $4^{\mathrm{a}}$ série de simulações - mensalidades em função do nível de utilização da capacidade instalada .95

5.4.5 $\quad 5^{\mathrm{a}}$ série de simulações - mensalidades em função do número de habitações acessíveis a pessoas que utilizam cadeira de rodas

5.4.6 $\quad 6^{\mathrm{a}}$ série de simulações - mensalidades em função da variação de áreas comuns

5.4.7 $\quad 7^{\mathrm{a}}$ série de simulações - variação dos créditos aos proprietários em função do nível de utilização da capacidade instalada 106

5.4.8 $\quad 8^{\mathrm{a}}$ série de simulações - variação dos créditos aos proprietários em função do número de habitações acessíveis a pessoas que utilizam cadeira de rodas.....112

5.4.9 $\quad 9^{\mathrm{a}}$ série de simulações - variação dos créditos aos proprietários em função da variação de áreas comuns 113

5.4.10 $10^{\mathrm{a}}$ série de simulações - valor médio da mensalidade final em função do nível de utilização da capacidade instalada. 114

5.4.11 $11^{\mathrm{a}}$ série de simulações - valor médio da mensalidade final em função do número de habitações acessíveis a pessoas que utilizam cadeira de rodas.....115

5.4.12 $12^{\mathrm{a}}$ série de simulações - valor médio da mensalidade final em função da variação de áreas comuns ....

5.4.13 $13^{\mathrm{a}}$ série de simulações - variação do investimento inicial em função do número de habitações e áreas externas construídas .....................................116

5.4.14 $14^{\mathrm{a}}$ série de simulações - variação da mensalidade em função do nível de utilização da capacidade instalada entre 20 e $90 \%$.....................................118

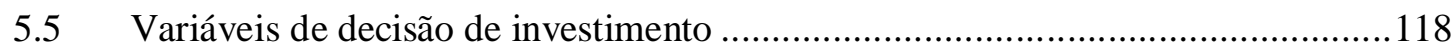

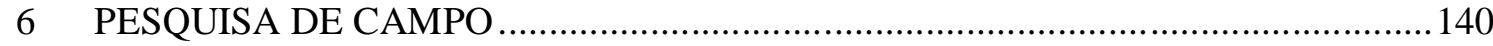

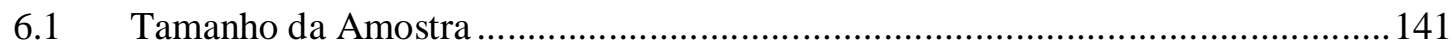

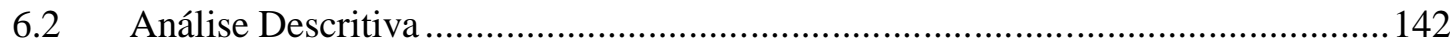

7 RESULTADOS DA PESQUISA DE CAMPO.................................................... 150

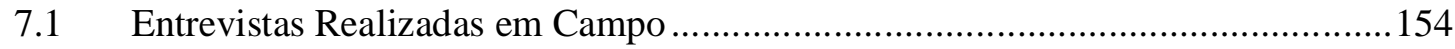

7.1.1 Resultados das entrevistas realizadas em campo em relação à questão 9 ...... 154

7.1.2 Resultados das entrevistas realizadas em campo em relação à questão 14 ...157

7.1.3 Resultados das entrevistas realizadas em campo em relação à questão 15 ....159

7.1.4 Resultados das entrevistas realizadas em campo em relação à questão 16 ....161

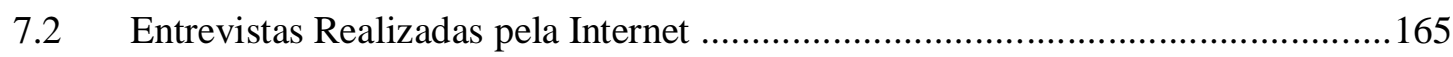

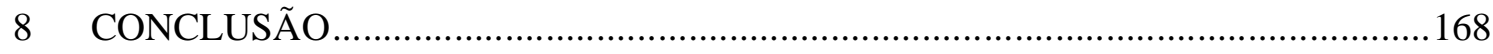

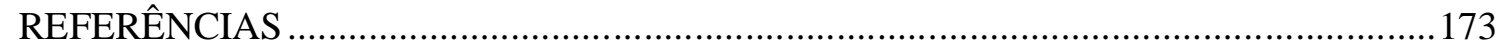

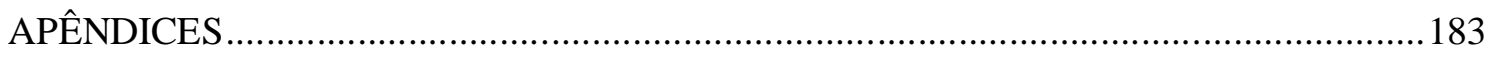

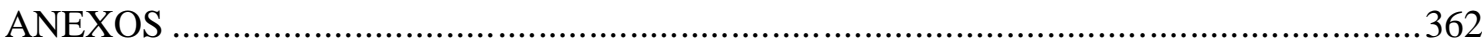




\section{LISTA DE TABELAS}

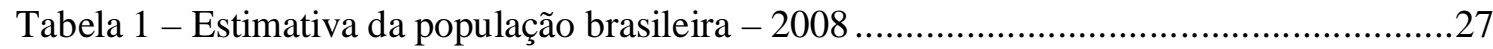
Tabela 2 - População brasileira de 1940 a 1970, esperança e crescimento de 1980 a 2050 ...28 Tabela 3 - Evolução da taxa de mortalidade por infecções gastrintestinais 1980-2000 (por mil habitantes de cada faixa etária)

Tabela 4 - População residente com 5 anos ou mais de idade, estudantes e não estudantes -

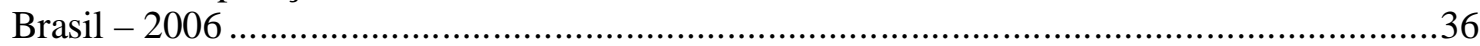

Tabela 5 - Número de empresas segundo seção da classificação de atividades - 2004 ..........45

Tabela 6 - Número de empresas no setor de saúde e serviços sociais em relação ao total de

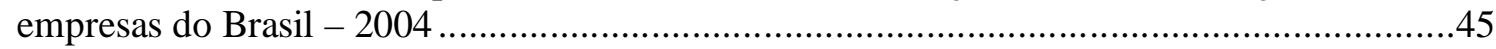

Tabela 7 - População total, com 60 anos ou mais e dependente no ano 2000 .......................54

Tabela 8 - População total e com 60 anos ou mais, projetados para o ano 2050 ....................54

Tabela 9 - Pressupostos em relação aos recursos humanos da organização ..........................65

Tabela 10 - Número de funcionários administrativos e despesas com salários mais encargos sociais por tipo de unidade.

Tabela 11 - Salário mensal de funcionários indiretos para 1 unidade ou matriz de pequeno

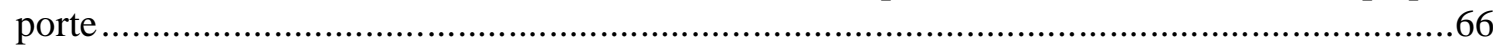

Tabela 12 - Salário mensal de funcionários indiretos para filial de pequeno porte..................66

Tabela 13 - Custo mensal com salário de funcionários indiretos para 1 unidade ou matriz de

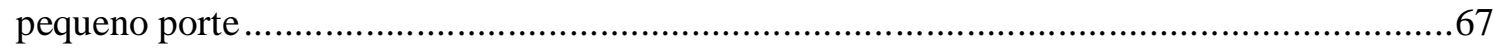

Tabela 14 - Custo mensal com salário de funcionários indiretos para filial de pequeno porte67

Tabela 15 - Número de funcionários indiretos fixos e custos com salários mais encargos

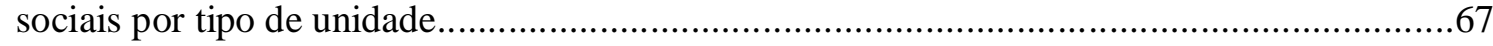

Tabela 16 - Salário mensal de funcionários indiretos, em função da área da organização......67

Tabela 17 - Custo mensal de funcionários indiretos em função da área da organização..........68

Tabela 18 - Equação número de funcionários e custo com salários mais encargos sociais de colaboradores indiretos em relação à área da organização ...................................................68

Tabela 19 - Salário mensal de pessoal operacional ............................................................68

Tabela 20 - Custo mensal com salário de pessoal operacional .........................................70

Tabela 21 - Custo mensal de funcionários diretos em função da área da organização.............70

Tabela 22 - Equação número de funcionários e custo com salários mais encargos sociais de colaboradores diretos em relação ao número de residentes .............................................. 70

Tabela 23 - Pressupostos em relação à infraestrutura física da organização ..........................71

Tabela 24 - Definição das variáveis utilizadas para cálculo completo de uma simulação ......79 Tabela 25 - Proporção dos residentes, para efeito de simulação, em relação ao grau de

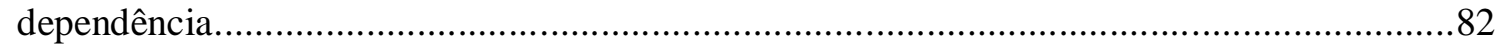

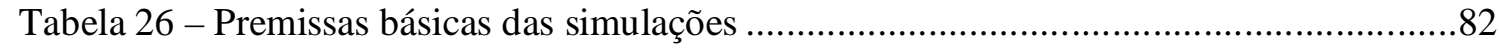

Tabela 27 - Valor médio do investimento por habitação com $60 \%$, 70\%, 80\% e 90\% de utilização da capacidade instalada para 100 residentes, com diversos graus de dependência.. 83 
Tabela 28 - Valor médio do investimento por habitação com $60 \%, 70 \%, 80 \%$ e $90 \%$ de utilização da capacidade instalada para 100 residentes, com diversos graus de dependência (informações realinhadas) 84

Tabela 29 - Resumo dos resultados da regressão do valor médio do investimento com simulação do nível de utilização da capacidade instalada para 100 residentes, com diversos graus de dependência.

Tabela 30 - Valor médio do investimento por habitação para 200, 300 e 400 residentes, com diversos graus de dependência

Tabela 31 - Valor médio do investimento por habitação com 20\%, 40\%, 60\%, $80 \%$ e $100 \%$ de habitações destinadas a pessoas que necessitam de cadeira de rodas, para 100 residentes, com diversos graus de dependência

Tabela 32 - Valor médio do investimento por habitação com 20\%, 40\%, 60\%, $80 \%$ e $100 \%$ de habitações destinadas a pessoas que necessitam de cadeira de rodas, para 100 residentes, com diversos graus de dependência (informações realinhadas)

Tabela 33 - Valor médio do investimento por habitação com $20 \%, 40 \%, 60 \%$, $80 \%$ e $100 \%$ de habitações destinadas a pessoas que necessitam de cadeira de rodas, para 200 residentes, com diversos graus de dependência

Tabela 34 - Valor médio do investimento por habitação com 20\%, 40\%, 60\%, $80 \%$ e $100 \%$ de habitações destinadas a pessoas que necessitam de cadeira de rodas, para 300 residentes, com diversos graus de dependência

Tabela 35 - Valor médio do investimento por habitação com 20\%, 40\%, 60\%, $80 \%$ e $100 \%$ de habitações destinadas a pessoas que necessitam de cadeira de rodas, para 400 residentes, com diversos graus de dependência

Tabela 36 - Premissas para cálculo de simulações com variação de áreas comuns para 100 e 200 residentes

Tabela 37 - Premissas para cálculo de simulações com variação de áreas comuns para 300 e 400 residentes

Tabela 38 - Valor médio do investimento por habitação em função de áreas externas, anfiteatro e minisshopping para 100 residentes, com diversos graus de dependência.

Tabela 39 - Valor médio do investimento por habitação em função de áreas externas, anfiteatro e minisshopping para 200 residentes, com diversos graus de dependência .91

Tabela 40 - Valor médio do investimento por habitação em função de áreas externas, anfiteatro e minisshopping para 300 residentes, com diversos graus de dependência.

Tabela 41 - Valor médio do investimento por habitação em função de áreas externas, anfiteatro e minisshopping para 400 residentes, com diversos graus de dependência.

Tabela 42 - Valor médio do investimento por habitação em função de áreas externas, anfiteatro e minisshopping para 100 residentes, com diversos graus de dependência (informações realinhadas para 15 variáveis independentes)

Tabela 43 - Resumo dos resultados da regressão do valor médio do investimento por habitação em função de áreas externas, anfiteatro e minisshopping para 100 residentes, com diversos graus de dependência, para 15 variáveis independentes

Tabela 44 - Valor médio do investimento por habitação em função de áreas externas, anfiteatro e minisshopping para 100 residentes, com diversos graus de dependência (informações realinhadas para 6 variáveis independentes).... 
Tabela 45 - Resumo dos resultados da regressão do valor médio do investimento por habitação em função de áreas externas, anfiteatro e minisshopping para 100 residentes, com diversos graus de dependência, para 6 variáveis independentes. .95

Tabela 46 - Valor médio de mensalidade com 60\%, 70\%, 80\% e 90\% de utilização da capacidade instalada para 100 residentes, com diversos graus de dependência 97 Tabela 47 - Valor médio de mensalidade com 60\%, 70\%, $80 \%$ e $90 \%$ de utilização da capacidade instalada para 200 residentes, com diversos graus de dependência .97

Tabela 48 - Valor médio de mensalidade com 60\%, 70\%, 80\% e 90\% de utilização da capacidade instalada para 300 residentes, com diversos graus de dependência .97

Tabela 49 - Valor médio de mensalidade com 60\%, 70\%, 80\% e 90\% de utilização da capacidade instalada para 400 residentes, com diversos graus de dependência .....................98

Tabela 50 - Número de cuidadores para simulação 50-40-10 e 60-30-10 em uma organização para 100 residentes .98

Tabela 51 - Número de cuidadores para simulação 50-40-10 e 60-30-10 em uma organização para 200 residentes

Tabela 52 - Valor médio da mensalidade com simulação de $20 \%, 40 \%, 60 \%, 80 \%$ e $100 \%$ de habitações destinadas a pessoas que dependem de cadeira de rodas, para 100 residentes, com diversos graus de dependência.... 100

Tabela 53 - Valor médio da mensalidade com simulação de 20\%, 40\%, 60\%, $80 \%$ e $100 \%$ de habitações destinadas a pessoas que dependem de cadeira de rodas, para 200 residentes, com diversos graus de dependência 101

Tabela 54 - Valor médio da mensalidade com simulação de 20\%, 40\%, 60\%, 80\% e 100\% de habitações destinadas a pessoas que dependem de cadeira de rodas, para 300 residentes, com diversos graus de dependência. 101

Tabela 55 - Valor médio da mensalidade com simulação de $20 \%, 40 \%, 60 \%, 80 \%$ e $100 \%$ de habitações destinadas a pessoas que dependem de cadeira de rodas, para 400 residentes, com diversos graus de dependência.....

Tabela 56-Valor médio das mensalidades em função de áreas externas, anfiteatro e minisshopping para 100 residentes, com diversos graus de dependência . .103

Tabela 57 - Valor médio das mensalidades em função de áreas externas, anfiteatro e minisshopping para 200 residentes, com diversos graus de dependência 103

Tabela 58 - Valor médio das mensalidades em função de áreas externas, anfiteatro e minisshopping para 300 residentes, com diversos graus de dependência .... 104

Tabela 59-Valor médio das mensalidades em função de áreas externas, anfiteatro e minisshopping para 400 residentes, com diversos graus de dependência ............................ 104

Tabela 60 - Ibovespa 1994-2008 106

Tabela 61 - Valorização anual de casas de médio padrão na cidade de São Paulo 2004-2008 107

Tabela 62 - Valorização anual de casas de padrão standard na cidade de São Paulo 20042008 107

Tabela 63 - Desvio padrão da valorização de casas na cidade de São Paulo 2004-2008 .......107

Tabela 64 - Índice Nacional de Custo da Construção - INCC - 1995-2008 .......................... 108

Tabela 65 - Rendimento da caderneta de poupança 1995-2008 ........................................ 108

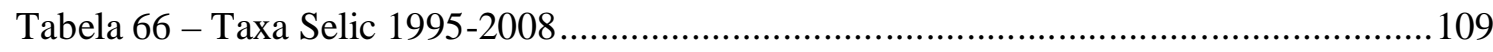

Tabela 67 - Simulação da taxa de retorno dos créditos 
Tabela 68 - Características da organização em função do número de residentes para

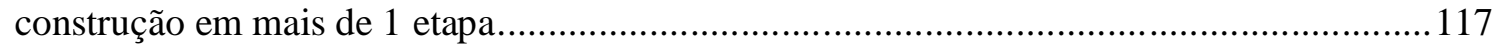

Tabela 69 - Áreas a serem construídas na $1^{\circ}$ etapa da construção......................................117

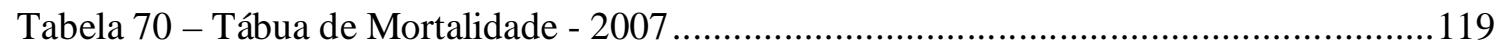

Tabela 71 - Índice nacional de preços ao consumidor - amplo, IPCA, 1995-2008 ..............121

Tabela 72 - Idade para aquisição de quotas que permita utilização futura da organização sem

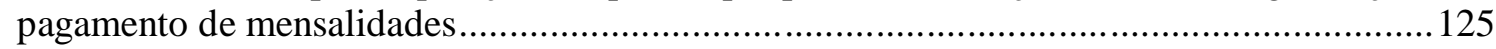

Tabela 73 - Valor de aquisição das quotas quando o período de locação da habitação é igual ao de utilização, sem pagamento de mensalidades ............................................................129

Tabela 74 - Valor de aquisição das quotas para um período de locação da habitação de 10 anos e utilização sem pagamento de mensalidades .......................................................129

Tabela 75 - Demonstração de superávit (déficit) de uma organização para 300 residentes atuando com nível de utilização da capacidade instalada de 70\%, 63\% e 77\% ....................132

Tabela 76 - Frequência de idade dos pesquisados (Questão 1 da Pesquisa) .........................143

Tabela 77 - Frequência de sexo dos pesquisados (Questão 2) ........................................143

Tabela 78 - Frequência da cidade onde residiam os pesquisados (Questão 4) .....................143

Tabela 79 - Frequência da região onde residiam os pesquisados ....................................144

Tabela 80 - Frequência de bens e serviços que os pesquisados de campo possuíam (Questão

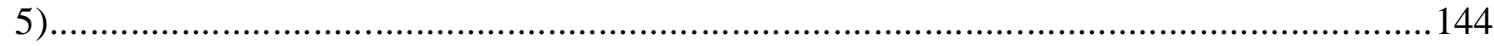

Tabela 81 - Frequência de bens e serviços que os pesquisados pela internet possuíam (Questão 5)... 144

Tabela 82 - Frequência da escolaridade do chefe da família dos pesquisados (Questão 6)...145

Tabela 83 - Frequência da classe social dos pesquisados ............................................ 145

Tabela 84 - Frequência do rendimento familiar bruto dos pesquisados (Questão 7) ............146

Tabela 85 - Frequência da forma de poupança dos pesquisados (Questão 8).......................146

Tabela 86 - Frequência de opinião dos pesquisados quanto aos rendimentos do INSS

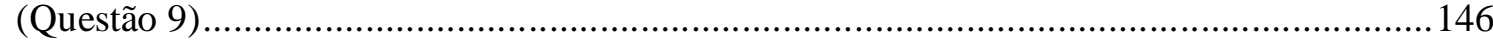

Tabela 87 - Frequência de intenção dos pesquisados, através de poupança ou previdência privada, complementarem a renda quando se aposentar (Questão 10) ...............................146

Tabela 88 - Frequência de intenção dos pesquisados quanto a ser sustentado ou ter a renda complementada pelos filhos quando não puderem mais trabalhar (Questão 11) ..................147

Tabela 89 - Frequência de opinião dos pesquisados quanto a morar com os filhos ou com um parente próximo se um dia ficar dependente fisicamente (Questão 12) ..............................147

Tabela 90 - Frequência do conhecimento que o pesquisado tem sobre instituições que tratam

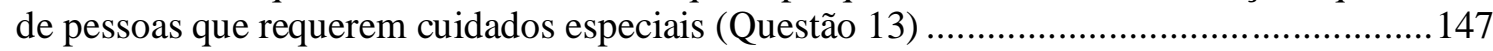

Tabela 91 - Frequência de confiança do pesquisado nos cuidados oferecidos por organizações que tratam de pessoas que requerem cuidados especiais (Questão 14) ..............................148

Tabela 92 - Frequência de intenção de o pesquisado residir, caso tenha necessidade e nos moldes dos modelos atuais, em uma instituição que trata de pessoas que requerem cuidados especiais (Questão 15)

Tabela 93 - Frequência de intenção de investimento, para uso futuro, em instituições que ofereçam garantias de qualidade de vida (Questão 16) .................................................... 148

Tabela 94 - Frequência de pesquisados que tem familiar próximo que está, ou já esteve, em organizações para pessoas que necessitam de cuidados especiais (Questão 17) ...................149 
Tabela 95 - Frequência esperada para a questão investiria em uma organização que oferecesse garantias de qualidade versus mora em região metropolitana ...........................153 Tabela 96 - Valores críticos do $\chi^{2}$ para nível de significância de 5\% e graus de liberdade de 1 a 6

Tabela 97 - Tabela de Contingência com nível de significância para $\chi^{2}$ calculado dos pesquisados em campo 155

Tabela 98 - Frequência observada e esperada para a questão no futuro, quando não estiver mais trabalhando, o valor a ser recebido do INSS a título de aposentadoria será suficiente para meu sustento versus a idade do pesquisado, para os pesquisados em campo................156 Tabela 99 - Frequência observada e esperada para a questão no futuro, quando não estiver mais trabalhando, o valor a ser recebido do INSS a título de aposentadoria será suficiente para meu sustento versus o sexo do pesquisado, para os pesquisados em campo..

Tabela 100 - Frequência observada e esperada para a questão no futuro, quando não estiver mais trabalhando, o valor a ser recebido do INSS a título de aposentadoria será suficiente para meu sustento versus até que ano da escola o chefe da família estudou, para os pesquisados em campo

Tabela 101 - Frequência observada e esperada para a questão no futuro, quando não estiver mais trabalhando, o valor a ser recebido do INSS a título de aposentadoria será suficiente para meu sustento versus a classe social do pesquisado, para os pesquisados em campo .....157

Tabela 102 - Frequência observada e esperada para a questão no futuro, quando não estiver mais trabalhando, o valor a ser recebido do INSS a título de aposentadoria será suficiente para meu sustento em relação à condição do pesquisado se ele poupa dinheiro atualmente, para os pesquisados em campo 157

Tabela 103 - Frequência observada e esperada para a questão confio plenamente nos cuidados oferecidos por organizações que tratam de pessoas que requerem cuidados especiais versus a cidade onde o pesquisado reside, para os pesquisados em campo. 158

Tabela 104 - Frequência observada e esperada para a questão confio plenamente nos cuidados oferecidos por organizações que tratam de pessoas que requerem cuidados especiais versus a região onde o pesquisado reside, para os pesquisados em campo 158

Tabela 105 - Frequência observada e esperada para a questão confio plenamente nos cuidados oferecidos por organizações que tratam de pessoas que requerem cuidados especiais versus o conhecimento que o pesquisado tem de instituições que tratam de pessoas que requerem cuidados especiais, para os pesquisados em campo 159

Tabela 106 - Frequência observada e esperada para a questão caso futuramente tenha necessidade, nos moldes dos modelos atuais, gostaria de ser residente em uma instituição que trata de pessoas que requerem cuidados especiais versus a cidade onde o pesquisado reside, para os pesquisados em campo 160

Tabela 107 - Frequência observada e esperada para a questão caso futuramente tenha necessidade, nos moldes dos modelos atuais, gostaria de ser residente em uma instituição que trata de pessoas que requerem cuidados especiais versus a região onde o pesquisado reside, para os pesquisados em campo 160

Tabela 108 - Frequência observada e esperada para a questão caso futuramente tenha necessidade, nos moldes dos modelos atuais, gostaria de ser residente em uma instituição que trata de pessoas que requerem cuidados especiais versus até que ano da escola o chefe da família estudou, para os pesquisados em campo...... 160 
Tabela 109 - Frequência observada e esperada para a questão caso futuramente tenha necessidade, nos moldes dos modelos atuais, gostaria de ser residente em uma instituição que trata de pessoas que requerem cuidados especiais versus o conhecimento que o pesquisado tem de instituições que tratam de pessoas que requerem cuidados especiais, para os pesquisados em campo

161

Tabela 110 - Frequência observada e esperada para a questão investiria em instituições que cuidam de pessoas que precisam de cuidados especiais para meu uso futuro desde que as mesmas ofereçam garantias de qualidade de vida versus o sexo do pesquisado, para os pesquisados em campo 162

Tabela 111 - Frequência observada e esperada para a questão investiria em instituições que cuidam de pessoas que precisam de cuidados especiais para meu uso futuro desde que as mesmas ofereçam garantias de qualidade de vida versus a cidade onde o pesquisado reside, para os pesquisados em campo

Tabela 112 - Frequência observada e esperada para a questão investiria em instituições que cuidam de pessoas que precisam de cuidados especiais para meu uso futuro desde que as mesmas ofereçam garantias de qualidade de vida versus até que ano da escola o chefe da família estudou, para os pesquisados em campo.

Tabela 113 - Frequência observada e esperada para a questão investiria em instituições que cuidam de pessoas que precisam de cuidados especiais para meu uso futuro desde que as mesmas ofereçam garantias de qualidade de vida versus a pretensão do pesquisado em complementar a renda quando se aposentar com poupança ou previdência privada, para os pesquisados em campo

Tabela 114 - Frequência observada e esperada para a questão investiria em instituições que cuidam de pessoas que precisam de cuidados especiais para meu uso futuro desde que as mesmas ofereçam garantias de qualidade de vida versus o conhecimento que o pesquisado tem de instituições que tratam de pessoas que requerem cuidados especiais, para os pesquisados em campo

163

Tabela 115 - Tabela de Contingência com nível de significância para $\chi^{2}$ calculado dos pesquisados pela internet 164

Tabela 116 - Frequência observada e esperada para a questão no futuro, quando não estiver mais trabalhando, o valor a ser recebido do INSS a título de aposentadoria será suficiente para meu sustento versus a questão se um dia ficar dependente fisicamente, o pesquisado quer morar com os filhos ou com um parente próximo, para os pesquisados pela internet ...165 Tabela 117 - Frequência observada e esperada para a questão confio plenamente nos cuidados oferecidos por organizações que tratam de pessoas que requerem cuidados especiais versus o conhecimento que o pesquisado tem de instituições que tratam de pessoas que requerem cuidados especiais, para os pesquisados pela internet. 166

Tabela 118 - Frequência observada e esperada para a questão caso futuramente tenha necessidade, nos moldes dos modelos atuais, gostaria de ser residente em uma instituição que trata de pessoas que requerem cuidados especiais versus o conhecimento que o pesquisado tem de instituições que tratam de pessoas que requerem cuidados especiais, para os pesquisados pela internet .166

Tabela 119 - Estimativa da população brasileira, com 50 anos ou mais, de 2008 a 2050, com variações percentuais base 2008 207

Tabela 120 - População brasileira com 50 anos ou mais - crescimento médio anual por faixa etária - 2008-2050. 207

Tabela 121 - Produto interno bruto (PIB) brasileiro - crescimento anual - 1948-2007 .......207 
Tabela 122 - Número de funcionários para 100 habitações ................................................218

Tabela 123 - Área para 100 habitações, sendo 20\% delas para cadeirantes .........................218

Tabela 124 - Área das salas de atividades coletivas, convivência, refeitório e lavanderia para

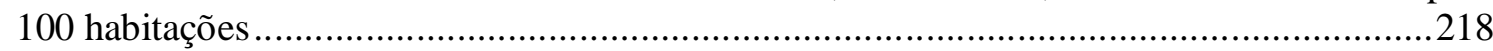

Tabela 125 - Área de ambientes secundários para 100 habitações.....................................219

Tabela 126 - Área para banheiros, vestiários e alojamento do caseiro para 100 habitações 219

Tabela 127 - Área interna, externa e total para 100 habitações.........................................219

Tabela 128 - Custo dos móveis e eletrodomésticos dos dormitórios....................................219

Tabela 129 - Custo total e despesas mensais de depreciação e manutenção dos móveis e

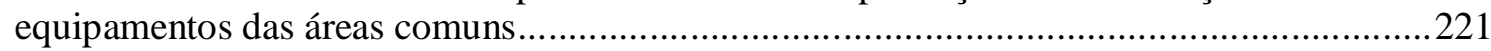

Tabela 130 - Custo total e despesas mensais de depreciação e manutenção das áreas externas

.

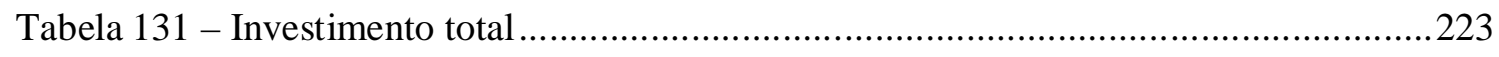

Tabela 132 - Número de residentes estimados para os primeiros 48 meses ........................224

Tabela 133 - Receita estimada para os primeiros 48 meses .............................................224

Tabela 134 - Despesas administrativas, custos diretos e indiretos ....................................225

Tabela 135 - Desembolsos estimados para os primeiros 48 meses ...................................225

Tabela 136 - Fluxo de caixa estimado para os primeiros 48 meses....................................226 


\section{LISTA DE GRÁFICOS}

Gráfico 1 - Pirâmide etária da população brasileira dividida por sexo - 1980 ......................29

Gráfico 2 - Pirâmide etária da população brasileira dividida por sexo - 1990 .......................30

Gráfico 3 - Pirâmide etária da população brasileira dividida por sexo - 2000 …....................30

Gráfico 4 - Pirâmide etária da população brasileira dividida por sexo - 2010 .......................31

Gráfico 5 - Pirâmide etária da população brasileira dividida por sexo - 2020 ......................31

Gráfico 6 - Pirâmide etária da população brasileira dividida por sexo - 2030 .......................32

Gráfico 7 - Pirâmide etária da população brasileira dividida por sexo - 2040 ......................32

Gráfico 8 - Pirâmide etária da população brasileira dividida por sexo -2050 .......................33

Gráfico 9-População residente com 5 anos ou mais de idade, segundo o nível que

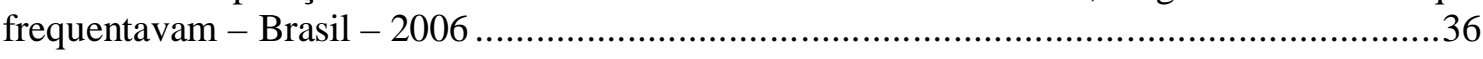

Gráfico 10 - Valor de aquisição das quotas quando o período de locação da habitação é igual ao de utilização, sem pagamento de mensalidades

Gráfico 11 - Valor de aquisição das quotas para um período de locação da habitação de 10 anos e utilização sem pagamento de mensalidades

Gráfico 12 - Taxa Interna de Retorno, TIR, para aquisição de quotas a R \$ 89.021, locação da habitação de 6 a 300 meses e nível de utilização da capacidade instalada de 45\% a 100\% ...134 Gráfico 13 - Taxa interna de retorno em função da economia de adquirir quotas correspondentes a 1 habitação e residir sozinho

Gráfico 14 - Taxa interna de retorno em função da economia de adquirir quotas correspondentes a 1 habitação e compartilhar a habitação com outro residente

Gráfico 15 - Taxa interna de retorno em função da economia de adquirir quotas correspondentes a 2 habitações e residir sozinho em 1 delas

Gráfico 16 - Taxa interna de retorno em função da economia de adquirir quotas correspondentes a 2 habitações e compartilhar 1 das habitações com outro residente ..........139

Gráfico 17 - Tabulação das Questões 14 e 15, em porcentagem, da Pesquisa de Campo e de Internet.

Gráfico 18 - Tabulação da Questão 16, em porcentagem, da Pesquisa de Campo e de Internet 151

Gráfico 19 - Produto interno bruto (PIB) brasileiro - crescimento anual - 1948-2007 .......208 


\section{LISTA DAS DEMAIS ILUSTRAÇÕES}

Ilustração 1 - Renda, consumo e poupança em função da idade ..........................................15

Ilustração 2 - Nível de dependência em crianças, adultos e idosos........................................54

Ilustração 3 - Exemplo de estrutura organizacional para uma instituição de investidores /

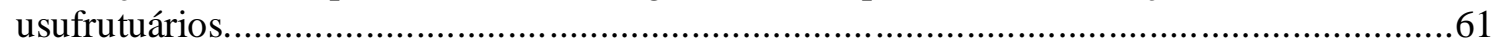

Ilustração 4 - Fluxograma de variáveis do modelo.............................................................. 77

Ilustração 5 - Fluxo de tempo necessário para adquirir quotas de uma habitação, alugar e passar a residir aos 80 anos com as mensalidades pagas ...............................................121

Ilustração 6 - Fluxo de caixa necessário para cobrir 108 mensalidades de R $\$ 3.047 \ldots \ldots \ldots . . . .122$

Ilustração 7 - Número de créditos de R \$ 1.157,27 necessários para um valor futuro de

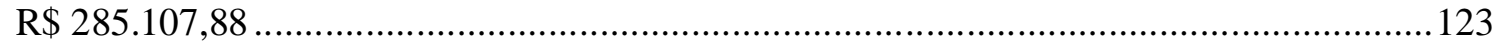

Ilustração 8 - Fluxo de tempo necessário para adquirir quotas de uma habitação, alugar e

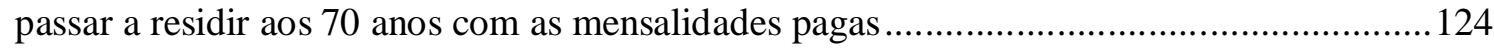

Ilustração 9 - Fluxo de caixa para adquirir quotas aos 71 anos, alugar e passar a residir aos 80

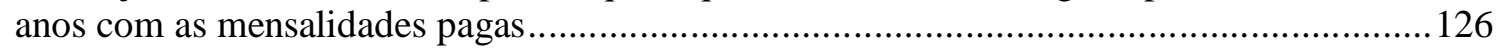

Ilustração 10 - Fluxo de caixa para adquirir quotas aos 71 anos, que gerem créditos de $\mathrm{R} \$ 1.798,20$ provenientes de locação, e passar a residir aos 80 anos com as mensalidades pagas. 128

Ilustração 11 - Opções de residir em organização como não proprietário ou proprietário de quotas correspondentes a 1 ou mais habitações ........................................................... 136

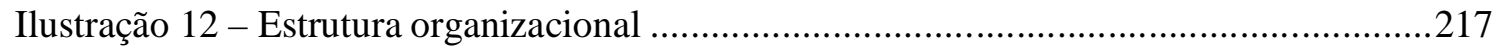




\section{INTRODUÇÃOO}

A população brasileira cresceu de forma representativa na segunda metade do século passado. De 1940 a 1970 a população brasileira mais que dobrou, passando de 41,2 para 93,1 milhões de pessoas (IBGE, 2007b). No período de 1950 a 1960 a população chegou a crescer 34,9\% (ibidem). Apesar de ocorrer uma desaceleração nas taxas de crescimento, o brasileiro está vivendo cada vez mais; em 2000 éramos 171,3 milhões de brasileiros compartilhando um mesmo território, devendo crescer $51,7 \%$ até o ano 2050, quando são previstos 259,8 milhões de pessoas (idem, 2007c).

Vários fatores proporcionaram aumento na expectativa de vida do brasileiro. Entre eles podese destacar a redução da mortalidade infantil em razão da generalização dos serviços de saúde e saneamento; a melhoria na educação, na assistência social; priorização da habitação popular em decorrência do êxodo rural entre outros fatores (CAETANO, 2006, p. 10). Em meados da década de 1930 vivia-se em média 42 anos (SIMÕES, 2008, p. 28); em 1980 essa média passou para 62,6 anos (IBGE, 2008e). No ano 2000 vivia-se em torno de 70,5 anos (ibidem), sendo que para 2050 estima-se que o brasileiro viverá em média 81,3 anos (IBGE, 2008c).

Com a desaceleração no crescimento da população e o envelhecimento da mesma (IBGE, 2008c), há mudança na pirâmide etária. Em 1980 a população entre zero e quatro anos totalizava 16,38 milhões de brasileiros, acima de 60 anos somavam 7,20 milhões e acima de 80 eram somente 0,59 milhão. Para 2050 a faixa de zero a quatro anos reduz ligeiramente, passando para 15,18 milhões de jovens; em compensação, a população acima de 60 anos passa para 64,05 milhões e, acima de 80, serão 13,75 milhões de brasileiros (IBGE, 2007c). Pode-se perceber que o Brasil contará com um número praticamente igual de crianças com quatro anos ou menos e adultos com 80 anos ou mais de idade.

Em relação à educação há uma desigualdade bastante representativa no Brasil. Em 2006 aproximadamente $45 \%$ da população com idade igual ou superior a 10 anos estudou oito anos, $29 \%$ estudou 11 e somente 6\% da população estudou 15 anos ou mais (IBGE, 2007f). Se não houvesse reprovação, poder-se-ia afirmar que esses percentuais equivaleriam ao ensino fundamental, médio e superior.

Uma das consequências da desigualdade na educação é a má distribuição de renda (RAMOS, 2006). Em 2006 15\% das famílias tinham um rendimento mensal inferior a um salário 
mínimo e contribuíam com $2 \%$ do rendimento total do país; $23 \%$ das famílias tinham um rendimento mensal superior a um e inferior a dois salários mínimos e contribuíam com $8 \%$ do rendimento. Somando as duas faixas, $38 \%$ das famílias tinham rendimento mensal inferior a dois salários mínimos e contribuíam com $10 \%$ da renda total. Na outra ponta, $3 \%$ das famílias tinham um rendimento maior que 20 salários mínimos e contribuíam com $21 \%$ do rendimento total do país (IBGE, 2007e).

Do ano 2000 ao ano 2050 a população brasileira deve aumentar em quase 90 milhões de habitantes. Esse aumento será percebido principalmente nas maiores faixas etárias, ou seja, ocorrerá um envelhecimento da população. O começo do século XXI ainda é marcado por uma grande desigualdade na educação e na distribuição da renda. Essas mudanças sociais provocam uma série de reflexões, uma delas é como se preparar para a aposentadoria.

Independente da distribuição de renda, as famílias podem poupar parte do seu rendimento. No século XX vários autores buscaram explicações sobre os fatores motivadores da poupança nos países. Alguns estudos indicavam que a poupança não dependia da renda, outros que a poupança estava relacionada à renda relativa à média global. Na década de 1980 Modigliani (1986) publicou um dos principais artigos que trata do comportamento dos indivíduos em termos de poupança ao longo da vida. É uma hipótese que evidencia a necessidade de as pessoas se prepararem, através de poupança, para a fase da vida quando deixam de trabalhar formalmente.

\section{Hipótese do Ciclo de Vida do Ser Humano}

Inicialmente Modigliani (1986, p. 297-298) remeteu o assunto a Keynes, onde afirmava que: 1) a função consumo individual era determinante da demanda agregada; 2) o excesso de poupança provocava estagnação de longo prazo, pois as pessoas deixariam de consumir e as empresas deixariam de produzir; 3) a renda era o fator determinante das poupanças, ou seja, quanto maior a renda, maior a poupança; 4) o estoque de capital era transferido por herança, e não pelo volume de recursos poupados; e 5) como pessoas ou países pobres poderiam gastar sem ter poupado antes?

Na segunda metade da década de 1940 três estudos contribuíram para a queda da visão do processo de poupança que predominava até então: 1) em 1946 Siamon Kuznets et al mostraram que, apesar do nível de renda per capita ter aumentado, os níveis de poupança se 
alteraram pouco da segunda metade do século XIX até aquela data, ou seja, a variação da poupança dependia pouco da variação da renda; em 1947, a partir desse estudo, Dorothy Brady e R. D. Friedman reconciliaram os resultados e demonstraram que a função consumo deslocou-se para cima enquanto a renda média da família aumentava, de forma que a poupança não estava relacionada à renda absoluta das famílias, e sim por sua renda relativa à renda média global; 2) James Duesenberry e Franco Modigliani tentaram conciliar, em 1949, as variações da taxa de poupança com a estabilidade de longo prazo, afirmando que o consumo corrente foi determinado não somente pela renda atual, mas também pelos altos picos anteriores, resultando em um lento e irreversível aumento da função consumo no curto prazo, ou seja, com a estabilidade as pessoas poderiam consumir mais e, portanto, poupar menos; 3) apesar de não publicada, a terceira contribuição foi de Margaret Reid, onde afirmava que a explicação entre a taxa de poupança e a renda relativa ocorria pelo consumo em função da renda permanente. Esta última contribuição foi uma importante fonte de inspiração para a Hipótese do Ciclo de Vida ( $\mathrm{LCH}$ - Life Cycle Hypothesis) e para a Hipótese da Renda Permanente (PIH - Permanent Income Hypothesis), de Milton Friedman, em 1957 (ibidem, p. 298-299).

Entre 1952 e 1954 Richard Brumberg e Franco Modigliani escreveram dois artigos que serviram de base para a Hipótese da Poupança em Função do Ciclo de Vida. São eles: Análise de utilidade e a função consumo: uma interpretação de dados cross-section (Utility analysis and the consumption function: an interpretation of cross-section data) e Análise de utilidade e a função consumo agregado: uma tentativa de integração (Utility analysis and the aggregate consumption function: an attempt at integration). O objetivo desses dois artigos era mostrar que todas as evidências empíricas bem estabelecidas poderiam ser consideradas em termos de: razão, maximização das utilidades e alocação de recursos para o consumo (ibidem, p. 299).

A hipótese de maximização da utilidade previa que os recursos que um consumidor aloca para o consumo, em qualquer idade, irão depender somente do valor presente da renda do trabalho mais a herança recebida, se houver, e não da sua renda corrente. Outro aspecto é que o tamanho da poupança individual em curtos espaços de tempo seria influenciado na medida em que a renda corrente afasta-se dos recursos médios, ou seja, a taxa de poupança depende mais da renda relativa do que da absoluta. Isso indica que se um indivíduo tem a expectativa de renda maior nos próximos períodos, ele tenderia a consumir mais no momento presente e, se a expectativa for de renda menor, a tendência seria poupar mais no presente. Essas 
considerações explicam uma famosa descoberta empírica observada nos Estados Unidos em 1936, onde famílias negras aparentemente poupavam mais do que as famílias brancas em qualquer nível de renda (MODIGLIANI, p. 300).

Para mostrar que a vida das pessoas é finita, a LCH pode trabalhar com outras variáveis que não aquelas resultantes dos desvios transitórios de renda. Exemplo: tamanho da família, partindo do princípio que as necessidades se alterariam em função dessa variável.

Em 1986 Modigliani apresenta um modelo com as variáveis renda, consumo, poupança e riqueza em função da idade. Trata-se de um modelo simples que pressupõe renda constante do nascimento até a aposentadoria. Depois dessa data não há renda. O modelo leva em consideração taxa de juros zero. O consumo é constante durante toda a vida, ou seja, do nascimento até a morte e não há nenhuma herança (ibidem, 1986, p. 300). A Ilustração 1, a seguir, representa um modelo aperfeiçoado, mantendo taxa de juros zero, com renda e consumo variáveis ao longo da vida.

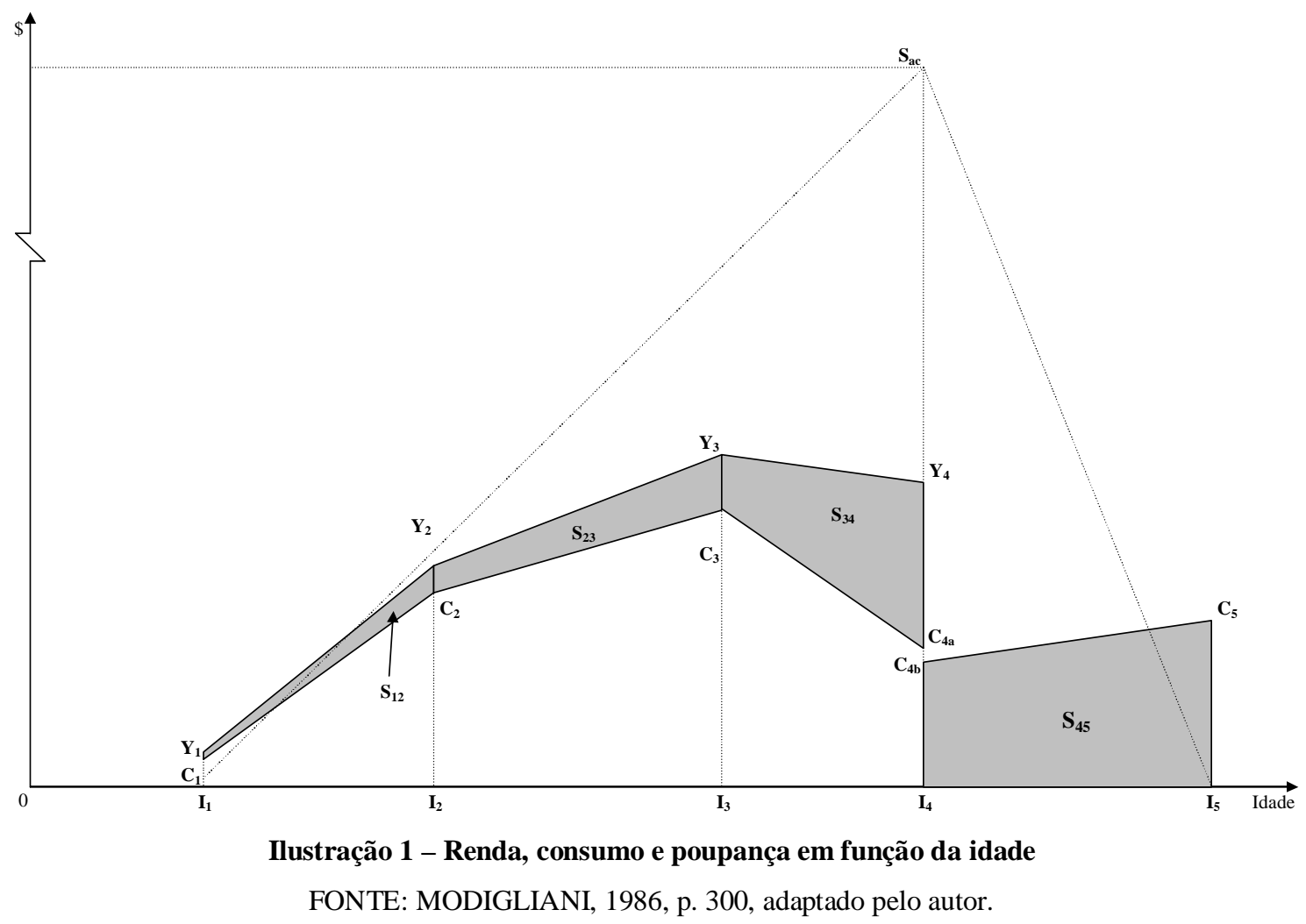

Em um primeiro momento a pessoa não tem renda. A partir de uma determinada idade $\left(\mathrm{I}_{1}\right)$ começa a trabalhar; tem uma pequena renda $\left(\mathrm{Y}_{1}\right)$, um pequeno consumo $\left(\mathrm{C}_{1}\right)$ e uma pequena poupança $\left(\mathrm{Y}_{1}-\mathrm{C}_{1}\right)$. Como está no início da carreira o rendimento inicial é baixo, mas a 
variação é grande nos primeiros anos. Em $\mathrm{I}_{2}$ a poupança aumentou significativamente em relação a $\mathrm{I}_{1}$, mas o montante absoluto ainda é baixo. No final da terceira fase a pessoa atinge sua maior renda $\left(\mathrm{Y}_{3}\right)$ e seu maior consumo $\left(\mathrm{C}_{3}\right)$; nesse ponto pressupõe-se que a pessoa tenha imóvel, automóvel, filhos independentes, etc. A partir daí haveria uma tendência de queda na renda com uma queda mais que proporcional no consumo, chegando a $\mathrm{Y}_{4}$ e $\mathrm{C}_{4 \mathrm{a}}$. Nesse momento a pessoa encerra suas atividades remuneradas e passa a consumir a poupança acumulada ao longo dos anos. $\mathrm{O}$ consumo tende a ser ligeiramente menor em $\mathrm{C}_{4 \mathrm{~b}}$, pois a pessoa não utiliza seus recursos com o trabalho, com o transporte, vestuário, alimentação, etc. Ao longo dos próximos anos, ou seja, de $\mathrm{C}_{4 \mathrm{~b}}$ a $\mathrm{C}_{5}$, haveria uma tendência de aumento do consumo em função de cuidados com a saúde.

Com o aumento da população idosa, da idade média e da expectativa de vida da população brasileira, o nível de preocupação com a fase da vida quando se deixa de trabalhar formalmente tende a se agravar. Contudo, um indivíduo precisa disponibilizar recursos para poder investir. Para tanto é necessário que haja uma disposição, uma educação, uma cultura financeira. Essa cultura, seja ela formal ou informal, é de extrema importância para que as pessoas administrem bem os seus recursos.

\section{Educação e Cultura Financeira}

De acordo com o Anexo 1 (p. 363), no Brasil 36\% da população estudam quatro anos ou menos. Mesmo que todos concluíssem o ensino médio, não há disciplina que permita ao cidadão lidar bem com recursos financeiros. Todos os indivíduos precisariam saber como adquirir uma casa, trocar um automóvel, contratar um seguro ou uma previdência privada (SILVA, 2005, p. 7). Muitas pessoas não têm a mínima idéia de quanto custa um financiamento ou qual uma boa opção de investimento. Países como Inglaterra tornou obrigatório o ensino da educação financeira desde a pré-escola (SEGUNDO FILHO, 2003, p. $30)$.

Para uma boa educação financeira há a necessidade de o indivíduo conhecer seu perfil. Ele precisa saber se tem propensão a consumir ou a poupar. Precisa definir se tem facilidade para guardar recursos ou precisa comprar ativos para evitar que os mesmos acabem.

Além de se conhecer, a pessoa precisa controlar o consumo ou, em outras palavras, ser ponderada nos seus gastos. Essa ponderação só é alcançada na medida em que conhece suas 
despesas. Para isso é necessário elencá-las, analisá-las e saber o grau de necessidade de cada uma delas. Partindo do princípio de que as pessoas devem ter reservas de recursos, ou seja, receitas maiores do que despesas, uma forma é a redução dos gastos a partir da análise sugerida.

A partir do momento que há o excedente a pessoa deve saber o que fazer com ele. Pode-se aplicar no mercado financeiro ou comprar ativos. Aplicando no mercado financeiro, deve-se decidir em que modalidade. Optando pela aquisição, a mesma pode ser feita à vista ou a prazo. Sendo a prazo existem várias formas de financiamento: crédito bancário, leasing, crédito direto com o vendedor e outros. (PIRES, 2007, p. 23).

Aplicando no mercado financeiro ou adquirindo bens através desse mesmo mercado, é essencial que a pessoa conheça bem suas regras. Existe um número grande de opções de financiamento para aquisição de ativos e um número maior ainda para aplicação de recursos. É muito comum que os investidores procurem ajuda de pessoas ligadas às próprias instituições, como gerentes de banco ou analistas. Contudo, ninguém melhor que o próprio investidor para conhecer seu perfil e decidir pela modalidade mais adequada.

Para que os objetivos sejam alcançados as famílias devem estabelecer metas de poupança (MARTINS, 2004, p. 67). Gerenciar gastos e buscar aumento de receitas é uma forma de atingir essas metas. Com capital acumulado o indivíduo pode investir no mercado financeiro a taxas mais atrativas, adquirir imóveis para alugar ou buscar ganhos no mercado acionário (PIRES, 2007, p. 23).

Poupar proporciona enriquecimento da nação e segurança para o futuro da família. Ao longo dos anos as reservas podem ser utilizadas para eventuais emergências, oportunidades de investimento de maior monta com retorno superior à média e, à sua época, como aposentadoria complementar. (PIRES, 2007, p. 32-33).

A educação e cultura financeira podem viabilizar tranquilidade e aquisição de ativos. Um grande desafio do século XXI é ter recursos suficientes para manter a qualidade de vida ao se aposentar (SEGUNDO FILHO, 2003, p. 27). Essa qualidade depende do padrão de consumo da família antes da aposentadoria e qual o padrão que deseja ter depois (SILVA, 2005, p. 97). 


\section{Previdência Social}

A previdência social é uma poupança compulsória para o trabalhador. Contudo, há uma inquietação. Quando a Previdência foi criada, nas décadas de 1920 e 1930 (FUNDAÇÃO ANASPS, 2007, p. 30), a expectativa de vida do brasileiro era de 42 anos (SIMÕES, 2008, p. 28); até a década de 60, para cada aposentado havia oito pessoas trabalhando e contribuindo. Hoje a expectativa de vida do brasileiro está em torno de 68 anos e o sistema conta com menos de dois contribuintes por beneficiário (BORGES, 2008).

Mesmo no período em que a relação contribuinte/beneficiário era favorável, o sistema previdenciário já tinha problemas estruturais. Em primeiro lugar os cálculos atuariais não previam reajustes em função da inflação. O modelo, criado a partir de um conceito tripartite, dividia em partes iguais as contribuições do Estado, empregados e empregadores. Contudo, a União faltava com os pagamentos e os empregadores sonegavam, produzindo déficits representativos. Estima-se, por exemplo, que em 1956 as contribuições não recolhidas foram da ordem de CR $\$ 10$ bilhões, ou R \$ 3,110 bilhões em valores de junho de 2008. Além da escassez de recursos, as reservas eram investidas em projetos, estratégicos segundo o governo, de baixa rentabilidade, como imóveis populares, hospitais, ambulatórios, hidrelétricas e companhias de siderurgia como Vale do Rio Doce e CSN. Na construção de Brasília foram gastos, até dezembro de 1965, mais de R \$ 500 milhões em valores também de junho de 2008 . Segundo Oliveira, Beltrão e David (1999), em 1990 a Previdência Social tinha um débito acumulado, em valores de junho de 2008, de R\$27,730 bilhões. Em 2002:

[...] a Previdência Social pagou $\mathrm{R} \$ 88$ bilhões a 19 milhões de beneficiários do INSS e arrecadou $\mathrm{R} \$ 71$ bilhões das contribuições de empresas e trabalhadores da iniciativa privada. No serviço público, foram pagos $\mathrm{R} \$ 61$ bilhões a 3,2 milhões de servidores inativos e pensionistas e arrecadou R \$ 22 bilhões. Assim, o governo complementou a diferença de R 39 bilhões para o serviço público e de R\$17 bilhões para a iniciativa privada. (MINISTÉRIO DA PREVIDÊNCIA SOCIAL, 2008).

Ainda em termos de débito, Giambiagi et al (2007, p. 33) estimam que o valor presente da dívida atuarial da Previdência Social de 2005 a 2050 equivale a 1,9 PIB anual.

Várias medidas reformistas, pós Plano Real, tomadas pelo governo, reduziram a trajetória expansionista das despesas previdenciárias; contudo não inibiram seu movimento ascendente (ROCHA; CAETANO, 2008, p. 7). Em relação à média internacional, o Brasil tem despesas previdenciárias superiores, um número maior de beneficiários e taxas de reposição elevadas. Se os rumos da previdência não forem alterados, as perspectivas para o futuro são pouco 
promissoras para a nação (ibidem, p. 26). Um dos resultados da pesquisa desenvolvida nesta tese deixa claro que os grupos pesquisados não acreditam que os rendimentos do INSS sejam suficientes quando se aposentarem.

\section{Opções de Poupança}

Uma opção de complementação de rendimentos é a previdência privada. Para se ter uma idéia, nos Estados Unidos, mais de 100 milhões de pessoas investem nessa modalidade (BAUTZER, 2003), sendo que uma substancial fração da poupança do país é proveniente dessas contribuições (BODIE, 1990, p. 28). Contudo, há uma preocupação muito grande das pessoas em relação ao risco de se investir para usar, depois de aposentado, essa poupança (BODIE, 1990, p. 35). Trata-se de um investimento que exige uma série de cuidados, pois o setor enfrenta problemas em nível mundial.

Em 2002, houve greve na França contra a privatização da seguridade social. Na Inglaterra existem empresas que o déficit previdenciário tem quase o mesmo valor do patrimônio. No período 1999-2003, calcula-se que 1,4 trilhões de dólares tenham sido perdidos pelos fundos de pensões nas bolsas européias (COGGIOLA, 2008a e 2008b).

Em 2002, nos Estados Unidos, 346 fundos de empresas americanas tinham risco de insolvência (COGGIOLA, 2008a e 2008b). Em 2006, de 1500 empresas com os piores problemas relacionados a fundos de pensão, as cinco primeiras eram do setor automotivo, energia e companhias aéreas, sendo este último principalmente em função do ataque aéreo ao World Trade Center em 2001 (OKUNADE, 2006).

Para minimizar os problemas relacionados aos fundos de pensão, algumas empresas americanas decidiram que não podem ou não querem manter as promessas incluídas nos planos de aposentadoria (WALSH, 2006). Nos Estados Unidos há uma tendência de cada vez menos empresas oferecerem fundos de pensão para seus funcionários. Os americanos que se aposentarem até meados de 2030 devem enfrentar o desafio de administrar suas contas médicas e lidar com o problema da "ilusão do valor global", ou seja, a tendência de ver a poupança da aposentadoria como uma quantia global em vez de um fluxo de renda. (OKUNADE, 2006).

A longevidade também tem sido um desafio para as organizações. "O exemplo mais contundente é a General Motors, quase falida por conta de despesas incontroláveis com 
seguro saúde e planos de previdência de seus empregados" (ROCHA, 2006). No Brasil o problema também é grave. Em 2002, por exemplo, a Petrobrás injetou 9,5 bilhões de reais na Petros, o fundo de pensão dos funcionários da empresa. Em 2006 a empresa tinha um novo déficit de mais nove bilhões de reais (GUANDALINI, 2006). A diferença teria sido causada por estimativas mal formuladas nos anos 70 entre arrecadação e despesas do fundo, agravada pelo uso de premissas desatualizadas em relação à expectativa de vida dos beneficiários do plano (ROCHA, 2006).

Pelo exposto, a complementação de renda através de previdência privada também é uma opção que traz em seu bojo uma série de incertezas.

Levando em consideração que uma parte dos recursos é utilizada para moradia e alimentação, uma alternativa é investir essa parcela em organizações que ofereçam esses serviços para uso futuro. Apesar da grande parte das instituições brasileiras cobrarem pelos serviços prestados a partir do ingresso do usuário, há empresas que vendem quotas de utilização e outras que também dão direito a construir uma casa.

No Brasil essas instituições normalmente eram conhecidas como Asilos. Acompanhando um perfil mais humano, essas passaram a ser denominadas Casas de Repouso, Casas de Repouso Residencial, Lar de Idosos, Lar da Terceira Idade, Residence Care, Instituições de Longa Permanência para Idosos - ILPI, entre outras.

Esta tese tratará esse tipo de organização como Ambiente Residencial Especial, pois nela poderão residir pessoas com menos de 60 anos, idade a partir da qual um brasileiro é considerado idoso (BRASIL, 2006c).

Investir em uma instituição para residir no futuro pode implicar algumas incertezas no primeiro momento. A primeira delas é se haverá necessidade de utilizar as dependências da organização algum dia. Nesse sentido duas vertentes podem ser identificadas. A primeira delas é quando a pessoa adquire grau de dependência e não possui familiar apto para oferecer cuidados. A segunda possibilidade é quando um familiar tem grau de dependência e a pessoa deseja garantir qualidade de vida para o mesmo. A segunda vertente é o desejo, em um segundo momento, de utilizar a organização. Um fato motivador é não preocupar os familiares. O outro motivo é a opção de residir por não ter familiares próximos. 
Outro fator que proporciona incerteza é em relação à perpetuidade da organização no tempo, ou seja, se a empresa continuará existindo no momento de ser utilizada. Em relação a essa inquietação esta tese apresentará parâmetros para sustentabilidade sob três pontos de vista: institucional, através de formatos jurídicos adequados ao objeto social da instituição; econômico-financeira, onde serão apresentadas opções de investimento, utilização, rentabilidade; e sustentabilidade gerencial, focando aspectos de governança corporativa.

\section{Objetivos}

Esta tese tem como objetivo identificar uma opção de investimento em ambientes residenciais especiais, com um formato jurídico e uma estrutura de governança corporativa que lhe assegure perenidade institucional e benefícios fiscais em função do caráter social da organização. Também tem como objetivo propor um formato econômico-financeiro que priorize qualidade de vida para os residentes, satisfação pessoal e conforto espiritual através de um modelo financeiro flexível em que possa haver variação do tempo de carência, quantidades, valor do investimento e de contribuições.

\section{Hipóteses}

Os objetivos serão alcançados na medida em que algumas hipóteses forem corroboradas. Em primeiro lugar, se a previdência social proporcionasse rendimentos compatíveis com a expectativa da população brasileira, possivelmente esta tese teria um teor diferente. Assim, a primeira hipótese é que o investidor usufrutuário não acredita na aposentadoria com base nos rendimentos da previdência social, e sim na necessidade de poupar para garantir um futuro com qualidade de vida.

Uma pessoa tem várias formas de se preparar para a fase da vida quando não estiver mais trabalhando. Um trabalhador que contribui para a previdência social terá proventos quando se aposentar, uma pessoa proprietária de um imóvel receberá aluguéis ou outra que faz aplicações financeiras receberá juros. Uma opção é investir em organizações que ofereçam moradia e alimentação futuramente. A segunda hipótese é que o investidor usufrutuário entende que as organizações atuais não trazem segurança ou o modelo proposto apresenta menor risco.

Propor um modelo sem oferecer mecanismos de controle e formatos adequados para o bom funcionamento desse tipo de organização seria de pouco valia para a sociedade. Assim, a 
terceira hipótese é que ambientes residenciais especiais que adotam práticas de governança corporativa, estrutura física, organizacional e formato jurídico-institucional adequados são opções de investimentos que proporcionam segurança ao investidor e aos futuros usufrutuários.

\subsection{Metodologia}

Há várias fontes de verdade. Uma delas é a intuição. O ser humano, sem o auxílio do raciocínio, estabelece uma verdade baseada na observação. Apesar de se tratar de uma forma de verdade insatisfatória, desempenha papel fundamental na formulação de hipóteses. Apesar de ser uma das formas mais frágeis, a autoridade é outra fonte de verdade. A tradição é uma forma de verdade transmitida verbalmente através dos tempos, que traz consigo tanto verdades quanto enganos do passado. Muitas vezes a tradição é adotada por ser a verdade mais cômoda. O bom-senso também é uma verdade, contudo pouco esclarecedora. É uma qualidade que as pessoas normalmente acreditam possuir, mas que pode estar comprometida por preconceitos ou enganos. A ciência é a forma de verdade de maior credibilidade, pois utiliza sistematização na busca de suas conclusões. (GIL, 1988, p. 15-17).

Em relação ao conhecimento pode-se dividi-lo em quatro grandes grupos: senso comum, filosófico, teológico e científico. O senso comum é o conhecimento adquirido no dia-a-dia que, apesar de limitado, é base do conhecimento científico. Pode-se notar que intuição e senso comum são enfoques diferentes de uma mesma realidade. O conhecimento filosófico é baseado na reflexão e lastreado somente no raciocínio, no ato de pensar, sendo que o teológico é produto da fé. O conhecimento científico, similar à ciência, é resultante da investigação metódica e sistemática da realidade, analisando, classificando, comparando e comprovando. Esse conhecimento é mais satisfatório quando se trata do mundo natural do que em relação ao mundo social, pois os resultados alcançados não são, em geral, verdades absolutas. (MARCONI; LAKATOS, 2008, p.18-21; MARTINS; THEÓPHILO, 2007, p.1-2).

O conhecimento científico precisa ter determinadas características. Clareza e precisão são características essenciais. O conhecimento exige a perfeita definição de seus próprios conceitos. Outra característica importante é o método. A investigação do conhecimento científico exige métodos baseados em lógicas e técnicas eficazes. A sistematicidade é outra característica onde as idéias são encadeadas e conectadas entre si (GIL, 1988, p. 18). A objetividade é uma característica fundamental, pois exige que o conhecimento científico não 
seja afetado por crenças, preferências, desejos ou valores pessoais (ibidem, p. 19; KERLINGER, 2007, p. 9-15). Uma característica essencial do conhecimento científico é a verificabilidade, ou seja, é a capacidade de replicar o experimento para encontrar resultados similares. (GIL, 1988, p. 19).

Apesar de o conhecimento científico ser mais eficaz no mundo natural, ele proporciona uma série de benefícios nas relações sociais. Um deles é conhecer as causas dos eventos. Entender os significados que estão por trás das ações pode ser considerado um segundo aspecto positivo do conhecimento científico. Um terceiro é identificar as organizações sociais que estão por trás das atividades de grupos. (GIL, 1988, p. 29; KERLINGER, 1979, p. 12).

\subsection{Concepção Atual do Método Científico}

Descobrir um problema é primeiro passo do método científico. O pesquisador identifica um problema alvo da sua ansiedade. Nesse ponto ele não sabe exatamente do que se trata; acredita, somente, que precisa aprofundar-se no assunto. A segunda fase consta da definição precisa do problema. Trata-se da identificação exata dos eventos, fatos ou agentes envolvidos. A partir de um problema perfeitamente identificado, o pesquisador busca conhecimentos ou instrumentos existentes para solucionar o problema. Na medida em que o conhecimento atual não soluciona o problema, o pesquisador cria novas idéias ou produz novos dados empíricos na busca de uma solução. A partir do momento que a solução é obtida, o pesquisador investiga as consequências do seu trabalho. Em função da verificabilidade, o próximo passo é a busca pela comprovação da solução, ou seja, se a solução pode ser obtida mais vezes. Caso haja qualquer desvio em relação às soluções que foram encontradas, o pesquisador deve corrigir cada passo seguido anteriormente e buscar uma nova solução para o problema. (MARCONI; LAKATOS, 2008, p. 51-52).

\subsection{Método de Abordagem}

Podem-se definir cinco métodos de abordagem: indutivo, dedutivo, hipotético dedutivo, dialético e métodos específicos das Ciências Sociais.

O método indutivo parte do particular, desde que devidamente comprovado, inferindo uma provável verdade geral ou universal. Ou seja, a conclusão é mais ampla do que as premissas analisadas. Segundo Marconi e Lakatos (2008, p. 54), este método possui três elementos fundamentais: a observação dos fenômenos, a descoberta da relação entre os fenômenos e a 
generalização da relação. O método dedutivo é o oposto ao indutivo, partindo-se das leis para o particular, ou seja, explica-se um fato a partir das leis gerais. (ibidem, p. 63-71; GIL, 1988, p. 22-23).

O método hipotético-dedutivo parte de uma lacuna no conhecimento, formula hipóteses e, pelo processo de inferência dedutiva, testa a ocorrência dos fenômenos alcançados pela hipótese. (MARCONI; LAKATOS, 2008, p. 71-78).

O método dialético, na investigação da realidade, entende que as mudanças quantitativas graduais geram mudanças qualitativas, onde os objetos e fenômenos da natureza possuem contradições internas responsáveis pelo desenvolvimento da realidade e que o desenvolvimento ocorre quando o novo substitui o velho nos pontos negativos. (ibidem, p. 8189; GIL, 1988, p. 24-27).

Em relação aos métodos específicos das Ciências Sociais existe o método histórico, onde se busca entender o presente a partir do estudo do passado, ou seja, da história. Há o método comparativo, onde um grupo ou sociedade é comparado a outros grupos com o objetivo de identificar semelhanças e divergências. O método monográfico estuda partes com o objetivo de obter generalizações. O estatístico busca comprovações a partir de métodos quantitativos. Semelhante ao método comparativo, o tipológico cria modelos ideais a partir dos estudos realizados. O funcionalista é mais um método de interpretação do que de investigação, pois estuda a sociedade sob a ótica do seu funcionamento. O método estruturalista parte de um fenômeno que se deseja analisar, passa para um modelo abstrato, ideal, e retorna ao concreto. (MARCONI; LAKATOS, 2008, p. 90-97).

\subsection{Técnicas de Pesquisa}

As técnicas de pesquisa podem ser classificadas sob vários aspectos. Ela pode ser original ou inédita quando não é baseada exclusivamente em um artigo, resumo ou em uma síntese de publicações anteriores.

A pesquisa pode ser pura ou aplicada. A pura, também chamada de básica ou teórica, não tem utilização prática, mas possibilita o avanço do conhecimento. A pesquisa aplicada é desenvolvida com o objetivo de utilização prática. (GIL, 1988, p. 36-37). 
Sob outro aspecto a pesquisa pode ser exploratória, descritiva ou explicativa. A exploratória pesquisa um fenômeno atual, ainda pouco examinado, com o objetivo de desenvolver, esclarecer ou modificar conceitos e idéias sobre o mesmo, descrevendo-o de forma mais precisa. Em geral este tipo de pesquisa utiliza pesquisa qualitativa. A descritiva é utilizada quando os objetivos e as questões de pesquisa estão claramente formulados e, como seu próprio nome sinaliza, basta a descrição para resolver a pesquisa. A pesquisa explicativa busca estabelecer relações de causa e efeito entre duas ou mais variáveis, determinando quais as variáveis dependentes e independentes de um fenômeno e qual a relação existente entre as mesmas. As pesquisas descritiva e explicativa são bem estruturadas em termos de procedimentos formais, pois as hipóteses são muito claras e precisas. Estas normalmente utilizam métodos quantitativos e muitas vezes se combinam. (GIL, 1999, p. 43-45).

\subsection{Metodologia Adotada}

Há várias formas de se encontrar uma ou mais respostas para um problema. Vários pressupostos podem ser definidos, existe mais de uma abordagem que poderia ser utilizada e, em relação às técnicas, há uma série delas que atendem às exigências desta pesquisa.

Contudo, existe a necessidade de se definir com bastante clareza quais foram as premissas adotadas. Em primeiro lugar em relação ao método. Adotou-se o hipotético-dedutivo e monográfico. Hipotético-dedutivo na medida em que se percebeu nos dias de hoje uma preocupação com a previdência social (ROCHA; CAETANO, 2008, p. 26) e a necessidade de poupar para a aposentadoria (HALFELD, 2008). Outro fato que desencadeou esta tese foi a lacuna existente em termos de segurança na qualidade de vida de um usuário de instituição de longa permanência (ANSA, 2007). Monográfico, pois foca somente os ambientes residenciais especiais. (GIL, 1999, p. 35).

Em relação às técnicas de pesquisa estas podem ser definidas como original, aplicada e descritiva. Original em função do ineditismo inerente às teses de doutoramento. Aplicada, pois pretende identificar opção de investimento em ambientes residenciais especiais. Descritiva em função dos procedimentos formais e por ter sido estruturada para identificar alternativas de investimento, além da clareza das questões e dos objetivos a serem pesquisados na busca de respostas ao problema focado. 
Ainda em relação à segunda etapa, técnicas de pesquisa, o primeiro tipo utilizado nesta tese é o secundário, consistindo no levantamento bibliográfico (MARTINS; THEÓPHILO, 2007, p. 54) da estrutura demográfica, da distribuição da renda, da riqueza e do nível de educação formal do brasileiro, principalmente junto ao IBGE - Instituto Brasileiro de Geografia e Estatística. Buscar-se-á, também, as peculiaridades da legislação brasileira no que tange a instituições de longa permanência e os modelos existentes no Brasil e no mundo.

Uma terceira etapa buscará a construção de evidências empíricas das causas que levariam uma pessoa a fazer investimentos de longo prazo. Em seguida serão apresentadas estrutura organizacional e práticas de governança corporativa que dariam sustentação ao empreendimento e segurança aos investidores, assim como propostas de sustentabilidade financeira.

A última etapa é o levantamento de dados primários através de pesquisa de campo na região metropolitana de São Paulo, além de cidades próximas. As técnicas de pesquisa adotadas serão abordadas no capítulo que tratará diretamente da pesquisa de campo. 


\section{PERFIL DA POPULAÇÃO BRASILEIRA}

\subsection{Estrutura Demográfica}

Para investir em um ambiente residencial especial deve haver oferta e demanda para esse tipo de organização. Se o número de brasileiros usuários potenciais permanecesse inalterado pelos próximos anos, o número de empresários dispostos a oferecer esses ambientes poderia ser reduzido. Contudo, estima-se que a população que normalmente utiliza essas instituições aumentará 3,5 vezes no período de 2008 a 2050.

Em 2008 o Brasil conta com 191,87 milhões de habitantes, sendo 94,23 milhões do sexo masculino e 97,64 do sexo feminino. Essas proporções equivaliam a 49,1\% e 50,9\% respectivamente. Do total, 17,98 milhões ou 9,4\% possuíam 60 anos ou mais. Em função da expectativa de vida da mulher ser maior que a do homem (CAETANO, 2006, p. 10), a proporção de habitantes do sexo feminino aumentava ligeiramente a partir dos 60 anos, passando para $55,5 \%$ contra $44,5 \%$ do sexo masculino.

Tabela 1 - Estimativa da população brasileira - 2008

\begin{tabular}{crrrrrr}
\hline Idade & Homens & \multicolumn{3}{c}{ Mulheres } & \multicolumn{2}{c}{ Total } \\
\hline Pop Total & 94.230 .907 & $49,1 \%$ & 97.638 .776 & $50,9 \%$ & 191.869 .683 & $100,0 \%$ \\
60 ou + & 8.003 .298 & $44,5 \%$ & 9.981 .623 & $55,5 \%$ & 17.984 .921 & $9,4 \%$ \\
\hline
\end{tabular}

FONTE: IBGE, 2007b.

De 1950 para 1960 a população brasileira cresceu 34,9\%, passando de 51,9 para 70,1 milhões de habitantes. Se o crescimento se repetisse ao longo dos anos o Brasil teria mais de um bilhão de habitantes em 2050. Contudo, na Tabela 2 (p. 28) pode-se notar que o ritmo de crescimento populacional tem diminuído ao longo dos anos. Espera-se que a população brasileira cresça 3,32\% de 2040 para 2050, passando de 251,4 para 259,8 milhões de habitantes. Mesmo com esta desaceleração, trata-se de uma população cinco vezes maior em um período de 100 anos.

No Apêndice 2 (p. 227) e no Anexo 2 (p. 363) pode-se avaliar a estimativa da população brasileira por faixa e a mudança na pirâmide etária. De 1980 para 2050 a população deve aumentar $119,10 \%$, enquanto que a faixa até quatro anos será 7,34\% menor. De 1990 para 2050, quando a população deve aumentar 77,21\%, a população até 14 anos deve decrescer 10,55\%. De 2008 para 2050 a população deve aumentar 35,39\% enquanto que os habitantes até 29 anos de idade devem decrescer 7,67\%. A população com mais de 80 anos, que é 
estimada em 2,41 milhões em 2008, deve passar para 13,75 milhões em 2050, ou seja, um aumento de quase seis vezes. Pode-se comparar tal número ao total de habitantes entre 35 e 39 anos em 2008, que é estimado em 13,71 milhões.

Tabela 2 - População brasileira de 1940 a 1970, esperança e crescimento de 1980 a 2050

\begin{tabular}{ccccc}
\hline Ano & Homens & Mulheres & Total & $\begin{array}{c}\text { Variação em relação } \\
\text { ao período anterior }\end{array}$ \\
\hline $\mathbf{1 9 4 0}^{\mathbf{1}}$ & 20.614 .088 & 20.622 .227 & 41.236 .315 & \\
$\mathbf{1 9 5 0}$ & 25.885 .001 & 26.059 .396 & 51.944 .397 & $25,97 \%$ \\
$\mathbf{1 9 6 0}$ & 35.055 .457 & 35.015 .000 & 70.070 .457 & $34,90 \%$ \\
$\mathbf{1 9 7 0}$ & 46.331 .343 & 46.807 .694 & 93.139 .037 & $32,92 \%$ \\
$\mathbf{1 9 8 0} \mathbf{2}^{\mathbf{1 9 5}}$ & 58.904 .681 & 59.657 .868 & 118.562 .549 & $27,30 \%$ \\
$\mathbf{1 9 9 0}$ & 72.524 .690 & 74.067 .889 & 146.592 .579 & $23,64 \%$ \\
$\mathbf{2 0 0 0}$ & 84.350 .720 & 86.929 .162 & 171.279 .882 & $16,84 \%$ \\
$\mathbf{2 0 1 0}$ & 96.611 .841 & 100.222 .245 & 196.834 .086 & $14,92 \%$ \\
$\mathbf{2 0 2 0}$ & 107.253 .243 & 111.824 .486 & 219.077 .729 & $11,30 \%$ \\
$\mathbf{2 0 3 0}$ & 116.169 .452 & 121.568 .224 & 237.737 .676 & $8,52 \%$ \\
$\mathbf{2 0 4 0}$ & 122.712 .665 & 128.705 .341 & 251.418 .006 & $5,75 \%$ \\
$\mathbf{2 0 5 0}$ & 126.770 .394 & 132.999 .570 & 259.769 .964 & $3,32 \%$ \\
\hline FONTE: $^{1}$ 1940-1970: IBGE, $2007 \mathrm{~b}{ }^{2}{ }^{2} 1980-2050:$ IBGE, $2007 \mathrm{c}$, adaptado pelo autor.
\end{tabular}

O crescimento da população com maior faixa etária é fruto do aumento da expectativa de vida do brasileiro. Na década de 30 vivia-se em média 42 anos (SIMÕES, 2008, p. 28). Em 1980 essa média subiu para 62,6 anos; no ano 2000 o brasileiro, ao nascer, tinha uma expectativa de viver 70,5 anos (IBGE, 2008e). Para o ano 2050 estima-se que o brasileiro passará a ter uma expectativa de vida de 81,3 anos (idem, 2008c).

Segundo Caetano (2006, p. 9-10), os avanços da medicina e da saúde pública permitiram o aumento da expectativa de vida do brasileiro em função da redução das taxas de mortalidade infantil e em idades avançadas. Em relação à saúde o saneamento básico teve um papel relevante na melhoria da condição de vida do brasileiro, pois principalmente as infecções gastrintestinais são provocadas pela falta de saneamento adequado (MARCOVITCH, 2007, p. 29). A redução da taxa de mortalidade, principalmente a infantil, pode ser observada na Tabela 3 (p. 29). Outro aspecto que favoreceu a queda da mortalidade infantil foi o processo de urbanização ocorrido no século XX (ibidem, p. 32).

Com o aumento da expectativa de vida, a pirâmide etária brasileira mudará de forma significativa no período de 1980 a 2050. Tal mudança pode ser observada nos gráficos de 1 (p. 29) a 8 (p. 33). Nota-se que em 1980 a base era muitíssimo maior que o topo da pirâmide. Já, em 2050, o topo é quase tão largo quanto a base, ou seja, há uma uniformidade bem maior 
nas faixas etárias da população. Com a uniformização a idade média do brasileiro aumentará. No Apêndice 3 (p. 228) pode-se observar que esta passará de 20,2 anos em 1980 para 40,0 anos em 2050.

Tabela 3 - Evolução da taxa de mortalidade por infecções gastrintestinais 1980-2000 (por mil habitantes de cada faixa etária)

\begin{tabular}{llll}
\hline \multicolumn{1}{c}{ Idade } & $\mathbf{1 9 8 0}$ & $\mathbf{1 9 9 0}$ & $\mathbf{2 0 0 0}$ \\
\hline De 0 a 4 anos & 2,01 & 0,63 & 0,11 \\
De 15 a 64 anos & 0,02 & 0,02 & 0,01 \\
Acima de 65 anos & 0,34 & 0,41 & 0,25 \\
\hline
\end{tabular}

FONTE: MARCOVITCH, 2007, p. 31, adaptado pelo autor.

Com a população de idosos passando de 17,98 milhões em 2008 para 64,05 milhões em 2050, haverá a necessidade de investimentos. De acordo com o Ministério da Saúde em 2007 a nação possuía 2,4 mil instituições de longa permanência. Em 2008 cerca de 100.000 idosos residiam nessas organizações, ou seja, $0,5 \%$ da população com mais de 60 anos. Dividindo o número de usuários pelo total de instituições chega-se a uma média de 42 pessoas por instituição. Se essa média se mantiver, o resultado desse crescimento populacional é a necessidade de se investir em mais de cinco mil instituições até o ano 2050. (INSTITUTO DE PESQUISA ECONÔMICA APLICADA, 2008).

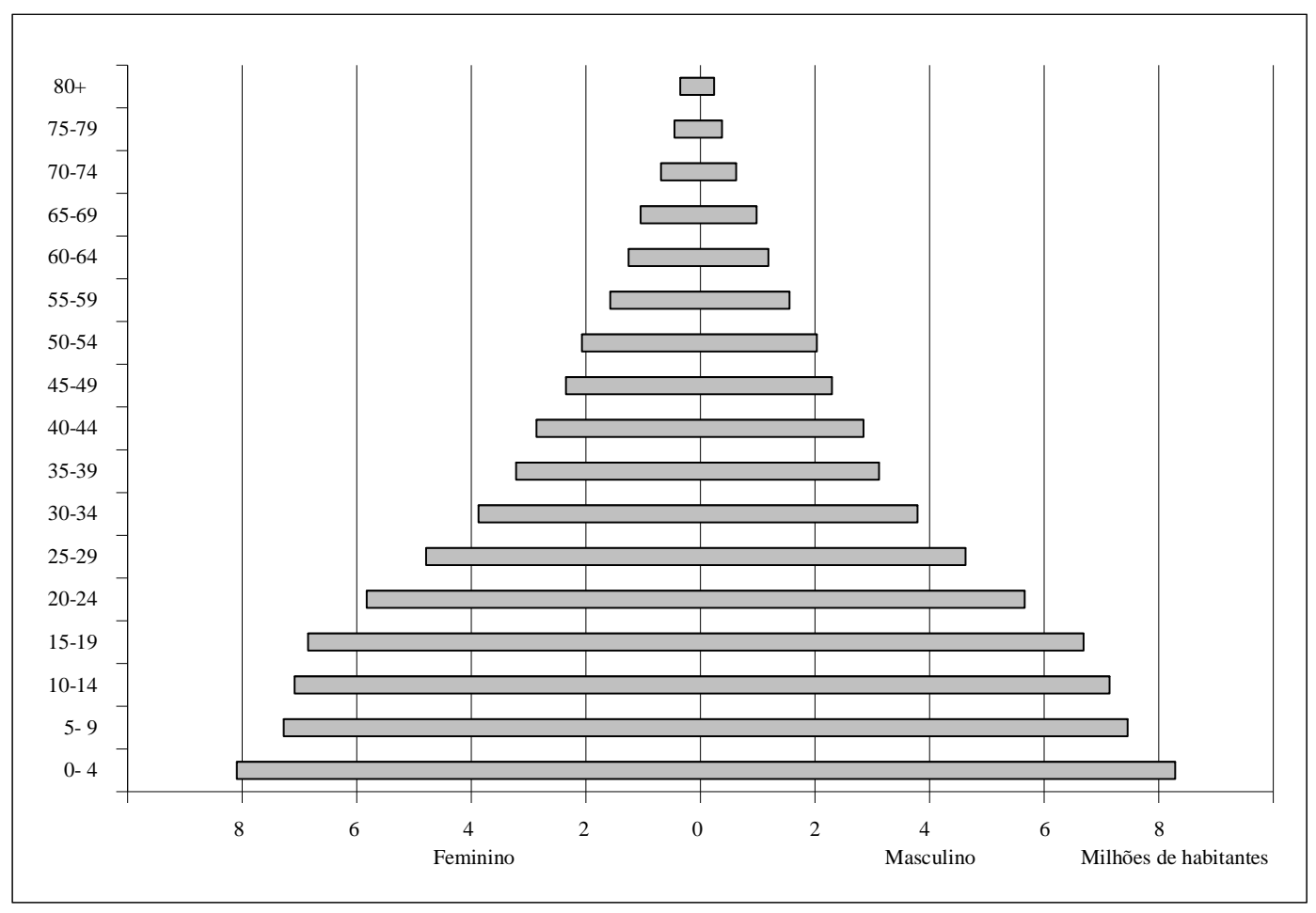

Gráfico 1 - Pirâmide etária da população brasileira dividida por sexo - 1980

FONTE: IBGE, 2007c, adaptado pelo autor. 


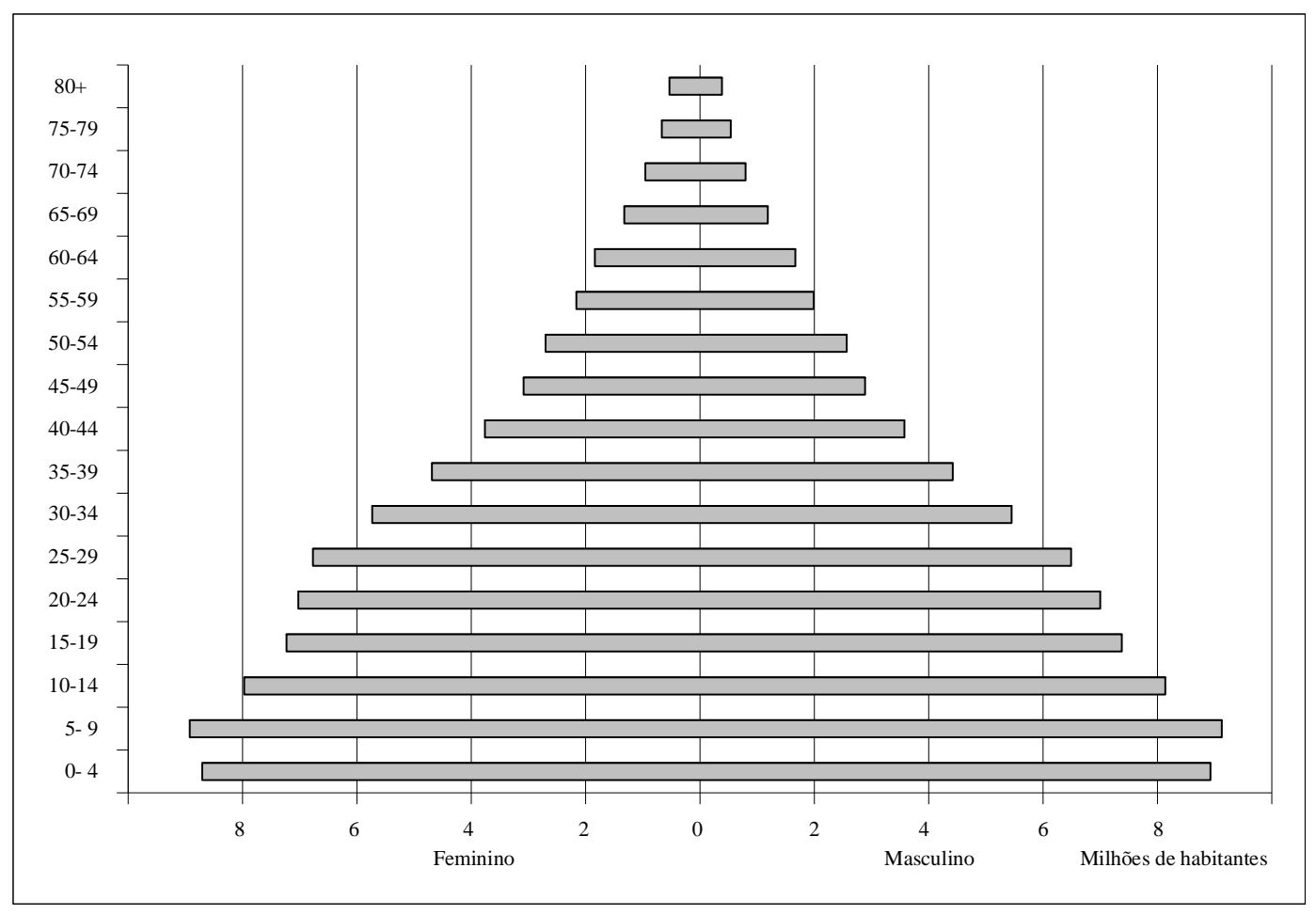

Gráfico 2 - Pirâmide etária da população brasileira dividida por sexo - 1990

FONTE: IBGE, 2007c, adaptado pelo autor.

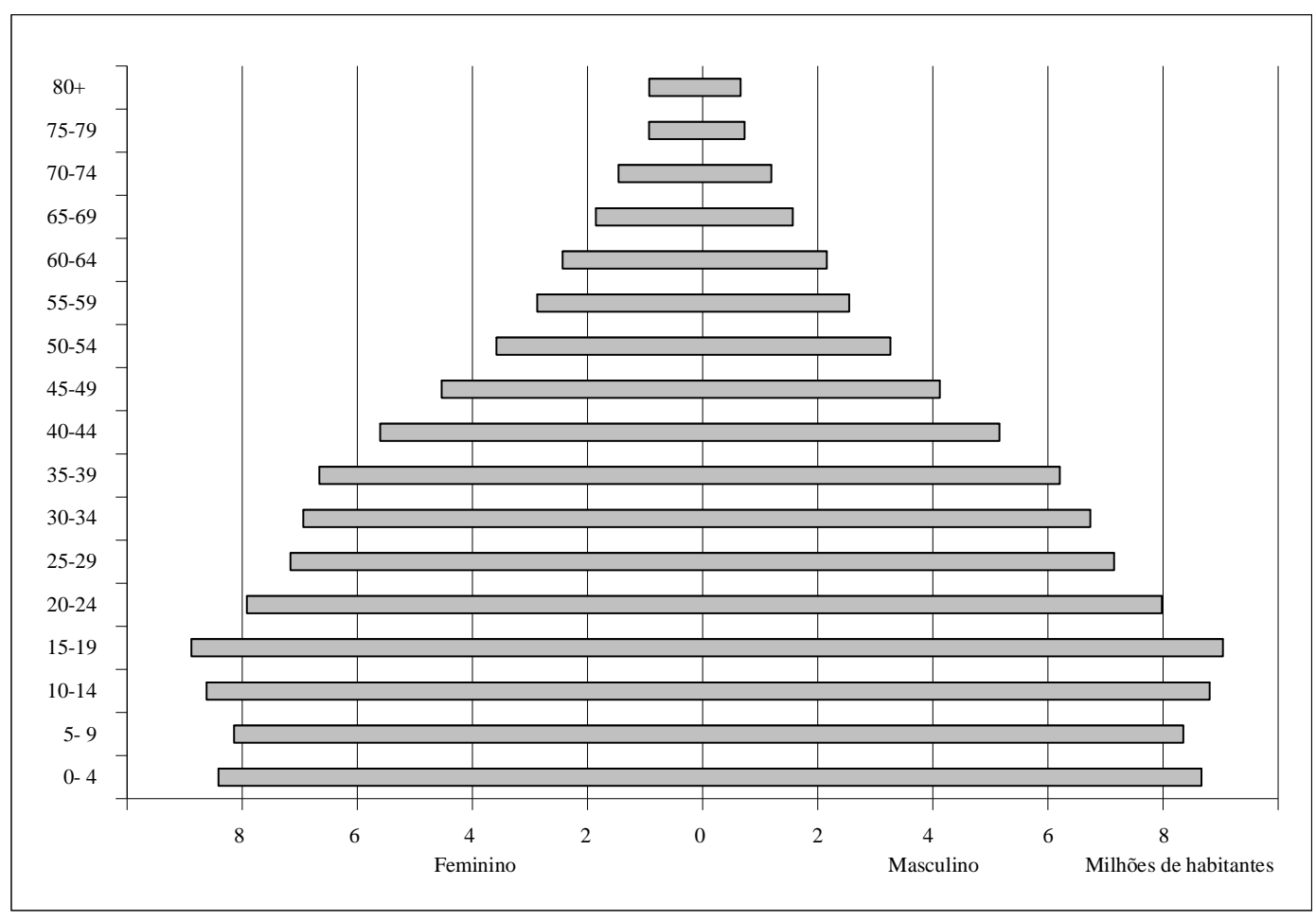

Gráfico 3 - Pirâmide etária da população brasileira dividida por sexo - 2000

FONTE: IBGE, 2007c, adaptado pelo autor. 


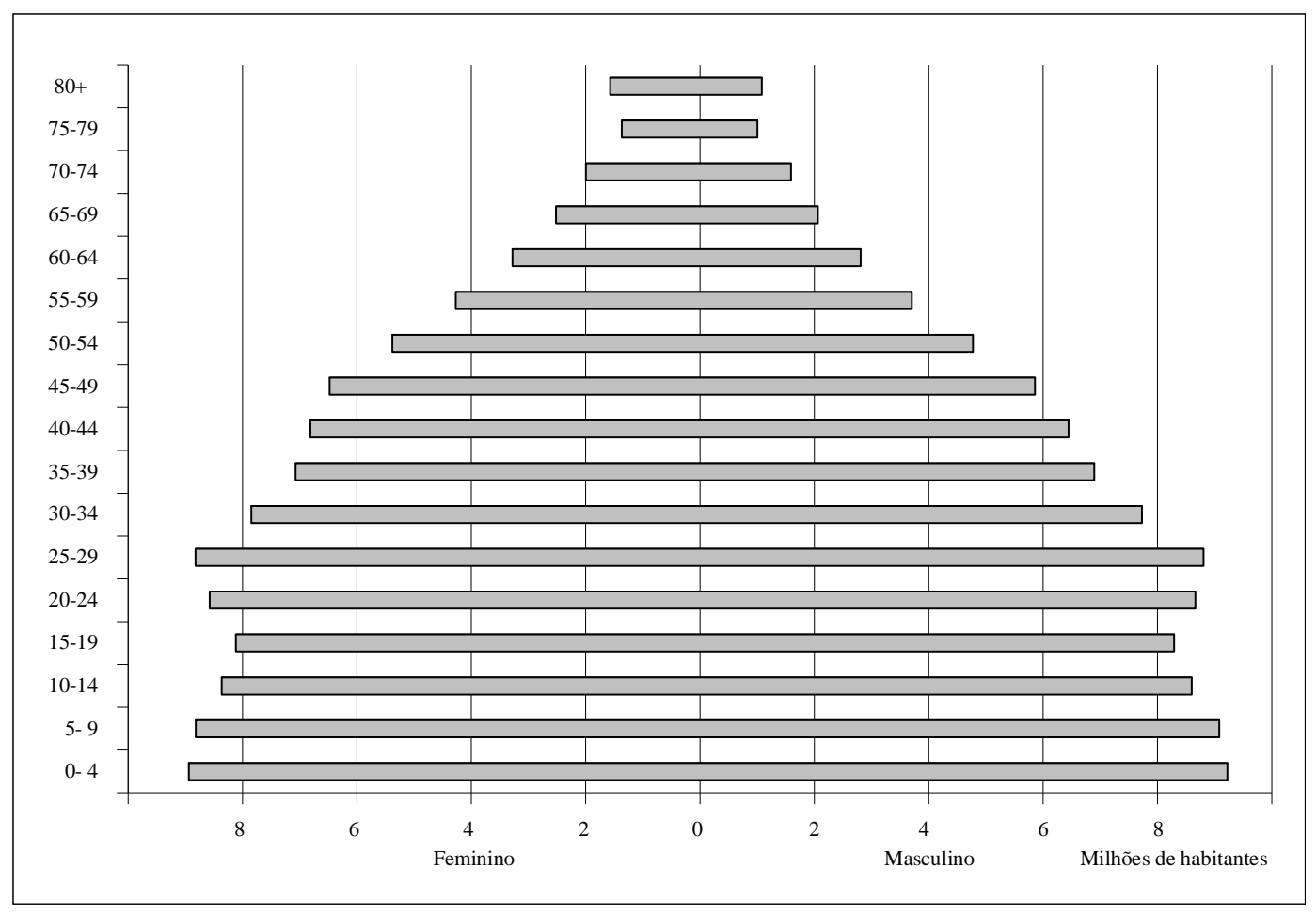

Gráfico 4 - Pirâmide etária da população brasileira dividida por sexo - 2010

FONTE: IBGE, 2007c, adaptado pelo autor.

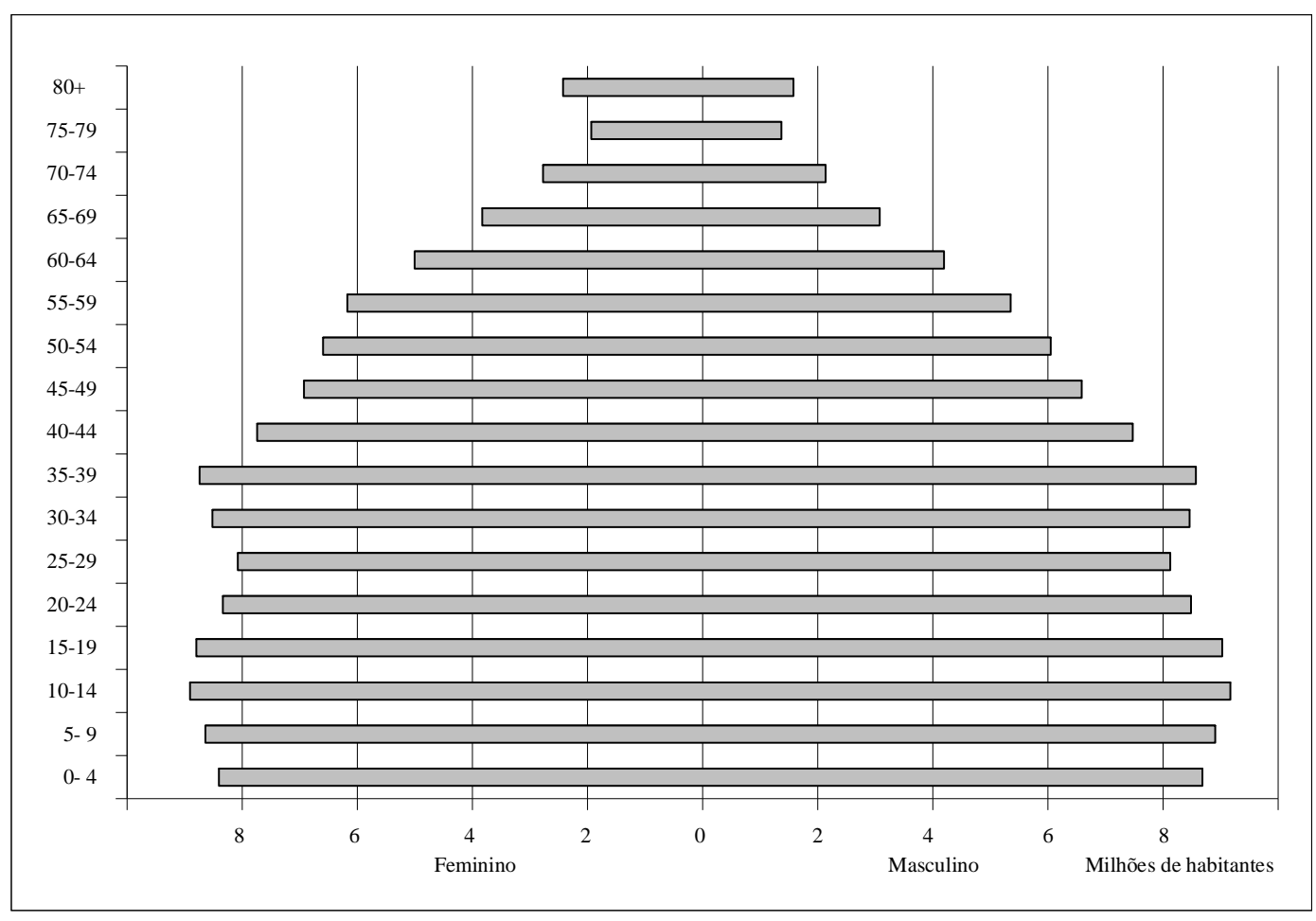

Gráfico 5 - Pirâmide etária da população brasileira dividida por sexo - 2020

FONTE: IBGE, 2007c, adaptado pelo autor. 


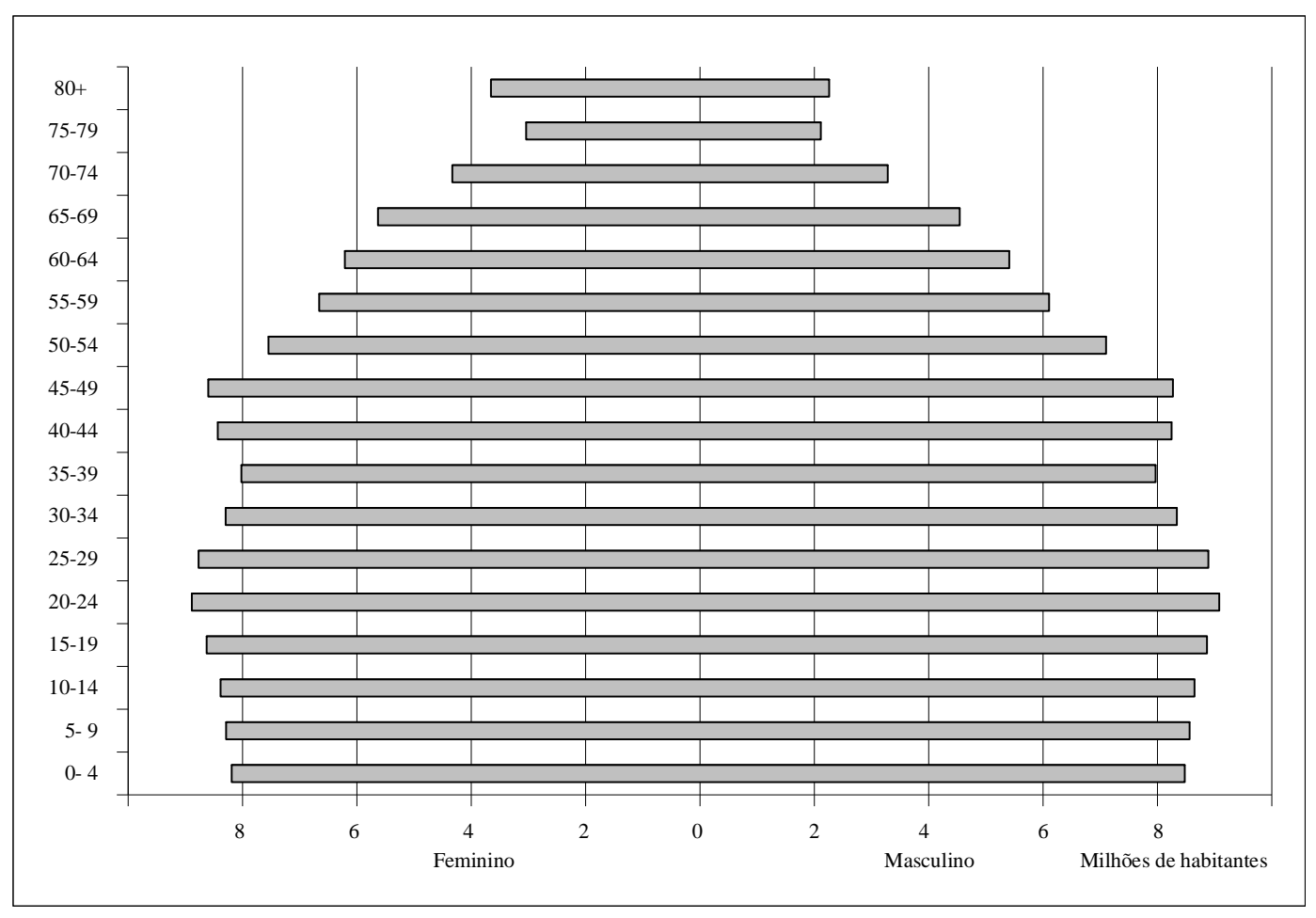

Gráfico 6 - Pirâmide etária da população brasileira dividida por sexo - 2030

FONTE: IBGE, 2007c, adaptado pelo autor.

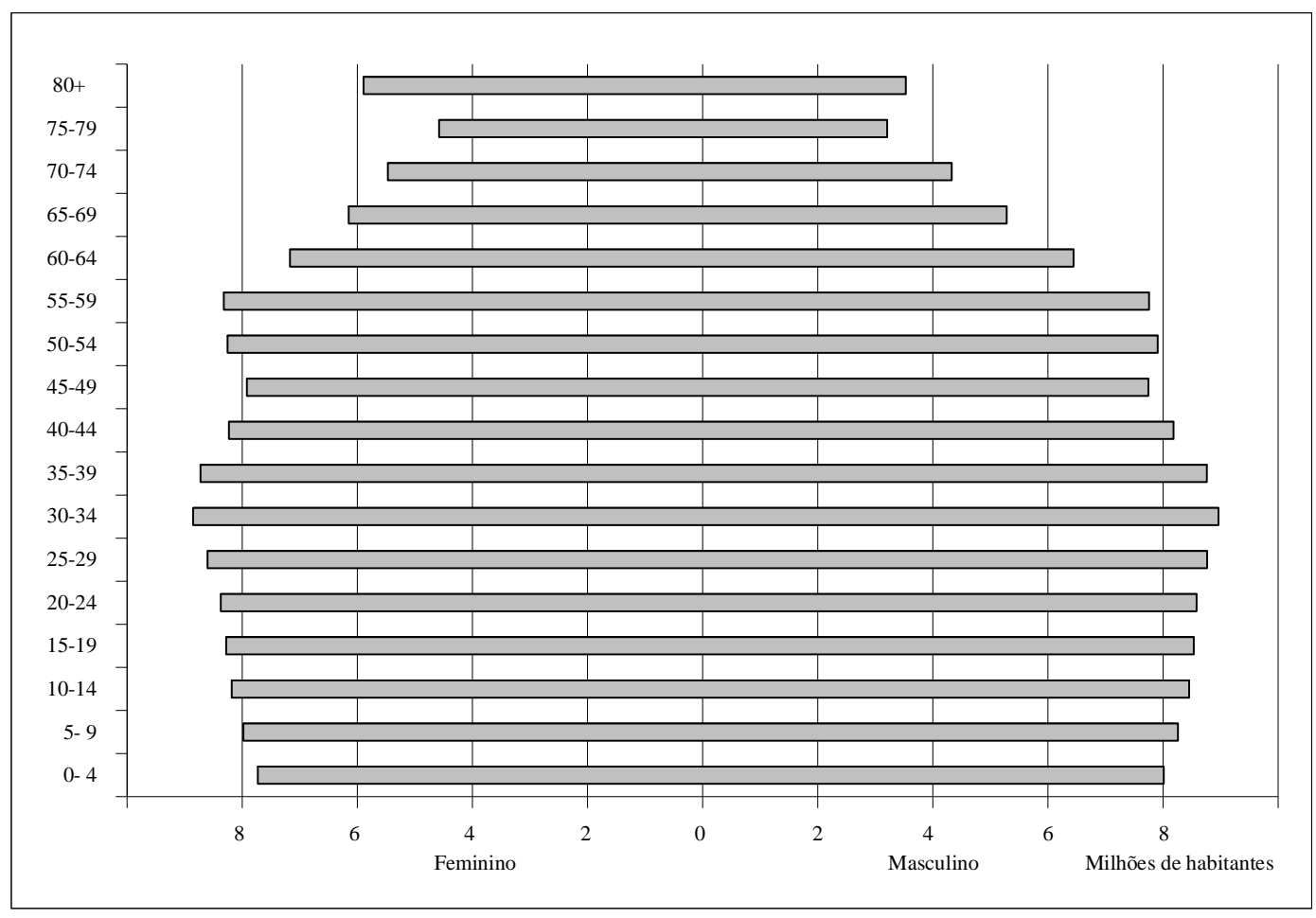

Gráfico 7 - Pirâmide etária da população brasileira dividida por sexo - 2040

FONTE: IBGE, 2007c, adaptado pelo autor. 


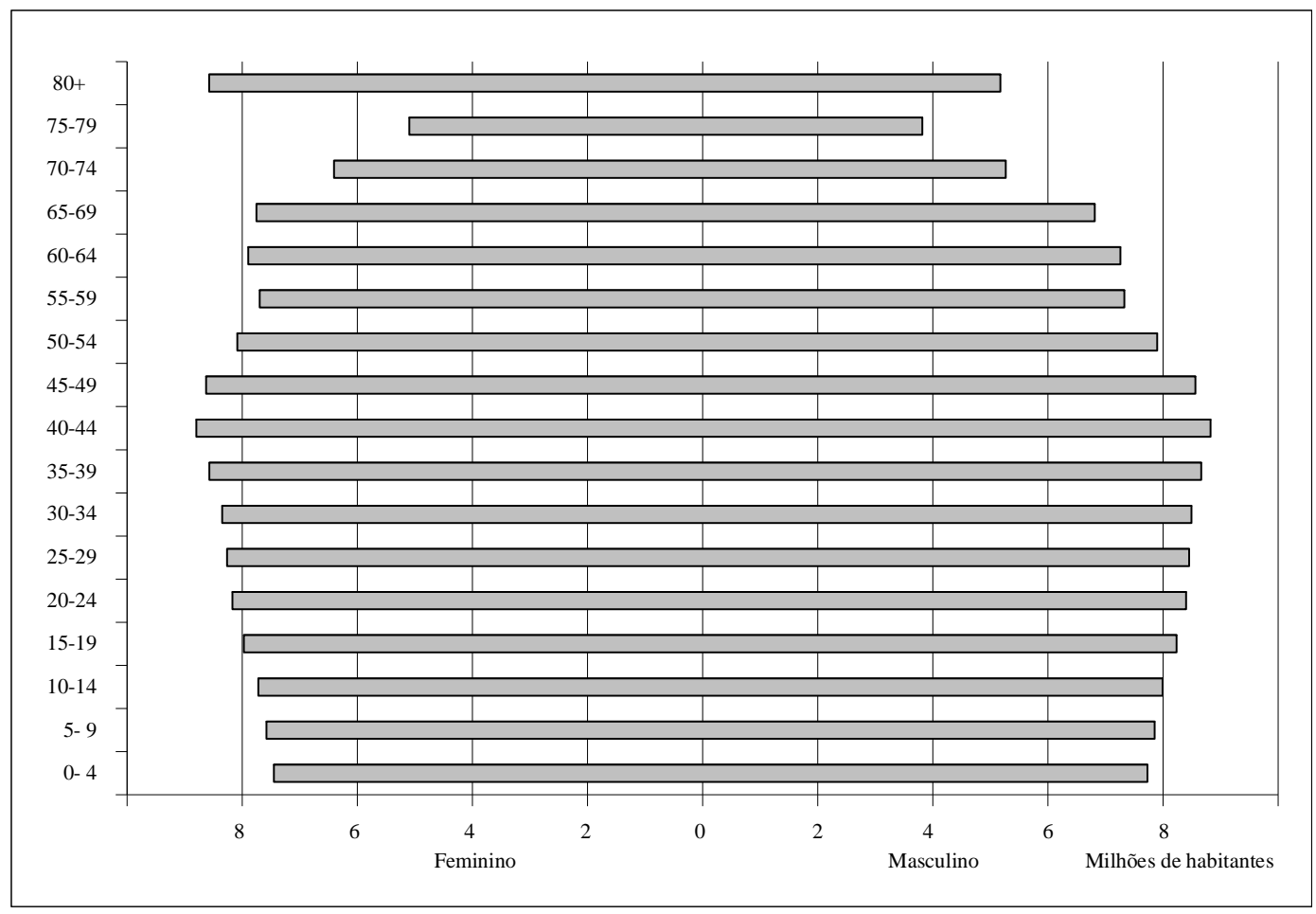

Gráfico 8 - Pirâmide etária da população brasileira dividida por sexo - 2050

FONTE: IBGE, 2007c, adaptado pelo autor.

\subsection{Distribuição da Renda e da Riqueza}

O objetivo principal desta tese é identificar uma opção de investimento em ambientes residenciais especiais. Contudo, a decisão de aplicar recursos neste tipo de organização pode depender da renda do investidor. Assim, este tópico delineará a distribuição de renda e riqueza da população brasileira.

Pode-se observar no Anexo 4 (p. 365) que em 2006 o Brasil contava com 187,2 milhões de residentes, sendo que $83 \%$ estavam na região urbana e $17 \%$ na rural. Na zona urbana $48 \%$ eram homens e 52\% eram mulheres; na zona rural essa proporção se inverte entre os sexos, ou seja, havia $4 \%$ mais homens do que mulheres.

A maior proporção da população estava entre cinco e 24 anos. Essa faixa de idade compreendia quase $37 \%$ da população brasileira. Cada agrupamento de cinco anos, ou seja, de cinco a nove anos, de 10 a 14, até de 20 a 24 anos, representava aproximadamente $9 \%$ da população. 
A concentração de pessoas na região urbana é crescente até a faixa de 25 a 29 anos. Até quatro anos são $80 \%$. A partir daí a participação aumenta até a faixa de 25 a 29 , onde atinge 86\%. A partir dos 30 anos a participação é decrescente, atingindo 83\% a partir dos 55 anos.

Segundo a legislação brasileira, é considerada idosa a pessoa com 60 anos ou mais idade (BRASIL, 2006c, art. $1^{\circ}$ ). No ano de 2006 10\% da população brasileira estava com 60 anos ou mais de idade, ou seja, existiam mais de 19 milhões de idosos no Brasil, sendo que aproximadamente 16 milhões deles estavam residindo em regiões urbanas. Desse total $42 \%$ da população urbana era masculina e $58 \%$ feminina; na zona rural quase havia um equilíbrio entre a proporção de homens e mulheres, $52 \%$ e $48 \%$ respectivamente.

O Brasil tinha em média 3,2 pessoas em cada lar, pois a população brasileira estava distribuída em um pouco mais de 59 milhões de famílias. Deste total, 15\% tinham um rendimento mensal familiar de até um salário mínimo, o que contribuía com $2 \%$ do rendimento total do país. As famílias que recebiam mais de um até dois salários perfaziam $23 \%$ do total, enquanto contribuíam com $8 \%$ do rendimento total. Somando as duas faixas pode-se perceber que $38 \%$ das famílias brasileiras recebiam dois salários mínimos ou menos, contribuindo com somente $10 \%$ da renda total. No outro extremo o Brasil tinha $3 \%$ das famílias recebendo mais de 20 salários mínimos, contribuindo com $21 \%$ do rendimento total do país.

A United Nations Development Program, em seu Human Development Report 2007/2008 (p. 282), publicou que entre 126 países analisados, o Brasil é o de número 116 em termos de distribuição de renda, ou seja, está entre os países com maior desigualdade no rendimento e consumo. O Apêndice 6 (p. 230) e Apêndice 7 (p. 231) ilustram essa desigualdade.

A situação do Brasil não se altera quando as estatísticas passam a avaliar as pessoas em vez das famílias. No Anexo 6 (p. 367) podem-se analisar as informações das pessoas de 10 anos ou mais de idade e ocupadas na semana de referência em 2006. As pessoas que tinham rendimento até meio salário somavam $12 \%$ da população analisada, mas contribuíam com somente $1 \%$ no rendimento total. A segunda faixa evidencia que $24 \%$ das pessoas recebiam mais de meio até um salário mínimo e contribuíam com 9\% no rendimento total. As pessoas que tinham um rendimento entre um e dois salários mínimos somavam 34\% da população, mas só contribuíam com $21 \%$ no rendimento total. Somando as três faixas pode-se afirmar 
que $70 \%$ da população analisada recebiam até dois salários mínimos e contribuíam com $31 \%$ do rendimento total.

Similar à situação das famílias, somente $1 \%$ das pessoas analisadas recebia mais de 20 salários mínimos, mas contribuía com $11 \%$ no rendimento total. Recuando duas faixas na tabela, percebe-se que $10 \%$ das pessoas tinham um rendimento superior a cinco salários mínimos; contudo, contribuíam com $44 \%$ do rendimento total da nação. Semelhante a condição das famílias, $7 \%$ das pessoas recebem de cinco a 10 salários mínimos e proporcionam a maior fatia de contribuição para o país, 20\%. A participação das pessoas no mercado de trabalho e no rendimento total está ilustrada no Apêndice 5 (p. 229) e no Apêndice 9 (p. 233).

\subsection{Nível da Educação Formal}

A primeira hipótese desta tese é que o investidor não acredita que os rendimentos da previdência social sejam suficientes ao se aposentar. Contudo, pessoas com um nível de educação formal básico podem entender que os recursos da previdência sejam suficientes, mesmo que reduzidos. Assim, este tópico destacará as faixas da população em relação ao nível de educação.

Em 2006, dos 173,018 milhões de habitantes residentes no Brasil com cinco anos ou mais de idade, 54,905 milhões estavam estudando, ou seja, 31,73\% (Tabela 4, p. 36). Levando em consideração que um estudante obtém sua graduação no ensino superior em torno dos 24 anos e a população residente entre essa idade e os cinco anos é de 69,146 milhões de habitantes, pode-se inferir que $79,40 \%$ desta parcela da população estavam estudando naquele ano.

Na média, a proporção de estudantes das regiões urbana e rural são as mesmas da população como um todo, ou seja, $83 \%$ e $17 \%$ respectivamente. Nota-se que até a $6^{a}$ série do ensino fundamental há um equilíbrio entre o número de homens e mulheres na região urbana, com uma ligeira diferença a favor dos homens de no máximo 6\%. A partir dessa série há uma redução da participação masculina, chegando a 43 e 57\% no ensino superior. Na zona rural há equilíbrio até a $7^{\mathrm{a}}$ série, também com uma pequena diferença a favor dos homens. A partir dessa série, as mulheres aumentam sua participação, chegando a $67 \%$ no ensino superior. Ao analisar a participação em função do sexo, deve-se considerar que há uma ligeira diferença no total da população. 
Ao longo dos anos percebe-se uma redução da participação em cada série. Na pré-escolar $9 \%$ da população, na $1^{\mathrm{a}}$ série do ensino fundamental também $9 \%$, depois passa para $8 \%$ até a $5^{\mathrm{a}}$ série, reduz para $7 \%$ na $6^{\mathrm{a}}$ série e depois para $6 \%$ nos dois últimos anos, totalizando aproximadamene $62 \%$. No ensino médio a participação inicial é da ordem de $5 \%$, encerrando os três anos com uma participação total de $18 \%$. No ensino superior, onde os cursos variam de dois a seis anos, a participação é de $11 \%$. Estes percentuais podem ser observados no Gráfico 9 (p. 36).

O número de anos de estudo pode ser observado no Anexo 1 (p. 363), Apêndice 10 (p. 234) e no Apêndice 11 (p. 235). No primeiro anexo há a indicação de quantos anos cada entrevistado estudou. No segundo é indicado o número acumulado de anos de estudo. Caso as pessoas não fossem reprovadas, as linhas pontilhadas de um até oito anos indicam o ensino fundamental, as pessoas que estudaram 11 anos completaram o ensino médio e, partindo do princípio que uma graduação em média dura quatro anos, formaram-se aqueles que estudaram no mínimo 15 anos.

Tabela 4 - População residente com 5 anos ou mais de idade, estudantes e não estudantes - Brasil - 2006

\begin{tabular}{lrr}
\hline \multicolumn{1}{c}{ Total } & $\mathbf{1 7 3 0 1 8}$ & $\mathbf{1 0 0 \%}$ \\
\hline Estudantes & 54905 & $32 \%$ \\
Não estudantes & 118112 & $68 \%$ \\
\hline
\end{tabular}

FONTE: IBGE, 2007c; idem, 2007e, adaptado pelo autor.

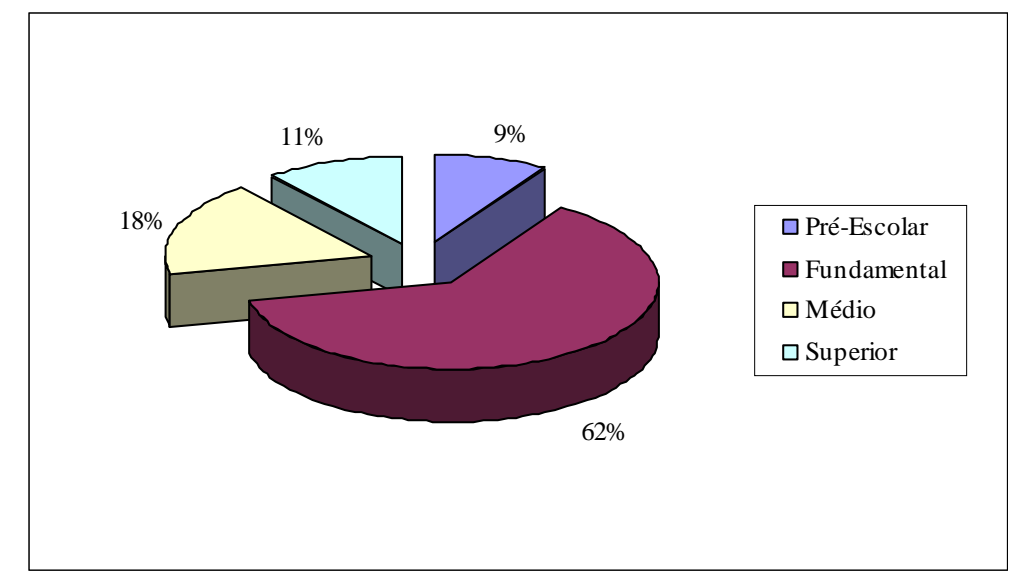

Gráfico 9 - População residente com 5 anos ou mais de idade, segundo o nível que frequentavam Brasil - 2006

FONTE: IBGE, 2007c; idem, 2007e, adaptado pelo autor.

Ainda considerando que não existe reprovação, no total 76\% de pessoas de 10 anos ou mais de idade completaram a $4^{\mathrm{a}}$ série, $45 \%$ completaram o ensino fundamental, $29 \%$ o médio e $6 \%$ se graduaram no ensino superior. É interessante notar que a proporção de pessoas do sexo 
feminino era ligeiramente superior ao do sexo masculino para o mesmo número de anos de estudo; para 15 anos, por exemplo, eram $44 \%$ de homens e $56 \%$ de mulheres. Na zona rural essa diferença era ainda maior; para os mesmos 15 anos havia $40 \%$ de homens e $60 \%$ de mulheres.

\subsection{População, Renda e Educação.}

A partir dos dados pesquisados pode-se avaliar o perfil da população brasileira. Desde 1950 está ocorrendo uma desaceleração no crescimento demográfico; de uma taxa de 34,90\% de 1950 para 1960 o Brasil deve crescer 3,32\% de 2040 para 2050. Com a desaceleração ocorre também mudança na pirâmide etária. Em 1980 a nação possuía 27,7 crianças com menos de cinco anos para cada pessoa com mais de 80. Em 2050 espera-se que sejam 1,1 crianças para cada pessoa com mais de 80 .

É importante notar que em 1980 a população com menos de cinco anos era da ordem de 16,4 milhões e que, para 2050, são esperadas 15,5 milhões. Ou seja, haverá um aumento do topo da pirâmide, onde as pessoas com mais de 80 anos devem passar de 0,6 milhão em 1980 para 13,7 milhões na metade do século XXI. Esse crescimento gera uma preocupação com o bemestar do idoso, pois há a necessidade de uma infraestrutura adequada para essa faixa de idade.

Em 2006 ainda havia uma grande desigualdade na distribuição de renda no Brasil. Em um extremo uma grande parcela das famílias, $15 \%$, contribuía pouco para o rendimento total, $2 \%$. No outro extremo uma pequena parcela das famílias, mais precisamente 3\%, contribuía com uma parcela bastante representativa no rendimento total da nação, 22\%. No mínimo essa desigualdade provoca diferença na qualidade de vida da população como um todo.

Em relação à educação 45\% da população com idade acima de 10 anos estudaram oito anos, $29 \%$ estudaram 11 e somente $6 \% 15$ ou mais. Se não houvesse reprovação, seria possível afirmar que esses percentuais equivalem ao número de concluintes do ensino fundamental, médio e superior.

Pode-se entender que o Brasil espera um aumento representativo da faixa de população com mais idade. Contudo, no início do século XXI, possui desigualdade representativa na distribuição de renda e uma pequena parcela da população conseguindo se graduar em nível superior. 


\section{INSTITUIÇÕES PRIVADAS SEM FINS LUCRATIVOS}

\subsection{Peculiaridades Conceituais e Formais da Legislação Brasileira}

As organizações podem ser divididas juridicamente de várias formas. Inicialmente elas são classificadas como pessoas jurídicas de direito público e de direito privado (BRASIL, 2006b, art. 40). Como o objetivo desta tese é apresentar uma opção de investimento, a atenção estará mais voltada às instituições privadas.

As pessoas jurídicas de direito privado estão divididas em associações, sociedades, fundações, organizações religiosas e partidos políticos (ibidem, art. 44). As associações são caracterizadas pela união de pessoas que se organizam para fins não econômicos, sendo que não há, entre os associados, direitos e obrigações recíprocos. A lei institui que os associados devem ter direitos iguais, mas o estatuto poderá definir categorias com vantagens (ibidem, art. 53). Deve-se notar que toda entidade de direito privado sem fins econômicos goza de imunidade tributária, ou seja, é a renúncia fiscal de tributos por parte do Estado (RESENDE, 2009).

Cabe uma atenção especial para o uso do termo fins não econômicos. Juristas entendem que melhor seria utilizar fins não lucrativos. A idéia básica é não haver intenção de distribuir o resultado de sua atividade. Não se entende, por exemplo, que uma associação se descaracterize por realizar negócios para manter ou aumentar seu patrimônio (PAES, 2006, p. 64; RAFAEL, 1997, p. 51). Do ponto de vista financeiro, entende-se que o objetivo de empresas com finalidade econômica, ou do ponto de vista jurídico, com finalidade lucrativa, é a maximização da riqueza dos acionistas (BRIGHAM; EHRHARDT, 2006, p. 10).

As sociedades são divididas em empresária e simples. A primeira é a sociedade por ações, e a segunda são as cooperativas. Uma outra forma de classificar as sociedades é com base no seu objeto. Quando se trata de atividade própria de empresário, a lei está se referindo à sociedade empresária, que pode ser uma metalúrgica, uma gráfica, em forma de sociedade limitada ou anônima, entre outros exemplos (BRASIL, 2006b, art. 982).

De acordo com o Código Civil (BRASIL, 2006b, art. 966) é considerado empresário aquele que exerce profissionalmente atividade econômica relacionada à produção ou circulação de bens ou serviços. Contudo, não são considerados empresários aqueles que exercem profissão intelectual, de natureza científica, literária ou artística. 
O terceiro formato jurídico são as fundações. Essas podem ser constituídas para fins religiosos, morais, culturais ou de assistência, desde que não tenham finalidade econômica. São criadas por um instituidor através de escritura pública ou testamento. Para a criação é obrigatória a dotação de bens livres, especificando o fim a que se destina. O instituidor pode ou não definir como a fundação será administrada (BRASIL, 2006b, art. 62). Contudo, o Ministério Público sempre velará por essas instituições (ibidem, art. 66).

As sociedades civis, as associações e as fundações constituídas com o objetivo de servir desinteressadamente à coletividade, podem requerer o enquadramento como entidades de Utilidade Pública nas três esferas: Federal, Estadual e Municipal (idem, 2008a, art. $1^{\circ}$ ). Os pedidos e concessões são independentes. Há algumas vantagens na obtenção do título. Uma delas é o reconhecimento oficial de ser uma organização de utilidade pública. Outra vantagem: as doações efetuadas por pessoas jurídicas a entidades com o título Federal podem ser abatidas do imposto de renda até o limite de $2 \%$ sobre o lucro operacional (idem, 2008c, art. 13). As organizações enquadradas como Utilidade Pública podem receber subvenções e auxílio do governo ou de autarquias, possuem imunidade fiscal e isenção da contribuição do empregador para custeio do sistema previdenciário, além de poder realizar sorteios (BOUDENS, 2008, p. 4).

As pessoas jurídicas de direito privado, sem fins lucrativos, também podem requerer o enquadramento como Organizações da Sociedade Civil de Interesse Público-OSCIPs (BRASIL, 2006a, art. 1º). Em março de 1999 o governo brasileiro publicou a lei que normatizou o enquadramento das OSCIPs. Nela podem qualificar-se as pessoas jurídicas de direito privado, sem fins lucrativos, desde que atendam aos requisitos instituídos na lei. Essa considera sem fim lucrativo a pessoa jurídica de direito privado que reinveste os excedentes operacionais totalmente na sua atividade fim, não distribuindo lucros, dividendos, bonificações ou participações entre os sócios, associados, conselheiros, diretores, empregados ou doadores (ibidem, art. $2^{\circ}$ ).

De acordo com a lei não podem ser qualificadas como Organizações da Sociedade Civil de Interesse Público, ainda que não distribuam os excedentes (ibidem, art. $2^{\circ}$ ):

I $\quad$ - as sociedades comerciais;

II - os sindicatos, as associações de classe ou de representação de categoria profissional;

III - as instituições religiosas ou voltadas para a disseminação de credos, cultos, práticas e visões devocionais e confessionais;

IV - as organizações partidárias e assemelhadas, inclusive suas fundações; 
V - as entidades de benefício mútuo destinadas a proporcionar bens ou serviços a um círculo restrito de associados ou sócios;

VI - as entidades e empresas que comercializam planos de saúde e assemelhados;

VII - as instituições hospitalares privadas não gratuitas e suas mantenedoras;

VIII - as escolas privadas dedicadas ao ensino formal não gratuito e suas mantenedoras;

IX - as organizações sociais;

$\mathrm{X}$ - as cooperativas;

XI - as fundações públicas;

XII - as fundações, sociedades civis ou associações de direito privado criadas por órgão público ou por fundações públicas;

XIII - as organizações creditícias que tenham qualquer tipo de vinculação com o sistema financeiro nacional a que se refere o art. 192 da Constituição Federal.

Para ser qualificada como OSCIP, uma pessoa jurídica de direito privado, sem fins lucrativos, deve ter como objetivo social pelos menos uma das finalidades abaixo (BRASIL, 2006a, Art. $\left.3^{\circ}\right)$ :

I - promoção da assistência social;

II - promoção da cultura, defesa e conservação do patrimônio histórico e artístico;

III - promoção gratuita da educação, observando-se a forma complementar de participação das organizações de que trata esta Lei;

IV - promoção gratuita da saúde, observando-se a forma complementar de participação das organizações de que trata esta Lei;

$\mathrm{V}$ - promoção da segurança alimentar e nutricional;

VI - defesa, preservação e conservação do meio ambiente e promoção do desenvolvimento sustentável;

VII - promoção do voluntariado;

VIII - promoção do desenvolvimento econômico e social e combate à pobreza;

IX - experimentação, não lucrativa, de novos modelos sócio-produtivos e de sistemas alternativos de produção, comércio, emprego e crédito;

X - promoção de direitos estabelecidos, construção de novos direitos e assessoria jurídica gratuita de interesse suplementar;

XI - promoção da ética, da paz, da cidadania, dos direitos humanos, da democracia e de outros valores universais;

XII - estudos e pesquisas, desenvolvimento de tecnologias alternativas, produção e divulgação de informações e conhecimentos técnicos e científicos que digam respeito às atividades mencionadas neste artigo.

A lei alerta para o fato de que a dedicação às atividades previstas na lei para as organizações qualificadas como OSCIPs configura-se:

[...] mediante a execução direta de projetos, programas, planos de ações correlatas, por meio da doação de recursos físicos, humanos e financeiros, ou ainda pela prestação de serviços intermediários de apoio a outras organizações sem fins lucrativos e a órgãos do setor público que atuem em áreas afins. (ibidem, art. $3^{\circ}$, parágrafo único).

Em relação às empresas de Utilidade Pública as OSCIPs possuem algumas vantagens. Uma delas é poder receber verbas públicas em função de termos de parceria. Até então os repasses de verbas podiam ser feitos através de convênios, mas com prestação de contas nos moldes do setor público, o que os tornava bastante burocratizado. No caso das parcerias a prestação de conta foi simplificada. Outra vantagem da OSCIP é a possibilidade de remunerar os dirigentes 
(MARTINS, 2008), diferente das organizações enquadradas como utilidade pública (BRASIL, 2008a, art. $1^{\circ}$ ).

Outro formato jurídico possível é o condomínio. Desde que exista uma edificação ou um conjunto delas e suas instalações, com áreas de uso comum dos proprietários ou titulares de direito à aquisição ou ocupação de unidades, constitui-se um condomínio (idem, 2008b, art. $\left.3^{\circ}\right)$. Se este auferir ou pagar rendimentos sujeitos à incidência do imposto de renda na fonte, como receitas financeiras ou funcionários registrados, o condomínio precisa se inscrever no Cadastro Nacional de Pessoa Jurídica (SECRETARIA DA RECEITA FEDERAL, 2008a). Neste tipo de pessoa jurídica as decisões são tomadas em assembléia, sendo os votos normalmente proporcionais às frações ideais de cada condômino (BRASIL, 2006b, art. 1.352).

Também existe a sociedade de propósito específico. Trata-se de uma companhia aberta que deve obedecer a padrões de governança corporativa, constituída com o objetivo de gerir parceiras público-privadas (BRASIL, 2008d, art. $9^{\circ}$ ). Essas parcerias são contratos administrativos de concessão, na modalidade patrocinada ou administrativa. Concessão patrocinada quando a concessão de obras ou serviços públicos envolver tarifa cobrada dos usuários e contraprestação pecuniária do parceiro público ao privado. Concessão administrativa quando houver contrato de prestação de serviços de que a Administração Pública seja a usuária (ibidem, art. $2^{\circ}$ ).

Não é permitida a celebração de contrato de parceria público-privada:

I. cujo valor do contrato seja inferior a $\mathrm{R} \$ 20.000 .000,00$ (vinte milhões de reais);

II. cujo período de prestação do serviço seja inferior a 5 (cinco) anos; ou

III. que tenha como objeto único o fornecimento de mão-de-obra, o fornecimento e instalação de equipamentos ou a execução de obra pública. (ibidem, art. $2^{\circ}, \S 4^{\circ}$ ).

O prazo de vigência dos contratos não pode ser inferior a cinco anos nem superior a 35 anos, incluindo eventual prorrogação. O risco é repartido entre as partes e a contratação sempre será precedida de licitação na modalidade concorrência. (ibidem, art. 10).

$\mathrm{Na}$ busca por um modelo que se adapte juridicamente à instituição proposta nesta tese entende-se que algumas peculiaridades são recomendadas: 1) deve existir conselho consultivo e de administração; 2) deve existir uma diretoria executiva; 3) o período para conselheiros e diretores deve ser limitado; 4) conselhos e diretoria não remunerados; 5) deve haver auditoria interna e externa; 6) a instituição deve contar com benefícios fiscais; 7) não deve ter fim 
lucrativo; 8) deve ser velado pelo Ministério Público; 9) o poder dos proprietários independe do capital investido; 10) cada proprietário possui sua unidade na instituição, no todo ou em parte, na condição de usufrutuário; 11) novos proprietários podem adquirir quotas a qualquer tempo; 12) as quotas retornam para a instituição por doação com o falecimento do $2^{\circ}$ usufrutuário; 13) a instituição proporciona serviços a um círculo restrito de pessoas; 14) pode haver securitização; 15) pode receber doações com ou sem contrapartidas; e 16) pode praticar filantropia.

Das peculiaridades recomendadas, algumas têm ligação com o formato jurídico que a organização poderá assumir. De forma sintetizada, o Quadro 1 (p. 43) apresenta a relação entre as características desejáveis da organização e os formatos jurídicos disponíveis. Nota-se que a sociedade de propósito específico não é apresentada no referido quadro, pois como se trata de uma companhia aberta para as parcerias público-privadas em forma de concessão por prazo determinado, o formato não atende os princípios básicos do modelo apresentado nesta tese.

Pode-se notar no Quadro 1 (p. 43) que a organização não poderia ser uma cooperativa, pois legalmente esse formato jurídico possui fim lucrativo e distribui o resultado entre os sócios. Em relação à instituição ser velada pelo Ministério Público somente as fundações têm essa prerrogativa. Contudo, não é permitido mais de um instituidor nem novos instituidores. Não poderia ser um condomínio, pois nele o poder dos proprietários depende do capital investido. Não pode ser uma OSCIP, pois a organização prestará serviços a um grupo restrito de proprietários. Ou seja, nenhum formato se enquadra perfeitamente nas necessidades jurídicas do modelo proposto. 
Quadro 1 - Peculiaridades administrativas e jurídicas do modelo proposto

\begin{tabular}{|c|c|c|c|c|c|c|}
\hline Peculiaridades & Associação & Condomínio & Cooperativa & Fundação & OSCIP & Utilidade Pública \\
\hline Conselho consultivo & \multirow{3}{*}{\multicolumn{6}{|c|}{ Todos os formatos jurídicos permitem a criação dos conselhos e da diretoria. }} \\
\hline Conselho de administraç̃a & & & & & & \\
\hline Diretoria executiva & & & & & & \\
\hline $\begin{array}{l}\text { Período limitado para conselhos e } \\
\text { diretorias }\end{array}$ & \multicolumn{6}{|c|}{ O período pode ser definido, mas legalmente não existe teto. } \\
\hline Conselhos e diretoria não remunerados & \multicolumn{5}{|c|}{ Não há restrição quanto à remuneração. } & \begin{tabular}{|c|} 
Não pode remunerar \\
os cargos de \\
diretoria, conselhos \\
fiscais, deliberativos \\
ou consultivos. \\
\end{tabular} \\
\hline Auditoria interna e externa & \multicolumn{6}{|c|}{ Todos os formatos jurídicos permitem auditoria interna e externa. } \\
\hline Sem fim lucrativo & \multicolumn{2}{|c|}{$\begin{array}{l}\text { Instituições de assistência social podem ser } \\
\text { instituídas sem fins lucrativos. }\end{array}$} & $\begin{array}{c}\text { Na cooperativa os } \\
\text { resultados devem ser } \\
\text { distribuídos entres os } \\
\text { sócios. Ou seja, } \\
\text { possui fim lucrativo. }\end{array}$ & \multicolumn{3}{|c|}{$\begin{array}{l}\text { Instituições de assistência social podem ser instituídas sem fins } \\
\text { lucrativos. }\end{array}$} \\
\hline Benefícios fiscais & $\begin{array}{l}\text { Instituições de ass } \\
\text { lucrativos, gozam }\end{array}$ & $\begin{array}{l}\text { ia social, sem fins } \\
\text { unidade tributária. }\end{array}$ & $\begin{array}{c}\text { Na cooperativa os } \\
\text { resultados devem ser } \\
\text { distribuídos entres os } \\
\text { sócios. Portanto, não } \\
\text { têm direito a } \\
\text { benefícios fiscais. }\end{array}$ & \multicolumn{3}{|c|}{$\begin{array}{c}\text { Instituições de assistência social, sem fins lucrativos, gozam de } \\
\text { imunidade tributária. }\end{array}$} \\
\hline $\begin{array}{l}\text { O Ministério Público vela pela } \\
\text { instituição }\end{array}$ & \multicolumn{3}{|c|}{ O Ministério Público não vela por estas instituições. } & $\begin{array}{l}\text { O Ministério Público } \\
\text { vela pelas fundações }\end{array}$ & \multicolumn{2}{|c|}{$\begin{array}{l}\text { O Ministério Público não vela por estas } \\
\text { instituições. }\end{array}$} \\
\hline
\end{tabular}

(continua) 
Quadro 1 - Peculiaridades administrativas e jurídicas do modelo proposto

(continuação)

\begin{tabular}{|c|c|c|c|c|c|c|}
\hline Peculiaridades & Associação & Condomínio & Cooperativa & Fundação & OSCIP & Utilidade Pública \\
\hline $\begin{array}{l}\text { O poder do proprietário independe do } \\
\text { capital investido. }\end{array}$ & $\begin{array}{c}\text { Nas associações o } \\
\text { poder do } \\
\text { proprietário } \\
\text { independe do capital } \\
\text { investido. }\end{array}$ & $\begin{array}{c}\text { O poder dos } \\
\text { proprietários } \\
\text { depende do capital } \\
\text { investido. }\end{array}$ & \begin{tabular}{|c|} 
Nas cooperativas o \\
poder do \\
proprietário \\
independe do capital \\
investido. \\
\end{tabular} & \multicolumn{3}{|c|}{ Os estatutos devem definir a forma de decisão da organização. } \\
\hline $\begin{array}{l}\text { Cada proprietário possui sua unidade } \\
\text { na instituição, no todo ou em parte, na } \\
\text { condição de usufrutuário. }\end{array}$ & \multicolumn{3}{|c|}{$\begin{array}{l}\text { Os formatos jurídicos permitem que cada proprietário possua sua } \\
\text { unidade. }\end{array}$} & \begin{tabular}{|c|} 
As fundações são \\
criadas por um \\
instituidor através de \\
escritura pública ou \\
testamento.
\end{tabular} & \multicolumn{2}{|c|}{$\begin{array}{l}\text { Os formatos jurídicos permitem que cada } \\
\text { proprietário possua sua unidade. }\end{array}$} \\
\hline Novos proprietários a qualquer tempo. & \multicolumn{3}{|c|}{$\begin{array}{l}\text { Os formatos jurídicos permitem novos proprietários a qualquer } \\
\text { tempo. }\end{array}$} & \begin{tabular}{|c|} 
Não há previsão em \\
lei para que novos \\
instituidores sejam \\
agregados às \\
fundações \\
\end{tabular} & \multicolumn{2}{|c|}{$\begin{array}{l}\text { Os formatos jurídicos permitem novos } \\
\text { proprietários a qualquer tempo. }\end{array}$} \\
\hline $\begin{array}{l}\text { De propriedade da instituição por } \\
\text { doação com o falecimento do } 2^{\circ}\end{array}$ & \multicolumn{6}{|c|}{ Todos os formatos jurídicos aceitam doações. } \\
\hline $\begin{array}{l}\text { Proporciona serviços a um círculo } \\
\text { restrito de pessoas. }\end{array}$ & \multicolumn{4}{|c|}{ Pode oferecer serviços a um número restrito de pessoas. } & $\begin{array}{c}\text { Para ser uma OSCIP } \\
\text { a organização não } \\
\text { pode prestar serviço } \\
\text { a um círculo restrito } \\
\text { de associados ou } \\
\text { sócios. }\end{array}$ & $\begin{array}{l}\text { Apesar da lei não } \\
\text { proibir, ela sinaliza } \\
\text { como objetivo servir } \\
\text { à coletividade. }\end{array}$ \\
\hline $\begin{array}{l}\text { Pode receber doações com ou sem } \\
\text { contrapartidas; poderá praticar } \\
\text { filantropia. }\end{array}$ & \multicolumn{6}{|c|}{ Sendo enquadrada como instituição de assistência social, todos os formatos podem receber doações e praticar filantropia } \\
\hline
\end{tabular}




\subsection{O que Existe no Brasil a Respeito, suas Finalidades e Respectivos Modelos Gerenciais.}

Em um primeiro momento deve-se analisar qual o enquadramento da atividade econômica do modelo analisado. Atividades de atenção à saúde humana, integradas com assistência social, prestadas em residências coletivas e particulares, são classificadas na seção 87 da Classificação Nacional de Atividades Econômicas - Versão 2.0, publicada pela Comissão Nacional de Classificação (IBGE, 2008b). A seção Q engloba saúde humana e serviços sociais. Essa seção contém as divisões 86 - atividades de atenção à saúde humana, 87 atividades de atenção à saúde humana integradas com assistência social, prestadas em residências coletivas e particulares e a 88 - serviços de assistência social sem alojamento. Essas classificações podem ser observadas com mais detalhes no Anexo 15 (p. 376).

Tabela 5 - Número de empresas segundo seção da classificação de atividades - 2004

\begin{tabular}{lrr}
\hline \multicolumn{1}{c}{ Seção da Classificação de Atividades } & Total & \% \\
\hline Agricultura, pecuária, silvicultura e exploração florestal & 47.661 & $0,8 \%$ \\
Pesca & 2.938 & $0,1 \%$ \\
Indústrias extrativas & 17.421 & $0,3 \%$ \\
Indústrias de transformação & 536.661 & $9,3 \%$ \\
Produção e distribuição de eletricidade, gás e água & 7.497 & $0,1 \%$ \\
Construção & 132.695 & $2,3 \%$ \\
Comércio; reparação de veículos automotores, objetos pessoais e domésticos & 2.775 .574 & $48,1 \%$ \\
Alojamento e alimentação & 369.039 & $6,4 \%$ \\
Transporte, armazenagem e comunicações & 237.584 & $4,1 \%$ \\
Intermediação financeira, seguros, previdência complementar e serviços relacionados & 101.556 & $1,8 \%$ \\
Atividades imobiliárias, aluguéis e serviços prestados às empresas & 784.911 & $13,6 \%$ \\
Administração pública, defesa e seguridade social & 18.667 & $0,3 \%$ \\
Educação & 102.593 & $1,8 \%$ \\
Saúde e serviços sociais & 131.624 & $2,3 \%$ \\
Outros serviços coletivos, sociais e pessoais & 499.420 \\
Organismos internacionais e outras instituições extraterritoriais & $8,7 \%$ \\
BRASIL & 85 & $0,0 \%$ \\
\hline
\end{tabular}

FONTE: IBGE, 2008b, adaptado pelo autor.

Tabela 6 - Número de empresas no setor de saúde e serviços sociais em relação ao total de empresas do Brasil - 2004

\begin{tabular}{lrrr}
\hline \multicolumn{1}{c}{ Saúde e serviços sociais } & \multicolumn{1}{c}{ Total } & \multicolumn{1}{c}{$\%$} & \multicolumn{1}{c}{$\%$} \\
\hline Atividades de atenção a saúde & 115.577 & $2,0 \%$ & $87,8 \%$ \\
Serviços veterinários & 2.624 & $0,0 \%$ & $2,0 \%$ \\
Serviços sociais & 13.423 & $0,2 \%$ & $10,2 \%$ \\
\hline TOTAL & $\mathbf{1 3 1 . 6 2 4}$ & $2,3 \%$ & $\mathbf{1 0 0 , 0 \%}$ \\
\hline TOTAL BRASIL & $\mathbf{5 . 7 6 5 . 9 2 7}$ & $\mathbf{1 0 0 , 0 \%}$ & \\
\hline
\end{tabular}

FONTE: IBGE, 2008b, adaptado pelo autor. 
A partir da classificação normatizada, pode-se verificar nas Tabelas 5 e 6 (p. 45) que em 2004 o Brasil contava com 5.765.927 de empresas em todo o território, sendo que 2,3\% delas, ou seja, 131.624 eram organizações ligadas à saúde e serviços sociais. Das empresas listadas no setor de saúde e serviços sociais, 115.577 estavam ligadas às atividades de atenção à saúde. Essas atividades estão listadas no Anexo 15 (p. 376), mas basicamente tratam-se de atendimento hospitalar e ambulatorial executados por médicos e odontólogos, serviços de complementação diagnóstica, terapêutica e apoio à gestão de saúde.

De acordo com o Anexo 7 (p. 368), em termos nacionais a região sudeste tinha, em 2004, o maior número de empresas, 2.915.694 com 50,57\% do total nacional. Em segundo lugar ficava o sul, com 1.351.187 ou 23,43\%. A região nordeste contava com 888.667 empresas ou $15,41 \%$, em seguida centro-oeste e norte, com 411.260 e 199.119 , representando $7,13 \%$ e $3,45 \%$, respectivamente.

Chama atenção o fato de São Paulo possuir 1.728 .708 empresas ou 29,98\% das empresas do Brasil. Esse número era maior do que nordeste, centro-oeste e norte juntos. Outro aspecto que denota o desequilíbrio era a soma das empresas de São Paulo, Minas Gerais e Rio Grande do Sul; o total superava os $50 \%$ do total de empresas no país.

O Anexo 8 (p. 369) destaca o número de empresas com atividade de atenção à saúde. Nessa área a região nordeste contemplava 53,3\% do total das organizações, ou seja, 61.558 de um universo de 115.577.

A região sul vinha em segundo lugar com 22.004 empresas ou 19,0\% do total, logo em seguida o nordeste com 19.438 ou $16,8 \%$, seguido do centro-oeste e do norte com 8.980, $3.597,7,8 \%$ e $3,1 \%$, respectivamente.

Novamente São Paulo tinha o maior número de organizações, 33.019 empresas, representando 28,6\% do total, seguido do Rio de Janeiro com 13.513 ou 11,7\% e da cidade de Minas Gerais com 12.267 ou $10,6 \%$ do total.

De acordo com o Anexo 9 (p. 370), em 2006 existiam 16.089 entidades de assistência social privadas sem fins lucrativos em todo o Brasil, sendo que mais de 50\% encontravam-se na região sudeste. O estado de São Paulo detinha sozinho, 4.761 empresas, ou 29,6\% do total do país. As regiões sul e sudeste, juntas, totalizavam $74,4 \%$. Das entidades listadas no mesmo 
anexo, em média 16,3\% são organizações da sociedade civil de interesse público, ou seja, 2.629 empresas em todo o país.

Conforme já mencionado, as organizações privadas sem fins lucrativos podem requerer o título de utilidade pública. Esse título pode ser dado pelo município, e/ou estado e/ou união. No Anexo 10 (p. 371) pode-se perceber o número de organizações com esse título.

O título de utilidade pública municipal era o mais requerido. Em média $73,8 \%$ das organizações brasileiras o solicitaram, ou seja, o Brasil possui 11.878 empresas com esse título. Do total, 50,0\% tinham o título junto aos estados e 39,1\% junto à união. Deve-se notar que a soma não era $100 \%$, pois uma organização pode solicitar o título em mais de um poder.

Em relação às características de financiamento das entidades de assistência social privadas sem fins lucrativos, o setor privado era o que disponibiliza a maior quantidade de recursos. $\mathrm{O}$ Anexo 11 (p. 372) indica que 58,4\% das organizações eram mantidas com recursos do setor privado, sendo $31,9 \%$ do setor público, 2,7\% com recursos internacionais e 5,0\% de outras fontes.

O modelo apresentado nesta tese, um Ambiente Residencial Especial, tem como característica a moradia e, portanto, a pernoite. Das 16.089 entidades de assistência social privadas sem fins lucrativos, 23,5\% possuíam alojamentos, ou seja, 3.799 empresas eram dotadas de instalações para serviços que implicavam pernoite ou moradia do usuário. O centro-oeste é a região com o maior número de organizações com alojamento, sendo que o sudeste vem em segundo lugar.

Em relação às fontes de financiamento das entidades com alojamento havia um ligeiro aumento em relação ao total das entidades. Enquanto $58,4 \%$ de todas as entidades eram financiadas com recursos do setor privado, 63,8\% das que possuíam alojamento eram financiadas pelo mesmo setor.

\subsection{Modelos Diferenciados no Brasil e no Mundo}

As instituições que cuidam de pessoas que requerem cuidados especiais podem ser constituídas a partir de vários formatos jurídicos. Uma organização assistencial, privada, pública. Uma instituição pública em geral oferece cuidados a pessoas carentes. Uma organização privada cobra mensalidade a partir dos serviços prestados ao residente. As organizações assistenciais podem ter outras formas de gestão. 
No Brasil existem algumas organizações que merecem destaque. A Associação Húngara é um exemplo de modelo diferenciado. Ela é responsável pelo Lar de Idosos Pedro Balázs, fundado em 1961 e localizado no bairro da Freguesia do Ó, na cidade de São Paulo. Tem o título de Utilidade Pública Estadual, concedido em dezembro de 1985, e qualificada como OSCIP em janeiro de 2006. Essa organização é direcionada aos idosos carentes da comunidade em geral. No final de 2007 a Associação fez uma campanha para aumentar o número de residentes pagantes. Essa campanha tinha como objetivo tornar o Lar auto-sustentável. Ou seja, como a instituição não tem finalidade econômica, ela auxilia as pessoas carentes a partir do excedente operacional de recursos levantados junto aos residentes pagantes. (ASSOCIAÇÃO HÚNGARA, 2007).

A Fundação Peirópolis tem um programa chamado Harambê, ambas instaladas na cidade de Uberaba no estado de Minas Gerais. Com todos os serviços de uma clínica e as facilidades de um clube, foi constituída como uma sociedade civil sem fins lucrativos. É uma fazenda de $280.000 \mathrm{~m}^{2}$ que oferece condições de lazer e fisioterapia. As casas são ligadas a um centro de atendimento. Comprando uma das cem cotas de $\mathrm{R} \$ 50.000$ o usuário tem direito a $1 \%$ do superávit de toda a instituição para abater o condomínio, além de poder construir uma casa em um terreno de $300 \mathrm{~m}^{2}$ na área residencial. Os cotistas têm acesso à contabilidade, aos contratos, ao regimento. O Harambê tem uma proposta de autosustentabilidade, em que as despesas são pagas com a venda de seus próprios programas. Os últimos programas eram de apicultura, cultivo de calêndula e de nim, sendo este último utilizado principalmente para controle de insetos na agricultura e pecuária. Os programas são realizados pelos residentes ou por pessoas contratadas. Como se trata de um programa gerido pela Fundação Peirópolis, a instituição é monitorada pelo Ministério Público e qualificada como Utilidade Pública nos âmbitos Municipal, Estadual e Federal. O Harambê é uma empresa comercial regida pelas leis de mercado, sem conotação política ou religiosa. (FUNDAÇÃO PEIRÓPOLIS, 2008).

Existem alguns programas públicos, mas sempre sujeitos à escassez de recursos. O governo do estado de São Paulo, através da Secretaria Estadual de Assistência e Desenvolvimento Social, SEADS, em parceria com a Companhia de Desenvolvimento Habitacional e Urbano, CDHU, lançou em 2004 o programa Condomínio República da Melhor Idade para atender idosos de baixa renda e suas famílias. Tratava-se de 66 apartamentos de $48 \mathrm{~m}^{2}$ com dois quartos, sala, cozinha e banheiro, adequados às necessidades de pessoas mais idosas. Os candidatos eram formados por pessoas com mais de 60 anos, independentes e com renda 
mensal de um a dois salários mínimos, selecionados por instituições credenciadas e depois sorteados. (SECRETARIA ESTADUAL DE ASSISTÊNCIA E DESENVOLVIMENTO SOCIAL, 2008).

A prefeitura de Uberlândia, no estado de Minas Gerais, tem uma série de programas públicos para atender o idoso. Um deles é um condomínio em construção no Bairro Guarani. São 24 chalés com aproximadamente $35 \mathrm{~m}^{2}$ cada. O condomínio possibilitará um atendimento amplo do idoso, pois além de moradia, existirão áreas comuns para alimentação, ginástica, natação, atividades ocupacionais, lazer e cultura, além de atendimento médico, psicossocial e odontológico. (UBERLÂNDIA, 2008).

O município de Francisco Beltrão, no estado do Paraná, desenvolve o projeto Condomínio do Idoso, que é um local de moradia para o idoso carente, situado ao lado do Centro de Convivência dos Idosos. Com os idosos contemplados nesse projeto será firmado um Termo de Comodato para uso do condomínio, onde o usuário residirá até o momento que for necessário. Cada unidade abrigará dois idosos. A construção do condomínio se dá em parceria com clubes de serviços, empresários, instituições e comunidade em geral. (FRANCISCO BELTRÃO, 2008).

\section{Portugal}

No exterior algumas organizações têm buscado alternativas para cuidar das pessoas que requerem cuidados especiais. Em Portugal existe a Obra Social Padre Miguel, uma instituição particular de solidariedade social na cidade de Bragança. Em 2007 iniciaram-se as obras do lar social e do lar residencial. As obras deverão consumir 2,5 milhões de euros cada e tem conclusão prevista para 2009. O lar social, com capacidade para 60 idosos, será financiado em parte pelo Ministério da Solidariedade Social e o residencial com recursos bancários, da instituição e provenientes da venda de suítes. O lar auto-sustentável terá 26 suítes; caso nem todas sejam vendidas, a Obra Social prevê a possibilidade de alugá-las. Quem adquire, compra apenas o usufruto vitalício; quando os residentes morrerem o espaço volta a ser propriedade da instituição e as suítes poderão ser vendidas novamente. Cada pessoa compra 1/26 de toda a estrutura, que vai funcionar como uma espécie de condomínio. Há dois tipos de unidade, as de 50 metros quadrados custam 82 mil euros, e 59 metros quadrados custam 92 mil euros. (O INFORMATIVO, 2008). 


\section{Estados Unidos}

Desde a década de 50 existem instituições americanas, as Continuing Care Retirement Communities (CCRCs), onde pessoas investiam para não se preocupar com moradia ou gastos imprevistos relacionados à saúde ao se aposentar. Com o aumento da expectativa de vida do americano as CCRCs passaram a ter problemas para cumprir seus contratos. Algumas faliram. Hoje existem variações em relação a esse modelo tradicional (CROWN RESEARCH CORPORATION, 2008).

Atualmente os planos podem incluir atendimentos relacionados à saúde ou somente cuidados básicos, como moradia e refeição (DEPT. OF HEALTH \& HUMAN SERVICE, 2008). São permitidos somente recursos privados, exceto para cuidados médicos e de enfermagem (CONTINUING CARE RETIREMENT COMMUNITIES, 2008).

Condomínio e cooperativas são formatos novos de CCRCs. Neles a taxa de ingresso pode ser dada ou vendida. A participação no patrimônio pode ser transmissível, despesas são dedutíveis para efeito de imposto e o investidor pode continuar aumentando sua participação na instituição ao longo do tempo com aporte de capital. Podem ser cobradas taxas mensais. Quando o residente deixa o condomínio sua participação é vendida; se houver lucro na operação a diferença lhe é repassada (CROWN RESEARCH CORPORATION, 2008).

Outro modelo é a locação de CCRCs. Ele é bastante procurado, pois não existe a taxa de ingresso. Houve um crescimento representativo desse conceito em função do oferecimento de uma ampla gama de políticas de saúde a longo prazo. No contrato a taxa de manutenção é definida, sendo que o locatário pode limitar esse valor através de contratação de seguro. A Lifecare Without Walls é uma modalidade das CCRCs onde a pessoa compra um imóvel e está automaticamente ligada a um programa de serviços que podem incluir serviços de saúde, seguro saúde de longo prazo, refeições, manutenção ou atividades como academia e recreação (ibidem).

\section{Japão}

No Japão a clínica de idosos Meisei Medical vendeu, em 2003, títulos de dívida no valor de dois milhões de dólares para atualização das instalações da clínica. A Meisei ofereceu $2 \%$ de juros ao ano, ou seja, $1 \%$ mais do que as taxas de juro de longo prazo dos bancos japoneses. 
Os recursos foram utilizados para recuperar um velho edifício no centro de Tóquio e transformá-lo em uma luxuosa moradia para idosos (GOLIATH, 2008).

\section{França}

Apesar do francês tradicionalmente cuidar do idoso na unidade da família, em 2006 existiam cerca de 5000 organizações especializadas nesse serviço (résidence pour retraités / seniors). Uma das modalidades disponíveis são as casas de saúde ou repouso, que podem ser públicas ou privadas. Também existem os apartamentos protegidos (sheltered apartments) destinados à população de baixa renda, divididos em blocos somente para idosos e mistos; são destinados às pessoas que desejam ou precisam de pequenos serviços, tais como lavanderia, restaurante, etc. Existe o apartamento com serviços, que pode ser comprado ou alugado sem mobília. (HAMPSHIRE, 2008).

Uma modalidade ainda pouco comum é o condomínio de aposentados, conhecido na França como aldeia ou vila; este modelo oferece segurança, serviços diversos como piscina, biblioteca, salas de exercício, música, além de serviços essenciais, como limpeza e restaurante, entre outros. Casas com um ou dois quartos podem ser alugadas por valores mensais que variam de $€ 300$ a $€ 600$ ou compradas a um custo de $€ 70.000$ a $€ 120.000$. A variação depende da modalidade do contrato: compra definitiva, vitalícia, locação ou arrendamento. Além do imóvel há a taxa de serviço mensal, que pode variar de $€ 150$ a $€ 500$. Dependendo da modalidade do contrato, a taxa pode incluir certo número de semanas de cuidados de enfermagem por ano (ibidem).

\section{Inglaterra}

Dados de 2008 indicam que a Inglaterra possui 600.000 propriedades para idosos, compradas ou alugadas, distribuídas em 25.000 organizações (HOUSINGCARE, 2008a). A habitação protegida (sheltered housing) é normalmente chamada de habitação de aposentados (retirement housing). Trata-se de uma estrutura que possui administrador geral e sistema de alarme. Muitas vezes existem jardins, lavanderias, mas restaurantes são pouco comuns. Não existe idade mínima, mas as unidades normalmente são ocupadas por pessoas com 50 anos ou mais. Em geral os moradores buscam vida autônoma, mas com garantia de atendimento em caso de emergência (idem, 2008b). 
Os residenciais com cuidados extras (extra care housing) oferecem mais serviços que os residenciais para aposentados e menos que os lares para idosos. Esta modalidade pode ser comprada ou alugada. Além dos serviços oferecidos nos residenciais para aposentados, podem ser encontrados restaurantes ou salas de jantar, sala de ginástica ou de computador, entre outros. Nesse modelo, além do administrador geral, existem funcionários (HOUSINGCARE, 2008b).

Os lares para idosos podem ser privados, de organizações sem fins lucrativos ou públicos. Todos os cuidados hospitalares na Inglaterra são registrados e fiscalizados pela Commission for Social Care Inspection, na Escócia pela Scottish Commission for the Regulation of Care e no País de Gales pela Care Standards Inspectorate for Wales. Essas instituições podem disponibilizar cuidados pessoais ou de enfermagem, variando em tamanho e em serviços oferecidos (ibidem).

\section{Espanha}

De acordo com o Instituto Nacional de Estadística (2008a) da Espanha, em julho de 2008 o país contava com 45,59 milhões de habitantes, dos quais 7,58 milhões tinham 65 anos ou mais idade. Essa faixa etária representava 16,63\% do total. Segundo a United Nations Population Division (2008), em 2050 a Espanha será o país mais velho do globo, com 53,15 milhões de habitantes, sendo 16,39 milhões com 65 anos ou mais de idade, ou seja, uma representatividade de 30,84\% (INSTITUTO NACIONAL DE ESTADÍSTICA, 2008b).

Segundo o Instituto de Mayores y Servicios Sociales (2008, p. 368), em janeiro de 2006 a Espanha tinha 7.477.761 pessoas com 65 anos ou mais. Na mesma data eram oferecidos 298.870 leitos em 6.052 organizações públicas e privadas, ou seja, uma cobertura de $4 \%$ da população. Do total, $83 \%$ das instituições (4.993) eram privadas e geriam $76 \%$ da oferta de lugares (225.882). Os 17\% do setor público (1.509) eram responsáveis pelos $24 \%$ da oferta de leitos (72.988). A maioria das organizações (84\%) tinha menos de 100 residentes; 58\% menos de 50 residentes e a diferença, 26\%, entre 50 e 100 residentes (ibidem, p. 371). 


\section{FORMATOS INSTITUCIONAIS ALTERNATIVOS}

\subsection{Pressupostos Fundamentais com Relação aos Objetivos e ao Perfil dos Investidores}

Uma pessoa nasce dependente, normalmente torna-se independente na idade adulta e pode voltar a ser dependente a partir de certa idade. Uma parte, no entanto, pode nascer e permanecer dependente até o final da vida. Por problemas de saúde ou por acidente um adulto pode se tornar dependente antes do tempo que ele previa. Enquanto idosa, uma pessoa pode ser independente até o final da vida, tornar-se dependente ou ter perdido sua independência antes de ser um idoso. Essa linha de pensamento pode ser representada na Ilustração 2 (p. 54).

A partir do exposto fica uma indagação: o que acontecerá com uma pessoa dependente quando os responsáveis morrerem ou também se tornarem dependentes? Em geral essa pessoa passa a viver com um familiar próximo ou é encaminhado a uma instituição de longa permanência.

Em se tratando de uma criança ela pode residir com a família ou com familiares; ela pode residir em um ambiente residencial especial em função da vontade da família ou mesmo por não ter família.

Um adulto independente, tendo ou não família, pode optar em morar em um tipo de ambiente residencial, mesmo estando trabalhando. Um adulto dependente pode residir com a família ou mesmo sozinho, mas com acompanhamento de enfermeiros. Caso não tenha família ou não queira depender dos familiares ou mesmo por vontade da família, essa pessoa pode morar em um ambiente residencial especial.

Um idoso independente pode optar em morar em um tipo de ambiente residencial com opções que lhe garanta qualidade de vida; não querer a proximidade com os familiares é outro motivo que leva um idoso a morar distante dos parentes. Não ter família seria um terceiro motivo que levaria um idoso a residir em um ambiente especial.

Um idoso dependente pode residir com a família; se não tiver família ou por vontade da mesma ou por não querer causar preocupações aos familiares, um idoso também pode vir a morar em um ambiente residencial especial. 


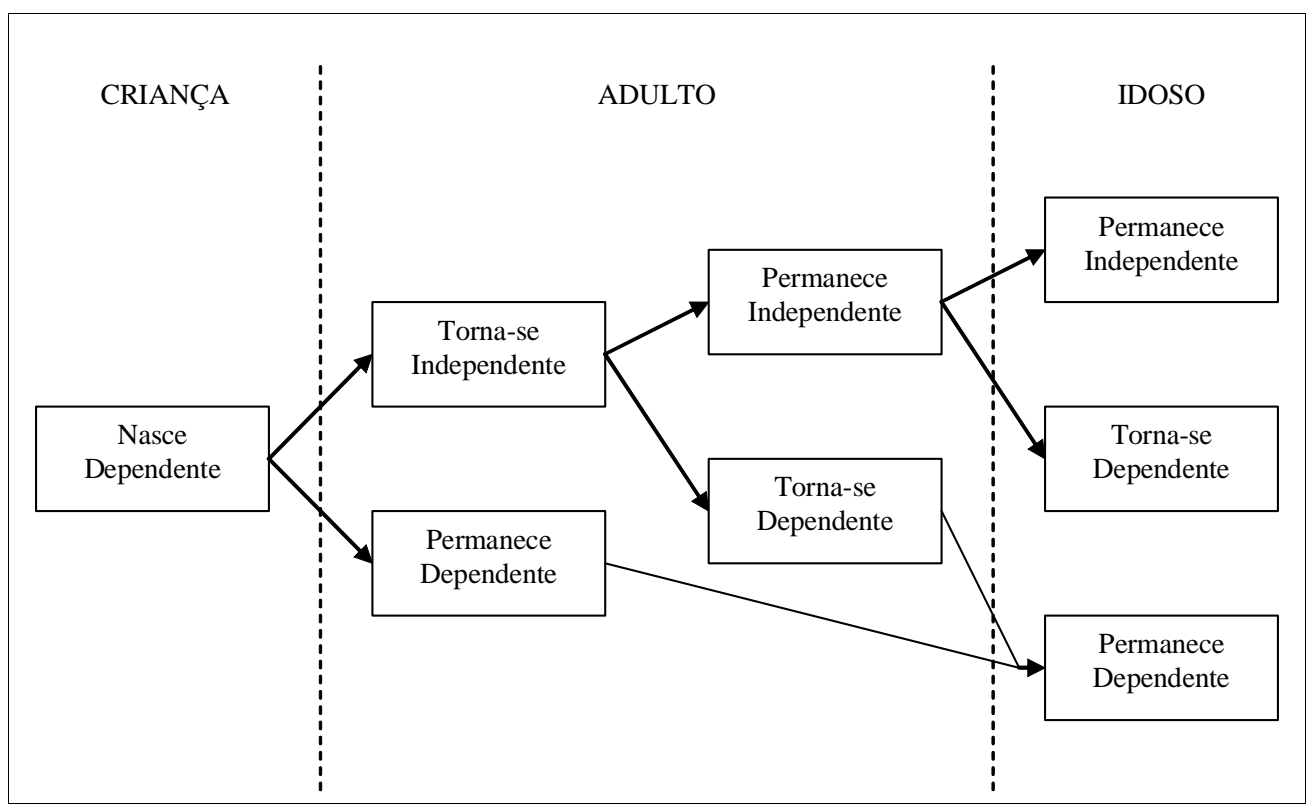

Ilustração 2 - Nível de dependência em crianças, adultos e idosos

Em relação ao número de idosos e ao número de pessoas com alto grau de dependência podese observar a Tabela 7 (p. 54). No ano $2000,8,56 \%$ da população brasileira tinha idade igual ou superior a 60 anos. Do total da população brasileira, 5,77 milhões de pessoas tinham grau alto de dependência, sendo que desse total 4,08 milhões tinham 60 anos ou mais de idade. $\mathrm{Na}$ Tabela 8 (p. 54) pode-se observar a estimativa de crescimento da população. Enquanto que em números gerais a população deve crescer 52,92\% em um período de 50 anos, as pessoas com 60 anos ou mais deverão crescer 340,55\%. Não há estimativas para o crescimento do número de dependentes, mas é perceptível o crescimento do número de idosos entre os anos 2000 e 2050.

Tabela 7 - População total, com 60 anos ou mais e dependente no ano 2000

\begin{tabular}{|c|c|c|c|c|c|c|c|c|}
\hline \multirow{3}{*}{ População } & \multirow{2}{*}{\multicolumn{2}{|c|}{ População residente }} & \multicolumn{6}{|c|}{ Dependentes } \\
\hline & & & \multicolumn{2}{|c|}{$\begin{array}{l}\text { Deficiente mental } \\
\text { permanente }\end{array}$} & \multicolumn{2}{|c|}{$\begin{array}{c}\text { Tetraplegia, } \\
\text { paraplegia ou } \\
\text { hemiplegia } \\
\text { permanente }\end{array}$} & \multicolumn{2}{|l|}{ Total } \\
\hline & $\mathbf{N}^{\circ}$ Pessoas & $\%$ & $N^{\circ}$ Pessoas & $\%$ & $\mathrm{~N}^{0}$ Pessoas & $\%$ & $\mathbf{N}^{\circ}$ Pessoas & $\%$ \\
\hline Total & 169.872 .856 & 100 & 2.844 .937 & 1,67 & 937.463 & 0,55 & 3.782 .400 & 2,23 \\
\hline 60 anos ou mais & 14.538 .988 & 8,56 & 573.312 & 3,94 & 353.978 & 2,43 & 927.290 & 6,38 \\
\hline
\end{tabular}

FONTE: IBGE, 2007a, adaptado pelo autor.

Tabela 8 - População total e com 60 anos ou mais, projetados para 0 ano 2050

\begin{tabular}{lccccc}
\hline & $\mathbf{2 0 0 0}$ & $\boldsymbol{\%}$ & $\mathbf{2 0 5 0}$ & $\boldsymbol{\%}$ & Var \% \\
\hline Total & 169.872 .856 & 100 & 259.769 .964 & 100 & 52,92 \\
60 anos ou mais & 14.538 .988 & 8,56 & 64.050 .979 & 24,66 & 340,55 \\
\hline
\end{tabular}

FONTE: IBGE, 2007c, adaptado pelo autor. 
Segunda a Anvisa (2007, 3.2-3.3), Agência Nacional de Vigilância Sanitária, um indivíduo idoso é dependente quando requer auxílio de pessoas ou de equipamento de auto-ajuda para realizar as atividades da vida diária. Esse equipamento é considerado qualquer utensílio utilizado para compensar ou potencializar habilidades funcionais, tais como bengala, andador, óculos, aparelho auditivo e cadeira de rodas, entre outros.

Há vários motivos que podem levar uma pessoa a residir em um ambiente residencial especial. Mesmo com saúde e trabalhando ela pode optar, em uma determinada fase da vida, em residir em uma instituição de longa permanência. Há casos onde pessoas, na busca de tranquilidade para desenvolver projetos ou escrever livros, residem durante semanas nessas instituições. Nessa condição ela pode trocar de organização caso o atendimento não esteja de acordo com suas expectativas.

Por motivo de saúde ou com o passar dos anos uma pessoa pode ficar dependente; neste caso ela pode morar com parentes ou residir em uma instituição especial. Não dispondo de recursos próprios nem da ajuda dos familiares uma pessoa pode ser obrigada a residir em instituições públicas; os recursos dessas organizações normalmente são exíguos, gerando grande insegurança ao usufrutuário. Se depender da ajuda de um familiar para residir ou para financiar sua moradia, haverá o provável sentimento de dependência e insegurança, pois este provedor pode vir a faltar primeiro.

Ter renda suficiente para custear uma instituição de longa permanência também não é sinônimo de segurança (PASINATO; CAMARANO; MACHADO, 2006, p. 8-11). Apesar da diversidade de cuidados, serviços e mensalidades que as instituições particulares oferecem, proprietários normalmente têm como interesse a maximização da riqueza (BODIE; MERTON, 2003, p. 40) ou, sob outra ótica, a maximização do valor da organização (BREALEY; MYERS; MARCUS, 2002, p. 19). Esses objetivos podem ser alcançados através de menores desembolsos e maiores receitas frente ao mínimo de investimento, o que pode comprometer a qualidade dos serviços prestados pela instituição. Contudo, deve haver uma preocupação social com as organizações (BRIGHAM; EHRHARDT, 2006, p. 10-18).

Se os proprietários forem potenciais usuários, haverá uma preocupação com os serviços oferecidos pela instituição a qualquer tempo. O investidor de hoje zelará pelo bem estar do residente atual partindo do princípio que no futuro ele será o residente e outros investidores cuidarão do seu bem estar. 
Com a identificação de uma estrutura administrativa adequada esse tipo de organização pode proporcionar um nível alto de segurança para o investidor que será um futuro usuário. Essa segurança deve ser obtida através de uma sociedade à prova de desmandos que proporcione qualidade de vida, satisfação pessoal e conforto espiritual. Entende-se que tanto o investidor quanto um familiar indicado por ele possa utilizar os serviços da organização.

\subsection{Estrutura Física e Operacional}

Sendo uma organização que provavelmente atenda pessoas com mais de 60 anos de idade, ao analisar um investimento uma pessoa deve ficar atenta à estrutura física e aos recursos humanos oferecidos ou disponíveis na instituição. A regulamentação básica é estabelecida pela Anvisa, Agência Nacional de Vigilância Sanitária, e tem como objetivo proporcionar segurança e qualidade de vida aos usufrutuários.

Em relação aos recursos humanos a Anvisa define que deve existir um responsável técnico com carga horária mínima por semana e um determinado número de cuidadores em função do número de residentes e em função do nível de dependência dos mesmos. Para as atividades de lazer, alimentação e lavanderia também há um número mínimo de funcionários por número de residentes; para os serviços de limpeza a quantidade de pessoas é definida em função do número de metros quadrados da instituição (ANVISA, 2007, 3.1 e 4.6).

Em relação à infraestrutura física a instituição deve atender as exigências legais, desde dimensões de corredores, rampas, escadas, portas, janelas, banheiros, até número de pessoas por dormitório.

Ou seja, o investidor que busca segurança para um parente ou para si encontra na legislação brasileira uma série de exigências em relação à estrutura física e aos recursos humanos que viabilizam qualidade de vida com amparo legal.

\subsection{Formato Jurídico-Institucional e suas Vantagens}

Esta pesquisa propõe uma opção de investimento em ambientes residenciais especiais onde a pessoa aplica seus recursos em uma organização que proporcionará qualidade de vida através da utilização das instalações da entidade pelo próprio investidor ou por um familiar indicado por ele. Cabe, nesse modelo, uma análise em relação aos formatos jurídicos existentes. 
Algumas características de formatos jurídicos aderentes ao modelo proposto são apresentadas no Quadro 2 (p. 58). Os formatos apresentados são as OSCIPs, Organizações de Sociedade Civil de Interesse Público, Associações, Fundações, Cooperativas e Condomínios. As características selecionadas foram quem pode criar, quem mantém, pré-requisitos para existir, finalidades declaradas, estrutura de governança, vantagens e restrições em relação ao modelo proposto.

Um tipo de instituição sem fins lucrativos é a OSCIP - Organização de Sociedade Civil de Interesse Público. A Lei 9.790 (BRASIL, 2006a) qualifica as OSCIPs como pessoas jurídicas de direito privado sem fins lucrativos, que proporcionem bens ou serviços a um número irrestrito de pessoas. Ou seja, o tipo de organização proposto nesta tese não poderia se enquadrar como uma OSCIP, pois os beneficiários seriam somente os investidores.

Outra restrição é que as OSCIPs só podem atuar por meio de doações de recursos físicos, humanos e financeiros, ou ainda pela prestação de serviços intermediários de apoio a outras organizações sem fins lucrativos e a órgãos do governo que atuem em áreas afins, ou seja, não seria viável investir na organização para uso posterior.

As associações não são pessoas jurídicas possíveis, pois o modelo proposto tem finalidade econômica e existem direitos e obrigações recíprocos entre os participantes (BRASIL, 2006b, Art. 53), condições que não podem existir nesse formato.

Quanto às fundações o criador deve fazer uma dotação de bens livres e definir o objetivo da organização. Contudo, no modelo aqui apresentado, pode haver o investimento de outras pessoas. Uma virtude desse formato jurídico-institucional é que o Ministério Público vela pelas fundações (BRASIL, 2006b, Art. 66). 
Quadro 2 - Tipos alternativos de pessoas jurídicas existentes na sociedade brasileira

\begin{tabular}{|c|c|c|c|c|c|c|c|}
\hline \multirow{2}{*}{ Formato } & \multirow{2}{*}{ Quem pode criar } & \multirow{2}{*}{ Quem mantém } & \multirow{2}{*}{$\begin{array}{l}\text { Pré-requisitos para } \\
\text { existir }\end{array}$} & \multirow{2}{*}{$\begin{array}{l}\text { Finalidades } \\
\text { declaradas }\end{array}$} & \multirow{2}{*}{$\begin{array}{l}\text { Estrutura de } \\
\text { governança }\end{array}$} & \multicolumn{2}{|c|}{ Em relação ao modelo proposto } \\
\hline & & & & & & Vantagens & Restrições \\
\hline $\begin{array}{l}\text { OSCIP - } \\
\text { Organização de } \\
\text { Sociedade Civil } \\
\text { de Interesse } \\
\text { Público }\end{array}$ & $\begin{array}{l}\text { Pessoa física ou } \\
\text { jurídica. }\end{array}$ & $\begin{array}{l}\text { É mantida por doações } \\
\text { ou pela prestação de } \\
\text { serviços intermediários } \\
\text { de apoio a outras } \\
\text { organizações sem fins } \\
\text { lucrativos e a órgãos do } \\
\text { setor público que } \\
\text { atuem em áreas afins. }\end{array}$ & $\begin{array}{l}\text { Ser pessoa jurídica de } \\
\text { direito privado sem } \\
\text { fim lucrativo. }\end{array}$ & $\begin{array}{l}\text { Promoção da } \\
\text { assistência } \\
\text { social. }\end{array}$ & $\begin{array}{l}\text { Regida por } \\
\text { estatutos; possui } \\
\text { conselho fiscal } \\
\text { ou órgão } \\
\text { equivalente. }\end{array}$ & Imunidade tributária. & $\begin{array}{l}\text { Não pode ser uma } \\
\text { entidade de benefício } \\
\text { mútuo destinada a } \\
\text { proporcionar bens ou } \\
\text { serviços a um círculo } \\
\text { restrito de associados } \\
\text { ou sócios. }\end{array}$ \\
\hline Associações & $\begin{array}{l}\text { União de } \\
\text { pessoas físicas } \\
\text { ou jurídicas. }\end{array}$ & $\begin{array}{l}\text { O estatuto define as } \\
\text { fontes de recursos para } \\
\text { sua manutenção. }\end{array}$ & $\begin{array}{l}\text { Constitui-se pela } \\
\text { união de pessoas que } \\
\text { se organizam para } \\
\text { fins não econômicos. }\end{array}$ & $\begin{array}{l}\text { O estatuto } \\
\text { define as } \\
\text { finalidades da } \\
\text { associação. }\end{array}$ & $\begin{array}{l}\text { Regida por } \\
\text { estatuto; } \\
\text { deliberações } \\
\text { através de } \\
\text { assembléias. }\end{array}$ & Imunidade tributária. & $\begin{array}{l}\text { Não há, entre os } \\
\text { associados, direitos e } \\
\text { obrigações recíprocos; } \\
\text { não tem finalidade } \\
\text { econômica. }\end{array}$ \\
\hline Fundações & Um instituidor. & $\begin{array}{l}\text { Os bens do instituidor e } \\
\text { a atividade econômica. }\end{array}$ & $\begin{array}{l}\text { O instituidor fará } \\
\text { dotação especial de } \\
\text { bens livres, } \\
\text { especificando o fim a } \\
\text { que se destina. }\end{array}$ & $\begin{array}{l}\text { Fins religiosos, } \\
\text { morais, culturais } \\
\text { ou de } \\
\text { assistência. }\end{array}$ & $\begin{array}{l}\text { Regida por } \\
\text { estatuto. }\end{array}$ & $\begin{array}{l}\text { O Ministério Público } \\
\text { vela pelas fundações } \\
\text { e goza de imunidade } \\
\text { tributária. }\end{array}$ & $\begin{array}{l}\text { Só o instituidor faz a } \\
\text { dotação. }\end{array}$ \\
\hline Cooperativa & $\begin{array}{l}\text { Concurso de } \\
\text { sócios. }\end{array}$ & $\begin{array}{l}\text { A atividade econômica } \\
\text { da organização. }\end{array}$ & Vários sócios. & $\begin{array}{l}\text { De acordo com } \\
\text { o contrato } \\
\text { social. }\end{array}$ & $\begin{array}{l}\text { Direito de cada } \\
\text { sócio a um só } \\
\text { voto nas } \\
\text { deliberações. }\end{array}$ & $\begin{array}{l}\text { O poder dos sócios } \\
\text { independe do capital } \\
\text { investido na } \\
\text { organização. }\end{array}$ & $\begin{array}{l}\text { Intransferibilidade das } \\
\text { quotas do capital a } \\
\text { terceiros estranhos à } \\
\text { sociedade, ainda que } \\
\text { por herança. }\end{array}$ \\
\hline Condomínio & $\begin{array}{l}\text { União de } \\
\text { pessoas físicas } \\
\text { ou jurídicas. }\end{array}$ & Os condôminos. & $\begin{array}{l}\text { Deliberação da } \\
\text { maioria dos } \\
\text { condôminos. }\end{array}$ & $\begin{array}{l}\text { Administrar o } \\
\text { condomìnio. }\end{array}$ & $\begin{array}{l}\text { Deliberações } \\
\text { através de } \\
\text { assembléias. }\end{array}$ & $\begin{array}{l}\text { Cada condômino } \\
\text { possui seu imóvel. }\end{array}$ & $\begin{array}{l}\text { Interesse meramente } \\
\text { privado e perfil } \\
\text { proprietário }\end{array}$ \\
\hline
\end{tabular}


Como empresa do setor privado uma opção é a cooperativa. Não existe limitação de número máximo de sócios, o poder dos sócios independe da quota que possui no capital social e a responsabilidade dos sócios pode ser limitada ou ilimitada. Contudo, as quotas de capital não podem ser transferidas a terceiros estranhos à sociedade, ainda que por herança.

Outra opção jurídica é o condomínio, onde as pessoas comprariam imóveis num determinado local e, além de zelador, pessoal de portaria, segurança, limpeza, existiriam profissionais ligados à saúde, como enfermeiros, médicos, fisioterapeutas, além do pessoal de cozinha. $\mathrm{O}$ proprietário teria as despesas do seu imóvel e a taxa de condomínio.

É interessante notar que em cada tipo de organização pode haver um ponto de interesse para a formação de uma organização com as características listadas nesta tese: por promover a assistência social, poderia ser uma OSCIP; por ser de interesse público, poderia ser assistida pelo Estado. No entanto, não existe nenhum formato onde esse tipo de organização poderia se enquadrar a não ser como uma empresa do setor privado.

\subsection{Estrutura Organizacional e os Aspectos de Governança Corporativa}

Como foi relatado no tópico anterior, deve-se procurar independência dos cuidados do Estado. Em função das características da legislação atual, em que não se consegue, por exemplo, supervisão por parte do Ministério Público, uma opção seria propor estrutura organizacional e práticas de Governança Corporativa que pudessem assegurar desenvolvimento e sustentabilidade financeira e gerencial ao longo do tempo para o modelo apresentado nesta tese.

Sob o aspecto estrutura organizacional, deve-se levar em consideração que podem residir pessoas com mais de 60 anos na instituição. Nesse caso o Ministério da Saúde, através da Portaria $n^{\circ} 810$ que trata das normas para funcionamento de organizações destinadas ao atendimento de idosos, exige uma estrutura mínima a ser seguida. Do ponto de vista recursos humanos ela estabelece, em seu artigo 4.1, que:

\footnotetext{
As instituições para idosos em geral devem contar com:

- assistência médica;

- assistência odontológica;

- assistência de enfermagem;

- assistência nutricional;

- assistência psicológica;

- assistência farmacêutica;

- atividades de lazer;
} 
- atividades de reabilitação (fisioterapia, terapia ocupacional e fonoaudiologia);

- serviço social;

- apoio jurídico e administrativo;

- serviços gerais. (MINISTÉRIO DA SAÚDE, 2007).

A Ilustração 3 (p. 61) apresenta um exemplo de estrutura organizacional que poderia ser utilizada no modelo proposto.

Contudo, mais do que uma estrutura organizacional, que por si só não garante o perfeito funcionamento da instituição, é de fundamental importância a estrutura de governança de uma entidade como a que se pretende propor. $O$ equilíbrio e a sustentabilidade financeira pressupõem, antes de tudo, a presença de uma gestão tecnicamente competente, além de social e eticamente responsável.

Deve-se lembrar que existem conflitos de interesses entre os gestores e os proprietários (JENSEN; MECKLING, 1976, p. 12); para mitigar esse desacordo as organizações precisam ser administradas através de mecanismos adequados (ibidem, p. 26). No modelo proposto os proprietários querem que a instituição cuide bem dos usufrutuários.

Um dos principais mecanismos utilizados para buscar os melhores resultados administrativos é o Conselho de Administração (SILVEIRA; BARROS; FAMÁ, 2003, p. 3). Ele representa os interesses dos proprietários e deve zelar pela segurança e favorável evolução dos valores patrimoniais da instituição, transformando os desejos dos mesmos em desempenho da empresa. (CARVER; OLIVER, 2002, p. 32).

A instituição, além do Conselho de Administração, deve adotar Práticas de Governança Corporativa, pois os proprietários "vêem na adoção [dessas práticas] um início de garantia de probidade, transparência e respeito às leis [...]" (LODI, 2000, p. 17). Deve-se notar que a organização precisa ser bem administrada, pois o investidor ou um familiar usufruirá, em um futuro mais ou menos próximo, dos serviços da instituição.

Os administradores da instituição precisam de recursos financeiros para pagar custos e despesas e fazer novos investimentos. Como as entradas de caixa por definição são limitadas, as saídas devem ser minimizadas. O modelo precisa buscar o equilíbrio dos ingressos e desembolsos financeiros de tal forma que possa oferecer qualidade de vida para os residentes e a perpetuidade da organização. 
O estatuto social a ser proposto deverá ter a necessária sustentação jurídica sobre todos seus aspectos; será o mais abrangente possível, mas deverá conter a flexibilidade necessária para não engessar a diretoria executiva. Daí a grande quantidade de órgãos e colegiados preliminarmente idealizados.

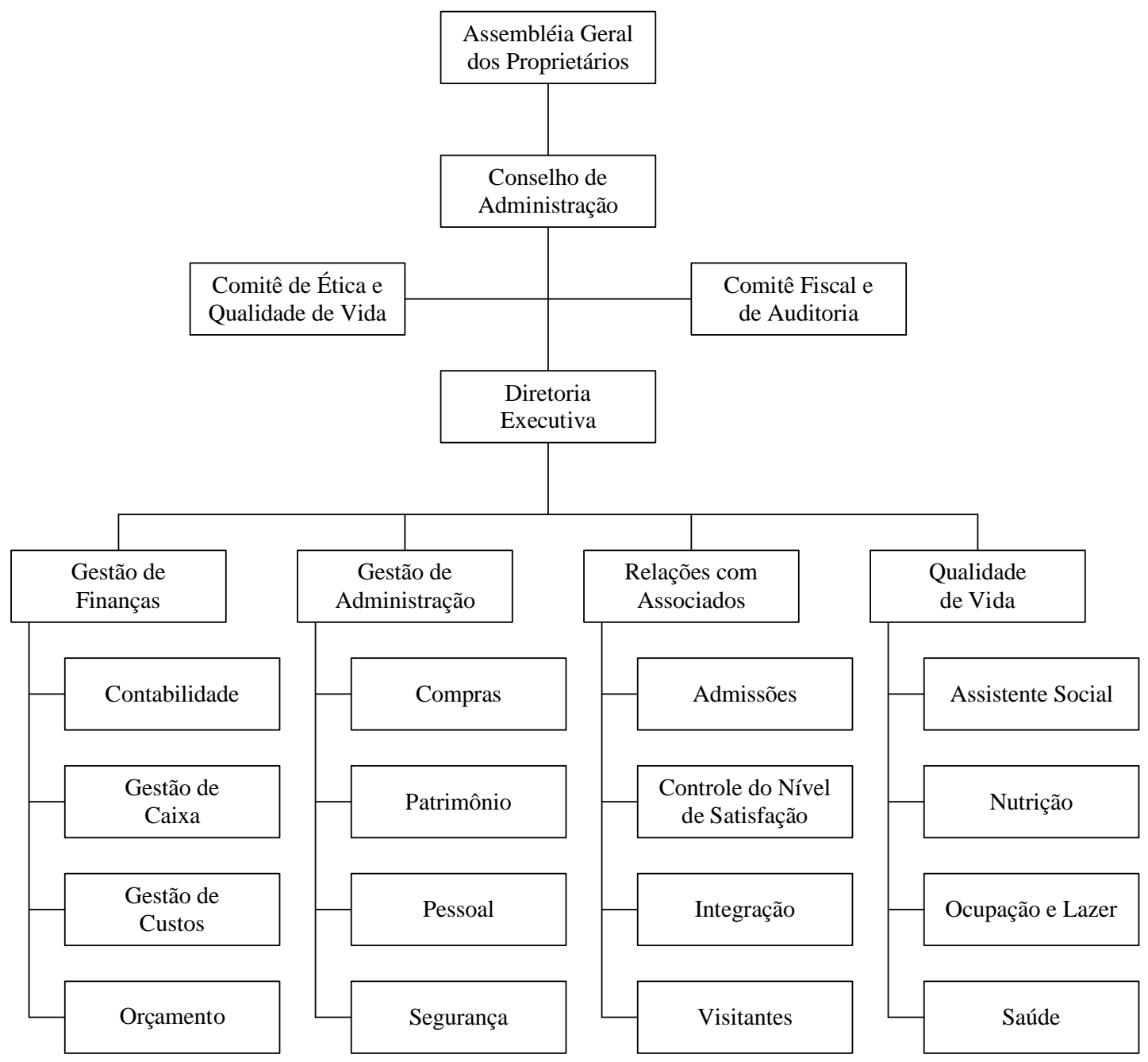

Ilustração 3 - Exemplo de estrutura organizacional para uma instituição de investidores / usufrutuários

Assembléia Geral: há que ser prevista a periodicidade das Assembléias ordinárias e as circunstâncias para convocação de Assembléias Extraordinárias, bem como os assuntos a serem submetidos à deliberação em cada uma delas.

Conselho de Administração: com função de cuidar das grandes diretrizes e da direção geral a seguir, será prevista a composição com membros internos (proprietários) e externos (da 
sociedade comprometida com o assunto), forma de eleição, mandato, renovação e suas reuniões ordinárias e extraordinárias.

Comitês Temáticos: com funções mais direcionadas aos respectivos temas, serão previstos composição, missão específica, forma de designação, mandato e renovação.

Diretoria Executiva: pressupõe-se uma gestão profissionalizada com atribuições muito bem definidas nos estatutos sociais, bem como atributos indispensáveis, forma de eleição, mandato e renovação de todo o colegiado. 


\section{SUSTENTABILIDADE ECONÔMICO-FINANCEIRA}

\subsection{Pressupostos para sustentabilidade e para seu desenvolvimento}

Em relação aos objetivos secundários desta tese, dois se destacam em relação aos aspectos econômico-financeiros. O primeiro é a definição de um modelo financeiro flexível com diferentes tempos de carência, quantidade de quotas, valor do investimento e de contribuições. O segundo objetivo secundário é a busca de um formato que priorize qualidade de vida para os residentes e a perpetuidade da organização.

O detentor do direito de uso ou de transferência, não necessariamente o usufrutuário, é denominado proprietário. O modelo propõe uma organização formada por vários proprietários, podendo haver participação diferenciada entre eles e ingresso antes ou depois do início das atividades. A participação diferenciada é traduzida em número de quotas.

Um determinado número de quotas dá direito a uma unidade de habitação. Em cada unidade podem residir duas pessoas concomitantemente ou em períodos de tempo diferentes. Com o falecimento dos mesmos a unidade passa a ser da instituição por doação, podendo ser vendida novamente.

O projeto inicia-se pela venda de quotas de participação. Estas podem ser integralizadas à vista ou a prazo. É importante que o volume de quotas à vista e a necessidade inicial de capital sejam dimensionados para permitir a aquisição do terreno, a construção e o início das operações da instituição.

Os recursos operacionais são provenientes das mensalidades dos residentes, de hospedagem de visitantes e, eventualmente, da receita de venda de produtos ou serviços prestados à sociedade, frutos de atividades desenvolvidas em terapias ocupacionais.

As unidades não utilizadas pelos usufrutuários serão locadas. Uma parte dos recursos é utilizada para cobrir os custos diretos e indiretos. Do excedente, parte permanece a título de taxa administrativa para cobrir as despesas, parte para formar um fundo de caixa e a diferença é creditada aos proprietários, dando-lhes direito a abater as mensalidades futuras.

Os créditos dependem da modalidade do ingresso. Esta se divide em antes da construção, durante ou depois do início das atividades. 
O modelo prevê transferência de participação. Uma pessoa pode adquirir quotas e vendê-las oportunamente. $\mathrm{Na}$ alienação, os créditos acompanham o novo proprietário. Essa peculiaridade pode atrair um número maior de participantes, ou seja, pessoas que desejam fazer investimentos com rentabilidade ou que buscam segurança para o futuro.

\subsubsection{Recursos humanos}

A Anvisa, Agência Nacional de Vigilância Sanitária, estabelece normas para as organizações destinadas à moradia coletiva de pessoas com idade igual ou superior a 60 anos. Apesar de o modelo proposto atender pessoas com qualquer idade, parte das diretrizes estabelecidas na Resolução da Diretoria Colegiada - RDC/ANVISA n 283, de 26 de setembro de 2005, foram atendidas.

A Anvisa (2007, art. 3) estabelece algumas definições relevantes em termos de recursos humanos:

\section{DEFINIÇÕES*}

3.1 - Cuidador de Idosos - pessoa capacitada para auxiliar o idoso que apresenta limitações para realizar atividades da vida diária.

3.2 - Dependência do Idoso - condição do indivíduo que requer o auxílio de pessoas ou de equipamentos especiais para realização de atividades da vida diária.

3.3 - Equipamento de Autoajuda - qualquer equipamento ou adaptação, utilizado para compensar ou potencializar habilidades funcionais, tais como bengala, andador, óculos, aparelho auditivo e cadeira de rodas, entre outros com função assemelhada.

3.4 - Grau de Dependência do Idoso

a) Grau de Dependência I - idosos independentes, mesmo que requeiram uso de equipamentos de autoajuda;

b) Grau de Dependência II - idosos com dependência em até três atividades de autocuidado para a vida diária tais como: alimentação, mobilidade, higiene; sem comprometimento cognitivo ou com alteração cognitiva controlada;

c) Grau de Dependência III - idosos com dependência que requeiram assistência em todas as atividades de autocuidado para a vida diária e ou com comprometimento cognitivo.

A partir dessas definições, os pressupostos envolvendo recursos humanos estão indicados na Tabela 9 (p. 65).

\footnotetext{
* Citação adaptada conforme novo acordo ortográfico da língua portuguesa.
} 
Tabela 9 - Pressupostos em relação aos recursos humanos da organização

\begin{tabular}{|c|c|c|c|c|c|}
\hline Recurso humano & $\begin{array}{c}\text { Nível de } \\
\text { escolaridade }\end{array}$ & $\begin{array}{c}\text { Carga } \\
\text { horária }\end{array}$ & $\begin{array}{c}\text { Número } \\
\text { de } \\
\text { turnos } \\
\text { (8 h/dia) } \\
\text { (1) }\end{array}$ & $\begin{array}{c}\text { Número } \\
\text { máximo de } \\
\text { residentes por } \\
\text { profissional } \\
\text { (2) }\end{array}$ & $\begin{array}{c}\text { Número } \\
\text { máximo de } \mathbf{m}^{2} \\
\text { por } \\
\text { profissional } \\
\text { (3) }\end{array}$ \\
\hline Responsável técnico & Superior & $20 \mathrm{~h} / \mathrm{sem}$ & - & - & - \\
\hline Cuidador para & & $8 \mathrm{~h} / \mathrm{dia}$ & 1 & 20 & - \\
\hline residentes com grau & & $8 \mathrm{~h} / \mathrm{dia}$ & 3 & 10 & - \\
\hline de dependência & & $8 \mathrm{~h} / \mathrm{dia}$ & 3 & 6 & - \\
\hline Atividades de lazer (4) & Superior & $12 \mathrm{~h} / \mathrm{sem}$ & - & 40 & - \\
\hline Serviço de limpeza interna & & $8 \mathrm{~h} / \mathrm{dia}$ & 3 & - & 100 \\
\hline Serviço de limpeza externa & & $8 \mathrm{~h} / \mathrm{dia}$ & 1 & - & 200 \\
\hline Alimentação & & $8 \mathrm{~h} / \mathrm{dia}$ & 2 & 20 & - \\
\hline Lavanderia & & $8 \mathrm{~h} / \mathrm{dia}$ & 1 & 30 & - \\
\hline Médico & Superior & $12 \mathrm{~h} / \mathrm{sem}$ & - & 100 & - \\
\hline Auxiliar de enfermagem & & $8 \mathrm{~h} / \mathrm{dia}$ & 3 & 100 & - \\
\hline Ajudante geral & & $8 \mathrm{~h} / \mathrm{dia}$ & 1 & - & 400 \\
\hline Jardineiro & & $8 \mathrm{~h} / \mathrm{dia}$ & 1 & - & 300 \\
\hline Vigia & & $8 \mathrm{~h} / \mathrm{dia}$ & 2 & - & 500 \\
\hline
\end{tabular}

(1) Não há definição de número de turnos para profissionais com carga horária semanal; (2) Não há definição de número máximo de residentes para os profissionais indicados com hífen; (3) Não há definição de número máximo de metros quadrados para os profissionais indicados com hífen; (4) Atividades de lazer destinam-se aos residentes com grau de dependência I e II.

FONTE: ANVISA, 2007, adaptado pelo autor.

Nota-se na Tabela 9 (p. 65) que existe número de residentes por profissional contratado. Tomando como exemplo cuidador para residentes com grau de dependência I a organização deve ter um cuidador para cada 20 residentes, oito horas por dia, em um único turno; para grau de dependência II é necessário um cuidador para cada 10 residentes, com cobertura de três turnos de oito horas por dia.

Também existe a definição de metros quadrados por profissional. Ainda na Tabela 9 (p. 65) tem-se, por exemplo, uma pessoa para limpeza interna para cada 100 metros quadrados, em um total de três turnos de oito horas por dia.

A estrutura administrativa depende do porte da organização e se a mesma é dividida em filiais. Tratando-se de uma instituição com poucos residentes a administração deve ser condensada. Um número maior de habitações exige uma administração mais complexa. Havendo mais de uma unidade, há uma administração centralizada na matriz e um pequeno corpo administrativo nas filiais.

Os pressupostos em relação a cargos e salários da administração para uma organização de pequeno porte estão representados no Apêndice 12 (p. 236). A estrutura administrativa de uma matriz e suas filiais estão representadas nos Apêndices 13 e 14 (p. 236). 
Acrescentado encargos sociais aos totais dos salários médios dos Apêndices 12, 13 e 14 (p. 236) e destacando o número de funcionários, elabora-se a Tabela 10 (p. 66).

Tabela 10 - Número de funcionários administrativos e despesas com salários mais encargos sociais por tipo de unidade

\begin{tabular}{lccc}
\hline \multicolumn{1}{c}{ Tipo de Unidade } & $\begin{array}{c}\text { Número de } \\
\text { funcionários }\end{array}$ & $\begin{array}{c}\text { Despesa com } \\
\text { salário (R\$) }\end{array}$ & $\begin{array}{c}\text { Despesa com } \\
\text { salário mais } \\
\text { encargos sociais } \\
(\mathbf{R} \mathbf{)}\end{array}$ \\
\hline Para 1 unidade de pequeno porte & 5 & & $\mathbf{1 0 0 \%}$ \\
Para matriz de pequeno porte & 7 & 13.266 & 26.532 \\
Para filial de pequeno porte & 2 & 23.941 & 47.882 \\
& & 6.379 & 12.758 \\
\hline
\end{tabular}

Há um número de colaboradores que atendem de forma indireta os propósitos da organização e estão ligados à atividade fim, ou seja, lidar com o residente. Estes independem do número de pessoas que moram na instituição. Podem ser fixos, como o responsável técnico, ou depender da área da organização, como o pessoal de limpeza. Os pressupostos em relação aos cargos e salários dos funcionários indiretos fixos estão representados nas Tabelas 11 e 12 (p. 66).

Tabela 11 - Salário mensal de funcionários indiretos para 1 unidade ou matriz de pequeno porte

\begin{tabular}{lrrr}
\hline \multicolumn{1}{c}{ Ocupação } & \multicolumn{3}{c}{ Salário $(\mathbf{R} \$)$} \\
\cline { 2 - 4 } & Menor valor & Maior valor & Valor médio \\
\hline Responsável técnico & 2.151 & 12.011 & 4.751 \\
Encarregado de lazer & 1.630 & 13.158 & 2.700 \\
Assistente social & 889 & 1.889 & 1.256 \\
Caseiro & 410 & 1.590 & 667 \\
\hline
\end{tabular}

FONTE: DATAFOLHA, 2008.

Tabela 12 - Salário mensal de funcionários indiretos para filial de pequeno porte

\begin{tabular}{lrrr}
\hline \multicolumn{1}{c}{ Ocupação } & \multicolumn{3}{c}{ Salário (R\$) } \\
\cline { 2 - 4 } & Menor valor & Maior valor & Valor médio \\
\hline Responsável técnico & 2.151 & 12.011 & 4.751 \\
Assistente social & 889 & 1.889 & 1.256 \\
Caseiro & 410 & 1.590 & 667 \\
\hline
\end{tabular}

FONTE: DATAFOLHA, 2008.

Um dos pressupostos na Tabela 9 (p. 65) indica que o responsável técnico deve atuar 20 horas por semana na instituição ou o correspondente a quatro horas por dia. Nas Tabelas 11 e 12 (p. 66) o salário refere-se a uma carga diária de oito horas, 30 dias por mês, ou seja, o dobro do que o responsável técnico vai trabalhar. Desta forma, deve-se ajustar o salário para a carga 
horária correspondente. No caso o custo mensal com salário será 50\% do salário indicado. Este ajuste está indicado nas Tabelas 13 e 14 (p. 67).

Tabela 13 - Custo mensal com salário de funcionários indiretos para 1 unidade ou matriz de pequeno porte

\begin{tabular}{lrrr}
\hline \multicolumn{1}{c}{ Ocupação } & \multicolumn{3}{c}{ Salário (R\$) } \\
\cline { 2 - 4 } & Menor valor & Maior valor & Valor médio \\
\hline Responsável técnico & 1.076 & 6.006 & 2.376 \\
Encarregado de lazer & 1.630 & 13.158 & 2.700 \\
Assistente social & 889 & 1.889 & 1.256 \\
Caseiro & 410 & 1.590 & 667 \\
\hline Total & $\mathbf{4 . 0 0 5}$ & $\mathbf{2 2 . 6 4 3}$ & $\mathbf{6 . 9 9 9}$ \\
\hline
\end{tabular}

Tabela 14 - Custo mensal com salário de funcionários indiretos para filial de pequeno porte

\begin{tabular}{lrrr}
\hline \multirow{2}{*}{ Ocupação } & \multicolumn{3}{c}{ Salário $(\mathbf{R}$ \$) } \\
\cline { 2 - 4 } & Menor valor & Maior valor & Valor médio \\
\hline Responsável técnico & 1.076 & 6.006 & 2.376 \\
Assistente social & 889 & 1.889 & 1.256 \\
Caseiro & 410 & 1.590 & 667 \\
\hline Total & $\mathbf{2 . 3 7 5}$ & $\mathbf{9 . 4 8 5}$ & $\mathbf{4 . 2 9 9}$ \\
\hline
\end{tabular}

Destacando o número de funcionários e o salário médio das Tabelas 13 e 14 (p. 67), acrescentando encargos sociais e dividindo por tipo de unidade obtém-se a Tabela 15 (p. 67).

Tabela 15 - Número de funcionários indiretos fixos e custos com salários mais encargos sociais por tipo de unidade

\begin{tabular}{lccc}
\hline \multicolumn{1}{c}{ Tipo de Unidade } & $\begin{array}{c}\text { Número de } \\
\text { funcionários }\end{array}$ & $\begin{array}{c}\text { Custo com } \\
\text { salário (R\$) }\end{array}$ & $\begin{array}{c}\text { Custo com } \\
\text { salário mais } \\
\text { encargos sociais } \\
\text { (R\$) }\end{array}$ \\
\cline { 3 - 4 } & & & $\mathbf{1 0 0 \%}$ \\
\hline Para 1 unidade de pequeno porte & 4 & 6.999 & 13.998 \\
Para matriz de pequeno porte & 4 & 6.999 & 13.998 \\
Para filial de pequeno porte & 3 & 4.299 & 8.598 \\
\hline
\end{tabular}

Em relação aos funcionários indiretos uma parte deles está relacionada à área da organização. A Tabela 16 (p. 67) destaca a média salarial de cada função. Utilizando os parâmetros da Tabela 9 (p. 65) juntamente com o salário médio de cada um dos colaboradores obtém-se a Tabela 17 (p. 68).

Tabela 16 - Salário mensal de funcionários indiretos, em função da área da organização.

\begin{tabular}{lrrr}
\hline \multirow{2}{*}{ Ocupação } & \multicolumn{3}{c}{ Salário (R\$) } \\
\cline { 2 - 4 } & Menor valor & Maior valor & Valor médio \\
\hline Serviços de limpeza & 410 & 1.409 & 595 \\
Jardineiro & 410 & 1.284 & 684 \\
Vigia & 497 & 1.658 & 1.010 \\
Ajudante geral & 410 & 1.590 & 667 \\
\hline
\end{tabular}

FONTE: DATAFOLHA, 2008. 
Tabela 17 - Custo mensal de funcionários indiretos em função da área da organização

\begin{tabular}{|c|c|c|c|c|c|c|}
\hline \multirow{3}{*}{ Ocupação (*) } & \multicolumn{2}{|c|}{ Área } & \multirow{3}{*}{$\begin{array}{c}\text { Custo com } \\
\text { salário }(R \$)\end{array}$} & \multirow{2}{*}{$\begin{array}{c}\text { Custo com salário } \\
\text { mais encargos } \\
\text { sociais }(\mathbf{R} \$)\end{array}$} & \multirow{3}{*}{ 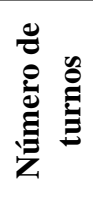 } & \multirow{3}{*}{$\begin{array}{c}\text { Custo com } \\
\text { salário mais } \\
\text { encargos sociais } \\
x \\
n^{0} \text { turnos }(\mathbf{R} \$)\end{array}$} \\
\hline & \multirow{2}{*}{ 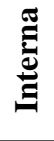 } & \multirow{2}{*}{ 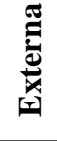 } & & & & \\
\hline & & & & $100 \%$ & & \\
\hline Serviços de limpeza & $\mathrm{x}$ & & 595 & 1.190 & 3 & 3.570 \\
\hline Serviços de limpeza & & $\mathrm{x}$ & 595 & 1.190 & 1 & 1.190 \\
\hline Jardineiro & & $\mathrm{x}$ & 684 & 1.368 & 1 & 1.368 \\
\hline Vigia & & $\mathrm{x}$ & 1.010 & 2.020 & 2 & 4.040 \\
\hline Ajudante geral & $\mathrm{x}$ & $\mathrm{x}$ & 667 & 1.334 & 1 & 1.334 \\
\hline
\end{tabular}

(*) AI - área interna da organização; AE - área externa.

Como todos os custos indicados na Tabela 17 (p. 68) dependem das áreas internas e ou externas, pode-se definir equações número de funcionários e custo para cada ocupação. Essas equações estão destacadas na Tabela 18 (p. 68).

Tabela 18 - Equação número de funcionários e custo com salários mais encargos sociais de colaboradores indiretos em relação à área da organização

\begin{tabular}{|c|c|c|c|c|}
\hline Ocupação (*) & $\begin{array}{c}\text { Custo com } \\
\text { salário mais } \\
\text { encargos sociais } \\
\text { x } \\
\mathbf{n}^{\circ} \text { turnos }(\mathbf{R} \$)\end{array}$ & 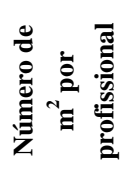 & $\begin{array}{c}\text { Equação número de } \\
\text { funcionários indiretos em } \\
\text { relação à área }\end{array}$ & $\begin{array}{l}\text { Equação custo com salário mais } \\
\text { encargos sociais de funcionários } \\
\text { indiretos em relação à área }\end{array}$ \\
\hline Serviços de limpeza (AI) & 3.570 & 100 & ARRED ( AI / 100 ) & $($ ARRED $($ AI / 100$)) \times 3.570$ \\
\hline Serviços de limpeza (AE) & 1.190 & 200 & ARRED ( AE / 200$)$ & $(\operatorname{ARRED}(\mathrm{AE} / 200)) \times 1.190$ \\
\hline Jardineiro (AE) & 1.368 & 300 & $\operatorname{ARRED~(~AE~/~} 300)$ & $(\operatorname{ARRED}(\mathrm{AE} / 300)) \times 1.368$ \\
\hline Vigia (AE) & 4.040 & 500 & $\operatorname{ARRED}(\mathrm{AE} / 500)$ & $(\operatorname{ARRED}(\mathrm{AE} / 500)) \times 4.040$ \\
\hline Ajudante geral (AI+AE) & 1.334 & 500 & $\operatorname{ARRED}((\mathrm{AI}+\mathrm{AE}) / 500)$ & $(\operatorname{ARRED}((\mathrm{AI}+\mathrm{AE}) / 500)) \times 1.334$ \\
\hline
\end{tabular}

(*) AI - área interna da organização; AE - área externa; ARRED - arredondamento de um quociente para o próximo inteiro.

Existem funcionários que lidam diretamente com os residentes. Dependendo do número de pessoas que moram na instituição, o número desses colaboradores se altera. Os cargos e salários dos funcionários diretos estão representados na Tabela 19 (p. 68). Como nem todas as ocupações necessitam de oito horas diárias e nem todos os salários referem-se às mesmas oito horas, são necessários ajustes para definir o custo mensal dos profissionais.

Tabela 19 - Salário mensal de pessoal operacional

\begin{tabular}{lrrr}
\hline \multicolumn{1}{c}{ Ocupação } & \multicolumn{3}{c}{ Salário (R\$) } \\
\cline { 2 - 4 } & Menor valor & Maior valor & Valor médio \\
\hline Cuidador & 562 & 2.014 & 1.383 \\
Atividade de lazer (2) & 1.630 & 13.158 & 4.186 \\
Lavanderia & 719 & 1.026 & 771 \\
Médico (1) & 2.806 & 5.325 & 3.445 \\
Auxiliar de enfermagem (2) & 562 & 2.014 & 1.383 \\
\hline
\end{tabular}

(1) jornada de 4h; (2) jornada de $6 \mathrm{~h}$.

FONTE: DATAFOLHA, 2008. 
Em relação às atividades de lazer pressupõe-se um professor de educação física. O salário indicado na Tabela 19 (p. 68) refere-se a uma jornada de seis horas diárias e a necessidade semanal indicada na Tabela 9 (p. 65) são de 12 horas semanais. Assim, o custo mensal com atividade de lazer para cada 40 residentes é calculado a partir da seguinte fórmula:

$$
\text { Custo mensal de atividades de lazer }=\frac{\text { Salário Mensal }}{6 \mathrm{~h} \times 5 \text { dias }} \times 12 \mathrm{~h}
$$

De acordo com a Tabela 9 (p. 65) há uma necessidade de atendimento médico de 12 horas semanais. A Tabela 19 (p. 68) evidencia o salário mensal para um médico que trabalha quatro horas por dia. A seguir indica-se a fórmula para o custo mensal ajustado de atendimento médico para cada 40 residentes.

$$
\text { Custo mensal de atendimento médico }=\frac{\text { Salário Mensal }}{4 \mathrm{~h} \times 5 \text { dias }} \times 12 \mathrm{~h}
$$

A Tabela 9 (p. 65) pressupõe uma cobertura de 24 horas diárias de serviços de enfermagem. Como a Tabela 19 (p. 68) evidencia salário para seis horas diárias, a fórmula para ajustar o custo mensal é a seguinte:

$$
\text { Custo mensal de serviços de enfermagem }=\frac{\text { Salário Mensal }}{6 \mathrm{~h}} \times 8 \mathrm{~h}
$$

A Tabela 20 (p. 70) representa o custo mensal com salário dos funcionários operacionais.

Utilizando os parâmetros da Tabela 9 (p. 65) juntamente com o salário médio de cada um dos colaboradores obtém-se a Tabela 21 (p. 70).

Como os custos indicados na Tabela 21 (p. 70) dependem do número de residentes, pode-se definir equações número de funcionários e custo para cada ocupação. Essas equações estão destacadas na Tabela 22 (p. 70). Como existe flexibilidade na contratação de pessoal, o número de funcionários operacionais depende do nível de utilização da capacidade instalada, ou seja, se a organização for construída para 100 residentes e atender 60 por um determinado período de tempo, pode-se ter $60 \%$ dos funcionários operacionais. Contudo, para o cálculo da área necessária para funcionários utiliza-se $100 \%$ da capacidade instalada. 
Tabela 20 - Custo mensal com salário de pessoal operacional

\begin{tabular}{lrrr}
\hline \multicolumn{1}{c}{ Ocupação } & \multicolumn{3}{c}{ Salário (R\$) } \\
\cline { 2 - 4 } & Menor valor & Maior valor & Valor médio \\
\hline Cuidador & 562 & 2.014 & 1.383 \\
Atividade de lazer & 652 & 5.263 & 1.674 \\
Lavanderia & 719 & 1.026 & 771 \\
Médico & 1.684 & 3.195 & 2.067 \\
Auxiliar de enfermagem & 749 & 2.685 & 1.844 \\
\hline
\end{tabular}

FONTE: DATAFOLHA, 2008.

Tabela 21 - Custo mensal de funcionários diretos em função da área da organização

\begin{tabular}{|c|c|c|c|c|}
\hline Ocupação & $\begin{array}{l}\text { Custo com } \\
\text { salário } \\
\text { (R\$) }\end{array}$ & $\begin{array}{l}\text { Custo com } \\
\text { salário mais } \\
\text { encargos } \\
\text { sociais } \\
(\mathbf{R} \$) \\
100 \%\end{array}$ & 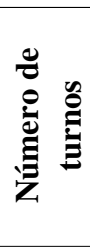 & $\begin{array}{c}\text { Custo com } \\
\text { salário mais } \\
\text { encargos } \\
\text { sociais } x \\
n^{\circ} \text { turnos } \\
(\mathbf{R} \$)\end{array}$ \\
\hline Cuidador para & 1.383 & 2.766 & 1 & 2.766 \\
\hline residentes com grau & 1.383 & 2.766 & 3 & 8.298 \\
\hline de dependência & 1.383 & 2.766 & 3 & 8.298 \\
\hline Atividade de lazer & 1.674 & 3.348 & 1 & 3.348 \\
\hline Lavanderia & 771 & 1.542 & 1 & 1.542 \\
\hline Médico & 2.067 & 4.134 & 1 & 4.134 \\
\hline Auxiliar de enfermagem & 1.844 & 3.688 & 3 & 11.064 \\
\hline
\end{tabular}

Tabela 22 - Equação número de funcionários e custo com salários mais encargos sociais de colaboradores diretos em relação ao número de residentes

\begin{tabular}{|c|c|c|c|c|c|}
\hline Ocupação & & $\begin{array}{c}\text { Custo com } \\
\text { salário mais } \\
\text { encargos } \\
\text { sociais } \mathbf{x} \\
\mathbf{n}^{0} \text { turnos } \\
(\mathbf{R} \$) \\
\end{array}$ & 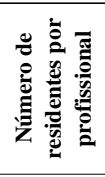 & $\begin{array}{l}\text { Equação número de funcionários diretos } \\
\text { em relação ao número de residentes } \\
\qquad(*)\end{array}$ & $\begin{array}{l}\text { Equação custo com salário mais encargos sociais } \\
\text { de funcionários diretos em relação ao número de } \\
\text { residentes } \\
(*)\end{array}$ \\
\hline \multirow{3}{*}{$\begin{array}{l}\text { Cuidador para } \\
\text { residentes com grau } \\
\text { de dependência }\end{array}$} & I & 2.766 & 20 & ARRED ( ( R1 x NUCI )/ 20$)$ & ARRED ( ( R1 x NUCI ) / 20$) \times 2.766$ \\
\hline & II & 8.298 & 10 & $\operatorname{ARRED}((\mathrm{R} 2 \times \mathrm{NUCI}) / 10)$ & ARRED ( ( R2 x NUCI ) / 10) x 8.298 \\
\hline & III & 8.298 & 6 & ARRED ( ( R3 x NUCI ) / 6) & ARRED ( ( R3 x NUCI ) / 6 ) x 8.298 \\
\hline Atividade de lazer & & 3.348 & 40 & ARRED ( ( ( R1+R2 ) x NUCI ) / 40$)$ & ARRED ( ( ( R1+R2 ) x NUCI ) / 40$) \times 3.348$ \\
\hline Lavanderia & & 1.542 & 30 & ARRED ( ( ( R1+R2+R3 ) x NUCI $) / 30)$ & $\operatorname{ARRED}(((\mathrm{R} 1+\mathrm{R} 2+\mathrm{R} 3) \times \mathrm{NUCI}) / 30) \times 1.542$ \\
\hline Médico & & 4.134 & 100 & ARRED ( ( ( R1+R2+R3 ) x NUCI )/ 100$)$ & ARRED ( ( ( R1+R2+R3 ) x NUCI )/ 100$) \times 4.134$ \\
\hline Auxiliar de enfermagem & & 11.064 & 100 & ARRED ( ( ( R1+R2+R3 ) x NUCI $) / 100)$ & ARRED $(((\mathrm{R} 1+\mathrm{R} 2+\mathrm{R} 3) \times \mathrm{NUCI}) / 100) \times 11.064$ \\
\hline
\end{tabular}

(*) NUCI - Nível de utilização da capacidade instalada; R1 - número de residentes com grau de dependência I; R2 - residentes com grau de dependência II; R3 - residentes com grau de dependência III; ARRED arredondamento de um quociente para o próximo inteiro.

\subsubsection{Infraestrutura física}

Em relação à infraestrutura parte dos pressupostos adotados atendem às exigências da Anvisa, Agência Nacional de Vigilância Sanitária, estabelecidas na Resolução da Diretoria Colegiada - RDC/ANVISA nº 283, de 26 de setembro de 2005. Quanto à infraestrutura física da organização existe área mínima por residente, funcionário e ambiente. A Tabela 23 (p. 71) apresenta as necessidades de espaço físico na instituição. 
Interpretando o ambiente dormitório para 1 residente na Tabela 23 (p. 71) percebe-se que o dormitório para uma pessoa deve ter $7,5 \mathrm{~m}^{2}$ com um banheiro de $3,6 \mathrm{~m}^{2}$, ambas as medidas mínimas, ou seja, um ambiente com no mínimo $11,1 \mathrm{~m}^{2}$. Um dormitório para dois residentes deve ter uma área mínima de $5,5 \mathrm{~m}^{2}$ por residente mais um banheiro de $3,6 \mathrm{~m}^{2}$. Neste caso o dormitório para dois residentes teria uma área mínima de $14,6 \mathrm{~m}^{2}$.

Tabela 23 - Pressupostos em relação à infraestrutura física da organização

\begin{tabular}{|c|c|c|c|}
\hline Ambiente & 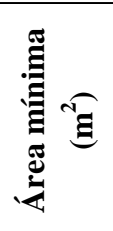 & 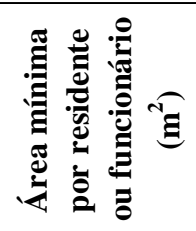 & 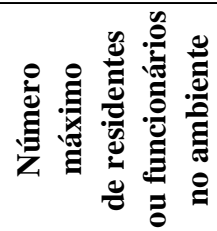 \\
\hline \multicolumn{4}{|l|}{ Para os residentes } \\
\hline \multicolumn{4}{|l|}{ Dormitório separado por sexo } \\
\hline para 1 residente & & 7,5 & 1 \\
\hline de 2 a 4 residentes & & 5,5 & 4 \\
\hline Banheiro do dormitório & 3,6 & & \\
\hline \multirow{2}{*}{\multicolumn{4}{|c|}{$\begin{array}{l}\text { Ambientes para residentes com grau de } \\
\text { dependência I e II }\end{array}$}} \\
\hline & & & \\
\hline Sala para atividades coletivas & & 1,0 & 15 \\
\hline Sala de convivência & & 1,3 & \\
\hline Sala de apoio individual & 9,0 & & \\
\hline Banheiros coletivos, separados por sexo & $(*)$ & & \\
\hline Espaço ecumênico & $(*)$ & & \\
\hline Sala administrativa / reunião & $(*)$ & & \\
\hline Refeitório & & 1,0 & \\
\hline Cozinha e despensa & $(*)$ & & \\
\hline Lavanderia & $(*)$ & & \\
\hline Almoxarifado & 10,0 & & \\
\hline \multicolumn{4}{|l|}{ Para os funcionários } \\
\hline Banheiro separado por sexo & 7,2 & & 10 \\
\hline Vestiário separado por sexo & & 0,5 & \\
\hline
\end{tabular}

(*) Ambiente exigido, mas sem definição de área mínima.

FONTE: ANVISA, 2007, adaptado pelo autor.

Outro exemplo são as salas para atividades coletivas destinadas aos residentes com grau de dependência I e II; elas devem ter $1 \mathrm{~m}^{2}$ por pessoa, sendo que no máximo 15 residentes podem ocupar a sala, ou seja, essas salas devem ter no máximo $15 \mathrm{~m}^{2}$.

Parte-se do pressuposto que a habitação possui um dormitório para duas pessoas, uma sala reversível para um segundo dormitório e um banheiro.

A norma brasileira ABNT NBR 9050 que trata da acessibilidade a edificações, mobiliário, espaço e equipamentos urbanos estabelece que no mínimo $5 \%$ dos dormitórios devem ser acessíveis a usuários de cadeira de rodas, sendo outros $10 \%$ adaptáveis. Em se tratando de 
serviços de saúde, no mínimo 10\% dos dormitórios devem ser acessíveis, com outros $10 \%$ adaptáveis.

Existem aspectos relevantes em ambientes destinados a pessoas que utilizam cadeiras de roda. Há um espaço mínimo de 0,80 x 1,20m, chamado de área de transferência, para que a pessoa se desloque da cadeira para um vaso sanitário, box ou similar. Também é necessária uma área de manobra de $180^{\circ}$ com diâmetro de 1,50m em cada ambiente, além de portas com largura de 0,90m e este mesmo espaço entre os móveis para o deslocamento da cadeira de rodas.

Em função das exigências legais podem existir dois tipos de habitações, um com dimensões padrões (Apêndice 15, p. 237) e outro com dimensões que atendam pessoas com necessidades especiais (Apêndice 16, p. 237). Este segundo tipo será tratado como habitação ampliada nesta tese.

A habitação padrão ocupa uma área de aproximadamente $37,9 \mathrm{~m}^{2}$ e a ampliada $54,4 \mathrm{~m}^{2}$. O termo aproximadamente se deve pelo fato das paredes ou corredores poderem ser compartilhados.

A área interna da organização depende do número de habitações que se deseja construir e do número de residentes que se pretende abrigar. Cada uma pode acomodar até dois residentes. Por medida de cautela a área interna será calculada com a utilização máxima da capacidade instalada, ou seja, o dobro de residentes em relação ao número de unidades.

A partir das dimensões das habitações e da Tabela 23 (p. 71) podem-se estabelecer as dimensões das áreas internas em função do número de residentes e de funcionários. Tais definições podem ser observadas no Apêndice 17 (p. 238). Pode-se observar que o minisshopping e o anfiteatro são opcionais. O primeiro trata-se de uma área terceirizada que pode acomodar uma lanhouse, um salão de cabeleireiro ou pequenas lojas. O anfiteatro pode, inclusive, ser aberto à sociedade local.

A partir do Apêndice 17 (p. 238) define-se a equação Área para cada ambiente. Esta depende da porcentagem de ambientes destinados a pessoas que dependem de cadeira de rodas (PAC), do número de residentes por grau de dependência (R1, R2 e R3) e do total de funcionários (Func). As equações podem ser visualizadas no Apêndice 18 (p. 239). 
De acordo com a Câmara Brasileira da Indústria da Construção (2008), o Custo Unitário Básico (CUB) por metro quadrado de construção civil, no estado de São Paulo, é de $\mathrm{R} \$ 730,00$. A partir do produto do valor da $\mathrm{CUB} / \mathrm{m}^{2}$ pela soma das áreas internas calcula-se a necessidade de investimento na construção civil, ou seja:

$$
\text { Custo da Construção Civil }=\text { Área Interna } \times 730
$$

Somando a área interna e externa obtém-se a área do terreno. O metro quadrado do terreno foi cotado a R $\$ 500$ (Anexo 17, p. 378), ou seja:

$$
\text { Custo do Terreno }=\text { Área Total } \times 500
$$

\subsubsection{Móveis e Equipamentos Internos}

As habitações padrões e estendidas serão dotadas de móveis e eletroeletrônicos. O investimento e o custo de depreciação estão indicados no Apêndice 19 (p. 239). A depreciação refere-se à diminuição do valor dos bens resultante de desgaste pelo uso, ação da natureza ou obsolescência normal (HIGUCHI et al, 2007, p. 309) e as porcentagens lançadas atendem à Instrução Normativa SRF no 162 da Secretaria da Receita Federal (2008b).

Como pode ser observado no Apêndice 17 (p. 238) as salas de atividades coletivas têm no máximo $15 \mathrm{~m}^{2}$. Em razão dessa característica, dependendo do número de residentes, a organização pode ter vários tipos de salas. No Apêndice 20 (p. 240) foram listadas algumas salas possíveis, o custo de investimento, depreciação e manutenção dos móveis e outros utensílios que as compõe, todas com $15 \mathrm{~m}^{2}$.

Podem-se observar no Apêndice 21 (p. 240) o custo de investimento, depreciação e manutenção de salas de convivência para 30 residentes. Seguindo a ordem do Apêndice 17 (p. 238), estão apresentados no Apêndice 22 (p. 241) os dados referentes à sala de apoio individual, espaço ecumênico, sala administrativa e de reunião.

No Apêndice 23 (p. 241), estão representados os investimentos, custos de depreciação e manutenção do refeitório, cozinha e despensa, lavanderia, almoxarifado, ambulatório e posto médico, lembrando que o custo de refeitório é para quatro residentes, que a despensa está cotada para 50, a lavanderia e o posto médico para 100 residentes. No Apêndice 24 (p. 242) existem as mesmas informações para um vestiário de 16 funcionários e para o anfiteatro opcional para 120 pessoas. 
Do Apêndice 19 (p. 239) ao Apêndice 24 (p. 242) podem-se estabelecer equações dos investimentos em móveis e equipamentos internos. As mesmas estão indicadas no Apêndice 25 (p. 242). As salas de atividades coletivas foram ordenadas aleatoriamente, mas esse procedimento interfere no cálculo do investimento.

As equações com os custos mensais dos ambientes internos, obtidos a partir do Apêndice 19 (p. 239) ao Apêndice 24 (p. 242), estão representadas no Apêndice 26 (p. 243).

Alguns investimentos possíveis em áreas externas estão destacados nos Apêndices 27 e 28 (p. 243), sendo que as equações investimento e depreciação estão listadas no Apêndice 29 (p. 244). Nos Apêndices 30 e 31 (p. 244) estão representadas outras despesas administrativas, custos indiretos, diretos e suas equações.

Agrupando as despesas e custos em relação ao comportamento frente ao número de residentes, as despesas e custos podem ser representados conforme os Apêndices 32, 33 e 34 (p. 245-247), para uma unidade, uma matriz e filiais, respectivamente. Os custos diretos não são totalmente variáveis, pois muitos deles se alteram em função de número de residentes. Tomando como exemplo residente com grau de dependência I, deve existir um cuidador para cada 20 pessoas. Havendo rigor, 100 residentes exigem cinco cuidadores; de 101 a 120 residentes são necessários seis cuidadores. Ou seja, o custo dos cuidadores eleva-se a cada variação de 20 residentes com grau de dependência I, a cada 10 residentes com grau II e a cada seis residentes com grau de dependência III. Assim como o custo dos cuidadores, existem outros custos que variam de forma similar.

\subsection{Variáveis de simulação}

Diversas variáveis podem ser alteradas no modelo proposto desta tese. Essas mudanças proporcionam diferentes resultados em termos de valor de investimento e de contribuições, tempo de carência ou retorno sobre o investimento em caso de venda das quotas de participação.

A primeira variável a ser considerada é o número de unidades. A organização pode ser formada por uma única unidade ou uma matriz e suas filiais. Essa variável interfere nas despesas administrativas e nos custos indiretos. 
Outra variável é o número de residentes por unidade. Estes podem ter grau de dependência I, II ou III. Os residentes com grau de dependência II e III exigem um número maior de cuidadores, além de serem necessários três turnos de trabalho. Além disso, deve-se levar em consideração que parte deles pode depender de cadeira de rodas, o que interfere nas medidas dos dormitórios e, consequentemente, no investimento inicial.

A relação entre a área externa e interna é um fator que determina o investimento no terreno e pode limitar a construção de áreas externas. Pode-se destinar uma área interna para um minisshopping com manicura, tabacaria, café, lanhouse, etc. Esse espaço é dividido em módulos e os mesmos podem ser terceirizados.

Uma opção é a construção de um pequeno anfiteatro para os residentes e para a sociedade local. Pode-se obter como benefício à integração da instituição na sociedade.

Outras variáveis são as construções de piscinas, saunas, campos de bocha e malha, quadras poliesportivas e de saibro, pista para pedestre, ciclovia, entre outras áreas possíveis. Para as áreas externas não construídas deve-se considerar o ajardinamento.

Conforme descrito no início deste capítulo, as habitações não utilizadas pelos usufrutuários são locadas e geram créditos aos proprietários. Tais valores precisam gerar uma valorização atrativa e adequada, pois em caso de venda das quotas esses créditos são transferidos ao novo proprietário.

A mensalidade do residente não proprietário cobre custos diretos, indiretos, despesas administrativas, gera fundo de caixa e a diferença é creditada aos proprietários. Esse crédito deve ser suficientemente alto para atrair investidores e baixo, a ponto de viabilizar a locação das habitações. O crédito gerado para o proprietário é outra variável de simulação.

A construção civil pode ser executada na sua totalidade ou em fases. As quotas podem ser vendidas de três maneiras em relação ao início ou término da construção. Uma delas é a venda total antes do início. Minimizam-se os riscos em relação à inadimplência, mas há a necessidade de um maior esforço comercial. Uma segunda forma é a venda parcial das quotas antes do início da construção. Define-se uma meta de venda inicial e, sendo alcançada, iniciase a construção. Outra maneira, que independe da adoção da primeira ou da segunda, é a venda de quotas após o fim da construção. A venda de quotas pode ser à vista ou a prazo. Para 
a venda a prazo deve-se ter atenção especial em relação ao fluxo de caixa, ou seja, se o ingresso de recursos é suficiente para cobrir todos os desembolsos.

Uma variável é a locação das habitações. Quanto menor o nível de ociosidade, melhor, ou seja, quanto menos tempo as mesmas ficarem desocupadas, maiores serão os créditos dos proprietários. O ideal é locar todas as habitações antes do início da construção. Contudo, entende-se que esse procedimento é bastante difícil de ser alcançado. No outro extremo não é aconselhável aguardar o início das operações para só então buscar residentes. Entende-se que deve haver um esforço comercial para a reserva de locação do maior número possível de habitações antes do início das operações.

O prazo para a construção é uma variável relevante, pois é um período que não gera crédito para os proprietários. Assim, é importante que este prazo seja o menor possível. Entende-se que um determinado número de quotas gere o direito a uma habitação. Contudo, o proprietário não tem a necessidade de adquiri-las em uma única compra.

A locação das habitações gera créditos para os proprietários. Esses créditos são proporcionais ao número de quotas adquiridas. Para as pessoas que adquirem quotas a prazo, os créditos podem ser calculados de forma proporcional ao valor pago. Os créditos são provenientes de uma parcela da contribuição mensal das habitações locadas, ou seja, o valor pago mensalmente pelo residente não proprietário é maior do que o valor do proprietário.

Ao final deve-se estabelecer uma faixa mínima e máxima de utilização da capacidade instalada. Como as locações geram créditos aos proprietários, quanto mais unidades locadas, melhor. Contudo, os proprietários também precisam de habitações disponíveis para o momento que precisarem utilizá-las.

As variáveis de simulação estão representadas na Ilustração 4 (p. 77). 


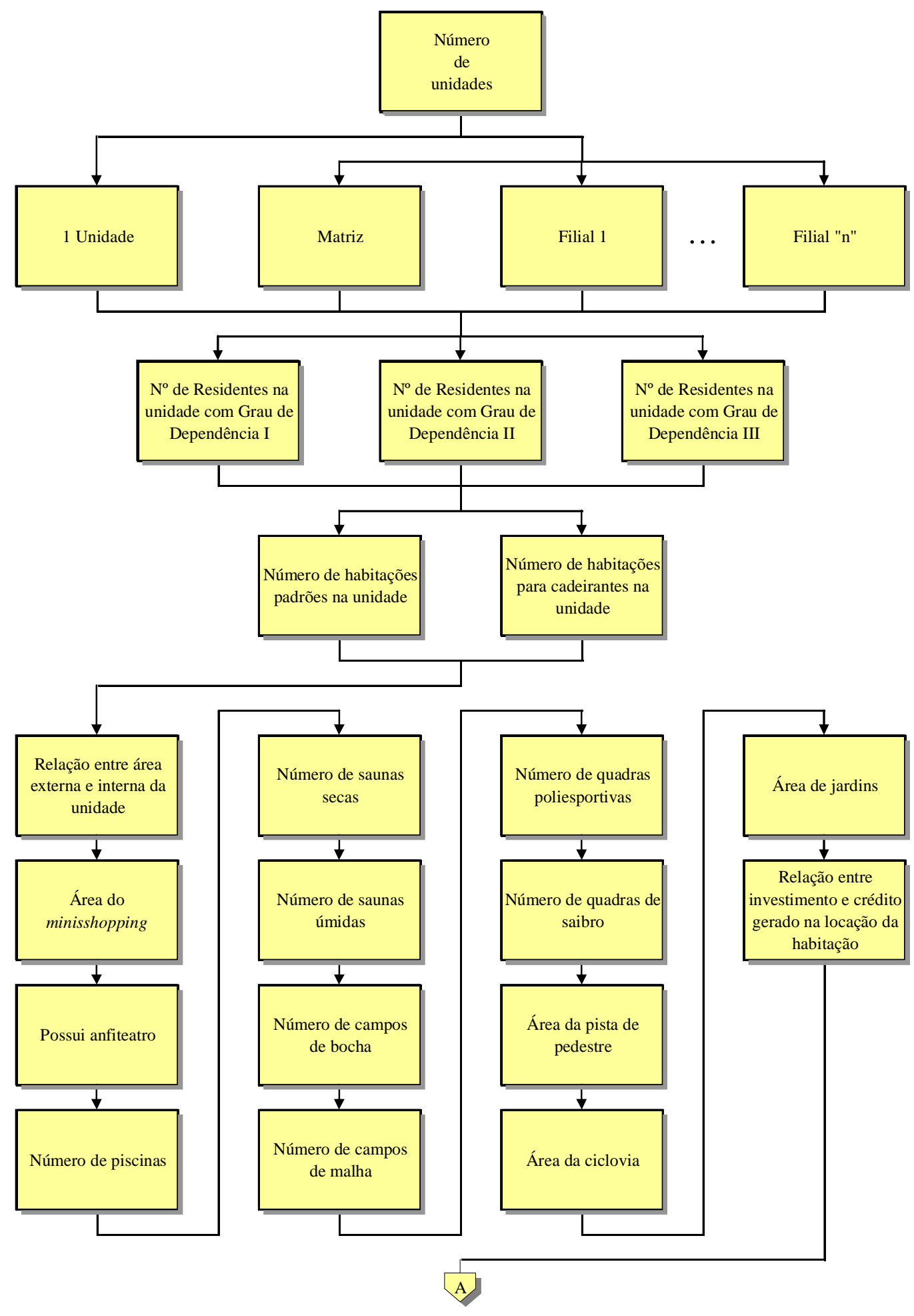

Ilustração 4 - Fluxograma de variáveis do modelo

(continua) 
(continuação)

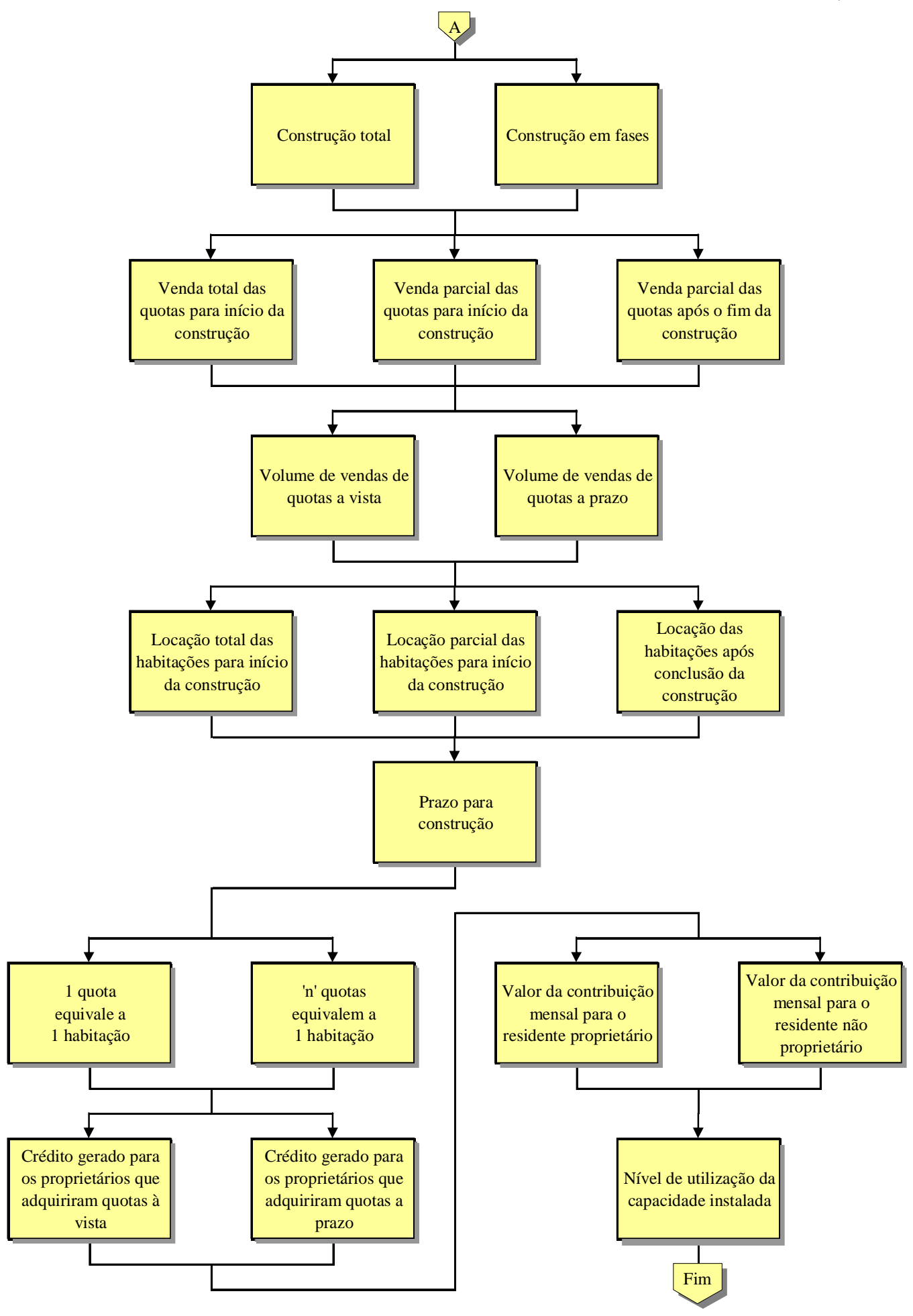

Ilustração 4 - Fluxograma de variáveis do modelo 


\subsection{Cálculo completo de uma simulação}

A primeira etapa das simulações é apresentar, para melhor entendimento, o cálculo completo de uma das opções que será avaliada. As variáveis desta opção estão listadas na Tabela 24 (p. 79).

Tabela 24 - Definição das variáveis utilizadas para cálculo completo de uma simulação

\begin{tabular}{lccc}
\hline \multicolumn{1}{c}{ Descrição } & $\begin{array}{c}\text { Área } \\
\left(\mathbf{m}^{\mathbf{2}} \mathbf{)}\right.\end{array}$ & $\begin{array}{c}\text { Nome da } \\
\text { Variável }\end{array}$ & Valor \\
\hline Número de unidades & NU & 1 \\
Residentes com grau de dependência I & R1 & 100 \\
Residentes com grau de dependência II & R2 & 80 \\
Residentes com grau de dependência III & R3 & 20 \\
Nível de utilização da capacidade instalada & & NUCI & $70 \%$ \\
Porcentagem de ambientes destinados a & & & \\
$\quad$ pessoas que dependem de cadeira de rodas & & PAC & $20 \%$ \\
Relação entre área externa e área interna & & AMS & 0,4 \\
Área do minisshopping & 150 & & 180 \\
Anfiteatro & 75 & NP & Sim \\
Número de piscinas & 9 & NSS & 1 \\
Número de saunas secas & 9 & NSU & 1 \\
Número de saunas úmidas & 96 & NCB & 1 \\
Número de campos de bocha & 100 & NCM & 1 \\
Número de campos de malha & 375 & NQP & 1 \\
Número de quadras poliesportivas & 275 & NQS & 1 \\
Número de quadras de saibro & & APP & 500 \\
Área da pista de pedestre & & AC & 500 \\
Área da ciclovia & &
\end{tabular}

O cálculo levará em consideração que a organização será edificada em uma única unidade, com o objetivo de atender 100 residentes com grau de dependência I, 80 com grau de dependência II e 20 residentes com grau III. Para efeito de cálculo, o nível médio de utilização da capacidade instalada será de $70 \%$.

De acordo com a norma ABNT NBR 9050, no mínimo 10\% dos dormitórios devem ser acessíveis a cadeirantes, com outros 10\% adaptáveis. Assim, do total das habitações, $20 \%$ serão destinadas a pessoas que utilizam cadeira de rodas. A área externa será correspondente a $40 \%$ da área interna. Serão construídos $180 \mathrm{~m}^{2}$ para um minisshopping e $150 \mathrm{~m}^{2}$ para um anfiteatro, ambos na área interna; na área externa serão construídas uma piscina de $75 \mathrm{~m}^{2}$; uma sauna seca e uma úmida, ambas com $9 \mathrm{~m}^{2}$; um campo de bocha e um de malha com $96 \mathrm{~m}^{2}$ e $100 \mathrm{~m}^{2}$, respectivamente. Ainda existirá uma quadra poliesportiva e uma quadra de saibro com $375 \mathrm{~m}^{2}$ e $275 \mathrm{~m}^{2}$, respectivamente. Estão previstos $500 \mathrm{~m}^{2}$ de pista de pedestre e a mesma área para ciclovia; no espaço restante da área externa haverá jardim. 
O primeiro passo é o cálculo da área interna. Como existe a necessidade de espaço em função do número de funcionários, primeiro calcula-se uma área interna parcial. Pode-se observar no Apêndice 35 (p. 248) que a organização precisa de $5.182,40 \mathrm{~m}^{2}$ para atender os residentes, mais um espaço externo de $2.072,96 \mathrm{~m}^{2}$.

A partir do número total de residentes e da área parcial interna, calcula-se o número de funcionários. Para esse cálculo o nível de utilização da capacidade instalada é $100 \%$. Um total de 139 colaboradores pode ser observado no Apêndice 36 (p. 248). A partir do número máximo de funcionários calcula-se a área destinada aos mesmos. O Apêndice 37 (p. 249) indica uma área total de $220,3 \mathrm{~m}^{2}$, incluindo o alojamento do caseiro com $50 \mathrm{~m}^{2}$.

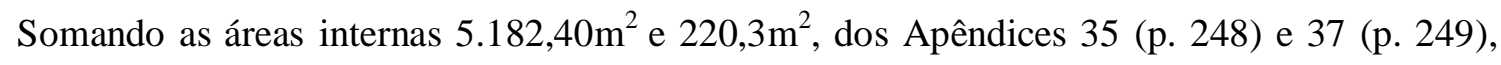
respectivamente, obtém-se uma área interna total de $5.402,7 \mathrm{~m}^{2}$. Multiplicando a soma pela relação área externa e área interna indicada na Tabela 24 (p. 79), 0,4, define-se a área externa de $2.161,08 \mathrm{~m}^{2}$. A área total para a organização é de $7.563,78 \mathrm{~m}^{2}$. Esses cálculos podem ser observados no Apêndice 38 (p. 249). As áreas externas não ocupadas por piscina, saunas, campos, etc., serão ajardinadas. Nota total serão $222,1 \mathrm{~m}^{2}$ de jardins. Os cálculos podem ser observados no Apêndice 39 (p. 249).

Com base nos dados do Anexo 17 (p. 378), adotou-se um custo de R $\$ 500,00$ por metro quadrado na região metropolitana do estado de São Paulo. Com uma área total de $7.563,78 \mathrm{~m}^{2}$, o terreno é avaliado em R \$3.781.890,00. De acordo com a Câmara Brasileira da Indústria da Construção (2008) o Custo Unitário Básico (CUB) por metro quadrado de construção civil, no estado de São Paulo, é de R $\$ 730,00$. Considerando que a área interna soma $5.402,7 \mathrm{~m}^{2}$, a construção custará R \$3.943.971,00. Esses cálculos podem ser observados nas primeiras linhas do Apêndice 40 (p. 250). Ainda no mesmo apêndice estão relacionados os cálculos dos demais investimentos. O investimento total é de $\mathrm{R} \$ 9.526 .943,00$. Como 200 habitações podem ser vendidas para até 100 proprietários, cada um desembolsaria $\mathrm{R} \$ 95.269,43$.

Apesar de 100 habitações serem construídas, raramente todas estarão locadas ao mesmo tempo. Existe, inclusive, a necessidade de uma reserva para proprietários que passarem a residir na organização. 
Independente do número de pessoas que residirão na organização, as despesas administrativas permanecem inalteradas. Com base nos pressupostos indicados no início do capítulo, as despesas administrativas estão listadas no Apêndice 41 (p. 250).

Em relação aos custos indiretos, os mesmos estão listados no Apêndice 42 (p. 251). Como a construção nesta simulação será feita em uma etapa, os custos relacionados à área interna são integrais. Apesar dos cálculos serem feitos para uma ocupação de $70 \%$ das habitações, os custos indiretos relacionados ao número de residentes foram feitos considerando ocupação total.

Os custos diretos estão destacados no Apêndice 43 (p. 252). Os cálculos consideraram o nível de utilização da capacidade instalada de $70 \%$, ou seja, a organização trabalharia com $70 \%$ dos seus custos diretos.

Somando as despesas administrativas, custos indiretos, diretos e acrescentando $3 \%$ a título de outras despesas e custos, obtém-se um valor mensal de $\mathrm{R} \$ 481.243$. Considerando que do total dos 200 residentes, 140 estarão ocupando a organização em função do nível de utilização da capacidade instalada de $70 \%$, a média de custos e despesas por residente será de $\mathrm{R} \$ 3.438$. Estes cálculos podem ser observados no Apêndice 44 (p.252).

A locação das habitações gera créditos aos proprietários. Calculando um crédito mensal de $1 \%$ em relação ao investimento de $\mathrm{R} \$ 95.269,43$ para a aquisição de uma habitação, obtém-se R\$ 952,69. Considerando que cada habitação pode ser locada para duas pessoas, esse valor pode ser dividido entre dois residentes, ou seja, $\mathrm{R} \$ 476,35$. Somando esse valor aos custos e despesas, por residente, chega-se a uma mensalidade média arredondada de R\$3.914 (Apêndice 45, p. 252).

\subsection{Simulações do modelo}

De uma forma geral, as simulações serão calculadas para várias combinações de grau de dependência dos residentes. As proporções estão indicadas na Tabela 25 (p. 82). Como exemplo, a simulação 50-40-10 indica que 50\% dos residentes têm grau de dependência I, $40 \%$ grau de dependência II e 10\% dos residentes têm grau III.

Os dados utilizados para os cálculos das simulações estão listados na Tabela 26 (p. 82). Devese notar que dependendo da simulação parte dos dados se altera. Na simulação 1, por 
exemplo, calculou-se a mensalidade média para 60\%, 70\%, 80\% e 90\% de utilização da capacidade instalada.

Tabela 25 - Proporção dos residentes, para efeito de simulação, em relação ao grau de dependência

\begin{tabular}{cccc}
\hline \multirow{2}{*}{ Simulação } & \multicolumn{3}{c}{ Grau de dependência } \\
\cline { 2 - 4 } & I & II & III \\
\hline $100-0-0$ & $100 \%$ & $0 \%$ & $0 \%$ \\
$0-100-0$ & $0 \%$ & $100 \%$ & $0 \%$ \\
$0-0-100$ & $0 \%$ & $0 \%$ & $100 \%$ \\
$70-30-0$ & $70 \%$ & $30 \%$ & $0 \%$ \\
$70-0-30$ & $70 \%$ & $0 \%$ & $30 \%$ \\
$50-40-10$ & $50 \%$ & $40 \%$ & $10 \%$ \\
$60-30-10$ & $60 \%$ & $30 \%$ & $10 \%$ \\
\hline
\end{tabular}

Tabela 26 - Premissas básicas das simulações

\begin{tabular}{lcccc}
\hline \multicolumn{1}{c}{ Descrição } & \multicolumn{4}{c}{ Premissa } \\
\hline Número máximo de residentes & 100 & 200 & 300 & 400 \\
Número de habitações & 50 & 100 & 150 & 200 \\
Número de unidades (mínimo=1) & 1 & 1 & 1 & 1 \\
Nível de utilização da capacidade instalada & $70 \%$ & $70 \%$ & $70 \%$ & $70 \%$ \\
Porcentagem de ambientes destinados a pessoas & & & & \\
que dependem de cadeira de rodas & $20 \%$ & $20 \%$ & $20 \%$ & $20 \%$ \\
Relação entre área externa e área interna & 0,4 & 0,4 & 0,3 & 0,3 \\
Área do minishopping & 90 & 180 & 180 & 180 \\
Possui anfiteatro? & Não & Sim & Sim & Sim \\
Quantidade de piscinas & 1 & 1 & 1 & 1 \\
Quantidade de saunas secas & 1 & 1 & 1 & 1 \\
Quantidade de saunas úmidas & 1 & 1 & 1 & 1 \\
Quantidade de campos de bocha & 1 & 1 & 1 & 1 \\
Quantidade de campos de malha & 1 & 1 & 1 & 1 \\
Quantidade de quadras poliesportivas & 0 & 1 & 1 & 1 \\
Quantidade de quadras de saibro & 0 & 1 & 1 & 1 \\
Área da pista de pedestre & 500 & 500 & 500 & 500 \\
Área da ciclovia & 0 & 500 & 500 & 500 \\
\hline
\end{tabular}

\subsection{1 $1^{\text {a }}$ série de simulações - investimentos em função do nível de utilização da capacidade instalada}

A primeira série de simulações de investimentos segue os dados indicados na Tabela 26 (p. 82), com variação do nível de utilização da capacidade instalada e construção de todas as instalações em uma única etapa. Como pode ser observado na Tabela 27 (p. 83), não existe variação de valor em função do nível de utilização da capacidade instalada, somente em função do grau de dependência dos residentes. Apesar de os valores serem iguais em todas as colunas, os dados foram mantidos para o cálculo da equação que será apresentado adiante.

Duas linhas foram destacadas na Tabela 27 (p. 83); uma com os maiores valores, outra com os menores. Organizações onde residem somente pessoas com grau de dependência III 
praticamente não necessitam de investimento em áreas comuns e externas, pois o nível de convívio desses residentes é mínimo.

Tabela 27 - Valor médio do investimento por habitação com $60 \%, 70 \%, 80 \%$ e $90 \%$ de utilização da capacidade instalada para 100 residentes, com diversos graus de dependência

\begin{tabular}{ccccccccc}
\hline $\begin{array}{c}\text { Porcentagem de } \\
\text { residentes com } \\
\text { grau de } \\
\text { dependência } \\
\text { I, II e III }\end{array}$ & \multicolumn{6}{c}{$\begin{array}{c}\text { Valor médio do investimento com simulação do nível de } \\
\text { utilização da capacidade instalada para 100 residentes com } \\
\text { diversos graus de dependência }\end{array}$} \\
\cline { 2 - 10 } & \multicolumn{6}{c}{$\mathbf{6 0 \%}$} & \multicolumn{7}{c}{$\mathbf{7 0 \%}$} & & $\mathbf{8 0 \%}$ & $\mathbf{9 0 \%}$ \\
\hline $\mathbf{1 0 0 - 0 - 0}$ & $\mathrm{R} \$$ & 95.267 & $\mathrm{R} \$$ & 95.267 & $\mathrm{R} \$$ & 95.267 & $\mathrm{R} \$$ & 95.267 \\
$\mathbf{0 - 1 0 0 - 0}$ & $\mathrm{R} \$$ & 95.339 & $\mathrm{R} \$$ & 95.339 & $\mathrm{R} \$$ & 95.339 & $\mathrm{R} \$$ & 95.339 \\
$\mathbf{0 - 0 - 1 0 0}$ & $\mathrm{R} \$$ & 85.599 & $\mathrm{R} \$$ & 85.599 & $\mathrm{R} \$$ & 85.599 & $\mathrm{R} \$$ & 85.599 \\
$\mathbf{7 0 - 3 0 - 0}$ & $\mathrm{R} \$$ & 95.296 & $\mathrm{R} \$$ & 95.296 & $\mathrm{R} \$$ & 95.296 & $\mathrm{R} \$$ & 95.296 \\
$\mathbf{7 0 - 0 - 3 0}$ & $\mathrm{R} \$$ & 92.965 & $\mathrm{R} \$$ & 92.965 & $\mathrm{R} \$$ & 92.965 & $\mathrm{R} \$$ & 92.965 \\
$\mathbf{5 0 - 4 0 - 1 0}$ & $\mathrm{R} \$$ & 94.663 & $\mathrm{R} \$$ & 94.663 & $\mathrm{R} \$$ & 94.663 & $\mathrm{R} \$$ & 94.663 \\
$\mathbf{6 0 - 3 0 - 1 0}$ & $\mathrm{R} \$$ & 94.649 & $\mathrm{R} \$$ & 94.649 & $\mathrm{R} \$$ & 94.649 & $\mathrm{R} \$$ & 94.649 \\
\hline
\end{tabular}

No outro extremo, os residentes com grau de dependência II são os que exigem mais investimentos, pois utilizam áreas comuns e necessitam de um número maior de cuidadores. Quanto mais funcionários a organização tiver, maior a necessidade de área de vestiário e banheiros. Essa diferença eleva ligeiramente o valor dos investimentos em relação aos residentes com grau de dependência I.

Nesta primeira simulação o valor do investimento por habitação depende do número de unidades que serão utilizadas por residentes com graus de dependência I, II e III e qual o nível de utilização da capacidade instalada. Um procedimento estatístico denominado análise de regressão pode ser usado para desenvolver uma equação que indique como as variáveis estão relacionadas (ANDERSON; SWEENEY; WILLIAMS, 2005, p. 441).

Nesta simulação o investimento é considerado uma variável dependente e as habitações destinadas aos residentes com diferentes graus de dependência são consideradas variáveis independentes. Se existisse somente uma variável dependente e uma independente, tratar-se-ia de uma regressão simples. Como se trata de mais de uma variável independente, o procedimento é chamado de regressão linear múltipla.

A primeira etapa é o cálculo da equação, em seguida deve-se analisar o nível de eficiência com que a equação aproxima os dados através de uma razão denominada coeficiente de determinação ou simplesmente $R^{2}$. Este número fica entre zero e um. Zero indica uma eficiência nula ou, em outras palavras, que alterações das variáveis independentes não 
explicam as mudanças da variável dependente. Um $R^{2}$ igual a um indica que as variáveis independentes explicam 100\% das variações da variável dependente. (ibidem, p. 456).

Contudo, o $R^{2}$ é influenciado pelo número de variáveis independentes e pelo tamanho da amostra. Segundo Hair et al (2005, p. 160) são necessárias de 10 a 15 observações por variável independente a um mínimo absoluto de quatro observações por observação. Quando o número de observações fica abaixo desse nível ou quando se aumenta o número de variáveis independentes para um mesmo número de observações, é necessário analisar o $R^{2}$ ajustado.

A terceira etapa consiste no cálculo do Teste $F$ que avalia se as variáveis têm uma relação estatisticamente significante. Se o $F_{\text {calculado }}$ for maior que o $F_{\text {tabelado }}$ em um determinado nível de significância, há uma relação significante entre a variável dependente e as variáveis independentes. Nos resumos dos resultados das regressões que serão apresentados há um campo chamado $F$ de significação. Este número apresenta o nível de significância alcançado pela regressão. Se o $F$ indicado no campo for, por exemplo, 0,005, significa que as variáveis têm uma relação estatisticamente significante em um nível de significância de 0,5\%. (ANDERSON; SWEENEY; WILLIAMS, 2005, p. 465-467).

Tabela 28 - Valor médio do investimento por habitação com $60 \%, 70 \%, 80 \%$ e $90 \%$ de utilização da capacidade instalada para 100 residentes, com diversos graus de dependência (informações realinhadas)

\begin{tabular}{ccccc}
\hline $\begin{array}{c}\text { Nível de } \\
\text { utilização da } \\
\text { Capacidade } \\
\text { Instalada }\end{array}$ & $\begin{array}{c}\text { Número de residente } \\
\text { em função do grau de } \\
\text { dependência }\end{array}$ & $\begin{array}{c}\text { Valor médio do } \\
\text { investimento por } \\
\text { proprietário }\end{array}$ \\
\cline { 2 - 4 } & I & II & III & \\
\hline & 60 & 0 & 0 & 95.267 \\
$60 \%$ & 0 & 60 & 0 & 95.339 \\
& 42 & 0 & 60 & 85.599 \\
& 42 & 0 & 18 & 95.296 \\
& 30 & 24 & 6 & 92.965 \\
& 36 & 18 & 6 & 94.663 \\
& 70 & 0 & 0 & 94.649 \\
\hline $0 \%$ & 0 & 70 & 0 & 95.267 \\
& 0 & 0 & 70 & 85.339 \\
& 49 & 21 & 0 & 95.296 \\
& 49 & 0 & 21 & 92.965 \\
& 35 & 28 & 7 & 94.663 \\
& 42 & 21 & 7 & 94.649 \\
\hline
\end{tabular}

\begin{tabular}{ccccc}
\hline $\begin{array}{c}\text { Nível de } \\
\text { utilização da } \\
\text { Capacidade } \\
\text { Instalada }\end{array}$ & $\begin{array}{c}\text { Número de residente } \\
\text { em função do grau de } \\
\text { dependência }\end{array}$ & $\begin{array}{c}\text { Valor médio do } \\
\text { investimento por } \\
\text { proprietário }\end{array}$ \\
\cline { 2 - 4 } & I & II & III & \\
\hline & 00 & 0 & 0 & 95.267 \\
$80 \%$ & 0 & 0 & 0 & 95.339 \\
& 56 & 24 & 0 & 85.599 \\
& 56 & 0 & 24 & 95.296 \\
& 40 & 32 & 8 & 92.965 \\
& 48 & 24 & 8 & 94.663 \\
& 90 & 0 & 0 & 95.267 \\
\hline $00 \%$ & 0 & 90 & 0 & 95.339 \\
& 0 & 0 & 90 & 85.599 \\
& 63 & 27 & 0 & 95.296 \\
& 63 & 0 & 27 & 92.965 \\
& 45 & 36 & 9 & 94.663 \\
& 54 & 27 & 9 & 94.649 \\
\hline
\end{tabular}

A partir da Tabela 27 (p. 83) pode-se estabelecer uma regressão linear múltipla onde a variável dependente $\mathrm{Y}$ é o valor médio do investimento por habitação e o número de residentes com grau de dependência I, II e III são as variáveis independentes X1, X2 e X3. A 
formulação desta regressão exige um realinhamento das informações. Pode-se observar esta representação na Tabela 28 (p. 84).

Tabela 29 - Resumo dos resultados da regressão do valor médio do investimento com simulação do nível de utilização da capacidade instalada para 100 residentes, com diversos graus de dependência

\begin{tabular}{lr}
\hline \multicolumn{2}{c}{ Estatística de regressão } \\
\hline R múltiplo & 0,987 \\
R-Quadrado & 0,974 \\
R-quadrado ajustado & 0,971 \\
Erro padrão & 568,372 \\
Observações & 28 \\
\hline
\end{tabular}

ANOVA

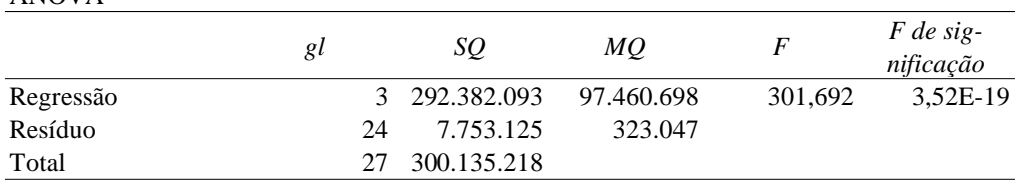

\begin{tabular}{|c|c|c|c|c|c|c|c|c|}
\hline & Coeficientes & Erro padrão & Stat $t$ & valor-P & $\begin{array}{c}95 \% \\
\text { inferiores }\end{array}$ & $\begin{array}{c}95 \% \\
\text { superiores }\end{array}$ & $\begin{array}{c}\text { Inferior } \\
95,0 \%\end{array}$ & $\begin{array}{c}\text { Superior } \\
95,0 \%\end{array}$ \\
\hline Interseção & $93.396,774$ & 728,505 & 128,203 & $1,49 \mathrm{E}-35$ & $91.893,213$ & $94.900,335$ & $91.893,213$ & $94.900,335$ \\
\hline Variável X 1 & 27,997 & 9,825 & 2,850 & 0,009 & 7,720 & 48,274 & 7,720 & 48,274 \\
\hline Variável X 2 & 25,928 & 10,097 & 2,568 & 0,017 & 5,089 & 46,766 & 5,089 & 46,766 \\
\hline Variável X 3 & $-99,898$ & 10,169 & $-9,824$ & $6,95 \mathrm{E}-10$ & $-120,886$ & $-78,909$ & $-120,886$ & $-78,909$ \\
\hline
\end{tabular}

O resumo dos resultados da regressão encontra-se na Tabela 29 (p. 85). Os números indicam que há uma relação significante entre a variável dependente e as variáveis independentes a um nível de significância abaixo de $1 \%$ ( $F$ de significância) e que a regressão explica 97,1\% ( $R$ quadrado ajustado) da variável independente.

A regressão resultante é a seguinte:

$$
Y_{100}=93.396,774+27,997 \times 1+25,928 \times 2-99,898 \times 3
$$

O sinal negativo de x3 é coerente, pois quanto maior o número de habitações para residentes com grau de dependência III, menor o investimento em áreas comuns. Deve-se lembrar que esses residentes normalmente permanecem em suas camas por um longo período de tempo, além de não se locomoverem sem auxílio dos cuidadores.

Como não há diferença de investimento em relação a diferentes níveis de utilização da capacidade instalada para uma organização construída em uma única etapa, a Tabela 30 (p. 86) apresenta o valor dos investimentos em função do número de residentes e dos diversos graus de dependência que os mesmos podem ter. As duas células destacadas indicam o investimento maior e o menor em função das variáveis apresentadas. 
Notam-se que os menores investimentos por habitação são para as organizações que atendem um número maior de residentes, principalmente em função do rateio das áreas comuns.

Tabela 30 - Valor médio do investimento por habitação para 200, 300 e 400 residentes, com diversos graus de dependência

\begin{tabular}{ccccccc}
\hline $\begin{array}{c}\text { Porcentagem de } \\
\text { residentes com } \\
\text { grau de } \\
\text { dependência }\end{array}$ & \multicolumn{6}{c}{$\begin{array}{c}\text { Valor médio do investimento para 200, 300 e } \\
\text { 400 residentes com diversos graus de } \\
\text { dependência }\end{array}$} \\
\cline { 2 - 7 } I, II e III & \multicolumn{5}{c}{$\mathbf{2 0 0}$} & \multicolumn{3}{c}{$\mathbf{3 0 0}$} & $\mathbf{4 0 0}$ \\
\hline $\mathbf{1 0 0 - 0 - 0}$ & $\mathrm{R} \$$ & 96.391 & $\mathrm{R} \$$ & 89.670 & $\mathrm{R} \$$ & 88.112 \\
$\mathbf{0 - 1 0 0 - 0}$ & $\mathrm{R} \$$ & 96.566 & $\mathrm{R} \$$ & 89.881 & $\mathrm{R} \$$ & 88.288 \\
$\mathbf{0 - 0 - 1 0 0}$ & $\mathrm{R} \$$ & 87.037 & $\mathrm{R} \$$ & 80.964 & $\mathrm{R} \$$ & 79.390 \\
$\mathbf{7 0 - 3 0 - 0}$ & $\mathrm{R} \$$ & 96.413 & $\mathrm{R} \$$ & 89.760 & $\mathrm{R} \$$ & 88.133 \\
$\mathbf{7 0 - 0 - 3 0}$ & $\mathrm{R} \$$ & 93.676 & $\mathrm{R} \$$ & 87.249 & $\mathrm{R} \$$ & 85.525 \\
$\mathbf{5 0 - 4 0 - 1 0}$ & $\mathrm{R} \$$ & 95.269 & $\mathrm{R} \$$ & 89.030 & $\mathrm{R} \$$ & 87.297 \\
$\mathbf{6 0 - 3 0 - 1 0}$ & $\mathrm{R} \$$ & 95.262 & $\mathrm{R} \$$ & 89.021 & $\mathrm{R} \$$ & 87.233 \\
\hline
\end{tabular}

Os resumos dos resultados das regressões da Tabela 30 (p. 86) estão representados do Apêndice 46 (p. 253) ao Apêndice 48 (p. 255) e suas equações são as seguintes:

$$
\begin{gathered}
Y_{200}=94.373,439+12,728 \times 1+13,586 \times 2-47,814 \times 3 \\
Y_{300}=87.939,315+8,004 \times 1+8,591 \times 2-30,131 \times 3 \\
Y_{400}=86.282,498+5,922 \times 1+6,478 \times 2-22,455 \times 3
\end{gathered}
$$

\subsection{2 $2^{\mathrm{a}}$ série de simulações - investimentos em função do número de habitações acessíveis a pessoas que utilizam cadeira de rodas}

Esta série de simulações apresenta as diferenças de investimento em função do número de habitações ampliadas, ou seja, para pessoas que necessitam de cadeira de rodas. A última coluna indica o volume de investimento por habitação, caso $100 \%$ das habitações atendessem cadeirantes. Na Tabela 31 (p. 87) pode-se notar que há uma diferença próxima dos $\mathrm{R} \$ 20.000$ por habitação, caso a organização opte por construir todas as habitações ampliadas em vez de $20 \%$ delas.

A célula destacada no valor de $\mathrm{R} \$ 104.226$ indica que este é o valor do investimento para uma organização que comporte 100 residentes, onde $60 \%$ das habitações são acessíveis a pessoas que necessitam de cadeira de rodas. Do total dos residentes, 50\% deles têm grau de dependência I, 40\% grau de dependência II e 10\% dos residentes com grau III. As outras duas células destacadas na Tabela 31 (p. 87) indicam o maior e o menor valor do investimento em função das diferentes combinações do grau de dependência e do número de habitações ampliadas. 
Tabela 31 - Valor médio do investimento por habitação com $20 \%, 40 \%, 60 \%, 80 \%$ e $100 \%$ de habitações destinadas a pessoas que necessitam de cadeira de rodas, para 100 residentes, com diversos graus de dependência

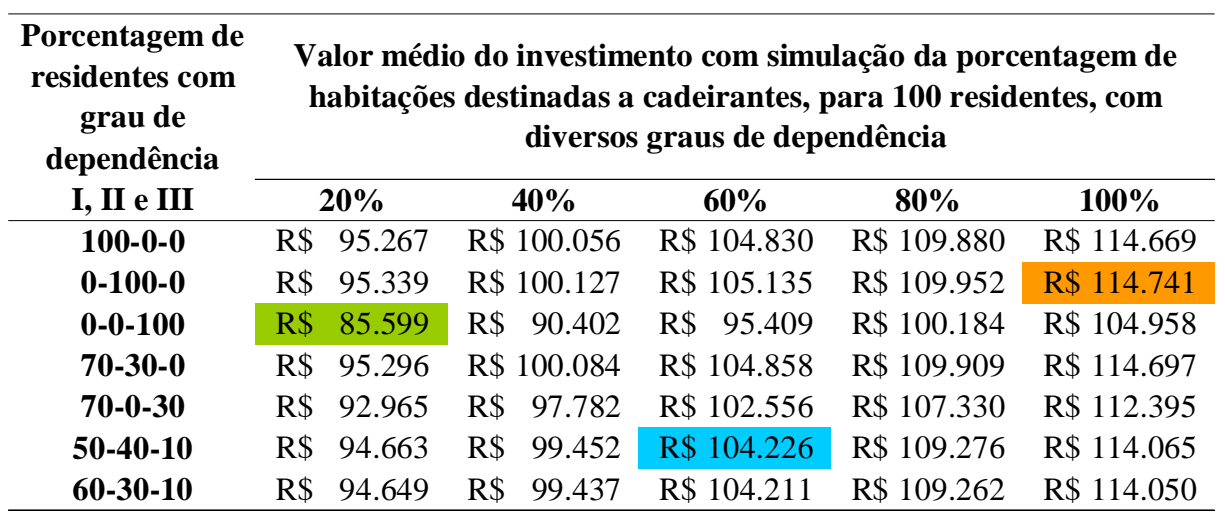

A Tabela 32 (p. 87) apresenta os dados realinhados da Tabela 31 (p. 87) para o cálculo da regressão linear múltipla. A variável dependente Y é o valor médio do investimento por habitação, X1 é a variável independente que representa a proporção de habitações destinadas a cadeirantes, X2, X3 e X4 são as variáveis independentes que representam o número de habitações destinadas aos residentes com graus de dependência I, II e III.

Tabela 32 - Valor médio do investimento por habitação com $20 \%, 40 \%, 60 \%, 80 \%$ e $100 \%$ de habitações destinadas a pessoas que necessitam de cadeira de rodas, para 100 residentes, com diversos graus de dependência (informações realinhadas)

\begin{tabular}{|c|c|c|c|c|c|c|c|c|c|}
\hline \multirow{2}{*}{$\begin{array}{l}\text { Proporção de } \\
\text { habitações } \\
\text { destinadas a } \\
\text { cadeirantes }\end{array}$} & \multicolumn{3}{|c|}{$\begin{array}{c}\text { Número de residente } \\
\text { em função do grau de } \\
\text { dependência }\end{array}$} & \multirow{2}{*}{$\begin{array}{l}\text { Valor médio do } \\
\text { investimento por } \\
\text { proprietário }\end{array}$} & \multirow{2}{*}{$\begin{array}{l}\text { Proporção de } \\
\text { habitações } \\
\text { destinadas a } \\
\text { cadeirantes }\end{array}$} & \multicolumn{3}{|c|}{$\begin{array}{l}\text { Número de residente } \\
\text { em função do grau de } \\
\text { dependência }\end{array}$} & \multirow{2}{*}{$\begin{array}{l}\text { Valor médio do } \\
\text { investimento por } \\
\text { proprietário }\end{array}$} \\
\hline & I & II & III & & & I & II & III & \\
\hline $20 \%$ & 70 & 0 & 0 & 95.267 & $80 \%$ & 70 & 0 & 0 & 109.880 \\
\hline $20 \%$ & 0 & 70 & 0 & 95.339 & $80 \%$ & 0 & 70 & 0 & 109.952 \\
\hline $20 \%$ & 0 & 0 & 70 & 85.599 & $80 \%$ & 0 & 0 & 70 & 100.184 \\
\hline $20 \%$ & 49 & 21 & 0 & 95.296 & $80 \%$ & 49 & 21 & 0 & 109.909 \\
\hline $20 \%$ & 49 & 0 & 21 & 92.965 & $80 \%$ & 49 & 0 & 21 & 107.330 \\
\hline $20 \%$ & 35 & 28 & 7 & 94.663 & $80 \%$ & 35 & 28 & 7 & 109.276 \\
\hline $20 \%$ & 42 & 21 & 7 & 94.649 & $80 \%$ & 42 & 21 & 7 & 109.262 \\
\hline $40 \%$ & 70 & 0 & 0 & 100.056 & $100 \%$ & 70 & 0 & 0 & 114.669 \\
\hline $40 \%$ & 0 & 70 & 0 & 100.127 & $100 \%$ & 0 & 70 & 0 & 114.741 \\
\hline $40 \%$ & 0 & 0 & 70 & 90.402 & $100 \%$ & 0 & 0 & 70 & 104.958 \\
\hline $40 \%$ & 49 & 21 & 0 & 100.084 & $100 \%$ & 49 & 21 & 0 & 114.697 \\
\hline $40 \%$ & 49 & 0 & 21 & 97.782 & $100 \%$ & 49 & 0 & 21 & 112.395 \\
\hline $40 \%$ & 35 & 28 & 7 & 99.452 & $100 \%$ & 35 & 28 & 7 & 114.065 \\
\hline $40 \%$ & 42 & 21 & 7 & 99.437 & $100 \%$ & 42 & 21 & 7 & 114.050 \\
\hline $60 \%$ & 70 & 0 & 0 & 104.830 & & & & & \\
\hline $60 \%$ & 0 & 70 & 0 & 105.135 & & & & & \\
\hline $60 \%$ & 0 & 0 & 70 & 95.409 & & & & & \\
\hline $60 \%$ & 49 & 21 & 0 & 104.858 & & & & & \\
\hline $60 \%$ & 49 & 0 & 21 & 102.556 & & & & & \\
\hline $60 \%$ & 35 & 28 & 7 & 104.226 & & & & & \\
\hline $60 \%$ & 42 & 21 & 7 & 104.211 & & & & & \\
\hline
\end{tabular}


O resumo do resultado da regressão da Tabela 31 (p. 87) está representado no Apêndice 49 (p. 256) e sua equação é a seguinte:

$$
Y_{100}=90.527,350+24.289,013 \times 1+1,337 \times 2+0 \times 3-138,006 \times 4
$$

Apesar da variável independente X3 estar zerada, seu valor é implícito no modelo. Como a equação está formulada para 100 residentes com um nível de aproveitamento da capacidade instalada de 70\%, ou seja, $\mathrm{X} 2+\mathrm{X} 3+\mathrm{X} 4=70$ (vide Tabela 26, p. 82), definindo-se os residentes com grau de dependência I, X2, e III, X4, o número de residentes com grau de dependência II, X3, é obtido por diferença. Para efeito de investimento nota-se aqui uma indiferença entre residentes com grau de dependência I e II, pois ambos utilizam a mesma estrutura da organização. O mesmo não ocorrerá em termos de mensalidades, pois os residentes com grau de dependência maior necessitam de mais cuidadores.

Da Tabela 33 (p. 88) à Tabela 35 (p. 89) também estão destacados o maior e o menor valor do investimento em função das diferentes combinações do grau de dependência e do número de habitações ampliadas para organizações que atendam 200, 300 e 400 residentes, respectivamente.

Tabela 33 - Valor médio do investimento por habitação com $20 \%, 40 \%, 60 \%, 80 \%$ e $100 \%$ de habitações destinadas a pessoas que necessitam de cadeira de rodas, para 200 residentes, com diversos graus de dependência

\begin{tabular}{|c|c|c|c|c|c|c|}
\hline \multirow{2}{*}{$\begin{array}{c}\text { Porcentagem de } \\
\text { residentes com } \\
\text { grau de } \\
\text { dependência } \\
\text { I, II e III }\end{array}$} & \multicolumn{6}{|c|}{$\begin{array}{c}\text { Valor médio do investimento com simulação da porcentagem de } \\
\text { habitações destinadas a cadeirantes, para } 200 \text { residentes, com } \\
\text { diversos graus de dependência }\end{array}$} \\
\hline & & $20 \%$ & $40 \%$ & $60 \%$ & $80 \%$ & $100 \%$ \\
\hline 100-0-0 & $\mathrm{R} \$$ & 96.391 & $\mathrm{R} \$ 101.180$ & $\mathrm{R} \$ 106.057$ & $\mathrm{R} \$ 110.977$ & $\mathrm{R} \$ 115.765$ \\
\hline 0-100-0 & $\mathrm{R} \$$ & 96.566 & $\mathrm{R} \$ 101.368$ & $\mathrm{R} \$ 106.246$ & $\mathrm{R} \$ 111.165$ & $\mathrm{R} \$ 115.954$ \\
\hline 0-0-100 & $\mathrm{R} \$$ & 87.037 & $\mathrm{R} \$ 91.845$ & $\mathrm{R} \$ \quad 96.730$ & $\mathrm{R} \$ 101.642$ & $\mathrm{R} \$ 106.438$ \\
\hline 70-30-0 & $\mathrm{R} \$$ & 96.413 & $\mathrm{R} \$ 101.305$ & $\mathrm{R} \$ 106.092$ & $\mathrm{R} \$ 110.998$ & $\mathrm{R} \$ 115.787$ \\
\hline $70-0-30$ & $\mathrm{R} \$$ & 93.676 & $\mathrm{R} \$ 98.561$ & $\mathrm{R} \$ 103.370$ & $\mathrm{R} \$ 108.269$ & $\mathrm{R} \$ 113.050$ \\
\hline $50-40-10$ & $\mathrm{R} \$$ & 95.269 & $\mathrm{R} \$ 100.182$ & $\mathrm{R} \$ 104.956$ & $\mathrm{R} \$ 109.855$ & $\mathrm{R} \$ 114.767$ \\
\hline $60-30-10$ & $\mathrm{R} \$$ & 95.262 & $\mathrm{R} \$ 100.175$ & $\mathrm{R} \$ 104.949$ & $\mathrm{R} \$ 109.848$ & $\mathrm{R} \$ 114.760$ \\
\hline
\end{tabular}

Com base nos resumos dos resultados representados do Apêndice 50 (p. 257) ao Apêndice 52 (p. 259), pode-se observar a seguir as equações das regressões para 200, 300 e 400 residentes:

$$
\begin{gathered}
\mathrm{Y}_{200}=91.597,934+24.282,488 \times 1-0,947 \times 2+0 \times 3-67,273 \times 4 \\
\mathrm{Y}_{300}=147.452 .847 .851 .440 .000+23.337,441 \times 1-702.156 .418 .339 .784 \times 2- \\
702.156 .418 .339 .783 \times 3-702.156 .418 .339 .826 \times 4 \\
\mathrm{Y}_{400}=83.592,894+23.418,461 \times 1-0,606 \times 2+0 \times 3-31,830 \times 4
\end{gathered}
$$


Tabela 34 - Valor médio do investimento por habitação com $20 \%, 40 \%, 60 \%, 80 \%$ e $100 \%$ de habitações destinadas a pessoas que necessitam de cadeira de rodas, para 300 residentes, com diversos graus de dependência

\begin{tabular}{|c|c|c|c|c|c|c|c|c|}
\hline \multirow{3}{*}{$\begin{array}{c}\text { Porcentagem de } \\
\text { residentes com } \\
\text { grau de } \\
\text { dependência } \\
\text { I, II e III } \\
\end{array}$} & \multicolumn{8}{|c|}{$\begin{array}{c}\text { Valor médio do investimento com simulação da porcentagem de } \\
\text { habitações destinadas a cadeirantes, para } 300 \text { residentes, com } \\
\text { diversos graus de dependência }\end{array}$} \\
\hline & \multicolumn{2}{|c|}{$20 \%$} & \multicolumn{2}{|c|}{$40 \%$} & \multicolumn{2}{|c|}{$60 \%$} & \multirow{2}{*}{$\begin{array}{c}\mathbf{8 0 \%} \\
\mathrm{R} \$ 103.715\end{array}$} & \multirow{2}{*}{$\begin{array}{c}\mathbf{1 0 0 \%} \\
\mathrm{R} \$ 108.411\end{array}$} \\
\hline & $\mathrm{R} \$$ & 896 & $\$$ & 042 & $\$$ & 000 & & \\
\hline & $\mathrm{R} \$$ & 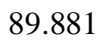 & \$ & & $\$$ & & $\mathrm{R} \$ 103.860$ & $\mathrm{R} \$ 108.555$ \\
\hline & $\mathrm{R} \$$ & 80.964 & $\$$ & & $\$$ & & $\$ 94$ & $\mathrm{R} \$ 99$ \\
\hline & $\mathrm{R} \$$ & 9.760 & $\mathrm{R} \$$ & 94.455 & $\mathrm{R} \$$ & 99.061 & $\$ 103$. & $\$ 108$ \\
\hline & $\mathrm{R} \$$ & 7.249 & $\mathrm{R} \$$ & 91.9 & $\mathrm{R} \$$ & 96. & $\$ 1$ & \\
\hline & $\mathrm{R} \$$ & 9.030 & $\$$ & 93 & $\$$ & & 4 & 07.770 \\
\hline $60-30-10$ & $\mathrm{R} \$$ & 89.021 & $\mathrm{R} \$$ & 93.716 & $\mathrm{R} \$$ & 98.318 & $\mathrm{R} \$ 103.008$ & $\mathrm{R} \$ 107.695$ \\
\hline
\end{tabular}

Tabela 35 - Valor médio do investimento por habitação com $20 \%, 40 \%, 60 \%, 80 \%$ e $100 \%$ de habitações destinadas a pessoas que necessitam de cadeira de rodas, para 400 residentes, com diversos graus de dependência

\begin{tabular}{|c|c|c|c|c|c|c|c|c|}
\hline \multirow{2}{*}{$\begin{array}{l}\text { Porcentagem de } \\
\text { residentes com } \\
\text { grau de } \\
\text { dependência } \\
\text { I, II e III } \\
\end{array}$} & \multicolumn{8}{|c|}{$\begin{array}{c}\text { Valor médio do investimento com simulação da porcentagem de } \\
\text { habitações destinadas a cadeirantes, para } 400 \text { residentes, com } \\
\text { diversos graus de dependência }\end{array}$} \\
\hline & \multicolumn{2}{|c|}{$20 \%$} & \multicolumn{2}{|c|}{$40 \%$} & \multicolumn{2}{|c|}{$60 \%$} & \multirow{2}{*}{$\begin{array}{c}\mathbf{8 0 \%} \\
\mathrm{R} \$ 102.243\end{array}$} & \multirow{2}{*}{$\begin{array}{c}\mathbf{1 0 0 \%} \\
\mathrm{R} \$ 106.911\end{array}$} \\
\hline 100-0-0 & $\mathrm{R} \$$ & 88.112 & $\mathrm{R} \$$ & 92.78 & $\mathrm{R} \$$ & 97.446 & & \\
\hline & $\mathrm{R} \$$ & 88.288 & $\mathrm{R} \$$ & 92 & $\mathrm{R} \$$ & & $\mathrm{R} \$ 102.418$ & $\mathrm{R} \$ 107.086$ \\
\hline & $\mathrm{R} \$$ & 79.390 & $\mathrm{R} \$$ & 84. & $\mathrm{R} \$$ & 0 & $\mathrm{R} \$ 93$ & $\mathrm{R} \$$ \\
\hline & $\mathrm{R} \$$ & 88.1 & $\mathrm{R} \$$ & & $\mathrm{R} \$$ & & $\$ 10$ & \\
\hline & K\$ & . & $\mathrm{R} \$$ & & $\mathrm{R} \$$ & & $\mathrm{R} \$ 9$ & \\
\hline & $\mathrm{R} \$$ & 87. & $\mathrm{R} \$$ & 91. & $\mathrm{R} \$$ & 96. & $\mathrm{R} \$ 10$ & $\mathrm{R} \$$ \\
\hline $60-30-10$ & $\mathrm{R} \$$ & 87.233 & $\mathrm{R} \$$ & 91.951 & $\mathrm{R} \$$ & 96.620 & $\mathrm{R} \$ 101.288$ & $\mathrm{R} \$ 105.957$ \\
\hline
\end{tabular}

Apesar dos valores atípicos da equação para 300 residentes, deve-se considerar que, de acordo com a Tabela 26 (p. 82), existem mais diferenças entre as organizações para 100, 200, 300 e 400 residentes do que simplesmente o número de usuários. A relação área externa e interna, a área do minisshopping, a existência do anfiteatro, das quadras poliesportivas e de saibro e a área da ciclovia são investimentos que diferem entre as organizações com diferentes números de habitações.

\subsection{3 $3^{\mathrm{a}}$ série de simulações - investimentos em função da variação de áreas comuns}

Este grupo de simulações analisa o impacto das áreas comuns no investimento por habitação. Se a organização for construída em uma região central, com pouca disponibilidade de espaço, talvez não seja adequado ou mesmo possível construir piscinas ou quadras, por exemplo.

As premissas destas simulações estão indicadas nas Tabelas 36 e 37 (p. 90). Pode-se perceber que há variação de área de minisshopping, se possui ou não anfiteatro, quantidade de piscinas, 
saunas, campos, quadras, área de pista de pedestre e ciclovia. Consequentemente, surgem variações nas áreas construídas externa e total.

Tabela 36 - Premissas para cálculo de simulações com variação de áreas comuns para 100 e 200 residentes

\begin{tabular}{|c|c|c|c|c|c|c|c|c|}
\hline \multirow{2}{*}{ Descrição } & \multicolumn{8}{|c|}{ Premissas } \\
\hline & $\mathbf{A}$ & $\mathbf{B}$ & $\mathbf{C}$ & D & $\mathbf{E}$ & $\mathbf{F}$ & $\mathbf{G}$ & $\mathbf{H}$ \\
\hline Número máximo de residentes & \multicolumn{4}{|c|}{100} & \multicolumn{4}{|c|}{200} \\
\hline Relação entre área externa e área interna & 0,4 & 0,3 & 0,2 & 0,2 & 0,4 & 0,3 & 0,2 & 0,1 \\
\hline Área do minisshopping & 90 & 90 & 90 & 0 & 180 & 180 & 90 & 0 \\
\hline Possui anfiteatro? & Não & Não & Não & Não & Sim & Sim & Sim & Não \\
\hline Quantidade de piscinas & 1 & 1 & 0 & 0 & 1 & 1 & 0 & 0 \\
\hline Quantidade de saunas secas & 1 & 1 & 0 & 0 & 1 & 1 & 0 & 0 \\
\hline Quantidade de saunas úmidas & 1 & 1 & 0 & 0 & 1 & 1 & 0 & 0 \\
\hline Quantidade de campos de bocha & 1 & 0 & 0 & 0 & 1 & 0 & 0 & 0 \\
\hline Quantidade de campos de malha & 1 & 0 & 0 & 0 & 1 & 0 & 0 & 0 \\
\hline Quantidade de quadras poliesportivas & 0 & 0 & 0 & 0 & 1 & 0 & 0 & 0 \\
\hline Quantidade de quadras de saibro & 0 & 0 & 0 & 0 & 1 & 0 & 0 & 0 \\
\hline Área da pista de pedestre & 500 & 400 & 300 & 200 & 500 & 500 & 500 & 250 \\
\hline Área da ciclovia & 0 & 0 & 0 & 0 & 500 & 0 & 0 & 0 \\
\hline Área construída & 2.710 & 2.701 & 2.699 & 2.609 & 5.446 & 5.434 & 5.333 & 5.080 \\
\hline Área externa & 1.084 & 810 & 540 & 522 & 2.178 & 1.630 & 1.067 & 508 \\
\hline Área total & 3.794 & 3.511 & 3.239 & 3.131 & 7.624 & 7.064 & 6.400 & 5.588 \\
\hline
\end{tabular}

Tabela 37 - Premissas para cálculo de simulações com variação de áreas comuns para 300 e 400 residentes

\begin{tabular}{|c|c|c|c|c|c|c|c|c|}
\hline \multirow{2}{*}{ Descrição } & \multicolumn{8}{|c|}{ Premissas } \\
\hline & $\mathbf{I}$ & $\mathbf{J}$ & $\mathbf{K}$ & $\mathbf{L}$ & M & $\mathbf{N}$ & $\mathbf{O}$ & $\mathbf{P}$ \\
\hline Número máximo de residentes & \multicolumn{4}{|c|}{300} & \multicolumn{4}{|c|}{400} \\
\hline Relação entre área externa e área interna & 0,3 & 0,2 & 0,1 & 0,05 & 0,3 & 0,2 & 0,1 & 0,05 \\
\hline Área do minisshopping & 180 & 180 & 90 & 0 & 180 & 180 & 90 & 0 \\
\hline Possui anfiteatro? & Sim & Sim & Não & Não & Sim & Sim & Não & Não \\
\hline Quantidade de piscinas & 1 & 1 & 0 & 0 & 1 & 1 & 0 & 0 \\
\hline Quantidade de saunas secas & 1 & 1 & 0 & 0 & 1 & 1 & 0 & 0 \\
\hline Quantidade de saunas úmidas & 1 & 1 & 0 & 0 & 1 & 1 & 0 & 0 \\
\hline Quantidade de campos de bocha & 1 & 0 & 0 & 0 & 1 & 0 & 0 & 0 \\
\hline Quantidade de campos de malha & 1 & 0 & 0 & 0 & 1 & 0 & 0 & 0 \\
\hline Quantidade de quadras poliesportivas & 1 & 0 & 0 & 0 & 1 & 0 & 0 & 0 \\
\hline Quantidade de quadras de saibro & 1 & 0 & 0 & 0 & 1 & 0 & 0 & 0 \\
\hline Área da pista de pedestre & 500 & 500 & 250 & 200 & 500 & 500 & 500 & 250 \\
\hline Área da ciclovia & 500 & 0 & 0 & 0 & 500 & 0 & 0 & 0 \\
\hline Área construída & 7.918 & 7.905 & 7.651 & 7.550 & 10.410 & 10.389 & 10.124 & 10.030 \\
\hline Área externa & 2.375 & 1.581 & 765 & 378 & 3.123 & 2.078 & 1.012 & 502 \\
\hline Área total & 10.293 & 9.486 & 8.416 & 7.928 & 13.533 & 12.467 & 11.136 & 10.532 \\
\hline
\end{tabular}

A partir das premissas indicadas nas Tabelas 36 e 37 (p. 90) foram calculados os investimentos em função das diferentes combinações de anfiteatro, área do minisshopping e áreas externas. A Tabela 38 (p. 91) apresenta os valores de uma organização para 100 residentes.

Combinando a premissa "B" da Tabela 36 (p. 90) com a célula destacada da Tabela 38 (p. 91), interpreta-se que uma organização com capacidade para 100 pessoas, com nível de aproveitamento da capacidade instalada de $70 \%$, onde $50 \%$ dos residentes têm grau de 
dependência I, 40\% têm grau de dependência II e 10\% dos residentes com grau III, sem anfiteatro, com um minisshopping de $90 \mathrm{~m}^{2}$, uma piscina, uma sauna seca e uma úmida e com $400 \mathrm{~m}^{2}$ de pista para pedestre, requer um investimento de $\mathrm{R} \$ 91.184$ por habitação.

Tabela 38 - Valor médio do investimento por habitação em função de áreas externas, anfiteatro e minisshopping para 100 residentes, com diversos graus de dependência

\begin{tabular}{|c|c|c|c|c|c|c|c|c|c|c|}
\hline \multirow{2}{*}{$\begin{array}{c}\text { Porcentagem de } \\
\text { residentes com } \\
\text { grau de } \\
\text { dependência } \\
\text { I, II e III }\end{array}$} & \multicolumn{10}{|c|}{$\begin{array}{l}\text { Valor médio do investimento em função de áreas externas, } \\
\text { anfiteatro e minisshopping para } 100 \text { residentes, com diversos graus } \\
\text { de dependência }\end{array}$} \\
\hline & & $\mathbf{A}$ & & B & & $\mathbf{C}$ & & D & & iação \\
\hline $100-0-0$ & $\mathrm{R} \$$ & 95.267 & $\mathrm{R} \$$ & 91.766 & $\mathrm{R} \$$ & 86.664 & $\mathrm{R} \$$ & 84.150 & $\mathrm{R} \$$ & 11.117 \\
\hline 0-100-0 & $\mathrm{R} \$$ & 95.339 & $\mathrm{R} \$$ & 92.035 & $\mathrm{R} \$$ & 86.757 & $\mathrm{R} \$$ & 84.243 & $\mathrm{R} \$$ & 11.096 \\
\hline 0-0-100 & $\mathrm{R} \$$ & 85.599 & $\mathrm{R} \$$ & 82.548 & $\mathrm{R} \$$ & 77.523 & $\mathrm{R} \$$ & 74.995 & $\mathrm{R} \$$ & 10.605 \\
\hline $70-30-0$ & $\mathrm{R} \$$ & 95.296 & $\mathrm{R} \$$ & 91.794 & $\mathrm{R} \$$ & 86.717 & $\mathrm{R} \$$ & 84.177 & $\mathrm{R} \$$ & 11.119 \\
\hline $70-0-30$ & $\mathrm{R} \$$ & 92.965 & $\mathrm{R} \$$ & 89.563 & $\mathrm{R} \$$ & 84.558 & $\mathrm{R} \$$ & 82.057 & $\mathrm{R} \$$ & 10.908 \\
\hline $50-40-10$ & $\mathrm{R} \$$ & 94.663 & $\mathrm{R} \$$ & 91.184 & $\mathrm{R} \$$ & 86.130 & $\mathrm{R} \$$ & 83.616 & $\mathrm{R} \$$ & 11.048 \\
\hline $60-30-10$ & $\mathrm{R} \$$ & 94.649 & $\mathrm{R} \$$ & 91.170 & $\mathrm{R} \$$ & 86.117 & $\mathrm{R} \$$ & 83.602 & $\mathrm{R} \$$ & 11.046 \\
\hline
\end{tabular}

As duas outras células destacadas na Tabela 38 (p. 91), assim como as duas destacadas da Tabela 39 (p. 91) à Tabela 41 (p. 92), indicam os maiores e menores valores de investimento para as premissas e proporções de grau de dependência dos residentes. A coluna "variação" indica a diferença de investimento, para uma mesma combinação de graus de dependência, entre organizações com e sem áreas de esporte e lazer.

Tabela 39 - Valor médio do investimento por habitação em função de áreas externas, anfiteatro e minisshopping para 200 residentes, com diversos graus de dependência

\begin{tabular}{|c|c|c|c|c|c|c|c|c|c|c|}
\hline \multirow{2}{*}{$\begin{array}{l}\text { Porcentagem de } \\
\text { residentes com } \\
\text { grau de } \\
\text { dependência } \\
\text { I, II e III }\end{array}$} & \multicolumn{10}{|c|}{$\begin{array}{l}\text { Valor médio do investimento em função de áreas externas, } \\
\text { anfiteatro e minisshopping para } 200 \text { residentes, com diversos graus } \\
\text { de dependência }\end{array}$} \\
\hline & & $\mathbf{E}$ & & $\mathbf{F}$ & & $\mathbf{G}$ & & $\mathbf{H}$ & & ção \\
\hline $100-0-0$ & $\mathrm{R} \$$ & 96.391 & $\mathrm{R} \$$ & 91.150 & $\mathrm{R} \$$ & 85.918 & $\$$ & & $\$$ & \\
\hline 0-1 & $\mathrm{R} \$$ & 96.566 & $\mathrm{R} \$$ & 91.332 & $\mathrm{R} \$$ & 86.0 & $\mathrm{R} \$$ & 79.702 & . & 16.864 \\
\hline 0-0-100 & $\mathrm{R} \$$ & 87.037 & $\mathrm{R} \$$ & 82.070 & $\mathrm{R} \$$ & 77.043 & $\mathrm{R} \$$ & 70.923 & $\lambda \$$ & 16.113 \\
\hline $70-30-0$ & $\mathrm{R} \$$ & 96.413 & $\mathrm{R} \$$ & 91.171 & $\mathrm{R} \$$ & 85.9 & $\$$ & & R\$ & 16.860 \\
\hline 70-0-30 & $\mathrm{R} \$$ & 93.676 & $\mathrm{R} \$$ & 88.513 & $\mathrm{R} \$$ & 83.454 & $\$$ & 77.044 & $\mathrm{R} \$$ & 16.632 \\
\hline $50-40-10$ & $\mathrm{R} \$$ & 95.269 & $\mathrm{R} \$$ & 90.064 & $\mathrm{R} \$$ & 84.937 & $\mathrm{R} \$$ & 78.577 & $\mathrm{R} \$$ & 16.692 \\
\hline $60-30-10$ & $\mathrm{R} \$$ & 95.262 & $\mathrm{R} \$$ & 90.044 & $\mathrm{R} \$$ & 84.931 & $\mathrm{R} \$$ & 78.479 & $\mathrm{R} \$$ & 16.784 \\
\hline
\end{tabular}

Com base nas Tabelas 36 e 37 (p. 90) foram definidas 15 variáveis independentes. De Relação entre área interna e externa até Área da ciclovia totalizam 12 variáveis. A estas se somam o número de habitações destinadas aos residentes com graus de dependência I, II e III. Tais informações foram realinhadas na Tabela 42 (p. 93) para o cálculo da regressão que 
expressa o comportamento da variável independente valor médio do investimento por habitação.

Tabela 40 - Valor médio do investimento por habitação em função de áreas externas, anfiteatro e minisshopping para 300 residentes, com diversos graus de dependência

\begin{tabular}{|c|c|c|c|c|c|c|c|c|c|c|}
\hline \multirow{2}{*}{$\begin{array}{l}\text { Porcentagem de } \\
\text { residentes com } \\
\text { grau de } \\
\text { dependência } \\
\text { I, II e III }\end{array}$} & \multicolumn{10}{|c|}{$\begin{array}{l}\text { Valor médio do investimento em função de áreas externas, } \\
\text { anfiteatro e minisshopping para } 300 \text { residentes, com diversos graus } \\
\text { de dependência }\end{array}$} \\
\hline & & I & & $\mathbf{J}$ & & $\mathbf{K}$ & & $\mathbf{L}$ & & iação \\
\hline $100-0-0$ & $\mathrm{R} \$$ & 89.670 & $\mathrm{R} \$$ & 85.315 & $\mathrm{R} \$$ & 79.449 & $\mathrm{R} \$$ & 77.263 & $\mathrm{R} \$$ & 12.407 \\
\hline $0-10$ & $\mathrm{R} \$$ & 89.881 & $\mathrm{R} \$$ & & $\mathrm{R} \$$ & & Q\$ & & $\$$ & \\
\hline 0-0-100 & $\mathrm{R} \$$ & 80.964 & $\mathrm{R} \$$ & 76.840 & $\mathrm{R} \$$ & 71.1 & $\mathrm{R} \$$ & 69.144 & $\mathrm{R} \$$ & 11.821 \\
\hline $70-30-0$ & $\mathrm{R} \$$ & 89.760 & $\mathrm{R} \$$ & 85.401 & $\mathrm{R} \$$ & 80.908 & $\mathrm{R} \$$ & 77.284 & $\mathrm{R} \$$ & 12.476 \\
\hline $70-0-30$ & $\mathrm{R} \$$ & 87.249 & $\mathrm{R} \$$ & 82.961 & $\mathrm{R} \$$ & 78.540 & $\$$ & 75.007 & $\mathrm{R} \$$ & 12.242 \\
\hline $50-40-10$ & $\mathrm{R} \$$ & 89.030 & $\mathrm{R} \$$ & 84.695 & $\mathrm{R} \$$ & 78.787 & $\mathrm{R} \$$ & 76.673 & $\mathrm{R} \$$ & 12.357 \\
\hline $60-30-10$ & $\mathrm{R} \$$ & 89.021 & $\mathrm{R} \$$ & 84.686 & $\mathrm{R} \$$ & 78.779 & $\mathrm{R} \$$ & 76.664 & $\mathrm{R} \$$ & 12.357 \\
\hline
\end{tabular}

Tabela 41 - Valor médio do investimento por habitação em função de áreas externas, anfiteatro e minisshopping para 400 residentes, com diversos graus de dependência

\begin{tabular}{|c|c|c|c|c|c|c|c|c|c|c|}
\hline \multirow{2}{*}{$\begin{array}{l}\text { Porcentagem de } \\
\text { residentes com } \\
\text { grau de } \\
\text { dependência } \\
\text { I, II e III }\end{array}$} & \multicolumn{10}{|c|}{$\begin{array}{l}\text { Valor médio do investimento em função de áreas externas, } \\
\text { anfiteatro e minisshopping para } 400 \text { residentes, com diversos graus } \\
\text { de dependência }\end{array}$} \\
\hline & & $\mathbf{M}$ & & $\mathbf{N}$ & & $\mathbf{O}$ & & $\mathbf{P}$ & & ação \\
\hline $100-0-0$ & $\mathrm{R} \$$ & 88.112 & $\mathrm{R} \$$ & 84.143 & $\mathrm{R} \$$ & 79.095 & $\mathrm{R} \$$ & 77.119 & $\mathrm{R} \$$ & 10.993 \\
\hline $0-10$ & $\mathrm{R} \$$ & 88.288 & $\mathrm{R} \$$ & 84.312 & $\mathrm{R} \$$ & 79.2 & $\mathrm{R} \$$ & 77.286 & $\mathrm{R} \$$ & 11. \\
\hline $0-0-100$ & $\mathrm{R} \$$ & 79.390 & $\mathrm{R} \$$ & 75.715 & $\mathrm{R} \$$ & 70.901 & $\mathrm{R} \$$ & 69.005 & $\mathrm{R} \$$ & 10.385 \\
\hline $70-30-0$ & $\mathrm{R} \$$ & 88.133 & $\mathrm{R} \$$ & 84.217 & $\mathrm{R} \$$ & & $\mathrm{R} \$$ & & $\mathrm{R} \$$ & 10.988 \\
\hline $70-0-30$ & $\mathrm{R} \$$ & 85.525 & $\mathrm{R} \$$ & 81.671 & $\mathrm{R} \$$ & 77.7 & $\mathrm{R} \$$ & 74. & $\mathrm{R} \$$ & 10.802 \\
\hline $50-40-10$ & $\mathrm{R} \$$ & 87.297 & $\mathrm{R} \$$ & 83.342 & $\mathrm{R} \$$ & 78.324 & $\mathrm{R} \$$ & 76.362 & $\mathrm{R} \$$ & 10.934 \\
\hline $60-30-10$ & $\mathrm{R} \$$ & 87.233 & $\mathrm{R} \$$ & 83.328 & $\mathrm{R} \$$ & 78.311 & $\mathrm{R} \$$ & 76.311 & $\mathrm{R} \$$ & 10.923 \\
\hline
\end{tabular}

De acordo com as premissas estabelecidas na Tabela 26 (p. 82), a simulação para 100 residentes tem um nível de aproveitamento da capacidade instalada de 70\%. Assim, a soma das variáveis x13, x14 e x15 totalizam 70 .

O resumo do resultado da regressão valor médio do investimento por habitação em função de áreas externas, anfiteatro e minisshopping para 100 residentes, com diversos graus de dependência, está expressa na Tabela 43 (p. 94). O $R^{2}$ ajustado, que até então estava tão próximo de um quanto o $R^{2}$, passou para $56,9 \%$. Este quociente mede a eficiência do modelo levando em consideração o número de variáveis independentes e o tamanho da amostra. Como as variáveis independentes $\mathrm{x} 1, \mathrm{x} 3, \mathrm{x} 4, \mathrm{x} 5, \mathrm{x} 6, \mathrm{x} 8, \mathrm{x} 9, \mathrm{x} 10$ e x12 foram zeradas, as informações foram novamente realinhadas sem estas variáveis e estão apresentadas na Tabela 44 (p. 94). 
Tabela 42 - Valor médio do investimento por habitação em função de áreas externas, anfiteatro e minisshopping para 100 residentes, com diversos graus de dependência (informações realinhadas para 15 variáveis independentes)

\begin{tabular}{|c|c|c|c|c|c|c|c|c|c|c|c|c|c|c|c|c|}
\hline \multirow{4}{*}{ 营 } & \multirow{3}{*}{ 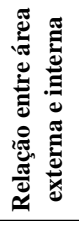 } & \multirow{3}{*}{ 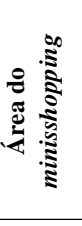 } & \multirow{3}{*}{ 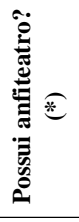 } & \multicolumn{7}{|c|}{ Quantidade de } & \multirow{3}{*}{ 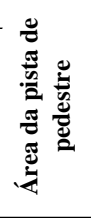 } & \multirow{3}{*}{ 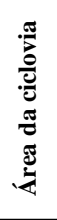 } & \multirow{2}{*}{\multicolumn{3}{|c|}{$\begin{array}{l}\text { Número de residentes } \\
\text { com grau de } \\
\text { dependência }\end{array}$}} & \multirow{3}{*}{ 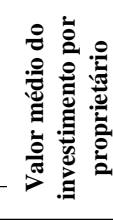 } \\
\hline & & & & \multirow{2}{*}{ 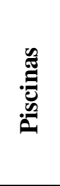 } & \multirow{2}{*}{ 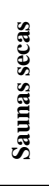 } & \multirow{2}{*}{ 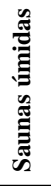 } & \multirow{2}{*}{ 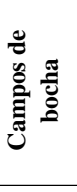 } & \multirow{2}{*}{ 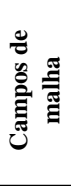 } & \multirow{2}{*}{ 苞 } & \multirow{2}{*}{ 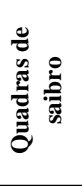 } & & & & & & \\
\hline & & & & & & & & & & & & & I & II & III & \\
\hline & $\mathrm{x1}$ & $\mathrm{x} 2$ & $\mathrm{x} 3$ & $\mathrm{x} 4$ & $\mathrm{x} 5$ & x6 & $\mathrm{x} 7$ & $\mathrm{x8}$ & $\mathrm{x9}$ & x10 & $\mathrm{x11}$ & $\mathrm{x12}$ & $\mathrm{x13}$ & $\mathrm{x14}$ & x15 & $\mathbf{Y}$ \\
\hline \multirow{7}{*}{ A } & 0,4 & 90 & 0 & 1 & 1 & 1 & 1 & 1 & 0 & 0 & 500 & 0 & 70 & 0 & 0 & 95.267 \\
\hline & 0,4 & 90 & 0 & 1 & 1 & 1 & 1 & 1 & 0 & 0 & 500 & 0 & 0 & 70 & 0 & 95.339 \\
\hline & 0,4 & 90 & 0 & 1 & 1 & 1 & 1 & 1 & 0 & 0 & 500 & 0 & 0 & 0 & 70 & 85.599 \\
\hline & 0,4 & 90 & 0 & 1 & 1 & 1 & 1 & 1 & 0 & 0 & 500 & 0 & 49 & 21 & 0 & 95.296 \\
\hline & 0,4 & 90 & 0 & 1 & 1 & 1 & 1 & 1 & 0 & 0 & 500 & 0 & 49 & 0 & 21 & 92.965 \\
\hline & 0,4 & 90 & 0 & 1 & 1 & 1 & 1 & 1 & 0 & 0 & 500 & 0 & 35 & 28 & 7 & 94.663 \\
\hline & 0,4 & 90 & 0 & 1 & 1 & 1 & 1 & 1 & 0 & 0 & 500 & 0 & 42 & 21 & 7 & 94.649 \\
\hline \multirow{7}{*}{ B } & 0,3 & 90 & 0 & 1 & 1 & 1 & 0 & 0 & 0 & 0 & 400 & 0 & 70 & 0 & 0 & 91.766 \\
\hline & 0,3 & 90 & 0 & 1 & 1 & 1 & 0 & 0 & 0 & 0 & 400 & 0 & 0 & 70 & 0 & 92.035 \\
\hline & 0,3 & 90 & 0 & 1 & 1 & 1 & 0 & 0 & 0 & 0 & 400 & 0 & 0 & 0 & 70 & 82.548 \\
\hline & 0,3 & 90 & 0 & 1 & 1 & 1 & 0 & 0 & 0 & 0 & 400 & 0 & 49 & 21 & 0 & 91.794 \\
\hline & 0,3 & 90 & 0 & 1 & 1 & 1 & 0 & 0 & 0 & 0 & 400 & 0 & 49 & 0 & 21 & 89.563 \\
\hline & 0,3 & 90 & 0 & 1 & 1 & 1 & 0 & 0 & 0 & 0 & 400 & 0 & 35 & 28 & 7 & 91.184 \\
\hline & 0,3 & 90 & 0 & 1 & 1 & 1 & 0 & 0 & 0 & 0 & 400 & 0 & 42 & 21 & 7 & 91.170 \\
\hline \multirow{7}{*}{ C } & 0,2 & 90 & 0 & 0 & 0 & 0 & 0 & 0 & 0 & 0 & 300 & 0 & 70 & 0 & 0 & 86.664 \\
\hline & 0,2 & 90 & 0 & 0 & 0 & 0 & 0 & 0 & 0 & 0 & 300 & 0 & 0 & 70 & 0 & 86.757 \\
\hline & 0,2 & 90 & 0 & 0 & 0 & 0 & 0 & 0 & 0 & 0 & 300 & 0 & 0 & 0 & 70 & 77.523 \\
\hline & 0,2 & 90 & 0 & 0 & 0 & 0 & 0 & 0 & 0 & 0 & 300 & 0 & 49 & 21 & 0 & 86.717 \\
\hline & 0,2 & 90 & 0 & 0 & 0 & 0 & 0 & 0 & 0 & 0 & 300 & 0 & 49 & 0 & 21 & 84.558 \\
\hline & 0,2 & 90 & 0 & 0 & 0 & 0 & 0 & 0 & 0 & 0 & 300 & 0 & 35 & 28 & 7 & 86.130 \\
\hline & 0,2 & 90 & 0 & 0 & 0 & 0 & 0 & 0 & 0 & 0 & 300 & 0 & 42 & 21 & 7 & 86.117 \\
\hline \multirow{7}{*}{ D } & 0,2 & 0 & 0 & 0 & 0 & 0 & 0 & 0 & 0 & 0 & 200 & 0 & 70 & 0 & 0 & 84.150 \\
\hline & 0,2 & 0 & 0 & 0 & 0 & 0 & 0 & 0 & 0 & 0 & 200 & 0 & 0 & 70 & 0 & 84.243 \\
\hline & 0,2 & 0 & 0 & 0 & 0 & 0 & 0 & 0 & 0 & 0 & 200 & 0 & 0 & 0 & 70 & 74.995 \\
\hline & 0,2 & 0 & 0 & 0 & 0 & 0 & 0 & 0 & 0 & 0 & 200 & 0 & 49 & 21 & 0 & 84.177 \\
\hline & 0,2 & 0 & 0 & 0 & 0 & 0 & 0 & 0 & 0 & 0 & 200 & 0 & 49 & 0 & 21 & 82.057 \\
\hline & 0,2 & 0 & 0 & 0 & 0 & 0 & 0 & 0 & 0 & 0 & 200 & 0 & 35 & 28 & 7 & 83.616 \\
\hline & 0,2 & 0 & 0 & 0 & 0 & 0 & 0 & 0 & 0 & 0 & 200 & 0 & 42 & 21 & 7 & 83.602 \\
\hline
\end{tabular}

* 0 = não possui anfiteatro; 1 = possui anfiteatro.

A partir das informações realinhadas para seis variáveis independentes, um novo cálculo foi feito para definir a equação. O resumo dos resultados encontra-se na Tabela 45 (p. 95). Podese perceber que os coeficientes das variáveis independentes x2, x7, x11, x13, x14 e x15 da Tabela 43 (p. 94) são iguais às variáveis de x1 a x6 do novo resumo. Como o número de observações ficou inalterado e o número de variáveis independentes diminuiu, o $R^{2}$ ajustado passou de $56,9 \%$ para $99,8 \%$.

A equação da regressão para 100 residentes pode ser observada a seguir:

$$
\begin{gathered}
\mathrm{Y}_{100}=279.825 .231 .263 .793 .000-27,877 \times 1-1.698,309 \times 2+50,656 \times 3 \\
-3.997 .503 .303 .767 .410 \times 4-3.997 .503 .303 .767 .410 \times 5 \\
-3.997 .503 .303 .767 .540 \times 6
\end{gathered}
$$


Tabela 43 - Resumo dos resultados da regressão do valor médio do investimento por habitação em função de áreas externas, anfiteatro e minisshopping para 100 residentes, com diversos graus de dependência, para 15 variáveis independentes

\begin{tabular}{lr}
\hline \multicolumn{2}{c}{ Estatística de regressão } \\
\hline R múltiplo & 0,999 \\
R-Quadrado & 0,998 \\
R-quadrado ajustado & 0,569 \\
Erro padrão & 260,613 \\
Observações & 28 \\
\hline
\end{tabular}

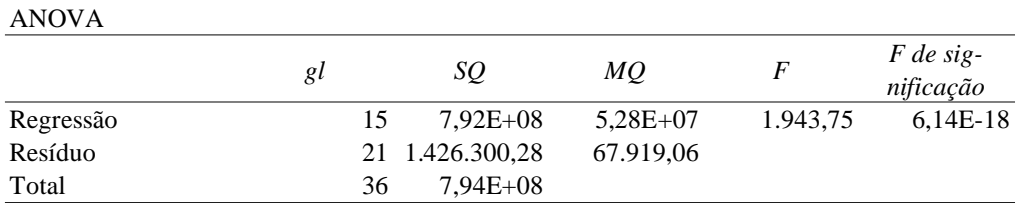

\begin{tabular}{|c|c|c|c|c|c|c|c|c|}
\hline & Coeficientes & Erro padrão & Stat $t$ & valor-P & $\begin{array}{c}95 \% \\
\text { inferiores }\end{array}$ & $\begin{array}{c}95 \% \\
\text { superiores }\end{array}$ & $\begin{array}{c}\text { Inferior } \\
95,0 \%\end{array}$ & $\begin{array}{c}\text { Superior } \\
95,0 \%\end{array}$ \\
\hline Interseção & $2,80 \mathrm{E}+17$ & $4,85 \mathrm{E}+17$ & 0,577 & 0,570 & $-7,30 \mathrm{E}+17$ & $1,29 \mathrm{E}+18$ & $-7,30 \mathrm{E}+17$ & $1,29 \mathrm{E}+18$ \\
\hline Variável X 1 & 0 & 0 & 65535 & - & 0 & 0 & 0 & 0 \\
\hline Variável X 2 & $-27,877$ & 2,900 & $-9,611$ & $3,86 \mathrm{E}-09$ & $-33,909$ & $-21,845$ & $-33,909$ & $-21,845$ \\
\hline Variável X 3 & 0 & 0 & 65535 & - & 0 & 0 & 0 & 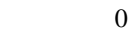 \\
\hline Variável X 4 & 0 & 0 & 65535 & - & 0 & 0 & 0 & \\
\hline Variável X 7 & $-1.698,309$ & 241,307 & $-7,038$ & $6,02 \mathrm{E}-07$ & $-2.200,134$ & $-1.196,484$ & $-2.200,134$ & $-1.196,484$ \\
\hline Variável X 8 & 0 & 0 & 65535 & - & 0 & 0 & 0 & 0 \\
\hline Variável X 9 & 0 & 0 & 65535 & - & 0 & 0 & 0 & 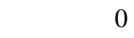 \\
\hline Variável X 10 & 0 & 0 & 65535 & - & 0 & 0 & 0 & 0 \\
\hline Variável X 11 & 50,656 & 1,432 & 35,385 & $3,32 \mathrm{E}-20$ & 47,679 & 53,633 & 47,679 & 53,633 \\
\hline Variável X 15 & $-4,00 \mathrm{E}+15$ & $6,93 \mathrm{E}+15$ & $-0,577$ & 0,570 & $-1,84 \mathrm{E}+16$ & $1,04 \mathrm{E}+16$ & $-1,84 \mathrm{E}+16$ & $1,04 \mathrm{E}+16$ \\
\hline
\end{tabular}

Tabela 44 - Valor médio do investimento por habitação em função de áreas externas, anfiteatro e minisshopping para 100 residentes, com diversos graus de dependência (informações realinhadas para 6 variáveis independentes)

\begin{tabular}{|c|c|c|c|c|c|c|c|}
\hline \multirow{3}{*}{ 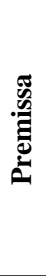 } & \multirow{3}{*}{ 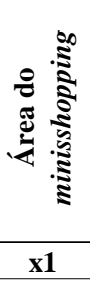 } & \multirow{2}{*}{ 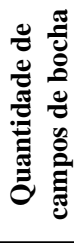 } & \multirow{2}{*}{ 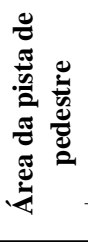 } & \multicolumn{3}{|c|}{$\begin{array}{c}\text { Número de } \\
\text { residentes com grau } \\
\text { de dependência }\end{array}$} & \multirow{2}{*}{ 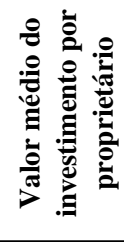 } \\
\hline & & & & I & II & III & \\
\hline & & $\mathrm{x} 2$ & $\mathrm{x3}$ & $x 4$ & $\mathrm{x5}$ & $\mathrm{x6}$ & $\mathbf{Y}$ \\
\hline \multirow{7}{*}{$\mathbf{A}$} & 90 & 1 & 500 & 70 & 0 & 0 & 95.267 \\
\hline & 90 & 1 & 500 & 0 & 70 & 0 & 95.339 \\
\hline & 90 & 1 & 500 & 0 & 0 & 70 & 85.599 \\
\hline & 90 & 1 & 500 & 49 & 21 & 0 & 95.296 \\
\hline & 90 & 1 & 500 & 49 & 0 & 21 & 92.965 \\
\hline & 90 & 1 & 500 & 35 & 28 & 7 & 94.663 \\
\hline & 90 & 1 & 500 & 42 & 21 & 7 & 94.649 \\
\hline \multirow{7}{*}{ B } & 90 & 0 & 400 & 70 & 0 & 0 & 91.766 \\
\hline & 90 & 0 & 400 & 0 & 70 & 0 & 92.035 \\
\hline & 90 & 0 & 400 & 0 & 0 & 70 & 82.548 \\
\hline & 90 & 0 & 400 & 49 & 21 & 0 & 91.794 \\
\hline & 90 & 0 & 400 & 49 & 0 & 21 & 89.563 \\
\hline & 90 & 0 & 400 & 35 & 28 & 7 & 91.184 \\
\hline & 90 & 0 & 400 & 42 & 21 & 7 & 91.170 \\
\hline
\end{tabular}

\begin{tabular}{|c|c|c|c|c|c|c|c|}
\hline \multirow{3}{*}{ 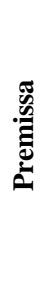 } & \multirow{2}{*}{ 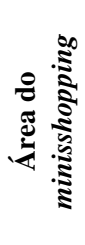 } & \multirow{2}{*}{ 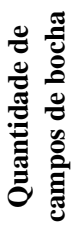 } & \multirow{2}{*}{ 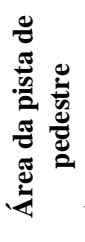 } & \multicolumn{3}{|c|}{$\begin{array}{l}\text { Número de } \\
\text { residentes com grau } \\
\text { de dependência }\end{array}$} & \multirow{2}{*}{ 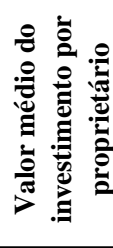 } \\
\hline & & & & I & II & III & \\
\hline & $\mathrm{x1}$ & $\mathbf{x 2}$ & x3 & $\mathrm{x4}$ & $\times 5$ & x6 & $\mathbf{Y}$ \\
\hline \multirow{7}{*}{ C } & 90 & 0 & 300 & 70 & 0 & 0 & 86.664 \\
\hline & 90 & 0 & 300 & 0 & 70 & 0 & 86.757 \\
\hline & 90 & 0 & 300 & 0 & 0 & 70 & 77.523 \\
\hline & 90 & 0 & 300 & 49 & 21 & 0 & 86.717 \\
\hline & 90 & 0 & 300 & 49 & 0 & 21 & 84.558 \\
\hline & 90 & 0 & 300 & 35 & 28 & 7 & 86.130 \\
\hline & 90 & 0 & 300 & 42 & 21 & 7 & 86.117 \\
\hline \multirow{7}{*}{ D } & 0 & 0 & 200 & 70 & 0 & 0 & 84.150 \\
\hline & 0 & 0 & 200 & 0 & 70 & 0 & 84.243 \\
\hline & 0 & 0 & 200 & 0 & 0 & 70 & 74.995 \\
\hline & 0 & 0 & 200 & 49 & 21 & 0 & 84.177 \\
\hline & 0 & 0 & 200 & 49 & 0 & 21 & 82.057 \\
\hline & 0 & 0 & 200 & 35 & 28 & 7 & 83.616 \\
\hline & 0 & 0 & 200 & 42 & 21 & 7 & 83.602 \\
\hline
\end{tabular}


Tabela 45 - Resumo dos resultados da regressão do valor médio do investimento por habitação em função de áreas externas, anfiteatro e minisshopping para 100 residentes, com diversos graus de dependência, para 6 variáveis independentes

\begin{tabular}{lr}
\hline \multicolumn{2}{c}{ Estatística de regressão } \\
\hline R múltiplo & 0,999 \\
R-Quadrado & 0,998 \\
R-quadrado ajustado & 0,998 \\
Erro padrão & 260,613 \\
Observações & 28 \\
\hline
\end{tabular}

\begin{tabular}{|c|c|c|c|c|c|}
\hline & & $S Q$ & $M Q$ & $F$ & $\begin{array}{l}\text { F de sig- } \\
\text { nificação }\end{array}$ \\
\hline Regressão & 6 & $7,92 \mathrm{E}+08$ & $1,32 \mathrm{E}+08$ & $1.943,745$ & $1,07 \mathrm{E}-27$ \\
\hline Resíduo & 21 & $1,43 E+06$ & $67.919,061$ & & \\
\hline Total & 27 & $7,94 \mathrm{E}+08$ & & & \\
\hline
\end{tabular}

\begin{tabular}{|c|c|c|c|c|c|c|c|c|}
\hline & Coeficientes & Erro padrão & Stat $t$ & valor- $P$ & $\begin{array}{c}95 \% \\
\text { inferiores }\end{array}$ & $\begin{array}{c}95 \% \\
\text { superiores }\end{array}$ & $\begin{array}{c}\text { Inferior } \\
95,0 \%\end{array}$ & $\begin{array}{c}\text { Superior } \\
95,0 \%\end{array}$ \\
\hline Interseção & $2,80 \mathrm{E}+17$ & $4,85 \mathrm{E}+17$ & 0,577 & 0,570 & $-7,30 \mathrm{E}+17$ & $1,29 \mathrm{E}+18$ & $-7,30 \mathrm{E}+17$ & $1,29 \mathrm{E}+18$ \\
\hline Variável X 1 & $-27,877$ & 2,900 & $-9,611$ & $3,86 \mathrm{E}-09$ & $-33,909$ & $-21,845$ & $-33,909$ & $-21,845$ \\
\hline Variável X 2 & $-1.698,309$ & 241,307 & $-7,038$ & $6,02 \mathrm{E}-07$ & $-2.200,134$ & $-1.196,484$ & $-2.200,134$ & $-1.196,484$ \\
\hline Variável X 3 & 50,656 & 1,432 & 35,385 & $3,32 \mathrm{E}-20$ & 47,679 & 53,633 & 47,679 & 53,633 \\
\hline Variável X 4 & $-4,00 \mathrm{E}+15$ & $6,93 E+15$ & $-0,577$ & 0,570 & $-1,84 \mathrm{E}+16$ & $1,04 \mathrm{E}+16$ & $-1,84 \mathrm{E}+16$ & $1,04 \mathrm{E}+16$ \\
\hline Variável X 5 & $-4,00 \mathrm{E}+15$ & $6,93 E+15$ & $-0,577$ & 0,570 & $-1,84 \mathrm{E}+16$ & $1,04 \mathrm{E}+16$ & $-1,84 \mathrm{E}+16$ & $1,04 \mathrm{E}+16$ \\
\hline Variável X 6 & $-4,00 \mathrm{E}+15$ & $6,93 \mathrm{E}+15$ & $-0,577$ & 0,570 & $-1,84 \mathrm{E}+16$ & $1,04 \mathrm{E}+16$ & $-1,84 \mathrm{E}+16$ & $1,04 \mathrm{E}+16$ \\
\hline
\end{tabular}

Tanto os resumos dos resultados das regressões da Tabela 39 (p. 91) à Tabela 41 (p. 92), quanto as informações realinhadas podem ser observados do Apêndice 53 (p. 260) ao Apêndice 64 (p. 271). As equações das regressões calculadas foram as seguintes:

$$
\begin{aligned}
& Y_{200}=69.437,171+57,209 \times 1+4,829 \times 2+10,363 \times 3+63,711 \times 4+64,578 \times 5 \\
& Y_{300}=65.979,998+20,109 \times 1+14,599 \times 2+8,617 \times 3+40,962 \times 4+40,512 \times 5 \\
& Y_{400}=71.173,273+52,090 \times 1-9,631 \times 2+7,785 \times 3+30,250 \times 4+30,261 \times 5
\end{aligned}
$$

Para as três equações x1 é a área do minisshopping, x2 é a área da pista de pedestre, x3 é a área da ciclovia, x4 é o número de residentes com grau de dependência I e x5 é o número de residentes com grau de dependência II.

Depois que as informações foram realinhadas e as variáveis nulas descartadas no cálculo das novas equações, os $R^{2}$ ajustados foram os seguintes:

$$
\mathrm{R}_{\text {ajustado 200 }}^{2}=0,999 \quad \mathrm{R}_{\text {ajustado 300 }}^{2}=0,996 \quad \mathrm{R}_{\text {ajustado } 400}^{2}=0,997
$$

\subsection{4 $4^{\text {a }}$ série de simulações - mensalidades em função do nível de utilização da capacidade instalada}

Estas simulações de valor de mensalidade foram feitas para 100, 200, 300 e 400 residentes com $60 \%, 70 \%, 80 \%$ e $90 \%$ de utilização da capacidade instalada. Nestas mensalidades não 
estão inclusos os créditos que serão gerados aos proprietários, pois uma simulação tratará somente desta variável.

Da Tabela 46 (p. 97) à Tabela 49 (p. 98), estão apresentados os resultados desta primeira simulação. Eles evidenciam os resultados para 100, 200, 300 e 400 residentes, respectivamente. As colunas destacam o nível de aproveitamento da capacidade instalada. Tomando como base uma organização que atende até 100 residentes, a primeira coluna apresenta a mensalidade quando 60 vagas estiverem ocupadas.

As linhas das tabelas diferenciam as mensalidades em função do grau de dependência dos residentes. As proporções utilizadas estão destacadas na Tabela 25 (p. 82). Na Tabela 46 (p. 97) três células foram destacadas. Uma com o valor máximo da mensalidade, outra com o valor mínimo e uma terceira, de valor intermediário, para exemplo.

A célula destacada na Tabela 46 (p. 97), de valor intermediário, indica que uma organização com capacidade para 100 residentes, trabalhando a $70 \%$ desta capacidade, ou seja, com 70 residentes, sendo 35 deles (50\%) com grau de dependência I, 28 (40\%) com grau de dependência II e 7 (10\%) com grau de dependência III, precisa cobrar em média R 3.820 para que seus custos e despesas sejam cobertos.

Pode-se notar que a menor mensalidade é obtida com o maior nível de aproveitamento da capacidade instalada e com o máximo de residentes com grau de dependência I. A maior mensalidade é alcançada com o menor nível de aproveitamento da capacidade instalada e com o máximo de residentes com grau de dependência III.

Da Tabela 47 (p. 97) à Tabela 49 (p. 98), as células destacadas indicam as menores e maiores mensalidades obtidas na simulação, sempre em função do número de residentes.

A mensalidade média tende a ser mais onerosa quanto maior o número de residentes com grau alto de dependência. Cada 20 residentes com grau de dependência I exigem um cuidador, oito horas por dia. Para os residentes com grau de dependência II, cada 10 precisam de um cuidador, 24 horas por dia, ou seja, três pessoas em turnos de oito horas. Cada grupo de seis residentes com grau de dependência III exige um cuidador, oito horas por dia. 
Tabela 46 - Valor médio de mensalidade com 60\%, 70\%, $80 \%$ e $90 \%$ de utilização da capacidade instalada para 100 residentes, com diversos graus de dependência

\begin{tabular}{|c|c|c|c|c|c|c|c|c|}
\hline \multirow{3}{*}{$\begin{array}{c}\text { Porcentagem de } \\
\text { residentes com } \\
\text { grau de } \\
\text { dependência } \\
\text { I, II e III } \\
100-0-0\end{array}$} & \multicolumn{8}{|c|}{$\begin{array}{l}\text { Valor médio de mensalidade com simulação do nível } \\
\text { de utilização da capacidade instalada para } 100 \\
\text { residentes, com diversos graus de dependência }\end{array}$} \\
\hline & \multicolumn{2}{|c|}{$60 \%$} & \multicolumn{2}{|c|}{$70 \%$} & \multicolumn{2}{|c|}{$80 \%$} & \multicolumn{2}{|c|}{$90 \%$} \\
\hline & $\mathrm{R} \$$ & 3.754 & $\mathrm{R} \$$ & 3.291 & $\mathrm{R} \$$ & 2.888 & $\mathrm{R} \$$ & 2.644 \\
\hline 0-100-0 & $\mathrm{R} \$$ & 4.466 & $\mathrm{R} \$$ & 3.982 & $\mathrm{R} \$$ & 3.600 & $\mathrm{R} \$$ & 3.341 \\
\hline 0-0-100 & $\mathrm{R} \$$ & 4.729 & $\mathrm{R} \$$ & 4.330 & $\mathrm{R} \$$ & 4.011 & $\mathrm{R} \$$ & 3.667 \\
\hline $70-30-0$ & $\mathrm{R} \$$ & 4.039 & $\mathrm{R} \$$ & 3.616 & $\mathrm{R} \$$ & 3.173 & $\mathrm{R} \$$ & 2.898 \\
\hline $70-0-30$ & $\mathrm{R} \$$ & 4.073 & $\mathrm{R} \$$ & 3.646 & $\mathrm{R} \$$ & 3.198 & $\mathrm{R} \$$ & 2.977 \\
\hline $50-40-10$ & $\mathrm{R} \$$ & 4.276 & $\mathrm{R} \$$ & 3.820 & $\mathrm{R} \$$ & 3.457 & $\mathrm{R} \$$ & 3.151 \\
\hline $60-30-10$ & $\mathrm{R} \$$ & 4.133 & $\mathrm{R} \$$ & 3.860 & $\mathrm{R} \$$ & 3.386 & $\mathrm{R} \$$ & 3.056 \\
\hline
\end{tabular}

Tabela 47 - Valor médio de mensalidade com 60\%, 70\%, $80 \%$ e $90 \%$ de utilização da capacidade instalada para 200 residentes, com diversos graus de dependência

\begin{tabular}{|c|c|c|c|c|c|c|c|c|}
\hline \multirow{3}{*}{$\begin{array}{c}\text { Porcentagem de } \\
\text { residentes com } \\
\text { grau de } \\
\text { dependência } \\
\text { I, II e III } \\
100-0-0\end{array}$} & \multicolumn{8}{|c|}{$\begin{array}{l}\text { Valor médio de mensalidade com simulação do nível } \\
\text { de utilização da capacidade instalada para } 200 \\
\text { residentes, com diversos graus de dependência }\end{array}$} \\
\hline & \multicolumn{2}{|c|}{$60 \%$} & \multicolumn{2}{|c|}{$70 \%$} & \multicolumn{2}{|c|}{$80 \%$} & \multicolumn{2}{|c|}{$90 \%$} \\
\hline & $\mathrm{R} \$$ & 3.392 & $\mathrm{R} \$$ & 2.973 & $\mathrm{R} \$$ & 2.638 & $\mathrm{R} \$$ & 2.387 \\
\hline 0-100-0 & $\mathrm{R} \$$ & 4.104 & $\mathrm{R} \$$ & 3.686 & $\mathrm{R} \$$ & 3.350 & $\mathrm{R} \$$ & 3.100 \\
\hline 0-0-100 & $\mathrm{R} \$$ & 4.333 & $\mathrm{R} \$$ & 3.980 & $\mathrm{R} \$$ & 3.661 & $\mathrm{R} \$$ & 3.404 \\
\hline $70-30-0$ & $\mathrm{R} \$$ & 3.653 & $\mathrm{R} \$$ & 3.238 & $\mathrm{R} \$$ & 2.869 & $\mathrm{R} \$$ & 2.641 \\
\hline $70-0-30$ & $\mathrm{R} \$$ & 3.717 & $\mathrm{R} \$$ & 3.268 & $\mathrm{R} \$$ & 2.949 & $\mathrm{R} \$$ & 2.711 \\
\hline $50-40-10$ & $\mathrm{R} \$$ & 3.785 & $\mathrm{R} \$$ & 3.432 & $\mathrm{R} \$$ & 3.075 & $\mathrm{R} \$$ & 2.823 \\
\hline $60-30-10$ & $\mathrm{R} \$$ & 3.738 & $\mathrm{R} \$$ & 3.392 & $\mathrm{R} \$$ & 2.986 & $\mathrm{R} \$$ & 2.744 \\
\hline
\end{tabular}

Tabela 48 - Valor médio de mensalidade com $60 \%$, 70\%, $80 \%$ e $90 \%$ de utilização da capacidade instalada para 300 residentes, com diversos graus de dependência

\begin{tabular}{|c|c|c|c|c|c|c|c|c|}
\hline \multirow{3}{*}{$\begin{array}{c}\text { Porcentagem de } \\
\text { residentes com } \\
\text { grau de } \\
\text { dependência } \\
\text { I, II e III } \\
100-0-0\end{array}$} & \multicolumn{8}{|c|}{$\begin{array}{l}\text { Valor médio de mensalidade com simulação do nível } \\
\text { de utilização da capacidade instalada para } 300 \\
\text { residentes, com diversos graus de dependência }\end{array}$} \\
\hline & \multicolumn{2}{|c|}{$60 \%$} & \multicolumn{2}{|c|}{$70 \%$} & \multicolumn{2}{|c|}{$80 \%$} & \multicolumn{2}{|c|}{$90 \%$} \\
\hline & $\mathrm{R} \$$ & 2.978 & $\mathrm{R} \$$ & 2.688 & $\mathrm{R} \$$ & 2.379 & $\mathrm{R} \$$ & 2.162 \\
\hline $0-100-0$ & $\mathrm{R} \$$ & 3.691 & $\mathrm{R} \$$ & 3.394 & $\mathrm{R} \$$ & 3.091 & $\mathrm{R} \$$ & 2.869 \\
\hline 0-0-100 & $\mathrm{R} \$$ & 3.971 & $\mathrm{R} \$$ & 3.699 & $\mathrm{R} \$$ & 3.429 & $\mathrm{R} \$$ & 3.220 \\
\hline $70-30-0$ & $\mathrm{R} \$$ & 3.232 & $\mathrm{R} \$$ & 2.932 & $\mathrm{R} \$$ & 2.628 & $\mathrm{R} \$$ & 2.405 \\
\hline $70-0-30$ & $\mathrm{R} \$$ & 3.309 & $\mathrm{R} \$$ & 3.023 & $\mathrm{R} \$$ & 2.722 & $\mathrm{R} \$$ & 2.318 \\
\hline $50-40-10$ & $\mathrm{R} \$$ & 3.416 & $\mathrm{R} \$$ & 3.115 & $\mathrm{R} \$$ & 2.790 & $\mathrm{R} \$$ & 2.580 \\
\hline $60-30-10$ & $\mathrm{R} \$$ & 3.337 & $\mathrm{R} \$$ & 3.047 & $\mathrm{R} \$$ & 2.743 & $\mathrm{R} \$$ & 2.538 \\
\hline
\end{tabular}

Assim, seria de se esperar que a mensalidade média dos residentes com graus de dependência I, II e III, na proporção de 50\%, 40\% e 10\%, respectivamente, fosse superior aos da proporção $60 \%, 30 \%$ e 10\%. Contudo, pode-se observar na Tabela 46 (p. 97) que a célula destacada, $\mathrm{R} \$ 3.820$, tem um valor menor que a célula logo abaixo, $\mathrm{R} \$ 3.860$. Como o número de 
cuidadores não tem uma distribuição perfeitamente linear em função do número de residentes, há situações onde menos pessoas com grau de dependência II não implica redução de cuidadores. Contudo, como o número de residentes com grau de dependência I estava no limite, uma pequena diferença pode provocar um aumento no número de cuidadores. Estes cálculos podem ser observados na Tabela 50 (p. 98).

Tabela 49 - Valor médio de mensalidade com 60\%, 70\%, $80 \%$ e $90 \%$ de utilização da capacidade instalada para 400 residentes, com diversos graus de dependência

\begin{tabular}{|c|c|c|c|c|c|c|c|c|}
\hline \multirow{3}{*}{$\begin{array}{c}\text { Porcentagem de } \\
\text { residentes com } \\
\text { grau de } \\
\text { dependência } \\
\text { I, II e III } \\
100-0-0\end{array}$} & \multicolumn{8}{|c|}{$\begin{array}{l}\text { Valor médio de mensalidade com simulação do nível } \\
\text { de utilização da capacidade instalada para } 400 \\
\text { residentes, com diversos graus de dependência }\end{array}$} \\
\hline & \multicolumn{2}{|c|}{$60 \%$} & \multicolumn{2}{|c|}{$70 \%$} & \multicolumn{2}{|c|}{$80 \%$} & \multicolumn{2}{|c|}{$90 \%$} \\
\hline & $\mathrm{RS}$ & 2.902 & & 2.5 & 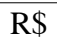 & 2.3 & $\mathrm{R} \$$ & 2.0 \\
\hline & & 3.61 & & & & & & \\
\hline & K\$ & 3.883 & & & & & & \\
\hline & & & & & & & & \\
\hline & & 1 & & 2.8 & & & & 2.417 \\
\hline & & & & & & & & 2.503 \\
\hline $60-30-10$ & $\Lambda \phi$ & 3.253 & $\Lambda \varphi$ & 2.893 & $\mathrm{R} \$$ & 2.667 & $\mathrm{R} \$$ & 2.424 \\
\hline
\end{tabular}

Tabela 50 - Número de cuidadores para simulação 50-40-10 e 60-30-10 em uma organização para 100 residentes

\begin{tabular}{|c|c|c|c|c|c|c|}
\hline \multirow[t]{3}{*}{ Descrição } & \multicolumn{3}{|c|}{$\begin{array}{c}\text { Grau de dependência } \\
\text { para simulação } \\
50-40-10\end{array}$} & \multicolumn{3}{|c|}{$\begin{array}{c}\text { Grau de dependência } \\
\text { para simulação } \\
60-30-10\end{array}$} \\
\hline & $\mathbf{I}$ & II & III & $\mathbf{I}$ & II & III \\
\hline & $50 \%$ & $40 \%$ & $10 \%$ & $60 \%$ & $30 \%$ & $10 \%$ \\
\hline Total de residentes a $100 \%$ da capacidade instalada & \multicolumn{6}{|c|}{100} \\
\hline Nível de utilização da capacidade instalada & \multicolumn{6}{|c|}{$70 \%$} \\
\hline Total de residentes & \multicolumn{6}{|c|}{70} \\
\hline Número de residentes por grau de dependência & 35 & 28 & 7 & 42 & 21 & 7 \\
\hline Número de residentes por cuidador & 20 & 10 & 6 & 20 & 10 & 6 \\
\hline Número de cuidadores & 2 & 3 & 2 & 3 & 3 & 2 \\
\hline Turnos & 1 & 3 & 3 & 1 & 3 & 3 \\
\hline Número de cuidadores $\mathrm{x}$ turnos & 2 & 9 & 6 & 3 & 9 & 6 \\
\hline Total de cuidadores & \multicolumn{3}{|c|}{17} & \multicolumn{3}{|c|}{18} \\
\hline
\end{tabular}

Uma opção é trabalhar com número fracionado de cuidadores. Contudo, nesta tese optou-se pelo arredondamento sempre para o próximo número inteiro. Pode-se observar na Tabela 51 (p. 99) que a mesma simulação com 200 de residentes provoca um comportamento diferente no número de cuidadores. 
Tabela 51 - Número de cuidadores para simulação 50-40-10 e 60-30-10 em uma organização para 200 residentes

\begin{tabular}{|c|c|c|c|c|c|c|}
\hline \multirow[t]{3}{*}{ Descrição } & \multicolumn{3}{|c|}{$\begin{array}{c}\text { Grau de dependência } \\
\text { para simulação } \\
50-40-10\end{array}$} & \multicolumn{3}{|c|}{$\begin{array}{c}\text { Grau de dependência } \\
\text { para simulação } \\
60-30-10\end{array}$} \\
\hline & I & II & III & I & II & III \\
\hline & $50 \%$ & $40 \%$ & $10 \%$ & $60 \%$ & $30 \%$ & $10 \%$ \\
\hline Total de residentes a $100 \%$ da capacidade instalada & \multicolumn{6}{|c|}{200} \\
\hline Nível de utilização da capacidade instalada & \multicolumn{6}{|c|}{$70 \%$} \\
\hline Total de residentes & \multicolumn{6}{|c|}{140} \\
\hline Número de residentes por grau de dependência & 70 & 56 & 14 & 84 & 42 & 14 \\
\hline Número de residentes por cuidador & 20 & 10 & 6 & 20 & 10 & 6 \\
\hline Número de cuidadores & 4 & 6 & 3 & 5 & 5 & 3 \\
\hline Turnos & 1 & 3 & 3 & 1 & 3 & 3 \\
\hline Número de cuidadores $\mathrm{x}$ turnos & 4 & 18 & 9 & 5 & 15 & 9 \\
\hline Total de cuidadores & & 31 & & & 29 & \\
\hline
\end{tabular}

Como o objetivo desta tese não é analisar as equações investimento e mensalidade, deste ponto em diante serão apresentadas as equações, os $R^{2}$ ajustados e os $f$ de Significação. Para esta série de simulações, os resultados são os seguintes:

$$
\begin{gathered}
\mathrm{Y}_{100}=6.413,497-42,509 \times 1-33,487 \times 2-29,759 \times 3 \\
\mathrm{R}_{\text {Ajustado } 100}{ }^{2}=97,0 \% \\
\text { f de Significação } 100=4,84 \mathrm{E}-19 \\
\mathrm{Y}_{200}=5.769,884-19,224 \times 1-14,638 \times 2-12,877 \times 3 \\
\mathrm{R}^{2} \text { Ajustado } 200=98,3 \%
\end{gathered}
$$

$\mathrm{f}$ de Significação ${ }_{200}=4,98 \mathrm{E}-22$

$Y_{300}=5.093,488-11,182 \times 1-8,068 \times 2-6,789 \times 3$

$$
\mathrm{R}^{2} \text { Ajustado } 300=98,4 \%
$$

$\mathrm{f}$ de Significação ${ }_{300}=2,51 \mathrm{E}-22$

$$
\begin{gathered}
\mathrm{Y}_{400}=4.866,148-7,932 \times 1-5,622 \times 2-4,614 \times 3 \\
\mathrm{R}^{2} \text { Ajustado } 400=98,2 \%
\end{gathered}
$$

$\mathrm{f}$ de Significação $400=9,27 \mathrm{E}-22$ 
Deve-se notar que x1 é o número de residentes com grau de dependência I, x2 é o número de residentes com grau II e x3 é o número de residentes com grau de dependência III da organização. A variável dependente Y é a mensalidade em função dos seguintes níveis de utilização da capacidade instalada: $60 \%, 70 \%, 80 \%$ e $90 \%$. Assim, no cálculo da mensalidade para um ambiente residencial especial para 100 residentes a $80 \%$ da capacidade, a soma de x1, x2 e x3 deve ser igual a 80. Os $R^{2}$ ajustados indicam que as regressões explicam, no mínimo, $97 \%$ da variável independente.

\subsubsection{5 série de simulações - mensalidades em função do número de habitações acessíveis a pessoas que utilizam cadeira de rodas}

Esta série de simulações apresenta o valor médio das mensalidades para 100, 200, 300 e 400 residentes com 20\%, 40\%, 60\%, $80 \%$ e 100\% de habitações destinadas a pessoas que necessitam de cadeira de rodas, com diversos graus de dependência. Da mesma forma que a simulação anterior, no valor da mensalidade não estão inclusos os créditos que serão gerados aos proprietários.

Na Tabela 52 (p. 100) três células estão destacadas. O valor $\mathrm{R} \$ 4.019$ foi calculado para uma organização de 100 residentes, sendo 50\% com grau de dependência I, 40\% dos residentes com grau de dependência II e 10\% com grau III, com $60 \%$ das habitações preparadas para pessoas que necessitam de cadeira de rodas.

Tabela 52 - Valor médio da mensalidade com simulação de $20 \%, 40 \%, 60 \%, 80 \%$ e $100 \%$ de habitações destinadas a pessoas que dependem de cadeira de rodas, para 100 residentes, com diversos graus de dependência

\begin{tabular}{|c|c|c|c|c|c|c|c|c|c|c|}
\hline \multirow{3}{*}{$\begin{array}{c}\text { Porcentagem de } \\
\text { residentes com } \\
\text { grau de } \\
\text { dependência } \\
\text { I, II e III } \\
100-0-0\end{array}$} & \multicolumn{10}{|c|}{$\begin{array}{l}\text { Valor médio de mensalidade com simulação da porcentagem de } \\
\text { habitações destinadas a cadeirantes, para } 100 \text { residentes, com } \\
\text { diversos graus de dependência }\end{array}$} \\
\hline & \multicolumn{2}{|c|}{$20 \%$} & \multicolumn{2}{|c|}{$40 \%$} & \multicolumn{2}{|c|}{$60 \%$} & \multicolumn{2}{|c|}{$80 \%$} & \multicolumn{2}{|c|}{$100 \%$} \\
\hline & $\mathrm{R} \$$ & 3.291 & $\mathrm{R} \$$ & 3.416 & $\mathrm{R} \$$ & 3.490 & $\mathrm{R} \$$ & 3.689 & $\mathrm{R} \$$ & 3.815 \\
\hline 0-100-0 & $\mathrm{R} \$$ & 3.982 & $\mathrm{R} \$$ & 4.108 & $\mathrm{R} \$$ & 4.182 & $\mathrm{R} \$$ & 4.381 & $\mathrm{R} \$$ & 4.507 \\
\hline $0-0-100$ & $\mathrm{R} \$$ & 4.330 & $\mathrm{R} \$$ & 4.473 & $\mathrm{R} \$$ & 4.547 & $\mathrm{R} \$$ & 4.653 & $\mathrm{R} \$$ & 4.726 \\
\hline $70-30-0$ & $\mathrm{R} \$$ & 3.616 & $\mathrm{R} \$$ & 3.742 & $\mathrm{R} \$$ & 3.815 & $\mathrm{R} \$$ & 4.014 & $\mathrm{R} \$$ & 4.140 \\
\hline $70-0-30$ & $\mathrm{R} \$$ & 3.646 & $\mathrm{R} \$$ & 3.809 & $\mathrm{R} \$$ & 3.915 & $\mathrm{R} \$$ & 3.989 & $\mathrm{R} \$$ & 4.207 \\
\hline $50-40-10$ & $\mathrm{R} \$$ & 3.820 & $\mathrm{R} \$$ & 3.945 & $\mathrm{R} \$$ & 4.019 & $\mathrm{R} \$$ & 4.218 & $\mathrm{R} \$$ & 4.344 \\
\hline $60-30-10$ & $\mathrm{R} \$$ & 3.860 & $\mathrm{R} \$$ & 3.986 & $\mathrm{R} \$$ & 4.059 & $\mathrm{R} \$$ & 4.259 & $\mathrm{R} \$$ & 4.384 \\
\hline
\end{tabular}

As outras duas células indicam o valor da maior e da menor mensalidade. Pode-se notar que o menor valor é obtido com $20 \%$ de habitações para cadeirantes, sendo $100 \%$ dos residentes com grau de dependência I. A maior mensalidade ocorre quando todos os residentes têm grau 
de dependência III e todas as habitações são destinadas a pessoas que necessitam de cadeira de rodas. As células destacadas da Tabela 53 (p. 101) à Tabela 55 (p. 101) também indicam os maiores e menores valores de mensalidade para cada uma das simulações propostas.

Tabela 53 - Valor médio da mensalidade com simulação de $20 \%, 40 \%, 60 \%, 80 \%$ e $100 \%$ de habitações destinadas a pessoas que dependem de cadeira de rodas, para 200 residentes, com diversos graus de dependência

\begin{tabular}{|c|c|c|c|c|c|c|c|c|c|c|}
\hline \multirow{3}{*}{$\begin{array}{c}\text { Porcentagem de } \\
\text { residentes com } \\
\text { grau de } \\
\text { dependência } \\
\text { I, II e III } \\
100-0-0\end{array}$} & \multicolumn{10}{|c|}{$\begin{array}{l}\text { Valor médio de mensalidade com simulação da porcentagem de } \\
\text { habitações destinadas a cadeirantes, para } 200 \text { residentes, com } \\
\text { diversos graus de dependência }\end{array}$} \\
\hline & \multicolumn{2}{|c|}{$20 \%$} & \multicolumn{2}{|c|}{$40 \%$} & \multicolumn{2}{|c|}{$60 \%$} & \multicolumn{2}{|c|}{$80 \%$} & \multicolumn{2}{|c|}{$100 \%$} \\
\hline & $\mathrm{R} \$$ & 2.973 & $\mathrm{R} \$$ & 3.082 & $\mathrm{R} \$$ & 3.172 & $\mathrm{R} \$$ & 3.334 & $\mathrm{R} \$$ & 3.443 \\
\hline 0-100-0 & $\mathrm{R} \$$ & 3.686 & $\mathrm{R} \$$ & 3.794 & $\mathrm{R} \$$ & 3.884 & $\mathrm{R} \$$ & 4.047 & $\mathrm{R} \$$ & 4.155 \\
\hline 0-0-100 & $\mathrm{R} \$$ & 3.980 & $\mathrm{R} \$$ & 4.116 & $\mathrm{R} \$$ & 4.232 & $\mathrm{R} \$$ & 4.350 & $\mathrm{R} \$$ & 4.486 \\
\hline $70-30-0$ & $\mathrm{R} \$$ & 3.238 & $\mathrm{R} \$$ & 3.347 & $\mathrm{R} \$$ & 3.436 & $\mathrm{R} \$$ & 3.599 & $\mathrm{R} \$$ & 3.707 \\
\hline $70-0-30$ & $\mathrm{R} \$$ & 3.268 & $\mathrm{R} \$$ & 3.384 & $\mathrm{R} \$$ & 3.502 & $\mathrm{R} \$$ & 3.638 & $\mathrm{R} \$$ & 3.754 \\
\hline $50-40-10$ & $\mathrm{R} \$$ & 3.432 & $\mathrm{R} \$$ & 3.567 & $\mathrm{R} \$$ & 3.657 & $\mathrm{R} \$$ & 3.793 & $\mathrm{R} \$$ & 3.928 \\
\hline $60-30-10$ & $\mathrm{R} \$$ & 3.392 & $\mathrm{R} \$$ & 3.527 & $\mathrm{R} \$$ & 3.616 & $\mathrm{R} \$$ & 3.752 & $\mathrm{R} \$$ & 3.887 \\
\hline
\end{tabular}

Tabela 54 - Valor médio da mensalidade com simulação de $20 \%, 40 \%, 60 \%, 80 \%$ e $100 \%$ de habitações destinadas a pessoas que dependem de cadeira de rodas, para 300 residentes, com diversos graus de dependência

\begin{tabular}{|c|c|c|c|c|c|c|c|c|c|c|}
\hline \multirow{3}{*}{$\begin{array}{c}\text { Porcentagem de } \\
\text { residentes com } \\
\text { grau de } \\
\text { dependência } \\
\text { I, II e III } \\
100-0-0\end{array}$} & \multicolumn{10}{|c|}{$\begin{array}{c}\text { Valor médio de mensalidade com simulação da porcentagem de } \\
\text { habitações destinadas a cadeirantes, para } 300 \text { residentes, com } \\
\text { diversos graus de dependência }\end{array}$} \\
\hline & \multicolumn{2}{|c|}{$20 \%$} & \multicolumn{2}{|c|}{$40 \%$} & \multicolumn{2}{|c|}{$60 \%$} & \multicolumn{2}{|c|}{$80 \%$} & \multicolumn{2}{|c|}{$100 \%$} \\
\hline & $\mathrm{R} \$$ & 2.688 & $\mathrm{R} \$$ & 2.821 & $\mathrm{R} \$$ & 2.923 & $\mathrm{R} \$$ & 3.030 & $\mathrm{R} \$$ & 3.163 \\
\hline 0-100-0 & $\mathrm{R} \$$ & 3.394 & $\mathrm{R} \$$ & 3.526 & $\mathrm{R} \$$ & 3.628 & $\mathrm{R} \$$ & 3.736 & $\mathrm{R} \$$ & 3.868 \\
\hline 0-0-100 & $\mathrm{R} \$$ & 3.699 & $\mathrm{R} \$$ & 3.813 & $\mathrm{R} \$$ & 3.908 & $\mathrm{R} \$$ & 4.041 & $\mathrm{R} \$$ & 4.155 \\
\hline $70-30-0$ & $\mathrm{R} \$$ & 2.932 & $\mathrm{R} \$$ & 3.065 & $\mathrm{R} \$$ & 3.167 & $\mathrm{R} \$$ & 3.274 & $\mathrm{R} \$$ & 3.407 \\
\hline $70-0-30$ & $\mathrm{R} \$$ & 3.023 & $\mathrm{R} \$$ & 3.118 & $\mathrm{R} \$$ & 3.251 & $\mathrm{R} \$$ & 3.365 & $\mathrm{R} \$$ & 3.491 \\
\hline $50-40-10$ & $\mathrm{R} \$$ & 3.115 & $\mathrm{R} \$$ & 3.247 & $\mathrm{R} \$$ & 3.343 & $\mathrm{R} \$$ & 3.457 & $\mathrm{R} \$$ & 3.589 \\
\hline $60-30-10$ & $\mathrm{R} \$$ & 3.047 & $\mathrm{R} \$$ & 3.180 & $\mathrm{R} \$$ & 3.275 & $\mathrm{R} \$$ & 3.389 & $\mathrm{R} \$$ & 3.522 \\
\hline
\end{tabular}

Tabela 55 - Valor médio da mensalidade com simulação de $20 \%, 40 \%, 60 \%, 80 \%$ e $100 \%$ de habitações destinadas a pessoas que dependem de cadeira de rodas, para 400 residentes, com diversos graus de dependência

\begin{tabular}{|c|c|c|c|c|c|c|c|c|c|c|}
\hline \multirow{3}{*}{$\begin{array}{c}\text { Porcentagem de } \\
\text { residentes com } \\
\text { grau de } \\
\text { dependência } \\
\text { I, II e III } \\
100-0-0\end{array}$} & \multicolumn{10}{|c|}{$\begin{array}{c}\text { Valor médio de mensalidade com simulação da porcentagem de } \\
\text { habitações destinadas a cadeirantes, para } 400 \text { residentes, com } \\
\text { diversos graus de dependência }\end{array}$} \\
\hline & \multicolumn{2}{|c|}{$20 \%$} & \multicolumn{2}{|c|}{$40 \%$} & \multicolumn{2}{|c|}{$60 \%$} & \multicolumn{2}{|c|}{$80 \%$} & \multicolumn{2}{|c|}{$100 \%$} \\
\hline & $\mathrm{R} \$$ & 2.541 & $\mathrm{R} \$$ & 2.667 & $\mathrm{R} \$$ & 2.771 & $\mathrm{R} \$$ & 2.897 & $\mathrm{R} \$$ & 3.010 \\
\hline 0-100-0 & $\mathrm{R} \$$ & 3.253 & $\mathrm{R} \$$ & 3.379 & $\mathrm{R} \$$ & 3.483 & $\mathrm{R} \$$ & 3.610 & $\mathrm{R} \$$ & 3.722 \\
\hline 0-0-100 & $\mathrm{R} \$$ & 3.563 & $\mathrm{R} \$$ & 3.689 & $\mathrm{R} \$$ & 3.793 & $\mathrm{R} \$$ & 3.919 & $\mathrm{R} \$$ & 4.018 \\
\hline $70-30-0$ & $\mathrm{R} \$$ & 2.775 & $\mathrm{R} \$$ & 2.901 & $\mathrm{R} \$$ & 3.005 & $\mathrm{R} \$$ & 3.131 & $\mathrm{R} \$$ & 3.243 \\
\hline $70-0-30$ & $\mathrm{R} \$$ & 2.844 & $\mathrm{R} \$$ & 2.956 & $\mathrm{R} \$$ & 3.087 & $\mathrm{R} \$$ & 3.186 & $\mathrm{R} \$$ & 3.312 \\
\hline $50-40-10$ & $\mathrm{R} \$$ & 2.964 & $\mathrm{R} \$$ & 3.076 & $\mathrm{R} \$$ & 3.189 & $\mathrm{R} \$$ & 3.301 & $\mathrm{R} \$$ & 3.432 \\
\hline $60-30-10$ & $\mathrm{R} \$$ & 2.893 & $\mathrm{R} \$$ & 3.005 & $\mathrm{R} \$$ & 3.118 & $\mathrm{R} \$$ & 3.230 & $\mathrm{R} \$$ & 3.361 \\
\hline
\end{tabular}


Para cada tabela calculou-se uma regressão linear múltipla que representa o valor da mensalidade (Y) em função da porcentagem de habitações destinadas a pessoas que dependem de cadeira de rodas (x1); do número de habitações para residentes com grau de dependência I (x2), II (x3) e III (x4). Somente o $R^{2}$ ajustado da equação para ambientes residenciais especiais para 100 residentes ficou abaixo de $90 \%$, mais precisamente $89,1 \%$. Os demais foram iguais ou maiores do que $95,0 \%$. Seus respectivos valores e as equações calculadas são os seguintes:

$$
\begin{gathered}
Y_{100}=6.413,497-42,509 \times 1-33,487 \times 2-29,759 \times 3 \\
R^{2} \text { Ajustado } 100=89,1 \%
\end{gathered}
$$

$\mathrm{f}_{\text {de }}$ Significação ${ }_{100}=8,54 \mathrm{E}-19$

$$
\mathrm{R}^{2} \text { Ajustado } 200=95,0 \%
$$

f de Significação $200=2,09 \mathrm{E}-28$

$$
\mathrm{R}^{2} \text { Ajustado } 300=99,7 \%
$$

f de Significação $300=2,95 \mathrm{E}-37$

$$
\mathrm{R}^{2} \text { Ajustado } 400=96,6 \%
$$

f de Significação $400=1,56 \mathrm{E}-43$

\subsection{6 $6^{\mathrm{a}}$ série de simulações - mensalidades em função da variação de áreas comuns}

As simulações a seguir apresentam o valor das mensalidades, sem os créditos que serão gerados aos proprietários, em função da existência de anfiteatro, da área do minisshopping, da existência de piscinas, saunas, campos, quadras e pistas de pedestres e ciclovia. As premissas de "A" até "P" foram estabelecidas nas Tabelas 36 e 37 (p. 90). Da Tabela 56 (p. 103) à Tabela 59 (p. 104) estão apresentados os valores de mensalidades para 100, 200, 300 e 400 
residentes, respectivamente. Todas as tabelas têm células destacadas com os maiores e menores valores de mensalidades em função das premissas.

Tabela 56 - Valor médio das mensalidades em função de áreas externas, anfiteatro e minisshopping para 100 residentes, com diversos graus de dependência

\begin{tabular}{|c|c|c|c|c|c|c|c|c|c|c|}
\hline \multirow{2}{*}{$\begin{array}{c}\text { Porcentagem de } \\
\text { residentes com } \\
\text { grau de } \\
\text { dependência } \\
\text { I, II e III } \\
\end{array}$} & \multicolumn{10}{|c|}{$\begin{array}{c}\text { Valor médio de mensalidade em função de áreas externas, anfiteatro } \\
\text { e minisshopping para } 100 \text { residentes, com diversos graus de } \\
\text { dependência }(*)\end{array}$} \\
\hline & \multicolumn{2}{|r|}{$\mathbf{A}$} & \multicolumn{2}{|r|}{ B } & \multicolumn{2}{|c|}{$\mathrm{C}$} & \multicolumn{2}{|c|}{ D } & \multicolumn{2}{|c|}{ Variação } \\
\hline 100-0-0 & $\mathrm{R} \$$ & 3.291 & $\mathrm{R} \$$ & 3.157 & $\mathrm{R} \$$ & 3.092 & $\mathrm{R} \$$ & 3.039 & $\mathrm{R} \$$ & 252 \\
\hline 0-100-0 & $\mathrm{R} \$$ & 3.982 & $\mathrm{R} \$$ & 3.849 & $\mathrm{R} \$$ & 3.784 & $\mathrm{R} \$$ & 3.731 & $\mathrm{R} \$$ & 252 \\
\hline $0-0-100$ & $\mathrm{R} \$$ & 4.330 & $\mathrm{R} \$$ & 4.215 & $\mathrm{R} \$$ & 4.169 & $\mathrm{R} \$$ & 4.096 & $\mathrm{R} \$$ & 234 \\
\hline $70-30-0$ & $\mathrm{R} \$$ & 3.616 & $\mathrm{R} \$$ & 3.483 & $\mathrm{R} \$$ & 3.418 & $\mathrm{R} \$$ & 3.364 & $\mathrm{R} \$$ & 252 \\
\hline $70-0-30$ & $\mathrm{R} \$$ & 3.646 & $\mathrm{R} \$$ & 3.550 & $\mathrm{R} \$$ & 3.485 & $\mathrm{R} \$$ & 3.484 & $\mathrm{R} \$$ & 162 \\
\hline $50-40-10$ & $\mathrm{R} \$$ & 3.820 & $\mathrm{R} \$$ & 3.686 & $\mathrm{R} \$$ & 3.621 & $\mathrm{R} \$$ & 3.568 & $\mathrm{R} \$$ & 252 \\
\hline $60-30-10$ & $\mathrm{R} \$$ & 3.860 & $\mathrm{R} \$$ & 3.727 & $\mathrm{R} \$$ & 3.662 & $\mathrm{R} \$$ & 3.608 & $\mathrm{R} \$$ & 252 \\
\hline
\end{tabular}

* As premissas “A”, “B”, “C” e "D” estão detalhadas na Tabela 36 (p. 90)

Tabela 57 - Valor médio das mensalidades em função de áreas externas, anfiteatro e minisshopping para 200 residentes, com diversos graus de dependência

\begin{tabular}{|c|c|c|c|c|c|c|c|c|c|c|}
\hline \multirow{2}{*}{$\begin{array}{c}\text { Porcentagem de } \\
\text { residentes com } \\
\text { grau de } \\
\text { dependência } \\
\text { I, II e III } \\
\end{array}$} & \multicolumn{10}{|c|}{$\begin{array}{c}\text { Valor médio de mensalidade em função de áreas externas, anfiteatro } \\
\text { e minisshopping para } 200 \text { residentes, com diversos graus de } \\
\text { dependência }(*)\end{array}$} \\
\hline & \multicolumn{2}{|c|}{$\mathbf{E}$} & \multicolumn{2}{|r|}{$\mathbf{F}$} & \multicolumn{2}{|c|}{$\mathbf{G}$} & \multicolumn{2}{|c|}{$\mathbf{H}$} & \multicolumn{2}{|c|}{ Variação } \\
\hline $100-0-0$ & $\mathrm{R} \$$ & 2.973 & $\mathrm{R} \$$ & 2.835 & $\mathrm{R} \$$ & 2.729 & $\mathrm{R} \$$ & 2.542 & $\mathrm{R} \$$ & 432 \\
\hline $0-100-0$ & $\mathrm{R} \$$ & 3.686 & $\mathrm{R} \$$ & 3.547 & $\mathrm{R} \$$ & 3.441 & $\mathrm{R} \$$ & 3.254 & $\mathrm{R} \$$ & 432 \\
\hline 0-0-100 & $\mathrm{R} \$$ & 3.980 & $\mathrm{R} \$$ & 3.897 & $\mathrm{R} \$$ & 3.777 & $\mathrm{R} \$$ & 3.631 & $\mathrm{R} \$$ & 349 \\
\hline $70-30-0$ & $\mathrm{R} \$$ & 3.238 & $\mathrm{R} \$$ & 3.099 & $\mathrm{R} \$$ & 2.993 & $\mathrm{R} \$$ & 2.806 & $\mathrm{R} \$$ & 432 \\
\hline $70-0-30$ & $\mathrm{R} \$$ & 3.268 & $\mathrm{R} \$$ & 3.139 & $\mathrm{R} \$$ & 3.059 & $\mathrm{R} \$$ & 2.872 & $\mathrm{R} \$$ & 396 \\
\hline $50-40-10$ & $\mathrm{R} \$$ & 3.432 & $\mathrm{R} \$$ & 3.294 & $\mathrm{R} \$$ & 3.187 & $\mathrm{R} \$$ & 3.027 & $\mathrm{R} \$$ & 406 \\
\hline $60-30-10$ & $\mathrm{R} \$$ & 3.392 & $\mathrm{R} \$$ & 3.253 & $\mathrm{R} \$$ & 3.147 & $\mathrm{R} \$$ & 2.986 & $\mathrm{R} \$$ & 406 \\
\hline
\end{tabular}

* As premissas “E”, "F”, "G” e "H” estão detalhadas na Tabela 36 (p. 90)

A Tabela 57 (p. 103) apresenta uma terceira célula destacada no valor de R \$3.147. Com base na premissa "G" da Tabela 36 (p. 90) pode-se afirmar que esse é o valor da mensalidade para a organização com capacidade para 200 residentes, operando a 70\% do limite da capacidade instalada, com $60 \%$ dos residentes com grau de dependência I, 30\% com grau de dependência II e $10 \%$ dos residentes com grau III. A organização possui minisshopping de $90 \mathrm{~m}^{2}$, anfiteatro e $500 \mathrm{~m}^{2}$ de pista para pedestre. Esta premissa não contempla piscinas, saunas, campos, quadras nem ciclovia. Pode-se perceber que, em termos de mensalidade, a maior variação é de $\mathrm{R} \$ 432$ entre organizações com e sem áreas comuns de esporte e lazer, para uma mesma combinação de graus de dependência. 
Tabela 58 - Valor médio das mensalidades em função de áreas externas, anfiteatro e minisshopping para 300 residentes, com diversos graus de dependência

\begin{tabular}{|c|c|c|c|c|c|c|c|c|c|c|}
\hline \multirow{2}{*}{$\begin{array}{l}\text { Porcentagem de } \\
\text { residentes com } \\
\text { grau de } \\
\text { dependência } \\
\text { I, II e III }\end{array}$} & \multicolumn{10}{|c|}{$\begin{array}{c}\text { Valor médio de mensalidade em função de áreas externas, anfiteatro } \\
\text { e minisshopping para } 300 \text { residentes, com diversos graus de } \\
\text { dependência }(*)\end{array}$} \\
\hline & \multicolumn{2}{|r|}{ I } & \multicolumn{2}{|r|}{$\mathbf{J}$} & \multicolumn{2}{|c|}{$\mathbf{K}$} & \multicolumn{2}{|c|}{$\mathbf{L}$} & \multicolumn{2}{|c|}{ Variação } \\
\hline 100-0-0 & $\mathrm{R} \$$ & 2.688 & $\mathrm{R} \$$ & 2.583 & $\mathrm{R} \$$ & 2.442 & $\mathrm{R} \$$ & 2.374 & $\mathrm{R} \$$ & 315 \\
\hline 0-100-0 & $\mathrm{R} \$$ & 3.394 & $\mathrm{R} \$$ & 3.288 & $\mathrm{R} \$$ & 3.148 & $\mathrm{R} \$$ & 3.079 & & 315 \\
\hline 0-0-100 & $\mathrm{R} \$$ & 3.699 & $\mathrm{R} \$$ & 3.593 & $\mathrm{R} \$$ & 3.465 & $\mathrm{R} \$$ & 3.397 & & 302 \\
\hline 70-30-0 & $\mathrm{R} \$$ & 2.932 & $\mathrm{R} \$$ & 2.827 & $\mathrm{R} \$$ & 2.705 & $\mathrm{R} \$$ & 2.618 & $\mathrm{R}$ & 315 \\
\hline $70-0-30$ & $\mathrm{R} \$$ & 3.023 & $\mathrm{R} \$$ & 2.918 & $\mathrm{R} \$$ & 2.796 & $\mathrm{R} \$$ & 2.702 & $\mathrm{R}$ & 321 \\
\hline $50-40-10$ & $\mathrm{R} \$$ & 3.115 & $\mathrm{R} \$$ & 3.009 & $\mathrm{R} \$$ & 2.869 & $\mathrm{R} \$$ & 2.800 & $\mathrm{R} \$$ & 315 \\
\hline $60-30-10$ & $\mathrm{R} \$$ & 3.047 & $\mathrm{R} \$$ & 2.941 & $\mathrm{R} \$$ & 2.801 & $\mathrm{R} \$$ & 2.732 & $\mathrm{R} \$$ & 315 \\
\hline
\end{tabular}

* As premissas "I", "J", "K" e "L” estão detalhadas na Tabela 37 (p. 90)

Tabela 59 - Valor médio das mensalidades em função de áreas externas, anfiteatro e minisshopping para 400 residentes, com diversos graus de dependência

\begin{tabular}{|c|c|c|c|c|c|c|c|c|c|c|}
\hline \multirow{2}{*}{$\begin{array}{l}\text { Porcentagem de } \\
\text { residentes com } \\
\text { grau de } \\
\text { dependência } \\
\text { I, II e III }\end{array}$} & \multicolumn{10}{|c|}{$\begin{array}{c}\text { Valor médio de mensalidade em função de áreas externas, anfiteatro } \\
\text { e minisshopping para } 400 \text { residentes, com diversos graus de } \\
\text { dependência }(*)\end{array}$} \\
\hline & \multicolumn{2}{|c|}{ M } & \multicolumn{2}{|r|}{$\mathbf{N}$} & \multicolumn{2}{|r|}{ O } & & \multicolumn{2}{|c|}{ Variação } \\
\hline $100-0-0$ & $\mathrm{R} \$$ & 2.541 & $\mathrm{R} \$$ & 2.452 & $\mathrm{R} \$$ & 2.309 & $\mathrm{R} \$$ & 2.252 & $\mathrm{R} \$$ & 288 \\
\hline $0-100-0$ & $\mathrm{R} \$$ & 3.253 & $\mathrm{R} \$$ & 3.164 & $\mathrm{R} \$$ & 3.021 & $\mathrm{R} \$$ & 2.965 & $\mathrm{R} \$$ & 288 \\
\hline $0-0-100$ & $\mathrm{R} \$$ & 3.563 & $\mathrm{R} \$$ & 3.484 & $\mathrm{R} \$$ & 3.364 & $\$$ & 3.313 & $\$$ & 251 \\
\hline $70-30-0$ & $\mathrm{R} \$$ & 2.775 & $\mathrm{R} \$$ & 2.686 & $\mathrm{R} \$$ & 2.557 & & 2.486 & $\mathrm{R}$ & 288 \\
\hline $70-0-30$ & $\mathrm{R} \$$ & 2.844 & $\mathrm{R} \$$ & 2.742 & $\mathrm{R} \$$ & 2.649 & $\mathrm{R} \$$ & 2.565 & $\mathrm{R} \$$ & 279 \\
\hline $50-40-10$ & $\mathrm{R} \$$ & 2.964 & $\mathrm{R} \$$ & 2.857 & $\mathrm{R} \$$ & 2.737 & $\mathrm{R} \$$ & 2.685 & $\mathrm{R} \$$ & 279 \\
\hline $60-30-10$ & $\mathrm{R} \$$ & 2.893 & $\mathrm{R} \$$ & 2.785 & $\mathrm{R} \$$ & 2.666 & $\mathrm{R} \$$ & 2.614 & $\mathrm{R} \$$ & 279 \\
\hline
\end{tabular}

* As premissas "M", “N”, "O” e "P” estão detalhadas na Tabela 37 (p. 90)

Para cada Tabela calculou-se uma regressão linear múltipla. Diversas variáveis independentes ficaram zeradas no cálculo inicial e os $R^{2}$ ajustados ficaram abaixo de $55 \%$. Como o poder de explicação das regressões depende do número de variáveis independentes, novos cálculos foram feitos eliminando as variáveis zeradas no procedimento inicial. A seguir, pode-se observar as equações e os $R^{2}$ ajustados para 100, 200, 300 e 400 residentes.

$$
\begin{gathered}
\mathrm{Y}_{100}=-80.868 .762 .228 .622 .000,000-0,337 \times 1+63,352 \times 2+0,679 \times 3 \\
+1.155 .268 .031 .837 .500,000 \times 4 \\
+1.155 .268 .031 .837 .510,000 \times 5 \\
+1.155 .268 .031 .837 .510,000 \times 6 \\
\mathrm{R}^{2} \text { Ajustado } 100=90,9 \%
\end{gathered}
$$

f de Significação ${ }_{100}=5,46 \mathrm{E}-11$ 
Onde:

x1 = Área do minisshopping;

x2 = Número de campos de bocha;

x3 = Área da pista de pedestre;

x4, x5 e x6 = Número de residentes com grau de dependência I, II e III, respectivamente.

$$
\begin{gathered}
\mathrm{Y}_{200}=3.538,189+1,160 \times 1+0,277 \times 2+0,259 \times 3-7,206 \times 4-2,157 \times 5 \\
\mathrm{R}^{2} \text { Ajustado } 200=98,3 \%
\end{gathered}
$$

$\mathrm{f}$ de Significação ${ }_{200}=9,07 \mathrm{E}-20$

$\mathrm{Y}_{300}=3.337,050+0,668 \times 1+0,293 \times 2+0,211 \times 3-4,713 \times 4-1,435 \times 5$

$$
\mathrm{R}^{2} \text { Ajustado } 300=99,6 \%
$$

f de Significação $300=1,36 \mathrm{E}-26$

$$
\begin{gathered}
\mathrm{Y}_{400}=3.363,491+1,376 \times 1-0,254 \times 2+0,190 \times 3-3,663 \times 4-1,124 \times 5 \\
\mathrm{R}^{2} \text { Ajustado } 400=99,7 \%
\end{gathered}
$$

$\mathrm{f}$ de Significação $400=4,80 \mathrm{E}-28$

Onde, para as três equações, definem-se:

x1 = Área do minisshopping;

x2 = Área de pista de pedestre;

x3 = Área da ciclovia;

x4 e x5 = Número de residentes com grau de dependência I e II, respectivamente. 


\subsection{7 $7^{\text {a }}$ série de simulações - variação dos créditos aos proprietários em função do nível de utilização da capacidade instalada}

Os créditos gerados na locação das habitações são aproveitados pelos proprietários quando os mesmos passam a residir na organização. Quanto mais tempo as habitações ficarem locadas, menos desembolsos os proprietários terão no futuro.

Caso o proprietário tenha a necessidade de vender suas quotas, os créditos são transferidos ao comprador. Para que essa operação seja possível, o montante acrescido ao valor das quotas precisa ser atrativo. Os créditos precisam render mensalmente taxas equivalentes a outras formas de investimento, pois caso isso não ocorra, em vez de adquirir quotas da organização, uma pessoa poderia aplicar seus recursos em ações ou mesmo caderneta de poupança.

Uma das possibilidades é comparar o rendimento das quotas ao Ibovespa, que é considerado o mais importante indicador de rentabilidade do mercado de ações brasileiro (FORTUNA, 2005, p. 598). Na Tabela 60 (p. 106) pode-se observar a evolução desse tipo de investimento do ano de 1994 a 2008.

Tabela 60 - Ibovespa 1994-2008

\begin{tabular}{|c|c|c|c|c|}
\hline \multirow{3}{*}{ Ano } & \multirow{3}{*}{$\begin{array}{c}\text { Ibovespa } \\
\text { (último dia } \\
\text { do ano) }\end{array}$} & \multicolumn{3}{|c|}{ Taxa Média } \\
\hline & & \multirow{2}{*}{ Anual } & \multicolumn{2}{|c|}{ Mensal } \\
\hline & & & do Ano & até 2008 \\
\hline 1994 & $4.353,92$ & & & \\
\hline 1995 & $4.299,00$ & $-1,26 \%$ & $-0,11 \%$ & $1,29 \%$ \\
\hline 1996 & $7.039,94$ & $63,76 \%$ & $4,20 \%$ & $1,40 \%$ \\
\hline 1997 & $10.196,50$ & $44,84 \%$ & $3,14 \%$ & $1,17 \%$ \\
\hline 1998 & $6.784,30$ & $-33,46 \%$ & $-3,34 \%$ & $0,99 \%$ \\
\hline 1999 & $17.091,60$ & $151,93 \%$ & $8,00 \%$ & $1,44 \%$ \\
\hline 2000 & $15.259,20$ & $-10,72 \%$ & $-0,94 \%$ & $0,73 \%$ \\
\hline 2001 & $13.577,50$ & $-11,02 \%$ & $-0,97 \%$ & $0,94 \%$ \\
\hline 2002 & $11.268,40$ & $-17,01 \%$ & $-1,54 \%$ & $1,22 \%$ \\
\hline 2003 & $22.236,30$ & $97,33 \%$ & $5,83 \%$ & $1,69 \%$ \\
\hline 2004 & $26.196,25$ & $17,81 \%$ & $1,38 \%$ & $0,88 \%$ \\
\hline 2005 & $33.455,94$ & $27,71 \%$ & $2,06 \%$ & $0,75 \%$ \\
\hline 2006 & $44.473,71$ & $32,93 \%$ & $2,40 \%$ & $0,32 \%$ \\
\hline 2007 & $63.886,10$ & $43,65 \%$ & $3,06 \%$ & $-0,70 \%$ \\
\hline 2008 & $37.550,31$ & $-41,22 \%$ & $-4,33 \%$ & $-4,33 \%$ \\
\hline
\end{tabular}

FONTE: BOVESPA, 2009, adaptado pelo autor.

A coluna Taxa Média Anual indica a variação do período. Tomando como exemplo 1995, a taxa de $-1,26 \%$ indica que houve uma redução do Ibovespa ao longo daquele ano. A coluna Taxa Média Mensal do Ano converte a taxa anual para mensal. Assim, no ano de 1995, a taxa média do Ibovespa foi de $-0,11 \%$ ao mês. A última coluna indica a variação do Ibovespa até 
2008. Ainda usando como exemplo 1995, o índice variou em média 1,29\% ao mês de 1995 até 2008.

Como o proprietário está adquirindo uma permissão de uso de um imóvel, uma comparação possível seria a evolução dos preços do setor. Contudo, além do período de análise ser reduzido (Tabelas 61 e 62, p. 107), o desvio padrão dos valores é muito alto (Tabela 63, p. 107).

Tabela 61 - Valorização anual de casas de médio padrão na cidade de São Paulo 2004-2008

\begin{tabular}{|c|c|c|c|c|c|c|c|c|c|c|c|c|c|c|c|}
\hline \multirow{3}{*}{$\begin{array}{l}\text { Ano } \\
\text { Zona }\end{array}$} & \multicolumn{15}{|c|}{ Valorização anual de casas de médio padrão } \\
\hline & \multicolumn{5}{|c|}{ Com menos de 8 anos de construção } & \multicolumn{5}{|c|}{ De 8 a 14 anos de construção } & \multicolumn{5}{|c|}{ Com mais de 14 anos de construção } \\
\hline & $\mathbf{A}$ & B & $\mathbf{C}$ & D & $\mathbf{E}$ & $\mathbf{A}$ & B & $\mathbf{C}$ & D & $\mathbf{E}$ & $\mathbf{A}$ & B & $\mathbf{C}$ & D & $\mathbf{E}$ \\
\hline 2004 & - & - & & $05 \%$ & 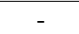 & $00 \%$ & & $-0,3 \%$ & & & & $-0,4 \%$ & $0,6 \%$ & $-1,0 \%$ & $1,3 \%$ \\
\hline & - & $1,8 \%$ & 1 & & & & & & & & $0,0 \%$ & & $-0,2 \%$ & & \\
\hline 200 & $1,6 c$ & $1,6 \%$ & $1,2 \%$ & $-0,2 \%$ & $0,0 \%$ & $2,2 \%$ & 1,2 & 0 & $0,9 \%$ & $0,4 \%$ & $1,8 \%$ & $0,0 \%$ & $0,7 \%$ & $-0,6 \%$ & $-1,6 \%$ \\
\hline 200 & 1, & & & & & & & & & & & & $\%$ & $\%$ & $1,4 \%$ \\
\hline 2008 & $-2,7 \%$ & $-0,9 \%$ & $-1,9 \%$ & $-0,2 \%$ & $-0,7 \%$ & $-2,1 \%$ & $-2,6 \%$ & $4,2 \%$ & $-16,8 \%$ & $-1,8 \%$ & $1,2 \%$ & $4,2 \%$ & $0,0 \%$ & $2,6 \%$ & $-0,6 \%$ \\
\hline
\end{tabular}

FONTE: CONSELHO REGIONAL DE CORRETORES DE IMÓVEIS DO ESTADO DE SÃO PAULO, 2009, adaptado pelo autor.

Tabela 62 - Valorização anual de casas de padrão standard na cidade de São Paulo 2004-2008

\begin{tabular}{cccccccccccccccc}
\hline \multirow{2}{*}{ Ano } & \multicolumn{10}{c}{ Valorização anual de casas padrão standard } \\
\cline { 2 - 16 } & \multicolumn{10}{c}{ Com menos de 8 anos de construção } & \multicolumn{10}{c}{ De 8 a 14 anos de construção } & \multicolumn{1}{c}{ Com mais de 14 anos de construção } \\
\hline Zona & A & B & C & D & E & A & B & C & D & E & A & B & C & D & E \\
\hline 2004 & - & - & - & - & - & - & - & - & $-2,1 \%$ & $-0,9 \%$ & - & - & $0,8 \%$ & $-0,5 \%$ & $-0,7 \%$ \\
2005 & - & - & - & - & $0,0 \%$ & - & - & - & $1,1 \%$ & $-0,1 \%$ & - & - & $1,5 \%$ & $-0,6 \%$ & $0,4 \%$ \\
2006 & - & - & - & $0,4 \%$ & $0,3 \%$ & - & - & - & $0,0 \%$ & $0,3 \%$ & - & - & $0,4 \%$ & $0,3 \%$ & $-0,3 \%$ \\
2007 & - & - & - & $0,8 \%$ & $1,6 \%$ & - & - & $0,4 \%$ & $0,1 \%$ & $-0,6 \%$ & - & - & $-1,0 \%$ & $-1,0 \%$ & $0,0 \%$ \\
2008 & - & - & - & $0,8 \%$ & $2,3 \%$ & - & - & $1,4 \%$ & $4,4 \%$ & $1,2 \%$ & - & - & $7,1 \%$ & $3,7 \%$ & $0,2 \%$ \\
\hline
\end{tabular}

FONTE: Ibidem, adaptado pelo autor.

Tabela 63 - Desvio padrão da valorização de casas na cidade de São Paulo 2004-2008

\begin{tabular}{llc}
\hline & Descrição & Desvio Padrão \\
\hline Valorização anual, de casas de & Com menos de 8 anos de construção & $1,21 \%$ \\
médio padrão & De 8 a 14 anos de construção & $3,71 \%$ \\
& Com mais de 14 anos de construção & $1,19 \%$ \\
\hline \multirow{2}{*}{ Valorização anual, de casas } & Com menos de 8 anos de construção & $0,80 \%$ \\
padrão standard & De 8 a 14 anos de construção & $1,59 \%$ \\
& Com mais de 14 anos de construção & $2,13 \%$ \\
\hline
\end{tabular}

Em termos de valorização de imóveis, uma possibilidade é a variação do INCC, Índice Nacional de Custo da Construção. Pode-se observar na Tabela 64 (p. 108) uma variação média de $0,81 \%$ de 1995 a 2008.

Entende-se que a pessoa interessada em adquirir quotas do Ambiente Residencial Especial proposto nesta tese busca mais segurança para o futuro do que altos retornos no curto prazo. Assim, uma possibilidade é a comparação com a caderneta de poupança. O rendimento médio mensal no período de 1999 a 2008 foi de $0,72 \%$ (Tabela 65, p. 108). 
Tabela 64 - Índice Nacional de Custo da Construção - INCC - 1995-2008

\begin{tabular}{ccc}
\hline \multirow{2}{*}{ Ano } & \multicolumn{2}{c}{ Taxa } \\
\cline { 2 - 3 } & Anual & Média Mensal \\
\hline 1995 & $31,5 \%$ & $2,31 \%$ \\
1996 & $9,6 \%$ & $0,76 \%$ \\
1997 & $6,8 \%$ & $0,55 \%$ \\
1998 & $2,8 \%$ & $0,23 \%$ \\
1999 & $9,2 \%$ & $0,74 \%$ \\
2000 & $7,7 \%$ & $0,62 \%$ \\
2001 & $8,8 \%$ & $0,71 \%$ \\
2002 & $12,9 \%$ & $1,01 \%$ \\
2003 & $14,4 \%$ & $1,13 \%$ \\
2004 & $11,0 \%$ & $0,88 \%$ \\
2005 & $6,8 \%$ & $0,55 \%$ \\
2006 & $5,0 \%$ & $0,41 \%$ \\
2007 & $6,2 \%$ & $0,50 \%$ \\
2008 & $11,9 \%$ & $0,94 \%$ \\
\hline Média & $10,3 \%$ & $0,81 \%$ \\
\hline
\end{tabular}

FONTE: CONSELHO REGIONAL DE ECONOMIA DO ESTADO DE SÃO PAULO, 2009, adaptado pelo autor.

Outra opção de comparação é a taxa Selic. Essa taxa é base de reajuste dos preços unitários dos títulos públicos (FORTUNA, 2005, p. 128). A evolução da mesma pode ser observada na Tabela 66 (p. 109).

Tabela 65 - Rendimento da caderneta de poupança 1995-2008

\begin{tabular}{ccc}
\hline \multirow{2}{*}{ Ano } & \multicolumn{2}{c}{ Taxa } \\
\cline { 2 - 3 } & Anual & Média Mensal \\
\hline 1995 & $38,6 \%$ & $2,76 \%$ \\
1996 & $15,8 \%$ & $1,23 \%$ \\
1997 & $17,0 \%$ & $1,32 \%$ \\
1998 & $13,7 \%$ & $1,08 \%$ \\
2009 & $11,9 \%$ & $0,94 \%$ \\
2001 & $8,3 \%$ & $0,67 \%$ \\
2002 & $8,7 \%$ & $0,70 \%$ \\
2003 & $9,4 \%$ & $0,75 \%$ \\
2004 & $10,7 \%$ & $0,85 \%$ \\
2005 & $8,2 \%$ & $0,66 \%$ \\
2006 & $9,2 \%$ & $0,74 \%$ \\
2007 & $8,3 \%$ & $0,67 \%$ \\
2008 & $7,6 \%$ & $0,61 \%$ \\
Média 1999-2008 & $8,0 \%$ & $0,64 \%$ \\
Média 2005-2008 & $9,03 \%$ & $0,72 \%$ \\
\hline
\end{tabular}

FONTE: BANCO CENTRAL DO BRASIL, 2009a, adaptado pelo autor. 
Tabela 66 - Taxa Selic 1995-2008

\begin{tabular}{ccc}
\hline \multirow{2}{*}{ Ano } & \multicolumn{2}{c}{ Taxa } \\
\cline { 2 - 3 } & Anual & Média Mensal \\
\hline 1995 & $53,1 \%$ & $3,61 \%$ \\
1996 & $27,4 \%$ & $2,04 \%$ \\
1997 & $24,8 \%$ & $1,86 \%$ \\
1998 & $28,8 \%$ & $2,13 \%$ \\
1999 & $25,6 \%$ & $1,92 \%$ \\
2000 & $17,4 \%$ & $1,35 \%$ \\
2001 & $17,3 \%$ & $1,34 \%$ \\
2003 & $19,2 \%$ & $1,47 \%$ \\
2004 & $23,3 \%$ & $1,76 \%$ \\
2005 & $16,2 \%$ & $1,26 \%$ \\
2006 & $19,0 \%$ & $1,46 \%$ \\
2007 & $15,1 \%$ & $1,18 \%$ \\
2008 & $11,9 \%$ & $0,94 \%$ \\
Média 1999-2008 & $12,5 \%$ & $0,98 \%$ \\
Média 2005-2008 & $17,76 \%$ & $1,37 \%$ \\
\hline
\end{tabular}

FONTE: BANCO CENTRAL DO BRASIL, 2009b, adaptado pelo autor.

Com base nos índices indicados, para efeito de simulação dos créditos gerados aos proprietários, serão usadas taxas mensais de $1,1 \%, 1,2 \%, 1,3 \%, 1,4 \%$ e $1,5 \%$ sobre o investimento, que significam retornos anuais de 14,03\%, 15,39\%, 16,77\%, 18,16\% e 19,56\%, respectivamente.

Partindo do princípio que durante a construção não haverá geração de créditos, as taxas idealizadas deverão ser ajustadas por um determinado período de tempo de tal forma que os retornos sejam alcançados. Para efeito de simulação, trabalhar-se-á com um prazo de construção de três meses e retorno correspondente de 12 e 24 meses a partir do início da construção. Em outras palavras, mesmo com 90 dias sem operação, a organização gerará em nove ou 21 meses o mesmo retorno que ocorreria sem os três meses iniciais.

Estas taxas estão representadas na Tabela 67 (p. 110). A linha Taxa para 1 ano é a taxa mensal elevada à $12^{\mathrm{a}}$ potência. Duas linhas abaixo, Taxa para 2 anos, é a taxa mensal elevada à $24^{\mathrm{a}}$ potência.

$$
\begin{aligned}
& \text { Taxa para } 1 \text { ano }=\left((1+0,0110)^{12}\right)-1 \\
& \text { Taxa para } 1 \text { ano }=0,1403=14,03 \% \\
& \text { Taxa para } 2 \text { anos }=\left((1+0,0110)^{24}\right)-1 \\
& \text { Taxa para } 2 \text { anos }=0,3003=30,03 \%
\end{aligned}
$$


Com uma estimativa de 90 dias para a construção, a taxa de 14,03\% ao ano, por exemplo, precisa ser diluída em nove meses. O cálculo foi feito a partir da seguinte fórmula:

$$
\begin{aligned}
& \text { Taxa Mensal Equivalente }=\left((1+0,1403)^{\frac{1}{9}}\right)-1 \\
& \text { Taxa Mensal Equivalente }=0,0147=1,47 \%
\end{aligned}
$$

Ou seja, no primeiro ano de atividade, para um crédito equivalente a 14,03\% ao ano em relação ao investimento dos proprietários, partindo da premissa que o início das atividades seria depois de três meses, período da construção, o crédito mensal será de 1,47\%. A partir do $2^{\circ}$ ano essa taxa passa para $1,10 \%$ ao mês.

Tabela 67 - Simulação da taxa de retorno dos créditos

\begin{tabular}{lrrrrr}
\hline \multicolumn{1}{c}{ Descrição } & \multicolumn{5}{c}{ Taxa Mensal } \\
\cline { 2 - 6 } & $\mathbf{1 , 1 0 \%}$ & $\mathbf{1 , 2 0 \%}$ & $\mathbf{1 , 3 0 \%}$ & $\mathbf{1 , 4 0 \%}$ & $\mathbf{1 , 5 0 \%}$ \\
\hline Taxa para 1 ano & $14,03 \%$ & $15,39 \%$ & $16,77 \%$ & $18,16 \%$ & $19,56 \%$ \\
Taxa mensal equivalente para 9 meses & $1,47 \%$ & $1,60 \%$ & $1,74 \%$ & $1,87 \%$ & $2,00 \%$ \\
Taxa para 2 anos & $30,03 \%$ & $33,15 \%$ & $36,34 \%$ & $39,61 \%$ & $42,95 \%$ \\
Taxa mensal equivalente para 21 meses & $1,26 \%$ & $1,37 \%$ & $1,49 \%$ & $1,60 \%$ & $1,72 \%$ \\
\hline
\end{tabular}

Se a opção é diluir em dois anos o período que os proprietários ficam sem créditos em função da construção, ainda tomando como base a taxa mensal de 1,10\%, são necessários 21 meses a uma taxa de $1,26 \%$ ao mês.

No Apêndice 65 (p. 272), estão evidenciados os créditos de 1,10\% sobre o valor do investimento, por mensalidade, para construção em 90 dias e compensação de retorno em 12 meses, para uma organização que comporte 100 residentes, com níveis de utilização da capacidade instalada de $60 \%, 70 \%, 80 \%$ e $90 \%$. O crédito mais representativo de $\mathrm{R} \$ 1.165$ seria cobrado dos residentes se todos tivessem grau de dependência II, com um nível de utilização da capacidade instalada de $60 \%$. O menor crédito, $\mathrm{R} \$ 697$, seria cobrado dos residentes, caso todos tivessem grau de dependência III, com um nível de utilização da capacidade instalada de $90 \%$.

Deve-se notar que o crédito é menor para residentes com grau de dependência III, pois não há a necessidade de investimento nas áreas externas. Contudo, deve-se notar que o crédito é acrescido ao valor da mensalidade, e esta é representativa principalmente em função da necessidade de um número de cuidadores. 
Para organizações de 200, 300 e 400 residentes, os menores créditos também são para 100\% de residentes com grau de dependência II, com nível de utilização da capacidade de $60 \%$; os maiores valores são para $100 \%$ de residentes com grau de dependência III a um nível de utilização da capacidade instalada de 90\%. Para uma organização de 200 residentes, os créditos são de $\mathrm{R} \$ 1.180$ e $\mathrm{R} \$ 709$ (Apêndice 66, p. 272); para 300 os crédito são de $\mathrm{R} \$ 1.099$ e R \$ 660 (Apêndice 67, p. 272) e para 400 residentes, os valores são de R \$ 1.079 e R \$ 647 (Apêndice 68, p. 273).

Deve-se notar que os créditos assumem valores diferentes em função do nível de utilização da capacidade instalada. A premissa adotada é que os residentes cobrem todos os créditos, ou seja, a ociosidade não gera perda aos proprietários. Contudo, esse posicionamento tem limite, pois uma gestão não comprometida com a organização poderia manter nível baixo de aproveitamento da capacidade instalada e mensalidades altas, possivelmente inviabilizando a perpetuidade da instituição.

Como os créditos são porcentagens dos investimentos, as equações das regressões lineares múltiplas não foram calculadas nesta simulação.

Do Apêndice 69 (p. 273) ao Apêndice 72 (p. 274) são apresentados os créditos de 1,2\% sobre o valor dos investimentos para 100, 200, 300 e 400 residentes. Para 1,3\%, os dados estão apresentados do Apêndice 73 (p. 274) ao Apêndice 76 (p. 275). Para 1,4\% e 1,5\% pode-se consultar do Apêndice 77 (p. 276) ao Apêndice 84 (p. 278). Em todos os casos, a construção ocorre em 90 dias e a compensação dos créditos desses três meses que a organização não loca as habitações ocorre nos primeiro ano.

Outra possibilidade é compensar a falta de crédito no período da construção ao longo de dois anos. As simulações para créditos de 1,1\%, 1,2\%, 1,3\%, 1,4\% e 1,5\%, para 100, 200, 300 e 400 residentes com diversas combinações de grau de dependência, com nível de utilização da capacidade instalada de 60\%, 70\%, 80\% e 90\%, estão representadas do Apêndice 85 (p. 278) ao Apêndice 104 (p. 285).

Tomando como exemplo um crédito de 1,1\%, para uma organização de 300 residentes, sendo $60 \%$ com grau de dependência I, 30\% com grau de dependência II e 10\% com grau III, trabalhando com uma ociosidade média de $20 \%$, para compensação do período de construção em um ano, o crédito necessário seria de $\mathrm{R} \$ 816$ (Apêndice 67, p. 272) e para dois anos 
R\$ 699 (Apêndice 87, p. 279). Se o crédito fosse de 1,5\% sobre o valor do investimento, os valores passariam para $\mathrm{R} \$ 1.113$ (Apêndice 83, p. 278) e $\mathrm{R} \$ 954$ (Apêndice 103, p. 284), respectivamente.

\subsection{8 $8^{\text {a }}$ série de simulações - variação dos créditos aos proprietários em função do número de habitações acessíveis a pessoas que utilizam cadeira de rodas}

As habitações destinadas a cadeirantes necessitam de dimensões maiores para a devida movimentação do residente. Com isso, quanto maior o número dessas unidades, maior o investimento e maior a necessidade de valor absoluto do crédito a ser gerado para os proprietários.

Se uma organização tivesse somente residentes com grau de dependência III praticamente não teria a necessidade de investimento nas áreas externas, o que reduziria o valor dos créditos. Se a organização tivesse somente residentes com grau de dependência II, os investimentos nas áreas externas seriam iguais aos residentes com grau de dependência I; contudo, há uma necessidade maior de cuidadores, o que aumenta ligeiramente o investimento em vestiários e banheiros para os funcionários.

Independente do tamanho das organizações, os créditos dos proprietários são diretamente proporcionais ao número de habitações que atendem cadeirantes, ou seja, quanto maior o número dessas unidades, maior o crédito a ser gerado. Em relação ao grau de dependência dos residentes, quanto maior o número de pessoas com grau III, menor o crédito, quanto maior o número de residentes com grau II, maior o crédito a ser gerado.

Para créditos de $1,1 \%$ sobre o valor do investimento, para construção em 90 dias e compensação de retorno em 12 meses, com simulação da porcentagem de habitações destinadas a cadeirantes, com diversas combinações de graus de dependência, os menores valores em organizações com 100 residentes (Apêndice 105, p. 285), 200 (Apêndice 106, p. 285), 300 (Apêndice 107, p. 286) e 400 residentes (Apêndice 108, p. 286) são de R\$897, $\mathrm{R} \$ 912, \mathrm{R} \$ 848$ e $\mathrm{R} \$ 832$, respectivamente. Os maiores valores são de $\mathrm{R} \$ 1.202$, $\mathrm{R} \$ 1.215$, $\mathrm{R} \$ 1.137$ e $\mathrm{R} \$ 1.122$.

Os créditos de 1,2\%,1,3\% e 1,4\% sobre o valor do investimento, seguindo as mesmas premissas indicadas no parágrafo anterior, estão demonstrados do Apêndice 109 (p. 286) ao Apêndice 120 (p. 290). Para 1,5\% os menores créditos são de R\$1.232 (Apêndice 121, p. 
290), R $\$ 1.243$ (Apêndice 122, p. 291), R $\$ 1.157$ (Apêndice 123, p. 291) e R\$1.134 (Apêndice 124, p. 291) para 100, 200, 300 e 400 residentes. Nos mesmos apêndices os maiores valores são de $\mathrm{R} \$ 1.639, \mathrm{R} \$ 1.656, \mathrm{R} \$ 1.551$ e $\mathrm{R} \$ 1.530$.

Se o prazo para compensar o período de construção passar de um para dois anos, os valores dos créditos reduzem ligeiramente. Para $1,1 \%$ de crédito sobre o investimento, os menores valores passam para R 769 (Apêndice 125, p. 292), R 782 (Apêndice 126, p. 292), R \$ 727 (Apêndice 127, p. 292) e R 713 (Apêndice 128, p. 293) para 100, 200, 300 e 400 residentes. Os créditos de $1,2 \%$ a $1,4 \%$ sobre o valor do investimento podem ser observados do Apêndice 129 (p. 293) ao Apêndice 140 (p. 297). Para 1,5\% os maiores valores são de R \$ 1.405 (Apêndice 141, p. 297), R \$ 1.420 (Apêndice 142, p. 297), R \$ 1.329 (Apêndice 143, p. 298) e R\$ 1.311 (Apêndice 144, p. 298).

\subsection{9 $9^{\mathrm{a}}$ série de simulações - variação dos créditos aos proprietários em função da variação de áreas comuns}

As simulações deste tópico apresentam o valor dos créditos gerados em função da existência de anfiteatro, da área do minisshopping, da existência de piscinas, saunas, campos, quadras e pistas de pedestres e ciclovia.

Para um crédito médio de 1,1\% sobre o valor do investimento, para construção em 90 dias e compensação de retorno em 12 meses, em função das premissas estabelecidas nas Tabelas 36 e 37 (p. 90), para várias combinações de números de residentes com graus de dependência diferentes, os menores valores são R 786 (Apêndice 145, p. 298), R\$ 743 (Apêndice 146, p. 299), R\$ 724 (Apêndice 147, p. 299) e R\$ 723 (Apêndice 148, p. 299) para 100, 200, 300 e 400 residentes, respectivamente. Os maiores valores são $\mathrm{R} \$ 999, \mathrm{R} \$ 1.012, \mathrm{R} \$ 942$ e R\$ 923. Os créditos de 1,2\%, 1,3\% e 1,4\% podem ser observados do Apêndice 149 (p. 300) ao Apêndice 160 (p. 303).

Para créditos de 1,5\%, os menores e maiores valores são $\mathrm{R} \$ 1.071$ e $\mathrm{R} \$ 1.362$ para 100 residentes (Apêndice 161, p. 304), R\$ 1.013 e R\$ 1.380 para 200 residentes (Apêndice 162, p. 304), R\$ 988 e R $\$ 1.284$ para 300 (Apêndice 163, p. 304) e $\mathrm{R} \$ 986$ e R\$ 1.261 para 400 residentes (Apêndice 164, p. 305).

Para construção em 90 dias e compensação de retorno em 24 meses, os créditos de 1,1\%, 1,2\%, 1,3\%, 1,4\% e 1,5\% podem ser observados do Apêndice 165 (p. 305) ao Apêndice 184 
(p. 311). Para se ter uma idéia, para créditos de 1,5\% os menores e maiores valores são R\$ 918 e R\$ 1.167 para 100 residentes (Apêndice 181, p. 310), R\$ 868 e R\$ 1.182 para 200 (Apêndice 182, p. 311), R \$ 847 e R $\$ 1.101$ para 300 (Apêndice 183, p. 311) e R 845 e $\mathrm{R}$ \$ 1.081 para 400 residentes (Apêndice 184, p. 311).

\subsubsection{0 $10^{\mathrm{a}}$ série de simulações - valor médio da mensalidade final em função do nível de utilização da capacidade instalada}

Pode-se observar nos tópicos anteriores que os créditos são quantificados em função do volume de investimento do proprietário. Contudo, o valor da mensalidade final é uma combinação da mensalidade que cobre os custos e despesas com o crédito que deve ser gerado aos proprietários.

Os maiores e menores valores das mensalidades, com crédito de $1,1 \%$ sobre o valor do investimento, para construção em 90 dias e compensação do retorno em um ano, com níveis de $60 \%, 70 \%, 80 \%$ e $90 \%$ de utilização da capacidade instalada, com várias combinações de grau de dependência, são $\mathrm{R} \$ 5.775$ e $\mathrm{R} \$ 3.421$ para 100 residentes (Apêndice 185, p. 312), $\mathrm{R} \$ 5.397$ e $\mathrm{R} \$ 3.173$ para 200 (Apêndice 186, p. 312), R\$ 4.960 e $\mathrm{R} \$ 2.893$ para 300 (Apêndice 187, p. 312) e R 4.854 e R 2.812 para 400 residentes (Apêndice 188, p. 313).

O valor das mensalidades para créditos de 1,2\%, 1,3\% e 1,4\% estão representados do Apêndice 189 (p. 313) ao Apêndice 200 (p. 317). Para 1,5\% os maiores e menores valores são R \$ 6.155 e R\$ 3.703 para 100 residentes (Apêndice 201, p. 317), R\$ 5.784 e R\$ 3.458 para 200 (Apêndice 202, p. 317), R \$ 5.320 e R 3.158 para 300 (Apêndice 203, p. 318) e R \$ 5.207 e R\$3.073 para 400 residentes (Apêndice 204, p. 318).

Para compensar os créditos de 1,1\% perdidos no período da construção em dois anos, os maiores valores são $R$ \$ 5.625 para 100 residentes (Apêndice 205, p. 318), R \$ 5.245 para 200 (Apêndice 206, p. 319), R\$ 4.819 para 300 (Apêndice 207, p. 319) e $\mathrm{R} \$ 4.715$ para 400 residentes (Apêndice 208, p. 319). Os menores valores são R \$ 3.310, R\$ 3.061, R \$ 2.788 e $\mathrm{R} \$ 2.710$ para 100, 200, 300 e 400 residentes, respectivamente. $\mathrm{O}$ valor das mensalidades para créditos de 1,2\%, 1,3\%,1,4\% e 1,5\% podem ser observados do Apêndice 209 (p. 320) ao Apêndice 224 (p. 325). 


\subsubsection{1 $11^{\mathrm{a}}$ série de simulações - valor médio da mensalidade final em função do número de habitações acessíveis a pessoas que utilizam cadeira de rodas}

Habitações acessíveis a cadeirantes exigem medidas especiais e, consequentemente, investimentos e créditos maiores. A mensalidade, por sua vez, é maior em função da depreciação e do maior número de funcionários, principalmente de limpeza.

Os maiores e menores valores da mensalidade média, com crédito de $1,1 \%$ sobre o valor do investimento, para construção em 90 dias e compensação de retorno em um ano, com simulação de $20 \%, 40 \%, 60 \%, 80 \%$ e $100 \%$ de habitações destinadas a cadeirantes, para várias combinações do grau de dependência dos residentes, são R \$ 5.826 e R \$ 4.289 para 100 residentes (Apêndice 225, p. 325), R $\$ 5.602$ e $\mathrm{R} \$ 3.983$ para 200 (Apêndice 226, p. 325), $\mathrm{R} \$ 5.199$ e $\mathrm{R} \$ 3.628$ para 300 (Apêndice 227, p. 326) e $\mathrm{R} \$ 5.406$ e $\mathrm{R} \$ 3.464$ para 400 residentes (Apêndice 228, p. 326).

O valor final das mensalidades para créditos de $1,2 \%, 1,3 \%$ e 1,4\% pode ser observado do Apêndice 229 (p. 326) ao Apêndice 240 (p. 330). Para efeito de comparação, os maiores e menores valores das mensalidades para um crédito de $1,5 \%$ sobre o investimento são $\mathrm{R}$ \$ 6.226 e R 4.652 para 100 residentes (Apêndice 241, p. 330), $\mathrm{R}$ \$ 6.007 e $\mathrm{R} \$ 4.351$ para 200 (Apêndice 242, p. 331), R 5.578 e R 3.969 para 300 (Apêndice 243, p. 331) e R \$ 5.419 e R\$3.800 para 400 residentes (Apêndice 244, p. 331).

Para a compensação dos créditos de 1,1\% perdidos com a construção em um período de dois anos, os maiores e menores valores das mensalidades são $\mathrm{R} \$ 5.669$ e $\mathrm{R} \$ 4.146$ para 100 residentes (Apêndice 245, p. 332), R\$ 5.442 e $\mathrm{R} \$ 3.839$ para 200 (Apêndice 246, p. 332), $\mathrm{R} \$ 5.050$ e $\mathrm{R} \$ 3.493$ para 300 (Apêndice 247, p. 332) e R 4.899 e $\mathrm{R} \$ 3.332$ para 100 residentes (Apêndice 248, p. 333). As mensalidades com créditos de 1,2\%, 1,3\% e 1,4\% podem ser observadas do Apêndice 249 (p. 333) ao Apêndice 260 (p. 337).

Para créditos de 1,5\% os maiores e menores valores das mensalidades são R 6.012 e $\mathrm{R} \$ 4.457$ para 100 residentes (Apêndice 261, p. 337), R\$5.790 e R\$4.154 para 200 (Apêndice 262, p. 337), R\$ 5.375 e R \$ 3.786 para 300 (Apêndice 263, p. 338) e R\$ 5.219 e R\$3.620 para 400 residentes (Apêndice 264, p. 338). 


\subsubsection{2 $12^{\mathrm{a}}$ série de simulações - valor médio da mensalidade final em função da variação de áreas comuns}

As áreas comuns determinam diferentes níveis de mensalidade em função de depreciação, manutenção e limpeza. As premissas desta série de simulações encontram-se nas Tabelas 36 e 37 (p. 90). As maiores e menores mensalidades para créditos de 1,1\% sobre o valor do investimento, para construção em 90 dias e compensação de retorno em 12 meses, com diversas combinações de grau de dependência para 100 residentes são $R$ \$ 5.226 e R $\$ 3.920$ (Apêndice 265, p. 338), para 200 R 4.891 e R 3.375 (Apêndice 266, p. 339), R 4.547 e $\mathrm{R} \$ 3.183$ para 300 (Apêndice 267, p. 339) e $\mathrm{R} \$ 4.395$ e $\mathrm{R} \$ 3.060$ para 400 residentes (Apêndice 268, p. 339).

Para créditos de 1,2\%, 1,3\% e 1,4\%, as mensalidades podem ser observadas do Apêndice 269 (p. 340) ao Apêndice 280 (p. 343). Os maiores e menores valores para as mensalidades com créditos de 1,5\% são $\mathrm{R} \$ 5.553$ e $\mathrm{R} \$ 4.241$ para 100 residentes (Apêndice 281, p. 344), $\mathrm{R} \$ 5.223$ e $\mathrm{R} \$ 3.678$ para 200 (Apêndice 282, p. 344), $\mathrm{R} \$ 4.855$ e $\mathrm{R} \$ 3.477$ para 300 (Apêndice 283, p. 344) e R 4.698 e R \$ 3.354 para 400 residentes (Apêndice 284, p. 345).

As maiores e menores mensalidades, para compensação de retorno em dois anos, com créditos de $1,1 \%$ sobre o valor do investimento, são $\mathrm{R} \$ 5.098$ e $\mathrm{R} \$ 3.794$ para 100 residentes (Apêndice 285, p. 345), R\$ 4.761 e $\mathrm{R} \$ 3.256$ para 200 (Apêndice 286, p. 345), R \$ 4.426 e $\mathrm{R} \$ 3.067$ para 300 (Apêndice 287, p. 346) e $\mathrm{R} \$ 4.276$ e $\mathrm{R} \$ 2.945$ para 400 residentes (Apêndice 288, p. 346).

As mensalidades para créditos de 1,2\%, 1,3\% e 1,4\% estão representadas do Apêndice 289 (p. 346) ao Apêndice 300 (p. 350). Para créditos de 1,5\%, os valores das mensalidades são $\mathrm{R} \$ 5.378$ e $\mathrm{R} \$ 4.069$ para 100 residentes (Apêndice 301, p. 350), $\mathrm{R} \$ 5.045$ e $\mathrm{R} \$ 3.515$ para 200 (Apêndice 302, p. 351), R 4.690 e $\mathrm{R} \$ 3.320$ para 300 (Apêndice 303, p. 351) e R \$ 4.535 e R\$ 3.197 para 400 residentes (Apêndice 304, p. 351).

\subsubsection{3 $13^{\mathrm{a}}$ série de simulações - variação do investimento inicial em função do número de habitações e áreas externas construídas}

Uma possibilidade é a construção da organização em fases. Nesta simulação, foram indicadas as necessidades para a construção da $1^{\text {a }}$ etapa. Na Tabela 68 (p. 117), foram indicadas as 
características desta simulação em função do número de residentes. Na Tabela seguinte, as áreas externas a serem construídas na $1^{\mathrm{a}}$ etapa, além do minisshopping e anfiteatro.

Tabela 68 - Características da organização em função do número de residentes para construção em mais de 1 etapa

\begin{tabular}{lcccc}
\hline \multicolumn{1}{c}{ Descrição } & Características da organização em função \\
do número de residentes
\end{tabular}

No Apêndice 305 (p. 352) estão indicadas as porcentagens de habitações construídas na $1^{\text {a }}$ fase. Para 100 residentes são necessárias 50 habitações e, consequentemente, 50 proprietários, onde cada um investe $\mathrm{R} \$ 95.267$, totalizando um investimento total de $\mathrm{R} \$$ 4.763.361. Para construir $80 \%$ das habitações e as áreas comuns, conforme a Tabela 69 (p. 117), o investimento inicial passa a ser $\mathrm{R}$ \$ 4.241.791; para esse valor são necessários 45 proprietários ou $90 \%$ dos 50 . Para construir $60 \%$ das habitações são necessários R $\$ 3.848 .031$ ou 41 proprietários e para $40 \% \mathrm{R} \$ 3.454 .271$ ou 37 proprietários.

Tabela 69 - Áreas a serem construídas na $1^{\circ}$ etapa da construção

\begin{tabular}{lc}
\hline \multicolumn{1}{c}{ Áreas } & Construção na 1a fase \\
\hline Minisshopping & Sim \\
Anfiteatro & Sim \\
Piscina & Não \\
Sauna seca & Não \\
Sauna úmida & Não \\
Campo de bocha & Não \\
Campo de malha & Não \\
Quadra poliesportiva & Não \\
Quadra de saibro & Não \\
Pista de pedestre & Sim \\
Ciclovia & Não \\
\hline
\end{tabular}


Para organizações que atendam 200, 300 e 400 residentes, as proporções ficam muito próximas de $90 \%, 80 \%$ e $70 \%$ de investidores iniciais para $80 \%, 60 \%$ e $40 \%$ de habitações construídas na primeira etapa.

\subsubsection{4 $14^{a}$ série de simulações - variação da mensalidade em função do nível de utilização da capacidade instalada entre 20 e $90 \%$}

Com base nas premissas estabelecidas na Tabela 26 (p. 82), foram calculadas mensalidades simulando níveis de utilização da capacidade instalada entre $20 \%$ e $90 \%$. Ou seja, definindo um nível ideal de utilização das instalações, as mensalidades indicadas cobrem os custos e as despesas. Nesta simulação os créditos dos proprietários não foram considerados. No Apêndice 306 (p. 353) as mensalidades propostas destinam-se a organizações para 100 residentes. Com $20 \%$ de utilização da capacidade instalada e só residindo pessoas com grau de dependência I, o valor da mensalidade deveria ser $\mathrm{R} \$ 10.589$. Com $90 \%$ de utilização, a mesma passaria a ser $\mathrm{R} \$ 2.644$. Uma combinação de $60 \%$ de residentes com grau de dependência I, 30\% com dependência II e 10\% dos residentes com grau de dependência III exigiria uma mensalidade de $\mathrm{R} \$ 11.444$ para $20 \%$ de utilização da capacidade instalada e $\mathrm{R} \$ 3.056$ para $90 \%$.

Organizações com capacidade para um número maior de residentes possuem mensalidades menores a partir das premissas assumidas nesta tese. Para a combinação de $60 \%, 30 \%$ e $10 \%$ de residentes com graus de dependência I, II e III, respectivamente, a $20 \%$ e $90 \%$ do nível de utilização da capacidade instalada, são de $\mathrm{R} \$ 9.651$ e $\mathrm{R} \$ 2.744$ para 200 residentes (Apêndice 307, p. 353), R\$ 8.292 e R \$ 2.538 para 300 (Apêndice 308, p. 354) e R \$ 8.035 e $\mathrm{R}$ \$ 2.424 para 400 residentes (Apêndice 309, p. 354).

\subsection{Variáveis de decisão de investimento}

Ao adquirir quotas com intenção de uso próprio no futuro, o investidor poderá analisar sua idade e a expectativa de vida para avaliar se o investimento é viável ou não. Pode-se observar, na Tabela 70 (p. 119), a expectativa de vida de uma pessoa em função de sua idade atual.

\section{Adquirir quotas para uma habitação}

Tomando como exemplo uma organização para 300 residentes, com $20 \%$ das habitações destinadas a cadeirantes, sendo $60 \%$ dos residentes com grau de dependência I, 30\% com grau 
II e 10\% com grau de dependência III, com nível de utilização da capacidade instalada de 70\%, o valor do investimento por habitação é de $\mathrm{R} \$ 89.021$ (Tabela 30, p. 86). Esse investimento dá direito a uma habitação que pode ser utilizada por duas pessoas. Com o falecimento de ambos, a habitação é doada à organização, que pode vendê-la novamente.

Enquanto o investidor ou a pessoa indicada por ele não utilizar a habitação, a mesma pode ser locada para dois residentes não proprietários. O valor da mensalidade do locador é maior, sendo que a diferença é acumulada em forma de crédito ao proprietário, que será utilizada no futuro para abater as mensalidades do proprietário. Se este precisar vender as quotas depois de um determinado tempo os créditos são transferidos ao comprador.

Tabela 70 - Tábua de Mortalidade - 2007

\begin{tabular}{|c|c|c|c|c|c|c|c|c|c|c|c|}
\hline \multirow{2}{*}{ Idade } & \multicolumn{2}{|c|}{ Expectativa de vida } & \multirow{2}{*}{ Idade } & \multicolumn{2}{|c|}{ Expectativa de vida } & \multirow{2}{*}{ Idade } & \multicolumn{2}{|c|}{ Expectativa de vida } & \multirow{2}{*}{ Idade } & \multicolumn{2}{|c|}{ Expectativa de vida } \\
\hline & à idade & total & & à idade & total & & à idade & total & & à idade & total \\
\hline 0 & 72,6 & 72,6 & 20 & 55,3 & 75,3 & 40 & 37,2 & 77,2 & 60 & 21,1 & 81,1 \\
\hline 1 & 73,4 & 74,4 & 21 & 54,3 & 75,3 & 41 & 36,4 & 77,4 & 61 & 20,3 & 81,3 \\
\hline 2 & 72,6 & 74,6 & 22 & 53,4 & 75,4 & 42 & 35,5 & 77,5 & 62 & 19,6 & 81,6 \\
\hline 3 & 71,7 & 74,7 & 23 & 52,5 & 75,5 & 43 & 34,6 & 77,6 & 63 & 18,9 & 81,9 \\
\hline 4 & 70,7 & 74,7 & 24 & 51,6 & 75,6 & 44 & 33,8 & 77,8 & 64 & 18,3 & 82,3 \\
\hline 5 & 69,7 & 74,7 & 25 & 50,7 & 75,7 & 45 & 32,9 & 77,9 & 65 & 17,6 & 82,6 \\
\hline 6 & 68,8 & 74,8 & 26 & 49,8 & 75,8 & 46 & 32,1 & 78,1 & 66 & 16,9 & 82,9 \\
\hline 7 & 67,8 & 74,8 & 27 & 48,9 & 75,9 & 47 & 31,2 & 78,2 & 67 & 16,3 & 83,3 \\
\hline 8 & 66,8 & 74,8 & 28 & 48,0 & 76,0 & 48 & 30,4 & 78,4 & 68 & 15,6 & 83,6 \\
\hline 9 & 65,8 & 74,8 & 29 & 47,1 & 76,1 & 49 & 29,6 & 78,6 & 69 & 15,0 & 84,0 \\
\hline 10 & 64,8 & 74,8 & 30 & 46,2 & 76,2 & 50 & 28,8 & 78,8 & 70 & 14,4 & 84,4 \\
\hline 11 & 63,8 & 74,8 & 31 & 45,3 & 76,3 & 51 & 27,9 & 78,9 & 71 & 13,8 & 84,8 \\
\hline 12 & 62,9 & 74,9 & 32 & 44,4 & 76,4 & 52 & 27,1 & 79,1 & 72 & 13,3 & 85,3 \\
\hline 13 & 61,9 & 74,9 & 33 & 43,5 & 76,5 & 53 & 26,3 & 79,3 & 73 & 12,7 & 85,7 \\
\hline 14 & 60,9 & 74,9 & 34 & 42,6 & 76,6 & 54 & 25,6 & 79,6 & 74 & 12,2 & 86,2 \\
\hline 15 & 59,9 & 74,9 & 35 & 41,7 & 76,7 & 55 & 24,8 & 79,8 & 75 & 11,7 & 86,7 \\
\hline 16 & 59,0 & 75,0 & 36 & 40,8 & 76,8 & 56 & 24,0 & 80,0 & 76 & 11,2 & 87,2 \\
\hline 17 & 58,0 & 75,0 & 37 & 39,9 & 76,9 & 57 & 23,3 & 80,3 & 77 & 10,7 & 87,7 \\
\hline 18 & 57,1 & 75,1 & 38 & 39,0 & 77,0 & 58 & 22,5 & 80,5 & 78 & 10,3 & 88,3 \\
\hline 19 & 56,2 & 75,2 & 39 & 38,1 & 77,1 & 59 & 21,8 & 80,8 & 79 & 9,9 & 88,9 \\
\hline & & & & & & & & & $80+$ & 9,4 & 89,4 \\
\hline
\end{tabular}

FONTE: IBGE, 2009, adaptado pelo autor.

Para o exemplo acima, o valor da mensalidade para um residente proprietário é de R\$3.047 (Tabela 48, p. 97). Enquanto o investidor não utiliza as dependências da organização, a habitação pode ser locada para dois residentes não proprietários. Uma das propostas desta tese é a geração mensal de 1,3\% de créditos (Tabela 67, p. 110) sobre o valor investido a partir da locação da habitação. Ou seja:

$$
\begin{aligned}
& \text { Crédito Mensal }=\text { Investimento } \times 0,013 \\
& \text { Crédito Mensal }=\mathrm{R} \$ 89.021 \times 0,013 \\
& \text { Crédito Mensal }=\mathrm{R} \$ 1.157,27
\end{aligned}
$$


O crédito é gerado se a habitação estiver locada. De acordo com o pressuposto indicado no início deste tópico (p. 118), espera-se que a organização trabalhe com um nível de aproveitamento da capacidade instalada de $70 \%$ ou, em outras palavras, com uma ociosidade máxima de $30 \%$. Ou seja, no longo prazo, em vez de um crédito de $\mathrm{R} \$ 1.157,27$, o investidor terá o equivalente a $70 \%$ deste valor. Uma forma de minimizar esse impacto é ajustar o valor do crédito pago pelo locatário através da seguinte fórmula:

Crédito Mensal Ajustado = Crédito Mensal $\div$ Nível de Utilização da Capacidade Instalada Crédito Mensal Ajustado $=1.157,27 \div 0,7$

Crédito Mensal Ajustado $\cong 1.654,00$

Cada habitação pode ser locada para duas pessoas. Assim, dividindo o Crédito Mensal Ajustado entre os dois locatários obtém-se R \$ 827,00. Apesar do Crédito Mensal Ajustado ser de $\mathrm{R} \$ 1.654$ e cada locatário pagar R \$ 827, o proprietário, em média, recebe R\$ 1.157,27.

Desta forma, uma pessoa investe $\mathrm{R} \$ 89.021 \mathrm{em}$ quotas que lhe dá direito a uma habitação e loca a mesma para duas pessoas. Cada uma paga $\mathrm{R} \$ 3.047$ para cobrir custos e despesas mais R\$ 827,00 para gerar os créditos ao proprietário. Esses créditos ficam em poder da organização que deverá investir o montante, com o objetivo de compensar a inflação, em aplicações de baixo risco, como títulos do governo. O valor total da mensalidade para um residente não proprietário seria, portanto, de $\mathrm{R} \$ 3.874,00$. Como espera-se uma ociosidade de até $30 \%$ na locação das habitações, para efeito de cálculo dos créditos mensais utilizar-se-á $\mathrm{R} \$ 1.157,27$.

Utilizar-se-á como exemplo uma pessoa que deseja residir na organização a partir dos 80 anos de idade com uma expectativa de viver aproximadamente mais nove anos ou 108 meses (Tabela 70, p. 119). Como a proposta é adquirir quotas para uma habitação, a variável de decisão é quando investir. Para essa análise será utilizado o conceito do Valor Presente Líquido, VPL. Trata-se de uma técnica que desconta as entradas e saídas futuras de caixa a uma determinada taxa. Essa taxa geralmente é a Taxa Mínima Aceitável pelo Investidor (SOUSA, 2007, p. 62). Utilizando o rendimento médio mensal da caderneta de poupança do período 2005-2008, 0,66\% (Tabela 65, p. 108), como taxa mínima e descontando a inflação medida pelo Índice Nacional de Preços ao Consumidor - Amplo, IPCA, 0,39\% (Tabela 71, p. 121), obtém-se uma taxa líquida de $0,27 \%$ ao mês. 
Tabela 71 - Índice nacional de preços ao consumidor - amplo, IPCA, 1995-2008

\begin{tabular}{ccc}
\hline \multirow{2}{*}{ Ano } & \multicolumn{2}{c}{ Taxa } \\
\cline { 2 - 3 } & Anual & Média Mensal \\
\hline 1995 & $22,41 \%$ & $1,70 \%$ \\
1996 & $9,56 \%$ & $0,76 \%$ \\
1997 & $5,22 \%$ & $0,43 \%$ \\
1998 & $1,65 \%$ & $0,14 \%$ \\
1999 & $8,94 \%$ & $0,72 \%$ \\
2000 & $5,97 \%$ & $0,48 \%$ \\
2001 & $7,67 \%$ & $0,62 \%$ \\
2002 & $12,53 \%$ & $0,99 \%$ \\
2003 & $9,30 \%$ & $0,74 \%$ \\
2004 & $7,60 \%$ & $0,61 \%$ \\
2005 & $5,69 \%$ & $0,46 \%$ \\
2006 & $3,14 \%$ & $0,26 \%$ \\
2007 & $4,46 \%$ & $0,36 \%$ \\
2008 & $5,90 \%$ & $0,48 \%$ \\
\hline Média $1999-2008$ & $7,12 \%$ & $0,57 \%$ \\
Média 2005-2008 & $4,80 \%$ & $0,39 \%$ \\
\hline
\end{tabular}

Fonte: BANCO CENTRAL DO BRASIL, 2009c, adaptado pelo autor.

A Ilustração 5 (p. 121) representa o fluxo de caixa completo do exemplo.

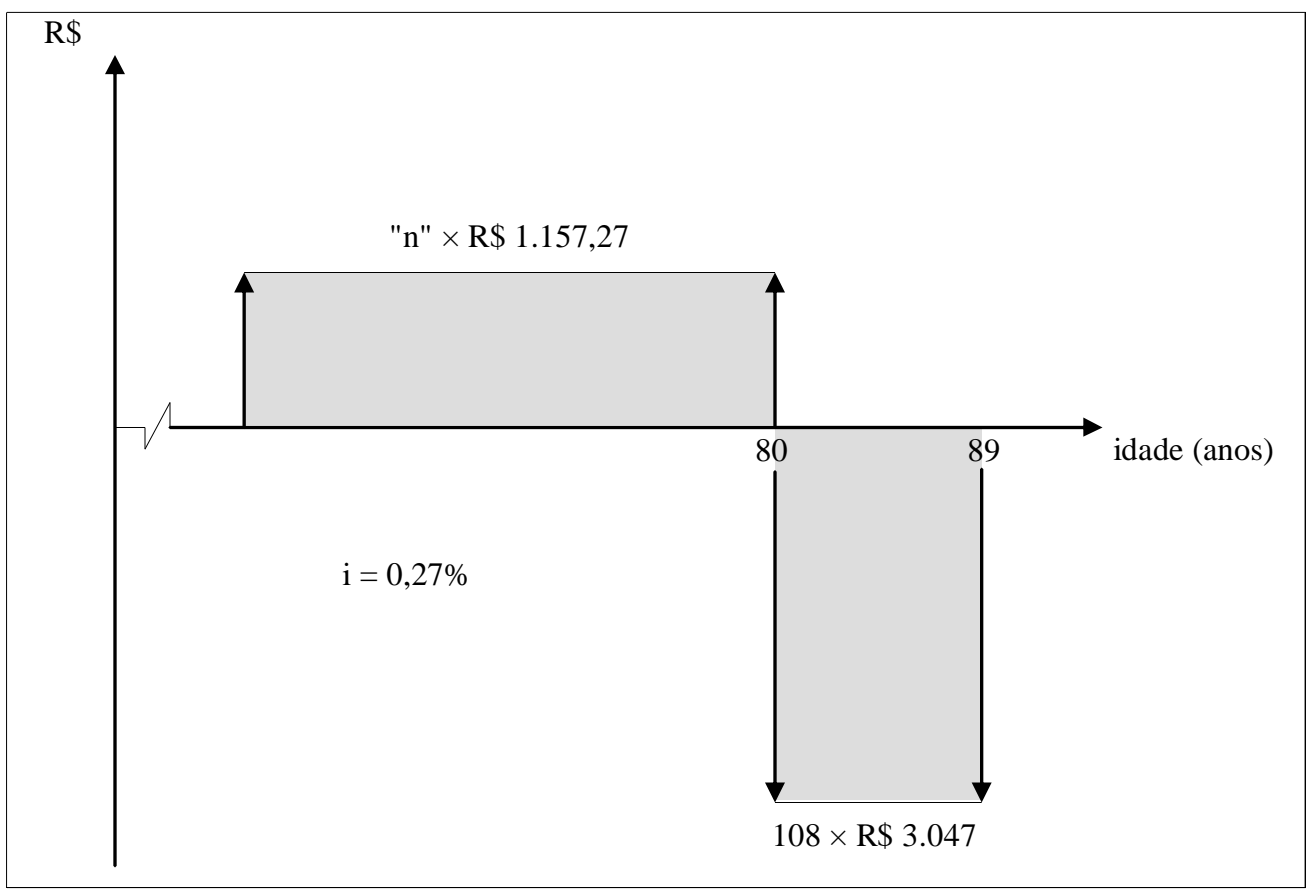

Ilustração 5 - Fluxo de tempo necessário para adquirir quotas de uma habitação, alugar e passar a residir aos 80 anos com as mensalidades pagas

Para um melhor entendimento, o fluxo de caixa será desmembrado em 2. A primeira parte indica a necessidade de recursos aos 80 anos para que o residente não desembolse qualquer valor a título de mensalidade pelos próximos nove anos. 


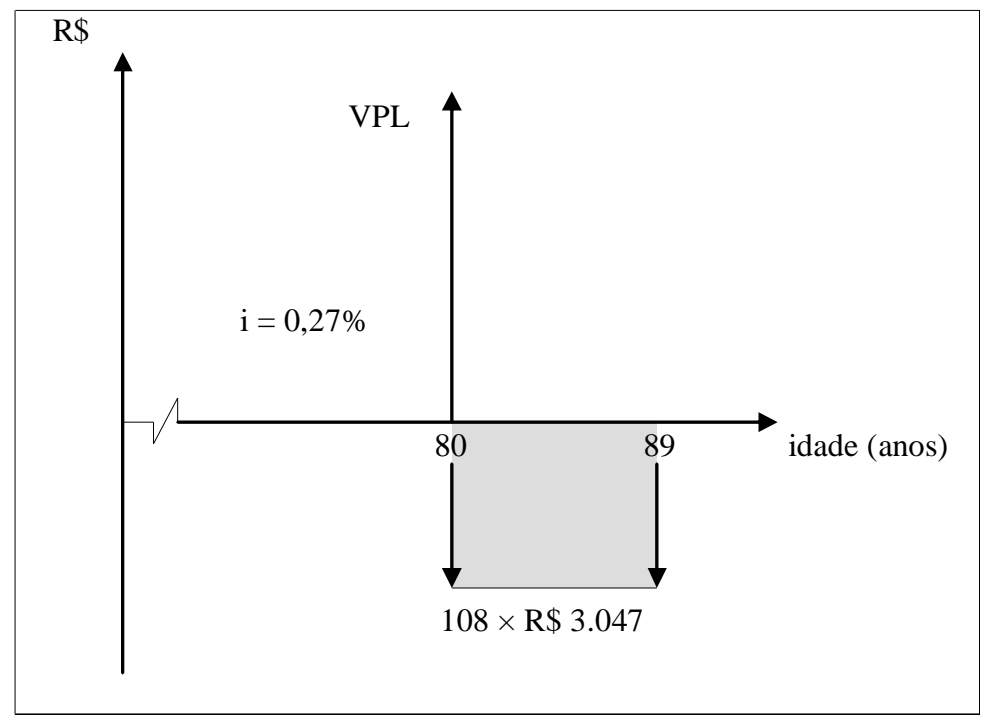

Ilustração 6 - Fluxo de caixa necessário para cobrir 108 mensalidades de R 3.047

Como a série é uniforme, pode-se utilizar a seguinte fórmula (HAZZAN; POMPEO, 2007, p. 152 , adaptado pelo autor):

$$
\mathrm{VPL}=\mathrm{P}_{1} \times\left[\frac{(1+\mathrm{i})^{\mathrm{n}}-1}{(1+\mathrm{i})^{\mathrm{n}} \times \mathrm{i}}\right]
$$

Onde:

$$
\begin{array}{ll}
\mathrm{VPL} & =\text { Valor presente líquido } \\
\mathrm{P}_{1} & =\text { Valor das mensalidades } \\
\mathrm{i} & =\text { Taxa líquida } \\
\mathrm{n} & =\text { Quantidade de parcelas }
\end{array}
$$

Calculando o valor que o proprietário precisa ter aos 80 anos:

$$
\begin{aligned}
\mathrm{VPL}_{80} & =3.047 \times\left[\frac{(1+0,0027)^{108}-1}{(1+0,0027)^{108} \times 0,0027}\right] \\
\mathrm{VPL}_{80} & =3.047 \times\left(\frac{0,338042}{0,003613}\right) \\
\mathrm{VPL}_{80} & =3.047 \times 93,570029 \\
\mathrm{VPL}_{80} & =\mathrm{R} \$ 285.107,88
\end{aligned}
$$

Considerando que o valor presente líquido aos 80 anos é o valor futuro no momento que o investidor estará adquirindo as quotas, pode-se utilizar a seguinte fórmula (HAZZAN; POMPEO, 2007, p. 174, adaptado pelo autor): 


$$
\mathrm{VF}=\mathrm{P}_{2} \times\left[\frac{(1+\mathrm{i})^{\mathrm{n}}-1}{\mathrm{i}}\right]
$$

Onde:

$$
\begin{aligned}
& \mathrm{VF}=\text { Montante ou valor futuro } \\
& \mathrm{P}_{2}=\text { Valor mensal dos créditos } \\
& \mathrm{i} \quad=\text { Taxa líquida } \\
& \mathrm{n} \quad=\text { Quantidade de parcelas }
\end{aligned}
$$

O fluxo de caixa pode ser representado conforme a Ilustração abaixo:

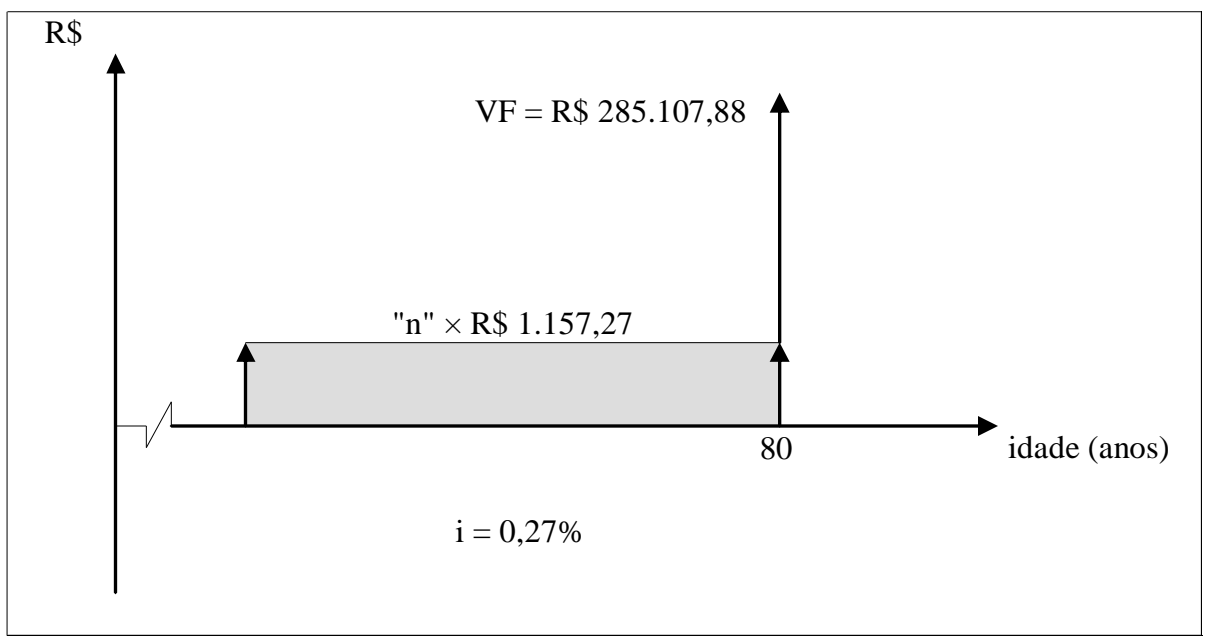

Ilustração 7 - Número de créditos de $\mathbf{R}$ \$1.157,27 necessários para um valor futuro de $\mathbf{R}$ \$285.107,88

Calculando a quantidade de parcelas necessárias de locação para que o proprietário tenha os $\mathrm{R} \$ 285.107,88$ aos 80 anos:

$$
\begin{aligned}
\mathrm{VF}_{80} & =\mathrm{P}_{2} \times\left[\frac{(1+\mathrm{i})^{\mathrm{n}}-1}{\mathrm{i}}\right] \\
285.107,88 & =1.157,27 \times\left[\frac{(1+0,0027)^{\mathrm{n}}-1}{0,0027}\right] \\
\frac{285.107,88 \times 0,0027}{1.157,27} & =1,0027^{\mathrm{n}}-1 \\
0,665179 & =1,0027^{\mathrm{n}}-1 \\
0,665179+1 & =1,0027^{\mathrm{n}} \\
1,665179 & =1,0027^{\mathrm{n}} \\
1,0027^{\mathrm{n}} & =1,665179 \\
\mathrm{n} \ln 1,0027 & =\ln 1,665179
\end{aligned}
$$




$$
\begin{aligned}
& \mathrm{n}=\frac{\ln 1,665179}{\ln 1,0027} \\
& \mathrm{n}=\frac{0,509932}{0,002696} \\
& \mathrm{n} \cong 190
\end{aligned}
$$

Dividindo 190 por 12, obtém-se 15 anos e 10 meses. Ou seja, para passar a residir na organização aos 80 anos, com expectativa de viver mais nove anos, a pessoa precisa adquirir as quotas 190 meses antes, ou, em outras palavras, com 64 anos e dois meses de idade.

Seguindo a mesma linha de raciocínio e considerando que uma pessoa com 70 anos de idade tem uma expectativa de viver aproximadamente até 85 (Tabela 70, p. 119), o fluxo de caixa pode ser representado conforme a Ilustração 8 (p. 124).

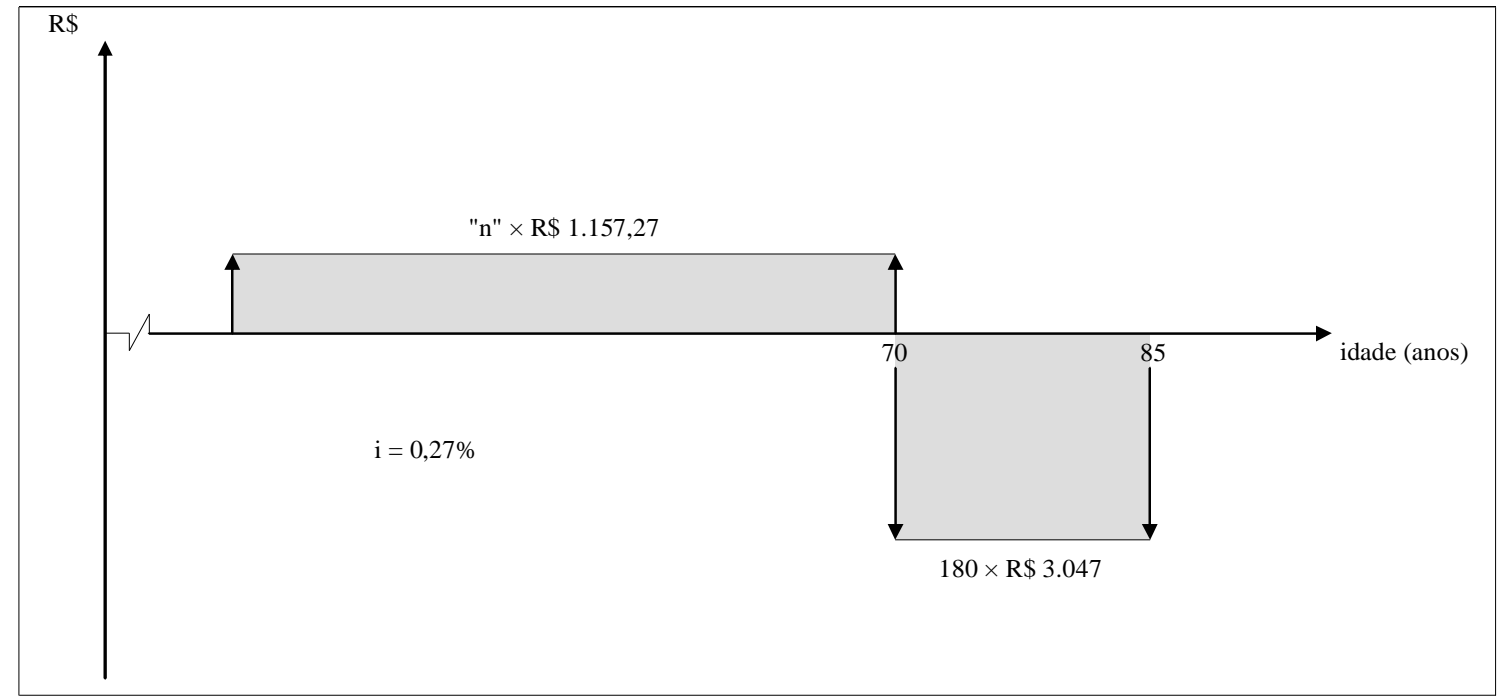

Ilustração 8 - Fluxo de tempo necessário para adquirir quotas de uma habitação, alugar e passar a residir aos 70 anos com as mensalidades pagas

Neste segundo exemplo, o fluxo de caixa não foi desmembrado. Calculando o valor que o proprietário precisa ter aos 70 anos:

$$
\begin{aligned}
& \mathrm{VPL}_{70}=\mathrm{P}_{1} \times\left[\frac{(1+\mathrm{i})^{\mathrm{n}}-1}{(1+\mathrm{i})^{\mathrm{n}} \times \mathrm{i}}\right] \\
& \mathrm{VPL}_{70}=3.047 \times\left[\frac{(1+0,0027)^{180}-1}{(1+0,0027)^{180} \times 0,0027}\right] \\
& \mathrm{VPL}_{70}=3.047 \times\left(\frac{0,624736}{0,004387}\right)
\end{aligned}
$$




$$
\begin{aligned}
\mathrm{VPL}_{70} & =3.047 \times 142,413048 \\
\mathrm{VPL}_{70} & =\mathrm{R} \$ 433.932,56
\end{aligned}
$$

Calculando a quantidade de parcelas necessárias de locação para que o proprietário tenha os $\mathrm{R} \$ 433.932,56$ aos 70 anos de idade:

$$
\begin{aligned}
\mathrm{VF}_{70} & =\mathrm{P}_{2} \times\left[\frac{(1+\mathrm{i})^{\mathrm{n}}-1}{\mathrm{i}}\right] \\
433.932,56 & =1.157,27 \times\left[\frac{(1+0,0027)^{\mathrm{n}}-1}{0,0027}\right] \\
\frac{433.932,56 \times 0,0027}{1.157,27} & =1,0027^{\mathrm{n}}-1 \\
1,012398 & =1,0027^{\mathrm{n}}-1 \\
1,012398+1 & =1,0027^{\mathrm{n}} \\
2,012398 & =1,0027^{\mathrm{n}} \\
1,0027^{\mathrm{n}} & =2,012398 \\
\mathrm{n} \ln 1,0027 & =\ln 2,012398 \\
\mathrm{n} & =\frac{\ln 2,012398}{\ln 1,0027} \\
\mathrm{n} & =\frac{0,699327}{0,002696} \\
\mathrm{n} & \cong 260
\end{aligned}
$$

Ou seja, para começar a residir na organização aos 70 anos de idade, com expectativa de viver até os 85 anos, com as mensalidades totalmente custeadas pelos créditos gerados devido à locação da habitação, uma pessoa deve adquirir as quotas 260 meses antes, ou seja, aos 48 anos e quatro meses de idade.

Acompanhando a mesma sequência de cálculos, a Tabela 72 (p. 125) apresenta a idade que uma pessoa precisaria ter ao adquirir as quotas para utilizar a organização, com as mensalidades pagas, a partir dos 50 anos de idade.

Tabela 72 - Idade para aquisição de quotas que permita utilização futura da organização sem pagamento de mensalidades

\begin{tabular}{lccccccc}
\hline Idade para início da moradia & 50 & 55 & 60 & 65 & 70 & 75 & 80 \\
Expectativa de vida & 79 & 80 & 82 & 83 & 85 & 87 & 89 \\
Idade para adquirir quotas & 20,42 & 27,17 & 33,67 & 41,08 & 48,33 & 56 & 64,17 \\
\hline
\end{tabular}




\section{Adquirir quotas correspondentes a mais de uma habitação}

Uma opção é adquirir quotas correspondentes a mais de uma habitação. Se um investidor adquirisse, por exemplo, duas habitações, os créditos seriam dobrados enquanto não fosse residente; depois receberia o equivalente aos créditos de uma habitação.

O exemplo de uma pessoa que deseja residir na organização a partir dos 80 anos, que espera viver até os 89 e deseja comprar quotas aos 71 anos, está representado na Ilustração 9 (p. 126). Pelos cálculos apresentados na página 124, quotas correspondentes a uma habitação precisam ser adquiridas 190 meses antes de uma pessoa passar a morar na instituição. Assim, passar de 190 para 108 parcelas implica adquirir um número maior de quotas. A área "A" da Ilustração indica o valor mensal dos 108 créditos. Quando a pessoa passar a residir na organização, os créditos de uma habitação deixarão de ser considerados; dessa forma, a área "B" é o valor total dos créditos que vinha sendo gerado menos R\$1.157,27.

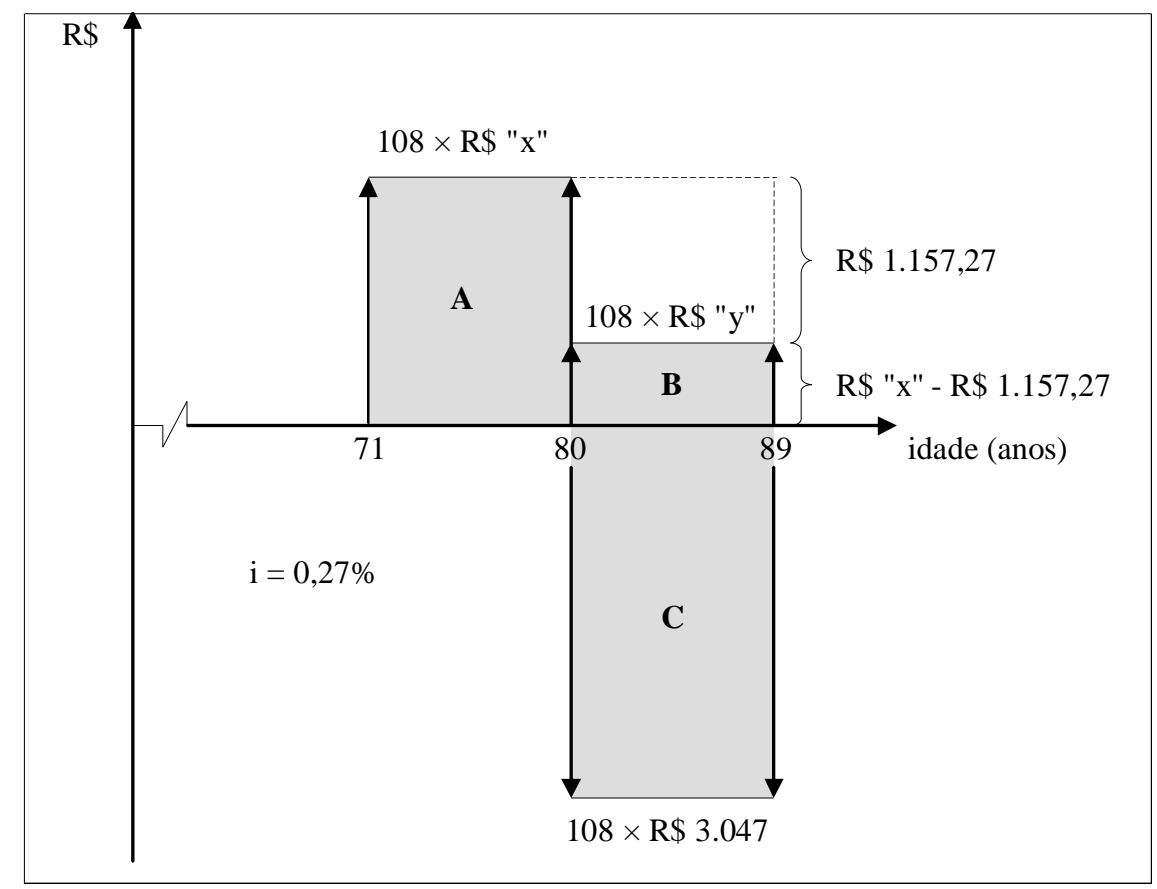

Ilustração 9 - Fluxo de caixa para adquirir quotas aos 71 anos, alugar e passar a residir aos 80 anos com as mensalidades pagas

Para o cálculo do valor do crédito inicial $\mathrm{R} \$$ " $\mathrm{x}$ ” as duas fórmulas serão igualadas, considerando que o valor presente líquido das mensalidades será igual ao valor futuro dos créditos, ou seja:

$$
\mathrm{VPL}_{80}=\mathrm{VF}_{80}
$$


Onde:

$$
\mathrm{VPL}_{80}=\mathrm{P}_{1} \times\left[\frac{(1+\mathrm{i})^{\mathrm{n}}-1}{(1+\mathrm{i})^{\mathrm{n}} \times \mathrm{i}}\right]
$$

E:

$$
\mathrm{VF}_{80}=\mathrm{P}_{2} \times\left[\frac{(1+\mathrm{i})^{\mathrm{n}}-1}{\mathrm{i}}\right]
$$

Ou seja:

$$
\mathrm{P}_{1} \times\left[\frac{(1+\mathrm{i})^{\mathrm{n}}-1}{(1+\mathrm{i})^{\mathrm{n}} \times \mathrm{i}}\right]=\mathrm{P}_{2} \times\left[\frac{(1+\mathrm{i})^{\mathrm{n}}-1}{\mathrm{i}}\right]
$$

Sendo:

$$
\begin{aligned}
& \mathrm{P}_{1}=\text { Valor da mensalidade }-\mathrm{R} \$ \text { "y", ou: } \\
& \mathrm{P}_{1}=\text { Valor da mensalidade }-(\mathrm{R} \$ \text { "x" }- \text { Créditos correspondentes a } 1 \text { habitação }) \text {, ou seja: } \\
& \mathrm{P}_{1}=3.047-(\text { "x" }-1.157,27) \\
& \mathrm{P}_{1}=4.204,27-\text { "x", lembrando que "x" }=\mathrm{P}_{2} \\
& \mathrm{P}_{1}=4.204,27-\mathrm{P}_{2}
\end{aligned}
$$

E:

$$
\begin{aligned}
& \mathrm{i}=\text { Taxa líquida de } 0,27 \% \\
& \mathrm{n}=108 \text { meses ou } 9 \text { anos } \\
& \mathrm{R}_{2}=\text { Valor mensal dos créditos dos } 71 \text { aos } 80 \text { anos }
\end{aligned}
$$

Então:

$$
\begin{aligned}
\mathrm{P}_{1} \times\left[\frac{(1+\mathrm{i})^{\mathrm{n}}-1}{(1+\mathrm{i})^{\mathrm{n}} \times \mathrm{i}}\right] & =\mathrm{P}_{2} \times\left[\frac{(1+\mathrm{i})^{\mathrm{n}}-1}{\mathrm{i}}\right] \\
\left(4.204,27-\mathrm{P}_{2}\right) \times\left[\frac{(1+0,0027)^{108}-1}{(1+0,0027)^{108} \times 0,0027}\right] & =\mathrm{P}_{2} \times\left[\frac{(1+0,0027)^{108}-1}{0,0027}\right] \\
\left(4.204,27-\mathrm{P}_{2}\right) \times 93,570029 & =\mathrm{P}_{2} \times 125,200590 \\
393.393,6637-\mathrm{P}_{2} \times 93,570029 & =\mathrm{P}_{2} \times 125,200590 \\
393.393,6637 & =\mathrm{P}_{2} \times 125,200590+\mathrm{P}_{2} \times 93,570029 \\
\mathrm{P}_{2} \times 125,200590+\mathrm{P}_{2} \times 93,570029 & =393.393,6637 \\
\mathrm{P}_{2} \times 218,770619 & =393.393,6637 \\
\mathrm{P}_{2} & =\frac{393.393,6637}{218,770619} \\
\mathrm{P}_{2} & =\mathrm{R} \$ 1.798,20
\end{aligned}
$$


A Ilustração do fluxo de caixa calculado pode ser visualizado na Ilustração 10 (p. 128).

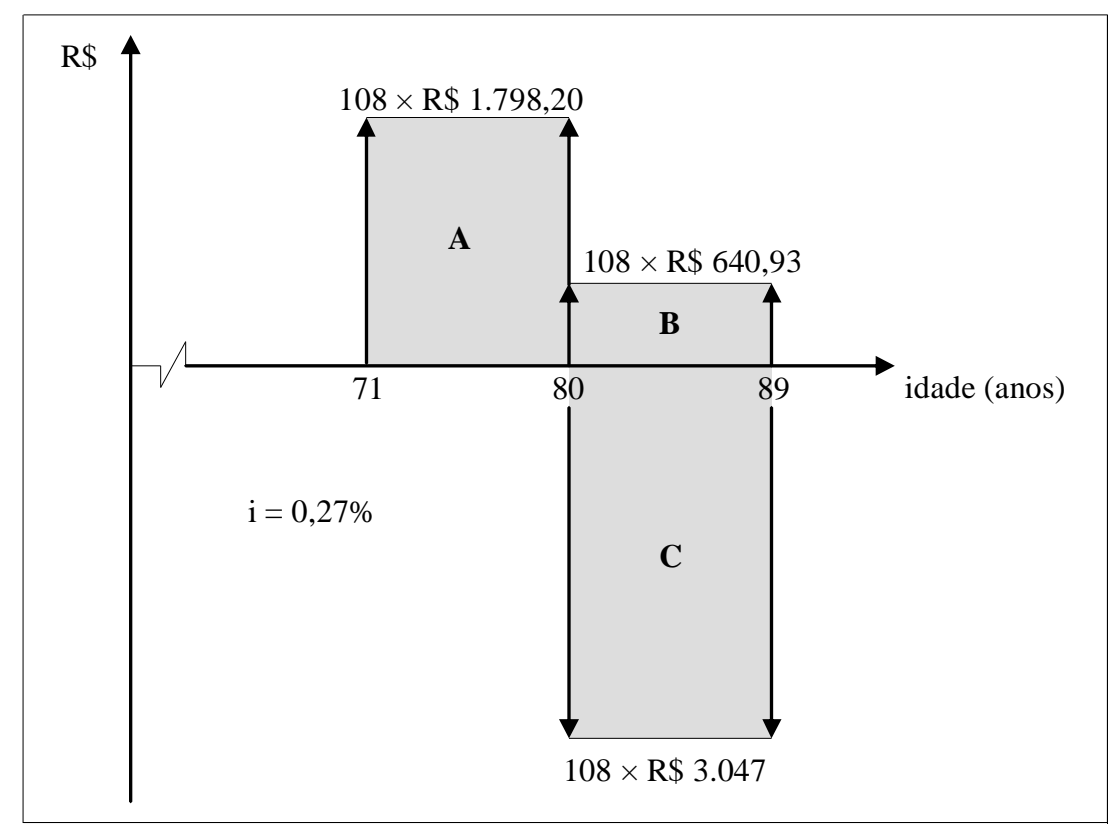

Ilustração 10 - Fluxo de caixa para adquirir quotas aos 71 anos, que gerem créditos de $\mathbf{R} \$ 1.798,20$ provenientes de locação, e passar a residir aos 80 anos com as mensalidades pagas.

Nos exemplos desenvolvidos neste tópico, o crédito de $\mathrm{R} \$ 1.157,27$ foi gerado a partir do seguinte cálculo:

$$
\text { Crédito }=\text { Valor do Investimento } \times \text { Taxa de Retorno Nominal }
$$

Considerando que a taxa de retorno nominal que está sendo utilizada é de 1,3\%:

$$
\begin{aligned}
& \text { Crédito }=\mathrm{R} \$ 89.021,00 \times 0,013 \\
& \text { Crédito }=\mathrm{R} \$ 1.157,27
\end{aligned}
$$

A partir desta mesma fórmula, calcula-se o valor do investimento para gerar um crédito de $\mathrm{R} \$ 1.798,20$, ou seja:

Crédito $=$ Valor do Investimento $\times$ Taxa de Retorno Nominal $1.798,20=$ Valor do Investimento $\times 0,013$

Valor do Investimento $=\frac{1.798,20}{0,013}$

Valor do Investimento $=\mathrm{R} \$ 138.323,08$

Em resumo, uma pessoa que deseja adquirir quotas aos 71 anos, residir dos 80 aos 89 anos sem desembolsar recursos com mensalidades, deveria investir R $\$ 138.323,08$. Seguindo a mesma linha de raciocínio onde a pessoa loca a habitação pelo mesmo período de tempo que 
pretende utilizá-la, a Tabela 73 (p. 129) e o Gráfico 10 (p. 129) apresentam início de utilização dos 50 aos 80 anos, em múltiplos de 5, e o valor de aquisição das quotas, sempre lembrando que a mensalidade é estimada em $\mathrm{R} \$ 3.047,00$, a taxa líquida em $0,27 \%$ ao mês e as expectativas de vida podem ser observadas na Tabela 70 (p. 119).

Tabela 73 - Valor de aquisição das quotas quando o período de locação da habitação é igual ao de utilização, sem pagamento de mensalidades

\begin{tabular}{lccccccc}
\hline Idade para início da moradia & 50 & 55 & 60 & 65 & 70 & 75 & 80 \\
Expectativa de vida & 79 & 80 & 82 & 83 & 85 & 87 & 89 \\
Idade para adquirir quotas & 21 & 30 & 38 & 47 & 55 & 63 & 71 \\
$\mathrm{~N}^{\circ}$ de anos de locação & 29 & 25 & 22 & 18 & 15 & 12 & 9 \\
Crédito total & 1.182 & 1.295 & 1.384 & 1.507 & 1.602 & 1.699 & 1.798 \\
Valor de aquisição das quotas & 90.954 & 99.649 & 106.463 & 115.901 & 123.214 & 130.699 & 138.323 \\
\hline
\end{tabular}

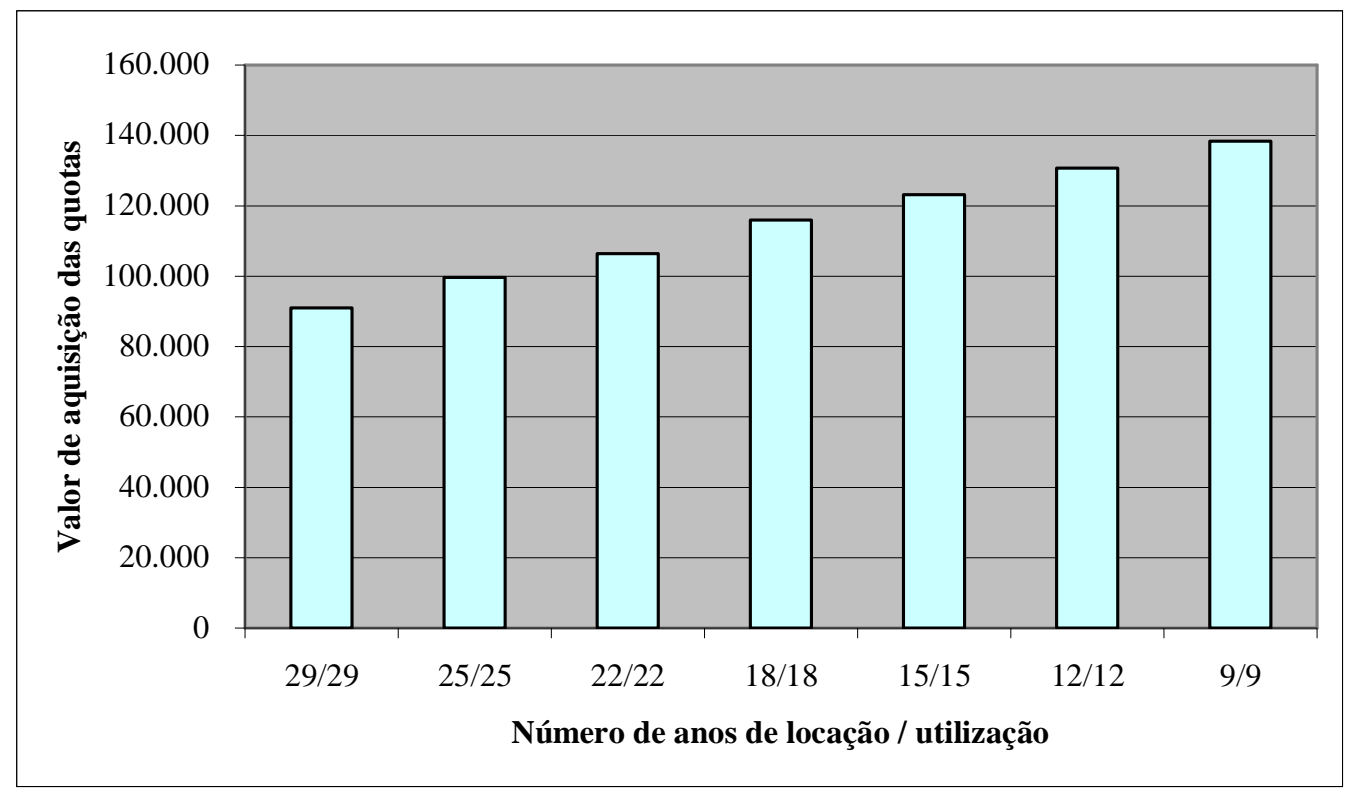

Gráfico 10 - Valor de aquisição das quotas quando o período de locação da habitação é igual ao de utilização, sem pagamento de mensalidades

Na Tabela 74 (p. 129) e no Gráfico 11 (p. 130) pode-se observar o início de utilização dos 50 aos 80 anos, também em múltiplos de cinco, e o valor de aquisição das quotas para locação por um período de 10 anos antes de utilizar a habitação.

Tabela 74 - Valor de aquisição das quotas para um período de locação da habitação de 10 anos e utilização sem pagamento de mensalidades

\begin{tabular}{lccccccc}
\hline Idade para início da moradia & 50 & 55 & 60 & 65 & 70 & 75 & 80 \\
Expectativa de vida & 79 & 80 & 82 & 83 & 85 & 87 & 89 \\
Idade para adquirir quotas & 40 & 45 & 50 & 55 & 60 & 65 & 70 \\
$\mathrm{~N}^{\circ}$ de anos de locação & 10 & 10 & 10 & 10 & 10 & 10 & 10 \\
Crédito total & 2.583 & 2.490 & 2.402 & 2.254 & 2.109 & 1.922 & 1.674 \\
Valor de aquisição das quotas & 198.699 & 191.501 & 184.782 & 173.368 & 162.224 & 147.856 & 128.733 \\
\hline
\end{tabular}




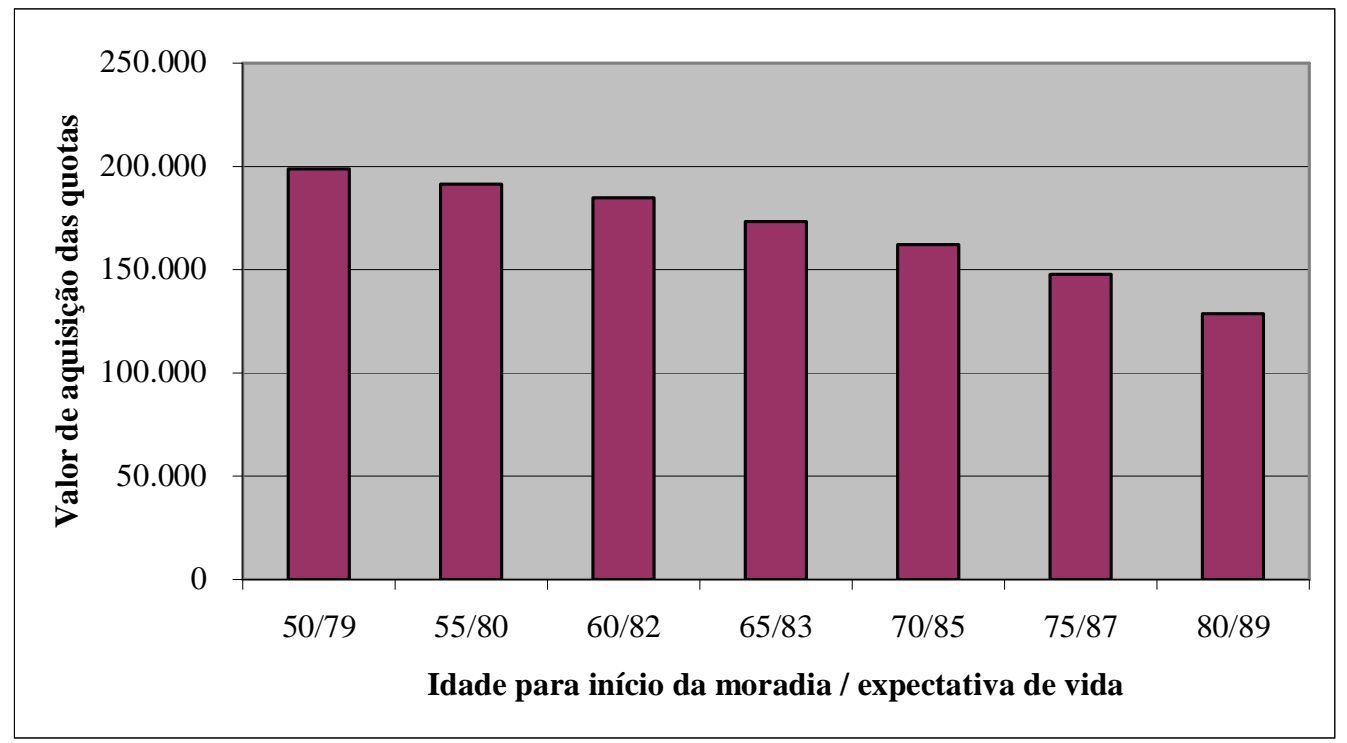

Gráfico 11 - Valor de aquisição das quotas para um período de locação da habitação de 10 anos e utilização sem pagamento de mensalidades

\section{Adquirir quotas antes ou no momento de utilizar as dependências da organização}

Um investidor pode adquirir quotas antes ou no momento de utilizar as dependências da organização. A pessoa pode, por exemplo, investir os R 89.021 em caderneta de poupança e comprar as quotas somente no momento de utilizar as dependências da organização, pagando R \$ 3.047 de mensalidade ao utilizar as dependências da organização, sem nenhum crédito acumulado. Outra opção é adquirir R $\$ 89.021$ em quotas que representam uma habitação e alugá-la para dois residentes não proprietários até o momento da utilização. Essa locação gera créditos que abaterão o valor da mensalidade no período de utilização.

Para avaliar estas duas alternativas deve-se utilizar o conceito da Taxa Interna de Retorno, TIR, que é a taxa que iguala o Valor Presente das Entradas de caixa ao Valor Presente das Saídas, “ou seja, é a taxa de desconto que torna o VPL igual a 0” (SOUSA, 2007, p. 77).

Pode-se tomar como exemplo uma pessoa de 40 anos que deseja residir em uma organização a partir dos 60 anos. Uma opção é adquirir uma habitação por R\$ 89.021 e locar a mesma para dois residentes não proprietários por 20 anos. Mensalmente são gerados R \$ 1.157,27 a título de créditos. Graficamente, o fluxo de caixa desta opção seria: 


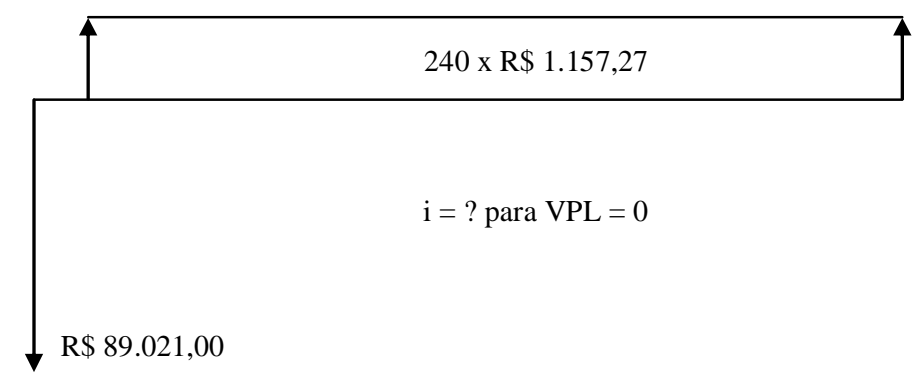

A fórmula do Valor Presente Líquido é a seguinte:

$$
\mathrm{VPL}=\sum_{\mathrm{t}=1}^{\mathrm{n}} \frac{\mathrm{FCE}_{\mathrm{t}}}{(1+\mathrm{i})^{\mathrm{t}}}-\sum_{\mathrm{t}=1}^{\mathrm{n}} \frac{\mathrm{FCS}_{\mathrm{t}}}{(1+\mathrm{i})^{\mathrm{t}}}
$$

Calculando a TIR:

$$
\begin{gathered}
0=\frac{-89.021}{(1+\mathrm{i})^{0}}+\frac{1.157,27}{(1+\mathrm{i})^{1}}+\frac{1.157,27}{(1+\mathrm{i})^{2}}+\ldots+\frac{1.157,27}{(1+\mathrm{i})^{240}} \\
\mathrm{i}=0,012310 \mathrm{ou} \\
\mathrm{TIR}=1,231 \%
\end{gathered}
$$

Ou seja, o retorno para essa opção é de $1,231 \%$ ao mês. Desconsiderando a inflação, pode-se comparar esta taxa com $0,27 \%$ ao mês, que é o rendimento da caderneta de poupança do período 2005-2008 (Tabela 65, p. 108) menos a inflação medida pelo Índice Nacional de Preços ao Consumidor - Amplo, IPCA, no mesmo período (Tabela 71, p. 121).

O crédito mensal de $\mathrm{R} \$ 1.157,27$ foi calculado a partir de uma taxa nominal de 1,3\% sobre os $\mathrm{R} \$ 89.021,00$. Contudo, a proposta desta tese é de que a habitação seja doada à organização com o falecimento dos dois usufrutuários. Não ocorrendo venda da habitação ao final do fluxo de caixa, deixa de existir o valor residual, proporcionando uma TIR menor do que a taxa nominal.

A TIR foi calculada para um nível de utilização da capacidade instalada de $70 \%$. Se essa porcentagem variar, a TIR alterar-se-á. De acordo com as premissas e equações apresentadas no capítulo 5.3 - Cálculo completo de uma simulação (p. 79), a organização do exemplo apresenta mensalmente os dados representados na Tabela 75 (p. 132).

A mensalidade de $\mathrm{R} \$ 3.047$ foi calculados para uma organização que comporte 300 residentes, mas que trabalhe com um nível de utilização da capacidade instalada de $70 \%$. Ou seja, os custos e as despesas foram rateados por 210 residentes. 
Tabela 75 - Demonstração de superávit (déficit) de uma organização para 300 residentes atuando com nível de utilização da capacidade instalada de $70 \%, 63 \%$ e $77 \%$

\begin{tabular}{|c|c|c|c|c|c|c|}
\hline \multirow{2}{*}{ Descrição } & \multicolumn{6}{|c|}{ Nível de utilização da capacidade instalada } \\
\hline & \multicolumn{2}{|c|}{$70 \%$} & \multicolumn{2}{|r|}{$63 \%$} & \multicolumn{2}{|r|}{$77 \%$} \\
\hline Número de residentes & \multicolumn{2}{|r|}{210} & \multicolumn{2}{|r|}{189} & \multicolumn{2}{|r|}{231} \\
\hline \multicolumn{7}{|l|}{ Despesas e custos indiretos } \\
\hline Despesas administrativas & $\mathrm{R} \$$ & 27.755 & $\mathrm{R} \$$ & 27.755 & $\mathrm{R} \$$ & 27.755 \\
\hline Custos indiretos & $\mathrm{R} \$$ & 395.913 & $\mathrm{R} \$$ & 395.913 & $\mathrm{R} \$$ & 395.913 \\
\hline Outros custos e despesas & $\mathrm{R} \$$ & 18.637 & $\mathrm{R} \$$ & 18.637 & $\mathrm{R} \$$ & 18.637 \\
\hline Total & $\mathrm{R} \$$ & 442.305 & $\mathrm{R} \$$ & 442.305 & $\mathrm{R} \$$ & 442.305 \\
\hline Total por residente & $\mathrm{R} \$$ & 2.106 & $\mathrm{R} \$$ & 2.340 & $\mathrm{R} \$$ & 1.915 \\
\hline \multicolumn{7}{|l|}{ Custos diretos } \\
\hline Custos diretos & $\mathrm{R} \$$ & 197.554 & $\mathrm{R} \$$ & 177.799 & $\mathrm{R} \$$ & 217.309 \\
\hline Total & $\mathrm{R} \$$ & 197.554 & $\mathrm{R} \$$ & 177.799 & $\mathrm{R} \$$ & 217.309 \\
\hline Total por residente & $\mathrm{R} \$$ & 941 & $\mathrm{R} \$$ & 941 & $\mathrm{R} \$$ & 941 \\
\hline \multicolumn{7}{|l|}{ Despesas, custos diretos e indiretos } \\
\hline Total & $\mathrm{R} \$$ & 639.859 & $\mathrm{R} \$$ & 620.104 & $\mathrm{R} \$$ & 659.614 \\
\hline Total por residente & $\mathrm{R} \$$ & 3.047 & $\mathrm{R} \$$ & 3.281 & $\mathrm{R} \$$ & 2.855 \\
\hline \multicolumn{7}{|l|}{ Receitas } \\
\hline Total & $\mathrm{R} \$$ & 639.870 & $\mathrm{R} \$$ & 575.883 & $\mathrm{R} \$$ & 703.857 \\
\hline Total por residente & $\mathrm{R} \$$ & 3.047 & $\mathrm{R} \$$ & 3.047 & $\mathrm{R} \$$ & 3.047 \\
\hline Superávit (déficit) operacional & $\mathrm{R} \$$ & 11 & $\mathrm{R} \$$ & $(44.221)$ & $\mathrm{R} \$$ & 44.243 \\
\hline Número de proprietários & & 150 & & 150 & & 150 \\
\hline $\begin{array}{l}\text { Superávit (déficit) } \\
\text { operacional por proprietário }\end{array}$ & $\mathrm{R} \$$ & 0 & $\mathrm{R} \$$ & (295) & $\mathrm{R} \$$ & 295 \\
\hline
\end{tabular}

Se o nível de utilização da capacidade instalada for menor que $70 \%$, os proprietários devem cobrir a diferença das despesas e custos indiretos. Havendo uma redução de 10\%, por exemplo, passando de 210 para 189 residentes, os 150 proprietários devem ratear o déficit operacional de R \$44.221,00. Neste caso, cada proprietário terá um desconto de R \$295,00 nos créditos (Tabela 75, p. 132). Com isso, em vez do proprietário ser creditado em $\mathrm{R} \$ 1.157,27$, ele terá direito a $\mathrm{R} \$ 862,27$. Lembrando que o exemplo pressupõe aquisição das quotas aos 40 anos de idade e utilização da organização aos 60 anos, o novo fluxo de caixa terá as seguintes características:

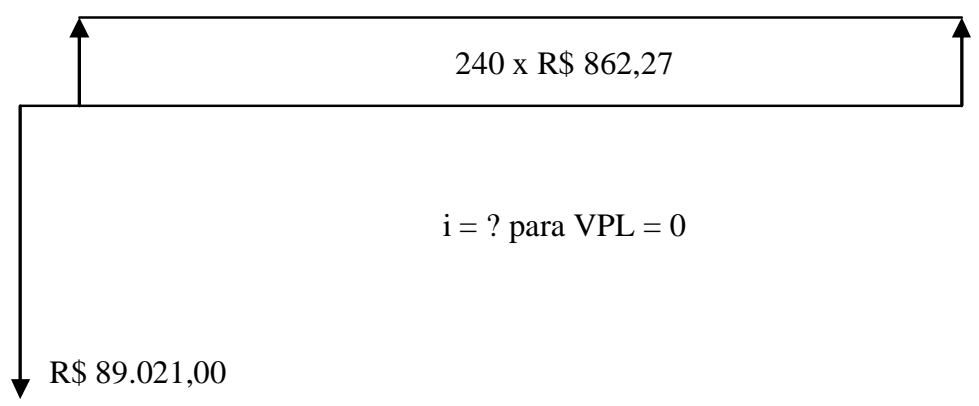


Calculando a nova taxa interna de retorno, TIR, chega-se a $0,8378 \%$, ou seja, um valor superior à taxa líquida dos rendimentos da poupança nos últimos quatro anos, ou seja, 0,27\% ao mês.

Sob outra ótica, levando em consideração que a população brasileira com 60 anos ou mais de idade passará de 17,98 milhões em 2008 para mais de 64 milhões em 2050 (Anexo 3, p. 364), $70 \%$ de utilização da capacidade instalada pode estar subestimada, o que aumentaria a taxa interna de retorno dos proprietários com níveis superiores de ocupação. Supondo que o nível de utilização da capacidade instalada passe para $77 \%$, haveria um superávit operacional de $\mathrm{R} \$ 44.243,00$ que, dividido entre os 150 proprietários, resultaria $\mathrm{R} \$ 294,95$ que, somando ao crédito de $\mathrm{R} \$ 1.157,27$, totalizaria $\mathrm{R} \$ 1.452,22$. Um novo fluxo de caixa se formaria com uma TIR de 1,5947\%:

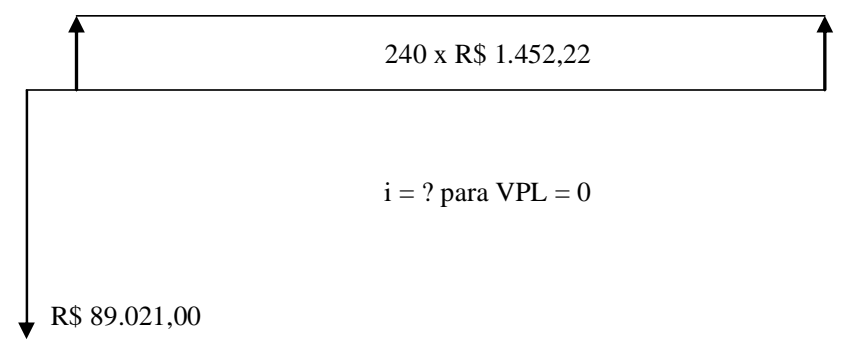

No Apêndice 310 (p. 355), estão representadas as taxas internas de retorno para nível de utilização da capacidade instalada de $45 \%$ a $100 \%$, com variações de $5 \%$, e número de meses para locação de seis a 300, com variações de seis meses. Foram destacadas as células referentes ao exemplo, ou seja, 240 meses com nível de utilização da capacidade instalada de $63 \%, 70 \%$ e $77 \%$. As taxas internas de retorno também podem ser visualizadas no Gráfico 12 (p. 134). 


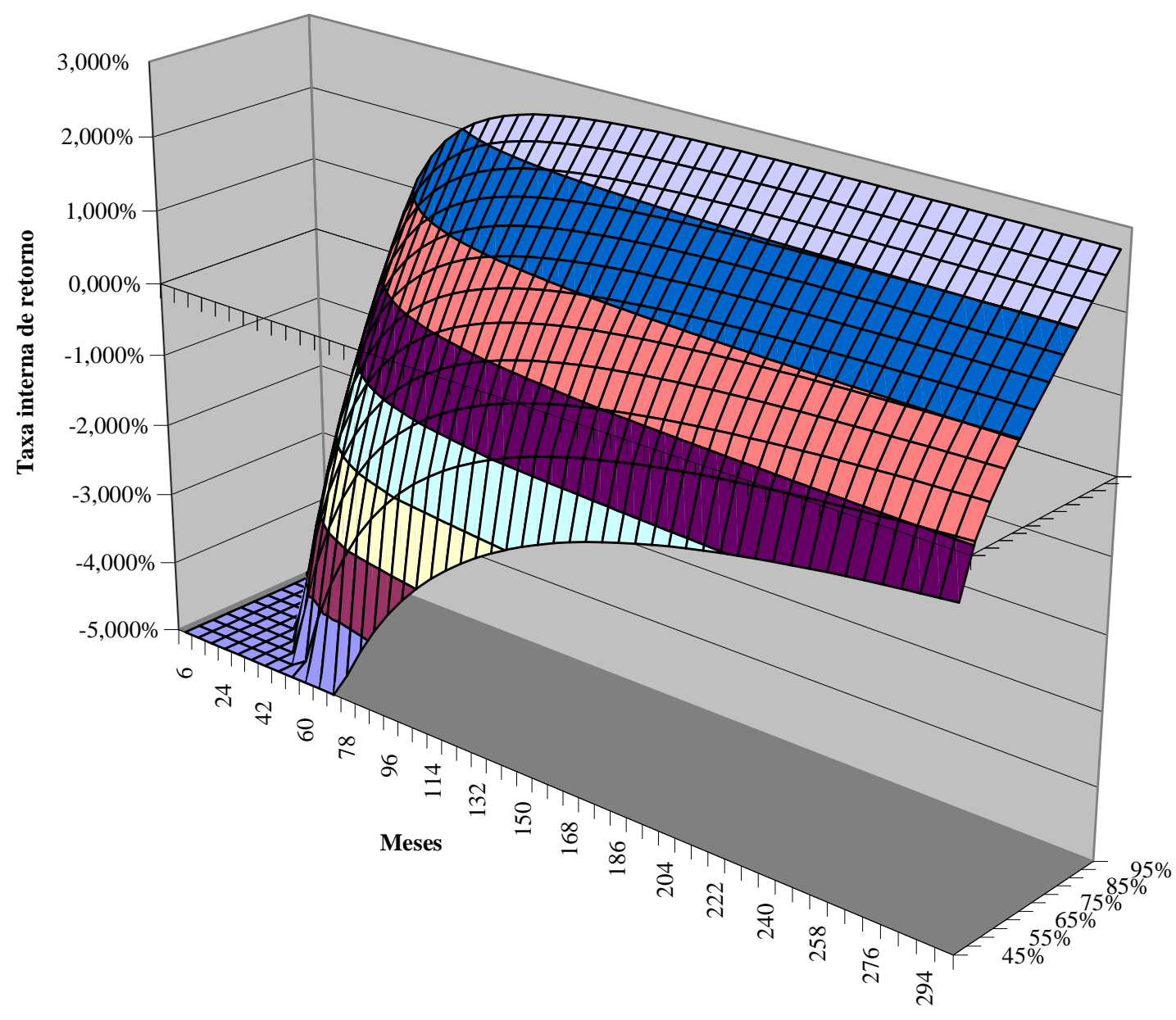
Nível de
utilização da capacidade instalada

Gráfico 12 - Taxa Interna de Retorno, TIR, para aquisição de quotas a R \$ 89.021, locação da habitação de 6 a 300 meses e nível de utilização da capacidade instalada de $45 \%$ a $100 \%$ 


\section{Adquirir quotas ou pagar mensalidades}

Esta análise procura elucidar quando é vantajoso adquirir quotas para uso imediato da organização.

Uma pessoa que deseja residir na organização, com recursos financeiros disponíveis, pode adquirir quotas e pagar mensalidades como proprietário ou não investir e pagar mensalidades como não proprietário. Como a habitação proposta nesta tese tem dois quartos e um banheiro (Apêndice 15, p. 237), sendo residente não proprietário a pessoa ocupará um quarto, mas dividirá a habitação com outro residente. Como proprietário, pode residir sozinho ou locar o outro cômodo, adquirindo créditos que são abatidos da mensalidade. Em termos de investimento, o proprietário pode adquirir quotas correspondentes a uma ou mais habitações. Esquematicamente, as opções estão delineadas na Ilustração 11 (p. 136).

Utilizando como exemplo uma pessoa com 60 anos de idade e expectativa de residir 21 anos (ou 252 meses) na organização (Tabela 70, p. 119), a diferença entre adquirir R \$ 89.021,00 em quotas correspondentes a uma habitação e não adquirir implica em uma economia mensal de $\mathrm{R} \$ 827,00$ residindo sozinho na habitação ou $\mathrm{R} \$ 1.405,64$ se optar em usar um quarto e locar o outro. Estes números podem ser observados na Ilustração 11 (p. 136). Como se trata de uma série uniforme, a Taxa Interna de Retorno, TIR, pode ser medida pela fórmula (HAZZAN; POMPEO, 2007, p. 152, adaptado pelo autor):

$$
\mathrm{VPL}=\mathrm{P} \times\left[\frac{(1+\mathrm{i})^{\mathrm{n}}-1}{(1+\mathrm{i})^{\mathrm{n}} \times \mathrm{i}}\right]
$$

Para uma economia mensal de $\mathrm{R} \$ 827,00$ :

$$
89.021=827 \times\left[\frac{(1+i)^{252}-1}{(1+i)^{252} \times i}\right]
$$

Resolvendo a equação obtém-se uma taxa mensal de:

$$
\mathrm{i}=0,80618 \%
$$

Para uma economia de R\$1.405,64: 


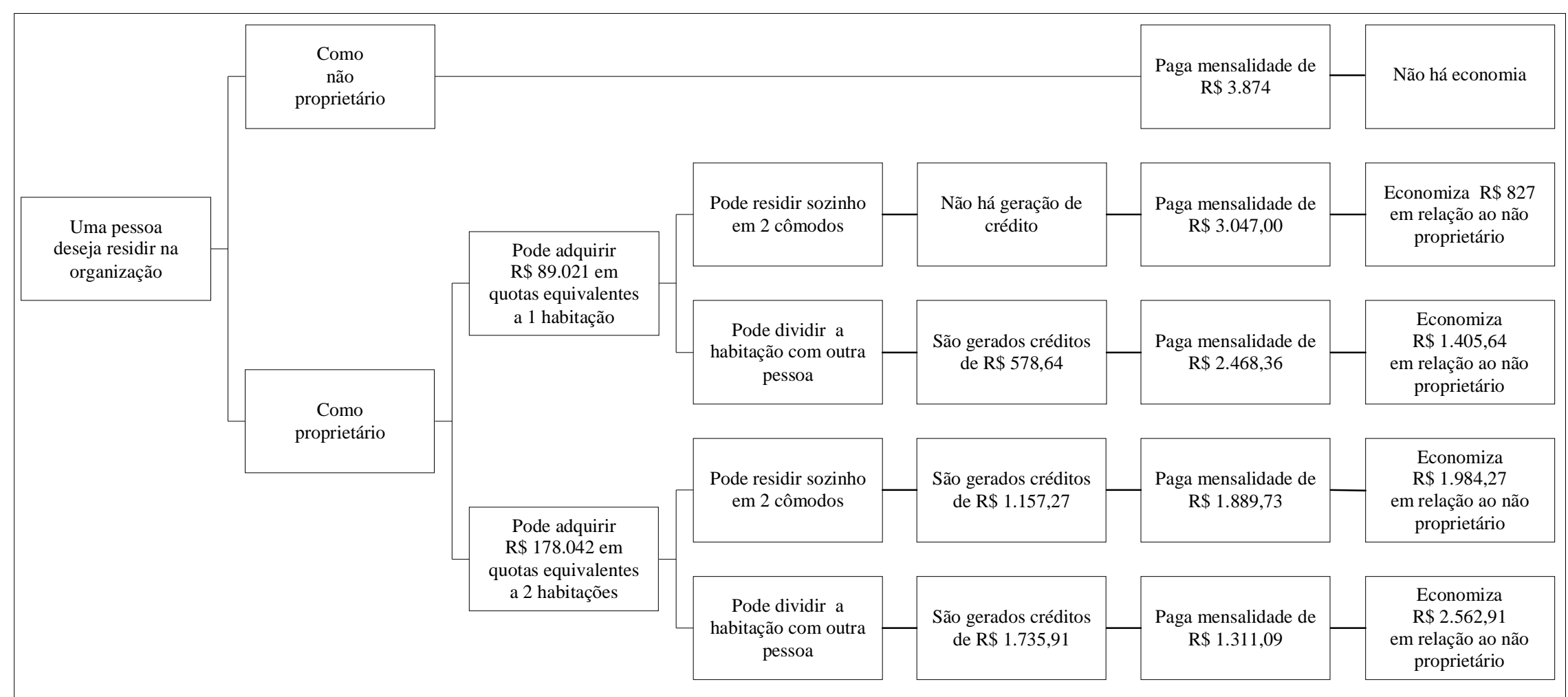

Ilustração 11 - Opções de residir em organização como não proprietário ou proprietário de quotas correspondentes a 1 ou mais habitações 


$$
89.021=1.405,64 \times\left[\frac{(1+\mathrm{i})^{252}-1}{(1+\mathrm{i})^{252} \times \mathrm{i}}\right]
$$

Resolvendo a equação:

$$
\mathrm{i}=1,545929 \%
$$

Para a economia de $\mathrm{R} \$ 827,00$ mensais, a taxa de retorno é de $0,81 \%$ para 252 meses. O Gráfico 13 (p. 137) indica as taxas de retorno de um a 480 meses, ou seja, de um a 40 anos de residência na organização. O período de 108 meses divide as taxas negativas das positivas.

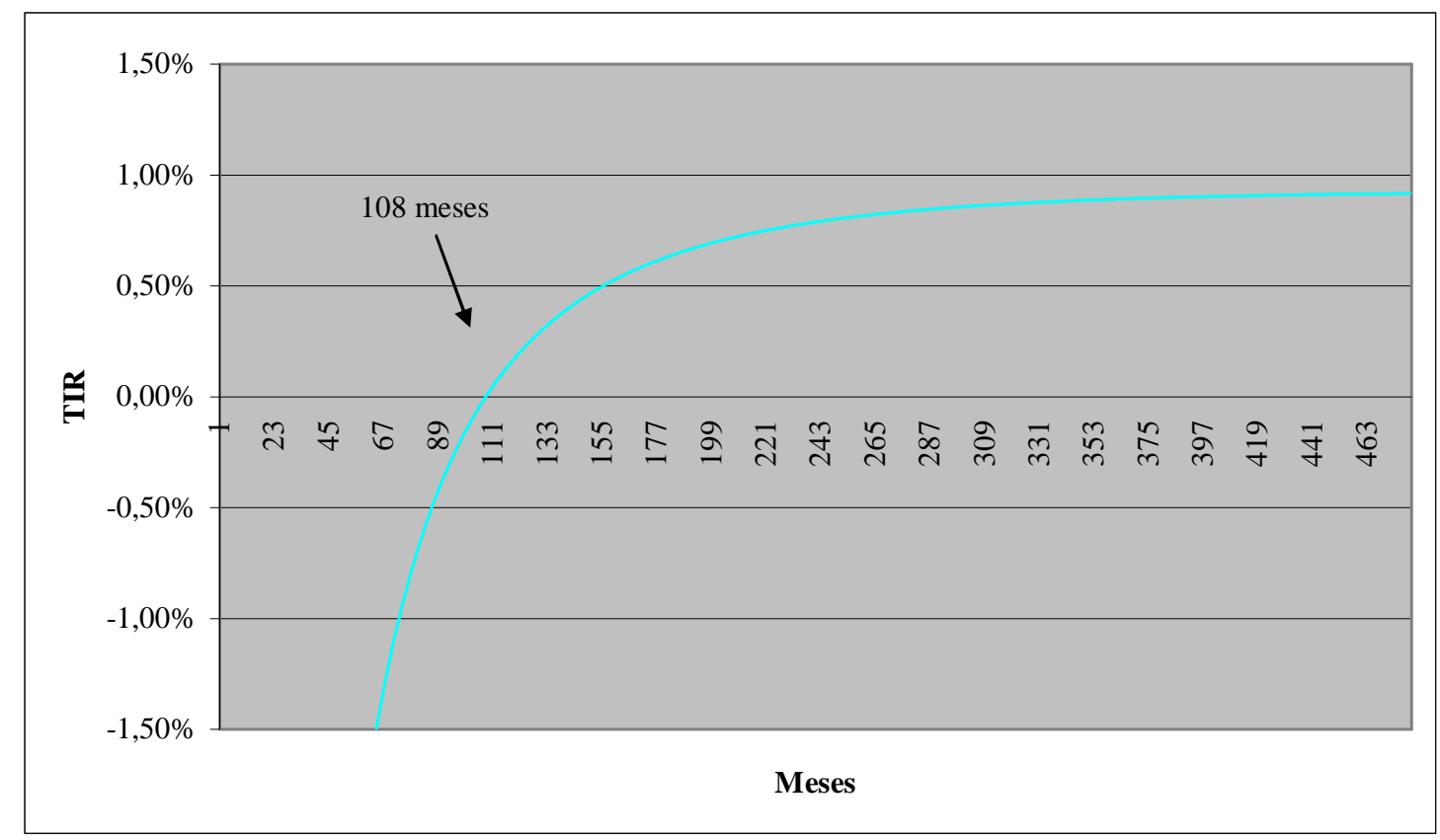

\section{Gráfico 13 - Taxa interna de retorno em função da economia de adquirir quotas correspondentes a 1 habitação e residir sozinho}

Para a economia de $\mathrm{R} \$ 1.405,64$ mensais, onde o proprietário compartilha a habitação com outro residente, a taxa de retorno é de 1,55\% para 252 meses. O Gráfico 14 (p. 29) indica as taxas de retorno de um a 40 anos de utilização da organização. O ponto de inflexão ocorre aos 64 meses. Ou seja, é vantajoso adquirir as quotas e residir sozinho desde que a habitação seja utilizada 108 meses ou mais ou, optando em compartilhá-la com outra pessoa, a habitação deveria ser utilizada no mínimo 64 meses. Deve-se lembrar que a habitação será doada à organização quando as duas pessoas que têm direito a utilizar a habitação falecerem, ou seja, não há valor residual para o cálculo da Taxa Interna de Retorno, TIR. 
Se forem adquiridas quotas correspondentes a duas habitações, o proprietário desembolsará $\mathrm{R} \$ 178.042,00$ e também poderá residir sozinho ou compartilhar sua unidade. No primeiro caso, tem créditos gerados por dois residentes não proprietários e desembolsará uma mensalidade de $\mathrm{R} \$ 1.889,73$; na segunda hipótese, $\mathrm{R} \$ 1.311,09$. Como o valor de mensalidade de um residente não proprietário é de $\mathrm{R} \$ 3.874$, os créditos geram economias de $\mathrm{R} \$ 1.984,27$ e $\mathrm{R} \$ 2.562,91$, respectivamente.

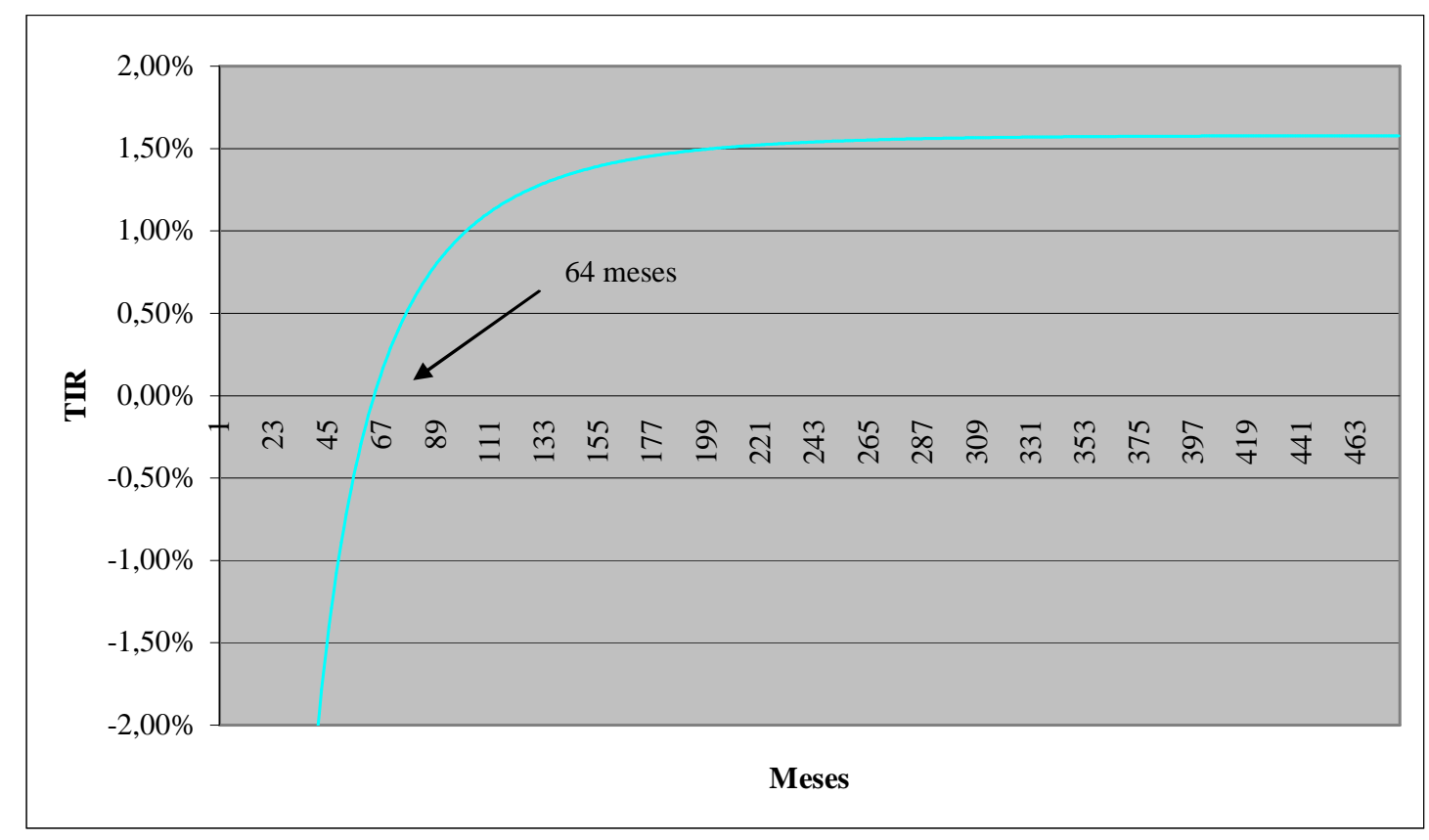

\section{Gráfico 14 - Taxa interna de retorno em função da economia de adquirir quotas correspondentes a 1} habitação e compartilhar a habitação com outro residente

Para a opção onde é gerada uma economia de $\mathrm{R} \$ 1.984,27$ é vantajoso adquirir as quotas desde que o proprietário ou pessoa indicada por ele resida 90 meses ou mais. As taxas internas de retorno por mês de utilização podem ser observadas no Gráfico 15 (p. 139).

Para a opção de adquirir quotas correspondentes a dois residentes, locar uma habitação e compartilhar a outra com um residente não proprietário, é vantajoso a partir de 70 meses. A taxa interna de retorno em função dos meses de uso da habitação pode ser observada no Gráfico 16 (p. 139).

Apesar dos aspectos financeiros serem relevantes na decisão de um investidor, deve-se notar que a organização será administrada pelos proprietários. Assim, se todos optarem em investir 
somente no momento de utilizar as instalações, a gestão poderá ficar a cargo de pessoas não comprometidas com a qualidade e continuidade da organização.

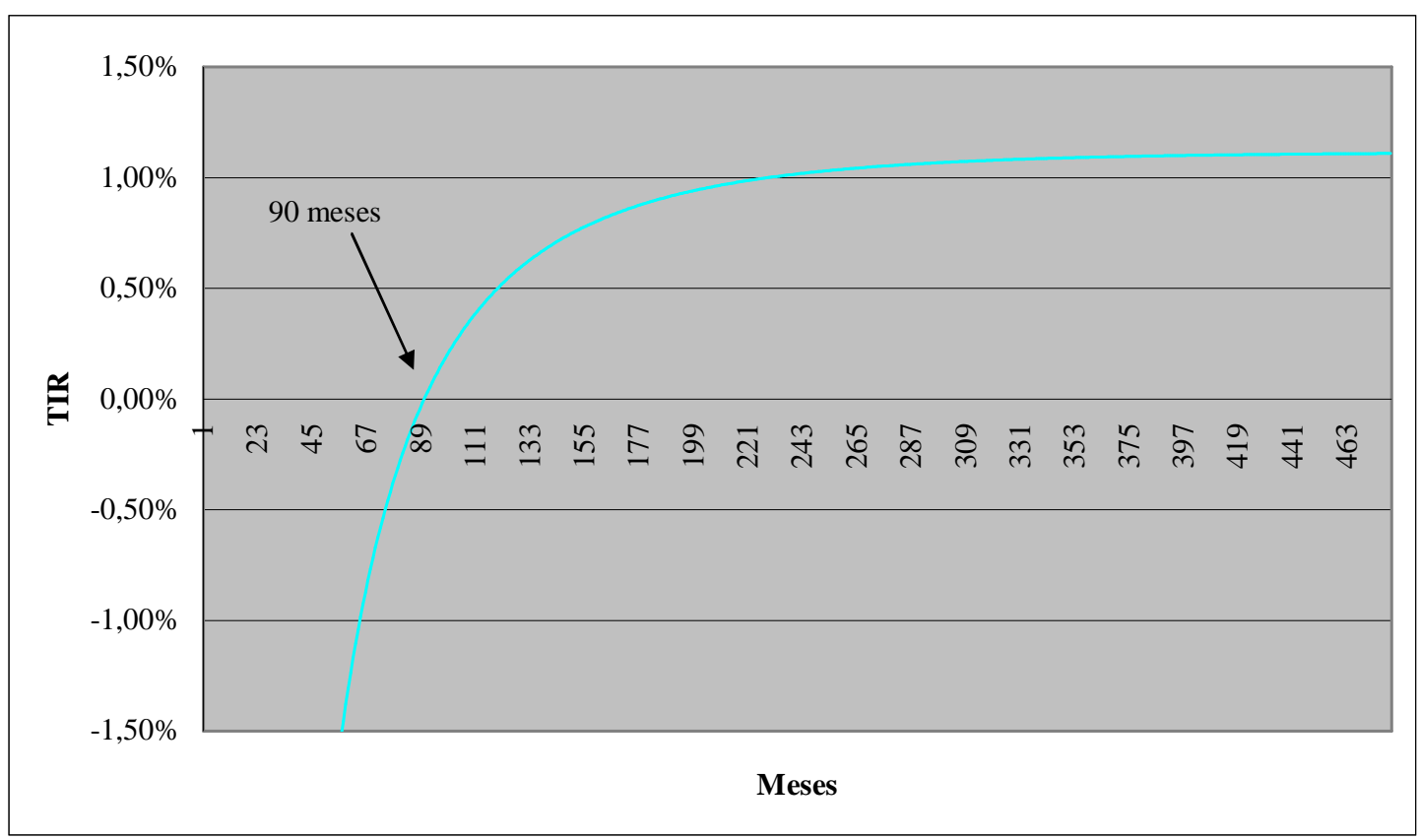

Gráfico 15 - Taxa interna de retorno em função da economia de adquirir quotas correspondentes a 2 habitações e residir sozinho em 1 delas

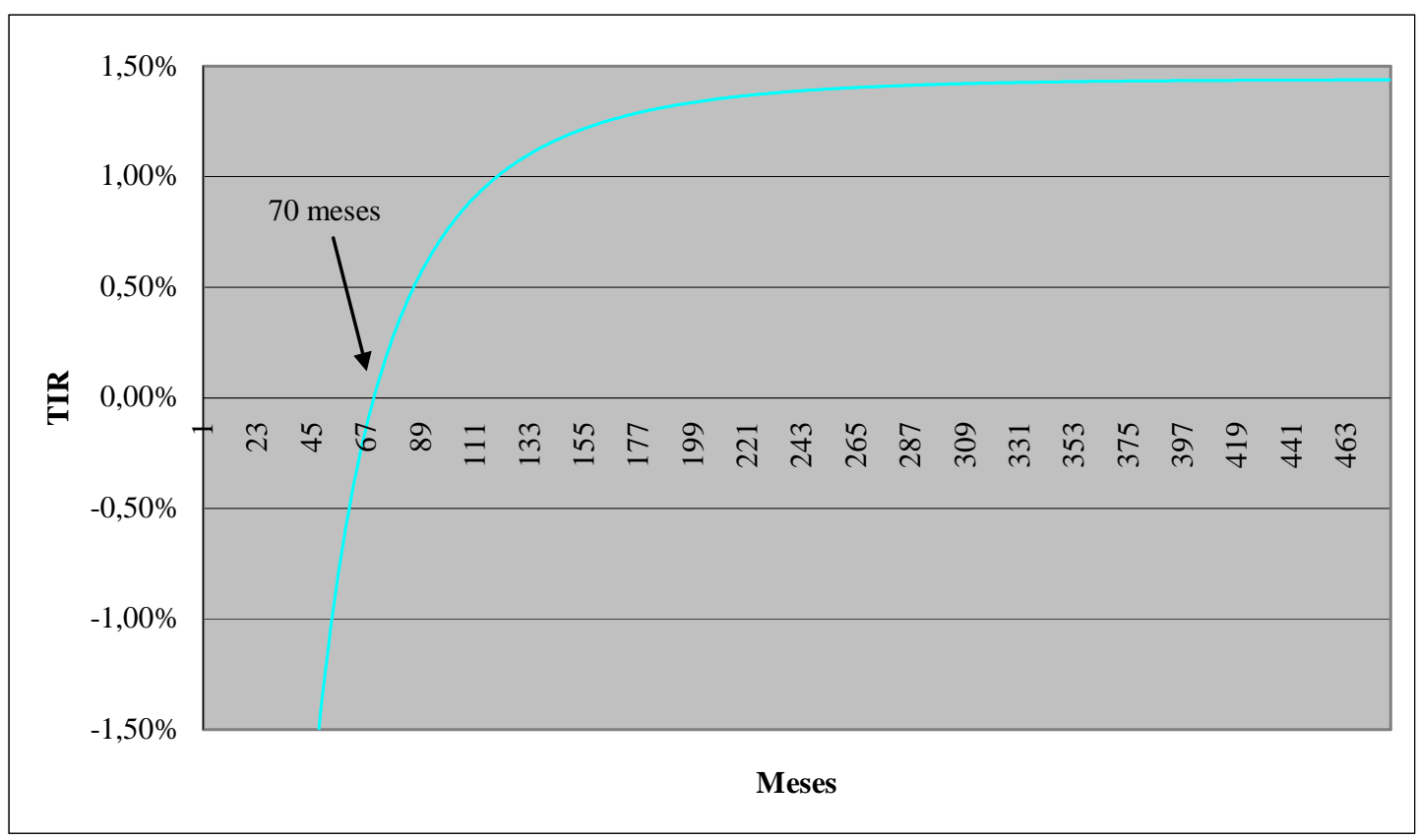

Gráfico 16 - Taxa interna de retorno em função da economia de adquirir quotas correspondentes a 2 habitações e compartilhar 1 das habitações com out ro residente 


\section{PESQUISA DE CAMPO}

Esta tese tem como objetivo principal identificar uma opção de investimento em ambientes residenciais especiais. Os objetivos secundários visam apresentar formatos jurídico e econômico-financeiro, estrutura gerencial norteada por conceito de governança corporativa e um modelo financeiro flexível onde exista variação do tempo de carência, quantidades, valor do investimento e de contribuições.

Para que os objetivos sejam alcançados algumas hipóteses precisam ser corroboradas. A primeira delas parte do princípio de que a previdência social não atende as expectativas de parte da população brasileira. A segunda hipótese é que o investidor usufrutuário entende que as organizações atuais onde se oferecem moradia e alimentação, com ou sem cuidados especiais, não trazem segurança ou o modelo proposto apresenta menor risco.

A pesquisa de campo foi elaborada com o objetivo de corroborar as hipóteses. O instrumento utilizado na coleta de dados na pesquisa de campo foi o questionário apresentado no Apêndice 311 (p. 356). Foram elaboradas questões do tipo fechadas dicotômicas, como a questão 2, onde o entrevistado indicava seu sexo, e de múltipla escolha. Nas de múltipla escolha existiam questões de várias alternativas com uma única marcação; a questão 1, idade, possuía seis alternativas onde o entrevistado indicava em qual faixa se enquadrava. Também existiam questões de várias alternativas com uma ou mais marcações, como a de número 8 onde o entrevistado podia indicar com um $x$ uma ou mais opções para a afirmativa poupo dinheiro atualmente para... Existiam, também, questões com escalas, onde o entrevistado poderia concordar plenamente, concordar, concordar parcialmente, discordar ou discordar totalmente; um exemplo é a questão 13 onde o entrevistado concordava ou não com a afirmativa conheço bem instituições que tratam de pessoas que requerem cuidados especiais.

Os questionários foram aplicados pela internet e pessoalmente em ruas, praças e locais de grande movimentação de pedestres. Na busca de se garantir melhores resultados, antes do início do levantamento de dados foram realizados cinco pré-testes para ajustes de compreensão das questões (SCHRADER, 1978, p. 157).

Pela internet foram enviados aproximadamente 1600 e-mails para pessoas com ensino superior completo. $\mathrm{O}$ objetivo era que os mesmos preenchessem a pesquisa e repassassem o email para outras pessoas. Assim, utilizou-se a amostra Auto-Gerada, onde um pesquisado 
podia pedir a outra pessoa que preenchesse a pesquisa. Como o resultado poderia ser enviesado, tanto em relação ao público quanto em relação à amostra auto-gerada, as pesquisas pela internet foram limitadas a $30 \%$ do total de questionários.

Ainda havia o risco de uma única pessoa responder o questionário várias vezes. A forma de minimizar esse risco era controlando o acesso de cada pesquisado. Uma forma de controle é o endereço IP. Basicamente esse endereço pode ser definido como um conjunto de números que representam o local de um computador, em geral pessoas jurídicas, ou o local de um provedor de acesso à internet. Desta forma seria mantido o sigilo em relação ao respondente. Quando a pessoa gravava as respostas no final da pesquisa, o sistema guardava esse endereço eletrônico. Uma empresa possui um endereço IP e vários funcionários. Assim, para permitir que mais de uma pessoa por empresa respondesse o questionário, o número de questionários gravados por IP não poderia passar de dez. Os questionários com o mesmo endereço IP e com as mesmas respostas foram considerados como únicos.

Em relação às entrevistas pessoais, os entrevistadores foram orientados a explanar brevemente o objetivo da pesquisa. Os questionários foram aplicados nas cidades de Jundiaí, Mogi das Cruzes, Santos, São Paulo, Taubaté e Grande ABC. Em cada cidade houve um pré-teste de dois entrevistados para avaliar se havia alguma interpretação regional que impedisse o entendimento adequado do questionário.

Em relação às técnicas, foi utilizada a avaliação quantitativa descritiva com o objetivo de organizar, sintetizar e interpretar os dados coletados. A avaliação foi do tipo inferencial, pois é possível definir características da população baseada nos resultados amostrais. Foram utilizados os programas de computadores Excel e SPSS.

O método de amostragem utilizado foi não probabilístico, pois as pessoas deveriam ter mais de 18 anos de idade para responder o questionário. (SELLTIZ; WRIGHTSMAN; COOK, 1987a, p. 85-89).

\subsection{Tamanho da Amostra}

Os dois primeiros pressupostos desta pesquisa possuem um nível de mensuração nominal. Como se trata de uma população considerada infinita, o tamanho da amostra para estimar a proporção $(p)$ da população foi calcula a partir da seguinte fórmula (ANDERSON; SWEENEY; WILLIAMS, 2005, p. 304): 


$$
\mathrm{n}=\frac{\left(\mathrm{z}_{\frac{\alpha}{2}}\right)^{2} \times \mathrm{p} \times(1-\mathrm{p})}{(\mathrm{E})^{2}}
$$

Onde:

$\begin{array}{lll}\mathrm{n} & = & \text { Tamanho da amostra } \\ \mathrm{E} & = & \text { Margem de erro } \\ \mathrm{p} & = & \text { Proporção da população } \\ \mathrm{z}_{\frac{\alpha}{2}} & = & \text { Valor tabelado em função do nível de confiança }\end{array}$

Será utilizada uma proporção $(p)$ da ordem de $50 \%$ por se tratar de uma posição segura e conservadora, resultando em um tamanho maior da amostra. Usando essa proporção está sendo garantido que o tamanho da amostra será suficiente para se obter a margem de erro desejada.

O nível de confiança adotado é da ordem de $95 \%$. Calculando o tamanho da amostra $n$ para uma proporção $p$ de $50 \%$ com $95 \%$ de confiança, tem-se:

$$
\mathrm{n}=\frac{(1,960)^{2} \times 0,50 \times(1-0,50)}{(0,025)^{2}} \cong 1.537
$$

\subsection{Análise Descritiva}

Ao todo 1253 questionários foram preenchidos em campo e 434 pela internet. Em um primeiro momento foram descartados os questionários preenchidos de forma incompleta e aqueles que apresentavam informações conflitantes. Em uma segunda etapa foram eliminadas as pesquisas de cidades com poucos respondentes. A amostra final ficou com 1128 questionários de campo e 373 questionários aplicados pela internet, somando 1501.

Para que a amostra fosse analisável, algumas faixas de respostas foram agrupadas para que se obtivesse, ao menos, cinco respondentes por linha. Os dados foram divididos por tipo de pesquisa em função das características da amostra, ou seja, de campo e por internet.

A idade dos respondentes foi dividida por faixa. Na pesquisa de campo os respondentes com 50 anos ou mais foram mais representativos, praticamente alcançando 40\%. Pelas características do meio de comunicação, somente $2,4 \%$ dos pesquisados pela internet tinham 
essa idade, sendo que 35,4\% desses pesquisados tinham entre 18 e 24 anos. As demais informações podem ser observadas na Tabela a seguir.

Tabela 76 - Frequência de idade dos pesquisados (Questão 1 da Pesquisa)

\begin{tabular}{lrrrrr}
\hline \multirow{2}{*}{ Idade do pesquisado } & \multicolumn{4}{c}{ Pesquisa } \\
\cline { 2 - 3 } \cline { 5 - 6 } \cline { 5 - 6 } & \multicolumn{2}{c}{ de Campo } & \multicolumn{3}{c}{ pela Internet } \\
\cline { 2 - 3 } 18 a 24 & 165 & 14,63 & & 132 & 35,39 \\
25 a 29 & 106 & 9,40 & & 125 & 33,51 \\
30 a 39 & 182 & 16,13 & & 88 & 23,59 \\
40 a 49 & 225 & 19,95 & & 19 & 5,09 \\
50 ou + & 450 & 39,89 & & 9 & 2,41 \\
Total & 1128 & 100,00 & 373 & 100,00 \\
\hline
\end{tabular}

Em relação ao sexo dos respondentes, houve equilíbrio em relação às formas de abordagem, sendo de $54,6 \%$ de mulheres e $45,4 \%$ de homens na pesquisa de campo e $57,4 \%$ de mulheres e $42,6 \%$ de homens respondentes na pesquisa pela internet.

Tabela 77 - Frequência de sexo dos pesquisados (Questão 2)

\begin{tabular}{lrrrrr}
\hline \multirow{2}{*}{ Sexo do pesquisado } & \multicolumn{4}{c}{ Pesquisa } \\
\cline { 2 - 3 } \cline { 5 - 6 } & \multicolumn{2}{c}{ de Campo } & & \multicolumn{2}{c}{ pela Internet } \\
\cline { 2 - 3 } \cline { 5 - 6 } & Freqüência & \multicolumn{1}{c}{$\%$} & & Freqüência & \multicolumn{1}{c}{$\%$} \\
\hline Feminino & 616 & 54,61 & & 214 & 57,37 \\
Masculino & 512 & 45,39 & & 159 & 42,63 \\
Total & 1128 & 100,00 & & 373 & 100,00 \\
\hline
\end{tabular}

Em relação à pesquisa de campo foram descartados os dados das cidades com menos de 100 respondentes e, em relação à pesquisa de internet, descartados os dados com menos de 20 respondentes. As cidades com dados válidos estão listadas na Tabela 78 (p. 143).

Tabela 78 - Frequência da cidade onde residiam os pesquisados (Questão 4)

\begin{tabular}{|c|c|c|c|c|}
\hline \multirow{3}{*}{$\begin{array}{c}\text { Cidade onde o pesquisado } \\
\text { reside }\end{array}$} & \multicolumn{4}{|c|}{ Pesquisa } \\
\hline & \multicolumn{2}{|c|}{ de Campo } & \multicolumn{2}{|c|}{ pela Internet } \\
\hline & Freqüência & $\%$ & Freqüência & $\%$ \\
\hline Jundiaí & 104 & 9,22 & & \\
\hline Mauá & 198 & 17,55 & 20 & 5,36 \\
\hline Ribeirão Pires & 162 & 14,36 & & \\
\hline Santo André & & & 144 & 38,61 \\
\hline Santos & 160 & 14,18 & & \\
\hline São Bernardo do Campo & 176 & 15,60 & 88 & 23,59 \\
\hline São Caetano do Sul & & & 20 & 5,36 \\
\hline São Paulo & 186 & 16,49 & 101 & 27,08 \\
\hline Taubaté & 142 & 12,59 & & \\
\hline Total & 1128 & 100,00 & 373 & 100,00 \\
\hline
\end{tabular}

Levando em consideração que Mauá, Ribeirão Pires, São Bernardo do Campo, São Paulo, Santo André e São Caetano do Sul são cidades da Grande São Paulo, a frequência das mesmas 
pela internet indicam que $100 \%$ dos pesquisados residem em região metropolitana. Em relação à pesquisa de campo, 36\% residiam fora da região metropolitana.

Tabela 79 - Frequência da região onde residiam os pesquisados

\begin{tabular}{|c|c|c|c|c|}
\hline \multirow{3}{*}{$\begin{array}{l}\text { O pesquisado reside em } \\
\text { região metropolitana }\end{array}$} & \multicolumn{4}{|c|}{ Pesquisa } \\
\hline & \multicolumn{2}{|c|}{ de Campo } & \multicolumn{2}{|c|}{ pela Internet } \\
\hline & Freqüência & $\%$ & Frequiência & $\%$ \\
\hline Sim & 722 & 64,01 & 373 & 100,00 \\
\hline Não & 406 & 35,99 & & \\
\hline Total & 1128 & 100,00 & 373 & 100,00 \\
\hline
\end{tabular}

Com o objetivo de definir a classe social, os respondentes foram questionados em relação a número de bens ou serviços que possuíam. A Tabela a seguir indica a frequência de cada bem ou serviço que o respondente da pesquisa de campo possuía.

Tabela 80 - Frequência de bens e serviços que os pesquisados de campo possuíam (Questão 5)

\begin{tabular}{|c|c|c|c|c|c|c|c|c|}
\hline \multirow[b]{2}{*}{ Itens } & \multirow{2}{*}{$\begin{array}{l}\text { Não } \\
\text { tem }\end{array}$} & \multicolumn{6}{|c|}{ Quantidade que possui } & \multirow{2}{*}{ Total } \\
\hline & & 1 & 2 & 3 & 4 & 5 & $6+$ & \\
\hline Televisão (colorida) & $2,7 \%$ & $48,0 \%$ & $30,5 \%$ & $13,5 \%$ & $4,0 \%$ & $1,2 \%$ & $0,1 \%$ & $100,0 \%$ \\
\hline Rádio & $9,5 \%$ & $64,1 \%$ & $19,1 \%$ & $5,2 \%$ & $1,4 \%$ & $0,4 \%$ & $0,3 \%$ & $100,0 \%$ \\
\hline Automóvel & $51,8 \%$ & $39,1 \%$ & $6,8 \%$ & $1,8 \%$ & $0,4 \%$ & $0,1 \%$ & $0,1 \%$ & $100,0 \%$ \\
\hline Empregada fixa mensalista & $92,4 \%$ & $7,2 \%$ & $0,4 \%$ & $0,0 \%$ & $0,0 \%$ & $0,0 \%$ & $0,0 \%$ & $100,0 \%$ \\
\hline Aspirador de pó & $61,0 \%$ & $38,4 \%$ & $0,4 \%$ & $0,2 \%$ & $0,0 \%$ & $0,0 \%$ & $0,0 \%$ & $100,0 \%$ \\
\hline Máquina de lavar roupa & $17,9 \%$ & $80,1 \%$ & $1,8 \%$ & $0,2 \%$ & $0,0 \%$ & $0,0 \%$ & $0,0 \%$ & $100,0 \%$ \\
\hline Videocassete / DVD & $20,7 \%$ & $69,7 \%$ & $7,6 \%$ & $1,5 \%$ & $0,4 \%$ & $0,1 \%$ & $0,0 \%$ & $100,0 \%$ \\
\hline Banheiro & $0,4 \%$ & $62,9 \%$ & $28,6 \%$ & $5,9 \%$ & $1,6 \%$ & $0,3 \%$ & $0,4 \%$ & $100,0 \%$ \\
\hline Geladeira & $1,7 \%$ & $90,4 \%$ & $7,1 \%$ & $0,6 \%$ & $0,1 \%$ & $0,0 \%$ & $0,1 \%$ & $100,0 \%$ \\
\hline $\begin{array}{l}\text { Freezer (aparelho independente } \\
\text { ou parte da geladeira duplex) }\end{array}$ & $75,4 \%$ & $23,4 \%$ & $0,7 \%$ & $0,4 \%$ & $0,0 \%$ & $0,0 \%$ & $0,0 \%$ & $100,0 \%$ \\
\hline
\end{tabular}

A seguir estão indicados os bens ou serviços que os pesquisados pela internet possuíam.

Tabela 81 - Frequência de bens e serviços que os pesquisados pela internet possuíam (Questão 5)

\begin{tabular}{|c|c|c|c|c|c|c|c|c|}
\hline \multirow[b]{2}{*}{ Itens } & \multirow{2}{*}{$\begin{array}{l}\text { Não } \\
\text { tem }\end{array}$} & \multicolumn{6}{|c|}{ Quantidade que possui } & \multirow{2}{*}{ Total } \\
\hline & & 1 & 2 & 3 & 4 & 5 & $6+$ & \\
\hline Televisão (colorida) & $0,0 \%$ & $12,1 \%$ & $35,1 \%$ & $29,2 \%$ & $14,2 \%$ & $7,2 \%$ & $2,1 \%$ & $100,0 \%$ \\
\hline Rádio & $1,9 \%$ & $28,4 \%$ & $34,9 \%$ & $20,9 \%$ & $8,6 \%$ & $3,5 \%$ & $1,9 \%$ & $100,0 \%$ \\
\hline Automóvel & $11,5 \%$ & $41,3 \%$ & $33,5 \%$ & $9,7 \%$ & $4,0 \%$ & $0,0 \%$ & $0,0 \%$ & $100,0 \%$ \\
\hline Empregada fixa mensalista & $78,8 \%$ & $20,6 \%$ & $0,5 \%$ & $0,0 \%$ & $0,0 \%$ & $0,0 \%$ & $0,0 \%$ & $100,0 \%$ \\
\hline Aspirador de pó & $26,8 \%$ & $70,2 \%$ & $2,7 \%$ & $0,3 \%$ & $0,0 \%$ & $0,0 \%$ & $0,0 \%$ & $100,0 \%$ \\
\hline Máquina de lavar roupa & $2,1 \%$ & $91,2 \%$ & $6,4 \%$ & $0,3 \%$ & $0,0 \%$ & $0,0 \%$ & $0,0 \%$ & $100,0 \%$ \\
\hline Videocassete / DVD & $0,8 \%$ & $52,3 \%$ & $33,0 \%$ & $11,5 \%$ & $1,9 \%$ & $0,5 \%$ & $0,0 \%$ & $100,0 \%$ \\
\hline Banheiro & $1,1 \%$ & $37,8 \%$ & $32,4 \%$ & $18,0 \%$ & $7,5 \%$ & $2,4 \%$ & $0,8 \%$ & $100,0 \%$ \\
\hline Geladeira & $1,9 \%$ & $85,3 \%$ & $11,0 \%$ & $1,6 \%$ & $0,3 \%$ & $0,0 \%$ & $0,0 \%$ & $100,0 \%$ \\
\hline $\begin{array}{l}\text { Freezer (aparelho independente } \\
\text { ou parte da geladeira duplex) }\end{array}$ & $34,0 \%$ & $61,7 \%$ & $4,3 \%$ & $0,0 \%$ & $0,0 \%$ & $0,0 \%$ & $0,0 \%$ & $100,0 \%$ \\
\hline
\end{tabular}


Novamente, em função das características do meio de comunicação, surge diferença representativa entre a pesquisa de campo e por internet quando se pergunta até que ano da escola o chefe da família estudou? Os resultados podem ser observados na próxima tabela. Nota-se claramente que o chefe da família dos pesquisados pela internet têm um nível maior de escolaridade.

Tabela 82 - Frequência da escolaridade do chefe da família dos pesquisados (Questão 6)

\begin{tabular}{|c|c|c|c|c|}
\hline \multirow{3}{*}{$\begin{array}{c}\text { Até que ano da escola o chefe da } \\
\text { família estudou? }\end{array}$} & \multicolumn{4}{|c|}{ Pesquisa } \\
\hline & \multicolumn{2}{|c|}{ de Campo } & \multicolumn{2}{|c|}{ pela Internet } \\
\hline & Freqüência & $\%$ & Freqüência & $\%$ \\
\hline Analfabeto/Ens Fundam Incompleto & 278 & 24,65 & 71 & 19,03 \\
\hline Ensino Fundamental Completo & 294 & 26,06 & 39 & 10,46 \\
\hline Ensino Médio Completo & 468 & 41,49 & 103 & 27,61 \\
\hline Ensino Superior Completo ou + & 88 & 7,80 & 160 & 42,90 \\
\hline Total & 1128 & 100,00 & 373 & 100,00 \\
\hline
\end{tabular}

A partir dos bens e serviços que o pesquisado possuía e do nível de escolaridade do chefe da família, determinou-se a classe social conforme os critérios brasileiros. Esses critérios podem ser observados no Anexo 16 (p. 377). Apesar das classes serem divididas em A1, A2, B1, B2, C, D e E, os mesmos foram agrupados em A, B e CDE para viabilizar a análise com amostra representativa.

Tabela 83 - Frequência da classe social dos pesquisados

\begin{tabular}{|c|c|c|c|c|}
\hline \multirow{3}{*}{$\begin{array}{c}\text { O respondente pertence à } \\
\text { classe social }\end{array}$} & \multicolumn{4}{|c|}{ Pesquisa } \\
\hline & \multicolumn{2}{|c|}{ de Campo } & \multicolumn{2}{|c|}{ pela Internet } \\
\hline & Freqüência & $\%$ & Freqüência & $\%$ \\
\hline $\bar{A}$ & 36 & 3,19 & 97 & 26,01 \\
\hline B & 344 & 30,50 & 228 & 61,13 \\
\hline $\mathrm{CDE}$ & 748 & 66,31 & 48 & 12,87 \\
\hline Total & 1128 & 100,00 & 373 & 100,00 \\
\hline
\end{tabular}

O rendimento familiar bruto mensal também teve bastante diferença comparando as pesquisas de campo e de internet. Essa diferença em parte pode ser explicada em função de o pesquisado ter acesso à internet em sua residência, por trabalhar em empresas conectadas à rede ou em função de possuir recursos que lhe permitam acessar a internet em locais que cobram por esse acesso.

$\mathrm{Na}$ Tabela 85 (p. 146) pode-se notar como os pesquisados poupam os recursos. Novamente pode-se notar diferença representativa entre os respondentes de campo e de internet. 
Tabela 84 - Frequência do rendimento familiar bruto dos pesquisados (Questão 7)

\begin{tabular}{lrrrrr}
\hline \multirow{2}{*}{$\begin{array}{c}\text { O rendimento familiar bruto mensal } \\
\text { do respondente se encaixa }\end{array}$} & \multicolumn{2}{c}{ de Campo } & & \multicolumn{2}{c}{ pela Internet } \\
\cline { 2 - 3 } \cline { 5 - 6 } & Freqüência & \multicolumn{1}{c}{$\%$} & & Freqüência & \multicolumn{1}{c}{$\%$} \\
\hline até 3 SMs & 152 & 13,48 & & 43 & 11,53 \\
+ de 3 a 5 SMs & 100 & 8,87 & & 115 & 30,83 \\
+ de 5 a 10 SMs & 38 & 3,37 & & 185 & 49,60 \\
+ de 10 SMs & 372 & 32,98 & & 17 & 4,56 \\
Sem rendimento / não sabe / não & 1128 & 100,00 & & 373 & 100,00 \\
deseja informar & & & & & \\
Total & & &
\end{tabular}

Tabela 85 - Frequência da forma de poupança dos pesquisados (Questão 8)

\begin{tabular}{|c|c|c|c|c|}
\hline \multirow{3}{*}{ O pesquisado poupa dinheiro atualmente para } & \multicolumn{4}{|c|}{ Pesquisa } \\
\hline & \multicolumn{2}{|c|}{ de Campo } & \multicolumn{2}{|c|}{ pela Internet } \\
\hline & Sim & Não & Sim & Não \\
\hline Utilizá-lo nas férias com transporte, hotel, alimentação, etc & $3,6 \%$ & $96,4 \%$ & $22,5 \%$ & $77,5 \%$ \\
\hline Eventuais gastos emergenciais com saúde, pequenos acidentes, etc & $16,0 \%$ & $84,0 \%$ & $21,7 \%$ & $78,3 \%$ \\
\hline Comprar bens duráveis como imóveis, automóveis, eletrodomésticos, & $6,4 \%$ & $93,6 \%$ & $66,0 \%$ & $34,0 \%$ \\
\hline Custear a educação do(s) filho(s) no futuro & $6,2 \%$ & $93,8 \%$ & $11,0 \%$ & $89,0 \%$ \\
\hline Completar a aposentadoria no futuro & $2,2 \%$ & $97,8 \%$ & $24,1 \%$ & $75,9 \%$ \\
\hline Não poupa & $71,2 \%$ & $28,8 \%$ & $17,7 \%$ & $82,3 \%$ \\
\hline
\end{tabular}

De uma forma geral os pesquisados acreditam pouco que o valor a ser recebido do INSS a título de aposentadoria será suficiente para o sustento futuro. Na pesquisa de campo 21,3\% acreditam que será suficiente e na pesquisa pela internet $3,8 \%$.

Tabela 86 - Frequência de opinião dos pesquisados quanto aos rendimentos do INSS (Questão 9)

\begin{tabular}{|c|c|c|c|c|}
\hline \multirow{3}{*}{$\begin{array}{l}\text { No fututo, quando não estiver mais } \\
\text { trabalhando, o valor a ser recebido do INSS a } \\
\text { título de aposentadoria será suficiente para o } \\
\text { sustento do pesquisado }\end{array}$} & \multicolumn{4}{|c|}{ Pesquisa } \\
\hline & \multicolumn{2}{|c|}{ de Campo } & \multicolumn{2}{|c|}{ pela Internet } \\
\hline & Freqüência & $\%$ & Freqüência & $\%$ \\
\hline Sim & 240 & 21,28 & 14 & 3,75 \\
\hline Não & 888 & 78,72 & 359 & 96,25 \\
\hline Total & 1128 & 100,00 & 373 & 100,00 \\
\hline
\end{tabular}

Através da poupança ou previdência privada, 41,0\% das pessoas pesquisadas em campo pretendem complementar a renda ao se aposentar; dos pesquisados pela internet, $92,8 \%$ têm a mesma intenção.

Tabela 87 - Frequência de intenção dos pesquisados, através de poupança ou previdência privada, complementarem a renda quando se aposentar (Questão 10)

\begin{tabular}{|c|c|c|c|c|}
\hline \multirow{3}{*}{$\begin{array}{c}\text { Através de poupança ou previdência privada, } \\
\text { o pesquisado pretende complementar a renda } \\
\text { quando se aposentar }\end{array}$} & \multicolumn{4}{|c|}{ Pesquisa } \\
\hline & \multicolumn{2}{|c|}{ de Campo } & \multicolumn{2}{|c|}{ pela Internet } \\
\hline & Freqüência & $\%$ & Freqüência & $\%$ \\
\hline Sim & 463 & 41,05 & 346 & 92,76 \\
\hline Não & 665 & 58,95 & 27 & 7,24 \\
\hline Total & 1128 & 100,00 & 373 & 100,00 \\
\hline
\end{tabular}


Das pessoas pesquisadas em campo, $47,7 \%$ querem que os filhos complementem suas rendas ou as sustentem quando não puderem mais trabalhar.

Tabela 88 - Frequência de intenção dos pesquisados quanto a ser sustentado ou ter a renda complementada pelos filhos quando não puderem mais trabalhar (Questão 11)

\begin{tabular}{|c|c|c|c|c|}
\hline \multirow{3}{*}{$\begin{array}{c}\text { Quando não puder mais trabalhar, o } \\
\text { pesquisado quer que os filhos complementem } \\
\text { a renda dele ou o sustentem }\end{array}$} & \multicolumn{4}{|c|}{ Pesquisa } \\
\hline & \multicolumn{2}{|c|}{ de Campo } & \multicolumn{2}{|c|}{ pela Internet } \\
\hline & Frequiência & $\%$ & Freqüência & $\%$ \\
\hline Sim & 538 & 47,70 & 20 & 5,36 \\
\hline Não & 590 & 52,30 & 353 & 94,64 \\
\hline Total & 1128 & 100,00 & 373 & 100,00 \\
\hline
\end{tabular}

Se ficarem dependentes fisicamente, $47,6 \%$ gostariam de morar com os filhos ou com parentes próximos. Dos pesquisados pela internet, somente 5,4\% querem que os filhos complementem suas rendas ou os sustentem e 56,3\% gostariam de morar com os filhos ou parentes.

Tabela 89 - Frequência de opinião dos pesquisados quanto a morar com os filhos ou com um parente próximo se um dia ficar dependente fisicamente (Questão 12)

\begin{tabular}{|c|c|c|c|c|}
\hline \multirow{3}{*}{$\begin{array}{l}\text { Se um dia ficar dependente fisicamente, o } \\
\text { pesquisado quer morar com os filhos ou com } \\
\text { um parente próximo }\end{array}$} & \multicolumn{4}{|c|}{ Pesquisa } \\
\hline & \multicolumn{2}{|c|}{ de Campo } & \multicolumn{2}{|c|}{ pela Internet } \\
\hline & Freqüência & $\%$ & Freqüência & $\%$ \\
\hline Sim & 537 & 47,61 & 210 & 56,30 \\
\hline Não & 591 & 52,39 & 163 & 43,70 \\
\hline Total & 1128 & 100,00 & 373 & 100,00 \\
\hline
\end{tabular}

Para que não houvesse tendência em relação às questões com escalas, as duas primeiras opções, concordo plenamente e concordo, foram consideradas concordo; as duas últimas opções, discordo e discordo totalmente, foram consideradas discordo. A opção concordo parcialmente foi considerada não concordo, nem discordo. Nas tabelas a opção concordo foi indicada como sim, discordo como não e não concordo nem discordo como indiferente. Desta forma, na pesquisa de campo, $62,5 \%$ dos pesquisados afirmaram conhecer bem instituições que cuidavam de pessoas que requeriam cuidados especiais; na pesquisa pela internet 19,8\% afirmaram conhecer bem.

Tabela 90 - Frequência do conhecimento que o pesquisado tem sobre instituições que tratam de pessoas que requerem cuidados especiais (Questão 13)

\begin{tabular}{|c|c|c|c|c|}
\hline \multirow{3}{*}{$\begin{array}{c}\text { O pesquisado conhece bem instituições que } \\
\text { tratam de pessoas que requerem cuidados } \\
\text { especiais }\end{array}$} & \multicolumn{4}{|c|}{ Pesquisa } \\
\hline & \multicolumn{2}{|c|}{ de Campo } & \multicolumn{2}{|c|}{ pela Internet } \\
\hline & Freqüência & $\%$ & Freqüûncia & $\%$ \\
\hline Sim & 705 & 62,50 & 74 & 19,84 \\
\hline Não & 199 & 17,64 & 151 & 40,48 \\
\hline Indiferente & 224 & 19,86 & 148 & 39,68 \\
\hline Total & 1128 & 100,00 & 373 & 100,00 \\
\hline
\end{tabular}


Em relação à pesquisa de campo, 17,1\% das pessoas confiam nos cuidados oferecidos pelas organizações que tratam de pessoas que requerem cuidados especiais. Quanto aos pesquisados pela internet, $9,1 \%$ confiam nesses cuidados.

Tabela 91 - Frequência de confiança do pesquisado nos cuidados oferecidos por organizações que tratam de pessoas que requerem cuidados especiais (Questão 14)

\begin{tabular}{|c|c|c|c|c|}
\hline \multirow{3}{*}{$\begin{array}{l}\text { O pesquisado confia plenamente nos cuidados } \\
\text { oferecidos por organizações que tratam de } \\
\text { pessoas que requerem cuidados especiais }\end{array}$} & \multicolumn{4}{|c|}{ Pesquisa } \\
\hline & \multicolumn{2}{|c|}{ de Campo } & \multicolumn{2}{|c|}{ pela Internet } \\
\hline & Frequiência & $\%$ & Frequiência & $\%$ \\
\hline Sim & 192 & 17,02 & 34 & 9,12 \\
\hline Não & 390 & 34,57 & 144 & 38,61 \\
\hline Indiferente & 546 & 48,40 & 195 & 52,28 \\
\hline Total & 1128 & 100,00 & 373 & 100,00 \\
\hline
\end{tabular}

Havendo necessidade, $31,4 \%$ das pessoas pesquisadas em campo e $33,5 \%$ das pesquisadas pela internet gostariam de ser residentes nessas organizações nos moldes atuais.

Tabela 92 - Frequência de intenção de o pesquisado residir, caso tenha necessidade e nos moldes dos modelos atuais, em uma instituição que trata de pessoas que requerem cuidados especiais (Questão 15)

\begin{tabular}{|c|c|c|c|c|}
\hline \multirow{3}{*}{$\begin{array}{l}\text { Caso futuramente tenha necessidade, nos moldes dos } \\
\text { modelos atuais, o pesquisado gostaria de ser residente } \\
\text { em uma instituição que trata de pessoas que requerem } \\
\text { cuidados especiais }\end{array}$} & \multicolumn{4}{|c|}{ Pesquisa } \\
\hline & \multicolumn{2}{|c|}{ de Campo } & \multicolumn{2}{|c|}{ pela Internet } \\
\hline & Freqüência & $\%$ & Freqüência & $\%$ \\
\hline Sim & 354 & 31,38 & 125 & 33,51 \\
\hline Não & 499 & 44,24 & 99 & 26,54 \\
\hline Indiferente & 275 & 24,38 & 149 & 39,95 \\
\hline Total & 1128 & 100,00 & 373 & 100,00 \\
\hline
\end{tabular}

Em contrapartida em relação à questão anterior, 73,2\% das pessoas entrevistadas em campo investiriam em instituições concebidas a partir de novos conceitos, para uso futuro, que garantisse qualidade de vida. Em relação às pessoas entrevistadas pela internet, 70,8\% delas investiriam nessas instituições.

Tabela 93 - Frequência de intenção de investimento, para uso futuro, em instituições que ofereçam garantias de qualidade de vida (Questão 16)

\begin{tabular}{|c|c|c|c|c|}
\hline \multirow{3}{*}{$\begin{array}{c}\text { O pesquisado investiria em instituições que cuidam de } \\
\text { pessoas que precisam de cuidados especiais, para uso } \\
\text { futuro, desde que as mesmas ofereçam garantias de } \\
\text { qualidade de vida }\end{array}$} & \multicolumn{4}{|c|}{ Pesquisa } \\
\hline & \multicolumn{2}{|c|}{ de Campo } & \multicolumn{2}{|c|}{ pela Internet } \\
\hline & Freqüência & $\%$ & Freqüência & $\%$ \\
\hline Sim & 826 & 73,23 & 264 & 70,78 \\
\hline Não & 156 & 13,83 & 25 & 6,70 \\
\hline Indiferente & 146 & 12,94 & 84 & 22,52 \\
\hline Total & 1128 & 100,00 & 373 & 100,00 \\
\hline
\end{tabular}

Dos pesquisados em campo, 9,9\% tinham familiar que estava ou já tinha estado em organizações para pessoas que necessitavam de cuidados especiais; dos pesquisados pela internet, $37,0 \%$ estavam nesta mesma condição. 
Tabela 94 - Frequência de pesquisados que tem familiar próximo que está, ou já esteve, em organizações para pessoas que necessitam de cuidados especiais (Questão 17)

\begin{tabular}{|c|c|c|c|c|}
\hline \multirow{3}{*}{$\begin{array}{c}\text { O pesquisado tem familiar próximo que está } \\
\text { (ou já esteve) em organizações para pessoas } \\
\text { que necessitam de cuidados especiais) }\end{array}$} & \multicolumn{4}{|c|}{ Pesquisa } \\
\hline & \multicolumn{2}{|c|}{ de Campo } & \multicolumn{2}{|c|}{ pela Internet } \\
\hline & Freqüência & $\%$ & Freqüência & $\%$ \\
\hline Sim & 112 & 9,93 & 138 & 37,00 \\
\hline Não & 1016 & 90,07 & 235 & 63,00 \\
\hline Total & 1128 & 100,00 & 373 & 100,00 \\
\hline
\end{tabular}

A próxima etapa será analisar se os resultados da pesquisa corroboram as hipóteses e se os mesmos podem definir um perfil do investidor usufrutuário. 


\section{RESULTADOS DA PESQUISA DE CAMPO}

As hipóteses desta tese são as seguintes: 1) em relação ao investidor usufrutuário, esse não acredita na aposentadoria com base nos rendimentos da previdência social, e sim na necessidade de poupar para garantir um futuro com qualidade de vida; 2) para aplicar recursos em ambientes residenciais especiais o investidor entende que as organizações atuais não trazem segurança ou que o modelo proposto apresenta menor risco; e 3) ambientes residenciais que proporcionam segurança a investidores, possíveis usufrutuários, através de políticas administrativas adequadas, são opções de investimentos.

A questão 9 da pesquisa corrobora a primeira hipótese. Sua redação é a seguinte: no futuro, quando não estiver mais trabalhando, o valor a ser recebido pelo INSS a título de aposentadoria será suficiente para meu sustento. Os pesquisados indicaram somente sim ou não. No caso, a Tabela 86 (p. 146) evidencia que 78,72\% dos pesquisados em campo e $96,25 \%$ dos pesquisados pela internet não acreditam que os rendimentos serão suficientes.

A segunda hipótese pode ser corroborada pelas questões 14 e 15 . As respostas encontradas estão representadas no Gráfico 17 (p. 151). Seus textos são os seguintes: 14) Confio plenamente nos cuidados oferecidos por organizações que tratam de pessoas que requerem cuidados especiais; e 15) Caso futuramente tenha necessidade, nos moldes dos modelos atuais, gostaria de ser residente em uma instituição que trata de pessoas que requerem cuidados especiais. Para as duas questões a tabulação agrupou as respostas da seguinte forma: sim, não e indiferente.

Pode-se notar que $17,02 \%$ dos pesquisados em campo e $9,12 \%$ dos pesquisados pela internet confiam nos cuidados oferecidos pelas instituições. Em relação a uma possível necessidade futura, nos moldes atuais, $31,38 \%$ e $33,51 \%$ dos pesquisados em campo e pela internet, respectivamente, gostariam de ser residentes em instituições.

Para corroborar a terceira hipótese a questão 16 foi elaborada com o seguinte formato: 16) Investiria em instituições que cuidam de pessoas que precisam de cuidados especiais para meu uso futuro desde que as mesmas ofereçam garantias de qualidade de vida. Apesar de mais de 1/3 dos pesquisados aceitarem residir nessas organizações, pode-se notar no Gráfico 18 (p. 151) que 73,23\% e 70,78\% dos pesquisados investiriam em instituições que oferecessem garantias de qualidade de vida para uso futuro. 


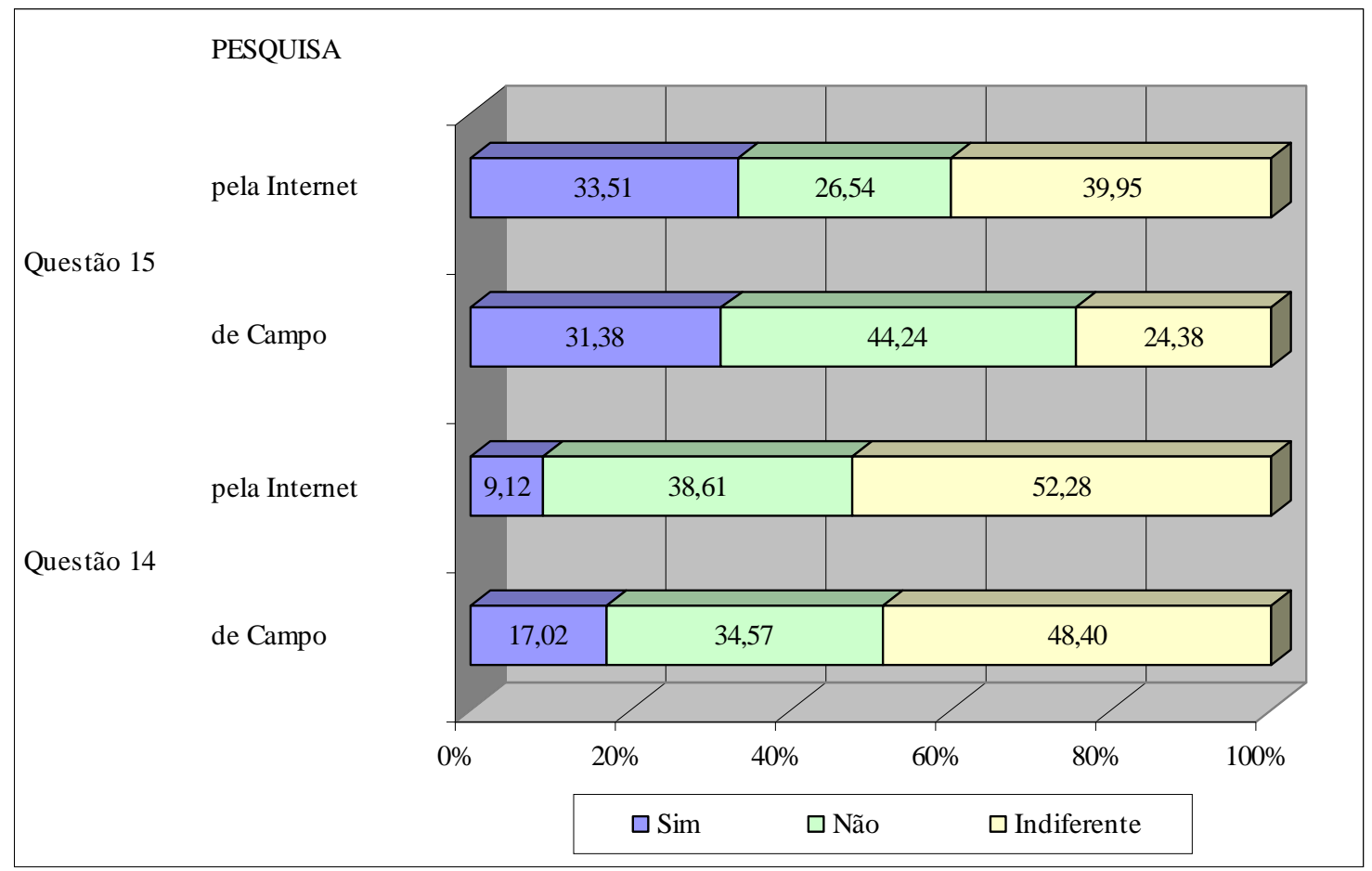

Gráfico 17 - Tabulação das Questões 14 e 15, em porcentagem, da Pesquisa de Campo e de Internet

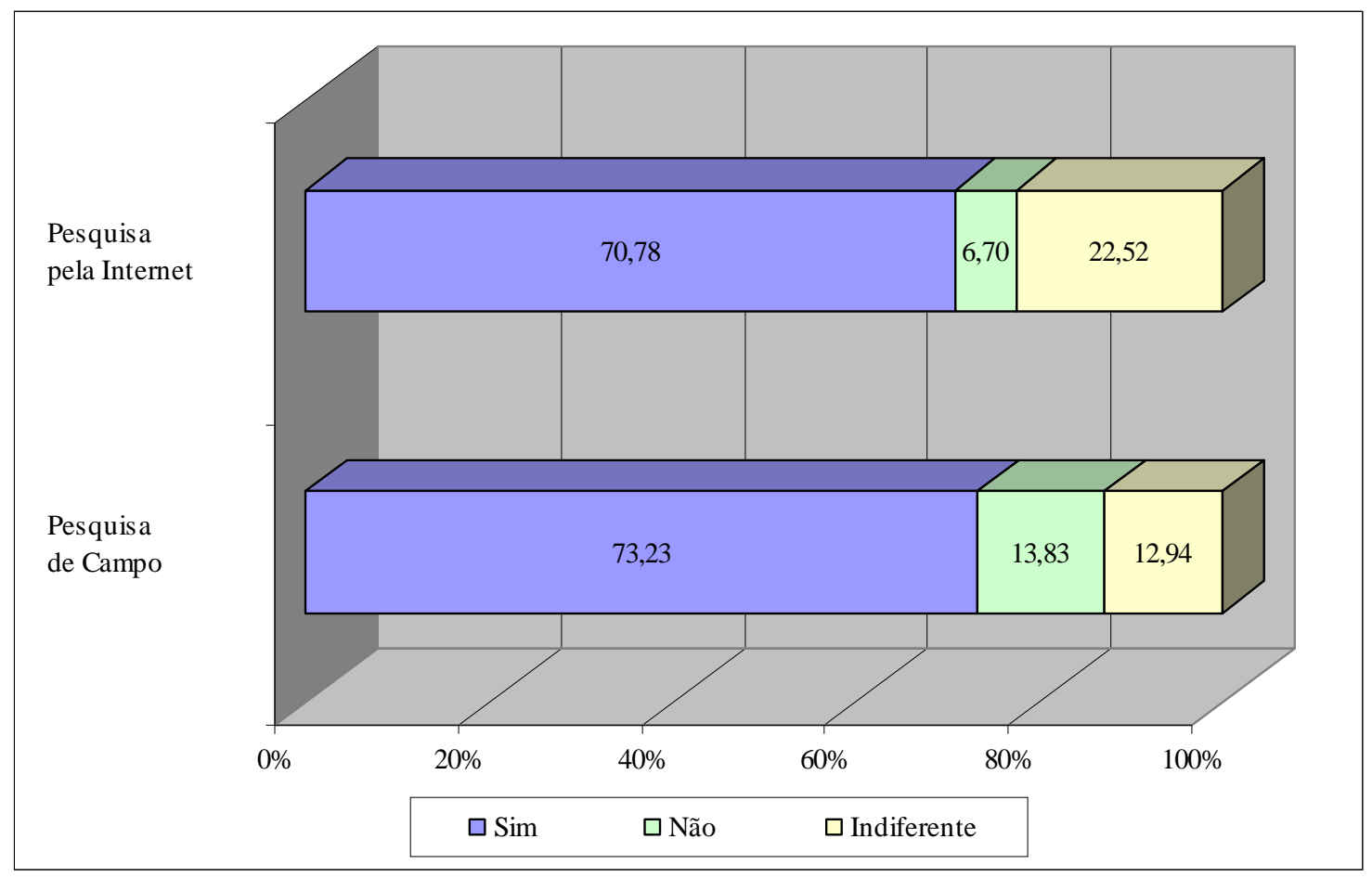

Gráfico 18 - Tabulação da Questão 16, em porcentagem, da Pesquisa de Campo e de Internet 
A partir do momento que os entrevistados expressam: - seu nível de confiança nos rendimentos do INSS, - sua confiança nos cuidados oferecidos pelas organizações, - se futuramente gostaria de residir em uma, - se investiria em um modelo que oferecesse qualidade de vida, pode-se traçar um perfil desses entrevistados.

Tomando o seguinte exemplo: 1128 entrevistados opinaram sobre a questão 16 (Gráfico 18, p. 151), ou seja, se investiriam ou não em uma organização que oferecesse garantias de qualidade de vida aos seus residentes. Desse total 73,2\% investiriam e 13,8\% não. Os outros 13,0\% não afirmaram se investiriam ou não. Desses 1128 entrevistados, 64,0\% residiam em região metropolitana e 36,0\% não (Tabela 79, p. 144). Se não há diferença de opinião em relação à região onde residiam, dos 73,2\% que investiriam é esperada uma frequência de $64,0 \%$ quanto aos residentes em região metropolitana e uma frequência de 36,0\% em relação aos que não moravam. Se a frequência observada for significativamente diferente da esperada, pode-se afirmar, por exemplo, que pessoas residentes em áreas metropolitanas investiriam mais no modelo do que não residentes.

Uma medida de discrepância entre as frequências esperadas e observadas é proporcionada pela estatística $\chi^{2}$ (lê-se qui-quadrado), expressa pela fórmula:

$$
\chi^{2}=\sum_{j=1}^{k} \frac{\left(o_{j}-e_{j}\right)^{2}}{e_{j}}
$$

onde:

$\mathrm{o}_{\mathrm{j}}=$ frequências observadas

$\mathrm{e}_{\mathrm{j}}=$ frequências esperadas

$\mathrm{j}=1,2,3, \ldots, \mathrm{k}$

$\mathrm{k}=$ número de classes ou valores considerados (SPIEGEL, 1994, p. 305)

Se $\chi^{2}=0$, as frequências observadas e teóricas são exatamente iguais. Se $\chi^{2}>0$, as frequências observadas são diferentes das esperadas. Quanto maior o valor do $\chi^{2}$, maior a discrepância entre as frequências. Deve-se comparar o $\chi^{2}$ com valores tabelados a partir do número de graus de liberdade e nível de significância desejado.

Em um primeiro momento o teste do $\chi^{2}$ é utilizado para determinar se as frequências observadas são iguais às esperadas. No caso desta tese o objetivo é determinar se há correspondências entre a frequência observada e a esperada de duas variáveis. Esse teste é obtido a partir das Tabelas de Contingência. No caso do exemplo citado há pouco, as colunas 
seriam, por exemplo, investiria e não investiria; as linhas seriam mora em região metropolitana e não mora em região metropolitana. A frequência esperada está representada na Tabela 95 (p. 153).

O valor 46,8\% ou 0,468, por exemplo, é obtido a partir de 0,732 x 0,64.

A $\chi^{2}$ será calculado a partir da frequência esperada em relação à observada com o programa SPSS. O grau de liberdade G.L. será calculado a partir da seguinte fórmula:

$$
\text { GL = número de linhas }-1 \times \text { número de colunas }-1
$$

Tabela 95 - Frequência esperada para a questão investiria em uma organização que oferecesse garantias de qualidade versus mora em região metropolitana

\begin{tabular}{ccccc}
\hline & & \multicolumn{3}{c}{$\begin{array}{c}\text { Investiria em uma organização que oferecesse } \\
\text { garantias de qualidade de vida }\end{array}$} \\
\cline { 2 - 4 } & & Sim & Não & Total \\
\hline \multirow{2}{*}{$\begin{array}{c}\text { Mora em região } \\
\text { metropolitana }\end{array}$} & Sim & $46,8 \%$ & $8,8 \%$ & $64,0 \%$ \\
\cline { 2 - 4 } & Não & $26,4 \%$ & $5,0 \%$ & $36,0 \%$ \\
\hline
\end{tabular}

Os valores críticos do $\chi^{2}$ para nível de significância de 5\% estão indicados na Tabela 96 (p. 153).

Tabela 96 - Valores críticos do $\chi^{2}$ para nível de significância de 5\% e graus de liberdade de 1 a 6

\begin{tabular}{cc}
\hline $\begin{array}{c}\text { Graus de } \\
\text { Liberdade }\end{array}$ & $\begin{array}{c}\text { Valores críticos } \\
\text { do } \chi^{2}\end{array}$ \\
\hline 1 & 3,841 \\
2 & 5,991 \\
3 & 7,815 \\
4 & 9,488 \\
5 & 11,070 \\
6 & 12,592 \\
\hline Fonte: NESBITT, 1995, p. 24
\end{tabular}

Para grau de liberdade 1 e nível de significância 5\%, o valor crítico do $\chi^{2}$ é 3,841. Ou seja, toda vez que o $\chi^{2}$ for maior que o valor crítico, a discrepância entre a frequência esperada e observada é significativa. Para o exemplo essa discrepância indicaria que residentes em regiões metropolitanas têm opinião diferente dos não residentes em relação a investir ou não em uma organização que oferecesse garantias de qualidade de vida. 
Como o valor crítico indica um nível de significância, outra forma de avaliar os resultados é analisar o nível de significância do resultado obtido. O programa SPSS indica a significância da discrepância entre a frequência esperada e a obtida. Desta forma, em vez de afirmar que a um nível de significância de 5\% determinadas variáveis tem discrepância, pode-se afirmar que determinadas variáveis têm discrepância a um nível de significância de, por exemplo, $2 \%$.

\subsection{Entrevistas Realizadas em Campo}

A Tabela 97 (p. 155) destaca as variáveis com nível de discrepância até 5\% para as pesquisa realizadas em campo. A próxima etapa é a análise das questões 9, 14, 15 e 16 que corroboram as hipóteses desta tese.

\subsubsection{Resultados das entrevistas realizadas em campo em relação à questão 9}

Em relação à questão 9, com redação no futuro, quando não estiver mais trabalhando, o valor a ser recebido do INSS a título de aposentadoria será suficiente para meu sustento, pode-se afirmar que a opinião dos pesquisados difere: em função da idade com nível de significância de $0,4 \%$; em função do sexo do pesquisado com nível de significância de 4\%; em função do nível de escolaridade do chefe da família com nível de significância de $0,1 \%$; em função da classe social com nível de significância de 4,5\%; e em função de não poupar com nível de significância $3,9 \%$.

Em relação à idade, a Tabela 98 (p. 156) indica a frequência observada e a esperada dos pesquisados em campo. A opinião difere quando há discrepância quanto à diferença das frequências. Pode-se observar que os entrevistados com 50 anos ou mais de idade acreditam, em maior número, que os valores a serem recebidos do INSS a título de aposentadoria serão suficientes para o sustento. Nota-se que a frequência esperada era de $8.49 \%$ e a observada foi de $10,82 \%$. Ou seja, havendo intenção de propor investimento e um ambiente residencial especial, pessoas com menos de 50 anos de idade tendem a ser mais sensíveis à proposta, pois acreditam menos na seguridade social brasileira.

Em relação ao sexo a pesquisa em campo indicou que a opinião em termos de rendimentos do INSS difere em relação ao sexo. Esta diferença pode ser observada na Tabela 99 (p. 156). Pode-se notar que as entrevistadas acreditam menos nos rendimentos do INSS a título de aposentadoria. 
Tabela 97 - Tabela de Contingência com nível de significância para $\chi^{2}$ calculado dos pesquisados em campo

\begin{tabular}{|c|c|c|c|c|c|}
\hline \multirow{2}{*}{\multicolumn{2}{|c|}{ Questões }} & \multicolumn{4}{|c|}{ Nível de significância para $\chi^{2}$ calculado (pesquisa em campo) } \\
\hline & & 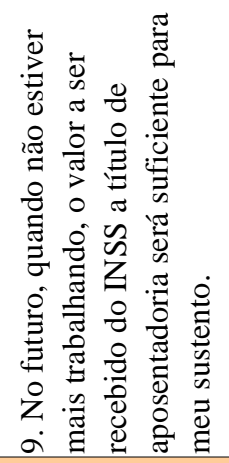 & 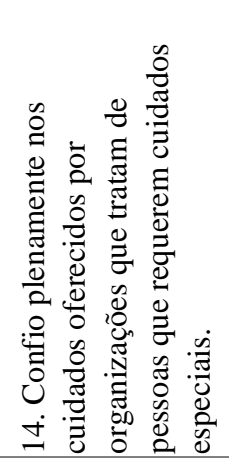 & 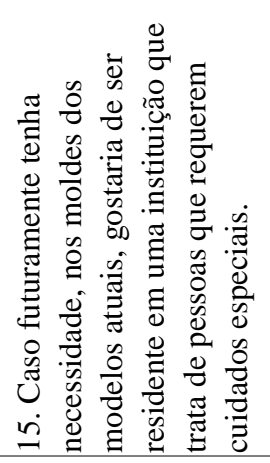 & 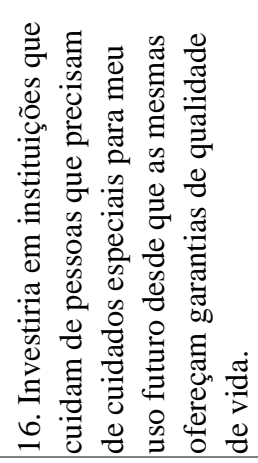 \\
\hline & Qual sua idade? & 0,004 & 0,240 & 0,271 & 0,914 \\
\hline & Sexo? & 0,040 & 0,200 & 0,836 & 0,009 \\
\hline & Em que cidade / estado você reside? & 0,495 & 0,000 & $\mathbf{0 , 0 0 3}$ & $\mathbf{0 , 0 2 7}$ \\
\hline & Reside em região metropolitana? & 0,316 & 0,010 & $\mathbf{0 , 0 2 3}$ & 0,995 \\
\hline & Até que ano da escola o chefe da família estudou? & 0,001 & 0,415 & $\mathbf{0 , 0 3 0}$ & 0,001 \\
\hline & Classe social a que pertence? & 0,045 & 0,448 & 0,155 & 0,955 \\
\hline & O rendimento familiar bruto mensal se encaixa: & 0,372 & 0,866 & 0,787 & 0,070 \\
\hline 8.5 . & $\begin{array}{l}\text { Poupo dinheiro atualmente com o objetivo de } \\
\text { completar a aposentadoria no futuro. }\end{array}$ & 0,514 & 0,671 & 0,854 & 0,420 \\
\hline 8.6 . & Não poupo dinheiro atualmente. & $\mathbf{0 , 0 3 9}$ & 0,064 & 0,572 & 0,823 \\
\hline & $\begin{array}{l}\text { Através de poupança ou previdência privada, pretendo } \\
\text { complementar minha renda quando me aposentar. }\end{array}$ & 0,160 & 0,298 & 0,754 & 0,009 \\
\hline & $\begin{array}{l}\text { Quando não puder mais trabalhar, quero que meus } \\
\text { filhos complementem minha renda ou me sustentem. }\end{array}$ & 0,831 & 0,415 & 0,844 & 0,487 \\
\hline & $\begin{array}{l}\text { Se um dia ficar dependente fisicamente, quero morar } \\
\text { com meus filhos ou com um parente próximo. }\end{array}$ & 0,489 & 0,825 & 0,151 & 0,736 \\
\hline & $\begin{array}{l}\text { Conheço bem instituições que tratam de pessoas que } \\
\text { requerem cuidados especiais. }\end{array}$ & 0,871 & 0,000 & $\mathbf{0 , 0 0 0}$ & $\mathbf{0 , 0 0 1}$ \\
\hline
\end{tabular}


A opinião dos entrevistados em campo também foi diferente em função do nível de escolaridade do chefe da família. A Tabela 100 (p. 156) evidencia esse aspecto. Pode-se notar que os entrevistados em campo com ensino médio completo ou grau de formação maior acreditam menos nos rendimentos da seguridade social, pois as frequências observadas foram maiores que as esperadas para a resposta não acredito.

Tabela 98 - Frequência observada e esperada para a questão no futuro, quando não estiver mais trabalhando, o valor a ser recebido do INSS a título de aposentadoria será suficiente para meu sustento versus a idade do pesquisado, para os pesquisados em campo

\begin{tabular}{llccc}
\hline \multirow{2}{*}{ Idade do pesquisado } & \multirow{2}{*}{ Freqüência } & \multicolumn{2}{c}{ No futuro... } & \multirow{2}{*}{ Total } \\
\cline { 3 - 4 } 18 a 24 & & Sim & Não & \\
\hline \multirow{2}{*}{25 a 29} & Observada & $2,57 \%$ & $12,06 \%$ & \multirow{2}{*}{$14,63 \%$} \\
& Esperada & $3,11 \%$ & $11,52 \%$ & \\
\multirow{2}{*}{30 a 39} & Observada & $1,60 \%$ & $7,80 \%$ & \multirow{2}{*}{$9,40 \%$} \\
& Esperada & $2,00 \%$ & $7,40 \%$ & \\
\multirow{2}{*}{40 a 49} & Observada & $2,66 \%$ & $13,48 \%$ & \multirow{2}{*}{$16,13 \%$} \\
& Esperada & $3,43 \%$ & $12,70 \%$ & \\
\multirow{2}{*}{50 ou +} & Observada & $3,63 \%$ & $16,31 \%$ & \multirow{2}{*}{$19,95 \%$} \\
& Esperada & $4,24 \%$ & $15,70 \%$ & \\
& Observada & $10,82 \%$ & $29,08 \%$ & $39,89 \%$ \\
\hline
\end{tabular}

Tabela 99 - Frequência observada e esperada para a questão no futuro, quando não estiver mais trabalhando, o valor a ser recebido do INSS a título de aposentadoria será suficiente para meu sustento versus o sexo do pesquisado, para os pesquisados em campo

\begin{tabular}{|c|c|c|c|c|}
\hline \multirow{2}{*}{ Sexo do pesquisado } & \multirow{2}{*}{ Freqüência } & \multicolumn{2}{|c|}{ No futuro... } & \multirow{2}{*}{ Total } \\
\hline & & Sim & Não & \\
\hline \multirow{2}{*}{ Feminino } & Observada & $10,37 \%$ & $44,24 \%$ & \multirow{2}{*}{$54,61 \%$} \\
\hline & Esperada & $11,62 \%$ & $42,99 \%$ & \\
\hline \multirow{2}{*}{ Masculino } & Observada & $10,90 \%$ & $34,49 \%$ & \multirow{2}{*}{$45,39 \%$} \\
\hline & Esperada & $9,66 \%$ & $35,73 \%$ & \\
\hline Total & & $21,28 \%$ & $78,72 \%$ & $100,00 \%$ \\
\hline
\end{tabular}

Tabela 100 - Frequência observada e esperada para a questão no futuro, quando não estiver mais trabalhando, o valor a ser recebido do INSS a título de aposentadoria será suficiente para meu sustento versus até que ano da escola o chefe da família estudou, para os pesquisados em campo

\begin{tabular}{|c|c|c|c|c|}
\hline \multirow{2}{*}{$\begin{array}{l}\text { Nível de escolaridade } \\
\text { do chefe da família }\end{array}$} & \multirow{2}{*}{ Freqüência } & \multicolumn{2}{|c|}{ No futuro... } & \multirow{2}{*}{ Total } \\
\hline & & Sim & Não & \\
\hline Analfabeto/Ensino & Observada & $6,74 \%$ & $17,91 \%$ & \multirow{2}{*}{$24,65 \%$} \\
\hline Fundamental & Esperada & $5,24 \%$ & $19,40 \%$ & \\
\hline Ensino Fundamental & Observada & $6,47 \%$ & $19,59 \%$ & \multirow{2}{*}{$26,06 \%$} \\
\hline Completo & Esperada & $5,55 \%$ & $20,52 \%$ & \\
\hline Ensino Médio & Observada & $7,00 \%$ & $34,49 \%$ & \multirow{2}{*}{$41,49 \%$} \\
\hline Completo & Esperada & $8,83 \%$ & $32,66 \%$ & \\
\hline Ensino Superior & Observada & $1,06 \%$ & $6,74 \%$ & \multirow{2}{*}{$7,80 \%$} \\
\hline Completo ou + & Esperada & $1,66 \%$ & $6,14 \%$ & \\
\hline Total & & $21,28 \%$ & $78,72 \%$ & $100,00 \%$ \\
\hline
\end{tabular}


Em relação à classe social dos entrevistados em campo, a Tabela 101 (157) evidencia que as classes sociais A e B acreditam menos nos rendimentos do INSS. Pode-se notar que a frequência observada em relação à resposta não acredito é maior que a frequência esperada.

Em termos de hábitos de poupança, os dados da pesquisa não foram conclusivos. Na Tabela 102 (p. 157) pode-se observar que as pessoas que acreditam mais nos rendimentos do INSS a título de aposentadoria eram as mais poupadoras no momento da pesquisa. Assim, não se pode definir uma relação entre a credibilidade dos rendimentos da seguridade social e os hábitos de poupança dos entrevistados em campo.

Tabela 101 - Frequência observada e esperada para a questão no futuro, quando não estiver mais trabalhando, o valor a ser recebido do INSS a título de aposentadoria será suficiente para meu sustento versus a classe social do pesquisado, para os pesquisados em campo

\begin{tabular}{|c|c|c|c|c|}
\hline \multirow{2}{*}{$\begin{array}{l}\text { Classe social do } \\
\text { pesquisado }\end{array}$} & \multirow{2}{*}{ Freqüência } & \multicolumn{2}{|c|}{ No futuro... } & \multirow{2}{*}{ Total } \\
\hline & & Sim & Não & \\
\hline \multirow{2}{*}{ A } & Observada & $0,44 \%$ & $2,75 \%$ & \multirow{2}{*}{$3,19 \%$} \\
\hline & Esperada & $0,68 \%$ & $2,51 \%$ & \\
\hline \multirow{2}{*}{ B } & Observada & $5,32 \%$ & $25,18 \%$ & \multirow{2}{*}{$30,50 \%$} \\
\hline & Esperada & $6,49 \%$ & $24,01 \%$ & \\
\hline \multirow{2}{*}{$\mathrm{CDE}$} & Observada & $15,51 \%$ & $50,80 \%$ & \multirow{2}{*}{$66,31 \%$} \\
\hline & Esperada & $14,11 \%$ & $52,20 \%$ & \\
\hline Total & & $21,28 \%$ & $78,72 \%$ & $100,00 \%$ \\
\hline
\end{tabular}

Tabela 102 - Frequência observada e esperada para a questão no futuro, quando não estiver mais trabalhando, o valor a ser recebido do INSS a título de aposentadoria será suficiente para meu sustento em relação à condição do pesquisado se ele poupa dinheiro atualmente, para os pesquisados em campo

\begin{tabular}{llccc}
\hline \multirow{2}{*}{$\begin{array}{l}\text { O pesquisado poupa } \\
\text { dinheiro atualmente }\end{array}$} & \multirow{2}{*}{ Freqüência } & \multicolumn{2}{c}{ No futuro... } & \multirow{2}{*}{ Total } \\
\cline { 3 - 4 } Sim & Observada & $7,27 \%$ & $21,54 \%$ & \multirow{2}{*}{$28,81 \%$} \\
& Esperada & $6,13 \%$ & $22,68 \%$ & \\
\multirow{2}{*}{ Não } & Observada & $14,01 \%$ & $57,18 \%$ & \multirow{2}{*}{$71,19 \%$} \\
\hline & Esperada & $15,15 \%$ & $56,04 \%$ & \\
\hline
\end{tabular}

Em relação aos pesquisados em campo nas cidades da amostra, no que diz respeito aos rendimentos do INSS serem suficientes ao se aposentar, pode-se afirmar que os seguintes grupos acreditam menos nessa condição: pessoas de 18 até 50 anos de idade, mulheres, pessoas com ensino médio completo ou grau de formação maior e das classes sociais A e B.

\subsubsection{Resultados das entrevistas realizadas em campo em relação à questão 14}

Quanto à questão 14, confio plenamente nos cuidados oferecidos por organizações que tratam de pessoas que requerem cuidados especiais, pode-se afirmar, a partir da Tabela 97 (p. 155), que a opinião dos pesquisados difere: em função da cidade que reside com nível de 
significância de 0\%; em função de residir em região metropolitana ou não com nível de significância de 1\%; e em função de conhecer instituições que tratam de pessoas que requerem cuidados especiais com nível de significância de $0 \%$.

Em relação à cidade onde o pesquisado reside, a Tabela 103 (p. 158) indica que os moradores das cidades de Jundiaí, Santos e São Bernardo do Campo confiam mais nos cuidados oferecidos pelas organizações que tratam de pessoas carentes de cuidados especiais.

Tabela 103 - Frequência observada e esperada para a questão confio plenamente nos cuidados oferecidos por organizações que tratam de pessoas que requerem cuidados especiais versus a cidade onde o pesquisado reside, para os pesquisados em campo

\begin{tabular}{|c|c|c|c|c|}
\hline \multirow{2}{*}{$\begin{array}{c}\text { Cidade onde o } \\
\text { pesquisado reside }\end{array}$} & \multirow{2}{*}{ Frequiência } & \multicolumn{2}{|c|}{ Confio plenamente... } & \multirow{2}{*}{ Total } \\
\hline & & Concordo & Discordo & \\
\hline \multirow{2}{*}{ Jundiaí } & Observada & $7,73 \%$ & $4,47 \%$ & \multirow{2}{*}{$12,20 \%$} \\
\hline & Esperada & $4,02 \%$ & $8,17 \%$ & \\
\hline \multirow{2}{*}{ Mauá } & Observada & $4,64 \%$ & $13,40 \%$ & \multirow{2}{*}{$18,04 \%$} \\
\hline & Esperada & $5,95 \%$ & $12,09 \%$ & \\
\hline \multirow{2}{*}{ Ribeirão Pires } & Observada & $3,78 \%$ & $10,65 \%$ & \multirow{2}{*}{$14,43 \%$} \\
\hline & Esperada & $4,76 \%$ & $9,67 \%$ & \\
\hline \multirow{2}{*}{ Santos } & Observada & $4,30 \%$ & $8,25 \%$ & \multirow{2}{*}{$12,54 \%$} \\
\hline & Esperada & $4,14 \%$ & $8,41 \%$ & \\
\hline \multirow{2}{*}{ São Bernardo do Campo } & Observada & $6,36 \%$ & $9,62 \%$ & \multirow{2}{*}{$15,98 \%$} \\
\hline & Esperada & $5,27 \%$ & $10,71 \%$ & \\
\hline \multirow{2}{*}{ São Paulo } & Observada & $3,44 \%$ & $10,65 \%$ & \multirow{2}{*}{$14,09 \%$} \\
\hline & Esperada & $4,65 \%$ & $9,44 \%$ & \\
\hline \multirow{2}{*}{ Taubaté } & Observada & $2,75 \%$ & $9,97 \%$ & \multirow{2}{*}{$12,71 \%$} \\
\hline & Esperada & $4,19 \%$ & $8,52 \%$ & \\
\hline Total & & $32,99 \%$ & $67,01 \%$ & $100,00 \%$ \\
\hline
\end{tabular}

Com referência à região onde o pesquisado reside, a Tabela 104 (p. 158) indica que os moradores de regiões metropolitanas confiam menos nos cuidados oferecidos por organizações que tratam de pessoas que necessitam de cuidados especiais.

Tabela 104 - Frequência observada e esperada para a questão confio plenamente nos cuidados oferecidos por organizações que tratam de pessoas que requerem cuidados especiais versus a região onde o pesquisado reside, para os pesquisados em campo

\begin{tabular}{|c|c|c|c|c|}
\hline \multirow{2}{*}{$\begin{array}{l}\text { O pesquisado reside em } \\
\text { região metropolitana }\end{array}$} & \multirow{2}{*}{ Freqüência } & \multicolumn{2}{|c|}{ Confio plenamante... } & \multirow{2}{*}{ Total } \\
\hline & & Concordo & Discordo & \\
\hline \multirow{2}{*}{ Sim } & Observada & $18,21 \%$ & $44,33 \%$ & \multirow{2}{*}{$62,54 \%$} \\
\hline & Esperada & $20,63 \%$ & $41,91 \%$ & \\
\hline \multirow{2}{*}{ Não } & Observada & $14,78 \%$ & $22,68 \%$ & \multirow{2}{*}{$19,33 \%$} \\
\hline & Esperada & $12,36 \%$ & $25,10 \%$ & \\
\hline Total & & $32,99 \%$ & $67,01 \%$ & $100,00 \%$ \\
\hline
\end{tabular}

A Tabela 105 (p. 159) indica que 64,11\% dos entrevistados em campo não confiam nos cuidados oferecidos por instituições que tratam de pessoas carentes de cuidados especiais. Contudo, pessoas que conhecem as instituições confiam mais nos cuidados oferecidos pelas mesmas. 
Tabela 105 - Frequência observada e esperada para a questão confio plenamente nos cuidados oferecidos por organizações que tratam de pessoas que requerem cuidados especiais versus o conhecimento que o pesquisado tem de instituições que tratam de pessoas que requerem cuidados especiais, para os pesquisados em campo

\begin{tabular}{|c|c|c|c|c|}
\hline \multirow{2}{*}{$\begin{array}{l}\mathrm{O} \text { pesquisado conhece } \\
\text { bem instituições que... }\end{array}$} & \multirow{2}{*}{ Freqüência } & \multicolumn{2}{|c|}{ Confio plenamante... } & \multirow{2}{*}{ Total } \\
\hline & & Concordo & Discordo & \\
\hline \multirow{2}{*}{ Concordo } & Observada & $32,86 \%$ & $39,31 \%$ & \multirow{2}{*}{$72,18 \%$} \\
\hline & Esperada & $25,90 \%$ & $46,28 \%$ & \\
\hline \multirow{2}{*}{ Discordo } & Observada & $3,02 \%$ & $24,80 \%$ & \multirow{2}{*}{$12,23 \%$} \\
\hline & Esperada & $9,98 \%$ & $17,84 \%$ & \\
\hline Total & & $35,89 \%$ & $64,11 \%$ & $100,00 \%$ \\
\hline
\end{tabular}

Em resumo, a pesquisa evidencia que os grupos a seguir têm um nível de confiabilidade maior nos cuidados oferecidos pelas organizações que tratam de pessoas que requerem cuidados especiais: moradores das cidades de Jundiaí, Santos e São Bernardo do Campo; pessoas que não residem em regiões metropolitanas; e pessoas que não conhecem com profundidade esses tipos de instituições.

Nota-se pelos resultados que a cidade de São Bernardo do Campo é atípica em relação ao nível de confiança, pois os pesquisados confiam mais nas instituições e trata-se de região metropolitana.

\subsubsection{Resultados das entrevistas realizadas em campo em relação à questão 15}

Em relação à questão 15 , caso futuramente tenha necessidade, nos moldes dos modelos atuais, gostaria de ser residente em uma instituição que trata de pessoas que requerem cuidados especiais, pode-se observar na Tabela 97 (p. 155) que a opinião dos pesquisados difere: em função da cidade que reside com nível de significância de 0,3\%; em função de residir em região metropolitana ou não com nível de significância de 2,3\%; em função do nível de escolaridade do chefe da família com nível de significância de 3,0\%; e em função de conhecer instituições que tratam de pessoas que requerem cuidados especiais com nível de significância de $0 \%$.

Pode-se observar na Tabela 106 (p. 160) que 58,5\% dos entrevistados em campo, caso futuramente tenham necessidade, nos moldes dos modelos atuais, não gostariam de residir em uma instituição que trata de pessoas necessitadas de cuidados especiais. Apesar dessa condição, residentes nas cidades de Jundiaí, Santos e São Bernardo do Campo possuem um nível de aceitação maior em relação às demais cidades. 
Tabela 106 - Frequência observada e esperada para a questão caso futuramente tenha necessidade, nos moldes dos modelos atuais, gostaria de ser residente em uma instituição que trata de pessoas que requerem cuidados especiais versus a cidade onde o pesquisado reside, para os pesquisados em campo

\begin{tabular}{|c|c|c|c|c|}
\hline \multirow{2}{*}{$\begin{array}{l}\text { Cidade onde o } \\
\text { pesquisado reside }\end{array}$} & \multirow{2}{*}{ Freqüência } & \multicolumn{2}{|c|}{ Caso futuramente... } & \multirow{2}{*}{ Total } \\
\hline & & Concordo & Discordo & \\
\hline \multirow{2}{*}{ Jundiaí } & Observada & $6,45 \%$ & $4,22 \%$ & \multirow{2}{*}{$10,67 \%$} \\
\hline & Esperada & $4,43 \%$ & $6,24 \%$ & \\
\hline \multirow{2}{*}{ Mauá } & Observada & $6,92 \%$ & $10,79 \%$ & \multirow{2}{*}{$17,70 \%$} \\
\hline & Esperada & $7,35 \%$ & $10,36 \%$ & \\
\hline \multirow{2}{*}{ Ribeirão Pires } & Observada & $4,92 \%$ & $10,20 \%$ & \multirow{2}{*}{$15,12 \%$} \\
\hline & Esperada & $6,28 \%$ & $8,85 \%$ & \\
\hline \multirow{2}{*}{ Santos } & Observada & $5,74 \%$ & $6,92 \%$ & \multirow{2}{*}{$12,66 \%$} \\
\hline & Esperada & $5,25 \%$ & $7,41 \%$ & \\
\hline \multirow{2}{*}{ São Bernardo do Campo } & Observada & $6,80 \%$ & $9,38 \%$ & \multirow{2}{*}{$16,18 \%$} \\
\hline & Esperada & $6,71 \%$ & $9,46 \%$ & \\
\hline \multirow{2}{*}{ São Paulo } & Observada & $6,33 \%$ & $9,26 \%$ & \multirow{2}{*}{$15,59 \%$} \\
\hline & Esperada & $6,47 \%$ & $9,12 \%$ & \\
\hline \multirow{2}{*}{ Taubaté } & Observada & $4,34 \%$ & $7,74 \%$ & \multirow{2}{*}{$12,08 \%$} \\
\hline & Esperada & $5,01 \%$ & $7,06 \%$ & \\
\hline Total & & $41,50 \%$ & $58,50 \%$ & $100,00 \%$ \\
\hline
\end{tabular}

Em relação à região de moradia do pesquisado em campo, pode-se notar através da Tabela 107 (p. 160) que os residentes em região metropolitana têm uma aversão maior às instituições, nos moldes dos modelos atuais, que tratam de pessoas que carecem de cuidados especiais.

Tabela 107 - Frequência observada e esperada para a questão caso futuramente tenha necessidade, nos moldes dos modelos atuais, gostaria de ser residente em uma instituição que trata de pessoas que requerem cuidados especiais versus a região onde o pesquisado reside, para os pesquisados em campo

\begin{tabular}{|c|c|c|c|c|}
\hline \multirow{2}{*}{$\begin{array}{l}\text { O pesquisado reside em } \\
\text { região metropolitana }\end{array}$} & \multirow{2}{*}{ Freqüêencia } & \multicolumn{2}{|c|}{ Caso futuramente... } & \multirow{2}{*}{ Total } \\
\hline & & Concordo & Discordo & \\
\hline \multirow{2}{*}{ Sim } & Observada & $24,97 \%$ & $39,62 \%$ & \multirow{2}{*}{$64,60 \%$} \\
\hline & Esperada & $26,81 \%$ & $37,79 \%$ & \\
\hline \multirow{2}{*}{ Não } & Observada & $16,53 \%$ & $18,87 \%$ & \multirow{2}{*}{$26,77 \%$} \\
\hline & Esperada & $14,69 \%$ & $20,71 \%$ & \\
\hline Total & & $41,50 \%$ & $58,50 \%$ & $100,00 \%$ \\
\hline
\end{tabular}

Tabela 108 - Frequência observada e esperada para a questão caso futuramente tenha necessidade, nos moldes dos modelos atuais, gostaria de ser residente em uma instituição que trata de pessoas que requerem cuidados especiais versus até que ano da escola o chefe da família estudou, para os pesquisados em campo

\begin{tabular}{|c|c|c|c|c|}
\hline \multirow{2}{*}{$\begin{array}{l}\text { Nível de escolaridade do } \\
\text { chefe da família }\end{array}$} & \multirow{2}{*}{ Freqüência } & \multicolumn{2}{|c|}{ Caso futuramente... } & \multirow{2}{*}{ Total } \\
\hline & & Concordo & Discordo & \\
\hline Analfabeto/Ensino & Observada & $12,08 \%$ & $12,54 \%$ & \multirow{2}{*}{$24,62 \%$} \\
\hline Fundamental Incompleto & Esperada & $10,22 \%$ & $14,40 \%$ & \\
\hline Ensino Fundamental & Observada & $10,08 \%$ & $15,59 \%$ & \multirow{2}{*}{$25,67 \%$} \\
\hline Completo & Esperada & $10,65 \%$ & $15,02 \%$ & \\
\hline \multirow{2}{*}{ Ensino Médio Completo } & Observada & $17,00 \%$ & $24,97 \%$ & \multirow{2}{*}{$41,97 \%$} \\
\hline & Esperada & $17,42 \%$ & $24,55 \%$ & \\
\hline Ensino Superior & Observada & $2,34 \%$ & $5,39 \%$ & \multirow{2}{*}{$7,74 \%$} \\
\hline Completo ou + & Esperada & $3,21 \%$ & $4,53 \%$ & \\
\hline Total & & $41,50 \%$ & $58,50 \%$ & $100,00 \%$ \\
\hline
\end{tabular}


De acordo com a Tabela 108 (p. 160) entrevistados com ensino fundamental completo ou escolaridade superior a esta têm um nível de aceitação menor em relação a residir em instituições que tratam de pessoas que requerem cuidados especiais, nos moldes dos modelos atuais, caso venham a precisar futuramente.

A Tabela 109 (p. 161) evidencia que, apesar de 55,40\% dos entrevistados em campo não concordarem em residir em instituições que tratam de pessoas carentes de cuidados especiais caso futuramente seja necessário, os que conhecem as instituições confiam mais nos cuidados oferecidos pelas mesmas.

Tabela 109 - Frequência observada e esperada para a questão caso futuramente tenha necessidade, nos moldes dos modelos atuais, gostaria de ser residente em uma instituição que trata de pessoas que requerem cuidados especiais versus o conhecimento que o pesquisado tem de instituições que tratam de pessoas que requerem cuidados especiais, para os pesquisados em campo

\begin{tabular}{llccc}
\hline \multirow{2}{*}{$\begin{array}{l}\text { O pesquisado conhece } \\
\text { bem instituições que... }\end{array}$} & \multirow{2}{*}{ Freqüência } & \multicolumn{2}{c}{ Caso futuramente... } & \multirow{2}{*}{ Total } \\
\cline { 2 - 4 } Concordo & Observada & $40,58 \%$ & $35,54 \%$ & \multirow{2}{*}{$76,12 \%$} \\
& Esperada & $33,95 \%$ & $42,16 \%$ & \\
\multirow{2}{*}{ Discordo } & Observada & $4,03 \%$ & $19,86 \%$ & \multirow{2}{*}{$14,72 \%$} \\
\hline & Esperada & $10,65 \%$ & $13,23 \%$ & \\
\hline
\end{tabular}

Caso futuramente os entrevistados em campo, nas cidades pesquisadas, tivessem a necessidade de residir em uma instituição, nos moldes dos modelos atuais, que oferecesse cuidados a pessoas carentes de tratamentos especiais, os mais receptivos têm o seguinte perfil: residem em cidades como Jundiaí, Santos, São Bernardo do Campo ou em regiões não metropolitanas, têm no máximo ensino fundamental incompleto e conhecem bem esses tipos de organizações.

\subsubsection{Resultados das entrevistas realizadas em campo em relação à questão 16}

$\mathrm{Na}$ questão 16, investiria em instituições que cuidam de pessoas que precisam de cuidados especiais para meu uso futuro desde que as mesmas ofereçam garantias de qualidade de vida, pode-se afirmar que a opinião dos pesquisados difere: em função da idade com nível de significância de 0,9\%; em função da cidade que reside com nível de significância de 2,7\%; em função do nível de escolaridade do chefe da família com nível de significância de $0,1 \%$; em função da intenção de complementar a renda quando se aposentar através de poupança ou previdência privada com nível de significância de $0,9 \%$; e em função de conhecer instituições que tratam de pessoas que requerem cuidados especiais com nível de significância de $0,1 \%$. 
Deve-se notar que os resultados apresentados na Tabela 93 (p. 148) indicam que 73,23\% dos pesquisados em campo investiriam nessas instituições.

Em relação ao sexo a pesquisa em campo indicou que as mulheres investiriam mais em instituições que tratam de pessoas carentes de cuidados especiais para uso futuro, desde que as organizações oferecessem garantias de qualidade de vida. Essas evidências podem ser observadas na Tabela 110 (p. 162).

Tabela 110 - Frequência observada e esperada para a questão investiria em instituições que cuidam de pessoas que precisam de cuidados especiais para meu uso futuro desde que as mesmas ofereçam garantias de qualidade de vida versus o sexo do pesquisado, para os pesquisados em campo

\begin{tabular}{|c|c|c|c|c|}
\hline \multirow{2}{*}{ Sexo do pesquisado } & \multirow{2}{*}{ Freqüência } & \multicolumn{2}{|c|}{ No futuro... } & \multirow{2}{*}{ Total } \\
\hline & & Concordo & Discordo & \\
\hline \multirow{2}{*}{ Feminino } & Observada & $47,25 \%$ & $7,13 \%$ & \multirow{2}{*}{$54,38 \%$} \\
\hline & Esperada & $45,74 \%$ & $8,64 \%$ & \\
\hline \multirow{2}{*}{ Masculino } & Observada & $36,86 \%$ & $8,76 \%$ & \multirow{2}{*}{$39,72 \%$} \\
\hline & Esperada & $38,37 \%$ & $7,25 \%$ & \\
\hline Total & & $84,11 \%$ & $15,89 \%$ & $100,00 \%$ \\
\hline
\end{tabular}

Com referência à cidade onde residem os pesquisados, a Tabela 111 (p. 162) indica que os moradores de Mauá, Santos e São Bernardo do Campo investiriam mais nas instituições que cuidam de pessoas que requerem cuidados especiais.

Tabela 111 - Frequência observada e esperada para a questão investiria em instituições que cuidam de pessoas que precisam de cuidados especiais para meu uso futuro desde que as mesmas ofereçam garantias de qualidade de vida versus a cidade onde o pesquisado reside, para os pesquisados em campo

\begin{tabular}{|c|c|c|c|c|}
\hline \multirow{2}{*}{$\begin{array}{c}\text { Cidade onde o } \\
\text { pesquisado reside }\end{array}$} & \multirow{2}{*}{ Freqüência } & \multicolumn{2}{|c|}{ Investiria... } & \multirow{2}{*}{ Total } \\
\hline & & Concordo & Discordo & \\
\hline \multirow{2}{*}{ Jundiaí } & Observada & $6,52 \%$ & $1,93 \%$ & \multirow{2}{*}{$8,45 \%$} \\
\hline & Esperada & $7,11 \%$ & $1,34 \%$ & \\
\hline \multirow{2}{*}{ Mauá } & Observada & $16,19 \%$ & $2,04 \%$ & \multirow{2}{*}{$18,23 \%$} \\
\hline & Esperada & $15,33 \%$ & $2,90 \%$ & \\
\hline \multirow{2}{*}{ Ribeirão Pires } & Observada & $11,20 \%$ & $2,14 \%$ & \multirow{2}{*}{$13,34 \%$} \\
\hline & Esperada & $11,22 \%$ & $2,12 \%$ & \\
\hline \multirow{2}{*}{ Santos } & Observada & $12,83 \%$ & $1,32 \%$ & \multirow{2}{*}{$14,15 \%$} \\
\hline & Esperada & $11,91 \%$ & $2,25 \%$ & \\
\hline \multirow{2}{*}{$\begin{array}{l}\text { São Bernardo do } \\
\text { Campo }\end{array}$} & Observada & $13,14 \%$ & $2,44 \%$ & \multirow{2}{*}{$15,58 \%$} \\
\hline & Esperada & $13,11 \%$ & $2,48 \%$ & \\
\hline \multirow{2}{*}{ São Paulo } & Observada & $13,95 \%$ & $3,67 \%$ & \multirow{2}{*}{$17,62 \%$} \\
\hline & Esperada & $14,82 \%$ & $2,80 \%$ & \\
\hline \multirow{2}{*}{ Taubaté } & Observada & $10,29 \%$ & $2,34 \%$ & \multirow{2}{*}{$12,63 \%$} \\
\hline & Esperada & $10,62 \%$ & $2,01 \%$ & \\
\hline Total & & $84,11 \%$ & $15,89 \%$ & $100,00 \%$ \\
\hline
\end{tabular}

A Tabela 112 (p. 163) indica que os chefes de família dos pesquisados em campo com ensino fundamental completo investiriam mais nas instituições que oferecessem garantias de qualidade de vida. 
Tabela 112 - Frequência observada e esperada para a questão investiria em instituições que cuidam de pessoas que precisam de cuidados especiais para meu uso futuro desde que as mesmas ofereçam garantias de qualidade de vida versus até que ano da escola o chefe da família estudou, para os pesquisados em campo

\begin{tabular}{llccc}
\hline \multirow{2}{*}{$\begin{array}{c}\text { Nível de escolaridade } \\
\text { do chefe da família }\end{array}$} & \multirow{2}{*}{ Freqüência } & \multicolumn{2}{c}{ Investiria... } & \multirow{2}{*}{ Total } \\
\cline { 3 - 4 } & & Concordo & Discordo & \\
\hline Analfabeto/Ens & Observada & $19,96 \%$ & $3,87 \%$ & \multirow{2}{*}{$23,83 \%$} \\
Fundam Incompleto & Esperada & $20,04 \%$ & $3,79 \%$ & \\
Ensino Fundamental & Observada & $23,83 \%$ & $2,44 \%$ & \multirow{2}{*}{$26,27 \%$} \\
Completo & Esperada & $22,10 \%$ & $4,17 \%$ & \\
Ensino Médio & Observada & $34,62 \%$ & $7,54 \%$ & \multirow{2}{*}{$42,16 \%$} \\
Completo & Esperada & $35,46 \%$ & $6,70 \%$ & \\
Ensino Superior & Observada & $5,70 \%$ & $2,04 \%$ & \multirow{2}{*}{$7,74 \%$} \\
Completo ou + & Esperada & $6,51 \%$ & $1,23 \%$ & \\
\hline \multicolumn{1}{c}{ Total } & & $84,11 \%$ & $15,89 \%$ & $100,00 \%$ \\
\hline
\end{tabular}

Em relação aos pesquisados em campo, a Tabela 113 (p. 163) indica que os pesquisados que pretendem complementar sua renda ao se aposentar, com poupança ou previdência privada, estão mais dispostos a investir em instituições que cuidam de pessoas que requerem cuidados especiais para uso futuro, desde que ofereçam garantias de qualidade de vida.

Tabela 113 - Frequência observada e esperada para a questão investiria em instituições que cuidam de pessoas que precisam de cuidados especiais para meu uso futuro desde que as mesmas ofereçam garantias de qualidade de vida versus a pretensão do pesquisado em complementar a renda quando se aposentar com poupança ou previdência privada, para os pesquisados em campo

\begin{tabular}{llccc}
\hline \multirow{2}{*}{$\begin{array}{c}\text { Através de poupança ou } \\
\text { previdência privada... }\end{array}$} & \multirow{2}{*}{ Frequiência } & \multicolumn{2}{c}{ Investiria... } & \multirow{2}{*}{ Total } \\
\cline { 3 - 4 } & Observada & Concordo & Discordo & \\
\hline \multirow{2}{*}{ Sim } & Obs,47\% & $5,30 \%$ & \multirow{2}{*}{$42,77 \%$} \\
\multirow{2}{*}{ Não } & Esperada & $35,98 \%$ & $6,79 \%$ & \\
& Observada & $46,64 \%$ & $10,59 \%$ & $49,82 \%$ \\
& Esperada & $48,14 \%$ & $9,09 \%$ & \\
\hline
\end{tabular}

A Tabela 114 (p. 163) evidencia que os pesquisados em campo, conhecedores das instituições que cuidam de pessoas carentes de cuidados especiais, para uso futuro, investiriam mais nessas organizações, desde que as mesmas oferecessem cuidados especiais.

Tabela 114 - Frequência observada e esperada para a questão investiria em instituições que cuidam de pessoas que precisam de cuidados especiais para meu uso futuro desde que as mesmas ofereçam garantias de qualidade de vida versus o conhecimento que o pesquisado tem de instituições que tratam de pessoas que requerem cuidados especiais, para os pesquisados em campo

\begin{tabular}{llccc}
\hline \multirow{2}{*}{$\begin{array}{l}\text { O pesquisado conhece } \\
\text { bem instituições que... }\end{array}$} & \multirow{2}{*}{ Freqüência } & \multicolumn{2}{c}{ Investiria... } & \multirow{2}{*}{ Total } \\
\cline { 3 - 4 } Concordo & Observada & $67,54 \%$ & $11,11 \%$ & \multirow{2}{*}{$78,65 \%$} \\
& Esperada & $65,79 \%$ & $12,86 \%$ & \\
\multirow{2}{*}{ Discordo } & Observada & $16,10 \%$ & $5,24 \%$ & \multirow{2}{*}{$15,16 \%$} \\
\hline & Esperada & $17,86 \%$ & $3,49 \%$ & \\
\hline & & $83,65 \%$ & $16,35 \%$ & $100,00 \%$ \\
\hline
\end{tabular}


Tabela 115 - Tabela de Contingência com nível de significância para $\chi^{2}$ calculado dos pesquisados pela internet

\begin{tabular}{|c|c|c|c|c|c|}
\hline \multirow{2}{*}{\multicolumn{2}{|c|}{ Questões }} & \multicolumn{4}{|c|}{ Nível de significância para $\chi^{2}$ calculado (pesquisa em campo) } \\
\hline & & 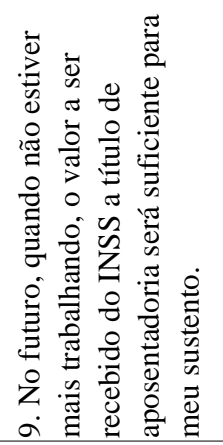 & 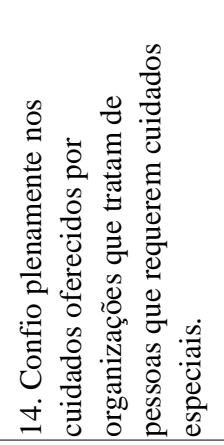 & 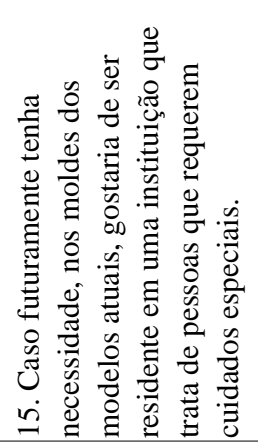 & 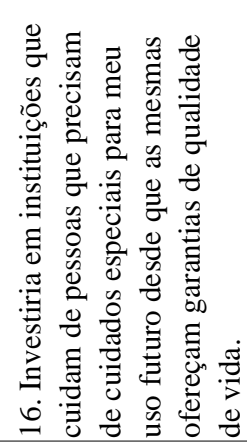 \\
\hline & Qual sua idade? & $(*)$ & 0,682 & 0,663 & 0,479 \\
\hline 2. & Sexo? & 0,263 & 0,033 & 0,857 & 0,582 \\
\hline & Em que cidade / estado você reside? & $(*)$ & 0,724 & 0,510 & 0,120 \\
\hline & Reside em região metropolitana? & $(* *)$ & $(* *)$ & $(* *)$ & $(* *)$ \\
\hline & Até que ano da escola o chefe da família estudou? & 0,270 & 0,661 & 0,845 & 0,355 \\
\hline & Classe social a que pertence? & $(*)$ & 0,215 & 0,436 & 0,741 \\
\hline 7. & O rendimento familiar bruto mensal se encaixa: & 0,214 & 0,638 & 0,795 & 0,503 \\
\hline & Poupo dinheiro atualmente com o objetivo de completar a aposentadoria no futuro. & $(*)$ & 0,992 & 0,484 & 0,145 \\
\hline 8.6. & Não poupo dinheiro atualmente. & $(*)$ & 0,373 & 0,348 & $(*)$ \\
\hline & $\begin{array}{l}\text { Através de poupança ou previdência privada, pretendo complementar minha renda } \\
\text { quando me aposentar. }\end{array}$ & $(*)$ & $(*)$ & 0,202 & $(*)$ \\
\hline & $\begin{array}{l}\text { Quando não puder mais trabalhar, quero que meus filhos complementem minha renda } \\
\text { ou me sustentem. }\end{array}$ & $(*)$ & $(*)$ & 0,970 & $(*)$ \\
\hline & $\begin{array}{l}\text { Se um dia ficar dependente fisicamente, quero morar com meus filhos ou com um } \\
\text { parente próximo. }\end{array}$ & $\mathbf{0 , 0 2 4}$ & 0,236 & 0,496 & 0,575 \\
\hline 13. & Conheço bem instituições que tratam de pessoas que requerem cuidados especiais. & $(*)$ & $\mathbf{0 , 0 0 0}$ & $\mathbf{0 , 0 0 0}$ & 0,375 \\
\hline
\end{tabular}

(*) valores não calculados em função de frequência esperada inferior a 5

(**) valores não calculados em função de todos os pesquisados pela internet residirem em região metropolitana 
Os entrevistados em campo, nas cidades pesquisadas, predispostos a investir em instituições que cuidam de pessoas que precisam de cuidados especiais, para uso futuro, desde que as mesmas oferecessem garantias de qualidade de vida, têm o seguinte perfil: mulheres, moradores de Mauá, Santos e São Bernardo do Campo, chefes de família com ensino fundamental completo, dispostos a complementar sua renda ao se aposentar com poupança ou previdência privada e conhecedores das instituições.

\subsection{Entrevistas Realizadas pela Internet}

A Tabela 115 (p. 164) destaca as variáveis com nível de discrepância até 5\% para as pesquisa realizadas pela internet. Diferente das realizadas em campo, os resultados obtidos para esses pesquisados possuem pouca diferença em relação às demais variáveis, tais como idade, sexo, cidade onde reside, entre outras.

Por exemplo, enquanto homens e mulheres, pesquisados em campo, têm percepção diferenciada em relação à questão 9 , se os rendimentos do INSS serão suficientes ao se aposentar, a opinião dos pesquisados pela internet independe do sexo. Ainda sim três discrepâncias podem ser destacadas.

Em relação à questão 9, com redação no futuro, quando não estiver mais trabalhando, o valor a ser recebido do INSS a título de aposentadoria será suficiente para meu sustento, pode-se afirmar que a opinião dos pesquisados pela internet difere em função da intenção de residir com os filhos ou parente próximo se ficar dependente fisicamente. O nível de significância de 2,4\% pode ser notado na Tabela 115 (p. 164). Na Tabela a seguir fica evidente que as pessoas que desejam morar com seus parentes acreditam mais nos rendimentos do INSS.

Tabela 116 - Frequência observada e esperada para a questão no futuro, quando não estiver mais trabalhando, o valor a ser recebido do INSS a título de aposentadoria será suficiente para meu sustento versus a questão se um dia ficar dependente fisicamente, o pesquisado quer morar com os filhos ou com um parente próximo, para os pesquisados pela internet

\begin{tabular}{llccc}
\hline \multirow{2}{*}{$\begin{array}{c}\text { Se um dia ficar dependente } \\
\text { fisicamente, o pesquisado }\end{array}$} & Freqüência & \multicolumn{2}{c}{ No futuro... } & \multirow{2}{*}{ Total } \\
\cline { 3 - 4 } quer morar com os filhos ... & & Sim & Não & \\
\hline \multirow{2}{*}{ Sim } & Observada & $3,22 \%$ & $53,08 \%$ & \multirow{2}{*}{$56,30 \%$} \\
& Esperada & $2,11 \%$ & $54,19 \%$ & \\
\multirow{2}{*}{ Não } & Observada & $0,54 \%$ & $43,16 \%$ & \multirow{2}{*}{$159,80 \%$} \\
\hline & Esperada & $1,64 \%$ & $42,06 \%$ & \\
\hline
\end{tabular}


Quanto à questão 14, confio plenamente nos cuidados oferecidos por organizações que tratam de pessoas que requerem cuidados especiais, pode-se afirmar, a partir da Tabela 115 (p. 164), que a opinião dos pesquisados pela internet difere em função de conhecer instituições que tratam de pessoas carentes de cuidados especiais com nível de significância de $0 \%$. Na Tabela 117 (p. 166) pode-se perceber que pessoas que conhecem melhor as instituições confiam mais nos cuidados oferecidos pelas mesmas.

Tabela 117 - Frequência observada e esperada para a questão confio plenamente nos cuidados oferecidos por organizações que tratam de pessoas que requerem cuidados especiais versus o conhecimento que o pesquisado tem de instituições que tratam de pessoas que requerem cuidados especiais, para os pesquisados pela internet

\begin{tabular}{|c|c|c|c|c|}
\hline \multirow{2}{*}{$\begin{array}{l}\text { O pesquisado conhece bem } \\
\text { instituições que... }\end{array}$} & \multirow{2}{*}{ Freqüência } & \multicolumn{2}{|c|}{ Confio plenamente... } & \multirow{2}{*}{ Total } \\
\hline & & Concordo & Discordo & \\
\hline \multirow{2}{*}{ Concordo } & Observada & $15,67 \%$ & $8,21 \%$ & \multirow{2}{*}{$23,88 \%$} \\
\hline & Esperada & $4,63 \%$ & $19,25 \%$ & \\
\hline \multirow{2}{*}{ Discordo } & Observada & $3,73 \%$ & $72,39 \%$ & \multirow{2}{*}{$100,00 \%$} \\
\hline & Esperada & $14,77 \%$ & $61,35 \%$ & \\
\hline Total & & $19,40 \%$ & $80,60 \%$ & $100,00 \%$ \\
\hline
\end{tabular}

Em relação à questão 15, caso futuramente tenha necessidade, nos moldes dos modelos atuais, gostaria de ser residente em uma instituição que trata de pessoas que requerem cuidados especiais, pode-se observar na Tabela 115 (p. 164) que a opinião dos pesquisados difere em função de conhecer instituições que tratam de pessoas carentes de cuidados especiais com nível de significância de 0\%. Pode-se notar na Tabela 118 (p. 166) que, assim como na questão 14, pessoas que conhecem melhor as instituições aceitariam mais residir nas mesmas em função de necessidade futura.

Tabela 118 - Frequência observada e esperada para a questão caso futuramente tenha necessidade, nos moldes dos modelos atuais, gostaria de ser residente em uma instituição que trata de pessoas que requerem cuidados especiais versus o conhecimento que o pesquisado tem de instituições que tratam de pessoas que requerem cuidados especiais, para os pesquisados pela internet

\begin{tabular}{|c|c|c|c|c|}
\hline \multirow{2}{*}{$\begin{array}{l}\text { O pesquisado conhece bem } \\
\text { instituiçõos que... }\end{array}$} & \multirow{2}{*}{ Freqüência } & \multicolumn{2}{|c|}{ Caso futuramente... } & \multirow{2}{*}{ Total } \\
\hline & & Concordo & Discordo & \\
\hline \multirow{2}{*}{ Concordo } & Observada & $26,62 \%$ & $8,63 \%$ & \multirow{2}{*}{$35,25 \%$} \\
\hline & Esperada & $17,75 \%$ & $17,50 \%$ & \\
\hline \multirow{2}{*}{ Discordo } & Observada & $23,74 \%$ & $41,01 \%$ & \multirow{2}{*}{$88,24 \%$} \\
\hline & Esperada & $32,61 \%$ & $32,14 \%$ & \\
\hline Total & & $50,36 \%$ & $49,64 \%$ & $100,00 \%$ \\
\hline
\end{tabular}

Os resultados obtidos pela internet estão mais relacionados à análise descritiva, pois ocorreram poucas discrepâncias em relação às demais variáveis. Em função da diferença em relação a pesquisa de campo, acredita-se que esse segundo grupo possui fatores homogeneizadores, que poderiam ser maior acesso à informação, à internet, nível de 
escolaridade ou outros. Contudo, esta tese não analisará esses fatores, restringindo-se à abordagem dos resultados obtidos. 


\section{CONCLUSÃO}

A população brasileira cresce em um ritmo menos acelerado do que crescia em meados do século XX. Contudo, ela está vivendo mais e envelhecendo. Em 1930, vivia-se em média 42 anos e em 2050 espera-se que o brasileiro viverá mais de 81 anos. Com essa mudança nas características da população, haverá alteração na pirâmide etária. Em 1980, o Brasil contava com 16,38 milhões de crianças até quatro anos de idade e 7,20 milhões de pessoas com mais de 60 anos. Em 2050, as crianças com a mesma faixa de idade devem passar para 15,18 milhões e os adultos com mais de 60 anos de idade devem ultrapassar a marca dos 64 milhões. Essas mudanças sociais, aliadas a uma má distribuição de renda e uma desigualdade na educação do brasileiro, suscitam uma reflexão: como se preparar para a aposentadoria?

Teorias como a Hipótese do Ciclo de Vida do ser humano indicam que as pessoas devem acumular recursos ao longo da vida para utilizá-los aos se aposentar. Existem várias formas de poupar, como adquirir bens ou aplicar no mercado financeiro, mas o ideal seria proporcionar educação e cultura financeira para o brasileiro. A Previdência Social é uma poupança compulsória para o trabalhador que possui registro em carteira profissional. Contudo, a previdência pública, tanto no Brasil como em outros países, tem passado dificuldades em função do envelhecimento da população. Na década de 60, para cada aposentado, a previdência brasileira contava com oito pessoas trabalhando. Em 2008, a relação baixou para menos de dois contribuintes por beneficiário.

Mesmo no período que a previdência social contava com um número maior de contribuintes por aposentado, o sistema já tinha problemas. Os cálculos atuariais não levavam em consideração a inflação; o governo não disponibilizou recursos quando as contribuições eram tripartites, havia sonegação e os recursos eram aplicados em investimentos pouco rentáveis. Ou seja, se não ocorrerem mudanças significativas na previdência social, há pouco o que se esperar dela.

O brasileiro pode acumular recursos de outras formas. Apesar de a previdência privada ser uma opção, uma série de problemas tem ocorrido no país e no mundo em termos de déficits, contratos não cumpridos e mesmo falências. Como uma parte dos recursos financeiros de uma pessoa que se aposenta é utilizada para moradia e alimentação, uma opção é investir em organizações que ofereçam esses serviços para uso futuro. 
Nesta tese, essas organizações foram tratadas como Ambientes Residenciais Especiais. Esse tipo de investimento também traz algumas incertezas, como a necessidade ou o desejo de utilização em um segundo momento, quanto à perpetuidade da organização, em relação à qualidade de atendimento futuro, entre outras.

Em relação à dúvida de futuramente utilizar ou não a organização, pode-se identificar dois fatores. O primeiro deles é adquirir grau de dependência em uma fase da vida. Nesse caso, alguns aspectos motivadores podem ser identificados, tais como não preocupar os familiares, ou os familiares não serem aptos para oferecer cuidados ou não possuir familiares próximos. Outro fator que pode levar uma pessoa a investir em um Ambiente Residencial Especial é garantir qualidade de vida a um familiar, portador ou não de necessidades especiais.

Para focar melhor o tema foram pesquisadas instituições nacionais e internacionais diferenciadas. Em algumas instituições públicas brasileiras oferecia-se moradia em condomínios com ou sem serviços complementares. Nos modelos privados havia preocupação com a autossustentação financeira, algumas com o objetivo de oferecer cuidados à comunidade carente. Nos modelos internacionais predominou a instituição privada com garantias de qualidade de vida, mas também foram encontradas organizações que se destinavam a investimento com retornos acima da média do país sede.

Do ponto de vista jurídico, há vários modelos sujeitos à reflexão ao se analisar uma organização que atenda pessoas e tenha um forte apelo social. Associação, condomínio, cooperativa, fundação, OSCIP, utilidade pública e sociedade de propósito específico foram os modelos analisados nesta tese. Contudo, nenhum deles atendeu conceitualmente as necessidades de uma instituição de longa permanência sujeita a investimento para uso futuro. Coube um modelo de Pessoa Jurídica de Direito Privado, em forma de Sociedade Civil sem Fins Lucrativos, enquadrada como OSCIP - Organização da Sociedade Civil de Interesse Público e de Utilidade Pública nas esferas federal, estadual e municipal, com uma estrutura de governança corporativa onde investidores usufrutuários pudessem acompanhar como conselheiros ou administradores, garantindo a qualidade de vida dos residentes e a perpetuidade da organização.

O objetivo da tese é identificar uma opção de investimento nessas instituições. Para que os objetivos fossem alcançados algumas hipóteses deveriam ser corroboradas. A primeira delas é que o investidor usufrutuário não acredita que os rendimentos da previdência social sejam 
suficientes para garantir um futuro com qualidade de vida. Essa hipótese foi corroborada através de pesquisa realizada com 1501 pessoas. Desse total, 1128 foram entrevistados pessoalmente e 373 pela internet, sendo que $78,72 \%$ e $96,25 \%$, respectivamente, afirmaram que não acreditam em tais rendimentos.

Como um dos objetivos desta tese é apresentar uma opção de investimento em organizações que ofereçam moradia e alimentação para uso futuro, uma segunda hipótese é de que o investidor usufrutuário entende que as instituições atuais não trazem segurança. Dos entrevistados pessoalmente e pela internet, quando questionados se confiavam nos cuidados oferecidos por organizações que tratam de pessoas que requerem cuidados especiais, $48,40 \%$ e 52,28\% não concordaram nem discordaram; $17,02 \%$ e 9,12\%, respectivamente, afirmaram confiar; e 34,57\% e 38,61\% não confiavam nas instituições. Ou seja, dos 51,60\% e 47,72\% que têm opinião formada sobre essas instituições, 32,98\% dos entrevistados pessoalmente e $19,11 \%$ dos entrevistados pela internet confiavam nessas organizações, enquanto que $67,02 \%$ e 80,89\% não confiavam. Assim, esta segunda hipótese também foi corroborada.

A terceira hipótese desta tese é que ambientes residenciais especiais que adotam práticas de governança corporativa, estrutura física, organizacional e formato jurídico-institucional adequados são opções de investimentos que proporcionam segurança ao investidor e aos futuros usufrutuários. Nas pesquisas, quando as pessoas foram questionadas se investiriam em organizações que tratam de pessoas que requerem cuidados especiais, desde que as mesmas ofereçam garantias de qualidade de vida, $12,94 \%$ dos entrevistados pessoalmente e $22,52 \%$ dos entrevistados pela internet não concordaram nem discordaram. Contudo, do total, 73,23\% e $70,78 \%$, respectivamente, afirmaram que investiriam. Assim, tanto para a segunda quanto para a terceira hipótese, pode-se afirmar que as mesmas foram corroboradas.

Em relação aos entrevistados em campo, nas cidades pesquisadas, foi possível definir um perfil dos investidores potenciais: mulheres, cujo chefe de família tem no mínimo ensino fundamental completo, que moram em Mauá, Santos e São Bernardo do Campo, dispostas a complementar sua renda ao se aposentar com poupança ou previdência privada e conhecedoras das instituições.

Em relação ao perfil dos pesquisados pela internet acredita-se que possa ter havido fatores homogeneizadores, como acesso à informação, à internet, ensino superior completo ou ainda outros fatores, o que inviabilizou a definição de um perfil para esse grupo 
O capítulo 5 (p. 63) tratou da sustentabilidade econômico-financeira. No modelo apresentado, uma pessoa adquire quotas que lhe dão direito a utilização de uma habitação para duas pessoas. Com o falecimento dos residentes, a habitação é doada à organização, que pode voltar a vendê-la. Enquanto o proprietário não utiliza a habitação, a mesma pode ser locada para dois residentes não proprietários. Na mensalidade, que cobre custos e despesas, soma-se um valor que é creditado ao proprietário em função do número de quotas adquiridas. Dependendo do tempo que a habitação fica locada e do número de quotas, os créditos podem cobrir vários meses ou anos de mensalidade para o proprietário. Por se tratar de uma organização sem fins lucrativos, os créditos não podem ser retirados em forma de lucro.

No Capítulo 5 também foram apresentados modelos com variação de tamanho, tipo de habitação, variação de áreas comuns e nível de utilização da capacidade instalada. Para estas variáveis foram desenvolvidas simulações com ênfase no investimento, nas mensalidades e nos créditos gerados aos proprietários.

No Apêndice 1 (p. 203) foi apresentado um Plano de Negócio que prioriza a perpetuidade da organização com flexibilidade em relação a tempo de carência, quantidades, valor do investimento e de contribuições. Contudo, o assunto não está esgotado. Há uma série de formatos que poderiam ser utilizados para minimizar os riscos de uma organização com as características apresentadas nesta tese.

Esta tese pode gerar vários desdobramentos. Um deles são estudos que evidenciem a necessidade de educação e cultura financeira para o brasileiro com o objetivo de proporcionar uma aposentadoria mais segura. Como a amostra da pesquisa indica insegurança em relação à previdência social e pré-disposição de investir em outros modelos, podem-se buscar outras alternativas que atendam ao anseio da população. Como há uma diferença entre o número de brasileiros com 60 anos ou mais em função do sexo, um estudo pode analisar a necessidade de investimento diferenciado. Do ponto de vista jurídico, novos estudos podem propor formatos mais adequados às necessidades do modelo apresentado, como benefícios fiscais, atuação do Ministério Público em entidades privadas, entre outras possibilidades. Em relação aos aspectos econômico-financeiros, uma vertente que pode ser avaliada em estudos futuros é a não doação da habitação à organização com o falecimento dos residentes.

Um estudo pode comparar o número de organizações brasileiras com a de outros países que atendem pessoas com 60 anos ou mais de idade. Outro desdobramento possível é replicar 
modelos internacionais. Novos estudos podem explorar a estrutura física e operacional, estrutura organizacional e aspectos relacionados à governança corporativa.

Quanto à pesquisa, outras cidades podem ser abordadas. Em função dos resultados obtidos nesta tese, outras perguntas podem ser formuladas buscando o refinamento das informações. A pesquisa pela internet pode ser reavaliada quanto a um possível comportamento homogenizador. Partindo do princípio de que uma parcela representativa da população estaria disposta a investir em modelos diferenciados, uma pesquisa poderia avaliar quanto se espera pagar por esses serviços. Também em função dos resultados obtidos, a pesquisa poderia ser direcionada para definir, de forma mais precisa, o perfil do possível investidor. 


\section{REFERÊNCIAS}

ABRAMS, Rhonda. The successful business plan: secrets \& strategies. $3^{\mathrm{a}}$ ed. California: Rhonda 'R' Media, 2000.

ANDERSON, David R.; SWEENEY, Dennis J.; WILLIAMS, Thomas A. Estatística aplicada à administração e economia. $1^{\mathrm{a}}$ ed. São Paulo: Pioneira Thomson Learning, 2005.

ANSA. Parlamento denuncia maus-tratos em asilos e hospitais do Reino Unido. Folha Online. Disponível em: <http://www1.folha.uol.com.br/folha/mundo/ult94u320287.shtml>. Acesso em: 02 out. 2007.

ANVISA - Agência Nacional de Vigilância Sanitária. Resolução ANVISA/DC nº 283 de 26 de setembro de 2005. Regulamento técnico para o funcionamento das instituições de longa permanência para idosos. Diário Oficial da União, Brasília, DF, 27 set. 2005. Disponível em: $<$ http://www.saude.mg.gov.br/atos_normativos/legislacao-sanitaria/estabelecimentos-de-saud e/atencao-ao-idoso/RES_283.pdf>. Acesso em: 23 abr. 2007.

ASSOCIAÇÃO BRASILEIRA DE EMPRESAS DE PESQUISA. Critério de classificação econômica Brasil. Disponível em: <http://www.abep.org/?usaritem=arquivos\&iditem=23> . Acesso em: 23 jan. 2006.

ASSOCIAÇÃO HÚNGARA. Lar Pedro Balázs. Disponível em: <http://www.ahungara.org. br/>. Acesso em: 25 set. 2007.

BANCO CENTRAL DO BRASIL. Sistema gerenciador de séries temporais: caderneta de poupança - rentabilidade. Disponível em: <https://www3.bcb.gov.br/sgspub/localizarseries/ localizarSeries.do?method=prepararTelaLocalizarSeries>. Acesso em: 11 fev. 2009a.

Sistema gerenciador de séries temporais: Selic acumulada no mês anualizada. Disponível em: <https://www3.bcb.gov.br/sgspub/localizarseries/localizarSeries.do?method= prepararTelaLocalizarSeries>. Acesso em: 11 fev. 2009b.

- Sistema gerenciador de séries temporais: Índice nacional de preços ao consumidor - amplo (IPCA). Disponível em: <https://www3.bcb.gov.br/sgspub/localizar series/localizarSeries.do?method=prepararTelaLocalizarSeries>. Acesso em: 11 abr. 2009c.

BAUTZER, Tatiana. Nos EUA, está difícil fechar a conta da previdência privada. Valor Econômico. São Paulo, 04 ago. 2003.

BODIE, Zvi. Pensions as retirement income insurance. Journal of Economic Literature. V. XXVIII, p. 28-49, Mar. 1990.

BODIE, Zvi; MERTON, Robert C. Finanças. $1^{\text {a }}$ ed. Porto Alegre: Bookman, 2002. 
BORGES, Mauro Ribeiro. A previdência funcional paranaense. Disponível em: <http:// www.paranaprevidencia.pr.gov.br/paranaprevidencia/modules/conteudo/conteudo.php?conteu do=15>. Acesso em: 28 out. 2008.

BOUDENS, Emile. Utilidade pública federal. Brasília, Câmara dos Deputados, jan. 2000. Disponível em: <http://www2.camara.gov.br/publicacoes/estnottec/tema11/pdf/000068.pdf>. Acesso em: 09 set. 2008.

BOVESPA. Ibovespa. Disponível em: <http://www.bovespa.com.br/Mercado/Renda Variavel/Indices/FormConsultaAnuaisTaxaMedia.asp?>. Acesso em: 09 fev. 2009.

BRASIL. Lei $n^{\circ}$ 9.790, de 23 de março de 1999. Dispõe sobre a qualificação de pessoas jurídicas de direito privado, sem fins lucrativos, como Organizações da Sociedade Civil de Interesse Público, institui e disciplina o Termo de Parceria, e dá outras providências. Diário Oficial da União, Brasília, DF, 24 mar. 1999. Disponível em: <https://www.planalto.gov.Br/ ccivil_03/Leis/L9790.htm>. Acesso em: 15 out. 2006a.

Lei $\mathrm{n}^{\circ}$ 10.406, de 10 de janeiro de 2002. Institui o Código Civil. Diário Oficial da União, Brasília, DF, 11 jan. 2002. Disponível em: <https://www.planalto.gov.Br/ccivil_03/ Leis/2002/L10406.htm>. Acesso em: 5 out. 2006b.

Lei $\mathrm{n}^{\circ} 10.741$, de $1^{\circ}$ de outubro de 2003. Dispõe sobre o Estatuto do Idoso e dá outras providências. Diário Oficial da União, Brasília, DF, 3 out. 2003. Disponível em: <https://www.planalto.gov.Br/ccivil/Leis/2003/L10.741.htm>. Acesso em: 15 out. 2006c.

Lei $\mathrm{n}^{\circ}$ 91, de 28 de agosto de 1935. Determina regras pelas quais são as sociedades declaradas de utilidade pública. Diário Oficial da União, Rio de Janeiro, DF, 28 ago. 1935. Disponível em: <http://www.planalto.gov.br/ccivil_03/Leis/1930-1949/L0091.htm>. Acesso em: 17 fev. 2008a.

Lei $\mathrm{n}^{\circ} 4.591$, de 16 de dezembro de 1964. Dispõe sobre o condomínio em edificações e as incorporações imobiliárias. Diário Oficial da União, Brasília, DF, 16 dez. 1964. Disponível em: <http://www.planalto.gov.br/ccivil_03/Leis/L4591.htm>. Acesso em: 31 mai. 2008b.

Lei $\mathrm{n}^{\circ} 9.249$, de 26 de dezembro de 1995. Altera a legislação do imposto de renda das pessoas jurídicas, bem como a contribuição social sobre o lucro líquido, e dá outras providências. Diário Oficial da União, Brasília, DF, 26 dez. 1995. Disponível em: <http:// www.planalto.gov.br/ccivil_03/Leis/L9249.htm>. Acesso em: 31 mai. 2008c.

Lei $\mathrm{n}^{\circ} 11.079$, de 30 de dezembro de 2004. Institui normas gerais para licitação e contratação de parceria público-privada no âmbito da administração pública. Diário Oficial da União, Brasília, DF, 31 dez. 2004. Disponível em: <http://www.planalto.gov.br/ccivil_03/ _Ato2004-2006/2004/Lei/L11079.htm>. Acesso em: 31 mai. 2008d.

BREALEY, Richard A.; MYERS, Stewart C.; MARCUS, Alan J. Fundamentos da administração financeira. $3^{a}$ ed. São Paulo: McGraw-Hill, 2002. 
BRIGHAM, Eugene F.; EHRHARDT, Michael C. Administração financeira: teoria e prática. $1^{\text {a }}$ ed. São Paulo: Thomson, 2006.

CAETANO, Marcelo Abi-Ramia. Determinantes da sustentabilidade e do custo previdenciário: aspectos conceituais e comparações internacionais. IPEA, Brasília, texto para discussão nº 1226, out. 2006.

CÂMARA BRASILEIRA DA INDÚSTRIA DA CONSTRUÇÃO. Análise do custo unitário básico: CUB médio Brasil. Disponível em: <http://www.cbicdados.com.br/cub.asp>. Acesso em: 01 fev. 2008.

CARVER, John; OLIVER, Caroline. Conselhos de administração que geram valor. $1^{\text {a }}$ ed. São Paulo: Cultrix, 2002.

CLASSIFICADOS. Pesquisa de preço de terrenos. Disponível em: <http://www.quebarato. com.br/imoveis--venda--terreno.html>. Acesso em: 01 fev. 2008.

COGGIOLA, Osvaldo. A falência mundial dos fundos de pensão (1). Correio da Cidadania, São Paulo, ed. 349, semana de 07/06 a 14/06/2003. Disponível em: <http://www2. correiocidadania.com.br/ed349/economia.htm>. Acesso em: 20 abr. 2008a.

. A falência mundial dos fundos de pensão (2). Correio da Cidadania, São Paulo, ed. 350, semana de 14/06 a 21/06/2003. Disponível em: <http://www2.correiocidadania.com.br/ ed350/economia.htm>. Acesso em: 20 abr. 2008b.

CONSELHO REGIONAL DE CORRETORES DE IMÓVEIS DO ESTADO DE SÃO PAULO - CRECI-SP. Pesquisas publicadas. Disponível em: <http://www.crecisp.gov.br/ pesquisas/pesquisa.asp>. Acesso em: 12 fev. 2009.

CONSELHO REGIONAL DE ECONOMIA DO ESTADO DE SÃO PAULO - CORECONSP. INCC - Índice nacional de custo da construção. Disponível em: <http://www. coreconsp.org.br/indicadores/dip/new_series_historicas/series/precos_nacionais/incc.xls>. Acesso em: 11 fev. 2009.

CONTINUING CARE RETIREMENT COMMUNITIES-CCRC. New LifeStyles. Disponível em: <http://www.newlifestyles.com/sitemap/pei-ccrc-455432-std-03.htm>. Acesso em: 14 set. 2008.

CROWN RESEARCH CORPORATION. Evolution of the old folks home. Disponível em: <http://www.crownresearch.com/OJA.htm>. Acesso em: 24 fev. 2008.

DATAFOLHA. Bolsa de salários. Disponível em: <http://datafolha.folha.uol.com.br/folha/ datafolha/scripts/tb_salarios.php?data=14012008\&action=lista>. Acesso em: 28 jan. 2008.

DEPT. OF HEALTH \& HUMAN SERVICE. Housing. Disponível em: <http://www.aoa. gov/eldfam/Housing/Housing_Services/CCRC.aspx>. Acesso em: 18 set. 2008. 
ELETROPAULO. Tarifas de energia. Disponível em: <http://www.eletropaulo.com.br/ portal/page.cfm?tipocli=com\&conteudo_id=666\&origem_id $=658 \& d e s c=$ Tarifas $\% 20 \mathrm{de} \% 20$ Energia\#point_1011>. Acesso em: 04 nov. 2008.

FORTUNA, Eduardo. Mercado financeiro: produtos e serviços. 16 ${ }^{\mathrm{a}}$ ed. São Paulo: Qualitymark, 2005.

FRANCISCO BELTRÃO, Município de. Descrição da experiência: condomínio do idoso. Disponível em: <http://www.pr.gov.br/sedu/PHO/descricao/DESCfcobeltrao.html>. Acesso em: 24 fev. 2008).

FUNDAÇÃO ANASPS. Evolução da Previdência Social. Rio de Janeiro: Anasps, 2007.

FUNDAÇÃO PEIRÓPOLIS. Harambê. Disponível em: <http://www.peiropolis.org.br/ blog.php?id=18>. Acesso em: 24 fev. 2008.

GIAMBIAGI, Fábio et al. Impacto de reformas paramétricas na previdência social brasileira: simulações alternativas. IPEA, Rio de Janeiro, texto para discussão nº 1289, jul. 2007.

GIL, Antônio Carlos. Métodos e técnicas de pesquisa social. 5ª ed. São Paulo: Atlas, 1999.

Pesquisa em economia. $1^{\text {a }}$ ed. São Paulo: Atlas, 1988.

GOLIATH. Patient profits: Meisei hospital bonds add another incentive to invest in the silver society. Disponível em: <http://goliath.ecnext.com/coms2/gi_0199-716274/Patientprofits-Meisei-hospital-bonds.html>. Acesso em: 18 set. 2008.

GUANDALINI, Giuliano. Os brasileiros pagarão o valor de quatro plataformas de petróleo para salvar o fundo de pensão da Petrobrás. Veja, ed. 1968, 09 ago. 2006.

HAIR JR, Joseph F. et al. Análise multivariada de dados. $5^{\text {a }}$ ed. Porto Alegre: Bookman, 2005.

HALFELD, Mauro. A poupança que garante tranquilidade. Revista Época. Disponível em: <http://revistaepoca.globo.com/Revista/Epoca/0,,EDG81875-9553-510,00.html>. Acesso em: 18 ago. 2008.

HAMPSHIRE, David. French retirement homes. Parisvoice: the webzine for englishspeaking parisians. Disponível em: <http://www.parisvoice.com/index.php?option=com content\&task=view\&id=104\&Itemid=29>. Acesso em: 14 set. 2008.

HAZZAN, Samuel; POMPEO, José Nicolau. Matemática financeira. $6^{\mathrm{a}}$ ed. São Paulo: Saraiva, 2007. 
HIGUCHI, Hiromi et al. Imposto de renda das empresas. 32a ed. São Paulo: IR Publicações, 2007.

HOUSINGCARE, EAC. EAC housing options. Disponível em: <http://www.housingcare. org/jargon-eac-housing-options.aspx>. Acesso em: 22 set. 2008a.

Guide to housing and care options for elderly people. Disponível em: <http:// www.housingcare.org/making-elderly-housing-choices/basic-options.aspx>. Acesso em: 22 set. 2008b.

IBGE - Instituto Brasileiro de Geografia e Estatística. Download de arquivos: censo demoGráfico 2000. Disponível em: <ftp://ftp.ibge.gov.br/Censos/Censo_Demografico_2000/ populacao/Brasil/Brasil_deficiencia.zip>. Acesso em: 20 abr. 2007a.

Dados históricos dos sensos. Disponível em: <http://www.ibge.gov.br/home/ estatistica/populacao/censohistorico/1940_1996.shtm>. Acesso em: 05 set. 2007b.

Download de arquivos: estimativas projeções população, revisão 2004 projeções 1980 2050, arquivo compactado projecoes_1980_2050_revisao_2004.zip, arquivo populacao_ projetada_1980_2050_rev_2004_quinquenais.xls. Disponível em: <ftp://ftp.ibge.gov.br>. Acesso em: 22 abr. 2007c.

Download de arquivos: trabalho e rendimento, pesquisa nacional por amostra de domicílios anual, 2006, volume Brasil, Brasil, arquivo compactado dados_gerais.zip, arquivo tab1_1.xls. Disponível em: <ftp://ftp.ibge.gov.br>. Acesso em: 22 nov. 2007d.

Download de arquivos: trabalho e rendimento, pesquisa nacional por amostra de domicílios anual, 2006, volume Brasil, Brasil, arquivo compactado familia.zip, arquivo tab6_1.xls. Disponível em: <ftp://ftp.ibge.gov.br>. Acesso em: 22 nov. 2007e.

Download de arquivos: trabalho e rendimento, pesquisa nacional por amostra de domicílios anual, 2006, volume Brasil, Brasil, arquivo compactado instrucao.zip. Disponível em: <ftp://ftp.ibge.gov.br>. Acesso em: 22 nov. $2007 f$.

Download de arquivos: trabalho e rendimento, pesquisa nacional por amostra de domicílios anual, 2006, volume Brasil, Brasil, arquivo compactado trabalho.zip, arquivo tab4_22.xls. Disponível em: <ftp://ftp.ibge.gov.br>. Acesso em: 22 nov. 2007g.

Download de arquivos: assistência social privada sem fins lucrativos, arquivo compactado resultados.zip. Disponível em: <ftp://ftp.ibge.gov.br>. Acesso em: 19 fev. 2008a.

Download de arquivos: cadastro de empresas. Disponível em: <ftp://ftp.ibge.gov.br/ Economia_Cadastro_de_Empresas/2004/Unidades.zip>. Acesso em: 19 fev. 2008b. 
Brasil já tem mais de 180 milhões de habitantes. Disponível em: <http://www. ibge.gov.br/home/presidencia/noticias/noticia_impressao.php?id_noticia=207>. Acesso em: 15 abr. $2008 \mathrm{c}$.

Comissão Nacional de Classificação. Disponível em: <http://www.cnae.ibge.gov. br/estrutura.asp?TabelaBusca=CNAE_200@CNAE\%202.0>. Acesso em: 26 fev. 2008d.

Em 2003, expectativa de vida do brasileiro sobe para 71,3 anos. Disponível em: <http://www.ibge.gov.br/home/presidencia/noticias/noticia_impressao.php?id_noticia $=266>$. Acesso em: 17 jul. 2008e.

. Contas nacionais trimestrais: indicadores de volume valores correntes. Disponível em: <http://www.ibge.gov.br/home/presidencia/noticias/noticia_impressao.php?id_noticia= 1106>. Acesso em: 30 nov. $2008 f$.

Sistema de contas nacionais. Disponível em: <ftp://ftp.ibge.gov.br/Contas_ Nacionais/Sistema_de_Contas_Nacionais/ Referencia_2000/2002_2006/PIBReal_947_2006. zip>. Acesso em: 30 nov. 2008g.

Tábuas completas de mortalidade - 2007. Disponível em: <http://www.ibge.gov. br/home/estatistica/populacao/tabuadevida/2007/default.shtm>. Acesso em: 09 mar. 2009.

INSTITUTO DE MAYORES Y SERVICIOS SOCIALES - IMSERSO. Las personas mayores en España: informe 2006, tomo I. Disponível em: <http://www.segsocial.es/imserso/estadisticas/ persmayoresesp.html>. Acesso em: 20 out. 2008.

INSTITUTO DE PESQUISA ECONÔMICA APLICADA - IPEA. Brasil precisa investir em instituições para idosos. Disponível em: <http://www.ipea.gov.br/003/00301009. jsp?ttCD_CHAVE=2806>. Acesso em: 19 ago. 2008.

INSTITUTO NACIONAL DE ESTADÍSTICA. Estimaciones de la población actual de España calculadas a partir del censo de 2001. Disponível em: <http://www.ine.es/jaxiBD/ tabla.do?per $=12 \&$ type $=$ db \&divi=EPOB\&idtab=1>. Acesso em: 20 out. $2008 \mathrm{a}$.

Proyecciones de población base censo 2001. Disponível em: <http://www.ine.es/ jaxi/tabla.do?path=/t20/p251/proy_2001/10/\&file=01002.px\&type=pcaxis $>$. Acesso em: 20 out. 2008 b.

JENSEN, Michael C.; MECKLING, William H. Theory of the firm: managerial behavior, agency cost and ownership structure. Journal of Financial Economics, V. 3, n ${ }^{\circ}$ 4, p. 305 360, Oct. 1976.

KERLINGER, Fred N. Metodologia da pesquisa em ciências sociais: um tratamento conceitual. São Paulo: EPU, 2007. 
LODI, João Bosco. Governança corporativa: o governo da empresa e o conselho de administração. $4^{\mathrm{a}}$ ed. Rio de Janeiro: Campus, 2000.

MARCONI, Marina de Andrade; LAKATOS, Eva Maria. Metodologia científica. $5^{\text {a }}$ ed. São Paulo: Atlas, 2008.

MARCOVITCH, Jacques (org.). Crescimento econômico e distribuição de renda: prioridades para ação. São Paulo: Edusp, 2007.

MARTINS, Gilberto de Andrade; THEÓPHILO, Carlos Renato. Metodologia da investigação científica para ciências sociais aplicadas. 1ª ed. São Paulo: Atlas, 2007.

MARTINS, José Pio. Educação financeira ao alcance de todos. $1^{\text {a }}$ ed. São Paulo: Fundamento, 2004.

MARTINS, Paulo Haus. Quais são as vantagens da qualificação como OSCIP? Disponível em: <http://www.rits.org.br/legislacao_teste/lg_testes/lg_tmes_maio2000.cfm>. Acesso em: 09 set. 2008.

MINISTÉRIO DA PREVIDÊNCIA SOCIAL. A nova previdência do servidor. Disponível em: <http:// www.previdencia.gov.br/reforma/verdade.htm>. Acesso em: 15 abr. 2008.

MINISTÉRIO DA SAÚDE. Portaria no 810, de 22 de setembro de 1989. Aprova normas e os padrões para o funcionamento de casas de repouso, clínicas geriátricas e outras instituições destinadas ao atendimento de idosos, a serem observados em todo o território nacional. Diário Oficial da União, Brasília, DF, 27 set. 1989. Disponível em: <http://www.senado.gov.br/ conleg/Idoso/DOCS/Federal/Portaria810.doc>. Acesso em: 24 abr. 2007.

MODIGLIANI, F. Life cycle, individual thrift and the wealth of nations. The American Economic Review. Jun. 1986.

NESBITT, Joseph Edward. Qui-quadrado. 1ª ed. São Paulo: Harbra, 1995.

O INFORMATIVO, O. Lar auto-sustentável vai financiar lar social.. Disponível em: <http://www.o-informativo.com/content/view/922/26/>. Acesso em: 24 fev. 2008.

OKUNADE, Albert A. The failing pension system in the U.S. private sector: have we seen the worst yet? Business Perspective, Memphis, Fall 2006, vol. 18, num. 2, pg. 8, 6 pgs.

OLIVEIRA, Francisco Eduardo Barreto de; BELTRÃO, Kaizô Iwakami; DAVID, Antonio Carlos de Albuquerque. A dívida da União com a Previdência Social: uma perspectiva histórica. IPEA, Rio de Janeiro, texto para discussão nº 638, abr. 1999.

PAES, José Eduardo Sabo. Fundações, associações e entidades de interesse social: aspectos jurídicos, administrativos, contábeis, trabalhistas e tributários. $6^{a}$ ed. Brasília: Brasília Jurídica, 2006. 
PASINATO, Maria Tereza; CAMARANO, Ana Amélia; MACHADO, Laura. Idosos vítimas de maus tratos domésticos: estudo exploratório das informações levantadas nos serviços de denúncias. IPEA, Rio de Janeiro, texto para discussão nº 1200, jul. 2006.

PIRES, Valdemir. Finanças pessoais: fundamentos e dicas. $1^{\mathrm{a}}$ ed. Piracicaba: Edição do autor, 2007.

RAFAEL, Edson José. Fundações e direito. 1ª ed. São Paulo: Melhoramentos, 1997.

RAMOS, Lauro. Desigualdade de rendimentos do trabalho no Brasil no período pós-Real. IPEA, Brasília, boletim de mercado de trabalho, conjuntura e análise $n^{\circ}$ 30, p. 21-26, mai. 2006.

RESENDE, Tomáz de Aquino. Imunidade tributária e isenções de impostos. Disponível em: <http://www.fundata.org.br/Artigos - Cefeis/17 - imunidade tributaria e isenções de impostos.pdf $>$. Acesso em: 30 mar. 2009.

ROCHA, Janes. Longevidade aumenta e ameaça sistema previdenciário. Valor Econômico, São Paulo, 11 jan. 2006.

ROCHA, Roberto de Azevedo; CAETANO, Marcelo Abi-Ramia. O sistema previdenciário brasileiro. IPEA, Brasília, texto para discussão nº 1331, mar. 2008.

SABESP, Companhia de Saneamento Básico de São Paulo. Tarifas de água e esgoto. Disponível em: <http://www2.sabesp.com.br/agvirtual2/tarifas/tarifa_sabesp_00108.pdf>. Acesso em: 04 nov. 2008>.

SCHRADER, Achim. Introdução à pesquisa social empírica. $2^{\mathrm{a}}$ ed. Porto Alegre: Globo, 1978.

SECRETARIA DA RECEITA FEDERAL. Instrução normativa SRF $n^{\circ}$ 082, de 30 de junho de 1999. Aprova instruções para a prática de atos perante o Cadastro Nacional da Pessoa Jurídica - CNPJ. Diário Oficial da União, Brasília, DF, 06 ago. 1999. Disponível em: <http://www.receita.fazenda.gov.br/Legislacao/ins/Ant2001/1999/in08299.htm>. Acesso em: 11 set. 2008 a.

Instrução Normativa SRF no 162 , de 31 de dezembro de 1998. Fixa prazo de vida útil e taxa de depreciação dos bens que relaciona. Diário Oficial da União, Brasília, DF, 07 jan. 1999. Disponível em: <http://www.receita.fazenda.gov.br/Legislacao/Ins/Ant2001/1998/ in16298.htm>. Acesso em: 30 out. 2008b.

SECRETARIA ESTADUAL DE ASSISTÊNCIA E DESENVOLVIMENTO SOCIAL SEADS. Condomínio República da Melhor Idade. Disponível em: <http://www. desenvolvimentosocial.sp.gov.br/social/materia.asp?id=269>. Acesso em: 24 fev. 2008. 
SEGUNDO FILHO, José. Finanças pessoais: invista no seu futuro. $1^{a}$ ed. Rio de Janeiro: Qualitymark, 2003.

SELLTIZ, Claire; WRIGHTSMAN, Lawrence Samuel; COOK, Stuart Wellford. Métodos de pesquisa nas relações sociais: 1 - delineamento de pesquisa. $2^{\text {a }}$ ed. São Paulo: EPU, 1987a.

SILVA, Eduardo D. Gestão em finanças pessoais: uma metodologia para se adquirir educação e saúde financeira. $1^{\text {a }}$ ed. Rio de Janeiro: Qualitymark, 2005.

SILVEIRA, A. M.; BARROS, L. A.; FAMÁ, R. Estrutura de governança e valor nas companhias abertas brasileiras: um estudo empírico. RAE/FGV - Revista de Administração de empresas da Fundação Getúlio Vargas. V. 43, n 3, jul/ago/set, p. 50-64, 2003.

SIMÕES, Celso Cardoso da Silva. Perfis de saúde e de mortalidade no Brasil: uma análise de seus componentes em grupos populacionais específicos. $1^{a}$ ed. Brasília: Organização PanAmericana da Saúde, 2002. Disponível em: <http://www.opas.org.br/publicmo.cfm? codigo=46>. Acesso em: 16 jul. 2008.

SOUSA, Almir Ferreira de. Avaliação de investimentos: uma abordagem prática. $1^{\text {a }}$ ed. São Paulo: Saraiva, 2007.

SPIEGEL, Murray R. Estatística. 3ª ed. São Paulo: Makron, 1994.

UBERLÂNDIA, Prefeitura de. Idoso. Disponível em: <http://www3.uberlandia.mg. gov.br/ servicos_programas.php?id=303>. Acesso em: 24 fev. 2008.

UNITED NATIONS DEVELOPMENT PROGRAM. Human development report 2007/2008. Disponível em: <http://hdr.undp.org/en/reports/global/hdr2007-2008/>. Acesso em: 08 fev. 2008.

UNITED NATIONS POPULATION DIVISION. World population ageing 1950-2050. Disponível em: <http://www.un.org/esa/population/publications/worldageing19502050/pdf/ 65executivesummary_spanish.pdf>. Acesso em: 20 out. 2008.

WALSH, Mary Williams. More companies ending promises for retirement. The New York Times, New York, 09 Jan. 2006. 
APÊNDICES 


\section{APÊNDICES}

Apêndice 1 - Plano de Negócio

Apêndice 2 - Estimativa da população brasileira dividida por faixa de idade - 1980-2050..227

Apêndice 3 - Estimativa da média de idade da população brasileira - 1980-2050 ..............228

Apêndice 4 - Estimativa da população brasileira com 60 anos ou mais - 1980-2050 ..........228

Apêndice 5 - Estimativa da população brasileira com 60 anos ou mais dividida por sexo 1980-2050

Apêndice 6 - Famílias residentes segundo as classes de rendimento mensal familiar - Brasil 2006

Apêndice 7 - Famílias residentes e participação no rendimento total, segundo as classes de rendimento mensal familiar - Brasil - 2006 .

Apêndice 8 - Pessoas de 10 anos ou mais de idade, ocupadas na semana de referência, com rendimento no trabalho principal, segundo as classes de rendimento mensal do trabalho principal - Brasil - 2006.

Apêndice 9 - Pessoas de 10 anos ou mais de idade, ocupadas na semana de referência, com rendimento no trabalho principal, segundo as classes de rendimento mensal do trabalho principal e participação no rendimento total - Brasil - 2006

Apêndice 10 - Anos de estudo acumulado de pessoas de 10 anos ou mais de idade, por situação do domicílio e sexo, segundo os anos de estudo - Brasil - 2006 234

Apêndice 11 - Anos de estudo acumulado de pessoas de 10 anos ou mais de idade - Brasil 2006

Apêndice 12 - Salário mensal de estrutura administrativa para organização de pequeno porte 236

Apêndice 13 - Salário mensal de estrutura administrativa para matriz de organização de

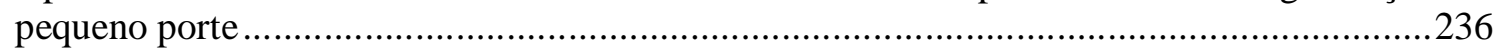
Apêndice 14 - Salário mensal de estrutura administrativa para filial de organização de

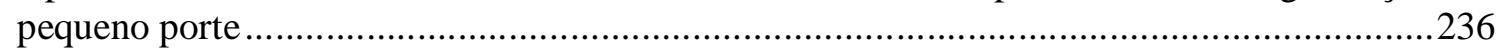

Apêndice 15 - Croqui de dimensões básicas de dormitório padrão ...................................237 Apêndice 16 - Croqui de dimensões básicas de dormitório que atende pessoas portadoras de necessidades especiais

Apêndice 17 - Necessidade de áreas internas em função do número de residentes e funcionários. 238

Apêndice 18 - Equação das áreas dos ambientes da organização em função do número de residentes e funcionários. 239

Apêndice 19 - Investimento e custo de depreciação da habitação. 239

Apêndice 20 - Investimento e custo de depreciação para salas de atividades coletivas de $15 \mathrm{~m}^{2}$

Apêndice 21 - Investimento e custo de depreciação de salas de convivência para 30 residentes..

Apêndice 22 - Investimento e custo de depreciação da sala de apoio, espaço ecumênico e administração e reunião. 241

Apêndice 23 - Investimento e custo de depreciação do refeitório e despensa, lavanderia, almoxarifado, ambulatório e posto médico. 
Apêndice 24 - Investimento e custo de depreciação do vestiário e anfiteatro.

Apêndice 25 - Equação investimento em móveis e utensílios nos ambientes internos em função do número de residentes e funcionários

Apêndice 26 - Equação custo com móveis e utensílios nos ambientes internos em função do número de residentes e funcionários

Apêndice 27 - Investimento e custo de depreciação de piscina, saunas, campos e quadras. .243 Apêndice 28 - Investimento e custo de depreciação de pista de pedestre, ciclovia e jardins. 243 Apêndice 29 - Equação investimento e custo de depreciação das áreas externas .................244 Apêndice 30 - Equação outras despesas administrativas e custos indiretos ........................244

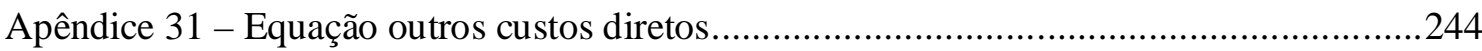
Apêndice 32 - Resumo das equações despesas e custos mensais, agrupados por comportamento em função do número de residentes, para 1 unidade.................................245

Apêndice 33 - Resumo das equações despesas e custos mensais, agrupados por comportamento em função do número de residentes, para matriz....................................246

Apêndice 34 - Resumo das equações despesas e custos mensais, agrupados por comportamento em função do número de residentes, para uma filial. ..................................247

Apêndice 35 - Área interna e externa, parciais, em função do número de residentes, para cálculo completo de uma simulação

Apêndice 36 - Número de funcionários a $100 \%$ da capacidade instalada para cálculo completo de uma simulação.

Apêndice 37 - Área destinada aos funcionários para cálculo completo de uma simulação...249

Apêndice 38 - Área total para cálculo completo de uma simulação..................................249

Apêndice 39 - Área ajardinada para cálculo completo de uma simulação ..........................249

Apêndice 40 - Valor do investimento total para cálculo completo de uma simulação..........250

Apêndice 41 - Despesas administrativas mensais para cálculo completo de uma simulação 250 Apêndice 42 - Custos indiretos mensais para cálculo completo de uma simulação...............251

Apêndice 43 - Custos diretos mensais para cálculo completo de uma simulação.................252

Apêndice 44 - Custos e despesas mensais para cálculo completo de uma simulação ...........252

Apêndice 45 - Mensalidade média por residente para cálculo completo de uma simulação.252 Apêndice 46 - Resumo dos resultados da regressão do valor médio do investimento com simulação do nível de utilização da capacidade instalada para 200 residentes, com diversos graus de dependência.

Apêndice 47 - Resumo dos resultados da regressão do valor médio do investimento com simulação do nível de utilização da capacidade instalada para 300 residentes, com diversos graus de dependência

Apêndice 48 - Resumo dos resultados da regressão do valor médio do investimento com simulação do nível de utilização da capacidade instalada para 400 residentes, com diversos graus de dependência.

Apêndice 49 - Resumo dos resultados da regressão do valor médio do investimento com simulação da porcentagem de habitações destinadas a cadeirantes para 100 residentes, com diversos graus de dependência. 256

Apêndice 50 - Resumo dos resultados da regressão do valor médio do investimento com simulação da porcentagem de habitações destinadas a cadeirantes para 200 residentes, com diversos graus de dependência 257 
Apêndice 51 - Resumo dos resultados da regressão do valor médio do investimento com simulação da porcentagem de habitações destinadas a cadeirantes para 300 residentes, com diversos graus de dependência 258

Apêndice 52 - Resumo dos resultados da regressão do valor médio do investimento com simulação da porcentagem de habitações destinadas a cadeirantes para 400 residentes, com diversos graus de dependência.

Apêndice 53 - Valor médio do investimento por habitação em função de áreas externas, anfiteatro e minisshopping para 200 residentes, com diversos graus de dependência (informações realinhadas para 15 variáveis independentes) 260

Apêndice 54 - Resumo dos resultados da regressão do valor médio do investimento por habitação em função de áreas externas, anfiteatro e minisshopping para 200 residentes, com diversos graus de dependência, para 15 variáveis independentes 261

Apêndice 55 - Valor médio do investimento por habitação em função de áreas externas, anfiteatro e minisshopping para 200 residentes, com diversos graus de dependência (informações realinhadas para 5 variáveis independentes)

Apêndice 56 - Resumo dos resultados da regressão do valor médio do investimento por habitação em função de áreas externas, anfiteatro e minisshopping para 200 residentes, com diversos graus de dependência, para 5 variáveis independentes

Apêndice 57 - Valor médio do investimento por habitação em função de áreas externas, anfiteatro e minisshopping para 300 residentes, com diversos graus de dependência (informações realinhadas para 15 variáveis independentes) ...........................................264

Apêndice 58 - Resumo dos resultados da regressão do valor médio do investimento por habitação em função de áreas externas, anfiteatro e minisshopping para 300 residentes, com diversos graus de dependência, para 15 variáveis independentes .265

Apêndice 59 - Valor médio do investimento por habitação em função de áreas externas, anfiteatro e minisshopping para 300 residentes, com diversos graus de dependência (informações realinhadas para 5 variáveis independentes) 266

Apêndice 60 - Resumo dos resultados da regressão do valor médio do investimento por habitação em função de áreas externas, anfiteatro e minisshopping para 300 residentes, com diversos graus de dependência, para 5 variáveis independentes.....

Apêndice 61 - Valor médio do investimento por habitação em função de áreas externas, anfiteatro e minisshopping para 400 residentes, com diversos graus de dependência (informações realinhadas para 15 variáveis independentes) 268

Apêndice 62 - Resumo dos resultados da regressão do valor médio do investimento por habitação em função de áreas externas, anfiteatro e minisshopping para 400 residentes, com diversos graus de dependência, para 15 variáveis independentes ......................................269

Apêndice 63 - Valor médio do investimento por habitação em função de áreas externas, anfiteatro e minisshopping para 400 residentes, com diversos graus de dependência (informações realinhadas para 5 variáveis independentes). 270

Apêndice 64 - Resumo dos resultados da regressão do valor médio do investimento por habitação em função de áreas externas, anfiteatro e minisshopping para 400 residentes, com diversos graus de dependência, para 5 variáveis independentes.... 271

Apêndice 65 - Crédito médio de 1,10\% sobre o valor do investimento, por mensalidade, para construção em 90 dias e compensação de retorno em 12 meses, com simulação do nível de utilização da capacidade instalada, para 100 residentes .272 
Apêndice 66 - Crédito médio de 1,10\% sobre o valor do investimento, por mensalidade, para construção em 90 dias e compensação de retorno em 12 meses, com simulação do nível de utilização da capacidade instalada, para 200 residentes 272

Apêndice 67 - Crédito médio de 1,10\% sobre o valor do investimento, por mensalidade, para construção em 90 dias e compensação de retorno em 12 meses, com simulação do nível de utilização da capacidade instalada, para 300 residentes 272

Apêndice 68 - Crédito médio de 1,10\% sobre o valor do investimento, por mensalidade, para construção em 90 dias e compensação de retorno em 12 meses, com simulação do nível de utilização da capacidade instalada, para 400 residentes

Apêndice 69 - Crédito médio de 1,20\% sobre o valor do investimento, por mensalidade, para construção em 90 dias e compensação de retorno em 12 meses, com simulação do nível de utilização da capacidade instalada, para 100 residentes 273 Apêndice 70 - Crédito médio de 1,20\% sobre o valor do investimento, por mensalidade, para construção em 90 dias e compensação de retorno em 12 meses, com simulação do nível de utilização da capacidade instalada, para 200 residentes 273

Apêndice 71 - Crédito médio de 1,20\% sobre o valor do investimento, por mensalidade, para construção em 90 dias e compensação de retorno em 12 meses, com simulação do nível de utilização da capacidade instalada, para 300 residentes 274

Apêndice 72 - Crédito médio de 1,20\% sobre o valor do investimento, por mensalidade, para construção em 90 dias e compensação de retorno em 12 meses, com simulação do nível de utilização da capacidade instalada, para 400 residentes 274 Apêndice 73 - Crédito médio de 1,30\% sobre o valor do investimento, por mensalidade, para construção em 90 dias e compensação de retorno em 12 meses, com simulação do nível de utilização da capacidade instalada, para 100 residentes 274

Apêndice 74 - Crédito médio de 1,30\% sobre o valor do investimento, por mensalidade, para construção em 90 dias e compensação de retorno em 12 meses, com simulação do nível de utilização da capacidade instalada, para 200 residentes

Apêndice 75 - Crédito médio de 1,30\% sobre o valor do investimento, por mensalidade, para construção em 90 dias e compensação de retorno em 12 meses, com simulação do nível de utilização da capacidade instalada, para 300 residentes 275

Apêndice 76 - Crédito médio de 1,30\% sobre o valor do investimento, por mensalidade, para construção em 90 dias e compensação de retorno em 12 meses, com simulação do nível de utilização da capacidade instalada, para 400 residentes 275

Apêndice 77 - Crédito médio de 1,40\% sobre o valor do investimento, por mensalidade, para construção em 90 dias e compensação de retorno em 12 meses, com simulação do nível de utilização da capacidade instalada, para 100 residentes 276

Apêndice 78 - Crédito médio de 1,40\% sobre o valor do investimento, por mensalidade, para construção em 90 dias e compensação de retorno em 12 meses, com simulação do nível de utilização da capacidade instalada, para 200 residentes 276 Apêndice 79 - Crédito médio de 1,40\% sobre o valor do investimento, por mensalidade, para construção em 90 dias e compensação de retorno em 12 meses, com simulação do nível de utilização da capacidade instalada, para 300 residentes 276 Apêndice 80 - Crédito médio de 1,40\% sobre o valor do investimento, por mensalidade, para construção em 90 dias e compensação de retorno em 12 meses, com simulação do nível de utilização da capacidade instalada, para 400 residentes 
Apêndice 81 - Crédito médio de 1,50\% sobre o valor do investimento, por mensalidade, para construção em 90 dias e compensação de retorno em 12 meses, com simulação do nível de utilização da capacidade instalada, para 100 residentes 277

Apêndice 82 - Crédito médio de 1,50\% sobre o valor do investimento, por mensalidade, para construção em 90 dias e compensação de retorno em 12 meses, com simulação do nível de utilização da capacidade instalada, para 200 residentes

Apêndice 83 - Crédito médio de 1,50\% sobre o valor do investimento, por mensalidade, para construção em 90 dias e compensação de retorno em 12 meses, com simulação do nível de utilização da capacidade instalada, para 300 residentes 278

Apêndice 84 - Crédito médio de 1,50\% sobre o valor do investimento, por mensalidade, para construção em 90 dias e compensação de retorno em 12 meses, com simulação do nível de utilização da capacidade instalada, para 400 residentes 278 Apêndice 85 - Crédito médio de 1,10\% sobre o valor do investimento, por mensalidade, para construção em 90 dias e compensação de retorno em 24 meses, com simulação do nível de utilização da capacidade instalada, para 100 residentes 278

Apêndice 86 - Crédito médio de 1,10\% sobre o valor do investimento, por mensalidade, para construção em 90 dias e compensação de retorno em 24 meses, com simulação do nível de utilização da capacidade instalada, para 200 residentes 279

Apêndice 87 - Crédito médio de 1,10\% sobre o valor do investimento, por mensalidade, para construção em 90 dias e compensação de retorno em 24 meses, com simulação do nível de utilização da capacidade instalada, para 300 residentes 279 Apêndice 88 - Crédito médio de 1,10\% sobre o valor do investimento, por mensalidade, para construção em 90 dias e compensação de retorno em 24 meses, com simulação do nível de utilização da capacidade instalada, para 400 residentes 279

Apêndice 89 - Crédito médio de 1,20\% sobre o valor do investimento, por mensalidade, para construção em 90 dias e compensação de retorno em 24 meses, com simulação do nível de utilização da capacidade instalada, para 100 residentes 280

Apêndice 90 - Crédito médio de 1,20\% sobre o valor do investimento, por mensalidade, para construção em 90 dias e compensação de retorno em 24 meses, com simulação do nível de utilização da capacidade instalada, para 200 residentes 280

Apêndice 91 - Crédito médio de 1,20\% sobre o valor do investimento, por mensalidade, para construção em 90 dias e compensação de retorno em 24 meses, com simulação do nível de utilização da capacidade instalada, para 300 residentes 280

Apêndice 92 - Crédito médio de 1,20\% sobre o valor do investimento, por mensalidade, para construção em 90 dias e compensação de retorno em 24 meses, com simulação do nível de utilização da capacidade instalada, para 400 residentes 281

Apêndice 93 - Crédito médio de 1,30\% sobre o valor do investimento, por mensalidade, para construção em 90 dias e compensação de retorno em 24 meses, com simulação do nível de utilização da capacidade instalada, para 100 residentes 281

Apêndice 94 - Crédito médio de 1,30\% sobre o valor do investimento, por mensalidade, para construção em 90 dias e compensação de retorno em 24 meses, com simulação do nível de utilização da capacidade instalada, para 200 residentes 281 Apêndice 95 - Crédito médio de 1,30\% sobre o valor do investimento, por mensalidade, para construção em 90 dias e compensação de retorno em 24 meses, com simulação do nível de utilização da capacidade instalada, para 300 residentes 282 
Apêndice 96 - Crédito médio de 1,30\% sobre o valor do investimento, por mensalidade, para construção em 90 dias e compensação de retorno em 24 meses, com simulação do nível de

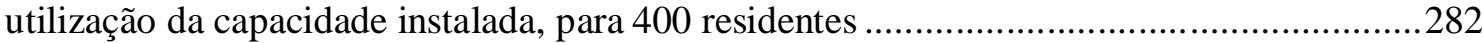

Apêndice 97 - Crédito médio de 1,40\% sobre o valor do investimento, por mensalidade, para construção em 90 dias e compensação de retorno em 24 meses, com simulação do nível de utilização da capacidade instalada, para 100 residentes 282

Apêndice 98 - Crédito médio de 1,40\% sobre o valor do investimento, por mensalidade, para construção em 90 dias e compensação de retorno em 24 meses, com simulação do nível de utilização da capacidade instalada, para 200 residentes

Apêndice 99 - Crédito médio de 1,40\% sobre o valor do investimento, por mensalidade, para construção em 90 dias e compensação de retorno em 24 meses, com simulação do nível de utilização da capacidade instalada, para 300 residentes 283 Apêndice 100 - Crédito médio de $1,40 \%$ sobre o valor do investimento, por mensalidade, para construção em 90 dias e compensação de retorno em 24 meses, com simulação do nível de utilização da capacidade instalada, para 400 residentes

Apêndice 101 - Crédito médio de $1,50 \%$ sobre o valor do investimento, por mensalidade, para construção em 90 dias e compensação de retorno em 24 meses, com simulação do nível de utilização da capacidade instalada, para 100 residentes 284

Apêndice 102 - Crédito médio de $1,50 \%$ sobre o valor do investimento, por mensalidade, para construção em 90 dias e compensação de retorno em 24 meses, com simulação do nível de utilização da capacidade instalada, para 200 residentes 284

Apêndice 103 - Crédito médio de $1,50 \%$ sobre o valor do investimento, por mensalidade, para construção em 90 dias e compensação de retorno em 24 meses, com simulação do nível de utilização da capacidade instalada, para 300 residentes 284

Apêndice 104 - Crédito médio de $1,50 \%$ sobre o valor do investimento, por mensalidade, para construção em 90 dias e compensação de retorno em 24 meses, com simulação do nível de utilização da capacidade instalada, para 400 residentes 285

Apêndice 105 - Crédito médio de $1,10 \%$ sobre o valor do investimento, por mensalidade, para construção em 90 dias e compensação de retorno em 12 meses, com simulação da porcentagem de habitações destinadas a cadeirantes, para 100 residentes 285

Apêndice 106 - Crédito médio de $1,10 \%$ sobre o valor do investimento, por mensalidade, para construção em 90 dias e compensação de retorno em 12 meses, com simulação da porcentagem de habitações destinadas a cadeirantes, para 200 residentes 285 Apêndice 107 - Crédito médio de $1,10 \%$ sobre o valor do investimento, por mensalidade, para construção em 90 dias e compensação de retorno em 12 meses, com simulação da porcentagem de habitações destinadas a cadeirantes, para 300 residentes ...........................286 Apêndice 108 - Crédito médio de $1,10 \%$ sobre o valor do investimento, por mensalidade, para construção em 90 dias e compensação de retorno em 12 meses, com simulação da porcentagem de habitações destinadas a cadeirantes, para 400 residentes ..........................286

Apêndice 109 - Crédito médio de 1,20\% sobre o valor do investimento, por mensalidade, para construção em 90 dias e compensação de retorno em 12 meses, com simulação da porcentagem de habitações destinadas a cadeirantes, para 100 residentes .........................286 Apêndice 110 - Crédito médio de 1,20\% sobre o valor do investimento, por mensalidade, para construção em 90 dias e compensação de retorno em 12 meses, com simulação da porcentagem de habitações destinadas a cadeirantes, para 200 residentes 287 
Apêndice 111 - Crédito médio de 1,20\% sobre o valor do investimento, por mensalidade, para construção em 90 dias e compensação de retorno em 12 meses, com simulação da porcentagem de habitações destinadas a cadeirantes, para 300 residentes ..........................287 Apêndice 112 - Crédito médio de 1,20\% sobre o valor do investimento, por mensalidade, para construção em 90 dias e compensação de retorno em 12 meses, com simulação da porcentagem de habitações destinadas a cadeirantes, para 400 residentes 287

Apêndice 113 - Crédito médio de $1,30 \%$ sobre o valor do investimento, por mensalidade, para construção em 90 dias e compensação de retorno em 12 meses, com simulação da porcentagem de habitações destinadas a cadeirantes, para 100 residentes 288

Apêndice 114 - Crédito médio de 1,30\% sobre o valor do investimento, por mensalidade, para construção em 90 dias e compensação de retorno em 12 meses, com simulação da porcentagem de habitações destinadas a cadeirantes, para 200 residentes ...........................28

Apêndice 115 - Crédito médio de 1,30\% sobre o valor do investimento, por mensalidade, para construção em 90 dias e compensação de retorno em 12 meses, com simulação da porcentagem de habitações destinadas a cadeirantes, para 300 residentes 288

Apêndice 116 - Crédito médio de 1,30\% sobre o valor do investimento, por mensalidade, para construção em 90 dias e compensação de retorno em 12 meses, com simulação da porcentagem de habitações destinadas a cadeirantes, para 400 residentes 289

Apêndice 117 - Crédito médio de 1,40\% sobre o valor do investimento, por mensalidade, para construção em 90 dias e compensação de retorno em 12 meses, com simulação da porcentagem de habitações destinadas a cadeirantes, para 100 residentes 289

Apêndice 118 - Crédito médio de $1,40 \%$ sobre o valor do investimento, por mensalidade, para construção em 90 dias e compensação de retorno em 12 meses, com simulação da porcentagem de habitações destinadas a cadeirantes, para 200 residentes 289

Apêndice 119 - Crédito médio de 1,40\% sobre o valor do investimento, por mensalidade, para construção em 90 dias e compensação de retorno em 12 meses, com simulação da porcentagem de habitações destinadas a cadeirantes, para 300 residentes 290

Apêndice 120 - Crédito médio de $1,40 \%$ sobre o valor do investimento, por mensalidade, para construção em 90 dias e compensação de retorno em 12 meses, com simulação da porcentagem de habitações destinadas a cadeirantes, para 400 residentes. 290

Apêndice 121 - Crédito médio de $1,50 \%$ sobre o valor do investimento, por mensalidade, para construção em 90 dias e compensação de retorno em 12 meses, com simulação da porcentagem de habitações destinadas a cadeirantes, para 100 residentes 290 Apêndice 122 - Crédito médio de 1,50\% sobre o valor do investimento, por mensalidade, para construção em 90 dias e compensação de retorno em 12 meses, com simulação da porcentagem de habitações destinadas a cadeirantes, para 200 residentes

Apêndice 123 - Crédito médio de 1,50\% sobre o valor do investimento, por mensalidade, para construção em 90 dias e compensação de retorno em 12 meses, com simulação da porcentagem de habitações destinadas a cadeirantes, para 300 residentes.....

Apêndice 124 - Crédito médio de 1,50\% sobre o valor do investimento, por mensalidade, para construção em 90 dias e compensação de retorno em 12 meses, com simulação da porcentagem de habitações destinadas a cadeirantes, para 400 residentes 291 Apêndice 125 - Crédito médio de $1,10 \%$ sobre o valor do investimento, por mensalidade, para construção em 90 dias e compensação de retorno em 24 meses, com simulação da porcentagem de habitações destinadas a cadeirantes, para 100 residentes 
Apêndice 126 - Crédito médio de $1,10 \%$ sobre o valor do investimento, por mensalidade, para construção em 90 dias e compensação de retorno em 24 meses, com simulação da porcentagem de habitações destinadas a cadeirantes, para 200 residentes ...........................292 Apêndice 127 - Crédito médio de 1,10\% sobre o valor do investimento, por mensalidade, para construção em 90 dias e compensação de retorno em 24 meses, com simulação da porcentagem de habitações destinadas a cadeirantes, para 300 residentes

Apêndice 128 - Crédito médio de $1,10 \%$ sobre o valor do investimento, por mensalidade, para construção em 90 dias e compensação de retorno em 24 meses, com simulação da porcentagem de habitações destinadas a cadeirantes, para 400 residentes

Apêndice 129 - Crédito médio de 1,20\% sobre o valor do investimento, por mensalidade, para construção em 90 dias e compensação de retorno em 24 meses, com simulação da porcentagem de habitações destinadas a cadeirantes, para 100 residentes 293

Apêndice 130 - Crédito médio de 1,20\% sobre o valor do investimento, por mensalidade, para construção em 90 dias e compensação de retorno em 24 meses, com simulação da porcentagem de habitações destinadas a cadeirantes, para 200 residentes

Apêndice 131 - Crédito médio de 1,20\% sobre o valor do investimento, por mensalidade, para construção em 90 dias e compensação de retorno em 24 meses, com simulação da porcentagem de habitações destinadas a cadeirantes, para 300 residentes 294

Apêndice 132 - Crédito médio de 1,20\% sobre o valor do investimento, por mensalidade, para construção em 90 dias e compensação de retorno em 24 meses, com simulação da porcentagem de habitações destinadas a cadeirantes, para 400 residentes ...........................294

Apêndice 133 - Crédito médio de 1,30\% sobre o valor do investimento, por mensalidade, para construção em 90 dias e compensação de retorno em 24 meses, com simulação da porcentagem de habitações destinadas a cadeirantes, para 100 residentes

Apêndice 134 - Crédito médio de 1,30\% sobre o valor do investimento, por mensalidade, para construção em 90 dias e compensação de retorno em 24 meses, com simulação da porcentagem de habitações destinadas a cadeirantes, para 200 residentes

Apêndice 135 - Crédito médio de $1,30 \%$ sobre o valor do investimento, por mensalidade, para construção em 90 dias e compensação de retorno em 24 meses, com simulação da porcentagem de habitações destinadas a cadeirantes, para 300 residentes. 295

Apêndice 136 - Crédito médio de $1,30 \%$ sobre o valor do investimento, por mensalidade, para construção em 90 dias e compensação de retorno em 24 meses, com simulação da porcentagem de habitações destinadas a cadeirantes, para 400 residentes .295 Apêndice 137 - Crédito médio de 1,40\% sobre o valor do investimento, por mensalidade, para construção em 90 dias e compensação de retorno em 24 meses, com simulação da porcentagem de habitações destinadas a cadeirantes, para 100 residentes ...........................296 Apêndice 138 - Crédito médio de 1,40\% sobre o valor do investimento, por mensalidade, para construção em 90 dias e compensação de retorno em 24 meses, com simulação da porcentagem de habitações destinadas a cadeirantes, para 200 residentes ..........................296

Apêndice 139 - Crédito médio de $1,40 \%$ sobre o valor do investimento, por mensalidade, para construção em 90 dias e compensação de retorno em 24 meses, com simulação da porcentagem de habitações destinadas a cadeirantes, para 300 residentes ...........................296 Apêndice 140 - Crédito médio de 1,40\% sobre o valor do investimento, por mensalidade, para construção em 90 dias e compensação de retorno em 24 meses, com simulação da porcentagem de habitações destinadas a cadeirantes, para 400 residentes. 
Apêndice 141 - Crédito médio de $1,50 \%$ sobre o valor do investimento, por mensalidade, para construção em 90 dias e compensação de retorno em 24 meses, com simulação da porcentagem de habitações destinadas a cadeirantes, para 100 residentes 297

Apêndice 142 - Crédito médio de 1,50\% sobre o valor do investimento, por mensalidade, para construção em 90 dias e compensação de retorno em 24 meses, com simulação da porcentagem de habitações destinadas a cadeirantes, para 200 residentes

Apêndice 143 - Crédito médio de 1,50\% sobre o valor do investimento, por mensalidade, para construção em 90 dias e compensação de retorno em 24 meses, com simulação da porcentagem de habitações destinadas a cadeirantes, para 300 residentes 298

Apêndice 144 - Crédito médio de $1,50 \%$ sobre o valor do investimento, por mensalidade, para construção em 90 dias e compensação de retorno em 24 meses, com simulação da porcentagem de habitações destinadas a cadeirantes, para 400 residentes ............................298 Apêndice 145 - Crédito médio de $1,10 \%$ sobre o valor do investimento, por mensalidade, para construção em 90 dias e compensação de retorno em 12 meses, em função de áreas externas, anfiteatro e minisshopping, para 100 residentes 298

Apêndice 146 - Crédito médio de $1,10 \%$ sobre o valor do investimento, por mensalidade, para construção em 90 dias e compensação de retorno em 12 meses, em função de áreas externas, anfiteatro e minisshopping, para 200 residentes 299

Apêndice 147 - Crédito médio de $1,10 \%$ sobre o valor do investimento, por mensalidade, para construção em 90 dias e compensação de retorno em 12 meses, em função de áreas externas, anfiteatro e minisshopping, para 300 residentes 299

Apêndice 148 - Crédito médio de $1,10 \%$ sobre o valor do investimento, por mensalidade, para construção em 90 dias e compensação de retorno em 12 meses, em função de áreas externas, anfiteatro e minisshopping, para 400 residentes

Apêndice 149 - Crédito médio de 1,20\% sobre o valor do investimento, por mensalidade, para construção em 90 dias e compensação de retorno em 12 meses, em função de áreas externas, anfiteatro e minisshopping, para 100 residentes 300

Apêndice 150 - Crédito médio de 1,20\% sobre o valor do investimento, por mensalidade, para construção em 90 dias e compensação de retorno em 12 meses, em função de áreas externas, anfiteatro e minisshopping, para 200 residentes 300

Apêndice 151 - Crédito médio de 1,20\% sobre o valor do investimento, por mensalidade, para construção em 90 dias e compensação de retorno em 12 meses, em função de áreas externas, anfiteatro e minisshopping, para 300 residentes 300

Apêndice 152 - Crédito médio de 1,20\% sobre o valor do investimento, por mensalidade, para construção em 90 dias e compensação de retorno em 12 meses, em função de áreas externas, anfiteatro e minisshopping, para 400 residentes 301

Apêndice 153 - Crédito médio de $1,30 \%$ sobre o valor do investimento, por mensalidade, para construção em 90 dias e compensação de retorno em 12 meses, em função de áreas externas, anfiteatro e minisshopping, para 100 residentes 301

Apêndice 154 - Crédito médio de 1,30\% sobre o valor do investimento, por mensalidade, para construção em 90 dias e compensação de retorno em 12 meses, em função de áreas externas, anfiteatro e minisshopping, para 200 residentes 301

Apêndice 155 - Crédito médio de $1,30 \%$ sobre o valor do investimento, por mensalidade, para construção em 90 dias e compensação de retorno em 12 meses, em função de áreas externas, anfiteatro e minisshopping, para 300 residentes 302 
Apêndice 156 - Crédito médio de 1,30\% sobre o valor do investimento, por mensalidade, para construção em 90 dias e compensação de retorno em 12 meses, em função de áreas externas, anfiteatro e minisshopping, para 400 residentes................................................302

Apêndice 157 - Crédito médio de $1,40 \%$ sobre o valor do investimento, por mensalidade, para construção em 90 dias e compensação de retorno em 12 meses, em função de áreas externas, anfiteatro e minisshopping, para 100 residentes

Apêndice 158 - Crédito médio de $1,40 \%$ sobre o valor do investimento, por mensalidade, para construção em 90 dias e compensação de retorno em 12 meses, em função de áreas externas, anfiteatro e minisshopping, para 200 residentes 303

Apêndice 159 - Crédito médio de $1,40 \%$ sobre o valor do investimento, por mensalidade, para construção em 90 dias e compensação de retorno em 12 meses, em função de áreas externas, anfiteatro e minisshopping, para 300 residentes................................................303

Apêndice 160 - Crédito médio de $1,40 \%$ sobre o valor do investimento, por mensalidade, para construção em 90 dias e compensação de retorno em 12 meses, em função de áreas externas, anfiteatro e minisshopping, para 400 residentes

Apêndice 161 - Crédito médio de $1,50 \%$ sobre o valor do investimento, por mensalidade, para construção em 90 dias e compensação de retorno em 12 meses, em função de áreas externas, anfiteatro e minisshopping, para 100 residentes 304

Apêndice 162 - Crédito médio de $1,50 \%$ sobre o valor do investimento, por mensalidade, para construção em 90 dias e compensação de retorno em 12 meses, em função de áreas externas, anfiteatro e minisshopping, para 200 residentes 304

Apêndice 163 - Crédito médio de $1,50 \%$ sobre o valor do investimento, por mensalidade, para construção em 90 dias e compensação de retorno em 12 meses, em função de áreas externas, anfiteatro e minisshopping, para 300 residentes 304

Apêndice 164 - Crédito médio de $1,50 \%$ sobre o valor do investimento, por mensalidade, para construção em 90 dias e compensação de retorno em 12 meses, em função de áreas externas, anfiteatro e minisshopping, para 400 residentes 305

Apêndice 165 - Crédito médio de $1,10 \%$ sobre o valor do investimento, por mensalidade, para construção em 90 dias e compensação de retorno em 24 meses, em função de áreas externas, anfiteatro e minisshopping, para 100 residentes 305

Apêndice 166 - Crédito médio de $1,10 \%$ sobre o valor do investimento, por mensalidade, para construção em 90 dias e compensação de retorno em 24 meses, em função de áreas externas, anfiteatro e minisshopping, para 200 residentes 305

Apêndice 167 - Crédito médio de 1,10\% sobre o valor do investimento, por mensalidade, para construção em 90 dias e compensação de retorno em 24 meses, em função de áreas externas, anfiteatro e minisshopping, para 300 residentes 306

Apêndice 168 - Crédito médio de $1,10 \%$ sobre o valor do investimento, por mensalidade, para construção em 90 dias e compensação de retorno em 24 meses, em função de áreas externas, anfiteatro e minisshopping, para 400 residentes 306

Apêndice 169 - Crédito médio de 1,20\% sobre o valor do investimento, por mensalidade, para construção em 90 dias e compensação de retorno em 24 meses, em função de áreas externas, anfiteatro e minisshopping, para 100 residentes 306 Apêndice 170 - Crédito médio de 1,20\% sobre o valor do investimento, por mensalidade, para construção em 90 dias e compensação de retorno em 24 meses, em função de áreas externas, anfiteatro e minisshopping, para 200 residentes 307 
Apêndice 171 - Crédito médio de 1,20\% sobre o valor do investimento, por mensalidade, para construção em 90 dias e compensação de retorno em 24 meses, em função de áreas externas, anfiteatro e minisshopping, para 300 residentes

Apêndice 172 - Crédito médio de 1,20\% sobre o valor do investimento, por mensalidade, para construção em 90 dias e compensação de retorno em 24 meses, em função de áreas externas, anfiteatro e minisshopping, para 400 residentes

Apêndice 173 - Crédito médio de $1,30 \%$ sobre o valor do investimento, por mensalidade, para construção em 90 dias e compensação de retorno em 24 meses, em função de áreas externas, anfiteatro e minisshopping, para 100 residentes 308

Apêndice 174 - Crédito médio de $1,30 \%$ sobre o valor do investimento, por mensalidade, para construção em 90 dias e compensação de retorno em 24 meses, em função de áreas externas, anfiteatro e minisshopping, para 200 residentes................................................308

Apêndice 175 - Crédito médio de 1,30\% sobre o valor do investimento, por mensalidade, para construção em 90 dias e compensação de retorno em 24 meses, em função de áreas

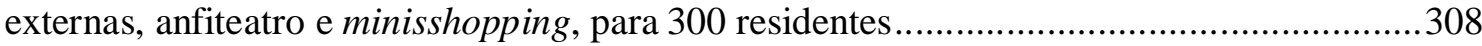

Apêndice 176 - Crédito médio de 1,30\% sobre o valor do investimento, por mensalidade, para construção em 90 dias e compensação de retorno em 24 meses, em função de áreas externas, anfiteatro e minisshopping, para 400 residentes 309

Apêndice 177 - Crédito médio de 1,40\% sobre o valor do investimento, por mensalidade, para construção em 90 dias e compensação de retorno em 24 meses, em função de áreas externas, anfiteatro e minisshopping, para 100 residentes

Apêndice 178 - Crédito médio de $1,40 \%$ sobre o valor do investimento, por mensalidade, para construção em 90 dias e compensação de retorno em 24 meses, em função de áreas externas, anfiteatro e minisshopping, para 200 residentes 309

Apêndice 179 - Crédito médio de $1,40 \%$ sobre o valor do investimento, por mensalidade, para construção em 90 dias e compensação de retorno em 24 meses, em função de áreas externas, anfiteatro e minisshopping, para 300 residentes 310

Apêndice 180 - Crédito médio de $1,40 \%$ sobre o valor do investimento, por mensalidade, para construção em 90 dias e compensação de retorno em 24 meses, em função de áreas externas, anfiteatro e minisshopping, para 400 residentes 310

Apêndice 181 - Crédito médio de 1,50\% sobre o valor do investimento, por mensalidade, para construção em 90 dias e compensação de retorno em 24 meses, em função de áreas externas, anfiteatro e minisshopping, para 100 residentes 310

Apêndice 182 - Crédito médio de $1,50 \%$ sobre o valor do investimento, por mensalidade, para construção em 90 dias e compensação de retorno em 24 meses, em função de áreas externas, anfiteatro e minisshopping, para 200 residentes

Apêndice 183 - Crédito médio de $1,50 \%$ sobre o valor do investimento, por mensalidade, para construção em 90 dias e compensação de retorno em 24 meses, em função de áreas externas, anfiteatro e minisshopping, para 300 residentes

Apêndice 184 - Crédito médio de 1,50\% sobre o valor do investimento, por mensalidade, para construção em 90 dias e compensação de retorno em 24 meses, em função de áreas externas, anfiteatro e minisshopping, para 400 residentes. 311

Apêndice 185 - Valor médio da mensalidade final, com crédito médio de 1,10\% sobre o valor do investimento, para construção em 90 dias e compensação de retorno em 12 meses, com simulação do nível de utilização da capacidade instalada, para 100 residentes 312 
Apêndice 186 - Valor médio da mensalidade final, com crédito médio de 1,10\% sobre o valor do investimento, para construção em 90 dias e compensação de retorno em 12 meses, com simulação do nível de utilização da capacidade instalada, para 200 residentes ....................312 Apêndice 187 - Valor médio da mensalidade final, com crédito médio de 1,10\% sobre o valor do investimento, para construção em 90 dias e compensação de retorno em 12 meses, com simulação do nível de utilização da capacidade instalada, para 300 residentes

Apêndice 188 - Valor médio da mensalidade final, com crédito médio de 1,10\% sobre o valor do investimento, para construção em 90 dias e compensação de retorno em 12 meses, com simulação do nível de utilização da capacidade instalada, para 400 residentes 313

Apêndice 189 - Valor médio da mensalidade final, com crédito médio de 1,20\% sobre o valor do investimento, para construção em 90 dias e compensação de retorno em 12 meses, com simulação do nível de utilização da capacidade instalada, para 100 residentes 313

Apêndice 190 - Valor médio da mensalidade final, com crédito médio de 1,20\% sobre o valor do investimento, para construção em 90 dias e compensação de retorno em 12 meses, com simulação do nível de utilização da capacidade instalada, para 200 residentes 313

Apêndice 191 - Valor médio da mensalidade final, com crédito médio de 1,20\% sobre o valor do investimento, para construção em 90 dias e compensação de retorno em 12 meses, com simulação do nível de utilização da capacidade instalada, para 300 residentes 314

Apêndice 192 - Valor médio da mensalidade final, com crédito médio de 1,20\% sobre o valor do investimento, para construção em 90 dias e compensação de retorno em 12 meses, com simulação do nível de utilização da capacidade instalada, para 400 residentes 314 Apêndice 193 - Valor médio da mensalidade final, com crédito médio de 1,30\% sobre o valor do investimento, para construção em 90 dias e compensação de retorno em 12 meses, com simulação do nível de utilização da capacidade instalada, para 100 residentes 314 Apêndice 194 - Valor médio da mensalidade final, com crédito médio de 1,30\% sobre o valor do investimento, para construção em 90 dias e compensação de retorno em 12 meses, com simulação do nível de utilização da capacidade instalada, para 200 residentes 315

Apêndice 195 - Valor médio da mensalidade final, com crédito médio de 1,30\% sobre o valor do investimento, para construção em 90 dias e compensação de retorno em 12 meses, com simulação do nível de utilização da capacidade instalada, para 300 residentes 315

Apêndice 196 - Valor médio da mensalidade final, com crédito médio de 1,30\% sobre o valor do investimento, para construção em 90 dias e compensação de retorno em 12 meses, com simulação do nível de utilização da capacidade instalada, para 400 residentes 315 Apêndice 197 - Valor médio da mensalidade final, com crédito médio de 1,40\% sobre o valor do investimento, para construção em 90 dias e compensação de retorno em 12 meses, com simulação do nível de utilização da capacidade instalada, para 100 residentes 316 Apêndice 198 - Valor médio da mensalidade final, com crédito médio de 1,40\% sobre o valor do investimento, para construção em 90 dias e compensação de retorno em 12 meses, com simulação do nível de utilização da capacidade instalada, para 200 residentes 316 Apêndice 199 - Valor médio da mensalidade final, com crédito médio de 1,40\% sobre o valor do investimento, para construção em 90 dias e compensação de retorno em 12 meses, com simulação do nível de utilização da capacidade instalada, para 300 residentes 316 Apêndice 200 - Valor médio da mensalidade final, com crédito médio de 1,40\% sobre o valor do investimento, para construção em 90 dias e compensação de retorno em 12 meses, com simulação do nível de utilização da capacidade instalada, para 400 residentes 317 
Apêndice 201 - Valor médio da mensalidade final, com crédito médio de 1,50\% sobre o valor do investimento, para construção em 90 dias e compensação de retorno em 12 meses, com simulação do nível de utilização da capacidade instalada, para 100 residentes 317 Apêndice 202 - Valor médio da mensalidade final, com crédito médio de 1,50\% sobre o valor do investimento, para construção em 90 dias e compensação de retorno em 12 meses, com simulação do nível de utilização da capacidade instalada, para 200 residentes

Apêndice 203 - Valor médio da mensalidade final, com crédito médio de 1,50\% sobre o valor do investimento, para construção em 90 dias e compensação de retorno em 12 meses, com simulação do nível de utilização da capacidade instalada, para 300 residentes 318

Apêndice 204 - Valor médio da mensalidade final, com crédito médio de 1,50\% sobre o valor do investimento, para construção em 90 dias e compensação de retorno em 12 meses, com simulação do nível de utilização da capacidade instalada, para 400 residentes 318

Apêndice 205 - Valor médio da mensalidade final, com crédito médio de 1,10\% sobre o valor do investimento, para construção em 90 dias e compensação de retorno em 24 meses, com simulação do nível de utilização da capacidade instalada, para 100 residentes 318

Apêndice 206 - Valor médio da mensalidade final, com crédito médio de 1,10\% sobre o valor do investimento, para construção em 90 dias e compensação de retorno em 24 meses, com simulação do nível de utilização da capacidade instalada, para 200 residentes 319

Apêndice 207 - Valor médio da mensalidade final, com crédito médio de 1,10\% sobre o valor do investimento, para construção em 90 dias e compensação de retorno em 24 meses, com simulação do nível de utilização da capacidade instalada, para 300 residentes

Apêndice 208 - Valor médio da mensalidade final, com crédito médio de 1,10\% sobre o valor do investimento, para construção em 90 dias e compensação de retorno em 24 meses, com simulação do nível de utilização da capacidade instalada, para 400 residentes 319

Apêndice 209 - Valor médio da mensalidade final, com crédito médio de 1,20\% sobre o valor do investimento, para construção em 90 dias e compensação de retorno em 24 meses, com simulação do nível de utilização da capacidade instalada, para 100 residentes 320

Apêndice 210 - Valor médio da mensalidade final, com crédito médio de 1,20\% sobre o valor do investimento, para construção em 90 dias e compensação de retorno em 24 meses, com simulação do nível de utilização da capacidade instalada, para 200 residentes

Apêndice 211 - Valor médio da mensalidade final, com crédito médio de 1,20\% sobre o valor do investimento, para construção em 90 dias e compensação de retorno em 24 meses, com simulação do nível de utilização da capacidade instalada, para 300 residentes 320 Apêndice 212 - Valor médio da mensalidade final, com crédito médio de 1,20\% sobre o valor do investimento, para construção em 90 dias e compensação de retorno em 24 meses, com simulação do nível de utilização da capacidade instalada, para 400 residentes

Apêndice 213 - Valor médio da mensalidade final, com crédito médio de 1,30\% sobre o valor do investimento, para construção em 90 dias e compensação de retorno em 24 meses, com simulação do nível de utilização da capacidade instalada, para 100 residentes

Apêndice 214 - Valor médio da mensalidade final, com crédito médio de 1,30\% sobre o valor do investimento, para construção em 90 dias e compensação de retorno em 24 meses, com simulação do nível de utilização da capacidade instalada, para 200 residentes 321 Apêndice 215 - Valor médio da mensalidade final, com crédito médio de 1,30\% sobre o valor do investimento, para construção em 90 dias e compensação de retorno em 24 meses, com simulação do nível de utilização da capacidade instalada, para 300 residentes 322 
Apêndice 216 - Valor médio da mensalidade final, com crédito médio de 1,30\% sobre o valor do investimento, para construção em 90 dias e compensação de retorno em 24 meses, com simulação do nível de utilização da capacidade instalada, para 400 residentes 322

Apêndice 217 - Valor médio da mensalidade final, com crédito médio de 1,40\% sobre o valor do investimento, para construção em 90 dias e compensação de retorno em 24 meses, com simulação do nível de utilização da capacidade instalada, para 100 residentes

Apêndice 218 - Valor médio da mensalidade final, com crédito médio de 1,40\% sobre o valor do investimento, para construção em 90 dias e compensação de retorno em 24 meses, com simulação do nível de utilização da capacidade instalada, para 200 residentes 323

Apêndice 219 - Valor médio da mensalidade final, com crédito médio de 1,40\% sobre o valor do investimento, para construção em 90 dias e compensação de retorno em 24 meses, com simulação do nível de utilização da capacidade instalada, para 300 residentes 323

Apêndice 220 - Valor médio da mensalidade final, com crédito médio de 1,40\% sobre o valor do investimento, para construção em 90 dias e compensação de retorno em 24 meses, com simulação do nível de utilização da capacidade instalada, para 400 residentes

Apêndice 221 - Valor médio da mensalidade final, com crédito médio de 1,50\% sobre o valor do investimento, para construção em 90 dias e compensação de retorno em 24 meses, com simulação do nível de utilização da capacidade instalada, para 100 residentes 324

Apêndice 222 - Valor médio da mensalidade final, com crédito médio de 1,50\% sobre o valor do investimento, para construção em 90 dias e compensação de retorno em 24 meses, com simulação do nível de utilização da capacidade instalada, para 200 residentes 324 Apêndice 223 - Valor médio da mensalidade final, com crédito médio de 1,50\% sobre o valor do investimento, para construção em 90 dias e compensação de retorno em 24 meses, com simulação do nível de utilização da capacidade instalada, para 300 residentes 324

Apêndice 224 - Valor médio da mensalidade final, com crédito médio de 1,50\% sobre o valor do investimento, para construção em 90 dias e compensação de retorno em 24 meses, com simulação do nível de utilização da capacidade instalada, para 400 residentes 325

Apêndice 225 - Valor médio da mensalidade final, com crédito médio de 1,10\% sobre o valor do investimento, para construção em 90 dias e compensação de retorno em 12 meses, com simulação da porcentagem de habitações destinadas a cadeirantes, para 100 residentes.......325

Apêndice 226 - Valor médio da mensalidade final, com crédito médio de 1,10\% sobre o valor do investimento, para construção em 90 dias e compensação de retorno em 12 meses, com simulação da porcentagem de habitações destinadas a cadeirantes, para 200 residentes........325 Apêndice 227 - Valor médio da mensalidade final, com crédito médio de 1,10\% sobre o valor do investimento, para construção em 90 dias e compensação de retorno em 12 meses, com simulação da porcentagem de habitações destinadas a cadeirantes, para 300 residentes........326 Apêndice 228 - Valor médio da mensalidade final, com crédito médio de 1,10\% sobre o valor do investimento, para construção em 90 dias e compensação de retorno em 12 meses, com simulação da porcentagem de habitações destinadas a cadeirantes, para 400 residentes........326 Apêndice 229 - Valor médio da mensalidade final, com crédito médio de 1,20\% sobre o valor do investimento, para construção em 90 dias e compensação de retorno em 12 meses, com simulação da porcentagem de habitações destinadas a cadeirantes, para 100 residentes........326 Apêndice 230 - Valor médio da mensalidade final, com crédito médio de 1,20\% sobre o valor do investimento, para construção em 90 dias e compensação de retorno em 12 meses, com simulação da porcentagem de habitações destinadas a cadeirantes, para 200 residentes........327 
Apêndice 231 - Valor médio da mensalidade final, com crédito médio de 1,20\% sobre o valor do investimento, para construção em 90 dias e compensação de retorno em 12 meses, com simulação da porcentagem de habitações destinadas a cadeirantes, para 300 residentes.......327 Apêndice 232 - Valor médio da mensalidade final, com crédito médio de 1,20\% sobre o valor do investimento, para construção em 90 dias e compensação de retorno em 12 meses, com simulação da porcentagem de habitações destinadas a cadeirantes, para 400 residentes........327

Apêndice 233 - Valor médio da mensalidade final, com crédito médio de 1,30\% sobre o valor do investimento, para construção em 90 dias e compensação de retorno em 12 meses, com simulação da porcentagem de habitações destinadas a cadeirantes, para 100 residentes........328 Apêndice 234 - Valor médio da mensalidade final, com crédito médio de 1,30\% sobre o valor do investimento, para construção em 90 dias e compensação de retorno em 12 meses, com simulação da porcentagem de habitações destinadas a cadeirantes, para 200 residentes........328 Apêndice 235 - Valor médio da mensalidade final, com crédito médio de 1,30\% sobre o valor do investimento, para construção em 90 dias e compensação de retorno em 12 meses, com simulação da porcentagem de habitações destinadas a cadeirantes, para 300 residentes.......328

Apêndice 236 - Valor médio da mensalidade final, com crédito médio de 1,30\% sobre o valor do investimento, para construção em 90 dias e compensação de retorno em 12 meses, com simulação da porcentagem de habitações destinadas a cadeirantes, para 400 residentes.......329

Apêndice 237 - Valor médio da mensalidade final, com crédito médio de 1,40\% sobre o valor do investimento, para construção em 90 dias e compensação de retorno em 12 meses, com simulação da porcentagem de habitações destinadas a cadeirantes, para 100 residentes........329 Apêndice 238 - Valor médio da mensalidade final, com crédito médio de 1,40\% sobre o valor do investimento, para construção em 90 dias e compensação de retorno em 12 meses, com simulação da porcentagem de habitações destinadas a cadeirantes, para 200 residentes.......329

Apêndice 239 - Valor médio da mensalidade final, com crédito médio de 1,40\% sobre o valor do investimento, para construção em 90 dias e compensação de retorno em 12 meses, com simulação da porcentagem de habitações destinadas a cadeirantes, para 300 residentes........330

Apêndice 240 - Valor médio da mensalidade final, com crédito médio de 1,40\% sobre o valor do investimento, para construção em 90 dias e compensação de retorno em 12 meses, com simulação da porcentagem de habitações destinadas a cadeirantes, para 400 residentes........330

Apêndice 241 - Valor médio da mensalidade final, com crédito médio de 1,50\% sobre o valor do investimento, para construção em 90 dias e compensação de retorno em 12 meses, com simulação da porcentagem de habitações destinadas a cadeirantes, para 100 residentes........330 Apêndice 242 - Valor médio da mensalidade final, com crédito médio de 1,50\% sobre o valor do investimento, para construção em 90 dias e compensação de retorno em 12 meses, com simulação da porcentagem de habitações destinadas a cadeirantes, para 200 residentes........331 Apêndice 243 - Valor médio da mensalidade final, com crédito médio de 1,50\% sobre o valor do investimento, para construção em 90 dias e compensação de retorno em 12 meses, com simulação da porcentagem de habitações destinadas a cadeirantes, para 300 residentes........331 Apêndice 244 - Valor médio da mensalidade final, com crédito médio de 1,50\% sobre o valor do investimento, para construção em 90 dias e compensação de retorno em 12 meses, com simulação da porcentagem de habitações destinadas a cadeirantes, para 400 residentes........331 Apêndice 245 - Valor médio da mensalidade final, com crédito médio de 1,10\% sobre o valor do investimento, para construção em 90 dias e compensação de retorno em 24 meses, com simulação da porcentagem de habitações destinadas a cadeirantes, para 100 residentes........332 
Apêndice 246 - Valor médio da mensalidade final, com crédito médio de 1,10\% sobre o valor do investimento, para construção em 90 dias e compensação de retorno em 24 meses, com simulação da porcentagem de habitações destinadas a cadeirantes, para 200 residentes........332 Apêndice 247 - Valor médio da mensalidade final, com crédito médio de 1,10\% sobre o valor do investimento, para construção em 90 dias e compensação de retorno em 24 meses, com simulação da porcentagem de habitações destinadas a cadeirantes, para 300 residentes........332

Apêndice 248 - Valor médio da mensalidade final, com crédito médio de 1,10\% sobre o valor do investimento, para construção em 90 dias e compensação de retorno em 24 meses, com simulação da porcentagem de habitações destinadas a cadeirantes, para 400 residentes........333 Apêndice 249 - Valor médio da mensalidade final, com crédito médio de 1,20\% sobre o valor do investimento, para construção em 90 dias e compensação de retorno em 24 meses, com simulação da porcentagem de habitações destinadas a cadeirantes, para 100 residentes........333 Apêndice 250 - Valor médio da mensalidade final, com crédito médio de 1,20\% sobre o valor do investimento, para construção em 90 dias e compensação de retorno em 24 meses, com simulação da porcentagem de habitações destinadas a cadeirantes, para 200 residentes........333

Apêndice 251 - Valor médio da mensalidade final, com crédito médio de 1,20\% sobre o valor do investimento, para construção em 90 dias e compensação de retorno em 24 meses, com simulação da porcentagem de habitações destinadas a cadeirantes, para 300 residentes.......334 Apêndice 252 - Valor médio da mensalidade final, com crédito médio de 1,20\% sobre o valor do investimento, para construção em 90 dias e compensação de retorno em 24 meses, com simulação da porcentagem de habitações destinadas a cadeirantes, para 400 residentes........334 Apêndice 253 - Valor médio da mensalidade final, com crédito médio de 1,30\% sobre o valor do investimento, para construção em 90 dias e compensação de retorno em 24 meses, com simulação da porcentagem de habitações destinadas a cadeirantes, para 100 residentes........334

Apêndice 254 - Valor médio da mensalidade final, com crédito médio de 1,30\% sobre o valor do investimento, para construção em 90 dias e compensação de retorno em 24 meses, com simulação da porcentagem de habitações destinadas a cadeirantes, para 200 residentes........335

Apêndice 255 - Valor médio da mensalidade final, com crédito médio de 1,30\% sobre o valor do investimento, para construção em 90 dias e compensação de retorno em 24 meses, com simulação da porcentagem de habitações destinadas a cadeirantes, para 300 residentes........335

Apêndice 256 - Valor médio da mensalidade final, com crédito médio de 1,30\% sobre o valor do investimento, para construção em 90 dias e compensação de retorno em 24 meses, com simulação da porcentagem de habitações destinadas a cadeirantes, para 400 residentes........335 Apêndice 257 - Valor médio da mensalidade final, com crédito médio de 1,40\% sobre o valor do investimento, para construção em 90 dias e compensação de retorno em 24 meses, com simulação da porcentagem de habitações destinadas a cadeirantes, para 100 residentes........336 Apêndice 258 - Valor médio da mensalidade final, com crédito médio de 1,40\% sobre o valor do investimento, para construção em 90 dias e compensação de retorno em 24 meses, com simulação da porcentagem de habitações destinadas a cadeirantes, para 200 residentes........336 Apêndice 259 - Valor médio da mensalidade final, com crédito médio de 1,40\% sobre o valor do investimento, para construção em 90 dias e compensação de retorno em 24 meses, com simulação da porcentagem de habitações destinadas a cadeirantes, para 300 residentes........336 Apêndice 260 - Valor médio da mensalidade final, com crédito médio de 1,40\% sobre o valor do investimento, para construção em 90 dias e compensação de retorno em 24 meses, com simulação da porcentagem de habitações destinadas a cadeirantes, para 400 residentes........337 
Apêndice 261 - Valor médio da mensalidade final, com crédito médio de 1,50\% sobre o valor do investimento, para construção em 90 dias e compensação de retorno em 24 meses, com simulação da porcentagem de habitações destinadas a cadeirantes, para 100 residentes........337 Apêndice 262 - Valor médio da mensalidade final, com crédito médio de 1,50\% sobre o valor do investimento, para construção em 90 dias e compensação de retorno em 24 meses, com simulação da porcentagem de habitações destinadas a cadeirantes, para 200 residentes.......337

Apêndice 263 - Valor médio da mensalidade final, com crédito médio de 1,50\% sobre o valor do investimento, para construção em 90 dias e compensação de retorno em 24 meses, com simulação da porcentagem de habitações destinadas a cadeirantes, para 300 residentes........338 Apêndice 264 - Valor médio da mensalidade final, com crédito médio de 1,50\% sobre o valor do investimento, para construção em 90 dias e compensação de retorno em 24 meses, com simulação da porcentagem de habitações destinadas a cadeirantes, para 400 residentes........338 Apêndice 265 - Valor médio da mensalidade final, com crédito médio de 1,10\% sobre o valor do investimento, para construção em 90 dias e compensação de retorno em 12 meses, em função de áreas externas, anfiteatro e minisshopping, para 100 residentes 338

Apêndice 266 - Valor médio da mensalidade final, com crédito médio de 1,10\% sobre o valor do investimento, para construção em 90 dias e compensação de retorno em 12 meses, em função de áreas externas, anfiteatro e minisshopping, para 200 residentes ..... 339

Apêndice 267 - Valor médio da mensalidade final, com crédito médio de 1,10\% sobre o valor do investimento, para construção em 90 dias e compensação de retorno em 12 meses, em função de áreas externas, anfiteatro e minisshopping, para 300 residentes 339

Apêndice 268 - Valor médio da mensalidade final, com crédito médio de 1,10\% sobre o valor do investimento, para construção em 90 dias e compensação de retorno em 12 meses, em função de áreas externas, anfiteatro e minisshopping, para 400 residentes 339

Apêndice 269 - Valor médio da mensalidade final, com crédito médio de 1,20\% sobre o valor do investimento, para construção em 90 dias e compensação de retorno em 12 meses, em função de áreas externas, anfiteatro e minisshopping, para 100 residentes....

Apêndice 270 - Valor médio da mensalidade final, com crédito médio de 1,20\% sobre o valor do investimento, para construção em 90 dias e compensação de retorno em 12 meses, em função de áreas externas, anfiteatro e minisshopping, para 200 residentes... 340

Apêndice 271 - Valor médio da mensalidade final, com crédito médio de 1,20\% sobre o valor do investimento, para construção em 90 dias e compensação de retorno em 12 meses, em função de áreas externas, anfiteatro e minisshopping, para 300 residentes

Apêndice 272 - Valor médio da mensalidade final, com crédito médio de 1,20\% sobre o valor do investimento, para construção em 90 dias e compensação de retorno em 12 meses, em função de áreas externas, anfiteatro e minisshopping, para 400 residentes...

Apêndice 273 - Valor médio da mensalidade final, com crédito médio de 1,30\% sobre o valor do investimento, para construção em 90 dias e compensação de retorno em 12 meses, em função de áreas externas, anfiteatro e minisshopping, para 100 residentes....

Apêndice 274 - Valor médio da mensalidade final, com crédito médio de 1,30\% sobre o valor do investimento, para construção em 90 dias e compensação de retorno em 12 meses, em função de áreas externas, anfiteatro e minisshopping, para 200 residentes

Apêndice 275 - Valor médio da mensalidade final, com crédito médio de 1,30\% sobre o valor do investimento, para construção em 90 dias e compensação de retorno em 12 meses, em função de áreas externas, anfiteatro e minisshopping, para 300 residentes 
Apêndice 276 - Valor médio da mensalidade final, com crédito médio de 1,30\% sobre o valor do investimento, para construção em 90 dias e compensação de retorno em 12 meses, em função de áreas externas, anfiteatro e minisshopping, para 400 residentes 342

Apêndice 277 - Valor médio da mensalidade final, com crédito médio de 1,40\% sobre o valor do investimento, para construção em 90 dias e compensação de retorno em 12 meses, em função de áreas externas, anfiteatro e minisshopping, para 100 residentes

Apêndice 278 - Valor médio da mensalidade final, com crédito médio de 1,40\% sobre o valor do investimento, para construção em 90 dias e compensação de retorno em 12 meses, em função de áreas externas, anfiteatro e minisshopping, para 200 residentes .....

Apêndice 279 - Valor médio da mensalidade final, com crédito médio de 1,40\% sobre o valor do investimento, para construção em 90 dias e compensação de retorno em 12 meses, em função de áreas externas, anfiteatro e minisshopping, para 300 residentes 343

Apêndice 280 - Valor médio da mensalidade final, com crédito médio de 1,40\% sobre o valor do investimento, para construção em 90 dias e compensação de retorno em 12 meses, em função de áreas externas, anfiteatro e minisshopping, para 400 residentes

Apêndice 281 - Valor médio da mensalidade final, com crédito médio de 1,50\% sobre o valor do investimento, para construção em 90 dias e compensação de retorno em 12 meses, em função de áreas externas, anfiteatro e minisshopping, para 100 residentes 344

Apêndice 282 - Valor médio da mensalidade final, com crédito médio de 1,50\% sobre o valor do investimento, para construção em 90 dias e compensação de retorno em 12 meses, em função de áreas externas, anfiteatro e minisshopping, para 200 residentes 344

Apêndice 283 - Valor médio da mensalidade final, com crédito médio de 1,50\% sobre o valor do investimento, para construção em 90 dias e compensação de retorno em 12 meses, em função de áreas externas, anfiteatro e minisshopping, para 300 residentes 344 Apêndice 284 - Valor médio da mensalidade final, com crédito médio de 1,50\% sobre o valor do investimento, para construção em 90 dias e compensação de retorno em 12 meses, em função de áreas externas, anfiteatro e minisshopping, para 400 residentes....

Apêndice 285 - Valor médio da mensalidade final, com crédito médio de 1,10\% sobre o valor do investimento, para construção em 90 dias e compensação de retorno em 24 meses, em função de áreas externas, anfiteatro e minisshopping, para 100 residentes... 345

Apêndice 286 - Valor médio da mensalidade final, com crédito médio de 1,10\% sobre o valor do investimento, para construção em 90 dias e compensação de retorno em 24 meses, em função de áreas externas, anfiteatro e minisshopping, para 200 residentes 345 Apêndice 287 - Valor médio da mensalidade final, com crédito médio de 1,10\% sobre o valor do investimento, para construção em 90 dias e compensação de retorno em 24 meses, em função de áreas externas, anfiteatro e minisshopping, para 300 residentes ..... 346 Apêndice 288 - Valor médio da mensalidade final, com crédito médio de 1,10\% sobre o valor do investimento, para construção em 90 dias e compensação de retorno em 24 meses, em função de áreas externas, anfiteatro e minisshopping, para 400 residentes.... 346

Apêndice 289 - Valor médio da mensalidade final, com crédito médio de 1,20\% sobre o valor do investimento, para construção em 90 dias e compensação de retorno em 24 meses, em função de áreas externas, anfiteatro e minisshopping, para 100 residentes 346 Apêndice 290 - Valor médio da mensalidade final, com crédito médio de 1,20\% sobre o valor do investimento, para construção em 90 dias e compensação de retorno em 24 meses, em função de áreas externas, anfiteatro e minisshopping, para 200 residentes. 
Apêndice 291 - Valor médio da mensalidade final, com crédito médio de 1,20\% sobre o valor do investimento, para construção em 90 dias e compensação de retorno em 24 meses, em função de áreas externas, anfiteatro e minisshopping, para 300 residentes....

Apêndice 292 - Valor médio da mensalidade final, com crédito médio de 1,20\% sobre o valor do investimento, para construção em 90 dias e compensação de retorno em 24 meses, em função de áreas externas, anfiteatro e minisshopping, para 400 residentes

Apêndice 293 - Valor médio da mensalidade final, com crédito médio de 1,30\% sobre o valor do investimento, para construção em 90 dias e compensação de retorno em 24 meses, em função de áreas externas, anfiteatro e minisshopping, para 100 residentes ..... 348

Apêndice 294 - Valor médio da mensalidade final, com crédito médio de 1,30\% sobre o valor do investimento, para construção em 90 dias e compensação de retorno em 24 meses, em função de áreas externas, anfiteatro e minisshopping, para 200 residentes ...........................348

Apêndice 295 - Valor médio da mensalidade final, com crédito médio de 1,30\% sobre o valor do investimento, para construção em 90 dias e compensação de retorno em 24 meses, em função de áreas externas, anfiteatro e minisshopping, para 300 residentes 348

Apêndice 296 - Valor médio da mensalidade final, com crédito médio de 1,30\% sobre o valor do investimento, para construção em 90 dias e compensação de retorno em 24 meses, em função de áreas externas, anfiteatro e minisshopping, para 400 residentes 349

Apêndice 297 - Valor médio da mensalidade final, com crédito médio de 1,40\% sobre o valor do investimento, para construção em 90 dias e compensação de retorno em 24 meses, em função de áreas externas, anfiteatro e minisshopping, para 100 residentes .... 349

Apêndice 298 - Valor médio da mensalidade final, com crédito médio de 1,40\% sobre o valor do investimento, para construção em 90 dias e compensação de retorno em 24 meses, em função de áreas externas, anfiteatro e minisshopping, para 200 residentes

Apêndice 299 - Valor médio da mensalidade final, com crédito médio de 1,40\% sobre o valor do investimento, para construção em 90 dias e compensação de retorno em 24 meses, em função de áreas externas, anfiteatro e minisshopping, para 300 residentes.

Apêndice 300 - Valor médio da mensalidade final, com crédito médio de 1,40\% sobre o valor do investimento, para construção em 90 dias e compensação de retorno em 24 meses, em função de áreas externas, anfiteatro e minisshopping, para 400 residentes....

Apêndice 301 - Valor médio da mensalidade final, com crédito médio de 1,50\% sobre o valor do investimento, para construção em 90 dias e compensação de retorno em 24 meses, em função de áreas externas, anfiteatro e minisshopping, para 100 residentes 350

Apêndice 302 - Valor médio da mensalidade final, com crédito médio de 1,50\% sobre o valor do investimento, para construção em 90 dias e compensação de retorno em 24 meses, em função de áreas externas, anfiteatro e minisshopping, para 200 residentes

Apêndice 303 - Valor médio da mensalidade final, com crédito médio de 1,50\% sobre o valor do investimento, para construção em 90 dias e compensação de retorno em 24 meses, em função de áreas externas, anfiteatro e minisshopping, para 300 residentes....

Apêndice 304 - Valor médio da mensalidade final, com crédito médio de 1,50\% sobre o valor do investimento, para construção em 90 dias e compensação de retorno em 24 meses, em função de áreas externas, anfiteatro e minisshopping, para 400 residentes ....

Apêndice 305 - Variação do investimento inicial em função do número de habitações e áreas externas construídas.... 352

Apêndice 306 - Valor médio da mensalidade com simulação do nível de utilização da capacidade instalada entre 20 e $90 \%$, para 100 residentes 353 
Apêndice 307 - Valor médio da mensalidade com simulação do nível de utilização da

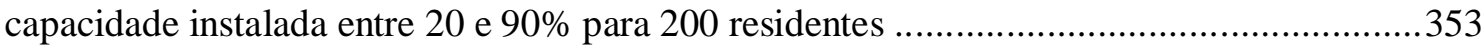

Apêndice 308 - Valor médio da mensalidade com simulação do nível de utilização da capacidade instalada entre 20 e $90 \%$ para 300 residentes ................................................354

Apêndice 309 - Valor médio da mensalidade com simulação do nível de utilização da

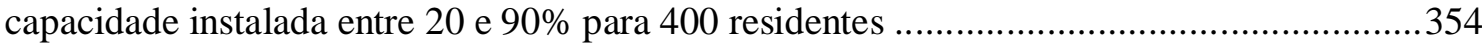

Apêndice 310 - Taxa Interna de Retorno, TIR, para aquisição de quotas a R \$ 89.021, locação da habitação de 6 a 300 meses e nível de utilização da capacidade instala de 45\% a 100\%..355

Apêndice 311 - Questionário 


\section{Apêndice 1 - Plano de Negócio ${ }^{\dagger}$}

\section{Sumário Executivo}

A população brasileira está envelhecendo. De 18,0 milhões de brasileiros com mais de 60 anos em 2008, espera-se que chegue a 64,1 milhões em 2050. A população com mais de 80 anos deve passar de 2,4 para 13,7 milhões no mesmo período.

Um assalariado pode se preparar para a aposentadoria através da previdência social, de previdência complementar, poupança, compra de ativos para locação ou venda futura. Como uma parte dos recursos será utilizada para moradia e alimentação, este Plano de Negócios detalha um Ambiente Residencial Especial. Uma pessoa pode adquirir o direito de uso comprando quotas.

Uma determinada quantidade de quotas, que pode ser adquirida à vista ou a prazo, dá direito a duas pessoas residirem na organização. As quotas não dão direito às despesas de alimentação, limpeza, higienização de roupas, etc. Contudo, enquanto o proprietário ou pessoa indicada por ele não utilizar as acomodações, o dormitório pode ser locado para residentes não proprietários. $\mathrm{O}$ valor da locação cobre os custos, a taxa de administração e gera um crédito para o proprietário. Dependendo do tempo que o dormitório ficar locado, os créditos podem cobrir vários meses ou anos das despesas futuras do quotista.

A organização será gerida por um conselho formado pelos proprietários que deverá assegurar perenidade institucional, autossustentabilidade financeira, qualidade de vida, satisfação pessoal e conforto espiritual para os residentes.

A primeira etapa da organização será instalada na região metropolitana de São Paulo, em uma área total de $7.600 \mathrm{~m}^{2}$. A construção comportará 100 dormitórios mobiliados para até 200 residentes, com áreas de convivência, lazer, salas de fitness, lanhouse, jogos, leitura, anfiteatro, restaurante e toda a estrutura necessária para moradia.

\footnotetext{
${ }^{\dagger}$ ABRAMS, 2000, adaptado pelo autor.
} 


\section{Descrição da Empresa}

Estima-se que a população brasileira deva passar de 191,9 milhões no ano de 2008 para 259,8 milhões em 2050. O crescimento se dará principalmente entre os adultos com maior faixa etária, ou seja, haverá um envelhecimento da população. Pessoas com 60 anos ou mais, consideradas idosas pela legislação brasileira, devem passar de 18,0 para 64,1 milhões no mesmo período indicado acima. A população com 80 anos ou mais, de 2,4 milhões em 2008 é estimada em 13,7 milhões também em 2050. Em 2008, o Brasil tem um idoso com mais de 80 anos para cada 7,6 jovens de até quatro anos; em 2050 estima-se que esta relação passará para 1,1. Ainda no período 2008-2050 estima-se que a população com menos de 30 anos decrescerá; no total devem passar de 103,8 para 95,8 milhões de habitantes.

Com mais idosos e uma população jovem menor surgem reflexões; uma delas é como se preparar para a aposentadoria. Existem teorias que buscam explicar os fatores motivadores da poupança. Um deles é se preparar para a fase da vida quando deixam de trabalhar formalmente. Uma forma de poupar é através de aplicação de recursos no mercado financeiro. Outra opção é a compra de ativos, como imóveis, para venda futura ou remuneração através de aluguel.

A previdência social é uma poupança compulsória do trabalhador formal. Contudo, tem-se mostrado incapaz de proporcionar segurança aos contribuintes que se tornarão beneficiários em um momento futuro. Uma opção para complementar os rendimentos futuros é a previdência privada. Contudo, trata-se de um setor que está enfrentando crises em nível mundial e proporcionando incertezas ao investidor.

Quando uma pessoa se aposenta, uma parte dos recursos é utilizada em moradia e alimentação. Assim, este Plano de Negócio apresenta uma organização, denominada Ambiente Residencial Especial, que oferece esses serviços para uso futuro. Nessa instituição podem residir pessoas com menos de 60 anos, ou seja, não se trata de uma organização que atende somente idosos.

A organização será estruturada a partir do ingresso de proprietários que adquirem quotas de utilização futura. As acomodações não utilizadas serão locadas para residentes não proprietários. Parte da mensalidade desses residentes será utilizada com o objetivo de cobrir 
os desembolsos operacionais e o excedente é creditado aos quotistas para abaterem suas mensalidades quando passarem a residir na organização.

\section{Missão}

- Oferecer um Ambiente Residencial Especial, através de um modelo de autogestão, que disponibilize moradia, alimentação, atividades de lazer e convivência;

- Assegurar perenidade institucional e autossustentabilidade financeira;

- Proporcionar ao residente qualidade de vida, satisfação pessoal e conforto espiritual;

- Estabelecer um porte de organização que priorize qualidade no atendimento ao residente;

\section{Formato Jurídico}

O Ambiente Residencial Especial será constituído como Pessoa Jurídica de Direito Privado, em forma de Sociedade Civil sem Fim Lucrativo, enquadrada como OSCIP - Organização da Sociedade Civil de Interesse Público e instituição de Utilidade Pública nas esferas federal, estadual e municipal.

\section{Tributação}

Por não distribuir lucro e não ter finalidade econômica será isenta de Imposto de Renda Pessoa Jurídica, apesar de ser obrigada a apresentar a Declaração de Ajuste Anual.

Em relação ao ISSQN, Imposto Sobre Serviço de Qualquer Natureza, será solicitada isenção junto à Secretaria de Finanças do município.

Há incidência de 3\% de Cofins, Contribuição para o Financiamento da Seguridade Social, sobre as receitas brutas advindas das mensalidades. Apesar de se tratar de um tributo controverso, o mesmo é regido pelo Art. 47 da Instrução Normativa SRF no 247, de 21 de novembro de 2002.

Os encargos trabalhistas que a organização deve pagar sobre a folha de pagamento são os seguintes:

- Sobre o salário nominal:

○ FGTS: $8,0 \%$; 
- INSS: $20 \%$

○ Férias: $8,3 \%$ ou $1 / 12$;

- Abono de férias: $2,7 \%$ ou $1 / 3$ de $1 / 12$;

○ Entidades de classe: $5,8 \%$

- Seguro de acidentes de trabalho: 1 a $3 \%$

- Indenização a ser paga no caso de dispensa do funcionário sem justa causa: $100 \%$ de um salário nominal, $40 \%$ + 10\% sobre o saldo do FGTS;

\section{Localidade}

A organização será sediada na região metropolitana de São Paulo, em uma área de aproximadamente $7.600 \mathrm{~m}^{2}$.

\section{Serviços}

A instituição oferece serviços de residência com cinco refeições diárias, roupas de cama e banho, higienização das mesmas e de roupas pessoais, atividades de lazer, visitas médicas semanais, cuidadores e auxiliar de enfermagem 24 horas por dia.

\section{Análise e Tendência do Setor}

A instituição enquadra-se no setor de serviços. Na Classificação Nacional de Atividades Econômicas, CNAE, está delineada na seção Q, Saúde Humana e Serviços Sociais, Divisão 87, Atividades de Atenção à Saúde Humana Integradas com Assistência Social, Prestadas em Residências Coletivas e Particulares. Como residirão idosos e pessoas com menos de 60 anos, o enquadramento ocorre no Grupo 87.3, Atividade de Assistência Social Prestadas em Residências Coletivas e Particulares, Classe 87.30-1.

Em função do envelhecimento da população brasileira, o crescimento do setor será bastante representativo nos próximos anos. Na Tabela 119 (p. 207) pode-se observar o crescimento por faixa etária. Para pessoas com 80 anos ou mais, por exemplo, estima-se um crescimento de $470,5 \%$ de 2008 a 2050.

A população com 50 anos ou mais tem seu crescimento até 2050 representado na Tabela 120 (p. 207). Pode-se comparar o crescimento da população com o produto interno bruto, PIB, através da Tabela 121 (p. 207) e Gráfico 19 (p. 208). 
Tabela 119 - Estimativa da população brasileira, com 50 anos ou mais, de 2008 a 2050, com variações percentuais base 2008

\begin{tabular}{crrrrrrrrrrr}
\hline \multirow{2}{*}{ Idade } & \multicolumn{1}{c}{ 2008 } & \multicolumn{2}{c}{ 2010 } & \multicolumn{2}{c}{ 2020} & \multicolumn{2}{c}{ 2030 } & \multicolumn{2}{c}{ 2040 } & \multicolumn{2}{c}{ 2050 } \\
\cline { 2 - 12 } & População População & Var \% & População & Var \% & População & Var \% & População & Var \% & População Var \% & Pary \\
\hline $50-54$ & 9.399 & 10.151 & $8,0 \%$ & 12.645 & $34,5 \%$ & 14.646 & $55,8 \%$ & 16.164 & $72,0 \%$ & 15.985 & $70,1 \%$ \\
$55-59$ & 7.347 & 7.974 & $8,5 \%$ & 11.527 & $56,9 \%$ & 12.765 & $73,7 \%$ & 16.078 & $118,8 \%$ & 15.023 & $104,5 \%$ \\
\hline $50-59$ & 16.746 & 18.125 & $8,2 \%$ & 24.172 & $44,3 \%$ & 27.411 & $63,7 \%$ & 32.242 & $92,5 \%$ & 31.008 & $85,2 \%$ \\
\hline $60-64$ & 5.607 & 6.088 & $8,6 \%$ & 9.197 & $64,0 \%$ & 11.619 & $107,2 \%$ & 13.615 & $142,8 \%$ & 15.152 & $170,2 \%$ \\
$65-69$ & 4.381 & 4.581 & $4,6 \%$ & 6.904 & $57,6 \%$ & 10.175 & $132,3 \%$ & 11.433 & $161,0 \%$ & 14.570 & $232,6 \%$ \\
$70-74$ & 3.333 & 3.586 & $7,6 \%$ & 4.911 & $47,3 \%$ & 7.615 & $128,5 \%$ & 9.801 & $194,1 \%$ & 11.669 & $250,1 \%$ \\
$75-79$ & 2.254 & 2.374 & $5,3 \%$ & 3.304 & $46,6 \%$ & 5.152 & $128,6 \%$ & 7.787 & $245,5 \%$ & 8.911 & $295,3 \%$ \\
$80+$ & 2.410 & 2.653 & $10,1 \%$ & 4.006 & $66,2 \%$ & 5.912 & $145,3 \%$ & 9.420 & $290,9 \%$ & 13.749 & $470,5 \%$ \\
\hline $60+$ & 17.985 & 19.282 & $7,2 \%$ & 28.322 & $57,5 \%$ & 40.473 & $125,0 \%$ & 52.056 & $189,4 \%$ & 64.051 & $256,1 \%$ \\
$50+$ & 34.731 & 37.407 & $7,7 \%$ & 52.494 & $51,1 \%$ & 67.884 & $95,5 \%$ & 84.298 & $142,7 \%$ & 95.059 & $173,7 \%$ \\
\hline
\end{tabular}

FONTE: IBGE, 2007c.

Tabela 120 - População brasileira com 50 anos ou mais - crescimento médio anual por faixa etária - 20082050

\begin{tabular}{cc}
\hline Idade & Crescimento \\
\hline $50-54$ & $1,27 \%$ \\
$55-59$ & $1,72 \%$ \\
\hline $50-59$ & $1,48 \%$ \\
\hline $60-64$ & $2,40 \%$ \\
$65-69$ & $2,90 \%$ \\
$70-74$ & $3,03 \%$ \\
$75-79$ & $3,33 \%$ \\
$80+$ & $4,23 \%$ \\
\hline $60+$ & $3,07 \%$ \\
$50+$ & $2,43 \%$ \\
\hline
\end{tabular}

FONTE: IBGE, 2007c, adaptado pelo autor.

Tabela 121 - Produto interno bruto (PIB) brasileiro - crescimento anual - 1948-2007

\begin{tabular}{cccccccc}
\hline Ano & $\begin{array}{c}\text { Crescimento } \\
\text { do PIB }\end{array}$ & Ano & $\begin{array}{c}\text { Crescimento } \\
\text { do PIB }\end{array}$ & Ano & $\begin{array}{c}\text { Crescimento } \\
\text { do PIB }\end{array}$ & Ano & $\begin{array}{c}\text { Crescimento } \\
\text { do PIB }\end{array}$ \\
\hline 1948 & 8,70 & 1963 & 1,99 & 1978 & 5,86 & 1993 & 5,38 \\
1949 & 7,25 & 1964 & 2,90 & 1979 & 7,99 & 1994 & 5,03 \\
1950 & 5,85 & 1965 & 4,53 & 1980 & 2,24 & 1995 & 3,44 \\
1951 & 6,09 & 1966 & 5,44 & 1981 & $-1,78$ & 1996 & 2,96 \\
1952 & 5,99 & 1967 & 6,96 & 1982 & $-1,07$ & 1997 & 1,73 \\
1953 & 6,24 & 1968 & 9,65 & 1983 & 1,16 & 1998 & 0,50 \\
1954 & 8,30 & 1969 & 9,95 & 1984 & 6,59 & 1999 & 2,53 \\
1955 & 5,81 & 1970 & 10,87 & 1985 & 7,65 & 2000 & 2,80 \\
1956 & 5,27 & 1971 & 11,64 & 1986 & 5,48 & 2001 & 1,98 \\
1957 & 9,24 & 1972 & 12,95 & 1987 & 1,68 & 2002 & 1,90 \\
1958 & 10,30 & 1973 & 11,02 & 1988 & 1,54 & 2003 & 3,40 \\
1959 & 9,60 & 1974 & 6,65 & 1989 & $-0,62$ & 2004 & 4,43 \\
1960 & 9,00 & 1975 & 7,68 & 1990 & $-1,67$ & 2005 & 3,58 \\
1961 & 7,60 & 1976 & 7,56 & 1991 & 0,24 & $2006 *$ & 3,80 \\
1962 & 3,56 & 1977 & 4,95 & 1992 & 2,15 & $2007 *$ & 5,40 \\
\hline
\end{tabular}

FONTE: IBGE, 2008g; * IBGE, $2008 \mathrm{f}$. 


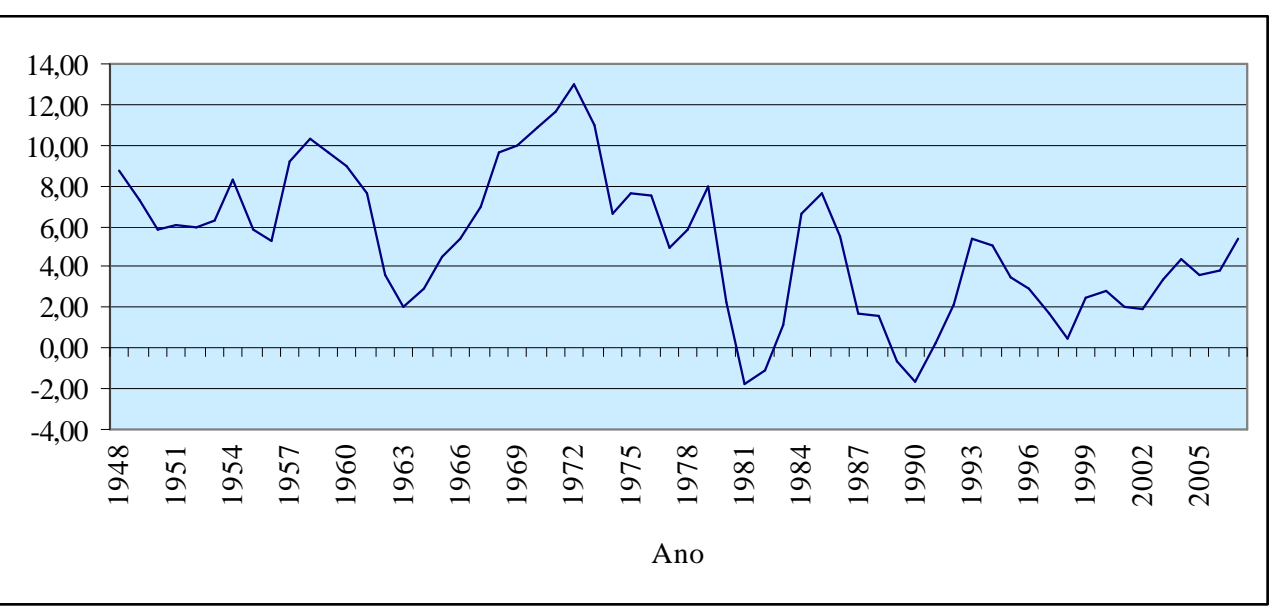

Gráfico 19 - Produto interno bruto (PIB) brasileiro - crescimento anual - 1948-2007

FONTE: IBGE, 2008f; IBGE, 2008g, adaptado pelo autor.

\section{Grau de Maturidade do Setor}

O estágio de desenvolvimento do setor de assistência social prestada em residências coletivas e particulares é considerado em expansão. Com isso, a taxa de crescimento é elevada, a concorrência está em fase de organização para atender as novas demandas e os líderes estão em formação.

Quanto às metas de marketing é necessário buscar uma diferenciação em relação aos concorrentes para conquistar participação de mercado. Os serviços oferecidos estão em fase de diversificação e os clientes devem ser fidelizados neste estágio.

\section{Sensibilidade aos Ciclos Econômicos}

Quotas adquiridas não geram custo para o proprietário. Quanto mais tempo o usufrutuário permanecer com a quota sem utilizar as dependências da instituição, maiores serão os créditos gerados pela locação dos dormitórios. Assim, a organização é pouco sensível aos ciclos econômicos em relação aos proprietários.

Contudo, a instituição é sensível a crises econômicas em relação aos residentes não proprietários, pois os mesmos desembolsam valores mensais.

\section{Sazonalidade e Tecnologia}

Em geral, os residentes permanecem por longos períodos de tempo, o que descaracteriza eventuais períodos com maior ou menor procura por acomodações. 
A instituição lida basicamente com mão-de-obra, o que diminui bastante a necessidade de pesquisa em busca de novas tecnologias.

\section{Regulação}

Principalmente em função do Estatuto do Idoso, esse tipo de organização é bastante regulado pelo governo. Os principais órgãos que atuam no setor é o Ministério da Saúde, através da Portaria $n^{\circ}$ 810, de 22 de setembro de 1989 e a Anvisa, Agência Nacional de Vigilância Sanitária, através da Resolução da Diretoria Colegiada-RDC/ANVISA no 283, de 26 de setembro de 2005 .

\section{Mercado Alvo}

As quotas de utilização futura do Ambiente Residencial Especial destinam-se a qualquer pessoa, com qualquer idade, que deseje assegurar qualidade de vida, satisfação pessoal e conforto espiritual para si ou para um familiar.

Em relação aos serviços oferecidos para residentes não proprietários, os mercados alvos são idosos, pessoas com necessidades especiais ou que desejem morar em um ambiente residencial que ofereça serviços de moradia, alimentação, esporte e lazer.

A renda do mercado alvo, tanto para aquisição de quotas quanto para os residentes não proprietários, situa-se nas faixas A e B.

Em relação à ocupação, o residente pode trabalhar ou estar aposentado. Quanto ao estado conjugal, o mesmo pode ser casado, solteiro ou viúvo. Os dormitórios possuem dois ambientes que podem ser dois quartos ou quarto e sala. Para marido e mulher, o quarto acomoda cama de casal. Para pai e filho, por exemplo, pode-se montar uma cama em cada quarto.

\section{Características Físicas}

A organização será edificada em um terreno de $7.600 \mathrm{~m}^{2}$ com uma área construída de $5.400 \mathrm{~m}^{2}$. Os dormitórios padrões possuem $37,9 \mathrm{~m}^{2}$ e os que atendem pessoas que necessitam de cadeira de rodas, aqui denominados dormitórios ampliados, $54,4 \mathrm{~m}^{2}$. Em ambos a área de circulação (corredores, por exemplo) foi considerada. Ao todo serão 80 habitações padrões e 20 
ampliados, totalizando $4.120 \mathrm{~m}^{2}$. Para viabilizar financeiramente a organização, ela deve iniciar suas atividades com um nível de aproveitamento da capacidade instalada de $70 \%$.

Os dormitórios serão mobiliados com:

- cama com colchão;

- cômoda;

- guarda-roupa de 6 portas;

- mesa com 4 cadeiras;

- $\quad$ sofá 3 lugares;

- frigobar;

- rack;

- televisor;

- minissystem;

- DVD player e

- ar condicionado.

As áreas comuns estão divididas em:

- 13 salas de convivência com $20 \mathrm{~m}^{2}$ cada, em uma área total de $260 \mathrm{~m}^{2}$, mobiliadas com:

○ 67 cadeiras;

○ 67 sofás de 1 lugar;

○ 33 sofás de 2 lugares;

- 13 salas de atividades coletivas com $15 \mathrm{~m}^{2}$ cada, em uma área total de $195 \mathrm{~m}^{2}$, divididas em:

- 2 salas de Fitness, equipadas com:

- 1 cadeira para abdominal;

- 1 arco para abdominal;

- 1 aparelho elíptico;

- 1 balança eletrônica;

- 2 bicicletas ergométricas;

- 1 estação de ginástica;

- 3 esteiras profissionais. 
○ 3 salas de atividades manuais mobiliadas com:

- 8 mesas com 4 cadeiras cada;

- material para bricolagem, pintura, artesanato, etc.

○ 3 salões de jogos com:

- 8 mesas para jogos;

- 32 cadeiras;

- 4 dominós;

- $4 \operatorname{jog} 0 \mathrm{~s} 3$ x 1 ;

- 10 carteados;

- 2 salas com mesa de sinuca.

- 3 salas de leitura mobiliadas com:

- 16 sofás de 1 lugar;

- 16 mesas com 4 cadeiras;

- 4 estantes;

- 300 livros.

- 3 restaurantes com uma área total de $200 \mathrm{~m}^{2}$, equipados com 50 mesas e 4 cadeiras para cada mesa, sendo que 1 será aberto à sociedade local através de uma porta específica e com controle de entrada e saída;

- anfiteatro com $150 \mathrm{~m}^{2}$ equipado com:

○ 120 cadeiras;

○ 1 televisor;

○ 1 computador;

○ 1 videocassete;

- 1 hometheater;

○ 1 projetor multimídia;

○ 1 tela de projeção.

- espaço ecumênico com $10 \mathrm{~m}^{2}$ e 20 cadeiras;

- ambulatório e posto médico com $12 \mathrm{~m}^{2}$ dotado de mesa, cadeiras, maca e armário;

- 2 salas de apoio com $10 \mathrm{~m}^{2}$ cada, dotadas de mesa, cadeiras, sofás de 2 e 3 lugares; 
- almoxarifado de $16 \mathrm{~m}^{2}$ com mesa, cadeiras e 10 armários de aço;

- acomodações do caseiro com $50 \mathrm{~m}^{2}$;

- 4 banheiros coletivos, separados por sexo, com um total de $14,4 \mathrm{~m}^{2}$;

- cozinha e despensa com $16 \mathrm{~m}^{2}$, equipadas com 5 armários de aço;

- lavanderia com $20 \mathrm{~m}^{2}, 2$ máquinas de lavar industrial e 6 equipamentos de passar;

- administração com $10 \mathrm{~m}^{2}$, equipada com:

- 6 mesas e cadeiras;

○ 5 computadores com softwares;

○ 2 impressoras;

○ 5 armários.

- 28 banheiros para funcionários, separados por sexo, com um total de $100,8 \mathrm{~m}^{2}$;

- vestiário para funcionários, separados por sexo, com um total de $69,5 \mathrm{~m}^{2}$, dotados de:

○ 34 armários;

○ 9 bancos.

- outras áreas: $180 \mathrm{~m}^{2}$. Uma opção é locar parte desta área para terceiros, buscando oferecer serviços de um minisshopping para os residentes, como cabeleireiro, loja de presentes, coffee-shop, etc.

\section{Concorrentes}

O consumidor acredita pouco na qualidade oferecida pelas instituições nos moldes atuais. Assim, no início, haverá pouca concorrência. Em função do crescimento do setor e da falta de barreiras de entrada, o mercado deve tornar-se acirrado nos próximos anos.

\section{Avaliação de Riscos}

O setor de serviços de moradia para idosos cresce às mesmas taxas do PIB. De 2008 a 2050 estima-se que haverá um crescimento de mais de $3 \%$ ao ano, alcançando uma taxa acumulada de $256,1 \%$. Assim, em relação a esse mercado os riscos são baixos.

Como não há barreiras de entrada, o risco em relação aos concorrentes pode ser considerado médio. Como se trata de um setor de serviços, há pouca tecnologia envolvida no processo e, consequentemente, baixo risco de defasagem tecnológica. 
Uma grande preocupação do consumidor é a qualidade dos serviços prestados pela instituição. Assim, mantendo-se um padrão de cuidados com o residente o risco em relação aos serviços prestados é baixo.

A aquisição do terreno e a construção das instalações ocorrerão quando as quotas forem vendidas. Durante a construção, o setor comercial promoverá a divulgação do empreendimento, reservando vagas para pessoas interessadas, de tal forma que o início das atividades ocorra com um número mínimo de residentes. Assim, não há risco de capitalização e não execução do projeto.

\section{Plano de Marketing}

\section{Produto}

A organização oferece quotas de utilização futura de um Ambiente Residencial Especial para qualquer pessoa, com qualquer idade, que deseje assegurar qualidade de vida, satisfação pessoal e conforto espiritual para si ou familiar.

Para residentes não proprietários, a organização disponibiliza moradia, alimentação, esporte e lazer para idosos, pessoas com necessidades especiais ou pessoas que desejem morar em um ambiente residencial especial.

Outro serviço oferecido são diárias avulsas para familiares de residentes ou pessoas que desejam conhecer a organização. Na diária, o visitante tem direito a cinco refeições e pode utilizar todos os ambientes da instituição.

\section{Preço}

Quotas no valor de R $\$ 96.000,00$ proporcionam direito a dois usufrutuários. Após o falecimento de ambos, a habitação passa a ser da instituição por doação. Sobre esse valor serão acrescidos $2 \%$ referente à comissão de venda. O preço de venda das quotas será de aproximadamente $\mathrm{R} \$ 98.000,00$.

Enquanto a habitação não for utilizada pelo comprador ou pessoa indicada por ele, a locação do mesmo para residentes não proprietários rende créditos ao quotista. Dependendo do tempo que o dormitório permanece locado para outras pessoas, os créditos podem cobrir vários anos de despesas mensais do proprietário. 
Caso um proprietário adquira quotas e logo em seguida passe a utilizar o dormitório, a mensalidade é de $\mathrm{R} \$ 3.438,00$. Este valor cobre os custo e despesas da organização.

A mensalidade dos residentes não proprietários é da ordem de $\mathrm{R} \$ 4.138,00$. Este valor, além do cobrir os custos e despesas, gera um crédito de $\mathrm{R} \$ 700,00$ para o proprietário. Como cada proprietário pode alugar sua habitação para duas pessoas, o crédito total é de $\mathrm{R} \$ 1.400,00$. A diária completa, avulsa, custa $\mathrm{R} \$ 131,00$ por pessoa.

\section{Local}

A organização estará situada na região metropolitana do Estado de São Paulo, área onde a pesquisa foi realizada. Buscar-se-á um local de fácil acesso, distante de rodovias ou avenidas de grande movimento, cercado por vegetação e pássaros.

\section{Composto de Comunicação}

Os serviços prestados pela organização destinam-se aos públicos das classes sociais A e B. Assim, a comunicação se dará através de veículos que alcancem essa faixa da população. Folhetos, site próprio, anúncios em sites dirigidos, jornais e revistas especializadas, mala direta, mailing e artigos em periódicos.

\section{Segurança}

Os serviços oferecidos pela organização têm como objetivo oferecer moradia, alimentação, roupa de cama e banho, higienização das mesmas e das roupas pessoais, esporte e lazer, com garantias de qualidade de vida.

Para o proprietário das quotas a organização disponibiliza um dormitório para até duas pessoas. Desde que não haja utilização imediata, o mesmo pode ser locado para terceiros, gerando créditos para o usufrutuário. Dependendo do tempo de locação, esses créditos podem cobrir as mensalidades por um longo período de tempo.

A segurança e a satisfação em relação aos serviços prestados são garantidas através da administração que é realizada pelos próprios quotistas. 


\section{Estrutura de Vendas}

A venda das quotas será realizada por terceiros. A comissão será de $2 \%$ sobre a unidade vendida, ou seja, $\mathrm{R} \$ 1.960,00$.

As vendas serão realizadas em um escritório central ou em visita agendada na residência da pessoa interessada. O site disponibilizará o maior número possível de informações e permitirá cadastro para contato pessoal.

\section{Mão-de-obra}

A mão-de-obra de organizações que cuidam de idosos é regulada pela Anvisa, Agência Nacional de Vigilância Sanitária. Como parte dos residentes pode ter mais de 60 anos, o número de funcionários é definido a partir da Resolução ANVISA/DC no 283 de 26 de setembro de 2005 .

O número de cuidadores depende do grau de dependência dos residentes. A previsão é de que $50 \%$ dos residentes tenham grau de dependência I, $40 \%$ grau II e $10 \%$ grau de dependência III. A organização trabalhará com um profissional, com carga horária de oito horas por dia, a cada 20 residentes grau I, um profissional com a mesma carga horária, três turnos diários, a cada 10 residentes com grau de dependência II e um profissional para cada seis residentes com grau III, também três turnos de oito horas ao dia.

Para as atividades de lazer a organização deve ter um profissional a cada 40 residentes, com uma carga horária de 20 horas por semana.

Em relação à alimentação, é necessária uma pessoa, em dois turnos de oito horas, a cada 20 residentes. Os serviços de cozinha, assim como os equipamentos necessários, são terceirizados.

Para a lavanderia é necessário um profissional a cada 30 residentes. Em relação às atividades de limpeza define-se uma pessoa para cada $100 \mathrm{~m}^{2}$ de área construída.

A organização conta com um médico, um auxiliar de enfermagem por turno de oito horas, um coordenador técnico e um caseiro. 


\section{Capacidade}

As habitações foram projetadas para comportar dois dormitórios ou um dormitório e uma sala. Dependendo da forma de utilização dos mesmos, o limite da capacidade instalada é de 200 residentes. As áreas comuns e os recursos humanos foram dimensionados para 200 pessoas.

\section{Gestão e Organização}

A gestão da organização se dá principalmente pela atuação dos proprietários. Estes garantem a qualidade de vida dos residentes atuais para, no momento que eles passarem a residir na instituição, terem a atenção dos proprietários que estiverem administrando na oportunidade.

Com 100 habitações, a organização tem uma estrutura enxuta. Em primeiro lugar, a Assembléia Geral dos Proprietários zela pela perpetuidade da instituição, em que cada quota dá direito a um voto.

O Conselho de Administração é formado por membros internos e externos. Os internos são proprietários e os externos são pessoas da sociedade comprometidas com o assunto. $\mathrm{O}$ objetivo desse Conselho é cuidar das diretrizes votadas na Assembléia Geral dos Proprietários. Os membros do Conselho não são remunerados, pois são proprietários zelando pelo seu próprio bem-estar futuro.

Os comitês, formados por quotista, têm funções específicas em relações aos temas. Nenhum dos membros é remunerado.

Nos quatro primeiros anos, a Diretoria Executiva será exercida por um profissional remunerado, auxiliado na gestão por um assistente financeiro, um administrativo, um de recursos humanos e um assistente social (Ilustração 12, p. 217).

\section{Responsabilidade Social}

Em termos de responsabilidade social, a organização será construída com aproveitamento da água de chuva para limpeza do piso, água de banho para abastecimento dos vasos sanitários e aquecimento solar.

Com o término da utilização do dormitório pelas pessoas indicadas pelo proprietário, o mesmo volta a ser da organização por doação. Esta poderá vender novamente esta quota. Em 
função do tempo e do número de unidades que voltam a ser propriedade da instituição, ela oferecerá abrigo para pessoas carentes.

A organização oferecerá vaga para estagiários em conformidade com a legislação vigente.

Por meio das salas de atividades coletivas e do restaurante, a organização buscará a integração dos familiares e da sociedade.

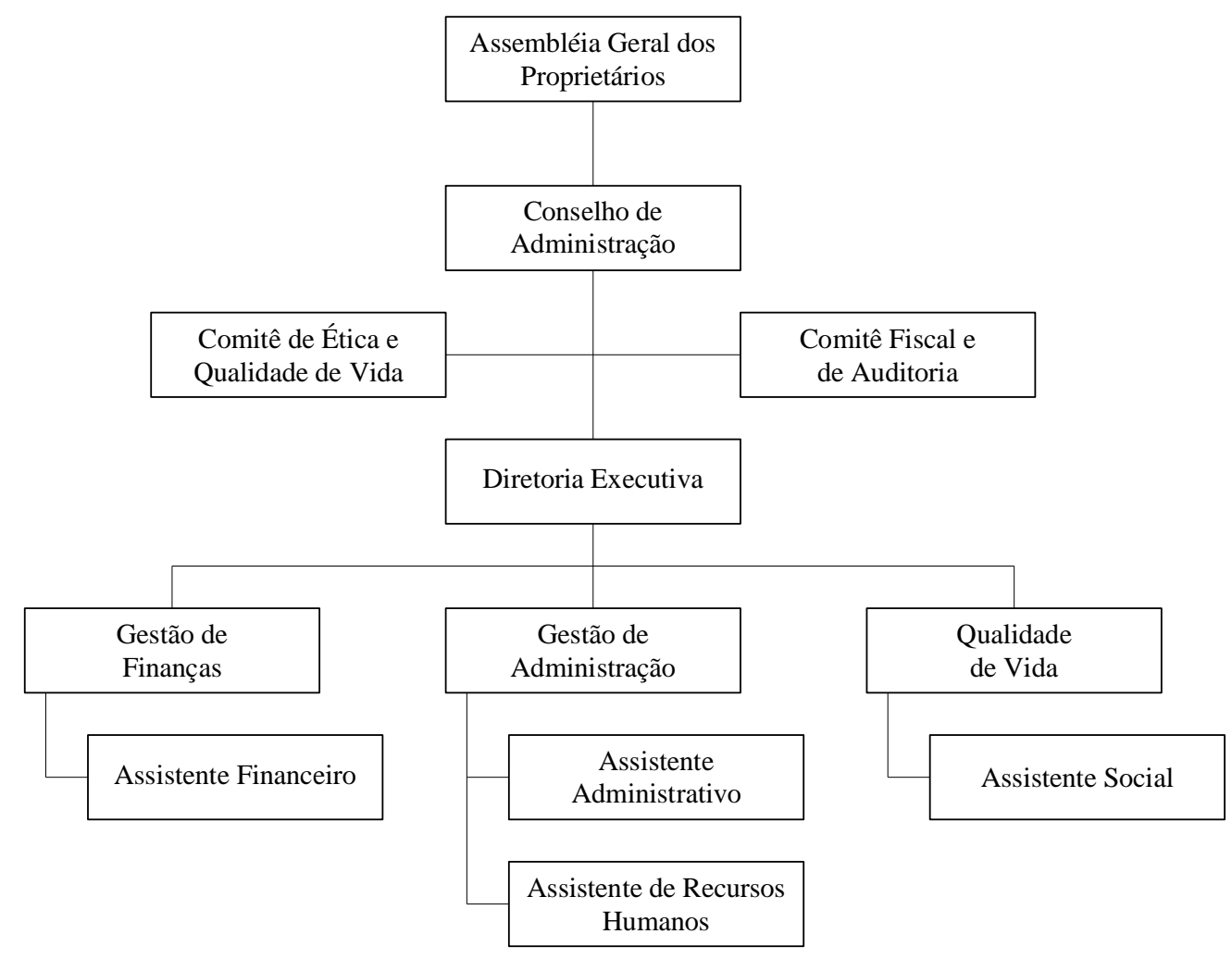

Ilustração 12 - Estrutura organizacional

\section{Metas}

A meta para o longo prazo é a construção de mais três unidades. Uma no campo, uma na montanha e a terceira na praia. Essas unidades serão projetadas com lazer externo compatível com a região. O objetivo é o aumento da qualidade de vida para os residentes com acomodação e lazer para seus familiares em dias de visita.

Será oferecida acomodação para pessoas que desejam conhecer a organização ou pequenos grupos que estejam buscando momentos de tranquilidade. 


\section{Finanças}

\section{Investimento}

O investimento, calculado para 100 habitações que comportam até 200 residentes, é de $\mathrm{R} \$$ 9.526.943,00. A venda deve ser total e para o início das atividades é necessário um mínimo de 140 residentes

A área necessária depende do número de residentes e do número de funcionários. O número total de funcionários depende do número de residentes. As áreas internas e externas estão representadas da Tabela 122 (p. 218) à Tabela 127 (p. 219).

Tabela 122 - Número de funcionários para 100 habitações

\begin{tabular}{|c|c|c|c|c|c|c|c|}
\hline \multirow{3}{*}{ Profissionais } & & \multirow{3}{*}{$\begin{array}{l}1 \text { Profissional } \\
\text { para cada "n" } \\
\text { residentes }\end{array}$} & \multirow{3}{*}{$\begin{array}{c}1 \text { Profissional } \\
\text { para cada } \\
\text { "n" m }\end{array}$} & \multirow{3}{*}{ Turnos } & \multicolumn{3}{|c|}{ Número de profissionais } \\
\hline & & & & & \multirow[b]{2}{*}{ Total } & \multicolumn{2}{|c|}{ Período diurno } \\
\hline & & & & & & Total & $\begin{array}{c}\text { Contra- } \\
\text { tados }\end{array}$ \\
\hline \multirow{3}{*}{$\begin{array}{l}\text { Cuidadores para residentes com } \\
\text { grau de dependência }\end{array}$} & $\mathbf{I}$ & 20 & & 1 & 5 & 5 & 5 \\
\hline & II & 10 & & 3 & 24 & 8 & 8 \\
\hline & III & 6 & & 3 & 9 & 3 & 3 \\
\hline Atividades de lazer & & 40 & & 1 & 5 & 5 & 5 \\
\hline Alimentação (terceirizada) & & 20 & & 2 & 10 & 5 & - \\
\hline Lavanderia & & 30 & & 1 & 7 & 7 & 7 \\
\hline Médico & & 100 & & 1 & 2 & 2 & 2 \\
\hline Auxiliar de enfermagem & & 100 & & 3 & 6 & 2 & 2 \\
\hline \multicolumn{2}{|l|}{ Serviços de limpeza - área interna } & & 100 & 1 & 54 & 54 & 54 \\
\hline \multicolumn{2}{|l|}{ Serviços de limpeza - área externa } & & 200 & 1 & 11 & 11 & 11 \\
\hline \multicolumn{2}{|l|}{ Jardineiro - área externa } & & 300 & 1 & 7 & 7 & 7 \\
\hline \multicolumn{2}{|l|}{ Vigia - área externa } & & 500 & 1 & 4 & 4 & 4 \\
\hline \multicolumn{2}{|l|}{ Ajudante geral - área total } & & 500 & 1 & 15 & 15 & 15 \\
\hline \multicolumn{2}{|l|}{ Caseiro } & & & 1 & 1 & 1 & 1 \\
\hline \multicolumn{2}{|l|}{ Administração } & & & 1 & 7 & 7 & 7 \\
\hline \multicolumn{2}{|l|}{ Total } & & & & 167 & 136 & 131 \\
\hline
\end{tabular}

Tabela 123 - Área para 100 habitações, sendo $20 \%$ delas para cadeirantes

\begin{tabular}{lccc}
\hline \multicolumn{1}{c}{ Habitação } & Quantidade & $\mathbf{~ m}^{\mathbf{2}}$ & Área Total \\
\hline Padrão & 80 & 37,9 & 3.032 \\
Extendida & 20 & 54,4 & 1.088 \\
\hline Total & & & $\mathbf{4 . 1 2 0}$ \\
\hline
\end{tabular}

Tabela 124 - Área das salas de atividades coletivas, convivência, refeitório e lavanderia para 100 habitações

\begin{tabular}{lcccc}
\hline \multicolumn{1}{c}{ Descrição } & $\begin{array}{c}\text { Número de } \\
\text { residentes }\end{array}$ & $\begin{array}{c}\text { m2 por } \\
\text { residente }\end{array}$ & $\begin{array}{c}\text { Número de } \\
\text { residentes por } \\
\mathbf{m}^{\mathbf{2}}\end{array}$ & Área Total \\
\hline $\begin{array}{l}\text { Ambientes para residentes com grau de } \\
\text { dependência I e II }\end{array}$ & & & & \\
$\quad$ Sala para atividades coletivas & 180 & 1 & & 234 \\
$\quad$ Sala de convivência & 180 & 1,3 & 200 \\
Refeitório & 200 & 1 & 10 & 20 \\
Lavanderia & 200 & & & $\mathbf{6 3 4}$ \\
\hline Total & & & \\
\hline
\end{tabular}


Tabela 125 - Área de ambientes secundários para 100 habitações

\begin{tabular}{lccc}
\hline \multicolumn{1}{c}{ Descrição } & Quantidade & $\mathbf{m}^{\mathbf{2}}$ & Área Total \\
\hline Sala de apoio individual & 2 & 20 & 40 \\
Banheiros coletivos, separados por sexo & 2 & 7,2 & 14 \\
Espaço ecumênico & 1 & 10 & 10 \\
Sala administrativa / reunião & 1 & 10 & 10 \\
Cozinha e despensa & 1 & 16 & 16 \\
Almoxarifado & 1 & 16 & 16 \\
Ambulatório & 1 & 4 & 4 \\
Posto médico & 2 & 4 & 8 \\
Minisshopping & 1 & 180 & 180 \\
Anfiteatro & 1 & 150 & 150 \\
\hline Total & & & $\mathbf{4 4 8}$ \\
\hline
\end{tabular}

Tabela 126 - Área para banheiros, vestiários e alojamento do caseiro para 100 habitações

\begin{tabular}{lccccc}
\hline \multicolumn{1}{c}{ Descrição } & $\begin{array}{c}\text { Número de } \\
\text { funcionários }\end{array}$ & $\begin{array}{c}\mathbf{1} \text { unidade para } \\
\text { cada "n" } \\
\text { funcionários }\end{array}$ & $\begin{array}{c}\mathbf{m}^{\mathbf{2}} \text { por } \\
\text { unidade }\end{array}$ & $\begin{array}{c}\mathbf{m}^{\mathbf{2}} \text { por } \\
\text { funcionário }\end{array}$ & Área Total \\
\hline Banheiro separado por sexo & 150 & 10 & 7,2 & 0,5 & 108 \\
Vestiário separado por sexo & 150 & & & 50 & 50 \\
Alojamento do caseiro & 1 & & & & $\mathbf{2 3 3}$ \\
\hline Total & & & & \\
\hline
\end{tabular}

Tabela 127 - Área interna, externa e total para 100 habitações

\begin{tabular}{lc}
\hline \multicolumn{1}{c}{ Descrição } & Área Total \\
\hline Área total interna & 5.388 \\
Área total externa & 2.155 \\
Área total & 7.543 \\
\hline
\end{tabular}

Tabela 128 - Custo dos móveis e eletrodomésticos dos dormitórios

\begin{tabular}{|c|c|c|c|c|c|c|c|}
\hline \multirow{3}{*}{ Descrição } & \multirow{3}{*}{ Unidade } & \multirow{3}{*}{$\begin{array}{l}\text { Quanti- } \\
\text { dade }\end{array}$} & \multicolumn{2}{|c|}{ Custo } & \multicolumn{3}{|c|}{ Depreciação $^{1}$} \\
\hline & & & \multirow{2}{*}{$\begin{array}{c}\text { Unitário } \\
\text { (R\$) }\end{array}$} & \multirow{2}{*}{$\begin{array}{l}\text { Total } \\
\text { (R\$) }\end{array}$} & \multicolumn{2}{|c|}{ Anual } & \multirow{2}{*}{$\begin{array}{c}\text { Mensal } \\
\text { (R\$) }\end{array}$} \\
\hline & & & & & $\%^{2}$ & $\mathbf{R} \mathbf{\$}^{3}$ & \\
\hline Cama de solteiro - $1 \mathrm{~m} \times 2 \mathrm{~m}$ & Unid & 2 & 300 & 600 & $10 \%$ & 60 & 5 \\
\hline Colchão de solteiro & Unid & 2 & 200 & 400 & $10 \%$ & 40 & 3 \\
\hline Cômoda - $1 \mathrm{~m}$ x 0,4m & Unid & 2 & 300 & 600 & $10 \%$ & 60 & 5 \\
\hline Guarda roupa 6 portas $-2,4 \mathrm{~m} \times 0,50 \mathrm{~m}$ & Unid & 2 & 900 & 1.800 & $10 \%$ & 180 & 15 \\
\hline Jogo de mesa com 4 cadeiras - $1 \mathrm{~m} \times 1 \mathrm{~m}$ & $\mathrm{Jg}$ & 1 & 1.600 & 1.600 & $10 \%$ & 160 & 13 \\
\hline Sofá 3 lugares - 2,1m x 1m & Unid & 1 & 1.200 & 1.200 & $10 \%$ & 120 & 10 \\
\hline Frigobar $116 \mathbf{L}-0,48 m \times 0,52 m$ & Unid & 1 & 700 & 700 & $10 \%$ & 70 & 6 \\
\hline Rack $-1,2 \mathrm{~m} \times 0,46 \mathrm{~m}$ & Unid & 1 & 200 & 200 & $10 \%$ & 20 & 2 \\
\hline Televisor - 21" & Unid & 1 & 500 & 500 & $20 \%$ & 100 & 8 \\
\hline Minissystem & Unid & 1 & 700 & 700 & $20 \%$ & 140 & 12 \\
\hline DVD player & Unid & 1 & 200 & 200 & $20 \%$ & 40 & 3 \\
\hline Ar condicionado - frio / quente & Unid & 1 & 800 & 800 & $10 \%$ & 80 & 7 \\
\hline Total para 1 dormitório & & & & 9.300 & & 1.070 & 89 \\
\hline
\end{tabular}

${ }^{1} \mathrm{O}$ termo depreciação refere-se à diminuição do valor dos bens resultante de desgaste pelo uso, ação da natureza ou obsolescência normal (HIGUCHI et al, 2007, p. 309).

${ }^{2}$ As porcentagens lançadas atendem a Instrução Normativa SRF no 162 da Secretaria da Receita Federal (2008b).

${ }^{3}$ Para o valor anual aplica-se a porcentagem anual sobre o custo. 
O metro quadrado do terreno custa $\mathrm{R} \$ 500,00$ e o de área construída $\mathrm{R} \$ 730,00$. Arredondando a área interna para $5.400 \mathrm{~m}^{2}$ e a área total para $7.600 \mathrm{~m}^{2}$, o terreno custará $\mathrm{R} \$ 3.800 .000,00$ e a construção $\mathrm{R} \$ 3.942 .000,00$.

Cada dormitório custará $\mathrm{R} \$ 9.300,00$. Os itens e os respectivos custos estão representados na Tabela 128 (p. 219). Para 100 dormitórios, o investimento total será de R \$930.000,00.

O custo dos móveis e equipamentos das áreas comuns está listado na Tabela 129 (p. 221). O total geral soma $\mathrm{R} \$ 435.740,00$.

O custo das áreas externas está representado na Tabela 130 (p. 223) e totalizam $\mathrm{R} \$ 396.460,00$.

A soma do custo do terreno, da construção, dos móveis e eletrodomésticos dos dormitórios, dos móveis e dos equipamentos das áreas comuns perfaz $\mathrm{R} \$ 9.504 .200,00$. Este valor será arredondado para $\mathrm{R} \$ \mathbf{9 . 6 0 0 . 0 0 0 , 0 0}$ para despesas acessórias. Os detalhes podem ser observados na Tabela 131 (p. 223).

\section{Mensalidade}

Para o cálculo da mensalidade, são necessárias as seguintes informações: desembolsos com manutenção, depreciação, salários e encargos sociais, desembolsos com alimentação, energia elétrica, água e esgoto. Estas informações podem ser observadas na Tabela 134 (p. 225). A partir destes dados obtém-se um custo por residente proprietário de R \$ 3.438,00. Deve-se notar que este valor é calculado para 140 residentes, ou seja, com a organização trabalhando a $70 \%$ da capacidade instalada. 
Tabela 129 - Custo total e despesas mensais de depreciação e manutenção dos móveis e equipamentos das áreas comuns

\begin{tabular}{|c|c|c|c|c|c|c|}
\hline \multirow{3}{*}{ Descrição } & \multirow{3}{*}{ 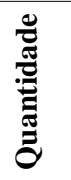 } & \multicolumn{2}{|c|}{ Custo } & \multicolumn{3}{|c|}{ Depreciação } \\
\hline & & \multirow{2}{*}{$\begin{array}{c}\text { Unitário } \\
\text { (R\$) }\end{array}$} & \multirow{2}{*}{ Total (R\$) } & \multicolumn{2}{|c|}{ Anual } & \multirow{2}{*}{$\begin{array}{c}\text { Mensal } \\
(\mathbf{R} \$)\end{array}$} \\
\hline & & & & $\%$ & $\mathbf{R} \$$ & \\
\hline \multicolumn{7}{|l|}{ Sala de Convivência } \\
\hline Cadeira & 67 & 600 & 40.200 & $10 \%$ & 4.020 & 335 \\
\hline Sofá 1 lugar & 67 & 800 & 53.600 & $10 \%$ & 5.360 & 447 \\
\hline Sofá 2 lugares & 33 & 1.000 & 33.000 & $10 \%$ & 3.300 & 275 \\
\hline Total para 13 salas & & & 126.800 & & 12.680 & 1.057 \\
\hline \multicolumn{7}{|l|}{ Sala de Fitness } \\
\hline Cadeira p/abdominal & 2 & 300 & 600 & $10 \%$ & 60 & 5 \\
\hline Arco p/abdominal & 2 & 120 & 240 & $10 \%$ & 24 & 2 \\
\hline Aparelho elíptico & 2 & 1.500 & 3.000 & $10 \%$ & 300 & 25 \\
\hline Balança eletrônica & 2 & 1.200 & 2.400 & $10 \%$ & 240 & 20 \\
\hline Bicicleta ergométrica & 4 & 1.600 & 6.400 & $10 \%$ & 640 & 53 \\
\hline Estação de ginástica & 2 & 2.000 & 4.000 & $10 \%$ & 400 & 33 \\
\hline Esteira profissional & 6 & 10.000 & 60.000 & $10 \%$ & 6.000 & 500 \\
\hline Total para 2 salas de fitness & & & 76.640 & & 7.664 & 638 \\
\hline \multicolumn{7}{|l|}{ Sala de Atividades Manuais } \\
\hline Jogo de mesa com 4 cadeiras & 8 & 600 & 4.800 & $10 \%$ & 480 & 40 \\
\hline $\begin{array}{l}\text { Material para pintura, artesanato, } \\
\text { bricolagem, etc }\end{array}$ & 1 & 1.000 & 1.000 & $10 \%$ & 100 & 8 \\
\hline Total para 3 salas de atividades manuais & & & 5.800 & & 580 & 48 \\
\hline \multicolumn{7}{|l|}{ Sala de Jogos } \\
\hline Mesas para Jogos & 8 & 250 & 2.000 & $10 \%$ & 200 & 17 \\
\hline Cadeiras & 32 & 200 & 6.400 & $10 \%$ & 640 & 53 \\
\hline Dominó & 3 & 60 & 180 & $100 \%$ & 180 & 15 \\
\hline Jogos 3x1 - xadrez, dama e gamão & 3 & 120 & 360 & $100 \%$ & 360 & 30 \\
\hline Carteado & 6 & 10 & 60 & $100 \%$ & 60 & 5 \\
\hline Total para 3 salas de jogos & & & 9.000 & & 1.440 & 120 \\
\hline \multicolumn{7}{|l|}{ Sala de Sinuca } \\
\hline Sinuca & 2 & 6.000 & 12.000 & $10 \%$ & 1.200 & 100 \\
\hline Total para 2 salas de sinuca & & & 12.000 & & 1.200 & 100 \\
\hline \multicolumn{7}{|l|}{ Sala de Leitura } \\
\hline Sofá 1 lugar & 16 & 800 & 12.800 & $10 \%$ & 1.280 & 107 \\
\hline Mesa com 4 cadeiras & 16 & 600 & 9.600 & $10 \%$ & 960 & 80 \\
\hline Estante & 4 & 2.000 & 8.000 & $10 \%$ & 800 & 67 \\
\hline Livros & 300 & 50 & 15.000 & $10 \%$ & 1.500 & 125 \\
\hline Total para 3 salas de leitura & & & 45.400 & & 4.540 & 379 \\
\hline \multicolumn{7}{|l|}{ Restaurante } \\
\hline Jogo de mesa com 4 cadeiras & 50 & 600 & 30.000 & $10 \%$ & 3.000 & 250 \\
\hline Total para 3 restaurantes & & & 30.000 & & 3.000 & 250 \\
\hline \multicolumn{7}{|l|}{ Anfiteatro } \\
\hline Cadeiras & 120 & 100 & 12.000 & $10 \%$ & 1.200 & 100 \\
\hline Televisor - 21" & 1 & 500 & 500 & $20 \%$ & 100 & 8 \\
\hline Computador & 1 & 3.000 & 3.000 & $20 \%$ & 600 & 50 \\
\hline Videocassete & 1 & 500 & 500 & $20 \%$ & 100 & 8 \\
\hline Hometheater & 1 & 600 & 600 & $20 \%$ & 120 & 10 \\
\hline Projetor multimídia & 1 & 6.000 & 6.000 & $20 \%$ & 1.200 & 100 \\
\hline Tela & 1 & 200 & 200 & $10 \%$ & 20 & 2 \\
\hline Total para 1 anfiteatro & & & 22.800 & & 3.340 & 278 \\
\hline
\end{tabular}


Tabela 129 - Custo total e despesas mensais de depreciação e manutenção dos móveis e equipamentos das áreas comuns

(continuação)

\begin{tabular}{|c|c|c|c|c|c|c|}
\hline \multirow{3}{*}{ Descrição } & \multirow{3}{*}{ 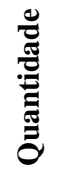 } & \multicolumn{2}{|c|}{ Custo } & \multicolumn{3}{|c|}{ Depreciação } \\
\hline & & \multirow{2}{*}{$\begin{array}{c}\text { Unitário } \\
\text { (R\$) }\end{array}$} & \multirow{2}{*}{ Total $(\mathbf{R} \$)$} & \multicolumn{2}{|c|}{ Anual } & \multirow{2}{*}{$\begin{array}{c}\text { Mensal } \\
(\mathbf{R} \$)\end{array}$} \\
\hline & & & & $\%$ & $\mathbf{R} \$$ & \\
\hline \multicolumn{7}{|l|}{ Espaço Ecumênico } \\
\hline Cadeiras & 20 & 100 & 2.000 & $10 \%$ & 200 & 17 \\
\hline Total & & & 2.000 & & 200 & 17 \\
\hline \multicolumn{7}{|l|}{ Ambulatório } \\
\hline Mesa c/cadeira & 1 & 400 & 400 & $10 \%$ & 40 & 3 \\
\hline Armário de aço & 1 & 400 & 400 & $10 \%$ & 40 & 3 \\
\hline Maca & 1 & 500 & 500 & $10 \%$ & 50 & 4 \\
\hline Total & & & 1.300 & & 130 & 10 \\
\hline \multicolumn{7}{|l|}{ Sala de Apoio } \\
\hline Mesa & 1 & 200 & 200 & $10 \%$ & 20 & 2 \\
\hline Cadeira & 4 & 100 & 400 & $10 \%$ & 40 & 3 \\
\hline Sofá 2 lugares & 1 & 1.000 & 1.000 & $10 \%$ & 100 & 8 \\
\hline Sofá 3 lugares & 1 & 1.200 & 1.200 & $10 \%$ & 120 & 10 \\
\hline Total & & & 2.800 & & 280 & 23 \\
\hline \multicolumn{7}{|l|}{ Almoxarifado } \\
\hline Mesa com cadeira & 1 & 400 & 400 & $10 \%$ & 40 & 3 \\
\hline Armário de aço & 10 & 400 & 4.000 & $10 \%$ & 400 & 33 \\
\hline Total & & & 4.400 & & 440 & 36 \\
\hline \multicolumn{7}{|l|}{ Cozinha - Terceirizada } \\
\hline \multicolumn{7}{|l|}{ Despensa } \\
\hline Armário de aço & 5 & 400 & 2.000 & $10 \%$ & 200 & 17 \\
\hline Total & & & 2.000 & & 200 & 17 \\
\hline \multicolumn{7}{|l|}{ Lavanderia } \\
\hline Máquina de lavar & 2 & 30.000 & 60.000 & $10 \%$ & 6.000 & 500 \\
\hline Equip de passar & 6 & 300 & 1.800 & $10 \%$ & 180 & 15 \\
\hline Total & & & 61.800 & & 6.180 & 515 \\
\hline \multicolumn{7}{|l|}{ Adminsitração / reunião } \\
\hline Mesa com cadeira & 6 & 400 & 2.400 & $10 \%$ & 240 & 20 \\
\hline Computador & 5 & 1.500 & 7.500 & $20 \%$ & 1.500 & 125 \\
\hline Software & 5 & 1.500 & 7.500 & $20 \%$ & 1.500 & 125 \\
\hline Impressora & 2 & 500 & 1.000 & $20 \%$ & 200 & 17 \\
\hline Armário & 5 & 500 & 2.500 & $10 \%$ & 250 & 21 \\
\hline Artigos de papelaria & & 1.000 & 1.000 & & 6.000 & 500 \\
\hline Total & & & 21.900 & & 9.690 & 808 \\
\hline \multicolumn{7}{|l|}{ Vestiário } \\
\hline Armário & 34 & 300 & 10.200 & $10 \%$ & 1.020 & 85 \\
\hline Bancos & 9 & 100 & 900 & $10 \%$ & 90 & 8 \\
\hline Total & & & 11.100 & & 1.110 & 93 \\
\hline Total geral & & & 435.740 & & 52.674 & 4.389 \\
\hline
\end{tabular}

${ }^{1} \mathrm{O}$ termo depreciação refere-se à diminuição do valor dos bens resultante de desgaste pelo uso, ação da natureza ou obsolescência normal (HIGUCHI et al, 2007, p. 309).

${ }^{2}$ As porcentagens lançadas atendem a Instrução Normativa SRF no 162 da Secretaria da Receita Federal (2008b).

${ }^{3}$ Para o valor anual aplica-se a porcentagem anual sobre o custo. 
Tabela 130 - Custo total e despesas mensais de depreciação e manutenção das áreas externas

\begin{tabular}{|c|c|c|c|c|c|c|c|}
\hline \multirow{3}{*}{ Descrição } & \multicolumn{2}{|c|}{ Quantidade } & \multicolumn{2}{|c|}{ Custo (R\$) } & \multicolumn{3}{|c|}{ Depreciação } \\
\hline & \multirow{2}{*}{$\mathbf{m}^{2}$} & \multirow{2}{*}{ Unidade } & \multirow{2}{*}{ Unitário } & \multirow{2}{*}{ Total } & \multicolumn{2}{|c|}{ Anual } & \multirow{2}{*}{$\begin{array}{c}\text { Mensal } \\
\text { (R\$) }\end{array}$} \\
\hline & & & & & $\%$ & $\mathbf{R} \$$ & \\
\hline Piscina - $15 \mathrm{~m} \times 5 \mathrm{~m} \times 1,2 \mathrm{~m} \times 1,7 \mathrm{~m}$ & 75 & & 1.000 & 75.000 & $4 \%$ & 3.000 & 250 \\
\hline \multicolumn{8}{|l|}{ Sauna seca $-3 \mathrm{~m} \times 3 \mathrm{~m} \times 2,5 \mathrm{~m}$} \\
\hline Revestimento (chão, parede e teto) & 48 & & 200 & 9.600 & $4 \%$ & 384 & 32 \\
\hline Equipamento & & 1 & 6.000 & 6.000 & $10 \%$ & 600 & 50 \\
\hline \multicolumn{8}{|l|}{ Sauna úmida $-3 \mathrm{~m} \times 3 \mathrm{~m} \times 2,5 \mathrm{~m}$} \\
\hline Revestimento (chão, parede e teto) & 48 & & 200 & 9.600 & $4 \%$ & 384 & 32 \\
\hline Equipamento & & 1 & 8.000 & 8.000 & $10 \%$ & 800 & 67 \\
\hline Campo de bocha $-24 \mathrm{~m} \times 4 \mathrm{~m}$ & 96 & & 100 & 9.600 & $4 \%$ & 384 & 32 \\
\hline Campo de malha - $40 \mathrm{~m} \times 2,5 \mathrm{~m}$ & 100 & & 100 & 10.000 & $4 \%$ & 400 & 33 \\
\hline Qudra poliesportiva $-25 \mathrm{~m} \times 15 \mathrm{~m}$ & 375 & & 300 & 112.500 & $4 \%$ & 4.500 & 375 \\
\hline Quadra de saibro - $25 \mathrm{~m} \times 11 \mathrm{~m}$ & 275 & & 300 & 82.500 & $4 \%$ & 3.300 & 275 \\
\hline Pista de pedestre & 500 & $\mathrm{~m} 2$ & 70 & 35.000 & $4 \%$ & 1.400 & 117 \\
\hline Ciclovia & 500 & $\mathrm{~m} 2$ & 70 & 35.000 & $4 \%$ & 1.400 & 117 \\
\hline Jardins & 183 & $\mathrm{~m} 2$ & 20 & 3.660 & & & \\
\hline Total & 2.200 & & & 396.460 & & 16.552 & 1.379 \\
\hline
\end{tabular}

Tabela 131 - Investimento total

\begin{tabular}{lr}
\hline \multicolumn{1}{c}{ Descrição } & \multicolumn{1}{c}{$\begin{array}{c}\text { Custo } \\
\text { (R\$) }\end{array}$} \\
\hline Terreno & 3.800 .000 \\
Construção & 3.942 .000 \\
Dormitórios & 930.000 \\
Áreas internas & 435.740 \\
Áreas externas & 396.460 \\
Despesas acessórias & 95.800 \\
\hline Total & $\mathbf{9 . 6 0 0 . 0 0 0}$ \\
\hline
\end{tabular}

\section{Créditos}

Quando o proprietário não utiliza a habitação, esta pode ser locada para duas pessoas. A locação para residentes não proprietários gera um crédito de $1 \%$ sobre o valor do investimento do proprietário. O crédito total, dividido entre os dois locatários, considera um nível de utilização da capacidade instalada de 70\%. Como o investimento é de R \$98.000,00, cada residente gera um crédito de $\mathrm{R} \$ 700,00$.

Crédito Total $=\frac{\mathrm{R} \$ 98.000,00 \times 0,01}{0,7}$

Crédito Total $=\mathrm{R} \$ 1.400,00$

Crédito por Residente $=\frac{\text { Crédito Total }}{2}$

Crédito por Residente $=\mathrm{R} \$ 700,00$ 


\section{Fluxo de receitas das mensalidades}

O número de residentes estimados para os primeiros 48 meses está indicado na Tabela 132 (p. 224). Não há indicação de residentes nos primeiros meses em função da construção. Os cálculos foram elaborados a partir de um nível de 70\% de utilização da capacidade instalada. As receitas projetadas estão indicadas na Tabela 133 (p. 224). Os cálculos foram feitos sem considerar os créditos, pois os mesmos não interferem nos custos e despesas.

Tabela 132 - Número de residentes estimados para os primeiros 48 meses

\begin{tabular}{|c|c|c|c|c|c|c|c|c|c|c|c|c|}
\hline \multirow{2}{*}{ Ano } & \multicolumn{12}{|c|}{ Mês } \\
\hline & 01 & 02 & $\mathbf{0 3}$ & 04 & 05 & 06 & 07 & 08 & 09 & 10 & 11 & 12 \\
\hline 1 & 0 & 0 & 0 & 140 & 142 & 144 & 146 & 148 & 150 & 152 & 154 & 156 \\
\hline 2 & 158 & 160 & 162 & 164 & 166 & 168 & 170 & 172 & 174 & 176 & 178 & 180 \\
\hline 3 & 180 & 180 & 180 & 180 & 180 & 180 & 180 & 180 & 180 & 180 & 180 & 180 \\
\hline 4 & 180 & 180 & 180 & 180 & 180 & 180 & 180 & 180 & 180 & 180 & 180 & 180 \\
\hline
\end{tabular}

Tabela 133 - Receita estimada para os primeiros 48 meses

\begin{tabular}{ccccc}
\hline \multirow{2}{*}{ Mês } & \multicolumn{4}{c}{ Ano } \\
\cline { 2 - 5 } & $\mathbf{1}$ & $\mathbf{2}$ & $\mathbf{3}$ & $\mathbf{4}$ \\
\hline Jan & - & 543.204 & 618.840 & 618.840 \\
Fev & - & 550.080 & 618.840 & 618.840 \\
Mar & - & 556.956 & 618.840 & 618.840 \\
Abr & 481.320 & 563.832 & 618.840 & 618.840 \\
Mai & 488.196 & 570.708 & 618.840 & 618.840 \\
Jun & 495.072 & 577.584 & 618.840 & 618.840 \\
Jul & 501.948 & 584.460 & 618.840 & 618.840 \\
Ago & 508.824 & 591.336 & 618.840 & 618.840 \\
Set & 515.700 & 598.212 & 618.840 & 618.840 \\
Out & 522.576 & 605.088 & 618.840 & 618.840 \\
Nov & 529.452 & 611.964 & 618.840 & 618.840 \\
Dez & 536.328 & 618.840 & 618.840 & 618.840 \\
\hline
\end{tabular}

\section{Fluxo de desembolsos}

As despesas administrativas e os custos indiretos indicados na Tabela 134 (p. 225) foram calculados para 200 residentes. Somando R 27.755 e R $\$ 293.036$ obtém-se um total de $\mathrm{R} \$ 320.791$.

Os custos diretos foram calculados para 140 residentes. Dividindo R\$146.434 por 140 obtém-se um resultado de $\mathrm{R} \$ 1.045,96$. Com estes dois valores obtém-se a equação custo total: 


$$
\begin{aligned}
& \mathrm{CT}=(320.791+1.045,96 \mathrm{Q}) \times 1,03 \\
& \mathrm{CT}=330.414,73+1.077,34 \mathrm{Q}
\end{aligned}
$$

A partir da equação pode-se observar os desembolsos estimados para os primeiros 48 meses na Tabela 135 (p. 225).

Tabela 134 - Despesas administrativas, custos diretos e indiretos

\begin{tabular}{lr}
\hline \multicolumn{1}{c}{ Descrição } & Valor $(\mathbf{R} \$ \mathbf{)}$ \\
\hline Despesas administrativas & $\mathbf{2 7 . 7 5 5}$ \\
Salários e encargos sociais & 26.532 \\
Depreciação e manutenção & 808 \\
Contabilidade & 415 \\
\hline Custos indiretos & $\mathbf{2 9 3 . 0 3 6}$ \\
Salários e encargos sociais & 262.514 \\
Depreciação e manutenção & 27.426 \\
Água e energia elétrica & 3.096 \\
\hline Custos Diretos & $\mathbf{1 4 6 . 4 3 4}$ \\
Salários e encargos sociais & 137.244 \\
Alimentação & 2.800 \\
Água e energia elétrica & 6.390 \\
\hline Outros custos e despesas (3\%) & $\mathbf{1 4 . 0 1 7}$ \\
\hline Custo total mensal & $\mathbf{4 8 1 . 2 4 2}$ \\
Custo mensal por residente & $\mathbf{3 . 4 3 8}$ \\
\hline
\end{tabular}

Tabela 135 - Desembolsos estimados para os primeiros 48 meses

\begin{tabular}{ccccc}
\hline \multirow{2}{*}{ Mês } & \multicolumn{4}{c}{ Ano } \\
\cline { 2 - 5 } & $\mathbf{1}$ & $\mathbf{2}$ & $\mathbf{3}$ & $\mathbf{4}$ \\
\hline Jan & 0 & 500.634 & 524.336 & 524.336 \\
Fev & 0 & 502.789 & 524.336 & 524.336 \\
Mar & 0 & 504.944 & 524.336 & 524.336 \\
Abr & 481.242 & 507.098 & 524.336 & 524.336 \\
Mai & 483.397 & 509.253 & 524.336 & 524.336 \\
Jun & 485.552 & 511.408 & 524.336 & 524.336 \\
Jul & 487.706 & 513.563 & 524.336 & 524.336 \\
Ago & 489.861 & 515.717 & 524.336 & 524.336 \\
Set & 492.016 & 517.872 & 524.336 & 524.336 \\
Out & 494.170 & 520.027 & 524.336 & 524.336 \\
Nov & 496.325 & 522.181 & 524.336 & 524.336 \\
Dez & 498.480 & 524.336 & 524.336 & 524.336 \\
\hline
\end{tabular}

\section{Fluxo de caixa}

Considerando as receitas, custos e despesas e o nível de utilização da capacidade instalada iniciando em $70 \%$ e alcançando $90 \%$ no final do $2^{\circ}$ ano de operação, o fluxo de caixa da organização será o seguinte: 
Tabela 136 - Fluxo de caixa estimado para os primeiros 48 meses

\begin{tabular}{|c|c|c|c|c|c|c|c|}
\hline Período & Ingressos & Desembolsos & Saldo de Caixa & Período & Ingressos & Desembolsos & Saldo de Caixa \\
\hline $\mathrm{jan} / \mathrm{x} 1$ & 0,00 & 0,00 & 0,00 & $\mathrm{jan} / \mathrm{x} 3$ & $618.840,00$ & $524.335,93$ & $1.087 .612,34$ \\
\hline fev/x1 & 0,00 & 0,00 & 0,00 & fev/x3 & $618.840,00$ & $524.335,93$ & $1.182 .116,41$ \\
\hline $\operatorname{mar} / x 1$ & 0,00 & 0,00 & 0,00 & $\operatorname{mar} / x 3$ & $618.840,00$ & $524.335,93$ & $1.276 .620,48$ \\
\hline $\mathrm{abr} / \mathrm{x} 1$ & $481.320,00$ & $481.242,33$ & 77,67 & $\mathrm{abr} / \mathrm{x} 3$ & $618.840,00$ & $524.335,93$ & $1.371 .124,55$ \\
\hline mai/x1 & $488.196,00$ & $483.397,01$ & $4.876,66$ & $\mathrm{mai} / \mathrm{x} 3$ & $618.840,00$ & $524.335,93$ & $1.465 .628,62$ \\
\hline jun/x1 & $495.072,00$ & $485.551,69$ & $14.396,97$ & jun/x3 & $618.840,00$ & $524.335,93$ & $1.560 .132,69$ \\
\hline $\mathrm{jul} / \mathrm{x} 1$ & $501.948,00$ & $487.706,37$ & $28.638,60$ & $\mathrm{jul} / \mathrm{x} 3$ & $618.840,00$ & $524.335,93$ & $1.654 .636,76$ \\
\hline $\mathrm{ago} / \mathrm{x} 1$ & $508.824,00$ & $489.861,05$ & $47.601,55$ & ago/x3 & $618.840,00$ & $524.335,93$ & $1.749 .140,83$ \\
\hline set/x1 & $515.700,00$ & $492.015,73$ & $71.285,82$ & set/x3 & $618.840,00$ & $524.335,93$ & $1.843 .644,90$ \\
\hline out/x1 & $522.576,00$ & $494.170,41$ & $99.691,41$ & out/x3 & $618.840,00$ & $524.335,93$ & $1.938 .148,97$ \\
\hline nov/x1 & $529.452,00$ & $496.325,09$ & $132.818,32$ & nov/x3 & $618.840,00$ & $524.335,93$ & $2.032 .653,04$ \\
\hline $\mathrm{dez} / \mathrm{x} 1$ & $536.328,00$ & $498.479,77$ & $170.666,55$ & $\operatorname{dez} / x 3$ & $618.840,00$ & $524.335,93$ & $2.127 .157,11$ \\
\hline $\mathrm{jan} / \mathrm{x} 2$ & $543.204,00$ & $500.634,45$ & $213.236,10$ & $\mathrm{jan} / \mathrm{x} 4$ & $618.840,00$ & $524.335,93$ & $2.221 .661,18$ \\
\hline $\mathrm{fev} / \mathrm{x} 2$ & $550.080,00$ & $502.789,13$ & $260.526,97$ & fev/x4 & $618.840,00$ & $524.335,93$ & $2.316 .165,25$ \\
\hline $\operatorname{mar} / x 2$ & $556.956,00$ & $504.943,81$ & $312.539,16$ & $\operatorname{mar} / x 4$ & $618.840,00$ & $524.335,93$ & $2.410 .669,32$ \\
\hline $\mathrm{abr} / \mathrm{x} 2$ & $563.832,00$ & $507.098,49$ & $369.272,67$ & $\mathrm{abr} / \mathrm{x} 4$ & $618.840,00$ & $524.335,93$ & $2.505 .173,39$ \\
\hline $\mathrm{mai} / \mathrm{x} 2$ & $570.708,00$ & $509.253,17$ & $430.727,50$ & $\mathrm{mai} / \mathrm{x} 4$ & $618.840,00$ & $524.335,93$ & $2.599 .677,46$ \\
\hline jun/x2 & $577.584,00$ & $511.407,85$ & $496.903,65$ & jun/x4 & $618.840,00$ & $524.335,93$ & $2.694 .181,53$ \\
\hline $\mathrm{ju} 1 / \mathrm{x} 2$ & $584.460,00$ & $513.562,53$ & $567.801,12$ & $\mathrm{jul} / \mathrm{x} 4$ & $618.840,00$ & $524.335,93$ & $2.788 .685,60$ \\
\hline $\mathrm{ago} / \mathrm{x} 2$ & $591.336,00$ & $515.717,21$ & $643.419,91$ & ago/x4 & $618.840,00$ & $524.335,93$ & $2.883 .189,67$ \\
\hline set/x2 & $598.212,00$ & $517.871,89$ & $723.760,02$ & set/x4 & $618.840,00$ & $524.335,93$ & $2.977 .693,74$ \\
\hline out/x2 & $605.088,00$ & $520.026,57$ & $808.821,45$ & out/x4 & $618.840,00$ & $524.335,93$ & $3.072 .197,81$ \\
\hline nov/x2 & $611.964,00$ & $522.181,25$ & $898.604,20$ & nov/x4 & $618.840,00$ & $524.335,93$ & $3.166 .701,88$ \\
\hline $\mathrm{dez} / \mathrm{x} 2$ & $618.840,00$ & $524.335,93$ & $993.108,27$ & $\mathrm{dez} / \mathrm{x} 4$ & $618.840,00$ & $524.335,93$ & $3.261 .205,95$ \\
\hline
\end{tabular}


Apêndice 2 - Estimativa da população brasileira dividida por faixa de idade - 1980-2050

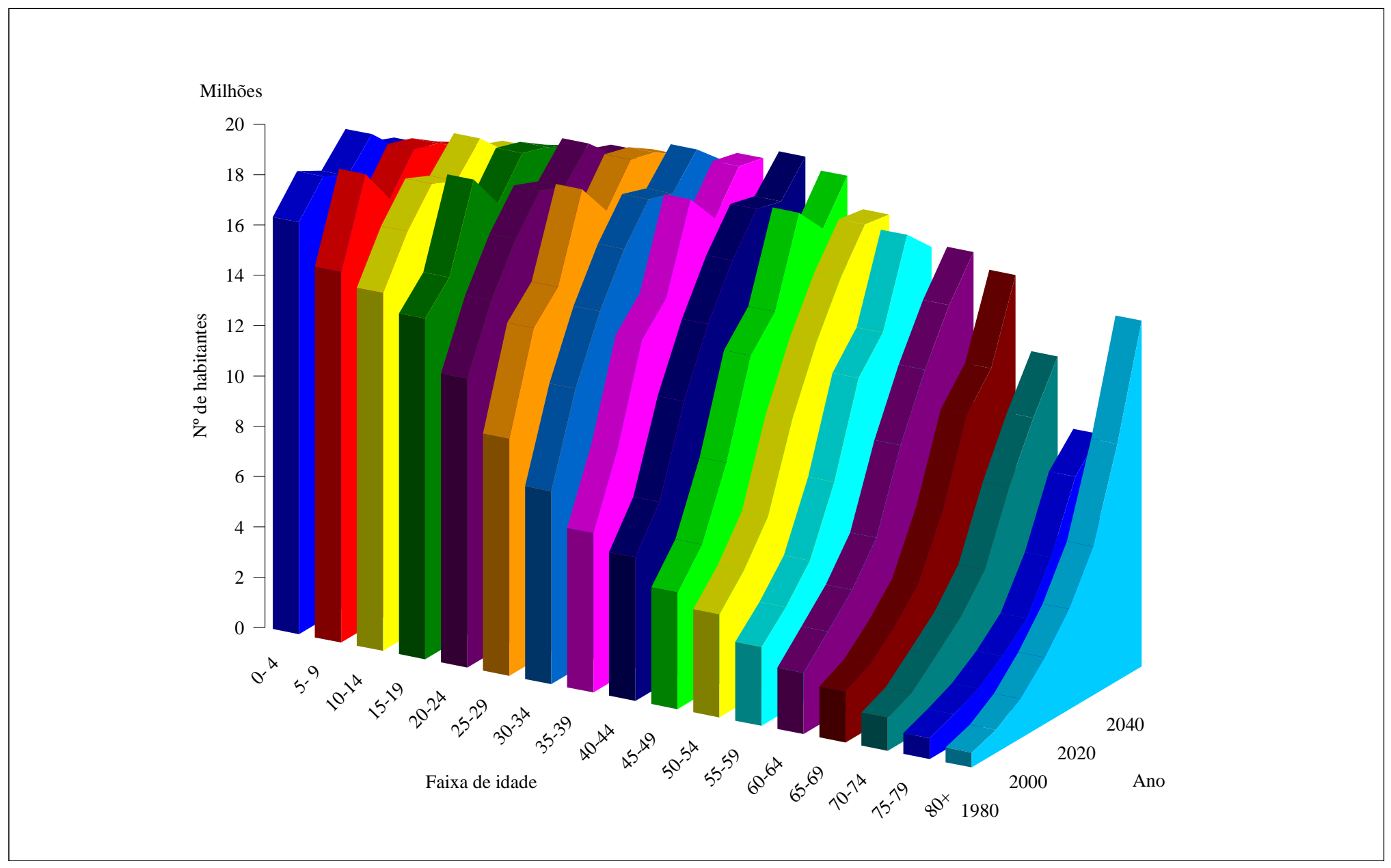

FONTE: IBGE, 2007c, adaptado pelo autor. 
Apêndice 3 - Estimativa da média de idade da população brasileira - 1980-2050

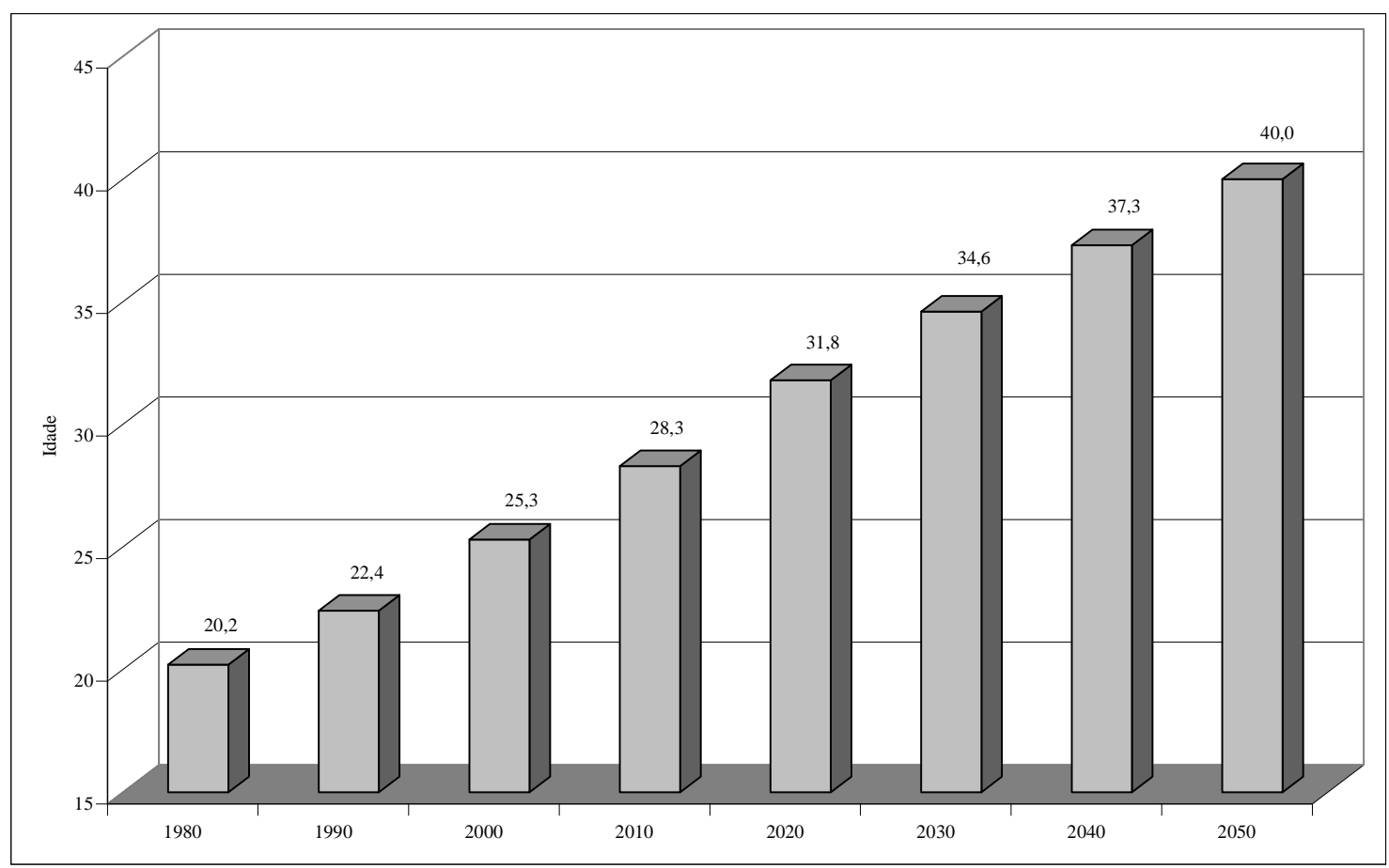

FONTE: IBGE, 2007c, adaptado pelo autor.

Apêndice 4 - Estimativa da população brasileira com 60 anos ou mais - 1980-2050

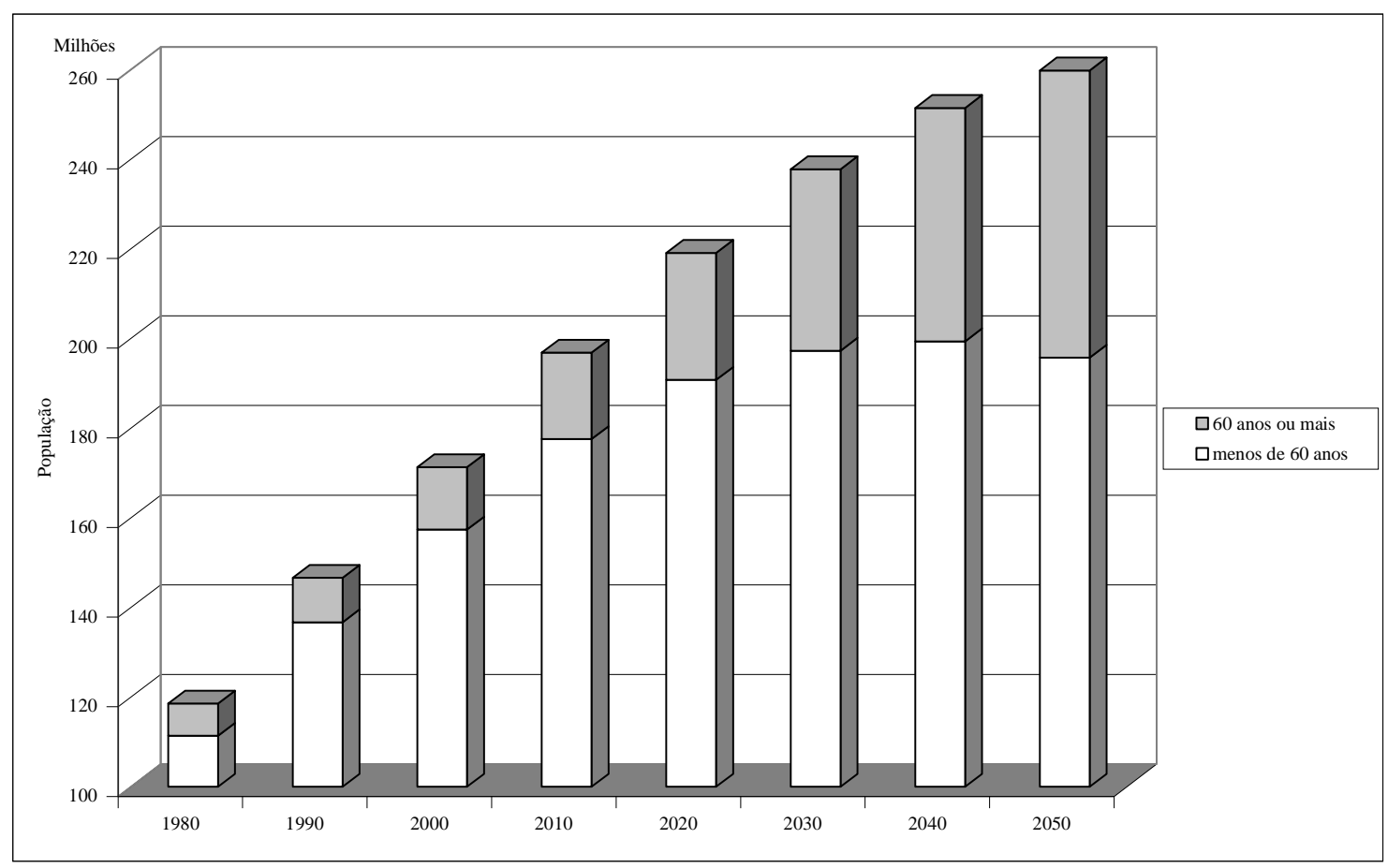

FONTE: IBGE, 2007c, adaptado pelo autor. 
Apêndice 5 - Estimativa da população brasileira com 60 anos ou mais dividida por sexo - 1980-2050

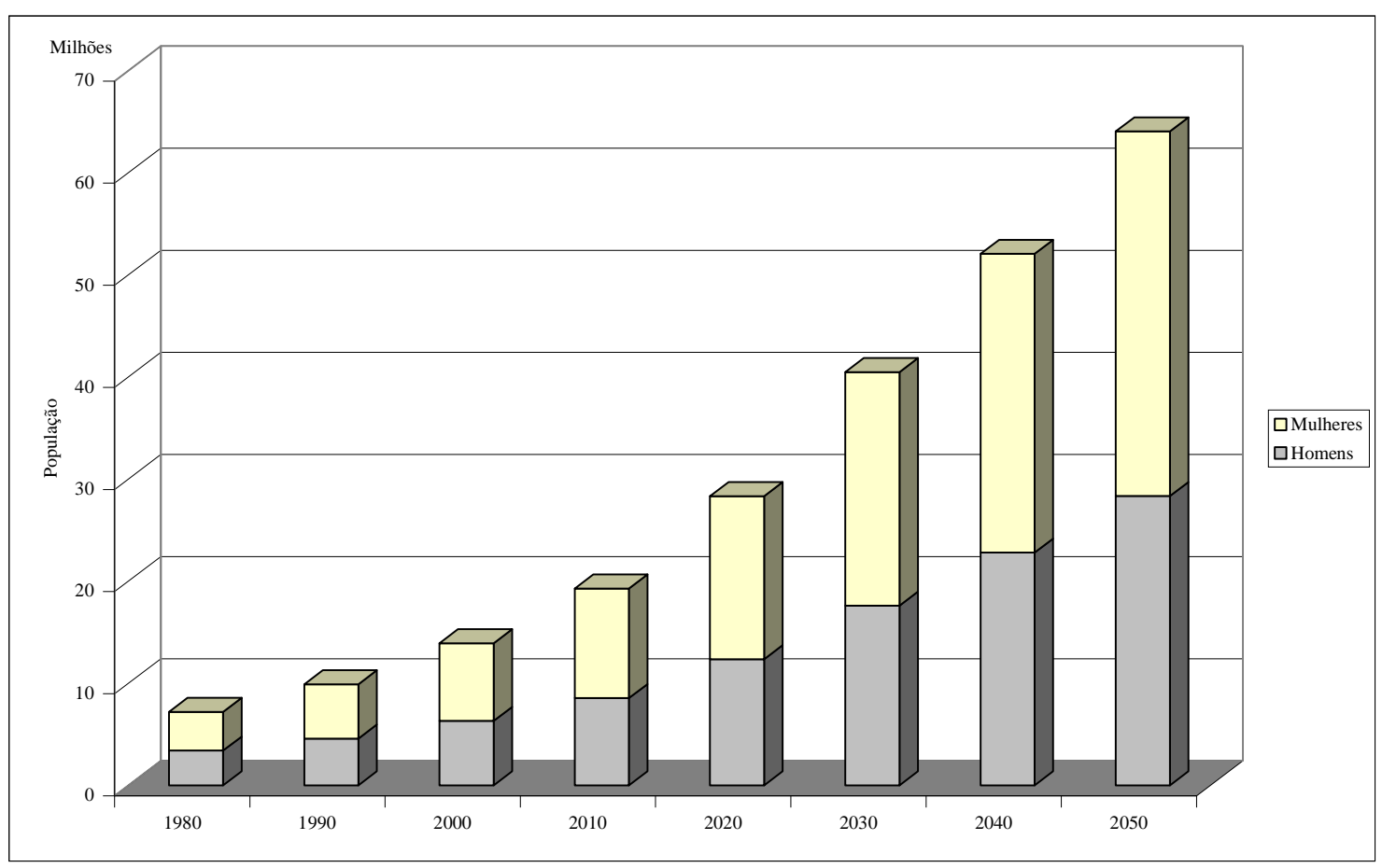

FONTE: IBGE, 2007c, adaptado pelo autor. 
Apêndice 6 - Famílias residentes segundo as classes de rendimento mensal familiar - Brasil - 2006

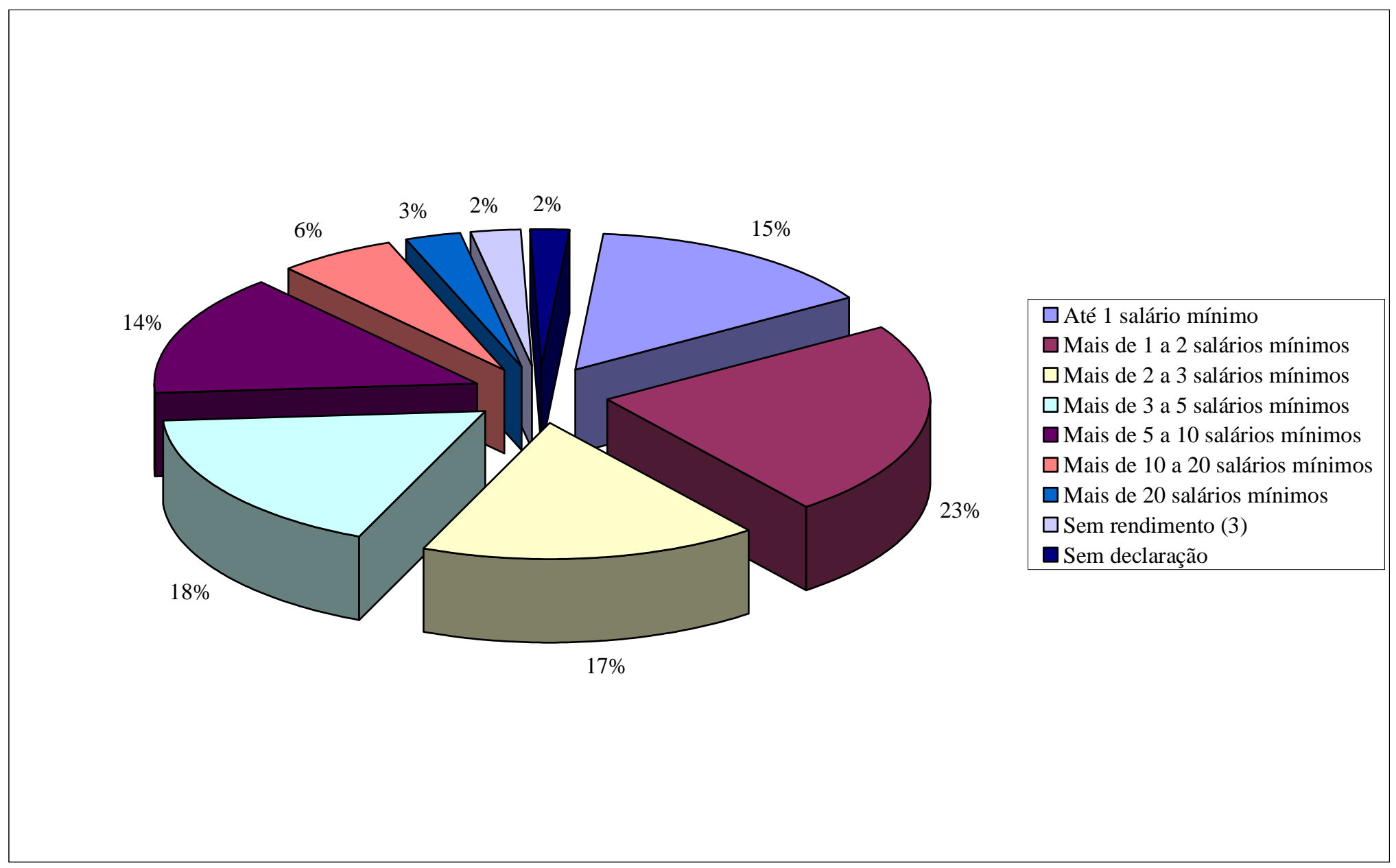

FONTE: IBGE, 2007e, adaptado pelo autor. 
Apêndice 7 - Famílias residentes e participação no rendimento total, segundo as classes de rendimento mensal familiar - Brasil - 2006

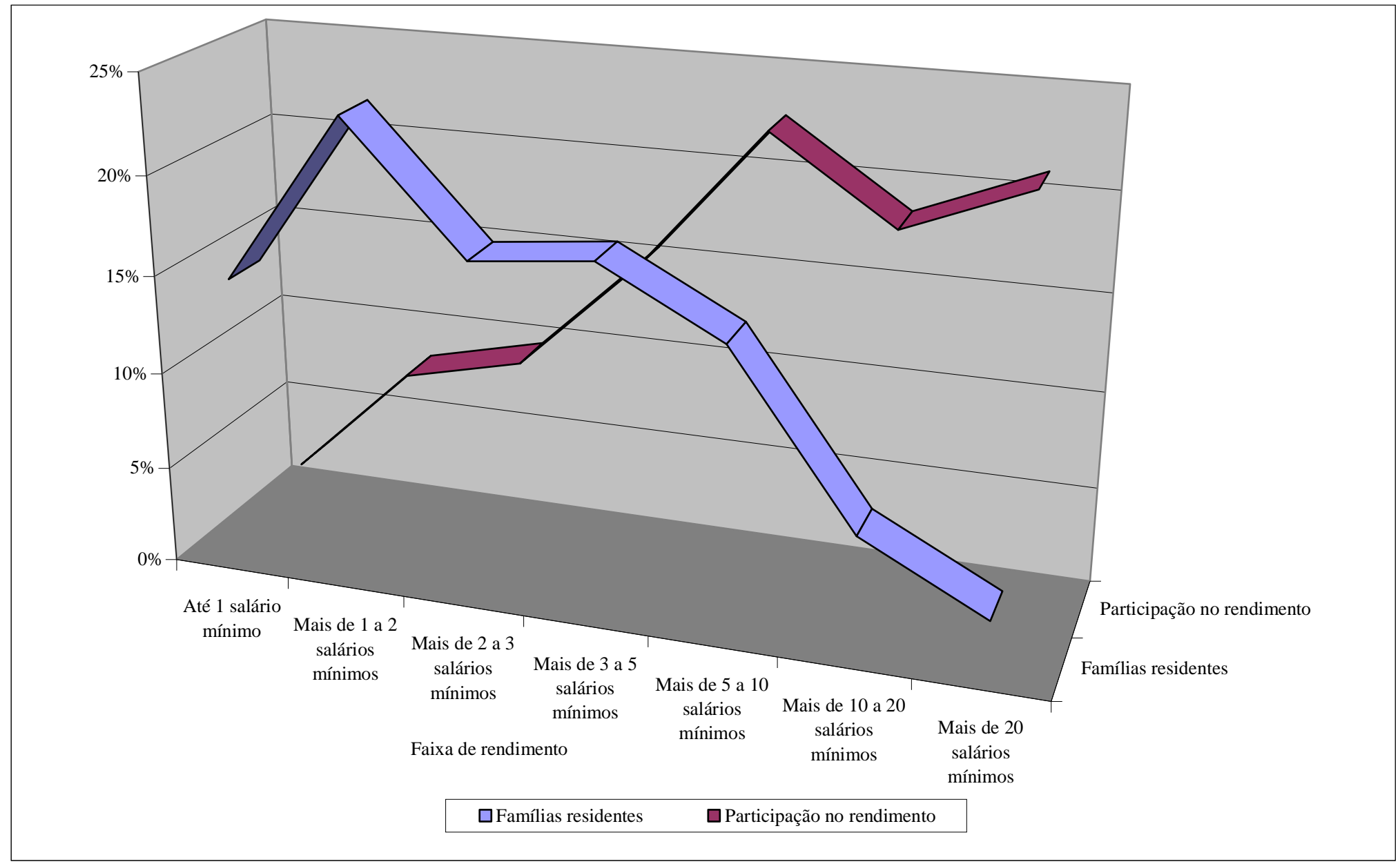

FONTE: IBGE, 2007e, adaptado pelo autor. 
Apêndice 8 - Pessoas de 10 anos ou mais de idade, ocupadas na semana de referência, com rendimento no trabalho principal, segundo as classes de rendimento mensal do trabalho principal - Brasil - 2006

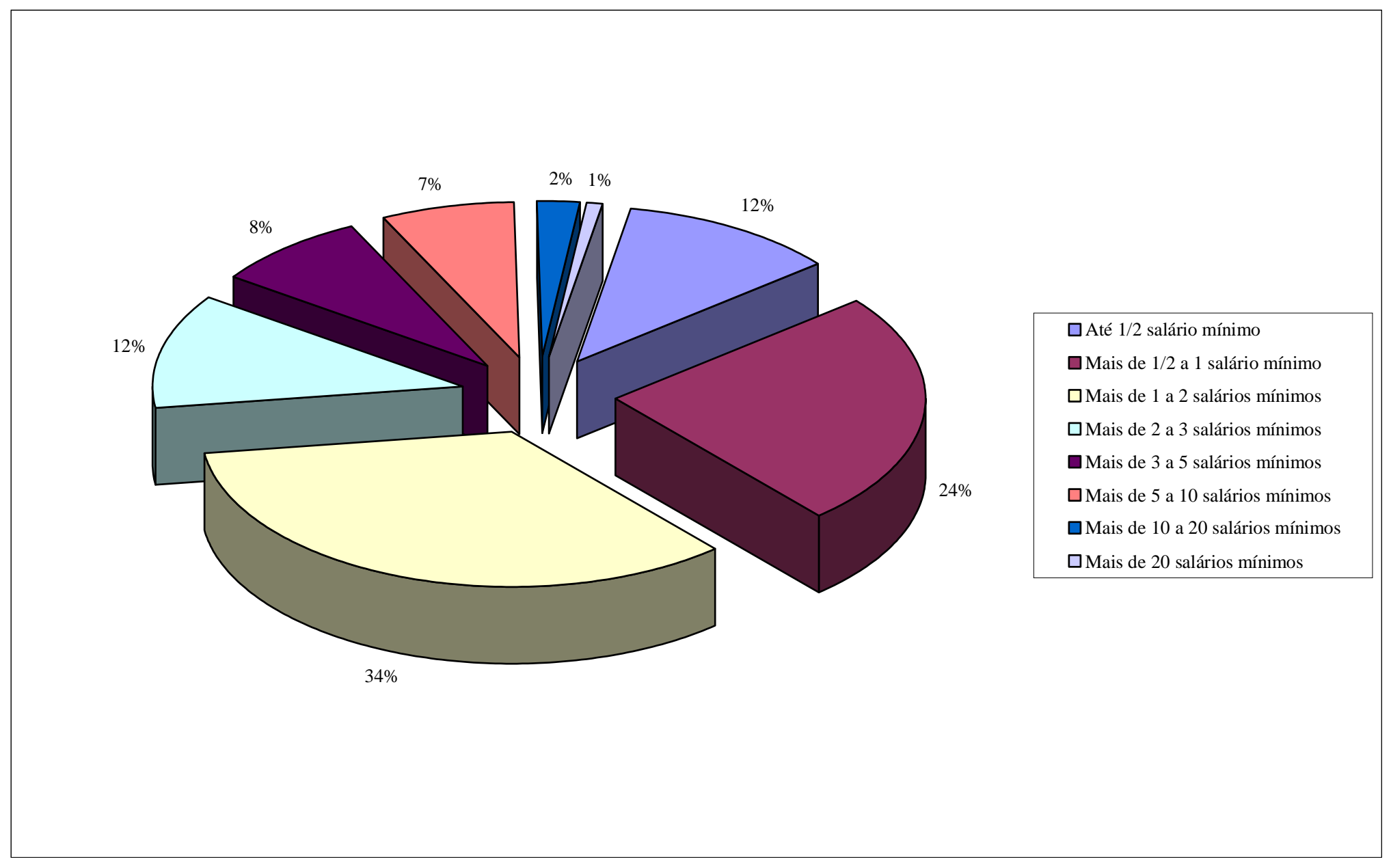

FONTE: IBGE, 2007g, adaptado pelo autor. 
Apêndice 9 - Pessoas de 10 anos ou mais de idade, ocupadas na semana de referência, com rendimento no trabalho principal, segundo as classes de rendimento mensal do trabalho principal e participação no rendimento total - Brasil - 2006

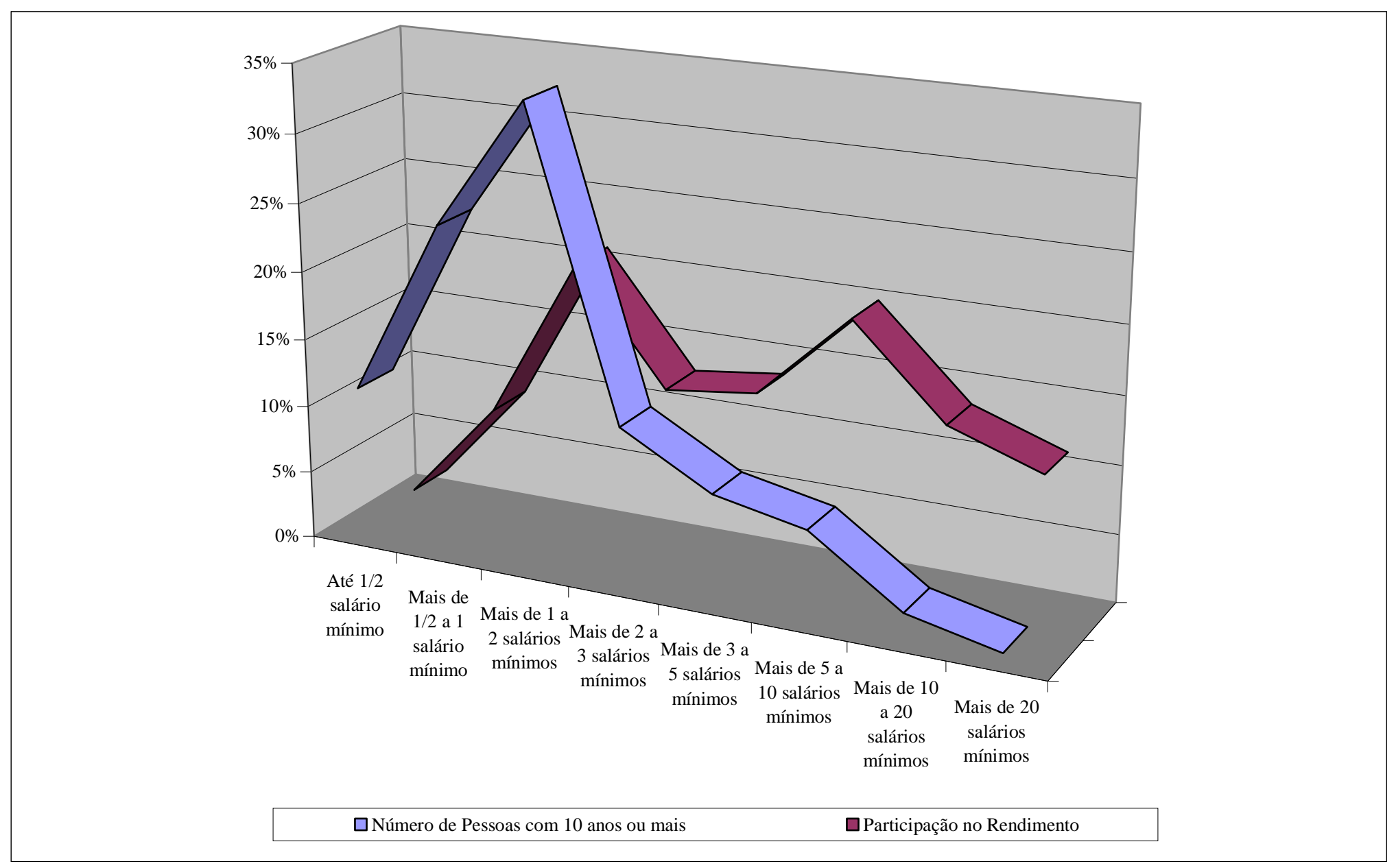

FONTE: IBGE, 2007g, adaptado pelo autor. 
Apêndice 10 - Anos de estudo acumulado de pessoas de 10 anos ou mais de idade, por situação do domicílio e sexo, segundo os anos de estudo - Brasil - 2006

\begin{tabular}{|c|c|c|c|c|c|c|c|c|c|c|c|c|c|c|c|c|c|c|}
\hline \multirow{4}{*}{$\begin{array}{c}\text { Anos de estudo } \\
\text { acumulado }\end{array}$} & \multicolumn{18}{|c|}{ Pessoas de 10 anos ou mais de idade (1 000 pessoas) } \\
\hline & \multirow{2}{*}{\multicolumn{2}{|c|}{ Total }} & \multirow{2}{*}{\multicolumn{2}{|c|}{ Homens }} & \multirow{2}{*}{\multicolumn{2}{|c|}{ Mulheres }} & \multicolumn{6}{|c|}{ Urbana } & \multicolumn{6}{|c|}{ Rural } \\
\hline & & & & & & & \multicolumn{2}{|c|}{ Total } & \multicolumn{2}{|c|}{ Homens } & \multicolumn{2}{|c|}{ Mulheres } & \multicolumn{2}{|c|}{ Total } & \multicolumn{2}{|c|}{ Homens } & \multicolumn{2}{|c|}{ Mulheres } \\
\hline & 156284 & $100 \%$ & 75326 & $48 \%$ & 80957 & $52 \%$ & 131091 & $84 \%$ & 62152 & $47 \%$ & 68938 & $\mathbf{5 3 \%}$ & 25193 & $16 \%$ & 13174 & $52 \%$ & 12019 & $48 \%$ \\
\hline 15 anos & 9514 & $6 \%$ & 4187 & $44 \%$ & 5328 & $56 \%$ & 9337 & $98 \%$ & 4116 & $43 \%$ & 5221 & $55 \%$ & 177 & $2 \%$ & 71 & $40 \%$ & 107 & $60 \%$ \\
\hline 14 anos & 11505 & $7 \%$ & 4985 & $43 \%$ & 6520 & $57 \%$ & 11269 & $98 \%$ & 4891 & $43 \%$ & 6378 & $55 \%$ & 237 & $2 \%$ & 94 & $40 \%$ & 143 & $60 \%$ \\
\hline 13 anos & 13417 & $9 \%$ & 5849 & $44 \%$ & 7568 & $56 \%$ & 13129 & $98 \%$ & 5734 & $43 \%$ & 7395 & $55 \%$ & 288 & $2 \%$ & 115 & $40 \%$ & 173 & $60 \%$ \\
\hline 12 anos & 15914 & $10 \%$ & 6955 & $44 \%$ & 8959 & $56 \%$ & 15528 & $98 \%$ & 6803 & $43 \%$ & 8725 & $55 \%$ & 386 & $2 \%$ & 152 & $39 \%$ & 234 & $61 \%$ \\
\hline 11 anos & 45160 & $29 \%$ & 20264 & $45 \%$ & 24896 & $55 \%$ & 43044 & $95 \%$ & 19350 & $43 \%$ & 23694 & $52 \%$ & 2116 & $5 \%$ & 914 & $43 \%$ & 1202 & $57 \%$ \\
\hline 10 anos & 50774 & $32 \%$ & 22921 & $45 \%$ & 27853 & $55 \%$ & 48120 & $95 \%$ & 21747 & $43 \%$ & 26373 & $52 \%$ & 2655 & $5 \%$ & 1174 & $44 \%$ & 1480 & $56 \%$ \\
\hline 9 anos & 56220 & $36 \%$ & 25523 & $45 \%$ & 30696 & $55 \%$ & 52959 & $94 \%$ & 24069 & $43 \%$ & 28889 & $51 \%$ & 3261 & $6 \%$ & 1454. & $45 \%$ & 1807. & $55 \%$ \\
\hline 8 anos & 70598 & $45 \%$ & 32617 & $46 \%$ & 37981 & $54 \%$ & 65704 & $93 \%$ & 30340 & $43 \%$ & 35363 & $50 \%$ & 4894 & $7 \%$ & 2277 & $47 \%$ & 2618 & $53 \%$ \\
\hline 7 anos & 78963 & $51 \%$ & 36789 & $47 \%$ & 42174 & $53 \%$ & 72829 & $92 \%$ & 33897 & $43 \%$ & 38932 & $49 \%$ & 6134 & $8 \%$ & 2892 & $47 \%$ & 3242 & $53 \%$ \\
\hline 6 anos & 86852 & $56 \%$ & 40685 & $47 \%$ & 46167 & $53 \%$ & 79419 & $91 \%$ & 37129 & $43 \%$ & 42290 & $49 \%$ & 7433 & $9 \%$ & 3556 & $48 \%$ & 3877 & $52 \%$ \\
\hline 5 anos & 98774 & $63 \%$ & 46644 & $47 \%$ & 52131 & $53 \%$ & 89127 & $90 \%$ & 41955 & $42 \%$ & 47171 & $48 \%$ & 9648 & $10 \%$ & 4688 & $49 \%$ & 4959 & $51 \%$ \\
\hline 4 anos & 118715 & $76 \%$ & 56465 & $48 \%$ & 62250 & $52 \%$ & 104742 & $88 \%$ & 49538 & $42 \%$ & 55205 & $47 \%$ & 13973 & $12 \%$ & 6928 & $50 \%$ & 7045 & $50 \%$ \\
\hline 3 anos & 129227 & $83 \%$ & 61742 & $48 \%$ & 67485 & $52 \%$ & 112644 & $87 \%$ & 53422 & $41 \%$ & 59222 & $46 \%$ & 16584 & $13 \%$ & 8320 & $50 \%$ & 8264 & $50 \%$ \\
\hline 2 anos & 135904 & $87 \%$ & 65257 & $48 \%$ & 70646 & $52 \%$ & 117348 & $86 \%$ & 55846 & $41 \%$ & 61502 & $45 \%$ & 18556 & $14 \%$ & 9411 & $51 \%$ & 9144 & $49 \%$ \\
\hline 1 ano. & 139794. & $89 \%$ & 67363 & $48 \%$ & 72431 & $52 \%$ & 120051 & $86 \%$ & 57249 & $41 \%$ & 62802 & $45 \%$ & 19743 & $14 \%$ & 10114 & $51 \%$ & 9629 & $49 \%$ \\
\hline Menos de 1 ano & 155660 & $100 \%$ & $75034^{-}$ & $48 \%$ & 80625 & $52 \%$ & 130533 & $84 \%$ & 61893 & $40 \%$ & 68640 & $44 \%$ & 25127 & $16 \%$ & 13141 & $52 \%$ & 11986 & $48 \%$ \\
\hline
\end{tabular}

FONTE: IBGE, 2007f, adaptado pelo autor. 
Apêndice 11 - Anos de estudo acumulado de pessoas de 10 anos ou mais de idade - Brasil - 2006

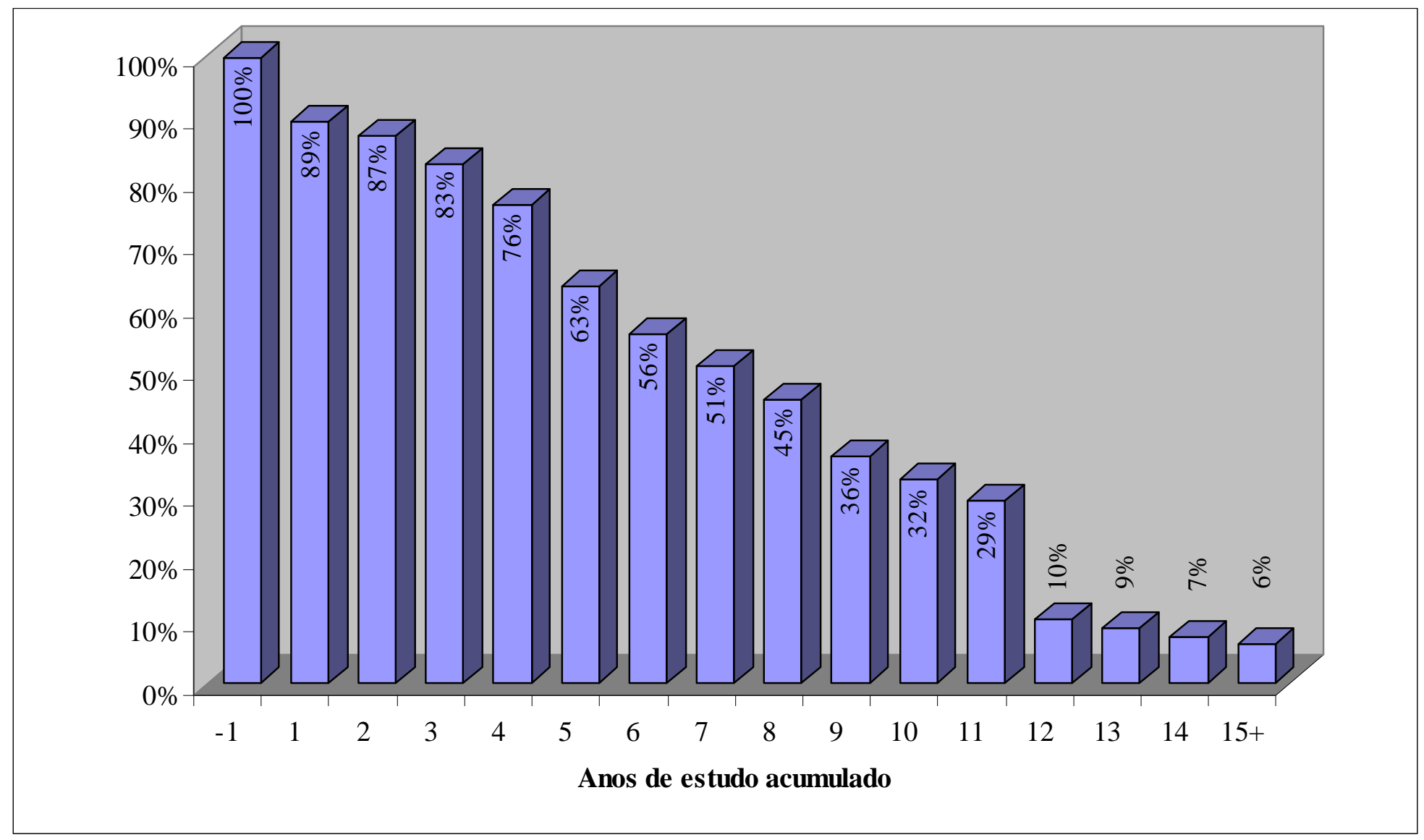

FONTE: IBGE, 2007f, adaptado pelo autor. 
Apêndice 12 - Salário mensal de estrutura administrativa para organização de pequeno porte

\begin{tabular}{lrrr}
\hline \multicolumn{1}{c}{ Ocupação } & \multicolumn{3}{c}{ Salário (R\$) } \\
\cline { 2 - 4 } & Menor valor & Maior valor & Valor médio \\
\hline Gerente geral & 2.151 & 12.011 & 4.751 \\
Auditor interno - pleno & 2.650 & 4.268 & 3.631 \\
Assistente financeiro & 564 & 5.319 & 1.628 \\
Assistente administrativo & 564 & 5.319 & 1.628 \\
Assistente de recursos humanos & 564 & 5.319 & 1.628 \\
\hline Total & $\mathbf{6 . 4 9 3}$ & $\mathbf{3 2 . 2 3 6}$ & $\mathbf{1 3 . 2 6 6}$ \\
\hline
\end{tabular}

FONTE: DATAFOLHA, 2008.

Apêndice 13 - Salário mensal de estrutura administrativa para matriz de organização de pequeno porte

\begin{tabular}{lrrr}
\hline \multicolumn{1}{c}{ Ocupação } & \multicolumn{3}{c}{ Salário (R\$) } \\
\cline { 2 - 4 } & Menor valor & Maior valor & Valor médio \\
\hline Gerente geral & 2.275 & 19.449 & 5.924 \\
Gerente administrativo-financeiro & 2.151 & 12.011 & 4.751 \\
Gerente de qualidade de vida & 2.151 & 12.011 & 4.751 \\
Auditor interno - pleno & 2.650 & 4.268 & 3.631 \\
Assistente financeiro & 564 & 5.319 & 1.628 \\
Assistente administrativo & 564 & 5.319 & 1.628 \\
Assistente de recursos humanos & 564 & 5.319 & 1.628 \\
\hline Total & $\mathbf{1 0 . 9 1 9}$ & $\mathbf{6 3 . 6 9 6}$ & $\mathbf{2 3 . 9 4 1}$ \\
\hline
\end{tabular}

FONTE: DATAFOLHA, 2008.

Apêndice 14 - Salário mensal de estrutura administrativa para filial de organização de pequeno porte

\begin{tabular}{lrrr}
\hline \multirow{2}{*}{ Ocupação } & \multicolumn{3}{c}{ Salário (R\$) } \\
\cline { 2 - 4 } & Menor valor & Maior valor & Valor médio \\
\hline Gerente da filial & 2.151 & 12.011 & 4.751 \\
Assistente administrativo-financeiro & 564 & 5.319 & 1.628 \\
\hline Total & $\mathbf{2 . 7 1 5}$ & $\mathbf{1 7 . 3 3 0}$ & $\mathbf{6 . 3 7 9}$ \\
\hline
\end{tabular}

FONTE: DATAFOLHA, 2008. 
Apêndice 15 - Croqui de dimensões básicas de dormitório padrão

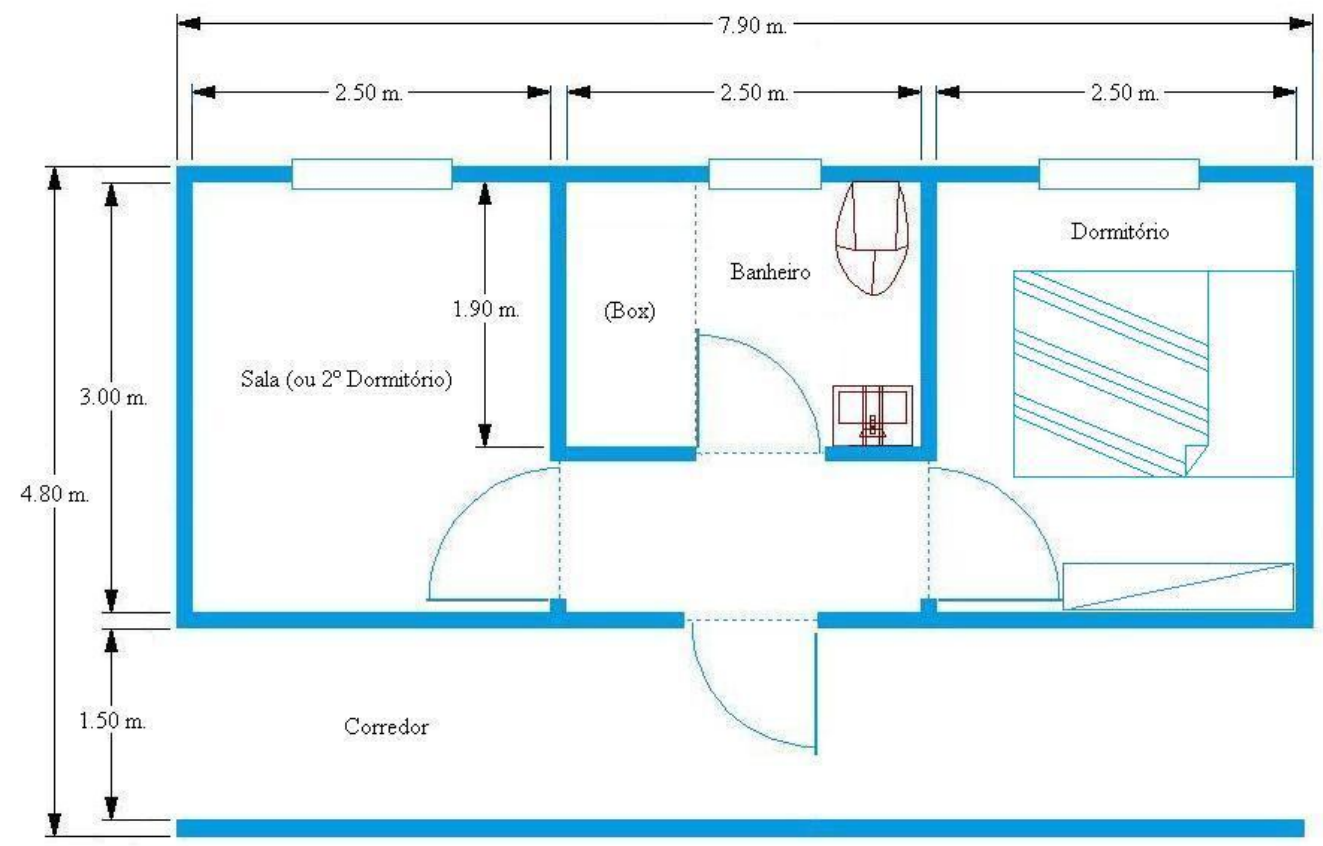

Apêndice 16 - Croqui de dimensões básicas de dormitório que atende pessoas portadoras de necessidades especiais

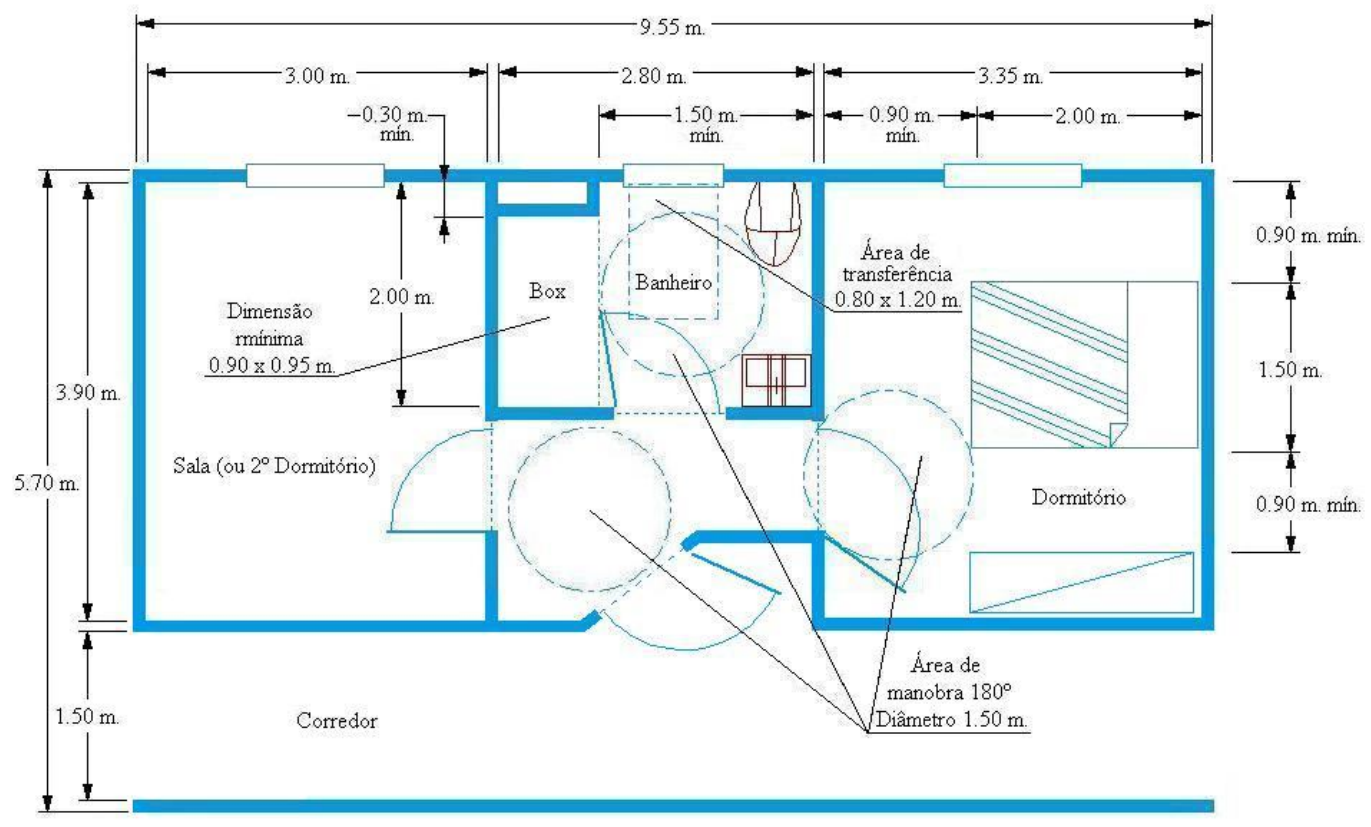


Apêndice 17 - Necessidade de áreas internas em função do número de residentes e funcionários

\begin{tabular}{|c|c|c|c|c|}
\hline Ambiente & 离 & 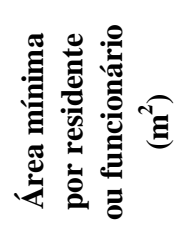 & 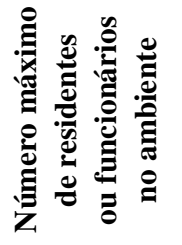 & 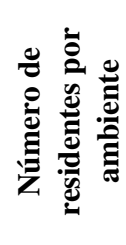 \\
\hline \multicolumn{5}{|l|}{ Habitação (2 residentes por unidade) } \\
\hline Padrão & 37,9 & & & \\
\hline Extendida & 54,4 & & & \\
\hline \multicolumn{5}{|l|}{ Para os residentes } \\
\hline \multicolumn{5}{|l|}{$\begin{array}{l}\text { Ambientes para residentes com grau de } \\
\text { dependência I e II }\end{array}$} \\
\hline Sala para atividades coletivas & & 1,0 & 15 & \\
\hline Sala de convivência & & 1,3 & & \\
\hline Sala de apoio individual & 10,0 & & & 100 \\
\hline Banheiros coletivos, separados por sexo $(*)$ & 7,2 & & & 100 \\
\hline Espaço ecumênico & 10,0 & & & \\
\hline Sala administrativa / reunião & 10,0 & & & \\
\hline Refeitório & & 1,0 & & \\
\hline Cozinha e despensa & 16,0 & & & \\
\hline Lavanderia & 10,0 & & & 100 \\
\hline Almoxarifado & 16,0 & & & \\
\hline Ambulatório & 4,0 & & & \\
\hline Posto médico & 4,0 & & & 100 \\
\hline \multicolumn{5}{|l|}{ Para os funcionários } \\
\hline Banheiro separado por sexo $(*)$ & 7,2 & & 10 & \\
\hline Vestiário separado por sexo & & 0,5 & & \\
\hline Alojamento do caseiro & 50,0 & & & \\
\hline \multicolumn{5}{|l|}{ Opcional } \\
\hline Minisshopping & & & & \\
\hline Anfiteatro & 150,0 & & & \\
\hline
\end{tabular}

(*) 7,20 $\mathrm{m}^{2}$ referem-se aos dois banheiros: masculino e feminino 
Apêndice 18 - Equação das áreas dos ambientes da organização em função do número de residentes e funcionários

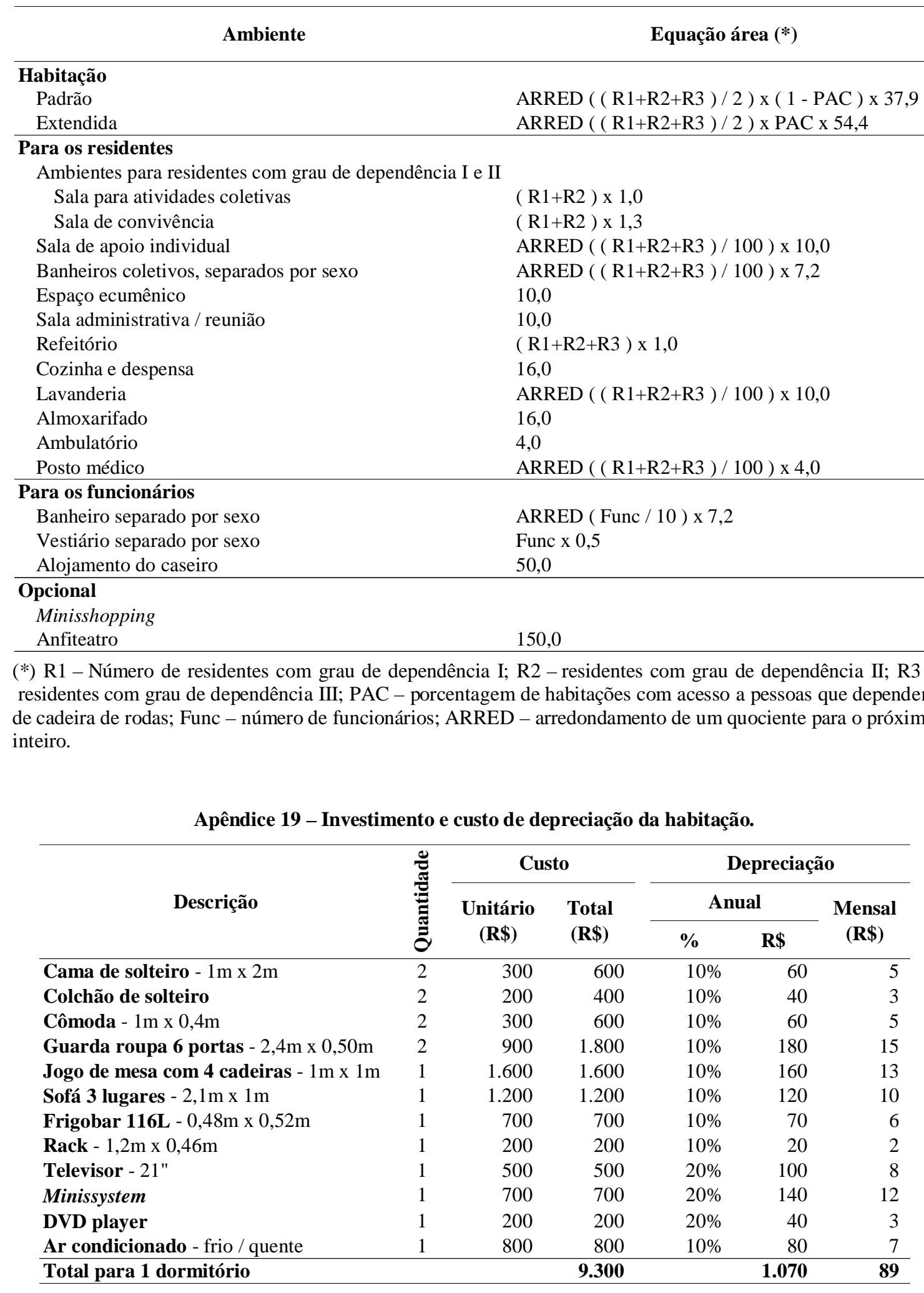


Apêndice 20 - Investimento e custo de depreciação para salas de atividades coletivas de $15 \mathrm{~m}^{2}$.

\begin{tabular}{|c|c|c|c|c|c|c|}
\hline \multirow{3}{*}{ Descrição } & \multirow{3}{*}{ 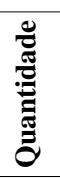 } & \multicolumn{2}{|c|}{ Custo } & \multicolumn{3}{|c|}{ Depreciação } \\
\hline & & \multirow{2}{*}{$\begin{array}{c}\text { Unitário } \\
\text { (R\$) }\end{array}$} & \multirow{2}{*}{$\begin{array}{c}\text { Total } \\
(\mathbf{R} \$)\end{array}$} & \multicolumn{2}{|c|}{ Anual } & \multirow{2}{*}{$\begin{array}{c}\text { Mensal } \\
\text { (R\$) }\end{array}$} \\
\hline & & & & $\%$ & $\mathbf{R} \$$ & \\
\hline \multicolumn{7}{|l|}{ Sala de Leitura } \\
\hline Sofá 1 lugar & 4 & 800 & 3.200 & $10 \%$ & 320 & 27 \\
\hline Mesa com 4 cadeiras & 4 & 600 & 2.400 & $10 \%$ & 240 & 20 \\
\hline Estante & 1 & 2.000 & 2.000 & $10 \%$ & 200 & 17 \\
\hline Livros & 50 & 50 & 2.500 & $10 \%$ & 250 & 21 \\
\hline Total para 1 sala de leitura & & & 10.100 & & 1.010 & 85 \\
\hline \multicolumn{7}{|l|}{ Sala de Atividades Manuais } \\
\hline Jogo de mesa com 4 cadeiras & 8 & 600 & 4.800 & $10 \%$ & 480 & 40 \\
\hline Material para pintura, artesanato, & 1 & 1000 & 1000 & $10 \%$ & 100 & 8 \\
\hline $\begin{array}{l}\text { bricolagem, etc } \\
\text { Total para } 1 \text { sala de atividades manuais }\end{array}$ & & & $\begin{array}{l}1.000 \\
5.800\end{array}$ & & $\mathbf{5 8 0}$ & $\begin{array}{r}8 \\
48\end{array}$ \\
\hline \multicolumn{7}{|l|}{ Sala de Jogos } \\
\hline Mesas para Jogos & 8 & 250 & 2.000 & $10 \%$ & 200 & 17 \\
\hline Cadeiras & 32 & 200 & 6.400 & $10 \%$ & 640 & 53 \\
\hline Dominó (*) & 3 & 60 & 180 & $100 \%$ & 180 & 15 \\
\hline Jogos 3x1 - xadrez, dama e gamão $(*)$ & 3 & 120 & 360 & $100 \%$ & 360 & 30 \\
\hline Carteado $(*)$ & 6 & 10 & 60 & $100 \%$ & 60 & 5 \\
\hline Total para 1 sala de jogos & & & 9.000 & & 1.440 & 120 \\
\hline \multicolumn{7}{|l|}{ Sala de Sinuca } \\
\hline Sinuca & 2 & 6.000 & 12.000 & $10 \%$ & 1.200 & 100 \\
\hline Total para 1 sala de sinuca & & & 12.000 & & 1.200 & 100 \\
\hline \multicolumn{7}{|l|}{ Sala de Fitness } \\
\hline Cadeira p/abdominal & 1 & 300 & 300 & $10 \%$ & 30 & 3 \\
\hline Arco p/abdominal & 1 & 120 & 120 & $10 \%$ & 12 & 1 \\
\hline Aparelho elíptico & 1 & 1.500 & 1.500 & $10 \%$ & 150 & 13 \\
\hline Balança eletrônica & 1 & 1.200 & 1.200 & $10 \%$ & 120 & 10 \\
\hline Bicicleta ergométrica & 2 & 1.600 & 3.200 & $10 \%$ & 320 & 27 \\
\hline Estação de ginástica & 1 & 2.000 & 2.000 & $10 \%$ & 200 & 17 \\
\hline Esteira profissional & 3 & 10.000 & 30.000 & $10 \%$ & 3.000 & 250 \\
\hline Total para 1 sala de fitness & & & 38.320 & & 3.832 & 321 \\
\hline
\end{tabular}

(*) Para os jogos considerou-se reposição anual.

Apêndice 21 - Investimento e custo de depreciação de salas de convivência para 30 residentes.

\begin{tabular}{|c|c|c|c|c|c|c|}
\hline \multirow{3}{*}{ Descrição } & \multirow{3}{*}{ 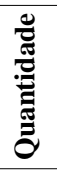 } & \multicolumn{2}{|c|}{ Custo } & \multicolumn{3}{|c|}{ Depreciação } \\
\hline & & \multirow{2}{*}{$\begin{array}{c}\text { Unitário } \\
\text { (R\$) }\end{array}$} & \multirow{2}{*}{$\begin{array}{c}\text { Total } \\
\text { (R\$) }\end{array}$} & \multicolumn{2}{|c|}{ Anual } & \multirow{2}{*}{$\begin{array}{c}\text { Mensal } \\
(\mathbf{R} \$)\end{array}$} \\
\hline & & & & $\%$ & $\mathbf{R} \$$ & \\
\hline \multicolumn{7}{|l|}{ Sala de Convivência } \\
\hline Cadeira & 10 & 600 & 6.000 & $10 \%$ & 600 & 50 \\
\hline Sofá 1 lugar & 10 & 800 & 8.000 & $10 \%$ & 800 & 67 \\
\hline Sofá 2 lugares & 5 & 1.000 & 5.000 & $10 \%$ & 500 & 42 \\
\hline Total & & & 19.000 & & 1.900 & 159 \\
\hline
\end{tabular}


Apêndice 22 - Investimento e custo de depreciação da sala de apoio, espaço ecumênico e administração e reunião.

\begin{tabular}{|c|c|c|c|c|c|c|}
\hline \multirow{3}{*}{ Descrição } & \multirow{3}{*}{ 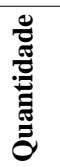 } & \multicolumn{2}{|c|}{ Custo } & \multicolumn{3}{|c|}{ Depreciação } \\
\hline & & \multirow{2}{*}{$\begin{array}{c}\text { Unitário } \\
\text { (R\$) }\end{array}$} & \multirow{2}{*}{$\begin{array}{l}\text { Total } \\
\text { (R\$) }\end{array}$} & \multicolumn{2}{|c|}{ Anual } & \multirow{2}{*}{$\begin{array}{c}\text { Mensal } \\
(\mathbf{R} \$)\end{array}$} \\
\hline & & & & $\%$ & $\mathbf{R} \$$ & \\
\hline \multicolumn{7}{|l|}{ Sala de Apoio } \\
\hline Mesa & 1 & 200 & 200 & $10 \%$ & 20 & 2 \\
\hline Cadeira & 4 & 100 & 400 & $10 \%$ & 40 & 3 \\
\hline Sofá 2 lugares & 1 & 1.000 & 1.000 & $10 \%$ & 100 & 8 \\
\hline Sofá 3 lugares & 1 & 1.200 & 1.200 & $10 \%$ & 120 & 10 \\
\hline Total para 100 residentes & & & 2.800 & & 280 & 23 \\
\hline \multicolumn{7}{|l|}{ Espaço Ecumênico } \\
\hline Cadeiras & 20 & 100 & 2.000 & $10 \%$ & 200 & 17 \\
\hline Total & & & 2.000 & & 200 & 17 \\
\hline \multicolumn{7}{|l|}{ Adminsitração / reunião } \\
\hline Mesa com cadeira & 6 & 400 & 2.400 & $10 \%$ & 240 & 20 \\
\hline Computador & 5 & 1.500 & 7.500 & $20 \%$ & 1.500 & 125 \\
\hline Software & 5 & 1.500 & 7.500 & $20 \%$ & 1.500 & 125 \\
\hline Impressora & 2 & 500 & 1.000 & $20 \%$ & 200 & 17 \\
\hline Armário & 5 & 500 & 2.500 & $10 \%$ & 250 & 21 \\
\hline Artigos de papelaria $(*)$ & & 1.000 & 1.000 & & 6.000 & 500 \\
\hline Total & & & 21.900 & & 9.690 & 808 \\
\hline
\end{tabular}

(*) Investimento inicial de $\mathrm{R} \$ 1.000$ em artigos de papelaria e despesa mensal de $\mathrm{R} \$ 500$.

Apêndice 23 - Investimento e custo de depreciação do refeitório e despensa, lavanderia, almoxarifado, ambulatório e posto médico.

\begin{tabular}{|c|c|c|c|c|c|c|}
\hline \multirow{3}{*}{ Descrição } & \multirow{3}{*}{ 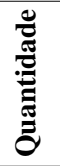 } & \multicolumn{2}{|c|}{ Custo } & \multicolumn{3}{|c|}{ Depreciação } \\
\hline & & \multirow{2}{*}{$\begin{array}{c}\text { Unitário } \\
\text { (R\$) }\end{array}$} & \multirow{2}{*}{$\begin{array}{l}\text { Total } \\
(\mathbf{R} \$)\end{array}$} & \multicolumn{2}{|c|}{ Anual } & \multirow{2}{*}{$\begin{array}{c}\text { Mensal } \\
\text { (R\$) }\end{array}$} \\
\hline & & & & $\%$ & $\mathbf{R} \$$ & \\
\hline \multicolumn{7}{|l|}{ Refeitório } \\
\hline Jogo de mesa com 4 cadeiras & 1 & 600 & 600 & $10 \%$ & 60 & 5 \\
\hline Total para 4 residentes & & & 600 & & 60 & 5 \\
\hline \multicolumn{7}{|l|}{ Cozinha - Terceirizada } \\
\hline \multicolumn{7}{|l|}{ Despensa } \\
\hline Armário de aço & 2 & 400 & 800 & $10 \%$ & 80 & 7 \\
\hline Total para 50 residentes & & & 800 & & 80 & 7 \\
\hline \multicolumn{7}{|l|}{ Lavanderia } \\
\hline Máquina de lavar & 1 & 30.000 & 30.000 & $10 \%$ & 3.000 & 250 \\
\hline Equip de passar & 3 & 300 & 900 & $10 \%$ & 90 & 8 \\
\hline Total para 100 residentes & & & 30.900 & & 3.090 & 258 \\
\hline \multicolumn{7}{|l|}{ Almoxarifado } \\
\hline Mesa com cadeira & 1 & 400 & 400 & $10 \%$ & 40 & 3 \\
\hline Armário de aço & 10 & 400 & 4.000 & $10 \%$ & 400 & 33 \\
\hline Total & & & 4.400 & & 440 & 36 \\
\hline \multicolumn{7}{|l|}{ Ambulatório } \\
\hline Mesa c/cadeira & 1 & 400 & 400 & $10 \%$ & 40 & 3 \\
\hline Armário de aço & 1 & 400 & 400 & $10 \%$ & 40 & 3 \\
\hline Maca & 1 & 500 & 500 & $10 \%$ & 50 & 4 \\
\hline Total & & & 1.300 & & 130 & 10 \\
\hline \multicolumn{7}{|l|}{ Posto Médico } \\
\hline Mesa c/cadeira & 1 & 400 & 400 & $10 \%$ & 40 & 3 \\
\hline Total para 100 residentes & & & 400 & & 40 & 3 \\
\hline
\end{tabular}


Apêndice 24 - Investimento e custo de depreciação do vestiário e anfiteatro.

\begin{tabular}{|c|c|c|c|c|c|c|}
\hline \multirow{3}{*}{ Descrição } & \multirow{3}{*}{ 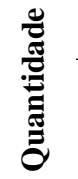 } & \multicolumn{2}{|c|}{ Custo } & \multicolumn{3}{|c|}{ Depreciação } \\
\hline & & \multirow{2}{*}{$\begin{array}{c}\text { Unitário } \\
\text { (R\$) }\end{array}$} & \multirow{2}{*}{$\begin{array}{l}\text { Total } \\
(\mathbf{R} \$)\end{array}$} & \multicolumn{2}{|c|}{ Anual } & \multirow{2}{*}{$\begin{array}{c}\text { Mensal } \\
(\mathbf{R} \$)\end{array}$} \\
\hline & & & & $\%$ & $\mathbf{R} \$$ & \\
\hline \multicolumn{7}{|l|}{ Vestiário } \\
\hline Armário & 4 & 300 & 1.200 & $10 \%$ & 120 & 10 \\
\hline Bancos & 1 & 100 & 100 & $10 \%$ & 10 & 1 \\
\hline Total para 16 funcionários & & & 1.300 & & 130 & 11 \\
\hline \multicolumn{7}{|l|}{ Anfiteatro } \\
\hline Cadeiras & 120 & 100 & 12.000 & $10 \%$ & 1.200 & 100 \\
\hline Televisor - 21" & 1 & 500 & 500 & $20 \%$ & 100 & 8 \\
\hline Computador & 1 & 3.000 & 3.000 & $20 \%$ & 600 & 50 \\
\hline Videocassete & 1 & 500 & 500 & $20 \%$ & 100 & 8 \\
\hline Hometheater & 1 & 600 & 600 & $20 \%$ & 120 & 10 \\
\hline Projetor multimídia & 1 & 6.000 & 6.000 & $20 \%$ & 1.200 & 100 \\
\hline Tela & 1 & 200 & 200 & $10 \%$ & 20 & 2 \\
\hline Total & & & 22.800 & & 3.340 & 278 \\
\hline
\end{tabular}

Apêndice 25 - Equação investimento em móveis e utensílios nos ambientes internos em função do número de residentes e funcionários

\begin{tabular}{|c|c|c|c|}
\hline Ambiente & $\begin{array}{l}\text { Investimento } \\
\qquad(\mathbf{R} \$)\end{array}$ & $\begin{array}{l}\text { Número de } \\
\text { residentes ou } \\
\text { funcionários } \\
\text { por ambiente }\end{array}$ & $\begin{array}{c}\text { Equação investimento em móveis e utensílios } \\
\text { nos ambientes internos }(*)\end{array}$ \\
\hline Habitação & 9.300 & 2 & ARRED ( ( R1+R2+R3 )/2 ) x 9.300 \\
\hline \multicolumn{4}{|l|}{ Sala de atividade coletiva } \\
\hline Sala de leitura & 10.100 & 15 & ARRED ( MÁX ( ( R1+R2 ); 0 ) / 70$)$ x 10.100 \\
\hline Sala de atividades manuais & 5.800 & 15 & ARRED ( MÁX ( ( R1+R2 ) - $15 ; 0$ ) / 70 ) x 5.800 \\
\hline Sala de jogos & 9.000 & 15 & ARRED ( MÁX ( ( R1+R2 ) - $30 ; 0$ ) / 70 ) x 9.000 \\
\hline Sala de fitness & 38.320 & 10 & ARRED ( MÁX ( ( R1+R2 ) - 45; 0 )/ 70$)$ x 38.320 \\
\hline Sala de sinuca & 12.000 & 15 & ARRED ( MÁX ( ( R1+R2 ) - $55 ; 0$ ) / 70 ) x 12.000 \\
\hline Sala de convivência & 19.000 & 30 & $\operatorname{ARRED}((\mathrm{R} 1+\mathrm{R} 2+\mathrm{R} 3) / 30) \times 19.000$ \\
\hline Sala de apoio & 2.800 & 100 & ARRED ( ( R1+R2+R3 )/ 100$) \times 2.800$ \\
\hline Espaço ecumênico & 2.000 & 20 & 2.000 \\
\hline Administração / reunião & 21.900 & & 21.900 \\
\hline Refeitório & 600 & 4 & ARRED ( ( R1+R2+R3 )/ 4$) \times 600$ \\
\hline Despensa & 800 & 50 & ARRED ( ( R1+R2+R3 )/ 50$) \times 800$ \\
\hline Lavanderia & 30.900 & 100 & $\operatorname{ARRED}((\mathrm{R} 1+\mathrm{R} 2+\mathrm{R} 3) / 100) \times 30.900$ \\
\hline Almoxarifado & 4.400 & & 4.400 \\
\hline Ambulatório & 1.300 & & 1.300 \\
\hline Posto Médico & 400 & 100 & $\operatorname{ARRED}((\mathrm{R} 1+\mathrm{R} 2+\mathrm{R} 3) / 100) \times 400$ \\
\hline Vestiário & 1.300 & 16 & ARRED ( Func / 16 ) x 1.300 \\
\hline Anfiteatro & 22.800 & & 22.800 \\
\hline
\end{tabular}

(*) R1 - Número de residentes com grau de dependência I; R2 - residentes com grau de dependência II; R3 residentes com grau de dependência III; Func - número de funcionários; ARRED - arredondamento de um quociente para o próximo inteiro; $\mathrm{MÁX}(\mathrm{X} ; \mathrm{Y})$ - deve-se utilizar o maior número entre $\mathrm{X}$ e $\mathrm{Y}$. 
Apêndice 26 - Equação custo com móveis e utensílios nos ambientes internos em função do número de residentes e funcionários

\begin{tabular}{|c|c|c|c|}
\hline Ambiente & $\begin{array}{l}\text { Custo total } \\
(\mathbf{R} \$)\end{array}$ & $\begin{array}{c}\text { Número de } \\
\text { residentes ou } \\
\text { funcionários } \\
\text { por ambiente }\end{array}$ & $\begin{array}{c}\text { Equação custo mensal com móveis e utensílios } \\
\text { nos ambientes internos }(*)\end{array}$ \\
\hline Habitação & 89 & 2 & ARRED ( ( R1+R2+R3 )/2) x 89 \\
\hline \multicolumn{4}{|l|}{ Sala de atividade coletiva } \\
\hline Sala de leitura & 85 & 15 & ARRED ( MÁX ( ( R1+R2 ); 0$) / 70)$ x 85 \\
\hline Sala de atividades manuais & 48 & 15 & ARRED ( MÁX ( ( R1+R2) - 15; 0 ) / 70$)$ x 48 \\
\hline Sala de jogos & 120 & 15 & ARRED ( MÁX ( ( R1+R2) - 30;0)/70) x 120 \\
\hline Sala de fitness & 321 & 10 & ARRED ( MÁX ( ( R1+R2 ) - $45 ; 0) / 70)$ x 321 \\
\hline Sala de sinuca & 100 & 15 & ARRED ( MÁX ( ( R1+R2 ) - 55; 0$) / 70)$ x 100 \\
\hline Sala de convivência & 159 & 30 & $\operatorname{ARRED}((\mathrm{R} 1+\mathrm{R} 2+\mathrm{R} 3) / 30) \times 159$ \\
\hline Sala de apoio & 23 & 100 & ARRED $((\mathrm{R} 1+\mathrm{R} 2+\mathrm{R} 3) / 100) \times 23$ \\
\hline Espaço ecumênico & 17 & 20 & 17 \\
\hline Administração / reunião & 808 & & 808 \\
\hline Refeitório & 5 & 4 & $\operatorname{ARRED}((\mathrm{R} 1+\mathrm{R} 2+\mathrm{R} 3) / 4) \times 5$ \\
\hline Despensa & 7 & 50 & ARRED ( ( R1+R2+R3 )/ 50$) \times 7$ \\
\hline Lavanderia & 258 & 100 & $\operatorname{ARRED}((\mathrm{R} 1+\mathrm{R} 2+\mathrm{R} 3) / 100) \times 258$ \\
\hline Almoxarifado & 36 & & 36 \\
\hline Ambulatório & 10 & & 10 \\
\hline Posto Médico & 3 & 100 & ARRED ( ( R1+R2+R3 )/ 100$) \times 3$ \\
\hline Vestiário & 11 & 16 & ARRED ( Func / 16 ) x 11 \\
\hline Anfiteatro & 278 & & 278 \\
\hline
\end{tabular}

(*) R1 - Número de residentes com grau de dependência I; R2 - residentes com grau de dependência II; R3 residentes com grau de dependência III; Func - número de funcionários; ARRED - arredondamento de um quociente para o próximo inteiro; $\mathrm{MÁX}(\mathrm{X} ; \mathrm{Y})$ - deve-se utilizar o maior número entre $\mathrm{X}$ e $\mathrm{Y}$.

Apêndice 27 - Investimento e custo de depreciação de piscina, saunas, campos e quadras.

\begin{tabular}{|c|c|c|c|c|c|c|c|}
\hline \multirow{3}{*}{ Descrição } & \multicolumn{2}{|c|}{ Quantidade } & \multicolumn{2}{|c|}{ Custo (R\$) } & \multicolumn{3}{|c|}{ Depreciação } \\
\hline & \multirow{2}{*}{$\mathbf{m}^{2}$} & \multirow{2}{*}{ Unidade } & \multirow{2}{*}{ Unitário } & \multirow{2}{*}{ Total } & \multicolumn{2}{|c|}{ Anual } & \multirow{2}{*}{$\begin{array}{c}\text { Mensal } \\
(\mathbf{R} \$)\end{array}$} \\
\hline & & & & & $\%$ & $\mathbf{R} \$$ & \\
\hline Piscina $-15 \mathrm{~m} \times 5 \mathrm{~m} \times 1,2 \mathrm{~m} \times 1,7 \mathrm{~m}$ & 75 & & 1.000 & 75.000 & $4 \%$ & 3.000 & 250 \\
\hline \multicolumn{8}{|l|}{ Sauna seca $-3 \mathrm{~m} \times 3 \mathrm{~m} \times 2,5 \mathrm{~m}$} \\
\hline Revestimento (chão, parede e teto) & 48 & & 200 & 9.600 & $4 \%$ & 384 & 32 \\
\hline Equipamento & & 1 & 6.000 & 6.000 & $10 \%$ & 600 & 50 \\
\hline \multicolumn{8}{|l|}{ Sauna úmida $-3 \mathrm{~m} \times 3 \mathrm{~m} \times 2,5 \mathrm{~m}$} \\
\hline Revestimento (chão, parede e teto) & 48 & & 200 & 9.600 & $4 \%$ & 384 & 32 \\
\hline Equipamento & & 1 & 8.000 & 8.000 & $10 \%$ & 800 & 67 \\
\hline Campo de bocha - $24 \mathrm{~m} \times 4 \mathrm{~m}$ & 96 & & 100 & 9.600 & $4 \%$ & 384 & 32 \\
\hline Campo de malha - $40 \mathrm{~m} \times 2,5 \mathrm{~m}$ & 100 & & 100 & 10.000 & $4 \%$ & 400 & 33 \\
\hline Qudra poliesportiva - $25 \mathrm{~m} \times 15 \mathrm{~m}$ & 375 & & 300 & 112.500 & $4 \%$ & 4.500 & 375 \\
\hline Quadra de saibro - $25 \mathrm{~m} \times 11 \mathrm{~m}$ & 275 & & 300 & 82.500 & $4 \%$ & 3.300 & 275 \\
\hline
\end{tabular}

Apêndice 28 - Investimento e custo de depreciação de pista de pedestre, ciclovia e jardins.

\begin{tabular}{|c|c|c|c|c|}
\hline \multirow{3}{*}{ Descrição } & \multirow{3}{*}{$\begin{array}{c}\text { Custo / } \mathbf{m}^{2} \\
(\mathbf{R} \$)\end{array}$} & \multicolumn{3}{|c|}{ Depreciação } \\
\hline & & \multicolumn{2}{|c|}{ Anual } & \multirow{2}{*}{$\begin{array}{c}\text { Mensal } \\
\text { (R\$) }\end{array}$} \\
\hline & & $\%$ & $\mathbf{R} \$$ & \\
\hline Pista de pedestre & 70 & $4 \%$ & 2,80 & 0,2333 \\
\hline Ciclovia & 70 & $4 \%$ & 2,80 & 0,2333 \\
\hline Jardins & 20 & & & \\
\hline
\end{tabular}


Apêndice 29 - Equação investimento e custo de depreciação das áreas externas

\begin{tabular}{lrcrrrr}
\hline \multirow{2}{*}{\multicolumn{1}{c}{ Área externa }} & \multicolumn{2}{c}{ Investimento } & & \multicolumn{2}{c}{ Depreciação mensal } \\
\cline { 2 - 3 } \cline { 6 - 7 } & \multicolumn{1}{c}{$\begin{array}{c}\text { Valor } \\
(\mathbf{R} \$)\end{array}$} & $\begin{array}{c}\text { Equação } \\
(*)\end{array}$ & & \multicolumn{2}{c}{$\begin{array}{c}\text { Valor } \\
(\mathbf{R} \$)\end{array}$} & $\begin{array}{c}\text { Equação } \\
(*)\end{array}$ \\
\hline Piscina 75m2 & 75.000 & $75.000 \times \mathrm{NP}$ & & 250 & $250 \times \mathrm{NP}$ \\
Sauna seca & 15.600 & $15.600 \times \mathrm{NSS}$ & & 82 & $82 \times \mathrm{NSS}$ \\
Sauna úmida & 17.600 & $17.600 \times \mathrm{NSU}$ & & 99 & $99 \times \mathrm{NSU}$ \\
Campo de bocha & 9.600 & $9.600 \times \mathrm{NCB}$ & & 32 & $32 \times \mathrm{NCB}$ \\
Campo de malha & 10.000 & $10.000 \times \mathrm{NCM}$ & & 33 & $33 \times \mathrm{NCM}$ \\
Quadra poliesportivan & 112.500 & $112.500 \times \mathrm{NQP}$ & & 375 & $375 \times \mathrm{NQP}$ \\
Quadra de saibro & 82.500 & $82.500 \times \mathrm{NQS}$ & & 275 & $275 \times \mathrm{NQS}$ \\
Pista de pedestre & 70 & $70 \times \mathrm{APP}$ & & 0,23 & $0,23 \times \mathrm{APP}$ \\
Ciclovia & 70 & $70 \times \mathrm{AC}$ & & 0,23 & $0,23 \times \mathrm{AC}$ \\
Jardins & 20 & $20 \times \mathrm{AJ}$ & & & \\
\hline
\end{tabular}

(*) NP $-\mathrm{n}^{\circ}$ de piscinas; NSS $-\mathrm{n}^{\circ}$ de saunas secas; NSU $-\mathrm{n}^{\circ}$ de saunas úmidas; $\mathrm{NCB}-\mathrm{n}^{\circ}$ de campos de bocha; $\mathrm{NCM}-\mathrm{n}^{\circ}$ de campos de malha; $\mathrm{NQP}-\mathrm{n}^{\circ}$ de quadras poliesportivas; $\mathrm{NQS}-\mathrm{n}^{\circ}$ de quadras de saibro; APP - área da pista de pedestre; AC - área da ciclovia; $\mathrm{AJ}$ - área dos jardins.

Apêndice 30 - Equação outras despesas administrativas e custos indiretos

\begin{tabular}{lcccc}
\hline \multicolumn{1}{c}{ Descrição } & $\begin{array}{c}\text { Unidade } \\
\text { (mensal) }\end{array}$ & Quant & $\begin{array}{c}\text { Vlr Unit } \\
(\mathbf{R} \$)\end{array}$ & Equação \\
\hline Energia elétrica $^{1}$ & $\mathrm{KWH} / \mathrm{m}^{2}$ & 0,6 & 0,3618 & ( $\mathrm{AI}+\mathrm{AE}$ ) x 0,21708 \\
Água e esgoto $^{2}$ & $\mathrm{~m}^{3} / \mathrm{m}^{2}$ & 0,01 & 10,16 & ( AI + AE ) x 0,1016 \\
Contabilidade & Salário Mínimo & 1 & 415,00 & 415 \\
\hline
\end{tabular}

FONTE: ${ }^{1}$ ELETROPAULO, 2008; ${ }^{2}$ SABESP, 2008.

Apêndice 31 - Equação outros custos diretos

\begin{tabular}{lcccc}
\hline \multicolumn{1}{c}{ Descrição } & $\begin{array}{c}\text { Unidade } \\
\text { (/residente/mês) }\end{array}$ & Quant & $\begin{array}{c}\text { Vlr Unit } \\
\text { (R\$ mensais) }\end{array}$ & Equação \\
\hline Alimentação & & 30 & 20,00 & $(\mathrm{R} 1+\mathrm{R} 2+\mathrm{R} 3)$ x 600 \\
Energia elétrica $^{1}$ & $\mathrm{KWH}$ & 70 & 0,3618 & $(\mathrm{R} 1+\mathrm{R} 2+\mathrm{R} 3) \times 25,326$ \\
Água e esgoto $^{2}$ & $\mathrm{~m}^{3}$ & 2 & 10,16 & $(\mathrm{R} 1+\mathrm{R} 2+\mathrm{R} 3) \times 20,32$ \\
\hline
\end{tabular}

FONTE: ${ }^{1}$ ELETROPAULO, 2008; ${ }^{2}$ SABESP, 2008. 
Apêndice 32 - Resumo das equações despesas e custos mensais, agrupados por comportamento em função do número de residentes, para 1 unidade.

\begin{tabular}{|c|c|c|}
\hline \multicolumn{2}{|c|}{ Descrição } & \multirow[t]{2}{*}{ Equação } \\
\hline Despesas administrativas & Salários e encargos sociais & \\
\hline & Contabilidade & 415 \\
\hline \multirow[t]{27}{*}{ Custos indiretos } & Fixos & \\
\hline & Salários e encargos sociais & 13.998 \\
\hline & Depreciação e manutenção & \\
\hline & Espaço ecumênico & 17 \\
\hline & Administração / reunião & 808 \\
\hline & Almoxarifado & 36 \\
\hline & Ambulatório & 10 \\
\hline & Anfiteatro & 278 \\
\hline & Piscina & $250 \times \mathrm{NP}$ \\
\hline & Sauna seca & $82 \times \mathrm{NSS}$ \\
\hline & Sauna úmida & $99 \times \mathrm{NSU}$ \\
\hline & Campo de bocha & $32 \times \mathrm{NCB}$ \\
\hline & Campo de malha & $33 \times \mathrm{NCM}$ \\
\hline & Quadra poliesportiva & $375 \times$ NQP \\
\hline & Quadra de saibro & $275 \times$ NQS \\
\hline & Pista de pedestre & $0,23 \times \mathrm{APP}$ \\
\hline & Ciclovia & $0,23 \times \mathrm{AC}$ \\
\hline & Variáveis em função de área & \\
\hline & Depreciação do prédio & $(\operatorname{ARRED}(\mathrm{AI} \times \mathrm{CUB} \times 0,04 / 12))$ \\
\hline & Salários e encargos sociais & \\
\hline & Serviço de limpeza interna & $(\operatorname{ARRED}(\mathrm{AI} / 100)) \times 3.570$ \\
\hline & Serviço de limpeza externa & $(\operatorname{ARRED}(\mathrm{AE} / 200)) \times 1.190$ \\
\hline & Jardineiro & $(\operatorname{ARRED}(\mathrm{AE} / 300)) \times 1.368$ \\
\hline & Vigia & $(\operatorname{ARRED}(\mathrm{AE} / 500)) \times 4.040$ \\
\hline & Ajudante geral & $(\operatorname{ARRED}((\mathrm{AI}+\mathrm{AE}) / 500)) \times 1.334$ \\
\hline & Energia elétrica & $(\mathrm{AI}+\mathrm{AE}) \times 0,21708$ \\
\hline & Água e esgoto & $(\mathrm{AI}+\mathrm{AE}) \times 0,1016$ \\
\hline \multirow[t]{27}{*}{ Custos diretos } & Salários e encargos sociais & \\
\hline & $\begin{array}{l}\text { Cuidador para residentes com } \\
\text { grau de dependência: }\end{array}$ & \\
\hline & I & $\operatorname{ARRED}((\mathrm{R} 1 \times \mathrm{NUCI}) / 20) \times 2.766$ \\
\hline & II & ARRED ( ( R2 x NUCI ) / 10$) \times 8.298$ \\
\hline & III & ARRED ( ( R3 x NUCI ) / 6 ) x 8.298 \\
\hline & Atividade de lazer & $\operatorname{ARRED}(((\mathrm{R} 1+\mathrm{R} 2) \times \mathrm{NUCI}) / 40) \times 3.348$ \\
\hline & Lavanderia & $\operatorname{ARRED}(((\mathrm{R} 1+\mathrm{R} 2+\mathrm{R} 3) \times \mathrm{NUCI}) / 30) \times 1.542$ \\
\hline & Médico & $\operatorname{ARRED}(((\mathrm{R} 1+\mathrm{R} 2+\mathrm{R} 3) \times \mathrm{NUCI}) / 100) \times 4.13$ \\
\hline & Auxiliar de enfermagem & $\operatorname{ARRED}(((\mathrm{R} 1+\mathrm{R} 2+\mathrm{R} 3) \times \mathrm{NUCI}) / 100) \times 11.0$ \\
\hline & Depreciação e manutenção & \\
\hline & Habitação & ARRED ( ( R1+R2+R3 )/ 2$) \times 89$ \\
\hline & Sala de atividade coletiva & \\
\hline & Sala de leitura & ARRED ( MÁX ( ( R1+R2 ); 0$) / 70)$ x 85 \\
\hline & Sala de atividades manuais & ARRED ( MÁX ( ( R1+R2 ) - 15;0)/ 70$)$ x 48 \\
\hline & Sala de jogos & ARRED ( MÁX ( ( R1+R2 ) - 30; 0$) / 70)$ x 120 \\
\hline & Sala de fitness & ARRED ( MÁX ( ( R1+R2 ) - 45; 0$) / 70)$ x 321 \\
\hline & Sala de sinuca & ARRED ( MÁX ( ( R1+R2 ) - 55; 0 )/ 70$)$ x 100 \\
\hline & Sala de convivência & ARRED $((\mathrm{R} 1+\mathrm{R} 2+\mathrm{R} 3) / 30) \times 159$ \\
\hline & Sala de apoio & $\operatorname{ARRED}((\mathrm{R} 1+\mathrm{R} 2+\mathrm{R} 3) / 100) \times 23$ \\
\hline & Refeitório & $\operatorname{ARRED}((\mathrm{R} 1+\mathrm{R} 2+\mathrm{R} 3) / 4) \times 5$ \\
\hline & Despensa & ARRED ( ( R1+R2+R3 )/ 50$) \times 7$ \\
\hline & Lavanderia & $\operatorname{ARRED}((\mathrm{R} 1+\mathrm{R} 2+\mathrm{R} 3) / 100) \times 258$ \\
\hline & Posto Médico & $\operatorname{ARRED}((\mathrm{R} 1+\mathrm{R} 2+\mathrm{R} 3) / 100) \times 3$ \\
\hline & Vestiário & ARRED ( Func / 16 ) x 11 \\
\hline & Alimentação & $(\mathrm{R} 1+\mathrm{R} 2+\mathrm{R} 3) \times 600 \times \mathrm{NUCI}$ \\
\hline & Energia elétrica & $(\mathrm{R} 1+\mathrm{R} 2+\mathrm{R} 3) \times 25,326 \times \mathrm{NUCI}$ \\
\hline & Água e esgoto & $(\mathrm{R} 1+\mathrm{R} 2+\mathrm{R} 3) \times 20,32 \times \mathrm{NUCI}$ \\
\hline Outros custos e despesas & & $3 \%$ do total \\
\hline
\end{tabular}


Apêndice 33 - Resumo das equações despesas e custos mensais, agrupados por comportamento em função do número de residentes, para matriz.

\begin{tabular}{|c|c|c|}
\hline \multicolumn{2}{|c|}{ Descrição } & Equação \\
\hline Despesas administrativas & Salários e encargos sociais & 47.882 \\
\hline & Contabilidade & 415 \\
\hline \multirow[t]{27}{*}{ Custos indiretos } & Fixos & \\
\hline & Salários e encargos sociais & 13.998 \\
\hline & Depreciação e manutenção & \\
\hline & Espaço ecumênico & 17 \\
\hline & Administração / reunião & 808 \\
\hline & Almoxarifado & 36 \\
\hline & Ambulatório & 10 \\
\hline & Anfiteatro & 278 \\
\hline & Piscina & $250 \times \mathrm{NP}$ \\
\hline & Sauna seca & $82 \times$ NSS \\
\hline & Sauna úmida & $99 \times \mathrm{NSU}$ \\
\hline & Campo de bocha & $32 \times \mathrm{NCB}$ \\
\hline & Campo de malha & $33 \times \mathrm{NCM}$ \\
\hline & Quadra poliesportiva & $375 \times \mathrm{NQP}$ \\
\hline & Quadra de saibro & $275 \times \mathrm{NQS}$ \\
\hline & Pista de pedestre & $0,23 \times \mathrm{APP}$ \\
\hline & Ciclovia & $0,23 \times \mathrm{AC}$ \\
\hline & Variáveis em função de área & \\
\hline & Depreciação do prédio & $(\operatorname{ARRED}(\operatorname{AI} \times$ CUB $\times 0,04 / 12))$ \\
\hline & Salários e encargos sociais & \\
\hline & Serviço de limpeza interna & $($ ARRED $($ AI / 100$)) \times 3.570$ \\
\hline & Serviço de limpeza externa & $(\operatorname{ARRED}(\mathrm{AE} / 200)) \times 1.190$ \\
\hline & Jardineiro & $($ ARRED $($ AE / 300$)) \times 1.368$ \\
\hline & Vigia & $($ ARRED $(\mathrm{AE} / 500)) \times 4.040$ \\
\hline & Ajudante geral & $(\operatorname{ARRED}((\mathrm{AI}+\mathrm{AE}) / 500)) \times 1.334$ \\
\hline & Energia elétrica & $(\mathrm{AI}+\mathrm{AE}) \times 0,21708$ \\
\hline & Água e esgoto & $(\mathrm{AI}+\mathrm{AE}) \times 0,1016$ \\
\hline \multirow[t]{26}{*}{ Custos diretos } & $\begin{array}{l}\text { Salários e encargos sociais } \\
\text { Cuidador para residentes com } \\
\text { grau de dependência: }\end{array}$ & \\
\hline & I & ARRED ( ( R1 x NUCI )/ 20$) \times 2.766$ \\
\hline & II & ARRED ( ( R2 x NUCI ) / 10$) \times 8.298$ \\
\hline & III & ARRED ( ( R3 x NUCI ) / 6$) \times 8.298$ \\
\hline & Atividade de lazer & ARRED ( ( ( R1+R2 ) x NUCI )/ 40$) \times 3.348$ \\
\hline & Lavanderia & $\operatorname{ARRED}(((\mathrm{R} 1+\mathrm{R} 2+\mathrm{R} 3) \times \mathrm{NUCI}) / 30) \times 1.542$ \\
\hline & Médico & $\operatorname{ARRED}(((\mathrm{R} 1+\mathrm{R} 2+\mathrm{R} 3) \times \mathrm{NUCI}) / 100) \times 4.13$ \\
\hline & Auxiliar de enfermagem & ARRED ( ( ( R1+R2+R3 ) x NUCI $) / 100) \times 11.0$ \\
\hline & Depreciação e manutenção & \\
\hline & Habitação & ARRED ( ( R1+R2+R3 )/ 2$) \times 89$ \\
\hline & Sala de atividade coletiva & \\
\hline & Sala de leitura & ARRED ( MÁX ( ( R1+R2 ); 0$) / 70)$ x 85 \\
\hline & Sala de atividades manuais & ARRED ( MÁX ( ( R1+R2 ) - 15; 0 ) / 70 ) x 48 \\
\hline & Sala de jogos & ARRED ( MÁX ( ( R1+R2 ) - 30;0 ) / 70 ) x 120 \\
\hline & Sala de fitness & ARRED ( MÁX ( ( R1+R2 ) - 45; 0 ) / 70$)$ x 321 \\
\hline & Sala de sinuca & ARRED ( MÁX ( ( R1+R2 ) - 55; 0 ) / 70$)$ x 100 \\
\hline & Sala de convivência & ARRED ( ( R1+R2+R3 )/ 30$) \times 159$ \\
\hline & Sala de apoio & ARRED ( ( R1+R2+R3 )/ 100$) \times 23$ \\
\hline & Refeitório & ARRED ( ( R1+R2+R3 )/ 4$) \times 5$ \\
\hline & Despensa & ARRED ( ( R1+R2+R3 )/ 50$) \times 7$ \\
\hline & Lavanderia & ARRED ( ( R1+R2+R3 )/ 100$) \times 258$ \\
\hline & Posto Médico & $\operatorname{ARRED}((\mathrm{R} 1+\mathrm{R} 2+\mathrm{R} 3) / 100) \times 3$ \\
\hline & Vestiário & ARRED ( Func / 16 ) x 11 \\
\hline & Alimentação & $(\mathrm{R} 1+\mathrm{R} 2+\mathrm{R} 3) \times 600 \times \mathrm{NUCI}$ \\
\hline & Energia elétrica & $(\mathrm{R} 1+\mathrm{R} 2+\mathrm{R} 3) \times 25,326 \times \mathrm{NUCI}$ \\
\hline & Água e esgoto & $(\mathrm{R} 1+\mathrm{R} 2+\mathrm{R} 3) \times 20,32 \times \mathrm{NUCI}$ \\
\hline Outros custos e despesas & & $3 \%$ do total \\
\hline
\end{tabular}


Apêndice 34 - Resumo das equações despesas e custos mensais, agrupados por comportamento em função do número de residentes, para uma filial.

\begin{tabular}{|c|c|c|}
\hline \multicolumn{2}{|c|}{ Descrição } & Equação \\
\hline Despesas administrativas & Salários e encargos sociais & 12.758 \\
\hline \multirow[t]{27}{*}{ Custos indiretos } & Fixos & \\
\hline & Salários e encargos sociais & 8.598 \\
\hline & Depreciação e manutenção & \\
\hline & Espaço ecumênico & 17 \\
\hline & Administração / reunião & 808 \\
\hline & Almoxarifado & 36 \\
\hline & Ambulatório & 10 \\
\hline & Anfiteatro & 278 \\
\hline & Piscina & $250 \times \mathrm{NP}$ \\
\hline & Sauna seca & $82 \times \mathrm{NSS}$ \\
\hline & Sauna úmida & $99 \times \mathrm{NSU}$ \\
\hline & Campo de bocha & $32 \times \mathrm{NCB}$ \\
\hline & Campo de malha & $33 \times \mathrm{NCM}$ \\
\hline & Quadra poliesportiva & $375 \times \mathrm{NQP}$ \\
\hline & Quadra de saibro & $275 \times \mathrm{NQS}$ \\
\hline & Pista de pedestre & $0,23 \times \mathrm{APP}$ \\
\hline & Ciclovia & $0,23 \times \mathrm{AC}$ \\
\hline & Variáveis em função de área & \\
\hline & Depreciação do prédio & $($ ARRED ( AI x CUB x 0,04 / 12 ) ) \\
\hline & Salários e encargos sociais & \\
\hline & Serviço de limpeza interna & $(\operatorname{ARRED}(\mathrm{AI} / 100)) \times 3.570$ \\
\hline & Serviço de limpeza externa & $(\operatorname{ARRED}(\mathrm{AE} / 200)) \times 1.190$ \\
\hline & Jardineiro & $($ ARRED $($ AE / 300$)) \times 1.368$ \\
\hline & Vigia & $(\mathrm{ARRED}(\mathrm{AE} / 500)) \times 4.040$ \\
\hline & Ajudante geral & $(\operatorname{ARRED}((\mathrm{AI}+\mathrm{AE}) / 500)) \times 1.334$ \\
\hline & Energia elétrica & $(\mathrm{AI}+\mathrm{AE}) \times 0,21708$ \\
\hline & Água e esgoto & $(\mathrm{AI}+\mathrm{AE}) \times 0,1016$ \\
\hline \multirow[t]{27}{*}{ Custos diretos } & $\begin{array}{l}\text { Salários e encargos sociais } \\
\text { Cuidador para residentes com } \\
\text { grau de dependência: }\end{array}$ & \\
\hline & I & ARRED ( ( R1 x NUCI )/ 20$) \times 2.766$ \\
\hline & II & ARRED ( ( R2 x NUCI ) / 10$) \times 8.298$ \\
\hline & III & ARRED ( ( R3 x NUCI ) / 6 ) x 8.298 \\
\hline & Atividade de lazer & ARRED ( ( ( R1+R2 ) x NUCI )/ 40$) \times 3.348$ \\
\hline & Lavanderia & ARRED ( ( ( R1+R2+R3 ) x NUCI )/ 30$) \times 1.542$ \\
\hline & Médico & $\operatorname{ARRED}(((\mathrm{R} 1+\mathrm{R} 2+\mathrm{R} 3) \times \mathrm{NUCI}) / 100) \times 4.13$ \\
\hline & Auxiliar de enfermagem & ARRED ( ( ( R1+R2+R3 ) x NUCI )/ 100$) \times 11.0$ \\
\hline & Depreciação e manutenção & \\
\hline & Habitação & ARRED ( ( R1+R2+R3 )/ 2$) \times 89$ \\
\hline & Sala de atividade coletiva & \\
\hline & Sala de leitura & ARRED ( MÁX ( ( R1+R2 ); 0$) / 70)$ x 85 \\
\hline & Sala de atividades manuais & ARRED ( MÁX ( ( R1+R2 ) - 15; 0 ) / 70 ) x 48 \\
\hline & Sala de jogos & ARRED ( MÁX ( ( R1+R2 ) - $30 ; 0) / 70)$ x 120 \\
\hline & Sala de fitness & ARRED ( MÁX ( ( R1+R2 ) - $45 ; 0$ ) / 70$)$ x 321 \\
\hline & Sala de sinuca & ARRED ( MÁX ( ( R1+R2 ) - $55 ; 0$ ) / 70$)$ x 100 \\
\hline & Sala de convivência & ARRED ( ( R1+R2+R3 )/30) x 159 \\
\hline & Sala de apoio & ARRED ( ( R1+R2+R3 )/ 100$) \times 23$ \\
\hline & Refeitório & $\operatorname{ARRED}((\mathrm{R} 1+\mathrm{R} 2+\mathrm{R} 3) / 4) \times 5$ \\
\hline & Despensa & ARRED ( ( R1+R2+R3)/ 50$) \times 7$ \\
\hline & Lavanderia & ARRED ( ( R1+R2+R3 )/ 100$) \times 258$ \\
\hline & Posto Médico & ARRED $((\mathrm{R} 1+\mathrm{R} 2+\mathrm{R} 3) / 100) \times 3$ \\
\hline & Vestiário & ARRED ( Func / 16 ) x 11 \\
\hline & Alimentação & $(\mathrm{R} 1+\mathrm{R} 2+\mathrm{R} 3) \times 600 \times \mathrm{NUCI}$ \\
\hline & Energia elétrica & $(\mathrm{R} 1+\mathrm{R} 2+\mathrm{R} 3) \times 25,326 \times \mathrm{NUCI}$ \\
\hline & Água e esgoto & $(\mathrm{R} 1+\mathrm{R} 2+\mathrm{R} 3) \times 20,32 \times \mathrm{NUCI}$ \\
\hline & & $3 \%$ do total \\
\hline
\end{tabular}


Apêndice 35 - Área interna e externa, parciais, em função do número de residentes, para cálculo completo de uma simulação

\begin{tabular}{|c|c|c|}
\hline Área da organização & Equação & $\begin{array}{c}\text { Área } \\
\left(\mathbf{m}^{2}\right)\end{array}$ \\
\hline \multicolumn{3}{|l|}{ Habitação } \\
\hline Padrão & ARRED ( ( R1+R2+R3 )/ 2$) \times(1-\mathrm{PAC}) \times 37,9$ & $3.032,0$ \\
\hline Extendida & ARRED ( ( R1+R2+R3 )/ 2$) \times$ PAC x 54,4 & $1.088,0$ \\
\hline \multicolumn{3}{|l|}{ Para os residentes } \\
\hline \multicolumn{3}{|l|}{$\begin{array}{l}\text { Ambientes para residentes com grau de } \\
\text { dependência I e II }\end{array}$} \\
\hline Sala para atividades coletivas & $(\mathrm{R} 1+\mathrm{R} 2) \times 1,0$ & 180,0 \\
\hline Sala de convivência & $(\mathrm{R} 1+\mathrm{R} 2) \times 1,3$ & 234,0 \\
\hline Sala de apoio individual & $\operatorname{ARRED}((\mathrm{R} 1+\mathrm{R} 2+\mathrm{R} 3) / 100) \times 10,0$ & 20,0 \\
\hline Banheiros coletivos, separados por sexo & $\operatorname{ARRED}((\mathrm{R} 1+\mathrm{R} 2+\mathrm{R} 3) / 100) \times 7,2$ & 14,4 \\
\hline Espaço ecumênico & 10 & 10,0 \\
\hline Sala administrativa / reunião & 10 & 10,0 \\
\hline Refeitório & $(\mathrm{R} 1+\mathrm{R} 2+\mathrm{R} 3) \times 1,0$ & 200,0 \\
\hline Cozinha e despensa & 16 & 16,0 \\
\hline Lavanderia & $\operatorname{ARRED}((\mathrm{R} 1+\mathrm{R} 2+\mathrm{R} 3) / 100) \times 10,0$ & 20,0 \\
\hline Almoxarifado & 16 & 16,0 \\
\hline Ambulatório & 4 & 4,0 \\
\hline Posto médico & $\operatorname{ARRED}((\mathrm{R} 1+\mathrm{R} 2+\mathrm{R} 3) / 100) \times 4,0$ & 8,0 \\
\hline \multicolumn{3}{|l|}{ Áreas opcionais } \\
\hline Minisshopping & AMS & 180,0 \\
\hline Anfiteatro & 150 & 150,0 \\
\hline Área interna parcial - AI & & $5.182,40$ \\
\hline Área externa parcial - AE & AI $x$ RAEI & $2.072,96$ \\
\hline
\end{tabular}

Apêndice 36 - Número de funcionários a $100 \%$ da capacidade instalada para cálculo completo de uma simulação

\begin{tabular}{|c|c|c|}
\hline Descrição & Equação & $\begin{array}{l}\text { Número de } \\
\text { Funcionários }\end{array}$ \\
\hline \multicolumn{3}{|l|}{ Diretos } \\
\hline Cuidador para residentes com grau & I ARRED ( ( R1 x NUCI ) / 20 ) & 5 \\
\hline \multirow[t]{2}{*}{ de dependência: } & II ARRED ( ( R2 x NUCI ) / 10 ) & 8 \\
\hline & III ARRED ( ( R3 x NUCI ) / 6 ) & 4 \\
\hline Atividade de lazer & ARRED ( ( ( R1+R2 ) x NUCI $) / 40)$ & 5 \\
\hline Alimentação (terceirizada) & ARRED ( ( ( R1+R2+R3 ) x NUCI )/ 20 ) & 10 \\
\hline Lavanderia & ARRED ( ( ( R1+R2+R3 ) x NUCI )/ 30$)$ & 7 \\
\hline Médico & ARRED ( ( ( R1+R2+R3 ) x NUCI )/ 100$)$ & 2 \\
\hline Auxiliar de enfermagem & ARRED ( ( ( R1+R2+R3 ) x NUCI )/ 100$)$ & 2 \\
\hline \multicolumn{3}{|l|}{ Funcionários indiretos } \\
\hline Serviços de limpeza (AI) & ARRED ( AI / 100 ) & 52 \\
\hline Serviços de limpeza (AE) & ARRED ( AE / 200 ) & 11 \\
\hline Jardineiro (AE) & ARRED ( AE / 300$)$ & 7 \\
\hline Vigia (AE) & ARRED ( AE / 500$)$ & 4 \\
\hline Ajudante geral (AI+AE) & $\operatorname{ARRED}((\mathrm{AI}+\mathrm{AE}) / 500)$ & 15 \\
\hline Administrativos & & 7 \\
\hline Número de funcionários - Func & & 139 \\
\hline
\end{tabular}


Apêndice 37 - Área destinada aos funcionários para cálculo completo de uma simulação

\begin{tabular}{llc}
\hline \multicolumn{1}{c}{ Área da organização } & \multicolumn{1}{c}{ Equação } & $\begin{array}{c}\text { Área } \\
\left(\mathbf{m}^{\mathbf{2}}\right)\end{array}$ \\
\hline Para os funcionários & & \\
Banheiro separado por sexo & ARRED ( Func / 10) x 7,2 & 100,8 \\
Vestiário separado por sexo & Func x 0,5 & 69,5 \\
Alojamento do caseiro & 50 & 50,0 \\
\hline Área interna parcial & & $\mathbf{2 2 0 , 3}$ \\
\hline
\end{tabular}

Apêndice 38 - Área total para cálculo completo de uma simulação

\begin{tabular}{lcc}
\hline \multicolumn{1}{c}{ Área da organização } & Equação & $\begin{array}{c}\text { Área } \\
\left(\mathbf{m}^{\mathbf{2}}\right)\end{array}$ \\
\hline Área total interna - AI & & $5.402,70$ \\
Área total externa - AE & AI x RAEI & $2.161,08$ \\
\hline Área total & & $\mathbf{7 . 5 6 3 , 7 8}$ \\
\hline
\end{tabular}

Apêndice 39 - Área ajardinada para cálculo completo de uma simulação

\begin{tabular}{lcr}
\hline \multicolumn{1}{c}{ Áreas externas } & Quantidade & \multicolumn{1}{c}{$\begin{array}{c}\text { Área } \\
(\mathbf{m 2})\end{array}$} \\
\hline Piscina & 1 & 75,0 \\
Sauna seca & 1 & 9,0 \\
Sauna úmida & 1 & 9,0 \\
Campo de bocha & 1 & 96,0 \\
Campo de malha & 1 & 100,0 \\
Quadra poliesportiva & 1 & 375,0 \\
Quadra de saibro & 1 & 275,0 \\
Área da pista de pedestre & & 500,0 \\
Área da ciclovia & & 500,0 \\
Total da construção externa (A) & & $1.939,0$ \\
Área externa total (B) & & $2.161,1$ \\
Jardim (B - A) & & 222,1 \\
\hline
\end{tabular}


Apêndice 40 - Valor do investimento total para cálculo completo de uma simulação

\begin{tabular}{|c|c|c|}
\hline Descrição & Equação & Valor $(\mathbf{R} \$)$ \\
\hline Terreno & $(\mathrm{AI}+\mathrm{AE}) \times$ CustoTerr & 3.781 .890 \\
\hline Construção civil & AI x CUB & 3.943 .971 \\
\hline Habitação & ARRED ( ( R1+R2+R3 )/ 2$) \times 9.300$ & 930.000 \\
\hline \multicolumn{3}{|l|}{ Sala de atividade coletiva } \\
\hline Sala de leitura & ARRED ( MÁX ( ( R1+R2 ); 0 )/ 70 ) x 10.100 & 30.300 \\
\hline Sala de atividades manuais & ARRED ( MÁX ( ( R1+R2 ) - $15 ; 0$ ) / 70 ) x 5.80 & 17.400 \\
\hline Sala de jogos & ARRED ( MÁX ( ( R1+R2 ) - 30 ; 0 ) / 70 ) x 9.00 & 27.000 \\
\hline Sala de fitness & ARRED ( MÁX ( ( R1+R2 ) - $45 ; 0$ ) / 70 ) x 38.3 & 76.640 \\
\hline Sala de sinuca & ARRED ( MÁX ( ( R1+R2 ) - 55; 0 ) / 70$)$ x 12.0 & 24.000 \\
\hline Sala de convivência & ARRED ( ( R1+R2+R3 )/ 30$) \times 19.000$ & 133.000 \\
\hline Sala de apoio & $\operatorname{ARRED}((\mathrm{R} 1+\mathrm{R} 2+\mathrm{R} 3) / 100) \times 2.800$ & 5.600 \\
\hline Espaço ecumênico & 2.000 & 2.000 \\
\hline Administração / reunião & 21.900 & 21.900 \\
\hline Refeitório & ARRED ( ( R1+R2+R3 )/ 4$) \times 600$ & 30.000 \\
\hline Despensa & ARRED ( ( R1+R2+R3 )/ 50$) \times 800$ & 3.200 \\
\hline Lavanderia & ARRED ( ( R1+R2+R3 )/ 100$) \times 30.900$ & 61.800 \\
\hline Almoxarifado & 4.400 & 4.400 \\
\hline Ambulatório & 1.300 & 1.300 \\
\hline Posto Médico & ARRED ( ( R1+R2+R3 )/ 100$) \times 400$ & 800 \\
\hline Vestiário & ARRED ( Func / 16 ) x 1.300 & 11.700 \\
\hline Anfiteatro & 22.800 & 22.800 \\
\hline Piscina & $75.000 \times \mathrm{NP}$ & 75.000 \\
\hline Sauna seca & $15.600 \times \mathrm{NSS}$ & 15.600 \\
\hline Sauna úmida & $17.600 \times \mathrm{NSU}$ & 17.600 \\
\hline Campo de bocha & $9.600 \times \mathrm{NBC}$ & 9.600 \\
\hline Campo de malha & $10.000 \times \mathrm{NCM}$ & 10.000 \\
\hline Quadra poliesportiva & $112.500 \times \mathrm{NQP}$ & 112.500 \\
\hline Quadra de saibro & $82.500 \times \mathrm{NQS}$ & 82.500 \\
\hline Pista de pedestre & $70 \times$ APP & 35.000 \\
\hline Ciclovia & $70 \times \mathrm{AC}$ & 35.000 \\
\hline Jardim & $20 \times \mathrm{AJ}$ & 4.442 \\
\hline Total & & 9.526 .943 \\
\hline Total por proprietário & Total / ( ( R1+R2 + R3 )/2) & $95.269,43$ \\
\hline
\end{tabular}

Apêndice 41 - Despesas administrativas mensais para cálculo completo de uma simulação

\begin{tabular}{lr}
\hline \multicolumn{1}{c}{ Descrição } & Valor $(\mathbf{R} \mathbf{\text { ) }}$ \\
\hline Salários e encargos sociais & 26.532 \\
Depreciação e manutenção & 808 \\
Contabilidade & 415 \\
\hline Total & $\mathbf{2 7 . 7 5 5}$ \\
\hline
\end{tabular}


Apêndice 42 - Custos indiretos mensais para cálculo completo de uma simulação

\begin{tabular}{|c|c|c|}
\hline Descrição & Equação & Valor $(\mathbf{R} \$)$ \\
\hline Fixos & 13998 & 13.998 \\
\hline \multicolumn{3}{|l|}{ Variáveis em função de área } \\
\hline Serviço de limpeza interna & $(\operatorname{ARRED}(\mathrm{AI} / 100)) \times 3.570$ & 185.640 \\
\hline Serviço de limpeza externa & $(\operatorname{ARRED}(\mathrm{AE} / 200)) \times 1.190$ & 13.090 \\
\hline Jardineiro & $(\operatorname{ARRED}(\mathrm{AE} / 200)) \times 1.368$ & 15.048 \\
\hline Vigia & $(\operatorname{ARRED}(\mathrm{AE} / 400)) \times 3.756$ & 22.536 \\
\hline Ajudante geral & $(\operatorname{ARRED}((\mathrm{AI}+\mathrm{AE}) / 400)) \times 1.334$ & 25.346 \\
\hline \multicolumn{3}{|l|}{ Depreciação e manutenção } \\
\hline Habitação & ARRED ( ( R1+R2+R3 )/ 2$) \times 89$ & 8.900 \\
\hline \multicolumn{3}{|l|}{ Sala de atividade coletiva } \\
\hline Sala de leitura & ARRED ( MÁX ( ( R1+R2 ); 0$) / 70)$ x 85 & 255 \\
\hline Sala de atividades manuais & ARRED ( MÁX ( ( R1+R2) - 15;0 )/ 70$)$ x 48 & 144 \\
\hline Sala de jogos & ARRED ( MÁX ( ( R1+R2) - 30; 0$) / 70)$ x 120 & 360 \\
\hline Sala de fitness & ARRED ( MÁX ( ( R1+R2 ) - 45; 0 ) / 70$)$ x 321 & 642 \\
\hline Sala de sinuca & ARRED ( MÁX ( ( R1+R2) - 55; 0$) / 70)$ x 100 & 200 \\
\hline Sala de convivência & ARRED ( ( R1+R2+R3 )/ 30$) \times 159$ & 1.113 \\
\hline Sala de apoio & ARRED ( ( R1+R2+R3 )/ 100$) \times 23$ & 46 \\
\hline Refeitório & ARRED ( ( R1+R2+R3 )/ 4$) \times 5$ & 250 \\
\hline Despensa & ARRED $((\mathrm{R} 1+\mathrm{R} 2+\mathrm{R} 3) / 50) \times 7$ & 28 \\
\hline Lavanderia & ARRED ( ( R1+R2+R3 )/ 100$) \times 258$ & 516 \\
\hline Posto Médico & ARRED ( ( R1+R2+R3 )/ 100$) \times 3$ & 6 \\
\hline Vestiário & ARRED ( Func / 16 ) x 11 & 99 \\
\hline Espaço ecumênico & 17 & 17 \\
\hline Almoxarifado & 36 & 36 \\
\hline Ambulatório & 10 & 10 \\
\hline Anfiteatro & 278 & 278 \\
\hline Piscina & $250 \times \mathrm{NP}$ & 250 \\
\hline Sauna seca & $82 \times \mathrm{NSS}$ & 82 \\
\hline Sauna úmida & $99 \times \mathrm{NSU}$ & 99 \\
\hline Campo de bocha & $32 \times \mathrm{NCB}$ & 32 \\
\hline Campo de malha & $33 \times \mathrm{NCM}$ & 33 \\
\hline Quadra poliesportiva & $375 \times \mathrm{NQP}$ & 375 \\
\hline Quadra de saibro & $275 \times$ NQS & 275 \\
\hline Pista de pedestre & $0,23 \times \mathrm{APP}$ & 117 \\
\hline Ciclovia & $0,23 \times \mathrm{AC}$ & 117 \\
\hline Energia elétrica & $(\mathrm{AI}+\mathrm{AE}) \times 0,21708$ & 2.111 \\
\hline Água e esgoto & $(\mathrm{AI}+\mathrm{AE}) \times 0,1016$ & 988 \\
\hline Total & & 293.036 \\
\hline
\end{tabular}


Apêndice 43 - Custos diretos mensais para cálculo completo de uma simulação

\begin{tabular}{|c|c|c|}
\hline Descrição & Equação & Valor $(\mathbf{R} \$)$ \\
\hline \multicolumn{3}{|l|}{ Salários e encargos sociais } \\
\hline \multicolumn{3}{|c|}{$\begin{array}{l}\text { Cuidador para residentes com } \\
\text { grau de dependência: }\end{array}$} \\
\hline I & ARRED ( ( R1 x NUCI )/ 20$) \times 2.766$ & 11.064 \\
\hline II & ARRED ( ( R2 x NUCI ) / 10$) \times 8.298$ & 49.788 \\
\hline III & ARRED ( ( R3 x NUCI ) / 6$) \times 8.298$ & 24.894 \\
\hline Atividade de lazer & $\operatorname{ARRED}(((\mathrm{R} 1+\mathrm{R} 2) \times \mathrm{NUCI}) / 40) \times 3.348$ & 13.392 \\
\hline Lavanderia & ARRED ( ( ( R1+R2+R3 ) x NUCI )/ 30$) \times 1.542$ & 7.710 \\
\hline Médico & ARRED $(((\mathrm{R} 1+\mathrm{R} 2+\mathrm{R} 3) \times \mathrm{NUCI}) / 100) \times 4.134$ & 8.268 \\
\hline Auxiliar de enfermagem & $\operatorname{ARRED}(((\mathrm{R} 1+\mathrm{R} 2+\mathrm{R} 3) \times \mathrm{NUCI}) / 100) \times 11.06$ & 22.128 \\
\hline Alimentação & $(\mathrm{R} 1+\mathrm{R} 2+\mathrm{R} 3) \times 600 \times \mathrm{NUCI}$ & 2.800 \\
\hline Energia elétrica & $(\mathrm{R} 1+\mathrm{R} 2+\mathrm{R} 3) \times 25,326 \times \mathrm{NUCI}$ & 3.546 \\
\hline Água e esgoto & $(\mathrm{R} 1+\mathrm{R} 2+\mathrm{R} 3) \times 20,32 \times \mathrm{NUCI}$ & 2.845 \\
\hline Total & & 146.434 \\
\hline
\end{tabular}

Apêndice 44 - Custos e despesas mensais para cálculo completo de uma simulação

\begin{tabular}{lr}
\hline \multicolumn{1}{c}{ Descrição } & Valor (R\$) \\
\hline Despesas administrativas & 27.755 \\
Custos indiretos & 293.036 \\
Custos diretos & 146.434 \\
$\quad$ Subtotal & 467.226 \\
Outros custos e despesas ( 3\% ) & 14.017 \\
\hline Total de despesas e custos médios mensais & $\mathbf{4 8 1 . 2 4 3}$ \\
\hline Número máximo de residentes & 200 \\
Nível de utilização da capacidade instalada & $70 \%$ \\
Total de residentes & 140 \\
\hline Despesas e custos médios mensais por residente & $\mathbf{3 . 4 3 8}$ \\
\hline
\end{tabular}

Apêndice 45 - Mensalidade média por residente para cálculo completo de uma simulação

\begin{tabular}{lr}
\hline \multicolumn{1}{c}{ Descrição } & Valor (R\$) \\
\hline Investimento por proprietário para 1 habitação & $95.269,43$ \\
Crédito mensal de 1\% & 952,69 \\
Número de residentes por habitação & 2 \\
Crédito mensal de 1\% por residente & 476,35 \\
Despesas e custos médios mensais por residente & 3.438 \\
Mensalidade média por residente & $\mathbf{3 . 9 1 4}$ \\
\hline
\end{tabular}


Apêndice 46 - Resumo dos resultados da regressão do valor médio do investimento com simulação do nível de utilização da capacidade instalada para 200 residentes, com diversos graus de dependência

\begin{tabular}{lr}
\hline \multicolumn{2}{c}{ Estatística de regressão } \\
\hline R múltiplo & 0,988 \\
R-Quadrado & 0,977 \\
R-quadrado ajustado & 0,974 \\
Erro padrão & 515,827 \\
Observações & 28 \\
\hline
\end{tabular}

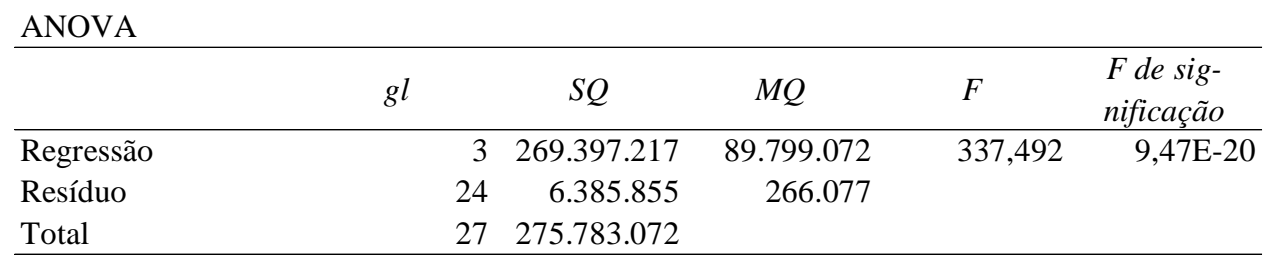

\begin{tabular}{|c|c|c|c|c|c|c|c|c|}
\hline & Coeficientes & Erro padrão & Stat $t$ & valor-P & $\begin{array}{c}95 \% \\
\text { inferiores }\end{array}$ & $\begin{array}{c}95 \% \\
\text { superiores }\end{array}$ & $\begin{array}{c}\text { Inferior } \\
95,0 \%\end{array}$ & $\begin{array}{c}\text { Superior } \\
95,0 \%\end{array}$ \\
\hline Interseção & $94.373,439$ & 661,156 & 142,740 & $1,13 \mathrm{E}-36$ & $93.008,881$ & $95.737,998$ & $93.008,881$ & $95.737,998$ \\
\hline Variável X 1 & 12,728 & 4,458 & 2,855 & 0,009 & 3,527 & 21,930 & 3,527 & 21,930 \\
\hline Variável X 2 & 13,586 & 4,582 & 2,965 & 0,007 & 4,130 & 23,042 & 4,130 & 23,042 \\
\hline Variável X 3 & $-47,814$ & 4,615 & $-10,362$ & $2,45 \mathrm{E}-10$ & $-57,338$ & $-38,290$ & $-57,338$ & $-38,290$ \\
\hline
\end{tabular}


Apêndice 47 - Resumo dos resultados da regressão do valor médio do investimento com simulação do nível de utilização da capacidade instalada para 300 residentes, com diversos graus de dependência

\begin{tabular}{lr}
\hline \multicolumn{2}{c}{ Estatística de regressão } \\
\hline R múltiplo & 0,989 \\
R-Quadrado & 0,978 \\
R-quadrado ajustado & 0,975 \\
Erro padrão & 479,214 \\
Observações & 28 \\
\hline
\end{tabular}

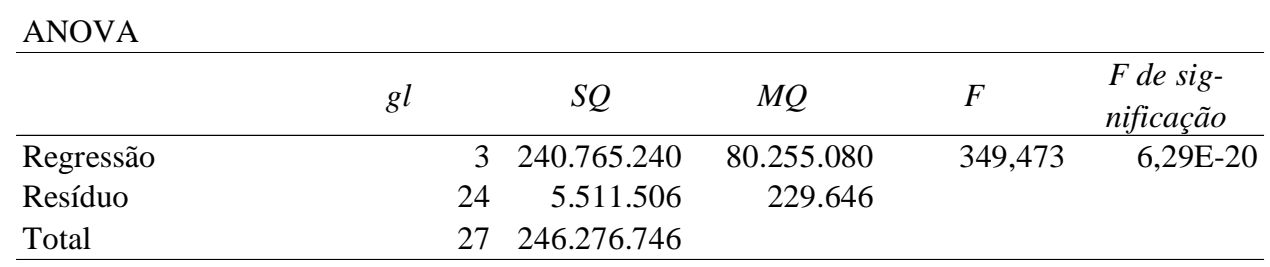

\begin{tabular}{lrrrrrrrr}
\hline & Coeficientes & Erro padrão & \multicolumn{1}{c}{ Stat $t$} & valor-P & $\begin{array}{c}\text { 95\% } \\
\text { inferiores }\end{array}$ & $\begin{array}{c}\text { 95\% } \\
\text { superiores }\end{array}$ & $\begin{array}{c}\text { Inferior } \\
95,0 \%\end{array}$ & $\begin{array}{c}\text { Superior } \\
95,0 \%\end{array}$ \\
\hline Interseção & $87.939,315$ & 614,228 & 143,171 & $1,06 \mathrm{E}-36$ & $86.671,612$ & $89.207,019$ & $86.671,612$ & $89.207,019$ \\
Variável X 1 & 8,004 & 2,761 & 2,899 & 0,008 & 2,305 & 13,703 & 2,305 & 13,703 \\
Variável X 2 & 8,591 & 2,838 & 3,028 & 0,006 & 2,734 & 14,448 & 2,734 & 14,448 \\
Variável X 3 & $-30,131$ & 2,858 & $-10,543$ & $1,73 \mathrm{E}-10$ & $-36,030$ & $-24,232$ & $-36,030$ & $-24,232$ \\
\hline
\end{tabular}


Apêndice 48 - Resumo dos resultados da regressão do valor médio do investimento com simulação do nível de utilização da capacidade instalada para 400 residentes, com diversos graus de dependência

\begin{tabular}{lr}
\hline \multicolumn{2}{c}{ Estatística de regressão } \\
\hline R múltiplo & 0,989 \\
R-Quadrado & 0,978 \\
R-quadrado ajustado & 0,975 \\
Erro padrão & 470,130 \\
Observações & 28 \\
\hline
\end{tabular}

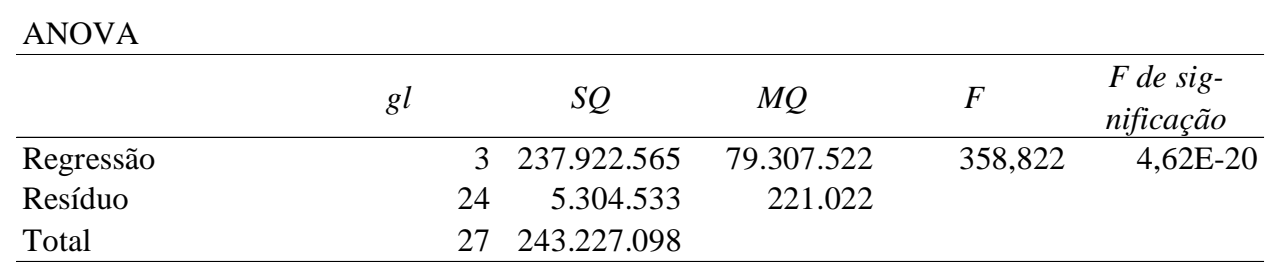

\begin{tabular}{|c|c|c|c|c|c|c|c|c|}
\hline & Coeficientes & Erro padrão & Stat $t$ & valor $-P$ & $\begin{array}{c}95 \% \\
\text { inferiores }\end{array}$ & $\begin{array}{c}95 \% \\
\text { superiores }\end{array}$ & $\begin{array}{c}\text { Inferior } \\
95,0 \%\end{array}$ & $\begin{array}{c}\text { Superior } \\
95,0 \%\end{array}$ \\
\hline Interseção & $86.282,498$ & 602,584 & 143,187 & $1,05 \mathrm{E}-36$ & $85.038,825$ & $87.526,171$ & $85.038,825$ & $87.526,171$ \\
\hline Variável X 1 & 5,922 & 2,032 & 2,915 & 0,008 & 1,729 & 10,115 & 1,729 & 10,115 \\
\hline Variável X 2 & 6,478 & 2,088 & 3,102 & 0,005 & 2,168 & 10,787 & 2,168 & 10,787 \\
\hline Variável X 3 & $-22,455$ & 2,103 & $-10,678$ & $1,34 \mathrm{E}-10$ & $-26,795$ & $-18,115$ & $-26,795$ & $-18,115$ \\
\hline
\end{tabular}


Apêndice 49 - Resumo dos resultados da regressão do valor médio do investimento com simulação da porcentagem de habitações destinadas a cadeirantes para 100 residentes, com diversos graus de dependência

\begin{tabular}{lr}
\hline \multicolumn{2}{c}{ Estatística de regressão } \\
\hline R múltiplo & 1,000 \\
R-Quadrado & 0,999 \\
R-quadrado ajustado & 0,967 \\
Erro padrão & 222,530 \\
Observações & 35 \\
\hline
\end{tabular}

\begin{tabular}{|c|c|c|c|c|c|c|c|c|}
\hline \multicolumn{9}{|l|}{ ANOVA } \\
\hline & $g l$ & $S Q$ & $M Q$ & $F$ & $\begin{array}{l}F \text { de sig- } \\
\text { nificação }\end{array}$ & & & \\
\hline Regressão & 4 & 2,E+09 & 505.941 .207 & $13.622,611$ & $2,05 \mathrm{E}-48$ & & & \\
\hline Resíduo & 31 & 1.535 .112 & 49.520 & & & & & \\
\hline \multirow[t]{2}{*}{ Total } & 35 & 2,E+09 & & & & & & \\
\hline & Coeficientes & Erro padrão & Stat $t$ & valor-P & $\begin{array}{c}95 \% \\
\text { inferiores }\end{array}$ & $\begin{array}{c}95 \% \\
\text { superiores }\end{array}$ & $\begin{array}{c}\text { Inferior } \\
95,0 \%\end{array}$ & $\begin{array}{c}\text { Superior } \\
95,0 \%\end{array}$ \\
\hline Interseção & $90.527,350$ & 120,755 & 749,676 & $1,40 \mathrm{E}-67$ & $90.281,067$ & $90.773,632$ & $90.281,067$ & $90.773,632$ \\
\hline Variável X 1 & $24.289,013$ & 132,987 & 182,642 & 0,000 & $24.017,783$ & $24.560,242$ & $24.017,783$ & $24.560,242$ \\
\hline Variável X 2 & 1,337 & 1,827 & 0,732 & 0,470 & $-2,390$ & 5,063 & $-2,390$ & 5,063 \\
\hline Variável X 3 & 0,000 & 0,000 & $65.535,000$ & - & 0,000 & 0,000 & 0,000 & 0,000 \\
\hline Variável X 4 & $-138,006$ & 1,886 & $-73,188$ & $2,71 \mathrm{E}-36$ & $-141,852$ & $-134,161$ & $-141,852$ & $-134,161$ \\
\hline
\end{tabular}


Apêndice 50 - Resumo dos resultados da regressão do valor médio do investimento com simulação da porcentagem de habitações destinadas a cadeirantes para 200 residentes, com diversos graus de dependência

\begin{tabular}{lr}
\hline \multicolumn{2}{c}{ Estatística de regressão } \\
\hline R múltiplo & 1,000 \\
R-Quadrado & 1,000 \\
R-quadrado ajustado & 0,968 \\
Erro padrão & 115,750 \\
Observações & 35 \\
\hline
\end{tabular}

\begin{tabular}{|c|c|c|c|c|c|c|c|c|}
\hline \multicolumn{6}{|l|}{ ANOVA } & & & \\
\hline & $g l$ & $S Q$ & $M Q$ & $F$ & $\begin{array}{l}\text { F de sig- } \\
\text { nificação }\end{array}$ & & & \\
\hline Regressão & 4 & $2, \mathrm{E}+09$ & 498.858 .001 & $49.644,671$ & $7,78 \mathrm{E}-57$ & & & \\
\hline Resíduo & 31 & 415.341 & 13.398 & & & & & \\
\hline \multirow[t]{2}{*}{ Total } & 35 & 2,E+09 & & & & & & \\
\hline & Coeficientes & Erro padrão & Stat $t$ & valor-P & $\begin{array}{c}95 \% \\
\text { inferiores }\end{array}$ & $\begin{array}{c}95 \% \\
\text { superiores }\end{array}$ & $\begin{array}{c}\text { Inferior } \\
95,0 \%\end{array}$ & $\begin{array}{c}\text { Superior } \\
95,0 \%\end{array}$ \\
\hline Interseção & $91.597,934$ & 62,811 & $1.458,301$ & $1,55 \mathrm{E}-76$ & $91.469,829$ & $91.726,039$ & $91.469,829$ & $91.726,039$ \\
\hline Variável X 1 & $24.282,488$ & 69,174 & 351,035 & 0,000 & $24.141,407$ & $24.423,569$ & $24.141,407$ & $24.423,569$ \\
\hline Variável X 2 & $-0,947$ & 0,475 & $-1,993$ & 0,055 & $-1,916$ & 0,022 & $-1,916$ & 0,022 \\
\hline Variável X 3 & 0,000 & 0,000 & $65.535,000$ & - & 0,000 & 0,000 & 0,000 & 0,000 \\
\hline Variável X 4 & $-67,273$ & 0,490 & $-137,176$ & $1,01 \mathrm{E}-44$ & $-68,273$ & $-66,272$ & $-68,273$ & $-66,272$ \\
\hline
\end{tabular}


Apêndice 51 - Resumo dos resultados da regressão do valor médio do investimento com simulação da porcentagem de habitações destinadas a cadeirantes para 300 residentes, com diversos graus de dependência

\begin{tabular}{lr}
\hline \multicolumn{2}{c}{ Estatística de regressão } \\
\hline R múltiplo & 1,000 \\
R-Quadrado & 1,000 \\
R-quadrado ajustado & 1,000 \\
Erro padrão & 85,568 \\
Observações & 35 \\
\hline
\end{tabular}

\begin{tabular}{|c|c|c|c|c|c|c|c|c|}
\hline \multicolumn{9}{|l|}{ ANOVA } \\
\hline & $g l$ & $S Q$ & $M Q$ & $F$ & $\begin{array}{l}F \text { de sig- } \\
\text { nificação }\end{array}$ & & & \\
\hline Regressão & 4 & $1,84 \mathrm{E}+09$ & 458.877 .957 & 62.672 & $2,36 \mathrm{E}-58$ & & & \\
\hline Resíduo & 30 & 219.657 & 7.322 & & & & & \\
\hline \multirow[t]{2}{*}{ Total } & 34 & $1,84 \mathrm{E}+09$ & & & & & & \\
\hline & Coeficientes & Erro padrão & Stat $t$ & valor $-P$ & $\begin{array}{c}95 \% \\
\text { inferiores }\end{array}$ & $\begin{array}{c}95 \% \\
\text { superiores }\end{array}$ & $\begin{array}{c}\text { Inferior } \\
95,0 \%\end{array}$ & $\begin{array}{c}\text { Superior } \\
95,0 \%\end{array}$ \\
\hline Interseção & $1,47 \mathrm{E}+17$ & $2,11 \mathrm{E}+17$ & 0,699 & 0,490 & $-2,84 \mathrm{E}+17$ & $5,78 \mathrm{E}+17$ & $-2,84 \mathrm{E}+17$ & $5,78 \mathrm{E}+17$ \\
\hline Variável X 1 & $23.337,441$ & 53,618 & 435,251 & $1,42 \mathrm{E}-58$ & $23.227,937$ & $23.446,944$ & $23.227,937$ & $23.446,944$ \\
\hline Variável X 2 & $-7,02 \mathrm{E}+14$ & $1,00 \mathrm{E}+15$ & $-0,699$ & 0,490 & $-2,75 E+15$ & $1,35 E+15$ & $-2,75 E+15$ & $1,35 E+15$ \\
\hline Variável X 3 & $-7,02 \mathrm{E}+14$ & $1,00 \mathrm{E}+15$ & $-0,699$ & 0,490 & $-2,75 E+15$ & $1,35 E+15$ & $-2,75 E+15$ & $1,35 \mathrm{E}+15$ \\
\hline Variável X 4 & $-7,02 \mathrm{E}+14$ & $1,00 \mathrm{E}+15$ & $-0,699$ & 0,490 & $-2,75 E+15$ & $1,35 \mathrm{E}+15$ & $-2,75 E+15$ & $1,35 \mathrm{E}+15$ \\
\hline
\end{tabular}


Apêndice 52 - Resumo dos resultados da regressão do valor médio do investimento com simulação da porcentagem de habitações destinadas a cadeirantes para 400 residentes, com diversos graus de dependência

\begin{tabular}{lr}
\hline \multicolumn{2}{c}{ Estatística de regressão } \\
\hline R múltiplo & 1,000 \\
R-Quadrado & 1,000 \\
R-quadrado ajustado & 0,968 \\
Erro padrão & 44,623 \\
Observações & 35 \\
\hline
\end{tabular}

\begin{tabular}{|c|c|c|c|c|c|c|c|c|}
\hline \multicolumn{9}{|l|}{ ANOVA } \\
\hline & $g l$ & $S Q$ & $M Q$ & $F$ & $\begin{array}{l}F \text { de sig- } \\
\text { nificação }\end{array}$ & & & \\
\hline Regressão & 4 & $1,84 \mathrm{E}+09$ & 460.596 .214 & 308.420 & $9,83 \mathrm{E}-69$ & & & \\
\hline Resíduo & 31 & 61.727 & 1.991 & & & & & \\
\hline \multirow[t]{2}{*}{ Total } & 35 & $1,84 \mathrm{E}+09$ & & & & & & \\
\hline & Coeficientes & Erro padrão & Stat $t$ & valor-P & $\begin{array}{c}95 \% \\
\text { inferiores }\end{array}$ & $\begin{array}{c}95 \% \\
\text { superiores }\end{array}$ & $\begin{array}{c}\text { Inferior } \\
95,0 \%\end{array}$ & $\begin{array}{c}\text { Superior } \\
95,0 \%\end{array}$ \\
\hline Interseção & $83.592,894$ & 24,214 & $3.452,186$ & $3,87 \mathrm{E}-88$ & $83.543,508$ & $83.642,280$ & $83.543,508$ & $83.642,280$ \\
\hline Variável X 1 & $23.418,461$ & 26,667 & 878,171 & $1,04 \mathrm{E}-69$ & $23.364,073$ & $23.472,850$ & $23.364,073$ & $23.472,850$ \\
\hline Variável X 2 & $-0,606$ & 0,092 & $-6,621$ & $2,13 \mathrm{E}-07$ & $-0,793$ & $-0,420$ & $-0,793$ & $-0,420$ \\
\hline Variável X 3 & 0 & 0 & 65535 & - & 0 & 0 & 0 & 0 \\
\hline Variável X 4 & $-31,830$ & 0,095 & $-336,719$ & $8,35 \mathrm{E}-57$ & $-32,023$ & $-31,637$ & $-32,023$ & $-31,637$ \\
\hline
\end{tabular}


Apêndice 53 - Valor médio do investimento por habitação em função de áreas externas, anfiteatro e minisshopping para 200 residentes, com diversos graus de dependência (informações realinhadas para 15 variáveis independentes)

\begin{tabular}{|c|c|c|c|c|c|c|c|c|c|c|c|c|c|c|c|c|}
\hline \multirow{4}{*}{ 焉 } & \multirow{3}{*}{ 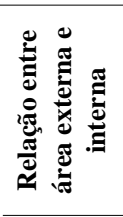 } & \multirow{3}{*}{ 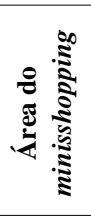 } & \multirow{3}{*}{ 离泀 } & \multicolumn{7}{|c|}{ Quantidade de } & \multirow{3}{*}{ 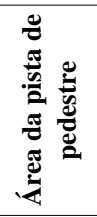 } & \multirow{3}{*}{ 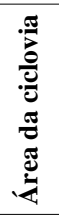 } & \multirow{2}{*}{\multicolumn{3}{|c|}{$\begin{array}{l}\text { Número de residentes com } \\
\text { grau de dependência }\end{array}$}} & \multirow{3}{*}{ 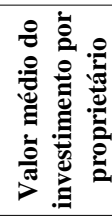 } \\
\hline & & & & \multirow{2}{*}{ 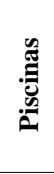 } & \multirow{2}{*}{ 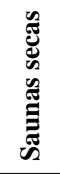 } & \multirow{2}{*}{ 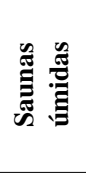 } & \multirow{2}{*}{ 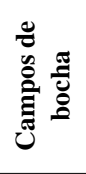 } & \multirow{2}{*}{ 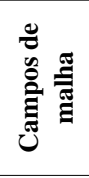 } & \multirow{2}{*}{ 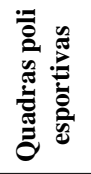 } & \multirow{2}{*}{ 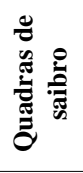 } & & & & & & \\
\hline & & & & & & & & & & & & & I & II & III & \\
\hline & $\mathrm{x1}$ & $\mathbf{x 2}$ & $\mathrm{x3}$ & $x 4$ & $\mathrm{x5}$ & $\mathrm{x6}$ & $\mathrm{x} 7$ & $\mathrm{x8}$ & x9 & $\mathbf{x 1 0}$ & $\mathrm{x} 11$ & $\mathbf{x 1 2}$ & $\mathrm{x13}$ & $\mathrm{x14}$ & x15 & $\mathbf{Y}$ \\
\hline \multirow{7}{*}{$\mathbf{A}$} & 0,4 & 180 & 1 & 1 & 1 & 1 & 1 & 1 & 1 & 1 & 500 & 500 & 140 & 0 & 0 & 96.391 \\
\hline & 0,4 & 180 & 1 & 1 & 1 & 1 & 1 & 1 & 1 & 1 & 500 & 500 & 0 & 140 & 0 & 96.566 \\
\hline & 0,4 & 180 & 1 & 1 & 1 & 1 & 1 & 1 & 1 & 1 & 500 & 500 & 0 & 0 & 140 & 87.037 \\
\hline & 0,4 & 180 & 1 & 1 & 1 & 1 & 1 & 1 & 1 & 1 & 500 & 500 & 98 & 42 & 0 & 96.413 \\
\hline & 0,4 & 180 & 1 & 1 & 1 & 1 & 1 & 1 & 1 & 1 & 500 & 500 & 98 & 0 & 42 & 93.676 \\
\hline & 0,4 & 180 & 1 & 1 & 1 & 1 & 1 & 1 & 1 & 1 & 500 & 500 & 70 & 56 & 14 & 95.269 \\
\hline & 0,4 & 180 & 1 & 1 & 1 & 1 & 1 & 1 & 1 & 1 & 500 & 500 & 84 & 42 & 14 & 95.262 \\
\hline \multirow{7}{*}{ B } & 0,3 & 180 & 1 & 1 & 1 & 1 & 0 & 0 & 0 & 0 & 500 & 0 & 140 & 0 & 0 & 91.150 \\
\hline & 0,3 & 180 & 1 & 1 & 1 & 1 & 0 & 0 & 0 & 0 & 500 & 0 & 0 & 140 & 0 & 91.332 \\
\hline & 0,3 & 180 & 1 & 1 & 1 & 1 & 0 & 0 & 0 & 0 & 500 & 0 & 0 & 0 & 140 & 82.070 \\
\hline & 0,3 & 180 & 1 & 1 & 1 & 1 & 0 & 0 & 0 & 0 & 500 & 0 & 98 & 42 & 0 & 91.171 \\
\hline & 0,3 & 180 & 1 & 1 & 1 & 1 & 0 & 0 & 0 & 0 & 500 & 0 & 98 & 0 & 42 & 88.513 \\
\hline & 0,3 & 180 & 1 & 1 & 1 & 1 & 0 & 0 & 0 & 0 & 500 & 0 & 70 & 56 & 14 & 90.064 \\
\hline & 0,3 & 180 & 1 & 1 & 1 & 1 & 0 & 0 & 0 & 0 & 500 & 0 & 84 & 42 & 14 & 90.044 \\
\hline \multirow{7}{*}{ C } & 0,2 & 90 & 1 & 0 & 0 & 0 & 0 & 0 & 0 & 0 & 500 & 0 & 140 & 0 & 0 & 85.918 \\
\hline & 0,2 & 90 & 1 & 0 & 0 & 0 & 0 & 0 & 0 & 0 & 500 & 0 & 0 & 140 & 0 & 86.081 \\
\hline & 0,2 & 90 & 1 & 0 & 0 & 0 & 0 & 0 & 0 & 0 & 500 & 0 & 0 & 0 & 140 & 77.043 \\
\hline & 0,2 & 90 & 1 & 0 & 0 & 0 & 0 & 0 & 0 & 0 & 500 & 0 & 98 & 42 & 0 & 85.938 \\
\hline & 0,2 & 90 & 1 & 0 & 0 & 0 & 0 & 0 & 0 & 0 & 500 & 0 & 98 & 0 & 42 & 83.454 \\
\hline & 0,2 & 90 & 1 & 0 & 0 & 0 & 0 & 0 & 0 & 0 & 500 & 0 & 70 & 56 & 14 & 84.937 \\
\hline & 0,2 & 90 & 1 & 0 & 0 & 0 & 0 & 0 & 0 & 0 & 500 & 0 & 84 & 42 & 14 & 84.931 \\
\hline \multirow{7}{*}{ D } & 0,1 & 0 & 0 & 0 & 0 & 0 & 0 & 0 & 0 & 0 & 250 & 0 & 140 & 0 & 0 & 79.533 \\
\hline & 0,1 & 0 & 0 & 0 & 0 & 0 & 0 & 0 & 0 & 0 & 250 & 0 & 0 & 140 & 0 & 79.702 \\
\hline & 0,1 & 0 & 0 & 0 & 0 & 0 & 0 & 0 & 0 & 0 & 250 & 0 & 0 & 0 & 140 & 70.923 \\
\hline & 0,1 & 0 & 0 & 0 & 0 & 0 & 0 & 0 & 0 & 0 & 250 & 0 & 98 & 42 & 0 & 79.552 \\
\hline & 0,1 & 0 & 0 & 0 & 0 & 0 & 0 & 0 & 0 & 0 & 250 & 0 & 98 & 0 & 42 & 77.044 \\
\hline & 0,1 & 0 & 0 & 0 & 0 & 0 & 0 & 0 & 0 & 0 & 250 & 0 & 70 & 56 & 14 & 78.577 \\
\hline & 0,1 & 0 & 0 & 0 & 0 & 0 & 0 & 0 & 0 & 0 & 250 & 0 & 84 & 42 & 14 & 78.479 \\
\hline
\end{tabular}

* $1=\operatorname{Sim} ; 0=$ Não 
Apêndice 54 - Resumo dos resultados da regressão do valor médio do investimento por habitação em função de áreas externas, anfiteatro e minisshopping para 200 residentes, com diversos graus de dependência, para 15 variáveis independentes

\begin{tabular}{lr}
\hline \multicolumn{2}{c}{ Estatística de regressão } \\
\hline R múltiplo & 1,000 \\
R-Quadrado & 1,000 \\
R-quadrado ajustado & 0,545 \\
Erro padrão & 162,005 \\
Observações & 28 \\
\hline
\end{tabular}

\begin{tabular}{|c|c|c|c|c|c|}
\hline & $g l$ & $S Q$ & $M Q$ & $F$ & $\begin{array}{l}\text { F de sig- } \\
\text { nificaçãoo }\end{array}$ \\
\hline Regressão & 15 & $1,32 \mathrm{E}+09$ & 88.253 .533 & 10.088 & $3,16 \mathrm{E}-22$ \\
\hline Resíduo & 22 & 577.401 & 26.245 & & \\
\hline Total & 37 & $1,32 \mathrm{E}+09$ & & & \\
\hline
\end{tabular}

\begin{tabular}{|c|c|c|c|c|c|c|c|c|}
\hline & Coeficientes & Erro padrão & Stat $t$ & valor $-P$ & $\begin{array}{c}95 \% \\
\text { inferiores }\end{array}$ & $\begin{array}{c}95 \% \\
\text { superiores }\end{array}$ & $\begin{array}{c}\text { Inferior } \\
95,0 \%\end{array}$ & $\begin{array}{c}\text { Superior } \\
95,0 \%\end{array}$ \\
\hline Interseção & $69.437,171$ & 197,323 & 351,896 & $9,34 \mathrm{E}-43$ & $69.027,948$ & $69.846,394$ & $69.027,948$ & $69.846,394$ \\
\hline Variável X 1 & 0 & 0 & 65535 & - & 0 & 0 & 0 & 0 \\
\hline Variável X 2 & 57,209 & 0,962 & 59,459 & $8,54 \mathrm{E}-26$ & 55,214 & 59,205 & 55,214 & 59,205 \\
\hline Variável X 3 & 0 & 0 & 65535 & - & 0 & 0 & 0 & 0 \\
\hline Variável X 4 & 0 & 0 & 65535 & - & 0 & 0 & 0 & 0 \\
\hline Variável X 5 & 0 & 0 & 65535 & - & 0 & 0 & 0 & 0 \\
\hline Variável X 6 & 0 & 0 & 65535 & - & 0 & 0 & 0 & 0 \\
\hline Variável X 7 & 0 & 0 & 65535 & - & 0 & 0 & 0 & 0 \\
\hline Variável X 8 & 0 & 0 & 65535 & - & 0 & 0 & 0 & 0 \\
\hline Variável X 9 & 0 & 0 & 65535 & - & 0 & 0 & 0 & 0 \\
\hline Variável X 10 & 0 & 0 & 65535 & - & 0 & 0 & 0 & 0 \\
\hline Variável X 11 & 4,829 & 0,600 & 8,049 & $5,34 \mathrm{E}-08$ & 3,585 & 6,073 & 3,585 & 6,073 \\
\hline Variável X 12 & 10,363 & 0,173 & 59,833 & $7,44 \mathrm{E}-26$ & 10,003 & 10,722 & 10,003 & 10,722 \\
\hline Variável X 13 & 63,711 & 0,734 & 86,794 & $2,15 \mathrm{E}-29$ & 62,188 & 65,233 & 62,188 & 65,233 \\
\hline Variável X 14 & 64,578 & 0,767 & 84,151 & $4,24 \mathrm{E}-29$ & 62,986 & 66,169 & 62,986 & 66,169 \\
\hline Variável X 15 & 0 & 0 & 65535 & - & 0 & 0 & 0 & 0 \\
\hline
\end{tabular}


Apêndice 55 - Valor médio do investimento por habitação em função de áreas externas, anfiteatro e minisshopping para 200 residentes, com diversos graus de dependência (informações realinhadas para 5 variáveis independentes)

\begin{tabular}{|c|c|c|c|c|c|c|c|c|c|c|c|c|c|}
\hline \multirow{4}{*}{ 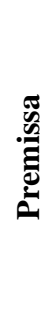 } & \multicolumn{3}{|c|}{ Área } & \multirow{2}{*}{\multicolumn{2}{|c|}{$\begin{array}{l}\text { Número de } \\
\text { residentes com } \\
\text { grau de } \\
\text { dependência }\end{array}$}} & \multirow{3}{*}{ 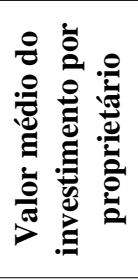 } & \multirow{4}{*}{ 总 } & \multicolumn{3}{|c|}{ Área } & \multirow{2}{*}{\multicolumn{2}{|c|}{$\begin{array}{c}\text { Número de } \\
\text { residentes com } \\
\text { grau de } \\
\text { dependência }\end{array}$}} & \multirow{3}{*}{ 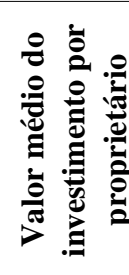 } \\
\hline & \multirow{2}{*}{ 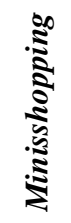 } & \multirow[t]{2}{*}{ 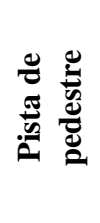 } & \multirow[t]{2}{*}{$\frac{\sqrt[\pi]{2}}{\stackrel{0}{e}}$} & & & & & 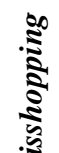 & 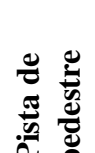 & & & & \\
\hline & & & & I & II & & & $z$ & & & I & II & \\
\hline & $\mathbf{x 1}$ & $\mathbf{x} 2$ & $\mathbf{x 3}$ & $\mathrm{x} 4$ & $\times 5$ & $\mathbf{Y}$ & & $\mathbf{x 1}$ & $\mathbf{x 2}$ & x3 & $\mathrm{x} 4$ & $\times 5$ & $\mathbf{Y}$ \\
\hline \multirow{7}{*}{$\mathbf{A}$} & 180 & 500 & 500 & 140 & 0 & 96.391 & \multirow{7}{*}{ C } & 90 & 500 & 0 & 140 & 0 & 85.918 \\
\hline & 180 & 500 & 500 & 0 & 140 & 96.566 & & 90 & 500 & 0 & 0 & 140 & 86.081 \\
\hline & 180 & 500 & 500 & 0 & 0 & 87.037 & & 90 & 500 & 0 & 0 & 0 & 77.043 \\
\hline & 180 & 500 & 500 & 98 & 42 & 96.413 & & 90 & 500 & 0 & 98 & 42 & 85.938 \\
\hline & 180 & 500 & 500 & 98 & 0 & 93.676 & & 90 & 500 & 0 & 98 & 0 & 83.454 \\
\hline & 180 & 500 & 500 & 70 & 56 & 95.269 & & 90 & 500 & 0 & 70 & 56 & 84.937 \\
\hline & 180 & 500 & 500 & 84 & 42 & 95.262 & & 90 & 500 & 0 & 84 & 42 & 84.931 \\
\hline \multirow{7}{*}{ B } & 180 & 500 & 0 & 140 & 0 & 91.150 & \multirow{7}{*}{ D } & 0 & 250 & 0 & 140 & 0 & 79.533 \\
\hline & 180 & 500 & 0 & 0 & 140 & 91.332 & & 0 & 250 & 0 & 0 & 140 & 79.702 \\
\hline & 180 & 500 & 0 & 0 & 0 & 82.070 & & 0 & 250 & 0 & 0 & 0 & 70.923 \\
\hline & 180 & 500 & 0 & 98 & 42 & 91.171 & & 0 & 250 & 0 & 98 & 42 & 79.552 \\
\hline & 180 & 500 & 0 & 98 & 0 & 88.513 & & 0 & 250 & 0 & 98 & 0 & 77.044 \\
\hline & 180 & 500 & 0 & 70 & 56 & 90.064 & & 0 & 250 & 0 & 70 & 56 & 78.577 \\
\hline & 180 & 500 & 0 & 84 & 42 & 90.044 & & 0 & 250 & 0 & 84 & 42 & 78.479 \\
\hline
\end{tabular}


Apêndice 56 - Resumo dos resultados da regressão do valor médio do investimento por habitação em função de áreas externas, anfiteatro e minisshopping para 200 residentes, com diversos graus de dependência, para 5 variáveis independentes

\begin{tabular}{lr}
\hline \multicolumn{2}{c}{ Estatística de regressão } \\
\hline $\mathrm{R}$ múltiplo & 1,000 \\
R-Quadrado & 1,000 \\
R-quadrado ajustado & 0,999 \\
Erro padrão & 162,005 \\
Observações & 28 \\
\hline
\end{tabular}

\begin{tabular}{|c|c|c|c|c|c|c|c|c|}
\hline \multicolumn{9}{|l|}{ ANOVA } \\
\hline & $g l$ & $S Q$ & $M Q$ & $F$ & $\begin{array}{l}F \text { de sig- } \\
\text { nificação }\end{array}$ & & & \\
\hline Regressão & 5 & $1,32 \mathrm{E}+09$ & $2,65 \mathrm{E}+08$ & $1,01 \mathrm{E}+04$ & $3,48 \mathrm{E}-36$ & & & \\
\hline Resíduo & 22 & $5,77 \mathrm{E}+05$ & $2,62 \mathrm{E}+04$ & & & & & \\
\hline \multirow[t]{2}{*}{ Total } & 27 & $1,32 \mathrm{E}+09$ & & & & & & \\
\hline & Coeficientes & Erro padrão & Stat $t$ & valor-P & $\begin{array}{c}95 \% \\
\text { inferiores }\end{array}$ & $\begin{array}{c}95 \% \\
\text { superiores }\end{array}$ & $\begin{array}{c}\text { Inferior } \\
95,0 \%\end{array}$ & $\begin{array}{c}\text { Superior } \\
95,0 \%\end{array}$ \\
\hline Interseção & $69.437,171$ & 197,323 & 351,896 & $9,34 \mathrm{E}-43$ & $69.027,948$ & $69.846,394$ & $69.027,948$ & $69.846,394$ \\
\hline Variável X 1 & 57,209 & 0,962 & 59,459 & $8,54 \mathrm{E}-26$ & 55,214 & 59,205 & 55,214 & 59,205 \\
\hline Variável X 2 & 4,829 & 0,600 & 8,049 & $5,34 \mathrm{E}-08$ & 3,585 & 6,073 & 3,585 & 6,073 \\
\hline Variável X 3 & 10,363 & 0,173 & 59,833 & $7,44 \mathrm{E}-26$ & 10,003 & 10,722 & 10,003 & 10,722 \\
\hline Variável X 4 & 63,711 & 0,734 & 86,794 & $2,15 \mathrm{E}-29$ & 62,188 & 65,233 & 62,188 & 65,233 \\
\hline Variável X 5 & 64,578 & 0,767 & 84,151 & 4,24E-29 & 62,986 & 66,169 & 62,986 & 66,169 \\
\hline
\end{tabular}


Apêndice 57 - Valor médio do investimento por habitação em função de áreas externas, anfiteatro e minisshopping para 300 residentes, com diversos graus de dependência (informações realinhadas para 15 variáveis independentes)

\begin{tabular}{|c|c|c|c|c|c|c|c|c|c|c|c|c|c|c|c|c|}
\hline \multirow{4}{*}{ 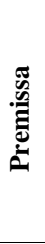 } & \multirow{3}{*}{ 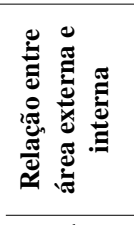 } & \multirow{3}{*}{ 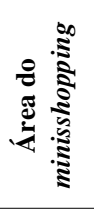 } & \multirow{3}{*}{ 昰高 } & \multicolumn{7}{|c|}{ Quantidade de } & \multirow{3}{*}{ 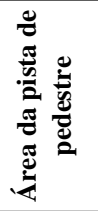 } & \multirow{3}{*}{ 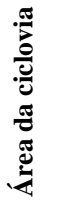 } & \multirow{2}{*}{\multicolumn{3}{|c|}{$\begin{array}{l}\text { Número de residentes com } \\
\text { grau de dependência }\end{array}$}} & \multirow{3}{*}{ 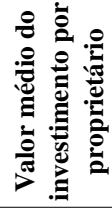 } \\
\hline & & & & \multirow{2}{*}{ 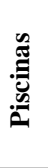 } & \multirow{2}{*}{ 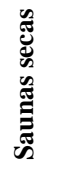 } & \multirow{2}{*}{ 营 } & \multirow{2}{*}{ 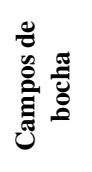 } & \multirow{2}{*}{ 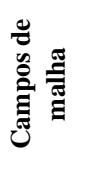 } & \multirow{2}{*}{ 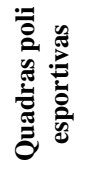 } & \multirow{2}{*}{ 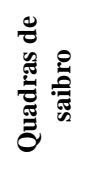 } & & & & & & \\
\hline & & & & & & & & & & & & & I & II & III & \\
\hline & $\mathrm{x1}$ & $\mathrm{x} 2$ & $\mathrm{x} 3$ & $\mathrm{x} 4$ & $\mathrm{x} 5$ & x6 & $\mathrm{x} 7$ & x8 & x9 & $\mathbf{x 1 0}$ & x11 & $\mathrm{x12}$ & x13 & x14 & x15 & $\mathbf{Y}$ \\
\hline \multirow{7}{*}{$\mathbf{A}$} & 0,3 & 180 & 1 & 1 & 1 & 1 & 1 & 1 & 1 & 1 & 500 & 500 & 210 & 0 & 0 & 89.670 \\
\hline & 0,3 & 180 & 1 & 1 & 1 & 1 & 1 & 1 & 1 & 1 & 500 & 500 & 0 & 210 & 0 & 89.881 \\
\hline & 0,3 & 180 & 1 & 1 & 1 & 1 & 1 & 1 & 1 & 1 & 500 & 500 & 0 & 0 & 210 & 80.964 \\
\hline & 0,3 & 180 & 1 & 1 & 1 & 1 & 1 & 1 & 1 & 1 & 500 & 500 & 147 & 63 & 0 & 89.760 \\
\hline & 0,3 & 180 & 1 & 1 & 1 & 1 & 1 & 1 & 1 & 1 & 500 & 500 & 147 & 0 & 63 & 87.249 \\
\hline & 0,3 & 180 & 1 & 1 & 1 & 1 & 1 & 1 & 1 & 1 & 500 & 500 & 105 & 84 & 21 & 89.030 \\
\hline & 0,3 & 180 & 1 & 1 & 1 & 1 & 1 & 1 & 1 & 1 & 500 & 500 & 126 & 63 & 21 & 89.021 \\
\hline \multirow{7}{*}{ B } & 0,2 & 180 & 1 & 1 & 1 & 1 & 0 & 0 & 0 & 0 & 500 & 0 & 210 & 0 & 0 & 85.315 \\
\hline & 0,2 & 180 & 1 & 1 & 1 & 1 & 0 & 0 & 0 & 0 & 500 & 0 & 0 & 210 & 0 & 85.518 \\
\hline & 0,2 & 180 & 1 & 1 & 1 & 1 & 0 & 0 & 0 & 0 & 500 & 0 & 0 & 0 & 210 & 76.840 \\
\hline & 0,2 & 180 & 1 & 1 & 1 & 1 & 0 & 0 & 0 & 0 & 500 & 0 & 147 & 63 & 0 & 85.401 \\
\hline & 0,2 & 180 & 1 & 1 & 1 & 1 & 0 & 0 & 0 & 0 & 500 & 0 & 147 & 0 & 63 & 82.961 \\
\hline & 0,2 & 180 & 1 & 1 & 1 & 1 & 0 & 0 & 0 & 0 & 500 & 0 & 105 & 84 & 21 & 84.695 \\
\hline & 0,2 & 180 & 1 & 1 & 1 & 1 & 0 & 0 & 0 & 0 & 500 & 0 & 126 & 63 & 21 & 84.686 \\
\hline \multirow{7}{*}{$\mathbf{C}$} & 0,1 & 90 & 0 & 0 & 0 & 0 & 0 & 0 & 0 & 0 & 250 & 0 & 210 & 0 & 0 & 79.449 \\
\hline & 0,1 & 90 & 0 & 0 & 0 & 0 & 0 & 0 & 0 & 0 & 250 & 0 & 0 & 210 & 0 & 79.583 \\
\hline & 0,1 & 90 & 0 & 0 & 0 & 0 & 0 & 0 & 0 & 0 & 250 & 0 & 0 & 0 & 210 & 71.153 \\
\hline & 0,1 & 90 & 0 & 0 & 0 & 0 & 0 & 0 & 0 & 0 & 250 & 0 & 147 & 63 & 0 & 80.908 \\
\hline & 0,1 & 90 & 0 & 0 & 0 & 0 & 0 & 0 & 0 & 0 & 250 & 0 & 147 & 0 & 63 & 78.540 \\
\hline & 0,1 & 90 & 0 & 0 & 0 & 0 & 0 & 0 & 0 & 0 & 250 & 0 & 105 & 84 & 21 & 78.787 \\
\hline & 0,1 & 90 & 0 & 0 & 0 & 0 & 0 & 0 & 0 & 0 & 250 & 0 & 126 & 63 & 21 & 78.779 \\
\hline \multirow{7}{*}{ D } & 0,05 & 0 & 0 & 0 & 0 & 0 & 0 & 0 & 0 & 0 & 200 & 0 & 210 & 0 & 0 & 77.263 \\
\hline & 0,05 & 0 & 0 & 0 & 0 & 0 & 0 & 0 & 0 & 0 & 200 & 0 & 0 & 210 & 0 & 77.386 \\
\hline & 0,05 & 0 & 0 & 0 & 0 & 0 & 0 & 0 & 0 & 0 & 200 & 0 & 0 & 0 & 210 & 69.144 \\
\hline & 0,05 & 0 & 0 & 0 & 0 & 0 & 0 & 0 & 0 & 0 & 200 & 0 & 147 & 63 & 0 & 77.284 \\
\hline & 0,05 & 0 & 0 & 0 & 0 & 0 & 0 & 0 & 0 & 0 & 200 & 0 & 147 & 0 & 63 & 75.007 \\
\hline & 0,05 & 0 & 0 & 0 & 0 & 0 & 0 & 0 & 0 & 0 & 200 & 0 & 105 & 84 & 21 & 76.673 \\
\hline & 0,05 & 0 & 0 & 0 & 0 & 0 & 0 & 0 & 0 & 0 & 200 & 0 & 126 & 63 & 21 & 76.664 \\
\hline
\end{tabular}

* $1=\operatorname{Sim} ; 0=$ Não 
Apêndice 58 - Resumo dos resultados da regressão do valor médio do investimento por habitação em função de áreas externas, anfiteatro e minisshopping para 300 residentes, com diversos graus de dependência, para 15 variáveis independentes

\begin{tabular}{|c|c|c|c|c|c|c|c|c|}
\hline \multicolumn{2}{|c|}{ Estatística de regressão } & & & & & & & \\
\hline R múltiplo & 0,998 & & & & & & & \\
\hline R-Quadrado & 0,996 & & & & & & & \\
\hline R-quadrado ajustado & 0,541 & & & & & & & \\
\hline Erro padrão & 379,592 & & & & & & & \\
\hline Observações & 28 & & & & & & & \\
\hline \multicolumn{9}{|l|}{ ANOVA } \\
\hline & $g l$ & $S Q$ & $M Q$ & $F$ & $\begin{array}{l}\text { F de sig- } \\
\text { nificação }\end{array}$ & & & \\
\hline Regressão & 15 & $8,71 \mathrm{E}+08$ & $5,81 \mathrm{E}+07$ & $1.209,09$ & $1,06 \mathrm{E}-16$ & & & \\
\hline Resíduo & 22 & $3,17 \mathrm{E}+06$ & $144.089,86$ & & & & & \\
\hline \multirow[t]{2}{*}{ Total } & 37 & $8,74 \mathrm{E}+08$ & & & & & & \\
\hline & Coeficientes & Erro padrão & Stat $t$ & valor-P & $\begin{array}{c}95 \% \\
\text { inferiores }\end{array}$ & $\begin{array}{c}95 \% \\
\text { superiores }\end{array}$ & $\begin{array}{c}\text { Inferior } \\
95,0 \%\end{array}$ & $\begin{array}{c}\text { Superior } \\
95,0 \%\end{array}$ \\
\hline Interseção & $65.979,998$ & 362,528 & 182,000 & $1,85 \mathrm{E}-36$ & $65.228,160$ & $66.731,836$ & $65.228,160$ & $66.731,836$ \\
\hline Variável X 1 & 0 & 0 & 65535 & - & 0 & 0 & 0 & 0 \\
\hline Variável X 2 & 20,109 & 3,138 & 6,408 & $1,90 \mathrm{E}-06$ & 13,602 & 26,617 & 13,602 & 26,617 \\
\hline Variável X 3 & 0 & 0 & 65535 & - & 0 & 0 & 0 & 0 \\
\hline Variável X 4 & 0 & 0 & 65535 & - & 0 & 0 & 0 & 0 \\
\hline Variável X 5 & 0 & 0 & 65535 & - & 0 & 0 & 0 & 0 \\
\hline Variável X 6 & 0 & 0 & 65535 & - & 0 & 0 & 0 & 0 \\
\hline Variável X 7 & 0 & 0 & 65535 & - & 0 & 0 & 0 & 0 \\
\hline Variável X 8 & 0 & 0 & 65535 & - & 0 & 0 & 0 & 0 \\
\hline Variável X 9 & 0 & 0 & 65535 & - & 0 & 0 & 0 & 0 \\
\hline Variável X 10 & 0 & 0 & 65535 & - & 0 & 0 & 0 & 0 \\
\hline Variável X 11 & 14,599 & 1,757 & 8,308 & $3,14 \mathrm{E}-08$ & 10,954 & 18,243 & 10,954 & 18,243 \\
\hline Variável X 12 & 8,617 & 0,406 & 21,235 & $3,80 \mathrm{E}-16$ & 7,776 & 9,459 & 7,776 & 9,459 \\
\hline Variável X 13 & 40,962 & 1,147 & 35,724 & $5,61 \mathrm{E}-21$ & 38,584 & 43,340 & 38,584 & 43,340 \\
\hline Variável X 14 & 40,512 & 1,199 & 33,796 & $1,86 \mathrm{E}-20$ & 38,026 & 42,998 & 38,026 & 42,998 \\
\hline Variável X 15 & 0 & 0 & 65535 & - & 0 & 0 & 0 & 0 \\
\hline
\end{tabular}


Apêndice 59 - Valor médio do investimento por habitação em função de áreas externas, anfiteatro e minisshopping para 300 residentes, com diversos graus de dependência (informações realinhadas para 5 variáveis independentes)

\begin{tabular}{|c|c|c|c|c|c|c|c|c|c|c|c|c|c|}
\hline \multirow{4}{*}{ 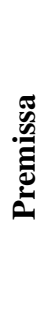 } & \multicolumn{3}{|c|}{ Área } & \multirow{2}{*}{\multicolumn{2}{|c|}{$\begin{array}{l}\text { Número de } \\
\text { residentes com } \\
\text { grau de } \\
\text { dependência }\end{array}$}} & \multirow{3}{*}{ 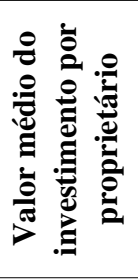 } & \multirow{4}{*}{ 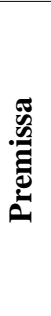 } & \multicolumn{3}{|c|}{ Área } & \multirow{2}{*}{\multicolumn{2}{|c|}{$\begin{array}{l}\text { Número de } \\
\text { residentes com } \\
\text { grau de } \\
\text { dependência }\end{array}$}} & \multirow{3}{*}{ 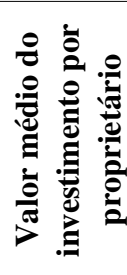 } \\
\hline & \multirow{2}{*}{ 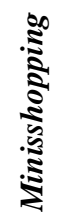 } & \multirow{2}{*}{ 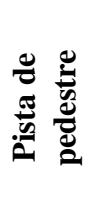 } & \multirow[t]{2}{*}{ 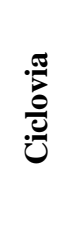 } & & & & & 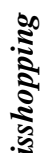 & 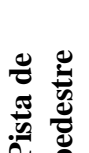 & 吾 & & & \\
\hline & & & & I & II & & & $z$ & & & I & II & \\
\hline & $\mathbf{x 1}$ & $\mathbf{x 2}$ & $\mathrm{x} 3$ & $\mathrm{x} 4$ & $\mathrm{x5}$ & $\mathbf{Y}$ & & $\mathrm{x1}$ & $\mathbf{x 2}$ & x3 & $\mathrm{x} 4$ & x5 & $\mathbf{Y}$ \\
\hline \multirow{7}{*}{$\mathbf{A}$} & 180 & 500 & 500 & 210 & 0 & 89.670 & \multirow{7}{*}{ C } & 90 & 250 & 0 & 210 & 0 & 79.449 \\
\hline & 180 & 500 & 500 & 0 & 210 & 89.881 & & 90 & 250 & 0 & 0 & 210 & 79.583 \\
\hline & 180 & 500 & 500 & 0 & 0 & 80.964 & & 90 & 250 & 0 & 0 & 0 & 71.153 \\
\hline & 180 & 500 & 500 & 147 & 63 & 89.760 & & 90 & 250 & 0 & 147 & 63 & 80.908 \\
\hline & 180 & 500 & 500 & 147 & 0 & 87.249 & & 90 & 250 & 0 & 147 & 0 & 78.540 \\
\hline & 180 & 500 & 500 & 105 & 84 & 89.030 & & 90 & 250 & 0 & 105 & 84 & 78.787 \\
\hline & 180 & 500 & 500 & 126 & 63 & 89.021 & & 90 & 250 & 0 & 126 & 63 & 78.779 \\
\hline \multirow{7}{*}{ B } & 180 & 500 & 0 & 210 & 0 & 85.315 & \multirow{7}{*}{ D } & 0 & 200 & 0 & 210 & 0 & 77.263 \\
\hline & 180 & 500 & 0 & 0 & 210 & 85.518 & & 0 & 200 & 0 & 0 & 210 & 77.386 \\
\hline & 180 & 500 & 0 & 0 & 0 & 76.840 & & 0 & 200 & 0 & 0 & 0 & 69.144 \\
\hline & 180 & 500 & 0 & 147 & 63 & 85.401 & & 0 & 200 & 0 & 147 & 63 & 77.284 \\
\hline & 180 & 500 & 0 & 147 & 0 & 82.961 & & 0 & 200 & 0 & 147 & 0 & 75.007 \\
\hline & 180 & 500 & 0 & 105 & 84 & 84.695 & & 0 & 200 & 0 & 105 & 84 & 76.673 \\
\hline & 180 & 500 & 0 & 126 & 63 & 84.686 & & 0 & 200 & 0 & 126 & 63 & 76.664 \\
\hline
\end{tabular}


Apêndice 60 - Resumo dos resultados da regressão do valor médio do investimento por habitação em função de áreas externas, anfiteatro e minisshopping para 300 residentes, com diversos graus de dependência, para 5 variáveis independentes

\begin{tabular}{lr}
\hline \multicolumn{2}{c}{ Estatística de regressão } \\
\hline R múltiplo & 0,998 \\
R-Quadrado & 0,996 \\
R-quadrado ajustado & 0,996 \\
Erro padrão & 379,592 \\
Observações & 28 \\
\hline
\end{tabular}

\begin{tabular}{|c|c|c|c|c|c|c|c|c|}
\hline \multicolumn{9}{|l|}{ ANOVA } \\
\hline & $g l$ & $S Q$ & $M Q$ & $F$ & $\begin{array}{l}F \text { de sig- } \\
\text { nificação }\end{array}$ & & & \\
\hline Regressão & 5 & $8,71 \mathrm{E}+08$ & $1,74 \mathrm{E}+08$ & $1.209,085$ & $4,57 \mathrm{E}-26$ & & & \\
\hline Resíduo & 22 & $3,17 \mathrm{E}+06$ & $144.089,857$ & & & & & \\
\hline \multirow[t]{2}{*}{ Total } & 27 & $8,74 \mathrm{E}+08$ & & & & & & \\
\hline & Coeficientes & Erro padrão & Stat $t$ & valor-P & $\begin{array}{c}95 \% \\
\text { inferiores }\end{array}$ & $\begin{array}{c}95 \% \\
\text { superiores }\end{array}$ & $\begin{array}{c}\text { Inferior } \\
95,0 \%\end{array}$ & $\begin{array}{c}\text { Superior } \\
95,0 \%\end{array}$ \\
\hline Interseção & $65.979,998$ & 362,528 & 182,000 & 0,000 & $65.228,160$ & $66.731,836$ & $65.228,160$ & $66.731,836$ \\
\hline Variável X 1 & 20,109 & 3,138 & 6,408 & 0,000 & 13,602 & 26,617 & 13,602 & 26,617 \\
\hline Variável X 2 & 14,599 & 1,757 & 8,308 & 0,000 & 10,954 & 18,243 & 10,954 & 18,243 \\
\hline Variável X 3 & 8,617 & 0,406 & 21,235 & 0,000 & 7,776 & 9,459 & 7,776 & 9,459 \\
\hline Variável X 4 & 40,962 & 1,147 & 35,724 & 0,000 & 38,584 & 43,340 & 38,584 & 43,340 \\
\hline Variável X 5 & 40,512 & 1,199 & 33,796 & 0,000 & 38,026 & 42,998 & 38,026 & 42,998 \\
\hline
\end{tabular}


Apêndice 61 - Valor médio do investimento por habitação em função de áreas externas, anfiteatro e minisshopping para 400 residentes, com diversos graus de dependência (informações realinhadas para 15 variáveis independentes)

\begin{tabular}{|c|c|c|c|c|c|c|c|c|c|c|c|c|c|c|c|c|}
\hline \multirow{4}{*}{ 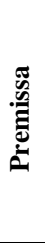 } & \multirow{3}{*}{ 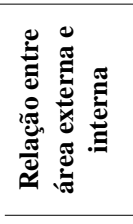 } & \multirow{3}{*}{ 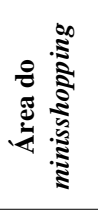 } & \multirow{3}{*}{ 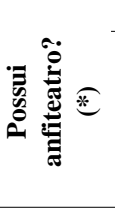 } & \multicolumn{7}{|c|}{ Quantidade de } & \multirow{3}{*}{ 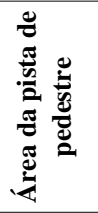 } & \multirow{3}{*}{ 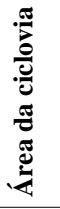 } & \multirow{2}{*}{\multicolumn{3}{|c|}{$\begin{array}{l}\text { Número de residentes com } \\
\text { grau de dependência }\end{array}$}} & \multirow{3}{*}{ 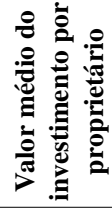 } \\
\hline & & & & \multirow{2}{*}{ 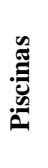 } & \multirow{2}{*}{ 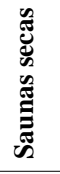 } & \multirow{2}{*}{ 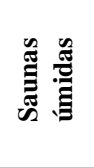 } & \multirow{2}{*}{ 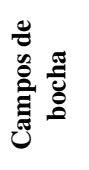 } & \multirow{2}{*}{ 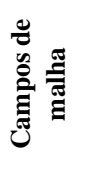 } & \multirow{2}{*}{ 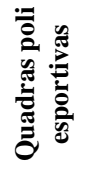 } & \multirow{2}{*}{ 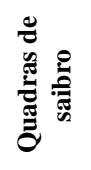 } & & & & & & \\
\hline & & & & & & & & & & & & & I & II & III & \\
\hline & $\mathrm{x1}$ & $\mathrm{x} 2$ & $\mathrm{x} 3$ & $\mathrm{x} 4$ & $\mathrm{x} 5$ & x6 & $\mathrm{x} 7$ & x8 & x9 & $\mathbf{x 1 0}$ & x11 & $\mathrm{x12}$ & x13 & x14 & x15 & $\mathbf{Y}$ \\
\hline \multirow{7}{*}{$\mathbf{A}$} & 0,3 & 180 & 1 & 1 & 1 & 1 & 1 & 1 & 1 & 1 & 500 & 500 & 280 & 0 & 0 & 88.112 \\
\hline & 0,3 & 180 & 1 & 1 & 1 & 1 & 1 & 1 & 1 & 1 & 500 & 500 & 0 & 280 & 0 & 88.288 \\
\hline & 0,3 & 180 & 1 & 1 & 1 & 1 & 1 & 1 & 1 & 1 & 500 & 500 & 0 & 0 & 280 & 79.390 \\
\hline & 0,3 & 180 & 1 & 1 & 1 & 1 & 1 & 1 & 1 & 1 & 500 & 500 & 196 & 84 & 0 & 88.133 \\
\hline & 0,3 & 180 & 1 & 1 & 1 & 1 & 1 & 1 & 1 & 1 & 500 & 500 & 196 & 0 & 84 & 85.525 \\
\hline & 0,3 & 180 & 1 & 1 & 1 & 1 & 1 & 1 & 1 & 1 & 500 & 500 & 140 & 112 & 28 & 87.297 \\
\hline & 0,3 & 180 & 1 & 1 & 1 & 1 & 1 & 1 & 1 & 1 & 500 & 500 & 168 & 84 & 28 & 87.233 \\
\hline \multirow{7}{*}{ B } & 0,2 & 180 & 1 & 1 & 1 & 1 & 0 & 0 & 0 & 0 & 500 & 0 & 280 & 0 & 0 & 84.143 \\
\hline & 0,2 & 180 & 1 & 1 & 1 & 1 & 0 & 0 & 0 & 0 & 500 & 0 & 0 & 280 & 0 & 84.312 \\
\hline & 0,2 & 180 & 1 & 1 & 1 & 1 & 0 & 0 & 0 & 0 & 500 & 0 & 0 & 0 & 280 & 75.715 \\
\hline & 0,2 & 180 & 1 & 1 & 1 & 1 & 0 & 0 & 0 & 0 & 500 & 0 & 196 & 84 & 0 & 84.217 \\
\hline & 0,2 & 180 & 1 & 1 & 1 & 1 & 0 & 0 & 0 & 0 & 500 & 0 & 196 & 0 & 84 & 81.671 \\
\hline & 0,2 & 180 & 1 & 1 & 1 & 1 & 0 & 0 & 0 & 0 & 500 & 0 & 140 & 112 & 28 & 83.342 \\
\hline & 0,2 & 180 & 1 & 1 & 1 & 1 & 0 & 0 & 0 & 0 & 500 & 0 & 168 & 84 & 28 & 83.328 \\
\hline \multirow{7}{*}{$\mathbf{C}$} & 0,1 & 90 & 0 & 0 & 0 & 0 & 0 & 0 & 0 & 0 & 500 & 0 & 280 & 0 & 0 & 79.095 \\
\hline & 0,1 & 90 & 0 & 0 & 0 & 0 & 0 & 0 & 0 & 0 & 500 & 0 & 0 & 280 & 0 & 79.258 \\
\hline & 0,1 & 90 & 0 & 0 & 0 & 0 & 0 & 0 & 0 & 0 & 500 & 0 & 0 & 0 & 280 & 70.901 \\
\hline & 0,1 & 90 & 0 & 0 & 0 & 0 & 0 & 0 & 0 & 0 & 500 & 0 & 196 & 84 & 0 & 80.239 \\
\hline & 0,1 & 90 & 0 & 0 & 0 & 0 & 0 & 0 & 0 & 0 & 500 & 0 & 196 & 0 & 84 & 77.784 \\
\hline & 0,1 & 90 & 0 & 0 & 0 & 0 & 0 & 0 & 0 & 0 & 500 & 0 & 140 & 112 & 28 & 78.324 \\
\hline & 0,1 & 90 & 0 & 0 & 0 & 0 & 0 & 0 & 0 & 0 & 500 & 0 & 168 & 84 & 28 & 78.311 \\
\hline \multirow{7}{*}{ D } & 0,05 & 0 & 0 & 0 & 0 & 0 & 0 & 0 & 0 & 0 & 250 & 0 & 280 & 0 & 0 & 77.119 \\
\hline & 0,05 & 0 & 0 & 0 & 0 & 0 & 0 & 0 & 0 & 0 & 250 & 0 & 0 & 280 & 0 & 77.286 \\
\hline & 0,05 & 0 & 0 & 0 & 0 & 0 & 0 & 0 & 0 & 0 & 250 & 0 & 0 & 0 & 280 & 69.005 \\
\hline & 0,05 & 0 & 0 & 0 & 0 & 0 & 0 & 0 & 0 & 0 & 250 & 0 & 196 & 84 & 0 & 77.145 \\
\hline & 0,05 & 0 & 0 & 0 & 0 & 0 & 0 & 0 & 0 & 0 & 250 & 0 & 196 & 0 & 84 & 74.722 \\
\hline & 0,05 & 0 & 0 & 0 & 0 & 0 & 0 & 0 & 0 & 0 & 250 & 0 & 140 & 112 & 28 & 76.362 \\
\hline & 0,05 & 0 & 0 & 0 & 0 & 0 & 0 & 0 & 0 & 0 & 250 & 0 & 168 & 84 & 28 & 76.311 \\
\hline
\end{tabular}

* $1=\operatorname{Sim} ; 0=$ Não 
Apêndice 62 - Resumo dos resultados da regressão do valor médio do investimento por habitação em função de áreas externas, anfiteatro e minisshopping para 400 residentes, com diversos graus de dependência, para 15 variáveis independentes

\begin{tabular}{|c|c|c|c|c|c|c|c|c|}
\hline \multicolumn{2}{|c|}{ Estatística de regressão } & & & & & & & \\
\hline R múltiplo & 0,999 & & & & & & & \\
\hline R-Quadrado & 0,997 & & & & & & & \\
\hline R-quadrado ajustado & 0,542 & & & & & & & \\
\hline Erro padrão & 293,308 & & & & & & & \\
\hline Observações & 28 & & & & & & & \\
\hline \multicolumn{9}{|l|}{ ANOVA } \\
\hline & $g l$ & $S Q$ & $M Q$ & $F$ & $\begin{array}{l}\text { F de sig- } \\
\text { nificação }\end{array}$ & & & \\
\hline Regressão & 15 & $7,21 \mathrm{E}+08$ & $4,80 \mathrm{E}+07$ & $1.675,513$ & $1,50 \mathrm{E}-17$ & & & \\
\hline Resíduo & 22 & $1,89 \mathrm{E}+06$ & $86.029,556$ & & & & & \\
\hline \multirow[t]{2}{*}{ Total } & 37 & $7,23 \mathrm{E}+08$ & & & & & & \\
\hline & Coeficientes & Erro padrão & Stat $t$ & valor-P & $\begin{array}{c}95 \% \\
\text { inferiores }\end{array}$ & $\begin{array}{c}95 \% \\
\text { superiores }\end{array}$ & $\begin{array}{c}\text { Inferior } \\
95,0 \%\end{array}$ & $\begin{array}{c}\text { Superior } \\
95,0 \%\end{array}$ \\
\hline Interseção & $71.173,273$ & 357,252 & 199,224 & $2,54 \mathrm{E}-37$ & $70.432,378$ & $71.914,167$ & $70.432,378$ & $71.914,167$ \\
\hline Variável X 1 & 0 & 0 & 65535 & - & 0 & 0 & 0 & 0 \\
\hline Variável X 2 & 52,090 & 1,742 & 29,903 & $2,60 \mathrm{E}-19$ & 48,477 & 55,703 & 48,477 & 55,703 \\
\hline Variável X 3 & 0 & 0 & 65535 & - & 0 & 0 & 0 & 0 \\
\hline Variável X 4 & 0 & 0 & 65535 & - & 0 & 0 & 0 & 0 \\
\hline Variável X 5 & 0 & 0 & 65535 & - & 0 & 0 & 0 & 0 \\
\hline Variável X 6 & 0 & 0 & 65535 & - & 0 & 0 & 0 & 0 \\
\hline Variável X 7 & 0 & 0 & 65535 & - & 0 & 0 & 0 & 0 \\
\hline Variável X 8 & 0 & 0 & 65535 & - & 0 & 0 & 0 & 0 \\
\hline Variável X 9 & 0 & 0 & 65535 & - & 0 & 0 & 0 & 0 \\
\hline Variável X 10 & 0 & 0 & 65535 & - & 0 & 0 & 0 & 0 \\
\hline Variável X 11 & $-9,631$ & 1,086 & $-8,867$ & $1,03 \mathrm{E}-08$ & $-11,884$ & $-7,379$ & $-11,884$ & $-7,379$ \\
\hline Variável X 12 & 7,785 & 0,314 & 24,829 & $1,39 \mathrm{E}-17$ & 7,135 & 8,436 & 7,135 & 8,436 \\
\hline Variável X 13 & 30,250 & 0,664 & 45,524 & $2,90 \mathrm{E}-23$ & 28,872 & 31,629 & 28,872 & 31,629 \\
\hline Variável X 14 & 30,261 & 0,695 & 43,561 & $7,58 \mathrm{E}-23$ & 28,821 & 31,702 & 28,821 & 31,702 \\
\hline Variável X 15 & 0 & 0 & 65535 & - & 0 & 0 & 0 & 0 \\
\hline
\end{tabular}


Apêndice 63 - Valor médio do investimento por habitação em função de áreas externas, anfiteatro e minisshopping para 400 residentes, com diversos graus de dependência (informações realinhadas para 5 variáveis independentes)

\begin{tabular}{|c|c|c|c|c|c|c|c|c|c|c|c|c|c|}
\hline \multirow{4}{*}{ 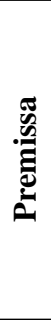 } & \multicolumn{3}{|c|}{ Área } & \multirow{2}{*}{\multicolumn{2}{|c|}{$\begin{array}{l}\text { Número de } \\
\text { residentes com } \\
\text { grau de } \\
\text { dependência }\end{array}$}} & \multirow{3}{*}{ 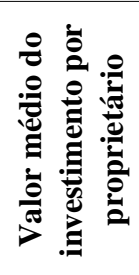 } & \multirow{4}{*}{ 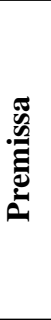 } & \multicolumn{3}{|c|}{ Área } & \multirow{2}{*}{\multicolumn{2}{|c|}{$\begin{array}{l}\text { Número de } \\
\text { residentes com } \\
\text { grau de } \\
\text { dependência }\end{array}$}} & \multirow{3}{*}{ 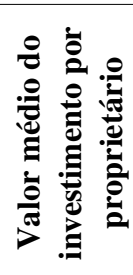 } \\
\hline & \multirow{2}{*}{ 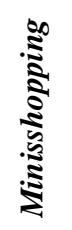 } & \multirow[t]{2}{*}{ 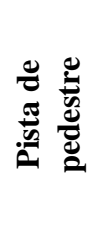 } & \multirow[t]{2}{*}{ 苞 } & & & & & \multirow{2}{*}{ 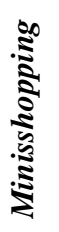 } & \multirow[t]{2}{*}{ 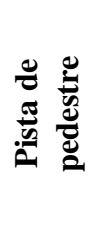 } & \multirow[t]{2}{*}{ } & & & \\
\hline & & & & I & II & & & & & & I & II & \\
\hline & $\mathbf{x 1}$ & $\mathbf{x} 2$ & $\mathrm{x} 3$ & $\mathrm{x4}$ & $\mathrm{x} 5$ & $\mathbf{Y}$ & & $\mathbf{x 1}$ & $\mathbf{x} 2$ & x3 & $x 4$ & x5 & $\mathbf{Y}$ \\
\hline \multirow{7}{*}{$\mathbf{A}$} & 180 & 500 & 500 & 280 & 0 & 88.112 & \multirow{7}{*}{ C } & 90 & 500 & 0 & 280 & 0 & 79.095 \\
\hline & 180 & 500 & 500 & 0 & 280 & 88.288 & & 90 & 500 & 0 & 0 & 280 & 79.258 \\
\hline & 180 & 500 & 500 & 0 & 0 & 79.390 & & 90 & 500 & 0 & 0 & 0 & 70.901 \\
\hline & 180 & 500 & 500 & 196 & 84 & 88.133 & & 90 & 500 & 0 & 196 & 84 & 80.239 \\
\hline & 180 & 500 & 500 & 196 & 0 & 85.525 & & 90 & 500 & 0 & 196 & 0 & 77.784 \\
\hline & 180 & 500 & 500 & 140 & 112 & 87.297 & & 90 & 500 & 0 & 140 & 112 & 78.324 \\
\hline & 180 & 500 & 500 & 168 & 84 & 87.233 & & 90 & 500 & 0 & 168 & 84 & 78.311 \\
\hline \multirow{7}{*}{ B } & 180 & 500 & 0 & 280 & 0 & 84.143 & \multirow{7}{*}{ D } & 0 & 250 & 0 & 280 & 0 & 77.119 \\
\hline & 180 & 500 & 0 & 0 & 280 & 84.312 & & 0 & 250 & 0 & 0 & 280 & 77.286 \\
\hline & 180 & 500 & 0 & 0 & 0 & 75.715 & & 0 & 250 & 0 & 0 & 0 & 69.005 \\
\hline & 180 & 500 & 0 & 196 & 84 & 84.217 & & 0 & 250 & 0 & 196 & 84 & 77.145 \\
\hline & 180 & 500 & 0 & 196 & 0 & 81.671 & & 0 & 250 & 0 & 196 & 0 & 74.722 \\
\hline & 180 & 500 & 0 & 140 & 112 & 83.342 & & 0 & 250 & 0 & 140 & 112 & 76.362 \\
\hline & 180 & 500 & 0 & 168 & 84 & 83.328 & & 0 & 250 & 0 & 168 & 84 & 76.311 \\
\hline
\end{tabular}


Apêndice 64 - Resumo dos resultados da regressão do valor médio do investimento por habitação em função de áreas externas, anfiteatro e minisshopping para 400 residentes, com diversos graus de dependência, para 5 variáveis independentes

\begin{tabular}{lr}
\hline \multicolumn{2}{c}{ Estatística de regressão } \\
\hline R múltiplo & 0,999 \\
R-Quadrado & 0,997 \\
R-quadrado ajustado & 0,997 \\
Erro padrão & 293,308 \\
Observações & 28 \\
\hline
\end{tabular}

\begin{tabular}{|c|c|c|c|c|c|c|c|c|}
\hline \multicolumn{9}{|l|}{ ANOVA } \\
\hline & $g l$ & $S Q$ & $M Q$ & $F$ & $\begin{array}{l}\text { F de sig- } \\
\text { nificação }\end{array}$ & & & \\
\hline Regressão & 5 & $7,21 \mathrm{E}+08$ & $1,44 \mathrm{E}+08$ & $1.675,513$ & $1,28 \mathrm{E}-27$ & & & \\
\hline Resíduo & 22 & $1,89 \mathrm{E}+06$ & $86.029,556$ & & & & & \\
\hline \multirow[t]{2}{*}{ Total } & 27 & $7,23 \mathrm{E}+08$ & & & & & & \\
\hline & Coeficientes & Erro padrão & Stat $t$ & valor-P & $\begin{array}{c}95 \% \\
\text { inferiores }\end{array}$ & $\begin{array}{c}95 \% \\
\text { superiores }\end{array}$ & $\begin{array}{c}\text { Inferior } \\
95,0 \%\end{array}$ & $\begin{array}{c}\text { Superior } \\
95,0 \%\end{array}$ \\
\hline Interseção & $71.173,273$ & 357,252 & 199,224 & $2,54 \mathrm{E}-37$ & $70.432,378$ & $71.914,167$ & $70.432,378$ & $71.914,167$ \\
\hline Variável X 1 & 52,090 & 1,742 & 29,903 & $2,60 \mathrm{E}-19$ & 48,477 & 55,703 & 48,477 & 55,703 \\
\hline Variável X 2 & $-9,631$ & 1,086 & $-8,867$ & $1,03 \mathrm{E}-08$ & $-11,884$ & $-7,379$ & $-11,884$ & $-7,379$ \\
\hline Variável X 3 & 7,785 & 0,314 & 24,829 & $1,39 \mathrm{E}-17$ & 7,135 & 8,436 & 7,135 & 8,436 \\
\hline Variável X 4 & 30,250 & 0,664 & 45,524 & $2,90 \mathrm{E}-23$ & 28,872 & 31,629 & 28,872 & 31,629 \\
\hline Variável X 5 & 30,261 & 0,695 & 43,561 & $7,58 \mathrm{E}-23$ & 28,821 & 31,702 & 28,821 & 31,702 \\
\hline
\end{tabular}


Apêndice 65 - Crédito médio de 1,10\% sobre o valor do investimento, por mensalidade, para construção em 90 dias e compensação de retorno em 12 meses, com simulação do nível de utilização da capacidade instalada, para 100 residentes

\begin{tabular}{|c|c|c|c|c|c|c|c|c|}
\hline \multirow{3}{*}{$\begin{array}{c}\text { Porcentagem de } \\
\text { residentes com } \\
\text { grau de } \\
\text { dependência } \\
\text { I, II e III } \\
100-0-0\end{array}$} & \multicolumn{8}{|c|}{$\begin{array}{l}\text { Crédito médio de } 1,10 \% \text { sobre o valor do investimento, por } \\
\text { mensalidade, com simulação do nível de utilização da } \\
\text { capacidade instalada, para } 100 \text { residentes, com diversos graus } \\
\text { de dependência }\end{array}$} \\
\hline & \multicolumn{2}{|c|}{$60 \%$} & \multicolumn{2}{|c|}{$70 \%$} & \multicolumn{2}{|c|}{$80 \%$} & \multicolumn{2}{|c|}{$90 \%$} \\
\hline & $\mathrm{R} \$$ & 1.164 & $\mathrm{R} \$$ & 998 & $\mathrm{R} \$$ & 873 & $\mathrm{R} \$$ & 776 \\
\hline $0-100-0$ & $\mathrm{R} \$$ & 1.165 & $\mathrm{R} \$$ & 999 & $\mathrm{R} \$$ & 874 & $\mathrm{R} \$$ & 777 \\
\hline $0-0-100$ & $\mathrm{R} \$$ & 1.046 & $\mathrm{R} \$$ & 897 & $\mathrm{R} \$$ & 785 & $\mathrm{R} \$$ & 697 \\
\hline $70-30-0$ & $\mathrm{R} \$$ & 1.165 & $\mathrm{R} \$$ & 998 & $\mathrm{R} \$$ & 874 & $\mathrm{R} \$$ & 776 \\
\hline 70-0-30 & $\mathrm{R} \$$ & 1.136 & $\mathrm{R} \$$ & 974 & $\mathrm{R} \$$ & 852 & $\mathrm{R} \$$ & 757 \\
\hline $50-40-10$ & $\mathrm{R} \$$ & 1.157 & $\mathrm{R} \$$ & 992 & $\mathrm{R} \$$ & 868 & $\mathrm{R} \$$ & 771 \\
\hline $60-30-10$ & $\mathrm{R} \$$ & 1.157 & $\mathrm{R} \$$ & 992 & $\mathrm{R} \$$ & 868 & $\mathrm{R} \$$ & 771 \\
\hline
\end{tabular}

Apêndice 66 - Crédito médio de 1,10\% sobre o valor do investimento, por mensalidade, para construção em 90 dias e compensação de retorno em 12 meses, com simulação do nível de utilização da capacidade instalada, para 200 residentes

\begin{tabular}{|c|c|c|c|c|c|c|c|c|}
\hline \multirow{3}{*}{$\begin{array}{l}\text { Porcentagem de } \\
\text { residentes com } \\
\text { grau de } \\
\text { dependência } \\
\text { I, II e III } \\
100-0-0\end{array}$} & \multicolumn{8}{|c|}{$\begin{array}{l}\text { Crédito médio de } 1,10 \% \text { sobre o valor do investimento, por } \\
\text { mensalidade, com simulação do nível de utilização da } \\
\text { capacidade instalada, para } 200 \text { residentes, com diversos graus } \\
\text { de dependência }\end{array}$} \\
\hline & \multicolumn{2}{|c|}{$60 \%$} & \multicolumn{2}{|c|}{$70 \%$} & \multicolumn{2}{|c|}{$80 \%$} & \multicolumn{2}{|c|}{$90 \%$} \\
\hline & $\mathrm{R} \$$ & 1.178 & $\mathrm{R} \$$ & 1.010 & $\mathrm{R} \$$ & 884 & $\mathrm{R} \$$ & 785 \\
\hline 0-100-0 & $\mathrm{R} \$$ & 1.180 & $\mathrm{R} \$$ & 1.012 & $\mathrm{R} \$$ & 885 & $\mathrm{R} \$$ & 787 \\
\hline $0-0-100$ & $\mathrm{R} \$$ & 1.064 & $\mathrm{R} \$$ & 912 & $\mathrm{R} \$$ & 798 & $\mathrm{R} \$$ & 709 \\
\hline $70-30-0$ & $\mathrm{R} \$$ & 1.178 & $\mathrm{R} \$$ & 1.010 & $\mathrm{R} \$$ & 884 & $\mathrm{R} \$$ & 786 \\
\hline $70-0-30$ & $\mathrm{R} \$$ & 1.145 & $\mathrm{R} \$$ & 981 & $\mathrm{R} \$$ & 859 & $\mathrm{R} \$$ & 763 \\
\hline $50-40-10$ & $\mathrm{R} \$$ & 1.164 & $\mathrm{R} \$$ & 998 & $\mathrm{R} \$$ & 873 & $\mathrm{R} \$$ & 776 \\
\hline $60-30-10$ & $\mathrm{R} \$$ & 1.164 & $\mathrm{R} \$$ & 998 & $\mathrm{R} \$$ & 873 & $\mathrm{R} \$$ & 776 \\
\hline
\end{tabular}

Apêndice 67 - Crédito médio de 1,10\% sobre o valor do investimento, por mensalidade, para construção em 90 dias e compensação de retorno em 12 meses, com simulação do nível de utilização da capacidade instalada, para 300 residentes

\begin{tabular}{|c|c|c|c|c|c|c|c|c|}
\hline \multirow{2}{*}{$\begin{array}{c}\text { Porcentagem de } \\
\text { residentes com } \\
\text { grau de } \\
\text { dependência } \\
\text { I, II e III } \\
\end{array}$} & \multicolumn{8}{|c|}{$\begin{array}{l}\text { Crédito médio de } 1,10 \% \text { sobre o valor do investimento, por } \\
\text { mensalidade, com simulação do nível de utilização da } \\
\text { capacidade instalada, para } 300 \text { residentes, com diversos graus } \\
\text { de dependência }\end{array}$} \\
\hline & \multicolumn{2}{|c|}{$60 \%$} & \multicolumn{2}{|c|}{$70 \%$} & \multicolumn{2}{|c|}{$80 \%$} & \multicolumn{2}{|c|}{$90 \%$} \\
\hline 100-0-0 & $\mathrm{R} \$$ & 1.096 & $\mathrm{R} \$$ & 939 & $\mathrm{R} \$$ & 822 & $\mathrm{R} \$$ & 731 \\
\hline $0-100-0$ & $\mathrm{R} \$$ & 1.099 & $\mathrm{R} \$$ & 942 & $\mathrm{R} \$$ & 824 & $\mathrm{R} \$$ & 732 \\
\hline 0-0-100 & $\mathrm{R} \$$ & 990 & $\mathrm{R} \$$ & 848 & $\mathrm{R} \$$ & 742 & $\mathrm{R} \$$ & 660 \\
\hline $70-30-0$ & $\mathrm{R} \$$ & 1.097 & $\mathrm{R} \$$ & 940 & $\mathrm{R} \$$ & 823 & $\mathrm{R} \$$ & 731 \\
\hline $70-0-30$ & $\mathrm{R} \$$ & 1.066 & $\mathrm{R} \$$ & 914 & $\mathrm{R} \$$ & 800 & $\mathrm{R} \$$ & 711 \\
\hline $50-40-10$ & $\mathrm{R} \$$ & 1.088 & $\mathrm{R} \$$ & 933 & $\mathrm{R} \$$ & 816 & $\mathrm{R} \$$ & 725 \\
\hline $60-30-10$ & $\mathrm{R} \$$ & 1.088 & $\mathrm{R} \$$ & 933 & $\mathrm{R} \$$ & 816 & $\mathrm{R} \$$ & 725 \\
\hline
\end{tabular}


Apêndice 68 - Crédito médio de 1,10\% sobre o valor do investimento, por mensalidade, para construção em 90 dias e compensação de retorno em 12 meses, com simulação do nível de utilização da capacidade instalada, para 400 residentes

\begin{tabular}{|c|c|c|c|c|c|c|c|c|}
\hline \multirow{2}{*}{$\begin{array}{c}\text { Porcentagem de } \\
\text { residentes com } \\
\text { grau de } \\
\text { dependência } \\
\text { I, II e III } \\
\end{array}$} & \multicolumn{8}{|c|}{$\begin{array}{l}\text { Crédito médio de } 1,10 \% \text { sobre o valor do investimento, por } \\
\text { mensalidade, com simulação do nível de utilização da } \\
\text { capacidade instalada, para } 400 \text { residentes, com diversos graus } \\
\text { de dependência }\end{array}$} \\
\hline & \multicolumn{2}{|c|}{$60 \%$} & \multicolumn{2}{|c|}{$70 \%$} & \multicolumn{2}{|c|}{$80 \%$} & \multicolumn{2}{|c|}{$90 \%$} \\
\hline 100-0-0 & $\mathrm{R} \$$ & 1.077 & $\mathrm{R} \$$ & 923 & $\mathrm{R} \$$ & 808 & $\mathrm{R} \$$ & 718 \\
\hline $0-100-0$ & $\mathrm{R} \$$ & 1.079 & $\mathrm{R} \$$ & 925 & $\mathrm{R} \$$ & 809 & $\mathrm{R} \$$ & 719 \\
\hline 0-0-100 & $\mathrm{R} \$$ & 970 & $\mathrm{R} \$$ & 832 & $\mathrm{R} \$$ & 728 & $\mathrm{R} \$$ & 647 \\
\hline $70-30-0$ & $\mathrm{R} \$$ & 1.077 & $\mathrm{R} \$$ & 923 & $\mathrm{R} \$$ & 808 & $\mathrm{R} \$$ & 718 \\
\hline $70-0-30$ & $\mathrm{R} \$$ & 1.045 & $\mathrm{R} \$$ & 896 & $\mathrm{R} \$$ & 784 & $\mathrm{R} \$$ & 697 \\
\hline $50-40-10$ & $\mathrm{R} \$$ & 1.067 & $\mathrm{R} \$$ & 915 & $\mathrm{R} \$$ & 800 & $\mathrm{R} \$$ & 711 \\
\hline $60-30-10$ & $\mathrm{R} \$$ & 1.066 & $\mathrm{R} \$$ & 914 & $\mathrm{R} \$$ & 800 & $\mathrm{R} \$$ & 711 \\
\hline
\end{tabular}

Apêndice 69 - Crédito médio de 1,20\% sobre o valor do investimento, por mensalidade, para construção em 90 dias e compensação de retorno em 12 meses, com simulação do nível de utilização da capacidade instalada, para 100 residentes

\begin{tabular}{|c|c|c|c|c|c|c|c|c|}
\hline \multirow[t]{2}{*}{$\begin{array}{l}\text { Porcentagem de } \\
\text { residentes com } \\
\text { grau de } \\
\text { dependência } \\
\text { I, II e III }\end{array}$} & \multicolumn{8}{|c|}{$\begin{array}{l}\text { Crédito médio de } 1,20 \% \text { sobre o valor do investimento, por } \\
\text { mensalidade, com simulação do nível de utilização da } \\
\text { capacidade instalada, para } 100 \text { residentes, com diversos graus } \\
\text { de dependência }\end{array}$} \\
\hline & \multicolumn{2}{|c|}{$60 \%$} & \multicolumn{2}{|c|}{$70 \%$} & \multicolumn{2}{|c|}{$80 \%$} & \multicolumn{2}{|c|}{$90 \%$} \\
\hline 100-0-0 & $\mathrm{R} \$$ & 1.270 & $\mathrm{R} \$$ & 1.089 & $\mathrm{R} \$$ & 953 & $\mathrm{R} \$$ & 847 \\
\hline 0-100-0 & $\mathrm{R} \$$ & 1.271 & $\mathrm{R} \$$ & 1.090 & $\mathrm{R} \$$ & 953 & $\mathrm{R} \$$ & 847 \\
\hline $0-0-100$ & $\mathrm{R} \$$ & 1.141 & $\mathrm{R} \$$ & 978 & $\mathrm{R} \$$ & 856 & $\mathrm{R} \$$ & 761 \\
\hline $70-30-0$ & $\mathrm{R} \$$ & 1.271 & $\mathrm{R} \$$ & 1.089 & $\mathrm{R} \$$ & 953 & $\mathrm{R} \$$ & 847 \\
\hline $70-0-30$ & $\mathrm{R} \$$ & 1.240 & $\mathrm{R} \$$ & 1.062 & $\mathrm{R} \$$ & 930 & $\mathrm{R} \$$ & 826 \\
\hline $50-40-10$ & $\mathrm{R} \$$ & 1.262 & $\mathrm{R} \$$ & 1.082 & $\mathrm{R} \$$ & 947 & $\mathrm{R} \$$ & 841 \\
\hline $60-30-10$ & $\mathrm{R} \$$ & 1.262 & $\mathrm{R} \$$ & 1.082 & $\mathrm{R} \$$ & 946 & $\mathrm{R} \$$ & 841 \\
\hline
\end{tabular}

Apêndice 70 - Crédito médio de 1,20\% sobre o valor do investimento, por mensalidade, para construção em 90 dias e compensação de retorno em 12 meses, com simulação do nível de utilização da capacidade instalada, para 200 residentes

\begin{tabular}{|c|c|c|c|c|c|c|c|c|}
\hline \multirow{2}{*}{$\begin{array}{l}\text { Porcentagem de } \\
\text { residentes com } \\
\text { grau de } \\
\text { dependência } \\
\text { I, II e III }\end{array}$} & \multicolumn{8}{|c|}{$\begin{array}{l}\text { Crédito médio de } 1,20 \% \text { sobre o valor do investimento, por } \\
\text { mensalidade, com simulação do nível de utilização da } \\
\text { capacidade instalada, para } 200 \text { residentes, com diversos graus } \\
\text { de dependência }\end{array}$} \\
\hline & \multicolumn{2}{|c|}{$60 \%$} & \multicolumn{2}{|c|}{$70 \%$} & \multicolumn{2}{|c|}{$80 \%$} & \multicolumn{2}{|c|}{$90 \%$} \\
\hline $100-0-0$ & $\mathrm{R} \$$ & 1.285 & $\mathrm{R} \$$ & 1.102 & $\mathrm{R} \$$ & 964 & $\mathrm{R} \$$ & 857 \\
\hline 0-100-0 & $\mathrm{R} \$$ & 1.288 & $\mathrm{R} \$$ & 1.104 & $\mathrm{R} \$$ & 966 & $\mathrm{R} \$$ & 858 \\
\hline 0-0-100 & $\mathrm{R} \$$ & 1.160 & $\mathrm{R} \$$ & 995 & $\mathrm{R} \$$ & 870 & $\mathrm{R} \$$ & 774 \\
\hline $70-30-0$ & $\mathrm{R} \$$ & 1.286 & $\mathrm{R} \$$ & 1.102 & $\mathrm{R} \$$ & 964 & $\mathrm{R} \$$ & 857 \\
\hline $70-0-30$ & $\mathrm{R} \$$ & 1.249 & $\mathrm{R} \$$ & 1.071 & $\mathrm{R} \$$ & 937 & $\mathrm{R} \$$ & 833 \\
\hline $50-40-10$ & $\mathrm{R} \$$ & 1.270 & $\mathrm{R} \$$ & 1.089 & $\mathrm{R} \$$ & 953 & $\mathrm{R} \$$ & 847 \\
\hline $60-30-10$ & $\mathrm{R} \$$ & 1.270 & $\mathrm{R} \$$ & 1.089 & $\mathrm{R} \$$ & 953 & $\mathrm{R} \$$ & 847 \\
\hline
\end{tabular}


Apêndice 71 - Crédito médio de 1,20\% sobre o valor do investimento, por mensalidade, para construção em 90 dias e compensação de retorno em 12 meses, com simulação do nível de utilização da capacidade instalada, para 300 residentes

\begin{tabular}{|c|c|c|c|c|c|c|c|c|}
\hline \multirow{2}{*}{$\begin{array}{l}\text { Porcentagem de } \\
\text { residentes com } \\
\text { grau de } \\
\text { dependência } \\
\text { I, II e III } \\
\end{array}$} & \multicolumn{8}{|c|}{$\begin{array}{l}\text { Crédito médio de } 1,20 \% \text { sobre o valor do investimento, por } \\
\text { mensalidade, com simulação do nível de utilização da } \\
\text { capacidade instalada, para } 300 \text { residentes, com diversos graus } \\
\text { de dependência }\end{array}$} \\
\hline & \multicolumn{2}{|c|}{$60 \%$} & \multicolumn{2}{|c|}{$70 \%$} & \multicolumn{2}{|c|}{$80 \%$} & \multicolumn{2}{|c|}{$90 \%$} \\
\hline 100-0-0 & $\mathrm{R} \$$ & 1.196 & $\mathrm{R} \$$ & 1.025 & $\mathrm{R} \$$ & 897 & $\mathrm{R} \$$ & 797 \\
\hline 0-100-0 & $\mathrm{R} \$$ & 1.198 & $\mathrm{R} \$$ & 1.027 & $\mathrm{R} \$$ & 899 & $\mathrm{R} \$$ & 799 \\
\hline 0-0-100 & $\mathrm{R} \$$ & 1.080 & $\mathrm{R} \$$ & 925 & $\mathrm{R} \$$ & 810 & $\mathrm{R} \$$ & 720 \\
\hline $70-30-0$ & $\mathrm{R} \$$ & 1.197 & $\mathrm{R} \$$ & 1.026 & $\mathrm{R} \$$ & 898 & $\mathrm{R} \$$ & 798 \\
\hline $70-0-30$ & $\mathrm{R} \$$ & 1.163 & $\mathrm{R} \$$ & 997 & $\mathrm{R} \$$ & 872 & $\mathrm{R} \$$ & 776 \\
\hline $50-40-10$ & $\mathrm{R} \$$ & 1.187 & $\mathrm{R} \$$ & 1.017 & $\mathrm{R} \$$ & 890 & $\mathrm{R} \$$ & 791 \\
\hline $60-30-10$ & $\mathrm{R} \$$ & 1.187 & $\mathrm{R} \$$ & 1.017 & $\mathrm{R} \$$ & 890 & $\mathrm{R} \$$ & 791 \\
\hline
\end{tabular}

Apêndice 72 - Crédito médio de 1,20\% sobre o valor do investimento, por mensalidade, para construção em 90 dias e compensação de retorno em 12 meses, com simulação do nível de utilização da capacidade instalada, para 400 residentes

\begin{tabular}{|c|c|c|c|c|c|c|c|c|}
\hline \multirow{2}{*}{$\begin{array}{l}\text { Porcentagem de } \\
\text { residentes com } \\
\text { grau de } \\
\text { dependência } \\
\text { I, II e III }\end{array}$} & \multicolumn{8}{|c|}{$\begin{array}{l}\text { Crédito médio de } 1,20 \% \text { sobre o valor do investimento, por } \\
\text { mensalidade, com simulação do nível de utilização da } \\
\text { capacidade instalada, para } 400 \text { residentes, com diversos graus } \\
\text { de dependência }\end{array}$} \\
\hline & \multicolumn{2}{|c|}{$60 \%$} & \multicolumn{2}{|c|}{$70 \%$} & \multicolumn{2}{|c|}{$80 \%$} & \multicolumn{2}{|c|}{$90 \%$} \\
\hline 100-0-0 & $\mathrm{R} \$$ & 1.175 & $\mathrm{R} \$$ & 1.007 & $\mathrm{R} \$$ & 881 & $\mathrm{R} \$$ & 783 \\
\hline 0-100-0 & $\mathrm{R} \$$ & 1.177 & $\mathrm{R} \$$ & 1.009 & $\mathrm{R} \$$ & 883 & $\mathrm{R} \$$ & 785 \\
\hline $0-0-100$ & $\mathrm{R} \$$ & 1.059 & $\mathrm{R} \$$ & 907 & $\mathrm{R} \$$ & 794 & $\mathrm{R} \$$ & 706 \\
\hline $70-30-0$ & $\mathrm{R} \$$ & 1.175 & $\mathrm{R} \$$ & 1.007 & $\mathrm{R} \$$ & 881 & $\mathrm{R} \$$ & 783 \\
\hline $70-0-30$ & $\mathrm{R} \$$ & 1.140 & $\mathrm{R} \$$ & 977 & $\mathrm{R} \$$ & 855 & $\mathrm{R} \$$ & 760 \\
\hline $50-40-10$ & $\mathrm{R} \$$ & 1.164 & $\mathrm{R} \$$ & 998 & $\mathrm{R} \$$ & 873 & $\mathrm{R} \$$ & 776 \\
\hline $60-30-10$ & $\mathrm{R} \$$ & 1.163 & $\mathrm{R} \$$ & 997 & $\mathrm{R} \$$ & 872 & $\mathrm{R} \$$ & 775 \\
\hline
\end{tabular}

Apêndice 73 - Crédito médio de 1,30\% sobre o valor do investimento, por mensalidade, para construção em 90 dias e compensação de retorno em 12 meses, com simulação do nível de utilização da capacidade instalada, para 100 residentes

\begin{tabular}{|c|c|c|c|c|c|c|c|c|}
\hline \multirow{2}{*}{$\begin{array}{l}\text { Porcentagem de } \\
\text { residentes com } \\
\text { grau de } \\
\text { dependência } \\
\text { I, II e III }\end{array}$} & \multicolumn{8}{|c|}{$\begin{array}{l}\text { Crédito médio de } 1,30 \% \text { sobre o valor do investimento, por } \\
\text { mensalidade, com simulação do nível de utilização da } \\
\text { capacidade instalada, para } 100 \text { residentes, com diversos graus } \\
\text { de dependência }\end{array}$} \\
\hline & \multicolumn{2}{|c|}{$60 \%$} & \multicolumn{2}{|c|}{$70 \%$} & \multicolumn{2}{|c|}{$80 \%$} & \multicolumn{2}{|c|}{$90 \%$} \\
\hline $100-0-0$ & $\mathrm{R} \$$ & 1.376 & $\mathrm{R} \$$ & 1.179 & $\mathrm{R} \$$ & 1.032 & $\mathrm{R} \$$ & 917 \\
\hline $0-100-0$ & $\mathrm{R} \$$ & 1.377 & $\mathrm{R} \$$ & 1.180 & $\mathrm{R} \$$ & 1.033 & $\mathrm{R} \$$ & 918 \\
\hline 0-0-100 & $\mathrm{R} \$$ & 1.236 & $\mathrm{R} \$$ & 1.060 & $\mathrm{R} \$$ & 927 & $\mathrm{R} \$$ & 824 \\
\hline $70-30-0$ & $\mathrm{R} \$$ & 1.376 & $\mathrm{R} \$$ & 1.180 & $\mathrm{R} \$$ & 1.032 & $\mathrm{R} \$$ & 918 \\
\hline $70-0-30$ & $\mathrm{R} \$$ & 1.343 & $\mathrm{R} \$$ & 1.151 & $\mathrm{R} \$$ & 1.007 & $\mathrm{R} \$$ & 895 \\
\hline $50-40-10$ & $\mathrm{R} \$$ & 1.367 & $\mathrm{R} \$$ & 1.172 & $\mathrm{R} \$$ & 1.026 & $\mathrm{R} \$$ & 912 \\
\hline $60-30-10$ & $\mathrm{R} \$$ & 1.367 & $\mathrm{R} \$$ & 1.172 & $\mathrm{R} \$$ & 1.025 & $\mathrm{R} \$$ & 911 \\
\hline
\end{tabular}


Apêndice 74 - Crédito médio de 1,30\% sobre o valor do investimento, por mensalidade, para construção em 90 dias e compensação de retorno em 12 meses, com simulação do nível de utilização da capacidade instalada, para 200 residentes

\begin{tabular}{|c|c|c|c|c|c|c|c|c|}
\hline \multirow{2}{*}{$\begin{array}{l}\text { Porcentagem de } \\
\text { residentes com } \\
\text { grau de } \\
\text { dependência } \\
\text { I, II e III } \\
\end{array}$} & \multicolumn{8}{|c|}{$\begin{array}{l}\text { Crédito médio de } 1,30 \% \text { sobre o valor do investimento, por } \\
\text { mensalidade, com simulação do nível de utilização da } \\
\text { capacidade instalada, para } 200 \text { residentes, com diversos graus } \\
\text { de dependência }\end{array}$} \\
\hline & \multicolumn{2}{|c|}{$60 \%$} & \multicolumn{2}{|c|}{$70 \%$} & \multicolumn{2}{|c|}{$80 \%$} & \multicolumn{2}{|c|}{$90 \%$} \\
\hline 100-0-0 & $\mathrm{R} \$$ & 1.392 & $\mathrm{R} \$$ & 1.193 & $\mathrm{R} \$$ & 1.044 & $\mathrm{R} \$$ & 928 \\
\hline 0-100-0 & $\mathrm{R} \$$ & 1.395 & $\mathrm{R} \$$ & 1.196 & $\mathrm{R} \$$ & 1.046 & $\mathrm{R} \$$ & 930 \\
\hline 0-0-100 & $\mathrm{R} \$$ & 1.257 & $\mathrm{R} \$$ & 1.078 & $\mathrm{R} \$$ & 943 & $\mathrm{R} \$$ & 838 \\
\hline $70-30-0$ & $\mathrm{R} \$$ & 1.393 & $\mathrm{R} \$$ & 1.194 & $\mathrm{R} \$$ & 1.044 & $\mathrm{R} \$$ & 928 \\
\hline $70-0-30$ & $\mathrm{R} \$$ & 1.353 & $\mathrm{R} \$$ & 1.160 & $\mathrm{R} \$$ & 1.015 & $\mathrm{R} \$$ & 902 \\
\hline $50-40-10$ & $\mathrm{R} \$$ & 1.376 & $\mathrm{R} \$$ & 1.180 & $\mathrm{R} \$$ & 1.032 & $\mathrm{R} \$$ & 917 \\
\hline $60-30-10$ & $\mathrm{R} \$$ & 1.376 & $\mathrm{R} \$$ & 1.179 & $\mathrm{R} \$$ & 1.032 & $\mathrm{R} \$$ & 917 \\
\hline
\end{tabular}

Apêndice 75 - Crédito médio de 1,30\% sobre o valor do investimento, por mensalidade, para construção em 90 dias e compensação de retorno em 12 meses, com simulação do nível de utilização da capacidade instalada, para 300 residentes

\begin{tabular}{|c|c|c|c|c|c|c|c|c|}
\hline \multirow{2}{*}{$\begin{array}{l}\text { Porcentagem de } \\
\text { residentes com } \\
\text { grau de } \\
\text { dependência } \\
\text { I, II e III } \\
\end{array}$} & \multicolumn{8}{|c|}{$\begin{array}{l}\text { Crédito médio de } 1,30 \% \text { sobre o valor do investimento, por } \\
\text { mensalidade, com simulação do nível de utilização da } \\
\text { capacidade instalada, para } 300 \text { residentes, com diversos graus } \\
\text { de dependência }\end{array}$} \\
\hline & \multicolumn{2}{|c|}{$60 \%$} & \multicolumn{2}{|c|}{$70 \%$} & \multicolumn{2}{|c|}{$80 \%$} & \multicolumn{2}{|c|}{$90 \%$} \\
\hline 100-0-0 & $\mathrm{R} \$$ & 1.295 & $\mathrm{R} \$$ & 1.110 & $\mathrm{R} \$$ & 971 & $\mathrm{R} \$$ & 863 \\
\hline 0-100-0 & $\mathrm{R} \$$ & 1.298 & $\mathrm{R} \$$ & 1.113 & $\mathrm{R} \$$ & 974 & $\mathrm{R} \$$ & 866 \\
\hline 0-0-100 & $\mathrm{R} \$$ & 1.169 & $\mathrm{R} \$$ & 1.002 & $\mathrm{R} \$$ & 877 & $\mathrm{R} \$$ & 780 \\
\hline $70-30-0$ & $\mathrm{R} \$$ & 1.297 & $\mathrm{R} \$$ & 1.111 & $\mathrm{R} \$$ & 972 & $\mathrm{R} \$$ & 864 \\
\hline $70-0-30$ & $\mathrm{R} \$$ & 1.260 & $\mathrm{R} \$$ & 1.080 & $\mathrm{R} \$$ & 945 & $\mathrm{R} \$$ & 840 \\
\hline $50-40-10$ & $\mathrm{R} \$$ & 1.286 & $\mathrm{R} \$$ & 1.102 & $\mathrm{R} \$$ & 964 & $\mathrm{R} \$$ & 857 \\
\hline $60-30-10$ & $\mathrm{R} \$$ & 1.286 & $\mathrm{R} \$$ & 1.102 & $\mathrm{R} \$$ & 964 & $\mathrm{R} \$$ & 857 \\
\hline
\end{tabular}

Apêndice 76 - Crédito médio de 1,30\% sobre o valor do investimento, por mensalidade, para construção em 90 dias e compensação de retorno em 12 meses, com simulação do nível de utilização da capacidade instalada, para 400 residentes

\begin{tabular}{|c|c|c|c|c|c|c|c|c|}
\hline \multirow{3}{*}{$\begin{array}{c}\text { Porcentagem de } \\
\text { residentes com } \\
\text { grau de } \\
\text { dependência } \\
\text { I, II e III } \\
100-0-0\end{array}$} & \multicolumn{8}{|c|}{$\begin{array}{l}\text { Crédito médio de } 1,30 \% \text { sobre o valor do investimento, por } \\
\text { mensalidade, com simulação do nível de utilização da } \\
\text { capacidade instalada, para } 400 \text { residentes, com diversos graus } \\
\text { de dependência }\end{array}$} \\
\hline & \multicolumn{2}{|c|}{$60 \%$} & \multicolumn{2}{|c|}{$70 \%$} & \multicolumn{2}{|c|}{$80 \%$} & \multicolumn{2}{|c|}{$90 \%$} \\
\hline & $\mathrm{R} \$$ & 1.273 & $\mathrm{R} \$$ & 1.091 & $\mathrm{R} \$$ & 955 & $\mathrm{R} \$$ & 848 \\
\hline $0-100-0$ & $\mathrm{R} \$$ & 1.275 & $\mathrm{R} \$$ & 1.093 & $\mathrm{R} \$$ & 956 & $\mathrm{R} \$$ & 850 \\
\hline 0-0-100 & $\mathrm{R} \$$ & 1.147 & $\mathrm{R} \$$ & 983 & $\mathrm{R} \$$ & 860 & $\mathrm{R} \$$ & 764 \\
\hline $70-30-0$ & $\mathrm{R} \$$ & 1.273 & $\mathrm{R} \$$ & 1.091 & $\mathrm{R} \$$ & 955 & $\mathrm{R} \$$ & 849 \\
\hline $70-0-30$ & $\mathrm{R} \$$ & 1.235 & $\mathrm{R} \$$ & 1.059 & $\mathrm{R} \$$ & 927 & $\mathrm{R} \$$ & 824 \\
\hline $50-40-10$ & $\mathrm{R} \$$ & 1.261 & $\mathrm{R} \$$ & 1.081 & $\mathrm{R} \$$ & 946 & $\mathrm{R} \$$ & 841 \\
\hline $60-30-10$ & $\mathrm{R} \$$ & 1.260 & $\mathrm{R} \$$ & 1.080 & $\mathrm{R} \$$ & 945 & $\mathrm{R} \$$ & 840 \\
\hline
\end{tabular}


Apêndice 77 - Crédito médio de $\mathbf{1 , 4 0 \%}$ sobre o valor do investimento, por mensalidade, para construção em 90 dias e compensação de retorno em 12 meses, com simulação do nível de utilização da capacidade instalada, para 100 residentes

\begin{tabular}{|c|c|c|c|c|c|c|c|c|}
\hline \multirow[t]{2}{*}{$\begin{array}{l}\text { Porcentagem de } \\
\text { residentes com } \\
\text { grau de } \\
\text { dependência } \\
\text { I, II e III }\end{array}$} & \multicolumn{8}{|c|}{$\begin{array}{l}\text { Crédito médio de } 1,40 \% \text { sobre o valor do investimento, por } \\
\text { mensalidade, com simulação do nível de utilização da } \\
\text { capacidade instalada, para } 100 \text { residentes, com diversos graus } \\
\text { de dependência }\end{array}$} \\
\hline & \multicolumn{2}{|c|}{$60 \%$} & \multicolumn{2}{|c|}{$70 \%$} & \multicolumn{2}{|c|}{$80 \%$} & \multicolumn{2}{|c|}{$90 \%$} \\
\hline $100-0-0$ & $\mathrm{R} \$$ & 1.482 & $\$$ & 1.270 & $\mathrm{R} \$$ & 1.111 & $\mathrm{R} \$$ & 988 \\
\hline $0-100-0$ & $\mathrm{R} \$$ & 1.483 & $\mathrm{R} \$$ & 1.271 & $\mathrm{R} \$$ & 1.112 & $\mathrm{R} \$$ & 989 \\
\hline $0-0-100$ & $\mathrm{R} \$$ & 1.332 & $\mathrm{R} \$$ & 1.141 & $\mathrm{R}$ & 999 & $\mathrm{R} \$$ & 888 \\
\hline 70-30-0 & $\mathrm{R} \$$ & 1.482 & $\mathrm{R} \$$ & 1.271 & $\mathrm{R}$ & 1.112 & & 988 \\
\hline $70-0-30$ & $\mathrm{R} \$$ & 1.446 & $\mathrm{R} \$$ & 1.240 & $\mathrm{R} \$$ & 1.085 & $\mathrm{R} \$$ & 964 \\
\hline $50-40-10$ & $\mathrm{R} \$$ & 1.473 & $\mathrm{R} \$$ & 1.262 & $\mathrm{R} \$$ & 1.104 & $\mathrm{R} \$$ & 982 \\
\hline $60-30-10$ & $\mathrm{R} \$$ & 1.472 & $\mathrm{R} \$$ & 1.262 & $\mathrm{R} \$$ & 1.104 & $\mathrm{R} \$$ & 982 \\
\hline
\end{tabular}

Apêndice 78 - Crédito médio de 1,40\% sobre o valor do investimento, por mensalidade, para construção em 90 dias e compensação de retorno em 12 meses, com simulação do nível de utilização da capacidade instalada, para 200 residentes

\begin{tabular}{|c|c|c|c|c|c|c|c|c|}
\hline \multirow{2}{*}{$\begin{array}{l}\text { Porcentagem de } \\
\text { residentes com } \\
\text { grau de } \\
\text { dependência } \\
\text { I, II e III }\end{array}$} & \multicolumn{8}{|c|}{$\begin{array}{l}\text { Crédito médio de } 1,40 \% \text { sobre o valor do investimento, por } \\
\text { mensalidade, com simulação do nível de utilização da } \\
\text { capacidade instalada, para } 200 \text { residentes, com diversos graus } \\
\text { de dependência }\end{array}$} \\
\hline & \multicolumn{2}{|c|}{$60 \%$} & \multicolumn{2}{|c|}{$70 \%$} & \multicolumn{2}{|c|}{$80 \%$} & \multicolumn{2}{|c|}{$90 \%$} \\
\hline 100-0-0 & $\mathrm{R} \$$ & 1.499 & $\mathrm{R} \$$ & 1.285 & $\mathrm{R} \$$ & 1.125 & $\mathrm{R} \$$ & 1.000 \\
\hline 0-100-0 & $\mathrm{R} \$$ & 1.502 & $\mathrm{R} \$$ & 1.2 & $\mathrm{R} \$$ & & $\mathrm{R} \$$ & 1.001 \\
\hline 0-0-100 & $\mathrm{R} \$$ & 1.354 & $\mathrm{R} \$$ & 1.160 & $\mathrm{R} \$$ & 1.015 & $\mathrm{R} \$$ & 903 \\
\hline $70-30-0$ & $\mathrm{R} \$$ & 1.500 & $\mathrm{R} \$$ & 1.286 & $\mathrm{R} \$$ & 1.125 & $\mathrm{R} \$$ & 1.000 \\
\hline $70-0-30$ & $\mathrm{R} \$$ & 1.457 & $\mathrm{R} \$$ & 1.249 & $\mathrm{R} \$$ & 1.093 & $\mathrm{R} \$$ & 971 \\
\hline $50-40-10$ & $\mathrm{R} \$$ & 1.482 & $\mathrm{R} \$$ & 1.270 & $\mathrm{R} \$$ & 1.111 & $\mathrm{R} \$$ & 988 \\
\hline $60-30-10$ & $\mathrm{R} \$$ & 1.482 & $\mathrm{R} \$$ & 1.270 & $\mathrm{R} \$$ & 1.111 & $\mathrm{R} \$$ & 988 \\
\hline
\end{tabular}

Apêndice 79 - Crédito médio de 1,40\% sobre o valor do investimento, por mensalidade, para construção em 90 dias e compensação de retorno em 12 meses, com simulação do nível de utilização da capacidade instalada, para 300 residentes

\begin{tabular}{|c|c|c|c|c|c|c|c|c|}
\hline \multirow{2}{*}{$\begin{array}{l}\text { Porcentagem de } \\
\text { residentes com } \\
\text { grau de } \\
\text { dependência } \\
\text { I, II e III }\end{array}$} & \multicolumn{8}{|c|}{$\begin{array}{l}\text { Crédito médio de } 1,40 \% \text { sobre o valor do investimento, por } \\
\text { mensalidade, com simulação do nível de utilização da } \\
\text { capacidade instalada, para } 300 \text { residentes, com diversos graus } \\
\text { de dependência }\end{array}$} \\
\hline & \multicolumn{2}{|c|}{$60 \%$} & \multicolumn{2}{|c|}{$70 \%$} & \multicolumn{2}{|c|}{$80 \%$} & \multicolumn{2}{|c|}{$90 \%$} \\
\hline 100-0-0 & $\mathrm{R} \$$ & 1.395 & $\mathrm{R} \$$ & 1.196 & $\mathrm{R} \$$ & 1.046 & $\mathrm{R} \$$ & 930 \\
\hline 0-100-0 & $\mathrm{R} \$$ & 1.398 & $\mathrm{R} \$$ & 1.198 & $\mathrm{R} \$$ & 1.049 & $\mathrm{R} \$$ & 932 \\
\hline $0-0-100$ & $\mathrm{R} \$$ & 1.259 & $\mathrm{R} \$$ & 1.080 & $\mathrm{R} \$$ & 945 & $\mathrm{R} \$$ & 840 \\
\hline $70-30-0$ & $\mathrm{R} \$$ & 1.396 & $\mathrm{R} \$$ & 1.197 & $\mathrm{R} \$$ & 1.047 & $\mathrm{R} \$$ & 931 \\
\hline $70-0-30$ & $\mathrm{R} \$$ & 1.357 & $\mathrm{R} \$$ & 1.163 & $\mathrm{R} \$$ & 1.018 & $\mathrm{R} \$$ & 905 \\
\hline $50-40-10$ & $\mathrm{R} \$$ & 1.385 & $\mathrm{R} \$$ & 1.187 & $\mathrm{R} \$$ & 1.039 & $\mathrm{R} \$$ & 923 \\
\hline $60-30-10$ & $\mathrm{R} \$$ & 1.385 & $\mathrm{R} \$$ & 1.187 & $\mathrm{R} \$$ & 1.039 & $\mathrm{R} \$$ & 923 \\
\hline
\end{tabular}


Apêndice 80 - Crédito médio de 1,40\% sobre o valor do investimento, por mensalidade, para construção em 90 dias e compensação de retorno em 12 meses, com simulação do nível de utilização da capacidade instalada, para 400 residentes

\begin{tabular}{|c|c|c|c|c|c|c|c|c|}
\hline \multirow[t]{2}{*}{$\begin{array}{l}\text { Porcentagem de } \\
\text { residentes com } \\
\text { grau de } \\
\text { dependência } \\
\text { I, II e III }\end{array}$} & \multicolumn{8}{|c|}{$\begin{array}{l}\text { Crédito médio de } 1,40 \% \text { sobre o valor do investimento, por } \\
\text { mensalidade, com simulação do nível de utilização da } \\
\text { capacidade instalada, para } 400 \text { residentes, com diversos graus } \\
\text { de dependência }\end{array}$} \\
\hline & \multicolumn{2}{|c|}{$60 \%$} & \multicolumn{2}{|c|}{$70 \%$} & \multicolumn{2}{|c|}{$80 \%$} & \multicolumn{2}{|c|}{$90 \%$} \\
\hline 100-0-0 & $\mathrm{R} \$$ & 1.371 & $\mathrm{R} \$$ & 1.175 & $\mathrm{R} \$$ & 1.028 & $\mathrm{R} \$$ & 914 \\
\hline $0-100-0$ & $\mathrm{R} \$$ & 1.373 & $\mathrm{R} \$$ & 1.177 & $\mathrm{R} \$$ & 1.030 & RS & 916 \\
\hline $0-0-100$ & $\mathrm{R} \$$ & 5 & $\mathrm{R} \$$ & 1.059 & $\mathrm{R} \$$ & 926 & $\mathrm{R} \$$ & 823 \\
\hline $70-30-0$ & $\mathrm{R} \$$ & 1. & $\mathrm{R} \$$ & 1.175 & $\mathrm{R} \$$ & 1.028 & & 914 \\
\hline $70-0-30$ & $\mathrm{R} \$$ & 1. & $\mathrm{R} \$$ & 1.140 & $\mathrm{R} \$$ & 998 & $\mathrm{R}$ & 887 \\
\hline $50-40-10$ & $\mathrm{R} \$$ & 1.2 & $\mathrm{R} \$$ & 1.164 & $\mathrm{~K}$ & 1.018 & & 905 \\
\hline $60-30-10$ & $\mathrm{R} \$$ & 1.357 & $\mathrm{R} \$$ & 1.163 & $\mathrm{R} \$$ & 1.018 & $\mathrm{R} \$$ & 905 \\
\hline
\end{tabular}

Apêndice 81 - Crédito médio de 1,50\% sobre o valor do investimento, por mensalidade, para construção em 90 dias e compensação de retorno em 12 meses, com simulação do nível de utilização da capacidade instalada, para 100 residentes

\begin{tabular}{|c|c|c|c|c|c|c|c|c|}
\hline \multirow[t]{2}{*}{$\begin{array}{c}\text { Porcentagem de } \\
\text { residentes com } \\
\text { grau de } \\
\text { dependência } \\
\text { I, II e III }\end{array}$} & \multicolumn{8}{|c|}{$\begin{array}{c}\text { Crédito médio de } 1,50 \% \text { sobre o valor do investimento, por } \\
\text { mensalidade, com simulação do nível de utilização da } \\
\text { capacidade instalada, para } 100 \text { residentes, com diversos graus } \\
\text { de dependência }\end{array}$} \\
\hline & \multicolumn{2}{|c|}{$60 \%$} & \multicolumn{2}{|c|}{$70 \%$} & \multicolumn{2}{|c|}{$80 \%$} & \multicolumn{2}{|c|}{ 90\% } \\
\hline 100-0-0 & $\mathrm{R} \$$ & 1.588 & $\mathrm{R} \$$ & 1.361 & $\mathrm{R} \$$ & 1.191 & $\mathrm{R} \$$ & 1.059 \\
\hline $0-100-0$ & $\mathrm{R} \$$ & 1.589 & $\mathrm{R} \$$ & 1.362 & $\mathrm{R} \$$ & 1.192 & $\mathrm{R} \$$ & 1.059 \\
\hline $0-0-100$ & $\mathrm{R} \$$ & 1.427 & $\mathrm{R} \$$ & 1.223 & $\mathrm{R} \$$ & 1.070 & $\mathrm{R} \$$ & 951 \\
\hline 70 & $\mathrm{R} \$$ & 8 & $\mathrm{R} \$$ & 1.361 & $\mathrm{R} \$$ & 1.191 & 5 & 1.059 \\
\hline 70-0-30 & $\mathrm{R} \$$ & 1.549 & $\mathrm{R} \$$ & 1.328 & $\mathrm{R}$ & 1.162 & $\mathrm{R} \$$ & 1.033 \\
\hline $50-40-10$ & $\mathrm{R} \$$ & 1.578 & $\mathrm{R} \$$ & 1.352 & R\$ & 1.183 & $\mathrm{R} \$$ & 1.052 \\
\hline $60-30-10$ & $\mathrm{R} \$$ & 1.577 & $\mathrm{R} \$$ & 1.352 & $\mathrm{R} \$$ & 1.183 & $\mathrm{R} \$$ & 1.052 \\
\hline
\end{tabular}

Apêndice 82 - Crédito médio de 1,50\% sobre o valor do investimento, por mensalidade, para construção em 90 dias e compensação de retorno em 12 meses, com simulação do nível de utilização da capacidade instalada, para 200 residentes

\begin{tabular}{|c|c|c|c|c|c|c|c|c|}
\hline \multirow[t]{2}{*}{$\begin{array}{l}\text { Porcentagem de } \\
\text { residentes com } \\
\text { grau de } \\
\text { dependência } \\
\text { I, II e III }\end{array}$} & \multicolumn{8}{|c|}{$\begin{array}{c}\text { Crédito médio de } 1,50 \% \text { sobre o valor do investimento, por } \\
\text { mensalidade, com simulação do nível de utilização da } \\
\text { capacidade instalada, para } 200 \text { residentes, com diversos graus } \\
\text { de dependência }\end{array}$} \\
\hline & \multicolumn{2}{|c|}{$60 \%$} & \multicolumn{2}{|c|}{$70 \%$} & \multicolumn{2}{|c|}{$80 \%$} & \multicolumn{2}{|c|}{$90 \%$} \\
\hline 100-0-0 & $\mathrm{R} \$$ & 1.607 & $\mathrm{R} \$$ & 1.377 & $\mathrm{R} \$$ & 1.205 & $\mathrm{R} \$$ & 1.071 \\
\hline 0- & $\mathrm{R} \$$ & 1.609 & $\mathrm{R} \$$ & 1.380 & $\mathrm{R} \$$ & 1.207 & R\$ & 1.073 \\
\hline $0-0-100$ & $\mathrm{R} \$$ & 1.451 & $\mathrm{R} \$$ & 1.243 & $\mathrm{R} \$$ & 1.088 & $\mathrm{R} \$$ & 967 \\
\hline 70 & $\mathrm{R} \$$ & 1.607 & $\mathrm{R} \$$ & 1.377 & $\mathrm{R} \$$ & 1.205 & $\mathrm{R} \$$ & 1.071 \\
\hline $70-1$ & $\mathrm{R} \$$ & 1.561 & $\mathrm{R} \$$ & 1.338 & $\mathrm{R} \$$ & 1.171 & $\mathrm{R} \$$ & 1.041 \\
\hline 50 & $\mathrm{R} \$$ & 1.588 & $\mathrm{R} \$$ & 1.361 & $\mathrm{R} \$$ & 1.191 & $\mathrm{R} \$$ & 1.059 \\
\hline $60-30-10$ & $\mathrm{R} \$$ & 1.588 & $\mathrm{R} \$$ & 1.361 & $\mathrm{R} \$$ & 1.191 & $\mathrm{R} \$$ & 1.058 \\
\hline
\end{tabular}


Apêndice 83 - Crédito médio de 1,50\% sobre o valor do investimento, por mensalidade, para construção em 90 dias e compensação de retorno em 12 meses, com simulação do nível de utilização da capacidade instalada, para 300 residentes

\begin{tabular}{|c|c|c|c|c|c|c|c|c|}
\hline \multirow{3}{*}{$\begin{array}{c}\text { Porcentagem de } \\
\text { residentes com } \\
\text { grau de } \\
\text { dependência } \\
\text { I, II e III } \\
100-0-0\end{array}$} & \multicolumn{8}{|c|}{$\begin{array}{c}\text { Crédito médio de } 1,50 \% \text { sobre o valor do investimento, por } \\
\text { mensalidade, com simulação do nível de utilização da } \\
\text { capacidade instalada, para } 300 \text { residentes, com diversos graus } \\
\text { de dependência } \\
\end{array}$} \\
\hline & \multicolumn{2}{|c|}{$60 \%$} & \multicolumn{2}{|c|}{$70 \%$} & \multicolumn{2}{|c|}{$80 \%$} & \multicolumn{2}{|c|}{ 90\% } \\
\hline & $\mathrm{R} \$$ & 1.495 & $\mathrm{R} \$$ & 1.281 & $\mathrm{R} \$$ & 1.121 & $\mathrm{R} \$$ & 996 \\
\hline $0-100$ & $\mathrm{R} \$$ & 1.498 & $\mathrm{R} \$$ & 1.284 & $\mathrm{R} \$$ & 1.124 & $\mathrm{R} \$$ & 999 \\
\hline 0-0-100 & $\mathrm{R} \$$ & 349 & $\mathrm{R} \$$ & 1.157 & $\mathrm{R} \$$ & .012 & $\mathrm{R} \$$ & 900 \\
\hline 70-30-0 & $\mathrm{R} \$$ & 1.496 & $\mathrm{R} \$$ & 1.282 & $\mathrm{R}$ & 1.122 & $\mathrm{R} \$$ & 997 \\
\hline 70-0-30 & $\mathrm{R} \$$ & .454 & $\mathrm{R} \$$ & 1.246 & $\mathrm{R} \$$ & 1.091 & $\mathrm{R} \$$ & 969 \\
\hline $50-40-10$ & $\mathrm{R} \$$ & 1.484 & $\mathrm{R} \$$ & 1.272 & $\mathrm{R} \$$ & 1.113 & $\mathrm{R} \$$ & 989 \\
\hline $60-30-10$ & $\mathrm{R} \$$ & 1.484 & $\mathrm{R} \$$ & 1.272 & $\mathrm{R} \$$ & 1.113 & $\mathrm{R} \$$ & 989 \\
\hline
\end{tabular}

Apêndice 84 - Crédito médio de 1,50\% sobre o valor do investimento, por mensalidade, para construção em 90 dias e compensação de retorno em 12 meses, com simulação do nível de utilização da capacidade instalada, para 400 residentes

\begin{tabular}{|c|c|c|c|c|c|c|c|c|}
\hline \multirow{2}{*}{$\begin{array}{c}\text { Porcentagem de } \\
\text { residentes com } \\
\text { grau de } \\
\text { dependência } \\
\text { I, II e III } \\
\end{array}$} & \multicolumn{8}{|c|}{$\begin{array}{l}\text { Crédito médio de } 1,50 \% \text { sobre o valor do investimento, por } \\
\text { mensalidade, com simulação do nível de utilização da } \\
\text { capacidade instalada, para } 400 \text { residentes, com diversos graus } \\
\text { de dependência }\end{array}$} \\
\hline & \multicolumn{2}{|c|}{$60 \%$} & \multicolumn{2}{|c|}{$70 \%$} & \multicolumn{2}{|c|}{$80 \%$} & \multicolumn{2}{|c|}{$90 \%$} \\
\hline $100-0-0$ & $\mathrm{R} \$$ & 1.469 & $\mathrm{R} \$$ & 1.259 & $\mathrm{R} \$$ & 1.101 & $\mathrm{R} \$$ & 979 \\
\hline 0-100-0 & $\mathrm{R} \$$ & 1.471 & $\mathrm{R} \$$ & 1.261 & $\mathrm{R} \$$ & 1.104 & $\mathrm{R} \$$ & 981 \\
\hline $0-0-100$ & $\mathrm{R} \$$ & 1.323 & $\mathrm{R} \$$ & 1.134 & $\mathrm{R} \$$ & 992 & $\mathrm{R} \$$ & 882 \\
\hline 70- & $\mathrm{R} \$$ & 1.469 & $\mathrm{R} \$$ & 1.259 & $\mathrm{R}$ & 1.102 & $\mathrm{R} \$$ & 979 \\
\hline $70-0-30$ & $\mathrm{R} \$$ & 1.425 & $\mathrm{R} \$$ & 1.222 & $\mathrm{R} \$$ & 1.069 & R\$ & 950 \\
\hline $50-40-10$ & $\mathrm{R} \$$ & 1.455 & $\mathrm{R} \$$ & 1.247 & $\mathrm{R}$ & 1.091 & $\mathrm{R} \$$ & 970 \\
\hline $60-30-10$ & $\mathrm{R} \$$ & 1.454 & $\mathrm{R} \$$ & 1.246 & $\mathrm{R} \$$ & 1.090 & $\mathrm{R} \$$ & 969 \\
\hline
\end{tabular}

Apêndice 85 - Crédito médio de 1,10\% sobre o valor do investimento, por mensalidade, para construção em 90 dias e compensação de retorno em 24 meses, com simulação do nível de utilização da capacidade instalada, para 100 residentes

\begin{tabular}{|c|c|c|c|c|c|c|c|c|}
\hline \multirow{2}{*}{$\begin{array}{c}\text { Porcentagem de } \\
\text { residentes com } \\
\text { grau de } \\
\text { dependência } \\
\text { I, II e III }\end{array}$} & \multicolumn{8}{|c|}{$\begin{array}{l}\text { Crédito médio de } 1,10 \% \text { sobre o valor do investimento, por } \\
\text { mensalidade, com simulação do nível de utilização da } \\
\text { capacidade instalada, para } 100 \text { residentes, com diversos graus } \\
\text { de dependência }\end{array}$} \\
\hline & \multicolumn{2}{|c|}{$60 \%$} & \multicolumn{2}{|c|}{$70 \%$} & \multicolumn{2}{|c|}{$80 \%$} & \multicolumn{2}{|c|}{ 90\% } \\
\hline 100-0-0 & $\mathrm{R} \$$ & 998 & $\mathrm{R} \$$ & 855 & $\mathrm{R} \$$ & 749 & $\mathrm{R} \$$ & 665 \\
\hline $0-100-0$ & $\mathrm{R} \$$ & 999 & $\mathrm{R} \$$ & 856 & $\mathrm{R} \$$ & 749 & $\mathrm{R} \$$ & 666 \\
\hline $0-0-100$ & $\mathrm{R} \$$ & 897 & $\mathrm{R} \$$ & 769 & $\mathrm{R} \$$ & 673 & $\mathrm{R} \$$ & 598 \\
\hline $70-30-0$ & $\mathrm{R} \$$ & 998 & $\mathrm{R} \$$ & 856 & $\mathrm{R} \$$ & 749 & $\mathrm{R} \$$ & 666 \\
\hline 70-0-30 & $\mathrm{R} \$$ & 974 & $\mathrm{R} \$$ & 835 & $\$$ & 730 & $\mathrm{R} \$$ & 649 \\
\hline $50-40-10$ & $\mathrm{R} \$$ & 992 & $\mathrm{R} \$$ & 850 & R\$ & 744 & $\mathrm{R} \$$ & 661 \\
\hline $60-30-10$ & $\mathrm{R} \$$ & 992 & $\mathrm{R} \$$ & 850 & $\mathrm{R} \$$ & 744 & $\mathrm{R} \$$ & 661 \\
\hline
\end{tabular}


Apêndice 86 - Crédito médio de 1,10\% sobre o valor do investimento, por mensalidade, para construção em 90 dias e compensação de retorno em 24 meses, com simulação do nível de utilização da capacidade instalada, para 200 residentes

\begin{tabular}{|c|c|c|c|c|c|c|c|c|}
\hline \multirow{2}{*}{$\begin{array}{c}\text { Porcentagem de } \\
\text { residentes com } \\
\text { grau de } \\
\text { dependência } \\
\text { I, II e III } \\
\end{array}$} & \multicolumn{8}{|c|}{$\begin{array}{l}\text { Crédito médio de } 1,10 \% \text { sobre o valor do investimento, por } \\
\text { mensalidade, com simulação do nível de utilização da } \\
\text { capacidade instalada, para } 200 \text { residentes, com diversos graus } \\
\text { de dependência }\end{array}$} \\
\hline & \multicolumn{2}{|c|}{$60 \%$} & \multicolumn{2}{|c|}{$70 \%$} & \multicolumn{2}{|c|}{$80 \%$} & \multicolumn{2}{|c|}{$90 \%$} \\
\hline 100-0-0 & $\mathrm{R} \$$ & 1.010 & $\mathrm{R} \$$ & 866 & $\mathrm{R} \$$ & 757 & $\mathrm{R} \$$ & 673 \\
\hline $0-100-0$ & $\mathrm{R} \$$ & 1.012 & $\mathrm{R} \$$ & 867 & $\mathrm{R} \$$ & 759 & $\mathrm{R} \$$ & 674 \\
\hline 0-0-100 & $\mathrm{R} \$$ & 912 & $\mathrm{R} \$$ & 782 & $\mathrm{R} \$$ & 684 & $\mathrm{R} \$$ & 608 \\
\hline $70-30-0$ & $\mathrm{R} \$$ & 1.010 & $\mathrm{R} \$$ & 866 & $\mathrm{R} \$$ & 758 & $\mathrm{R} \$$ & 673 \\
\hline $70-0-30$ & $\mathrm{R} \$$ & 981 & $\mathrm{R} \$$ & 841 & $\mathrm{R} \$$ & 736 & $\mathrm{R} \$$ & 654 \\
\hline $50-40-10$ & $\mathrm{R} \$$ & 998 & $\mathrm{R} \$$ & 855 & $\mathrm{R} \$$ & 749 & $\mathrm{R} \$$ & 665 \\
\hline $60-30-10$ & $\mathrm{R} \$$ & 998 & $\mathrm{R} \$$ & 855 & $\mathrm{R} \$$ & 748 & $\mathrm{R} \$$ & 665 \\
\hline
\end{tabular}

Apêndice 87 - Crédito médio de 1,10\% sobre o valor do investimento, por mensalidade, para construção em 90 dias e compensação de retorno em 24 meses, com simulação do nível de utilização da capacidade instalada, para 300 residentes

\begin{tabular}{|c|c|c|c|c|c|c|c|c|}
\hline \multirow{3}{*}{$\begin{array}{c}\text { Porcentagem de } \\
\text { residentes com } \\
\text { grau de } \\
\text { dependência } \\
\text { I, II e III } \\
100-0-0\end{array}$} & \multicolumn{8}{|c|}{$\begin{array}{l}\text { Crédito médio de } 1,10 \% \text { sobre o valor do investimento, por } \\
\text { mensalidade, com simulação do nível de utilização da } \\
\text { capacidade instalada, para } 300 \text { residentes, com diversos graus } \\
\text { de dependência }\end{array}$} \\
\hline & \multicolumn{2}{|c|}{$60 \%$} & \multicolumn{2}{|c|}{$70 \%$} & \multicolumn{2}{|c|}{$80 \%$} & \multicolumn{2}{|c|}{$90 \%$} \\
\hline & $\mathrm{R} \$$ & 939 & $\mathrm{R} \$$ & 805 & $\mathrm{R} \$$ & 705 & $\mathrm{R} \$$ & 626 \\
\hline $0-100-0$ & $\mathrm{R} \$$ & 942 & $\mathrm{R} \$$ & 807 & $\mathrm{R} \$$ & 706 & $\mathrm{R} \$$ & 628 \\
\hline 0-0-100 & $\mathrm{R} \$$ & 848 & $\mathrm{R} \$$ & 727 & $\mathrm{R} \$$ & 636 & $\mathrm{R} \$$ & 565 \\
\hline $70-30-0$ & $\mathrm{R} \$$ & 940 & $\mathrm{R} \$$ & 806 & $\mathrm{R} \$$ & 705 & $\mathrm{R} \$$ & 627 \\
\hline $70-0-30$ & $\mathrm{R} \$$ & 914 & $\mathrm{R} \$$ & 783 & $\mathrm{R} \$$ & 686 & $\mathrm{R} \$$ & 609 \\
\hline $50-40-10$ & $\mathrm{R} \$$ & 933 & $\mathrm{R} \$$ & 799 & $\mathrm{R} \$$ & 700 & $\mathrm{R} \$$ & 622 \\
\hline $60-30-10$ & $\mathrm{R} \$$ & 933 & $\mathrm{R} \$$ & 799 & $\mathrm{R} \$$ & 699 & $\mathrm{R} \$$ & 622 \\
\hline
\end{tabular}

Apêndice 88 - Crédito médio de 1,10\% sobre o valor do investimento, por mensalidade, para construção em 90 dias e compensação de retorno em 24 meses, com simulação do nível de utilização da capacidade instalada, para 400 residentes

\begin{tabular}{|c|c|c|c|c|c|c|c|c|}
\hline \multirow{2}{*}{$\begin{array}{l}\text { Porcentagem de } \\
\text { residentes com } \\
\text { grau de } \\
\text { dependência } \\
\text { I, II e III }\end{array}$} & \multicolumn{8}{|c|}{$\begin{array}{l}\text { Crédito médio de } 1,10 \% \text { sobre o valor do investimento, por } \\
\text { mensalidade, com simulação do nível de utilização da } \\
\text { capacidade instalada, para } 400 \text { residentes, com diversos graus } \\
\text { de dependência }\end{array}$} \\
\hline & \multicolumn{2}{|c|}{$60 \%$} & \multicolumn{2}{|c|}{$70 \%$} & \multicolumn{2}{|c|}{$80 \%$} & \multicolumn{2}{|c|}{$90 \%$} \\
\hline 100-0-0 & $\mathrm{R} \$$ & 923 & $\mathrm{R} \$$ & 791 & $\mathrm{R} \$$ & 692 & $\mathrm{R} \$$ & 615 \\
\hline 0-100-0 & $\mathrm{R} \$$ & 925 & $\mathrm{R} \$$ & 793 & $\mathrm{R} \$$ & 694 & $\mathrm{R} \$$ & 617 \\
\hline 0-0-100 & $\mathrm{R} \$$ & 832 & $\mathrm{R} \$$ & 713 & $\mathrm{R} \$$ & 624 & $\mathrm{R} \$$ & 554 \\
\hline $70-30-0$ & $\mathrm{R} \$$ & 923 & $\mathrm{R} \$$ & 791 & $\mathrm{R} \$$ & 692 & $\mathrm{R} \$$ & 616 \\
\hline $70-0-30$ & $\mathrm{R} \$$ & 896 & $\mathrm{R} \$$ & 768 & $\mathrm{R} \$$ & 672 & $\mathrm{R} \$$ & 597 \\
\hline $50-40-10$ & $\mathrm{R} \$$ & 915 & $\mathrm{R} \$$ & 784 & $\mathrm{R} \$$ & 686 & $\mathrm{R} \$$ & 610 \\
\hline $60-30-10$ & $\mathrm{R} \$$ & 914 & $\mathrm{R} \$$ & 783 & $\mathrm{R} \$$ & 685 & $\mathrm{R} \$$ & 609 \\
\hline
\end{tabular}


Apêndice 89 - Crédito médio de 1,20\% sobre o valor do investimento, por mensalidade, para construção em 90 dias e compensação de retorno em 24 meses, com simulação do nível de utilização da capacidade instalada, para 100 residentes

\begin{tabular}{|c|c|c|c|c|c|c|c|c|}
\hline \multirow[t]{2}{*}{$\begin{array}{l}\text { Porcentagem de } \\
\text { residentes com } \\
\text { grau de } \\
\text { dependência } \\
\text { I, II e III }\end{array}$} & \multicolumn{8}{|c|}{$\begin{array}{l}\text { Crédito médio de } 1,20 \% \text { sobre o valor do investimento, por } \\
\text { mensalidade, com simulação do nível de utilização da } \\
\text { capacidade instalada, para } 100 \text { residentes, com diversos graus } \\
\text { de dependência }\end{array}$} \\
\hline & \multicolumn{2}{|c|}{$60 \%$} & \multicolumn{2}{|c|}{$70 \%$} & \multicolumn{2}{|c|}{$80 \%$} & \multicolumn{2}{|c|}{$90 \%$} \\
\hline 100-0-0 & $\mathrm{R} \$$ & 1.089 & $\mathrm{R} \$$ & 933 & $\mathrm{R} \$$ & 817 & $\mathrm{R} \$$ & 726 \\
\hline $0-100-0$ & $\mathrm{R} \$$ & 1.090 & $\mathrm{R} \$$ & 934 & $\mathrm{R}$ & 817 & RS & 726 \\
\hline $0-0-100$ & $\mathrm{R} \$$ & 978 & $\mathrm{R} \$$ & 839 & $\mathrm{R} \$$ & 734 & $\mathrm{R} \$$ & 652 \\
\hline $70-30-0$ & $\mathrm{R} \$$ & 1.089 & $\mathrm{R} \$$ & 934 & $\mathrm{R} \$$ & 817 & & 726 \\
\hline $70-0-30$ & $\mathrm{R} \$$ & 1.062 & $\mathrm{R} \$$ & 911 & $\mathrm{R} \$$ & 797 & $\mathrm{R} \$$ & 708 \\
\hline $50-40-10$ & $\mathrm{R} \$$ & 1.082 & $\mathrm{R} \$$ & 927 & $\mathrm{~K}$ & 811 & $\mathrm{R} \$$ & 721 \\
\hline $60-30-10$ & $\mathrm{R} \$$ & 1.082 & $\mathrm{R} \$$ & 927 & $\mathrm{R} \$$ & 811 & $\mathrm{R} \$$ & 721 \\
\hline
\end{tabular}

Apêndice 90 - Crédito médio de 1,20\% sobre o valor do investimento, por mensalidade, para construção em 90 dias e compensação de retorno em 24 meses, com simulação do nível de utilização da capacidade instalada, para 200 residentes

\begin{tabular}{|c|c|c|c|c|c|c|c|c|}
\hline \multirow[t]{2}{*}{$\begin{array}{c}\text { Porcentagem de } \\
\text { residentes com } \\
\text { grau de } \\
\text { dependência } \\
\text { I, II e III }\end{array}$} & \multicolumn{8}{|c|}{$\begin{array}{l}\text { Crédito médio de } 1,20 \% \text { sobre o valor do investimento, por } \\
\text { mensalidade, com simulação do nível de utilização da } \\
\text { capacidade instalada, para } 200 \text { residentes, com diversos graus } \\
\text { de dependência }\end{array}$} \\
\hline & \multicolumn{2}{|c|}{$60 \%$} & \multicolumn{2}{|c|}{$70 \%$} & \multicolumn{2}{|c|}{$80 \%$} & \multicolumn{2}{|c|}{ 90\% } \\
\hline 100-0-0 & $\mathrm{R} \$$ & 1.102 & $\mathrm{R} \$$ & 944 & $\mathrm{R} \$$ & 826 & $\mathrm{R} \$$ & 734 \\
\hline $0-100-0$ & $\mathrm{R} \$$ & 1.104 & $\mathrm{R} \$$ & 946 & $\mathrm{R} \$$ & 828 & $\mathrm{R} \$$ & 736 \\
\hline $0-0-100$ & $\mathrm{R} \$$ & 995 & $\mathrm{R} \$$ & 853 & $\mathrm{R} \$$ & 746 & $\mathrm{R} \$$ & 663 \\
\hline $70-30-0$ & $\mathrm{R} \$$ & 1.102 & $\mathrm{R} \$$ & 944 & $\mathrm{R} \$$ & 826 & R & 735 \\
\hline 70-0-30 & $\mathrm{R} \$$ & 1.071 & $\mathrm{R} \$$ & 918 & $R_{S}$ & 803 & p & 714 \\
\hline $50-40-10$ & $\mathrm{R} \$$ & 1.089 & $\mathrm{R} \$$ & 933 & $\mathrm{R} \$$ & 817 & $\mathrm{R} \$$ & 726 \\
\hline $60-30-10$ & $\mathrm{R} \$$ & 1.089 & $\mathrm{R} \$$ & 933 & $\mathrm{R} \$$ & 817 & $\mathrm{R} \$$ & 726 \\
\hline
\end{tabular}

Apêndice 91 - Crédito médio de 1,20\% sobre o valor do investimento, por mensalidade, para construção em 90 dias e compensação de retorno em 24 meses, com simulação do nível de utilização da capacidade instalada, para 300 residentes

\begin{tabular}{|c|c|c|c|c|c|c|c|c|}
\hline \multirow[t]{2}{*}{$\begin{array}{l}\text { Porcentagem de } \\
\text { residentes com } \\
\text { grau de } \\
\text { dependência } \\
\text { I, II e III }\end{array}$} & \multicolumn{8}{|c|}{$\begin{array}{c}\text { Crédito médio de } 1,20 \% \text { sobre o valor do investimento, por } \\
\text { mensalidade, com simulação do nível de utilização da } \\
\text { capacidade instalada, para } 300 \text { residentes, com diversos graus } \\
\text { de dependência }\end{array}$} \\
\hline & \multicolumn{2}{|c|}{$60 \%$} & \multicolumn{2}{|c|}{$70 \%$} & \multicolumn{2}{|c|}{$80 \%$} & \multicolumn{2}{|c|}{ 90\% } \\
\hline 100-0-0 & $\mathrm{R} \$$ & 1.025 & $\mathrm{R} \$$ & 878 & $\mathrm{R} \$$ & 769 & $\mathrm{R} \$$ & 683 \\
\hline $0-100-0$ & $\mathrm{R} \$$ & 1.027 & $\mathrm{R} \$$ & 880 & $\mathrm{R} \$$ & 770 & $\mathrm{R} \$$ & 685 \\
\hline $0-0-100$ & $\mathrm{R} \$$ & 925 & $\mathrm{R} \$$ & 793 & $\mathrm{R} \$$ & 694 & $\mathrm{R} \$$ & 617 \\
\hline $70-30-0$ & $\mathrm{R} \$$ & 1.026 & $\mathrm{R} \$$ & 879 & $\mathrm{R} \$$ & 769 & $\mathrm{R} \$$ & 684 \\
\hline 70-0-30 & $\mathrm{R} \$$ & 997 & $\mathrm{R} \$$ & 855 & $\mathrm{R}$ & 748 & $\mathrm{R} \$$ & 665 \\
\hline $50-40-10$ & $\mathrm{R} \$$ & 1.017 & $\mathrm{R} \$$ & 872 & R\$ & 763 & N & 678 \\
\hline $60-30-10$ & $\mathrm{R} \$$ & 1.017 & $\mathrm{R} \$$ & 872 & $\mathrm{R} \$$ & 763 & $\mathrm{R} \$$ & 678 \\
\hline
\end{tabular}


Apêndice 92 - Crédito médio de 1,20\% sobre o valor do investimento, por mensalidade, para construção em 90 dias e compensação de retorno em 24 meses, com simulação do nível de utilização da capacidade instalada, para 400 residentes

\begin{tabular}{|c|c|c|c|c|c|c|c|c|}
\hline \multirow{3}{*}{$\begin{array}{c}\text { Porcentagem de } \\
\text { residentes com } \\
\text { grau de } \\
\text { dependência } \\
\text { I, II e III } \\
100-0-0\end{array}$} & \multicolumn{8}{|c|}{$\begin{array}{l}\text { Crédito médio de } 1,20 \% \text { sobre o valor do investimento, por } \\
\text { mensalidade, com simulação do nível de utilização da } \\
\text { capacidade instalada, para } 400 \text { residentes, com diversos graus } \\
\text { de dependência }\end{array}$} \\
\hline & \multicolumn{2}{|c|}{$60 \%$} & \multicolumn{2}{|c|}{$70 \%$} & \multicolumn{2}{|c|}{$80 \%$} & \multicolumn{2}{|c|}{$90 \%$} \\
\hline & $\mathrm{R} \$$ & 1.007 & $\mathrm{R} \$$ & 863 & $\mathrm{R} \$$ & 755 & $\mathrm{R} \$$ & 671 \\
\hline $0-100-0$ & $\mathrm{R} \$$ & 1.009 & $\mathrm{R} \$$ & 865 & $\mathrm{R} \$$ & 757 & $\mathrm{R} \$$ & 673 \\
\hline $0-0-100$ & $\mathrm{R} \$$ & 907 & $\mathrm{R} \$$ & 778 & $\mathrm{R} \$$ & 680 & $\mathrm{R} \$$ & 605 \\
\hline $70-30-0$ & $\mathrm{R} \$$ & 1.007 & $\mathrm{R} \$$ & 863 & $\mathrm{R} \$$ & 755 & $\mathrm{R} \$$ & 671 \\
\hline $70-0-30$ & $\mathrm{R} \$$ & 977 & $\mathrm{R} \$$ & 838 & $\mathrm{R} \$$ & 733 & $\mathrm{R} \$$ & 652 \\
\hline $50-40-10$ & $\mathrm{R} \$$ & 998 & $\mathrm{R} \$$ & 855 & $\mathrm{R} \$$ & 748 & $\mathrm{R} \$$ & 665 \\
\hline $60-30-10$ & $\mathrm{R} \$$ & 997 & $\mathrm{R} \$$ & 855 & $\mathrm{R} \$$ & 748 & $\mathrm{R} \$$ & 665 \\
\hline
\end{tabular}

Apêndice 93 - Crédito médio de 1,30\% sobre o valor do investimento, por mensalidade, para construção em 90 dias e compensação de retorno em 24 meses, com simulação do nível de utilização da capacidade instalada, para 100 residentes

\begin{tabular}{|c|c|c|c|c|c|c|c|c|}
\hline \multirow[t]{2}{*}{$\begin{array}{c}\text { Porcentagem de } \\
\text { residentes com } \\
\text { grau de } \\
\text { dependência } \\
\text { I, II e III }\end{array}$} & \multicolumn{8}{|c|}{$\begin{array}{l}\text { Crédito médio de } 1,30 \% \text { sobre o valor do investimento, por } \\
\text { mensalidade, com simulação do nível de utilização da } \\
\text { capacidade instalada, para } 100 \text { residentes, com diversos graus } \\
\text { de dependência }\end{array}$} \\
\hline & \multicolumn{2}{|c|}{$60 \%$} & \multicolumn{2}{|c|}{$70 \%$} & \multicolumn{2}{|c|}{$80 \%$} & \multicolumn{2}{|c|}{ 90\% } \\
\hline 100-0-0 & $\mathrm{R} \$$ & 1.179 & $\mathrm{R} \$$ & 1.011 & $\mathrm{R} \$$ & 885 & $\mathrm{R} \$$ & 786 \\
\hline $0-100-0$ & $\mathrm{R} \$$ & 1.180 & $\mathrm{R} \$$ & 1.012 & $\mathrm{R}$ & 885 & $\mathrm{R} \$$ & 787 \\
\hline $0-0-100$ & $\mathrm{R} \$$ & 1.060 & $\mathrm{R} \$$ & 908 & $\mathrm{R} \$$ & 795 & $\mathrm{R} \$$ & 707 \\
\hline $70-30-0$ & $\mathrm{R} \$$ & 1.180 & $\mathrm{R} \$$ & 1.011 & R\$ & 885 & R & 787 \\
\hline 70-0-30 & $\mathrm{R} \$$ & 1.151 & $\mathrm{R} \$$ & 987 & $\mathrm{R}$ & 863 & $\mathrm{R} \$$ & 767 \\
\hline $50-40-10$ & $\mathrm{R} \$$ & 1.172 & $\mathrm{R} \$$ & 1.005 & R\$ & 879 & $\mathrm{R} \$$ & 781 \\
\hline $60-30-10$ & $\mathrm{R} \$$ & 1.172 & $\mathrm{R} \$$ & 1.004 & $\mathrm{R} \$$ & 879 & $\mathrm{R} \$$ & 781 \\
\hline
\end{tabular}

Apêndice 94 - Crédito médio de 1,30\% sobre o valor do investimento, por mensalidade, para construção em 90 dias e compensação de retorno em 24 meses, com simulação do nível de utilização da capacidade instalada, para 200 residentes

\begin{tabular}{|c|c|c|c|c|c|c|c|c|}
\hline \multirow[t]{2}{*}{$\begin{array}{l}\text { Porcentagem de } \\
\text { residentes com } \\
\text { grau de } \\
\text { dependência } \\
\text { I, II e III }\end{array}$} & \multicolumn{8}{|c|}{$\begin{array}{l}\text { Crédito médio de } 1,30 \% \text { sobre o valor do investimento, por } \\
\text { mensalidade, com simulação do nível de utilização da } \\
\text { capacidade instalada, para } 200 \text { residentes, com diversos graus } \\
\text { de dependência }\end{array}$} \\
\hline & \multicolumn{2}{|c|}{$60 \%$} & \multicolumn{2}{|c|}{$70 \%$} & \multicolumn{2}{|c|}{$80 \%$} & \multicolumn{2}{|c|}{$90 \%$} \\
\hline 100-0-0 & $\mathrm{R} \$$ & 1.193 & $\mathrm{R} \$$ & 1.023 & $\mathrm{R} \$$ & 895 & $\mathrm{R} \$$ & 796 \\
\hline $0-100-0$ & $\mathrm{R} \$$ & 1.196 & $\mathrm{R} \$$ & 1.025 & $\mathrm{R} \$$ & 897 & R & 797 \\
\hline $0-0-100$ & $\mathrm{R} \$$ & 1.078 & $\mathrm{R} \$$ & 924 & $\mathrm{R}$ & 808 & $R$ & 718 \\
\hline $70-30-0$ & $\mathrm{R} \$$ & 1.194 & $\mathrm{R} \$$ & 1.023 & $\mathrm{R} \$$ & 895 & & 796 \\
\hline 70-0-30 & $\mathrm{R} \$$ & 1.160 & $\mathrm{R} \$$ & 994 & $\mathrm{R} \$$ & 870 & & 773 \\
\hline 50 & $\mathrm{R} \$$ & 1.180 & $\mathrm{R} \$$ & 1.011 & $\mathrm{R} \$$ & 885 & & 786 \\
\hline $60-30-10$ & $\mathrm{R} \$$ & 1.179 & $\mathrm{R} \$$ & 1.011 & $\mathrm{R} \$$ & 885 & $\mathrm{R} \$$ & 786 \\
\hline
\end{tabular}


Apêndice 95 - Crédito médio de 1,30\% sobre o valor do investimento, por mensalidade, para construção em 90 dias e compensação de retorno em 24 meses, com simulação do nível de utilização da capacidade instalada, para 300 residentes

\begin{tabular}{|c|c|c|c|c|c|c|c|c|}
\hline \multirow{3}{*}{$\begin{array}{c}\text { Porcentagem de } \\
\text { residentes com } \\
\text { grau de } \\
\text { dependência } \\
\text { I, II e III } \\
100-0-0\end{array}$} & \multicolumn{8}{|c|}{$\begin{array}{c}\text { Crédito médio de } 1,30 \% \text { sobre o valor do investimento, por } \\
\text { mensalidade, com simulação do nível de utilização da } \\
\text { capacidade instalada, para } 300 \text { residentes, com diversos graus } \\
\text { de dependência } \\
\end{array}$} \\
\hline & \multicolumn{2}{|c|}{$60 \%$} & \multicolumn{2}{|c|}{$70 \%$} & \multicolumn{2}{|c|}{$80 \%$} & \multicolumn{2}{|c|}{$90 \%$} \\
\hline & $\mathrm{R} \$$ & 1.110 & $\mathrm{R} \$$ & 952 & $\mathrm{R} \$$ & 833 & $\mathrm{R} \$$ & 740 \\
\hline $0-100-0$ & $\mathrm{R} \$$ & 1.113 & $\mathrm{R} \$$ & 954 & $\mathrm{R} \$$ & 835 & $\mathrm{R} \$$ & 742 \\
\hline 0-0-100 & $\mathrm{R} \$$ & 1.002 & $\mathrm{R} \$$ & 859 & $\mathrm{R} \$$ & 752 & $\mathrm{R} \$$ & 668 \\
\hline 70-30-0 & $\mathrm{R} \$$ & 1.111 & $\mathrm{R} \$$ & 953 & $\mathrm{R} \$$ & 833 & $\mathrm{R} \$$ & 741 \\
\hline 70-0-30 & $\mathrm{R} \$$ & 1.080 & $\mathrm{R} \$$ & 926 & $\mathrm{R} \$$ & 810 & $\mathrm{R} \$$ & 720 \\
\hline $50-40-10$ & $\mathrm{R} \$$ & 1.102 & $\mathrm{R} \$$ & 945 & $\mathrm{R} \$$ & 827 & $\mathrm{R} \$$ & 735 \\
\hline $60-30-10$ & $\mathrm{R} \$$ & 1.102 & $\mathrm{R} \$$ & 945 & $\mathrm{R} \$$ & 827 & $\mathrm{R} \$$ & 735 \\
\hline
\end{tabular}

Apêndice 96 - Crédito médio de 1,30\% sobre o valor do investimento, por mensalidade, para construção em 90 dias e compensação de retorno em 24 meses, com simulação do nível de utilização da capacidade instalada, para 400 residentes

\begin{tabular}{|c|c|c|c|c|c|c|c|c|}
\hline \multirow{2}{*}{$\begin{array}{c}\text { Porcentagem de } \\
\text { residentes com } \\
\text { grau de } \\
\text { dependência } \\
\text { I, II e III } \\
\end{array}$} & \multicolumn{8}{|c|}{$\begin{array}{l}\text { Crédito médio de } 1,30 \% \text { sobre o valor do investimento, por } \\
\text { mensalidade, com simulação do nível de utilização da } \\
\text { capacidade instalada, para } 400 \text { residentes, com diversos graus } \\
\text { de dependência }\end{array}$} \\
\hline & \multicolumn{2}{|c|}{$60 \%$} & \multicolumn{2}{|c|}{$70 \%$} & \multicolumn{2}{|c|}{$80 \%$} & \multicolumn{2}{|c|}{$90 \%$} \\
\hline $100-0-0$ & $\mathrm{R} \$$ & 1.091 & $\mathrm{R} \$$ & 935 & $\mathrm{R} \$$ & 818 & $\mathrm{R} \$$ & 727 \\
\hline 0-100-0 & $\mathrm{R} \$$ & 1.093 & $\mathrm{R} \$$ & 937 & $\mathrm{R}$ & 820 & $\mathrm{R} \$$ & 729 \\
\hline $0-0-100$ & $\mathrm{R} \$$ & 983 & $\mathrm{R} \$$ & 843 & $\mathrm{R} \$$ & 737 & $\mathrm{R} \$$ & 655 \\
\hline $70-30-0$ & $\mathrm{R} \$$ & 1.091 & $\mathrm{R} \$$ & 935 & $\mathrm{R} \$$ & 818 & $\mathrm{R} \$$ & 727 \\
\hline $70-0-30$ & $\mathrm{R} \$$ & 1.059 & $\mathrm{R} \$$ & 908 & $\mathrm{R}$ & 794 & K\$ & 706 \\
\hline $50-40-10$ & $\mathrm{R} \$$ & 1.081 & $\mathrm{R} \$$ & 926 & $\mathrm{R} \$$ & 811 & $\mathrm{R} \$$ & 721 \\
\hline $60-30-10$ & $\mathrm{R} \$$ & 1.080 & $\mathrm{R} \$$ & 926 & $\mathrm{R} \$$ & 810 & $\mathrm{R} \$$ & 720 \\
\hline
\end{tabular}

Apêndice 97 - Crédito médio de 1,40\% sobre o valor do investimento, por mensalidade, para construção em 90 dias e compensação de retorno em 24 meses, com simulação do nível de utilização da capacidade instalada, para 100 residentes

\begin{tabular}{|c|c|c|c|c|c|c|c|c|}
\hline \multirow{2}{*}{$\begin{array}{c}\text { Porcentagem de } \\
\text { residentes com } \\
\text { grau de } \\
\text { dependência } \\
\text { I, II e III }\end{array}$} & \multicolumn{8}{|c|}{$\begin{array}{l}\text { Crédito médio de } 1,40 \% \text { sobre o valor do investimento, por } \\
\text { mensalidade, com simulação do nível de utilização da } \\
\text { capacidade instalada, para } 100 \text { residentes, com diversos graus } \\
\text { de dependência }\end{array}$} \\
\hline & \multicolumn{2}{|c|}{$60 \%$} & \multicolumn{2}{|c|}{$70 \%$} & \multicolumn{2}{|c|}{$80 \%$} & \multicolumn{2}{|c|}{ 90\% } \\
\hline 100-0-0 & $\mathrm{R} \$$ & 1.270 & $\mathrm{R} \$$ & 1.089 & $\mathrm{R} \$$ & 953 & $\mathrm{R} \$$ & 847 \\
\hline $0-100-0$ & $\mathrm{R} \$$ & 1.271 & $\mathrm{R} \$$ & 1.090 & $\mathrm{R} \$$ & 953 & $\mathrm{R} \$$ & 847 \\
\hline $0-0-100$ & $\mathrm{R} \$$ & 1.141 & $\mathrm{R} \$$ & 978 & $\mathrm{R} \$$ & 856 & $\mathrm{R} \$$ & 761 \\
\hline $70-30-0$ & $\mathrm{R} \$$ & 1.271 & $\mathrm{R} \$$ & 1.089 & $\mathrm{R} \$$ & 953 & $\mathrm{R} \$$ & 847 \\
\hline 70-0-30 & $\mathrm{R} \$$ & 1.240 & $\mathrm{R} \$$ & 1.062 & $\$$ & 930 & $\mathrm{R} \$$ & 826 \\
\hline 50 & $\mathrm{R} \$$ & 1.262 & $\mathrm{R} \$$ & 1.082 & R\$ & 947 & $\mathrm{R} \$$ & 841 \\
\hline $60-30-10$ & $\mathrm{R} \$$ & 1.262 & $\mathrm{R} \$$ & 1.082 & $\mathrm{R} \$$ & 946 & $\mathrm{R} \$$ & 841 \\
\hline
\end{tabular}


Apêndice 98 - Crédito médio de 1,40\% sobre o valor do investimento, por mensalidade, para construção em 90 dias e compensação de retorno em 24 meses, com simulação do nível de utilização da capacidade instalada, para 200 residentes

\begin{tabular}{|c|c|c|c|c|c|c|c|c|}
\hline \multirow{3}{*}{$\begin{array}{c}\text { Porcentagem de } \\
\text { residentes com } \\
\text { grau de } \\
\text { dependência } \\
\text { I, II e III } \\
100-0-0\end{array}$} & \multicolumn{8}{|c|}{$\begin{array}{c}\text { Crédito médio de } 1,40 \% \text { sobre o valor do investimento, por } \\
\text { mensalidade, com simulação do nível de utilização da } \\
\text { capacidade instalada, para } 200 \text { residentes, com diversos graus } \\
\text { de dependência } \\
\end{array}$} \\
\hline & \multicolumn{2}{|c|}{$60 \%$} & \multicolumn{2}{|c|}{$70 \%$} & \multicolumn{2}{|c|}{$80 \%$} & \multicolumn{2}{|c|}{$90 \%$} \\
\hline & $\mathrm{R} \$$ & 1.285 & $\mathrm{R} \$$ & 1.102 & $\mathrm{R} \$$ & 964 & $\mathrm{R} \$$ & 857 \\
\hline $0-100-0$ & $\mathrm{R} \$$ & 1.288 & $\mathrm{R} \$$ & 1.104 & $\mathrm{~K}$ & 966 & $\mathrm{R} \$$ & 858 \\
\hline 0-0-100 & $\mathrm{R} \$$ & 1.160 & $\mathrm{R} \$$ & 995 & $\mathrm{~K}$ & 870 & $\mathrm{R} \$$ & 774 \\
\hline 70-30-0 & $\mathrm{R} \$$ & 1.286 & $\mathrm{R} \$$ & 1.102 & $\mathrm{R}$ & 964 & $\mathrm{R} \$$ & 857 \\
\hline 70-0-30 & $\mathrm{R} \$$ & 249 & $\mathrm{R} \$$ & 1.071 & $\mathrm{R}$ & 937 & $\mathrm{R} \$$ & 833 \\
\hline $50-40-10$ & $\mathrm{R} \$$ & 1.270 & $\mathrm{R} \$$ & 1.089 & $\mathrm{R} \$$ & 953 & $\mathrm{R} \$$ & 847 \\
\hline $60-30-10$ & $\mathrm{R} \$$ & 1.270 & $\mathrm{R} \$$ & 1.089 & $\mathrm{R} \$$ & 953 & $\mathrm{R} \$$ & 847 \\
\hline
\end{tabular}

Apêndice 99 - Crédito médio de 1,40\% sobre o valor do investimento, por mensalidade, para construção em 90 dias e compensação de retorno em 24 meses, com simulação do nível de utilização da capacidade instalada, para 300 residentes

\begin{tabular}{|c|c|c|c|c|c|c|c|c|}
\hline \multirow{2}{*}{$\begin{array}{c}\text { Porcentagem de } \\
\text { residentes com } \\
\text { grau de } \\
\text { dependência } \\
\text { I, II e III } \\
\end{array}$} & \multicolumn{8}{|c|}{$\begin{array}{l}\text { Crédito médio de } 1,40 \% \text { sobre o valor do investimento, por } \\
\text { mensalidade, com simulação do nível de utilização da } \\
\text { capacidade instalada, para } 300 \text { residentes, com diversos graus } \\
\text { de dependência }\end{array}$} \\
\hline & \multicolumn{2}{|c|}{$60 \%$} & \multicolumn{2}{|c|}{$70 \%$} & \multicolumn{2}{|c|}{$80 \%$} & \multicolumn{2}{|c|}{$90 \%$} \\
\hline $100-0-0$ & $\mathrm{R} \$$ & 1.196 & $\mathrm{R} \$$ & 1.025 & $\mathrm{R} \$$ & 897 & $\mathrm{R} \$$ & 797 \\
\hline 0-100-0 & $\mathrm{R} \$$ & 1.198 & $\mathrm{R} \$$ & 1.027 & $\mathrm{R} \$$ & 899 & $\mathrm{R} \$$ & 799 \\
\hline $0-0-100$ & $\mathrm{R} \$$ & 1.080 & $\mathrm{R} \$$ & 925 & $\mathrm{R} \$$ & 810 & $\mathrm{R} \$$ & 720 \\
\hline $70-30-0$ & $\mathrm{R} \$$ & 1.197 & $\mathrm{R} \$$ & 1.026 & $\mathrm{R}$ & 898 & $\mathrm{R} \$$ & 798 \\
\hline $70-0-30$ & $\mathrm{R} \$$ & 163 & $\mathrm{R} \$$ & 997 & $\mathrm{~K}$ & 872 & K\$ & 776 \\
\hline $50-40-10$ & $\mathrm{R} \$$ & 1.187 & $\mathrm{R} \$$ & 1.017 & $\mathrm{R}$ & 890 & $\mathrm{R} \$$ & 791 \\
\hline $60-30-10$ & $\mathrm{R} \$$ & 1.187 & $\mathrm{R} \$$ & 1.017 & $\mathrm{R} \$$ & 890 & $\mathrm{R} \$$ & 791 \\
\hline
\end{tabular}

Apêndice 100 - Crédito médio de 1,40\% sobre o valor do investimento, por mensalidade, para construção em 90 dias e compensação de retorno em 24 meses, com simulação do nível de utilização da capacidade instalada, para 400 residentes

\begin{tabular}{|c|c|c|c|c|c|c|c|c|}
\hline \multirow[t]{2}{*}{$\begin{array}{l}\text { Porcentagem de } \\
\text { residentes com } \\
\text { grau de } \\
\text { dependência } \\
\text { I, II e III }\end{array}$} & \multicolumn{8}{|c|}{$\begin{array}{c}\text { Crédito médio de } 1,40 \% \text { sobre o valor do investimento, por } \\
\text { mensalidade, com simulação do nível de utilização da } \\
\text { capacidade instalada, para } 400 \text { residentes, com diversos graus } \\
\text { de dependência }\end{array}$} \\
\hline & \multicolumn{2}{|c|}{$60 \%$} & \multicolumn{2}{|c|}{$70 \%$} & \multicolumn{2}{|c|}{$80 \%$} & \multicolumn{2}{|c|}{$90 \%$} \\
\hline 100-0-0 & $\mathrm{R} \$$ & 1.175 & $\mathrm{R} \$$ & 1.007 & $\mathrm{R} \$$ & 881 & $\mathrm{R} \$$ & 783 \\
\hline $0-100-0$ & $\mathrm{R} \$$ & 1.177 & $\mathrm{R} \$$ & 1.009 & $\mathrm{R} \$$ & 883 & $\mathrm{R} \$$ & 785 \\
\hline $0-0-100$ & $\mathrm{R} \$$ & 1.059 & $\mathrm{R} \$$ & 907 & $\mathrm{R} \$$ & 794 & $\mathrm{R} \$$ & 706 \\
\hline $70-30-0$ & $\mathrm{R} \$$ & 1.175 & $\mathrm{R} \$$ & 1.007 & $\mathrm{R} \$$ & 881 & $\hat{\delta}$ & 783 \\
\hline 70-0-30 & $\mathrm{R} \$$ & 1.140 & $\mathrm{R} \$$ & 977 & $\mathrm{R}$ & 855 & $\mathrm{R} \$$ & 760 \\
\hline $50-41$ & $\mathrm{R} \$$ & 1.164 & $\mathrm{R} \$$ & 998 & $\mathrm{R}$ & 873 & $\mathbf{N}$ & 776 \\
\hline $60-30-10$ & $\mathrm{R} \$$ & 1.163 & $\mathrm{R} \$$ & 997 & $\mathrm{R} \$$ & 872 & $\mathrm{R} \$$ & 775 \\
\hline
\end{tabular}


Apêndice 101 - Crédito médio de 1,50\% sobre o valor do investimento, por mensalidade, para construção em 90 dias e compensação de retorno em 24 meses, com simulação do nível de utilização da capacidade instalada, para 100 residentes

\begin{tabular}{|c|c|c|c|c|c|c|c|c|}
\hline \multirow[t]{2}{*}{$\begin{array}{l}\text { Porcentagem de } \\
\text { residentes com } \\
\text { grau de } \\
\text { dependência } \\
\text { I, II e III }\end{array}$} & \multicolumn{8}{|c|}{$\begin{array}{l}\text { Crédito médio de } 1,50 \% \text { sobre o valor do investimento, por } \\
\text { mensalidade, com simulação do nível de utilização da } \\
\text { capacidade instalada, para } 100 \text { residentes, com diversos graus } \\
\text { de dependência }\end{array}$} \\
\hline & \multicolumn{2}{|c|}{$60 \%$} & \multicolumn{2}{|c|}{$70 \%$} & \multicolumn{2}{|c|}{$80 \%$} & \multicolumn{2}{|c|}{$90 \%$} \\
\hline 100-0-0 & $\mathrm{R} \$$ & 1.361 & $\$$ & 1.167 & $\mathrm{R} \$$ & 1.021 & $\mathrm{R} \$$ & 907 \\
\hline $0-100-0$ & $\mathrm{R} \$$ & 1.362 & K\$ & 1.167 & $\mathrm{R} \$$ & 1.021 & $\mathrm{R} \$$ & 908 \\
\hline $0-0-100$ & $\mathrm{R} \$$ & 1.223 & $\mathrm{R} \$$ & 1.048 & $\mathrm{R} \$$ & 917 & $\mathrm{R} \$$ & 815 \\
\hline $70-30-0$ & $\mathrm{R} \$$ & 1.361 & $\mathrm{R} \$$ & 1.167 & $\mathrm{R} \$$ & 1.021 & $D T$ & 908 \\
\hline $70-0-30$ & $\mathrm{R} \$$ & 1.328 & $\mathrm{R} \$$ & 1.138 & $\mathrm{R} \$$ & 996 & $\mathrm{R} \$$ & 885 \\
\hline $50-40-10$ & $\mathrm{R} \$$ & 1.352 & $\mathrm{R} \$$ & 1.159 & $\mathrm{R} \$$ & 1.014 & $\mathrm{R} \$$ & 902 \\
\hline $60-30-10$ & $\mathrm{R} \$$ & 1.352 & $\mathrm{R} \$$ & 1.159 & $\mathrm{R} \$$ & 1.014 & $\mathrm{R} \$$ & 901 \\
\hline
\end{tabular}

Apêndice 102 - Crédito médio de 1,50\% sobre o valor do investimento, por mensalidade, para construção em 90 dias e compensação de retorno em 24 meses, com simulação do nível de utilização da capacidade instalada, para 200 residentes

\begin{tabular}{|c|c|c|c|c|c|c|c|c|}
\hline \multirow{2}{*}{$\begin{array}{l}\text { Porcentagem de } \\
\text { residentes com } \\
\text { grau de } \\
\text { dependência } \\
\text { I, II e III }\end{array}$} & \multicolumn{8}{|c|}{$\begin{array}{l}\text { Crédito médio de } 1,50 \% \text { sobre o valor do investimento, por } \\
\text { mensalidade, com simulação do nível de utilização da } \\
\text { capacidade instalada, para } 200 \text { residentes, com diversos graus } \\
\text { de dependência }\end{array}$} \\
\hline & \multicolumn{2}{|c|}{$60 \%$} & \multicolumn{2}{|c|}{$70 \%$} & \multicolumn{2}{|c|}{$80 \%$} & \multicolumn{2}{|c|}{$90 \%$} \\
\hline 100-0-0 & $\mathrm{R} \$$ & 1.377 & $\mathrm{R} \$$ & 1.180 & $\mathrm{R} \$$ & 1.033 & $\mathrm{R} \$$ & 918 \\
\hline 0-100-0 & $\mathrm{R} \$$ & 1.380 & $\mathrm{R} \$$ & 1.182 & $\mathrm{R} \$$ & 1.035 & $\mathrm{R} \$$ & 920 \\
\hline $0-0-100$ & $\mathrm{R} \$$ & 1.243 & $\mathrm{R} \$$ & 1.066 & $\mathrm{R} \$$ & 933 & $\mathrm{R} \$$ & 829 \\
\hline $70-30-0$ & $\mathrm{R} \$$ & 1.377 & $\mathrm{R} \$$ & 1.181 & $\mathrm{R} \$$ & 1.033 & $\mathrm{R} \$$ & 918 \\
\hline $70-0-30$ & $\mathrm{R} \$$ & 1.338 & $\mathrm{R} \$$ & 1.147 & $\mathrm{R} \$$ & 1.004 & $\mathrm{R} \$$ & 892 \\
\hline $50-40-10$ & $\mathrm{R} \$$ & 1.361 & $\mathrm{R} \$$ & 1.167 & $\mathrm{R} \$$ & 1.021 & $\mathrm{R} \$$ & 907 \\
\hline $60-30-10$ & $\mathrm{R} \$$ & 1.361 & $\mathrm{R} \$$ & 1.166 & $\mathrm{R} \$$ & 1.021 & $\mathrm{R} \$$ & 907 \\
\hline
\end{tabular}

Apêndice 103 - Crédito médio de 1,50\% sobre o valor do investimento, por mensalidade, para construção em 90 dias e compensação de retorno em 24 meses, com simulação do nível de utilização da capacidade instalada, para 300 residentes

\begin{tabular}{|c|c|c|c|c|c|c|c|c|}
\hline \multirow[t]{2}{*}{$\begin{array}{l}\text { Porcentagem de } \\
\text { residentes com } \\
\text { grau de } \\
\text { dependência } \\
\text { I, II e III }\end{array}$} & \multicolumn{8}{|c|}{$\begin{array}{l}\text { Crédito médio de } 1,50 \% \text { sobre o valor do investimento, por } \\
\text { mensalidade, com simulação do nível de utilização da } \\
\text { capacidade instalada, para } 300 \text { residentes, com diversos graus } \\
\text { de dependência }\end{array}$} \\
\hline & \multicolumn{2}{|c|}{$60 \%$} & \multicolumn{2}{|c|}{$70 \%$} & \multicolumn{2}{|c|}{$80 \%$} & \multicolumn{2}{|c|}{$90 \%$} \\
\hline 100-0-0 & $\mathrm{R} \$$ & 1.281 & $\mathrm{R} \$$ & 1.098 & $\mathrm{R} \$$ & 961 & $\mathrm{R} \$$ & 854 \\
\hline 0-100-0 & $\mathrm{R} \$$ & 1.284 & $\mathrm{R} \$$ & 1.101 & $\mathrm{R} \$$ & 963 & $\mathrm{R} \$$ & 856 \\
\hline 0-0-100 & $\mathrm{R} \$$ & 1.157 & $\mathrm{R} \$$ & 991 & $\mathrm{R} \$$ & 867 & $\mathrm{R} \$$ & 771 \\
\hline $70-30-0$ & $\mathrm{R} \$$ & 1.282 & $\mathrm{R} \$$ & 1.099 & $\mathrm{R} \$$ & 962 & $\mathrm{R} \$$ & 855 \\
\hline $70-0-30$ & $\mathrm{R} \$$ & 1.246 & $\mathrm{R} \$$ & 1.068 & $\mathrm{R} \$$ & 935 & $\mathrm{R} \$$ & 831 \\
\hline $50-40-10$ & $\mathrm{R} \$$ & 1.272 & $\mathrm{R} \$$ & 1.090 & $\mathrm{R} \$$ & 954 & $\mathrm{R} \$$ & 848 \\
\hline $60-30-10$ & $\mathrm{R} \$$ & 1.272 & $\mathrm{R} \$$ & 1.090 & $\mathrm{R} \$$ & 954 & $\mathrm{R} \$$ & 848 \\
\hline
\end{tabular}


Apêndice 104 - Crédito médio de 1,50\% sobre o valor do investimento, por mensalidade, para construção em 90 dias e compensação de retorno em 24 meses, com simulação do nível de utilização da capacidade instalada, para 400 residentes

\begin{tabular}{|c|c|c|c|c|c|c|c|c|}
\hline \multirow{3}{*}{$\begin{array}{c}\text { Porcentagem de } \\
\text { residentes com } \\
\text { grau de } \\
\text { dependência } \\
\text { I, II e III } \\
100-0-0\end{array}$} & \multicolumn{8}{|c|}{$\begin{array}{l}\text { Crédito médio de } 1,50 \% \text { sobre o valor do investimento, por } \\
\text { mensalidade, com simulação do nível de utilização da } \\
\text { capacidade instalada, para } 400 \text { residentes, com diversos graus } \\
\text { de dependência }\end{array}$} \\
\hline & \multicolumn{2}{|c|}{$60 \%$} & \multicolumn{2}{|c|}{$70 \%$} & \multicolumn{2}{|c|}{$80 \%$} & \multicolumn{2}{|c|}{$90 \%$} \\
\hline & $\mathrm{R} \$$ & 1.259 & $\mathrm{R} \$$ & 1.079 & $\mathrm{R} \$$ & 944 & $\mathrm{R} \$$ & 839 \\
\hline $0-100-0$ & $\mathrm{R} \$$ & 1.261 & $\mathrm{R} \$$ & 1.081 & $\mathrm{R} \$$ & 946 & $\mathrm{R} \$$ & 841 \\
\hline $0-0-100$ & $\mathrm{R} \$$ & 1.134 & $\mathrm{R} \$$ & 972 & $\mathrm{R} \$$ & 851 & $\mathrm{R} \$$ & 756 \\
\hline 70-30-0 & $\mathrm{R} \$$ & 1.259 & $\mathrm{R} \$$ & 1.079 & $\mathrm{R} \$$ & 944 & $\mathrm{R} \$$ & 839 \\
\hline $70-0-30$ & $\mathrm{R} \$$ & 1.222 & $\mathrm{R} \$$ & 1.047 & $\mathrm{R} \$$ & 916 & $\mathrm{R} \$$ & 815 \\
\hline $50-40-10$ & $\mathrm{R} \$$ & 1.247 & $\mathrm{R} \$$ & 1.069 & $\mathrm{R} \$$ & 935 & $\mathrm{R} \$$ & 831 \\
\hline $60-30-10$ & $\mathrm{R} \$$ & 1.246 & $\mathrm{R} \$$ & 1.068 & $\mathrm{R} \$$ & 935 & $\mathrm{R} \$$ & 831 \\
\hline
\end{tabular}

Apêndice 105 - Crédito médio de 1,10\% sobre o valor do investimento, por mensalidade, para construção em 90 dias e compensação de retorno em 12 meses, com simulação da porcentagem de habitações destinadas a cadeirantes, para 100 residentes

\begin{tabular}{|c|c|c|c|c|c|c|c|c|c|c|}
\hline \multirow{2}{*}{$\begin{array}{l}\text { Porcentagem de } \\
\text { residentes com } \\
\text { grau de } \\
\text { dependência } \\
\text { I, II e III }\end{array}$} & \multicolumn{10}{|c|}{$\begin{array}{c}\text { Crédito médio de } 1,10 \% \text { sobre o valor do investimento, por mensalidade, com } \\
\text { simulação da porcentagem de habitações destinadas a cadeirantes, para } 100 \\
\text { residentes, com diversos graus de dependência }\end{array}$} \\
\hline & \multicolumn{2}{|c|}{$20 \%$} & \multicolumn{2}{|c|}{$40 \%$} & \multicolumn{2}{|c|}{$60 \%$} & \multicolumn{2}{|c|}{$80 \%$} & \multicolumn{2}{|c|}{$100 \%$} \\
\hline $100-0-0$ & $\mathrm{R} \$$ & 998 & $\mathrm{R} \$$ & 1.048 & $\mathrm{R} \$$ & 1.098 & $\mathrm{R} \$$ & 1.151 & $\mathrm{R} \$$ & 1.201 \\
\hline 0-100-0 & $\mathrm{R} \$$ & 999 & $\mathrm{R} \$$ & 1.049 & $\mathrm{R} \$$ & 1.101 & $\mathrm{R} \$$ & 1.152 & $\mathrm{R} \$$ & 1.202 \\
\hline 0-0-100 & $\mathrm{R} \$$ & 897 & $\mathrm{R} \$$ & 947 & $\mathrm{R} \$$ & 1.000 & $\mathrm{R} \$$ & 1.050 & $\mathrm{R} \$$ & 1.100 \\
\hline $70-30-0$ & $\mathrm{R} \$$ & 998 & $\mathrm{R} \$$ & 1.049 & $\mathrm{R} \$$ & 1.099 & $\mathrm{R} \$$ & 1.151 & $\mathrm{R} \$$ & 1.202 \\
\hline $70-0-30$ & $\mathrm{R} \$$ & 974 & $\mathrm{R} \$$ & 1.024 & $\mathrm{R} \$$ & 1.074 & $\mathrm{R} \$$ & 1.124 & $\mathrm{R} \$$ & 1.177 \\
\hline $50-40-10$ & $\mathrm{R} \$$ & 992 & $\mathrm{R} \$$ & 1.042 & $\mathrm{R} \$$ & 1.092 & $\mathrm{R} \$$ & 1.145 & $\mathrm{R} \$$ & 1.195 \\
\hline $60-30-10$ & $\mathrm{R} \$$ & 992 & $\mathrm{R} \$$ & 1.042 & $\mathrm{R} \$$ & 1.092 & $\mathrm{R} \$$ & 1.145 & $\mathrm{R} \$$ & 1.195 \\
\hline
\end{tabular}

Apêndice 106 - Crédito médio de 1,10\% sobre o valor do investimento, por mensalidade, para construção em 90 dias e compensação de retorno em 12 meses, com simulação da porcentagem de habitações destinadas a cadeirantes, para 200 residentes

\begin{tabular}{|c|c|c|c|c|c|c|c|c|c|c|}
\hline \multirow{2}{*}{$\begin{array}{l}\text { Porcentagem de } \\
\text { residentes com } \\
\text { grau de } \\
\text { dependência } \\
\text { I, II e III }\end{array}$} & \multicolumn{10}{|c|}{$\begin{array}{c}\text { Crédito médio de } 1,10 \% \text { sobre o valor do investimento, por mensalidade, com } \\
\text { simulação da porcentagem de habitações destinadas a cadeirantes, para } 200 \\
\text { residentes, com diversos graus de dependência }\end{array}$} \\
\hline & \multicolumn{2}{|c|}{$20 \%$} & \multicolumn{2}{|c|}{$40 \%$} & \multicolumn{2}{|c|}{$60 \%$} & \multicolumn{2}{|c|}{$80 \%$} & \multicolumn{2}{|c|}{$100 \%$} \\
\hline 100-0-0 & $\mathrm{R} \$$ & 1.010 & $\mathrm{R} \$$ & 1.060 & $\mathrm{R} \$$ & 1.111 & $\mathrm{R} \$$ & 1.163 & $\mathrm{R} \$$ & 1.213 \\
\hline 0-100-0 & $\mathrm{R} \$$ & 1.012 & $\mathrm{R} \$$ & 1.062 & $\mathrm{R} \$$ & 1.113 & K\$ & 1.165 & $\mathrm{R} \$$ & 1.215 \\
\hline 0-0-100 & $\mathrm{R} \$$ & 912 & $D T$ & 962 & $\mathrm{R} \$$ & 1.013 & & 1.065 & $\mathrm{R} \$$ & 1.115 \\
\hline $70-30-0$ & $\mathrm{R} \$$ & 1.010 & $\mathrm{R} \$$ & 1.061 & $\mathrm{R} \$$ & 1.111 & $\mathrm{R}$ & 1.163 & $\mathrm{R}$ & 1.213 \\
\hline $70-0-30$ & $\mathrm{R} \$$ & 981 & $\mathrm{R} \$$ & 1.033 & $\mathrm{R} \$$ & 1.083 & $\mathrm{R} \$$ & 1.134 & $\mathrm{R} \$$ & 1.184 \\
\hline $50-40-10$ & $\mathrm{R} \$$ & 998 & $\mathrm{R} \$$ & 1.050 & $\mathrm{R} \$$ & 1.100 & $\mathrm{R} \$$ & 1.151 & $\mathrm{R} \$$ & 1.202 \\
\hline $60-30-10$ & $\mathrm{R} \$$ & 998 & $\mathrm{R} \$$ & 1.049 & $\mathrm{R} \$$ & 1.099 & $\mathrm{R} \$$ & 1.151 & $\mathrm{R} \$$ & 1.202 \\
\hline
\end{tabular}


Apêndice 107 - Crédito médio de 1,10\% sobre o valor do investimento, por mensalidade, para construção em 90 dias e compensação de retorno em 12 meses, com simulação da porcentagem de habitações destinadas a cadeirantes, para 300 residentes

\begin{tabular}{|c|c|c|c|c|c|c|c|c|c|c|}
\hline \multirow{3}{*}{$\begin{array}{c}\text { Porcentagem de } \\
\text { residentes com } \\
\text { grau de } \\
\text { dependência } \\
\text { I, II e III } \\
100-0-0\end{array}$} & \multicolumn{10}{|c|}{$\begin{array}{c}\text { Crédito médio de } 1,10 \% \text { sobre o valor do investimento, por mensalidade, com } \\
\text { simulação da porcentagem de habitações destinadas a cadeirantes, para } 300 \\
\text { residentes, com diversos graus de dependência }\end{array}$} \\
\hline & \multicolumn{2}{|c|}{$20 \%$} & \multicolumn{2}{|c|}{$40 \%$} & \multicolumn{2}{|c|}{$60 \%$} & \multicolumn{2}{|c|}{$80 \%$} & \multicolumn{2}{|c|}{$100 \%$} \\
\hline & $\mathrm{R} \$$ & 939 & $\mathrm{R} \$$ & 988 & $\mathrm{R} \$$ & 1.038 & $\mathrm{R} \$$ & 1.087 & $\mathrm{R} \$$ & 1.136 \\
\hline $0-100-0$ & $\mathrm{R} \$$ & 942 & $\mathrm{R} \$$ & 991 & $\mathrm{R} \$$ & 1.039 & $\mathrm{R} \$$ & 1.088 & $\mathrm{R} \$$ & 1.137 \\
\hline $0-0-100$ & $\mathrm{R} \$$ & 848 & $\mathrm{R} \$$ & 897 & $\mathrm{R} \$$ & 946 & $\mathrm{R} \$$ & 995 & $\mathrm{R} \$$ & 1.044 \\
\hline $70-30-0$ & $\mathrm{R} \$$ & 940 & $\mathrm{R} \$$ & 990 & $\mathrm{R} \$$ & 1.038 & $\mathrm{R} \$$ & 1.087 & $\mathrm{R} \$$ & 1.136 \\
\hline $70-0-30$ & $\mathrm{R} \$$ & 914 & $\mathrm{R} \$$ & 963 & $\mathrm{R} \$$ & 1.012 & $\mathrm{R} \$$ & 1.061 & $\mathrm{R} \$$ & 1.110 \\
\hline $50-40-10$ & $\mathrm{R} \$$ & 933 & $\mathrm{R} \$$ & 982 & $\mathrm{R} \$$ & 1.031 & $\mathrm{R} \$$ & 1.080 & $\mathrm{R} \$$ & 1.129 \\
\hline $60-30-10$ & $\mathrm{R} \$$ & 933 & $\mathrm{R} \$$ & 982 & $\mathrm{R} \$$ & 1.030 & $\mathrm{R} \$$ & 1.079 & $\mathrm{R} \$$ & 1.128 \\
\hline
\end{tabular}

Apêndice 108 - Crédito médio de 1,10\% sobre o valor do investimento, por mensalidade, para construção em 90 dias e compensação de retorno em 12 meses, com simulação da porcentagem de habitações destinadas a cadeirantes, para 400 residentes

\begin{tabular}{|c|c|c|c|c|c|c|c|c|c|c|}
\hline \multirow{3}{*}{$\begin{array}{c}\text { Porcentagem de } \\
\text { residentes com } \\
\text { grau de } \\
\text { dependência } \\
\text { I, II e III } \\
100-0-0\end{array}$} & \multicolumn{10}{|c|}{$\begin{array}{c}\text { Crédito médio de } 1,10 \% \text { sobre o valor do investimento, por mensalidade, com } \\
\text { simulação da porcentagem de habitações destinadas a cadeirantes, para } 400 \\
\text { residentes, com diversos graus de dependência }\end{array}$} \\
\hline & \multicolumn{2}{|c|}{$20 \%$} & \multicolumn{2}{|c|}{$40 \%$} & \multicolumn{2}{|c|}{$60 \%$} & \multicolumn{2}{|c|}{$80 \%$} & \multicolumn{2}{|c|}{$100 \%$} \\
\hline & $\mathrm{R} \$$ & 923 & $\mathrm{R} \$$ & 972 & $\mathrm{R} \$$ & 1.021 & $\mathrm{R} \$$ & 1.071 & $\mathrm{R} \$$ & 1.120 \\
\hline $0-100-0$ & $\mathrm{R} \$$ & 925 & $\mathrm{R} \$$ & 974 & $\mathrm{R} \$$ & 1.023 & $\mathrm{R} \$$ & 1.073 & $\mathrm{R} \$$ & 1.122 \\
\hline $0-0-100$ & $\mathrm{R} \$$ & 832 & $\mathrm{R} \$$ & 881 & $\mathrm{R} \$$ & 930 & $\mathrm{R} \$$ & 978 & $\mathrm{R} \$$ & 1.027 \\
\hline $70-30-0$ & $\mathrm{R} \$$ & 923 & $\mathrm{R} \$$ & 973 & $\mathrm{R} \$$ & 1.022 & $\mathrm{R} \$$ & 1.071 & $\mathrm{R} \$$ & 1.119 \\
\hline $70-0-30$ & $\mathrm{R} \$$ & 896 & $\mathrm{R} \$$ & 945 & $\mathrm{R} \$$ & 994 & $\mathrm{R} \$$ & 1.043 & $\mathrm{R} \$$ & 1.092 \\
\hline $50-40-10$ & $\mathrm{R} \$$ & 915 & $\mathrm{R} \$$ & 963 & $\mathrm{R} \$$ & 1.012 & $\mathrm{R} \$$ & 1.061 & $\mathrm{R} \$$ & 1.110 \\
\hline $60-30-10$ & $\mathrm{R} \$$ & 914 & $\mathrm{R} \$$ & 963 & $\mathrm{R} \$$ & 1.012 & $\mathrm{R} \$$ & 1.061 & $\mathrm{R} \$$ & 1.110 \\
\hline
\end{tabular}

Apêndice 109 - Crédito médio de 1,20\% sobre o valor do investimento, por mensalidade, para construção em 90 dias e compensação de retorno em 12 meses, com simulação da porcentagem de habitações destinadas a cadeirantes, para 100 residentes

\begin{tabular}{|c|c|c|c|c|c|c|c|c|c|c|}
\hline \multirow{3}{*}{$\begin{array}{c}\text { Porcentagem de } \\
\text { residentes com } \\
\text { grau de } \\
\text { dependência } \\
\text { I, II e III } \\
100-0-0\end{array}$} & \multicolumn{10}{|c|}{$\begin{array}{c}\text { Crédito médio de } 1,20 \% \text { sobre o valor do investimento, por mensalidade, com } \\
\text { simulação da porcentagem de habitações destinadas a cadeirantes, para } 100 \\
\text { residentes, com diversos graus de dependência }\end{array}$} \\
\hline & \multicolumn{2}{|c|}{$20 \%$} & \multicolumn{2}{|c|}{$40 \%$} & \multicolumn{2}{|c|}{$60 \%$} & \multicolumn{2}{|c|}{$80 \%$} & \multicolumn{2}{|c|}{$100 \%$} \\
\hline & $\mathrm{R} \$$ & 1.089 & $\mathrm{R} \$$ & 1.143 & $\mathrm{R} \$$ & 1.198 & $\mathrm{R} \$$ & 1.256 & $\mathrm{R} \$$ & 1.310 \\
\hline $0-100-0$ & $\mathrm{R} \$$ & 1.090 & $\mathrm{R} \$$ & 1.144 & $\mathrm{R} \$$ & 1.202 & $\mathrm{R} \$$ & 1.257 & $\mathrm{R} \$$ & 1.311 \\
\hline $0-0-100$ & $\mathrm{R} \$$ & 978 & $\mathrm{R} \$$ & 1.033 & $\mathrm{R} \$$ & 1.090 & $\mathrm{R} \$$ & 1.145 & $\mathrm{R} \$$ & 1.200 \\
\hline $70-30-0$ & $\mathrm{R} \$$ & 1.089 & $\mathrm{R} \$$ & 1.144 & $\mathrm{R} \$$ & 1.198 & $\mathrm{R} \$$ & 1.256 & $\mathrm{R} \$$ & 1.311 \\
\hline $70-0-30$ & $\mathrm{R} \$$ & 1.062 & $\mathrm{R} \$$ & 1.118 & $\mathrm{R} \$$ & 1.172 & $\mathrm{R} \$$ & 1.227 & $\mathrm{R} \$$ & 1.285 \\
\hline $50-40-10$ & $\mathrm{R} \$$ & 1.082 & $\mathrm{R} \$$ & 1.137 & $\mathrm{R} \$$ & 1.191 & $\mathrm{R} \$$ & 1.249 & $\mathrm{R} \$$ & 1.304 \\
\hline $60-30-10$ & $\mathrm{R} \$$ & 1.082 & $\mathrm{R} \$$ & 1.136 & $\mathrm{R} \$$ & 1.191 & $\mathrm{R} \$$ & 1.249 & $\mathrm{R} \$$ & 1.303 \\
\hline
\end{tabular}


Apêndice 110 - Crédito médio de 1,20\% sobre o valor do investimento, por mensalidade, para construção em 90 dias e compensação de retorno em 12 meses, com simulação da porcentagem de habitações destinadas a cadeirantes, para 200 residentes

\begin{tabular}{|c|c|c|c|c|c|c|c|c|c|c|}
\hline \multirow{3}{*}{$\begin{array}{c}\text { Porcentagem de } \\
\text { residentes com } \\
\text { grau de } \\
\text { dependência } \\
\text { I, II e III } \\
100-0-0\end{array}$} & \multicolumn{10}{|c|}{$\begin{array}{c}\text { Crédito médio de } 1,20 \% \text { sobre o valor do investimento, por mensalidade, com } \\
\text { simulação da porcentagem de habitações destinadas a cadeirantes, para } 200 \\
\text { residentes, com diversos graus de dependência }\end{array}$} \\
\hline & \multicolumn{2}{|c|}{$20 \%$} & \multicolumn{2}{|c|}{$40 \%$} & \multicolumn{2}{|c|}{$60 \%$} & \multicolumn{2}{|c|}{$80 \%$} & \multicolumn{2}{|c|}{$100 \%$} \\
\hline & $\mathrm{R} \$$ & 1.102 & $\mathrm{R} \$$ & 1.156 & $\mathrm{R} \$$ & 1.212 & $\mathrm{R} \$$ & 1.268 & $\mathrm{R} \$$ & 1.323 \\
\hline $0-100-0$ & $\mathrm{R} \$$ & 1.104 & $\mathrm{R} \$$ & 1.158 & $\mathrm{R}$ & 1.214 & $\mathrm{R} \$$ & 1.270 & $\mathrm{R} \$$ & 1.325 \\
\hline $0-0-100$ & $\mathrm{R} \$$ & 995 & $\mathrm{R} \$$ & 1.050 & $\mathrm{R} \$$ & 1.105 & $\mathrm{R} \$$ & 1.162 & $\mathrm{R} \$$ & 1.216 \\
\hline $70-30-0$ & $\mathrm{R} \$$ & 1.102 & $\mathrm{R} \$$ & 1.158 & $\mathrm{R} \$$ & 1.212 & $\mathrm{R} \$$ & 1.269 & $\mathrm{R} \$$ & 1.323 \\
\hline 70-0-30 & $\mathrm{R} \$$ & 1.071 & $\mathrm{R} \$$ & 1.126 & $\mathrm{R} \$$ & 1.181 & $\mathrm{R} \$$ & 1.237 & $\mathrm{R} \$$ & 1.292 \\
\hline $50-40-10$ & $\mathrm{R} \$$ & 1.089 & $\mathrm{R} \$$ & 1.145 & $\mathrm{R} \$$ & 1.199 & $\mathrm{R} \$$ & 1.255 & $\mathrm{R} \$$ & 1.312 \\
\hline $60-30-10$ & $\mathrm{R} \$$ & 1.089 & $\mathrm{R} \$$ & 1.145 & $\mathrm{R} \$$ & 1.199 & $\mathrm{R} \$$ & 1.255 & $\mathrm{R} \$$ & 1.312 \\
\hline
\end{tabular}

Apêndice 111 - Crédito médio de 1,20\% sobre o valor do investimento, por mensalidade, para construção em 90 dias e compensação de retorno em 12 meses, com simulação da porcentagem de habitações destinadas a cadeirantes, para 300 residentes

\begin{tabular}{|c|c|c|c|c|c|c|c|c|c|c|}
\hline \multirow{3}{*}{$\begin{array}{c}\text { Porcentagem de } \\
\text { residentes com } \\
\text { grau de } \\
\text { dependência } \\
\text { I, II e III } \\
100-0-0\end{array}$} & \multicolumn{10}{|c|}{$\begin{array}{c}\text { Crédito médio de } 1,20 \% \text { sobre o valor do investimento, por mensalidade, com } \\
\text { simulação da porcentagem de habitações destinadas a cadeirantes, para } 300 \\
\text { residentes, com diversos graus de dependência }\end{array}$} \\
\hline & \multicolumn{2}{|c|}{$20 \%$} & \multicolumn{2}{|c|}{$40 \%$} & \multicolumn{2}{|c|}{$60 \%$} & \multicolumn{2}{|c|}{$80 \%$} & \multicolumn{2}{|c|}{$100 \%$} \\
\hline & $\mathrm{R} \$$ & 1.025 & $\mathrm{R} \$$ & 1.078 & $\mathrm{R} \$$ & 1.132 & $\mathrm{R} \$$ & 1.185 & $\mathrm{R} \$$ & 1.239 \\
\hline $0-100-0$ & $\mathrm{R} \$$ & 1.027 & $\mathrm{R} \$$ & 1.081 & $\mathrm{R} \$$ & 1.134 & $\mathrm{R} \$$ & 1.187 & $\mathrm{R} \$$ & 1.241 \\
\hline $0-0-100$ & $\mathrm{R} \$$ & 925 & $\mathrm{R} \$$ & 979 & $\mathrm{R} \$$ & 1.032 & $\mathrm{R} \$$ & 1.085 & $\mathrm{R} \$$ & 1.139 \\
\hline $70-30-0$ & $\mathrm{R} \$$ & 1.026 & $\mathrm{R} \$$ & 1.079 & $\mathrm{R} \$$ & 1.132 & $\mathrm{R} \$$ & 1.186 & $\mathrm{R} \$$ & 1.239 \\
\hline $70-0-30$ & $\mathrm{R} \$$ & 997 & $\mathrm{R} \$$ & 1.050 & $\mathrm{R} \$$ & 1.104 & $\mathrm{R} \$$ & 1.157 & R\$ & 1.210 \\
\hline $50-40-10$ & $\mathrm{R} \$$ & 1.017 & $\mathrm{R} \$$ & 1.071 & $\mathrm{R} \$$ & 1.124 & $\mathrm{R} \$$ & 1.178 & $\mathrm{R} \$$ & 1.232 \\
\hline $60-30-10$ & $\mathrm{R} \$$ & 1.017 & $\mathrm{R} \$$ & 1.071 & $\mathrm{R} \$$ & 1.124 & $\mathrm{R} \$$ & 1.177 & $\mathrm{R} \$$ & 1.231 \\
\hline
\end{tabular}

Apêndice 112 - Crédito médio de 1,20\% sobre o valor do investimento, por mensalidade, para construção em 90 dias e compensação de retorno em 12 meses, com simulação da porcentagem de habitações destinadas a cadeirantes, para 400 residentes

\begin{tabular}{|c|c|c|c|c|c|c|c|c|c|c|}
\hline \multirow{3}{*}{$\begin{array}{c}\text { Porcentagem de } \\
\text { residentes com } \\
\text { grau de } \\
\text { dependência } \\
\text { I, II e III } \\
100-0-0\end{array}$} & \multicolumn{10}{|c|}{$\begin{array}{c}\text { Crédito médio de } 1,20 \% \text { sobre o valor do investimento, por mensalidade, com } \\
\text { simulação da porcentagem de habitações destinadas a cadeirantes, para } 400 \\
\text { residentes, com diversos graus de dependência }\end{array}$} \\
\hline & \multicolumn{2}{|c|}{$20 \%$} & \multicolumn{2}{|c|}{$40 \%$} & \multicolumn{2}{|c|}{$60 \%$} & \multicolumn{2}{|c|}{$80 \%$} & \multicolumn{2}{|c|}{$100 \%$} \\
\hline & $\mathrm{R} \$$ & 1.007 & $\mathrm{R} \$$ & 1.060 & $\mathrm{R} \$$ & 1.114 & $\mathrm{R} \$$ & 1.168 & $\mathrm{R} \$$ & 1.222 \\
\hline 0-100-0 & $\mathrm{R} \$$ & 1.009 & $\mathrm{R} \$$ & 1.062 & $\mathrm{R} \$$ & 1.116 & $\mathrm{R} \$$ & 1.170 & $\mathrm{R} \$$ & 1.224 \\
\hline 0-0-100 & $\mathrm{R} \$$ & 907 & $\mathrm{R} \$$ & 961 & $\mathrm{R} \$$ & 1.014 & $\mathrm{R} \$$ & 1.067 & $\mathrm{R} \$$ & 1.121 \\
\hline $70-30-0$ & $\mathrm{R} \$$ & 1.007 & $\mathrm{R} \$$ & 1.061 & $\mathrm{R} \$$ & 1.115 & $\mathrm{R} \$$ & 1.168 & $\mathrm{R} \$$ & 1.221 \\
\hline $70-0-30$ & $\mathrm{R} \$$ & 977 & $\mathrm{R} \$$ & 1.031 & $\mathrm{R} \$$ & 1.085 & $\mathrm{R} \$$ & 1.138 & $\mathrm{R} \$$ & 1.191 \\
\hline $50-40-10$ & $\mathrm{R} \$$ & 998 & $\mathrm{R} \$$ & 1.051 & $\mathrm{R} \$$ & 1.104 & $\mathrm{R} \$$ & 1.158 & $\mathrm{R} \$$ & 1.211 \\
\hline $60-30-10$ & $\mathrm{R} \$$ & 997 & $\mathrm{R} \$$ & 1.051 & $\mathrm{R} \$$ & 1.104 & $\mathrm{R} \$$ & 1.158 & $\mathrm{R} \$$ & 1.211 \\
\hline
\end{tabular}


Apêndice 113 - Crédito médio de 1,30\% sobre o valor do investimento, por mensalidade, para construção em 90 dias e compensação de retorno em 12 meses, com simulação da porcentagem de habitações destinadas a cadeirantes, para 100 residentes

\begin{tabular}{|c|c|c|c|c|c|c|c|c|c|c|}
\hline \multirow{3}{*}{$\begin{array}{c}\text { Porcentagem de } \\
\text { residentes com } \\
\text { grau de } \\
\text { dependência } \\
\text { I, II e III } \\
100-0-0\end{array}$} & \multicolumn{10}{|c|}{$\begin{array}{c}\text { Crédito médio de } 1,30 \% \text { sobre o valor do investimento, por mensalidade, com } \\
\text { simulação da porcentagem de habitações destinadas a cadeirantes, para } 100 \\
\text { residentes, com diversos graus de dependência }\end{array}$} \\
\hline & \multicolumn{2}{|c|}{$20 \%$} & \multicolumn{2}{|c|}{$40 \%$} & \multicolumn{2}{|c|}{$60 \%$} & \multicolumn{2}{|c|}{$80 \%$} & \multicolumn{2}{|c|}{$100 \%$} \\
\hline & $\mathrm{R} \$$ & 1.179 & $\mathrm{R} \$$ & 1.239 & $\mathrm{R} \$$ & 1.298 & $\mathrm{R} \$$ & 1.360 & $\mathrm{R} \$$ & 1.420 \\
\hline $0-100-0$ & $\mathrm{R} \$$ & 1.180 & $\mathrm{R} \$$ & 1.240 & $\mathrm{R} \$$ & 1.302 & $\mathrm{R} \$$ & 1.361 & $\mathrm{R} \$$ & 1.421 \\
\hline $0-0-100$ & $\mathrm{R} \$$ & 1.060 & $\mathrm{R} \$$ & 1.119 & $\mathrm{R} \$$ & 1.181 & $\mathrm{R} \$$ & 1.240 & $\mathrm{R} \$$ & 1.299 \\
\hline $70-30-0$ & $\mathrm{R} \$$ & 1.180 & $\mathrm{R} \$$ & 1.239 & $\mathrm{R} \$$ & 1.298 & $\mathrm{R} \$$ & 1.361 & $\mathrm{R} \$$ & 1.420 \\
\hline $70-0-30$ & $\mathrm{R} \$$ & 1.151 & $\mathrm{R} \$$ & 1.211 & $\mathrm{R} \$$ & 1.270 & $\mathrm{R} \$$ & 1.329 & $\mathrm{R} \$$ & 1.392 \\
\hline $50-40-10$ & $\mathrm{R} \$$ & 1.172 & $\mathrm{R} \$$ & 1.231 & $\mathrm{R} \$$ & 1.290 & $\mathrm{R} \$$ & 1.353 & $\mathrm{R} \$$ & 1.412 \\
\hline $60-30-10$ & $\mathrm{R} \$$ & 1.172 & $\mathrm{R} \$$ & 1.231 & $\mathrm{R} \$$ & 1.290 & $\mathrm{R} \$$ & 1.353 & $\mathrm{R} \$$ & 1.412 \\
\hline
\end{tabular}

Apêndice 114 - Crédito médio de 1,30\% sobre o valor do investimento, por mensalidade, para construção em 90 dias e compensação de retorno em 12 meses, com simulação da porcentagem de habitações destinadas a cadeirantes, para 200 residentes

\begin{tabular}{|c|c|c|c|c|c|c|c|c|c|c|}
\hline \multirow{3}{*}{$\begin{array}{c}\text { Porcentagem de } \\
\text { residentes com } \\
\text { grau de } \\
\text { dependência } \\
\text { I, II e III } \\
100-0-0\end{array}$} & \multicolumn{10}{|c|}{$\begin{array}{c}\text { Crédito médio de } 1,30 \% \text { sobre o valor do investimento, por mensalidade, com } \\
\text { simulação da porcentagem de habitações destinadas a cadeirantes, para } 200 \\
\text { residentes, com diversos graus de dependência }\end{array}$} \\
\hline & \multicolumn{2}{|c|}{$20 \%$} & \multicolumn{2}{|c|}{$40 \%$} & \multicolumn{2}{|c|}{$60 \%$} & \multicolumn{2}{|c|}{$80 \%$} & \multicolumn{2}{|c|}{$100 \%$} \\
\hline & $\mathrm{R} \$$ & 1.193 & $\mathrm{R} \$$ & 1.253 & $\mathrm{R} \$$ & 1.313 & $\mathrm{R} \$$ & 1.374 & $\mathrm{R} \$$ & 1.433 \\
\hline $0-100-0$ & $\mathrm{R} \$$ & 1.196 & $\mathrm{R} \$$ & 1.255 & $\mathrm{R} \$$ & 1.315 & $\mathrm{R} \$$ & 1.376 & $\mathrm{R} \$$ & 1.436 \\
\hline $0-0-100$ & $\mathrm{R} \$$ & 1.078 & $\mathrm{R} \$$ & 1.137 & $\mathrm{R} \$$ & 1.198 & $\mathrm{R} \$$ & 1.258 & $\mathrm{R} \$$ & 1.318 \\
\hline $70-30-0$ & $\mathrm{R} \$$ & 1.194 & $\mathrm{R} \$$ & 1.254 & $\mathrm{R} \$$ & 1.314 & $\mathrm{R} \$$ & 1.374 & $\mathrm{R} \$$ & 1.434 \\
\hline $70-0-30$ & $\mathrm{R} \$$ & 1.160 & $\mathrm{R} \$$ & 1.220 & $\mathrm{R} \$$ & 1.280 & $\mathrm{R} \$$ & 1.340 & R\$ & 1.400 \\
\hline $50-40-10$ & $\mathrm{R} \$$ & 1.180 & $\mathrm{R} \$$ & 1.240 & $\mathrm{R} \$$ & 1.299 & $\mathrm{R} \$$ & 1.360 & $\mathrm{R} \$$ & 1.421 \\
\hline $60-30-10$ & $\mathrm{R} \$$ & 1.179 & $\mathrm{R} \$$ & 1.240 & $\mathrm{R} \$$ & 1.299 & $\mathrm{R} \$$ & 1.360 & $\mathrm{R} \$$ & 1.421 \\
\hline
\end{tabular}

Apêndice 115 - Crédito médio de 1,30\% sobre o valor do investimento, por mensalidade, para construção em 90 dias e compensação de retorno em 12 meses, com simulação da porcentagem de habitações destinadas a cadeirantes, para 300 residentes

\begin{tabular}{|c|c|c|c|c|c|c|c|c|c|c|}
\hline \multirow{3}{*}{$\begin{array}{c}\text { Porcentagem de } \\
\text { residentes com } \\
\text { grau de } \\
\text { dependência } \\
\text { I, II e III } \\
100-0-0\end{array}$} & \multicolumn{10}{|c|}{$\begin{array}{c}\text { Crédito médio de } 1,30 \% \text { sobre o valor do investimento, por mensalidade, com } \\
\text { simulação da porcentagem de habitações destinadas a cadeirantes, para } 300 \\
\text { residentes, com diversos graus de dependência }\end{array}$} \\
\hline & \multicolumn{2}{|c|}{$20 \%$} & \multicolumn{2}{|c|}{$40 \%$} & \multicolumn{2}{|c|}{$60 \%$} & \multicolumn{2}{|c|}{$80 \%$} & \multicolumn{2}{|c|}{$100 \%$} \\
\hline & $\mathrm{R} \$$ & 1.110 & $\mathrm{R} \$$ & 1.168 & $\mathrm{R} \$$ & 1.226 & $\mathrm{R} \$$ & 1.284 & $\mathrm{R} \$$ & 1.342 \\
\hline 0-100-0 & $\mathrm{R} \$$ & 1.113 & $\mathrm{R} \$$ & 1.171 & $\mathrm{R} \$$ & 1.228 & $\mathrm{R} \$$ & 1.286 & $\mathrm{R} \$$ & 1.344 \\
\hline 0-0-100 & $\mathrm{R} \$$ & 1.002 & $\mathrm{R} \$$ & 1.060 & $\mathrm{R} \$$ & 1.117 & $\mathrm{R} \$$ & 1.175 & $\mathrm{R} \$$ & 1.234 \\
\hline $70-30-0$ & $\mathrm{R} \$$ & 1.111 & $\mathrm{R} \$$ & 1.169 & $\mathrm{R} \$$ & 1.226 & $\mathrm{R} \$$ & 1.284 & R\$ & 1.343 \\
\hline $70-0-30$ & $\mathrm{R} \$$ & 1.080 & $\mathrm{R} \$$ & 1.138 & $\mathrm{R} \$$ & 1.196 & $\mathrm{R} \$$ & 1.253 & $\mathrm{R} \$$ & 1.311 \\
\hline $50-40-10$ & $\mathrm{R} \$$ & 1.102 & $\mathrm{R} \$$ & 1.160 & $\mathrm{R} \$$ & 1.218 & $\mathrm{R} \$$ & 1.276 & $\mathrm{R} \$$ & 1.334 \\
\hline $60-30-10$ & $\mathrm{R} \$$ & 1.102 & $\mathrm{R} \$$ & 1.160 & $\mathrm{R} \$$ & 1.217 & $\mathrm{R} \$$ & 1.275 & $\mathrm{R} \$$ & 1.333 \\
\hline
\end{tabular}


Apêndice 116 - Crédito médio de 1,30\% sobre o valor do investimento, por mensalidade, para construção em 90 dias e compensação de retorno em 12 meses, com simulação da porcentagem de habitações destinadas a cadeirantes, para 400 residentes

\begin{tabular}{|c|c|c|c|c|c|c|c|c|c|c|}
\hline \multirow{3}{*}{$\begin{array}{c}\text { Porcentagem de } \\
\text { residentes com } \\
\text { grau de } \\
\text { dependência } \\
\text { I, II e III } \\
100-0-0\end{array}$} & \multicolumn{10}{|c|}{$\begin{array}{c}\text { Crédito médio de } 1,30 \% \text { sobre o valor do investimento, por mensalidade, com } \\
\text { simulação da porcentagem de habitações destinadas a cadeirantes, para } 400 \\
\text { residentes, com diversos graus de dependência }\end{array}$} \\
\hline & \multicolumn{2}{|c|}{$20 \%$} & \multicolumn{2}{|c|}{$40 \%$} & \multicolumn{2}{|c|}{$60 \%$} & \multicolumn{2}{|c|}{$80 \%$} & \multicolumn{2}{|c|}{$100 \%$} \\
\hline & $\mathrm{R} \$$ & 1.091 & $\mathrm{R} \$$ & 1.149 & $\mathrm{R} \$$ & 1.206 & $\mathrm{R} \$$ & 1.266 & $\mathrm{R} \$$ & 1.324 \\
\hline 0-100-0 & $\mathrm{R} \$$ & 1.093 & $\mathrm{R} \$$ & 1.151 & $\mathrm{R} \$$ & 1.209 & $\mathrm{R} \$$ & 1.268 & $\mathrm{R} \$$ & 1.326 \\
\hline $0-0-100$ & $\mathrm{R} \$$ & 983 & $\mathrm{R} \$$ & 1.041 & $\mathrm{R} \$$ & 1.099 & $\mathrm{R} \$$ & 1.156 & $\mathrm{R} \$$ & 1.214 \\
\hline $70-30-0$ & $\mathrm{R} \$$ & 1.091 & $\mathrm{R} \$$ & 1.150 & $\mathrm{R} \$$ & 1.207 & $\mathrm{R} \$$ & 1.265 & $\mathrm{R} \$$ & 1.323 \\
\hline 70-0-30 & $\mathrm{R} \$$ & 1.059 & $\mathrm{R} \$$ & 1.117 & $\mathrm{R} \$$ & 1.175 & $\mathrm{R} \$$ & 1.233 & $\mathrm{R} \$$ & 1.291 \\
\hline $50-40-10$ & $\mathrm{R} \$$ & 1.081 & $\mathrm{R} \$$ & 1.139 & $\mathrm{R} \$$ & 1.196 & $\mathrm{R} \$$ & 1.254 & $\mathrm{R} \$$ & 1.312 \\
\hline $60-30-10$ & $\mathrm{R} \$$ & 1.080 & $\mathrm{R} \$$ & 1.138 & $\mathrm{R} \$$ & 1.196 & $\mathrm{R} \$$ & 1.254 & $\mathrm{R} \$$ & 1.312 \\
\hline
\end{tabular}

Apêndice 117 - Crédito médio de 1,40\% sobre o valor do investimento, por mensalidade, para construção em 90 dias e compensação de retorno em 12 meses, com simulação da porcentagem de habitações destinadas a cadeirantes, para 100 residentes

\begin{tabular}{|c|c|c|c|c|c|c|c|c|c|c|}
\hline \multirow{2}{*}{$\begin{array}{c}\text { Porcentagem de } \\
\text { residentes com } \\
\text { grau de } \\
\text { dependência } \\
\text { I, II e III } \\
\end{array}$} & \multicolumn{10}{|c|}{$\begin{array}{c}\text { Crédito médio de } 1,40 \% \text { sobre o valor do investimento, por mensalidade, com } \\
\text { simulação da porcentagem de habitações destinadas a cadeirantes, para } 100 \\
\text { residentes, com diversos graus de dependência }\end{array}$} \\
\hline & \multicolumn{2}{|c|}{$20 \%$} & \multicolumn{2}{|c|}{$40 \%$} & \multicolumn{2}{|c|}{$60 \%$} & \multicolumn{2}{|c|}{$80 \%$} & \multicolumn{2}{|c|}{$100 \%$} \\
\hline $100-0-0$ & $\mathrm{R} \$$ & 1.270 & $\mathrm{R} \$$ & 1.334 & $\mathrm{R} \$$ & 1.398 & $\mathrm{R} \$$ & 1.465 & $\mathrm{R} \$$ & 1.529 \\
\hline 0-100-0 & $\mathrm{R} \$$ & 1.271 & $\mathrm{R} \$$ & 1.335 & $\mathrm{R} \$$ & 1.402 & $\mathrm{R} \$$ & 1.466 & $\mathrm{R} \$$ & 1.530 \\
\hline $0-0-100$ & $\mathrm{R} \$$ & 1.141 & $\mathrm{R} \$$ & 1.205 & $\mathrm{R} \$$ & 1.272 & $\mathrm{R} \$$ & 1.336 & $\mathrm{R} \$$ & 1.399 \\
\hline $70-30-0$ & $\mathrm{R} \$$ & 1.271 & $\mathrm{R} \$$ & 1.334 & $\mathrm{R} \$$ & 1.398 & $\mathrm{R} \$$ & 1.465 & $\mathrm{R} \$$ & 1.529 \\
\hline $70-0-30$ & $\mathrm{R} \$$ & 1.240 & $\mathrm{R} \$$ & 1.304 & $\mathrm{R} \$$ & 1.367 & $\mathrm{R} \$$ & 1.431 & $\mathrm{R} \$$ & 1.499 \\
\hline $50-40-10$ & $\mathrm{R} \$$ & 1.262 & $\mathrm{R} \$$ & 1.326 & $\mathrm{R} \$$ & 1.390 & $\mathrm{R} \$$ & 1.457 & $\mathrm{R} \$$ & 1.521 \\
\hline $60-30-10$ & $\mathrm{R} \$$ & 1.262 & $\mathrm{R} \$$ & 1.326 & $\mathrm{R} \$$ & 1.389 & $\mathrm{R} \$$ & 1.457 & $\mathrm{R} \$$ & 1.521 \\
\hline
\end{tabular}

Apêndice 118 - Crédito médio de 1,40\% sobre o valor do investimento, por mensalidade, para construção em 90 dias e compensação de retorno em 12 meses, com simulação da porcentagem de habitações destinadas a cadeirantes, para 200 residentes

\begin{tabular}{|c|c|c|c|c|c|c|c|c|c|c|}
\hline \multirow{3}{*}{$\begin{array}{c}\text { Porcentagem de } \\
\text { residentes com } \\
\text { grau de } \\
\text { dependência } \\
\text { I, II e III } \\
100-0-0\end{array}$} & \multicolumn{10}{|c|}{$\begin{array}{c}\text { Crédito médio de } 1,40 \% \text { sobre o valor do investimento, por mensalidade, com } \\
\text { simulação da porcentagem de habitações destinadas a cadeirantes, para } 200 \\
\text { residentes, com diversos graus de dependência }\end{array}$} \\
\hline & \multicolumn{2}{|c|}{$20 \%$} & \multicolumn{2}{|c|}{$40 \%$} & \multicolumn{2}{|c|}{$60 \%$} & \multicolumn{2}{|c|}{$80 \%$} & \multicolumn{2}{|c|}{$100 \%$} \\
\hline & $\mathrm{R} \$$ & 1.285 & $\mathrm{R} \$$ & 1.349 & $\mathrm{R} \$$ & 1.414 & $\mathrm{R} \$$ & 1.480 & $\mathrm{R} \$$ & 1.544 \\
\hline 0-100-0 & $\mathrm{R} \$$ & 1.288 & $\mathrm{R} \$$ & 1.352 & $\mathrm{R} \$$ & 1.417 & $\mathrm{R} \$$ & 1.482 & $\mathrm{R} \$$ & 1.546 \\
\hline 0-0-100 & $\mathrm{R} \$$ & 1.160 & $\mathrm{R} \$$ & 1.225 & $\mathrm{R} \$$ & 1.290 & $\mathrm{R} \$$ & 1.355 & $\mathrm{R} \$$ & 1.419 \\
\hline $70-30-0$ & $\mathrm{R} \$$ & 1.286 & $\mathrm{R} \$$ & 1.351 & $\mathrm{R} \$$ & 1.415 & $\mathrm{R} \$$ & 1.480 & R\$ & 1.544 \\
\hline $70-0-30$ & $\mathrm{R} \$$ & 1.249 & $\mathrm{R} \$$ & 1.314 & $\mathrm{R} \$$ & 1.378 & $\mathrm{R} \$$ & 1.444 & $\mathrm{R} \$$ & 1.507 \\
\hline $50-40-10$ & $\mathrm{R} \$$ & 1.270 & $\mathrm{R} \$$ & 1.336 & $\mathrm{R} \$$ & 1.399 & $\mathrm{R} \$$ & 1.465 & $\mathrm{R} \$$ & 1.530 \\
\hline $60-30-10$ & $\mathrm{R} \$$ & 1.270 & $\mathrm{R} \$$ & 1.336 & $\mathrm{R} \$$ & 1.399 & $\mathrm{R} \$$ & 1.465 & $\mathrm{R} \$$ & 1.530 \\
\hline
\end{tabular}


Apêndice 119 - Crédito médio de 1,40\% sobre o valor do investimento, por mensalidade, para construção em 90 dias e compensação de retorno em 12 meses, com simulação da porcentagem de habitações destinadas a cadeirantes, para 300 residentes

\begin{tabular}{|c|c|c|c|c|c|c|c|c|c|c|}
\hline \multirow{3}{*}{$\begin{array}{c}\text { Porcentagem de } \\
\text { residentes com } \\
\text { grau de } \\
\text { dependência } \\
\text { I, II e III } \\
100-0-0\end{array}$} & \multicolumn{10}{|c|}{$\begin{array}{c}\text { Crédito médio de } 1,40 \% \text { sobre o valor do investimento, por mensalidade, com } \\
\text { simulação da porcentagem de habitações destinadas a cadeirantes, para } 300 \\
\text { residentes, com diversos graus de dependência }\end{array}$} \\
\hline & \multicolumn{2}{|c|}{$20 \%$} & \multicolumn{2}{|c|}{$40 \%$} & \multicolumn{2}{|c|}{$60 \%$} & \multicolumn{2}{|c|}{$80 \%$} & \multicolumn{2}{|c|}{$100 \%$} \\
\hline & $\mathrm{R} \$$ & 1.196 & $\mathrm{R} \$$ & 1.258 & $\mathrm{R} \$$ & 1.321 & $\mathrm{R} \$$ & 1.383 & $\mathrm{R} \$$ & 1.445 \\
\hline $0-100-0$ & $\mathrm{R} \$$ & 1.198 & $\mathrm{R} \$$ & 1.261 & $\mathrm{R} \$$ & 1.322 & $\mathrm{R} \$$ & 1.385 & $\mathrm{R} \$$ & 1.447 \\
\hline $0-0-100$ & $\mathrm{R} \$$ & 1.080 & $\mathrm{R} \$$ & 1.142 & $\mathrm{R} \$$ & 1.203 & $\mathrm{R} \$$ & 1.266 & $\mathrm{R} \$$ & 1.328 \\
\hline $70-30-0$ & $\mathrm{R} \$$ & 1.197 & $\mathrm{R} \$$ & 1.259 & $\mathrm{R} \$$ & 1.321 & $\mathrm{R} \$$ & 1.383 & $\mathrm{R} \$$ & 1.446 \\
\hline 70-0-30 & $\mathrm{R} \$$ & 1.163 & $\mathrm{R} \$$ & 1.226 & $\mathrm{R} \$$ & 1.288 & $\mathrm{R} \$$ & 1.350 & $\mathrm{R} \$$ & 1.412 \\
\hline $50-40-10$ & $\mathrm{R} \$$ & 1.187 & $\mathrm{R} \$$ & 1.250 & $\mathrm{R} \$$ & 1.312 & $\mathrm{R} \$$ & 1.374 & $\mathrm{R} \$$ & 1.437 \\
\hline $60-30-10$ & $\mathrm{R} \$$ & 1.187 & $\mathrm{R} \$$ & 1.250 & $\mathrm{R} \$$ & 1.311 & $\mathrm{R} \$$ & 1.373 & $\mathrm{R} \$$ & 1.436 \\
\hline
\end{tabular}

Apêndice 120 - Crédito médio de 1,40\% sobre o valor do investimento, por mensalidade, para construção em 90 dias e compensação de retorno em 12 meses, com simulação da porcentagem de habitações destinadas a cadeirantes, para 400 residentes

\begin{tabular}{|c|c|c|c|c|c|c|c|c|c|c|}
\hline \multirow{3}{*}{$\begin{array}{c}\text { Porcentagem de } \\
\text { residentes com } \\
\text { grau de } \\
\text { dependência } \\
\text { I, II e III } \\
100-0-0\end{array}$} & \multicolumn{10}{|c|}{$\begin{array}{c}\text { Crédito médio de } 1,40 \% \text { sobre o valor do investimento, por mensalidade, com } \\
\text { simulação da porcentagem de habitações destinadas a cadeirantes, para } 400 \\
\text { residentes, com diversos graus de dependência }\end{array}$} \\
\hline & \multicolumn{2}{|c|}{$20 \%$} & \multicolumn{2}{|c|}{$40 \%$} & \multicolumn{2}{|c|}{$60 \%$} & \multicolumn{2}{|c|}{$80 \%$} & \multicolumn{2}{|c|}{$100 \%$} \\
\hline & $\mathrm{R} \$$ & 1.175 & $\mathrm{R} \$$ & 1.237 & $\mathrm{R} \$$ & 1.299 & $\mathrm{R} \$$ & 1.363 & $\mathrm{R} \$$ & 1.425 \\
\hline $0-100-0$ & $\mathrm{R} \$$ & 1.177 & $\mathrm{R} \$$ & 1.239 & $\mathrm{R} \$$ & 1.302 & $\mathrm{R} \$$ & 1.366 & $\mathrm{R} \$$ & 1.428 \\
\hline $0-0-100$ & $\mathrm{R} \$$ & 1.059 & $\mathrm{R} \$$ & 1.121 & $\mathrm{R} \$$ & 1.183 & $\mathrm{R} \$$ & 1.245 & $\mathrm{R} \$$ & 1.307 \\
\hline $70-30-0$ & $\mathrm{R} \$$ & 1.175 & $\mathrm{R} \$$ & 1.238 & $\mathrm{R} \$$ & 1.300 & $\mathrm{R} \$$ & 1.363 & $\mathrm{R} \$$ & 1.425 \\
\hline $70-0-30$ & $\mathrm{R} \$$ & 1.140 & $\mathrm{R} \$$ & 1.203 & $\mathrm{R} \$$ & 1.266 & $\mathrm{R} \$$ & 1.328 & R\$ & 1.390 \\
\hline $50-40-10$ & $\mathrm{R} \$$ & 1.164 & $\mathrm{R} \$$ & 1.226 & $\mathrm{R} \$$ & 1.288 & $\mathrm{R} \$$ & 1.351 & $\mathrm{R} \$$ & 1.413 \\
\hline $60-30-10$ & $\mathrm{R} \$$ & 1.163 & $\mathrm{R} \$$ & 1.226 & $\mathrm{R} \$$ & 1.288 & $\mathrm{R} \$$ & 1.351 & $\mathrm{R} \$$ & 1.413 \\
\hline
\end{tabular}

Apêndice 121 - Crédito médio de 1,50\% sobre o valor do investimento, por mensalidade, para construção em 90 dias e compensação de retorno em 12 meses, com simulação da porcentagem de habitações destinadas a cadeirantes, para 100 residentes

\begin{tabular}{|c|c|c|c|c|c|c|c|c|c|c|}
\hline \multirow{3}{*}{$\begin{array}{c}\text { Porcentagem de } \\
\text { residentes com } \\
\text { grau de } \\
\text { dependência } \\
\text { I, II e III } \\
100-0-0\end{array}$} & \multicolumn{10}{|c|}{$\begin{array}{c}\text { Crédito médio de } 1,50 \% \text { sobre o valor do investimento, por mensalidade, com } \\
\text { simulação da porcentagem de habitações destinadas a cadeirantes, para } 100 \\
\text { residentes, com diversos graus de dependência }\end{array}$} \\
\hline & \multicolumn{2}{|c|}{$20 \%$} & \multicolumn{2}{|c|}{$40 \%$} & \multicolumn{2}{|c|}{$60 \%$} & \multicolumn{2}{|c|}{$80 \%$} & \multicolumn{2}{|c|}{$100 \%$} \\
\hline & $\mathrm{R} \$$ & 1.361 & $\mathrm{R} \$$ & 1.429 & $\mathrm{R} \$$ & 1.498 & $\mathrm{R} \$$ & 1.570 & $\mathrm{R} \$$ & 1.638 \\
\hline 0-100-0 & $\mathrm{R} \$$ & 1.362 & $\mathrm{R} \$$ & 1.430 & $\mathrm{R} \$$ & 1.502 & $\mathrm{R} \$$ & 1.571 & $\mathrm{R} \$$ & 1.639 \\
\hline 0-0-100 & $\mathrm{R} \$$ & 1.223 & $\mathrm{R} \$$ & 1.291 & $\mathrm{R} \$$ & 1.363 & $\mathrm{R} \$$ & 1.431 & $\mathrm{R} \$$ & 1.499 \\
\hline $70-30-0$ & $\mathrm{R} \$$ & 1.361 & $\mathrm{R} \$$ & 1.430 & $\mathrm{R} \$$ & 1.498 & $\mathrm{R} \$$ & 1.570 & R\$ & 1.639 \\
\hline $70-0-30$ & $\mathrm{R} \$$ & 1.328 & $\mathrm{R} \$$ & 1.397 & $\mathrm{R} \$$ & 1.465 & $\mathrm{R} \$$ & 1.533 & $\mathrm{R} \$$ & 1.606 \\
\hline $50-40-10$ & $\mathrm{R} \$$ & 1.352 & $\mathrm{R} \$$ & 1.421 & $\mathrm{R} \$$ & 1.489 & $\mathrm{R} \$$ & 1.561 & $\mathrm{R} \$$ & 1.629 \\
\hline $60-30-10$ & $\mathrm{R} \$$ & 1.352 & $\mathrm{R} \$$ & 1.421 & $\mathrm{R} \$$ & 1.489 & $\mathrm{R} \$$ & 1.561 & $\mathrm{R} \$$ & 1.629 \\
\hline
\end{tabular}


Apêndice 122 - Crédito médio de 1,50\% sobre o valor do investimento, por mensalidade, para construção em 90 dias e compensação de retorno em 12 meses, com simulação da porcentagem de habitações destinadas a cadeirantes, para 200 residentes

\begin{tabular}{|c|c|c|c|c|c|c|c|c|c|c|}
\hline \multirow{3}{*}{$\begin{array}{c}\text { Porcentagem de } \\
\text { residentes com } \\
\text { grau de } \\
\text { dependência } \\
\text { I, II e III } \\
100-0-0\end{array}$} & \multicolumn{10}{|c|}{$\begin{array}{c}\text { Crédito médio de } 1,50 \% \text { sobre o valor do investimento, por mensalidade, com } \\
\text { simulação da porcentagem de habitações destinadas a cadeirantes, para } 200 \\
\text { residentes, com diversos graus de dependência }\end{array}$} \\
\hline & \multicolumn{2}{|c|}{$20 \%$} & \multicolumn{2}{|c|}{$40 \%$} & \multicolumn{2}{|c|}{$60 \%$} & \multicolumn{2}{|c|}{$80 \%$} & \multicolumn{2}{|c|}{$100 \%$} \\
\hline & $\mathrm{R} \$$ & 1.377 & $\mathrm{R} \$$ & 1.445 & $\mathrm{R} \$$ & 1.515 & $\mathrm{R} \$$ & 1.585 & $\mathrm{R} \$$ & 1.654 \\
\hline $0-100-0$ & $\mathrm{R} \$$ & 1.380 & $\mathrm{R} \$$ & 1.448 & $\mathrm{R} \$$ & 1.518 & $\mathrm{R} \$$ & 1.588 & $\mathrm{R} \$$ & 1.656 \\
\hline $0-0-100$ & $\mathrm{R} \$$ & 1.243 & $\mathrm{R} \$$ & 1.312 & $\mathrm{R} \$$ & 1.382 & $\mathrm{R} \$$ & 1.452 & $\mathrm{R} \$$ & 1.521 \\
\hline $70-30-0$ & $\mathrm{R} \$$ & 1.377 & $\mathrm{R} \$$ & 1.447 & $\mathrm{R} \$$ & 1.516 & $\mathrm{R} \$$ & 1.586 & $\mathrm{R} \$$ & 1.654 \\
\hline $70-0-30$ & $\mathrm{R} \$$ & 1.338 & $\mathrm{R} \$$ & 1.408 & $\mathrm{R} \$$ & 1.477 & $\mathrm{R} \$$ & 1.547 & $\mathrm{R} \$$ & 1.615 \\
\hline $50-40-10$ & $\mathrm{R} \$$ & 1.361 & $\mathrm{R} \$$ & 1.431 & $\mathrm{R} \$$ & 1.499 & $\mathrm{R} \$$ & 1.569 & $\mathrm{R} \$$ & 1.640 \\
\hline $60-30-10$ & $\mathrm{R} \$$ & 1.361 & $\mathrm{R} \$$ & 1.431 & $\mathrm{R} \$$ & 1.499 & $\mathrm{R} \$$ & 1.569 & $\mathrm{R} \$$ & 1.639 \\
\hline
\end{tabular}

Apêndice 123 - Crédito médio de 1,50\% sobre o valor do investimento, por mensalidade, para construção em 90 dias e compensação de retorno em 12 meses, com simulação da porcentagem de habitações destinadas a cadeirantes, para 300 residentes

\begin{tabular}{|c|c|c|c|c|c|c|c|c|c|c|}
\hline \multirow{3}{*}{$\begin{array}{c}\text { Porcentagem de } \\
\text { residentes com } \\
\text { grau de } \\
\text { dependência } \\
\text { I, II e III } \\
100-0-0\end{array}$} & \multicolumn{10}{|c|}{$\begin{array}{c}\text { Crédito médio de } 1,50 \% \text { sobre o valor do investimento, por mensalidade, com } \\
\text { simulação da porcentagem de habitações destinadas a cadeirantes, para } 300 \\
\text { residentes, com diversos graus de dependência }\end{array}$} \\
\hline & \multicolumn{2}{|c|}{$20 \%$} & \multicolumn{2}{|c|}{$40 \%$} & \multicolumn{2}{|c|}{$60 \%$} & \multicolumn{2}{|c|}{$80 \%$} & \multicolumn{2}{|c|}{$100 \%$} \\
\hline & $\mathrm{R} \$$ & 1.281 & $\mathrm{R} \$$ & 1.348 & $\mathrm{R} \$$ & 1.415 & $\mathrm{R} \$$ & 1.482 & $\mathrm{R} \$$ & 1.549 \\
\hline $0-100-0$ & $\mathrm{R} \$$ & 1.284 & $\mathrm{R} \$$ & 1.351 & $\mathrm{R} \$$ & 1.417 & $\mathrm{R} \$$ & 1.484 & $\mathrm{R} \$$ & 1.551 \\
\hline $0-0-100$ & $\mathrm{R} \$$ & 1.157 & $\mathrm{R} \$$ & 1.224 & $\mathrm{R} \$$ & 1.289 & $\mathrm{R} \$$ & 1.356 & $\mathrm{R} \$$ & 1.423 \\
\hline $70-30-0$ & $\mathrm{R} \$$ & 1.282 & $\mathrm{R} \$$ & 1.349 & $\mathrm{R} \$$ & 1.415 & $\mathrm{R} \$$ & 1.482 & $\mathrm{R} \$$ & 1.549 \\
\hline $70-0-30$ & $\mathrm{R} \$$ & 1.246 & $\mathrm{R} \$$ & 1.313 & $\mathrm{R} \$$ & 1.380 & $\mathrm{R} \$$ & 1.446 & $\mathrm{R} \$$ & 1.513 \\
\hline $50-40-10$ & $\mathrm{R} \$$ & 1.272 & $\mathrm{R} \$$ & 1.339 & $\mathrm{R} \$$ & 1.406 & $\mathrm{R} \$$ & 1.473 & $\mathrm{R} \$$ & 1.540 \\
\hline $60-30-10$ & $\mathrm{R} \$$ & 1.272 & $\mathrm{R} \$$ & 1.339 & $\mathrm{R} \$$ & 1.405 & $\mathrm{R} \$$ & 1.472 & $\mathrm{R} \$$ & 1.538 \\
\hline
\end{tabular}

Apêndice 124 - Crédito médio de 1,50\% sobre o valor do investimento, por mensalidade, para construção em 90 dias e compensação de retorno em 12 meses, com simulação da porcentagem de habitações destinadas a cadeirantes, para 400 residentes

\begin{tabular}{|c|c|c|c|c|c|c|c|c|c|c|}
\hline \multirow{3}{*}{$\begin{array}{c}\text { Porcentagem de } \\
\text { residentes com } \\
\text { grau de } \\
\text { dependência } \\
\text { I, II e III } \\
100-0-0\end{array}$} & \multicolumn{10}{|c|}{$\begin{array}{c}\text { Crédito médio de } 1,50 \% \text { sobre o valor do investimento, por mensalidade, com } \\
\text { simulação da porcentagem de habitações destinadas a cadeirantes, para } 400 \\
\text { residentes, com diversos graus de dependência }\end{array}$} \\
\hline & \multicolumn{2}{|c|}{$20 \%$} & \multicolumn{2}{|c|}{$40 \%$} & \multicolumn{2}{|c|}{$60 \%$} & \multicolumn{2}{|c|}{$80 \%$} & \multicolumn{2}{|c|}{$100 \%$} \\
\hline & $\mathrm{R} \$$ & 1.259 & $\mathrm{R} \$$ & 1.325 & $\mathrm{R} \$$ & 1.392 & $\mathrm{R} \$$ & 1.461 & $\mathrm{R} \$$ & 1.527 \\
\hline $0-100-0$ & $\mathrm{R} \$$ & 1.261 & $\mathrm{R} \$$ & 1.328 & $\mathrm{R} \$$ & 1.395 & $\mathrm{R} \$$ & 1.463 & $\mathrm{R} \$$ & 1.530 \\
\hline $0-0-100$ & $\mathrm{R} \$$ & 1.134 & $\mathrm{R} \$$ & 1.201 & $\mathrm{R} \$$ & 1.268 & $\mathrm{R} \$$ & 1.334 & $\mathrm{R} \$$ & 1.401 \\
\hline $70-30-0$ & $\mathrm{R} \$$ & 1.259 & $\mathrm{R} \$$ & 1.326 & $\mathrm{R} \$$ & 1.393 & $\mathrm{R} \$$ & 1.460 & $\mathrm{R} \$$ & 1.527 \\
\hline $70-0-30$ & $\mathrm{R} \$$ & 1.222 & $\mathrm{R} \$$ & 1.288 & $\mathrm{R} \$$ & 1.356 & $\mathrm{R} \$$ & 1.423 & $\mathrm{R} \$$ & 1.489 \\
\hline $50-40-10$ & $\mathrm{R} \$$ & 1.247 & $\mathrm{R} \$$ & 1.314 & $\mathrm{R} \$$ & 1.380 & $\mathrm{R} \$$ & 1.447 & $\mathrm{R} \$$ & 1.514 \\
\hline $60-30-10$ & $\mathrm{R} \$$ & 1.246 & $\mathrm{R} \$$ & 1.314 & $\mathrm{R} \$$ & 1.380 & $\mathrm{R} \$$ & 1.447 & $\mathrm{R} \$$ & 1.514 \\
\hline
\end{tabular}


Apêndice 125 - Crédito médio de 1,10\% sobre o valor do investimento, por mensalidade, para construção em 90 dias e compensação de retorno em 24 meses, com simulação da porcentagem de habitações destinadas a cadeirantes, para 100 residentes

\begin{tabular}{|c|c|c|c|c|c|c|c|c|c|c|}
\hline \multirow{3}{*}{$\begin{array}{c}\text { Porcentagem de } \\
\text { residentes com } \\
\text { grau de } \\
\text { dependência } \\
\text { I, II e III } \\
100-0-0\end{array}$} & \multicolumn{10}{|c|}{$\begin{array}{c}\text { Crédito médio de } 1,10 \% \text { sobre o valor do investimento, por mensalidade, com } \\
\text { simulação da porcentagem de habitações destinadas a cadeirantes, para } 100 \\
\text { residentes, com diversos graus de dependência }\end{array}$} \\
\hline & \multicolumn{2}{|c|}{$20 \%$} & \multicolumn{2}{|c|}{$40 \%$} & \multicolumn{2}{|c|}{$60 \%$} & \multicolumn{2}{|c|}{$80 \%$} & \multicolumn{2}{|c|}{$100 \%$} \\
\hline & $\mathrm{R} \$$ & 855 & $\mathrm{R} \$$ & 898 & $\mathrm{R} \$$ & 941 & $\mathrm{R} \$$ & 987 & $\mathrm{R} \$$ & 1.030 \\
\hline $0-100-0$ & $\mathrm{R} \$$ & 856 & $\mathrm{R} \$$ & 899 & $\mathrm{R} \$$ & 944 & $\mathrm{R} \$$ & 987 & $\mathrm{R} \$$ & 1.030 \\
\hline $0-0-100$ & $\mathrm{R} \$$ & 769 & $\mathrm{R} \$$ & 812 & $\mathrm{R} \$$ & 857 & $\mathrm{R} \$$ & 900 & $\mathrm{R} \$$ & 942 \\
\hline $70-30-0$ & $\mathrm{R} \$$ & 856 & $\mathrm{R} \$$ & 899 & $\mathrm{R} \$$ & 942 & $\mathrm{R} \$$ & 987 & $\mathrm{R} \$$ & 1.030 \\
\hline 70-0-30 & $\mathrm{R} \$$ & 835 & $\mathrm{R} \$$ & 878 & $\mathrm{R} \$$ & 921 & $\mathrm{R} \$$ & 964 & $\mathrm{R} \$$ & 1.009 \\
\hline $50-40-10$ & $\mathrm{R} \$$ & 850 & $\mathrm{R} \$$ & 893 & $\mathrm{R} \$$ & 936 & $\mathrm{R} \$$ & 981 & $\mathrm{R} \$$ & 1.024 \\
\hline $60-30-10$ & $\mathrm{R} \$$ & 850 & $\mathrm{R} \$$ & 893 & $\mathrm{R} \$$ & 936 & $\mathrm{R} \$$ & 981 & $\mathrm{R} \$$ & 1.024 \\
\hline
\end{tabular}

Apêndice 126 - Crédito médio de 1,10\% sobre o valor do investimento, por mensalidade, para construção em 90 dias e compensação de retorno em 24 meses, com simulação da porcentagem de habitações destinadas a cadeirantes, para 200 residentes

\begin{tabular}{|c|c|c|c|c|c|c|c|c|c|c|}
\hline \multirow{3}{*}{$\begin{array}{c}\text { Porcentagem de } \\
\text { residentes com } \\
\text { grau de } \\
\text { dependência } \\
\text { I, II e III } \\
100-0-0\end{array}$} & \multicolumn{10}{|c|}{$\begin{array}{c}\text { Crédito médio de } 1,10 \% \text { sobre o valor do investimento, por mensalidade, com } \\
\text { simulação da porcentagem de habitações destinadas a cadeirantes, para } 200 \\
\text { residentes, com diversos graus de dependência }\end{array}$} \\
\hline & \multicolumn{2}{|c|}{$20 \%$} & \multicolumn{2}{|c|}{$40 \%$} & \multicolumn{2}{|c|}{$60 \%$} & \multicolumn{2}{|c|}{$80 \%$} & \multicolumn{2}{|c|}{$100 \%$} \\
\hline & $\mathrm{R} \$$ & 866 & $\mathrm{R} \$$ & 909 & $\mathrm{R} \$$ & 952 & $\mathrm{R} \$$ & 997 & $\mathrm{R} \$$ & 1.040 \\
\hline $0-100-0$ & $\mathrm{R} \$$ & 867 & $\mathrm{R} \$$ & 910 & $\mathrm{R} \$$ & 954 & $\mathrm{R} \$$ & 998 & $\mathrm{R} \$$ & 1.041 \\
\hline $0-0-100$ & $\mathrm{R} \$$ & 782 & $\mathrm{R} \$$ & 825 & $\mathrm{R} \$$ & 869 & $\mathrm{R} \$$ & 913 & $\mathrm{R} \$$ & 956 \\
\hline $70-30-0$ & $\mathrm{R} \$$ & 866 & $\mathrm{R} \$$ & 910 & $\mathrm{R} \$$ & 953 & $\mathrm{R} \$$ & 997 & $\mathrm{R} \$$ & 1.040 \\
\hline 70-0-30 & $\mathrm{R} \$$ & 841 & $\mathrm{R} \$$ & 885 & $\mathrm{R} \$$ & 928 & $\mathrm{R} \$$ & 972 & $\mathrm{R} \$$ & 1.015 \\
\hline $50-40-10$ & $\mathrm{R} \$$ & 855 & $\mathrm{R} \$$ & 900 & $\mathrm{R} \$$ & 942 & $\mathrm{R} \$$ & 986 & $\mathrm{R} \$$ & 1.031 \\
\hline $60-30-10$ & $\mathrm{R} \$$ & 855 & $\mathrm{R} \$$ & 900 & $\mathrm{R} \$$ & 942 & $\mathrm{R} \$$ & 986 & $\mathrm{R} \$$ & 1.030 \\
\hline
\end{tabular}

Apêndice 127 - Crédito médio de 1,10\% sobre o valor do investimento, por mensalidade, para construção em 90 dias e compensação de retorno em 24 meses, com simulação da porcentagem de habitações destinadas a cadeirantes, para 300 residentes

\begin{tabular}{|c|c|c|c|c|c|c|c|c|c|c|}
\hline \multirow{2}{*}{$\begin{array}{c}\text { Porcentagem de } \\
\text { residentes com } \\
\text { grau de } \\
\text { dependência } \\
\text { I, II e III } \\
\end{array}$} & \multicolumn{10}{|c|}{$\begin{array}{c}\text { Crédito médio de } 1,10 \% \text { sobre o valor do investimento, por mensalidade, com } \\
\text { simulação da porcentagem de habitações destinadas a cadeirantes, para } 300 \\
\text { residentes, com diversos graus de dependência }\end{array}$} \\
\hline & \multicolumn{2}{|c|}{$20 \%$} & \multicolumn{2}{|c|}{$40 \%$} & \multicolumn{2}{|c|}{$60 \%$} & \multicolumn{2}{|c|}{$80 \%$} & \multicolumn{2}{|c|}{$100 \%$} \\
\hline $100-0-0$ & $\mathrm{R} \$$ & 805 & $\mathrm{R} \$$ & 847 & $\mathrm{R} \$$ & 889 & $\mathrm{R} \$$ & 931 & $\mathrm{R} \$$ & 973 \\
\hline $0-100-0$ & $\mathrm{R} \$$ & 807 & $\mathrm{R} \$$ & 849 & $\mathrm{R} \$$ & 891 & $\mathrm{R} \$$ & 933 & $\mathrm{R} \$$ & 975 \\
\hline $0-0-100$ & $\mathrm{R} \$$ & 727 & $\mathrm{R} \$$ & 769 & $\mathrm{R} \$$ & 810 & $\mathrm{R} \$$ & 853 & $\mathrm{R} \$$ & 895 \\
\hline $70-30-0$ & $\mathrm{R} \$$ & 806 & $\mathrm{R} \$$ & 848 & $\mathrm{R} \$$ & 890 & $\mathrm{R} \$$ & 932 & $\mathrm{R} \$$ & 974 \\
\hline $70-0-30$ & $\mathrm{R} \$$ & 783 & $\mathrm{R} \$$ & 825 & $\mathrm{R} \$$ & 868 & $\mathrm{R} \$$ & 909 & $\mathrm{R} \$$ & 951 \\
\hline $50-40-10$ & $\mathrm{R} \$$ & 799 & $\mathrm{R} \$$ & 842 & $\mathrm{R} \$$ & 884 & $\mathrm{R} \$$ & 926 & $\mathrm{R} \$$ & 968 \\
\hline $60-30-10$ & $\mathrm{R} \$$ & 799 & $\mathrm{R} \$$ & 842 & $\mathrm{R} \$$ & 883 & $\mathrm{R} \$$ & 925 & $\mathrm{R} \$$ & 967 \\
\hline
\end{tabular}


Apêndice 128 - Crédito médio de 1,10\% sobre o valor do investimento, por mensalidade, para construção em 90 dias e compensação de retorno em 24 meses, com simulação da porcentagem de habitações destinadas a cadeirantes, para 400 residentes

\begin{tabular}{|c|c|c|c|c|c|c|c|c|c|c|}
\hline \multirow{2}{*}{$\begin{array}{c}\text { Porcentagem de } \\
\text { residentes com } \\
\text { grau de } \\
\text { dependência } \\
\text { I, II e III } \\
\end{array}$} & \multicolumn{10}{|c|}{$\begin{array}{c}\text { Crédito médio de } 1,10 \% \text { sobre o valor do investimento, por mensalidade, com } \\
\text { simulação da porcentagem de habitações destinadas a cadeirantes, para } 400 \\
\text { residentes, com diversos graus de dependência }\end{array}$} \\
\hline & \multicolumn{2}{|c|}{$20 \%$} & \multicolumn{2}{|c|}{$40 \%$} & \multicolumn{2}{|c|}{$60 \%$} & \multicolumn{2}{|c|}{$80 \%$} & \multicolumn{2}{|c|}{$100 \%$} \\
\hline $100-0-0$ & $\mathrm{R} \$$ & 791 & $\mathrm{R} \$$ & 833 & $\mathrm{R} \$$ & 875 & $\mathrm{R} \$$ & 918 & $\mathrm{R} \$$ & 960 \\
\hline $0-100-0$ & $\mathrm{R} \$$ & 793 & $\mathrm{R} \$$ & 835 & $\mathrm{R} \$$ & 877 & $\mathrm{R} \$$ & 920 & $\mathrm{R} \$$ & 962 \\
\hline $0-0-100$ & $\mathrm{R} \$$ & 713 & $\mathrm{R} \$$ & 755 & $\mathrm{R} \$$ & 797 & $\mathrm{R} \$$ & 839 & $\mathrm{R} \$$ & 881 \\
\hline $70-30-0$ & $\mathrm{R} \$$ & 791 & $\mathrm{R} \$$ & 834 & $\mathrm{R} \$$ & 876 & $\mathrm{R} \$$ & 918 & $\mathrm{R} \$$ & 960 \\
\hline $70-0-30$ & $\mathrm{R} \$$ & 768 & $\mathrm{R} \$$ & 810 & $\mathrm{R} \$$ & 852 & $\mathrm{R} \$$ & 894 & $\mathrm{R} \$$ & 936 \\
\hline $50-40-10$ & $\mathrm{R} \$$ & 784 & $\mathrm{R} \$$ & 826 & $\mathrm{R} \$$ & 868 & $\mathrm{R} \$$ & 910 & $\mathrm{R} \$$ & 952 \\
\hline $60-30-10$ & $\mathrm{R} \$$ & 783 & $\mathrm{R} \$$ & 826 & $\mathrm{R} \$$ & 868 & $\mathrm{R} \$$ & 910 & $\mathrm{R} \$$ & 951 \\
\hline
\end{tabular}

Apêndice 129 - Crédito médio de 1,20\% sobre o valor do investimento, por mensalidade, para construção em 90 dias e compensação de retorno em 24 meses, com simulação da porcentagem de habitações destinadas a cadeirantes, para 100 residentes

\begin{tabular}{|c|c|c|c|c|c|c|c|c|c|c|}
\hline \multirow{3}{*}{$\begin{array}{c}\text { Porcentagem de } \\
\text { residentes com } \\
\text { grau de } \\
\text { dependência } \\
\text { I, II e III } \\
100-0-0\end{array}$} & \multicolumn{10}{|c|}{$\begin{array}{c}\text { Crédito médio de } 1,20 \% \text { sobre o valor do investimento, por mensalidade, com } \\
\text { simulação da porcentagem de habitações destinadas a cadeirantes, para } 100 \\
\text { residentes, com diversos graus de dependência }\end{array}$} \\
\hline & \multicolumn{2}{|c|}{$20 \%$} & \multicolumn{2}{|c|}{$40 \%$} & \multicolumn{2}{|c|}{$60 \%$} & \multicolumn{2}{|c|}{$80 \%$} & \multicolumn{2}{|c|}{$100 \%$} \\
\hline & $\mathrm{R} \$$ & 933 & $\mathrm{R} \$$ & 980 & $\mathrm{R} \$$ & 1.027 & $\mathrm{R} \$$ & 1.076 & $\mathrm{R} \$$ & 1.123 \\
\hline $0-100-0$ & $\mathrm{R} \$$ & 934 & $\mathrm{R} \$$ & 981 & $\mathrm{R} \$$ & 1.030 & $\mathrm{R} \$$ & 1.077 & $\mathrm{R} \$$ & 1.124 \\
\hline $0-0-100$ & $\mathrm{R} \$$ & 839 & $\mathrm{R} \$$ & 886 & $\mathrm{R} \$$ & 935 & $\mathrm{R} \$$ & 981 & $\mathrm{R} \$$ & 1.028 \\
\hline $70-30-0$ & $\mathrm{R} \$$ & 934 & $\mathrm{R} \$$ & 980 & $\mathrm{R} \$$ & 1.027 & $\mathrm{R} \$$ & 1.077 & $\mathrm{R} \$$ & 1.124 \\
\hline 70-0-30 & $\mathrm{R} \$$ & 911 & $\mathrm{R} \$$ & 958 & $\mathrm{R} \$$ & 1.005 & $\mathrm{R} \$$ & 1.051 & $\mathrm{R} \$$ & 1.101 \\
\hline $50-40-10$ & $\mathrm{R} \$$ & 927 & $\mathrm{R} \$$ & 974 & $\mathrm{R} \$$ & 1.021 & $\mathrm{R} \$$ & 1.070 & $\mathrm{R} \$$ & 1.117 \\
\hline $60-30-10$ & $\mathrm{R} \$$ & 927 & $\mathrm{R} \$$ & 974 & $\mathrm{R} \$$ & 1.021 & $\mathrm{R} \$$ & 1.070 & $\mathrm{R} \$$ & 1.117 \\
\hline
\end{tabular}

Apêndice 130 - Crédito médio de 1,20\% sobre o valor do investimento, por mensalidade, para construção em 90 dias e compensação de retorno em 24 meses, com simulação da porcentagem de habitações destinadas a cadeirantes, para 200 residentes

\begin{tabular}{|c|c|c|c|c|c|c|c|c|c|c|}
\hline \multirow{3}{*}{$\begin{array}{c}\text { Porcentagem de } \\
\text { residentes com } \\
\text { grau de } \\
\text { dependência } \\
\text { I, II e III } \\
100-0-0\end{array}$} & \multicolumn{10}{|c|}{$\begin{array}{c}\text { Crédito médio de } 1,20 \% \text { sobre o valor do investimento, por mensalidade, com } \\
\text { simulação da porcentagem de habitações destinadas a cadeirantes, para } 200 \\
\text { residentes, com diversos graus de dependência }\end{array}$} \\
\hline & \multicolumn{2}{|c|}{$20 \%$} & \multicolumn{2}{|c|}{$40 \%$} & \multicolumn{2}{|c|}{$60 \%$} & \multicolumn{2}{|c|}{$80 \%$} & \multicolumn{2}{|c|}{$100 \%$} \\
\hline & $\mathrm{R} \$$ & 944 & $\mathrm{R} \$$ & 991 & $\mathrm{R} \$$ & 1.039 & $\mathrm{R} \$$ & 1.087 & $\mathrm{R} \$$ & 1.134 \\
\hline $0-100-0$ & $\mathrm{R} \$$ & 946 & $\mathrm{R} \$$ & 993 & $\mathrm{R} \$$ & 1.041 & $\mathrm{R} \$$ & 1.089 & $\mathrm{R} \$$ & 1.136 \\
\hline $0-0-100$ & $\mathrm{R} \$$ & 853 & $\mathrm{R} \$$ & 900 & $\mathrm{R} \$$ & 948 & $\mathrm{R} \$$ & 996 & $\mathrm{R} \$$ & 1.043 \\
\hline $70-30-0$ & $\mathrm{R} \$$ & 944 & $\mathrm{R} \$$ & 992 & $\mathrm{R} \$$ & 1.039 & $\mathrm{R} \$$ & 1.087 & $\mathrm{R} \$$ & 1.134 \\
\hline $70-0-30$ & $\mathrm{R} \$$ & 918 & $\mathrm{R} \$$ & 965 & $\mathrm{R} \$$ & 1.013 & $\mathrm{R} \$$ & 1.061 & $\mathrm{R} \$$ & 1.107 \\
\hline $50-40-10$ & $\mathrm{R} \$$ & 933 & $\mathrm{R} \$$ & 981 & $\mathrm{R} \$$ & 1.028 & $\mathrm{R} \$$ & 1.076 & $\mathrm{R} \$$ & 1.124 \\
\hline $60-30-10$ & $\mathrm{R} \$$ & 933 & $\mathrm{R} \$$ & 981 & $\mathrm{R} \$$ & 1.028 & $\mathrm{R} \$$ & 1.076 & $\mathrm{R} \$$ & 1.124 \\
\hline
\end{tabular}


Apêndice 131 - Crédito médio de 1,20\% sobre o valor do investimento, por mensalidade, para construção em 90 dias e compensação de retorno em 24 meses, com simulação da porcentagem de habitações destinadas a cadeirantes, para 300 residentes

\begin{tabular}{|c|c|c|c|c|c|c|c|c|c|c|}
\hline \multirow{3}{*}{$\begin{array}{c}\text { Porcentagem de } \\
\text { residentes com } \\
\text { grau de } \\
\text { dependência } \\
\text { I, II e III } \\
100-0-0\end{array}$} & \multicolumn{10}{|c|}{$\begin{array}{c}\text { Crédito médio de } 1,20 \% \text { sobre o valor do investimento, por mensalidade, com } \\
\text { simulação da porcentagem de habitações destinadas a cadeirantes, para } 300 \\
\text { residentes, com diversos graus de dependência }\end{array}$} \\
\hline & \multicolumn{2}{|c|}{$20 \%$} & \multicolumn{2}{|c|}{$40 \%$} & \multicolumn{2}{|c|}{$60 \%$} & \multicolumn{2}{|c|}{$80 \%$} & \multicolumn{2}{|c|}{$100 \%$} \\
\hline & $\mathrm{R} \$$ & 878 & $\mathrm{R} \$$ & 924 & $\mathrm{R} \$$ & 970 & $\mathrm{R} \$$ & 1.016 & $\mathrm{R} \$$ & 1.062 \\
\hline $0-100-0$ & $\mathrm{R} \$$ & 880 & $\mathrm{R} \$$ & 926 & $\mathrm{R} \$$ & 972 & $\mathrm{R} \$$ & 1.017 & $\mathrm{R} \$$ & 1.063 \\
\hline $0-0-100$ & $\mathrm{R} \$$ & 793 & $\mathrm{R} \$$ & 839 & $\mathrm{R} \$$ & 884 & $\mathrm{R} \$$ & 930 & $\mathrm{R} \$$ & 976 \\
\hline $70-30-0$ & $\mathrm{R} \$$ & 879 & $\mathrm{R} \$$ & 925 & $\mathrm{R} \$$ & 970 & $\mathrm{R} \$$ & 1.016 & $\mathrm{R} \$$ & 1.062 \\
\hline $70-0-30$ & $\mathrm{R} \$$ & 855 & $\mathrm{R} \$$ & 900 & $\mathrm{R} \$$ & 946 & $\mathrm{R} \$$ & 992 & $\mathrm{R} \$$ & 1.038 \\
\hline $50-40-10$ & $\mathrm{R} \$$ & 872 & $\mathrm{R} \$$ & 918 & $\mathrm{R} \$$ & 964 & $\mathrm{R} \$$ & 1.010 & $\mathrm{R} \$$ & 1.056 \\
\hline $60-30-10$ & $\mathrm{R} \$$ & 872 & $\mathrm{R} \$$ & 918 & $\mathrm{R} \$$ & 963 & $\mathrm{R} \$$ & 1.009 & $\mathrm{R} \$$ & 1.055 \\
\hline
\end{tabular}

Apêndice 132 - Crédito médio de 1,20\% sobre o valor do investimento, por mensalidade, para construção em 90 dias e compensação de retorno em 24 meses, com simulação da porcentagem de habitações destinadas a cadeirantes, para 400 residentes

\begin{tabular}{|c|c|c|c|c|c|c|c|c|c|c|}
\hline \multirow{3}{*}{$\begin{array}{c}\text { Porcentagem de } \\
\text { residentes com } \\
\text { grau de } \\
\text { dependência } \\
\text { I, II e III } \\
100-0-0\end{array}$} & \multicolumn{10}{|c|}{$\begin{array}{c}\text { Crédito médio de } 1,20 \% \text { sobre o valor do investimento, por mensalidade, com } \\
\text { simulação da porcentagem de habitações destinadas a cadeirantes, para } 400 \\
\text { residentes, com diversos graus de dependência }\end{array}$} \\
\hline & \multicolumn{2}{|c|}{$20 \%$} & \multicolumn{2}{|c|}{$40 \%$} & \multicolumn{2}{|c|}{$60 \%$} & \multicolumn{2}{|c|}{$80 \%$} & \multicolumn{2}{|c|}{$100 \%$} \\
\hline & $\mathrm{R} \$$ & 863 & $\mathrm{R} \$$ & 909 & $\mathrm{R} \$$ & 955 & $\mathrm{R} \$$ & 1.002 & $\mathrm{R} \$$ & 1.047 \\
\hline $0-100-0$ & $\mathrm{R} \$$ & 865 & $\mathrm{R} \$$ & 911 & $\mathrm{R} \$$ & 956 & $\mathrm{R} \$$ & 1.003 & $\mathrm{R} \$$ & 1.049 \\
\hline $0-0-100$ & $\mathrm{R} \$$ & 778 & $\mathrm{R} \$$ & 823 & $\mathrm{R} \$$ & 869 & $\mathrm{R} \$$ & 915 & $\mathrm{R} \$$ & 961 \\
\hline $70-30-0$ & $\mathrm{R} \$$ & 863 & $\mathrm{R} \$$ & 910 & $\mathrm{R} \$$ & 955 & $\mathrm{R} \$$ & 1.001 & $\mathrm{R} \$$ & 1.047 \\
\hline 70-0-30 & $\mathrm{R} \$$ & 838 & $\mathrm{R} \$$ & 884 & $\mathrm{R} \$$ & 930 & $\mathrm{R} \$$ & 975 & $\mathrm{R} \$$ & 1.021 \\
\hline $50-40-10$ & $\mathrm{R} \$$ & 855 & $\mathrm{R} \$$ & 901 & $\mathrm{R} \$$ & 947 & $\mathrm{R} \$$ & 992 & $\mathrm{R} \$$ & 1.038 \\
\hline $60-30-10$ & $\mathrm{R} \$$ & 855 & $\mathrm{R} \$$ & 901 & $\mathrm{R} \$$ & 946 & $\mathrm{R} \$$ & 992 & $\mathrm{R} \$$ & 1.038 \\
\hline
\end{tabular}

Apêndice 133 - Crédito médio de 1,30\% sobre o valor do investimento, por mensalidade, para construção em 90 dias e compensação de retorno em 24 meses, com simulação da porcentagem de habitações destinadas a cadeirantes, para 100 residentes

\begin{tabular}{|c|c|c|c|c|c|c|c|c|c|c|}
\hline \multirow{3}{*}{$\begin{array}{c}\text { Porcentagem de } \\
\text { residentes com } \\
\text { grau de } \\
\text { dependência } \\
\text { I, II e III } \\
100-0-0\end{array}$} & \multicolumn{10}{|c|}{$\begin{array}{c}\text { Crédito médio de } 1,30 \% \text { sobre o valor do investimento, por mensalidade, com } \\
\text { simulação da porcentagem de habitações destinadas a cadeirantes, para } 100 \\
\text { residentes, com diversos graus de dependência }\end{array}$} \\
\hline & \multicolumn{2}{|c|}{$20 \%$} & \multicolumn{2}{|c|}{$40 \%$} & \multicolumn{2}{|c|}{$60 \%$} & \multicolumn{2}{|c|}{$80 \%$} & \multicolumn{2}{|c|}{$100 \%$} \\
\hline & $\mathrm{R} \$$ & 1.011 & $\mathrm{R} \$$ & 1.062 & $\mathrm{R} \$$ & 1.112 & $\mathrm{R} \$$ & 1.166 & $\mathrm{R} \$$ & 1.217 \\
\hline 0-100-0 & $\mathrm{R} \$$ & 1.012 & $\mathrm{R} \$$ & 1.063 & $\mathrm{R} \$$ & 1.116 & $\mathrm{R} \$$ & 1.167 & $\mathrm{R} \$$ & 1.218 \\
\hline 0-0-100 & $\mathrm{R} \$$ & 908 & $\mathrm{R} \$$ & 959 & $\mathrm{R} \$$ & 1.013 & $\mathrm{R} \$$ & 1.063 & $\mathrm{R} \$$ & 1.114 \\
\hline $70-30-0$ & $\mathrm{R} \$$ & 1.011 & $\mathrm{R} \$$ & 1.062 & $\mathrm{R} \$$ & 1.113 & $\mathrm{R} \$$ & 1.166 & $\mathrm{R} \$$ & 1.217 \\
\hline $70-0-30$ & $\mathrm{R} \$$ & 987 & $\mathrm{R} \$$ & 1.038 & $\mathrm{R} \$$ & 1.088 & $\mathrm{R} \$$ & 1.139 & $\mathrm{R} \$$ & 1.193 \\
\hline $50-40-10$ & $\mathrm{R} \$$ & 1.005 & $\mathrm{R} \$$ & 1.055 & $\mathrm{R} \$$ & 1.106 & $\mathrm{R} \$$ & 1.160 & $\mathrm{R} \$$ & 1.210 \\
\hline $60-30-10$ & $\mathrm{R} \$$ & 1.004 & $\mathrm{R} \$$ & 1.055 & $\mathrm{R} \$$ & 1.106 & $\mathrm{R} \$$ & 1.160 & $\mathrm{R} \$$ & 1.210 \\
\hline
\end{tabular}


Apêndice 134 - Crédito médio de 1,30\% sobre o valor do investimento, por mensalidade, para construção em 90 dias e compensação de retorno em 24 meses, com simulação da porcentagem de habitações destinadas a cadeirantes, para 200 residentes

\begin{tabular}{|c|c|c|c|c|c|c|c|c|c|c|}
\hline \multirow{3}{*}{$\begin{array}{c}\text { Porcentagem de } \\
\text { residentes com } \\
\text { grau de } \\
\text { dependência } \\
\text { I, II e III } \\
100-0-0\end{array}$} & \multicolumn{10}{|c|}{$\begin{array}{c}\text { Crédito médio de } 1,30 \% \text { sobre o valor do investimento, por mensalidade, com } \\
\text { simulação da porcentagem de habitações destinadas a cadeirantes, para } 200 \\
\text { residentes, com diversos graus de dependência }\end{array}$} \\
\hline & \multicolumn{2}{|c|}{$20 \%$} & \multicolumn{2}{|c|}{$40 \%$} & \multicolumn{2}{|c|}{$60 \%$} & \multicolumn{2}{|c|}{$80 \%$} & \multicolumn{2}{|c|}{$100 \%$} \\
\hline & $\mathrm{R} \$$ & 1.023 & $\mathrm{R} \$$ & 1.074 & $\mathrm{R} \$$ & 1.126 & $\mathrm{R} \$$ & 1.178 & $\mathrm{R} \$$ & 1.229 \\
\hline $0-100-0$ & $\mathrm{R} \$$ & 1.025 & $\mathrm{R} \$$ & 1.076 & $\mathrm{R} \$$ & 1.128 & $\mathrm{R} \$$ & 1.180 & $\mathrm{R} \$$ & 1.231 \\
\hline $0-0-100$ & $\mathrm{R} \$$ & 924 & $\mathrm{R} \$$ & 975 & $\mathrm{R} \$$ & 1.027 & $\mathrm{R} \$$ & 1.079 & $\mathrm{R} \$$ & 1.130 \\
\hline $70-30-0$ & $\mathrm{R} \$$ & 1.023 & $\mathrm{R} \$$ & 1.075 & $\mathrm{R} \$$ & 1.126 & $\mathrm{R} \$$ & 1.178 & $\mathrm{R} \$$ & 1.229 \\
\hline $70-0-30$ & $\mathrm{R} \$$ & 994 & $\mathrm{R} \$$ & 1.046 & $\mathrm{R} \$$ & 1.097 & $\mathrm{R} \$$ & 1.149 & $\mathrm{R} \$$ & 1.200 \\
\hline $50-40-10$ & $\mathrm{R} \$$ & 1.011 & $\mathrm{R} \$$ & 1.063 & $\mathrm{R} \$$ & 1.114 & $\mathrm{R} \$$ & 1.166 & $\mathrm{R} \$$ & 1.218 \\
\hline $60-30-10$ & $\mathrm{R} \$$ & 1.011 & $\mathrm{R} \$$ & 1.063 & $\mathrm{R} \$$ & 1.114 & $\mathrm{R} \$$ & 1.166 & $\mathrm{R} \$$ & 1.218 \\
\hline
\end{tabular}

Apêndice 135 - Crédito médio de 1,30\% sobre o valor do investimento, por mensalidade, para construção em 90 dias e compensação de retorno em 24 meses, com simulação da porcentagem de habitações destinadas a cadeirantes, para 300 residentes

\begin{tabular}{|c|c|c|c|c|c|c|c|c|c|c|}
\hline \multirow{3}{*}{$\begin{array}{c}\text { Porcentagem de } \\
\text { residentes com } \\
\text { grau de } \\
\text { dependência } \\
\text { I, II e III } \\
100-0-0\end{array}$} & \multicolumn{10}{|c|}{$\begin{array}{c}\text { Crédito médio de } 1,30 \% \text { sobre o valor do investimento, por mensalidade, com } \\
\text { simulação da porcentagem de habitações destinadas a cadeirantes, para } 300 \\
\text { residentes, com diversos graus de dependência }\end{array}$} \\
\hline & \multicolumn{2}{|c|}{$20 \%$} & \multicolumn{2}{|c|}{$40 \%$} & \multicolumn{2}{|c|}{$60 \%$} & \multicolumn{2}{|c|}{$80 \%$} & \multicolumn{2}{|c|}{$100 \%$} \\
\hline & $\mathrm{R} \$$ & 952 & $\mathrm{R} \$$ & 1.001 & $\mathrm{R} \$$ & 1.051 & $\mathrm{R} \$$ & 1.101 & $\mathrm{R} \$$ & 1.150 \\
\hline $0-100-0$ & $\mathrm{R} \$$ & 954 & $\mathrm{R} \$$ & 1.004 & $\mathrm{R} \$$ & 1.053 & $\mathrm{R} \$$ & 1.102 & $\mathrm{R} \$$ & 1.152 \\
\hline $0-0-100$ & $\mathrm{R} \$$ & 859 & $\mathrm{R} \$$ & 909 & $\mathrm{R} \$$ & 958 & $\mathrm{R} \$$ & 1.008 & $\mathrm{R} \$$ & 1.057 \\
\hline $70-30-0$ & $\mathrm{R} \$$ & 953 & $\mathrm{R} \$$ & 1.002 & $\mathrm{R} \$$ & 1.051 & $\mathrm{R} \$$ & 1.101 & $\mathrm{R} \$$ & 1.151 \\
\hline $70-0-30$ & $\mathrm{R} \$$ & 926 & $\mathrm{R} \$$ & 975 & $\mathrm{R} \$$ & 1.025 & $\mathrm{R} \$$ & 1.074 & $\mathrm{R} \$$ & 1.124 \\
\hline $50-40-10$ & $\mathrm{R} \$$ & 945 & $\mathrm{R} \$$ & 995 & $\mathrm{R} \$$ & 1.044 & $\mathrm{R} \$$ & 1.094 & $\mathrm{R} \$$ & 1.144 \\
\hline $60-30-10$ & $\mathrm{R} \$$ & 945 & $\mathrm{R} \$$ & 995 & $\mathrm{R} \$$ & 1.043 & $\mathrm{R} \$$ & 1.093 & $\mathrm{R} \$$ & 1.143 \\
\hline
\end{tabular}

Apêndice 136 - Crédito médio de 1,30\% sobre o valor do investimento, por mensalidade, para construção em 90 dias e compensação de retorno em 24 meses, com simulação da porcentagem de habitações destinadas a cadeirantes, para 400 residentes

\begin{tabular}{|c|c|c|c|c|c|c|c|c|c|c|}
\hline \multirow{3}{*}{$\begin{array}{c}\text { Porcentagem de } \\
\text { residentes com } \\
\text { grau de } \\
\text { dependência } \\
\text { I, II e III } \\
100-0-0\end{array}$} & \multicolumn{10}{|c|}{$\begin{array}{c}\text { Crédito médio de } 1,30 \% \text { sobre o valor do investimento, por mensalidade, com } \\
\text { simulação da porcentagem de habitações destinadas a cadeirantes, para } 400 \\
\text { residentes, com diversos graus de dependência }\end{array}$} \\
\hline & \multicolumn{2}{|c|}{$20 \%$} & \multicolumn{2}{|c|}{$40 \%$} & \multicolumn{2}{|c|}{$60 \%$} & \multicolumn{2}{|c|}{$80 \%$} & \multicolumn{2}{|c|}{$100 \%$} \\
\hline & $\mathrm{R} \$$ & 935 & $\mathrm{R} \$$ & 985 & $\mathrm{R} \$$ & 1.034 & $\mathrm{R} \$$ & 1.085 & $\mathrm{R} \$$ & 1.135 \\
\hline $0-100-0$ & $\mathrm{R} \$$ & 937 & $\mathrm{R} \$$ & 987 & $\mathrm{R} \$$ & 1.036 & $\mathrm{R} \$$ & 1.087 & $\mathrm{R} \$$ & 1.136 \\
\hline $0-0-100$ & $\mathrm{R} \$$ & 843 & $\mathrm{R} \$$ & 892 & $\mathrm{R} \$$ & 942 & $\mathrm{R} \$$ & 991 & $\mathrm{R} \$$ & 1.041 \\
\hline $70-30-0$ & $\mathrm{R} \$$ & 935 & $\mathrm{R} \$$ & 985 & $\mathrm{R} \$$ & 1.035 & $\mathrm{R} \$$ & 1.085 & $\mathrm{R} \$$ & 1.134 \\
\hline $70-0-30$ & $\mathrm{R} \$$ & 908 & $\mathrm{R} \$$ & 957 & $\mathrm{R} \$$ & 1.007 & $\mathrm{R} \$$ & 1.057 & $\mathrm{R} \$$ & 1.106 \\
\hline $50-40-10$ & $\mathrm{R} \$$ & 926 & $\mathrm{R} \$$ & 976 & $\mathrm{R} \$$ & 1.025 & $\mathrm{R} \$$ & 1.075 & $\mathrm{R} \$$ & 1.125 \\
\hline $60-30-10$ & $\mathrm{R} \$$ & 926 & $\mathrm{R} \$$ & 976 & $\mathrm{R} \$$ & 1.025 & $\mathrm{R} \$$ & 1.075 & $\mathrm{R} \$$ & 1.124 \\
\hline
\end{tabular}


Apêndice 137 - Crédito médio de 1,40\% sobre o valor do investimento, por mensalidade, para construção em 90 dias e compensação de retorno em 24 meses, com simulação da porcentagem de habitações destinadas a cadeirantes, para 100 residentes

\begin{tabular}{|c|c|c|c|c|c|c|c|c|c|c|}
\hline \multirow{3}{*}{$\begin{array}{c}\text { Porcentagem de } \\
\text { residentes com } \\
\text { grau de } \\
\text { dependência } \\
\text { I, II e III } \\
100-0-0\end{array}$} & \multicolumn{10}{|c|}{$\begin{array}{c}\text { Crédito médio de } 1,40 \% \text { sobre o valor do investimento, por mensalidade, com } \\
\text { simulação da porcentagem de habitações destinadas a cadeirantes, para } 100 \\
\text { residentes, com diversos graus de dependência }\end{array}$} \\
\hline & \multicolumn{2}{|c|}{$20 \%$} & \multicolumn{2}{|c|}{$40 \%$} & \multicolumn{2}{|c|}{$60 \%$} & \multicolumn{2}{|c|}{$80 \%$} & \multicolumn{2}{|c|}{$100 \%$} \\
\hline & $\mathrm{R} \$$ & 1.089 & $\mathrm{R} \$$ & 1.143 & $\mathrm{R} \$$ & 1.198 & $\mathrm{R} \$$ & 1.256 & $\mathrm{R} \$$ & 1.310 \\
\hline $0-100-0$ & $\mathrm{R} \$$ & 1.090 & $\mathrm{R} \$$ & 1.144 & $\mathrm{R} \$$ & 1.202 & $\mathrm{R} \$$ & 1.257 & $\mathrm{R} \$$ & 1.311 \\
\hline $0-0-100$ & $\mathrm{R} \$$ & 978 & $\mathrm{R} \$$ & 1.033 & $\mathrm{R} \$$ & 1.090 & $\mathrm{R} \$$ & 1.145 & $\mathrm{R} \$$ & 1.200 \\
\hline $70-30-0$ & $\mathrm{R} \$$ & 1.089 & $\mathrm{R} \$$ & 1.144 & $\mathrm{R} \$$ & 1.198 & $\mathrm{R} \$$ & 1.256 & $\mathrm{R} \$$ & 1.311 \\
\hline 70-0-30 & $\mathrm{R} \$$ & 1.062 & $\mathrm{R} \$$ & 1.118 & $\mathrm{R} \$$ & 1.172 & $\mathrm{R} \$$ & 1.227 & $\mathrm{R} \$$ & 1.285 \\
\hline $50-40-10$ & $\mathrm{R} \$$ & 1.082 & $\mathrm{R} \$$ & 1.137 & $\mathrm{R} \$$ & 1.191 & $\mathrm{R} \$$ & 1.249 & $\mathrm{R} \$$ & 1.304 \\
\hline $60-30-10$ & $\mathrm{R} \$$ & 1.082 & $\mathrm{R} \$$ & 1.136 & $\mathrm{R} \$$ & 1.191 & $\mathrm{R} \$$ & 1.249 & $\mathrm{R} \$$ & 1.303 \\
\hline
\end{tabular}

Apêndice 138 - Crédito médio de 1,40\% sobre o valor do investimento, por mensalidade, para construção em 90 dias e compensação de retorno em 24 meses, com simulação da porcentagem de habitações destinadas a cadeirantes, para 200 residentes

\begin{tabular}{|c|c|c|c|c|c|c|c|c|c|c|}
\hline \multirow{3}{*}{$\begin{array}{c}\text { Porcentagem de } \\
\text { residentes com } \\
\text { grau de } \\
\text { dependência } \\
\text { I, II e III } \\
100-0-0\end{array}$} & \multicolumn{10}{|c|}{$\begin{array}{c}\text { Crédito médio de } 1,40 \% \text { sobre o valor do investimento, por mensalidade, com } \\
\text { simulação da porcentagem de habitações destinadas a cadeirantes, para } 200 \\
\text { residentes, com diversos graus de dependência }\end{array}$} \\
\hline & \multicolumn{2}{|c|}{$20 \%$} & \multicolumn{2}{|c|}{$40 \%$} & \multicolumn{2}{|c|}{$60 \%$} & \multicolumn{2}{|c|}{$80 \%$} & \multicolumn{2}{|c|}{$100 \%$} \\
\hline & $\mathrm{R} \$$ & 1.102 & $\mathrm{R} \$$ & 1.156 & $\mathrm{R} \$$ & 1.212 & $\mathrm{R} \$$ & 1.268 & $\mathrm{R} \$$ & 1.323 \\
\hline $0-100-0$ & $\mathrm{R} \$$ & 1.104 & $\mathrm{R} \$$ & 1.158 & $\mathrm{R} \$$ & 1.214 & $\mathrm{R} \$$ & 1.270 & $\mathrm{R} \$$ & 1.325 \\
\hline $0-0-100$ & $\mathrm{R} \$$ & 995 & $\mathrm{R} \$$ & 1.050 & $\mathrm{R} \$$ & 1.105 & $\mathrm{R} \$$ & 1.162 & $\mathrm{R} \$$ & 1.216 \\
\hline $70-30-0$ & $\mathrm{R} \$$ & 1.102 & $\mathrm{R} \$$ & 1.158 & $\mathrm{R} \$$ & 1.212 & $\mathrm{R} \$$ & 1.269 & $\mathrm{R} \$$ & 1.323 \\
\hline $70-0-30$ & $\mathrm{R} \$$ & 1.071 & $\mathrm{R} \$$ & 1.126 & $\mathrm{R} \$$ & 1.181 & $\mathrm{R} \$$ & 1.237 & R\$ & 1.292 \\
\hline $50-40-10$ & $\mathrm{R} \$$ & 1.089 & $\mathrm{R} \$$ & 1.145 & $\mathrm{R} \$$ & 1.199 & $\mathrm{R} \$$ & 1.255 & $\mathrm{R} \$$ & 1.312 \\
\hline $60-30-10$ & $\mathrm{R} \$$ & 1.089 & $\mathrm{R} \$$ & 1.145 & $\mathrm{R} \$$ & 1.199 & $\mathrm{R} \$$ & 1.255 & $\mathrm{R} \$$ & 1.312 \\
\hline
\end{tabular}

Apêndice 139 - Crédito médio de 1,40\% sobre o valor do investimento, por mensalidade, para construção em 90 dias e compensação de retorno em 24 meses, com simulação da porcentagem de habitações destinadas a cadeirantes, para 300 residentes

\begin{tabular}{|c|c|c|c|c|c|c|c|c|c|c|}
\hline \multirow{2}{*}{$\begin{array}{c}\text { Porcentagem de } \\
\text { residentes com } \\
\text { grau de } \\
\text { dependência } \\
\text { I, II e III } \\
\end{array}$} & \multicolumn{10}{|c|}{$\begin{array}{c}\text { Crédito médio de } 1,40 \% \text { sobre o valor do investimento, por mensalidade, com } \\
\text { simulação da porcentagem de habitações destinadas a cadeirantes, para } 300 \\
\text { residentes, com diversos graus de dependência }\end{array}$} \\
\hline & \multicolumn{2}{|c|}{$20 \%$} & \multicolumn{2}{|c|}{$40 \%$} & \multicolumn{2}{|c|}{$60 \%$} & \multicolumn{2}{|c|}{$80 \%$} & \multicolumn{2}{|c|}{$100 \%$} \\
\hline 100-0-0 & $\mathrm{R} \$$ & 1.025 & $\mathrm{R} \$$ & 1.078 & $\mathrm{R} \$$ & 1.132 & $\mathrm{R} \$$ & 1.185 & $\mathrm{R} \$$ & 1.239 \\
\hline $0-100-0$ & $\mathrm{R} \$$ & 1.027 & $\mathrm{R} \$$ & 1.081 & $\mathrm{R} \$$ & 1.134 & $\mathrm{R} \$$ & 1.187 & $\mathrm{R} \$$ & 1.241 \\
\hline 0-0-100 & $\mathrm{R} \$$ & 925 & $\mathrm{R} \$$ & 979 & $\mathrm{R} \$$ & 1.032 & $\mathrm{R} \$$ & 1.085 & $\mathrm{R} \$$ & 1.139 \\
\hline $70-30-0$ & $\mathrm{R} \$$ & 1.026 & $\mathrm{R} \$$ & 1.079 & $\mathrm{R} \$$ & 1.132 & $\mathrm{R} \$$ & 86 & $\mathrm{R} \$$ & 1.239 \\
\hline $70-0-30$ & $\mathrm{R} \$$ & 997 & $\mathrm{R} \$$ & 1.050 & $\mathrm{R} \$$ & 1.104 & $\mathrm{R} \$$ & 1.157 & $\mathrm{R} \$$ & 1.210 \\
\hline $50-40-10$ & $\mathrm{R} \$$ & 1.017 & $\mathrm{R} \$$ & 1.071 & $\mathrm{R} \$$ & 1.124 & $\mathrm{R} \$$ & 1.178 & $\mathrm{R} \$$ & 1.232 \\
\hline $60-30-10$ & $\mathrm{R} \$$ & 1.017 & $\mathrm{R} \$$ & 1.071 & $\mathrm{R} \$$ & 1.124 & $\mathrm{R} \$$ & 1.177 & $\mathrm{R} \$$ & 1.231 \\
\hline
\end{tabular}


Apêndice 140 - Crédito médio de 1,40\% sobre o valor do investimento, por mensalidade, para construção em 90 dias e compensação de retorno em 24 meses, com simulação da porcentagem de habitações destinadas a cadeirantes, para 400 residentes

\begin{tabular}{|c|c|c|c|c|c|c|c|c|c|c|}
\hline \multirow{3}{*}{$\begin{array}{c}\text { Porcentagem de } \\
\text { residentes com } \\
\text { grau de } \\
\text { dependência } \\
\text { I, II e III } \\
100-0-0\end{array}$} & \multicolumn{10}{|c|}{$\begin{array}{c}\text { Crédito médio de } 1,40 \% \text { sobre o valor do investimento, por mensalidade, com } \\
\text { simulação da porcentagem de habitações destinadas a cadeirantes, para } 400 \\
\text { residentes, com diversos graus de dependência }\end{array}$} \\
\hline & \multicolumn{2}{|c|}{$20 \%$} & \multicolumn{2}{|c|}{$40 \%$} & \multicolumn{2}{|c|}{$60 \%$} & \multicolumn{2}{|c|}{$80 \%$} & \multicolumn{2}{|c|}{$100 \%$} \\
\hline & $\mathrm{R} \$$ & 1.007 & $\mathrm{R} \$$ & 1.060 & $\mathrm{R} \$$ & 1.114 & $\mathrm{R} \$$ & 1.168 & $\mathrm{R} \$$ & 1.222 \\
\hline 0-100-0 & $\mathrm{R} \$$ & 1.009 & $\mathrm{R} \$$ & 1.062 & $\mathrm{R} \$$ & 1.116 & $\mathrm{R} \$$ & 1.170 & $\mathrm{R} \$$ & 1.224 \\
\hline $0-0-100$ & $\mathrm{R} \$$ & 907 & $\mathrm{R} \$$ & 961 & $\mathrm{R} \$$ & 1.014 & $\mathrm{R} \$$ & 1.067 & $\mathrm{R} \$$ & 1.121 \\
\hline $70-30-0$ & $\mathrm{R} \$$ & 1.007 & $\mathrm{R} \$$ & 1.061 & $\mathrm{R} \$$ & 1.115 & $\mathrm{R} \$$ & 1.168 & $\mathrm{R} \$$ & 1.221 \\
\hline 70-0-30 & $\mathrm{R} \$$ & 977 & $\mathrm{R} \$$ & 1.031 & $\mathrm{R} \$$ & 1.085 & $\mathrm{R} \$$ & 1.138 & $\mathrm{R} \$$ & 1.191 \\
\hline $50-40-10$ & $\mathrm{R} \$$ & 998 & $\mathrm{R} \$$ & 1.051 & $\mathrm{R} \$$ & 1.104 & $\mathrm{R} \$$ & 1.158 & $\mathrm{R} \$$ & 1.211 \\
\hline $60-30-10$ & $\mathrm{R} \$$ & 997 & $\mathrm{R} \$$ & 1.051 & $\mathrm{R} \$$ & 1.104 & $\mathrm{R} \$$ & 1.158 & $\mathrm{R} \$$ & 1.211 \\
\hline
\end{tabular}

Apêndice 141 - Crédito médio de 1,50\% sobre o valor do investimento, por mensalidade, para construção em 90 dias e compensação de retorno em 24 meses, com simulação da porcentagem de habitações destinadas a cadeirantes, para 100 residentes

\begin{tabular}{|c|c|c|c|c|c|c|c|c|c|c|}
\hline \multirow{2}{*}{$\begin{array}{l}\text { Porcentagem de } \\
\text { residentes com } \\
\text { grau de } \\
\text { dependência } \\
\text { I, II e III } \\
\end{array}$} & \multicolumn{10}{|c|}{$\begin{array}{c}\text { Crédito médio de } 1,50 \% \text { sobre o valor do investimento, por mensalidade, com } \\
\text { simulação da porcentagem de habitações destinadas a cadeirantes, para } 100 \\
\text { residentes, com diversos graus de dependência }\end{array}$} \\
\hline & \multicolumn{2}{|c|}{$20 \%$} & \multicolumn{2}{|c|}{$40 \%$} & \multicolumn{2}{|c|}{$60 \%$} & \multicolumn{2}{|c|}{$80 \%$} & \multicolumn{2}{|c|}{$100 \%$} \\
\hline $100-0-0$ & $\mathrm{R} \$$ & 1.167 & $\mathrm{R} \$$ & 1.225 & $\mathrm{R} \$$ & 1.284 & $\mathrm{R} \$$ & 1.345 & $\mathrm{R} \$$ & 1.404 \\
\hline 0-100-0 & $\mathrm{R} \$$ & 1.167 & $\mathrm{R} \$$ & 1.226 & $\mathrm{R} \$$ & 1.287 & $\mathrm{R} \$$ & 1.346 & $\mathrm{R} \$$ & 1.405 \\
\hline $0-0-100$ & $\mathrm{R} \$$ & 1.048 & $\mathrm{R} \$$ & 1.107 & $\mathrm{R} \$$ & 1.168 & $\mathrm{R} \$$ & 1.227 & $\mathrm{R} \$$ & 1.285 \\
\hline $70-30-0$ & $\mathrm{R} \$$ & 1.167 & $\mathrm{R} \$$ & 1.226 & $\mathrm{R} \$$ & 1.284 & $\mathrm{R} \$$ & 1.346 & $\mathrm{R} \$$ & 1.404 \\
\hline $70-0-30$ & $\mathrm{R} \$$ & 1.138 & $\mathrm{R} \$$ & 1.197 & $\mathrm{R} \$$ & 1.256 & $\mathrm{R} \$$ & 1.314 & $\mathrm{R} \$$ & 1.376 \\
\hline $50-40-10$ & $\mathrm{R} \$$ & 1.159 & $\mathrm{R} \$$ & 1.218 & $\mathrm{R} \$$ & 1.276 & $\mathrm{R} \$$ & 1.338 & $\mathrm{R} \$$ & 1.397 \\
\hline $60-30-10$ & $\mathrm{R} \$$ & 1.159 & $\mathrm{R} \$$ & 1.218 & $\mathrm{R} \$$ & 1.276 & $\mathrm{R} \$$ & 1.338 & $\mathrm{R} \$$ & 1.397 \\
\hline
\end{tabular}

Apêndice 142 - Crédito médio de 1,50\% sobre o valor do investimento, por mensalidade, para construção em 90 dias e compensação de retorno em 24 meses, com simulação da porcentagem de habitações destinadas a cadeirantes, para 200 residentes

\begin{tabular}{|c|c|c|c|c|c|c|c|c|c|c|}
\hline \multirow{3}{*}{$\begin{array}{c}\text { Porcentagem de } \\
\text { residentes com } \\
\text { grau de } \\
\text { dependência } \\
\text { I, II e III } \\
100-0-0\end{array}$} & \multicolumn{10}{|c|}{$\begin{array}{c}\text { Crédito médio de } 1,50 \% \text { sobre o valor do investimento, por mensalidade, com } \\
\text { simulação da porcentagem de habitações destinadas a cadeirantes, para } 200 \\
\text { residentes, com diversos graus de dependência }\end{array}$} \\
\hline & \multicolumn{2}{|c|}{$20 \%$} & \multicolumn{2}{|c|}{$40 \%$} & \multicolumn{2}{|c|}{$60 \%$} & \multicolumn{2}{|c|}{$80 \%$} & \multicolumn{2}{|c|}{$100 \%$} \\
\hline & $\mathrm{R} \$$ & 1.180 & $\mathrm{R} \$$ & 1.239 & $\mathrm{R} \$$ & 1.299 & $\mathrm{R} \$$ & 1.359 & $\mathrm{R} \$$ & 1.418 \\
\hline 0-100-0 & $\mathrm{R} \$$ & 1.182 & $\mathrm{R} \$$ & 1.241 & $\mathrm{R} \$$ & 1.301 & $\mathrm{R} \$$ & 1.361 & $\mathrm{R} \$$ & 1.420 \\
\hline 0-0-100 & $\mathrm{R} \$$ & 1.066 & $\mathrm{R} \$$ & 1.125 & $\mathrm{R} \$$ & 1.184 & $\mathrm{R} \$$ & 1.245 & $\mathrm{R} \$$ & 1.303 \\
\hline $70-30-0$ & $\mathrm{R} \$$ & 1.181 & $\mathrm{R} \$$ & 1.240 & $\mathrm{R} \$$ & 1.299 & $\mathrm{R} \$$ & 1.359 & R\$ & 1.418 \\
\hline $70-0-30$ & $\mathrm{R} \$$ & 1.147 & $\mathrm{R} \$$ & 1.207 & $\mathrm{R} \$$ & 1.266 & $\mathrm{R} \$$ & 1.326 & $\mathrm{R} \$$ & 1.384 \\
\hline $50-40-10$ & $\mathrm{R} \$$ & 1.167 & $\mathrm{R} \$$ & 1.227 & $\mathrm{R} \$$ & 1.285 & $\mathrm{R} \$$ & 1.345 & $\mathrm{R} \$$ & 1.405 \\
\hline $60-30-10$ & $\mathrm{R} \$$ & 1.166 & $\mathrm{R} \$$ & 1.227 & $\mathrm{R} \$$ & 1.285 & $\mathrm{R} \$$ & 1.345 & $\mathrm{R} \$$ & 1.405 \\
\hline
\end{tabular}


Apêndice 143 - Crédito médio de 1,50\% sobre o valor do investimento, por mensalidade, para construção em 90 dias e compensação de retorno em 24 meses, com simulação da porcentagem de habitações destinadas a cadeirantes, para 300 residentes

\begin{tabular}{|c|c|c|c|c|c|c|c|c|c|c|}
\hline \multirow{3}{*}{$\begin{array}{c}\text { Porcentagem de } \\
\text { residentes com } \\
\text { grau de } \\
\text { dependência } \\
\text { I, II e III } \\
100-0-0\end{array}$} & \multicolumn{10}{|c|}{$\begin{array}{c}\text { Crédito médio de } 1,50 \% \text { sobre o valor do investimento, por mensalidade, com } \\
\text { simulação da porcentagem de habitações destinadas a cadeirantes, para } 300 \\
\text { residentes, com diversos graus de dependência }\end{array}$} \\
\hline & \multicolumn{2}{|c|}{$20 \%$} & \multicolumn{2}{|c|}{$40 \%$} & \multicolumn{2}{|c|}{$60 \%$} & \multicolumn{2}{|c|}{$80 \%$} & \multicolumn{2}{|c|}{$100 \%$} \\
\hline & $\mathrm{R} \$$ & 1.098 & $\mathrm{R} \$$ & 1.155 & $\mathrm{R} \$$ & 1.213 & $\mathrm{R} \$$ & 1.270 & $\mathrm{R} \$$ & 1.327 \\
\hline 0-100-0 & $\mathrm{R} \$$ & 1.101 & $\mathrm{R} \$$ & 1.158 & $\mathrm{R} \$$ & 1.214 & $\mathrm{R} \$$ & 1.272 & $\mathrm{R} \$$ & 1.329 \\
\hline $0-0-100$ & $\mathrm{R} \$$ & 991 & $\mathrm{R} \$$ & 1.049 & $\mathrm{R} \$$ & 1.105 & $\mathrm{R} \$$ & 1.163 & $\mathrm{R} \$$ & 1.220 \\
\hline 70-30-0 & $\mathrm{R} \$$ & 1.099 & $\mathrm{R} \$$ & 1.157 & $\mathrm{R} \$$ & 1.213 & $\mathrm{R} \$$ & 1.270 & $\mathrm{R} \$$ & 1.328 \\
\hline 70-0-30 & $\mathrm{R} \$$ & 1.068 & $\mathrm{R} \$$ & 1.126 & $\mathrm{R} \$$ & 1.183 & $\mathrm{R} \$$ & 1.240 & $\mathrm{R} \$$ & 1.297 \\
\hline $50-40-10$ & $\mathrm{R} \$$ & 1.090 & $\mathrm{R} \$$ & 1.148 & $\mathrm{R} \$$ & 1.205 & $\mathrm{R} \$$ & 1.262 & $\mathrm{R} \$$ & 1.320 \\
\hline $60-30-10$ & $\mathrm{R} \$$ & 1.090 & $\mathrm{R} \$$ & 1.148 & $\mathrm{R} \$$ & 1.204 & $\mathrm{R} \$$ & 1.261 & $\mathrm{R} \$$ & 1.319 \\
\hline
\end{tabular}

Apêndice 144 - Crédito médio de 1,50\% sobre o valor do investimento, por mensalidade, para construção em 90 dias e compensação de retorno em 24 meses, com simulação da porcentagem de habitações destinadas a cadeirantes, para 400 residentes

\begin{tabular}{|c|c|c|c|c|c|c|c|c|c|c|}
\hline \multirow{2}{*}{$\begin{array}{l}\text { Porcentagem de } \\
\text { residentes com } \\
\text { grau de } \\
\text { dependência } \\
\text { I, II e III } \\
\end{array}$} & \multicolumn{10}{|c|}{$\begin{array}{c}\text { Crédito médio de } 1,50 \% \text { sobre o valor do investimento, por mensalidade, com } \\
\text { simulação da porcentagem de habitações destinadas a cadeirantes, para } 400 \\
\text { residentes, com diversos graus de dependência }\end{array}$} \\
\hline & \multicolumn{2}{|c|}{$20 \%$} & \multicolumn{2}{|c|}{$40 \%$} & \multicolumn{2}{|c|}{$60 \%$} & \multicolumn{2}{|c|}{$80 \%$} & \multicolumn{2}{|c|}{$100 \%$} \\
\hline $100-0-0$ & $\mathrm{R} \$$ & 1.079 & $\mathrm{R} \$$ & 1.136 & $\mathrm{R} \$$ & 1.193 & $\mathrm{R} \$$ & 1.252 & $\mathrm{R} \$$ & 1.309 \\
\hline 0-100-0 & $\mathrm{R} \$$ & 1.081 & $\mathrm{R} \$$ & 1.138 & $\mathrm{R} \$$ & 1.195 & $\mathrm{R} \$$ & 1.254 & $\mathrm{R} \$$ & 1.311 \\
\hline $0-0-100$ & $\mathrm{R} \$$ & 972 & $\mathrm{R} \$$ & 1.029 & $\mathrm{R} \$$ & 1.086 & $\mathrm{R} \$$ & 1.144 & $\mathrm{R} \$$ & 1.201 \\
\hline $70-30-0$ & $\mathrm{R} \$$ & 1.079 & $\mathrm{R} \$$ & 1.137 & $\mathrm{R} \$$ & 1.194 & $\mathrm{R} \$$ & 1.251 & $\mathrm{R} \$$ & 1.308 \\
\hline $70-0-30$ & $\mathrm{R} \$$ & 1.047 & $\mathrm{R} \$$ & 1.104 & $\mathrm{R} \$$ & 1.162 & $\mathrm{R} \$$ & 1.219 & $\mathrm{R} \$$ & 1.277 \\
\hline $50-40-10$ & $\mathrm{R} \$$ & 1.069 & $\mathrm{R} \$$ & 1.126 & $\mathrm{R} \$$ & 1.183 & $\mathrm{R} \$$ & 1.240 & $\mathrm{R} \$$ & 1.298 \\
\hline $60-30-10$ & $\mathrm{R} \$$ & 1.068 & $\mathrm{R} \$$ & 1.126 & $\mathrm{R} \$$ & 1.183 & $\mathrm{R} \$$ & 1.240 & $\mathrm{R} \$$ & 1.297 \\
\hline
\end{tabular}

Apêndice 145 - Crédito médio de 1,10\% sobre o valor do investimento, por mensalidade, para construção em 90 dias e compensação de retorno em 12 meses, em função de áreas externas, anfiteatro e minisshopping, para 100 residentes

\begin{tabular}{|c|c|c|c|c|c|c|c|c|}
\hline \multirow[t]{2}{*}{$\begin{array}{c}\text { Porcentagem de } \\
\text { residentes com } \\
\text { grau de } \\
\text { dependência } \\
\text { I, II e III }\end{array}$} & \multicolumn{8}{|c|}{$\begin{array}{c}\text { Crédito médio de } 1,10 \% \text { sobre o valor do investimento, por } \\
\text { mensalidade, em função de áreas externas, anfiteatro e } \\
\text { minisshopping, para } 100 \text { residentes, com diversos graus de } \\
\text { dependência }\end{array}$} \\
\hline & \multicolumn{2}{|c|}{ "A" } & \multicolumn{2}{|c|}{ "B" } & \multicolumn{2}{|c|}{ "C" } & \multicolumn{2}{|c|}{ "D" } \\
\hline $100-0-0$ & $\mathrm{R} \$$ & 998 & $\mathrm{R} \$$ & 961 & $\mathrm{R} \$$ & 908 & $\mathrm{R} \$$ & 882 \\
\hline $0-100-0$ & $\mathrm{R} \$$ & 999 & $\mathrm{R} \$$ & 964 & $\mathrm{R} \$$ & 909 & $\mathrm{R} \$$ & 883 \\
\hline $0-0-100$ & $\mathrm{R} \$$ & 897 & $\mathrm{R} \$$ & 865 & $\mathrm{R} \$$ & 812 & $\mathrm{R} \$$ & 786 \\
\hline $70-30-0$ & $\mathrm{R} \$$ & 998 & $\mathrm{R} \$$ & 962 & $\mathrm{R} \$$ & 908 & $\mathrm{R} \$$ & 882 \\
\hline 70-0-30 & $\mathrm{R} \$$ & 974 & $\mathrm{R} \$$ & 938 & $\mathrm{R} \$$ & 886 & $\mathrm{R} \$$ & 860 \\
\hline $50-40-10$ & $\mathrm{R} \$$ & 992 & $\mathrm{R} \$$ & 955 & $\mathrm{R} \$$ & 902 & R\$ & 876 \\
\hline $60-30-10$ & $\mathrm{R} \$$ & 992 & $\mathrm{R} \$$ & 955 & $\mathrm{R} \$$ & 902 & $\mathrm{R} \$$ & 876 \\
\hline
\end{tabular}


Apêndice 146 - Crédito médio de 1,10\% sobre o valor do investimento, por mensalidade, para construção em 90 dias e compensação de retorno em 12 meses, em função de áreas externas, anfiteatro e minisshopping, para 200 residentes

\begin{tabular}{|c|c|c|c|c|c|c|c|c|}
\hline \multirow{3}{*}{$\begin{array}{c}\text { Porcentagem de } \\
\text { residentes com } \\
\text { grau de } \\
\text { dependência } \\
\text { I, II e III } \\
\text { 100-0-0 }\end{array}$} & \multicolumn{8}{|c|}{$\begin{array}{c}\text { Crédito médio de } 1,10 \% \text { sobre o valor do investimento, por } \\
\text { mensalidade, em função de áreas externas, anfiteatro e } \\
\text { minisshopping, para } 200 \text { residentes, com diversos graus de } \\
\text { dependência }\end{array}$} \\
\hline & \multicolumn{2}{|c|}{ "A" } & \multicolumn{2}{|c|}{ "B" } & \multicolumn{2}{|c|}{ "C" } & \multicolumn{2}{|c|}{ "D" } \\
\hline & $\mathrm{R} \$$ & 1.010 & $\mathrm{R} \$$ & 955 & $\mathrm{R} \$$ & 900 & $\mathrm{R} \$$ & 833 \\
\hline 0-100-0 & $\mathrm{R} \$$ & 1.012 & $\mathrm{R} \$$ & 957 & $\mathrm{R} \$$ & 902 & $\mathrm{R} \$$ & 835 \\
\hline $0-0-100$ & $\mathrm{R} \$$ & 912 & $\mathrm{R} \$$ & 860 & $\mathrm{R} \$$ & 807 & $\mathrm{R} \$$ & 743 \\
\hline 70-30-0 & $\mathrm{R} \$$ & 1.010 & $\mathrm{R} \$$ & 955 & $\mathrm{R} \$$ & 900 & $\mathrm{R} \$$ & 833 \\
\hline 70-0-30 & $\mathrm{R} \$$ & 981 & $\mathrm{R} \$$ & 927 & $\mathrm{R} \$$ & 874 & $\mathrm{R} \$$ & 807 \\
\hline $50-40-10$ & $\mathrm{R} \$$ & 998 & $\mathrm{R} \$$ & 944 & $\mathrm{R} \$$ & 890 & $\mathrm{R} \$$ & 823 \\
\hline $60-30-10$ & $\mathrm{R} \$$ & 998 & $\mathrm{R} \$$ & 943 & $\mathrm{R} \$$ & 890 & $\mathrm{R} \$$ & 822 \\
\hline
\end{tabular}

Apêndice 147 - Crédito médio de 1,10\% sobre o valor do investimento, por mensalidade, para construção em 90 dias e compensação de retorno em 12 meses, em função de áreas externas, anfiteatro e minisshopping, para 300 residentes

\begin{tabular}{|c|c|c|c|c|c|c|c|c|}
\hline \multirow[t]{2}{*}{$\begin{array}{l}\text { Porcentagem de } \\
\text { residentes com } \\
\text { grau de } \\
\text { dependência } \\
\text { I, II e III }\end{array}$} & \multicolumn{8}{|c|}{$\begin{array}{c}\text { Crédito médio de } 1,10 \% \text { sobre o valor do investimento, por } \\
\text { mensalidade, em função de áreas externas, anfiteatro e } \\
\text { minisshopping, para } 300 \text { residentes, com diversos graus de } \\
\text { dependência }\end{array}$} \\
\hline & \multicolumn{2}{|c|}{ "A" } & \multicolumn{2}{|c|}{ "B" } & \multicolumn{2}{|c|}{ "C" } & \multicolumn{2}{|c|}{ "D" } \\
\hline $100-0-0$ & $\mathrm{R} \$$ & 939 & $\mathrm{R} \$$ & 894 & $\mathrm{R} \$$ & 832 & $\mathrm{R} \$$ & 809 \\
\hline $0-100-0$ & $\mathrm{R} \$$ & 942 & $\mathrm{R} \$$ & 896 & $\mathrm{R} \$$ & 834 & $\mathrm{R} \$$ & 811 \\
\hline $0-0-100$ & $\mathrm{R} \$$ & 848 & $\mathrm{R} \$$ & 805 & $\mathrm{R} \$$ & 745 & $\mathrm{R} \$$ & 724 \\
\hline $70-30-0$ & $\mathrm{R} \$$ & 940 & $\mathrm{R} \$$ & 895 & $\mathrm{R} \$$ & 848 & $\mathrm{R} \$$ & 810 \\
\hline 70-0-30 & $\mathrm{R} \$$ & 914 & $\mathrm{R} \$$ & 869 & $\mathrm{R} \$$ & 823 & R\$ & 786 \\
\hline $50-40-10$ & $\mathrm{R} \$$ & 933 & $\mathrm{R} \$$ & 887 & $\mathrm{R} \$$ & 825 & $\mathrm{R} \$$ & 803 \\
\hline $60-30-10$ & $\mathrm{R} \$$ & 933 & $\mathrm{R} \$$ & 887 & $\mathrm{R} \$$ & 825 & $\mathrm{R} \$$ & 803 \\
\hline
\end{tabular}

Apêndice 148 - Crédito médio de 1,10\% sobre o valor do investimento, por mensalidade, para construção em 90 dias e compensação de retorno em 12 meses, em função de áreas externas, anfiteatro e minisshopping, para 400 residentes

\begin{tabular}{|c|c|c|c|c|c|c|c|c|}
\hline \multirow[t]{2}{*}{$\begin{array}{c}\text { Porcentagem de } \\
\text { residentes com } \\
\text { grau de } \\
\text { dependência } \\
\text { I, II e III }\end{array}$} & \multicolumn{8}{|c|}{$\begin{array}{c}\text { Crédito médio de } 1,10 \% \text { sobre o valor do investimento, por } \\
\text { mensalidade, em função de áreas externas, anfiteatro e } \\
\text { minisshopping, para } 400 \text { residentes, com diversos graus de } \\
\text { dependência }\end{array}$} \\
\hline & \multicolumn{2}{|c|}{ "A" } & \multicolumn{2}{|c|}{ "B" } & \multicolumn{2}{|c|}{ "C" } & \multicolumn{2}{|c|}{ "D" } \\
\hline $100-0-0$ & $\mathrm{R} \$$ & 923 & $\mathrm{R} \$$ & 881 & $\mathrm{R} \$$ & 829 & $\mathrm{R} \$$ & 808 \\
\hline $0-100-0$ & $\mathrm{R} \$$ & 925 & $\mathrm{R} \$$ & 883 & $\mathrm{R} \$$ & 830 & $\mathrm{R} \$$ & 810 \\
\hline $0-0-100$ & $\mathrm{R} \$$ & 832 & $\mathrm{R} \$$ & 793 & $\mathrm{R} \$$ & 743 & $\mathrm{R} \$$ & 723 \\
\hline $70-30-0$ & $\mathrm{R} \$$ & 923 & $\mathrm{R} \$$ & 882 & $\mathrm{R} \$$ & 841 & $\mathrm{R} \$$ & 808 \\
\hline 70-0-30 & $\mathrm{R} \$$ & 896 & $\mathrm{R} \$$ & 856 & $\mathrm{R} \$$ & 815 & R\$ & 783 \\
\hline $50-40-10$ & $\mathrm{R} \$$ & 915 & $\mathrm{R} \$$ & 873 & $\mathrm{R} \$$ & 821 & $\mathrm{R}$ & 800 \\
\hline $60-30-10$ & $\mathrm{R} \$$ & 914 & $\mathrm{R} \$$ & 873 & $\mathrm{R} \$$ & 820 & $\mathrm{R} \$$ & 799 \\
\hline
\end{tabular}


Apêndice 149 - Crédito médio de 1,20\% sobre o valor do investimento, por mensalidade, para construção em 90 dias e compensação de retorno em 12 meses, em função de áreas externas, anfiteatro e minisshopping, para 100 residentes

\begin{tabular}{|c|c|c|c|c|c|c|c|c|}
\hline \multirow{3}{*}{$\begin{array}{c}\begin{array}{c}\text { Porcentagem de } \\
\text { residentes com } \\
\text { grau de } \\
\text { dependência } \\
\text { I, II e III }\end{array} \\
100-0-0\end{array}$} & \multicolumn{8}{|c|}{$\begin{array}{c}\text { Crédito médio de } 1,20 \% \text { sobre o valor do investimento, por } \\
\text { mensalidade, em função de áreas externas, anfiteatro e } \\
\text { minisshopping, para } 100 \text { residentes, com diversos graus de } \\
\text { dependência }\end{array}$} \\
\hline & \multicolumn{2}{|c|}{ "A" } & \multicolumn{2}{|c|}{ "B" } & \multicolumn{2}{|c|}{ "C" } & \multicolumn{2}{|c|}{ "D" } \\
\hline & $\mathrm{R} \$$ & 1.089 & $\mathrm{R} \$$ & 1.049 & $\mathrm{R} \$$ & 990 & $\mathrm{R} \$$ & 962 \\
\hline $0-100-0$ & $\mathrm{R} \$$ & 1.090 & $\mathrm{R} \$$ & 1.052 & $\mathrm{R} \$$ & 992 & $\mathrm{R} \$$ & 963 \\
\hline 0-0-100 & $\mathrm{R} \$$ & 978 & $\mathrm{R} \$$ & 943 & $\mathrm{R} \$$ & 886 & $\mathrm{R} \$$ & 857 \\
\hline 70-30-0 & $\mathrm{R} \$$ & 1.089 & $\mathrm{R} \$$ & 1.049 & $\mathrm{R} \$$ & 991 & $\mathrm{R} \$$ & 962 \\
\hline 70-0-30 & $\mathrm{R} \$$ & 1.062 & $\mathrm{R} \$$ & 1.024 & $\mathrm{R} \$$ & 966 & $\mathrm{R} \$$ & 938 \\
\hline $50-40-10$ & $\mathrm{R} \$$ & 1.082 & $\mathrm{R} \$$ & 1.042 & $\mathrm{R} \$$ & 984 & $\mathrm{R} \$$ & 956 \\
\hline $60-30-10$ & $\mathrm{R} \$$ & 1.082 & $\mathrm{R} \$$ & 1.042 & $\mathrm{R} \$$ & 984 & $\mathrm{R} \$$ & 955 \\
\hline
\end{tabular}

Apêndice 150 - Crédito médio de 1,20\% sobre o valor do investimento, por mensalidade, para construção em 90 dias e compensação de retorno em 12 meses, em função de áreas externas, anfiteatro e minisshopping, para 200 residentes

\begin{tabular}{|c|c|c|c|c|c|c|c|c|}
\hline \multirow{3}{*}{$\begin{array}{c}\text { Porcentagem de } \\
\text { residentes com } \\
\text { grau de } \\
\text { dependência } \\
\text { I, II e III } \\
100-0-0\end{array}$} & \multicolumn{8}{|c|}{$\begin{array}{l}\text { Crédito médio de } 1,20 \% \text { sobre o valor do investimento, por } \\
\text { mensalidade, em função de áreas externas, anfiteatro e } \\
\text { minisshopping, para } 200 \text { residentes, com diversos graus de } \\
\text { dependência }\end{array}$} \\
\hline & \multicolumn{2}{|c|}{ "A" } & \multicolumn{2}{|c|}{ "B" } & \multicolumn{2}{|c|}{ "C" } & \multicolumn{2}{|c|}{ "D" } \\
\hline & $\mathrm{R} \$$ & 1.102 & $\mathrm{R} \$$ & 1.042 & $\mathrm{R} \$$ & 982 & $\mathrm{R} \$$ & 909 \\
\hline 0-100-0 & $\mathrm{R} \$$ & 1.104 & $\mathrm{R} \$$ & 1.044 & $\mathrm{R}$ & 984 & $\mathrm{R} \$$ & 911 \\
\hline $0-0-100$ & $\mathrm{R} \$$ & 995 & $\mathrm{R} \$$ & 938 & $\mathrm{R} \$$ & 880 & $\mathrm{R} \$$ & 811 \\
\hline $70-30-0$ & $\mathrm{R} \$$ & 1.102 & $\mathrm{R} \$$ & 1.042 & $\mathrm{R} \$$ & 982 & $\mathrm{R} \$$ & $90 s$ \\
\hline 70-0-30 & $\mathrm{R} \$$ & 1.071 & $\mathrm{R} \$$ & 1.012 & K\$ & 954 & $\mathrm{R} \$$ & 881 \\
\hline $50-40-10$ & $\mathrm{R} \$$ & 1.089 & $\mathrm{R} \$$ & 1.029 & $\mathrm{R} \$$ & 971 & $\mathrm{R} \$$ & 898 \\
\hline $60-30-10$ & $\mathrm{R} \$$ & 1.089 & $\mathrm{R} \$$ & 1.029 & $\mathrm{R} \$$ & 971 & $\mathrm{R} \$$ & 897 \\
\hline
\end{tabular}

Apêndice 151 - Crédito médio de 1,20\% sobre o valor do investimento, por mensalidade, para construção em 90 dias e compensação de retorno em 12 meses, em função de áreas externas, anfiteatro e minisshopping, para 300 residentes

\begin{tabular}{|c|c|c|c|c|c|c|c|c|}
\hline \multirow[t]{2}{*}{$\begin{array}{c}\text { Porcentagem de } \\
\text { residentes com } \\
\text { grau de } \\
\text { dependência } \\
\text { I, II e III }\end{array}$} & \multicolumn{8}{|c|}{$\begin{array}{c}\text { Crédito médio de } 1,20 \% \text { sobre o valor do investimento, por } \\
\text { mensalidade, em função de áreas externas, anfiteatro e } \\
\text { minisshopping, para } 300 \text { residentes, com diversos graus de } \\
\text { dependência }\end{array}$} \\
\hline & \multicolumn{2}{|c|}{ "A" } & \multicolumn{2}{|c|}{ "B" } & \multicolumn{2}{|c|}{ "C" } & \multicolumn{2}{|c|}{ "D" } \\
\hline $100-0-0$ & $\mathrm{R} \$$ & 1.025 & $\mathrm{R} \$$ & 975 & $\mathrm{R} \$$ & 908 & $\mathrm{R} \$$ & 883 \\
\hline $0-100-0$ & $\mathrm{R} \$$ & 1.027 & $\mathrm{R} \$$ & 977 & $\mathrm{R} \$$ & 910 & $\mathrm{R} \$$ & 884 \\
\hline $0-0-100$ & $\mathrm{R} \$$ & 925 & $\mathrm{R} \$$ & 878 & $\mathrm{R} \$$ & 813 & $\mathrm{R} \$$ & 790 \\
\hline $70-30-0$ & $\mathrm{R} \$$ & 1.026 & $\mathrm{R} \$$ & 976 & $\mathrm{R} \$$ & 925 & $\$$ & 883 \\
\hline 70-0-30 & $\mathrm{R} \$$ & 997 & $\mathrm{R} \$$ & 948 & $\mathrm{R} \$$ & 898 & $\mathrm{R} \$$ & 857 \\
\hline $50-40-10$ & $\mathrm{R} \$$ & 1.017 & $\mathrm{R} \$$ & 968 & $\mathrm{R} \$$ & 900 & K\$ & 876 \\
\hline $60-30-10$ & $\mathrm{R} \$$ & 1.017 & $\mathrm{R} \$$ & 968 & $\mathrm{R} \$$ & 900 & $\mathrm{R} \$$ & 876 \\
\hline
\end{tabular}


Apêndice 152 - Crédito médio de 1,20\% sobre o valor do investimento, por mensalidade, para construção em 90 dias e compensação de retorno em 12 meses, em função de áreas externas, anfiteatro e minisshopping, para 400 residentes

\begin{tabular}{|c|c|c|c|c|c|c|c|c|}
\hline \multirow{3}{*}{$\begin{array}{c}\text { Porcentagem de } \\
\text { residentes com } \\
\text { grau de } \\
\text { dependência } \\
\text { I, II e III } \\
\text { 100-0-0 }\end{array}$} & \multicolumn{8}{|c|}{$\begin{array}{c}\text { Crédito médio de } 1,20 \% \text { sobre o valor do investimento, por } \\
\text { mensalidade, em função de áreas externas, anfiteatro e } \\
\text { minisshopping, para } 400 \text { residentes, com diversos graus de } \\
\text { dependência }\end{array}$} \\
\hline & \multicolumn{2}{|c|}{ "A" } & \multicolumn{2}{|c|}{ "B" } & \multicolumn{2}{|c|}{ "C" } & \multicolumn{2}{|c|}{ "D" } \\
\hline & $\mathrm{R} \$$ & 1.007 & $\mathrm{R} \$$ & 962 & $\mathrm{R} \$$ & 904 & $\mathrm{R} \$$ & 881 \\
\hline 0-100-0 & $\mathrm{R} \$$ & 1.009 & $\mathrm{R} \$$ & 964 & $\mathrm{R} \$$ & 906 & $\mathrm{R} \$$ & 883 \\
\hline $0-0-100$ & $\mathrm{R} \$$ & 907 & $\mathrm{R} \$$ & 865 & $\mathrm{R} \$$ & 810 & $\mathrm{R} \$$ & 789 \\
\hline 70-30-0 & $\mathrm{R} \$$ & 1.007 & $\mathrm{R} \$$ & 962 & $\mathrm{R} \$$ & 917 & $\mathrm{R} \$$ & 882 \\
\hline 70-0-30 & $\mathrm{R} \$$ & 977 & $\mathrm{R} \$$ & 933 & $\mathrm{R} \$$ & 889 & $\mathrm{R} \$$ & 854 \\
\hline $50-40-10$ & $\mathrm{R} \$$ & 998 & $\mathrm{R} \$$ & 952 & $\mathrm{R} \$$ & 895 & $\mathrm{R} \$$ & 873 \\
\hline $60-30-10$ & $\mathrm{R} \$$ & 997 & $\mathrm{R} \$$ & 952 & $\mathrm{R} \$$ & 895 & $\mathrm{R} \$$ & 872 \\
\hline
\end{tabular}

Apêndice 153 - Crédito médio de 1,30\% sobre o valor do investimento, por mensalidade, para construção em 90 dias e compensação de retorno em 12 meses, em função de áreas externas, anfiteatro e minisshopping, para 100 residentes

\begin{tabular}{|c|c|c|c|c|c|c|c|c|}
\hline \multirow{2}{*}{$\begin{array}{c}\text { Porcentagem de } \\
\text { residentes com } \\
\text { grau de } \\
\text { dependência } \\
\text { I, II e III } \\
\end{array}$} & \multicolumn{8}{|c|}{$\begin{array}{l}\text { Crédito médio de } 1,30 \% \text { sobre o valor do investimento, por } \\
\text { mensalidade, em função de áreas externas, anfiteatro e } \\
\text { minisshopping, para } 100 \text { residentes, com diversos graus de } \\
\text { dependência }\end{array}$} \\
\hline & \multicolumn{2}{|c|}{ "A" } & \multicolumn{2}{|c|}{ "B" } & \multicolumn{2}{|c|}{ "C" } & \multicolumn{2}{|c|}{ "D" } \\
\hline $100-0-0$ & $\mathrm{R} \$$ & 1.179 & $\mathrm{R} \$$ & 1.136 & $\mathrm{R} \$$ & 1.073 & $\mathrm{R} \$$ & 1.042 \\
\hline $0-100-0$ & $\mathrm{R} \$$ & 1.180 & $\mathrm{R} \$$ & 1.139 & $\mathrm{R}$ & 1.074 & $\mathrm{R} \$$ & 1.043 \\
\hline $0-0-100$ & $\mathrm{R} \$$ & 1.060 & $\mathrm{R} \$$ & 1.022 & $\mathrm{R} \$$ & 960 & $\mathrm{R} \$$ & 929 \\
\hline $70-30-0$ & $\mathrm{R} \$$ & 1.180 & $\mathrm{R} \$$ & 1.136 & $\mathrm{R} \$$ & 1.074 & $\mathrm{R} \$$ & 1.042 \\
\hline $70-0-30$ & $\mathrm{R} \$$ & 1.151 & $\mathrm{R} \$$ & 1.109 & $\mathrm{R}$ & 1.047 & R\$ & 1.016 \\
\hline $50-40-10$ & $\mathrm{R} \$$ & 1.172 & $\mathrm{R} \$$ & 1.129 & $\mathrm{R} \$$ & 1.066 & $\mathrm{R} \$$ & 1.035 \\
\hline $60-30-10$ & $\mathrm{R} \$$ & 1.172 & $\mathrm{R} \$$ & 1.129 & $\mathrm{R} \$$ & 1.066 & $\mathrm{R} \$$ & 1.035 \\
\hline
\end{tabular}

Apêndice 154 - Crédito médio de 1,30\% sobre o valor do investimento, por mensalidade, para construção em 90 dias e compensação de retorno em 12 meses, em função de áreas externas, anfiteatro e minisshopping, para 200 residentes

\begin{tabular}{|c|c|c|c|c|c|c|c|c|}
\hline \multirow[t]{2}{*}{$\begin{array}{c}\text { Porcentagem de } \\
\text { residentes com } \\
\text { grau de } \\
\text { dependência } \\
\text { I, II e III }\end{array}$} & \multicolumn{8}{|c|}{$\begin{array}{l}\text { Crédito médio de } 1,30 \% \text { sobre o valor do investimento, por } \\
\text { mensalidade, em função de áreas externas, anfiteatro e } \\
\text { minisshopping, para } 200 \text { residentes, com diversos graus de } \\
\text { dependência }\end{array}$} \\
\hline & \multicolumn{2}{|c|}{ "A" } & \multicolumn{2}{|c|}{ "B" } & \multicolumn{2}{|c|}{ "C" } & \multicolumn{2}{|c|}{ "D" } \\
\hline $100-0-0$ & $\mathrm{R} \$$ & 1.193 & $\mathrm{R} \$$ & 1.129 & $\mathrm{R} \$$ & 1.064 & $\mathrm{R} \$$ & 985 \\
\hline $0-100-0$ & $\mathrm{R} \$$ & 1.196 & $\mathrm{R} \$$ & 1.131 & $\mathrm{R} \$$ & 1.066 & $\mathrm{R} \$$ & 987 \\
\hline $0-0-100$ & $\mathrm{R} \$$ & 1.078 & $\mathrm{R} \$$ & 1.016 & $\mathrm{R} \$$ & 954 & $\mathrm{R} \$$ & $87 \varepsilon$ \\
\hline $70-30-0$ & $\mathrm{R} \$$ & 1.194 & $\mathrm{R} \$$ & 1.129 & $\mathrm{R} \$$ & 1.064 & $\$$ & 985 \\
\hline 70-0-30 & $\mathrm{R} \$$ & 1.160 & $\mathrm{R} \$$ & 1.096 & $\mathrm{R} \$$ & 1.033 & $\mathrm{R} \$$ & 954 \\
\hline $50-4$ & $\mathrm{R} \$$ & 1.180 & $\mathrm{R} \$$ & 1.115 & R\$ & 1.052 & 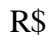 & 973 \\
\hline $60-30-10$ & $\mathrm{R} \$$ & 1.179 & $\mathrm{R} \$$ & 1.115 & $\mathrm{R} \$$ & 1.052 & $\mathrm{R} \$$ & 972 \\
\hline
\end{tabular}


Apêndice 155 - Crédito médio de 1,30\% sobre o valor do investimento, por mensalidade, para construção em 90 dias e compensação de retorno em 12 meses, em função de áreas externas, anfiteatro e minisshopping, para 300 residentes

\begin{tabular}{|c|c|c|c|c|c|c|c|c|}
\hline \multirow{3}{*}{$\begin{array}{c}\text { Porcentagem de } \\
\text { residentes com } \\
\text { grau de } \\
\text { dependência } \\
\text { I, II e III } \\
\text { 100-0-0 }\end{array}$} & \multicolumn{8}{|c|}{$\begin{array}{c}\text { Crédito médio de } 1,30 \% \text { sobre o valor do investimento, por } \\
\text { mensalidade, em função de áreas externas, anfiteatro e } \\
\text { minisshopping, para } 300 \text { residentes, com diversos graus de } \\
\text { dependência }\end{array}$} \\
\hline & \multicolumn{2}{|c|}{ "A" } & \multicolumn{2}{|c|}{ "B" } & \multicolumn{2}{|c|}{ "C" } & \multicolumn{2}{|c|}{ "D" } \\
\hline & $\mathrm{R} \$$ & 1.110 & $\mathrm{R} \$$ & 1.056 & $\mathrm{R} \$$ & 984 & $\mathrm{R} \$$ & 957 \\
\hline 0-100-0 & $\mathrm{R} \$$ & 1.113 & $\mathrm{R} \$$ & 1.059 & $\mathrm{R} \$$ & 985 & $\mathrm{R} \$$ & 958 \\
\hline $0-0-100$ & $\mathrm{R} \$$ & 1.002 & $\mathrm{R} \$$ & 951 & $\mathrm{R} \$$ & 881 & $\mathrm{R} \$$ & 856 \\
\hline 70-30-0 & $\mathrm{R} \$$ & 1.111 & $\mathrm{R} \$$ & 1.057 & $\mathrm{R} \$$ & 1.002 & $\mathrm{R} \$$ & 957 \\
\hline 70-0-30 & $\mathrm{R} \$$ & 1.080 & $\mathrm{R} \$$ & 1.027 & $\mathrm{R} \$$ & 972 & $\mathrm{R} \$$ & 929 \\
\hline $50-40-10$ & $\mathrm{R} \$$ & 1.102 & $\mathrm{R} \$$ & 1.049 & $\mathrm{R} \$$ & 975 & $\mathrm{R} \$$ & 949 \\
\hline $60-30-10$ & $\mathrm{R} \$$ & 1.102 & $\mathrm{R} \$$ & 1.048 & $\mathrm{R} \$$ & 975 & $\mathrm{R} \$$ & 949 \\
\hline
\end{tabular}

Apêndice 156 - Crédito médio de 1,30\% sobre o valor do investimento, por mensalidade, para construção em 90 dias e compensação de retorno em 12 meses, em função de áreas externas, anfiteatro e minisshopping, para 400 residentes

\begin{tabular}{|c|c|c|c|c|c|c|c|c|}
\hline \multirow[t]{2}{*}{$\begin{array}{c}\text { Porcentagem de } \\
\text { residentes com } \\
\text { grau de } \\
\text { dependência } \\
\text { I, II e III }\end{array}$} & \multicolumn{8}{|c|}{$\begin{array}{c}\text { Crédito médio de } 1,30 \% \text { sobre o valor do investimento, por } \\
\text { mensalidade, em função de áreas externas, anfiteatro e } \\
\text { minisshopping, para } 400 \text { residentes, com diversos graus de } \\
\text { dependência }\end{array}$} \\
\hline & \multicolumn{2}{|c|}{ "A" } & \multicolumn{2}{|c|}{ "B" } & \multicolumn{2}{|c|}{ "C" } & \multicolumn{2}{|c|}{ "D" } \\
\hline $100-0-0$ & $\mathrm{R} \$$ & 1.091 & $\mathrm{R} \$$ & 1.042 & $\mathrm{R} \$$ & 979 & $\mathrm{R} \$$ & 955 \\
\hline $0-100-0$ & $\mathrm{R} \$$ & 1.093 & $\mathrm{R} \$$ & 1.044 & $\mathrm{R} \$$ & 981 & $\mathrm{R} \$$ & 957 \\
\hline $0-0-100$ & $\mathrm{R} \$$ & 983 & $\mathrm{R} \$$ & 937 & $\mathrm{R} \$$ & 878 & $\mathrm{R} \$$ & 85 \\
\hline $70-30-0$ & $\mathrm{R} \$$ & 1.091 & $\mathrm{R} \$$ & 1.043 & $\mathrm{R} \$$ & 993 & $\mathrm{R} \$$ & 955 \\
\hline 70-0-30 & $\mathrm{R} \$$ & 1.059 & $\mathrm{R} \$$ & 1.011 & $\mathrm{R}$ & 963 & R\$ & 925 \\
\hline $50-40-10$ & $\mathrm{R} \$$ & 1.081 & $\mathrm{R} \$$ & 1.032 & $\mathrm{R} \$$ & 970 & K & 945 \\
\hline $60-30-10$ & $\mathrm{R} \$$ & 1.080 & $\mathrm{R} \$$ & 1.032 & $\mathrm{R} \$$ & 970 & $\mathrm{R} \$$ & 945 \\
\hline
\end{tabular}

Apêndice 157 - Crédito médio de 1,40\% sobre o valor do investimento, por mensalidade, para construção em 90 dias e compensação de retorno em 12 meses, em função de áreas externas, anfiteatro e minisshopping, para 100 residentes

\begin{tabular}{|c|c|c|c|c|c|c|c|c|}
\hline \multirow[t]{2}{*}{$\begin{array}{c}\text { Porcentagem de } \\
\text { residentes com } \\
\text { grau de } \\
\text { dependência } \\
\text { I, II e III }\end{array}$} & \multicolumn{8}{|c|}{$\begin{array}{l}\text { Crédito médio de } 1,40 \% \text { sobre o valor do investimento, por } \\
\text { mensalidade, em função de áreas externas, anfiteatro e } \\
\text { minisshopping, para } 100 \text { residentes, com diversos graus de } \\
\text { dependência }\end{array}$} \\
\hline & \multicolumn{2}{|c|}{ "A" } & \multicolumn{2}{|c|}{ "B" } & \multicolumn{2}{|c|}{ "C" } & \multicolumn{2}{|c|}{ "D" } \\
\hline $100-0-0$ & $\mathrm{R} \$$ & 1.270 & $\mathrm{R} \$$ & 1.224 & $\mathrm{R} \$$ & 1.156 & $\mathrm{R} \$$ & 1.122 \\
\hline $0-100-0$ & $\mathrm{R} \$$ & 1.271 & $\mathrm{R} \$$ & 1.227 & $\mathrm{R} \$$ & 1.157 & $\mathrm{R} \$$ & 1.123 \\
\hline $0-0-100$ & $\mathrm{R} \$$ & 1.141 & $\mathrm{R} \$$ & 1.101 & $\mathrm{R} \$$ & 1.034 & $\mathrm{R} \$$ & 1.000 \\
\hline $70-30-0$ & $\mathrm{R} \$$ & 1.271 & $\mathrm{R} \$$ & 1.224 & $\mathrm{R} \$$ & 1.156 & $\mathrm{R} \$$ & 1.122 \\
\hline 70-0-30 & $\mathrm{R} \$$ & 1.240 & $\mathrm{R} \$$ & 1.194 & $\mathrm{R}$ & 1.127 & $\mathrm{R} \$$ & 1.094 \\
\hline 50 - & $\mathrm{R} \$$ & 1.262 & $\mathrm{R} \$$ & 1.216 & $\mathrm{R}$ & 1.148 & 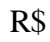 & 1.115 \\
\hline $60-30-10$ & $\mathrm{R} \$$ & 1.262 & $\mathrm{R} \$$ & 1.216 & $\mathrm{R} \$$ & 1.148 & $\mathrm{R} \$$ & 1.115 \\
\hline
\end{tabular}


Apêndice 158 - Crédito médio de 1,40\% sobre o valor do investimento, por mensalidade, para construção em 90 dias e compensação de retorno em 12 meses, em função de áreas externas, anfiteatro e minisshopping, para 200 residentes

\begin{tabular}{|c|c|c|c|c|c|c|c|c|}
\hline \multirow{3}{*}{$\begin{array}{c}\begin{array}{c}\text { Porcentagem de } \\
\text { residentes com } \\
\text { grau de } \\
\text { dependência } \\
\text { I, II e III }\end{array} \\
100-0-0\end{array}$} & \multicolumn{8}{|c|}{$\begin{array}{c}\text { Crédito médio de } 1,40 \% \text { sobre o valor do investimento, por } \\
\text { mensalidade, em função de áreas externas, anfiteatro e } \\
\text { minisshopping, para } 200 \text { residentes, com diversos graus de } \\
\text { dependência }\end{array}$} \\
\hline & \multicolumn{2}{|c|}{ "A" } & \multicolumn{2}{|c|}{ "B" } & \multicolumn{2}{|c|}{ "C" } & \multicolumn{2}{|c|}{ "D" } \\
\hline & $\mathrm{R} \$$ & 1.285 & $\mathrm{R} \$$ & 1.215 & $\mathrm{R} \$$ & 1.146 & $\mathrm{R} \$$ & 1.060 \\
\hline $0-100-0$ & $\mathrm{R} \$$ & 1.288 & $\mathrm{R} \$$ & 1.218 & $\mathrm{R} \$$ & 1.148 & $\mathrm{R} \$$ & 1.063 \\
\hline 0-0-100 & $\mathrm{R} \$$ & 1.160 & $\mathrm{R} \$$ & 1.094 & $\mathrm{R} \$$ & 1.027 & $\mathrm{R} \$$ & 946 \\
\hline 70-30-0 & $\mathrm{R} \$$ & 1.286 & $\mathrm{R} \$$ & 1.216 & $\mathrm{R} \$$ & 1.146 & $\mathrm{R} \$$ & 1.061 \\
\hline 70-0-30 & $\mathrm{R} \$$ & 1.249 & $\mathrm{R} \$$ & 1.180 & $\mathrm{R} \$$ & 1.113 & $\mathrm{R} \$$ & 1.027 \\
\hline $50-40-10$ & $\mathrm{R} \$$ & 1.270 & $\mathrm{R} \$$ & 1.201 & $\mathrm{R} \$$ & 1.132 & $\mathrm{R} \$$ & 1.048 \\
\hline $60-30-10$ & $\mathrm{R} \$$ & 1.270 & $\mathrm{R} \$$ & 1.201 & $\mathrm{R} \$$ & 1.132 & $\mathrm{R} \$$ & 1.046 \\
\hline
\end{tabular}

Apêndice 159 - Crédito médio de 1,40\% sobre o valor do investimento, por mensalidade, para construção em 90 dias e compensação de retorno em 12 meses, em função de áreas externas, anfiteatro e minisshopping, para 300 residentes

\begin{tabular}{|c|c|c|c|c|c|c|c|c|}
\hline \multirow{2}{*}{$\begin{array}{c}\text { Porcentagem de } \\
\text { residentes com } \\
\text { grau de } \\
\text { dependência } \\
\text { I, II e III } \\
\end{array}$} & \multicolumn{8}{|c|}{$\begin{array}{c}\text { Crédito médio de } 1,40 \% \text { sobre o valor do investimento, por } \\
\text { mensalidade, em função de áreas externas, anfiteatro e } \\
\text { minisshopping, para } 300 \text { residentes, com diversos graus de } \\
\text { dependência }\end{array}$} \\
\hline & \multicolumn{2}{|c|}{ "A" } & \multicolumn{2}{|c|}{ "B" } & \multicolumn{2}{|c|}{ "C" } & \multicolumn{2}{|c|}{ "D" } \\
\hline $100-0-0$ & $\mathrm{R} \$$ & 1.196 & $\mathrm{R} \$$ & 1.138 & $\mathrm{R} \$$ & 1.059 & $\mathrm{R} \$$ & 1.030 \\
\hline $0-100-0$ & $\mathrm{R} \$$ & 1.198 & $\mathrm{R} \$$ & 1.140 & $\mathrm{R}$ & 1.061 & $\mathrm{R} \$$ & 1.032 \\
\hline $0-0-100$ & $\mathrm{R} \$$ & 1.080 & $\mathrm{R} \$$ & 1.025 & $\mathrm{R} \$$ & 949 & $\mathrm{R} \$$ & 922 \\
\hline $70-30-0$ & $\mathrm{R} \$$ & 1.197 & $\mathrm{R} \$$ & 1.139 & $\mathrm{R} \$$ & 1.079 & $\mathrm{R} \$$ & 1.030 \\
\hline $70-0-30$ & $\mathrm{R} \$$ & 1.163 & $\mathrm{R} \$$ & 1.106 & $\mathrm{R}$ & 1.047 & R\$ & 1.000 \\
\hline $50-40-10$ & $\mathrm{R} \$$ & 1.187 & $\mathrm{R} \$$ & 1.129 & R\$ & 1.050 & $\mathrm{R} \$$ & 1.022 \\
\hline $60-30-10$ & $\mathrm{R} \$$ & 1.187 & $\mathrm{R} \$$ & 1.129 & $\mathrm{R} \$$ & 1.050 & $\mathrm{R} \$$ & 1.022 \\
\hline
\end{tabular}

Apêndice 160 - Crédito médio de 1,40\% sobre o valor do investimento, por mensalidade, para construção em 90 dias e compensação de retorno em 12 meses, em função de áreas externas, anfiteatro e minisshopping, para 400 residentes

\begin{tabular}{|c|c|c|c|c|c|c|c|c|}
\hline \multirow{2}{*}{$\begin{array}{l}\text { Porcentagem de } \\
\text { residentes com } \\
\text { grau de } \\
\text { dependência } \\
\text { I, II e III } \\
\end{array}$} & \multicolumn{8}{|c|}{$\begin{array}{l}\text { Crédito médio de } 1,40 \% \text { sobre o valor do investimento, por } \\
\text { mensalidade, em função de áreas externas, anfiteatro e } \\
\text { minisshopping, para } 400 \text { residentes, com diversos graus de } \\
\text { dependência }\end{array}$} \\
\hline & \multicolumn{2}{|c|}{ "A" } & \multicolumn{2}{|c|}{ "B" } & \multicolumn{2}{|c|}{ "C" } & \multicolumn{2}{|c|}{ "D" } \\
\hline 100-0-0 & $\mathrm{R} \$$ & 1.175 & $\mathrm{R} \$$ & 1.122 & $\mathrm{R} \$$ & 1.055 & $\mathrm{R} \$$ & 1.028 \\
\hline $0-100-0$ & $\mathrm{R} \$$ & 1.177 & $\mathrm{R} \$$ & 1.124 & $\mathrm{R} \$$ & 1.057 & $\mathrm{R} \$$ & 1.030 \\
\hline $0-0-100$ & $\mathrm{R} \$$ & 1.059 & $\mathrm{R} \$$ & 1.010 & $\mathrm{R} \$$ & 945 & $\mathrm{R} \$$ & 920 \\
\hline $70-30-0$ & $\mathrm{R} \$$ & 1.175 & $\mathrm{R} \$$ & 1.123 & $\mathrm{R} \$$ & 1.070 & $\mathrm{R} \$$ & 1.029 \\
\hline 70-0-30 & $\mathrm{R} \$$ & 1.140 & $\mathrm{R} \$$ & 1.089 & $\mathrm{R} \$$ & 1.037 & $\mathrm{R} \$$ & 996 \\
\hline $50-40-10$ & $\mathrm{R} \$$ & 1.164 & $\mathrm{R} \$$ & 1.111 & $\mathrm{R} \$$ & 1.044 & $\mathrm{R} \$$ & 1.018 \\
\hline $60-30-10$ & $\mathrm{R} \$$ & 1.163 & $\mathrm{R} \$$ & 1.111 & $\mathrm{R} \$$ & 1.044 & $\mathrm{R} \$$ & 1.017 \\
\hline
\end{tabular}


Apêndice 161 - Crédito médio de 1,50\% sobre o valor do investimento, por mensalidade, para construção em 90 dias e compensação de retorno em 12 meses, em função de áreas externas, anfiteatro e minisshopping, para 100 residentes

\begin{tabular}{|c|c|c|c|c|c|c|c|c|}
\hline \multirow[t]{2}{*}{$\begin{array}{l}\text { Porcentagem de } \\
\text { residentes com } \\
\text { grau de } \\
\text { dependência } \\
\text { I, II e III }\end{array}$} & \multicolumn{8}{|c|}{$\begin{array}{l}\text { Crédito médio de } \mathbf{1 , 5 0 \%} \text { sobre o valor do investimento, por } \\
\text { mensalidade, em função de áreas externas, anfiteatro e } \\
\text { minisshopping, para } 100 \text { residentes, com diversos graus de } \\
\text { dependência }\end{array}$} \\
\hline & \multicolumn{2}{|c|}{ "A" } & \multicolumn{2}{|c|}{ "B" } & \multicolumn{2}{|c|}{ "C" } & \multicolumn{2}{|c|}{ "D" } \\
\hline 100-0-0 & $\mathrm{R} \$$ & 1.361 & $\mathrm{R} \$$ & 1.311 & $\mathrm{R} \$$ & 1.238 & $\mathrm{R} \$$ & 1.202 \\
\hline $0-100-0$ & $\mathrm{R} \$$ & 1.362 & $\mathrm{R} \$$ & 1.315 & $\mathrm{R} \$$ & 1.239 & $\mathrm{R} \$$ & 1.203 \\
\hline $0-0-100$ & $\mathrm{R} \$$ & 1.223 & $\mathrm{R} \$$ & 1.179 & $\mathrm{R} \$$ & 1.107 & $\mathrm{R} \$$ & 1.071 \\
\hline $70-30-0$ & $\mathrm{R} \$$ & 1.361 & $\mathrm{R} \$$ & 1.311 & $\mathrm{R} \$$ & 1.239 & $\mathrm{R} \$$ & 1.203 \\
\hline $70-0-30$ & $\mathrm{R} \$$ & 1.328 & $\mathrm{R} \$$ & 1.279 & $\mathrm{R} \$$ & 1.208 & $\mathrm{R} \$$ & 1.172 \\
\hline $50-40-10$ & $\mathrm{R} \$$ & 1.352 & $\mathrm{R} \$$ & 1.303 & $\mathrm{R} \$$ & 1.230 & $\mathrm{R} \$$ & 1.195 \\
\hline $60-30-10$ & $\mathrm{R} \$$ & 1.352 & $\mathrm{R} \$$ & 1.302 & $\mathrm{R} \$$ & 1.230 & $\mathrm{R} \$$ & 1.194 \\
\hline
\end{tabular}

Apêndice 162 - Crédito médio de 1,50\% sobre o valor do investimento, por mensalidade, para construção em 90 dias e compensação de retorno em 12 meses, em função de áreas externas, anfiteatro e minisshopping, para 200 residentes

\begin{tabular}{|c|c|c|c|c|c|c|c|c|}
\hline \multirow[t]{2}{*}{$\begin{array}{l}\text { Porcentagem de } \\
\text { residentes com } \\
\text { grau de } \\
\text { dependência } \\
\text { I, II e III }\end{array}$} & \multicolumn{8}{|c|}{$\begin{array}{l}\text { Crédito médio de } 1,50 \% \text { sobre o valor do investimento, por } \\
\text { mensalidade, em função de áreas externas, anfiteatro e } \\
\text { minisshopping, para } 200 \text { residentes, com diversos graus de } \\
\text { dependência }\end{array}$} \\
\hline & \multicolumn{2}{|c|}{ "A" } & \multicolumn{2}{|c|}{ "B" } & \multicolumn{2}{|c|}{ "C" } & \multicolumn{2}{|c|}{ "D" } \\
\hline 100-0-0 & $\mathrm{R} \$$ & 1.377 & $\mathrm{R} \$$ & 1.302 & $\mathrm{R} \$$ & 1.227 & $\mathrm{R} \$$ & 1.136 \\
\hline 0-100-0 & $\mathrm{R} \$$ & 1.380 & $\mathrm{R} \$$ & 1.305 & $\mathrm{R} \$$ & 1.230 & $\mathrm{R} \$$ & 1.139 \\
\hline $0-0-100$ & $\mathrm{R} \$$ & 1.243 & $\mathrm{R} \$$ & 1.172 & $\mathrm{R} \$$ & 1.101 & $\mathrm{R} \$$ & 1.013 \\
\hline $70-30-0$ & $\mathrm{R} \$$ & 1.377 & $\mathrm{R} \$$ & 1.302 & $\mathrm{R} \$$ & 1.228 & $\mathrm{R} \$$ & 1.136 \\
\hline $70-0-30$ & $\mathrm{R} \$$ & 1.338 & $\mathrm{R} \$$ & 1.264 & $\mathrm{R} \$$ & 1.192 & $\mathrm{R} \$$ & 1.101 \\
\hline $50-40-10$ & $\mathrm{R} \$$ & 1.361 & $\mathrm{R} \$$ & 1.287 & $\mathrm{R} \$$ & 1.213 & $\mathrm{R} \$$ & 1.123 \\
\hline $60-30-10$ & $\mathrm{R} \$$ & 1.361 & $\mathrm{R} \$$ & 1.286 & $\mathrm{R} \$$ & 1.213 & $\mathrm{R} \$$ & 1.121 \\
\hline
\end{tabular}

Apêndice 163 - Crédito médio de 1,50\% sobre o valor do investimento, por mensalidade, para construção em 90 dias e compensação de retorno em 12 meses, em função de áreas externas, anfiteatro e minisshopping, para 300 residentes

\begin{tabular}{|c|c|c|c|c|c|c|c|c|}
\hline \multirow{2}{*}{$\begin{array}{l}\text { Porcentagem de } \\
\text { residentes com } \\
\text { grau de } \\
\text { dependência } \\
\text { I, II e III }\end{array}$} & \multicolumn{8}{|c|}{$\begin{array}{l}\text { Crédito médio de } 1,50 \% \text { sobre o valor do investimento, por } \\
\text { mensalidade, em função de áreas externas, anfiteatro e } \\
\text { minisshopping, para } 300 \text { residentes, com diversos graus de } \\
\text { dependência }\end{array}$} \\
\hline & \multicolumn{2}{|c|}{ "A" } & \multicolumn{2}{|c|}{ "B" } & \multicolumn{2}{|c|}{ "C" } & \multicolumn{2}{|c|}{ "D" } \\
\hline 100-0-0 & $\mathrm{R} \$$ & 1.281 & $\mathrm{R} \$$ & 1.219 & $\mathrm{R} \$$ & 1.135 & $\mathrm{R} \$$ & 1.104 \\
\hline 0-100-0 & $\mathrm{R} \$$ & 1.284 & $\mathrm{R} \$$ & 1.222 & $\mathrm{R} \$$ & 1.137 & $\mathrm{R} \$$ & 1.106 \\
\hline 0-0-100 & $\mathrm{R} \$$ & 1.157 & $\mathrm{R} \$$ & 1.098 & $\mathrm{R} \$$ & 1.016 & $\mathrm{R} \$$ & 988 \\
\hline $70-30-0$ & $\mathrm{R} \$$ & 1.282 & $\mathrm{R} \$$ & 1.220 & $\mathrm{R} \$$ & 1.156 & $\mathrm{R} \$$ & 1.104 \\
\hline $70-0-30$ & $\mathrm{R} \$$ & 1.246 & $\mathrm{R} \$$ & 1.185 & $\mathrm{R} \$$ & 1.122 & $\mathrm{R} \$$ & 1.072 \\
\hline $50-40-10$ & $\mathrm{R} \$$ & 1.272 & $\mathrm{R} \$$ & 1.210 & $\mathrm{R} \$$ & 1.126 & $\mathrm{R} \$$ & 1.095 \\
\hline $60-30-10$ & $\mathrm{R} \$$ & 1.272 & $\mathrm{R} \$$ & 1.210 & $\mathrm{R} \$$ & 1.125 & $\mathrm{R} \$$ & 1.095 \\
\hline
\end{tabular}


Apêndice 164 - Crédito médio de 1,50\% sobre o valor do investimento, por mensalidade, para construção em 90 dias e compensação de retorno em 12 meses, em função de áreas externas, anfiteatro e minisshopping, para 400 residentes

\begin{tabular}{|c|c|c|c|c|c|c|c|c|}
\hline \multirow{2}{*}{$\begin{array}{c}\text { Porcentagem de } \\
\text { residentes com } \\
\text { grau de } \\
\text { dependência } \\
\text { I, II e III } \\
\end{array}$} & \multicolumn{8}{|c|}{$\begin{array}{l}\text { Crédito médio de } 1,50 \% \text { sobre o valor do investimento, por } \\
\text { mensalidade, em função de áreas externas, anfiteatro e } \\
\text { minisshopping, para } 400 \text { residentes, com diversos graus de } \\
\text { dependência }\end{array}$} \\
\hline & \multicolumn{2}{|c|}{ "A" } & \multicolumn{2}{|c|}{ "B" } & \multicolumn{2}{|c|}{ "C" } & \multicolumn{2}{|c|}{ "D" } \\
\hline 100-0-0 & $\mathrm{R} \$$ & 1.259 & $\mathrm{R} \$$ & 1.202 & $\mathrm{R} \$$ & 1.130 & $\mathrm{R} \$$ & 1.102 \\
\hline $0-100-0$ & $\mathrm{R} \$$ & 1.261 & $\mathrm{R} \$$ & 1.204 & $\mathrm{R} \$$ & 1.132 & $\mathrm{R} \$$ & 1.104 \\
\hline $0-0-100$ & $\mathrm{R} \$$ & 1.134 & $\mathrm{R} \$$ & 1.082 & $\mathrm{R} \$$ & 1.013 & $\mathrm{R} \$$ & 986 \\
\hline 70-30-0 & $\mathrm{R} \$$ & 1.259 & $\mathrm{R} \$$ & 1.203 & $\mathrm{R} \$$ & 1.146 & $\mathrm{R} \$$ & 1.102 \\
\hline 70-0-30 & $\mathrm{R} \$$ & 1.222 & $\mathrm{R} \$$ & 1.167 & $\mathrm{R} \$$ & 1.111 & $\mathrm{R} \$$ & 1.067 \\
\hline $50-40-10$ & $\mathrm{R} \$$ & 1.247 & $\mathrm{R} \$$ & 1.191 & $\mathrm{R} \$$ & 1.119 & $\mathrm{R} \$$ & 1.091 \\
\hline $60-30-10$ & $\mathrm{R} \$$ & 1.246 & $\mathrm{R} \$$ & 1.190 & $\mathrm{R} \$$ & 1.119 & $\mathrm{R} \$$ & 1.090 \\
\hline
\end{tabular}

Apêndice 165 - Crédito médio de 1,10\% sobre o valor do investimento, por mensalidade, para construção em 90 dias e compensação de retorno em 24 meses, em função de áreas externas, anfiteatro e minisshopping, para 100 residentes

\begin{tabular}{|c|c|c|c|c|c|c|c|c|}
\hline \multirow{3}{*}{$\begin{array}{c}\text { Porcentagem de } \\
\text { residentes com } \\
\text { grau de } \\
\text { dependência } \\
\text { I, II e III } \\
100-0-0\end{array}$} & \multicolumn{8}{|c|}{$\begin{array}{l}\text { Crédito médio de } 1,10 \% \text { sobre o valor do investimento, por } \\
\text { mensalidade, em função de áreas externas, anfiteatro e } \\
\text { minisshopping, para } 100 \text { residentes, com diversos graus de } \\
\text { dependência }\end{array}$} \\
\hline & \multicolumn{2}{|c|}{ "A" } & \multicolumn{2}{|c|}{ "B" } & \multicolumn{2}{|c|}{ "C" } & \multicolumn{2}{|c|}{ "D" } \\
\hline & $\mathrm{R} \$$ & 855 & $\mathrm{R} \$$ & 824 & $\mathrm{R} \$$ & 778 & $\mathrm{R} \$$ & 756 \\
\hline 0-100-0 & $\mathrm{R} \$$ & 856 & $\mathrm{R} \$$ & 826 & $\mathrm{R} \$$ & 779 & $\mathrm{R} \$$ & 756 \\
\hline $0-0-100$ & $\mathrm{R} \$$ & 769 & $\mathrm{R} \$$ & 741 & $\mathrm{R} \$$ & 696 & $\mathrm{R} \$$ & 673 \\
\hline $70-30-0$ & $\mathrm{R} \$$ & 856 & $\mathrm{R} \$$ & 824 & $\mathrm{R} \$$ & 779 & $\mathrm{R} \$$ & 756 \\
\hline 70-0-30 & $\mathrm{R} \$$ & 835 & $\mathrm{R} \$$ & 804 & RS & 759 & $\mathrm{R} \$$ & 737 \\
\hline $50-40-10$ & $\mathrm{R} \$$ & 850 & $\mathrm{R} \$$ & 819 & $\mathrm{R} \$$ & 773 & $\mathrm{R} \$$ & 751 \\
\hline $60-30-10$ & $\mathrm{R} \$$ & 850 & $\mathrm{R} \$$ & 819 & $\mathrm{R} \$$ & 773 & $\mathrm{R} \$$ & 751 \\
\hline
\end{tabular}

Apêndice 166 - Crédito médio de 1,10\% sobre o valor do investimento, por mensalidade, para construção em 90 dias e compensação de retorno em 24 meses, em função de áreas externas, anfiteatro e minisshopping, para 200 residentes

\begin{tabular}{|c|c|c|c|c|c|c|c|c|}
\hline \multirow[t]{2}{*}{$\begin{array}{c}\text { Porcentagem de } \\
\text { residentes com } \\
\text { grau de } \\
\text { dependência } \\
\text { I, II e III }\end{array}$} & \multicolumn{8}{|c|}{$\begin{array}{l}\text { Crédito médio de } 1,10 \% \text { sobre o valor do investimento, por } \\
\text { mensalidade, em função de áreas externas, anfiteatro e } \\
\text { minisshopping, para } 200 \text { residentes, com diversos graus de } \\
\text { dependência }\end{array}$} \\
\hline & \multicolumn{2}{|c|}{ "A" } & \multicolumn{2}{|c|}{ "B" } & \multicolumn{2}{|c|}{ "C" } & \multicolumn{2}{|c|}{ "D" } \\
\hline $100-0-0$ & $\mathrm{R} \$$ & 866 & $\mathrm{R} \$$ & 818 & $\mathrm{R} \$$ & 772 & $\mathrm{R} \$$ & 714 \\
\hline $0-100-0$ & $\mathrm{R} \$$ & 867 & $\mathrm{R} \$$ & 820 & $\mathrm{R} \$$ & 773 & $\mathrm{R} \$$ & 716 \\
\hline $0-0-100$ & $\mathrm{R} \$$ & 782 & $\mathrm{R} \$$ & 737 & $\mathrm{R} \$$ & 692 & $\mathrm{R} \$$ & 637 \\
\hline $70-30-0$ & $\mathrm{R} \$$ & 866 & $\mathrm{R} \$$ & 819 & $\mathrm{R} \$$ & 772 & $\mathrm{R} \$$ & 714 \\
\hline 70-0-30 & $\mathrm{R} \$$ & 841 & $\mathrm{R} \$$ & 795 & $\mathrm{R} \$$ & 749 & $\mathrm{R} \$$ & 692 \\
\hline $50-40-10$ & $\mathrm{R} \$$ & 855 & $\mathrm{R} \$$ & 809 & $\mathrm{R} \$$ & 763 & K\$ & 706 \\
\hline $60-30-10$ & $\mathrm{R} \$$ & 855 & $\mathrm{R} \$$ & 809 & $\mathrm{R} \$$ & 763 & $\mathrm{R} \$$ & 705 \\
\hline
\end{tabular}


Apêndice 167 - Crédito médio de 1,10\% sobre o valor do investimento, por mensalidade, para construção em 90 dias e compensação de retorno em 24 meses, em função de áreas externas, anfiteatro e minisshopping, para 300 residentes

\begin{tabular}{|c|c|c|c|c|c|c|c|c|}
\hline \multirow{3}{*}{$\begin{array}{c}\text { Porcentagem de } \\
\text { residentes com } \\
\text { grau de } \\
\text { dependência } \\
\text { I, II e III } \\
100-0-0\end{array}$} & \multicolumn{8}{|c|}{$\begin{array}{c}\text { Crédito médio de } 1,10 \% \text { sobre o valor do investimento, por } \\
\text { mensalidade, em função de áreas externas, anfiteatro e } \\
\text { minisshopping, para } 300 \text { residentes, com diversos graus de } \\
\text { dependência }\end{array}$} \\
\hline & \multicolumn{2}{|c|}{ "A" } & \multicolumn{2}{|c|}{ "B" } & \multicolumn{2}{|c|}{ "C" } & \multicolumn{2}{|c|}{ "D" } \\
\hline & $\mathrm{R} \$$ & 805 & $\mathrm{R} \$$ & 766 & $\mathrm{R} \$$ & 713 & $\mathrm{R} \$$ & 694 \\
\hline 0-100-0 & $\mathrm{R} \$$ & 807 & $\mathrm{R} \$$ & 768 & $\mathrm{R} \$$ & 715 & $\mathrm{R} \$$ & 695 \\
\hline 0-0-100 & $\mathrm{R} \$$ & 727 & $\mathrm{R} \$$ & 690 & $\mathrm{R} \$$ & 639 & $\mathrm{R} \$$ & 621 \\
\hline 70-30-0 & $\mathrm{R} \$$ & 806 & $\mathrm{R} \$$ & 767 & $\mathrm{R} \$$ & 727 & $\mathrm{R} \$$ & 694 \\
\hline $70-0-30$ & $\mathrm{R} \$$ & 783 & $\mathrm{R} \$$ & 745 & $\mathrm{R} \$$ & 705 & $\mathrm{R} \$$ & 674 \\
\hline $50-40-10$ & $\mathrm{R} \$$ & 799 & $\mathrm{R} \$$ & 761 & $\mathrm{R} \$$ & 707 & $\mathrm{R} \$$ & 688 \\
\hline $60-30-10$ & $\mathrm{R} \$$ & 799 & $\mathrm{R} \$$ & 760 & $\mathrm{R} \$$ & 707 & $\mathrm{R} \$$ & 688 \\
\hline
\end{tabular}

Apêndice 168 - Crédito médio de 1,10\% sobre o valor do investimento, por mensalidade, para construção em 90 dias e compensação de retorno em 24 meses, em função de áreas externas, anfiteatro e minisshopping, para 400 residentes

\begin{tabular}{ccccccccc}
\hline $\begin{array}{c}\text { Porcentagem de } \\
\text { residentes com } \\
\text { grau de } \\
\text { dependência } \\
\text { I, II e III }\end{array}$ & $\begin{array}{c}\text { Crédito médio de 1,10\% sobre o valor do investimento, por } \\
\text { mensalidade, em função de áreas externas, anfiteatro e } \\
\text { minisshopping, para 400 residentes, com diversos graus de } \\
\text { dependência }\end{array}$ \\
\cline { 2 - 10 } & \multicolumn{6}{c}{ "A" } & \multicolumn{6}{c}{ "B" } \\
\hline $\mathbf{1 0 0 - 0 - 0}$ & $\mathrm{R} \$$ & 791 & $\mathrm{R} \$$ & 756 & $\mathrm{R} \$$ & 710 & $\mathrm{R} \$$ & 693 \\
$\mathbf{0 - 1 0 0 - 0}$ & $\mathrm{R} \$$ & 793 & $\mathrm{R} \$$ & 757 & $\mathrm{R} \$$ & 712 & $\mathrm{R} \$$ & 694 \\
$\mathbf{0 - 0 - 1 0 0}$ & $\mathrm{R} \$$ & 713 & $\mathrm{R} \$$ & 680 & $\mathrm{R} \$$ & 637 & $\mathrm{R} \$$ & 620 \\
$\mathbf{7 0 - 3 0 - 0}$ & $\mathrm{R} \$$ & 791 & $\mathrm{R} \$$ & 756 & $\mathrm{R} \$$ & 721 & $\mathrm{R} \$$ & 693 \\
$\mathbf{7 0 - 0 - 3 0}$ & $\mathrm{R} \$$ & 768 & $\mathrm{R} \$$ & 733 & $\mathrm{R} \$$ & 698 & $\mathrm{R} \$$ & 671 \\
$\mathbf{5 0 - 4 0 - 1 0}$ & $\mathrm{R} \$$ & 784 & $\mathrm{R} \$$ & 748 & $\mathrm{R} \$$ & 703 & $\mathrm{R} \$$ & 686 \\
$\mathbf{6 0 - 3 0 - 1 0}$ & $\mathrm{R} \$$ & 783 & $\mathrm{R} \$$ & 748 & $\mathrm{R} \$$ & 703 & $\mathrm{R} \$$ & 685 \\
\hline
\end{tabular}

Apêndice 169 - Crédito médio de 1,20\% sobre o valor do investimento, por mensalidade, para construção em 90 dias e compensação de retorno em 24 meses, em função de áreas externas, anfiteatro e minisshopping, para 100 residentes

\begin{tabular}{ccccccccr}
\hline $\begin{array}{c}\text { Porcentagem de } \\
\text { residentes com } \\
\text { grau de } \\
\text { dependência } \\
\text { I, II e III }\end{array}$ & $\begin{array}{c}\text { Crédito médio de 1,20\% sobre o valor do investimento, por } \\
\text { mensalidade, em função de áreas externas, anfiteatro e } \\
\text { minisshopping, para 100 residentes, com diversos graus de } \\
\text { dependência }\end{array}$ \\
\cline { 2 - 10 } & \multicolumn{2}{c}{ "A" } & \multicolumn{5}{c}{ "B" } & \multicolumn{3}{c}{ "C" } & \multicolumn{2}{c}{ "D" } \\
\hline $\mathbf{1 0 0 - 0 - 0}$ & $\mathrm{R} \$$ & 933 & $\mathrm{R} \$$ & 899 & $\mathrm{R} \$$ & 849 & $\mathrm{R} \$$ & 824 \\
$\mathbf{0 - 1 0 0 - 0}$ & $\mathrm{R} \$$ & 934 & $\mathrm{R} \$$ & 902 & $\mathrm{R} \$$ & 850 & $\mathrm{R} \$$ & 825 \\
$\mathbf{0 - 0 - 1 0 0}$ & $\mathrm{R} \$$ & 839 & $\mathrm{R} \$$ & 809 & $\mathrm{R} \$$ & 759 & $\mathrm{R} \$$ & 735 \\
$\mathbf{7 0 - 3 0 - 0}$ & $\mathrm{R} \$$ & 934 & $\mathrm{R} \$$ & 899 & $\mathrm{R} \$$ & 849 & $\mathrm{R} \$$ & 825 \\
$\mathbf{7 0 - 0 - 3 0}$ & $\mathrm{R} \$$ & 911 & $\mathrm{R} \$$ & 877 & $\mathrm{R} \$$ & 828 & $\mathrm{R} \$$ & 804 \\
$\mathbf{5 0 - 4 0 - 1 0}$ & $\mathrm{R} \$$ & 927 & $\mathrm{R} \$$ & 893 & $\mathrm{R} \$$ & 844 & $\mathrm{R} \$$ & 819 \\
$\mathbf{6 0 - 3 0 - 1 0}$ & $\mathrm{R} \$$ & 927 & $\mathrm{R} \$$ & 893 & $\mathrm{R} \$$ & 844 & $\mathrm{R} \$$ & 819 \\
\hline
\end{tabular}


Apêndice 170 - Crédito médio de 1,20\% sobre o valor do investimento, por mensalidade, para construção em 90 dias e compensação de retorno em 24 meses, em função de áreas externas, anfiteatro e minisshopping, para 200 residentes

\begin{tabular}{|c|c|c|c|c|c|c|c|c|}
\hline \multirow{3}{*}{$\begin{array}{c}\text { Porcentagem de } \\
\text { residentes com } \\
\text { grau de } \\
\text { dependência } \\
\text { I, II e III } \\
100-0-0\end{array}$} & \multicolumn{8}{|c|}{$\begin{array}{c}\text { Crédito médio de } 1,20 \% \text { sobre o valor do investimento, por } \\
\text { mensalidade, em função de áreas externas, anfiteatro e } \\
\text { minisshopping, para } 200 \text { residentes, com diversos graus de } \\
\text { dependência }\end{array}$} \\
\hline & \multicolumn{2}{|c|}{ "A" } & \multicolumn{2}{|c|}{ "B" } & \multicolumn{2}{|c|}{ "C" } & \multicolumn{2}{|c|}{ "D" } \\
\hline & $\mathrm{R} \$$ & 944 & $\mathrm{R} \$$ & 893 & $\mathrm{R} \$$ & 842 & $\mathrm{R} \$$ & 779 \\
\hline $0-100-0$ & $\mathrm{R} \$$ & 946 & $\mathrm{R} \$$ & 895 & $\mathrm{R} \$$ & 843 & $\mathrm{R} \$$ & 781 \\
\hline 0-0-100 & $\mathrm{R} \$$ & 853 & $\mathrm{R} \$$ & 804 & $\mathrm{R} \$$ & 755 & $\mathrm{R} \$$ & 695 \\
\hline 70-30-0 & $\mathrm{R} \$$ & 944 & $\mathrm{R} \$$ & 893 & $\mathrm{R} \$$ & 842 & $\mathrm{R} \$$ & 779 \\
\hline 70-0-30 & $\mathrm{R} \$$ & 918 & $\mathrm{R} \$$ & 867 & $\mathrm{R} \$$ & 818 & $\mathrm{R} \$$ & 755 \\
\hline $50-40-10$ & $\mathrm{R} \$$ & 933 & $\mathrm{R} \$$ & 882 & $\mathrm{R} \$$ & 832 & $\mathrm{R} \$$ & 770 \\
\hline $60-30-10$ & $\mathrm{R} \$$ & 933 & $\mathrm{R} \$$ & 882 & $\mathrm{R} \$$ & 832 & $\mathrm{R} \$$ & 769 \\
\hline
\end{tabular}

Apêndice 171 - Crédito médio de 1,20\% sobre o valor do investimento, por mensalidade, para construção em 90 dias e compensação de retorno em 24 meses, em função de áreas externas, anfiteatro e minisshopping, para 300 residentes

\begin{tabular}{|c|c|c|c|c|c|c|c|c|}
\hline \multirow{2}{*}{$\begin{array}{c}\text { Porcentagem de } \\
\text { residentes com } \\
\text { grau de } \\
\text { dependência } \\
\text { I, II e III }\end{array}$} & \multicolumn{8}{|c|}{$\begin{array}{c}\text { Crédito médio de } 1,20 \% \text { sobre o valor do investimento, por } \\
\text { mensalidade, em função de áreas externas, anfiteatro e } \\
\text { minisshopping, para } 300 \text { residentes, com diversos graus de } \\
\text { dependência }\end{array}$} \\
\hline & \multicolumn{2}{|c|}{ "A" } & \multicolumn{2}{|c|}{ "B" } & \multicolumn{2}{|c|}{ "C" } & \multicolumn{2}{|c|}{ "D" } \\
\hline 100-0-0 & $\mathrm{R} \$$ & 878 & $\mathrm{R} \$$ & 836 & $\mathrm{R} \$$ & 778 & $\mathrm{R} \$$ & 757 \\
\hline $0-100-0$ & $\mathrm{R} \$$ & 880 & $\mathrm{R} \$$ & 838 & $\mathrm{R} \$$ & 780 & $\mathrm{R} \$$ & 758 \\
\hline $0-0-100$ & $\mathrm{R} \$$ & 793 & $\mathrm{R} \$$ & 753 & $\mathrm{R} \$$ & 697 & $\mathrm{R} \$$ & 677 \\
\hline $70-30-0$ & $\mathrm{R} \$$ & 879 & $\mathrm{R} \$$ & 837 & $\mathrm{R} \$$ & 793 & $\mathrm{R} \$$ & 757 \\
\hline 70-0-30 & $\mathrm{R} \$$ & 855 & $\mathrm{R} \$$ & 813 & $\mathrm{R} \$$ & 769 & R\$ & 735 \\
\hline $50-40-10$ & $\mathrm{R} \$$ & 872 & $\mathrm{R} \$$ & 830 & $\mathrm{R} \$$ & 772 & R\$ & 751 \\
\hline $60-30-10$ & $\mathrm{R} \$$ & 872 & $\mathrm{R} \$$ & 830 & $\mathrm{R} \$$ & 772 & $\mathrm{R} \$$ & 751 \\
\hline
\end{tabular}

Apêndice 172 - Crédito médio de 1,20\% sobre o valor do investimento, por mensalidade, para construção em 90 dias e compensação de retorno em 24 meses, em função de áreas externas, anfiteatro e minisshopping, para 400 residentes

\begin{tabular}{|c|c|c|c|c|c|c|c|c|}
\hline \multirow[t]{2}{*}{$\begin{array}{c}\text { Porcentagem de } \\
\text { residentes com } \\
\text { grau de } \\
\text { dependência } \\
\text { I, II e III }\end{array}$} & \multicolumn{8}{|c|}{$\begin{array}{c}\text { Crédito médio de } 1,20 \% \text { sobre o valor do investimento, por } \\
\text { mensalidade, em função de áreas externas, anfiteatro e } \\
\text { minisshopping, para } 400 \text { residentes, com diversos graus de } \\
\text { dependência }\end{array}$} \\
\hline & \multicolumn{2}{|c|}{ "A" } & \multicolumn{2}{|c|}{ "B" } & \multicolumn{2}{|c|}{ "C" } & \multicolumn{2}{|c|}{ "D" } \\
\hline $100-0-0$ & $\mathrm{R} \$$ & 863 & $\mathrm{R} \$$ & 824 & $\mathrm{R} \$$ & 775 & $\mathrm{R} \$$ & 755 \\
\hline $0-100-0$ & $\mathrm{R} \$$ & 865 & $\mathrm{R} \$$ & 826 & $\mathrm{R} \$$ & 776 & $\mathrm{R} \$$ & 757 \\
\hline $0-0-100$ & $\mathrm{R} \$$ & 778 & $\mathrm{R} \$$ & 742 & $\mathrm{R} \$$ & 695 & $\mathrm{R} \$$ & 676 \\
\hline $70-30-0$ & $\mathrm{R} \$$ & 863 & $\mathrm{R} \$$ & 825 & $\mathrm{R} \$$ & 786 & $\$$ & 756 \\
\hline 70-0-30 & $\mathrm{R} \$$ & 838 & $\mathrm{R} \$$ & 800 & $\mathrm{R} \$$ & 762 & $\mathrm{R} \$$ & 732 \\
\hline $50-40-10$ & $\mathrm{R} \$$ & 855 & $\mathrm{R} \$$ & 816 & $\mathrm{R} \$$ & 767 & R\$ & 748 \\
\hline $60-30-10$ & $\mathrm{R} \$$ & 855 & $\mathrm{R} \$$ & 816 & $\mathrm{R} \$$ & 767 & $\mathrm{R} \$$ & 748 \\
\hline
\end{tabular}


Apêndice 173 - Crédito médio de 1,30\% sobre o valor do investimento, por mensalidade, para construção em 90 dias e compensação de retorno em 24 meses, em função de áreas externas, anfiteatro e minisshopping, para 100 residentes

\begin{tabular}{|c|c|c|c|c|c|c|c|c|}
\hline \multirow{3}{*}{$\begin{array}{c}\text { Porcentagem de } \\
\text { residentes com } \\
\text { grau de } \\
\text { dependência } \\
\text { I, II e III } \\
\text { 100-0-0 }\end{array}$} & \multicolumn{8}{|c|}{$\begin{array}{c}\text { Crédito médio de } 1,30 \% \text { sobre o valor do investimento, por } \\
\text { mensalidade, em função de áreas externas, anfiteatro e } \\
\text { minisshopping, para } 100 \text { residentes, com diversos graus de } \\
\text { dependência }\end{array}$} \\
\hline & \multicolumn{2}{|c|}{ "A" } & \multicolumn{2}{|c|}{ "B" } & \multicolumn{2}{|c|}{ "C" } & \multicolumn{2}{|c|}{ "D" } \\
\hline & $\mathrm{R} \$$ & 1.011 & $\mathrm{R} \$$ & 974 & $\mathrm{R} \$$ & 920 & $\mathrm{R} \$$ & 893 \\
\hline 0-100-0 & $\mathrm{R} \$$ & 1.012 & $\mathrm{R} \$$ & 977 & $\mathrm{R} \$$ & 921 & $\mathrm{R} \$$ & 894 \\
\hline $0-0-100$ & $\mathrm{R} \$$ & 908 & $\mathrm{R} \$$ & 876 & $\mathrm{R} \$$ & 823 & $\mathrm{R} \$$ & 796 \\
\hline 70-30-0 & $\mathrm{R} \$$ & 1.011 & $\mathrm{R} \$$ & 974 & $\mathrm{R} \$$ & 920 & $\mathrm{R} \$$ & 893 \\
\hline 70-0-30 & $\mathrm{R} \$$ & 987 & $\mathrm{R} \$$ & 950 & $\mathrm{R} \$$ & 897 & $\mathrm{R} \$$ & 871 \\
\hline $50-40-10$ & $\mathrm{R} \$$ & 1.005 & $\mathrm{R} \$$ & 968 & $\mathrm{R} \$$ & 914 & $\mathrm{R} \$$ & 887 \\
\hline $60-30-10$ & $\mathrm{R} \$$ & 1.004 & $\mathrm{R} \$$ & 968 & $\mathrm{R} \$$ & 914 & $\mathrm{R} \$$ & 887 \\
\hline
\end{tabular}

Apêndice 174 - Crédito médio de 1,30\% sobre o valor do investimento, por mensalidade, para construção em 90 dias e compensação de retorno em 24 meses, em função de áreas externas, anfiteatro e minisshopping, para 200 residentes

\begin{tabular}{|c|c|c|c|c|c|c|c|c|}
\hline \multirow[t]{2}{*}{$\begin{array}{c}\text { Porcentagem de } \\
\text { residentes com } \\
\text { grau de } \\
\text { dependência } \\
\text { I, II e III }\end{array}$} & \multicolumn{8}{|c|}{$\begin{array}{l}\text { Crédito médio de } 1,30 \% \text { sobre o valor do investimento, por } \\
\text { mensalidade, em função de áreas externas, anfiteatro e } \\
\text { minisshopping, para } 200 \text { residentes, com diversos graus de } \\
\text { dependência }\end{array}$} \\
\hline & \multicolumn{2}{|c|}{ "A" } & \multicolumn{2}{|c|}{ "B" } & \multicolumn{2}{|c|}{ "C" } & \multicolumn{2}{|c|}{ "D" } \\
\hline $100-0-0$ & $\mathrm{R} \$$ & 1.023 & $\mathrm{R} \$$ & 967 & $\mathrm{R} \$$ & 912 & $\mathrm{R} \$$ & 844 \\
\hline $0-100-0$ & $\mathrm{R} \$$ & 1.025 & $\mathrm{R} \$$ & 969 & $\mathrm{R} \$$ & 914 & $\mathrm{R} \$$ & 846 \\
\hline $0-0-100$ & $\mathrm{R} \$$ & 924 & $\mathrm{R} \$$ & 871 & $\mathrm{R} \$$ & 818 & $\mathrm{R} \$$ & 753 \\
\hline $70-30-0$ & $\mathrm{R} \$$ & 1.023 & $\mathrm{R} \$$ & 968 & $\mathrm{R} \$$ & 912 & $\mathrm{R} \$$ & 844 \\
\hline $70-0-30$ & $\mathrm{R} \$$ & 994 & $\mathrm{R} \$$ & 939 & K\$ & 886 & R\$ & 818 \\
\hline $50-40-10$ & $\mathrm{R} \$$ & 1.011 & $\mathrm{R} \$$ & 956 & $\mathrm{R} \$$ & 901 & R\$ & 834 \\
\hline $60-30-10$ & $\mathrm{R} \$$ & 1.011 & $\mathrm{R} \$$ & 956 & $\mathrm{R} \$$ & 901 & $\mathrm{R} \$$ & 833 \\
\hline
\end{tabular}

Apêndice 175 - Crédito médio de 1,30\% sobre o valor do investimento, por mensalidade, para construção em 90 dias e compensação de retorno em 24 meses, em função de áreas externas, anfiteatro e minisshopping, para 300 residentes

\begin{tabular}{|c|c|c|c|c|c|c|c|c|}
\hline \multirow[t]{2}{*}{$\begin{array}{c}\text { Porcentagem de } \\
\text { residentes com } \\
\text { grau de } \\
\text { dependência } \\
\text { I, II e III }\end{array}$} & \multicolumn{8}{|c|}{$\begin{array}{c}\text { Crédito médio de } 1,30 \% \text { sobre o valor do investimento, por } \\
\text { mensalidade, em função de áreas externas, anfiteatro e } \\
\text { minisshopping, para } 300 \text { residentes, com diversos graus de } \\
\text { dependência }\end{array}$} \\
\hline & \multicolumn{2}{|c|}{ "A" } & \multicolumn{2}{|c|}{ "B" } & \multicolumn{2}{|c|}{ "C" } & \multicolumn{2}{|c|}{ "D" } \\
\hline $100-0-0$ & $\mathrm{R} \$$ & 952 & $\mathrm{R} \$$ & 905 & $\mathrm{R} \$$ & 843 & $\mathrm{R} \$$ & 820 \\
\hline $0-100-0$ & $\mathrm{R} \$$ & 954 & $\mathrm{R} \$$ & 908 & $\mathrm{R} \$$ & 845 & $\mathrm{R} \$$ & 821 \\
\hline $0-0-100$ & $\mathrm{R} \$$ & 859 & $\mathrm{R} \$$ & 815 & $\mathrm{R} \$$ & 755 & $\mathrm{R} \$$ & 734 \\
\hline $70-30-0$ & $\mathrm{R} \$$ & 953 & $\mathrm{R} \$$ & 906 & $\mathrm{R} \$$ & 859 & $\mathrm{R} \$$ & 820 \\
\hline 70-0-30 & $\mathrm{R} \$$ & 926 & $\mathrm{R} \$$ & 880 & $\mathrm{R} \$$ & 833 & $\mathrm{R} \$$ & 796 \\
\hline $50-40-10$ & $\mathrm{R} \$$ & 945 & $\mathrm{R} \$$ & 899 & $\mathrm{R} \$$ & 836 & R\$ & 814 \\
\hline $60-30-10$ & $\mathrm{R} \$$ & 945 & $\mathrm{R} \$$ & 899 & $\mathrm{R} \$$ & 836 & $\mathrm{R} \$$ & 814 \\
\hline
\end{tabular}


Apêndice 176 - Crédito médio de 1,30\% sobre o valor do investimento, por mensalidade, para construção em 90 dias e compensação de retorno em 24 meses, em função de áreas externas, anfiteatro e minisshopping, para 400 residentes

\begin{tabular}{|c|c|c|c|c|c|c|c|c|}
\hline \multirow{3}{*}{$\begin{array}{c}\text { Porcentagem de } \\
\text { residentes com } \\
\text { grau de } \\
\text { dependência } \\
\text { I, II e III } \\
100-0-0\end{array}$} & \multicolumn{8}{|c|}{$\begin{array}{c}\text { Crédito médio de } 1,30 \% \text { sobre o valor do investimento, por } \\
\text { mensalidade, em função de áreas externas, anfiteatro e } \\
\text { minisshopping, para } 400 \text { residentes, com diversos graus de } \\
\text { dependência }\end{array}$} \\
\hline & \multicolumn{2}{|c|}{ "A" } & \multicolumn{2}{|c|}{ "B" } & \multicolumn{2}{|c|}{ "C" } & \multicolumn{2}{|c|}{ "D" } \\
\hline & $\mathrm{R} \$$ & 935 & $\mathrm{R} \$$ & 893 & $\mathrm{R} \$$ & 839 & $\mathrm{R} \$$ & 818 \\
\hline $0-100-0$ & $\mathrm{R} \$$ & 937 & $\mathrm{R} \$$ & 895 & $\mathrm{R} \$$ & 841 & $\mathrm{R} \$$ & 820 \\
\hline 0-0-100 & $\mathrm{R} \$$ & 843 & $\mathrm{R} \$$ & 804 & $\mathrm{R} \$$ & 752 & $\mathrm{R} \$$ & 732 \\
\hline 70-30-0 & $\mathrm{R} \$$ & 935 & $\mathrm{R} \$$ & 894 & $\mathrm{R} \$$ & 852 & $\mathrm{R} \$$ & 819 \\
\hline 70-0-30 & $\mathrm{R} \$$ & 908 & $\mathrm{R} \$$ & 867 & $\mathrm{R} \$$ & 825 & $\mathrm{R} \$$ & 793 \\
\hline $50-40-10$ & $\mathrm{R} \$$ & 926 & $\mathrm{R} \$$ & 884 & $\mathrm{R} \$$ & 831 & $\mathrm{R} \$$ & 810 \\
\hline $60-30-10$ & $\mathrm{R} \$$ & 926 & $\mathrm{R} \$$ & 884 & $\mathrm{R} \$$ & 831 & $\mathrm{R} \$$ & 810 \\
\hline
\end{tabular}

Apêndice 177 - Crédito médio de 1,40\% sobre o valor do investimento, por mensalidade, para construção em 90 dias e compensação de retorno em 24 meses, em função de áreas externas, anfiteatro e minisshopping, para 100 residentes

\begin{tabular}{|c|c|c|c|c|c|c|c|c|}
\hline \multirow[t]{2}{*}{$\begin{array}{l}\text { Porcentagem de } \\
\text { residentes com } \\
\text { grau de } \\
\text { dependência } \\
\text { I, II e III }\end{array}$} & \multicolumn{8}{|c|}{$\begin{array}{c}\text { Crédito médio de } 1,40 \% \text { sobre o valor do investimento, por } \\
\text { mensalidade, em função de áreas externas, anfiteatro e } \\
\text { minisshopping, para } 100 \text { residentes, com diversos graus de } \\
\text { dependência }\end{array}$} \\
\hline & \multicolumn{2}{|c|}{ "A" } & \multicolumn{2}{|c|}{ "B" } & \multicolumn{2}{|c|}{ "C" } & \multicolumn{2}{|c|}{ "D" } \\
\hline $100-0-0$ & $\mathrm{R} \$$ & 1.089 & $\mathrm{R} \$$ & 1.049 & $\mathrm{R} \$$ & 990 & $\mathrm{R} \$$ & 962 \\
\hline $0-100-0$ & $\mathrm{R} \$$ & 1.090 & $\mathrm{R} \$$ & 1.052 & $\mathrm{R}$ & 992 & $\mathrm{R} \$$ & 963 \\
\hline $0-0-100$ & $\mathrm{R} \$$ & 978 & $\mathrm{R} \$$ & 943 & $\mathrm{R} \$$ & 886 & $\mathrm{R} \$$ & 857 \\
\hline $70-30-0$ & $\mathrm{R} \$$ & 1.089 & $\mathrm{R} \$$ & 1.049 & $\mathrm{R} \$$ & 991 & $\mathrm{R} \$$ & 962 \\
\hline 70-0-30 & $\mathrm{R} \$$ & 1.062 & $\mathrm{R} \$$ & 1.024 & $\mathrm{R}$ & 966 & R\$ & 938 \\
\hline $50-40-10$ & $\mathrm{R} \$$ & 1.082 & $\mathrm{R} \$$ & 1.042 & $\mathrm{R} \$$ & 984 & $\mathrm{R}$ & 956 \\
\hline $60-30-10$ & $\mathrm{R} \$$ & 1.082 & $\mathrm{R} \$$ & 1.042 & $\mathrm{R} \$$ & 984 & $\mathrm{R} \$$ & 955 \\
\hline
\end{tabular}

Apêndice 178 - Crédito médio de 1,40\% sobre o valor do investimento, por mensalidade, para construção em 90 dias e compensação de retorno em 24 meses, em função de áreas externas, anfiteatro e minisshopping, para 200 residentes

\begin{tabular}{|c|c|c|c|c|c|c|c|c|}
\hline \multirow{2}{*}{$\begin{array}{c}\text { Porcentagem de } \\
\text { residentes com } \\
\text { grau de } \\
\text { dependência } \\
\text { I, II e III } \\
\end{array}$} & \multicolumn{8}{|c|}{$\begin{array}{l}\text { Crédito médio de } 1,40 \% \text { sobre o valor do investimento, por } \\
\text { mensalidade, em função de áreas externas, anfiteatro e } \\
\text { minisshopping, para } 200 \text { residentes, com diversos graus de } \\
\text { dependência }\end{array}$} \\
\hline & \multicolumn{2}{|c|}{ "A" } & \multicolumn{2}{|c|}{ "B" } & \multicolumn{2}{|c|}{ "C" } & \multicolumn{2}{|c|}{ "D" } \\
\hline 100-0-0 & $\mathrm{R} \$$ & 1.102 & $\mathrm{R} \$$ & 1.042 & $\mathrm{R} \$$ & 982 & $\mathrm{R} \$$ & 909 \\
\hline $0-100-0$ & $\mathrm{R} \$$ & 1.104 & $\mathrm{R} \$$ & 1.044 & $\mathrm{R} \$$ & 984 & $\mathrm{R} \$$ & 911 \\
\hline $0-0-100$ & $\mathrm{R} \$$ & 995 & $\mathrm{R} \$$ & 938 & $\mathrm{R} \$$ & 880 & $\mathrm{R} \$$ & 811 \\
\hline 70-30-0 & $\mathrm{R} \$$ & 1.102 & $\mathrm{R} \$$ & 1.042 & $\mathrm{R} \$$ & 982 & $\mathrm{R} \$$ & 909 \\
\hline 70-0-30 & $\mathrm{R} \$$ & 1.071 & $\mathrm{R} \$$ & 1.012 & $\mathrm{R} \$$ & 954 & $\mathrm{R} \$$ & 881 \\
\hline $50-40-10$ & $\mathrm{R} \$$ & 1.089 & $\mathrm{R} \$$ & 1.029 & $\mathrm{R} \$$ & 971 & $\mathrm{R} \$$ & 898 \\
\hline $60-30-10$ & $\mathrm{R} \$$ & 1.089 & $\mathrm{R} \$$ & 1.029 & $\mathrm{R} \$$ & 971 & $\mathrm{R} \$$ & 897 \\
\hline
\end{tabular}


Apêndice 179 - Crédito médio de 1,40\% sobre o valor do investimento, por mensalidade, para construção em 90 dias e compensação de retorno em 24 meses, em função de áreas externas, anfiteatro e minisshopping, para 300 residentes

\begin{tabular}{|c|c|c|c|c|c|c|c|c|}
\hline \multirow{2}{*}{$\begin{array}{l}\text { Porcentagem de } \\
\text { residentes com } \\
\text { grau de } \\
\text { dependência } \\
\text { I, II e III } \\
\end{array}$} & \multicolumn{8}{|c|}{$\begin{array}{c}\text { Crédito médio de } 1,40 \% \text { sobre o valor do investimento, por } \\
\text { mensalidade, em função de áreas externas, anfiteatro e } \\
\text { minisshopping, para } 300 \text { residentes, com diversos graus de } \\
\text { dependência }\end{array}$} \\
\hline & \multicolumn{2}{|c|}{ "A" } & \multicolumn{2}{|c|}{ "B" } & \multicolumn{2}{|c|}{ "C" } & \multicolumn{2}{|c|}{ "D" } \\
\hline $100-0-0$ & $\mathrm{R} \$$ & 1.025 & $\mathrm{R} \$$ & 975 & $\mathrm{R} \$$ & 908 & $\mathrm{R} \$$ & 883 \\
\hline $0-100-0$ & $\mathrm{R} \$$ & 1.027 & $\mathrm{R} \$$ & 977 & $\mathrm{R} \$$ & 910 & $\mathrm{R} \$$ & 884 \\
\hline $0-0-100$ & $\mathrm{R} \$$ & 925 & $\mathrm{R} \$$ & 878 & $\mathrm{R} \$$ & 813 & $\mathrm{R} \$$ & 790 \\
\hline $70-30-0$ & $\mathrm{R} \$$ & 1.026 & $\mathrm{R} \$$ & 976 & $\mathrm{R} \$$ & 925 & $\mathrm{R} \$$ & 883 \\
\hline 70-0-30 & $\mathrm{R} \$$ & 997 & $\mathrm{R} \$$ & 948 & $\mathrm{R} \$$ & 898 & $\mathrm{R} \$$ & 857 \\
\hline $50-40-10$ & $\mathrm{R} \$$ & 1.017 & $\mathrm{R} \$$ & 968 & $\mathrm{R} \$$ & 900 & $\mathrm{R} \$$ & 876 \\
\hline $60-30-10$ & $\mathrm{R} \$$ & 1.017 & $\mathrm{R} \$$ & 968 & $\mathrm{R} \$$ & 900 & $\mathrm{R} \$$ & 876 \\
\hline
\end{tabular}

Apêndice 180 - Crédito médio de 1,40\% sobre o valor do investimento, por mensalidade, para construção em 90 dias e compensação de retorno em 24 meses, em função de áreas externas, anfiteatro e minisshopping, para 400 residentes

\begin{tabular}{|c|c|c|c|c|c|c|c|c|}
\hline \multirow{2}{*}{$\begin{array}{c}\text { Porcentagem de } \\
\text { residentes com } \\
\text { grau de } \\
\text { dependência } \\
\text { I, II e III } \\
\end{array}$} & \multicolumn{8}{|c|}{$\begin{array}{l}\text { Crédito médio de } 1,40 \% \text { sobre o valor do investimento, por } \\
\text { mensalidade, em função de áreas externas, anfiteatro e } \\
\text { minisshopping, para } 400 \text { residentes, com diversos graus de } \\
\text { dependência }\end{array}$} \\
\hline & \multicolumn{2}{|c|}{ "A" } & \multicolumn{2}{|c|}{ "B" } & \multicolumn{2}{|c|}{ "C" } & \multicolumn{2}{|c|}{ "D" } \\
\hline 100-0-0 & $\mathrm{R} \$$ & 1.007 & $\mathrm{R} \$$ & 962 & $\mathrm{R} \$$ & 904 & $\mathrm{R} \$$ & 881 \\
\hline $0-100-0$ & $\mathrm{R} \$$ & 1.009 & $\mathrm{R} \$$ & 964 & $\mathrm{R} \$$ & 906 & $\mathrm{R} \$$ & 883 \\
\hline $0-0-100$ & $\mathrm{R} \$$ & 907 & $\mathrm{R} \$$ & 865 & $\mathrm{R} \$$ & 810 & $\mathrm{R} \$$ & 789 \\
\hline $70-30-0$ & $\mathrm{R} \$$ & 1.007 & $\mathrm{R} \$$ & 962 & $\mathrm{R} \$$ & 917 & $\mathrm{R} \$$ & 882 \\
\hline 70-0-30 & $\mathrm{R} \$$ & 977 & $\mathrm{R} \$$ & 933 & $\mathrm{R} \$$ & 889 & R\$ & 854 \\
\hline $50-40-10$ & $\mathrm{R} \$$ & 998 & $\mathrm{R} \$$ & 952 & $\mathrm{R} \$$ & 895 & $\mathrm{R}$ & 873 \\
\hline $60-30-10$ & $\mathrm{R} \$$ & 997 & $\mathrm{R} \$$ & 952 & $\mathrm{R} \$$ & 895 & $\mathrm{R} \$$ & 872 \\
\hline
\end{tabular}

Apêndice 181 - Crédito médio de 1,50\% sobre o valor do investimento, por mensalidade, para construção em 90 dias e compensação de retorno em 24 meses, em função de áreas externas, anfiteatro e minisshopping, para 100 residentes

\begin{tabular}{|c|c|c|c|c|c|c|c|c|}
\hline \multirow{2}{*}{$\begin{array}{c}\text { Porcentagem de } \\
\text { residentes com } \\
\text { grau de } \\
\text { dependência } \\
\text { I, II e III } \\
\end{array}$} & \multicolumn{8}{|c|}{$\begin{array}{l}\text { Crédito médio de } 1,50 \% \text { sobre o valor do investimento, por } \\
\text { mensalidade, em função de áreas externas, anfiteatro e } \\
\text { minisshopping, para } 100 \text { residentes, com diversos graus de } \\
\text { dependência }\end{array}$} \\
\hline & \multicolumn{2}{|c|}{ "A" } & \multicolumn{2}{|c|}{ "B" } & \multicolumn{2}{|c|}{ "C" } & \multicolumn{2}{|c|}{ "D" } \\
\hline 100-0-0 & $\mathrm{R} \$$ & 1.167 & $\mathrm{R} \$$ & 1.124 & $\mathrm{R} \$$ & 1.061 & $\mathrm{R} \$$ & 1.030 \\
\hline $0-100-0$ & $\mathrm{R} \$$ & 1.167 & $\mathrm{R} \$$ & 1.127 & $\mathrm{R} \$$ & 1.062 & $\mathrm{R} \$$ & 1.032 \\
\hline $0-0-100$ & $\mathrm{R} \$$ & 1.048 & $\mathrm{R} \$$ & 1.011 & $\mathrm{R} \$$ & 949 & $\mathrm{R} \$$ & 918 \\
\hline $70-30-0$ & $\mathrm{R} \$$ & 1.167 & $\mathrm{R} \$$ & 1.124 & $\mathrm{R} \$$ & 1.062 & $\mathrm{R} \$$ & 1.031 \\
\hline 70-0-30 & $\mathrm{R} \$$ & 1.138 & $\mathrm{R} \$$ & 1.097 & $\mathrm{R} \$$ & 1.035 & $\mathrm{R} \$$ & 1.005 \\
\hline $50-40-10$ & $\mathrm{R} \$$ & 1.159 & $\mathrm{R} \$$ & 1.117 & $\mathrm{R} \$$ & 1.055 & $\mathrm{R}$ & 1.024 \\
\hline $60-30-10$ & $\mathrm{R} \$$ & 1.159 & $\mathrm{R} \$$ & 1.116 & $\mathrm{R} \$$ & 1.054 & $\mathrm{R} \$$ & 1.024 \\
\hline
\end{tabular}


Apêndice 182 - Crédito médio de 1,50\% sobre o valor do investimento, por mensalidade, para construção em 90 dias e compensação de retorno em 24 meses, em função de áreas externas, anfiteatro e minisshopping, para 200 residentes

\begin{tabular}{|c|c|c|c|c|c|c|c|c|}
\hline \multirow{3}{*}{$\begin{array}{c}\text { Porcentagem de } \\
\text { residentes com } \\
\text { grau de } \\
\text { dependência } \\
\text { I, II e III } \\
100-0-0\end{array}$} & \multicolumn{8}{|c|}{$\begin{array}{c}\text { Crédito médio de } 1,50 \% \text { sobre o valor do investimento, por } \\
\text { mensalidade, em função de áreas externas, anfiteatro e } \\
\text { minisshopping, para } 200 \text { residentes, com diversos graus de } \\
\text { dependência }\end{array}$} \\
\hline & \multicolumn{2}{|c|}{ "A" } & \multicolumn{2}{|c|}{ "B" } & \multicolumn{2}{|c|}{ "C" } & \multicolumn{2}{|c|}{ "D" } \\
\hline & $\mathrm{R} \$$ & 1.180 & $\mathrm{R} \$$ & 1.116 & $\mathrm{R} \$$ & 1.052 & $\mathrm{R} \$$ & 974 \\
\hline $0-100-0$ & $\mathrm{R} \$$ & 1.182 & $\mathrm{R} \$$ & 1.118 & $\mathrm{R} \$$ & 1.054 & $\mathrm{R} \$$ & 976 \\
\hline 0-0-100 & $\mathrm{R} \$$ & 1.066 & $\mathrm{R} \$$ & 1.005 & $\mathrm{R} \$$ & 943 & $\mathrm{R} \$$ & 868 \\
\hline 70-30-0 & $\mathrm{R} \$$ & 1.181 & $\mathrm{R} \$$ & 1.116 & $\mathrm{R} \$$ & 1.052 & $\mathrm{R} \$$ & 974 \\
\hline 70-0-30 & $\mathrm{R} \$$ & 1.147 & $\mathrm{R} \$$ & 1.084 & $\mathrm{R} \$$ & 1.022 & $\mathrm{R} \$$ & 943 \\
\hline $50-40-10$ & $\mathrm{R} \$$ & 1.167 & $\mathrm{R} \$$ & 1.103 & $\mathrm{R} \$$ & 1.040 & $\mathrm{R} \$$ & 962 \\
\hline $60-30-10$ & $\mathrm{R} \$$ & 1.166 & $\mathrm{R} \$$ & 1.103 & $\mathrm{R} \$$ & 1.040 & $\mathrm{R} \$$ & 961 \\
\hline
\end{tabular}

Apêndice 183 - Crédito médio de 1,50\% sobre o valor do investimento, por mensalidade, para construção em 90 dias e compensação de retorno em 24 meses, em função de áreas externas, anfiteatro e minisshopping, para 300 residentes

\begin{tabular}{|c|c|c|c|c|c|c|c|c|}
\hline \multirow{3}{*}{$\begin{array}{c}\text { Porcentagem de } \\
\text { residentes com } \\
\text { grau de } \\
\text { dependência } \\
\text { I, II e III } \\
100-0-0\end{array}$} & \multicolumn{8}{|c|}{$\begin{array}{l}\text { Crédito médio de } 1,50 \% \text { sobre o valor do investimento, por } \\
\text { mensalidade, em função de áreas externas, anfiteatro e } \\
\text { minisshopping, para } 300 \text { residentes, com diversos graus de } \\
\text { dependência }\end{array}$} \\
\hline & \multicolumn{2}{|c|}{ "A" } & \multicolumn{2}{|c|}{ "B" } & \multicolumn{2}{|c|}{ "C" } & \multicolumn{2}{|c|}{ "D" } \\
\hline & $\mathrm{R} \$$ & 1.098 & $\mathrm{R} \$$ & 1.045 & $\mathrm{R} \$$ & 973 & $\mathrm{R} \$$ & 946 \\
\hline 0-100-0 & $\mathrm{R} \$$ & 1.101 & $\mathrm{R} \$$ & 1.047 & $\mathrm{R}$ & 974 & $\mathrm{R} \$$ & 948 \\
\hline $0-0-100$ & $\mathrm{R} \$$ & 991 & $\mathrm{R} \$$ & 941 & $\mathrm{R} \$$ & 871 & $\mathrm{R} \$$ & 847 \\
\hline $70-30-0$ & $\mathrm{R} \$$ & 1.099 & $\mathrm{R} \$$ & 1.046 & $\mathrm{R} \$$ & 991 & $\mathrm{R} \$$ & 946 \\
\hline 70-0-30 & $\mathrm{R} \$$ & 1.068 & $\mathrm{R} \$$ & 1.016 & K\$ & 962 & $\mathrm{R} \$$ & 918 \\
\hline $50-40-10$ & $\mathrm{R} \$$ & 1.090 & $\mathrm{R} \$$ & 1.037 & R\$ & 965 & $\mathrm{R} \$$ & 939 \\
\hline $60-30-10$ & $\mathrm{R} \$$ & 1.090 & $\mathrm{R} \$$ & 1.037 & $\mathrm{R} \$$ & 965 & $\mathrm{R} \$$ & 939 \\
\hline
\end{tabular}

Apêndice 184 - Crédito médio de 1,50\% sobre o valor do investimento, por mensalidade, para construção em 90 dias e compensação de retorno em 24 meses, em função de áreas externas, anfiteatro e minisshopping, para 400 residentes

\begin{tabular}{|c|c|c|c|c|c|c|c|c|}
\hline \multirow{3}{*}{$\begin{array}{c}\text { Porcentagem de } \\
\text { residentes com } \\
\text { grau de } \\
\text { dependência } \\
\text { I, II e III } \\
100-0-0\end{array}$} & \multicolumn{8}{|c|}{$\begin{array}{l}\text { Crédito médio de } 1,50 \% \text { sobre o valor do investimento, por } \\
\text { mensalidade, em função de áreas externas, anfiteatro e } \\
\text { minisshopping, para } 400 \text { residentes, com diversos graus de } \\
\text { dependência }\end{array}$} \\
\hline & \multicolumn{2}{|c|}{ "A" } & \multicolumn{2}{|c|}{ "B" } & \multicolumn{2}{|c|}{ "C" } & \multicolumn{2}{|c|}{ "D" } \\
\hline & $\mathrm{R} \$$ & 1.079 & $\mathrm{R} \$$ & 1.030 & $\mathrm{R} \$$ & 969 & $\mathrm{R} \$$ & 944 \\
\hline $0-100-0$ & $\mathrm{R} \$$ & 1.081 & $\mathrm{R} \$$ & 1.032 & $\mathrm{R} \$$ & 971 & $\mathrm{R} \$$ & 946 \\
\hline 0-0-100 & $\mathrm{R} \$$ & 972 & $\mathrm{R} \$$ & 927 & $\mathrm{R} \$$ & 868 & $\mathrm{R} \$$ & 845 \\
\hline 70-30-0 & $\mathrm{R} \$$ & 1.079 & $\mathrm{R} \$$ & 1.031 & $\mathrm{R} \$$ & 983 & $\mathrm{R} \$$ & 945 \\
\hline 70-0-30 & $\mathrm{R} \$$ & 1.047 & $\mathrm{R} \$$ & 1.000 & $\mathrm{R} \$$ & 952 & $\mathrm{R} \$$ & 915 \\
\hline $50-40-10$ & $\mathrm{R} \$$ & 1.069 & $\mathrm{R} \$$ & 1.021 & $\mathrm{R} \$$ & 959 & $\mathrm{R} \$$ & 935 \\
\hline $60-30-10$ & $\mathrm{R} \$$ & 1.068 & $\mathrm{R} \$$ & 1.020 & $\mathrm{R} \$$ & 959 & $\mathrm{R} \$$ & 934 \\
\hline
\end{tabular}


Apêndice 185 - Valor médio da mensalidade final, com crédito médio de $1,10 \%$ sobre o valor do investimento, para construção em 90 dias e compensação de retorno em 12 meses, com simulação do nível de utilização da capacidade instalada, para 100 residentes

\begin{tabular}{|c|c|c|c|c|c|c|c|c|}
\hline \multirow{3}{*}{$\begin{array}{c}\text { Porcentagem de } \\
\text { residentes com } \\
\text { grau de } \\
\text { dependência } \\
\text { I, II e III } \\
\mathbf{1 0 0 - 0 - 0}\end{array}$} & \multicolumn{8}{|c|}{$\begin{array}{l}\text { Valor médio de mensalidade final, com simulação do nível de } \\
\text { utilização da capacidade instalada, para } 100 \text { residentes, com } \\
\text { diversos graus de dependência }\end{array}$} \\
\hline & \multicolumn{2}{|c|}{$60 \%$} & \multicolumn{2}{|c|}{$70 \%$} & \multicolumn{2}{|c|}{$80 \%$} & \multicolumn{2}{|c|}{$90 \%$} \\
\hline & $\mathrm{R} \$$ & 4.918 & $\mathrm{R} \$$ & 4.289 & $\mathrm{R} \$$ & 3.761 & $\mathrm{R} \$$ & 3.421 \\
\hline $0-100-0$ & $\mathrm{R} \$$ & 5.631 & $\mathrm{R} \$$ & 4.981 & $\mathrm{R} \$$ & 4.474 & $\mathrm{R} \$$ & 4.118 \\
\hline $0-0-100$ & $\mathrm{R} \$$ & 5.775 & $\mathrm{R} \$$ & 5.226 & $\mathrm{R} \$$ & 4.795 & $\mathrm{R} \$$ & 4.365 \\
\hline $70-30-0$ & $\mathrm{R} \$$ & 5.203 & $\mathrm{R} \$$ & 4.614 & $\mathrm{R} \$$ & 4.046 & $\mathrm{R} \$$ & 3.674 \\
\hline 70-0-30 & $\mathrm{R} \$$ & 5.209 & $\mathrm{R} \$$ & 4.620 & $\mathrm{R} \$$ & 4.051 & $\mathrm{R} \$$ & 3.735 \\
\hline $50-40-10$ & $\mathrm{R} \$$ & 5.433 & $\mathrm{R} \$$ & 4.811 & $\mathrm{R} \$$ & 4.325 & $\mathrm{R} \$$ & 3.922 \\
\hline $60-30-10$ & $\mathrm{R} \$$ & 5.290 & $\mathrm{R} \$$ & 4.852 & $\mathrm{R} \$$ & 4.254 & $\mathrm{R} \$$ & 3.827 \\
\hline
\end{tabular}

Apêndice 186 - Valor médio da mensalidade final, com crédito médio de 1,10\% sobre o valor do investimento, para construção em 90 dias e compensação de retorno em 12 meses, com simulação do nível de utilização da capacidade instalada, para 200 residentes

\begin{tabular}{|c|c|c|c|c|c|c|c|c|}
\hline \multirow{2}{*}{$\begin{array}{c}\text { Porcentagem de } \\
\text { residentes com } \\
\text { grau de } \\
\text { dependência } \\
\text { I, II e III } \\
\end{array}$} & \multicolumn{8}{|c|}{$\begin{array}{l}\text { Valor médio de mensalidade final, com simulação do nível de } \\
\text { utilização da capacidade instalada, para } 200 \text { residentes, com } \\
\text { diversos graus de dependência }\end{array}$} \\
\hline & \multicolumn{2}{|c|}{$60 \%$} & \multicolumn{2}{|c|}{$70 \%$} & \multicolumn{2}{|c|}{$80 \%$} & \multicolumn{2}{|c|}{ 90\% } \\
\hline $100-0-0$ & $\mathrm{R} \$$ & 4.570 & $\mathrm{R} \$$ & 3.983 & $\mathrm{R} \$$ & 3.522 & $\mathrm{R} \$$ & 3.173 \\
\hline $0-100-0$ & $\mathrm{R} \$$ & 5.285 & $\mathrm{R} \$$ & 4.697 & $\mathrm{R} \$$ & 4.235 & $\mathrm{R} \$$ & 3.886 \\
\hline $0-0-100$ & $\mathrm{R} \$$ & 5.397 & $\mathrm{R} \$$ & 4.891 & $\mathrm{R} \$$ & 4.459 & $\mathrm{R} \$$ & 4.113 \\
\hline $70-30-0$ & $\mathrm{R} \$$ & 4.832 & $\mathrm{R} \$$ & 4.248 & $\mathrm{R} \$$ & 3.753 & $\mathrm{R} \$$ & 3.426 \\
\hline 70-0-30 & $\mathrm{R} \$$ & 4.862 & $\mathrm{R} \$$ & 4.249 & $\mathrm{R} \$$ & 3.808 & $\mathrm{R} \$$ & 3.474 \\
\hline $50-40-10$ & $\mathrm{R} \$$ & 4.949 & $\mathrm{R} \$$ & 4.430 & $\mathrm{R} \$$ & 3.948 & $\mathrm{R} \$$ & 3.600 \\
\hline $60-30-10$ & $\mathrm{R} \$$ & 4.902 & $\mathrm{R} \$$ & 4.390 & $\mathrm{R} \$$ & 3.859 & $\mathrm{R} \$$ & 3.521 \\
\hline
\end{tabular}

Apêndice 187 - Valor médio da mensalidade final, com crédito médio de 1,10\% sobre o valor do investimento, para construção em 90 dias e compensação de retorno em 12 meses, com simulação do nível de utilização da capacidade instalada, para 300 residentes

\begin{tabular}{|c|c|c|c|c|c|c|c|c|}
\hline \multirow{2}{*}{$\begin{array}{c}\text { Porcentagem de } \\
\text { residentes com } \\
\text { grau de } \\
\text { dependência } \\
\text { I, II e III }\end{array}$} & \multicolumn{8}{|c|}{$\begin{array}{l}\text { Valor médio de mensalidade final, com simulação do nível de } \\
\text { utilização da capacidade instalada, para } 300 \text { residentes, com } \\
\text { diversos graus de dependência }\end{array}$} \\
\hline & \multicolumn{2}{|c|}{$60 \%$} & \multicolumn{2}{|c|}{$70 \%$} & \multicolumn{2}{|c|}{$80 \%$} & \multicolumn{2}{|c|}{$90 \%$} \\
\hline 100-0-0 & $\mathrm{R} \$$ & 4.074 & $\mathrm{R} \$$ & 3.628 & $\mathrm{R} \$$ & 3.201 & $\mathrm{R} \$$ & 2.893 \\
\hline $0-100-0$ & $\mathrm{R} \$$ & 4.789 & $\mathrm{R} \$$ & 4.335 & $\mathrm{R} \$$ & 3.915 & $\mathrm{R} \$$ & 3.601 \\
\hline $0-0-100$ & $\mathrm{R} \$$ & 4.960 & $\mathrm{R} \$$ & 4.547 & $\mathrm{R} \$$ & 4.172 & P & 3.880 \\
\hline 70-30-0 & $\mathrm{R} \$$ & 4.329 & $\mathrm{R} \$$ & 3.873 & $\mathrm{R} \$$ & 3.451 & ? & 3.136 \\
\hline 70-0-30 & $\mathrm{R} \$$ & 4.375 & $\mathrm{R} \$$ & 3.937 & $\mathrm{R}$ & 3.522 & ? & 3.029 \\
\hline $50-40-10$ & $\mathrm{R} \$$ & 4.504 & $\mathrm{R} \$$ & 4.047 & $\mathrm{R} \$$ & 3.607 & ? & 3.306 \\
\hline $60-30-10$ & $\mathrm{R} \$$ & 4.425 & $\mathrm{R} \$$ & 3.980 & $\mathrm{R} \$$ & 3.559 & $\mathrm{R} \$$ & 3.264 \\
\hline
\end{tabular}


Apêndice 188 - Valor médio da mensalidade final, com crédito médio de 1,10\% sobre o valor do investimento, para construção em 90 dias e compensação de retorno em 12 meses, com simulação do nível de utilização da capacidade instalada, para 400 residentes

\begin{tabular}{|c|c|c|c|c|c|c|c|c|}
\hline \multirow{2}{*}{$\begin{array}{l}\text { Porcentagem de } \\
\text { residentes com } \\
\text { grau de } \\
\text { dependência } \\
\text { I, II e III }\end{array}$} & \multicolumn{8}{|c|}{$\begin{array}{l}\text { Valor médio de mensalidade final, com simulação do nível de } \\
\text { utilização da capacidade instalada, para } 400 \text { residentes, com } \\
\text { diversos graus de dependência }\end{array}$} \\
\hline & \multicolumn{2}{|c|}{$60 \%$} & \multicolumn{2}{|c|}{$70 \%$} & \multicolumn{2}{|c|}{$80 \%$} & \multicolumn{2}{|c|}{$90 \%$} \\
\hline 100-0-0 & $\mathrm{R} \$$ & 3.979 & $\mathrm{R} \$$ & 3.464 & $\mathrm{R} \$$ & 3.122 & $\mathrm{R} \$$ & 2.812 \\
\hline $0-100-0$ & $\mathrm{R} \$$ & 4.693 & $\mathrm{R} \$$ & 4.178 & $\mathrm{R} \$$ & 3.836 & $\mathrm{R} \$$ & 3.526 \\
\hline 0-0-100 & $\mathrm{R} \$$ & 4.854 & $\mathrm{R} \$$ & 4.395 & $\mathrm{R} \$$ & 4.095 & $\mathrm{R} \$$ & 3.794 \\
\hline $70-30-0$ & $\mathrm{R} \$$ & 4.228 & $\mathrm{R} \$$ & 3.698 & $\mathrm{R} \$$ & 3.354 & $\mathrm{R} \$$ & 3.034 \\
\hline $70-0-30$ & $\mathrm{R} \$$ & 4.256 & $\mathrm{R} \$$ & 3.740 & $\mathrm{R} \$$ & 3.417 & $\mathrm{R} \$$ & 3.114 \\
\hline $50-40-10$ & $\mathrm{R} \$$ & 4.368 & $\mathrm{R} \$$ & 3.879 & $\mathrm{R} \$$ & 3.529 & $\mathrm{R} \$$ & 3.214 \\
\hline $60-30-10$ & $\mathrm{R} \$$ & 4.319 & $\mathrm{R} \$$ & 3.807 & $\mathrm{R} \$$ & 3.466 & $\mathrm{R} \$$ & 3.134 \\
\hline
\end{tabular}

Apêndice 189 - Valor médio da mensalidade final, com crédito médio de 1,20\% sobre o valor do investimento, para construção em 90 dias e compensação de retorno em 12 meses, com simulação do nível de utilização da capacidade instalada, para 100 residentes

\begin{tabular}{|c|c|c|c|c|c|c|c|c|}
\hline \multirow{2}{*}{$\begin{array}{l}\text { Porcentagem de } \\
\text { residentes com } \\
\text { grau de } \\
\text { dependência } \\
\text { I, II e III }\end{array}$} & \multicolumn{8}{|c|}{$\begin{array}{l}\text { Valor médio de mensalidade final, com simulação do nível de } \\
\text { utilização da capacidade instalada, para } 100 \text { residentes, com } \\
\text { diversos graus de dependência }\end{array}$} \\
\hline & \multicolumn{2}{|c|}{$60 \%$} & \multicolumn{2}{|c|}{$70 \%$} & \multicolumn{2}{|c|}{$80 \%$} & \multicolumn{2}{|c|}{$90 \%$} \\
\hline $100-0-0$ & $\mathrm{R} \$$ & 5.024 & $\mathrm{R} \$$ & 4.379 & $\mathrm{R} \$$ & 3.840 & $\mathrm{R} \$$ & 3.491 \\
\hline 0-100-0 & $\mathrm{R} \$$ & 5.737 & $\mathrm{R} \$$ & 5.072 & $\mathrm{R} \$$ & 4.553 & $\mathrm{R} \$$ & 4.188 \\
\hline 0-0-100 & $\mathrm{R} \$$ & 5.870 & $\mathrm{R} \$$ & 5.308 & $\mathrm{R} \$$ & 4.867 & $\mathrm{R} \$$ & 4.428 \\
\hline $70-30-0$ & $\mathrm{R} \$$ & 5.309 & $\mathrm{R} \$$ & 4.705 & $\mathrm{R} \$$ & 4.126 & $\mathrm{R} \$$ & 3.745 \\
\hline $70-0-30$ & $\mathrm{R} \$$ & 5.313 & $\mathrm{R} \$$ & 4.708 & $\mathrm{R} \$$ & 4.128 & $\mathrm{R} \$$ & 3.804 \\
\hline $50-40-10$ & $\mathrm{R} \$$ & 5.538 & $\mathrm{R} \$$ & 4.901 & $\mathrm{R} \$$ & 4.404 & $\mathrm{R} \$$ & 3.992 \\
\hline $60-30-10$ & $\mathrm{R} \$$ & 5.395 & $\mathrm{R} \$$ & 4.942 & $\mathrm{R} \$$ & 4.333 & $\mathrm{R} \$$ & 3.897 \\
\hline
\end{tabular}

Apêndice 190 - Valor médio da mensalidade final, com crédito médio de 1,20\% sobre o valor do investimento, para construção em 90 dias e compensação de retorno em 12 meses, com simulação do nível de utilização da capacidade instalada, para 200 residentes

\begin{tabular}{ccccccccc}
\hline $\begin{array}{c}\text { Porcentagem de } \\
\text { residentes com } \\
\text { grau de }\end{array}$ & \multicolumn{6}{c}{$\begin{array}{c}\text { Valor médio de mensalidade final, com simulação do nível de } \\
\text { utilização da capacidade instalada, para 200 residentes, com } \\
\text { dependência } \\
\text { Iiversos graus de dependência }\end{array}$} \\
\cline { 2 - 9 } II e III & \multicolumn{6}{c}{$\mathbf{6 0 \%}$} & \multicolumn{7}{c}{$\mathbf{7 0 \%}$} & $\mathbf{8 0 \%}$ & \multicolumn{1}{c}{$\mathbf{9 0 \%}$} \\
\hline $\mathbf{1 0 0 - 0 - 0}$ & $\mathrm{R} \$$ & 4.677 & $\mathrm{R} \$$ & 4.075 & $\mathrm{R} \$$ & 3.602 & $\mathrm{R} \$$ & 3.244 \\
$\mathbf{0 - 1 0 0 - 0}$ & $\mathrm{R} \$$ & 5.392 & $\mathrm{R} \$$ & 4.789 & $\mathrm{R} \$$ & 4.316 & $\mathrm{R} \$$ & 3.958 \\
$\mathbf{0 - 0 - 1 0 0}$ & $\mathrm{R} \$$ & 5.494 & $\mathrm{R} \$$ & 4.974 & $\mathrm{R} \$$ & 4.531 & $\mathrm{R} \$$ & 4.178 \\
$\mathbf{7 0 - 3 0 - 0}$ & $\mathrm{R} \$$ & 4.939 & $\mathrm{R} \$$ & 4.340 & $\mathrm{R} \$$ & 3.834 & $\mathrm{R} \$$ & 3.498 \\
$\mathbf{7 0 - 0 - 3 0}$ & $\mathrm{R} \$$ & 4.966 & $\mathrm{R} \$$ & 4.338 & $\mathrm{R} \$$ & 3.886 & $\mathrm{R} \$$ & 3.544 \\
$\mathbf{5 0 - 4 0 - 1 0}$ & $\mathrm{R} \$$ & 5.055 & $\mathrm{R} \$$ & 4.521 & $\mathrm{R} \$$ & 4.028 & $\mathrm{R} \$$ & 3.670 \\
$\mathbf{6 0 - 3 0 - 1 0}$ & $\mathrm{R} \$$ & 5.008 & $\mathrm{R} \$$ & 4.480 & $\mathrm{R} \$$ & 3.939 & $\mathrm{R} \$$ & 3.591 \\
\hline
\end{tabular}


Apêndice 191 - Valor médio da mensalidade final, com crédito médio de 1,20\% sobre o valor do investimento, para construção em 90 dias e compensação de retorno em 12 meses, com simulação do nível de utilização da capacidade instalada, para 300 residentes

\begin{tabular}{|c|c|c|c|c|c|c|c|c|}
\hline \multirow{3}{*}{$\begin{array}{c}\text { Porcentagem de } \\
\text { residentes com } \\
\text { grau de } \\
\text { dependência } \\
\text { I, II e III } \\
100-0-0\end{array}$} & \multicolumn{8}{|c|}{$\begin{array}{l}\text { Valor médio de mensalidade final, com simulação do nível de } \\
\text { utilização da capacidade instalada, para } 300 \text { residentes, com } \\
\text { diversos graus de dependência }\end{array}$} \\
\hline & \multicolumn{2}{|c|}{$60 \%$} & \multicolumn{2}{|c|}{$70 \%$} & \multicolumn{2}{|c|}{$80 \%$} & \multicolumn{2}{|c|}{$90 \%$} \\
\hline & $\mathrm{R} \$$ & 4.174 & $\mathrm{R} \$$ & 3.713 & $\mathrm{R} \$$ & 3.276 & $\mathrm{R} \$$ & 2.959 \\
\hline $0-100-0$ & $\mathrm{R} \$$ & 4.889 & $\mathrm{R} \$$ & 4.421 & $\mathrm{R} \$$ & 3.990 & $\mathrm{R} \$$ & 3.668 \\
\hline $0-0-100$ & $\mathrm{R} \$$ & 5.050 & $\mathrm{R} \$$ & 4.624 & $\mathrm{R} \$$ & 4.239 & $\mathrm{R} \$$ & 3.940 \\
\hline $70-30-0$ & $\mathrm{R} \$$ & 4.428 & $\mathrm{R} \$$ & 3.958 & $\mathrm{R} \$$ & 3.526 & $\mathrm{R} \$$ & 3.203 \\
\hline $70-0-30$ & $\mathrm{R} \$$ & 4.472 & $\mathrm{R} \$$ & 4.020 & $\mathrm{R} \$$ & 3.595 & $\mathrm{R} \$$ & 3.093 \\
\hline $50-40-10$ & $\mathrm{R} \$$ & 4.603 & $\mathrm{R} \$$ & 4.132 & $\mathrm{R} \$$ & 3.681 & $\mathrm{R} \$$ & 3.372 \\
\hline $60-30-10$ & $\mathrm{R} \$$ & 4.524 & $\mathrm{R} \$$ & 4.064 & $\mathrm{R} \$$ & 3.633 & $\mathrm{R} \$$ & 3.330 \\
\hline
\end{tabular}

Apêndice 192 - Valor médio da mensalidade final, com crédito médio de 1,20\% sobre o valor do investimento, para construção em 90 dias e compensação de retorno em 12 meses, com simulação do nível de utilização da capacidade instalada, para 400 residentes

\begin{tabular}{|c|c|c|c|c|c|c|c|c|}
\hline \multirow{2}{*}{$\begin{array}{c}\text { Porcentagem de } \\
\text { residentes com } \\
\text { grau de } \\
\text { dependência } \\
\text { I, II e III } \\
\end{array}$} & \multicolumn{8}{|c|}{$\begin{array}{l}\text { Valor médio de mensalidade final, com simulação do nível de } \\
\text { utilização da capacidade instalada, para } 400 \text { residentes, com } \\
\text { diversos graus de dependência }\end{array}$} \\
\hline & \multicolumn{2}{|c|}{$60 \%$} & \multicolumn{2}{|c|}{$70 \%$} & \multicolumn{2}{|c|}{$80 \%$} & \multicolumn{2}{|c|}{ 90\% } \\
\hline 100-0-0 & $\mathrm{R} \$$ & 4.077 & $\mathrm{R} \$$ & 3.548 & $\mathrm{R} \$$ & 3.195 & $\mathrm{R} \$$ & 2.878 \\
\hline $0-100-0$ & $\mathrm{R} \$$ & 4.791 & $\mathrm{R} \$$ & 4.262 & $\mathrm{R} \$$ & 3.909 & $\mathrm{R} \$$ & 3.592 \\
\hline $0-0-100$ & $\mathrm{R} \$$ & 4.942 & $\mathrm{R} \$$ & 4.471 & $\mathrm{R} \$$ & 4.161 & $\mathrm{R} \$$ & 3.853 \\
\hline $70-30-0$ & $\mathrm{R} \$$ & 4.326 & $\mathrm{R} \$$ & 3.782 & $\mathrm{R} \$$ & 3.427 & $\mathrm{R} \$$ & 3.099 \\
\hline 70-0-30 & $\mathrm{R} \$$ & 4.351 & $\mathrm{R} \$$ & 3.822 & $\mathrm{R} \$$ & 3.488 & $\mathrm{R} \$$ & 3.178 \\
\hline $50-40-10$ & $\mathrm{R} \$$ & 4.465 & $\mathrm{R} \$$ & 3.962 & $\mathrm{R} \$$ & 3.602 & $\mathrm{R} \$$ & 3.279 \\
\hline $60-30-10$ & $\mathrm{R} \$$ & 4.416 & $\mathrm{R} \$$ & 3.890 & $\mathrm{R} \$$ & 3.539 & $\mathrm{R} \$$ & 3.199 \\
\hline
\end{tabular}

Apêndice 193 - Valor médio da mensalidade final, com crédito médio de 1,30\% sobre o valor do investimento, para construção em 90 dias e compensação de retorno em 12 meses, com simulação do nível de utilização da capacidade instalada, para 100 residentes

\begin{tabular}{|c|c|c|c|c|c|c|c|c|}
\hline \multirow{2}{*}{$\begin{array}{c}\text { Porcentagem de } \\
\text { residentes com } \\
\text { grau de } \\
\text { dependência } \\
\text { I, II e III }\end{array}$} & \multicolumn{8}{|c|}{$\begin{array}{l}\text { Valor médio de mensalidade final, com simulação do nível de } \\
\text { utilização da capacidade instalada, para } 100 \text { residentes, com } \\
\text { diversos graus de dependência }\end{array}$} \\
\hline & \multicolumn{2}{|c|}{$60 \%$} & \multicolumn{2}{|c|}{$70 \%$} & \multicolumn{2}{|c|}{$80 \%$} & \multicolumn{2}{|c|}{$90 \%$} \\
\hline $100-0-0$ & $\mathrm{R} \$$ & 5.130 & $\mathrm{R} \$$ & 4.470 & $\mathrm{R} \$$ & 3.920 & $\mathrm{R} \$$ & 3.562 \\
\hline $0-100-0$ & $\mathrm{R} \$$ & 5.843 & $\mathrm{R} \$$ & 5.163 & $\mathrm{R}$ & 4.633 & $\mathrm{R} \$$ & 4.259 \\
\hline $0-0-100$ & $\mathrm{R} \$$ & 5.965 & $\mathrm{R} \$$ & 5.389 & $\mathrm{R} \$$ & 4.938 & $\mathrm{R} \$$ & 4.492 \\
\hline $70-30-0$ & $\mathrm{R} \$$ & 5.415 & $\mathrm{R} \$$ & 4.796 & $\mathrm{R} \$$ & 4.205 & $\mathrm{R} \$$ & 3.815 \\
\hline 70-0-30 & $\mathrm{R} \$$ & 5.416 & $\mathrm{R} \$$ & 4.797 & $\mathrm{R} \$$ & 4.206 & $\mathrm{R} \$$ & 3.872 \\
\hline $50-40-10$ & $\mathrm{R} \$$ & 5.643 & $\mathrm{R} \$$ & 4.992 & $\mathrm{R} \$$ & 4.483 & $\mathrm{R} \$$ & 4.062 \\
\hline $60-30-10$ & $\mathrm{R} \$$ & 5.501 & $\mathrm{R} \$$ & 5.032 & $\mathrm{R} \$$ & 4.411 & $\mathrm{R} \$$ & 3.967 \\
\hline
\end{tabular}


Apêndice 194 - Valor médio da mensalidade final, com crédito médio de $1,30 \%$ sobre o valor do investimento, para construção em 90 dias e compensação de retorno em 12 meses, com simulação do nível de utilização da capacidade instalada, para 200 residentes

\begin{tabular}{|c|c|c|c|c|c|c|c|c|}
\hline \multirow{2}{*}{$\begin{array}{l}\text { Porcentagem de } \\
\text { residentes com } \\
\text { grau de } \\
\text { dependência } \\
\text { I, II e III }\end{array}$} & \multicolumn{8}{|c|}{$\begin{array}{l}\text { Valor médio de mensalidade final, com simulação do nível de } \\
\text { utilização da capacidade instalada, para } 200 \text { residentes, com } \\
\text { diversos graus de dependência }\end{array}$} \\
\hline & \multicolumn{2}{|c|}{$60 \%$} & \multicolumn{2}{|c|}{$70 \%$} & \multicolumn{2}{|c|}{$80 \%$} & \multicolumn{2}{|c|}{$90 \%$} \\
\hline 100-0-0 & $\mathrm{R} \$$ & 4.784 & $\mathrm{R} \$$ & 4.167 & $\mathrm{R} \$$ & 3.682 & $\mathrm{R} \$$ & 3.316 \\
\hline $0-100-0$ & $\mathrm{R} \$$ & 5.499 & $\mathrm{R} \$$ & 4.881 & $\mathrm{R} \$$ & 4.396 & $\mathrm{R} \$$ & 4.030 \\
\hline 0-0-100 & $\mathrm{R} \$$ & 5.591 & $\mathrm{R} \$$ & 5.057 & $\mathrm{R} \$$ & 4.604 & $\mathrm{R} \$$ & 4.242 \\
\hline $70-30-0$ & $\mathrm{R} \$$ & 5.046 & $\mathrm{R} \$$ & 4.432 & $\mathrm{R} \$$ & 3.914 & $\mathrm{R} \$$ & 3.569 \\
\hline $70-0-30$ & $\mathrm{R} \$$ & 5.070 & $\mathrm{R} \$$ & 4.428 & $\mathrm{R} \$$ & 3.964 & $\mathrm{R} \$$ & 3.613 \\
\hline $50-40-10$ & $\mathrm{R} \$$ & 5.161 & $\mathrm{R} \$$ & 4.612 & $\mathrm{R} \$$ & 4.107 & $\mathrm{R} \$$ & 3.741 \\
\hline $60-30-10$ & $\mathrm{R} \$$ & 5.114 & $\mathrm{R} \$$ & 4.571 & $\mathrm{R} \$$ & 4.018 & $\mathrm{R} \$$ & 3.662 \\
\hline
\end{tabular}

Apêndice 195 - Valor médio da mensalidade final, com crédito médio de 1,30\% sobre o valor do investimento, para construção em 90 dias e compensação de retorno em 12 meses, com simulação do nível de utilização da capacidade instalada, para 300 residentes

\begin{tabular}{|c|c|c|c|c|c|c|c|c|}
\hline \multirow{2}{*}{$\begin{array}{c}\text { Porcentagem de } \\
\text { residentes com } \\
\text { grau de } \\
\text { dependência } \\
\text { I, II e III } \\
\end{array}$} & \multicolumn{8}{|c|}{$\begin{array}{l}\text { Valor médio de mensalidade final, com simulação do nível de } \\
\text { utilização da capacidade instalada, para } 300 \text { residentes, com } \\
\text { diversos graus de dependência }\end{array}$} \\
\hline & \multicolumn{2}{|c|}{$60 \%$} & \multicolumn{2}{|c|}{$70 \%$} & \multicolumn{2}{|c|}{$80 \%$} & \multicolumn{2}{|c|}{$90 \%$} \\
\hline $100-0-0$ & $\mathrm{R} \$$ & 4.274 & $\mathrm{R} \$$ & 3.798 & $\mathrm{R} \$$ & 3.351 & $\mathrm{R} \$$ & 3.026 \\
\hline 0-100-0 & $\mathrm{R} \$$ & 4.989 & $\mathrm{R} \$$ & 4.507 & $\mathrm{R} \$$ & 4.065 & $\mathrm{R} \$$ & 3.735 \\
\hline 0-0-100 & $\mathrm{R} \$$ & 5.140 & $\mathrm{R} \$$ & 4.701 & $\mathrm{R} \$$ & 4.307 & $\mathrm{R} \$$ & 4.000 \\
\hline $70-30-0$ & $\mathrm{R} \$$ & 4.528 & $\mathrm{R} \$$ & 4.044 & $\mathrm{R} \$$ & 3.601 & $\mathrm{R} \$$ & 3.269 \\
\hline $70-0-30$ & $\mathrm{R} \$$ & 4.569 & $\mathrm{R} \$$ & 4.103 & $\mathrm{R} \$$ & 3.667 & $\mathrm{R} \$$ & 3.158 \\
\hline $50-40-10$ & $\mathrm{R} \$$ & 4.702 & $\mathrm{R} \$$ & 4.217 & $\mathrm{R} \$$ & 3.755 & $\mathrm{R} \$$ & 3.438 \\
\hline $60-30-10$ & $\mathrm{R} \$$ & 4.623 & $\mathrm{R} \$$ & 4.149 & $\mathrm{R} \$$ & 3.707 & $\mathrm{R} \$$ & 3.395 \\
\hline
\end{tabular}

Apêndice 196 - Valor médio da mensalidade final, com crédito médio de 1,30\% sobre o valor do investimento, para construção em 90 dias e compensação de retorno em 12 meses, com simulação do nível de utilização da capacidade instalada, para 400 residentes

\begin{tabular}{|c|c|c|c|c|c|c|c|c|}
\hline \multirow{2}{*}{$\begin{array}{c}\text { Porcentagem de } \\
\text { residentes com } \\
\text { grau de } \\
\text { dependência } \\
\text { I, II e III }\end{array}$} & \multicolumn{8}{|c|}{$\begin{array}{l}\text { Valor médio de mensalidade final, com simulação do nível de } \\
\text { utilização da capacidade instalada, para } 400 \text { residentes, com } \\
\text { diversos graus de dependência }\end{array}$} \\
\hline & \multicolumn{2}{|c|}{$60 \%$} & \multicolumn{2}{|c|}{$70 \%$} & \multicolumn{2}{|c|}{$80 \%$} & \multicolumn{2}{|c|}{$90 \%$} \\
\hline 100-0-0 & $\mathrm{R} \$$ & 4.175 & $\mathrm{R} \$$ & 3.632 & $\mathrm{R} \$$ & 3.269 & $\mathrm{R} \$$ & 2.943 \\
\hline $0-100-0$ & $\mathrm{R} \$$ & 4.889 & $\mathrm{R} \$$ & 4.346 & $\mathrm{R} \$$ & 3.983 & $\mathrm{R} \$$ & 3.657 \\
\hline $0-0-100$ & $\mathrm{R} \$$ & 5.030 & $\mathrm{R} \$$ & 4.546 & $\mathrm{R} \$$ & 4.227 & $\mathrm{R} \$$ & 3.912 \\
\hline 70-30-0 & $\mathrm{R} \$$ & 4.424 & $\mathrm{R} \$$ & 3.866 & $\mathrm{R} \$$ & 3.500 & $\mathrm{R} \$$ & 3.165 \\
\hline 70-0-30 & $\mathrm{R} \$$ & 4.446 & $\mathrm{R} \$$ & 3.903 & $\mathrm{R} \$$ & 3.560 & $\mathrm{R} \$$ & 3.241 \\
\hline $50-40-10$ & $\mathrm{R} \$$ & 4.562 & $\mathrm{R} \$$ & 4.045 & $\mathrm{R} \$$ & 3.675 & $\mathrm{R} \$$ & 3.343 \\
\hline $60-30-10$ & $\mathrm{R} \$$ & 4.513 & $\mathrm{R} \$$ & 3.973 & $\mathrm{R} \$$ & 3.612 & $\mathrm{R} \$$ & 3.264 \\
\hline
\end{tabular}


Apêndice 197 - Valor médio da mensalidade final, com crédito médio de $1,40 \%$ sobre o valor do investimento, para construção em 90 dias e compensação de retorno em 12 meses, com simulação do nível de utilização da capacidade instalada, para 100 residentes

\begin{tabular}{|c|c|c|c|c|c|c|c|c|}
\hline \multirow{3}{*}{$\begin{array}{c}\text { Porcentagem de } \\
\text { residentes com } \\
\text { grau de } \\
\text { dependência } \\
\text { I, II e III } \\
100-0-0\end{array}$} & \multicolumn{8}{|c|}{$\begin{array}{l}\text { Valor médio de mensalidade final, com simulação do nível de } \\
\text { utilização da capacidade instalada, para } 100 \text { residentes, com } \\
\text { diversos graus de dependência }\end{array}$} \\
\hline & \multicolumn{2}{|c|}{$60 \%$} & \multicolumn{2}{|c|}{$70 \%$} & \multicolumn{2}{|c|}{$80 \%$} & \multicolumn{2}{|c|}{$90 \%$} \\
\hline & $\mathrm{R} \$$ & 5.236 & $\mathrm{R} \$$ & 4.561 & $\mathrm{R} \$$ & 3.999 & $\mathrm{R} \$$ & 3.632 \\
\hline $0-100-0$ & $\mathrm{R} \$$ & 5.949 & $\mathrm{R} \$$ & 5.254 & $\mathrm{R} \$$ & 4.712 & $\mathrm{R} \$$ & 4.329 \\
\hline $0-0-100$ & $\mathrm{R} \$$ & 6.060 & $\mathrm{R} \$$ & 5.471 & $\mathrm{R} \$$ & 5.009 & $\mathrm{R} \$$ & 4.555 \\
\hline $70-30-0$ & $\mathrm{R} \$$ & 5.521 & $\mathrm{R} \$$ & 4.887 & $\mathrm{R} \$$ & 4.284 & $\mathrm{R} \$$ & 3.886 \\
\hline $70-0-30$ & $\mathrm{R} \$$ & 5.519 & $\mathrm{R} \$$ & 4.885 & $\mathrm{R} \$$ & 4.283 & $\mathrm{R} \$$ & 3.941 \\
\hline $50-40-10$ & $\mathrm{R} \$$ & 5.748 & $\mathrm{R} \$$ & 5.082 & $\mathrm{R} \$$ & 4.562 & $\mathrm{R} \$$ & 4.132 \\
\hline $60-30-10$ & $\mathrm{R} \$$ & 5.606 & $\mathrm{R} \$$ & 5.122 & $\mathrm{R} \$$ & 4.490 & $\mathrm{R} \$$ & 4.037 \\
\hline
\end{tabular}

Apêndice 198 - Valor médio da mensalidade final, com crédito médio de 1,40\% sobre o valor do investimento, para construção em 90 dias e compensação de retorno em 12 meses, com simulação do nível de utilização da capacidade instalada, para 200 residentes

\begin{tabular}{|c|c|c|c|c|c|c|c|c|}
\hline \multirow{2}{*}{$\begin{array}{c}\text { Porcentagem de } \\
\text { residentes com } \\
\text { grau de } \\
\text { dependência } \\
\text { I, II e III } \\
\end{array}$} & \multicolumn{8}{|c|}{$\begin{array}{l}\text { Valor médio de mensalidade final, com simulação do nível de } \\
\text { utilização da capacidade instalada, para } 200 \text { residentes, com } \\
\text { diversos graus de dependência }\end{array}$} \\
\hline & \multicolumn{2}{|c|}{$60 \%$} & \multicolumn{2}{|c|}{$70 \%$} & \multicolumn{2}{|c|}{$80 \%$} & \multicolumn{2}{|c|}{ 90\% } \\
\hline 100-0-0 & $\mathrm{R} \$$ & 4.892 & $\mathrm{R} \$$ & 4.259 & $\mathrm{R} \$$ & 3.763 & $\mathrm{R} \$$ & 3.387 \\
\hline $0-100-0$ & $\mathrm{R} \$$ & 5.607 & $\mathrm{R} \$$ & 4.973 & $\mathrm{R} \$$ & 4.477 & $\mathrm{R} \$$ & 4.101 \\
\hline $0-0-100$ & $\mathrm{R} \$$ & 5.687 & $\mathrm{R} \$$ & 5.140 & $\mathrm{R} \$$ & 4.676 & $\mathrm{R} \$$ & 4.307 \\
\hline $70-30-0$ & $\mathrm{R} \$$ & 5.153 & $\mathrm{R} \$$ & 4.524 & $\mathrm{R} \$$ & 3.994 & $\mathrm{R} \$$ & 3.640 \\
\hline 70-0-30 & $\mathrm{R} \$$ & 5.174 & $\mathrm{R} \$$ & 4.517 & $\mathrm{R} \$$ & 4.042 & $\mathrm{R} \$$ & 3.683 \\
\hline $50-40-10$ & $\mathrm{R} \$$ & 5.267 & $\mathrm{R} \$$ & 4.703 & $\mathrm{R} \$$ & 4.187 & $\mathrm{R} \$$ & 3.811 \\
\hline $60-30-10$ & $\mathrm{R} \$$ & 5.219 & $\mathrm{R} \$$ & 4.662 & $\mathrm{R} \$$ & 4.097 & $\mathrm{R} \$$ & 3.732 \\
\hline
\end{tabular}

Apêndice 199 - Valor médio da mensalidade final, com crédito médio de 1,40\% sobre o valor do investimento, para construção em 90 dias e compensação de retorno em 12 meses, com simulação do nível de utilização da capacidade instalada, para 300 residentes

\begin{tabular}{|c|c|c|c|c|c|c|c|c|}
\hline \multirow{2}{*}{$\begin{array}{c}\text { Porcentagem de } \\
\text { residentes com } \\
\text { grau de } \\
\text { dependência } \\
\text { I, II e III }\end{array}$} & \multicolumn{8}{|c|}{$\begin{array}{l}\text { Valor médio de mensalidade final, com simulação do nível de } \\
\text { utilização da capacidade instalada, para } 300 \text { residentes, com } \\
\text { diversos graus de dependência }\end{array}$} \\
\hline & \multicolumn{2}{|c|}{$60 \%$} & \multicolumn{2}{|c|}{$70 \%$} & \multicolumn{2}{|c|}{$80 \%$} & \multicolumn{2}{|c|}{$90 \%$} \\
\hline 100-0-0 & $\mathrm{R} \$$ & 4.373 & $\mathrm{R} \$$ & 3.884 & $\mathrm{R} \$$ & 3.425 & $\mathrm{R} \$$ & 3.092 \\
\hline $0-100-0$ & $\mathrm{R} \$$ & 5.089 & $\mathrm{R} \$$ & 4.592 & $\mathrm{R} \$$ & 4.140 & $\mathrm{R} \$$ & 3.801 \\
\hline $0-0-100$ & $\mathrm{R} \$$ & 5.230 & $\mathrm{R} \$$ & 4.778 & $\mathrm{R} \$$ & 4.374 & $\mathrm{R} \$$ & 4.060 \\
\hline $70-30-0$ & $\mathrm{R} \$$ & 4.628 & $\mathrm{R} \$$ & 4.129 & $\mathrm{R} \$$ & 3.676 & $\mathrm{R} \$$ & 3.336 \\
\hline 70-0-30 & $\mathrm{R} \$$ & 4.666 & $\mathrm{R} \$$ & 4.186 & $\mathrm{R} \$$ & 3.740 & $\mathrm{R} \$$ & 3.223 \\
\hline $50-4$ & $\mathrm{R} \$$ & 4.801 & $\mathrm{R} \$$ & 4.302 & $\mathrm{R} \$$ & 3.829 & $\mathrm{R} \$$ & 3.504 \\
\hline $60-30-10$ & $\mathrm{R} \$$ & 4.722 & $\mathrm{R} \$$ & 4.234 & $\mathrm{R} \$$ & 3.782 & $\mathrm{R} \$$ & 3.461 \\
\hline
\end{tabular}


Apêndice 200 - Valor médio da mensalidade final, com crédito médio de $1,40 \%$ sobre o valor do investimento, para construção em 90 dias e compensação de retorno em 12 meses, com simulação do nível de utilização da capacidade instalada, para 400 residentes

\begin{tabular}{|c|c|c|c|c|c|c|c|c|}
\hline \multirow{3}{*}{$\begin{array}{c}\text { Porcentagem de } \\
\text { residentes com } \\
\text { grau de } \\
\text { dependência } \\
\text { I, II e III } \\
100-0-0\end{array}$} & \multicolumn{8}{|c|}{$\begin{array}{l}\text { Valor médio de mensalidade final, com simulação do nível de } \\
\text { utilização da capacidade instalada, para } 400 \text { residentes, com } \\
\text { diversos graus de dependência }\end{array}$} \\
\hline & \multicolumn{2}{|c|}{$60 \%$} & \multicolumn{2}{|c|}{$70 \%$} & \multicolumn{2}{|c|}{$80 \%$} & \multicolumn{2}{|c|}{$90 \%$} \\
\hline & $\mathrm{R} \$$ & 4.272 & $\mathrm{R} \$$ & 3.716 & $\mathrm{R} \$$ & 3.342 & $\mathrm{R} \$$ & 3.008 \\
\hline 0-100-0 & $\mathrm{R} \$$ & 4.987 & $\mathrm{R} \$$ & 4.430 & $\mathrm{R} \$$ & 4.057 & $\mathrm{R} \$$ & 3.722 \\
\hline 0-0-100 & $\mathrm{R} \$$ & 5.118 & $\mathrm{R} \$$ & 4.622 & $\mathrm{R} \$$ & 4.293 & $\mathrm{R} \$$ & 3.971 \\
\hline 70-30-0 & $\mathrm{R} \$$ & 4.522 & $\mathrm{R} \$$ & 3.950 & $\mathrm{R} \$$ & 3.574 & $\mathrm{R} \$$ & 3.230 \\
\hline 70-0-30 & $\mathrm{R} \$$ & 4.541 & $\mathrm{R} \$$ & 3.985 & $\mathrm{R} \$$ & 3.631 & $\mathrm{R} \$$ & 3.304 \\
\hline $50-40-10$ & $\mathrm{R} \$$ & 4.659 & $\mathrm{R} \$$ & 4.128 & $\mathrm{R} \$$ & 3.748 & $\mathrm{R} \$$ & 3.408 \\
\hline $60-30-10$ & $\mathrm{R} \$$ & 4.610 & $\mathrm{R} \$$ & 4.056 & $\mathrm{R} \$$ & 3.684 & $\mathrm{R} \$$ & 3.328 \\
\hline
\end{tabular}

Apêndice 201 - Valor médio da mensalidade final, com crédito médio de 1,50\% sobre o valor do investimento, para construção em 90 dias e compensação de retorno em 12 meses, com simulação do nível de utilização da capacidade instalada, para 100 residentes

\begin{tabular}{|c|c|c|c|c|c|c|c|c|}
\hline \multirow{2}{*}{$\begin{array}{c}\text { Porcentagem de } \\
\text { residentes com } \\
\text { grau de } \\
\text { dependência } \\
\text { I, II e III } \\
\end{array}$} & \multicolumn{8}{|c|}{$\begin{array}{l}\text { Valor médio de mensalidade final, com simulação do nível de } \\
\text { utilização da capacidade instalada, para } 100 \text { residentes, com } \\
\text { diversos graus de dependência }\end{array}$} \\
\hline & \multicolumn{2}{|c|}{$60 \%$} & \multicolumn{2}{|c|}{$70 \%$} & \multicolumn{2}{|c|}{$80 \%$} & \multicolumn{2}{|c|}{ 90\% } \\
\hline $100-0-0$ & $\mathrm{R} \$$ & 5.342 & $\mathrm{R} \$$ & 4.652 & $\mathrm{R} \$$ & 4.079 & $\mathrm{R} \$$ & 3.703 \\
\hline $0-100-0$ & $\mathrm{R} \$$ & 6.055 & $\mathrm{R} \$$ & 5.344 & $\mathrm{R} \$$ & 4.792 & $\mathrm{R} \$$ & 4.400 \\
\hline $0-0-100$ & $\mathrm{R} \$$ & 6.155 & $\mathrm{R} \$$ & 5.553 & $\mathrm{R} \$$ & 5.081 & $\mathrm{R} \$$ & 4.619 \\
\hline $70-30-0$ & $\mathrm{R} \$$ & 5.627 & $\mathrm{R} \$$ & 4.978 & $\mathrm{R} \$$ & 4.364 & $\mathrm{R} \$$ & 3.956 \\
\hline 70-0-30 & $\mathrm{R} \$$ & 5.623 & $\mathrm{R} \$$ & 4.974 & $\mathrm{R} \$$ & 4.360 & $\mathrm{R} \$$ & 4.010 \\
\hline $50-40-10$ & $\mathrm{R} \$$ & 5.854 & $\mathrm{R} \$$ & 5.172 & $\mathrm{R} \$$ & 4.641 & $\mathrm{R} \$$ & 4.203 \\
\hline $60-30-10$ & $\mathrm{R} \$$ & 5.711 & $\mathrm{R} \$$ & 5.212 & $\mathrm{R} \$$ & 4.569 & $\mathrm{R} \$$ & 4.107 \\
\hline
\end{tabular}

Apêndice 202 - Valor médio da mensalidade final, com crédito médio de 1,50\% sobre o valor do investimento, para construção em 90 dias e compensação de retorno em 12 meses, com simulação do nível de utilização da capacidade instalada, para 200 residentes

\begin{tabular}{|c|c|c|c|c|c|c|c|c|}
\hline \multirow{2}{*}{$\begin{array}{c}\text { Porcentagem de } \\
\text { residentes com } \\
\text { grau de } \\
\text { dependência } \\
\text { I, II e III }\end{array}$} & \multicolumn{8}{|c|}{$\begin{array}{l}\text { Valor médio de mensalidade final, com simulação do nível de } \\
\text { utilização da capacidade instalada, para } 200 \text { residentes, com } \\
\text { diversos graus de dependência }\end{array}$} \\
\hline & \multicolumn{2}{|c|}{$60 \%$} & \multicolumn{2}{|c|}{$70 \%$} & \multicolumn{2}{|c|}{$80 \%$} & \multicolumn{2}{|c|}{$90 \%$} \\
\hline 100-0-0 & $\mathrm{R} \$$ & 4.999 & $\mathrm{R} \$$ & 4.351 & $\mathrm{R} \$$ & 3.843 & $\mathrm{R} \$$ & 3.458 \\
\hline $0-100-0$ & $\mathrm{R} \$$ & 5.714 & $\mathrm{R} \$$ & 5.065 & $\mathrm{R} \$$ & 4.557 & $\mathrm{R} \$$ & 4.173 \\
\hline $0-0-100$ & $\mathrm{R} \$$ & 5.784 & $\mathrm{R} \$$ & 5.223 & $\mathrm{R} \$$ & 4.749 & $\mathrm{R} \$$ & 4.371 \\
\hline $70-30-0$ & $\mathrm{R} \$$ & 5.260 & $\mathrm{R} \$$ & 4.615 & $\mathrm{R} \$$ & 4.075 & $\mathrm{R} \$$ & 3.712 \\
\hline 70-0-30 & $\mathrm{R} \$$ & 5.278 & $\mathrm{R} \$$ & 4.606 & $\mathrm{R} \$$ & 4.120 & $\mathrm{R} \$$ & 3.752 \\
\hline $50-4$ & $\mathrm{R} \$$ & 5.373 & $\mathrm{R} \$$ & 4.793 & $\mathrm{R} \$$ & 4.266 & $\mathrm{R} \$$ & 3.882 \\
\hline $60-30-10$ & $\mathrm{R} \$$ & 5.325 & $\mathrm{R} \$$ & 4.753 & $\mathrm{R} \$$ & 4.177 & $\mathrm{R} \$$ & 3.803 \\
\hline
\end{tabular}


Apêndice 203 - Valor médio da mensalidade final, com crédito médio de $1,50 \%$ sobre o valor do investimento, para construção em 90 dias e compensação de retorno em 12 meses, com simulação do nível de utilização da capacidade instalada, para 300 residentes

\begin{tabular}{|c|c|c|c|c|c|c|c|c|}
\hline \multirow{3}{*}{ 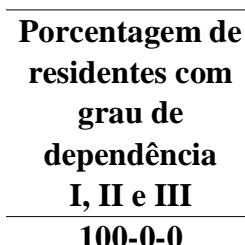 } & \multicolumn{8}{|c|}{$\begin{array}{l}\text { Valor médio de mensalidade final, com simulação do nível de } \\
\text { utilização da capacidade instalada, para } 300 \text { residentes, com } \\
\text { diversos graus de dependência }\end{array}$} \\
\hline & \multicolumn{2}{|c|}{$60 \%$} & \multicolumn{2}{|c|}{$70 \%$} & \multicolumn{2}{|c|}{$80 \%$} & \multicolumn{2}{|c|}{$90 \%$} \\
\hline & $\mathrm{R} \$$ & 4.473 & $\mathrm{R} \$$ & 3.969 & $\mathrm{R} \$$ & 3.500 & $\mathrm{R} \$$ & 3.158 \\
\hline $0-100-0$ & $\mathrm{R} \$$ & 5.189 & $\mathrm{R} \$$ & 4.678 & $\mathrm{R} \$$ & 4.215 & $\mathrm{R} \$$ & 3.868 \\
\hline $0-0-100$ & $\mathrm{R} \$$ & 5.320 & $\mathrm{R} \$$ & 4.855 & $\mathrm{R} \$$ & 4.442 & $\mathrm{R} \$$ & 4.120 \\
\hline 70-30-0 & $\mathrm{R} \$$ & 4.728 & $\mathrm{R} \$$ & 4.215 & $\mathrm{R} \$$ & 3.750 & $\mathrm{R} \$$ & 3.402 \\
\hline 70-0-30 & $\mathrm{R} \$$ & 4.763 & $\mathrm{R} \$$ & 4.269 & $\mathrm{R} \$$ & 3.813 & $\mathrm{R} \$$ & 3.287 \\
\hline $50-40-10$ & $\mathrm{R} \$$ & 4.900 & $\mathrm{R} \$$ & 4.387 & $\mathrm{R} \$$ & 3.903 & $\mathrm{R} \$$ & 3.570 \\
\hline $60-30-10$ & $\mathrm{R} \$$ & 4.821 & $\mathrm{R} \$$ & 4.319 & $\mathrm{R} \$$ & 3.856 & $\mathrm{R} \$$ & 3.527 \\
\hline
\end{tabular}

Apêndice 204 - Valor médio da mensalidade final, com crédito médio de 1,50\% sobre o valor do investimento, para construção em 90 dias e compensação de retorno em 12 meses, com simulação do nível de utilização da capacidade instalada, para 400 residentes

\begin{tabular}{|c|c|c|c|c|c|c|c|c|}
\hline \multirow{2}{*}{$\begin{array}{c}\text { Porcentagem de } \\
\text { residentes com } \\
\text { grau de } \\
\text { dependência } \\
\text { I, II e III } \\
\end{array}$} & \multicolumn{8}{|c|}{$\begin{array}{l}\text { Valor médio de mensalidade final, com simulação do nível de } \\
\text { utilização da capacidade instalada, para } 400 \text { residentes, com } \\
\text { diversos graus de dependência }\end{array}$} \\
\hline & \multicolumn{2}{|c|}{$60 \%$} & \multicolumn{2}{|c|}{$70 \%$} & \multicolumn{2}{|c|}{$80 \%$} & \multicolumn{2}{|c|}{ 90\% } \\
\hline 100-0-0 & $\mathrm{R} \$$ & 4.370 & $\mathrm{R} \$$ & 3.800 & $\mathrm{R} \$$ & 3.416 & $\mathrm{R} \$$ & 3.073 \\
\hline $0-100-0$ & $\mathrm{R} \$$ & 5.086 & $\mathrm{R} \$$ & 4.514 & $\mathrm{R} \$$ & 4.130 & $\mathrm{R} \$$ & 3.788 \\
\hline $0-0-100$ & $\mathrm{R} \$$ & 5.207 & $\mathrm{R} \$$ & 4.698 & $\mathrm{R} \$$ & 4.360 & $\mathrm{R} \$$ & 4.030 \\
\hline $70-30-0$ & $\mathrm{R} \$$ & 4.620 & $\mathrm{R} \$$ & 4.034 & $\mathrm{R} \$$ & 3.647 & $\mathrm{R} \$$ & 3.295 \\
\hline 70-0-30 & $\mathrm{R} \$$ & 4.636 & $\mathrm{R} \$$ & 4.066 & $\mathrm{R} \$$ & 3.702 & $\mathrm{R} \$$ & 3.368 \\
\hline $50-40-10$ & $\mathrm{R} \$$ & 4.756 & $\mathrm{R} \$$ & 4.211 & $\mathrm{R} \$$ & 3.820 & $\mathrm{R} \$$ & 3.473 \\
\hline $60-30-10$ & $\mathrm{R} \$$ & 4.707 & $\mathrm{R} \$$ & 4.139 & $\mathrm{R} \$$ & 3.757 & $\mathrm{R} \$$ & 3.393 \\
\hline
\end{tabular}

Apêndice 205 - Valor médio da mensalidade final, com crédito médio de 1,10\% sobre o valor do investimento, para construção em 90 dias e compensação de retorno em 24 meses, com simulação do nível de utilização da capacidade instalada, para 100 residentes

\begin{tabular}{|c|c|c|c|c|c|c|c|c|}
\hline \multirow{3}{*}{$\begin{array}{c}\text { Porcentagem de } \\
\text { residentes com } \\
\text { grau de } \\
\text { dependência } \\
\text { I, II e III } \\
100-0-0\end{array}$} & \multicolumn{8}{|c|}{$\begin{array}{l}\text { Valor médio de mensalidade final, com simulação do nível de } \\
\text { utilização da capacidade instalada, para } 100 \text { residentes, com } \\
\text { diversos graus de dependência }\end{array}$} \\
\hline & \multicolumn{2}{|c|}{$60 \%$} & \multicolumn{2}{|c|}{$70 \%$} & \multicolumn{2}{|c|}{$80 \%$} & \multicolumn{2}{|c|}{$90 \%$} \\
\hline & $\mathrm{R} \$$ & 4.752 & $\mathrm{R} \$$ & 4.146 & $\mathrm{R} \$$ & 3.636 & $\mathrm{R} \$$ & 3.310 \\
\hline $0-100-0$ & $\mathrm{R} \$$ & 5.465 & $\mathrm{R} \$$ & 4.839 & $\mathrm{R} \$$ & 4.349 & $\mathrm{R} \$$ & 4.007 \\
\hline 0-0-100 & $\mathrm{R} \$$ & 5.625 & $\mathrm{R} \$$ & 5.098 & $\mathrm{R} \$$ & 4.683 & $\mathrm{R} \$$ & 4.265 \\
\hline $70-30-0$ & $\mathrm{R} \$$ & 5.037 & $\mathrm{R} \$$ & 4.472 & $\mathrm{R} \$$ & 3.921 & $\mathrm{R} \$$ & 3.563 \\
\hline $70-0-30$ & $\mathrm{R} \$$ & 5.047 & $\mathrm{R} \$$ & 4.480 & $\mathrm{R} \$$ & 3.929 & $\mathrm{R} \$$ & 3.626 \\
\hline $50-40-10$ & $\mathrm{R} \$$ & 5.268 & $\mathrm{R} \$$ & 4.670 & $\mathrm{R} \$$ & 4.201 & $\mathrm{R}$ & 3.812 \\
\hline $60-30-10$ & $\mathrm{R} \$$ & 5.125 & $\mathrm{R} \$$ & 4.710 & $\mathrm{R} \$$ & 4.130 & $\mathrm{R} \$$ & 3.717 \\
\hline
\end{tabular}


Apêndice 206 - Valor médio da mensalidade final, com crédito médio de 1,10\% sobre o valor do investimento, para construção em 90 dias e compensação de retorno em 24 meses, com simulação do nível de utilização da capacidade instalada, para 200 residentes

\begin{tabular}{|c|c|c|c|c|c|c|c|c|}
\hline \multirow{3}{*}{$\begin{array}{c}\text { Porcentagem de } \\
\text { residentes com } \\
\text { grau de } \\
\text { dependência } \\
\text { I, II e III } \\
100-0-0\end{array}$} & \multicolumn{8}{|c|}{$\begin{array}{l}\text { Valor médio de mensalidade final, com simulação do nível de } \\
\text { utilização da capacidade instalada, para } 200 \text { residentes, com } \\
\text { diversos graus de dependência }\end{array}$} \\
\hline & \multicolumn{2}{|c|}{$60 \%$} & \multicolumn{2}{|c|}{$70 \%$} & \multicolumn{2}{|c|}{$80 \%$} & \multicolumn{2}{|c|}{$90 \%$} \\
\hline & $\mathrm{R} \$$ & 4.402 & $\mathrm{R} \$$ & 3.839 & $\mathrm{R} \$$ & 3.395 & $\mathrm{R} \$$ & 3.061 \\
\hline $0-100-0$ & $\mathrm{R} \$$ & 5.116 & $\mathrm{R} \$$ & 4.553 & $\mathrm{R} \$$ & 4.109 & $\mathrm{R} \$$ & 3.774 \\
\hline $0-0-100$ & $\mathrm{R} \$$ & 5.245 & $\mathrm{R} \$$ & 4.761 & $\mathrm{R} \$$ & 4.345 & $\mathrm{R} \$$ & 4.012 \\
\hline 70-30-0 & $\mathrm{R} \$$ & 4.663 & $\mathrm{R} \$$ & 4.104 & $\mathrm{R} \$$ & 3.627 & $\mathrm{R} \$$ & 3.314 \\
\hline 70-0-30 & $\mathrm{R} \$$ & 4.698 & $\mathrm{R} \$$ & 4.109 & $\mathrm{R} \$$ & 3.685 & $\mathrm{R} \$$ & 3.365 \\
\hline $50-40-10$ & $\mathrm{R} \$$ & 4.783 & $\mathrm{R} \$$ & 4.288 & $\mathrm{R} \$$ & 3.824 & $\mathrm{R} \$$ & 3.489 \\
\hline $60-30-10$ & $\mathrm{R} \$$ & 4.736 & $\mathrm{R} \$$ & 4.247 & $\mathrm{R} \$$ & 3.735 & $\mathrm{R} \$$ & 3.410 \\
\hline
\end{tabular}

Apêndice 207 - Valor médio da mensalidade final, com crédito médio de 1,10\% sobre o valor do investimento, para construção em 90 dias e compensação de retorno em 24 meses, com simulação do nível de utilização da capacidade instalada, para 300 residentes

\begin{tabular}{|c|c|c|c|c|c|c|c|c|}
\hline \multirow{2}{*}{$\begin{array}{c}\text { Porcentagem de } \\
\text { residentes com } \\
\text { grau de } \\
\text { dependência } \\
\text { I, II e III } \\
\end{array}$} & \multicolumn{8}{|c|}{$\begin{array}{l}\text { Valor médio de mensalidade final, com simulação do nível de } \\
\text { utilização da capacidade instalada, para } 300 \text { residentes, com } \\
\text { diversos graus de dependência }\end{array}$} \\
\hline & \multicolumn{2}{|c|}{$60 \%$} & \multicolumn{2}{|c|}{$70 \%$} & \multicolumn{2}{|c|}{$80 \%$} & \multicolumn{2}{|c|}{ 90\% } \\
\hline 100-0-0 & $\mathrm{R} \$$ & 3.918 & $\mathrm{R} \$$ & 3.493 & $\mathrm{R} \$$ & 3.084 & $\mathrm{R} \$$ & 2.788 \\
\hline $0-100-0$ & $\mathrm{R} \$$ & 4.632 & $\mathrm{R} \$$ & 4.201 & $\mathrm{R} \$$ & 3.798 & $\mathrm{R} \$$ & 3.497 \\
\hline $0-0-100$ & $\mathrm{R} \$$ & 4.819 & $\mathrm{R} \$$ & 4.426 & $\mathrm{R} \$$ & 4.066 & $\mathrm{R} \$$ & 3.786 \\
\hline $70-30-0$ & $\mathrm{R} \$$ & 4.172 & $\mathrm{R} \$$ & 3.738 & $\mathrm{R} \$$ & 3.334 & $\mathrm{R} \$$ & 3.032 \\
\hline 70-0-30 & $\mathrm{R} \$$ & 4.223 & $\mathrm{R} \$$ & 3.806 & $\mathrm{R} \$$ & 3.408 & $\mathrm{R} \$$ & 2.927 \\
\hline $50-40-10$ & $\mathrm{R} \$$ & 4.349 & $\mathrm{R} \$$ & 3.914 & $\mathrm{R} \$$ & 3.490 & $\mathrm{R} \$$ & 3.202 \\
\hline $60-30-10$ & $\mathrm{R} \$$ & 4.270 & $\mathrm{R} \$$ & 3.846 & $\mathrm{R} \$$ & 3.442 & $\mathrm{R} \$$ & 3.160 \\
\hline
\end{tabular}

Apêndice 208 - Valor médio da mensalidade final, com crédito médio de 1,10\% sobre o valor do investimento, para construção em 90 dias e compensação de retorno em 24 meses, com simulação do nível de utilização da capacidade instalada, para 400 residentes

\begin{tabular}{|c|c|c|c|c|c|c|c|c|}
\hline \multirow{2}{*}{$\begin{array}{c}\text { Porcentagem de } \\
\text { residentes com } \\
\text { grau de } \\
\text { dependência } \\
\text { I, II e III }\end{array}$} & \multicolumn{8}{|c|}{$\begin{array}{l}\text { Valor médio de mensalidade final, com simulação do nível de } \\
\text { utilização da capacidade instalada, para } 400 \text { residentes, com } \\
\text { diversos graus de dependência }\end{array}$} \\
\hline & \multicolumn{2}{|c|}{$60 \%$} & \multicolumn{2}{|c|}{$70 \%$} & \multicolumn{2}{|c|}{$80 \%$} & \multicolumn{2}{|c|}{$90 \%$} \\
\hline 100-0-0 & $\mathrm{R} \$$ & 3.825 & $\mathrm{R} \$$ & 3.332 & $\mathrm{R} \$$ & 3.007 & $\mathrm{R} \$$ & 2.710 \\
\hline $0-100-0$ & $\mathrm{R} \$$ & 4.539 & $\mathrm{R} \$$ & 4.046 & $\mathrm{R} \$$ & 3.720 & $\mathrm{R} \$$ & 3.423 \\
\hline $0-0-100$ & $\mathrm{R} \$$ & 4.715 & $\mathrm{R} \$$ & 4.276 & $\mathrm{R} \$$ & 3.991 & ? & 3.702 \\
\hline $70-30-0$ & $\mathrm{R} \$$ & 4.074 & $\mathrm{R} \$$ & 3.566 & $\mathrm{R} \$$ & 3.238 & ? & 2.932 \\
\hline 70-0-30 & $\mathrm{R} \$$ & 4.107 & $\mathrm{R} \$$ & 3.612 & $\mathrm{R} \$$ & 3.305 & ? & 3.015 \\
\hline $50-4$ & $\mathrm{R} \$$ & 4.215 & $\mathrm{R} \$$ & 3.748 & $\mathrm{R} \$$ & 3.415 & S & 3.112 \\
\hline $60-30-10$ & $\mathrm{R} \$$ & 4.167 & $\mathrm{R} \$$ & 3.676 & $\mathrm{R} \$$ & 3.352 & $\mathrm{R} \$$ & 3.033 \\
\hline
\end{tabular}


Apêndice 209 - Valor médio da mensalidade final, com crédito médio de $1,20 \%$ sobre o valor do investimento, para construção em 90 dias e compensação de retorno em 24 meses, com simulação do nível de utilização da capacidade instalada, para 100 residentes

\begin{tabular}{|c|c|c|c|c|c|c|c|c|}
\hline \multirow{3}{*}{$\begin{array}{c}\text { Porcentagem de } \\
\text { residentes com } \\
\text { grau de } \\
\text { dependência } \\
\text { I, II e III } \\
100-0-0\end{array}$} & \multicolumn{8}{|c|}{$\begin{array}{l}\text { Valor médio de mensalidade final, com simulação do nível de } \\
\text { utilização da capacidade instalada, para } 100 \text { residentes, com } \\
\text { diversos graus de dependência }\end{array}$} \\
\hline & \multicolumn{2}{|c|}{$60 \%$} & \multicolumn{2}{|c|}{$70 \%$} & \multicolumn{2}{|c|}{$80 \%$} & \multicolumn{2}{|c|}{$90 \%$} \\
\hline & $\mathrm{R} \$$ & 4.843 & $\mathrm{R} \$$ & 4.224 & $\mathrm{R} \$$ & 3.704 & $\mathrm{R} \$$ & 3.370 \\
\hline $0-100-0$ & $\mathrm{R} \$$ & 5.556 & $\mathrm{R} \$$ & 4.916 & $\mathrm{R} \$$ & 4.417 & $\mathrm{R} \$$ & 4.067 \\
\hline $0-0-100$ & $\mathrm{R} \$$ & 5.707 & $\mathrm{R} \$$ & 5.168 & $\mathrm{R} \$$ & 4.744 & $\mathrm{R} \$$ & 4.320 \\
\hline $70-30-0$ & $\mathrm{R} \$$ & 5.128 & $\mathrm{R} \$$ & 4.550 & $\mathrm{R} \$$ & 3.989 & $\mathrm{R} \$$ & 3.624 \\
\hline $70-0-30$ & $\mathrm{R} \$$ & 5.136 & $\mathrm{R} \$$ & 4.556 & $\mathrm{R} \$$ & 3.995 & $\mathrm{R} \$$ & 3.685 \\
\hline $50-40-10$ & $\mathrm{R} \$$ & 5.358 & $\mathrm{R} \$$ & 4.747 & $\mathrm{R} \$$ & 4.269 & $\mathrm{R} \$$ & 3.872 \\
\hline $60-30-10$ & $\mathrm{R} \$$ & 5.215 & $\mathrm{R} \$$ & 4.787 & $\mathrm{R} \$$ & 4.197 & $\mathrm{R} \$$ & 3.777 \\
\hline
\end{tabular}

Apêndice 210 - Valor médio da mensalidade final, com crédito médio de 1,20\% sobre o valor do investimento, para construção em 90 dias e compensação de retorno em 24 meses, com simulação do nível de utilização da capacidade instalada, para 200 residentes

\begin{tabular}{|c|c|c|c|c|c|c|c|c|}
\hline \multirow{2}{*}{$\begin{array}{c}\text { Porcentagem de } \\
\text { residentes com } \\
\text { grau de } \\
\text { dependência } \\
\text { I, II e III } \\
\end{array}$} & \multicolumn{8}{|c|}{$\begin{array}{l}\text { Valor médio de mensalidade final, com simulação do nível de } \\
\text { utilização da capacidade instalada, para } 200 \text { residentes, com } \\
\text { diversos graus de dependência }\end{array}$} \\
\hline & \multicolumn{2}{|c|}{$60 \%$} & \multicolumn{2}{|c|}{$70 \%$} & \multicolumn{2}{|c|}{$80 \%$} & \multicolumn{2}{|c|}{ 90\% } \\
\hline $100-0-0$ & $\mathrm{R} \$$ & 4.494 & $\mathrm{R} \$$ & 3.918 & $\mathrm{R} \$$ & 3.464 & $\mathrm{R} \$$ & 3.122 \\
\hline $0-100-0$ & $\mathrm{R} \$$ & 5.208 & $\mathrm{R} \$$ & 4.632 & $\mathrm{R} \$$ & 4.178 & $\mathrm{R} \$$ & 3.835 \\
\hline $0-0-100$ & $\mathrm{R} \$$ & 5.328 & $\mathrm{R} \$$ & 4.832 & $\mathrm{R} \$$ & 4.407 & $\mathrm{R} \$$ & 4.067 \\
\hline $70-30-0$ & $\mathrm{R} \$$ & 4.755 & $\mathrm{R} \$$ & 4.182 & $\mathrm{R} \$$ & 3.696 & $\mathrm{R} \$$ & 3.375 \\
\hline 70-0-30 & $\mathrm{R} \$$ & 4.787 & $\mathrm{R} \$$ & 4.185 & $\mathrm{R} \$$ & 3.752 & $\mathrm{R} \$$ & 3.425 \\
\hline $50-40-10$ & $\mathrm{R} \$$ & 4.874 & $\mathrm{R} \$$ & 4.366 & $\mathrm{R} \$$ & 3.892 & $\mathrm{R} \$$ & 3.549 \\
\hline $60-30-10$ & $\mathrm{R} \$$ & 4.826 & $\mathrm{R} \$$ & 4.325 & $\mathrm{R} \$$ & 3.803 & $\mathrm{R} \$$ & 3.470 \\
\hline
\end{tabular}

Apêndice 211 - Valor médio da mensalidade final, com crédito médio de 1,20\% sobre o valor do investimento, para construção em 90 dias e compensação de retorno em 24 meses, com simulação do nível de utilização da capacidade instalada, para 300 residentes

\begin{tabular}{|c|c|c|c|c|c|c|c|c|}
\hline \multirow{2}{*}{$\begin{array}{c}\text { Porcentagem de } \\
\text { residentes com } \\
\text { grau de } \\
\text { dependência } \\
\text { I, II e III }\end{array}$} & \multicolumn{8}{|c|}{$\begin{array}{l}\text { Valor médio de mensalidade final, com simulação do nível de } \\
\text { utilização da capacidade instalada, para } 300 \text { residentes, com } \\
\text { diversos graus de dependência }\end{array}$} \\
\hline & \multicolumn{2}{|c|}{$60 \%$} & \multicolumn{2}{|c|}{$70 \%$} & \multicolumn{2}{|c|}{$80 \%$} & \multicolumn{2}{|c|}{$90 \%$} \\
\hline 100-0-0 & $\mathrm{R} \$$ & 4.003 & $\mathrm{R} \$$ & 3.567 & $\mathrm{R} \$$ & 3.148 & $\mathrm{R} \$$ & 2.845 \\
\hline $0-100-0$ & $\mathrm{R} \$$ & 4.718 & $\mathrm{R} \$$ & 4.274 & $\mathrm{R} \$$ & 3.862 & $\mathrm{R} \$$ & 3.554 \\
\hline $0-0-100$ & $\mathrm{R} \$$ & 4.896 & $\mathrm{R} \$$ & 4.492 & $\mathrm{R} \$$ & 4.123 & P & 3.837 \\
\hline 70-30-0 & $\mathrm{R} \$$ & 4.257 & $\mathrm{R} \$$ & 3.812 & $\mathrm{R} \$$ & 3.398 & 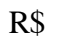 & 3.089 \\
\hline 70-0-30 & $\mathrm{R} \$$ & 4.306 & $\mathrm{R} \$$ & 3.878 & $\mathrm{R}$ & 3.470 & ? & 2.982 \\
\hline $50-40-10$ & $\mathrm{R} \$$ & 4.434 & $\mathrm{R} \$$ & 3.987 & $\mathrm{R} \$$ & 3.554 & ? & 3.259 \\
\hline $60-30-10$ & $\mathrm{R} \$$ & 4.354 & $\mathrm{R} \$$ & 3.919 & $\mathrm{R} \$$ & 3.506 & $\mathrm{R} \$$ & 3.217 \\
\hline
\end{tabular}


Apêndice 212 - Valor médio da mensalidade final, com crédito médio de $1,20 \%$ sobre o valor do investimento, para construção em 90 dias e compensação de retorno em 24 meses, com simulação do nível de utilização da capacidade instalada, para 400 residentes

\begin{tabular}{|c|c|c|c|c|c|c|c|c|}
\hline \multirow{3}{*}{$\begin{array}{c}\text { Porcentagem de } \\
\text { residentes com } \\
\text { grau de } \\
\text { dependência } \\
\text { I, II e III } \\
100-0-0\end{array}$} & \multicolumn{8}{|c|}{$\begin{array}{l}\text { Valor médio de mensalidade final, com simulação do nível de } \\
\text { utilização da capacidade instalada, para } 400 \text { residentes, com } \\
\text { diversos graus de dependência }\end{array}$} \\
\hline & \multicolumn{2}{|c|}{$60 \%$} & \multicolumn{2}{|c|}{$70 \%$} & \multicolumn{2}{|c|}{$80 \%$} & \multicolumn{2}{|c|}{$90 \%$} \\
\hline & $\mathrm{R} \$$ & 3.909 & $\mathrm{R} \$$ & 3.404 & $\mathrm{R} \$$ & 3.069 & $\mathrm{R} \$$ & 2.766 \\
\hline $0-100-0$ & $\mathrm{R} \$$ & 4.623 & $\mathrm{R} \$$ & 4.118 & $\mathrm{R} \$$ & 3.783 & $\mathrm{R} \$$ & 3.479 \\
\hline $0-0-100$ & $\mathrm{R} \$$ & 4.791 & $\mathrm{R} \$$ & 4.341 & $\mathrm{R} \$$ & 4.048 & $\mathrm{R} \$$ & 3.752 \\
\hline $70-30-0$ & $\mathrm{R} \$$ & 4.158 & $\mathrm{R} \$$ & 3.638 & $\mathrm{R} \$$ & 3.301 & $\mathrm{R} \$$ & 2.987 \\
\hline 70-0-30 & $\mathrm{R} \$$ & 4.188 & $\mathrm{R} \$$ & 3.682 & $\mathrm{R} \$$ & 3.366 & $\mathrm{R} \$$ & 3.069 \\
\hline $50-40-10$ & $\mathrm{R} \$$ & 4.298 & $\mathrm{R} \$$ & 3.819 & $\mathrm{R} \$$ & 3.477 & $\mathrm{R} \$$ & 3.168 \\
\hline $60-30-10$ & $\mathrm{R} \$$ & 4.250 & $\mathrm{R} \$$ & 3.747 & $\mathrm{R} \$$ & 3.414 & $\mathrm{R} \$$ & 3.088 \\
\hline
\end{tabular}

Apêndice 213 - Valor médio da mensalidade final, com crédito médio de 1,30\% sobre o valor do investimento, para construção em 90 dias e compensação de retorno em 24 meses, com simulação do nível de utilização da capacidade instalada, para 100 residentes

\begin{tabular}{|c|c|c|c|c|c|c|c|c|}
\hline \multirow{2}{*}{$\begin{array}{c}\text { Porcentagem de } \\
\text { residentes com } \\
\text { grau de } \\
\text { dependência } \\
\text { I, II e III } \\
\end{array}$} & \multicolumn{8}{|c|}{$\begin{array}{l}\text { Valor médio de mensalidade final, com simulação do nível de } \\
\text { utilização da capacidade instalada, para } 100 \text { residentes, com } \\
\text { diversos graus de dependência }\end{array}$} \\
\hline & \multicolumn{2}{|c|}{$60 \%$} & \multicolumn{2}{|c|}{$70 \%$} & \multicolumn{2}{|c|}{$80 \%$} & \multicolumn{2}{|c|}{ 90\% } \\
\hline 100-0-0 & $\mathrm{R} \$$ & 4.933 & $\mathrm{R} \$$ & 4.302 & $\mathrm{R} \$$ & 3.772 & $\mathrm{R} \$$ & 3.431 \\
\hline $0-100-0$ & $\mathrm{R} \$$ & 5.646 & $\mathrm{R} \$$ & 4.994 & $\mathrm{R} \$$ & 4.485 & $\mathrm{R} \$$ & 4.128 \\
\hline $0-0-100$ & $\mathrm{R} \$$ & 5.788 & $\mathrm{R} \$$ & 5.238 & $\mathrm{R} \$$ & 4.805 & $\mathrm{R} \$$ & 4.374 \\
\hline $70-30-0$ & $\mathrm{R} \$$ & 5.219 & $\mathrm{R} \$$ & 4.627 & $\mathrm{R} \$$ & 4.057 & $\mathrm{R} \$$ & 3.684 \\
\hline 70-0-30 & $\mathrm{R} \$$ & 5.224 & $\mathrm{R} \$$ & 4.632 & $\mathrm{R} \$$ & 4.062 & $\mathrm{R} \$$ & 3.744 \\
\hline $50-40-10$ & $\mathrm{R} \$$ & 5.448 & $\mathrm{R} \$$ & 4.824 & $\mathrm{R} \$$ & 4.336 & $\mathrm{R} \$$ & 3.932 \\
\hline $60-30-10$ & $\mathrm{R} \$$ & 5.305 & $\mathrm{R} \$$ & 4.865 & $\mathrm{R} \$$ & 4.265 & $\mathrm{R} \$$ & 3.837 \\
\hline
\end{tabular}

Apêndice 214 - Valor médio da mensalidade final, com crédito médio de 1,30\% sobre o valor do investimento, para construção em 90 dias e compensação de retorno em 24 meses, com simulação do nível de utilização da capacidade instalada, para 200 residentes

\begin{tabular}{ccccccccc}
\hline $\begin{array}{c}\text { Porcentagem de } \\
\text { residentes com } \\
\text { grau de }\end{array}$ & \multicolumn{6}{c}{$\begin{array}{c}\text { Valor médio de mensalidade final, com simulação do nível de } \\
\text { utilização da capacidade instalada, para 200 residentes, com } \\
\text { dependência } \\
\text { Iiversos graus de dependência }\end{array}$} \\
\cline { 2 - 9 } II e III & \multicolumn{6}{c}{$\mathbf{6 0 \%}$} & \multicolumn{7}{c}{$\mathbf{7 0 \%}$} & $\mathbf{8 0 \%}$ & $\mathbf{9 0 \%}$ \\
\hline $\mathbf{1 0 0 - 0 - 0}$ & $\mathrm{R} \$$ & 4.585 & $\mathrm{R} \$$ & 3.996 & $\mathrm{R} \$$ & 3.533 & $\mathrm{R} \$$ & 3.183 \\
$\mathbf{0 - 1 0 0 - 0}$ & $\mathrm{R} \$$ & 5.300 & $\mathrm{R} \$$ & 4.711 & $\mathrm{R} \$$ & 4.247 & $\mathrm{R} \$$ & 3.897 \\
$\mathbf{0 - 0 - 1 0 0}$ & $\mathrm{R} \$$ & 5.411 & $\mathrm{R} \$$ & 4.903 & $\mathrm{R} \$$ & 4.469 & $\mathrm{R} \$$ & 4.122 \\
$\mathbf{7 0 - 3 0 - 0}$ & $\mathrm{R} \$$ & 4.847 & $\mathrm{R} \$$ & 4.261 & $\mathrm{R} \$$ & 3.765 & $\mathrm{R} \$$ & 3.436 \\
$\mathbf{7 0 - 0 - 3 0}$ & $\mathrm{R} \$$ & 4.876 & $\mathrm{R} \$$ & 4.262 & $\mathrm{R} \$$ & 3.819 & $\mathrm{R} \$$ & 3.484 \\
$\mathbf{5 0 - 4 0 - 1 0}$ & $\mathrm{R} \$$ & 4.965 & $\mathrm{R} \$$ & 4.443 & $\mathrm{R} \$$ & 3.960 & $\mathrm{R} \$$ & 3.610 \\
$\mathbf{6 0 - 3 0 - 1 0}$ & $\mathrm{R} \$$ & 4.917 & $\mathrm{R} \$$ & 4.403 & $\mathrm{R} \$$ & 3.871 & $\mathrm{R} \$$ & 3.531 \\
\hline
\end{tabular}


Apêndice 215 - Valor médio da mensalidade final, com crédito médio de $1,30 \%$ sobre o valor do investimento, para construção em 90 dias e compensação de retorno em 24 meses, com simulação do nível de utilização da capacidade instalada, para 300 residentes

\begin{tabular}{|c|c|c|c|c|c|c|c|c|}
\hline \multirow{3}{*}{$\begin{array}{c}\text { Porcentagem de } \\
\text { residentes com } \\
\text { grau de } \\
\text { dependência } \\
\text { I, II e III } \\
100-0-0\end{array}$} & \multicolumn{8}{|c|}{$\begin{array}{c}\text { Valor médio de mensalidade final, com simulação do nível de } \\
\text { utilização da capacidade instalada, para } 300 \text { residentes, com } \\
\text { diversos graus de dependência }\end{array}$} \\
\hline & \multicolumn{2}{|c|}{$60 \%$} & \multicolumn{2}{|c|}{$70 \%$} & \multicolumn{2}{|c|}{$80 \%$} & \multicolumn{2}{|c|}{$90 \%$} \\
\hline & $\mathrm{R} \$$ & 4.089 & $\mathrm{R} \$$ & 3.640 & $\mathrm{R} \$$ & 3.212 & $\mathrm{R} \$$ & 2.902 \\
\hline $0-100-0$ & $\mathrm{R} \$$ & 4.804 & $\mathrm{R} \$$ & 4.348 & $\mathrm{R} \$$ & 3.926 & $\mathrm{R} \$$ & 3.611 \\
\hline $0-0-100$ & $\mathrm{R} \$$ & 4.973 & $\mathrm{R} \$$ & 4.558 & $\mathrm{R} \$$ & 4.181 & $\mathrm{R} \$$ & 3.888 \\
\hline 70-30-0 & $\mathrm{R} \$$ & 4.343 & $\mathrm{R} \$$ & 3.885 & $\mathrm{R} \$$ & 3.462 & $\mathrm{R} \$$ & 3.146 \\
\hline 70-0-30 & $\mathrm{R} \$$ & 4.389 & $\mathrm{R} \$$ & 3.949 & $\mathrm{R} \$$ & 3.532 & $\mathrm{R} \$$ & 3.038 \\
\hline $50-40-10$ & $\mathrm{R} \$$ & 4.518 & $\mathrm{R} \$$ & 4.060 & $\mathrm{R} \$$ & 3.617 & $\mathrm{R} \$$ & 3.315 \\
\hline $60-30-10$ & $\mathrm{R} \$$ & 4.439 & $\mathrm{R} \$$ & 3.992 & $\mathrm{R} \$$ & 3.570 & $\mathrm{R} \$$ & 3.273 \\
\hline
\end{tabular}

Apêndice 216 - Valor médio da mensalidade final, com crédito médio de 1,30\% sobre o valor do investimento, para construção em 90 dias e compensação de retorno em 24 meses, com simulação do nível de utilização da capacidade instalada, para 400 residentes

\begin{tabular}{|c|c|c|c|c|c|c|c|c|}
\hline \multirow{2}{*}{$\begin{array}{c}\text { Porcentagem de } \\
\text { residentes com } \\
\text { grau de } \\
\text { dependência } \\
\text { I, II e III } \\
\end{array}$} & \multicolumn{8}{|c|}{$\begin{array}{l}\text { Valor médio de mensalidade final, com simulação do nível de } \\
\text { utilização da capacidade instalada, para } 400 \text { residentes, com } \\
\text { diversos graus de dependência }\end{array}$} \\
\hline & \multicolumn{2}{|c|}{$60 \%$} & \multicolumn{2}{|c|}{$70 \%$} & \multicolumn{2}{|c|}{$80 \%$} & \multicolumn{2}{|c|}{ 90\% } \\
\hline $100-0-0$ & $\mathrm{R} \$$ & 3.993 & $\mathrm{R} \$$ & 3.476 & $\mathrm{R} \$$ & 3.132 & $\mathrm{R} \$$ & 2.822 \\
\hline $0-100-0$ & $\mathrm{R} \$$ & 4.707 & $\mathrm{R} \$$ & 4.190 & $\mathrm{R} \$$ & 3.846 & $\mathrm{R} \$$ & 3.535 \\
\hline $0-0-100$ & $\mathrm{R} \$$ & 4.866 & $\mathrm{R} \$$ & 4.406 & $\mathrm{R} \$$ & 4.104 & $\mathrm{R} \$$ & 3.803 \\
\hline $70-30-0$ & $\mathrm{R} \$$ & 4.242 & $\mathrm{R} \$$ & 3.710 & $\mathrm{R} \$$ & 3.364 & $\mathrm{R} \$$ & 3.043 \\
\hline 70-0-30 & $\mathrm{R} \$$ & 4.270 & $\mathrm{R} \$$ & 3.752 & $\mathrm{R} \$$ & 3.427 & $\mathrm{R} \$$ & 3.123 \\
\hline $50-40-10$ & $\mathrm{R} \$$ & 4.381 & $\mathrm{R} \$$ & 3.891 & $\mathrm{R} \$$ & 3.540 & $\mathrm{R} \$$ & 3.223 \\
\hline $60-30-10$ & $\mathrm{R} \$$ & 4.333 & $\mathrm{R} \$$ & 3.819 & $\mathrm{R} \$$ & 3.477 & $\mathrm{R} \$$ & 3.144 \\
\hline
\end{tabular}

Apêndice 217 - Valor médio da mensalidade final, com crédito médio de 1,40\% sobre o valor do investimento, para construção em 90 dias e compensação de retorno em 24 meses, com simulação do nível de utilização da capacidade instalada, para 100 residentes

\begin{tabular}{|c|c|c|c|c|c|c|c|c|}
\hline \multirow{2}{*}{$\begin{array}{c}\text { Porcentagem de } \\
\text { residentes com } \\
\text { grau de } \\
\text { dependência } \\
\text { I, II e III }\end{array}$} & \multicolumn{8}{|c|}{$\begin{array}{l}\text { Valor médio de mensalidade final, com simulação do nível de } \\
\text { utilização da capacidade instalada, para } 100 \text { residentes, com } \\
\text { diversos graus de dependência }\end{array}$} \\
\hline & \multicolumn{2}{|c|}{$60 \%$} & \multicolumn{2}{|c|}{$70 \%$} & \multicolumn{2}{|c|}{$80 \%$} & \multicolumn{2}{|c|}{$90 \%$} \\
\hline $100-0-0$ & $\mathrm{R} \$$ & 5.024 & $\mathrm{R} \$$ & 4.379 & $\mathrm{R} \$$ & 3.840 & $\mathrm{R} \$$ & 3.491 \\
\hline $0-100-0$ & $\mathrm{R} \$$ & 5.737 & $\mathrm{R} \$$ & 5.072 & $\mathrm{R} \$$ & 4.553 & $\mathrm{R} \$$ & 4.188 \\
\hline $0-0-100$ & $\mathrm{R} \$$ & 5.870 & $\mathrm{R} \$$ & 5.308 & $\mathrm{R} \$$ & 4.867 & $\mathrm{R} \$$ & 4.428 \\
\hline $70-30-0$ & $\mathrm{R} \$$ & 5.309 & $\mathrm{R} \$$ & 4.705 & $\mathrm{R} \$$ & 4.126 & $\mathrm{R} \$$ & 3.745 \\
\hline 70-0-30 & $\mathrm{R} \$$ & 5.3 & $\mathrm{R} \$$ & 4.708 & $\mathrm{R}$ & 4.128 & $\mathrm{R} \$$ & 3.804 \\
\hline $50-40-10$ & $\mathrm{R} \$$ & 5.538 & $\mathrm{R} \$$ & 4.901 & $\mathrm{R}$ & 4.404 & $\mathrm{R} \$$ & 3.992 \\
\hline $60-30-10$ & $\mathrm{R} \$$ & 5.395 & $\mathrm{R} \$$ & 4.942 & $\mathrm{R} \$$ & 4.333 & $\mathrm{R} \$$ & 3.897 \\
\hline
\end{tabular}


Apêndice 218 - Valor médio da mensalidade final, com crédito médio de $1,40 \%$ sobre o valor do investimento, para construção em 90 dias e compensação de retorno em 24 meses, com simulação do nível de utilização da capacidade instalada, para 200 residentes

\begin{tabular}{|c|c|c|c|c|c|c|c|c|}
\hline \multirow{3}{*}{$\begin{array}{c}\text { Porcentagem de } \\
\text { residentes com } \\
\text { grau de } \\
\text { dependência } \\
\text { I, II e III } \\
100-0-0\end{array}$} & \multicolumn{8}{|c|}{$\begin{array}{l}\text { Valor médio de mensalidade final, com simulação do nível de } \\
\text { utilização da capacidade instalada, para } 200 \text { residentes, com } \\
\text { diversos graus de dependência }\end{array}$} \\
\hline & \multicolumn{2}{|c|}{$60 \%$} & \multicolumn{2}{|c|}{$70 \%$} & \multicolumn{2}{|c|}{$80 \%$} & \multicolumn{2}{|c|}{$90 \%$} \\
\hline & $\mathrm{R} \$$ & 4.677 & $\mathrm{R} \$$ & 4.075 & $\mathrm{R} \$$ & 3.602 & $\mathrm{R} \$$ & 3.244 \\
\hline $0-100-0$ & $\mathrm{R} \$$ & 5.392 & $\mathrm{R} \$$ & 4.789 & $\mathrm{R} \$$ & 4.316 & $\mathrm{R} \$$ & 3.958 \\
\hline $0-0-100$ & $\mathrm{R} \$$ & 5.494 & $\mathrm{R} \$$ & 4.974 & $\mathrm{R} \$$ & 4.531 & $\mathrm{R} \$$ & 4.178 \\
\hline $70-30-0$ & $\mathrm{R} \$$ & 4.939 & $\mathrm{R} \$$ & 4.340 & $\mathrm{R} \$$ & 3.834 & $\mathrm{R} \$$ & 3.498 \\
\hline 70-0-30 & $\mathrm{R} \$$ & 4.966 & $\mathrm{R} \$$ & 4.338 & $\mathrm{R} \$$ & 3.886 & $\mathrm{R} \$$ & 3.544 \\
\hline $50-40-10$ & $\mathrm{R} \$$ & 5.055 & $\mathrm{R} \$$ & 4.521 & $\mathrm{R} \$$ & 4.028 & $\mathrm{R} \$$ & 3.670 \\
\hline $60-30-10$ & $\mathrm{R} \$$ & 5.008 & $\mathrm{R} \$$ & 4.480 & $\mathrm{R} \$$ & 3.939 & $\mathrm{R} \$$ & 3.591 \\
\hline
\end{tabular}

Apêndice 219 - Valor médio da mensalidade final, com crédito médio de 1,40\% sobre o valor do investimento, para construção em 90 dias e compensação de retorno em 24 meses, com simulação do nível de utilização da capacidade instalada, para 300 residentes

\begin{tabular}{|c|c|c|c|c|c|c|c|c|}
\hline \multirow{2}{*}{$\begin{array}{c}\text { Porcentagem de } \\
\text { residentes com } \\
\text { grau de } \\
\text { dependência } \\
\text { I, II e III } \\
\end{array}$} & \multicolumn{8}{|c|}{$\begin{array}{l}\text { Valor médio de mensalidade final, com simulação do nível de } \\
\text { utilização da capacidade instalada, para } 300 \text { residentes, com } \\
\text { diversos graus de dependência }\end{array}$} \\
\hline & \multicolumn{2}{|c|}{$60 \%$} & \multicolumn{2}{|c|}{$70 \%$} & \multicolumn{2}{|c|}{$80 \%$} & \multicolumn{2}{|c|}{ 90\% } \\
\hline $100-0-0$ & $\mathrm{R} \$$ & 4.174 & $\mathrm{R} \$$ & 3.713 & $\mathrm{R} \$$ & 3.276 & $\mathrm{R} \$$ & 2.959 \\
\hline $0-100-0$ & $\mathrm{R} \$$ & 4.889 & $\mathrm{R} \$$ & 4.421 & $\mathrm{R} \$$ & 3.990 & $\mathrm{R} \$$ & 3.668 \\
\hline $0-0-100$ & $\mathrm{R} \$$ & 5.050 & $\mathrm{R} \$$ & 4.624 & $\mathrm{R} \$$ & 4.239 & $\mathrm{R} \$$ & 3.940 \\
\hline 70-30-0 & $\mathrm{R} \$$ & 4.428 & $\mathrm{R} \$$ & 3.958 & $\mathrm{R} \$$ & 3.526 & $\mathrm{R} \$$ & 3.203 \\
\hline 70-0-30 & $\mathrm{R} \$$ & 4.472 & $\mathrm{R} \$$ & 4.020 & $\mathrm{R} \$$ & 3.595 & $\mathrm{R} \$$ & 3.093 \\
\hline $50-40-10$ & $\mathrm{R} \$$ & 4.603 & $\mathrm{R} \$$ & 4.132 & $\mathrm{R} \$$ & 3.681 & $\mathrm{R} \$$ & 3.372 \\
\hline $60-30-10$ & $\mathrm{R} \$$ & 4.524 & $\mathrm{R} \$$ & 4.064 & $\mathrm{R} \$$ & 3.633 & $\mathrm{R} \$$ & 3.330 \\
\hline
\end{tabular}

Apêndice 220 - Valor médio da mensalidade final, com crédito médio de 1,40\% sobre o valor do investimento, para construção em 90 dias e compensação de retorno em 24 meses, com simulação do nível de utilização da capacidade instalada, para 400 residentes

\begin{tabular}{|c|c|c|c|c|c|c|c|c|}
\hline \multirow{2}{*}{$\begin{array}{c}\text { Porcentagem de } \\
\text { residentes com } \\
\text { grau de } \\
\text { dependência } \\
\text { I, II e III }\end{array}$} & \multicolumn{8}{|c|}{$\begin{array}{l}\text { Valor médio de mensalidade final, com simulação do nível de } \\
\text { utilização da capacidade instalada, para } 400 \text { residentes, com } \\
\text { diversos graus de dependência }\end{array}$} \\
\hline & \multicolumn{2}{|c|}{$60 \%$} & \multicolumn{2}{|c|}{$70 \%$} & \multicolumn{2}{|c|}{$80 \%$} & \multicolumn{2}{|c|}{$90 \%$} \\
\hline 100-0-0 & $\mathrm{R} \$$ & 4.077 & $\mathrm{R} \$$ & 3.548 & $\mathrm{R} \$$ & 3.195 & $\mathrm{R} \$$ & 2.878 \\
\hline $0-100-0$ & $\mathrm{R} \$$ & 4.791 & $\mathrm{R} \$$ & 4.262 & $\mathrm{R} \$$ & 3.909 & $\mathrm{R} \$$ & 3.592 \\
\hline $0-0-100$ & $\mathrm{R} \$$ & 4.942 & $\mathrm{R} \$$ & 4.471 & $\mathrm{R} \$$ & 4.161 & $\mathrm{R} \$$ & 3.853 \\
\hline $70-30-0$ & $\mathrm{R} \$$ & 4.326 & $\mathrm{R} \$$ & 3.782 & $\mathrm{R} \$$ & 3.427 & $\mathrm{R} \$$ & 3.099 \\
\hline 70-0-30 & $\mathrm{R} \$$ & 4.351 & $\mathrm{R} \$$ & 3.822 & $\mathrm{R} \$$ & 3.488 & $\mathrm{R} \$$ & 3.178 \\
\hline $50-40-10$ & $\mathrm{R} \$$ & 4.465 & $\mathrm{R} \$$ & 3.962 & $\mathrm{R} \$$ & 3.602 & $\mathrm{R} \$$ & 3.279 \\
\hline $60-30-10$ & $\mathrm{R} \$$ & 4.416 & $\mathrm{R} \$$ & 3.890 & $\mathrm{R} \$$ & 3.539 & $\mathrm{R} \$$ & 3.199 \\
\hline
\end{tabular}


Apêndice 221 - Valor médio da mensalidade final, com crédito médio de $1,50 \%$ sobre o valor do investimento, para construção em 90 dias e compensação de retorno em 24 meses, com simulação do nível de utilização da capacidade instalada, para 100 residentes

\begin{tabular}{|c|c|c|c|c|c|c|c|c|}
\hline \multirow{3}{*}{$\begin{array}{c}\text { Porcentagem de } \\
\text { residentes com } \\
\text { grau de } \\
\text { dependência } \\
\text { I, II e III } \\
100-0-0\end{array}$} & \multicolumn{8}{|c|}{$\begin{array}{l}\text { Valor médio de mensalidade final, com simulação do nível de } \\
\text { utilização da capacidade instalada, para } 100 \text { residentes, com } \\
\text { diversos graus de dependência }\end{array}$} \\
\hline & \multicolumn{2}{|c|}{$60 \%$} & \multicolumn{2}{|c|}{$70 \%$} & \multicolumn{2}{|c|}{$80 \%$} & \multicolumn{2}{|c|}{$90 \%$} \\
\hline & $\mathrm{R} \$$ & 5.115 & $\mathrm{R} \$$ & 4.457 & $\mathrm{R} \$$ & 3.908 & $\mathrm{R} \$$ & 3.552 \\
\hline $0-100-0$ & $\mathrm{R} \$$ & 5.828 & $\mathrm{R} \$$ & 5.150 & $\mathrm{R} \$$ & 4.621 & $\mathrm{R} \$$ & 4.249 \\
\hline $0-0-100$ & $\mathrm{R} \$$ & 5.952 & $\mathrm{R} \$$ & 5.378 & $\mathrm{R} \$$ & 4.928 & $\mathrm{R} \$$ & 4.483 \\
\hline 70-30-0 & $\mathrm{R} \$$ & 5.400 & $\mathrm{R} \$$ & 4.783 & $\mathrm{R} \$$ & 4.194 & $\mathrm{R} \$$ & 3.805 \\
\hline 70-0-30 & $\mathrm{R} \$$ & 5.401 & $\mathrm{R} \$$ & 4.784 & $\mathrm{R} \$$ & 4.194 & $\mathrm{R} \$$ & 3.863 \\
\hline $50-40-10$ & $\mathrm{R} \$$ & 5.628 & $\mathrm{R} \$$ & 4.979 & $\mathrm{R} \$$ & 4.472 & $\mathrm{R} \$$ & 4.052 \\
\hline $60-30-10$ & $\mathrm{R} \$$ & 5.486 & $\mathrm{R} \$$ & 5.019 & $\mathrm{R} \$$ & 4.400 & $\mathrm{R} \$$ & 3.957 \\
\hline
\end{tabular}

Apêndice 222 - Valor médio da mensalidade final, com crédito médio de 1,50\% sobre o valor do investimento, para construção em 90 dias e compensação de retorno em 24 meses, com simulação do nível de utilização da capacidade instalada, para 200 residentes

\begin{tabular}{|c|c|c|c|c|c|c|c|c|}
\hline \multirow{2}{*}{$\begin{array}{c}\text { Porcentagem de } \\
\text { residentes com } \\
\text { grau de } \\
\text { dependência } \\
\text { I, II e III } \\
\end{array}$} & \multicolumn{8}{|c|}{$\begin{array}{l}\text { Valor médio de mensalidade final, com simulação do nível de } \\
\text { utilização da capacidade instalada, para } 200 \text { residentes, com } \\
\text { diversos graus de dependência }\end{array}$} \\
\hline & \multicolumn{2}{|c|}{$60 \%$} & \multicolumn{2}{|c|}{$70 \%$} & \multicolumn{2}{|c|}{$80 \%$} & \multicolumn{2}{|c|}{ 90\% } \\
\hline 100-0-0 & $\mathrm{R} \$$ & 4.769 & $\mathrm{R} \$$ & 4.154 & $\mathrm{R} \$$ & 3.671 & $\mathrm{R} \$$ & 3.305 \\
\hline $0-100-0$ & $\mathrm{R} \$$ & 5.484 & $\mathrm{R} \$$ & 4.868 & $\mathrm{R} \$$ & 4.385 & $\mathrm{R} \$$ & 4.019 \\
\hline $0-0-100$ & $\mathrm{R} \$$ & 5.577 & $\mathrm{R} \$$ & 5.045 & $\mathrm{R} \$$ & 4.593 & $\mathrm{R} \$$ & 4.233 \\
\hline $70-30-0$ & $\mathrm{R} \$$ & 5.031 & $\mathrm{R} \$$ & 4.419 & $\mathrm{R} \$$ & 3.902 & $\mathrm{R} \$$ & 3.559 \\
\hline 70-0-30 & $\mathrm{R} \$$ & 5.055 & $\mathrm{R} \$$ & 4.415 & $\mathrm{R} \$$ & 3.953 & $\mathrm{R} \$$ & 3.603 \\
\hline $50-40-10$ & $\mathrm{R} \$$ & 5.146 & $\mathrm{R} \$$ & 4.599 & $\mathrm{R} \$$ & 4.096 & $\mathrm{R} \$$ & 3.731 \\
\hline $60-30-10$ & $\mathrm{R} \$$ & 5.098 & $\mathrm{R} \$$ & 4.558 & $\mathrm{R} \$$ & 4.007 & $\mathrm{R} \$$ & 3.652 \\
\hline
\end{tabular}

Apêndice 223 - Valor médio da mensalidade final, com crédito médio de 1,50\% sobre o valor do investimento, para construção em 90 dias e compensação de retorno em 24 meses, com simulação do nível de utilização da capacidade instalada, para 300 residentes

\begin{tabular}{|c|c|c|c|c|c|c|c|c|}
\hline \multirow{2}{*}{$\begin{array}{c}\text { Porcentagem de } \\
\text { residentes com } \\
\text { grau de } \\
\text { dependência } \\
\text { I, II e III }\end{array}$} & \multicolumn{8}{|c|}{$\begin{array}{l}\text { Valor médio de mensalidade final, com simulação do nível de } \\
\text { utilização da capacidade instalada, para } 300 \text { residentes, com } \\
\text { diversos graus de dependência }\end{array}$} \\
\hline & \multicolumn{2}{|c|}{$60 \%$} & \multicolumn{2}{|c|}{$70 \%$} & \multicolumn{2}{|c|}{$80 \%$} & \multicolumn{2}{|c|}{$90 \%$} \\
\hline 100-0-0 & $\mathrm{R} \$$ & 4.259 & $\mathrm{R} \$$ & 3.786 & $\mathrm{R} \$$ & 3.340 & $\mathrm{R} \$$ & 3.016 \\
\hline $0-100-0$ & $\mathrm{R} \$$ & 4.975 & $\mathrm{R} \$$ & 4.494 & $\mathrm{R} \$$ & 4.054 & $\mathrm{R} \$$ & 3.725 \\
\hline $0-0-100$ & $\mathrm{R} \$$ & 5.127 & $\mathrm{R} \$$ & 4.690 & $\mathrm{R} \$$ & 4.297 & $\mathrm{R} \$$ & 3.991 \\
\hline $70-30-0$ & $\mathrm{R} \$$ & 4.514 & $\mathrm{R} \$$ & 4.032 & $\mathrm{R} \$$ & 3.590 & $\mathrm{R} \$$ & 3.260 \\
\hline 70-0-30 & $\mathrm{R} \$$ & 4.555 & $\mathrm{R} \$$ & 4.091 & $\mathrm{R} \$$ & 3.657 & $\mathrm{R} \$$ & 3.149 \\
\hline $50-4$ & $\mathrm{R} \$$ & 4.688 & $\mathrm{R} \$$ & 4.205 & $\mathrm{R} \$$ & 3.744 & $\mathrm{R} \$$ & 3.428 \\
\hline $60-30-10$ & $\mathrm{R} \$$ & 4.609 & $\mathrm{R} \$$ & 4.137 & $\mathrm{R} \$$ & 3.697 & $\mathrm{R} \$$ & 3.386 \\
\hline
\end{tabular}


Apêndice 224 - Valor médio da mensalidade final, com crédito médio de $1,50 \%$ sobre o valor do investimento, para construção em 90 dias e compensação de retorno em 24 meses, com simulação do nível de utilização da capacidade instalada, para 400 residentes

\begin{tabular}{|c|c|c|c|c|c|c|c|c|}
\hline \multirow{3}{*}{$\begin{array}{c}\text { Porcentagem de } \\
\text { residentes com } \\
\text { grau de } \\
\text { dependência } \\
\text { I, II e III } \\
100-0-0\end{array}$} & \multicolumn{8}{|c|}{$\begin{array}{l}\text { Valor médio de mensalidade final, com simulação do nível de } \\
\text { utilização da capacidade instalada, para } 400 \text { residentes, com } \\
\text { diversos graus de dependência }\end{array}$} \\
\hline & \multicolumn{2}{|c|}{$60 \%$} & \multicolumn{2}{|c|}{$70 \%$} & \multicolumn{2}{|c|}{$80 \%$} & \multicolumn{2}{|c|}{$90 \%$} \\
\hline & $\mathrm{R} \$$ & 4.161 & $\mathrm{R} \$$ & 3.620 & $\mathrm{R} \$$ & 3.258 & $\mathrm{R} \$$ & 2.934 \\
\hline $0-100-0$ & $\mathrm{R} \$$ & 4.875 & $\mathrm{R} \$$ & 4.334 & R\$ & 3.972 & $\mathrm{R} \$$ & 3.648 \\
\hline $0-0-100$ & $\mathrm{R} \$$ & 5.018 & $\mathrm{R} \$$ & 4.535 & $\mathrm{R} \$$ & 4.218 & $\mathrm{R} \$$ & 3.904 \\
\hline $70-30-0$ & $\mathrm{R} \$$ & 4.410 & $\mathrm{R} \$$ & 3.854 & $\mathrm{R} \$$ & 3.490 & $\mathrm{R} \$$ & 3.155 \\
\hline 70-0-30 & $\mathrm{R} \$$ & 4.432 & $\mathrm{R} \$$ & 3.891 & $\mathrm{R} \$$ & 3.549 & $\mathrm{R} \$$ & 3.232 \\
\hline $50-40-10$ & $\mathrm{R} \$$ & 4.548 & $\mathrm{R} \$$ & 4.033 & $\mathrm{R} \$$ & 3.664 & $\mathrm{R} \$$ & 3.334 \\
\hline $60-30-10$ & $\mathrm{R} \$$ & 4.499 & $\mathrm{R} \$$ & 3.961 & $\mathrm{R} \$$ & 3.601 & $\mathrm{R} \$$ & 3.254 \\
\hline
\end{tabular}

Apêndice 225 - Valor médio da mensalidade final, com crédito médio de 1,10\% sobre o valor do investimento, para construção em 90 dias e compensação de retorno em 12 meses, com simulação da porcentagem de habitações destinadas a cadeirantes, para 100 residentes

\begin{tabular}{|c|c|c|c|c|c|c|c|c|c|c|}
\hline \multirow{2}{*}{$\begin{array}{c}\text { Porcentagem de } \\
\text { residentes com } \\
\text { grau de } \\
\text { dependência } \\
\text { I, II e III } \\
\end{array}$} & \multicolumn{10}{|c|}{$\begin{array}{l}\text { Valor médio de mensalidade final, com simulação da porcentagem de } \\
\text { habitações destinadas a cadeirantes, para } 100 \text { residentes, com diversos graus } \\
\text { de dependência }\end{array}$} \\
\hline & \multicolumn{2}{|c|}{$20 \%$} & \multicolumn{2}{|c|}{$40 \%$} & \multicolumn{2}{|c|}{$60 \%$} & \multicolumn{2}{|c|}{$80 \%$} & \multicolumn{2}{|c|}{$100 \%$} \\
\hline 100-0-0 & $\mathrm{R} \$$ & 4.289 & $\mathrm{R} \$$ & 4.465 & $\mathrm{R} \$$ & 4.588 & $\mathrm{R} \$$ & 4.840 & $\mathrm{R} \$$ & 5.016 \\
\hline $0-100-0$ & $\mathrm{R} \$$ & 4.981 & $\mathrm{R} \$$ & 5.157 & $\mathrm{R} \$$ & 5.283 & $\mathrm{R} \$$ & 5.533 & $\mathrm{R} \$$ & 5.709 \\
\hline $0-0-100$ & $\mathrm{R} \$$ & 5.226 & $\mathrm{R} \$$ & 5.421 & $\mathrm{R} \$$ & 5.546 & $\mathrm{R} \$$ & 5.703 & $\mathrm{R} \$$ & 5.826 \\
\hline 70-30-0 & $\mathrm{R} \$$ & 4.614 & $\mathrm{R} \$$ & 4.790 & $\mathrm{R} \$$ & 4.914 & $\mathrm{R} \$$ & 5.166 & $\mathrm{R} \$$ & 5.342 \\
\hline $70-0-30$ & $\mathrm{R} \$$ & 4.620 & $\mathrm{R} \$$ & 4.833 & $\mathrm{R} \$$ & 4.990 & $\mathrm{R} \$$ & 5.113 & $\mathrm{R} \$$ & 5.385 \\
\hline $50-40-10$ & $\mathrm{R} \$$ & 4.811 & $\mathrm{R} \$$ & 4.987 & $\mathrm{R} \$$ & 5.110 & $\mathrm{R} \$$ & 5.363 & $\mathrm{R} \$$ & 5.539 \\
\hline $60-30-10$ & $\mathrm{R} \$$ & 4.852 & $\mathrm{R} \$$ & 5.028 & $\mathrm{R} \$$ & 5.151 & $\mathrm{R} \$$ & 5.403 & $\mathrm{R} \$$ & 5.579 \\
\hline
\end{tabular}

Apêndice 226 - Valor médio da mensalidade final, com crédito médio de 1,10\% sobre o valor do investimento, para construção em 90 dias e compensação de retorno em 12 meses, com simulação da porcentagem de habitações destinadas a cadeirantes, para 200 residentes

\begin{tabular}{|c|c|c|c|c|c|c|c|c|c|c|}
\hline \multirow{2}{*}{$\begin{array}{l}\text { Porcentagem de } \\
\text { residentes com } \\
\text { grau de } \\
\text { dependência } \\
\text { I, II e III }\end{array}$} & \multicolumn{10}{|c|}{$\begin{array}{l}\text { Valor médio de mensalidade final, com simulação da porcentagem de } \\
\text { habitações destinadas a cadeirantes, para } 200 \text { residentes, com diversos graus } \\
\text { de dependência }\end{array}$} \\
\hline & \multicolumn{2}{|c|}{$20 \%$} & \multicolumn{2}{|c|}{$40 \%$} & \multicolumn{2}{|c|}{$60 \%$} & \multicolumn{2}{|c|}{$80 \%$} & \multicolumn{2}{|c|}{$100 \%$} \\
\hline $100-0-0$ & $\mathrm{R} \$$ & 3.983 & $\mathrm{R} \$$ & 4.142 & $\mathrm{R} \$$ & 4.283 & $\mathrm{R} \$$ & 4.497 & $\mathrm{R} \$$ & 4.656 \\
\hline $0-100-0$ & $\mathrm{R} \$$ & 4.697 & $\mathrm{R} \$$ & 4.856 & $\mathrm{R} \$$ & 4.997 & $\mathrm{R} \$$ & 5.211 & $\mathrm{R} \$$ & 5.370 \\
\hline $0-0-100$ & $\mathrm{R} \$$ & 4.891 & $\mathrm{R} \$$ & 5.078 & $\mathrm{R} \$$ & 5.245 & $\mathrm{R} \$$ & 5.415 & $\mathrm{R} \$$ & 5.602 \\
\hline $70-30-0$ & $\mathrm{R} \$$ & 4.248 & $\mathrm{R} \$$ & 4.408 & $\mathrm{R} \$$ & 4.548 & $\mathrm{R} \$$ & 4.762 & $\mathrm{R} \$$ & 4.920 \\
\hline $70-0-30$ & $\mathrm{R} \$$ & 4.249 & $\mathrm{R} \$$ & 4.416 & $\mathrm{R} \$$ & 4.585 & $\mathrm{R} \$$ & 4.773 & $\mathrm{R} \$$ & 4.939 \\
\hline $50-40-10$ & $\mathrm{R} \$$ & 4.430 & $\mathrm{R} \$$ & 4.617 & $\mathrm{R} \$$ & 4.757 & $\mathrm{R} \$$ & 4.944 & $\mathrm{R} \$$ & 5.130 \\
\hline $60-30-10$ & $\mathrm{R} \$$ & 4.390 & $\mathrm{R} \$$ & 4.576 & $\mathrm{R} \$$ & 4.716 & $\mathrm{R} \$$ & 4.903 & $\mathrm{R} \$$ & 5.090 \\
\hline
\end{tabular}


Apêndice 227 - Valor médio da mensalidade final, com crédito médio de 1,10\% sobre o valor do investimento, para construção em 90 dias e compensação de retorno em 12 meses, com simulação da porcentagem de habitações destinadas a cadeirantes, para 300 residentes

\begin{tabular}{|c|c|c|c|c|c|c|c|c|c|c|}
\hline \multirow{2}{*}{$\begin{array}{c}\text { Porcentagem de } \\
\text { residentes com } \\
\text { grau de } \\
\text { dependência } \\
\text { I, II e III } \\
\end{array}$} & \multicolumn{10}{|c|}{$\begin{array}{l}\text { Valor médio de mensalidade final, com simulação da porcentagem de } \\
\text { habitações destinadas a cadeirantes, para } 300 \text { residentes, com diversos graus } \\
\text { de dependência }\end{array}$} \\
\hline & \multicolumn{2}{|c|}{$20 \%$} & \multicolumn{2}{|c|}{$40 \%$} & \multicolumn{2}{|c|}{$60 \%$} & \multicolumn{2}{|c|}{$80 \%$} & \multicolumn{2}{|c|}{$100 \%$} \\
\hline 100-0-0 & $\mathrm{R} \$$ & 3.628 & $\mathrm{R} \$$ & 3.809 & $\mathrm{R} \$$ & 3.960 & $\mathrm{R} \$$ & 4.117 & $\mathrm{R} \$$ & 4.299 \\
\hline $0-100-0$ & $\mathrm{R} \$$ & 4.335 & $\mathrm{R} \$$ & 4.517 & $\mathrm{R} \$$ & 4.667 & $\mathrm{R} \$$ & 4.824 & $\mathrm{R} \$$ & 5.006 \\
\hline $0-0-100$ & $\mathrm{R} \$$ & 4.547 & $\mathrm{R} \$$ & 4.710 & $\mathrm{R} \$$ & 4.854 & $\mathrm{R} \$$ & 5.035 & $\mathrm{R} \$$ & 5.199 \\
\hline $70-30-0$ & $\mathrm{R} \$$ & 3.873 & $\mathrm{R} \$$ & 4.055 & $\mathrm{R} \$$ & 4.205 & $\mathrm{R} \$$ & 4.361 & $\mathrm{R} \$$ & 4.543 \\
\hline $70-0-30$ & $\mathrm{R} \$$ & 3.937 & $\mathrm{R} \$$ & 4.081 & $\mathrm{R} \$$ & 4.263 & $\mathrm{R} \$$ & 4.426 & $\mathrm{R} \$$ & 4.601 \\
\hline $50-40-10$ & $\mathrm{R} \$$ & 4.047 & $\mathrm{R} \$$ & 4.229 & $\mathrm{R} \$$ & 4.373 & $\mathrm{R} \$$ & 4.537 & $\mathrm{R} \$$ & 4.719 \\
\hline $60-30-10$ & $\mathrm{R} \$$ & 3.980 & $\mathrm{R} \$$ & 4.161 & $\mathrm{R} \$$ & 4.305 & $\mathrm{R} \$$ & 4.468 & $\mathrm{R} \$$ & 4.650 \\
\hline
\end{tabular}

Apêndice 228 - Valor médio da mensalidade final, com crédito médio de 1,10\% sobre o valor do investimento, para construção em 90 dias e compensação de retorno em 12 meses, com simulação da porcentagem de habitações destinadas a cadeirantes, para 400 residentes

\begin{tabular}{|c|c|c|c|c|c|c|c|c|c|c|}
\hline \multirow{2}{*}{$\begin{array}{l}\text { Porcentagem de } \\
\text { residentes com } \\
\text { grau de } \\
\text { dependência } \\
\text { I, II e III }\end{array}$} & \multicolumn{10}{|c|}{$\begin{array}{l}\text { Valor médio de mensalidade final, com simulação da porcentagem de } \\
\text { habitações destinadas a cadeirantes, para } 400 \text { residentes, com diversos graus } \\
\text { de dependência }\end{array}$} \\
\hline & \multicolumn{2}{|c|}{$20 \%$} & \multicolumn{2}{|c|}{$40 \%$} & \multicolumn{2}{|c|}{$60 \%$} & \multicolumn{2}{|c|}{$80 \%$} & \multicolumn{2}{|c|}{$100 \%$} \\
\hline $100-0-0$ & $\mathrm{R} \$$ & 3.464 & $\mathrm{R} \$$ & 3.639 & $\mathrm{R} \$$ & 3.792 & $\mathrm{R} \$$ & 3.968 & $\mathrm{R} \$$ & 4.130 \\
\hline $0-100-0$ & $\mathrm{R} \$$ & 4.178 & $\mathrm{R} \$$ & 4.353 & $\mathrm{R} \$$ & 4.506 & $\mathrm{R} \$$ & 4.683 & $\mathrm{R} \$$ & 4.844 \\
\hline $0-0-100$ & $\mathrm{R} \$$ & 4.395 & $\mathrm{R} \$$ & 4.570 & $\mathrm{R} \$$ & 4.723 & $\mathrm{R} \$$ & 4.898 & $\mathrm{R} \$$ & 5.046 \\
\hline $70-30-0$ & $\mathrm{R} \$$ & 3.698 & $\mathrm{R} \$$ & 3.874 & $\mathrm{R} \$$ & 4.027 & $\mathrm{R} \$$ & 4.202 & $\mathrm{R} \$$ & 4.363 \\
\hline $70-0-30$ & $\mathrm{R} \$$ & 3.740 & $\mathrm{R} \$$ & 3.901 & $\mathrm{R}$ & 4.082 & $\mathrm{R} \$$ & 4.230 & $\mathrm{R} \$$ & 4.405 \\
\hline $50-40-10$ & $\mathrm{R} \$$ & 3.879 & $\mathrm{R} \$$ & 4.040 & $\mathrm{R} \$$ & 4.202 & $\mathrm{R} \$$ & 4.363 & $\mathrm{R}$ & 4.542 \\
\hline $60-30-10$ & $\mathrm{R} \$$ & 3.807 & $\mathrm{R} \$$ & 3.968 & $\mathrm{R} \$$ & 4.130 & $\mathrm{R} \$$ & 4.291 & $\mathrm{R} \$$ & 4.471 \\
\hline
\end{tabular}

Apêndice 229 - Valor médio da mensalidade final, com crédito médio de 1,20\% sobre o valor do investimento, para construção em 90 dias e compensação de retorno em 12 meses, com simulação da porcentagem de habitações destinadas a cadeirantes, para 100 residentes

\begin{tabular}{|c|c|c|c|c|c|c|c|c|c|c|}
\hline \multirow{2}{*}{$\begin{array}{l}\text { Porcentagem de } \\
\text { residentes com } \\
\text { grau de } \\
\text { dependência } \\
\text { I, II e III }\end{array}$} & \multicolumn{10}{|c|}{$\begin{array}{c}\text { Valor médio de mensalidade final, com simulação da porcentagem de } \\
\text { habitações destinadas a cadeirantes, para } 100 \text { residentes, com diversos graus } \\
\text { de dependência }\end{array}$} \\
\hline & \multicolumn{2}{|c|}{$20 \%$} & \multicolumn{2}{|c|}{$40 \%$} & \multicolumn{2}{|c|}{$60 \%$} & \multicolumn{2}{|c|}{$80 \%$} & \multicolumn{2}{|c|}{$100 \%$} \\
\hline $100-0-0$ & $\mathrm{R} \$$ & 4.379 & $\mathrm{R} \$$ & 4.560 & $\mathrm{R} \$$ & 4.688 & $\mathrm{R} \$$ & 4.945 & $\mathrm{R} \$$ & 5.125 \\
\hline $0-100-0$ & $\mathrm{R} \$$ & 5.072 & $\mathrm{R} \$$ & 5.253 & $\mathrm{R} \$$ & 5.383 & $\mathrm{R} \$$ & 5.637 & $\mathrm{R} \$$ & 5.818 \\
\hline $0-0-100$ & $\mathrm{R} \$$ & 5.308 & $\mathrm{R} \$$ & 5.507 & $\mathrm{R} \$$ & 5.637 & $\mathrm{R} \$$ & 5.798 & $\mathrm{R} \$$ & 5.926 \\
\hline $70-30-0$ & $\mathrm{R} \$$ & 4.705 & $\mathrm{R} \$$ & 4.886 & $\mathrm{R} \$$ & 5.014 & $\mathrm{R} \$$ & 5.271 & $\mathrm{R} \$$ & 5.451 \\
\hline $70-0-30$ & $\mathrm{R} \$$ & 4.708 & $\mathrm{R} \$$ & 4.927 & $\mathrm{R} \$$ & 5.087 & $\mathrm{R} \$$ & 5.215 & $\mathrm{R} \$$ & 5.492 \\
\hline $50-40-10$ & $\mathrm{R} \$$ & 4.901 & $\mathrm{R} \$$ & 5.082 & $\mathrm{R} \$$ & 5.210 & $\mathrm{R} \$$ & 5.467 & $\mathrm{R} \$$ & 5.647 \\
\hline $60-30-10$ & $\mathrm{R} \$$ & 4.942 & $\mathrm{R} \$$ & 5.122 & $\mathrm{R} \$$ & 5.250 & $\mathrm{R} \$$ & 5.507 & $\mathrm{R} \$$ & 5.688 \\
\hline
\end{tabular}


Apêndice 230 - Valor médio da mensalidade final, com crédito médio de 1,20\% sobre o valor do investimento, para construção em 90 dias e compensação de retorno em 12 meses, com simulação da porcentagem de habitações destinadas a cadeirantes, para 200 residentes

\begin{tabular}{|c|c|c|c|c|c|c|c|c|c|c|}
\hline \multirow{2}{*}{$\begin{array}{c}\text { Porcentagem de } \\
\text { residentes com } \\
\text { grau de } \\
\text { dependência } \\
\text { I, II e III } \\
\end{array}$} & \multicolumn{10}{|c|}{$\begin{array}{l}\text { Valor médio de mensalidade final, com simulação da porcentagem de } \\
\text { habitações destinadas a cadeirantes, para } 200 \text { residentes, com diversos graus } \\
\text { de dependência }\end{array}$} \\
\hline & \multicolumn{2}{|c|}{$20 \%$} & \multicolumn{2}{|c|}{$40 \%$} & \multicolumn{2}{|c|}{$60 \%$} & \multicolumn{2}{|c|}{$80 \%$} & \multicolumn{2}{|c|}{$100 \%$} \\
\hline 100-0-0 & $\mathrm{R} \$$ & 4.075 & $\mathrm{R} \$$ & 4.238 & $\mathrm{R} \$$ & 4.384 & $\mathrm{R} \$$ & 4.603 & $\mathrm{R} \$$ & 4.766 \\
\hline $0-100-0$ & $\mathrm{R} \$$ & 4.789 & $\mathrm{R} \$$ & 4.953 & $\mathrm{R} \$$ & 5.098 & $\mathrm{R} \$$ & 5.317 & $\mathrm{R} \$$ & 5.480 \\
\hline $0-0-100$ & $\mathrm{R} \$$ & 4.974 & $\mathrm{R} \$$ & 5.166 & $\mathrm{R} \$$ & 5.337 & $\mathrm{R} \$$ & 5.512 & $\mathrm{R} \$$ & 5.703 \\
\hline $70-30-0$ & $\mathrm{R} \$$ & 4.340 & $\mathrm{R} \$$ & 4.504 & $\mathrm{R} \$$ & 4.649 & $\mathrm{R} \$$ & 4.867 & $\mathrm{R} \$$ & 5.031 \\
\hline $70-0-30$ & $\mathrm{R} \$$ & 4.338 & $\mathrm{R} \$$ & 4.510 & $\mathrm{R} \$$ & 4.684 & $\mathrm{R} \$$ & 4.876 & $\mathrm{R} \$$ & 5.046 \\
\hline $50-40-10$ & $\mathrm{R} \$$ & 4.521 & $\mathrm{R} \$$ & 4.712 & $\mathrm{R} \$$ & 4.856 & $\mathrm{R} \$$ & 5.049 & $\mathrm{R} \$$ & 5.240 \\
\hline $60-30-10$ & $\mathrm{R} \$$ & 4.480 & $\mathrm{R} \$$ & 4.671 & $\mathrm{R} \$$ & 4.816 & $\mathrm{R} \$$ & 5.008 & $\mathrm{R} \$$ & 5.199 \\
\hline
\end{tabular}

Apêndice 231 - Valor médio da mensalidade final, com crédito médio de 1,20\% sobre o valor do investimento, para construção em 90 dias e compensação de retorno em 12 meses, com simulação da porcentagem de habitações destinadas a cadeirantes, para 300 residentes

\begin{tabular}{|c|c|c|c|c|c|c|c|c|c|c|}
\hline \multirow{2}{*}{$\begin{array}{l}\text { Porcentagem de } \\
\text { residentes com } \\
\text { grau de } \\
\text { dependência } \\
\text { I, II e III }\end{array}$} & \multicolumn{10}{|c|}{$\begin{array}{l}\text { Valor médio de mensalidade final, com simulação da porcentagem de } \\
\text { habitações destinadas a cadeirantes, para } 300 \text { residentes, com diversos graus } \\
\text { de dependência }\end{array}$} \\
\hline & \multicolumn{2}{|c|}{$20 \%$} & \multicolumn{2}{|c|}{$40 \%$} & \multicolumn{2}{|c|}{$60 \%$} & \multicolumn{2}{|c|}{$80 \%$} & \multicolumn{2}{|c|}{$100 \%$} \\
\hline $100-0-0$ & $\mathrm{R} \$$ & 3.713 & $\mathrm{R} \$$ & 3.899 & $\mathrm{R} \$$ & 4.054 & $\mathrm{R} \$$ & 4.216 & $\mathrm{R} \$$ & 4.402 \\
\hline $0-100-0$ & $\mathrm{R} \$$ & 4.421 & $\mathrm{R} \$$ & 4.607 & $\mathrm{R} \$$ & 4.762 & $\mathrm{R} \$$ & 4.923 & $\mathrm{R} \$$ & 5.109 \\
\hline $0-0-100$ & $\mathrm{R} \$$ & 4.624 & $\mathrm{R} \$$ & 4.792 & $\mathrm{R} \$$ & 4.940 & $\mathrm{R} \$$ & 5.126 & $\mathrm{R} \$$ & 5.294 \\
\hline $70-30-0$ & $\mathrm{R} \$$ & 3.958 & $\mathrm{R} \$$ & 4.145 & $\mathrm{R}$ & 4.299 & $\mathrm{R} \$$ & 4.460 & $\mathrm{R} \$$ & 4.646 \\
\hline $70-0-30$ & $\mathrm{R} \$$ & 4.020 & $\mathrm{R} \$$ & 4.169 & $\mathrm{R}$ & 4.355 & $\mathrm{R} \$$ & 4.522 & $\mathrm{R} \$$ & 4.702 \\
\hline $50-40-10$ & $\mathrm{R} \$$ & 4.132 & $\mathrm{R} \$$ & 4.319 & $\mathrm{R} \$$ & 4.467 & $\mathrm{R}$ & 4.635 & $\mathrm{R} \$$ & 4.821 \\
\hline $60-30-10$ & $\mathrm{R} \$$ & 4.064 & $\mathrm{R} \$$ & 4.251 & $\mathrm{R} \$$ & 4.398 & $\mathrm{R} \$$ & 4.566 & $\mathrm{R} \$$ & 4.752 \\
\hline
\end{tabular}

Apêndice 232 - Valor médio da mensalidade final, com crédito médio de 1,20\% sobre o valor do investimento, para construção em 90 dias e compensação de retorno em 12 meses, com simulação da porcentagem de habitações destinadas a cadeirantes, para 400 residentes

\begin{tabular}{|c|c|c|c|c|c|c|c|c|c|c|}
\hline \multirow{2}{*}{$\begin{array}{l}\text { Porcentagem de } \\
\text { residentes com } \\
\text { grau de } \\
\text { dependência } \\
\text { I, II e III }\end{array}$} & \multicolumn{10}{|c|}{$\begin{array}{l}\text { Valor médio de mensalidade final, com simulação da porcentagem de } \\
\text { habitações destinadas a cadeirantes, para } 400 \text { residentes, com diversos graus } \\
\text { de dependência }\end{array}$} \\
\hline & \multicolumn{2}{|c|}{$20 \%$} & \multicolumn{2}{|c|}{$40 \%$} & \multicolumn{2}{|c|}{$60 \%$} & \multicolumn{2}{|c|}{$80 \%$} & \multicolumn{2}{|c|}{$100 \%$} \\
\hline $100-0-0$ & $\mathrm{R} \$$ & 3.548 & $\mathrm{R} \$$ & 3.727 & $\mathrm{R} \$$ & 3.885 & $\mathrm{R} \$$ & 4.066 & $\mathrm{R} \$$ & 4.231 \\
\hline $0-100-0$ & $\mathrm{R} \$$ & 4.262 & $\mathrm{R} \$$ & 4.442 & $\mathrm{R} \$$ & 4.599 & $\mathrm{R} \$$ & 4.780 & $\mathrm{R} \$$ & 4.946 \\
\hline $0-0-100$ & $\mathrm{R} \$$ & 4.471 & $\mathrm{R} \$$ & 4.650 & $\mathrm{R} \$$ & 4.807 & $\mathrm{R} \$$ & 4.987 & $\mathrm{R} \$$ & 5.139 \\
\hline $70-30-0$ & $\mathrm{R} \$$ & 3.782 & $\mathrm{R} \$$ & 3.962 & $\mathrm{R} \$$ & 4.120 & $\mathrm{R} \$$ & 4.299 & $\mathrm{R} \$$ & 4.464 \\
\hline $70-0-30$ & $\mathrm{R} \$$ & 3.822 & $\mathrm{R} \$$ & 3.987 & $\mathrm{R} \$$ & 4.172 & $\mathrm{R} \$$ & 4.324 & $\mathrm{R} \$$ & 4.504 \\
\hline $50-40-10$ & $\mathrm{R} \$$ & 3.962 & $\mathrm{R} \$$ & 4.127 & $\mathrm{R} \$$ & 4.294 & $\mathrm{R} \$$ & 4.459 & $\mathrm{R} \$$ & 4.643 \\
\hline $60-30-10$ & $\mathrm{R} \$$ & 3.890 & $\mathrm{R} \$$ & 4.056 & $\mathrm{R} \$$ & 4.222 & $\mathrm{R} \$$ & 4.388 & $\mathrm{R} \$$ & 4.572 \\
\hline
\end{tabular}


Apêndice 233 - Valor médio da mensalidade final, com crédito médio de 1,30\% sobre o valor do investimento, para construção em 90 dias e compensação de retorno em 12 meses, com simulação da porcentagem de habitações destinadas a cadeirantes, para 100 residentes

\begin{tabular}{|c|c|c|c|c|c|c|c|c|c|c|}
\hline \multirow{2}{*}{$\begin{array}{l}\text { Porcentagem de } \\
\text { residentes com } \\
\text { grau de } \\
\text { dependência } \\
\text { I, II e III } \\
\end{array}$} & \multicolumn{10}{|c|}{$\begin{array}{l}\text { Valor médio de mensalidade final, com simulação da porcentagem de } \\
\text { habitações destinadas a cadeirantes, para } 100 \text { residentes, com diversos graus } \\
\text { de dependência }\end{array}$} \\
\hline & \multicolumn{2}{|c|}{$20 \%$} & \multicolumn{2}{|c|}{$40 \%$} & \multicolumn{2}{|c|}{$60 \%$} & \multicolumn{2}{|c|}{$80 \%$} & \multicolumn{2}{|c|}{$100 \%$} \\
\hline 100-0-0 & $\mathrm{R} \$$ & 4.470 & $\mathrm{R} \$$ & 4.655 & $\mathrm{R} \$$ & 4.787 & $\mathrm{R} \$$ & 5.049 & $\mathrm{R} \$$ & 5.234 \\
\hline $0-100-0$ & $\mathrm{R} \$$ & 5.163 & $\mathrm{R} \$$ & 5.348 & $\mathrm{R} \$$ & 5.483 & $\mathrm{R} \$$ & 5.742 & $\mathrm{R} \$$ & 5.927 \\
\hline $0-0-100$ & $\mathrm{R} \$$ & 5.389 & $\mathrm{R} \$$ & 5.593 & $\mathrm{R} \$$ & 5.728 & $\mathrm{R} \$$ & 5.893 & $\mathrm{R} \$$ & 6.026 \\
\hline $70-30-0$ & $\mathrm{R} \$$ & 4.796 & $\mathrm{R} \$$ & 4.981 & $\mathrm{R} \$$ & 5.113 & $\mathrm{R} \$$ & 5.375 & $\mathrm{R} \$$ & 5.560 \\
\hline $70-0-30$ & $\mathrm{R} \$$ & 4.797 & $\mathrm{R} \$$ & 5.020 & $\mathrm{R} \$$ & 5.185 & $\mathrm{R} \$$ & 5.317 & $\mathrm{R} \$$ & 5.599 \\
\hline $50-40-10$ & $\mathrm{R} \$$ & 4.992 & $\mathrm{R} \$$ & 5.177 & $\mathrm{R} \$$ & 5.309 & $\mathrm{R} \$$ & 5.571 & $\mathrm{R} \$$ & 5.756 \\
\hline $60-30-10$ & $\mathrm{R} \$$ & 5.032 & $\mathrm{R} \$$ & 5.217 & $\mathrm{R} \$$ & 5.349 & $\mathrm{R} \$$ & 5.611 & $\mathrm{R} \$$ & 5.796 \\
\hline
\end{tabular}

Apêndice 234 - Valor médio da mensalidade final, com crédito médio de 1,30\% sobre o valor do investimento, para construção em 90 dias e compensação de retorno em 12 meses, com simulação da porcentagem de habitações destinadas a cadeirantes, para 200 residentes

\begin{tabular}{|c|c|c|c|c|c|c|c|c|c|c|}
\hline \multirow{2}{*}{$\begin{array}{l}\text { Porcentagem de } \\
\text { residentes com } \\
\text { grau de } \\
\text { dependência } \\
\text { I, II e III }\end{array}$} & \multicolumn{10}{|c|}{$\begin{array}{l}\text { Valor médio de mensalidade final, com simulação da porcentagem de } \\
\text { habitações destinadas a cadeirantes, para } 200 \text { residentes, com diversos graus } \\
\text { de dependência }\end{array}$} \\
\hline & \multicolumn{2}{|c|}{$20 \%$} & \multicolumn{2}{|c|}{$40 \%$} & \multicolumn{2}{|c|}{$60 \%$} & \multicolumn{2}{|c|}{$80 \%$} & \multicolumn{2}{|c|}{$100 \%$} \\
\hline $100-0-0$ & $\mathrm{R} \$$ & 4.167 & $\mathrm{R} \$$ & 4.335 & $\mathrm{R} \$$ & 4.485 & $\mathrm{R} \$$ & 4.708 & $\mathrm{R} \$$ & 4.876 \\
\hline $0-100-0$ & $\mathrm{R} \$$ & 4.881 & $\mathrm{R} \$$ & 5.049 & $\mathrm{R} \$$ & 5.200 & $\mathrm{R} \$$ & 5.423 & $\mathrm{R} \$$ & 5.591 \\
\hline $0-0-100$ & $\mathrm{R} \$$ & 5.057 & $\mathrm{R} \$$ & 5.253 & $\mathrm{R} \$$ & 5.429 & $\mathrm{R} \$$ & 5.609 & $\mathrm{R} \$$ & 5.804 \\
\hline $70-30-0$ & $\mathrm{R} \$$ & 4.432 & $\mathrm{R} \$$ & 4.601 & $\mathrm{R} \$$ & 4.750 & $\mathrm{R} \$$ & 4.973 & $\mathrm{R} \$$ & 5.141 \\
\hline $70-0-30$ & $\mathrm{R} \$$ & 4.428 & $\mathrm{R} \$$ & 4.604 & $\mathrm{R}$ & 4.782 & $\mathrm{R} \$$ & 4.979 & $\mathrm{R} \$$ & 5.154 \\
\hline $50-40-10$ & $\mathrm{R} \$$ & 4.612 & $\mathrm{R} \$$ & 4.808 & $\mathrm{R} \$$ & 4.956 & $\mathrm{R} \$$ & 5.153 & $\mathrm{R}$ & 5.349 \\
\hline $60-30-10$ & $\mathrm{R} \$$ & 4.571 & $\mathrm{R} \$$ & 4.767 & $\mathrm{R} \$$ & 4.916 & $\mathrm{R} \$$ & 5.112 & $\mathrm{R} \$$ & 5.308 \\
\hline
\end{tabular}

Apêndice 235 - Valor médio da mensalidade final, com crédito médio de 1,30\% sobre o valor do investimento, para construção em 90 dias e compensação de retorno em 12 meses, com simulação da porcentagem de habitações destinadas a cadeirantes, para 300 residentes

\begin{tabular}{|c|c|c|c|c|c|c|c|c|c|c|}
\hline \multirow{2}{*}{$\begin{array}{l}\text { Porcentagem de } \\
\text { residentes com } \\
\text { grau de } \\
\text { dependência } \\
\text { I, II e III }\end{array}$} & \multicolumn{10}{|c|}{$\begin{array}{c}\text { Valor médio de mensalidade final, com simulação da porcentagem de } \\
\text { habitações destinadas a cadeirantes, para } 300 \text { residentes, com diversos graus } \\
\text { de dependência }\end{array}$} \\
\hline & \multicolumn{2}{|c|}{$20 \%$} & \multicolumn{2}{|c|}{$40 \%$} & \multicolumn{2}{|c|}{$60 \%$} & \multicolumn{2}{|c|}{$80 \%$} & \multicolumn{2}{|c|}{$100 \%$} \\
\hline $100-0-0$ & $\mathrm{R} \$$ & 3.798 & $\mathrm{R} \$$ & 3.989 & $\mathrm{R} \$$ & 4.149 & $\mathrm{R} \$$ & 4.314 & $\mathrm{R} \$$ & 4.505 \\
\hline $0-100-0$ & $\mathrm{R} \$$ & 4.507 & $\mathrm{R} \$$ & 4.697 & $\mathrm{R} \$$ & 4.856 & $\mathrm{R} \$$ & 5.022 & $\mathrm{R} \$$ & 5.212 \\
\hline $0-0-100$ & $\mathrm{R} \$$ & 4.701 & $\mathrm{R} \$$ & 4.873 & $\mathrm{R} \$$ & 5.026 & $\mathrm{R} \$$ & 5.216 & $\mathrm{R} \$$ & 5.389 \\
\hline $70-30-0$ & $\mathrm{R} \$$ & 4.044 & $\mathrm{R} \$$ & 4.235 & $\mathrm{R} \$$ & 4.393 & $\mathrm{R} \$$ & 4.559 & $\mathrm{R} \$$ & 4.750 \\
\hline $70-0-30$ & $\mathrm{R} \$$ & 4.103 & $\mathrm{R} \$$ & 4.256 & $\mathrm{R} \$$ & 4.447 & $\mathrm{R} \$$ & 4.618 & $\mathrm{R} \$$ & 4.803 \\
\hline $50-40-10$ & $\mathrm{R} \$$ & 4.217 & $\mathrm{R} \$$ & 4.408 & $\mathrm{R} \$$ & 4.561 & $\mathrm{R} \$$ & 4.733 & $\mathrm{R} \$$ & 4.924 \\
\hline $60-30-10$ & $\mathrm{R} \$$ & 4.149 & $\mathrm{R} \$$ & 4.340 & $\mathrm{R} \$$ & 4.492 & $\mathrm{R} \$$ & 4.664 & $\mathrm{R} \$$ & 4.855 \\
\hline
\end{tabular}


Apêndice 236 - Valor médio da mensalidade final, com crédito médio de 1,30\% sobre o valor do investimento, para construção em 90 dias e compensação de retorno em 12 meses, com simulação da porcentagem de habitações destinadas a cadeirantes, para 400 residentes

\begin{tabular}{|c|c|c|c|c|c|c|c|c|c|c|}
\hline \multirow{2}{*}{$\begin{array}{l}\text { Porcentagem de } \\
\text { residentes com } \\
\text { grau de } \\
\text { dependência } \\
\text { I, II e III } \\
\end{array}$} & \multicolumn{10}{|c|}{$\begin{array}{l}\text { Valor médio de mensalidade final, com simulação da porcentagem de } \\
\text { habitações destinadas a cadeirantes, para } 400 \text { residentes, com diversos graus } \\
\text { de dependência }\end{array}$} \\
\hline & \multicolumn{2}{|c|}{$20 \%$} & \multicolumn{2}{|c|}{$40 \%$} & \multicolumn{2}{|c|}{$60 \%$} & \multicolumn{2}{|c|}{$80 \%$} & \multicolumn{2}{|c|}{$100 \%$} \\
\hline $100-0-0$ & $\mathrm{R} \$$ & 3.632 & $\mathrm{R} \$$ & 3.816 & $\mathrm{R} \$$ & 3.977 & $\mathrm{R} \$$ & 4.163 & $\mathrm{R} \$$ & 4.333 \\
\hline $0-100-0$ & $\mathrm{R} \$$ & 4.346 & $\mathrm{R} \$$ & 4.530 & $\mathrm{R} \$$ & 4.692 & $\mathrm{R} \$$ & 4.878 & $\mathrm{R} \$$ & 5.048 \\
\hline $0-0-100$ & $\mathrm{R} \$$ & 4.546 & $\mathrm{R} \$$ & 4.730 & $\mathrm{R} \$$ & 4.892 & $\mathrm{R} \$$ & 5.076 & $\mathrm{R} \$$ & 5.233 \\
\hline $70-30-0$ & $\mathrm{R} \$$ & 3.866 & $\mathrm{R} \$$ & 4.051 & $\mathrm{R} \$$ & 4.212 & $\mathrm{R} \$$ & 4.396 & $\mathrm{R} \$$ & 4.566 \\
\hline $70-0-30$ & $\mathrm{R} \$$ & 3.903 & $\mathrm{R} \$$ & 4.073 & $\mathrm{R} \$$ & 4.263 & $\mathrm{R} \$$ & 4.419 & $\mathrm{R} \$$ & 4.603 \\
\hline $50-40-10$ & $\mathrm{R} \$$ & 4.045 & $\mathrm{R} \$$ & 4.215 & $\mathrm{R} \$$ & 4.386 & $\mathrm{R} \$$ & 4.556 & $\mathrm{R} \$$ & 4.744 \\
\hline $60-30-10$ & $\mathrm{R} \$$ & 3.973 & $\mathrm{R} \$$ & 4.144 & $\mathrm{R} \$$ & 4.314 & $\mathrm{R} \$$ & 4.484 & $\mathrm{R} \$$ & 4.673 \\
\hline
\end{tabular}

Apêndice 237 - Valor médio da mensalidade final, com crédito médio de 1,40\% sobre o valor do investimento, para construção em 90 dias e compensação de retorno em 12 meses, com simulação da porcentagem de habitações destinadas a cadeirantes, para 100 residentes

\begin{tabular}{|c|c|c|c|c|c|c|c|c|c|c|}
\hline \multirow{2}{*}{$\begin{array}{l}\text { Porcentagem de } \\
\text { residentes com } \\
\text { grau de } \\
\text { dependência } \\
\text { I, II e III }\end{array}$} & \multicolumn{10}{|c|}{$\begin{array}{l}\text { Valor médio de mensalidade final, com simulação da porcentagem de } \\
\text { habitações destinadas a cadeirantes, para } 100 \text { residentes, com diversos graus } \\
\text { de dependência }\end{array}$} \\
\hline & \multicolumn{2}{|c|}{$20 \%$} & \multicolumn{2}{|c|}{$40 \%$} & \multicolumn{2}{|c|}{$60 \%$} & \multicolumn{2}{|c|}{$80 \%$} & \multicolumn{2}{|c|}{$100 \%$} \\
\hline $100-0-0$ & $\mathrm{R} \$$ & 4.561 & $\mathrm{R} \$$ & 4.750 & $\mathrm{R} \$$ & 4.887 & $\mathrm{R} \$$ & 5.154 & $\mathrm{R} \$$ & 5.344 \\
\hline $0-100-0$ & $\mathrm{R} \$$ & 5.254 & $\mathrm{R} \$$ & 5.443 & $\mathrm{R} \$$ & 5.584 & $\mathrm{R} \$$ & 5.847 & $\mathrm{R} \$$ & 6.036 \\
\hline $0-0-100$ & $\mathrm{R} \$$ & 5.471 & $\mathrm{R} \$$ & 5.679 & $\mathrm{R} \$$ & 5.819 & $\mathrm{R} \$$ & 5.989 & $\mathrm{R} \$$ & 6.126 \\
\hline $70-30-0$ & $\mathrm{R} \$$ & 4.887 & $\mathrm{R} \$$ & 5.076 & $\mathrm{R}$ & 5.213 & $\mathrm{R} \$$ & 5.480 & $\mathrm{R} \$$ & 5.670 \\
\hline $70-0-30$ & $\mathrm{R} \$$ & 4.885 & $\mathrm{R} \$$ & 5.113 & $\mathrm{R}$ & 5.283 & $\mathrm{R}$ & 5.420 & $\mathrm{R} \$$ & 5.706 \\
\hline $50-40-10$ & $\mathrm{R} \$$ & 5.082 & $\mathrm{R} \$$ & 5.271 & $\mathrm{R} \$$ & 5.408 & $\mathrm{R} \$$ & 5.675 & $\mathrm{R}$ & 5.864 \\
\hline $60-30-10$ & $\mathrm{R} \$$ & 5.122 & $\mathrm{R} \$$ & 5.312 & $\mathrm{R} \$$ & 5.449 & $\mathrm{R} \$$ & 5.715 & $\mathrm{R} \$$ & 5.905 \\
\hline
\end{tabular}

Apêndice 238 - Valor médio da mensalidade final, com crédito médio de 1,40\% sobre o valor do investimento, para construção em 90 dias e compensação de retorno em 12 meses, com simulação da porcentagem de habitações destinadas a cadeirantes, para 200 residentes

\begin{tabular}{|c|c|c|c|c|c|c|c|c|c|c|}
\hline \multirow{2}{*}{$\begin{array}{l}\text { Porcentagem de } \\
\text { residentes com } \\
\text { grau de } \\
\text { dependência } \\
\text { I, II e III }\end{array}$} & \multicolumn{10}{|c|}{$\begin{array}{c}\text { Valor médio de mensalidade final, com simulação da porcentagem de } \\
\text { habitações destinadas a cadeirantes, para } 200 \text { residentes, com diversos graus } \\
\text { de dependência }\end{array}$} \\
\hline & \multicolumn{2}{|c|}{$20 \%$} & \multicolumn{2}{|c|}{$40 \%$} & \multicolumn{2}{|c|}{$60 \%$} & \multicolumn{2}{|c|}{$80 \%$} & \multicolumn{2}{|c|}{$100 \%$} \\
\hline $100-0-0$ & $\mathrm{R} \$$ & 4.259 & $\mathrm{R} \$$ & 4.431 & $\mathrm{R} \$$ & 4.586 & $\mathrm{R} \$$ & 4.814 & $\mathrm{R} \$$ & 4.986 \\
\hline $0-100-0$ & $\mathrm{R} \$$ & 4.973 & $\mathrm{R} \$$ & 5.146 & $\mathrm{R} \$$ & 5.301 & $\mathrm{R} \$$ & 5.529 & $\mathrm{R} \$$ & 5.701 \\
\hline $0-0-100$ & $\mathrm{R} \$$ & 5.140 & $\mathrm{R} \$$ & 5.340 & $\mathrm{R} \$$ & 5.522 & $\mathrm{R} \$$ & 5.706 & $\mathrm{R} \$$ & 5.906 \\
\hline $70-30-0$ & $\mathrm{R} \$$ & 4.524 & $\mathrm{R} \$$ & 4.697 & $\mathrm{R} \$$ & 4.851 & $\mathrm{R} \$$ & 5.079 & $\mathrm{R} \$$ & 5.251 \\
\hline $70-0-30$ & $\mathrm{R} \$$ & 4.517 & $\mathrm{R} \$$ & 4.698 & $\mathrm{R} \$$ & 4.880 & $\mathrm{R} \$$ & 5.082 & $\mathrm{R}$ & 5.262 \\
\hline $50-40-10$ & $\mathrm{R} \$$ & 4.703 & $\mathrm{R} \$$ & 4.903 & $\mathrm{R} \$$ & 5.056 & $\mathrm{R} \$$ & 5.258 & $\mathrm{R}$ & 5.458 \\
\hline $60-30-10$ & $\mathrm{R} \$$ & 4.662 & $\mathrm{R} \$$ & 4.862 & $\mathrm{R} \$$ & 5.016 & $\mathrm{R} \$$ & 5.217 & $\mathrm{R} \$$ & 5.417 \\
\hline
\end{tabular}


Apêndice 239 - Valor médio da mensalidade final, com crédito médio de 1,40\% sobre o valor do investimento, para construção em 90 dias e compensação de retorno em 12 meses, com simulação da porcentagem de habitações destinadas a cadeirantes, para 300 residentes

\begin{tabular}{|c|c|c|c|c|c|c|c|c|c|c|}
\hline \multirow{2}{*}{$\begin{array}{l}\text { Porcentagem de } \\
\text { residentes com } \\
\text { grau de } \\
\text { dependência } \\
\text { I, II e III } \\
\end{array}$} & \multicolumn{10}{|c|}{$\begin{array}{l}\text { Valor médio de mensalidade final, com simulação da porcentagem de } \\
\text { habitações destinadas a cadeirantes, para } 300 \text { residentes, com diversos graus } \\
\text { de dependência }\end{array}$} \\
\hline & \multicolumn{2}{|c|}{$20 \%$} & \multicolumn{2}{|c|}{$40 \%$} & \multicolumn{2}{|c|}{$60 \%$} & \multicolumn{2}{|c|}{$80 \%$} & \multicolumn{2}{|c|}{$100 \%$} \\
\hline $100-0-0$ & $\mathrm{R} \$$ & 3.884 & $\mathrm{R} \$$ & 4.079 & $\mathrm{R} \$$ & 4.243 & $\mathrm{R} \$$ & 4.413 & $\mathrm{R} \$$ & 4.608 \\
\hline $0-100-0$ & $\mathrm{R} \$$ & 4.592 & $\mathrm{R} \$$ & 4.787 & $\mathrm{R} \$$ & 4.951 & $\mathrm{R} \$$ & 5.121 & $\mathrm{R} \$$ & 5.316 \\
\hline $0-0-100$ & $\mathrm{R} \$$ & 4.778 & $\mathrm{R} \$$ & 4.955 & $\mathrm{R} \$$ & 5.111 & $\mathrm{R} \$$ & 5.307 & $\mathrm{R} \$$ & 5.483 \\
\hline $70-30-0$ & $\mathrm{R} \$$ & 4.129 & $\mathrm{R} \$$ & 4.325 & $\mathrm{R} \$$ & 4.488 & $\mathrm{R} \$$ & 4.658 & $\mathrm{R} \$$ & 4.853 \\
\hline $70-0-30$ & $\mathrm{R} \$$ & 4.186 & $\mathrm{R} \$$ & 4.344 & $\mathrm{R} \$$ & 4.539 & $\mathrm{R} \$$ & 4.715 & $\mathrm{R} \$$ & 4.903 \\
\hline $50-40-10$ & $\mathrm{R} \$$ & 4.302 & $\mathrm{R} \$$ & 4.497 & $\mathrm{R} \$$ & 4.655 & $\mathrm{R} \$$ & 4.831 & $\mathrm{R} \$$ & 5.026 \\
\hline $60-30-10$ & $\mathrm{R} \$$ & 4.234 & $\mathrm{R} \$$ & 4.429 & $\mathrm{R} \$$ & 4.586 & $\mathrm{R} \$$ & 4.762 & $\mathrm{R} \$$ & 4.958 \\
\hline
\end{tabular}

Apêndice 240 - Valor médio da mensalidade final, com crédito médio de 1,40\% sobre o valor do investimento, para construção em 90 dias e compensação de retorno em 12 meses, com simulação da porcentagem de habitações destinadas a cadeirantes, para 400 residentes

\begin{tabular}{|c|c|c|c|c|c|c|c|c|c|c|}
\hline \multirow{2}{*}{$\begin{array}{l}\text { Porcentagem de } \\
\text { residentes com } \\
\text { grau de } \\
\text { dependência } \\
\text { I, II e III }\end{array}$} & \multicolumn{10}{|c|}{$\begin{array}{l}\text { Valor médio de mensalidade final, com simulação da porcentagem de } \\
\text { habitações destinadas a cadeirantes, para } 400 \text { residentes, com diversos graus } \\
\text { de dependência }\end{array}$} \\
\hline & \multicolumn{2}{|c|}{$20 \%$} & \multicolumn{2}{|c|}{$40 \%$} & \multicolumn{2}{|c|}{$60 \%$} & \multicolumn{2}{|c|}{$80 \%$} & \multicolumn{2}{|c|}{$100 \%$} \\
\hline $100-0-0$ & $\mathrm{R} \$$ & 3.716 & $\mathrm{R} \$$ & 3.904 & $\mathrm{R} \$$ & 4.070 & $\mathrm{R} \$$ & 4.261 & $\mathrm{R} \$$ & 4.435 \\
\hline $0-100-0$ & $\mathrm{R} \$$ & 4.430 & $\mathrm{R} \$$ & 4.619 & $\mathrm{R} \$$ & 4.785 & $\mathrm{R} \$$ & 4.975 & $\mathrm{R} \$$ & 5.150 \\
\hline $0-0-100$ & $\mathrm{R} \$$ & 4.622 & $\mathrm{R} \$$ & 4.810 & $\mathrm{R} \$$ & 4.976 & $\mathrm{R} \$$ & 5.165 & $\mathrm{R} \$$ & 5.326 \\
\hline $70-30-0$ & $\mathrm{R} \$$ & 3.950 & $\mathrm{R} \$$ & 4.139 & $\mathrm{R} \$$ & 4.305 & $\mathrm{R} \$$ & 4.494 & $\mathrm{R} \$$ & 4.668 \\
\hline $70-0-30$ & $\mathrm{R} \$$ & 3.985 & $\mathrm{R} \$$ & 4.159 & $\mathrm{R}$ & 4.353 & $\mathrm{R} \$$ & 4.514 & $\mathrm{R} \$$ & 4.702 \\
\hline $50-40-10$ & $\mathrm{R} \$$ & 4.128 & $\mathrm{R} \$$ & 4.302 & $\mathrm{R} \$$ & 4.478 & $\mathrm{R} \$$ & 4.652 & $\mathrm{R} \$$ & 4.845 \\
\hline $60-30-10$ & $\mathrm{R} \$$ & 4.056 & $\mathrm{R} \$$ & 4.231 & $\mathrm{R} \$$ & 4.406 & $\mathrm{R} \$$ & 4.581 & $\mathrm{R} \$$ & 4.774 \\
\hline
\end{tabular}

Apêndice 241 - Valor médio da mensalidade final, com crédito médio de 1,50\% sobre o valor do investimento, para construção em 90 dias e compensação de retorno em 12 meses, com simulação da porcentagem de habitações destinadas a cadeirantes, para 100 residentes

\begin{tabular}{|c|c|c|c|c|c|c|c|c|c|c|}
\hline \multirow{2}{*}{$\begin{array}{l}\text { Porcentagem de } \\
\text { residentes com } \\
\text { grau de } \\
\text { dependência } \\
\text { I, II e III }\end{array}$} & \multicolumn{10}{|c|}{$\begin{array}{c}\text { Valor médio de mensalidade final, com simulação da porcentagem de } \\
\text { habitações destinadas a cadeirantes, para } 100 \text { residentes, com diversos graus } \\
\text { de dependência }\end{array}$} \\
\hline & \multicolumn{2}{|c|}{$20 \%$} & \multicolumn{2}{|c|}{$40 \%$} & \multicolumn{2}{|c|}{$60 \%$} & \multicolumn{2}{|c|}{$80 \%$} & \multicolumn{2}{|c|}{$100 \%$} \\
\hline $100-0-0$ & $\mathrm{R} \$$ & 4.652 & $\mathrm{R} \$$ & 4.846 & $\mathrm{R} \$$ & 4.987 & $\mathrm{R} \$$ & 5.259 & $\mathrm{R} \$$ & 5.453 \\
\hline $0-100-0$ & $\mathrm{R} \$$ & 5.344 & $\mathrm{R} \$$ & 5.539 & $\mathrm{R} \$$ & 5.684 & $\mathrm{R} \$$ & 5.952 & $\mathrm{R} \$$ & 6.146 \\
\hline $0-0-100$ & $\mathrm{R} \$$ & 5.553 & $\mathrm{R} \$$ & 5.765 & $\mathrm{R} \$$ & 5.910 & $\mathrm{R} \$$ & 6.084 & $\mathrm{R} \$$ & 6.226 \\
\hline $70-30-0$ & $\mathrm{R} \$$ & 4.978 & $\mathrm{R} \$$ & 5.172 & $\mathrm{R} \$$ & 5.313 & $\mathrm{R} \$$ & 5.585 & $\mathrm{R} \$$ & 5.779 \\
\hline $70-0-30$ & $\mathrm{R} \$$ & 4.974 & $\mathrm{R} \$$ & 5.206 & $\mathrm{R} \$$ & 5.380 & $\mathrm{R} \$$ & 5.522 & $\mathrm{R} \$$ & 5.813 \\
\hline $50-40-10$ & $\mathrm{R} \$$ & 5.172 & $\mathrm{R} \$$ & 5.366 & $\mathrm{R} \$$ & 5.507 & $\mathrm{R} \$$ & 5.779 & $\mathrm{R} \$$ & 5.973 \\
\hline $60-30-10$ & $\mathrm{R} \$$ & 5.212 & $\mathrm{R} \$$ & 5.407 & $\mathrm{R} \$$ & 5.548 & $\mathrm{R} \$$ & 5.819 & $\mathrm{R} \$$ & 6.014 \\
\hline
\end{tabular}


Apêndice 242 - Valor médio da mensalidade final, com crédito médio de 1,50\% sobre o valor do investimento, para construção em 90 dias e compensação de retorno em 12 meses, com simulação da porcentagem de habitações destinadas a cadeirantes, para 200 residentes

\begin{tabular}{|c|c|c|c|c|c|c|c|c|c|c|}
\hline \multirow{2}{*}{$\begin{array}{l}\text { Porcentagem de } \\
\text { residentes com } \\
\text { grau de } \\
\text { dependência } \\
\text { I, II e III } \\
\end{array}$} & \multicolumn{10}{|c|}{$\begin{array}{l}\text { Valor médio de mensalidade final, com simulação da porcentagem de } \\
\text { habitações destinadas a cadeirantes, para } 200 \text { residentes, com diversos graus } \\
\text { de dependência }\end{array}$} \\
\hline & \multicolumn{2}{|c|}{$20 \%$} & \multicolumn{2}{|c|}{$40 \%$} & \multicolumn{2}{|c|}{$60 \%$} & \multicolumn{2}{|c|}{$80 \%$} & \multicolumn{2}{|c|}{$100 \%$} \\
\hline 100-0-0 & $\mathrm{R} \$$ & 4.351 & $\mathrm{R} \$$ & 4.527 & $\mathrm{R} \$$ & 4.687 & $\mathrm{R} \$$ & 4.920 & $\mathrm{R} \$$ & 5.097 \\
\hline $0-100-0$ & $\mathrm{R} \$$ & 5.065 & $\mathrm{R} \$$ & 5.242 & $\mathrm{R} \$$ & 5.402 & $\mathrm{R} \$$ & 5.635 & $\mathrm{R} \$$ & 5.812 \\
\hline $0-0-100$ & $\mathrm{R} \$$ & 5.223 & $\mathrm{R} \$$ & 5.428 & $\mathrm{R} \$$ & 5.614 & $\mathrm{R} \$$ & 5.802 & $\mathrm{R} \$$ & 6.007 \\
\hline $70-30-0$ & $\mathrm{R} \$$ & 4.615 & $\mathrm{R} \$$ & 4.794 & $\mathrm{R} \$$ & 4.952 & $\mathrm{R} \$$ & 5.185 & $\mathrm{R} \$$ & 5.361 \\
\hline $70-0-30$ & $\mathrm{R} \$$ & 4.606 & $\mathrm{R} \$$ & 4.792 & $\mathrm{R} \$$ & 4.979 & $\mathrm{R} \$$ & 5.185 & $\mathrm{R} \$$ & 5.369 \\
\hline $50-40-10$ & $\mathrm{R} \$$ & 4.793 & $\mathrm{R} \$$ & 4.998 & $\mathrm{R} \$$ & 5.156 & $\mathrm{R} \$$ & 5.363 & $\mathrm{R} \$$ & 5.568 \\
\hline $60-30-10$ & $\mathrm{R} \$$ & 4.753 & $\mathrm{R} \$$ & 4.958 & $\mathrm{R} \$$ & 5.116 & $\mathrm{R} \$$ & 5.322 & $\mathrm{R} \$$ & 5.527 \\
\hline
\end{tabular}

Apêndice 243 - Valor médio da mensalidade final, com crédito médio de 1,50\% sobre o valor do investimento, para construção em 90 dias e compensação de retorno em 12 meses, com simulação da porcentagem de habitações destinadas a cadeirantes, para 300 residentes

\begin{tabular}{|c|c|c|c|c|c|c|c|c|c|c|}
\hline \multirow{2}{*}{$\begin{array}{l}\text { Porcentagem de } \\
\text { residentes com } \\
\text { grau de } \\
\text { dependência } \\
\text { I, II e III }\end{array}$} & \multicolumn{10}{|c|}{$\begin{array}{l}\text { Valor médio de mensalidade final, com simulação da porcentagem de } \\
\text { habitações destinadas a cadeirantes, para } 300 \text { residentes, com diversos graus } \\
\text { de dependência }\end{array}$} \\
\hline & \multicolumn{2}{|c|}{$20 \%$} & \multicolumn{2}{|c|}{$40 \%$} & \multicolumn{2}{|c|}{$60 \%$} & \multicolumn{2}{|c|}{$80 \%$} & \multicolumn{2}{|c|}{$100 \%$} \\
\hline $100-0-0$ & $\mathrm{R} \$$ & 3.969 & $\mathrm{R} \$$ & 4.169 & $\mathrm{R} \$$ & 4.337 & $\mathrm{R} \$$ & 4.512 & $\mathrm{R} \$$ & 4.712 \\
\hline $0-100-0$ & $\mathrm{R} \$$ & 4.678 & $\mathrm{R} \$$ & 4.877 & $\mathrm{R} \$$ & 5.045 & $\mathrm{R} \$$ & 5.219 & $\mathrm{R} \$$ & 5.419 \\
\hline $0-0-100$ & $\mathrm{R} \$$ & 4.855 & $\mathrm{R} \$$ & 5.036 & $\mathrm{R} \$$ & 5.197 & $\mathrm{R} \$$ & 5.397 & $\mathrm{R} \$$ & 5.578 \\
\hline $70-30-0$ & $\mathrm{R} \$$ & 4.215 & $\mathrm{R} \$$ & 4.414 & $\mathrm{R} \$$ & 4.582 & $\mathrm{R} \$$ & 4.756 & $\mathrm{R} \$$ & 4.956 \\
\hline $70-0-30$ & $\mathrm{R} \$$ & 4.269 & $\mathrm{R} \$$ & 4.431 & $\mathrm{R}$ & 4.631 & $\mathrm{R} \$$ & 4.811 & $\mathrm{R} \$$ & 5.004 \\
\hline $50-40-10$ & $\mathrm{R} \$$ & 4.387 & $\mathrm{R} \$$ & 4.586 & $\mathrm{R} \$$ & 4.748 & $\mathrm{R} \$$ & 4.929 & $\mathrm{R}$ & 5.129 \\
\hline $60-30-10$ & $\mathrm{R} \$$ & 4.319 & $\mathrm{R} \$$ & 4.518 & $\mathrm{R} \$$ & 4.679 & $\mathrm{R} \$$ & 4.861 & $\mathrm{R} \$$ & 5.060 \\
\hline
\end{tabular}

Apêndice 244 - Valor médio da mensalidade final, com crédito médio de 1,50\% sobre o valor do investimento, para construção em 90 dias e compensação de retorno em 12 meses, com simulação da porcentagem de habitações destinadas a cadeirantes, para 400 residentes

\begin{tabular}{|c|c|c|c|c|c|c|c|c|c|c|}
\hline \multirow{2}{*}{$\begin{array}{l}\text { Porcentagem de } \\
\text { residentes com } \\
\text { grau de } \\
\text { dependência } \\
\text { I, II e III }\end{array}$} & \multicolumn{10}{|c|}{$\begin{array}{l}\text { Valor médio de mensalidade final, com simulação da porcentagem de } \\
\text { habitações destinadas a cadeirantes, para } 400 \text { residentes, com diversos graus } \\
\text { de dependência }\end{array}$} \\
\hline & \multicolumn{2}{|c|}{$20 \%$} & \multicolumn{2}{|c|}{$40 \%$} & \multicolumn{2}{|c|}{$60 \%$} & \multicolumn{2}{|c|}{$80 \%$} & \multicolumn{2}{|c|}{$100 \%$} \\
\hline $100-0-0$ & $\mathrm{R} \$$ & 3.800 & $\mathrm{R} \$$ & 3.992 & $\mathrm{R} \$$ & 4.163 & $\mathrm{R} \$$ & 4.358 & $\mathrm{R} \$$ & 4.537 \\
\hline $0-100-0$ & $\mathrm{R} \$$ & 4.514 & $\mathrm{R} \$$ & 4.707 & $\mathrm{R} \$$ & 4.878 & $\mathrm{R} \$$ & 5.073 & $\mathrm{R} \$$ & 5.252 \\
\hline $0-0-100$ & $\mathrm{R} \$$ & 4.698 & $\mathrm{R} \$$ & 4.890 & $\mathrm{R} \$$ & 5.061 & $\mathrm{R} \$$ & 5.254 & $\mathrm{R} \$$ & 5.419 \\
\hline $70-30-0$ & $\mathrm{R} \$$ & 4.034 & $\mathrm{R} \$$ & 4.227 & $\mathrm{R} \$$ & 4.398 & $\mathrm{R} \$$ & 4.591 & $\mathrm{R} \$$ & 4.770 \\
\hline $70-0-30$ & $\mathrm{R} \$$ & 4.066 & $\mathrm{R} \$$ & 4.245 & $\mathrm{R} \$$ & 4.443 & $\mathrm{R} \$$ & 4.609 & $\mathrm{R} \$$ & 4.802 \\
\hline $50-40-10$ & $\mathrm{R} \$$ & 4.211 & $\mathrm{R} \$$ & 4.390 & $\mathrm{R} \$$ & 4.570 & $\mathrm{R} \$$ & 4.749 & $\mathrm{R} \$$ & 4.946 \\
\hline $60-30-10$ & $\mathrm{R} \$$ & 4.139 & $\mathrm{R} \$$ & 4.319 & $\mathrm{R} \$$ & 4.498 & $\mathrm{R} \$$ & 4.677 & $\mathrm{R} \$$ & 4.875 \\
\hline
\end{tabular}


Apêndice 245 - Valor médio da mensalidade final, com crédito médio de 1,10\% sobre o valor do investimento, para construção em 90 dias e compensação de retorno em 24 meses, com simulação da porcentagem de habitações destinadas a cadeirantes, para 100 residentes

\begin{tabular}{|c|c|c|c|c|c|c|c|c|c|c|}
\hline \multirow{2}{*}{$\begin{array}{l}\text { Porcentagem de } \\
\text { residentes com } \\
\text { grau de } \\
\text { dependência } \\
\text { I, II e III } \\
\end{array}$} & \multicolumn{10}{|c|}{$\begin{array}{l}\text { Valor médio de mensalidade final, com simulação da porcentagem de } \\
\text { habitações destinadas a cadeirantes, para } 100 \text { residentes, com diversos graus } \\
\text { de dependência }\end{array}$} \\
\hline & \multicolumn{2}{|c|}{$20 \%$} & \multicolumn{2}{|c|}{$40 \%$} & \multicolumn{2}{|c|}{$60 \%$} & \multicolumn{2}{|c|}{$80 \%$} & \multicolumn{2}{|c|}{$100 \%$} \\
\hline 100-0-0 & $\mathrm{R} \$$ & 4.146 & $\mathrm{R} \$$ & 4.315 & $\mathrm{R} \$$ & 4.431 & $\mathrm{R} \$$ & 4.676 & $\mathrm{R} \$$ & 4.844 \\
\hline $0-100-0$ & $\mathrm{R} \$$ & 4.839 & $\mathrm{R} \$$ & 5.007 & $\mathrm{R} \$$ & 5.126 & $\mathrm{R} \$$ & 5.368 & $\mathrm{R} \$$ & 5.537 \\
\hline $0-0-100$ & $\mathrm{R} \$$ & 5.098 & $\mathrm{R} \$$ & 5.285 & $\mathrm{R} \$$ & 5.404 & $\mathrm{R} \$$ & 5.553 & $\mathrm{R} \$$ & 5.669 \\
\hline $70-30-0$ & $\mathrm{R} \$$ & 4.472 & $\mathrm{R} \$$ & 4.641 & $\mathrm{R} \$$ & 4.757 & $\mathrm{R} \$$ & 5.001 & $\mathrm{R} \$$ & 5.170 \\
\hline $70-0-30$ & $\mathrm{R} \$$ & 4.480 & $\mathrm{R} \$$ & 4.687 & $\mathrm{R} \$$ & 4.836 & $\mathrm{R} \$$ & 4.952 & $\mathrm{R} \$$ & 5.217 \\
\hline $50-40-10$ & $\mathrm{R} \$$ & 4.670 & $\mathrm{R} \$$ & 4.838 & $\mathrm{R} \$$ & 4.954 & $\mathrm{R} \$$ & 5.199 & $\mathrm{R} \$$ & 5.368 \\
\hline $60-30-10$ & $\mathrm{R} \$$ & 4.710 & $\mathrm{R} \$$ & 4.879 & $\mathrm{R} \$$ & 4.995 & $\mathrm{R} \$$ & 5.240 & $\mathrm{R} \$$ & 5.408 \\
\hline
\end{tabular}

Apêndice 246 - Valor médio da mensalidade final, com crédito médio de 1,10\% sobre o valor do investimento, para construção em 90 dias e compensação de retorno em 24 meses, com simulação da porcentagem de habitações destinadas a cadeirantes, para 200 residentes

\begin{tabular}{|c|c|c|c|c|c|c|c|c|c|c|}
\hline \multirow{2}{*}{$\begin{array}{l}\text { Porcentagem de } \\
\text { residentes com } \\
\text { grau de } \\
\text { dependência } \\
\text { I, II e III }\end{array}$} & \multicolumn{10}{|c|}{$\begin{array}{l}\text { Valor médio de mensalidade final, com simulação da porcentagem de } \\
\text { habitações destinadas a cadeirantes, para } 200 \text { residentes, com diversos graus } \\
\text { de dependência }\end{array}$} \\
\hline & \multicolumn{2}{|c|}{$20 \%$} & \multicolumn{2}{|c|}{$40 \%$} & \multicolumn{2}{|c|}{$60 \%$} & \multicolumn{2}{|c|}{$80 \%$} & \multicolumn{2}{|c|}{$100 \%$} \\
\hline $100-0-0$ & $\mathrm{R} \$$ & 3.839 & $\mathrm{R} \$$ & 3.991 & $\mathrm{R} \$$ & 4.124 & $\mathrm{R} \$$ & 4.331 & $\mathrm{R} \$$ & 4.482 \\
\hline $0-100-0$ & $\mathrm{R} \$$ & 4.553 & $\mathrm{R} \$$ & 4.705 & $\mathrm{R} \$$ & 4.838 & $\mathrm{R} \$$ & 5.045 & $\mathrm{R} \$$ & 5.196 \\
\hline $0-0-100$ & $\mathrm{R} \$$ & 4.761 & $\mathrm{R} \$$ & 4.941 & $\mathrm{R} \$$ & 5.100 & $\mathrm{R} \$$ & 5.263 & $\mathrm{R} \$$ & 5.442 \\
\hline $70-30-0$ & $\mathrm{R} \$$ & 4.104 & $\mathrm{R} \$$ & 4.256 & $\mathrm{R} \$$ & 4.389 & $\mathrm{R} \$$ & 4.596 & $\mathrm{R} \$$ & 4.747 \\
\hline $70-0-30$ & $\mathrm{R} \$$ & 4.109 & $\mathrm{R} \$$ & 4.269 & $\mathrm{R}$ & 4.430 & $\mathrm{R} \$$ & 4.611 & $\mathrm{R} \$$ & 4.769 \\
\hline $50-40-10$ & $\mathrm{R} \$$ & 4.288 & $\mathrm{R} \$$ & 4.467 & $\mathrm{R} \$$ & 4.599 & $\mathrm{R} \$$ & 4.780 & $\mathrm{R} \$$ & 4.959 \\
\hline $60-30-10$ & $\mathrm{R} \$$ & 4.247 & $\mathrm{R} \$$ & 4.426 & $\mathrm{R} \$$ & 4.559 & $\mathrm{R} \$$ & 4.739 & $\mathrm{R} \$$ & 4.918 \\
\hline
\end{tabular}

Apêndice 247 - Valor médio da mensalidade final, com crédito médio de 1,10\% sobre o valor do investimento, para construção em 90 dias e compensação de retorno em 24 meses, com simulação da porcentagem de habitações destinadas a cadeirantes, para 300 residentes

\begin{tabular}{|c|c|c|c|c|c|c|c|c|c|c|}
\hline \multirow{2}{*}{$\begin{array}{l}\text { Porcentagem de } \\
\text { residentes com } \\
\text { grau de } \\
\text { dependência } \\
\text { I, II e III }\end{array}$} & \multicolumn{10}{|c|}{$\begin{array}{c}\text { Valor médio de mensalidade final, com simulação da porcentagem de } \\
\text { habitações destinadas a cadeirantes, para } 300 \text { residentes, com diversos graus } \\
\text { de dependência }\end{array}$} \\
\hline & \multicolumn{2}{|c|}{$20 \%$} & \multicolumn{2}{|c|}{$40 \%$} & \multicolumn{2}{|c|}{$60 \%$} & \multicolumn{2}{|c|}{$80 \%$} & \multicolumn{2}{|c|}{$100 \%$} \\
\hline $100-0-0$ & $\mathrm{R} \$$ & 3.493 & $\mathrm{R} \$$ & 3.668 & $\mathrm{R} \$$ & 3.812 & $\mathrm{R} \$$ & 3.962 & $\mathrm{R} \$$ & 4.136 \\
\hline $0-100-0$ & $\mathrm{R} \$$ & 4.201 & $\mathrm{R} \$$ & 4.376 & $\mathrm{R} \$$ & 4.519 & $\mathrm{R} \$$ & 4.668 & $\mathrm{R} \$$ & 4.843 \\
\hline $0-0-100$ & $\mathrm{R} \$$ & 4.426 & $\mathrm{R} \$$ & 4.582 & $\mathrm{R} \$$ & 4.719 & $\mathrm{R} \$$ & 4.893 & $\mathrm{R} \$$ & 5.050 \\
\hline $70-30-0$ & $\mathrm{R} \$$ & 3.738 & $\mathrm{R} \$$ & 3.913 & $\mathrm{R} \$$ & 4.056 & $\mathrm{R} \$$ & 4.206 & $\mathrm{R} \$$ & 4.381 \\
\hline $70-0-30$ & $\mathrm{R} \$$ & 3.806 & $\mathrm{R} \$$ & 3.943 & $\mathrm{R} \$$ & 4.118 & $\mathrm{R} \$$ & 4.274 & $\mathrm{R} \$$ & 4.442 \\
\hline $50-40-10$ & $\mathrm{R} \$$ & 3.914 & $\mathrm{R} \$$ & 4.089 & $\mathrm{R} \$$ & 4.226 & $\mathrm{R} \$$ & 4.383 & $\mathrm{R} \$$ & 4.557 \\
\hline $60-30-10$ & $\mathrm{R} \$$ & 3.846 & $\mathrm{R} \$$ & 4.021 & $\mathrm{R} \$$ & 4.158 & $\mathrm{R} \$$ & 4.314 & $\mathrm{R} \$$ & 4.489 \\
\hline
\end{tabular}


Apêndice 248 - Valor médio da mensalidade final, com crédito médio de 1,10\% sobre o valor do investimento, para construção em 90 dias e compensação de retorno em 24 meses, com simulação da porcentagem de habitações destinadas a cadeirantes, para 400 residentes

\begin{tabular}{|c|c|c|c|c|c|c|c|c|c|c|}
\hline \multirow{3}{*}{$\begin{array}{c}\text { Porcentagem de } \\
\text { residentes com } \\
\text { grau de } \\
\text { dependência } \\
\text { I, II e III } \\
100-0-0\end{array}$} & \multicolumn{10}{|c|}{$\begin{array}{l}\text { Valor médio de mensalidade final, com simulação da porcentagem de } \\
\text { habitações destinadas a cadeirantes, para } 400 \text { residentes, com diversos graus } \\
\text { de dependência }\end{array}$} \\
\hline & \multicolumn{2}{|c|}{$20 \%$} & \multicolumn{2}{|c|}{$40 \%$} & \multicolumn{2}{|c|}{$60 \%$} & \multicolumn{2}{|c|}{$80 \%$} & \multicolumn{2}{|c|}{$100 \%$} \\
\hline & $\mathrm{R} \$$ & 3.332 & $\mathrm{R} \$$ & 3.500 & $\mathrm{R} \$$ & 3.646 & $\mathrm{R} \$$ & 3.815 & $\mathrm{R} \$$ & 3.970 \\
\hline 0-100-0 & $\mathrm{R} \$$ & 4.046 & $\mathrm{R} \$$ & 4.214 & $\mathrm{R} \$$ & 4.360 & $\mathrm{R} \$$ & 4.529 & $\mathrm{R} \$$ & 4.684 \\
\hline 0-0-100 & $\mathrm{R} \$$ & 4.276 & $\mathrm{R} \$$ & 4.444 & $\mathrm{R} \$$ & 4.590 & $\mathrm{R} \$$ & 4.758 & $\mathrm{R} \$$ & 4.899 \\
\hline $70-30-0$ & $\mathrm{R} \$$ & 3.566 & $\mathrm{R} \$$ & 3.735 & $\mathrm{R} \$$ & 3.881 & $\mathrm{R} \$$ & 4.049 & $\mathrm{R} \$$ & 4.203 \\
\hline $70-0-30$ & $\mathrm{R} \$$ & 3.612 & $\mathrm{R} \$$ & 3.766 & $\mathrm{R} \$$ & 3.940 & $\mathrm{R} \$$ & 4.081 & $\mathrm{R} \$$ & 4.249 \\
\hline $50-40-10$ & $\mathrm{R} \$$ & 3.748 & $\mathrm{R} \$$ & 3.902 & $\mathrm{R} \$$ & 4.057 & $\mathrm{R} \$$ & 4.211 & $\mathrm{R} \$$ & 4.384 \\
\hline $60-30-10$ & $\mathrm{R} \$$ & 3.676 & $\mathrm{R} \$$ & 3.831 & $\mathrm{R} \$$ & 3.986 & $\mathrm{R} \$$ & 4.140 & $\mathrm{R} \$$ & 4.313 \\
\hline
\end{tabular}

Apêndice 249 - Valor médio da mensalidade final, com crédito médio de 1,20\% sobre o valor do investimento, para construção em 90 dias e compensação de retorno em 24 meses, com simulação da porcentagem de habitações destinadas a cadeirantes, para 100 residentes

\begin{tabular}{|c|c|c|c|c|c|c|c|c|c|c|}
\hline \multirow{2}{*}{$\begin{array}{l}\text { Porcentagem de } \\
\text { residentes com } \\
\text { grau de } \\
\text { dependência } \\
\text { I, II e III }\end{array}$} & \multicolumn{10}{|c|}{$\begin{array}{l}\text { Valor médio de mensalidade final, com simulação da porcentagem de } \\
\text { habitações destinadas a cadeirantes, para } 100 \text { residentes, com diversos graus } \\
\text { de dependência }\end{array}$} \\
\hline & \multicolumn{2}{|c|}{$20 \%$} & \multicolumn{2}{|c|}{$40 \%$} & \multicolumn{2}{|c|}{$60 \%$} & \multicolumn{2}{|c|}{$80 \%$} & \multicolumn{2}{|c|}{$100 \%$} \\
\hline $100-0-0$ & $\mathrm{R} \$$ & 4.224 & $\mathrm{R} \$$ & 4.396 & $\mathrm{R} \$$ & 4.516 & $\mathrm{R} \$$ & 4.765 & $\mathrm{R} \$$ & 4.938 \\
\hline 0-100-0 & $\mathrm{R} \$$ & 4.916 & $\mathrm{R} \$$ & 5.089 & $\mathrm{R} \$$ & 5.212 & $\mathrm{R} \$$ & 5.458 & $\mathrm{R} \$$ & 5.631 \\
\hline 0-0-100 & $\mathrm{R} \$$ & 5.168 & $\mathrm{R} \$$ & 5.359 & $\mathrm{R} \$$ & 5.482 & $\mathrm{R} \$$ & 5.634 & $\mathrm{R} \$$ & 5.754 \\
\hline $70-30-0$ & $\mathrm{R} \$$ & 4.550 & $\mathrm{R} \$$ & 4.722 & $\mathrm{R} \$$ & 4.842 & $\mathrm{R} \$$ & 5.091 & $\mathrm{R} \$$ & 5.264 \\
\hline $70-0-30$ & $\mathrm{R} \$$ & 4.556 & $\mathrm{R} \$$ & 4.767 & $\mathrm{R} \$$ & 4.920 & $\mathrm{R} \$$ & 5.040 & $\mathrm{R} \$$ & 5.308 \\
\hline $50-40-10$ & $\mathrm{R} \$$ & 4.747 & $\mathrm{R} \$$ & 4.920 & $\mathrm{R} \$$ & 5.040 & $\mathrm{R} \$$ & 5.288 & $\mathrm{R} \$$ & 5.461 \\
\hline $60-30-10$ & $\mathrm{R} \$$ & 4.787 & $\mathrm{R} \$$ & 4.960 & $\mathrm{R} \$$ & 5.080 & $\mathrm{R} \$$ & 5.329 & $\mathrm{R} \$$ & 5.502 \\
\hline
\end{tabular}

Apêndice 250 - Valor médio da mensalidade final, com crédito médio de 1,20\% sobre o valor do investimento, para construção em 90 dias e compensação de retorno em 24 meses, com simulação da porcentagem de habitações destinadas a cadeirantes, para 200 residentes

\begin{tabular}{|c|c|c|c|c|c|c|c|c|c|c|}
\hline \multirow{2}{*}{$\begin{array}{l}\text { Porcentagem de } \\
\text { residentes com } \\
\text { grau de } \\
\text { dependência } \\
\text { I, II e III }\end{array}$} & \multicolumn{10}{|c|}{$\begin{array}{l}\text { Valor médio de mensalidade final, com simulação da porcentagem de } \\
\text { habitações destinadas a cadeirantes, para } 200 \text { residentes, com diversos graus } \\
\text { de dependência }\end{array}$} \\
\hline & \multicolumn{2}{|c|}{$20 \%$} & \multicolumn{2}{|c|}{$40 \%$} & \multicolumn{2}{|c|}{$60 \%$} & \multicolumn{2}{|c|}{$80 \%$} & \multicolumn{2}{|c|}{$100 \%$} \\
\hline 100-0-0 & $\mathrm{R} \$$ & 3.918 & $\mathrm{R} \$$ & 4.073 & $\mathrm{R} \$$ & 4.211 & $\mathrm{R} \$$ & 4.421 & $\mathrm{R} \$$ & 4.577 \\
\hline 0-100-0 & $\mathrm{R} \$$ & 4.632 & $\mathrm{R} \$$ & 4.787 & $\mathrm{R} \$$ & 4.925 & $\mathrm{R} \$$ & 5.136 & $\mathrm{R} \$$ & 5.291 \\
\hline 0-0-100 & $\mathrm{R} \$$ & 4.832 & $\mathrm{R} \$$ & 5.016 & $\mathrm{R} \$$ & 5.179 & $\mathrm{R} \$$ & 5.346 & $\mathrm{R} \$$ & 5.529 \\
\hline $70-30-0$ & $\mathrm{R} \$$ & 4.182 & $\mathrm{R} \$$ & 4.339 & $\mathrm{R} \$$ & 4.476 & $\mathrm{R} \$$ & 4.686 & $\mathrm{R} \$$ & 4.842 \\
\hline $70-0-30$ & $\mathrm{R} \$$ & 4.185 & $\mathrm{R} \$$ & 4.349 & $\mathrm{R} \$$ & 4.515 & $\mathrm{R} \$$ & 4.699 & $\mathrm{R} \$$ & 4.862 \\
\hline $50-40-10$ & $\mathrm{R} \$$ & 4.366 & $\mathrm{R} \$$ & 4.549 & $\mathrm{R} \$$ & 4.685 & $\mathrm{R} \$$ & 4.869 & $\mathrm{R} \$$ & 5.052 \\
\hline $60-30-10$ & $\mathrm{R} \$$ & 4.325 & $\mathrm{R} \$$ & 4.508 & $\mathrm{R} \$$ & 4.644 & $\mathrm{R} \$$ & 4.829 & $\mathrm{R} \$$ & 5.012 \\
\hline
\end{tabular}


Apêndice 251 - Valor médio da mensalidade final, com crédito médio de 1,20\% sobre o valor do investimento, para construção em 90 dias e compensação de retorno em 24 meses, com simulação da porcentagem de habitações destinadas a cadeirantes, para 300 residentes

\begin{tabular}{|c|c|c|c|c|c|c|c|c|c|c|}
\hline \multirow{2}{*}{$\begin{array}{l}\text { Porcentagem de } \\
\text { residentes com } \\
\text { grau de } \\
\text { dependência } \\
\text { I, II e III } \\
\end{array}$} & \multicolumn{10}{|c|}{$\begin{array}{l}\text { Valor médio de mensalidade final, com simulação da porcentagem de } \\
\text { habitações destinadas a cadeirantes, para } 300 \text { residentes, com diversos graus } \\
\text { de dependência }\end{array}$} \\
\hline & \multicolumn{2}{|c|}{$20 \%$} & \multicolumn{2}{|c|}{$40 \%$} & \multicolumn{2}{|c|}{$60 \%$} & \multicolumn{2}{|c|}{$80 \%$} & \multicolumn{2}{|c|}{$100 \%$} \\
\hline 100-0-0 & $\mathrm{R} \$$ & 3.567 & $\mathrm{R} \$$ & 3.745 & $\mathrm{R} \$$ & 3.893 & $\mathrm{R} \$$ & 4.046 & $\mathrm{R} \$$ & 4.225 \\
\hline $0-100-0$ & $\mathrm{R} \$$ & 4.274 & $\mathrm{R} \$$ & 4.453 & $\mathrm{R} \$$ & 4.600 & $\mathrm{R} \$$ & 4.753 & $\mathrm{R} \$$ & 4.932 \\
\hline $0-0-100$ & $\mathrm{R} \$$ & 4.492 & $\mathrm{R} \$$ & 4.652 & $\mathrm{R} \$$ & 4.792 & $\mathrm{R} \$$ & 4.971 & $\mathrm{R} \$$ & 5.131 \\
\hline $70-30-0$ & $\mathrm{R} \$$ & 3.812 & $\mathrm{R} \$$ & 3.990 & $\mathrm{R} \$$ & 4.137 & $\mathrm{R} \$$ & 4.291 & $\mathrm{R} \$$ & 4.469 \\
\hline $70-0-30$ & $\mathrm{R} \$$ & 3.878 & $\mathrm{R} \$$ & 4.019 & $\mathrm{R} \$$ & 4.197 & $\mathrm{R} \$$ & 4.357 & $\mathrm{R} \$$ & 4.529 \\
\hline $50-40-10$ & $\mathrm{R} \$$ & 3.987 & $\mathrm{R} \$$ & 4.166 & $\mathrm{R} \$$ & 4.306 & $\mathrm{R} \$$ & 4.467 & $\mathrm{R} \$$ & 4.645 \\
\hline $60-30-10$ & $\mathrm{R} \$$ & 3.919 & $\mathrm{R} \$$ & 4.098 & $\mathrm{R} \$$ & 4.238 & $\mathrm{R} \$$ & 4.398 & $\mathrm{R} \$$ & 4.577 \\
\hline
\end{tabular}

Apêndice 252 - Valor médio da mensalidade final, com crédito médio de 1,20\% sobre o valor do investimento, para construção em 90 dias e compensação de retorno em 24 meses, com simulação da porcentagem de habitações destinadas a cadeirantes, para 400 residentes

\begin{tabular}{|c|c|c|c|c|c|c|c|c|c|c|}
\hline \multirow{2}{*}{$\begin{array}{l}\text { Porcentagem de } \\
\text { residentes com } \\
\text { grau de } \\
\text { dependência } \\
\text { I, II e III }\end{array}$} & \multicolumn{10}{|c|}{$\begin{array}{l}\text { Valor médio de mensalidade final, com simulação da porcentagem de } \\
\text { habitações destinadas a cadeirantes, para } 400 \text { residentes, com diversos graus } \\
\text { de dependência }\end{array}$} \\
\hline & \multicolumn{2}{|c|}{$20 \%$} & \multicolumn{2}{|c|}{$40 \%$} & \multicolumn{2}{|c|}{$60 \%$} & \multicolumn{2}{|c|}{$80 \%$} & \multicolumn{2}{|c|}{$100 \%$} \\
\hline $100-0-0$ & $\mathrm{R} \$$ & 3.404 & $\mathrm{R} \$$ & 3.576 & $\mathrm{R} \$$ & 3.725 & $\mathrm{R} \$$ & 3.899 & $\mathrm{R} \$$ & 4.057 \\
\hline $0-100-0$ & $\mathrm{R} \$$ & 4.118 & $\mathrm{R} \$$ & 4.290 & $\mathrm{R} \$$ & 4.440 & $\mathrm{R} \$$ & 4.613 & $\mathrm{R} \$$ & 4.771 \\
\hline $0-0-100$ & $\mathrm{R} \$$ & 4.341 & $\mathrm{R} \$$ & 4.513 & $\mathrm{R} \$$ & 4.663 & $\mathrm{R} \$$ & 4.834 & $\mathrm{R} \$$ & 4.979 \\
\hline $70-30-0$ & $\mathrm{R} \$$ & 3.638 & $\mathrm{R} \$$ & 3.811 & $\mathrm{R}$ & 3.960 & $\mathrm{R} \$$ & 4.132 & $\mathrm{R} \$$ & 4.290 \\
\hline $70-0-30$ & $\mathrm{R} \$$ & 3.682 & $\mathrm{R} \$$ & 3.840 & $\mathrm{R}$ & 4.017 & $\mathrm{R} \$$ & 4.162 & $\mathrm{R} \$$ & 4.334 \\
\hline $50-40-10$ & $\mathrm{R} \$$ & 3.819 & $\mathrm{R} \$$ & 3.977 & $\mathrm{R} \$$ & 4.136 & $\mathrm{R}$ & 4.294 & $\mathrm{R} \$$ & 4.470 \\
\hline $60-30-10$ & $\mathrm{R} \$$ & 3.747 & $\mathrm{R} \$$ & 3.906 & $\mathrm{R} \$$ & 4.065 & $\mathrm{R} \$$ & 4.222 & $\mathrm{R} \$$ & 4.399 \\
\hline
\end{tabular}

Apêndice 253 - Valor médio da mensalidade final, com crédito médio de 1,30\% sobre o valor do investimento, para construção em 90 dias e compensação de retorno em 24 meses, com simulação da porcentagem de habitações destinadas a cadeirantes, para 100 residentes

\begin{tabular}{|c|c|c|c|c|c|c|c|c|c|c|}
\hline \multirow{2}{*}{$\begin{array}{l}\text { Porcentagem de } \\
\text { residentes com } \\
\text { grau de } \\
\text { dependência } \\
\text { I, II e III }\end{array}$} & \multicolumn{10}{|c|}{$\begin{array}{c}\text { Valor médio de mensalidade final, com simulação da porcentagem de } \\
\text { habitações destinadas a cadeirantes, para } 100 \text { residentes, com diversos graus } \\
\text { de dependência }\end{array}$} \\
\hline & \multicolumn{2}{|c|}{$20 \%$} & \multicolumn{2}{|c|}{$40 \%$} & \multicolumn{2}{|c|}{$60 \%$} & \multicolumn{2}{|c|}{$80 \%$} & \multicolumn{2}{|c|}{$100 \%$} \\
\hline $100-0-0$ & $\mathrm{R} \$$ & 4.302 & $\mathrm{R} \$$ & 4.478 & $\mathrm{R} \$$ & 4.602 & $\mathrm{R} \$$ & 4.855 & $\mathrm{R} \$$ & 5.032 \\
\hline $0-100-0$ & $\mathrm{R} \$$ & 4.994 & $\mathrm{R} \$$ & 5.171 & $\mathrm{R} \$$ & 5.297 & $\mathrm{R} \$$ & 5.548 & $\mathrm{R} \$$ & 5.724 \\
\hline $0-0-100$ & $\mathrm{R} \$$ & 5.238 & $\mathrm{R} \$$ & 5.433 & $\mathrm{R} \$$ & 5.559 & $\mathrm{R} \$$ & 5.716 & $\mathrm{R} \$$ & 5.840 \\
\hline $70-30-0$ & $\mathrm{R} \$$ & 4.627 & $\mathrm{R} \$$ & 4.804 & $\mathrm{R} \$$ & 4.928 & $\mathrm{R} \$$ & 5.181 & $\mathrm{R} \$$ & 5.357 \\
\hline $70-0-30$ & $\mathrm{R} \$$ & 4.632 & $\mathrm{R} \$$ & 4.847 & $\mathrm{R} \$$ & 5.004 & $\mathrm{R} \$$ & 5.128 & $\mathrm{R} \$$ & 5.400 \\
\hline $50-40-10$ & $\mathrm{R} \$$ & 4.824 & $\mathrm{R} \$$ & 5.001 & $\mathrm{R} \$$ & 5.125 & $\mathrm{R} \$$ & 5.377 & $\mathrm{R} \$$ & 5.554 \\
\hline $60-30-10$ & $\mathrm{R} \$$ & 4.865 & $\mathrm{R} \$$ & 5.041 & $\mathrm{R} \$$ & 5.165 & $\mathrm{R} \$$ & 5.418 & $\mathrm{R} \$$ & 5.595 \\
\hline
\end{tabular}


Apêndice 254 - Valor médio da mensalidade final, com crédito médio de 1,30\% sobre o valor do investimento, para construção em 90 dias e compensação de retorno em 24 meses, com simulação da porcentagem de habitações destinadas a cadeirantes, para 200 residentes

\begin{tabular}{|c|c|c|c|c|c|c|c|c|c|c|}
\hline \multirow{2}{*}{$\begin{array}{l}\text { Porcentagem de } \\
\text { residentes com } \\
\text { grau de } \\
\text { dependência } \\
\text { I, II e III } \\
\end{array}$} & \multicolumn{10}{|c|}{$\begin{array}{l}\text { Valor médio de mensalidade final, com simulação da porcentagem de } \\
\text { habitações destinadas a cadeirantes, para } 200 \text { residentes, com diversos graus } \\
\text { de dependência }\end{array}$} \\
\hline & \multicolumn{2}{|c|}{$20 \%$} & \multicolumn{2}{|c|}{$40 \%$} & \multicolumn{2}{|c|}{$60 \%$} & \multicolumn{2}{|c|}{$80 \%$} & \multicolumn{2}{|c|}{$100 \%$} \\
\hline 100-0-0 & $\mathrm{R} \$$ & 3.996 & $\mathrm{R} \$$ & 4.156 & $\mathrm{R} \$$ & 4.297 & $\mathrm{R} \$$ & 4.512 & $\mathrm{R} \$$ & 4.671 \\
\hline $0-100-0$ & $\mathrm{R} \$$ & 4.711 & $\mathrm{R} \$$ & 4.870 & $\mathrm{R} \$$ & 5.012 & $\mathrm{R} \$$ & 5.226 & $\mathrm{R} \$$ & 5.386 \\
\hline $0-0-100$ & $\mathrm{R} \$$ & 4.903 & $\mathrm{R} \$$ & 5.091 & $\mathrm{R} \$$ & 5.258 & $\mathrm{R} \$$ & 5.429 & $\mathrm{R} \$$ & 5.616 \\
\hline $70-30-0$ & $\mathrm{R} \$$ & 4.261 & $\mathrm{R} \$$ & 4.422 & $\mathrm{R} \$$ & 4.562 & $\mathrm{R} \$$ & 4.777 & $\mathrm{R} \$$ & 4.936 \\
\hline $70-0-30$ & $\mathrm{R} \$$ & 4.262 & $\mathrm{R} \$$ & 4.430 & $\mathrm{R} \$$ & 4.599 & $\mathrm{R} \$$ & 4.787 & $\mathrm{R} \$$ & 4.954 \\
\hline $50-40-10$ & $\mathrm{R} \$$ & 4.443 & $\mathrm{R} \$$ & 4.630 & $\mathrm{R} \$$ & 4.771 & $\mathrm{R} \$$ & 4.959 & $\mathrm{R} \$$ & 5.146 \\
\hline $60-30-10$ & $\mathrm{R} \$$ & 4.403 & $\mathrm{R} \$$ & 4.590 & $\mathrm{R} \$$ & 4.730 & $\mathrm{R} \$$ & 4.918 & $\mathrm{R} \$$ & 5.105 \\
\hline
\end{tabular}

Apêndice 255 - Valor médio da mensalidade final, com crédito médio de 1,30\% sobre o valor do investimento, para construção em 90 dias e compensação de retorno em 24 meses, com simulação da porcentagem de habitações destinadas a cadeirantes, para 300 residentes

\begin{tabular}{|c|c|c|c|c|c|c|c|c|c|c|}
\hline \multirow{2}{*}{$\begin{array}{l}\text { Porcentagem de } \\
\text { residentes com } \\
\text { grau de } \\
\text { dependência } \\
\text { I, II e III }\end{array}$} & \multicolumn{10}{|c|}{$\begin{array}{l}\text { Valor médio de mensalidade final, com simulação da porcentagem de } \\
\text { habitações destinadas a cadeirantes, para } 300 \text { residentes, com diversos graus } \\
\text { de dependência }\end{array}$} \\
\hline & \multicolumn{2}{|c|}{$20 \%$} & \multicolumn{2}{|c|}{$40 \%$} & \multicolumn{2}{|c|}{$60 \%$} & \multicolumn{2}{|c|}{$80 \%$} & \multicolumn{2}{|c|}{$100 \%$} \\
\hline $100-0-0$ & $\mathrm{R} \$$ & 3.640 & $\mathrm{R} \$$ & 3.822 & $\mathrm{R} \$$ & 3.974 & $\mathrm{R} \$$ & 4.131 & $\mathrm{R} \$$ & 4.313 \\
\hline $0-100-0$ & $\mathrm{R} \$$ & 4.348 & $\mathrm{R} \$$ & 4.530 & $\mathrm{R} \$$ & 4.681 & $\mathrm{R} \$$ & 4.838 & $\mathrm{R} \$$ & 5.020 \\
\hline $0-0-100$ & $\mathrm{R} \$$ & 4.558 & $\mathrm{R} \$$ & 4.722 & $\mathrm{R} \$$ & 4.866 & $\mathrm{R} \$$ & 5.048 & $\mathrm{R} \$$ & 5.212 \\
\hline $70-30-0$ & $\mathrm{R} \$$ & 3.885 & $\mathrm{R} \$$ & 4.068 & $\mathrm{R}$ & 4.218 & $\mathrm{R} \$$ & 4.375 & $\mathrm{R} \$$ & 4.558 \\
\hline $70-0-30$ & $\mathrm{R} \$$ & 3.949 & $\mathrm{R} \$$ & 4.094 & $\mathrm{R}$ & 4.276 & $\mathrm{R} \$$ & 4.439 & $\mathrm{R} \$$ & 4.615 \\
\hline $50-40-10$ & $\mathrm{R} \$$ & 4.060 & $\mathrm{R} \$$ & 4.242 & $\mathrm{R} \$$ & 4.387 & $\mathrm{R}$ & 4.551 & $\mathrm{R} \$$ & 4.733 \\
\hline $60-30-10$ & $\mathrm{R} \$$ & 3.992 & $\mathrm{R} \$$ & 4.174 & $\mathrm{R} \$$ & 4.318 & $\mathrm{R} \$$ & 4.482 & $\mathrm{R} \$$ & 4.665 \\
\hline
\end{tabular}

Apêndice 256 - Valor médio da mensalidade final, com crédito médio de 1,30\% sobre o valor do investimento, para construção em 90 dias e compensação de retorno em 24 meses, com simulação da porcentagem de habitações destinadas a cadeirantes, para 400 residentes

\begin{tabular}{|c|c|c|c|c|c|c|c|c|c|c|}
\hline \multirow{2}{*}{$\begin{array}{l}\text { Porcentagem de } \\
\text { residentes com } \\
\text { grau de } \\
\text { dependência } \\
\text { I, II e III }\end{array}$} & \multicolumn{10}{|c|}{$\begin{array}{l}\text { Valor médio de mensalidade final, com simulação da porcentagem de } \\
\text { habitações destinadas a cadeirantes, para } 400 \text { residentes, com diversos graus } \\
\text { de dependência }\end{array}$} \\
\hline & \multicolumn{2}{|c|}{$20 \%$} & \multicolumn{2}{|c|}{$40 \%$} & \multicolumn{2}{|c|}{$60 \%$} & \multicolumn{2}{|c|}{$80 \%$} & \multicolumn{2}{|c|}{$100 \%$} \\
\hline $100-0-0$ & $\mathrm{R} \$$ & 3.476 & $\mathrm{R} \$$ & 3.652 & $\mathrm{R} \$$ & 3.805 & $\mathrm{R} \$$ & 3.982 & $\mathrm{R} \$$ & 4.144 \\
\hline $0-100-0$ & $\mathrm{R} \$$ & 4.190 & $\mathrm{R} \$$ & 4.366 & $\mathrm{R} \$$ & 4.519 & $\mathrm{R} \$$ & 4.697 & $\mathrm{R} \$$ & 4.858 \\
\hline $0-0-100$ & $\mathrm{R} \$$ & 4.406 & $\mathrm{R} \$$ & 4.581 & $\mathrm{R} \$$ & 4.735 & $\mathrm{R} \$$ & 4.911 & $\mathrm{R} \$$ & 5.059 \\
\hline $70-30-0$ & $\mathrm{R} \$$ & 3.710 & $\mathrm{R} \$$ & 3.886 & $\mathrm{R} \$$ & 4.040 & $\mathrm{R} \$$ & 4.216 & $\mathrm{R} \$$ & 4.377 \\
\hline $70-0-30$ & $\mathrm{R} \$$ & 3.752 & $\mathrm{R} \$$ & 3.914 & $\mathrm{R} \$$ & 4.095 & $\mathrm{R} \$$ & 4.243 & $\mathrm{R} \$$ & 4.419 \\
\hline $50-40-10$ & $\mathrm{R} \$$ & 3.891 & $\mathrm{R} \$$ & 4.052 & $\mathrm{R} \$$ & 4.215 & $\mathrm{R} \$$ & 4.376 & $\mathrm{R} \$$ & 4.557 \\
\hline $60-30-10$ & $\mathrm{R} \$$ & 3.819 & $\mathrm{R} \$$ & 3.981 & $\mathrm{R} \$$ & 4.143 & $\mathrm{R} \$$ & 4.305 & $\mathrm{R} \$$ & 4.486 \\
\hline
\end{tabular}


Apêndice 257 - Valor médio da mensalidade final, com crédito médio de 1,40\% sobre o valor do investimento, para construção em 90 dias e compensação de retorno em 24 meses, com simulação da porcentagem de habitações destinadas a cadeirantes, para 100 residentes

\begin{tabular}{|c|c|c|c|c|c|c|c|c|c|c|}
\hline \multirow{2}{*}{$\begin{array}{l}\text { Porcentagem de } \\
\text { residentes com } \\
\text { grau de } \\
\text { dependência } \\
\text { I, II e III } \\
\end{array}$} & \multicolumn{10}{|c|}{$\begin{array}{l}\text { Valor médio de mensalidade final, com simulação da porcentagem de } \\
\text { habitações destinadas a cadeirantes, para } 100 \text { residentes, com diversos graus } \\
\text { de dependência }\end{array}$} \\
\hline & \multicolumn{2}{|c|}{$20 \%$} & \multicolumn{2}{|c|}{$40 \%$} & \multicolumn{2}{|c|}{$60 \%$} & \multicolumn{2}{|c|}{$80 \%$} & \multicolumn{2}{|c|}{$100 \%$} \\
\hline 100-0-0 & $\mathrm{R} \$$ & 4.379 & $\mathrm{R} \$$ & 4.560 & $\mathrm{R} \$$ & 4.688 & $\mathrm{R} \$$ & 4.945 & $\mathrm{R} \$$ & 5.125 \\
\hline $0-100-0$ & $\mathrm{R} \$$ & 5.072 & $\mathrm{R} \$$ & 5.253 & $\mathrm{R} \$$ & 5.383 & $\mathrm{R} \$$ & 5.637 & $\mathrm{R} \$$ & 5.818 \\
\hline $0-0-100$ & $\mathrm{R} \$$ & 5.308 & $\mathrm{R} \$$ & 5.507 & $\mathrm{R} \$$ & 5.637 & $\mathrm{R} \$$ & 5.798 & $\mathrm{R} \$$ & 5.926 \\
\hline $70-30-0$ & $\mathrm{R} \$$ & 4.705 & $\mathrm{R} \$$ & 4.886 & $\mathrm{R} \$$ & 5.014 & $\mathrm{R} \$$ & 5.271 & $\mathrm{R} \$$ & 5.451 \\
\hline $70-0-30$ & $\mathrm{R} \$$ & 4.708 & $\mathrm{R} \$$ & 4.927 & $\mathrm{R} \$$ & 5.087 & $\mathrm{R} \$$ & 5.215 & $\mathrm{R} \$$ & 5.492 \\
\hline $50-40-10$ & $\mathrm{R} \$$ & 4.901 & $\mathrm{R} \$$ & 5.082 & $\mathrm{R} \$$ & 5.210 & $\mathrm{R} \$$ & 5.467 & $\mathrm{R} \$$ & 5.647 \\
\hline $60-30-10$ & $\mathrm{R} \$$ & 4.942 & $\mathrm{R} \$$ & 5.122 & $\mathrm{R} \$$ & 5.250 & $\mathrm{R} \$$ & 5.507 & $\mathrm{R} \$$ & 5.688 \\
\hline
\end{tabular}

Apêndice 258 - Valor médio da mensalidade final, com crédito médio de 1,40\% sobre o valor do investimento, para construção em 90 dias e compensação de retorno em 24 meses, com simulação da porcentagem de habitações destinadas a cadeirantes, para 200 residentes

\begin{tabular}{|c|c|c|c|c|c|c|c|c|c|c|}
\hline \multirow{2}{*}{$\begin{array}{l}\text { Porcentagem de } \\
\text { residentes com } \\
\text { grau de } \\
\text { dependência } \\
\text { I, II e III }\end{array}$} & \multicolumn{10}{|c|}{$\begin{array}{l}\text { Valor médio de mensalidade final, com simulação da porcentagem de } \\
\text { habitações destinadas a cadeirantes, para } 200 \text { residentes, com diversos graus } \\
\text { de dependência }\end{array}$} \\
\hline & \multicolumn{2}{|c|}{$20 \%$} & \multicolumn{2}{|c|}{$40 \%$} & \multicolumn{2}{|c|}{$60 \%$} & \multicolumn{2}{|c|}{$80 \%$} & \multicolumn{2}{|c|}{$100 \%$} \\
\hline $100-0-0$ & $\mathrm{R} \$$ & 4.075 & $\mathrm{R} \$$ & 4.238 & $\mathrm{R} \$$ & 4.384 & $\mathrm{R} \$$ & 4.603 & $\mathrm{R} \$$ & 4.766 \\
\hline $0-100-0$ & $\mathrm{R} \$$ & 4.789 & $\mathrm{R} \$$ & 4.953 & $\mathrm{R} \$$ & 5.098 & $\mathrm{R} \$$ & 5.317 & $\mathrm{R} \$$ & 5.480 \\
\hline $0-0-100$ & $\mathrm{R} \$$ & 4.974 & $\mathrm{R} \$$ & 5.166 & $\mathrm{R} \$$ & 5.337 & $\mathrm{R} \$$ & 5.512 & $\mathrm{R} \$$ & 5.703 \\
\hline $70-30-0$ & $\mathrm{R} \$$ & 4.340 & $\mathrm{R} \$$ & 4.504 & $\mathrm{R} \$$ & 4.649 & $\mathrm{R} \$$ & 4.867 & $\mathrm{R} \$$ & 5.031 \\
\hline $70-0-30$ & $\mathrm{R} \$$ & 4.338 & $\mathrm{R} \$$ & 4.510 & $\mathrm{R}$ & 4.684 & $\mathrm{R} \$$ & 4.876 & $\mathrm{R} \$$ & 5.046 \\
\hline $50-40-10$ & $\mathrm{R} \$$ & 4.521 & $\mathrm{R} \$$ & 4.712 & $\mathrm{R} \$$ & 4.856 & $\mathrm{R} \$$ & 5.049 & $\mathrm{R} \$$ & 5.240 \\
\hline $60-30-10$ & $\mathrm{R} \$$ & 4.480 & $\mathrm{R} \$$ & 4.671 & $\mathrm{R} \$$ & 4.816 & $\mathrm{R} \$$ & 5.008 & $\mathrm{R} \$$ & 5.199 \\
\hline
\end{tabular}

Apêndice 259 - Valor médio da mensalidade final, com crédito médio de 1,40\% sobre o valor do investimento, para construção em 90 dias e compensação de retorno em 24 meses, com simulação da porcentagem de habitações destinadas a cadeirantes, para 300 residentes

\begin{tabular}{|c|c|c|c|c|c|c|c|c|c|c|}
\hline \multirow{2}{*}{$\begin{array}{l}\text { Porcentagem de } \\
\text { residentes com } \\
\text { grau de } \\
\text { dependência } \\
\text { I, II e III }\end{array}$} & \multicolumn{10}{|c|}{$\begin{array}{l}\text { Valor médio de mensalidade final, com simulação da porcentagem de } \\
\text { habitações destinadas a cadeirantes, para } 300 \text { residentes, com diversos graus } \\
\text { de dependência }\end{array}$} \\
\hline & \multicolumn{2}{|c|}{$20 \%$} & \multicolumn{2}{|c|}{$40 \%$} & \multicolumn{2}{|c|}{$60 \%$} & \multicolumn{2}{|c|}{$80 \%$} & \multicolumn{2}{|c|}{$100 \%$} \\
\hline $100-0-0$ & $\mathrm{R} \$$ & 3.713 & $\mathrm{R} \$$ & 3.899 & $\mathrm{R} \$$ & 4.054 & $\mathrm{R} \$$ & 4.216 & $\mathrm{R} \$$ & 4.402 \\
\hline $0-100-0$ & $\mathrm{R} \$$ & 4.421 & $\mathrm{R} \$$ & 4.607 & $\mathrm{R} \$$ & 4.762 & $\mathrm{R} \$$ & 4.923 & $\mathrm{R} \$$ & 5.109 \\
\hline $0-0-100$ & $\mathrm{R} \$$ & 4.624 & $\mathrm{R} \$$ & 4.792 & $\mathrm{R} \$$ & 4.940 & $\mathrm{R} \$$ & 5.126 & $\mathrm{R} \$$ & 5.294 \\
\hline $70-30-0$ & $\mathrm{R} \$$ & 3.958 & $\mathrm{R} \$$ & 4.145 & $\mathrm{R} \$$ & 4.299 & $\mathrm{R} \$$ & 4.460 & $\mathrm{R} \$$ & 4.646 \\
\hline $70-0-30$ & $\mathrm{R} \$$ & 4.020 & $\mathrm{R} \$$ & 4.169 & $\mathrm{R} \$$ & 4.355 & $\mathrm{R} \$$ & 4.522 & $\mathrm{R} \$$ & 4.702 \\
\hline $50-40-10$ & $\mathrm{R} \$$ & 4.132 & $\mathrm{R} \$$ & 4.319 & $\mathrm{R} \$$ & 4.467 & $\mathrm{R} \$$ & 4.635 & $\mathrm{R} \$$ & 4.821 \\
\hline $60-30-10$ & $\mathrm{R} \$$ & 4.064 & $\mathrm{R} \$$ & 4.251 & $\mathrm{R} \$$ & 4.398 & $\mathrm{R} \$$ & 4.566 & $\mathrm{R} \$$ & 4.752 \\
\hline
\end{tabular}


Apêndice 260 - Valor médio da mensalidade final, com crédito médio de 1,40\% sobre o valor do investimento, para construção em 90 dias e compensação de retorno em 24 meses, com simulação da porcentagem de habitações destinadas a cadeirantes, para 400 residentes

\begin{tabular}{|c|c|c|c|c|c|c|c|c|c|c|}
\hline \multirow{2}{*}{$\begin{array}{l}\text { Porcentagem de } \\
\text { residentes com } \\
\text { grau de } \\
\text { dependência } \\
\text { I, II e III } \\
\end{array}$} & \multicolumn{10}{|c|}{$\begin{array}{l}\text { Valor médio de mensalidade final, com simulação da porcentagem de } \\
\text { habitações destinadas a cadeirantes, para } 400 \text { residentes, com diversos graus } \\
\text { de dependência }\end{array}$} \\
\hline & \multicolumn{2}{|c|}{$20 \%$} & \multicolumn{2}{|c|}{$40 \%$} & \multicolumn{2}{|c|}{$60 \%$} & \multicolumn{2}{|c|}{$80 \%$} & \multicolumn{2}{|c|}{$100 \%$} \\
\hline $100-0-0$ & $\mathrm{R} \$$ & 3.548 & $\mathrm{R} \$$ & 3.727 & $\mathrm{R} \$$ & 3.885 & $\mathrm{R} \$$ & 4.066 & $\mathrm{R} \$$ & 4.231 \\
\hline $0-100-0$ & $\mathrm{R} \$$ & 4.262 & $\mathrm{R} \$$ & 4.442 & $\mathrm{R} \$$ & 4.599 & $\mathrm{R} \$$ & 4.780 & $\mathrm{R} \$$ & 4.946 \\
\hline $0-0-100$ & $\mathrm{R} \$$ & 4.471 & $\mathrm{R} \$$ & 4.650 & $\mathrm{R} \$$ & 4.807 & $\mathrm{R} \$$ & 4.987 & $\mathrm{R} \$$ & 5.139 \\
\hline $70-30-0$ & $\mathrm{R} \$$ & 3.782 & $\mathrm{R} \$$ & 3.962 & $\mathrm{R} \$$ & 4.120 & $\mathrm{R} \$$ & 4.299 & $\mathrm{R} \$$ & 4.464 \\
\hline $70-0-30$ & $\mathrm{R} \$$ & 3.822 & $\mathrm{R} \$$ & 3.987 & $\mathrm{R} \$$ & 4.172 & $\mathrm{R} \$$ & 4.324 & $\mathrm{R} \$$ & 4.504 \\
\hline $50-40-10$ & $\mathrm{R} \$$ & 3.962 & $\mathrm{R} \$$ & 4.127 & $\mathrm{R} \$$ & 4.294 & $\mathrm{R} \$$ & 4.459 & $\mathrm{R} \$$ & 4.643 \\
\hline $60-30-10$ & $\mathrm{R} \$$ & 3.890 & $\mathrm{R} \$$ & 4.056 & $\mathrm{R} \$$ & 4.222 & $\mathrm{R} \$$ & 4.388 & $\mathrm{R} \$$ & 4.572 \\
\hline
\end{tabular}

Apêndice 261 - Valor médio da mensalidade final, com crédito médio de 1,50\% sobre o valor do investimento, para construção em 90 dias e compensação de retorno em 24 meses, com simulação da porcentagem de habitações destinadas a cadeirantes, para 100 residentes

\begin{tabular}{|c|c|c|c|c|c|c|c|c|c|c|}
\hline \multirow{2}{*}{$\begin{array}{l}\text { Porcentagem de } \\
\text { residentes com } \\
\text { grau de } \\
\text { dependência } \\
\text { I, II e III } \\
\end{array}$} & \multicolumn{10}{|c|}{$\begin{array}{l}\text { Valor médio de mensalidade final, com simulação da porcentagem de } \\
\text { habitações destinadas a cadeirantes, para } 100 \text { residentes, com diversos graus } \\
\text { de dependência }\end{array}$} \\
\hline & \multicolumn{2}{|c|}{$20 \%$} & \multicolumn{2}{|c|}{$40 \%$} & \multicolumn{2}{|c|}{$60 \%$} & \multicolumn{2}{|c|}{$80 \%$} & \multicolumn{2}{|c|}{$100 \%$} \\
\hline $100-0-0$ & $\mathrm{R} \$$ & 4.457 & $\mathrm{R} \$$ & 4.642 & $\mathrm{R} \$$ & 4.773 & $\mathrm{R} \$$ & 5.034 & $\mathrm{R} \$$ & 5.219 \\
\hline $0-100-0$ & $\mathrm{R} \$$ & 5.150 & $\mathrm{R} \$$ & 5.334 & $\mathrm{R} \$$ & 5.469 & $\mathrm{R} \$$ & 5.727 & $\mathrm{R} \$$ & 5.912 \\
\hline $0-0-100$ & $\mathrm{R} \$$ & 5.378 & $\mathrm{R} \$$ & 5.580 & $\mathrm{R} \$$ & 5.715 & $\mathrm{R} \$$ & 5.880 & $\mathrm{R} \$$ & 6.012 \\
\hline $70-30-0$ & $\mathrm{R} \$$ & 4.783 & $\mathrm{R} \$$ & 4.967 & $\mathrm{R} \$$ & 5.099 & $\mathrm{R} \$$ & 5.360 & $\mathrm{R} \$$ & 5.545 \\
\hline $70-0-30$ & $\mathrm{R} \$$ & 4.784 & $\mathrm{R} \$$ & 5.006 & $\mathrm{R} \$$ & 5.171 & $\mathrm{R} \$$ & 5.303 & $\mathrm{R} \$$ & 5.584 \\
\hline $50-40-10$ & $\mathrm{R} \$$ & 4.979 & $\mathrm{R} \$$ & 5.163 & $\mathrm{R} \$$ & 5.295 & $\mathrm{R} \$$ & 5.556 & $\mathrm{R} \$$ & 5.740 \\
\hline $60-30-10$ & $\mathrm{R} \$$ & 5.019 & $\mathrm{R} \$$ & 5.204 & $\mathrm{R} \$$ & 5.335 & $\mathrm{R} \$$ & 5.596 & $\mathrm{R} \$$ & 5.781 \\
\hline
\end{tabular}

Apêndice 262 - Valor médio da mensalidade final, com crédito médio de 1,50\% sobre o valor do investimento, para construção em 90 dias e compensação de retorno em 24 meses, com simulação da porcentagem de habitações destinadas a cadeirantes, para 200 residentes

\begin{tabular}{|c|c|c|c|c|c|c|c|c|c|c|}
\hline \multirow{2}{*}{$\begin{array}{l}\text { Porcentagem de } \\
\text { residentes com } \\
\text { grau de } \\
\text { dependência } \\
\text { I, II e III }\end{array}$} & \multicolumn{10}{|c|}{$\begin{array}{l}\text { Valor médio de mensalidade final, com simulação da porcentagem de } \\
\text { habitações destinadas a cadeirantes, para } 200 \text { residentes, com diversos graus } \\
\text { de dependência }\end{array}$} \\
\hline & \multicolumn{2}{|c|}{$20 \%$} & \multicolumn{2}{|c|}{$40 \%$} & \multicolumn{2}{|c|}{$60 \%$} & \multicolumn{2}{|c|}{$80 \%$} & \multicolumn{2}{|c|}{$100 \%$} \\
\hline $100-0-0$ & $\mathrm{R} \$$ & 4.154 & $\mathrm{R} \$$ & 4.321 & $\mathrm{R} \$$ & 4.470 & $\mathrm{R} \$$ & 4.693 & $\mathrm{R} \$$ & 4.860 \\
\hline $0-100-0$ & $\mathrm{R} \$$ & 4.868 & $\mathrm{R} \$$ & 5.036 & $\mathrm{R} \$$ & 5.185 & $\mathrm{R} \$$ & 5.408 & $\mathrm{R} \$$ & 5.575 \\
\hline $0-0-100$ & $\mathrm{R} \$$ & 5.045 & $\mathrm{R} \$$ & 5.240 & $\mathrm{R} \$$ & 5.416 & $\mathrm{R} \$$ & 5.595 & $\mathrm{R} \$$ & 5.790 \\
\hline $70-30-0$ & $\mathrm{R} \$$ & 4.419 & $\mathrm{R} \$$ & 4.587 & $\mathrm{R} \$$ & 4.735 & $\mathrm{R} \$$ & 4.958 & $\mathrm{R} \$$ & 5.125 \\
\hline $70-0-30$ & $\mathrm{R} \$$ & 4.415 & $\mathrm{R} \$$ & 4.591 & $\mathrm{R} \$$ & 4.768 & $\mathrm{R} \$$ & 4.964 & $\mathrm{R} \$$ & 5.139 \\
\hline $50-40-10$ & $\mathrm{R} \$$ & 4.599 & $\mathrm{R} \$$ & 4.794 & $\mathrm{R} \$$ & 4.942 & $\mathrm{R} \$$ & 5.138 & $\mathrm{R} \$$ & 5.333 \\
\hline $60-30-10$ & $\mathrm{R} \$$ & 4.558 & $\mathrm{R} \$$ & 4.753 & $\mathrm{R} \$$ & 4.901 & $\mathrm{R} \$$ & 5.098 & $\mathrm{R} \$$ & 5.293 \\
\hline
\end{tabular}


Apêndice 263 - Valor médio da mensalidade final, com crédito médio de 1,50\% sobre o valor do investimento, para construção em 90 dias e compensação de retorno em 24 meses, com simulação da porcentagem de habitações destinadas a cadeirantes, para 300 residentes

\begin{tabular}{|c|c|c|c|c|c|c|c|c|c|c|}
\hline \multirow{3}{*}{ 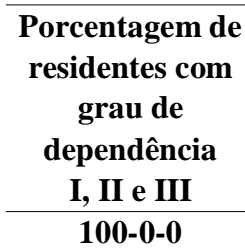 } & \multicolumn{10}{|c|}{$\begin{array}{l}\text { Valor médio de mensalidade final, com simulação da porcentagem de } \\
\text { habitações destinadas a cadeirantes, para } 300 \text { residentes, com diversos graus } \\
\text { de dependência }\end{array}$} \\
\hline & \multicolumn{2}{|c|}{$20 \%$} & \multicolumn{2}{|c|}{$40 \%$} & \multicolumn{2}{|c|}{$60 \%$} & \multicolumn{2}{|c|}{$80 \%$} & \multicolumn{2}{|c|}{$100 \%$} \\
\hline & $\mathrm{R} \$$ & 3.786 & $\mathrm{R} \$$ & 3.976 & $\mathrm{R} \$$ & 4.135 & $\mathrm{R} \$$ & 4.300 & $\mathrm{R} \$$ & 4.490 \\
\hline 0-100-0 & $\mathrm{R} \$$ & 4.494 & $\mathrm{R} \$$ & 4.684 & $\mathrm{R} \$$ & 4.843 & $\mathrm{R} \$$ & 5.008 & $\mathrm{R} \$$ & 5.198 \\
\hline 0-0-100 & $\mathrm{R} \$$ & 4.690 & $\mathrm{R} \$$ & 4.862 & $\mathrm{R} \$$ & 5.013 & $\mathrm{R} \$$ & 5.203 & $\mathrm{R} \$$ & 5.375 \\
\hline 70-30-0 & $\mathrm{R} \$$ & 4.032 & $\mathrm{R} \$$ & 4.222 & $\mathrm{R} \$$ & 4.380 & $\mathrm{R} \$$ & 4.545 & $\mathrm{R} \$$ & 4.735 \\
\hline 70-0-30 & $\mathrm{R} \$$ & 4.091 & $\mathrm{R} \$$ & 4.244 & $\mathrm{R} \$$ & 4.434 & $\mathrm{R} \$$ & 4.605 & $\mathrm{R} \$$ & 4.788 \\
\hline $50-40-10$ & $\mathrm{R} \$$ & 4.205 & $\mathrm{R} \$$ & 4.395 & $\mathrm{R} \$$ & 4.547 & $\mathrm{R} \$$ & 4.719 & $\mathrm{R} \$$ & 4.909 \\
\hline $60-30-10$ & $\mathrm{R} \$$ & 4.137 & $\mathrm{R} \$$ & 4.327 & $\mathrm{R} \$$ & 4.479 & $\mathrm{R} \$$ & 4.650 & $\mathrm{R} \$$ & 4.840 \\
\hline
\end{tabular}

Apêndice 264 - Valor médio da mensalidade final, com crédito médio de 1,50\% sobre o valor do investimento, para construção em 90 dias e compensação de retorno em 24 meses, com simulação da porcentagem de habitações destinadas a cadeirantes, para 400 residentes

\begin{tabular}{|c|c|c|c|c|c|c|c|c|c|c|}
\hline \multirow{2}{*}{$\begin{array}{c}\text { Porcentagem de } \\
\text { residentes com } \\
\text { grau de } \\
\text { dependência } \\
\text { I, II e III } \\
\end{array}$} & \multicolumn{10}{|c|}{$\begin{array}{l}\text { Valor médio de mensalidade final, com simulação da porcentagem de } \\
\text { habitações destinadas a cadeirantes, para } 400 \text { residentes, com diversos graus } \\
\text { de dependência }\end{array}$} \\
\hline & \multicolumn{2}{|c|}{$20 \%$} & \multicolumn{2}{|c|}{$40 \%$} & \multicolumn{2}{|c|}{$60 \%$} & \multicolumn{2}{|c|}{$80 \%$} & \multicolumn{2}{|c|}{$100 \%$} \\
\hline $100-0-0$ & $\mathrm{R} \$$ & 3.620 & $\mathrm{R} \$$ & 3.803 & $\mathrm{R} \$$ & 3.964 & $\mathrm{R} \$$ & 4.149 & $\mathrm{R} \$$ & 4.319 \\
\hline 0-100-0 & $\mathrm{R} \$$ & 4.334 & $\mathrm{R} \$$ & 4.518 & $\mathrm{R} \$$ & 4.679 & $\mathrm{R} \$$ & 4.864 & $\mathrm{R} \$$ & 5.033 \\
\hline $0-0-100$ & $\mathrm{R} \$$ & 4.535 & $\mathrm{R} \$$ & 4.719 & $\mathrm{R} \$$ & 4.880 & $\mathrm{R} \$$ & 5.063 & $\mathrm{R} \$$ & 5.219 \\
\hline $70-30-0$ & $\mathrm{R} \$$ & 3.854 & $\mathrm{R} \$$ & 4.038 & $\mathrm{R} \$$ & 4.199 & $\mathrm{R} \$$ & 4.382 & $\mathrm{R} \$$ & 4.552 \\
\hline $70-0-30$ & $\mathrm{R} \$$ & 3.891 & $\mathrm{R} \$$ & 4.061 & $\mathrm{R} \$$ & 4.250 & $\mathrm{R} \$$ & 4.406 & $\mathrm{R}$ & 4.589 \\
\hline $50-40-10$ & $\mathrm{R} \$$ & 4.033 & $\mathrm{R} \$$ & 4.202 & $\mathrm{R} \$$ & 4.372 & $\mathrm{R} \$$ & 4.542 & $\mathrm{R}$ & 4.730 \\
\hline $60-30-10$ & $\mathrm{R} \$$ & 3.961 & $\mathrm{R} \$$ & 4.131 & $\mathrm{R} \$$ & 4.301 & $\mathrm{R} \$$ & 4.471 & $\mathrm{R} \$$ & 4.659 \\
\hline
\end{tabular}

Apêndice 265 - Valor médio da mensalidade final, com crédito médio de 1,10\% sobre o valor do investimento, para construção em 90 dias e compensação de retorno em 12 meses, em função de áreas externas, anfiteatro e minisshopping, para 100 residentes

\begin{tabular}{|c|c|c|c|c|c|c|c|c|}
\hline \multirow{2}{*}{$\begin{array}{c}\text { Porcentagem de } \\
\text { residentes com } \\
\text { grau de } \\
\text { dependência } \\
\text { I, II e III }\end{array}$} & \multicolumn{8}{|c|}{$\begin{array}{l}\text { Valor médio de mensalidade final, em função de áreas } \\
\text { externas, anfiteatro e minisshopping, para } 100 \text { residentes, } \\
\text { com diversos graus de dependência }\end{array}$} \\
\hline & \multicolumn{2}{|c|}{ "A" } & \multicolumn{2}{|c|}{ "B" } & \multicolumn{2}{|c|}{ "C" } & \multicolumn{2}{|c|}{ "D" } \\
\hline 100-0-0 & $\mathrm{R} \$$ & 4.289 & $\mathrm{R} \$$ & 4.119 & $\mathrm{R} \$$ & 4.000 & $\mathrm{R} \$$ & 3.920 \\
\hline $0-100-0$ & $\mathrm{R} \$$ & 4.981 & $\mathrm{R} \$$ & 4.814 & $\mathrm{R} \$$ & 4.693 & $\mathrm{R} \$$ & 4.613 \\
\hline $0-0-100$ & $\mathrm{R} \$$ & 5.226 & $\mathrm{R} \$$ & 5.079 & $\mathrm{R} \$$ & 4.981 & $\mathrm{R} \$$ & 4.882 \\
\hline 70-30-0 & $\mathrm{R} \$$ & 4.614 & $\mathrm{R} \$$ & 4.445 & $\mathrm{R} \$$ & 4.326 & $\mathrm{R} \$$ & 4.246 \\
\hline 70-0-30 & $\mathrm{R} \$$ & 4.620 & $\mathrm{R} \$$ & 4.488 & $\mathrm{R} \$$ & 4.371 & $\mathrm{R} \$$ & 4.344 \\
\hline $50-40-10$ & $\mathrm{R} \$$ & 4.811 & $\mathrm{R} \$$ & 4.642 & $\mathrm{R} \$$ & 4.523 & $\mathrm{R} \$$ & 4.444 \\
\hline $60-30-10$ & $\mathrm{R} \$$ & 4.852 & $\mathrm{R} \$$ & 4.682 & $\mathrm{R} \$$ & 4.564 & $\mathrm{R} \$$ & 4.484 \\
\hline
\end{tabular}


Apêndice 266 - Valor médio da mensalidade final, com crédito médio de 1,10\% sobre o valor do investimento, para construção em 90 dias e compensação de retorno em 12 meses, em função de áreas externas, anfiteatro e minisshopping, para 200 residentes

\begin{tabular}{|c|c|c|c|c|c|c|c|c|}
\hline \multirow{3}{*}{$\begin{array}{c}\text { Porcentagem de } \\
\text { residentes com } \\
\text { grau de } \\
\text { dependência } \\
\text { I, II e III } \\
100-0-0\end{array}$} & \multicolumn{8}{|c|}{$\begin{array}{l}\text { Valor médio de mensalidade final, em função de áreas } \\
\text { externas, anfiteatro e minisshopping, para } 200 \text { residentes, } \\
\text { com diversos graus de dependência }\end{array}$} \\
\hline & \multicolumn{2}{|c|}{ "A" } & \multicolumn{2}{|c|}{ "B" } & \multicolumn{2}{|c|}{ "C" } & \multicolumn{2}{|c|}{ "D" } \\
\hline & $\mathrm{R} \$$ & 3.983 & $\mathrm{R} \$$ & 3.790 & $\mathrm{R} \$$ & 3.629 & $\mathrm{R} \$$ & 3.375 \\
\hline $0-100-0$ & $\mathrm{R} \$$ & 4.697 & $\mathrm{R} \$$ & 4.504 & $\mathrm{R} \$$ & 4.343 & $\mathrm{R} \$$ & 4.089 \\
\hline 0-0-100 & $\mathrm{R} \$$ & 4.891 & $\mathrm{R} \$$ & 4.757 & $\mathrm{R} \$$ & 4.584 & $\mathrm{R} \$$ & 4.374 \\
\hline 70-30-0 & $\mathrm{R} \$$ & 4.248 & $\mathrm{R} \$$ & 4.054 & $\mathrm{R} \$$ & 3.893 & $\mathrm{R} \$$ & 3.640 \\
\hline $70-0-30$ & $\mathrm{R} \$$ & 4.249 & $\mathrm{R} \$$ & 4.066 & $\mathrm{R} \$$ & 3.933 & $\mathrm{R} \$$ & 3.679 \\
\hline $50-40-10$ & $\mathrm{R} \$$ & 4.430 & $\mathrm{R} \$$ & 4.237 & $\mathrm{R} \$$ & 4.077 & $\mathrm{R} \$$ & 3.850 \\
\hline $60-30-10$ & $\mathrm{R} \$$ & 4.390 & $\mathrm{R} \$$ & 4.196 & $\mathrm{R} \$$ & 4.037 & $\mathrm{R} \$$ & 3.808 \\
\hline
\end{tabular}

Apêndice 267 - Valor médio da mensalidade final, com crédito médio de 1,10\% sobre o valor do investimento, para construção em 90 dias e compensação de retorno em 12 meses, em função de áreas externas, anfiteatro e minisshopping, para 300 residentes

\begin{tabular}{|c|c|c|c|c|c|c|c|c|}
\hline \multirow{3}{*}{$\begin{array}{c}\text { Porcentagem de } \\
\text { residentes com } \\
\text { grau de } \\
\text { dependência } \\
\text { I, II e III } \\
100-0-0\end{array}$} & \multicolumn{8}{|c|}{$\begin{array}{l}\text { Valor médio de mensalidade final, em função de áreas } \\
\text { externas, anfiteatro e minisshopping, para } 300 \text { residentes, } \\
\text { com diversos graus de dependência }\end{array}$} \\
\hline & \multicolumn{2}{|c|}{ "A" } & \multicolumn{2}{|c|}{ "B" } & \multicolumn{2}{|c|}{ "C" } & \multicolumn{2}{|c|}{ "D" } \\
\hline & $\mathrm{R} \$$ & 3.628 & $\mathrm{R} \$$ & 3.476 & $\mathrm{R} \$$ & 3.274 & $\mathrm{R} \$$ & 3.183 \\
\hline 0-100-0 & $\mathrm{R} \$$ & 4.335 & $\mathrm{R} \$$ & 4.184 & $\mathrm{R} \$$ & 3.981 & $\mathrm{R} \$$ & 3.890 \\
\hline 0-0-100 & $\mathrm{R} \$$ & 4.547 & $\mathrm{R} \$$ & 4.398 & $\mathrm{R} \$$ & 4.211 & $\mathrm{R} \$$ & 4.121 \\
\hline $70-30-0$ & $\mathrm{R} \$$ & 3.873 & $\mathrm{R} \$$ & 3.722 & $\mathrm{R} \$$ & 3.553 & $\mathrm{R} \$$ & 3.428 \\
\hline $70-0-30$ & $\mathrm{R} \$$ & 3.937 & $\mathrm{R} \$$ & 3.787 & $\mathrm{R} \$$ & 3.619 & $\mathrm{R} \$$ & 3.488 \\
\hline $50-40-10$ & $\mathrm{R} \$$ & 4.047 & $\mathrm{R} \$$ & 3.897 & $\mathrm{R} \$$ & 3.694 & $\mathrm{R} \$$ & 3.604 \\
\hline $60-30-10$ & $\mathrm{R} \$$ & 3.980 & $\mathrm{R} \$$ & 3.829 & $\mathrm{R} \$$ & 3.626 & $\mathrm{R} \$$ & 3.536 \\
\hline
\end{tabular}

Apêndice 268 - Valor médio da mensalidade final, com crédito médio de 1,10\% sobre o valor do investimento, para construção em 90 dias e compensação de retorno em 12 meses, em função de áreas externas, anfiteatro e minisshopping, para 400 residentes

\begin{tabular}{ccccccccc}
\hline $\begin{array}{c}\text { Porcentagem de } \\
\text { residentes com } \\
\text { grau de } \\
\text { dependência } \\
\text { I, II e III }\end{array}$ & \multicolumn{6}{c}{$\begin{array}{c}\text { Valor médio de mensalidade final, em função de áreas } \\
\text { externas, anfiteatro e minisshopping, para 400 residentes, } \\
\text { com diversos graus de dependência }\end{array}$} \\
\cline { 2 - 10 } & \multicolumn{2}{c}{ "A" } & \multicolumn{2}{c}{ "B" } & \multicolumn{2}{c}{ "C" } & \multicolumn{1}{c}{ "D" } \\
\hline $\mathbf{1 0 0 - 0 - 0}$ & $\mathrm{R} \$$ & 3.464 & $\mathrm{R} \$$ & 3.334 & $\mathrm{R} \$$ & 3.138 & $\mathrm{R} \$$ & 3.060 \\
$\mathbf{0 - 1 0 0 - 0}$ & $\mathrm{R} \$$ & 4.178 & $\mathrm{R} \$$ & 4.048 & $\mathrm{R} \$$ & 3.852 & $\mathrm{R} \$$ & 3.774 \\
$\mathbf{0 - 0 - 1 0 0}$ & $\mathrm{R} \$$ & 4.395 & $\mathrm{R} \$$ & 4.277 & $\mathrm{R} \$$ & 4.107 & $\mathrm{R} \$$ & 4.036 \\
$\mathbf{7 0 - 3 0 - 0}$ & $\mathrm{R} \$$ & 3.698 & $\mathrm{R} \$$ & 3.568 & $\mathrm{R} \$$ & 3.398 & $\mathrm{R} \$$ & 3.295 \\
$\mathbf{7 0 - 0 - 3 0}$ & $\mathrm{R} \$$ & 3.740 & $\mathrm{R} \$$ & 3.597 & $\mathrm{R} \$$ & 3.464 & $\mathrm{R} \$$ & 3.348 \\
$\mathbf{5 0 - 4 0 - 1 0}$ & $\mathrm{R} \$$ & 3.879 & $\mathrm{R} \$$ & 3.730 & $\mathrm{R} \$$ & 3.557 & $\mathrm{R} \$$ & 3.485 \\
$\mathbf{6 0 - 3 0 - 1 0}$ & $\mathrm{R} \$$ & 3.807 & $\mathrm{R} \$$ & 3.658 & $\mathrm{R} \$$ & 3.486 & $\mathrm{R} \$$ & 3.413 \\
\hline
\end{tabular}


Apêndice 269 - Valor médio da mensalidade final, com crédito médio de 1,20\% sobre o valor do investimento, para construção em 90 dias e compensação de retorno em 12 meses, em função de áreas externas, anfiteatro e minisshopping, para 100 residentes

\begin{tabular}{|c|c|c|c|c|c|c|c|c|}
\hline \multirow{3}{*}{$\begin{array}{c}\text { Porcentagem de } \\
\text { residentes com } \\
\text { grau de } \\
\text { dependência } \\
\text { I, II e III } \\
100-0-0\end{array}$} & \multicolumn{8}{|c|}{$\begin{array}{l}\text { Valor médio de mensalidade final, em função de áreas } \\
\text { externas, anfiteatro e minisshopping, para } 100 \text { residentes, } \\
\text { com diversos graus de dependência }\end{array}$} \\
\hline & \multicolumn{2}{|c|}{ "A" } & \multicolumn{2}{|c|}{ "B" } & \multicolumn{2}{|c|}{ "C" } & \multicolumn{2}{|c|}{ "D" } \\
\hline & $\mathrm{R} \$$ & 4.379 & $\mathrm{R} \$$ & 4.206 & $\mathrm{R} \$$ & 4.082 & $\mathrm{R} \$$ & 4.000 \\
\hline $0-100-0$ & $\mathrm{R} \$$ & 5.072 & $\mathrm{R} \$$ & 4.901 & $\mathrm{R} \$$ & 4.776 & $\mathrm{R} \$$ & 4.693 \\
\hline $0-0-100$ & $\mathrm{R} \$$ & 5.308 & $\mathrm{R} \$$ & 5.158 & $\mathrm{R} \$$ & 5.055 & $\mathrm{R} \$$ & 4.953 \\
\hline $70-30-0$ & $\mathrm{R} \$$ & 4.705 & $\mathrm{R} \$$ & 4.532 & $\mathrm{R} \$$ & 4.409 & $\mathrm{R} \$$ & 4.326 \\
\hline 70-0-30 & $\mathrm{R} \$$ & 4.708 & $\mathrm{R} \$$ & 4.574 & $\mathrm{R} \$$ & 4.451 & $\mathrm{R} \$$ & 4.422 \\
\hline $50-40-10$ & $\mathrm{R} \$$ & 4.901 & $\mathrm{R} \$$ & 4.728 & $\mathrm{R} \$$ & 4.605 & $\mathrm{R} \$$ & 4.523 \\
\hline $60-30-10$ & $\mathrm{R} \$$ & 4.942 & $\mathrm{R} \$$ & 4.769 & $\mathrm{R} \$$ & 4.646 & $\mathrm{R} \$$ & 4.564 \\
\hline
\end{tabular}

Apêndice 270 - Valor médio da mensalidade final, com crédito médio de 1,20\% sobre o valor do investimento, para construção em 90 dias e compensação de retorno em 12 meses, em função de áreas externas, anfiteatro e minisshopping, para 200 residentes

\begin{tabular}{|c|c|c|c|c|c|c|c|c|}
\hline \multirow{2}{*}{$\begin{array}{c}\text { Porcentagem de } \\
\text { residentes com } \\
\text { grau de } \\
\text { dependência } \\
\text { I, II e III } \\
\end{array}$} & \multicolumn{8}{|c|}{$\begin{array}{l}\text { Valor médio de mensalidade final, em função de áreas } \\
\text { externas, anfiteatro e minisshopping, para } 200 \text { residentes, } \\
\text { com diversos graus de dependência }\end{array}$} \\
\hline & \multicolumn{2}{|c|}{ "A" } & \multicolumn{2}{|c|}{ "B" } & \multicolumn{2}{|c|}{ "C" } & \multicolumn{2}{|c|}{ "D" } \\
\hline 100-0-0 & $\mathrm{R} \$$ & 4.075 & $\mathrm{R} \$$ & 3.876 & $\mathrm{R} \$$ & 3.710 & $\mathrm{R} \$$ & 3.451 \\
\hline $0-100-0$ & $\mathrm{R} \$$ & 4.789 & $\mathrm{R} \$$ & 4.591 & $\mathrm{R} \$$ & 4.425 & $\mathrm{R} \$$ & 4.165 \\
\hline $0-0-100$ & $\mathrm{R} \$$ & 4.974 & $\mathrm{R} \$$ & 4.835 & $\mathrm{R} \$$ & 4.657 & $\mathrm{R} \$$ & 4.441 \\
\hline $70-30-0$ & $\mathrm{R} \$$ & 4.340 & $\mathrm{R} \$$ & 4.141 & $\mathrm{R} \$$ & 3.975 & $\mathrm{R} \$$ & 3.715 \\
\hline 70-0-30 & $\mathrm{R} \$$ & 4.338 & $\mathrm{R} \$$ & 4.150 & $\mathrm{R} \$$ & 4.013 & $\mathrm{R} \$$ & 3.753 \\
\hline $50-40-10$ & $\mathrm{R} \$$ & 4.521 & $\mathrm{R} \$$ & 4.323 & $\mathrm{R} \$$ & 4.158 & $\mathrm{R} \$$ & 3.925 \\
\hline $60-30-10$ & $\mathrm{R} \$$ & 4.480 & $\mathrm{R} \$$ & 4.282 & $\mathrm{R} \$$ & 4.117 & $\mathrm{R} \$$ & 3.883 \\
\hline
\end{tabular}

Apêndice 271 - Valor médio da mensalidade final, com crédito médio de 1,20\% sobre o valor do investimento, para construção em 90 dias e compensação de retorno em 12 meses, em função de áreas externas, anfiteatro e minisshopping, para 300 residentes

\begin{tabular}{|c|c|c|c|c|c|c|c|c|}
\hline \multirow{2}{*}{$\begin{array}{c}\text { Porcentagem de } \\
\text { residentes com } \\
\text { grau de } \\
\text { dependência } \\
\text { I, II e III }\end{array}$} & \multicolumn{8}{|c|}{$\begin{array}{l}\text { Valor médio de mensalidade final, em função de áreas } \\
\text { externas, anfiteatro e minisshopping, para } 300 \text { residentes, } \\
\text { com diversos graus de dependência }\end{array}$} \\
\hline & \multicolumn{2}{|c|}{ "A" } & \multicolumn{2}{|c|}{ "B" } & \multicolumn{2}{|c|}{ "C" } & \multicolumn{2}{|c|}{ "D" } \\
\hline 100-0-0 & $\mathrm{R} \$$ & 3.713 & $\mathrm{R} \$$ & 3.558 & $\mathrm{R} \$$ & 3.350 & $\mathrm{R} \$$ & 3.257 \\
\hline $0-100-0$ & $\mathrm{R} \$$ & 4.421 & $\mathrm{R} \$$ & 4.266 & $\mathrm{R} \$$ & 4.057 & $\mathrm{R} \$$ & 3.964 \\
\hline $0-0-100$ & $\mathrm{R} \$$ & 4.624 & $\mathrm{R} \$$ & 4.471 & $\mathrm{R} \$$ & 4.278 & $\mathrm{R} \$$ & 4.187 \\
\hline 70-30-0 & $\mathrm{R} \$$ & 3.958 & $\mathrm{R} \$$ & 3.803 & $\mathrm{R} \$$ & 3.630 & $\mathrm{R} \$$ & 3.501 \\
\hline 70-0-30 & $\mathrm{R} \$$ & 4.020 & $\mathrm{R} \$$ & 3.866 & $\mathrm{R} \$$ & 3.694 & $\mathrm{R} \$$ & 3.559 \\
\hline $50-40-10$ & $\mathrm{R} \$$ & 4.132 & $\mathrm{R} \$$ & 3.977 & $\mathrm{R} \$$ & 3.769 & $\mathrm{R} \$$ & 3.677 \\
\hline $60-30-10$ & $\mathrm{R} \$$ & 4.064 & $\mathrm{R} \$$ & 3.909 & $\mathrm{R} \$$ & 3.701 & $\mathrm{R} \$$ & 3.609 \\
\hline
\end{tabular}


Apêndice 272 - Valor médio da mensalidade final, com crédito médio de 1,20\% sobre o valor do investimento, para construção em 90 dias e compensação de retorno em 12 meses, em função de áreas externas, anfiteatro e minisshopping, para 400 residentes

\begin{tabular}{|c|c|c|c|c|c|c|c|c|}
\hline \multirow{3}{*}{$\begin{array}{c}\text { Porcentagem de } \\
\text { residentes com } \\
\text { grau de } \\
\text { dependência } \\
\text { I, II e III } \\
100-0-0\end{array}$} & \multicolumn{8}{|c|}{$\begin{array}{l}\text { Valor médio de mensalidade final, em função de áreas } \\
\text { externas, anfiteatro e minisshopping, para } 400 \text { residentes, } \\
\text { com diversos graus de dependência }\end{array}$} \\
\hline & \multicolumn{2}{|c|}{ "A" } & \multicolumn{2}{|c|}{ "B" } & \multicolumn{2}{|c|}{ "C" } & \multicolumn{2}{|c|}{ "D" } \\
\hline & $\mathrm{R} \$$ & 3.548 & $\mathrm{R} \$$ & 3.414 & $\mathrm{R} \$$ & 3.213 & $\mathrm{R} \$$ & 3.134 \\
\hline $0-100-0$ & $\mathrm{R} \$$ & 4.262 & $\mathrm{R} \$$ & 4.128 & $\mathrm{R} \$$ & 3.927 & $\mathrm{R} \$$ & 3.848 \\
\hline $0-0-100$ & $\mathrm{R} \$$ & 4.471 & $\mathrm{R} \$$ & 4.349 & $\mathrm{R} \$$ & 4.175 & $\mathrm{R} \$$ & 4.101 \\
\hline $70-30-0$ & $\mathrm{R} \$$ & 3.782 & $\mathrm{R} \$$ & 3.649 & $\mathrm{R} \$$ & 3.474 & $\mathrm{R} \$$ & 3.368 \\
\hline 70-0-30 & $\mathrm{R} \$$ & 3.822 & $\mathrm{R} \$$ & 3.675 & $\mathrm{R} \$$ & 3.538 & $\mathrm{R} \$$ & 3.419 \\
\hline $50-40-10$ & $\mathrm{R} \$$ & 3.962 & $\mathrm{R} \$$ & 3.809 & $\mathrm{R} \$$ & 3.632 & $\mathrm{R} \$$ & 3.558 \\
\hline $60-30-10$ & $\mathrm{R} \$$ & 3.890 & $\mathrm{R} \$$ & 3.738 & $\mathrm{R} \$$ & 3.560 & $\mathrm{R} \$$ & 3.486 \\
\hline
\end{tabular}

Apêndice 273 - Valor médio da mensalidade final, com crédito médio de 1,30\% sobre o valor do investimento, para construção em 90 dias e compensação de retorno em 12 meses, em função de áreas externas, anfiteatro e minisshopping, para 100 residentes

\begin{tabular}{|c|c|c|c|c|c|c|c|c|}
\hline \multirow{3}{*}{$\begin{array}{c}\text { Porcentagem de } \\
\text { residentes com } \\
\text { grau de } \\
\text { dependência } \\
\text { I, II e III } \\
100-0-0\end{array}$} & \multicolumn{8}{|c|}{$\begin{array}{l}\text { Valor médio de mensalidade final, em função de áreas } \\
\text { externas, anfiteatro e minisshopping, para } 100 \text { residentes, } \\
\text { com diversos graus de dependência }\end{array}$} \\
\hline & \multicolumn{2}{|c|}{ "A" } & \multicolumn{2}{|c|}{ "B" } & \multicolumn{2}{|c|}{ "C" } & \multicolumn{2}{|c|}{ "D" } \\
\hline & $\mathrm{R} \$$ & 4.470 & $\mathrm{R} \$$ & 4.294 & $\mathrm{R} \$$ & 4.165 & $\mathrm{R} \$$ & 4.080 \\
\hline $0-100-0$ & $\mathrm{R} \$$ & 5.163 & $\mathrm{R} \$$ & 4.989 & $\mathrm{R} \$$ & 4.858 & $\mathrm{R} \$$ & 4.774 \\
\hline $0-0-100$ & $\mathrm{R} \$$ & 5.389 & $\mathrm{R} \$$ & 5.237 & $\mathrm{R} \$$ & 5.129 & $\mathrm{R} \$$ & 5.025 \\
\hline $70-30-0$ & $\mathrm{R} \$$ & 4.796 & $\mathrm{R} \$$ & 4.619 & $\mathrm{R} \$$ & 4.491 & $\mathrm{R} \$$ & 4.406 \\
\hline 70-0-30 & $\mathrm{R} \$$ & 4.797 & $\mathrm{R} \$$ & 4.659 & $\mathrm{R} \$$ & 4.532 & $\mathrm{R} \$$ & 4.500 \\
\hline $50-40-10$ & $\mathrm{R} \$$ & 4.992 & $\mathrm{R} \$$ & 4.815 & $\mathrm{R} \$$ & 4.688 & $\mathrm{R} \$$ & 4.603 \\
\hline $60-30-10$ & $\mathrm{R} \$$ & 5.032 & $\mathrm{R} \$$ & 4.856 & $\mathrm{R} \$$ & 4.728 & $\mathrm{R} \$$ & 4.644 \\
\hline
\end{tabular}

Apêndice 274 - Valor médio da mensalidade final, com crédito médio de 1,30\% sobre o valor do investimento, para construção em 90 dias e compensação de retorno em 12 meses, em função de áreas externas, anfiteatro e minisshopping, para 200 residentes

\begin{tabular}{|c|c|c|c|c|c|c|c|c|}
\hline \multirow{2}{*}{$\begin{array}{c}\text { Porcentagem de } \\
\text { residentes com } \\
\text { grau de } \\
\text { dependência } \\
\text { I, II e III }\end{array}$} & \multicolumn{8}{|c|}{$\begin{array}{l}\text { Valor médio de mensalidade final, em função de áreas } \\
\text { externas, anfiteatro e minisshopping, para } 200 \text { residentes, } \\
\text { com diversos graus de dependência }\end{array}$} \\
\hline & \multicolumn{2}{|c|}{ "A" } & \multicolumn{2}{|c|}{ "B" } & \multicolumn{2}{|c|}{ "C" } & \multicolumn{2}{|c|}{ "D" } \\
\hline $100-0-0$ & $\mathrm{R} \$$ & 4.167 & $\mathrm{R} \$$ & 3.963 & $\mathrm{R} \$$ & 3.792 & $\mathrm{R} \$$ & 3.526 \\
\hline $0-100-0$ & $\mathrm{R} \$$ & 4.881 & $\mathrm{R} \$$ & 4.678 & $\mathrm{R} \$$ & 4.507 & $\mathrm{R} \$$ & 4.241 \\
\hline $0-0-100$ & $\mathrm{R} \$$ & 5.057 & $\mathrm{R} \$$ & 4.913 & $\mathrm{R} \$$ & 4.731 & $\mathrm{R} \$$ & 4.509 \\
\hline $70-30-0$ & $\mathrm{R} \$$ & 4.432 & $\mathrm{R} \$$ & 4.228 & $\mathrm{R} \$$ & 4.057 & $\mathrm{R} \$$ & 3.791 \\
\hline 70-0-30 & $\mathrm{R} \$$ & 4.428 & $\mathrm{R} \$$ & 4.235 & $\mathrm{R} \$$ & 4.092 & $\mathrm{R} \$$ & 3.826 \\
\hline $50-40-10$ & $\mathrm{R} \$$ & 4.612 & $\mathrm{R} \$$ & 4.409 & $\mathrm{R} \$$ & 4.239 & $\mathrm{R} \$$ & 4.000 \\
\hline $60-30-10$ & $\mathrm{R} \$$ & 4.571 & $\mathrm{R} \$$ & 4.368 & $\mathrm{R} \$$ & 4.198 & $\mathrm{R} \$$ & 3.958 \\
\hline
\end{tabular}


Apêndice 275 - Valor médio da mensalidade final, com crédito médio de 1,30\% sobre o valor do investimento, para construção em 90 dias e compensação de retorno em 12 meses, em função de áreas externas, anfiteatro e minisshopping, para 300 residentes

\begin{tabular}{|c|c|c|c|c|c|c|c|c|}
\hline \multirow{3}{*}{$\begin{array}{c}\text { Porcentagem de } \\
\text { residentes com } \\
\text { grau de } \\
\text { dependência } \\
\text { I, II e III } \\
100-0-0\end{array}$} & \multicolumn{8}{|c|}{$\begin{array}{l}\text { Valor médio de mensalidade final, em função de áreas } \\
\text { externas, anfiteatro e minisshopping, para } 300 \text { residentes, } \\
\text { com diversos graus de dependência }\end{array}$} \\
\hline & \multicolumn{2}{|c|}{ "A" } & \multicolumn{2}{|c|}{ "B" } & \multicolumn{2}{|c|}{ "C" } & \multicolumn{2}{|c|}{ "D" } \\
\hline & $\mathrm{R} \$$ & 3.798 & $\mathrm{R} \$$ & 3.639 & $\mathrm{R} \$$ & 3.426 & $\mathrm{R} \$$ & 3.330 \\
\hline $0-100-0$ & $\mathrm{R} \$$ & 4.507 & $\mathrm{R} \$$ & 4.347 & $\mathrm{R} \$$ & 4.133 & $\mathrm{R} \$$ & 4.037 \\
\hline $0-0-100$ & $\mathrm{R} \$$ & 4.701 & $\mathrm{R} \$$ & 4.545 & $\mathrm{R} \$$ & 4.346 & $\mathrm{R} \$$ & 4.253 \\
\hline $70-30-0$ & $\mathrm{R} \$$ & 4.044 & $\mathrm{R} \$$ & 3.884 & $\mathrm{R} \$$ & 3.707 & $\mathrm{R} \$$ & 3.575 \\
\hline 70-0-30 & $\mathrm{R} \$$ & 4.103 & $\mathrm{R} \$$ & 3.945 & $\mathrm{R} \$$ & 3.768 & $\mathrm{R} \$$ & 3.631 \\
\hline $50-40-10$ & $\mathrm{R} \$$ & 4.217 & $\mathrm{R} \$$ & 4.058 & $\mathrm{R} \$$ & 3.844 & $\mathrm{R} \$$ & 3.750 \\
\hline $60-30-10$ & $\mathrm{R} \$$ & 4.149 & $\mathrm{R} \$$ & 3.990 & $\mathrm{R} \$$ & 3.776 & $\mathrm{R} \$$ & 3.682 \\
\hline
\end{tabular}

Apêndice 276 - Valor médio da mensalidade final, com crédito médio de 1,30\% sobre o valor do investimento, para construção em 90 dias e compensação de retorno em 12 meses, em função de áreas externas, anfiteatro e minisshopping, para 400 residentes

\begin{tabular}{|c|c|c|c|c|c|c|c|c|}
\hline \multirow{3}{*}{$\begin{array}{l}\text { Porcentagem de } \\
\text { residentes com } \\
\text { grau de } \\
\text { dependência } \\
\text { I, II e III } \\
\end{array}$} & \multicolumn{8}{|c|}{$\begin{array}{l}\text { Valor médio de mensalidade final, em função de áreas } \\
\text { externas, anfiteatro e minisshopping, para } 400 \text { residentes, } \\
\text { com diversos graus de dependência }\end{array}$} \\
\hline & \multicolumn{2}{|c|}{ "A" } & \multicolumn{2}{|c|}{ "B" } & \multicolumn{2}{|c|}{ "C" } & \multicolumn{2}{|c|}{ "D" } \\
\hline & $\mathrm{R} \$$ & 3.632 & $\mathrm{R} \$$ & 3.494 & $\mathrm{R} \$$ & 3.288 & $\mathrm{R} \$$ & 3.207 \\
\hline $0-100-0$ & $\mathrm{R} \$$ & 4.346 & $\mathrm{R} \$$ & 4.208 & $\mathrm{R} \$$ & 4.003 & $\mathrm{R} \$$ & 3.922 \\
\hline $0-0-100$ & $\mathrm{R} \$$ & 4.546 & $\mathrm{R} \$$ & 4.422 & $\mathrm{R} \$$ & 4.242 & $\mathrm{R} \$$ & 4.167 \\
\hline $70-30-0$ & $\mathrm{R} \$$ & 3.866 & $\mathrm{R} \$$ & 3.729 & $\mathrm{R} \$$ & 3.551 & $\mathrm{R} \$$ & 3.442 \\
\hline 70-0-30 & $\mathrm{R} \$$ & 3.903 & $\mathrm{R} \$$ & 3.753 & $\mathrm{R} \$$ & 3.612 & $\mathrm{R} \$$ & 3.490 \\
\hline $50-40-10$ & $\mathrm{R} \$$ & 4.045 & $\mathrm{R} \$$ & 3.888 & $\mathrm{R} \$$ & 3.706 & $\mathrm{R} \$$ & 3.631 \\
\hline $60-30-10$ & $\mathrm{R} \$$ & 3.973 & $\mathrm{R} \$$ & 3.817 & $\mathrm{R} \$$ & 3.635 & $\mathrm{R} \$$ & 3.559 \\
\hline
\end{tabular}

Apêndice 277 - Valor médio da mensalidade final, com crédito médio de 1,40\% sobre o valor do investimento, para construção em 90 dias e compensação de retorno em 12 meses, em função de áreas externas, anfiteatro e minisshopping, para 100 residentes

\begin{tabular}{|c|c|c|c|c|c|c|c|c|}
\hline \multirow{3}{*}{$\begin{array}{c}\text { Porcentagem de } \\
\text { residentes com } \\
\text { grau de } \\
\text { dependência } \\
\text { I, II e III } \\
100-0-0\end{array}$} & \multicolumn{8}{|c|}{$\begin{array}{l}\text { Valor médio de mensalidade final, em função de áreas } \\
\text { externas, anfiteatro e minisshopping, para } 100 \text { residentes, } \\
\text { com diversos graus de dependência }\end{array}$} \\
\hline & \multicolumn{2}{|c|}{ "A" } & \multicolumn{2}{|c|}{ "B" } & \multicolumn{2}{|c|}{ "C" } & \multicolumn{2}{|c|}{ "D" } \\
\hline & $\mathrm{R} \$$ & 4.561 & $\mathrm{R} \$$ & 4.381 & $\mathrm{R} \$$ & 4.248 & $\mathrm{R} \$$ & 4.161 \\
\hline $0-100-0$ & $\mathrm{R} \$$ & 5.254 & $\mathrm{R} \$$ & 5.076 & $\mathrm{R} \$$ & 4.941 & $\mathrm{R} \$$ & 4.854 \\
\hline $0-0-100$ & $\mathrm{R} \$$ & 5.471 & $\mathrm{R} \$$ & 5.315 & $\mathrm{R} \$$ & 5.203 & $\mathrm{R} \$$ & 5.096 \\
\hline $70-30-0$ & $\mathrm{R} \$$ & 4.887 & $\mathrm{R} \$$ & 4.707 & $\mathrm{R} \$$ & 4.574 & $\mathrm{R} \$$ & 4.487 \\
\hline 70-0-30 & $\mathrm{R} \$$ & 4.885 & $\mathrm{R} \$$ & 4.744 & $\mathrm{R} \$$ & 4.612 & $\mathrm{R} \$$ & 4.578 \\
\hline $50-40-10$ & $\mathrm{R} \$$ & 5.082 & $\mathrm{R} \$$ & 4.902 & $\mathrm{R} \$$ & 4.770 & $\mathrm{R} \$$ & 4.683 \\
\hline $60-30-10$ & $\mathrm{R} \$$ & 5.122 & $\mathrm{R} \$$ & 4.943 & $\mathrm{R} \$$ & 4.810 & $\mathrm{R} \$$ & 4.723 \\
\hline
\end{tabular}


Apêndice 278 - Valor médio da mensalidade final, com crédito médio de 1,40\% sobre o valor do investimento, para construção em 90 dias e compensação de retorno em 12 meses, em função de áreas externas, anfiteatro e minisshopping, para 200 residentes

\begin{tabular}{|c|c|c|c|c|c|c|c|c|}
\hline \multirow{3}{*}{ 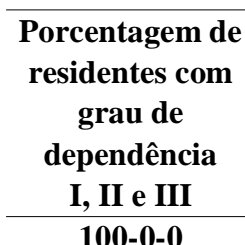 } & \multicolumn{8}{|c|}{$\begin{array}{l}\text { Valor médio de mensalidade final, em função de áreas } \\
\text { externas, anfiteatro e minisshopping, para } 200 \text { residentes, } \\
\text { com diversos graus de dependência }\end{array}$} \\
\hline & \multicolumn{2}{|c|}{ "A" } & \multicolumn{2}{|c|}{ "B" } & \multicolumn{2}{|c|}{ "C" } & \multicolumn{2}{|c|}{ "D" } \\
\hline & $\mathrm{R} \$$ & 4.259 & $\mathrm{R} \$$ & 4.050 & $\mathrm{R} \$$ & 3.874 & $\mathrm{R} \$$ & 3.602 \\
\hline $0-100-0$ & $\mathrm{R} \$$ & 4.973 & $\mathrm{R} \$$ & 4.765 & $\mathrm{R} \$$ & 4.589 & $\mathrm{R} \$$ & 4.317 \\
\hline $0-0-100$ & $\mathrm{R} \$$ & 5.140 & $\mathrm{R} \$$ & 4.991 & $\mathrm{R} \$$ & 4.804 & $\mathrm{R} \$$ & 4.576 \\
\hline 70-30-0 & $\mathrm{R} \$$ & 4.524 & $\mathrm{R} \$$ & 4.315 & $\mathrm{R} \$$ & 4.139 & $\mathrm{R} \$$ & 3.867 \\
\hline 70-0-30 & $\mathrm{R} \$$ & 4.517 & $\mathrm{R} \$$ & 4.319 & $\mathrm{R} \$$ & 4.172 & $\mathrm{R} \$$ & 3.899 \\
\hline $50-40-10$ & $\mathrm{R} \$$ & 4.703 & $\mathrm{R} \$$ & 4.494 & $\mathrm{R} \$$ & 4.320 & $\mathrm{R} \$$ & 4.074 \\
\hline $60-30-10$ & $\mathrm{R} \$$ & 4.662 & $\mathrm{R} \$$ & 4.453 & $\mathrm{R} \$$ & 4.279 & $\mathrm{R} \$$ & 4.032 \\
\hline
\end{tabular}

Apêndice 279 - Valor médio da mensalidade final, com crédito médio de 1,40\% sobre o valor do investimento, para construção em 90 dias e compensação de retorno em 12 meses, em função de áreas externas, anfiteatro e minisshopping, para 300 residentes

\begin{tabular}{|c|c|c|c|c|c|c|c|c|}
\hline \multirow{3}{*}{$\begin{array}{c}\text { Porcentagem de } \\
\text { residentes com } \\
\text { grau de } \\
\text { dependência } \\
\text { I, II e III } \\
100-0-0\end{array}$} & \multicolumn{8}{|c|}{$\begin{array}{l}\text { Valor médio de mensalidade final, em função de áreas } \\
\text { externas, anfiteatro e minisshopping, para } 300 \text { residentes, } \\
\text { com diversos graus de dependência }\end{array}$} \\
\hline & \multicolumn{2}{|c|}{ "A" } & \multicolumn{2}{|c|}{ "B" } & \multicolumn{2}{|c|}{ "C" } & \multicolumn{2}{|c|}{ "D" } \\
\hline & $\mathrm{R} \$$ & 3.884 & $\mathrm{R} \$$ & 3.720 & $\mathrm{R} \$$ & 3.501 & $\mathrm{R} \$$ & 3.404 \\
\hline $0-100-0$ & $\mathrm{R} \$$ & 4.592 & $\mathrm{R} \$$ & 4.429 & $\mathrm{R} \$$ & 4.209 & $\mathrm{R} \$$ & 4.111 \\
\hline $0-0-100$ & $\mathrm{R} \$$ & 4.778 & $\mathrm{R} \$$ & 4.618 & $\mathrm{R} \$$ & 4.414 & $\mathrm{R} \$$ & 4.319 \\
\hline $70-30-0$ & $\mathrm{R} \$$ & 4.129 & $\mathrm{R} \$$ & 3.966 & $\mathrm{R} \$$ & 3.784 & $\mathrm{R} \$$ & 3.648 \\
\hline 70-0-30 & $\mathrm{R} \$$ & 4.186 & $\mathrm{R} \$$ & 4.024 & $\mathrm{R} \$$ & 3.843 & $\mathrm{R} \$$ & 3.702 \\
\hline $50-40-10$ & $\mathrm{R} \$$ & 4.302 & $\mathrm{R} \$$ & 4.139 & $\mathrm{R} \$$ & 3.919 & $\mathrm{R} \$$ & 3.823 \\
\hline $60-30-10$ & $\mathrm{R} \$$ & 4.234 & $\mathrm{R} \$$ & 4.071 & $\mathrm{R} \$$ & 3.851 & $\mathrm{R} \$$ & 3.755 \\
\hline
\end{tabular}

Apêndice 280 - Valor médio da mensalidade final, com crédito médio de 1,40\% sobre o valor do investimento, para construção em 90 dias e compensação de retorno em 12 meses, em função de áreas externas, anfiteatro e minisshopping, para 400 residentes

\begin{tabular}{|c|c|c|c|c|c|c|c|c|}
\hline \multirow{2}{*}{$\begin{array}{c}\text { Porcentagem de } \\
\text { residentes com } \\
\text { grau de } \\
\text { dependência } \\
\text { I, II e III }\end{array}$} & \multicolumn{8}{|c|}{$\begin{array}{l}\text { Valor médio de mensalidade final, em função de áreas } \\
\text { externas, anfiteatro e minisshopping, para } 400 \text { residentes, } \\
\text { com diversos graus de dependência }\end{array}$} \\
\hline & \multicolumn{2}{|c|}{ "A" } & \multicolumn{2}{|c|}{ "B" } & \multicolumn{2}{|c|}{ "C" } & \multicolumn{2}{|c|}{ "D" } \\
\hline 100-0-0 & $\mathrm{R} \$$ & 3.716 & $\mathrm{R} \$$ & 3.574 & $\mathrm{R} \$$ & 3.364 & $\mathrm{R} \$$ & 3.281 \\
\hline $0-100-0$ & $\mathrm{R} \$$ & 4.430 & $\mathrm{R} \$$ & 4.289 & $\mathrm{R} \$$ & 4.078 & $\mathrm{R} \$$ & 3.995 \\
\hline $0-0-100$ & $\mathrm{R} \$$ & 4.622 & $\mathrm{R} \$$ & 4.494 & $\mathrm{R} \$$ & 4.310 & $\mathrm{R} \$$ & 4.233 \\
\hline 70-30-0 & $\mathrm{R} \$$ & 3.950 & $\mathrm{R} \$$ & 3.809 & $\mathrm{R} \$$ & 3.627 & $\mathrm{R} \$$ & 3.515 \\
\hline 70-0-30 & $\mathrm{R} \$$ & 3.985 & $\mathrm{R} \$$ & 3.831 & $\mathrm{R} \$$ & 3.686 & $\mathrm{R} \$$ & 3.562 \\
\hline $50-40-10$ & $\mathrm{R} \$$ & 4.128 & $\mathrm{R} \$$ & 3.968 & $\mathrm{R} \$$ & 3.781 & $\mathrm{R} \$$ & 3.703 \\
\hline $60-30-10$ & $\mathrm{R} \$$ & 4.056 & $\mathrm{R} \$$ & 3.896 & $\mathrm{R} \$$ & 3.710 & $\mathrm{R} \$$ & 3.631 \\
\hline
\end{tabular}


Apêndice 281 - Valor médio da mensalidade final, com crédito médio de 1,50\% sobre o valor do investimento, para construção em 90 dias e compensação de retorno em 12 meses, em função de áreas externas, anfiteatro e minisshopping, para 100 residentes

\begin{tabular}{|c|c|c|c|c|c|c|c|c|}
\hline \multirow{3}{*}{$\begin{array}{c}\text { Porcentagem de } \\
\text { residentes com } \\
\text { grau de } \\
\text { dependência } \\
\text { I, II e III } \\
100-0-0\end{array}$} & \multicolumn{8}{|c|}{$\begin{array}{l}\text { Valor médio de mensalidade final, em função de áreas } \\
\text { externas, anfiteatro e minisshopping, para } 100 \text { residentes, } \\
\text { com diversos graus de dependência }\end{array}$} \\
\hline & \multicolumn{2}{|c|}{ "A" } & \multicolumn{2}{|c|}{ "B" } & \multicolumn{2}{|c|}{ "C" } & \multicolumn{2}{|c|}{ "D" } \\
\hline & $\mathrm{R} \$$ & 4.652 & $\mathrm{R} \$$ & 4.468 & $\mathrm{R} \$$ & 4.330 & $\mathrm{R} \$$ & 4.241 \\
\hline $0-100-0$ & $\mathrm{R} \$$ & 5.344 & $\mathrm{R} \$$ & 5.164 & $\mathrm{R} \$$ & 5.023 & $\mathrm{R} \$$ & 4.934 \\
\hline $0-0-100$ & $\mathrm{R} \$$ & 5.553 & $\mathrm{R} \$$ & 5.394 & $\mathrm{R} \$$ & 5.277 & $\mathrm{R} \$$ & 5.167 \\
\hline $70-30-0$ & $\mathrm{R} \$$ & 4.978 & $\mathrm{R} \$$ & 4.794 & $\mathrm{R} \$$ & 4.657 & $\mathrm{R} \$$ & 4.567 \\
\hline 70-0-30 & $\mathrm{R} \$$ & 4.974 & $\mathrm{R} \$$ & 4.830 & $\mathrm{R} \$$ & 4.693 & $\mathrm{R} \$$ & 4.656 \\
\hline $50-40-10$ & $\mathrm{R} \$$ & 5.172 & $\mathrm{R} \$$ & 4.989 & $\mathrm{R} \$$ & 4.852 & $\mathrm{R} \$$ & 4.762 \\
\hline $60-30-10$ & $\mathrm{R} \$$ & 5.212 & $\mathrm{R} \$$ & 5.029 & $\mathrm{R} \$$ & 4.892 & $\mathrm{R} \$$ & 4.803 \\
\hline
\end{tabular}

Apêndice 282 - Valor médio da mensalidade final, com crédito médio de 1,50\% sobre o valor do investimento, para construção em 90 dias e compensação de retorno em 12 meses, em função de áreas externas, anfiteatro e minisshopping, para 200 residentes

\begin{tabular}{|c|c|c|c|c|c|c|c|c|}
\hline \multirow{3}{*}{$\begin{array}{c}\text { Porcentagem de } \\
\text { residentes com } \\
\text { grau de } \\
\text { dependência } \\
\text { I, II e III } \\
100-0-0\end{array}$} & \multicolumn{8}{|c|}{$\begin{array}{l}\text { Valor médio de mensalidade final, em função de áreas } \\
\text { externas, anfiteatro e minisshopping, para } 200 \text { residentes, } \\
\text { com diversos graus de dependência }\end{array}$} \\
\hline & \multicolumn{2}{|c|}{ "A" } & \multicolumn{2}{|c|}{ "B" } & \multicolumn{2}{|c|}{ "C" } & \multicolumn{2}{|c|}{ "D" } \\
\hline & $\mathrm{R} \$$ & 4.351 & $\mathrm{R} \$$ & 4.137 & $\mathrm{R} \$$ & 3.956 & $\mathrm{R} \$$ & 3.678 \\
\hline $0-100-0$ & $\mathrm{R} \$$ & 5.065 & $\mathrm{R} \$$ & 4.852 & $\mathrm{R} \$$ & 4.671 & $\mathrm{R} \$$ & 4.393 \\
\hline $0-0-100$ & $\mathrm{R} \$$ & 5.223 & $\mathrm{R} \$$ & 5.070 & $\mathrm{R} \$$ & 4.877 & $\mathrm{R} \$$ & 4.644 \\
\hline $70-30-0$ & $\mathrm{R} \$$ & 4.615 & $\mathrm{R} \$$ & 4.402 & $\mathrm{R} \$$ & 4.221 & $\mathrm{R} \$$ & 3.943 \\
\hline 70-0-30 & $\mathrm{R} \$$ & 4.606 & $\mathrm{R} \$$ & 4.403 & $\mathrm{R} \$$ & 4.251 & $\mathrm{R} \$$ & 3.973 \\
\hline $50-40-10$ & $\mathrm{R} \$$ & 4.793 & $\mathrm{R} \$$ & 4.580 & $\mathrm{R} \$$ & 4.401 & $\mathrm{R} \$$ & 4.149 \\
\hline $60-30-10$ & $\mathrm{R} \$$ & 4.753 & $\mathrm{R} \$$ & 4.539 & $\mathrm{R} \$$ & 4.360 & $\mathrm{R} \$$ & 4.107 \\
\hline
\end{tabular}

Apêndice 283 - Valor médio da mensalidade final, com crédito médio de $1,50 \%$ sobre o valor do investimento, para construção em 90 dias e compensação de retorno em 12 meses, em função de áreas externas, anfiteatro e minisshopping, para 300 residentes

\begin{tabular}{|c|c|c|c|c|c|c|c|c|}
\hline \multirow{2}{*}{$\begin{array}{c}\text { Porcentagem de } \\
\text { residentes com } \\
\text { grau de } \\
\text { dependência } \\
\text { I, II e III }\end{array}$} & \multicolumn{8}{|c|}{$\begin{array}{l}\text { Valor médio de mensalidade final, em função de áreas } \\
\text { externas, anfiteatro e minisshopping, para } 300 \text { residentes, } \\
\text { com diversos graus de dependência }\end{array}$} \\
\hline & \multicolumn{2}{|c|}{ "A" } & \multicolumn{2}{|c|}{ "B" } & \multicolumn{2}{|c|}{ "C" } & \multicolumn{2}{|c|}{ "D" } \\
\hline $100-0-0$ & $\mathrm{R} \$$ & 3.969 & $\mathrm{R} \$$ & 3.801 & $\mathrm{R} \$$ & 3.577 & $\mathrm{R} \$$ & 3.477 \\
\hline $0-100-0$ & $\mathrm{R} \$$ & 4.678 & $\mathrm{R} \$$ & 4.510 & $\mathrm{R} \$$ & 4.285 & $\mathrm{R} \$$ & 4.185 \\
\hline $0-0-100$ & $\mathrm{R} \$$ & 4.855 & $\mathrm{R} \$$ & 4.691 & $\mathrm{R} \$$ & 4.482 & $\mathrm{R} \$$ & 4.385 \\
\hline $70-30-0$ & $\mathrm{R} \$$ & 4.215 & $\mathrm{R} \$$ & 4.047 & $\mathrm{R} \$$ & 3.861 & $\mathrm{R} \$$ & 3.722 \\
\hline 70-0-30 & $\mathrm{R} \$$ & 4.269 & $\mathrm{R} \$$ & 4.103 & $\mathrm{R} \$$ & 3.918 & $\mathrm{R} \$$ & 3.774 \\
\hline $50-40-10$ & $\mathrm{R} \$$ & 4.387 & $\mathrm{R} \$$ & 4.219 & $\mathrm{R} \$$ & 3.994 & $\mathrm{R} \$$ & 3.896 \\
\hline $60-30-10$ & $\mathrm{R} \$$ & 4.319 & $\mathrm{R} \$$ & 4.151 & $\mathrm{R} \$$ & 3.926 & $\mathrm{R} \$$ & 3.828 \\
\hline
\end{tabular}


Apêndice 284 - Valor médio da mensalidade final, com crédito médio de 1,50\% sobre o valor do investimento, para construção em 90 dias e compensação de retorno em 12 meses, em função de áreas externas, anfiteatro e minisshopping, para 400 residentes

\begin{tabular}{|c|c|c|c|c|c|c|c|c|}
\hline \multirow{2}{*}{$\begin{array}{l}\text { Porcentagem de } \\
\text { residentes com } \\
\text { grau de } \\
\text { dependência } \\
\text { I, II e III } \\
\end{array}$} & \multicolumn{8}{|c|}{$\begin{array}{l}\text { Valor médio de mensalidade final, em função de áreas } \\
\text { externas, anfiteatro e minisshopping, para } 400 \text { residentes, } \\
\text { com diversos graus de dependência }\end{array}$} \\
\hline & \multicolumn{2}{|c|}{ "A" } & \multicolumn{2}{|c|}{ "B" } & \multicolumn{2}{|c|}{ "C" } & \multicolumn{2}{|c|}{ "D" } \\
\hline $100-0-0$ & $\mathrm{R} \$$ & 3.800 & $\mathrm{R} \$$ & 3.654 & $\mathrm{R} \$$ & 3.439 & $\mathrm{R} \$$ & 3.354 \\
\hline $0-100-0$ & $\mathrm{R} \$$ & 4.514 & $\mathrm{R} \$$ & 4.369 & $\mathrm{R} \$$ & 4.154 & $\mathrm{R} \$$ & 4.069 \\
\hline $0-0-100$ & $\mathrm{R} \$$ & 4.698 & $\mathrm{R} \$$ & 4.566 & $\mathrm{R} \$$ & 4.377 & $\mathrm{R} \$$ & 4.299 \\
\hline 70-30-0 & $\mathrm{R} \$$ & 4.034 & $\mathrm{R} \$$ & 3.889 & $\mathrm{R} \$$ & 3.704 & $\mathrm{R} \$$ & 3.589 \\
\hline 70-0-30 & $\mathrm{R} \$$ & 4.066 & $\mathrm{R} \$$ & 3.908 & $\mathrm{R} \$$ & 3.760 & $\mathrm{R} \$$ & 3.633 \\
\hline $50-40-10$ & $\mathrm{R} \$$ & 4.211 & $\mathrm{R} \$$ & 4.047 & $\mathrm{R} \$$ & 3.856 & $\mathrm{R} \$$ & 3.776 \\
\hline $60-30-10$ & $\mathrm{R} \$$ & 4.139 & $\mathrm{R} \$$ & 3.976 & $\mathrm{R} \$$ & 3.784 & $\mathrm{R} \$$ & 3.704 \\
\hline
\end{tabular}

Apêndice 285 - Valor médio da mensalidade final, com crédito médio de 1,10\% sobre o valor do investimento, para construção em 90 dias e compensação de retorno em 24 meses, em função de áreas externas, anfiteatro e minisshopping, para 100 residentes

\begin{tabular}{|c|c|c|c|c|c|c|c|c|}
\hline \multirow{3}{*}{$\begin{array}{c}\text { Porcentagem de } \\
\text { residentes com } \\
\text { grau de } \\
\text { dependência } \\
\text { I, II e III } \\
100-0-0\end{array}$} & \multicolumn{8}{|c|}{$\begin{array}{l}\text { Valor médio de mensalidade final, em função de áreas } \\
\text { externas, anfiteatro e minisshopping, para } 100 \text { residentes, } \\
\text { com diversos graus de dependência }\end{array}$} \\
\hline & \multicolumn{2}{|c|}{ "A" } & \multicolumn{2}{|c|}{ "B" } & \multicolumn{2}{|c|}{ "C" } & \multicolumn{2}{|c|}{ "D" } \\
\hline & $\mathrm{R} \$$ & 4.146 & $\mathrm{R} \$$ & 3.981 & $\mathrm{R} \$$ & 3.870 & $\mathrm{R} \$$ & 3.794 \\
\hline $0-100-0$ & $\mathrm{R} \$$ & 4.839 & $\mathrm{R} \$$ & 4.676 & $\mathrm{R} \$$ & 4.563 & $\mathrm{R} \$$ & 4.487 \\
\hline $0-0-100$ & $\mathrm{R} \$$ & 5.098 & $\mathrm{R} \$$ & 4.956 & $\mathrm{R} \$$ & 4.865 & $\mathrm{R} \$$ & 4.770 \\
\hline $70-30-0$ & $\mathrm{R} \$$ & 4.472 & $\mathrm{R} \$$ & 4.307 & $\mathrm{R} \$$ & 4.196 & $\mathrm{R} \$$ & 4.120 \\
\hline $70-0-30$ & $\mathrm{R} \$$ & 4.480 & $\mathrm{R} \$$ & 4.354 & $\mathrm{R} \$$ & 4.244 & $\mathrm{R} \$$ & 4.221 \\
\hline $50-40-10$ & $\mathrm{R} \$$ & 4.670 & $\mathrm{R} \$$ & 4.505 & $\mathrm{R} \$$ & 4.395 & $\mathrm{R} \$$ & 4.319 \\
\hline $60-30-10$ & $\mathrm{R} \$$ & 4.710 & $\mathrm{R} \$$ & 4.546 & $\mathrm{R} \$$ & 4.435 & $\mathrm{R} \$$ & 4.359 \\
\hline
\end{tabular}

Apêndice 286 - Valor médio da mensalidade final, com crédito médio de 1,10\% sobre o valor do investimento, para construção em 90 dias e compensação de retorno em 24 meses, em função de áreas externas, anfiteatro e minisshopping, para 200 residentes

\begin{tabular}{|c|c|c|c|c|c|c|c|c|}
\hline \multirow{2}{*}{$\begin{array}{c}\text { Porcentagem de } \\
\text { residentes com } \\
\text { grau de } \\
\text { dependência } \\
\text { I, II e III }\end{array}$} & \multicolumn{8}{|c|}{$\begin{array}{l}\text { Valor médio de mensalidade final, em função de áreas } \\
\text { externas, anfiteatro e minisshopping, para } 200 \text { residentes, } \\
\text { com diversos graus de dependência }\end{array}$} \\
\hline & \multicolumn{2}{|c|}{ "A" } & \multicolumn{2}{|c|}{ "B" } & \multicolumn{2}{|c|}{ "C" } & \multicolumn{2}{|c|}{ "D" } \\
\hline 100-0-0 & $\mathrm{R} \$$ & 3.839 & $\mathrm{R} \$$ & 3.653 & $\mathrm{R} \$$ & 3.500 & $\mathrm{R} \$$ & 3.256 \\
\hline $0-100-0$ & $\mathrm{R} \$$ & 4.553 & $\mathrm{R} \$$ & 4.367 & $\mathrm{R} \$$ & 4.214 & $\mathrm{R} \$$ & 3.970 \\
\hline $0-0-100$ & $\mathrm{R} \$$ & 4.761 & $\mathrm{R} \$$ & 4.634 & $\mathrm{R} \$$ & 4.468 & $\mathrm{R} \$$ & 4.267 \\
\hline $70-30-0$ & $\mathrm{R} \$$ & 4.104 & $\mathrm{R} \$$ & 3.918 & $\mathrm{R} \$$ & 3.765 & $\$$ & 3.520 \\
\hline 70-0-30 & $\mathrm{R} \$$ & 4.109 & $\mathrm{R} \$$ & 3.934 & $\mathrm{R} \$$ & 3.808 & $\mathrm{R} \$$ & 3.564 \\
\hline $50-40-10$ & $\mathrm{R} \$$ & 4.288 & $\mathrm{R} \$$ & 4.102 & $\mathrm{R} \$$ & 3.950 & N & 3.732 \\
\hline $60-30-10$ & $\mathrm{R} \$$ & 4.247 & $\mathrm{R} \$$ & 4.061 & $\mathrm{R} \$$ & 3.909 & $\mathrm{R} \$$ & 3.691 \\
\hline
\end{tabular}


Apêndice 287 - Valor médio da mensalidade final, com crédito médio de 1,10\% sobre o valor do investimento, para construção em 90 dias e compensação de retorno em 24 meses, em função de áreas externas, anfiteatro e minisshopping, para 300 residentes

\begin{tabular}{|c|c|c|c|c|c|c|c|c|}
\hline \multirow{2}{*}{$\begin{array}{l}\text { Porcentagem de } \\
\text { residentes com } \\
\text { grau de } \\
\text { dependência } \\
\text { I, II e III } \\
\end{array}$} & \multicolumn{8}{|c|}{$\begin{array}{l}\text { Valor médio de mensalidade final, em função de áreas } \\
\text { externas, anfiteatro e minisshopping, para } 300 \text { residentes, } \\
\text { com diversos graus de dependência }\end{array}$} \\
\hline & \multicolumn{2}{|c|}{ "A" } & \multicolumn{2}{|c|}{ "B" } & \multicolumn{2}{|c|}{ "C" } & \multicolumn{2}{|c|}{ "D" } \\
\hline $100-0-0$ & $\mathrm{R} \$$ & 3.493 & $\mathrm{R} \$$ & 3.349 & $\mathrm{R} \$$ & 3.155 & $\mathrm{R} \$$ & 3.067 \\
\hline $0-100-0$ & $\mathrm{R} \$$ & 4.201 & $\mathrm{R} \$$ & 4.056 & $\mathrm{R} \$$ & 3.862 & $\mathrm{R} \$$ & 3.774 \\
\hline $0-0-100$ & $\mathrm{R} \$$ & 4.426 & $\mathrm{R} \$$ & 4.283 & $\mathrm{R} \$$ & 4.104 & $\mathrm{R} \$$ & 4.018 \\
\hline $70-30-0$ & $\mathrm{R} \$$ & 3.738 & $\mathrm{R} \$$ & 3.594 & $\mathrm{R} \$$ & 3.432 & $\mathrm{R} \$$ & 3.312 \\
\hline 70-0-30 & $\mathrm{R} \$$ & 3.806 & $\mathrm{R} \$$ & 3.662 & $\mathrm{R} \$$ & 3.501 & $\mathrm{R} \$$ & 3.376 \\
\hline $50-40-10$ & $\mathrm{R} \$$ & 3.914 & $\mathrm{R} \$$ & 3.770 & $\mathrm{R} \$$ & 3.576 & $\mathrm{R} \$$ & 3.489 \\
\hline $60-30-10$ & $\mathrm{R} \$$ & 3.846 & $\mathrm{R} \$$ & 3.702 & $\mathrm{R} \$$ & 3.508 & $\mathrm{R} \$$ & 3.421 \\
\hline
\end{tabular}

Apêndice 288 - Valor médio da mensalidade final, com crédito médio de 1,10\% sobre o valor do investimento, para construção em 90 dias e compensação de retorno em 24 meses, em função de áreas externas, anfiteatro e minisshopping, para 400 residentes

\begin{tabular}{|c|c|c|c|c|c|c|c|c|}
\hline \multirow{2}{*}{$\begin{array}{c}\text { Porcentagem de } \\
\text { residentes com } \\
\text { grau de } \\
\text { dependência } \\
\text { I, II e III } \\
\end{array}$} & \multicolumn{8}{|c|}{$\begin{array}{l}\text { Valor médio de mensalidade final, em função de áreas } \\
\text { externas, anfiteatro e minisshopping, para } 400 \text { residentes, } \\
\text { com diversos graus de dependência }\end{array}$} \\
\hline & \multicolumn{2}{|c|}{ "A" } & \multicolumn{2}{|c|}{ "B" } & \multicolumn{2}{|c|}{ "C" } & \multicolumn{2}{|c|}{ "D" } \\
\hline $100-0-0$ & $\mathrm{R} \$$ & 3.332 & $\mathrm{R} \$$ & 3.208 & $\mathrm{R} \$$ & 3.019 & $\mathrm{R} \$$ & 2.945 \\
\hline $0-100-0$ & $\mathrm{R} \$$ & 4.046 & $\mathrm{R} \$$ & 3.921 & $\mathrm{R} \$$ & 3.733 & $\mathrm{R} \$$ & 3.659 \\
\hline $0-0-100$ & $\mathrm{R} \$$ & 4.276 & $\mathrm{R} \$$ & 4.164 & $\mathrm{R} \$$ & 4.001 & $\mathrm{R} \$$ & 3.932 \\
\hline 70-30-0 & $\mathrm{R} \$$ & 3.566 & $\mathrm{R} \$$ & 3.442 & $\mathrm{R} \$$ & 3.278 & $\mathrm{R} \$$ & 3.179 \\
\hline 70-0-30 & $\mathrm{R} \$$ & 3.612 & $\mathrm{R} \$$ & 3.475 & $\mathrm{R} \$$ & 3.348 & $\mathrm{R} \$$ & 3.236 \\
\hline $50-40-10$ & $\mathrm{R} \$$ & 3.748 & $\mathrm{R} \$$ & 3.605 & $\mathrm{R} \$$ & 3.440 & $\mathrm{R} \$$ & 3.371 \\
\hline $60-30-10$ & $\mathrm{R} \$$ & 3.676 & $\mathrm{R} \$$ & 3.534 & $\mathrm{R} \$$ & 3.369 & $\mathrm{R} \$$ & 3.299 \\
\hline
\end{tabular}

Apêndice 289 - Valor médio da mensalidade final, com crédito médio de 1,20\% sobre o valor do investimento, para construção em 90 dias e compensação de retorno em 24 meses, em função de áreas externas, anfiteatro e minisshopping, para 100 residentes

\begin{tabular}{|c|c|c|c|c|c|c|c|c|}
\hline \multirow{2}{*}{$\begin{array}{c}\text { Porcentagem de } \\
\text { residentes com } \\
\text { grau de } \\
\text { dependência } \\
\text { I, II e III }\end{array}$} & \multicolumn{8}{|c|}{$\begin{array}{l}\text { Valor médio de mensalidade final, em função de áreas } \\
\text { externas, anfiteatro e minisshopping, para } 100 \text { residentes, } \\
\text { com diversos graus de dependência }\end{array}$} \\
\hline & \multicolumn{2}{|c|}{ "A" } & \multicolumn{2}{|c|}{ "B" } & \multicolumn{2}{|c|}{ "C" } & \multicolumn{2}{|c|}{ "D" } \\
\hline 100-0-0 & $\mathrm{R} \$$ & 4.224 & $\mathrm{R} \$$ & 4.056 & $\mathrm{R} \$$ & 3.941 & $\mathrm{R} \$$ & 3.863 \\
\hline $0-100-0$ & $\mathrm{R} \$$ & 4.916 & $\mathrm{R} \$$ & 4.751 & $\mathrm{R} \$$ & 4.634 & $\mathrm{R} \$$ & 4.556 \\
\hline $0-0-100$ & $\mathrm{R} \$$ & 5.168 & $\mathrm{R} \$$ & 5.023 & $\mathrm{R} \$$ & 4.929 & $\mathrm{R} \$$ & 4.831 \\
\hline $70-30-0$ & $\mathrm{R} \$$ & 4.550 & $\mathrm{R} \$$ & 4.382 & $\mathrm{R} \$$ & 4.267 & $\mathrm{R} \$$ & 4.189 \\
\hline 70-0-30 & $\mathrm{R} \$$ & 4.556 & $\mathrm{R} \$$ & 4.428 & $\mathrm{R} \$$ & 4.313 & $\mathrm{R} \$$ & 4.288 \\
\hline $50-40-10$ & $\mathrm{R} \$$ & 4.747 & $\mathrm{R} \$$ & 4.580 & $\mathrm{R} \$$ & 4.465 & $\mathrm{R} \$$ & 4.387 \\
\hline $60-30-10$ & $\mathrm{R} \$$ & 4.787 & $\mathrm{R} \$$ & 4.620 & $\mathrm{R} \$$ & 4.505 & $\mathrm{R} \$$ & 4.427 \\
\hline
\end{tabular}


Apêndice 290 - Valor médio da mensalidade final, com crédito médio de 1,20\% sobre o valor do investimento, para construção em 90 dias e compensação de retorno em 24 meses, em função de áreas externas, anfiteatro e minisshopping, para 200 residentes

\begin{tabular}{|c|c|c|c|c|c|c|c|c|}
\hline \multirow{2}{*}{$\begin{array}{l}\text { Porcentagem de } \\
\text { residentes com } \\
\text { grau de } \\
\text { dependência } \\
\text { I, II e III } \\
\end{array}$} & \multicolumn{8}{|c|}{$\begin{array}{l}\text { Valor médio de mensalidade final, em função de áreas } \\
\text { externas, anfiteatro e minisshopping, para } 200 \text { residentes, } \\
\text { com diversos graus de dependência }\end{array}$} \\
\hline & \multicolumn{2}{|c|}{ "A" } & \multicolumn{2}{|c|}{ "B" } & \multicolumn{2}{|c|}{ "C" } & \multicolumn{2}{|c|}{ "D" } \\
\hline $100-0-0$ & $\mathrm{R} \$$ & 3.918 & $\mathrm{R} \$$ & 3.728 & $\mathrm{R} \$$ & 3.570 & $\mathrm{R} \$$ & 3.321 \\
\hline $0-100-0$ & $\mathrm{R} \$$ & 4.632 & $\mathrm{R} \$$ & 4.442 & $\mathrm{R} \$$ & 4.284 & $\mathrm{R} \$$ & 4.035 \\
\hline $0-0-100$ & $\mathrm{R} \$$ & 4.832 & $\mathrm{R} \$$ & 4.701 & $\mathrm{R} \$$ & 4.531 & $\mathrm{R} \$$ & 4.325 \\
\hline $70-30-0$ & $\mathrm{R} \$$ & 4.182 & $\mathrm{R} \$$ & 3.992 & $\mathrm{R} \$$ & 3.835 & $\mathrm{R} \$$ & 3.585 \\
\hline 70-0-30 & $\mathrm{R} \$$ & 4.185 & $\mathrm{R} \$$ & 4.006 & $\mathrm{R} \$$ & 3.876 & $\mathrm{R} \$$ & 3.627 \\
\hline $50-40-10$ & $\mathrm{R} \$$ & 4.366 & $\mathrm{R} \$$ & 4.176 & $\mathrm{R} \$$ & 4.020 & $\mathrm{R} \$$ & 3.797 \\
\hline $60-30-10$ & $\mathrm{R} \$$ & 4.325 & $\mathrm{R} \$$ & 4.135 & $\mathrm{R} \$$ & 3.979 & $\mathrm{R} \$$ & 3.755 \\
\hline
\end{tabular}

Apêndice 291 - Valor médio da mensalidade final, com crédito médio de 1,20\% sobre o valor do investimento, para construção em 90 dias e compensação de retorno em 24 meses, em função de áreas externas, anfiteatro e minisshopping, para 300 residentes

\begin{tabular}{|c|c|c|c|c|c|c|c|c|}
\hline \multirow{2}{*}{$\begin{array}{c}\text { Porcentagem de } \\
\text { residentes com } \\
\text { grau de } \\
\text { dependência } \\
\text { I, II e III } \\
\end{array}$} & \multicolumn{8}{|c|}{$\begin{array}{l}\text { Valor médio de mensalidade final, em função de áreas } \\
\text { externas, anfiteatro e minisshopping, para } 300 \text { residentes, } \\
\text { com diversos graus de dependência }\end{array}$} \\
\hline & \multicolumn{2}{|c|}{ "A" } & \multicolumn{2}{|c|}{ "B" } & \multicolumn{2}{|c|}{ "C" } & \multicolumn{2}{|c|}{ "D" } \\
\hline $100-0-0$ & $\mathrm{R} \$$ & 3.567 & $\mathrm{R} \$$ & 3.418 & $\mathrm{R} \$$ & 3.220 & $\mathrm{R} \$$ & 3.131 \\
\hline $0-100-0$ & $\mathrm{R} \$$ & 4.274 & $\mathrm{R} \$$ & 4.126 & $\mathrm{R} \$$ & 3.927 & $\mathrm{R} \$$ & 3.837 \\
\hline $0-0-100$ & $\mathrm{R} \$$ & 4.492 & $\mathrm{R} \$$ & 4.346 & $\mathrm{R} \$$ & 4.162 & $\mathrm{R} \$$ & 4.074 \\
\hline $70-30-0$ & $\mathrm{R} \$$ & 3.812 & $\mathrm{R} \$$ & 3.664 & $\mathrm{R} \$$ & 3.498 & $\mathrm{R} \$$ & 3.375 \\
\hline 70-0-30 & $\mathrm{R} \$$ & 3.878 & $\mathrm{R} \$$ & 3.730 & $\mathrm{R} \$$ & 3.565 & $\mathrm{R} \$$ & 3.437 \\
\hline $50-40-10$ & $\mathrm{R} \$$ & 3.987 & $\mathrm{R} \$$ & 3.839 & $\mathrm{R} \$$ & 3.640 & $\mathrm{R} \$$ & 3.551 \\
\hline $60-30-10$ & $\mathrm{R} \$$ & 3.919 & $\mathrm{R} \$$ & 3.771 & $\mathrm{R} \$$ & 3.573 & $\mathrm{R} \$$ & 3.483 \\
\hline
\end{tabular}

Apêndice 292 - Valor médio da mensalidade final, com crédito médio de 1,20\% sobre o valor do investimento, para construção em 90 dias e compensação de retorno em 24 meses, em função de áreas externas, anfiteatro e minisshopping, para 400 residentes

\begin{tabular}{|c|c|c|c|c|c|c|c|c|}
\hline \multirow{2}{*}{$\begin{array}{c}\text { Porcentagem de } \\
\text { residentes com } \\
\text { grau de } \\
\text { dependência } \\
\text { I, II e III }\end{array}$} & \multicolumn{8}{|c|}{$\begin{array}{l}\text { Valor médio de mensalidade final, em função de áreas } \\
\text { externas, anfiteatro e minisshopping, para } 400 \text { residentes, } \\
\text { com diversos graus de dependência }\end{array}$} \\
\hline & \multicolumn{2}{|c|}{ "A" } & \multicolumn{2}{|c|}{ "B" } & \multicolumn{2}{|c|}{ "C" } & \multicolumn{2}{|c|}{ "D" } \\
\hline $100-0-0$ & $\mathrm{R} \$$ & 3.404 & $\mathrm{R} \$$ & 3.276 & $\mathrm{R} \$$ & 3.084 & $\mathrm{R} \$$ & 3.008 \\
\hline $0-100-0$ & $\mathrm{R} \$$ & 4.118 & $\mathrm{R} \$$ & 3.990 & $\mathrm{R} \$$ & 3.798 & $\mathrm{R} \$$ & 3.722 \\
\hline $0-0-100$ & $\mathrm{R} \$$ & 4.341 & $\mathrm{R} \$$ & 4.226 & $\mathrm{R} \$$ & 4.059 & $\mathrm{R} \$$ & 3.989 \\
\hline $70-30-0$ & $\mathrm{R} \$$ & 3.638 & $\mathrm{R} \$$ & 3.511 & $\mathrm{R} \$$ & 3.343 & $\mathrm{R} \$$ & 3.242 \\
\hline 70-0-30 & $\mathrm{R} \$$ & 3.682 & $\mathrm{R} \$$ & 3.542 & $\mathrm{R} \$$ & 3.411 & $\mathrm{R} \$$ & 3.297 \\
\hline $50-40-10$ & $\mathrm{R} \$$ & 3.819 & $\mathrm{R} \$$ & 3.673 & $\mathrm{R} \$$ & 3.504 & $\mathrm{R} \$$ & 3.433 \\
\hline $60-30-10$ & $\mathrm{R} \$$ & 3.747 & $\mathrm{R} \$$ & 3.602 & $\mathrm{R} \$$ & 3.433 & $\mathrm{R} \$$ & 3.361 \\
\hline
\end{tabular}


Apêndice 293 - Valor médio da mensalidade final, com crédito médio de 1,30\% sobre o valor do investimento, para construção em 90 dias e compensação de retorno em 24 meses, em função de áreas externas, anfiteatro e minisshopping, para 100 residentes

\begin{tabular}{|c|c|c|c|c|c|c|c|c|}
\hline \multirow{3}{*}{$\begin{array}{c}\text { Porcentagem de } \\
\text { residentes com } \\
\text { grau de } \\
\text { dependência } \\
\text { I, II e III } \\
100-0-0\end{array}$} & \multicolumn{8}{|c|}{$\begin{array}{l}\text { Valor médio de mensalidade final, em função de áreas } \\
\text { externas, anfiteatro e minisshopping, para } 100 \text { residentes, } \\
\text { com diversos graus de dependência }\end{array}$} \\
\hline & \multicolumn{2}{|c|}{ "A" } & \multicolumn{2}{|c|}{ "B" } & \multicolumn{2}{|c|}{ "C" } & \multicolumn{2}{|c|}{ "D" } \\
\hline & $\mathrm{R} \$$ & 4.302 & $\mathrm{R} \$$ & 4.131 & $\mathrm{R} \$$ & 4.012 & $\mathrm{R} \$$ & 3.932 \\
\hline $0-100-0$ & $\mathrm{R} \$$ & 4.994 & $\mathrm{R} \$$ & 4.826 & $\mathrm{R} \$$ & 4.705 & $\mathrm{R} \$$ & 4.625 \\
\hline $0-0-100$ & $\mathrm{R} \$$ & 5.238 & $\mathrm{R} \$$ & 5.091 & $\mathrm{R} \$$ & 4.992 & $\mathrm{R} \$$ & 4.892 \\
\hline 70-30-0 & $\mathrm{R} \$$ & 4.627 & $\mathrm{R} \$$ & 4.457 & $\mathrm{R} \$$ & 4.338 & $\mathrm{R} \$$ & 4.258 \\
\hline 70-0-30 & $\mathrm{R} \$$ & 4.632 & $\mathrm{R} \$$ & 4.501 & $\mathrm{R} \$$ & 4.382 & $\mathrm{R} \$$ & 4.355 \\
\hline $50-40-10$ & $\mathrm{R} \$$ & 4.824 & $\mathrm{R} \$$ & 4.654 & $\mathrm{R} \$$ & 4.535 & $\mathrm{R} \$$ & 4.455 \\
\hline $60-30-10$ & $\mathrm{R} \$$ & 4.865 & $\mathrm{R} \$$ & 4.695 & $\mathrm{R} \$$ & 4.576 & $\mathrm{R} \$$ & 4.496 \\
\hline
\end{tabular}

Apêndice 294 - Valor médio da mensalidade final, com crédito médio de 1,30\% sobre o valor do investimento, para construção em 90 dias e compensação de retorno em 24 meses, em função de áreas externas, anfiteatro e minisshopping, para 200 residentes

\begin{tabular}{|c|c|c|c|c|c|c|c|c|}
\hline \multirow{3}{*}{$\begin{array}{c}\text { Porcentagem de } \\
\text { residentes com } \\
\text { grau de } \\
\text { dependência } \\
\text { I, II e III } \\
100-0-0\end{array}$} & \multicolumn{8}{|c|}{$\begin{array}{l}\text { Valor médio de mensalidade final, em função de áreas } \\
\text { externas, anfiteatro e minisshopping, para } 200 \text { residentes, } \\
\text { com diversos graus de dependência }\end{array}$} \\
\hline & \multicolumn{2}{|c|}{ "A" } & \multicolumn{2}{|c|}{ "B" } & \multicolumn{2}{|c|}{ "C" } & \multicolumn{2}{|c|}{ "D" } \\
\hline & $\mathrm{R} \$$ & 3.996 & $\mathrm{R} \$$ & 3.802 & $\mathrm{R} \$$ & 3.640 & $\mathrm{R} \$$ & 3.386 \\
\hline $0-100-0$ & $\mathrm{R} \$$ & 4.711 & $\mathrm{R} \$$ & 4.516 & $\mathrm{R} \$$ & 4.354 & $\mathrm{R} \$$ & 4.100 \\
\hline $0-0-100$ & $\mathrm{R} \$$ & 4.903 & $\mathrm{R} \$$ & 4.768 & $\mathrm{R} \$$ & 4.594 & $\mathrm{R} \$$ & 4.383 \\
\hline $70-30-0$ & $\mathrm{R} \$$ & 4.261 & $\mathrm{R} \$$ & 4.067 & $\mathrm{R} \$$ & 3.905 & $\mathrm{R} \$$ & 3.650 \\
\hline $70-0-30$ & $\mathrm{R} \$$ & 4.262 & $\mathrm{R} \$$ & 4.078 & $\mathrm{R} \$$ & 3.945 & $\mathrm{R} \$$ & 3.690 \\
\hline $50-40-10$ & $\mathrm{R} \$$ & 4.443 & $\mathrm{R} \$$ & 4.249 & $\mathrm{R} \$$ & 4.089 & $\mathrm{R} \$$ & 3.861 \\
\hline $60-30-10$ & $\mathrm{R} \$$ & 4.403 & $\mathrm{R} \$$ & 4.208 & $\mathrm{R} \$$ & 4.048 & $\mathrm{R} \$$ & 3.819 \\
\hline
\end{tabular}

Apêndice 295 - Valor médio da mensalidade final, com crédito médio de 1,30\% sobre o valor do investimento, para construção em 90 dias e compensação de retorno em 24 meses, em função de áreas externas, anfiteatro e minisshopping, para 300 residentes

\begin{tabular}{|c|c|c|c|c|c|c|c|c|}
\hline \multirow{2}{*}{$\begin{array}{c}\text { Porcentagem de } \\
\text { residentes com } \\
\text { grau de } \\
\text { dependência } \\
\text { I, II e III }\end{array}$} & \multicolumn{8}{|c|}{$\begin{array}{l}\text { Valor médio de mensalidade final, em função de áreas } \\
\text { externas, anfiteatro e minisshopping, para } 300 \text { residentes, } \\
\text { com diversos graus de dependência }\end{array}$} \\
\hline & \multicolumn{2}{|c|}{ "A" } & \multicolumn{2}{|c|}{ "B" } & \multicolumn{2}{|c|}{ "C" } & \multicolumn{2}{|c|}{ "D" } \\
\hline $100-0-0$ & $\mathrm{R} \$$ & 3.640 & $\mathrm{R} \$$ & 3.488 & $\mathrm{R} \$$ & 3.285 & $\mathrm{R} \$$ & 3.194 \\
\hline $0-100-0$ & $\mathrm{R} \$$ & 4.348 & $\mathrm{R} \$$ & 4.196 & $\mathrm{R} \$$ & 3.992 & $\mathrm{R} \$$ & 3.900 \\
\hline $0-0-100$ & $\mathrm{R} \$$ & 4.558 & $\mathrm{R} \$$ & 4.409 & $\mathrm{R} \$$ & 4.220 & $\mathrm{R} \$$ & 4.131 \\
\hline $70-30-0$ & $\mathrm{R} \$$ & 3.885 & $\mathrm{R} \$$ & 3.733 & $\mathrm{R} \$$ & 3.564 & $\mathrm{R} \$$ & 3.438 \\
\hline 70-0-30 & $\mathrm{R} \$$ & 3.949 & $\mathrm{R} \$$ & 3.798 & $\mathrm{R} \$$ & 3.630 & $\mathrm{R} \$$ & 3.498 \\
\hline $50-40-10$ & $\mathrm{R} \$$ & 4.060 & $\mathrm{R} \$$ & 3.908 & $\mathrm{R} \$$ & 3.705 & $\mathrm{R} \$$ & 3.614 \\
\hline $60-30-10$ & $\mathrm{R} \$$ & 3.992 & $\mathrm{R} \$$ & 3.840 & $\mathrm{R} \$$ & 3.637 & $\mathrm{R} \$$ & 3.546 \\
\hline
\end{tabular}


Apêndice 296 - Valor médio da mensalidade final, com crédito médio de 1,30\% sobre o valor do investimento, para construção em 90 dias e compensação de retorno em 24 meses, em função de áreas externas, anfiteatro e minisshopping, para 400 residentes

\begin{tabular}{|c|c|c|c|c|c|c|c|c|}
\hline \multirow{2}{*}{$\begin{array}{l}\text { Porcentagem de } \\
\text { residentes com } \\
\text { grau de } \\
\text { dependência } \\
\text { I, II e III } \\
\end{array}$} & \multicolumn{8}{|c|}{$\begin{array}{l}\text { Valor médio de mensalidade final, em função de áreas } \\
\text { externas, anfiteatro e minisshopping, para } 400 \text { residentes, } \\
\text { com diversos graus de dependência }\end{array}$} \\
\hline & \multicolumn{2}{|c|}{ "A" } & \multicolumn{2}{|c|}{ "B" } & \multicolumn{2}{|c|}{ "C" } & \multicolumn{2}{|c|}{ "D" } \\
\hline $100-0-0$ & $\mathrm{R} \$$ & 3.476 & $\mathrm{R} \$$ & 3.345 & $\mathrm{R} \$$ & 3.148 & $\mathrm{R} \$$ & 3.071 \\
\hline $0-100-0$ & $\mathrm{R} \$$ & 4.190 & $\mathrm{R} \$$ & 4.059 & $\mathrm{R} \$$ & 3.862 & $\mathrm{R} \$$ & 3.785 \\
\hline $0-0-100$ & $\mathrm{R} \$$ & 4.406 & $\mathrm{R} \$$ & 4.288 & $\mathrm{R} \$$ & 4.117 & $\mathrm{R} \$$ & 4.045 \\
\hline $70-30-0$ & $\mathrm{R} \$$ & 3.710 & $\mathrm{R} \$$ & 3.580 & $\mathrm{R} \$$ & 3.409 & $\mathrm{R} \$$ & 3.305 \\
\hline 70-0-30 & $\mathrm{R} \$$ & 3.752 & $\mathrm{R} \$$ & 3.608 & $\mathrm{R} \$$ & 3.475 & $\mathrm{R} \$$ & 3.358 \\
\hline $50-40-10$ & $\mathrm{R} \$$ & 3.891 & $\mathrm{R} \$$ & 3.741 & $\mathrm{R} \$$ & 3.568 & $\mathrm{R} \$$ & 3.496 \\
\hline $60-30-10$ & $\mathrm{R} \$$ & 3.819 & $\mathrm{R} \$$ & 3.670 & $\mathrm{R} \$$ & 3.497 & $\mathrm{R} \$$ & 3.424 \\
\hline
\end{tabular}

Apêndice 297 - Valor médio da mensalidade final, com crédito médio de 1,40\% sobre o valor do investimento, para construção em 90 dias e compensação de retorno em 24 meses, em função de áreas externas, anfiteatro e minisshopping, para 100 residentes

\begin{tabular}{|c|c|c|c|c|c|c|c|c|}
\hline \multirow{2}{*}{$\begin{array}{c}\text { Porcentagem de } \\
\text { residentes com } \\
\text { grau de } \\
\text { dependência } \\
\text { I, II e III } \\
\end{array}$} & \multicolumn{8}{|c|}{$\begin{array}{l}\text { Valor médio de mensalidade final, em função de áreas } \\
\text { externas, anfiteatro e minisshopping, para } 100 \text { residentes, } \\
\text { com diversos graus de dependência }\end{array}$} \\
\hline & \multicolumn{2}{|c|}{ "A" } & \multicolumn{2}{|c|}{ "B" } & \multicolumn{2}{|c|}{ "C" } & \multicolumn{2}{|c|}{ "D" } \\
\hline 100-0-0 & $\mathrm{R} \$$ & 4.379 & $\mathrm{R} \$$ & 4.206 & $\mathrm{R} \$$ & 4.082 & $\mathrm{R} \$$ & 4.000 \\
\hline $0-100-0$ & $\mathrm{R} \$$ & 5.072 & $\mathrm{R} \$$ & 4.901 & $\mathrm{R} \$$ & 4.776 & $\mathrm{R} \$$ & 4.693 \\
\hline $0-0-100$ & $\mathrm{R} \$$ & 5.308 & $\mathrm{R} \$$ & 5.158 & $\mathrm{R} \$$ & 5.055 & $\mathrm{R} \$$ & 4.953 \\
\hline $70-30-0$ & $\mathrm{R} \$$ & 4.705 & $\mathrm{R} \$$ & 4.532 & $\mathrm{R} \$$ & 4.409 & $\mathrm{R} \$$ & 4.326 \\
\hline 70-0-30 & $\mathrm{R} \$$ & 4.708 & $\mathrm{R} \$$ & 4.574 & $\mathrm{R} \$$ & 4.451 & $\mathrm{R} \$$ & 4.422 \\
\hline $50-40-10$ & $\mathrm{R} \$$ & 4.901 & $\mathrm{R} \$$ & 4.728 & $\mathrm{R} \$$ & 4.605 & $\mathrm{R} \$$ & 4.523 \\
\hline $60-30-10$ & $\mathrm{R} \$$ & 4.942 & $\mathrm{R} \$$ & 4.769 & $\mathrm{R} \$$ & 4.646 & $\mathrm{R} \$$ & 4.564 \\
\hline
\end{tabular}

Apêndice 298 - Valor médio da mensalidade final, com crédito médio de 1,40\% sobre o valor do investimento, para construção em 90 dias e compensação de retorno em 24 meses, em função de áreas externas, anfiteatro e minisshopping, para 200 residentes

\begin{tabular}{|c|c|c|c|c|c|c|c|c|}
\hline \multirow{2}{*}{$\begin{array}{c}\text { Porcentagem de } \\
\text { residentes com } \\
\text { grau de } \\
\text { dependência } \\
\text { I, II e III }\end{array}$} & \multicolumn{8}{|c|}{$\begin{array}{l}\text { Valor médio de mensalidade final, em função de áreas } \\
\text { externas, anfiteatro e minisshopping, para } 200 \text { residentes, } \\
\text { com diversos graus de dependência }\end{array}$} \\
\hline & \multicolumn{2}{|c|}{ "A" } & \multicolumn{2}{|c|}{ "B" } & \multicolumn{2}{|c|}{ "C" } & \multicolumn{2}{|c|}{ "D" } \\
\hline 100-0-0 & $\mathrm{R} \$$ & 4.075 & $\mathrm{R} \$$ & 3.876 & $\mathrm{R} \$$ & 3.710 & $\mathrm{R} \$$ & 3.451 \\
\hline $0-100-0$ & $\mathrm{R} \$$ & 4.789 & $\mathrm{R} \$$ & 4.591 & $\mathrm{R} \$$ & 4.425 & $\mathrm{R} \$$ & 4.165 \\
\hline $0-0-100$ & $\mathrm{R} \$$ & 4.974 & $\mathrm{R} \$$ & 4.835 & $\mathrm{R} \$$ & 4.657 & $\mathrm{R} \$$ & 4.441 \\
\hline $70-30-0$ & $\mathrm{R} \$$ & 4.340 & $\mathrm{R} \$$ & 4.141 & $\mathrm{R} \$$ & 3.975 & $\mathrm{R} \$$ & 3.715 \\
\hline 70-0-30 & $\mathrm{R} \$$ & 4.338 & $\mathrm{R} \$$ & 4.150 & $\mathrm{R} \$$ & 4.013 & $\mathrm{R} \$$ & 3.753 \\
\hline $50-40-10$ & $\mathrm{R} \$$ & 4.521 & $\mathrm{R} \$$ & 4.323 & $\mathrm{R} \$$ & 4.158 & $\mathrm{R} \$$ & 3.925 \\
\hline $60-30-10$ & $\mathrm{R} \$$ & 4.480 & $\mathrm{R} \$$ & 4.282 & $\mathrm{R} \$$ & 4.117 & $\mathrm{R} \$$ & 3.883 \\
\hline
\end{tabular}


Apêndice 299 - Valor médio da mensalidade final, com crédito médio de 1,40\% sobre o valor do investimento, para construção em 90 dias e compensação de retorno em 24 meses, em função de áreas externas, anfiteatro e minisshopping, para 300 residentes

\begin{tabular}{|c|c|c|c|c|c|c|c|c|}
\hline \multirow{2}{*}{$\begin{array}{l}\text { Porcentagem de } \\
\text { residentes com } \\
\text { grau de } \\
\text { dependência } \\
\text { I, II e III } \\
\end{array}$} & \multicolumn{8}{|c|}{$\begin{array}{l}\text { Valor médio de mensalidade final, em função de áreas } \\
\text { externas, anfiteatro e minisshopping, para } 300 \text { residentes, } \\
\text { com diversos graus de dependência }\end{array}$} \\
\hline & \multicolumn{2}{|c|}{ "A" } & \multicolumn{2}{|c|}{ "B" } & \multicolumn{2}{|c|}{ "C" } & \multicolumn{2}{|c|}{ "D" } \\
\hline $100-0-0$ & $\mathrm{R} \$$ & 3.713 & $\mathrm{R} \$$ & 3.558 & $\mathrm{R} \$$ & 3.350 & $\mathrm{R} \$$ & 3.257 \\
\hline $0-100-0$ & $\mathrm{R} \$$ & 4.421 & $\mathrm{R} \$$ & 4.266 & $\mathrm{R} \$$ & 4.057 & $\mathrm{R} \$$ & 3.964 \\
\hline $0-0-100$ & $\mathrm{R} \$$ & 4.624 & $\mathrm{R} \$$ & 4.471 & $\mathrm{R} \$$ & 4.278 & $\mathrm{R} \$$ & 4.187 \\
\hline $70-30-0$ & $\mathrm{R} \$$ & 3.958 & $\mathrm{R} \$$ & 3.803 & $\mathrm{R} \$$ & 3.630 & $\mathrm{R} \$$ & 3.501 \\
\hline 70-0-30 & $\mathrm{R} \$$ & 4.020 & $\mathrm{R} \$$ & 3.866 & $\mathrm{R} \$$ & 3.694 & $\mathrm{R} \$$ & 3.559 \\
\hline $50-40-10$ & $\mathrm{R} \$$ & 4.132 & $\mathrm{R} \$$ & 3.977 & $\mathrm{R} \$$ & 3.769 & $\mathrm{R} \$$ & 3.677 \\
\hline $60-30-10$ & $\mathrm{R} \$$ & 4.064 & $\mathrm{R} \$$ & 3.909 & $\mathrm{R} \$$ & 3.701 & $\mathrm{R} \$$ & 3.609 \\
\hline
\end{tabular}

Apêndice 300 - Valor médio da mensalidade final, com crédito médio de 1,40\% sobre o valor do investimento, para construção em 90 dias e compensação de retorno em 24 meses, em função de áreas externas, anfiteatro e minisshopping, para 400 residentes

\begin{tabular}{|c|c|c|c|c|c|c|c|c|}
\hline \multirow{2}{*}{$\begin{array}{c}\text { Porcentagem de } \\
\text { residentes com } \\
\text { grau de } \\
\text { dependência } \\
\text { I, II e III } \\
\end{array}$} & \multicolumn{8}{|c|}{$\begin{array}{l}\text { Valor médio de mensalidade final, em função de áreas } \\
\text { externas, anfiteatro e minisshopping, para } 400 \text { residentes, } \\
\text { com diversos graus de dependência }\end{array}$} \\
\hline & \multicolumn{2}{|c|}{ "A" } & \multicolumn{2}{|c|}{ "B" } & \multicolumn{2}{|c|}{ "C" } & \multicolumn{2}{|c|}{ "D" } \\
\hline 100-0-0 & $\mathrm{R} \$$ & 3.548 & $\mathrm{R} \$$ & 3.414 & $\mathrm{R} \$$ & 3.213 & $\mathrm{R} \$$ & 3.134 \\
\hline $0-100-0$ & $\mathrm{R} \$$ & 4.262 & $\mathrm{R} \$$ & 4.128 & $\mathrm{R} \$$ & 3.927 & $\mathrm{R} \$$ & 3.848 \\
\hline $0-0-100$ & $\mathrm{R} \$$ & 4.471 & $\mathrm{R} \$$ & 4.349 & $\mathrm{R} \$$ & 4.175 & $\mathrm{R} \$$ & 4.101 \\
\hline $70-30-0$ & $\mathrm{R} \$$ & 3.782 & $\mathrm{R} \$$ & 3.649 & $\mathrm{R} \$$ & 3.474 & $\mathrm{R} \$$ & 3.368 \\
\hline 70-0-30 & $\mathrm{R} \$$ & 3.822 & $\mathrm{R} \$$ & 3.675 & $\mathrm{R} \$$ & 3.538 & $\mathrm{R} \$$ & 3.419 \\
\hline $50-40-10$ & $\mathrm{R} \$$ & 3.962 & $\mathrm{R} \$$ & 3.809 & $\mathrm{R} \$$ & 3.632 & $\mathrm{R} \$$ & 3.558 \\
\hline $60-30-10$ & $\mathrm{R} \$$ & 3.890 & $\mathrm{R} \$$ & 3.738 & $\mathrm{R} \$$ & 3.560 & $\mathrm{R} \$$ & 3.486 \\
\hline
\end{tabular}

Apêndice 301 - Valor médio da mensalidade final, com crédito médio de 1,50\% sobre o valor do investimento, para construção em 90 dias e compensação de retorno em 24 meses, em função de áreas externas, anfiteatro e minisshopping, para 100 residentes

\begin{tabular}{|c|c|c|c|c|c|c|c|c|}
\hline \multirow{3}{*}{$\begin{array}{c}\text { Porcentagem de } \\
\text { residentes com } \\
\text { grau de } \\
\text { dependência } \\
\text { I, II e III } \\
100-0-0\end{array}$} & \multicolumn{8}{|c|}{$\begin{array}{l}\text { Valor médio de mensalidade final, em função de áreas } \\
\text { externas, anfiteatro e minisshopping, para } 100 \text { residentes, } \\
\text { com diversos graus de dependência }\end{array}$} \\
\hline & \multicolumn{2}{|c|}{ "A" } & \multicolumn{2}{|c|}{ "B" } & \multicolumn{2}{|c|}{ "C" } & \multicolumn{2}{|c|}{ "D" } \\
\hline & $\mathrm{R} \$$ & 4.457 & $\mathrm{R} \$$ & 4.281 & $\mathrm{R} \$$ & 4.153 & $\mathrm{R} \$$ & 4.069 \\
\hline $0-100-0$ & $\mathrm{R} \$$ & 5.150 & $\mathrm{R} \$$ & 4.976 & $\mathrm{R} \$$ & 4.846 & $\mathrm{R} \$$ & 4.762 \\
\hline $0-0-100$ & $\mathrm{R} \$$ & 5.378 & $\mathrm{R} \$$ & 5.225 & $\mathrm{R} \$$ & 5.118 & $\mathrm{R} \$$ & 5.014 \\
\hline $70-30-0$ & $\mathrm{R} \$$ & 4.783 & $\mathrm{R} \$$ & 4.607 & $\mathrm{R} \$$ & 4.480 & $\mathrm{R} \$$ & 4.395 \\
\hline 70-0-30 & $\mathrm{R} \$$ & 4.784 & $\mathrm{R} \$$ & 4.647 & $\mathrm{R} \$$ & 4.520 & $\mathrm{R} \$$ & 4.489 \\
\hline $50-40-10$ & $\mathrm{R} \$$ & 4.979 & $\mathrm{R} \$$ & 4.803 & $\mathrm{R} \$$ & 4.676 & $\mathrm{R} \$$ & 4.592 \\
\hline $60-30-10$ & $\mathrm{R} \$$ & 5.019 & $\mathrm{R} \$$ & 4.843 & $\mathrm{R} \$$ & 4.716 & $\mathrm{R} \$$ & 4.632 \\
\hline
\end{tabular}


Apêndice 302 - Valor médio da mensalidade final, com crédito médio de 1,50\% sobre o valor do investimento, para construção em 90 dias e compensação de retorno em 24 meses, em função de áreas externas, anfiteatro e minisshopping, para 200 residentes

\begin{tabular}{|c|c|c|c|c|c|c|c|c|}
\hline \multirow{3}{*}{$\begin{array}{c}\text { Porcentagem de } \\
\text { residentes com } \\
\text { grau de } \\
\text { dependência } \\
\text { I, II e III } \\
\mathbf{1 0 0 - 0 - 0}\end{array}$} & \multicolumn{8}{|c|}{$\begin{array}{l}\text { Valor médio de mensalidade final, em função de áreas } \\
\text { externas, anfiteatro e minisshopping, para } 200 \text { residentes, } \\
\text { com diversos graus de dependência }\end{array}$} \\
\hline & \multicolumn{2}{|c|}{ "A" } & \multicolumn{2}{|c|}{ "B" } & \multicolumn{2}{|c|}{ "C" } & \multicolumn{2}{|c|}{ "D" } \\
\hline & $\mathrm{R} \$$ & 4.154 & $\mathrm{R} \$$ & 3.951 & $\mathrm{R} \$$ & 3.781 & $\mathrm{R} \$$ & 3.515 \\
\hline $0-100-0$ & $\mathrm{R} \$$ & 4.868 & $\mathrm{R} \$$ & 4.665 & $\mathrm{R} \$$ & 4.495 & $\mathrm{R} \$$ & 4.230 \\
\hline $0-0-100$ & $\mathrm{R} \$$ & 5.045 & $\mathrm{R} \$$ & 4.902 & $\mathrm{R} \$$ & 4.720 & $\mathrm{R} \$$ & 4.499 \\
\hline $70-30-0$ & $\mathrm{R} \$$ & 4.419 & $\mathrm{R} \$$ & 4.216 & $\mathrm{R} \$$ & 4.045 & $\mathrm{R} \$$ & 3.780 \\
\hline 70-0-30 & $\mathrm{R} \$$ & 4.415 & $\mathrm{R} \$$ & 4.223 & $\mathrm{R} \$$ & 4.081 & $\mathrm{R} \$$ & 3.815 \\
\hline $50-40-10$ & $\mathrm{R} \$$ & 4.599 & $\mathrm{R} \$$ & 4.396 & $\mathrm{R} \$$ & 4.228 & $\mathrm{R} \$$ & 3.989 \\
\hline $60-30-10$ & $\mathrm{R} \$$ & 4.558 & $\mathrm{R} \$$ & 4.355 & $\mathrm{R} \$$ & 4.187 & $\mathrm{R} \$$ & 3.947 \\
\hline
\end{tabular}

Apêndice 303 - Valor médio da mensalidade final, com crédito médio de 1,50\% sobre o valor do investimento, para construção em 90 dias e compensação de retorno em 24 meses, em função de áreas externas, anfiteatro e minisshopping, para 300 residentes

\begin{tabular}{|c|c|c|c|c|c|c|c|c|}
\hline \multirow{2}{*}{$\begin{array}{c}\text { Porcentagem de } \\
\text { residentes com } \\
\text { grau de } \\
\text { dependência } \\
\text { I, II e III } \\
\end{array}$} & \multicolumn{8}{|c|}{$\begin{array}{l}\text { Valor médio de mensalidade final, em função de áreas } \\
\text { externas, anfiteatro e minisshopping, para } 300 \text { residentes, } \\
\text { com diversos graus de dependência }\end{array}$} \\
\hline & \multicolumn{2}{|c|}{ "A" } & \multicolumn{2}{|c|}{ "B" } & \multicolumn{2}{|c|}{ "C" } & \multicolumn{2}{|c|}{ "D" } \\
\hline 100-0-0 & $\mathrm{R} \$$ & 3.786 & $\mathrm{R} \$$ & 3.627 & $\mathrm{R} \$$ & 3.415 & $\mathrm{R} \$$ & 3.320 \\
\hline $0-100-0$ & $\mathrm{R} \$$ & 4.494 & $\mathrm{R} \$$ & 4.335 & $\mathrm{R} \$$ & 4.122 & $\mathrm{R} \$$ & 4.027 \\
\hline $0-0-100$ & $\mathrm{R} \$$ & 4.690 & $\mathrm{R} \$$ & 4.534 & $\mathrm{R} \$$ & 4.337 & $\mathrm{R} \$$ & 4.244 \\
\hline $70-30-0$ & $\mathrm{R} \$$ & 4.032 & $\mathrm{R} \$$ & 3.873 & $\mathrm{R} \$$ & 3.696 & $\mathrm{R} \$$ & 3.564 \\
\hline 70-0-30 & $\mathrm{R} \$$ & 4.091 & $\mathrm{R} \$$ & 3.933 & $\mathrm{R} \$$ & 3.758 & $\mathrm{R} \$$ & 3.620 \\
\hline $50-40-10$ & $\mathrm{R} \$$ & 4.205 & $\mathrm{R} \$$ & 4.046 & $\mathrm{R} \$$ & 3.833 & $\mathrm{R} \$$ & 3.739 \\
\hline $60-30-10$ & $\mathrm{R} \$$ & 4.137 & $\mathrm{R} \$$ & 3.978 & $\mathrm{R} \$$ & 3.765 & $\mathrm{R} \$$ & 3.671 \\
\hline
\end{tabular}

Apêndice 304 - Valor médio da mensalidade final, com crédito médio de 1,50\% sobre o valor do investimento, para construção em 90 dias e compensação de retorno em 24 meses, em função de áreas externas, anfiteatro e minisshopping, para 400 residentes

\begin{tabular}{|c|c|c|c|c|c|c|c|c|}
\hline \multirow{2}{*}{$\begin{array}{l}\text { Porcentagem de } \\
\text { residentes com } \\
\text { grau de } \\
\text { dependência } \\
\text { I, II e III }\end{array}$} & \multicolumn{8}{|c|}{$\begin{array}{l}\text { Valor médio de mensalidade final, em função de áreas } \\
\text { externas, anfiteatro e minisshopping, para } 400 \text { residentes, } \\
\text { com diversos graus de dependência }\end{array}$} \\
\hline & \multicolumn{2}{|c|}{ "A" } & \multicolumn{2}{|c|}{ "B" } & \multicolumn{2}{|c|}{ "C" } & \multicolumn{2}{|c|}{ "D" } \\
\hline 100-0-0 & $\mathrm{R} \$$ & 3.620 & $\mathrm{R} \$$ & 3.482 & $\mathrm{R} \$$ & 3.277 & $\mathrm{R} \$$ & 3.197 \\
\hline $0-100-0$ & $\mathrm{R} \$$ & 4.334 & $\mathrm{R} \$$ & 4.197 & $\mathrm{R} \$$ & 3.992 & $\mathrm{R} \$$ & 3.911 \\
\hline $0-0-100$ & $\mathrm{R} \$$ & 4.535 & $\mathrm{R} \$$ & 4.411 & $\mathrm{R} \$$ & 4.232 & $\mathrm{R} \$$ & 4.158 \\
\hline $70-30-0$ & $\mathrm{R} \$$ & 3.854 & $\mathrm{R} \$$ & 3.717 & $\mathrm{R} \$$ & 3.540 & $\mathrm{R} \$$ & 3.431 \\
\hline 70-0-30 & $\mathrm{R} \$$ & 3.891 & $\mathrm{R} \$$ & 3.742 & $\mathrm{R} \$$ & 3.602 & $\mathrm{R} \$$ & 3.480 \\
\hline $50-40-10$ & $\mathrm{R} \$$ & 4.033 & $\mathrm{R} \$$ & 3.877 & $\mathrm{R} \$$ & 3.696 & $\mathrm{R} \$$ & 3.620 \\
\hline $60-30-10$ & $\mathrm{R} \$$ & 3.961 & $\mathrm{R} \$$ & 3.806 & $\mathrm{R} \$$ & 3.624 & $\mathrm{R} \$$ & 3.548 \\
\hline
\end{tabular}


Apêndice 305 - Variação do investimento inicial em função do número de habitações e áreas externas construídas

\begin{tabular}{|c|c|c|c|c|c|c|c|c|c|}
\hline \multirow{2}{*}{$\begin{array}{l}\text { Número de } \\
\text { residentes }\end{array}$} & \multirow{2}{*}{ Descrição } & \multicolumn{8}{|c|}{ Porcentagem de habitações construídas na $1^{\text {a }}$ fase } \\
\hline & & \multicolumn{2}{|r|}{$100 \%$} & \multicolumn{2}{|r|}{$80 \%$} & \multicolumn{2}{|r|}{$60 \%$} & \multicolumn{2}{|r|}{$40 \%$} \\
\hline \multirow{8}{*}{100} & $\mathrm{~N}^{\mathrm{o}}$ Habitações & & 50 & & 40 & & 30 & & 20 \\
\hline & Construção civil das habitações & $\mathrm{R} \$$ & 1.503 .800 & $\mathrm{R} \$$ & 1.203 .040 & $\mathrm{R} \$$ & 902.280 & $\mathrm{R} \$$ & 601.520 \\
\hline & Móveis e eletrodomésticos das habitações & $\mathrm{R} \$$ & 465.000 & $\mathrm{R} \$$ & 372.000 & $\mathrm{R} \$$ & 279.000 & $\mathrm{R} \$$ & 186.000 \\
\hline & Investimento em áreas externas & $\mathrm{R} \$$ & 162.800 & $\mathrm{R} \$$ & 35.000 & $\mathrm{R} \$$ & 35.000 & $\mathrm{R} \$$ & 35.000 \\
\hline & Demais investimentos & $\mathrm{R} \$$ & 2.631 .751 & $\mathrm{R} \$$ & 2.631 .751 & $\mathrm{R} \$$ & 2.631 .751 & $\mathrm{R} \$$ & 2.631 .751 \\
\hline & Investimento total & $\mathrm{R} \$$ & 4.763 .351 & $\mathrm{R} \$$ & 4.241 .791 & $\mathrm{R} \$$ & 3.848 .031 & $\mathrm{R} \$$ & 3.454 .271 \\
\hline & Volume de investimento & & $100 \%$ & & $89 \%$ & & $81 \%$ & & $73 \%$ \\
\hline & $\mathrm{N}^{\circ}$ de Proprietários necessários à $\mathrm{R} \$ 95.267$ & & 50 & & 45 & & 41 & & 37 \\
\hline \multirow{8}{*}{200} & $\mathrm{~N}^{\circ}$ Habitações & & 100 & & 80 & & 60 & & 40 \\
\hline & Construção civil das habitações & $\mathrm{R} \$$ & 3.007 .600 & $\mathrm{R} \$$ & 2.406 .080 & $\mathrm{R} \$$ & 1.804 .560 & $\mathrm{R} \$$ & 1.203 .040 \\
\hline & Móveis e eletrodomésticos das habitações & $\mathrm{R} \$$ & 930.000 & $\mathrm{R} \$$ & 744.000 & $\mathrm{R} \$$ & 558.000 & $\mathrm{R} \$$ & 372.000 \\
\hline & Investimento em áreas externas & $\mathrm{R} \$$ & 392.800 & $\mathrm{R} \$$ & 35.000 & $\mathrm{R} \$$ & 35.000 & $\mathrm{R} \$$ & 35.000 \\
\hline & Demais investimentos & $\mathrm{R} \$$ & 5.308 .697 & $\mathrm{R} \$$ & 5.308 .697 & $\mathrm{R} \$$ & 5.308 .697 & $\mathrm{R} \$$ & 5.308 .697 \\
\hline & Investimento total & $\mathrm{R} \$$ & 9.639 .097 & $\mathrm{R} \$$ & 8.493 .777 & $\mathrm{R} \$$ & 7.706 .257 & $\mathrm{R} \$$ & 6.918 .737 \\
\hline & Volume de investimento & & $100 \%$ & & $88 \%$ & & $80 \%$ & & $72 \%$ \\
\hline & $\mathrm{N}^{\circ}$ de Proprietários necessários à $\mathrm{R} \$ 96.391$ & & 100 & & 89 & & 80 & & 72 \\
\hline \multirow{8}{*}{300} & $\mathrm{~N}^{\circ}$ Habitações & & 150 & & 120 & & 90 & & 60 \\
\hline & Construção civil das habitações & $\mathrm{R} \$$ & 4.511 .400 & $\mathrm{R} \$$ & 3.609 .120 & $\mathrm{R} \$$ & 2.706 .840 & $\mathrm{R} \$$ & 1.804 .560 \\
\hline & Móveis e eletrodomésticos das habitações & $\mathrm{R} \$$ & 1.395 .000 & $\mathrm{R} \$$ & 1.116 .000 & $\mathrm{R} \$$ & 837.000 & $\mathrm{R} \$$ & 558.000 \\
\hline & Investimento em áreas externas & $\mathrm{R} \$$ & 392.800 & $\mathrm{R} \$$ & 35.000 & $\mathrm{R} \$$ & 35.000 & $\mathrm{R} \$$ & 35.000 \\
\hline & Demais investimentos & $\mathrm{R} \$$ & 7.151 .325 & $\mathrm{R} \$$ & 7.151 .325 & $\mathrm{R} \$$ & 7.151 .325 & $\mathrm{R} \$$ & 7.151 .325 \\
\hline & Investimento total & $\mathrm{R} \$$ & 13.450 .525 & $\mathrm{R} \$$ & 11.911 .445 & $\mathrm{R} \$$ & 10.730 .165 & $\mathrm{R} \$$ & 9.548 .885 \\
\hline & Volume de investimento & & $100 \%$ & & $89 \%$ & & $80 \%$ & & $71 \%$ \\
\hline & $\mathrm{N}^{\circ}$ de Proprietários necessários à $\mathrm{R} \$ 89.670$ & & 150 & & 133 & & 120 & & 107 \\
\hline \multirow{8}{*}{400} & $\mathrm{~N}^{\mathrm{o}}$ Habitações & & 200 & & 160 & & 120 & & 80 \\
\hline & Construção civil das habitações & $\mathrm{R} \$$ & 6.015 .200 & $\mathrm{R} \$$ & 4.812 .160 & $\mathrm{R} \$$ & 3.609 .120 & $\mathrm{R} \$$ & 2.406 .080 \\
\hline & Móveis e eletrodomésticos das habitações & $\mathrm{R} \$$ & 1.860 .000 & $\mathrm{R} \$$ & 1.488 .000 & $\mathrm{R} \$$ & 1.116 .000 & $\mathrm{R} \$$ & 744.000 \\
\hline & Investimento em áreas externas & $\mathrm{R} \$$ & 392.800 & $\mathrm{R} \$$ & 35.000 & $\mathrm{R} \$$ & 35.000 & $\mathrm{R} \$$ & 35.000 \\
\hline & Demais investimentos & $\mathrm{R} \$$ & 9.354 .439 & $\mathrm{R} \$$ & 9.354 .439 & $\mathrm{R} \$$ & 9.354 .439 & $\mathrm{R} \$$ & 9.354 .439 \\
\hline & Investimento total & $\mathrm{R} \$$ & 17.622 .439 & $\mathrm{R} \$$ & 15.689 .599 & $\mathrm{R} \$$ & 14.114 .559 & $\mathrm{R} \$$ & 12.539 .519 \\
\hline & Volume de investimento & & $100 \%$ & & $89 \%$ & & $80 \%$ & & $71 \%$ \\
\hline & $\mathrm{N}^{\circ}$ de Proprietários necessários à $\mathrm{R} \$ 88.112$ & & 200 & & 179 & & 161 & & 143 \\
\hline
\end{tabular}


Apêndice 306 - Valor médio da mensalidade com simulação do nível de utilização da capacidade instalada entre 20 e $90 \%$, para 100 residentes

\begin{tabular}{|c|c|c|c|c|c|c|c|c|c|c|c|c|c|c|c|c|}
\hline \multirow{3}{*}{$\begin{array}{c}\text { Porcentagem de } \\
\text { residentes com } \\
\text { grau de } \\
\text { dependência } \\
\text { I, II e III } \\
100-0-0\end{array}$} & \multicolumn{16}{|c|}{$\begin{array}{l}\text { Valor médio de mensalidade com simulação do nível de utilização da capacidade instalada } \\
\text { entre } 20 \text { e } 90 \% \text {, para } 100 \text { residentes, com diversos graus de dependência }\end{array}$} \\
\hline & \multicolumn{2}{|c|}{$20 \%$} & \multicolumn{2}{|c|}{$30 \%$} & \multicolumn{2}{|c|}{$40 \%$} & \multicolumn{2}{|c|}{$50 \%$} & \multicolumn{2}{|c|}{$60 \%$} & \multicolumn{2}{|c|}{$70 \%$} & \multicolumn{2}{|c|}{$80 \%$} & \multicolumn{2}{|c|}{$90 \%$} \\
\hline & $\mathrm{R} \$$ & 10.589 & $\mathrm{R} \$$ & 7.177 & $\mathrm{R} \$$ & 5.439 & $\mathrm{R} \$$ & 4.491 & $\mathrm{R} \$$ & 3.754 & $\mathrm{R} \$$ & 3.291 & $\mathrm{R} \$$ & 2.888 & $\mathrm{R} \$$ & 2.644 \\
\hline $0-100-0$ & $\mathrm{R} \$$ & 11.302 & $\mathrm{R} \$$ & 7.842 & $\mathrm{R} \$$ & 6.152 & $\mathrm{R} \$$ & 5.175 & $\mathrm{R} \$$ & 4.466 & $\mathrm{R} \$$ & 3.982 & $\mathrm{R} \$$ & 3.600 & $\mathrm{R} \$$ & 3.341 \\
\hline $0-0-100$ & $\mathrm{R} \$$ & 11.438 & $\mathrm{R} \$$ & 7.933 & $\mathrm{R} \$$ & 6.433 & $\mathrm{R} \$$ & 5.502 & $\mathrm{R} \$$ & 4.739 & $\mathrm{R} \$$ & 4.338 & $\mathrm{R} \$$ & 4.018 & $\mathrm{R} \$$ & 3.674 \\
\hline $70-30-0$ & $\mathrm{R} \$$ & 11.017 & $\mathrm{R} \$$ & 7.462 & $\mathrm{R} \$$ & 5.867 & $\mathrm{R} \$$ & 4.776 & $\mathrm{R} \$$ & 4.039 & $\mathrm{R} \$$ & 3.616 & $\mathrm{R} \$$ & 3.173 & $\mathrm{R} \$$ & 2.898 \\
\hline 70-0-30 & $\mathrm{R} \$$ & 10.693 & $\mathrm{R} \$$ & 7.531 & $\mathrm{R} \$$ & 5.705 & $\mathrm{R} \$$ & 4.748 & $\mathrm{R} \$$ & 4.073 & $\mathrm{R} \$$ & 3.646 & $\mathrm{R} \$$ & 3.198 & $\mathrm{R} \$$ & 2.977 \\
\hline $50-40-10$ & $\mathrm{R} \$$ & 11.444 & $\mathrm{R} \$$ & 7.936 & $\mathrm{R} \$$ & 6.009 & $\mathrm{R} \$$ & 4.947 & $\mathrm{R} \$$ & 4.276 & $\mathrm{R} \$$ & 3.820 & $\mathrm{R} \$$ & 3.457 & $\mathrm{R} \$$ & 3.151 \\
\hline $60-30-10$ & $\mathrm{R} \$$ & 11.444 & $\mathrm{R} \$$ & 7.652 & $\mathrm{R} \$$ & 6.080 & $\mathrm{R} \$$ & 4.947 & $\mathrm{R} \$$ & 4.133 & $\mathrm{R} \$$ & 3.860 & $\mathrm{R} \$$ & 3.386 & $\mathrm{R} \$$ & 3.056 \\
\hline
\end{tabular}

Apêndice 307 - Valor médio da mensalidade com simulação do nível de utilização da capacidade instalada entre 20 e $90 \%$ para 200 residentes

\begin{tabular}{|c|c|c|c|c|c|c|c|c|c|c|c|c|c|c|c|c|}
\hline \multirow{3}{*}{$\begin{array}{c}\text { Porcentagem de } \\
\text { residentes com } \\
\text { grau de } \\
\text { dependência } \\
\text { I, II e III } \\
100-0-0\end{array}$} & \multicolumn{16}{|c|}{$\begin{array}{l}\text { Valor médio de mensalidade com simulação do nível de utilização da capacidade instalada } \\
\text { entre } 20 \text { e } 90 \% \text {, para } 200 \text { residentes, com diversos graus de dependência }\end{array}$} \\
\hline & \multicolumn{2}{|c|}{$20 \%$} & \multicolumn{2}{|c|}{$30 \%$} & \multicolumn{2}{|c|}{$40 \%$} & \multicolumn{2}{|c|}{$50 \%$} & \multicolumn{2}{|c|}{$60 \%$} & \multicolumn{2}{|c|}{$70 \%$} & \multicolumn{2}{|c|}{$80 \%$} & \multicolumn{2}{|c|}{$90 \%$} \\
\hline & $\mathrm{R} \$$ & 9.113 & $\mathrm{R} \$$ & 6.203 & $\mathrm{R} \$$ & 4.724 & $\mathrm{R} \$$ & 3.872 & $\mathrm{R} \$$ & 3.392 & $\mathrm{R} \$$ & 2.973 & $\mathrm{R} \$$ & 2.638 & $\mathrm{R} \$$ & 2.387 \\
\hline $0-100-0$ & $\mathrm{R} \$$ & 9.825 & $\mathrm{R} \$$ & 6.915 & $\mathrm{R} \$$ & 5.437 & $\mathrm{R} \$$ & 4.584 & $\mathrm{R} \$$ & 4.104 & $\mathrm{R} \$$ & 3.686 & $\mathrm{R} \$$ & 3.350 & $\mathrm{R} \$$ & 3.100 \\
\hline $0-0-100$ & $\mathrm{R} \$$ & 9.632 & $\mathrm{R} \$$ & 6.871 & $\mathrm{R} \$$ & 5.617 & $\mathrm{R} \$$ & 4.780 & $\mathrm{R} \$$ & 4.339 & $\mathrm{R} \$$ & 3.984 & $\mathrm{R} \$$ & 3.665 & $\mathrm{R} \$$ & 3.407 \\
\hline $70-30-0$ & $\mathrm{R} \$$ & 9.540 & $\mathrm{R} \$$ & 6.488 & $\mathrm{R} \$$ & 5.009 & $\mathrm{R} \$$ & 4.100 & $\mathrm{R} \$$ & 3.653 & $\mathrm{R} \$$ & 3.238 & $\mathrm{R} \$$ & 2.869 & $\mathrm{R} \$$ & 2.641 \\
\hline $70-0-30$ & $\mathrm{R} \$$ & 9.303 & $\mathrm{R} \$$ & 6.472 & $\mathrm{R} \$$ & 4.998 & $\mathrm{R} \$$ & 4.141 & $\mathrm{R} \$$ & 3.717 & $\mathrm{R} \$$ & 3.268 & $\mathrm{R} \$$ & 2.949 & $\mathrm{R} \$$ & 2.711 \\
\hline $50-40-10$ & $\mathrm{R} \$$ & 9.579 & $\mathrm{R} \$$ & 6.656 & $\mathrm{R} \$$ & 5.243 & $\mathrm{R} \$$ & 4.286 & $\mathrm{R} \$$ & 3.785 & $\mathrm{R} \$$ & 3.432 & $\mathrm{R} \$$ & 3.075 & $\mathrm{R} \$$ & 2.823 \\
\hline $60-30-10$ & $\mathrm{R} \$$ & 9.651 & $\mathrm{R} \$$ & 6.514 & $\mathrm{R} \$$ & 5.171 & $\mathrm{R} \$$ & 4.201 & $\mathrm{R} \$$ & 3.738 & $\mathrm{R} \$$ & 3.392 & $\mathrm{R} \$$ & 2.986 & $\mathrm{R} \$$ & 2.744 \\
\hline
\end{tabular}


Apêndice 308 - Valor médio da mensalidade com simulação do nível de utilização da capacidade instalada entre 20 e $90 \%$ para 300 residentes

\begin{tabular}{|c|c|c|c|c|c|c|c|c|c|c|c|c|c|c|c|c|}
\hline \multirow{3}{*}{$\begin{array}{c}\text { Porcentagem de } \\
\text { residentes com } \\
\text { grau de } \\
\text { dependência } \\
\text { I, II e III } \\
100-0-0\end{array}$} & \multicolumn{16}{|c|}{$\begin{array}{c}\text { Valor médio de mensalidade com simulação do nível de utilização da capacidade instalada } \\
\text { entre } 20 \text { e } 90 \% \text {, para } 300 \text { residentes, com diversos graus de dependência }\end{array}$} \\
\hline & \multicolumn{2}{|c|}{$20 \%$} & \multicolumn{2}{|c|}{$30 \%$} & \multicolumn{2}{|c|}{$40 \%$} & \multicolumn{2}{|c|}{$50 \%$} & \multicolumn{2}{|c|}{$60 \%$} & \multicolumn{2}{|c|}{$70 \%$} & \multicolumn{2}{|c|}{$80 \%$} & \multicolumn{2}{|c|}{$90 \%$} \\
\hline & $\mathrm{R} \$$ & 7.976 & $\mathrm{R} \$$ & 5.459 & $\mathrm{R} \$$ & 4.279 & $\mathrm{R} \$$ & 3.508 & $\mathrm{R} \$$ & 2.978 & $\mathrm{R} \$$ & 2.688 & $\mathrm{R} \$$ & 2.379 & $\mathrm{R} \$$ & 2.162 \\
\hline $0-100-0$ & $\mathrm{R} \$$ & 8.688 & $\mathrm{R} \$$ & 6.156 & $\mathrm{R} \$$ & 4.991 & $\mathrm{R} \$$ & 4.211 & $\mathrm{R} \$$ & 3.691 & $\mathrm{R} \$$ & 3.394 & $\mathrm{R} \$$ & 3.091 & $\mathrm{R} \$$ & 2.869 \\
\hline $0-0-100$ & $\mathrm{R} \$$ & 8.571 & $\mathrm{R} \$$ & 6.229 & $\mathrm{R} \$$ & 5.189 & $\mathrm{R} \$$ & 4.460 & $\mathrm{R} \$$ & 3.974 & $\mathrm{R} \$$ & 3.702 & $\mathrm{R} \$$ & 3.432 & $\mathrm{R} \$$ & 3.222 \\
\hline $70-30-0$ & $\mathrm{R} \$$ & 8.261 & $\mathrm{R} \$$ & 5.712 & $\mathrm{R} \$$ & 4.540 & $\mathrm{R} \$$ & 3.755 & $\mathrm{R} \$$ & 3.232 & $\mathrm{R} \$$ & 2.932 & $\mathrm{R} \$$ & 2.628 & $\mathrm{R} \$$ & 2.405 \\
\hline 70-0-30 & $\mathrm{R} \$$ & 8.265 & $\mathrm{R} \$$ & 5.772 & $\mathrm{R} \$$ & 4.613 & $\mathrm{R} \$$ & 3.848 & $\mathrm{R} \$$ & 3.309 & $\mathrm{R} \$$ & 3.023 & $\mathrm{R} \$$ & 2.722 & $\mathrm{R} \$$ & 2.507 \\
\hline $50-40-10$ & $\mathrm{R} \$$ & 8.434 & $\mathrm{R} \$$ & 5.923 & $\mathrm{R} \$$ & 4.674 & $\mathrm{R} \$$ & 3.919 & $\mathrm{R} \$$ & 3.416 & $\mathrm{R} \$$ & 3.115 & $\mathrm{R} \$$ & 2.790 & $\mathrm{R} \$$ & 2.580 \\
\hline $60-30-10$ & $\mathrm{R} \$$ & 8.292 & $\mathrm{R} \$$ & 5.828 & $\mathrm{R} \$$ & 4.626 & $\mathrm{R} \$$ & 3.881 & $\mathrm{R} \$$ & 3.337 & $\mathrm{R} \$$ & 3.047 & $\mathrm{R} \$$ & 2.743 & $\mathrm{R} \$$ & 2.538 \\
\hline
\end{tabular}

Apêndice 309 - Valor médio da mensalidade com simulação do nível de utilização da capacidade instalada entre 20 e $90 \%$ para 400 residentes

\begin{tabular}{|c|c|c|c|c|c|c|c|c|c|c|c|c|c|c|c|c|}
\hline \multirow{3}{*}{$\begin{array}{c}\text { Porcentagem de } \\
\text { residentes com } \\
\text { grau de } \\
\text { dependência } \\
\text { I, II e III } \\
100-0-0\end{array}$} & \multicolumn{16}{|c|}{$\begin{array}{l}\text { Valor médio de mensalidade com simulação do nível de utilização da capacidade instalada } \\
\text { entre } 20 \text { e } 90 \% \text {, para } 400 \text {, residentes com diversos graus de dependência }\end{array}$} \\
\hline & \multicolumn{2}{|c|}{$20 \%$} & \multicolumn{2}{|c|}{$30 \%$} & \multicolumn{2}{|c|}{$40 \%$} & \multicolumn{2}{|c|}{$50 \%$} & \multicolumn{2}{|c|}{$60 \%$} & \multicolumn{2}{|c|}{$70 \%$} & \multicolumn{2}{|c|}{$80 \%$} & \multicolumn{2}{|c|}{$90 \%$} \\
\hline & $\mathrm{R} \$$ & 7.622 & $\mathrm{R} \$$ & 5.324 & $\mathrm{R} \$$ & 4.087 & $\mathrm{R} \$$ & 3.337 & $\mathrm{R} \$$ & 2.902 & $\mathrm{R} \$$ & 2.541 & $\mathrm{R} \$$ & 2.314 & $\mathrm{R} \$$ & 2.094 \\
\hline $0-100-0$ & $\mathrm{R} \$$ & 8.335 & $\mathrm{R} \$$ & 6.036 & $\mathrm{R} \$$ & 4.799 & $\mathrm{R} \$$ & 4.049 & $\mathrm{R} \$$ & 3.614 & $\mathrm{R} \$$ & 3.253 & $\mathrm{R} \$$ & 3.027 & $\mathrm{R} \$$ & 2.807 \\
\hline $0-0-100$ & $\mathrm{R} \$$ & 8.254 & $\mathrm{R} \$$ & 6.097 & $\mathrm{R} \$$ & 4.983 & $\mathrm{R} \$$ & 4.307 & $\mathrm{R} \$$ & 3.886 & $\mathrm{R} \$$ & 3.566 & $\mathrm{R} \$$ & 3.369 & $\mathrm{R} \$$ & 3.149 \\
\hline $70-30-0$ & $\mathrm{R} \$$ & 7.907 & $\mathrm{R} \$$ & 5.585 & $\mathrm{R} \$$ & 4.318 & $\mathrm{R} \$$ & 3.550 & $\mathrm{R} \$$ & 3.151 & $\mathrm{R} \$$ & 2.775 & $\mathrm{R} \$$ & 2.546 & $\mathrm{R} \$$ & 2.316 \\
\hline $70-0-30$ & $\mathrm{R} \$$ & 7.808 & $\mathrm{R} \$$ & 5.591 & $\mathrm{R} \$$ & 4.354 & $\mathrm{R} \$$ & 3.622 & $\mathrm{R} \$$ & 3.211 & $\mathrm{R} \$$ & 2.844 & $\mathrm{R} \$$ & 2.633 & $\mathrm{R} \$$ & 2.417 \\
\hline $50-40-10$ & $\mathrm{R} \$$ & 8.107 & $\mathrm{R} \$$ & 5.694 & $\mathrm{R} \$$ & 4.507 & $\mathrm{R} \$$ & 3.744 & $\mathrm{R} \$$ & 3.301 & $\mathrm{R} \$$ & 2.964 & $\mathrm{R} \$$ & 2.729 & $\mathrm{R} \$$ & 2.503 \\
\hline $60-30-10$ & $\mathrm{R} \$$ & 8.035 & $\mathrm{R} \$$ & 5.647 & $\mathrm{R} \$$ & 4.418 & $\mathrm{R} \$$ & 3.673 & $\mathrm{R} \$$ & 3.253 & $\mathrm{R} \$$ & 2.893 & $\mathrm{R} \$$ & 2.667 & $\mathrm{R} \$$ & 2.424 \\
\hline
\end{tabular}


Apêndice 310 - Taxa Interna de Retorno, TIR, para aquisição de quotas a R\$ 89.021, locação da habitação de 6 a 300 meses e nível de utilização da capacidade instala de $45 \%$ a $100 \%$

\begin{tabular}{|c|c|c|c|c|c|c|c|c|c|c|c|c|c|c|}
\hline \multirow{2}{*}{ Meses } & \multicolumn{14}{|c|}{ Nível de Utilização da Capacidade Instalada } \\
\hline & $45 \%$ & $50 \%$ & $55 \%$ & $60 \%$ & $63 \%$ & $65 \%$ & $70 \%$ & $75 \%$ & $77 \%$ & $80 \%$ & $85 \%$ & $90 \%$ & $95 \%$ & $100 \%$ \\
\hline 6 & $-65,16 \%$ & $-57,21 \%$ & $-52,81 \%$ & $-49,60 \%$ & $-48,00 \%$ & $-47,02 \%$ & $-44,84 \%$ & $-42,93 \%$ & $-42,23 \%$ & $-41,22 \%$ & $-39,67 \%$ & $-38,24 \%$ & $-36,92 \%$ & $-35,68 \%$ \\
\hline 12 & $-38,31 \%$ & $-31,23 \%$ & $-27,53 \%$ & $-24,92 \%$ & $-23,63 \%$ & $-22,85 \%$ & $-21,13 \%$ & $-19,64 \%$ & $-19,09 \%$ & $-18,31 \%$ & $-17,12 \%$ & $-16,03 \%$ & $-15,02 \%$ & $-14,08 \%$ \\
\hline 18 & $-25,95 \%$ & $-20,21 \%$ & $-17,26 \%$ & $-15,18 \%$ & $-14,16 \%$ & $-13,55 \%$ & $-12,19 \%$ & $-11,01 \%$ & $-10,58 \%$ & $-9,972 \%$ & $-9,031 \%$ & $-8,170 \%$ & $-7,375 \%$ & $-6,632 \%$ \\
\hline 24 & $-19,17 \%$ & $-14,40 \%$ & $-11,96 \%$ & $-10,25 \%$ & $-9,410 \%$ & $-8,904 \%$ & $-7,781 \%$ & $-6,808 \%$ & $-6,452 \%$ & $-5,945 \%$ & $-5,164 \%$ & $-4,449 \%$ & $-3,786 \%$ & $-3,166 \%$ \\
\hline 30 & $-14,96 \%$ & $-10,89 \%$ & $-8,818 \%$ & $-7,358 \%$ & $-6,641 \%$ & $-6,208 \%$ & $-5,247 \%$ & $-4,413 \%$ & $-4,106 \%$ & $-3,670 \%$ & $-2,997 \%$ & $-2,379 \%$ & $-1,805 \%$ & $-1,267 \%$ \\
\hline 36 & $-12,12 \%$ & $-8,582 \%$ & $-6,771 \%$ & $-5,494 \%$ & $-4,866 \%$ & $-4,487 \%$ & $-3,642 \%$ & $-2,907 \%$ & $-2,637 \%$ & $-2,251 \%$ & $-1,656 \%$ & $-1,107 \%$ & $-0,595 \%$ & $-0,115 \%$ \\
\hline 42 & $-10,10 \%$ & $-6,960 \%$ & $-5,350 \%$ & $-4,213 \%$ & $-3,652 \%$ & $-3,313 \%$ & $-2,556 \%$ & $-1,895 \%$ & $-1,652 \%$ & $-1,304 \%$ & $-0,766 \%$ & $-0,269 \%$ & $0,196 \%$ & $33 \%$ \\
\hline 48 & $-8,591 \%$ & $-5,769 \%$ & $-4,318 \%$ & $-3,289 \%$ & $-2,780 \%$ & $-2,472 \%$ & $-1,784 \%$ & $-1,181 \%$ & $-0,959 \%$ & $-0,641 \%$ & $-0,147 \%$ & $0,311 \%$ & $0,740 \%$ & $1,144 \%$ \\
\hline 54 & $-7,429 \%$ & $-4,863 \%$ & $-3,539 \%$ & $-2,598 \%$ & $-2,131 \%$ & $-1,848 \%$ & $-1,214 \%$ & $-0,658 \%$ & & $-0,157 \%$ & & $0,727 \%$ & $1,127 \%$ & $1,506 \%$ \\
\hline 60 & $-6,509 \%$ & $-4,155 \%$ & $-2,936 \%$ & $-2,066 \%$ & $-1,634 \%$ & $-1,372 \%$ & $-0,782 \%$ & $-0,263 \%$ & $-0,071 \%$ & $0,205 \%$ & $0,635 \%$ & $1,035 \%$ & $1,412 \%$ & $1,770 \%$ \\
\hline 66 & & $-3,588 \%$ & $-2,457 \%$ & $-1,647 \%$ & $-1,244 \%$ & $8 \%$ & & & & & & & $7 \%$ & \\
\hline 72 & $-5,153 \%$ & $-3,127 \%$ & $-2,070 \%$ & $-1,311 \%$ & $-0,932 \%$ & $-0,701 \%$ & $-0,180 \%$ & $0,281 \%$ & 0,4 & $0,700 \%$ & $1,086 \%$ & $1,448 \%$ & $1,791 \%$ & $2,118 \%$ \\
\hline 78 & & $-2,7$ & $-1,7$ & $-1,0$ & $8 \%$ & $9 \%$ & & & & & & $0 \%$ & $9 \%$ & $4 \%$ \\
\hline 84 & $-4,209 \%$ & $-2,425 \%$ & $-1,487 \%$ & $-0,810 \%$ & $-0,469 \%$ & $-0,261 \%$ & $0,210 \%$ & $0,629 \%$ & 0,7 & $1,012 \%$ & $7 \%$ & $2 \%$ & $0 \%$ & $25 \%$ \\
\hline 90 & $-3,8$ & $-2,1$ & $-1,2$ & -0, & $-0,2$ & $6 \%$ & & & & & & $2 \%$ & $0 \%$ & $6 \%$ \\
\hline 96 & & & & & & & & & & & & & & \\
\hline 102 & $8 \%$ & $-1,720 \%$ & $-0,912 \%$ & $-0,322 \%$ & $-0,024 \%$ & $0,160 \%$ & 0,5 & $2 \%$ & $2 \%$ & $1,296 \%$ & $9 \%$ & $5 \%$ & 2,2 & $00 \%$ \\
\hline 108 & & $-1,544 \%$ & $-0,771 \%$ & $-0,204 \%$ & $0,083 \%$ & $0,260 \%$ & $3 \%$ & $6 \%$ & & & & $4 \%$ & $0 \%$ & $8 \%$ \\
\hline 114 & $-2,776 \%$ & $-1,391 \%$ & $-0,648 \%$ & $-0,102 \%$ & $0,175 \%$ & $0,346 \%$ & $0,737 \%$ & $1,090 \%$ & 1,2 & $1,416 \%$ & $1,723 \%$ & $2,015 \%$ & $2,296 \%$ & $2,568 \%$ \\
\hline 120 & $-2,583 \%$ & $-1,255 \%$ & $-0,540 \%$ & $-0,014 \%$ & $0,255 \%$ & $0,421 \%$ & $0,800 \%$ & $4 \%$ & & $2 \%$ & $2 \%$ & $9 \%$ & $5 \%$ & $3 \%$ \\
\hline 126 & $-2,411 \%$ & $-1,134 \%$ & $-0,445 \%$ & $0,064 \%$ & $0,325 \%$ & $0,486 \%$ & $5 \%$ & $1,190 \%$ & $7 \%$ & $1,502 \%$ & $96 \%$ & $2,078 \%$ & $2,349 \%$ & $14 \%$ \\
\hline 132 & & $-1,027 \%$ & $-0,361 \%$ & $\%$ & $36 \%$ & $3 \%$ & & & & & $5 \%$ & $2 \%$ & $0 \%$ & $1 \%$ \\
\hline 138 & $-2,115 \%$ & $-0,931 \%$ & $-0,286 \%$ & $0,194 \%$ & $0,440 \%$ & $0,593 \%$ & $0,945 \%$ & $1,265 \%$ & 1,3 & $1,565 \%$ & $9 \%$ & $2,122 \%$ & $2,387 \%$ & $2,645 \%$ \\
\hline 144 & $-1,9$ & $-0,844 \%$ & $-0,219 \%$ & $0,248 \%$ & $0,488 \%$ & $7 \%$ & & 1,2 & & $0 \%$ & $0 \%$ & $9 \%$ & $1 \%$ & $57 \%$ \\
\hline 150 & $-1,872 \%$ & $-0,765 \%$ & $-0,159 \%$ & $0,296 \%$ & $0,531 \%$ & $0,676 \%$ & $1,013 \%$ & $1,322 \%$ & $1,440 \%$ & $1,612 \%$ & $1,888 \%$ & 2, & $2,413 \%$ & $2,667 \%$ \\
\hline 156 & $-1,767 \%$ & $-0,694 \%$ & $-0,104 \%$ & 0,33 & $0,569 \%$ & 0,7 & & & & & $3 \%$ & $7 \%$ & $3 \%$ & $75 \%$ \\
\hline 162 & & $-0,629 \%$ & $-0,05$ & & & $0,742 \%$ & & 1,36 & & & & & & \\
\hline 168 & $-1,580 \%$ & $-0,570 \%$ & $-0,011 \%$ & $0,413 \%$ & $0,633 \%$ & $0,770 \%$ & 1,0 & 1,3 & 1,4 & 1,6 & $3 \%$ & $7 \%$ & 2,4 & $8 \%$ \\
\hline 174 & & & & & & & & & & & & & & \\
\hline 180 & $-1,422 \%$ & $-0,466 \%$ & $0,067 \%$ & $0,473 \%$ & $0,685 \%$ & $8 \%$ & 1,1 & $3 \%$ & 1,5 & $5 \%$ & $7 \%$ & 2,2 & $1 \%$ & $96 \%$ \\
\hline 186 & $-1,352 \%$ & $-0,421 \%$ & $0,101 \%$ & $0,499 \%$ & $0,707 \%$ & $8 \%$ & $3 \%$ & $5 \%$ & $5 \%$ & $5 \%$ & $4 \%$ & $7 \%$ & $5 \%$ & $00 \%$ \\
\hline 192 & $-1,287 \%$ & $-0,378 \%$ & $0,132 \%$ & $0,523 \%$ & $0,728 \%$ & $0,856 \%$ & 1,1 & 1,4 & & $4 \%$ & $1 \%$ & $2 \%$ & $9 \%$ & $33 \%$ \\
\hline 198 & $-1,226 \%$ & $-0,339 \%$ & $0,160 \%$ & $0,544 \%$ & $0,746 \%$ & $0,873 \%$ & $1,170 \%$ & $1,447 \%$ & $1 \%$ & $1 \%$ & $7 \%$ & $7 \%$ & $2 \%$ & $55 \%$ \\
\hline 204 & $-1,169 \%$ & $-0,303 \%$ & $0,187 \%$ & $0,564 \%$ & $0,763 \%$ & $0,888 \%$ & $1,181 \%$ & $1,456 \%$ & 1, & $1,718 \%$ & $1,972 \%$ & $2,221 \%$ & $2,465 \%$ & $2,707 \%$ \\
\hline 210 & $-1,116 \%$ & $-0,270 \%$ & $0,211 \%$ & $0,582 \%$ & $0,778 \%$ & $0,902 \%$ & $1,192 \%$ & $1,464 \%$ & $9 \%$ & $24 \%$ & $1,976 \%$ & $2,224 \%$ & $2,468 \%$ & $2,709 \%$ \\
\hline 216 & $-1,066 \%$ & $-0,239 \%$ & $0,233 \%$ & $0,599 \%$ & $0,792 \%$ & $0,914 \%$ & $1,201 \%$ & $1,471 \%$ & 1,5 & $1,729 \%$ & $1,980 \%$ & $2,227 \%$ & $2,470 \%$ & $2,711 \%$ \\
\hline 222 & $-1,020 \%$ & $-0,209 \%$ & $0,254 \%$ & $0,614 \%$ & $0,805 \%$ & $0,926 \%$ & $1,210 \%$ & $1,477 \%$ & $1 \%$ & $1,734 \%$ & $1,984 \%$ & $2,229 \%$ & $2,472 \%$ & $2,712 \%$ \\
\hline 228 & $-0,976 \%$ & $-0,182 \%$ & $0,273 \%$ & $0,628 \%$ & $0,817 \%$ & $0,936 \%$ & $1,217 \%$ & $1,483 \%$ & $1,586 \%$ & $1,738 \%$ & $1,987 \%$ & $2,231 \%$ & $2,473 \%$ & $2,713 \%$ \\
\hline 234 & $-0,935 \%$ & $-0,157 \%$ & $0,291 \%$ & $0,641 \%$ & $0,828 \%$ & $0,946 \%$ & $1,224 \%$ & $1,488 \%$ & $1,590 \%$ & $1,742 \%$ & $1,989 \%$ & $2,233 \%$ & $2,474 \%$ & $2,714 \%$ \\
\hline 240 & $-0,896 \%$ & $-0,133 \%$ & $0,308 \%$ & $0,653 \%$ & $0,838 \%$ & & & & & & & & $2,476 \%$ & $2,715 \%$ \\
\hline 246 & $-0,859 \%$ & $-0,111 \%$ & $0,323 \%$ & $0,664 \%$ & $0,847 \%$ & $0,962 \%$ & $1,236 \%$ & $1,496 \%$ & $8 \%$ & $1,748 \%$ & $1,994 \%$ & $2,236 \%$ & $2,476 \%$ & $2,715 \%$ \\
\hline 252 & $-0,825 \%$ & $-0,090 \%$ & $0,338 \%$ & $0,675 \%$ & $0,855 \%$ & $0,970 \%$ & $1,242 \%$ & $1,500 \%$ & & $1,750 \%$ & $96 \%$ & $2,237 \%$ & $2,477 \%$ & $2,716 \%$ \\
\hline 258 & $-0,792 \%$ & $-0,070 \%$ & $0,351 \%$ & $0,684 \%$ & $0,863 \%$ & $0,976 \%$ & $1,246 \%$ & $1,504 \%$ & $1,604 \%$ & $1,753 \%$ & $1,997 \%$ & $2,239 \%$ & $2,478 \%$ & $2,716 \%$ \\
\hline 264 & $-0,761 \%$ & $-0,052 \%$ & $0,364 \%$ & $0,693 \%$ & $0,870 \%$ & $0,983 \%$ & $1,251 \%$ & $1,507 \%$ & $1,607 \%$ & $1,755 \%$ & $1,999 \%$ & $2,239 \%$ & $2,479 \%$ & $2,717 \%$ \\
\hline 270 & $-0,732 \%$ & $-0,034 \%$ & $0,375 \%$ & $0,701 \%$ & $0,877 \%$ & $0,988 \%$ & $1,255 \%$ & $1,509 \%$ & $1,609 \%$ & $1,757 \%$ & $2,000 \%$ & $2,240 \%$ & $2,479 \%$ & $2,717 \%$ \\
\hline 276 & $-0,704 \%$ & $-0,018 \%$ & $0,387 \%$ & $0,709 \%$ & $0,883 \%$ & $0,994 \%$ & $1,258 \%$ & $1,512 \%$ & $1,611 \%$ & $1,758 \%$ & $2,001 \%$ & $2,241 \%$ & $2,480 \%$ & $2,717 \%$ \\
\hline 282 & $-0,678 \%$ & $-0,002 \%$ & $0,397 \%$ & $0,716 \%$ & $0,889 \%$ & $0,999 \%$ & $1,262 \%$ & $1,514 \%$ & $1,613 \%$ & $1,760 \%$ & $2,002 \%$ & $2,242 \%$ & $2,480 \%$ & $2,718 \%$ \\
\hline 288 & $-0,652 \%$ & $0,012 \%$ & $0,407 \%$ & $0,723 \%$ & $0,894 \%$ & $1,003 \%$ & $1,265 \%$ & $1,516 \%$ & $1,615 \%$ & $1,761 \%$ & $2,003 \%$ & $2,242 \%$ & $2,480 \%$ & $2,718 \%$ \\
\hline 294 & $-0,628 \%$ & $0,026 \%$ & $0,416 \%$ & $0,729 \%$ & $0,899 \%$ & $1,007 \%$ & $1,268 \%$ & $1,518 \%$ & $1,616 \%$ & $1,762 \%$ & $2,003 \%$ & $2,243 \%$ & $2,481 \%$ & $2,718 \%$ \\
\hline 300 & $-0,606 \%$ & $0,039 \%$ & $0,424 \%$ & $0,735 \%$ & $0,903 \%$ & $1,011 \%$ & $1,270 \%$ & $1,520 \%$ & $1,618 \%$ & $1,763 \%$ & $2,004 \%$ & $2,243 \%$ & $2,481 \%$ & $2,718 \%$ \\
\hline
\end{tabular}




\section{Apêndice 311 - Questionário \\ QUESTIONÁRIO}

Data:

I__ / 2008

$N^{\circ}$ Quest.:

Em primeiro lugar gostaria de agradecer sua participação neste projeto. Minha tese de doutorado trata de investimentos no terceiro setor com foco no retorno social e, para concluí-la, preciso de algumas informações. Assim, estou realizando esta pesquisa para analisar o quanto pessoas como você estariam dispostas a investir nessas instituições. Acredito que levará em torno de 10 minutos.

A primeira parte da pesquisa tem por objetivo classificar você em relação aos demais respondentes. Não se preocupe; todas as informações serão tratadas de forma sigilosa e em nenhum momento você precisará se identificar.

\section{Qual sua idade?}

25 a 29

\section{Sexo?}

Masculino.

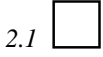

Feminino 2.3

\section{Reside em região:}

Urbana

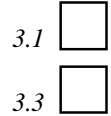

Rural 3.3

\section{Em que cidade / estado você reside?}

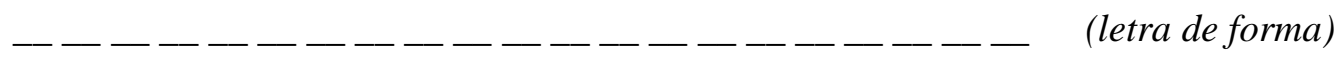


5. Quantos itens abaixo você tem em sua casa?

(Marque com um ' $\mathrm{x}$ ' no respectivo espaço)

\begin{tabular}{|c|c|c|c|c|c|c|c|c|}
\hline \multirow{2}{*}{\multicolumn{2}{|c|}{ Itens }} & \multirow{2}{*}{$\begin{array}{l}\text { Não } \\
\text { tem }\end{array}$} & \multicolumn{6}{|c|}{ Quantidade que possui } \\
\hline & & & 1 & 2 & 3 & 4 & 5 & $6+$ \\
\hline Televisão (colorida) & 5.1 & & & & & & & \\
\hline Rádio & 5.2 & & & & & & & \\
\hline Automóvel & 5.3 & & & & & & & \\
\hline Empregada fixa mensalista & 5.4 & & & & & & & \\
\hline Aspirador de pó & 5.5 & & & & & & & \\
\hline Máquina de lavar roupa & 5.6 & & & & & & & \\
\hline Videocassete / DVD & 5.7 & & & & & & & \\
\hline Banheiro & 5.8 & & & & & & & \\
\hline Geladeira & 5.9 & & & & & & & \\
\hline $\begin{array}{l}\text { Freezer (aparelho independ } \\
\text { parte da geladeira duplex) }\end{array}$ & 5.10 & & & & & & & \\
\hline
\end{tabular}

6. Até que ano da escola o chefe da família estudou?

Analfabeto/Primário Incompleto

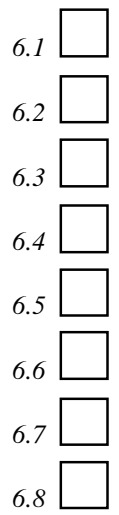

Primário Completo/Ginasial Incompleto

Ginásio Completo

Colegial Incompleto

Colegial Completo

Superior Incompleto

Superior Completo

6.8

\section{O rendimento familiar bruto mensal se encaixa:}

Até R \$ 190,00 (até 1/2 salário mínimo)

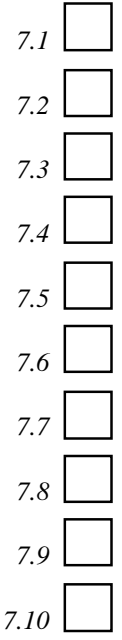

De R \$ 190,01 até R \$ 380,00 (mais de 1/2 a 1 salário mínimo)

De $R$ \$ 380,01 até $R$ \$ 760,00 (mais de 1 a 2 salários mínimos)

De $\mathrm{R} \$ 760,01$ até $\mathrm{R} \$$ 1.140,00 (mais de 2 a 3 salários mínimos)

De $\mathrm{R} \$ 1.140,01$ até $\mathrm{R} \$ 1.900,00$ (mais de 3 a 5 salários mínimos)

De $\mathrm{R} \$ 1.900,01$ até $\mathrm{R} \$ 3.800,00$ (mais de 5 a 10 salários mínimos)

De $\mathrm{R} \$ 3.800,01$ até $\mathrm{R} \$$ 7.600,00 (mais de 10 a 20 salários mínimos)

Acima de R \$ 7.600,00 (mais de 20 salários mínimos)

Não sabe / não deseja informar 


\section{Poupo dinheiro atualmente para:}

(Marque com um ' $\mathrm{x}$ ' em uma ou mais opções)

Utilizá-lo nas férias com transporte, hotel, alimentação, etc

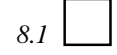

Eventuais gastos emergenciais com saúde, pequenos acidentes, etc

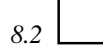

Comprar bens duráveis como imóveis, automóveis, eletrodomésticos, etc 8.3

Custear a educação do(s) filho(s) no futuro 8.4

Completar a aposentadoria no futuro 8.5

Não poupa 8.6

9. No futuro, quando não estiver mais trabalhando, o valor a ser recebido do INSS a título de aposentadoria será suficiente para meu sustento.

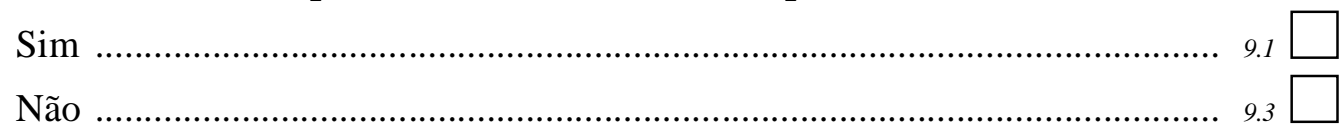

10. Através de poupança ou previdência privada, pretendo complementar minha renda quando me aposentar.

Sim

11. Quando não puder mais trabalhar, quero que meus filhos complementem minha renda ou me sustentem.

$\operatorname{Sim}$

11.1

Não 11.3

12. Se um dia ficar dependente fisicamente, quero morar com meus filhos ou com um parente próximo.

Sim

12.1

Não 12.3

13. Conheço bem instituições que tratam de pessoas que requerem cuidados especiais (casas de repouso, instituições de longa permanência, etc.).

(Marque com um ' $x$ ' a opção que expressa melhor sua opinião em relação à afirmativa)

Concordo plenamente

13.1

Concordo 13.2

Concordo parcialmente 13.3

Discordo $13.4 \square$

Discordo totalmente 13.5 
14. Confio plenamente nos cuidados oferecidos por organizações que tratam de pessoas que requerem cuidados especiais.

(Marque com um 'x' a opção que expressa melhor sua opinião em relação à afirmativa)

Concordo plenamente

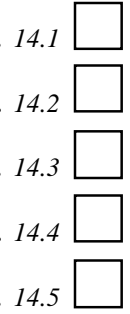

Concordo

Concordo parcialmente

Discordo

Discordo totalmente

14.5

15. Caso futuramente tenha necessidade, nos moldes dos modelos atuais, gostaria de ser residente em uma instituição que trata de pessoas que requerem cuidados especiais.

(Marque com um ' $x$ ' a opção que expressa melhor sua opinião em relação à afirmativa)

Concordo plenamente

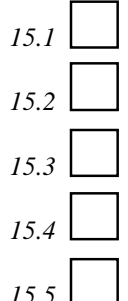

Discordo totalmente

15.5

16. Investiria em instituições que cuidam de pessoas que precisam de cuidados especiais para meu uso futuro desde que as mesmas ofereçam garantias de qualidade de vida.

(Marque com um ' $x$ ' a opção que expressa melhor sua opinião em relação à afirmativa)

Concordo plenamente 16.1

Concordo 16.2

Concordo parcialmente 16.3

Discordo 16.4

Discordo totalmente 16.5

17. Tem familiar próximo que está (ou já esteve) em organizações para pessoas que necessitam de cuidados especiais?

Sim 17.1

Não 17.3

Caso a resposta da questão anterior tenha sido $\mathrm{NÃ} O$, a pesquisa termina aqui. 


\section{A organização cobra(va) mensalidade?}

Sim

18.1

Não

19. As despesas do familiar, incluindo mensalidade (se houver), medicamentos, higiene pessoal, etc, atingem(iam) mensalmente:

Até R \$ 190,00 (até 1/2 salário mínimo)

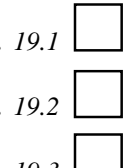

De $\mathrm{R} \$ 380,01$ até $\mathrm{R} \$ 760,00$ (mais de 1 a 2 salários mínimos) 19.3

De R \$ 760,01 até R \$ 1.140,00 (mais de 2 a 3 salários mínimos) 19.4

De R \$ 1.140,01 até R \$ 1.900,00 (mais de 3 a 5 salários mínimos) 19.5

De R \$ 1.900,01 até R \$ 3.800,00 (mais de 5 a 10 salários mínimos) 19.6

De R \$ 3.800,01 até R \$ 7.600,00 (mais de 10 a 20 salários mínimos) 19.7

Acima de R \$ 7.600,00 (mais de 20 salários mínimos) 19.8

Não sabe / não deseja informar 19.9

20. Os recursos próprios do familiar (aposentadoria, aluguéis, aplicações financeiras, etc) utilizados para pagar a organização (se cobrada) e as demais despesas, como medicamentos, higiene pessoal ou outros gastos, cobrem(iam):

Até R \$ 190,00 (até 1/2 salário mínimo) 20.1

De R \$ 190,01 até R \$380,00 (mais de 1/2 a 1 salário mínimo) 20.2

De R \$ 380,01 até R \$ 760,00 (mais de 1 a 2 salários mínimos) 20.3

De R \$ 760,01 até R \$ 1.140,00 (mais de 2 a 3 salários mínimos) 20.4

De R \$ 1.140,01 até R \$ 1.900,00 (mais de 3 a 5 salários mínimos) 20.5

De R \$ 1.900,01 até R \$ 3.800,00 (mais de 5 a 10 salários mínimos) 20.6

De R \$ 3.800,01 até R \$ 7.600,00 (mais de 10 a 20 salários mínimos) 20.7

Acima de R \$ 7.600,00 (mais de 20 salários mínimos) 20.8

Não sabe / não deseja informar 20.9

O familiar não tem(tinha) rendimento próprio 20.10 
ANEXOS 


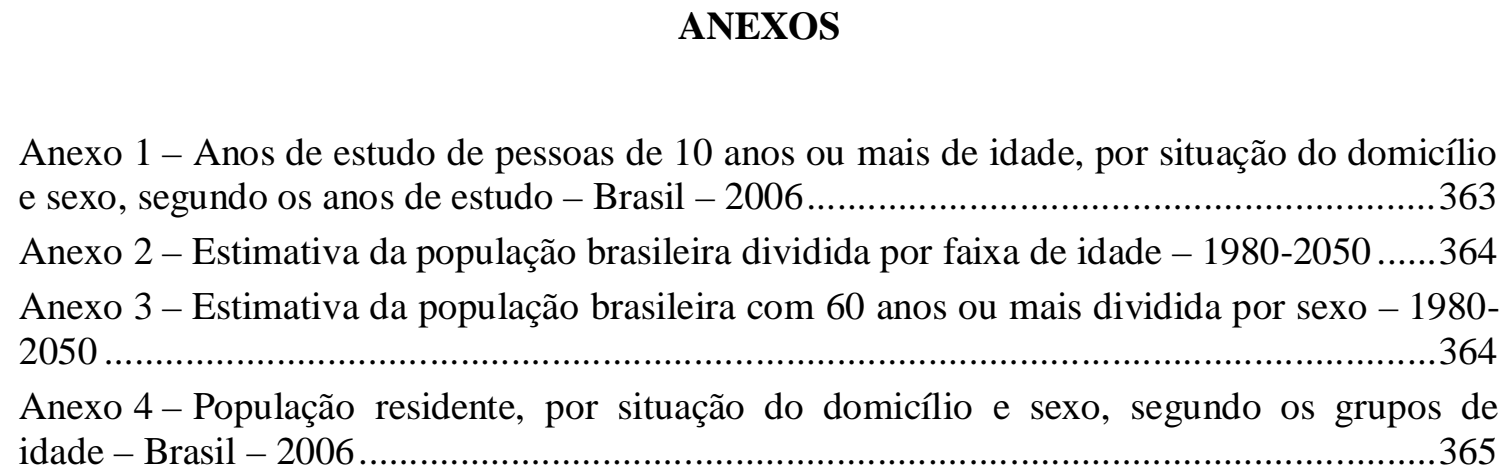

Anexo 5 - Famílias residentes em domicílios particulares e valor do rendimento médio e total mensal das famílias residentes em domicílios particulares, por situação do domicílio, segundo as classes de rendimento mensal familiar - Brasil - 2006 366

Anexo 6 - Pessoas de 10 anos ou mais de idade, ocupadas na semana de referência, com rendimento no trabalho principal, e valor do rendimento médio mensal, segundo a posição na ocupação e as classes de rendimento mensal do trabalho principal - Brasil - 2006

Anexo 7 - Número de empresas segundo grandes regiões e unidades da federação - 2004 .368

Anexo 8 - Número de empresas com atividade de atenção à saúde, segundo grandes regiões e unidades da federação - 2004 . 369

Anexo 9 - Entidades de assistência social privadas sem fins lucrativos, classificadas como Oscip - Organização da Sociedade Civil de Interesse Público, segundo grandes regiões e unidades da federação - 2006

Anexo 10 - Entidades de assistência social privadas sem fins lucrativos, detentoras de título de utilidade pública federal, estadual e municipal, segundo grandes regiões e unidades da federação - 2006

Anexo 11 - Entidades de Assistência Social Privadas sem Fins Lucrativos, por características dos financiamentos, segundo grandes regiões e unidades da federação - 2006 . 372

Anexo 12 - Entidades de assistência social privadas sem fins lucrativos, por existência de alojamento, segundo grandes regiões e unidades da federação - 2006

Anexo 13 - Entidades de Assistência Social Privadas sem Fins Lucrativos, com alojamento, por fonte de financiamento que disponibiliza a maior quantidade de recursos, segundo grandes regiões e unidades da federação - 2006 . 374

Anexo 14 - Estudantes de 5 anos ou mais de idade, por situação do domicílio e sexo, segundo o nível e a série que frequentavam - Brasil - 2006. 375

Anexo 15 - Classificação nacional de atividades econômicas - versão $2.0 \ldots \ldots \ldots \ldots \ldots \ldots \ldots \ldots \ldots . . . . . . .376$

Anexo 16 - Critério de classificação econômica Brasil - sistema de pontos ........................377

Anexo 17 - Pesquisa de preço de terrenos em região metropolitana, campo e praia. ............378 
Anexo 1 - Anos de estudo de pessoas de 10 anos ou mais de idade, por situação do domicílio e sexo, segundo os anos de estudo - Brasil - 2006

\begin{tabular}{|c|c|c|c|c|c|c|c|c|c|c|c|c|c|c|c|c|c|c|}
\hline \multirow{4}{*}{ Anos de estudo } & \multicolumn{18}{|c|}{ Pessoas de 10 anos ou mais de idade ( 1000 pessoas) } \\
\hline & \multirow{2}{*}{\multicolumn{2}{|c|}{ Total }} & \multirow{2}{*}{\multicolumn{2}{|c|}{ Homens }} & \multirow{2}{*}{\multicolumn{2}{|c|}{ Mulheres }} & \multicolumn{6}{|c|}{ Urbana } & \multicolumn{6}{|c|}{ Rural } \\
\hline & & & & & & & Tot: & & Hom & & Mulhe & & Tot & & Hom & & Mulhe & \\
\hline & 156284 & $100 \%$ & 75326 & $48 \%$ & 80957 & $52 \%$ & 131091 & $84 \%$ & 62152 & $47 \%$ & 68938 & $53 \%$ & 25193 & $16 \%$ & 13174 & $52 \%$ & 12019 & $48 \%$ \\
\hline Sem instrução e menos de 1 ano & 15866 & $10 \%$ & 7671 & $48 \%$ & 8194 & $52 \%$ & 10481 & $66 \%$ & 4644 & $44 \%$ & 5837 & $56 \%$ & 5384 & $34 \%$ & 3027 & $56 \%$ & 2357 & $44 \%$ \\
\hline 1 ano & 3890 & $2 \%$ & 2106 & $54 \%$ & 1785 & $46 \%$ & 2703 & $69 \%$ & 1403 & $52 \%$ & 1300 & $48 \%$ & 1187 & $31 \%$ & 703 & $59 \%$ & 484 & $41 \%$ \\
\hline 2 anos & 6676 & $4 \%$ & 3515 & $53 \%$ & 3161 & $47 \%$ & 4704 & $70 \%$ & 2424 & $52 \%$ & 2280 & $48 \%$ & 1972 & $30 \%$ & 1091 & $55 \%$ & 881 & $45 \%$ \\
\hline 3 anos & 10512 & $7 \%$ & 5277 & $50 \%$ & 5235 & $50 \%$ & 7901 & $75 \%$ & 3885 & $49 \%$ & 4017 & $51 \%$ & 2611 & $25 \%$ & 1392 & $53 \%$ & 1219 & $47 \%$ \\
\hline 4 anos & 19941 & $13 \%$ & 9822 & $49 \%$ & 10119 & $51 \%$ & 15616 & $78 \%$ & 7582 & $49 \%$ & 8033 & $51 \%$ & 4325 & $22 \%$ & 2240 & $52 \%$ & 2086 & $48 \%$ \\
\hline 5 anos & 11923 & $8 \%$ & 5959 & $50 \%$ & 5964 & $50 \%$ & 9708 & $81 \%$ & 4826 & $50 \%$ & 4882 & $50 \%$ & 2214 & $19 \%$ & 1132 & $51 \%$ & 1082 & $49 \%$ \\
\hline 6 anos & 7889 & $5 \%$ & 3896 & $49 \%$ & 3993 & $51 \%$ & 6590 & $84 \%$ & 3232 & $49 \%$ & 3357 & $51 \%$ & 1299 & $16 \%$ & 664 & $51 \%$ & 635 & $49 \%$ \\
\hline 7 anos & 8365 & $5 \%$ & 4172 & $50 \%$ & 4193 & $50 \%$ & 7125 & $85 \%$ & 3557 & $50 \%$ & 3569 & $50 \%$ & 1240 & $15 \%$ & 616 & $50 \%$ & 624 & $50 \%$ \\
\hline 8 anos & 14378 & $9 \%$ & 7094 & $49 \%$ & 7285 & $51 \%$ & 12745 & $89 \%$ & 6271 & $49 \%$ & 6474 & $51 \%$ & 1633 & $11 \%$ & 823 & $50 \%$ & 811 & $50 \%$ \\
\hline 9 anos & 5445 & $3 \%$ & 2602 & $48 \%$ & 2843 & $52 \%$ & 4839 & $89 \%$ & 2322 & $48 \%$ & 2517 & $52 \%$ & 606 & $11 \%$ & 280 & $46 \%$ & 327 & $54 \%$ \\
\hline 10 anos & 5614 & $4 \%$ & 2657 & $47 \%$ & 2957 & $53 \%$ & 5076 & $90 \%$ & 2397 & $47 \%$ & 2679 & $53 \%$ & 538 & $10 \%$ & 260 & $48 \%$ & 278 & $52 \%$ \\
\hline 11 anos & 29246 & $19 \%$ & 13309 & $46 \%$ & 15937 & $54 \%$ & 27516 & $94 \%$ & 12546 & $46 \%$ & 14969 & $54 \%$ & 1730 & $6 \%$ & 763 & $44 \%$ & 967 & $56 \%$ \\
\hline 12 anos & 2497 & $2 \%$ & 1106 & $44 \%$ & 1391 & $56 \%$ & 2399 & $96 \%$ & 1069 & $45 \%$ & 1330 & $55 \%$ & 98 & $4 \%$ & 36 & $37 \%$ & 61 & $63 \%$ \\
\hline 13 anos & 1912 & $1 \%$ & 864 & $45 \%$ & 1047 & $55 \%$ & 1860 & $97 \%$ & 843 & $45 \%$ & 1017 & $55 \%$ & 52 & $3 \%$ & 21 & $41 \%$ & 30 & $59 \%$ \\
\hline 14 anos & 1991 & $1 \%$ & 798 & $40 \%$ & 1193 & $60 \%$ & 1932 & $97 \%$ & 775 & $40 \%$ & 1157 & $60 \%$ & 59 & $3 \%$ & 23 & $39 \%$ & 36 & $61 \%$ \\
\hline 15 anos ou mais & 9514 & $6 \%$ & 4187 & $44 \%$ & 5328 & $56 \%$ & 9337 & $98 \%$ & 4116 & $44 \%$ & 5221 & $56 \%$ & 177 & $2 \%$ & 71 & $40 \%$ & 107 & $60 \%$ \\
\hline Não-determinados e sem declaração & 624 & $0 \%$ & 292 & $47 \%$ & 332 & $53 \%$ & 558 & $89 \%$ & 259 & $46 \%$ & 299 & $54 \%$ & 66 & $11 \%$ & 33 & $50 \%$ & 33 & $50 \%$ \\
\hline
\end{tabular}

FONTE: IBGE, 2007f, adaptado pelo autor 
Anexo 2 - Estimativa da população brasileira dividida por faixa de idade - 1980-2050

\begin{tabular}{|c|c|c|c|c|c|c|c|c|c|}
\hline $\begin{array}{l}\text { Faixa de } \\
\text { Idade }\end{array}$ & 1980 & 1990 & 2000 & 2008 & 2010 & 2020 & 2030 & 2040 & 2050 \\
\hline Total & 118.562 .549 & 146.592 .579 & 171.279 .882 & 191.869 .683 & 196.834 .086 & 219.077 .729 & 237.737 .676 & 251.418 .006 & 259.769 .964 \\
\hline $0-4$ & 16.379 .841 & 17.630 .935 & 17.078 .098 & 18.218 .224 & 18.161 .030 & 17.086 .317 & 16.670 .154 & 15.740 .639 & 15.177 .184 \\
\hline 5- 9 & 14.734 .278 & 18.050 .204 & 16.496 .273 & 17.552 .194 & 17.896 .682 & 17.546 .762 & 16.849 .800 & 16.236 .530 & 15.431 .571 \\
\hline $10-14$ & 14.225 .731 & 16.108 .797 & 17.428 .566 & 16.673 .065 & 16.963 .219 & 18.079 .105 & 17.033 .881 & 16.634 .148 & 15.715 .610 \\
\hline $15-19$ & 13.540 .421 & 14.604 .289 & 17.921 .483 & 16.646 .518 & 16.405 .427 & 17.824 .627 & 17.494 .074 & 16.811 .279 & 16.207 .182 \\
\hline $20-24$ & 11.482 .826 & 14.024 .012 & 15.896 .714 & 17.683 .695 & 17.238 .588 & 16.825 .056 & 17.967 .302 & 16.952 .393 & 16.570 .725 \\
\hline $25-29$ & 9.417 .259 & 13.261 .833 & 14.313 .963 & 17.006 .221 & 17.625 .115 & 16.201 .254 & 17.657 .441 & 17.367 .756 & 16.715 .267 \\
\hline $30-34$ & 7.666 .129 & 11.181 .570 & 13.677 .030 & 14.848 .709 & 15.575 .070 & 16.980 .999 & 16.639 .445 & 17.817 .908 & 16.842 .865 \\
\hline 35-39 & 6.336 .190 & 9.107 .721 & 12.867 .234 & 13.711 .950 & 13.966 .840 & 17.311 .112 & 15.988 .314 & 17.482 .859 & 17.234 .124 \\
\hline $40-44$ & 5.708 .987 & 7.338 .054 & 10.761 .253 & 13.101 .747 & 13.256 .642 & 15.213 .816 & 16.681 .297 & 16.412 .931 & 17.624 .349 \\
\hline $45-49$ & 4.641 .373 & 5.974 .611 & 8.656 .170 & 11.696 .516 & 12.337 .720 & 13.514 .571 & 16.872 .109 & 15.663 .978 & 17.192 .379 \\
\hline $50-54$ & 4.098 .740 & 5.264 .008 & 6.845 .720 & 9.399 .048 & 10.151 .330 & 12.645 .294 & 14.645 .577 & 16.164 .247 & 15.984 .719 \\
\hline $55-59$ & 3.132 .870 & 4.149 .393 & 5.422 .021 & 7.346 .875 & 7.974 .375 & 11.527 .015 & 12.765 .481 & 16.077 .538 & 15.023 .010 \\
\hline $60-64$ & 2.439 .428 & 3.505 .255 & 4.589 .750 & 5.607 .071 & 6.088 .342 & 9.197 .062 & 11.618 .874 & 13.614 .762 & 15.152 .326 \\
\hline $65-69$ & 2.023 .842 & 2.508 .999 & 3.422 .927 & 4.380 .518 & 4.580 .999 & 6.904 .332 & 10.174 .739 & 11.432 .613 & 14.569 .758 \\
\hline $70-74$ & 1.313 .301 & 1.753 .997 & 2.655 .431 & 3.332 .984 & 3.585 .834 & 4.910 .943 & 7.614 .854 & 9.800 .943 & 11.668 .955 \\
\hline $75-79$ & 830.365 & 1.209 .691 & 1.660 .291 & 2.254 .241 & 2.373 .812 & 3.303 .935 & 5.152 .109 & 7.786 .995 & 8.911 .235 \\
\hline $80+$ & 590.968 & 919.210 & 1.586 .958 & 2.410 .107 & 2.653 .061 & 4.005 .529 & 5.912 .225 & 9.420 .487 & 13.748 .705 \\
\hline
\end{tabular}

FONTE: IBGE, 2007c

Anexo 3 - Estimativa da população brasileira com 60 anos ou mais dividida por sexo - 1980-2050

\begin{tabular}{|c|c|c|c|c|c|c|c|c|c|}
\hline & 1980 & 1990 & 2000 & 2008 & 2010 & 2020 & 2030 & 2040 & 2050 \\
\hline Total & 7.197 .904 & 9.897 .152 & 13.915 .357 & 17.984 .921 & 19.282 .048 & 28.321 .801 & 40.472 .801 & 52.055 .800 & 64.050 .979 \\
\hline Homens & 3.405 .006 & 4.579 .214 & 6.309 .588 & 8.003 .298 & 8.549 .259 & 12.355 .834 & 17.605 .760 & 22.798 .864 & 28.329 .840 \\
\hline Mulheres & 3.792 .898 & 5.317 .938 & 7.605 .769 & 9.981 .623 & 10.732 .789 & 15.965 .967 & 22.867 .041 & 29.256 .936 & 35.721 .139 \\
\hline
\end{tabular}

FONTE: IBGE, 2007c. 
Anexo 4 - População residente, por situação do domicílio e sexo, segundo os grupos de idade - Brasil - 2006

\begin{tabular}{|c|c|c|c|c|c|c|c|c|c|c|c|c|c|c|c|c|c|c|}
\hline \multirow{4}{*}{$\begin{array}{c}\text { Grupos de idade } \\
\text { Total }\end{array}$} & \multicolumn{18}{|c|}{ População residente (1 000 pessoas) } \\
\hline & \multirow{2}{*}{\multicolumn{2}{|c|}{ Total }} & \multirow{2}{*}{\multicolumn{2}{|c|}{ Homens }} & \multirow{2}{*}{\multicolumn{2}{|c|}{ Mulheres }} & \multicolumn{6}{|c|}{ Urbana } & \multicolumn{6}{|c|}{ Rural } \\
\hline & & & & & & & \multicolumn{2}{|l|}{ Total } & \multicolumn{2}{|c|}{ Homens } & \multicolumn{2}{|c|}{ Mulheres } & \multicolumn{2}{|c|}{ Total } & \multicolumn{2}{|c|}{ Homens } & \multicolumn{2}{|c|}{ Mulheres } \\
\hline & 187228 & $100 \%$ & 91196 & $49 \%$ & 96031 & $51 \%$ & 155934 & $83 \%$ & 74874 & $48 \%$ & 81060 & $52 \%$ & 31294 & $17 \%$ & 16322 & $52 \%$ & 14972 & $48 \%$ \\
\hline 0 a 4 anos & 14210 & $8 \%$ & 7335 & $52 \%$ & 6875 & $48 \%$ & 11384 & $80 \%$ & 5884 & $52 \%$ & 5500 & $48 \%$ & 2826 & $20 \%$ & 1451 & $51 \%$ & 1375 & $49 \%$ \\
\hline Menos de 1 ano & 2767 & $1 \%$ & 1431 & $52 \%$ & 1336 & $48 \%$ & 2245 & $81 \%$ & 1167 & $52 \%$ & 1077 & $48 \%$ & 523 & $19 \%$ & 263 & $50 \%$ & 259 & $50 \%$ \\
\hline 1 a 4 anos & 11443 & $6 \%$ & 5904 & $52 \%$ & 5539 & $48 \%$ & 9139 & $80 \%$ & 4716 & $52 \%$ & 4423 & $48 \%$ & 2304 & $20 \%$ & 1188 & $52 \%$ & 1116 & $48 \%$ \\
\hline 5 a 9 anos & 16734 & $9 \%$ & 8535 & $51 \%$ & 8199 & $49 \%$ & 13459 & $80 \%$ & 6838 & $51 \%$ & 6621 & $49 \%$ & 3275 & $20 \%$ & 1697 & $52 \%$ & 1578 & $48 \%$ \\
\hline 10 a 14 anos & 17702 & $9 \%$ & 9017 & $51 \%$ & 8685 & $49 \%$ & 14163 & $80 \%$ & 7216 & $51 \%$ & 6946 & $49 \%$ & 3540 & $20 \%$ & 1801 & $51 \%$ & 1739 & $49 \%$ \\
\hline 15 a 19 anos & 17435 & $9 \%$ & 8739 & $50 \%$ & 8695 & $50 \%$ & 14275 & $82 \%$ & 7072 & $50 \%$ & 7204 & $50 \%$ & 3159 & $18 \%$ & 1668 & $53 \%$ & 1492 & $47 \%$ \\
\hline 15 a 17 anos & 10425 & $6 \%$ & 5231 & $50 \%$ & 5194 & $50 \%$ & 8435 & $81 \%$ & 4178 & $50 \%$ & 4257 & $50 \%$ & 1989 & $19 \%$ & 1052 & $53 \%$ & 937 & $47 \%$ \\
\hline 18 e 19 anos & 7010 & $4 \%$ & 3509 & $50 \%$ & 3501 & $50 \%$ & 5840 & $83 \%$ & 2893 & $50 \%$ & 2947 & $50 \%$ & 1170 & $17 \%$ & 615 & $53 \%$ & 555 & $47 \%$ \\
\hline 20 a 24 anos & 17275 & $9 \%$ & 8550 & $49 \%$ & 8725 & $51 \%$ & 14650 & $85 \%$ & 7148 & $49 \%$ & 7502 & $51 \%$ & 2625 & $15 \%$ & 1402 & $53 \%$ & 1223 & $47 \%$ \\
\hline 25 a 29 anos & 15821 & $8 \%$ & 7730 & $49 \%$ & 8091 & $51 \%$ & 13531 & $86 \%$ & 6539 & $48 \%$ & 6992 & $52 \%$ & 2290 & $14 \%$ & 1191 & $52 \%$ & 1099 & $48 \%$ \\
\hline 30 a 34 anos & 14091 & $8 \%$ & 6779 & $48 \%$ & 7312 & $52 \%$ & 11973 & $85 \%$ & 5664 & $47 \%$ & 6308 & $53 \%$ & 2118 & $15 \%$ & 1114 & $53 \%$ & 1004 & $47 \%$ \\
\hline 35 a 39 anos & 13488 & $7 \%$ & 6452 & $48 \%$ & 7035 & $52 \%$ & 11450 & $85 \%$ & 5381 & $47 \%$ & 6070 & $53 \%$ & 2037 & $15 \%$ & 1072 & $53 \%$ & 966 & $47 \%$ \\
\hline 40 a 44 anos & 13069 & $7 \%$ & 6265 & $48 \%$ & 6804 & $52 \%$ & 11174 & $85 \%$ & 5272 & $47 \%$ & 5902 & $53 \%$ & 1895 & $15 \%$ & 993 & $52 \%$ & 902 & $48 \%$ \\
\hline 45 a 49 anos & 10933 & $6 \%$ & 5115 & $47 \%$ & 5818 & $53 \%$ & 9339 & $85 \%$ & 4285 & $46 \%$ & 5055 & $54 \%$ & 1594 & $15 \%$ & 830 & $52 \%$ & 763 & $48 \%$ \\
\hline 50 a 54 anos & 9787 & $5 \%$ & 4676 & $48 \%$ & 5111 & $52 \%$ & 8360 & $85 \%$ & 3947 & $47 \%$ & 4413 & $53 \%$ & 1427 & $15 \%$ & 730 & $51 \%$ & 698 & $49 \%$ \\
\hline 55 a 59 anos & 7605 & $4 \%$ & 3597 & $47 \%$ & 4008 & $53 \%$ & 6347 & $83 \%$ & 2928 & $46 \%$ & 3419 & $54 \%$ & 1258 & $17 \%$ & 669 & $53 \%$ & 589 & $47 \%$ \\
\hline 60 anos ou mais & 19077 & $10 \%$ & 8406 & $44 \%$ & 10672 & $56 \%$ & 15827 & $83 \%$ & 6701 & $42 \%$ & 9127 & $58 \%$ & 3250 & $17 \%$ & 1705 & $52 \%$ & 1545 & $48 \%$ \\
\hline 60 a 64 anos & 5824 & $3 \%$ & 2674 & $46 \%$ & 3151 & $54 \%$ & 4810 & $83 \%$ & 2135 & $44 \%$ & 2675 & $56 \%$ & 1014 & $17 \%$ & 539 & $53 \%$ & 475 & $47 \%$ \\
\hline 65 a 69 anos & 4721 & $3 \%$ & 2143 & $45 \%$ & 2578 & $55 \%$ & 3899 & $83 \%$ & 1704 & $44 \%$ & 2195 & $56 \%$ & 822 & $17 \%$ & 439 & $53 \%$ & 383 & $47 \%$ \\
\hline 70 anos ou mais & 8532 & $5 \%$ & 3589 & $42 \%$ & 4943 & $58 \%$ & 7119 & $83 \%$ & 2862 & $40 \%$ & 4257 & $60 \%$ & 1413 & $17 \%$ & 727 & $51 \%$ & 686 & $49 \%$ \\
\hline Idade ignorada & - & - & - & - & - & - & - & - & - & - & - & - & - & - & - & - & - & - \\
\hline
\end{tabular}

FONTE: IBGE, 2007d. 
Anexo 5 - Famílias residentes em domicílios particulares e valor do rendimento médio e total mensal das famílias residentes em domicílios particulares, por situação do domicílio, segundo as classes de rendimento mensal familiar - Brasil - 2006

\begin{tabular}{|c|c|c|c|c|c|c|c|c|c|c|c|c|c|c|c|}
\hline \multirow{3}{*}{$\begin{array}{c}\text { Classes de rendimento } \\
\text { mensal familiar } \\
(1) \\
\text { Total }\end{array}$} & \multicolumn{6}{|c|}{$\begin{array}{l}\text { Famílias residentes em domicílios particulares } \\
\qquad(1000 \text { famílias })\end{array}$} & \multicolumn{3}{|c|}{$\begin{array}{l}\text { Valor do rendimento médio } \\
\text { mensal das famílias } \\
(\mathrm{R} \$)(1)(2)\end{array}$} & \multicolumn{6}{|c|}{$\begin{array}{l}\text { Rendimento Total } \\
\text { (R\$ milhão) }\end{array}$} \\
\hline & \multicolumn{2}{|c|}{ Total } & \multicolumn{2}{|c|}{ Urbana } & \multicolumn{2}{|c|}{ Rural } & \multirow{2}{*}{$\begin{aligned} \text { Total } \\
\mathbf{1 5 4 5}\end{aligned}$} & \multirow{2}{*}{$\begin{array}{r}\text { Urbana } \\
1682\end{array}$} & \multirow{2}{*}{$\begin{array}{r}\text { Rural } \\
\mathbf{7 8 2}\end{array}$} & \multicolumn{2}{|c|}{ Total } & \multicolumn{2}{|c|}{ Urbana } & \multicolumn{2}{|c|}{ Rural } \\
\hline & 59094 & $100 \%$ & 50172 & $85 \%$ & 8922 & $15 \%$ & & & & 91.300 & $100 \%$ & 84390 & $100 \%$ & 6977 & $100 \%$ \\
\hline Até 1 salário mínimo & 8691 & $15 \%$ & 6218 & $72 \%$ & 2473 & $28 \%$ & 257 & 266 & 235 & 2.234 & $2 \%$ & 1654 & $2 \%$ & 581 & $8 \%$ \\
\hline Mais de 1 a 2 salários mínimos & 13787 & $23 \%$ & 10953 & $79 \%$ & 2834 & $21 \%$ & 544 & 547 & 535 & 7.500 & $8 \%$ & 5991 & $7 \%$ & 1516 & $22 \%$ \\
\hline Mais de 2 a 3 salários mínimos & 10013 & $17 \%$ & 8471 & $85 \%$ & 1542 & $15 \%$ & 882 & 884 & 871 & 8.831 & $10 \%$ & 7489 & $9 \%$ & 1343 & $19 \%$ \\
\hline Mais de 3 a 5 salários mínimos & 10407 & $18 \%$ & 9336 & $90 \%$ & 1071 & $10 \%$ & 1359 & 1363 & 1330 & 14.143 & $15 \%$ & 12725 & $15 \%$ & 1424 & $20 \%$ \\
\hline Mais de 5 a 10 salários mínimos & 8501 & $14 \%$ & 8010 & $94 \%$ & 490 & $6 \%$ & 2431 & 2435 & 2367 & 20.665 & $23 \%$ & 19505 & $23 \%$ & 1160 & $17 \%$ \\
\hline Mais de 10 a 20 salários mínimos & 3482 & $6 \%$ & 3377 & $97 \%$ & 105 & $3 \%$ & 4856 & 4864 & 4613 & 16.907 & $19 \%$ & 16426 & $19 \%$ & 482 & $7 \%$ \\
\hline Mais de 20 salários mínimos & 1574 & $3 \%$ & 1546 & $98 \%$ & 28 & $2 \%$ & 12199 & 12183 & 13103 & 19.205 & $21 \%$ & 18837 & $22 \%$ & 368 & $5 \%$ \\
\hline Sem rendimento (3) & 1465 & $2 \%$ & 1215 & $83 \%$ & 250 & $17 \%$ & - & - & - & - & - & - & - & - & - \\
\hline Sem declaração & 1175 & $2 \%$ & 1046 & $89 \%$ & 129 & $11 \%$ & - & - & - & - & - & - & - & - & - \\
\hline
\end{tabular}

FONTE: IBGE, 2007e.

( 1 ) Exclusive os rendimentos das pessoas de menos de 10 anos de idade e das pessoas cuja condição na família era pensionista, empregado doméstico ou parente de empregado doméstico.

( 2 ) Exclusive as famílias sem declaração do valor do rendimento familiar.

( 3 ) Inclusive as famílias cujos componentes receberam somente em benefícios. 
Anexo 6 - Pessoas de 10 anos ou mais de idade, ocupadas na semana de referência, com rendimento no trabalho principal, e valor do rendimento médio mensal, segundo a posição na ocupação e as classes de rendimento mensal do trabalho principal - Brasil - 2006

\begin{tabular}{|c|c|c|c|c|c|}
\hline \multirow{2}{*}{$\begin{array}{l}\text { Posição na ocupação e classes de } \\
\text { rendimento mensal do trabalho } \\
\text { principal } \\
\text { Total }\end{array}$} & \multicolumn{2}{|c|}{$\begin{array}{c}\text { Pessoas de } 10 \text { anos ou mais de idade, ocupadas } \\
\text { na semana de referência e com rendimento no } \\
\text { trabalho principal } \\
\text { (1000 pessoas })\end{array}$} & \multirow{2}{*}{$\begin{array}{l}\text { Valor do rendimento } \\
\text { médio mensal do } \\
\text { trabalho principal } \\
(\mathrm{R} \$) \\
\mathbf{8 4 8}\end{array}$} & \multicolumn{2}{|c|}{$\begin{array}{l}\text { Rendimento Total } \\
\text { (R\$ milhão) }\end{array}$} \\
\hline & 78371 & $100 \%$ & & 66458 & $100 \%$ \\
\hline Até $1 / 2$ salário mínimo & 9031 & $12 \%$ & 99 & 894 & $1 \%$ \\
\hline Mais de $1 / 2$ a 1 salário mínimo & 19136 & $24 \%$ & 303 & 5798 & $9 \%$ \\
\hline Mais de 1 a 2 salários mínimos & 26612 & $34 \%$ & 517 & 13758 & $21 \%$ \\
\hline Mais de 2 a 3 salários mínimos & 9344 & $12 \%$ & 883 & 8251 & $12 \%$ \\
\hline Mais de 3 a 5 salários mínimos & 6462 & $8 \%$ & 1361 & 8794 & $13 \%$ \\
\hline Mais de 5 a 10 salários mínimos & 5408 & $7 \%$ & 2410 & 13034 & $20 \%$ \\
\hline Mais de 10 a 20 salários mínimos & 1774 & $2 \%$ & 4920 & 8728 & $13 \%$ \\
\hline Mais de 20 salários mínimos & 603 & $1 \%$ & 11873 & 7163 & $11 \%$ \\
\hline
\end{tabular}

FONTE: IBGE, 2007g.

Nota: Exclusive as pessoas que receberam somente em benefícios ou sem declaração de rendimento do trabalho principal, inclusive as pessoas sem declaração de posição na ocupação no trabalho principal. 
Anexo 7 - Número de empresas segundo grandes regiões e unidades da federação - 2004

\begin{tabular}{|c|c|c|}
\hline Unidades da Federeação & Total & $\%$ \\
\hline Norte & 199.119 & $3,45 \%$ \\
\hline Rondônia & 34.325 & $0,60 \%$ \\
\hline Acre & 10.903 & $0,19 \%$ \\
\hline Amazonas & 37.751 & $0,65 \%$ \\
\hline Roraima & 9.340 & $0,16 \%$ \\
\hline Pará & 71.747 & $1,24 \%$ \\
\hline Amapa & 8.232 & $0,14 \%$ \\
\hline Tocantins & 26.821 & $0,47 \%$ \\
\hline Nordeste & 888.667 & $15,41 \%$ \\
\hline Maranhão & 65.361 & $1,13 \%$ \\
\hline Piauí & 48.769 & $0,85 \%$ \\
\hline Ceará & 169.513 & $2,94 \%$ \\
\hline Rio Grande do Norte & 58.905 & $1,02 \%$ \\
\hline Paraíba & 62.325 & $1,08 \%$ \\
\hline Pernambuco & 142.542 & $2,47 \%$ \\
\hline Alagoas & 41.128 & $0,71 \%$ \\
\hline Sergipe & 28.696 & $0,50 \%$ \\
\hline Bahia & 271.428 & $4,71 \%$ \\
\hline Sudeste & 2.915 .694 & $50,57 \%$ \\
\hline Minas Gerais & 661.461 & $11,47 \%$ \\
\hline Espírito Santo & 109.341 & $1,90 \%$ \\
\hline Rio de Janeiro & 416.184 & $7,22 \%$ \\
\hline São Paulo & 1.728 .708 & $29,98 \%$ \\
\hline$\overline{\text { Sul }}$ & 1.351.187 & $23,43 \%$ \\
\hline Paraná & 449.962 & $7,80 \%$ \\
\hline Santa Catarina & 302.973 & $5,25 \%$ \\
\hline Rio Grande do Sul & 598.252 & $10,38 \%$ \\
\hline Centro-Oeste & 411.260 & $7,13 \%$ \\
\hline Mato Grosso do sul & 67.151 & $1,16 \%$ \\
\hline Mato Grosso & 91.093 & $1,58 \%$ \\
\hline Goiás & 167.232 & $2,90 \%$ \\
\hline Distrito Federal & 85.784 & $1,49 \%$ \\
\hline BRASIL & 5.765 .927 & $100,00 \%$ \\
\hline
\end{tabular}

FONTE: IBGE, 2008b, adaptado pelo autor. 
Anexo 8 - Número de empresas com atividade de atenção à saúde, segundo grandes regiões e unidades da federação - 2004

\begin{tabular}{lrr}
\hline \multicolumn{1}{c}{ Unidades da Federeação } & \multicolumn{1}{l}{ Total } & \multicolumn{1}{c}{$\boldsymbol{\%}$} \\
\hline Norte & $\mathbf{3 . 5 9 7}$ & $\mathbf{3 , 1 \%}$ \\
Rondônia & 664 & $0,6 \%$ \\
Acre & 138 & $0,1 \%$ \\
Amazonas & 765 & $0,7 \%$ \\
Roraima & 81 & $0,1 \%$ \\
Pará & 1.349 & $1,2 \%$ \\
Amapá & 137 & $0,1 \%$ \\
Tocantins & 463 & $0,4 \%$ \\
\hline Nordeste & $\mathbf{1 9 . 4 3 8}$ & $\mathbf{1 6 , 8 \%}$ \\
Maranhão & 1.402 & $1,2 \%$ \\
Piauí & 1.171 & $1,0 \%$ \\
Ceará & 2.244 & $1,9 \%$ \\
Rio Grande do Norte & 1.340 & $1,2 \%$ \\
Paraíba & 1.383 & $1,2 \%$ \\
Pernambuco & 3.091 & $2,7 \%$ \\
Alagoas & 666 & $0,6 \%$ \\
Sergipe & 797 & $0,7 \%$ \\
Bahia & 7.344 & $6,4 \%$ \\
\hline Sudeste & $\mathbf{6 1 . 5 5 8}$ & $\mathbf{5 3 , 3 \%}$ \\
Minas Gerais & 12.267 & $10,6 \%$ \\
Espírito Santo & 2.759 & $2,4 \%$ \\
Rio de Janeiro & 13.513 & $11,7 \%$ \\
São Paulo & 33.019 & $28,6 \%$ \\
\hline Sul & $\mathbf{2 2 . 0 0 4}$ & $\mathbf{1 9 , 0 \%}$ \\
Paraná & 7.869 & $6,8 \%$ \\
Santa Catarina & 4.710 & $4,1 \%$ \\
Rio Grande do Sul & 9.425 & $8,2 \%$ \\
\hline Centro-Oeste & $\mathbf{8 . 9 8 0}$ & $\mathbf{7 , 8 \%}$ \\
Mato Grosso do Sul & 1.201 & $1,0 \%$ \\
Mato Grosso & 1.507 & $1,3 \%$ \\
Goiás & 2.713 & $2,3 \%$ \\
Distrito Federal & 3.559 & $3,1 \%$ \\
\hline Brasil & $\mathbf{1 1 5 . 5 7 7}$ & $\mathbf{1 0 0 , 0 \%}$ \\
\hline FONT: & &
\end{tabular}

FONTE: IBGE, 2008b, adaptado pelo autor. 
Anexo 9 - Entidades de assistência social privadas sem fins lucrativos, classificadas como Oscip Organização da Sociedade Civil de Interesse Público, segundo grandes regiões e unidades da federação 2006

\begin{tabular}{|c|c|c|c|c|}
\hline Unidades da Federação & To & & $\begin{array}{l}\text { Organiz } \\
\text { sociedad } \\
\text { interesse }\end{array}$ & $\begin{array}{l}\text { ão da } \\
\text { ivil de } \\
\text { úblico }\end{array}$ \\
\hline Norte & 552 & $3,4 \%$ & 119 & $21,6 \%$ \\
\hline Rondônia & 97 & $0,6 \%$ & 18 & $18,6 \%$ \\
\hline Acre & 11 & $0,1 \%$ & 9 & $81,8 \%$ \\
\hline Amazonas & 60 & $0,4 \%$ & 12 & $20,0 \%$ \\
\hline Roraima & 8 & $0,0 \%$ & 0 & $0,0 \%$ \\
\hline Pará & 266 & $1,7 \%$ & 56 & $21,1 \%$ \\
\hline Amapá & 15 & $0,1 \%$ & 5 & $33,3 \%$ \\
\hline Tocantins & 95 & $0,6 \%$ & 19 & $20,0 \%$ \\
\hline Nordeste & 2.382 & $14,8 \%$ & 341 & $14,3 \%$ \\
\hline Maranhão & 288 & $1,8 \%$ & 56 & $19,4 \%$ \\
\hline Piauí & 164 & $1,0 \%$ & 17 & $10,4 \%$ \\
\hline Ceará & 392 & $2,4 \%$ & 65 & $16,6 \%$ \\
\hline Rio Grande do Norte & 189 & $1,2 \%$ & 6 & $3,2 \%$ \\
\hline Paraíba & 177 & $1,1 \%$ & 16 & $9,0 \%$ \\
\hline Pernambuco & 446 & $2,8 \%$ & 53 & $11,9 \%$ \\
\hline Alagoas & 81 & $0,5 \%$ & 12 & $14,8 \%$ \\
\hline Sergipe & 90 & $0,6 \%$ & 24 & $26,7 \%$ \\
\hline Bahia & 555 & $3,4 \%$ & 92 & $16,6 \%$ \\
\hline Sudeste & 8.332 & $51,8 \%$ & 1.299 & $15,6 \%$ \\
\hline Minas Gerais & 2.391 & $14,9 \%$ & 382 & $16,0 \%$ \\
\hline Espírito Santo & 224 & $1,4 \%$ & 27 & $12,1 \%$ \\
\hline Rio de Janeiro & 956 & $5,9 \%$ & 168 & $17,6 \%$ \\
\hline São Paulo & 4.761 & $29,6 \%$ & 722 & $15,2 \%$ \\
\hline Sul & 3.631 & $22,6 \%$ & 629 & $17,3 \%$ \\
\hline Paraná & 1.780 & $11,1 \%$ & 288 & $16,2 \%$ \\
\hline Santa Catarina & 652 & $4,1 \%$ & 114 & $17,5 \%$ \\
\hline Rio Grande do Sul & 1.199 & $7,5 \%$ & 227 & $18,9 \%$ \\
\hline Centro-Oeste & 1.192 & $7,4 \%$ & 241 & $20,2 \%$ \\
\hline Mato Grosso do Sul & 239 & $1,5 \%$ & 46 & $19,2 \%$ \\
\hline Mato Grosso & 306 & $1,9 \%$ & 80 & $26,1 \%$ \\
\hline Goiás & 455 & $2,8 \%$ & 87 & $19,1 \%$ \\
\hline Distrito Federal & 192 & $1,2 \%$ & 28 & $14,6 \%$ \\
\hline BRASIL & 16.089 & $100,0 \%$ & 2.629 & $16,3 \%$ \\
\hline
\end{tabular}

FONTE: IBGE, 2008a, adaptado pelo autor. 
Anexo 10 - Entidades de assistência social privadas sem fins lucrativos, detentoras de título de utilidade pública federal, estadual e municipal, segundo grandes regiões e unidades da federação - 2006

\begin{tabular}{|c|c|c|c|c|c|c|c|c|}
\hline \multirow{2}{*}{$\begin{array}{l}\text { Unidades da Federação } \\
\text { Norte }\end{array}$} & \multicolumn{2}{|c|}{ Total } & \multicolumn{2}{|c|}{$\begin{array}{c}\text { Título de Utilidade } \\
\text { Pública Federal }\end{array}$} & \multicolumn{2}{|c|}{$\begin{array}{c}\text { Título de Utilidade } \\
\text { Pública Estadual }\end{array}$} & \multicolumn{2}{|c|}{$\begin{array}{l}\text { Título de Utilidade } \\
\text { Pública Municipal }\end{array}$} \\
\hline & 552 & $3,4 \%$ & 148 & $26,8 \%$ & 220 & $39,9 \%$ & 327 & $59,2 \%$ \\
\hline Rondônia & 97 & $0,6 \%$ & 27 & $27,8 \%$ & 37 & $38,1 \%$ & 65 & $67,0 \%$ \\
\hline Acre & 11 & $0,1 \%$ & 7 & $63,6 \%$ & 8 & $72,7 \%$ & 8 & $72,7 \%$ \\
\hline Amazonas & 60 & $0,4 \%$ & 17 & $28,3 \%$ & 29 & $48,3 \%$ & 39 & $65,0 \%$ \\
\hline Roraima & 8 & $0,0 \%$ & 1 & $12,5 \%$ & 1 & $12,5 \%$ & 0 & $0,0 \%$ \\
\hline Pará & 266 & $1,7 \%$ & 65 & $24,4 \%$ & 92 & $34,6 \%$ & 145 & $54,5 \%$ \\
\hline Amapá & 15 & $0,1 \%$ & 6 & $40,0 \%$ & 4 & $26,7 \%$ & 8 & $53,3 \%$ \\
\hline Tocantins & 95 & $0,6 \%$ & 25 & $26,3 \%$ & 49 & $51,6 \%$ & 62 & $65,3 \%$ \\
\hline Nordeste & 2.382 & $14,8 \%$ & 620 & $26,0 \%$ & 1.116 & $46,9 \%$ & 1.602 & $67,3 \%$ \\
\hline Maranhão & 288 & $1,8 \%$ & 79 & $27,4 \%$ & 132 & $45,8 \%$ & 190 & $66,0 \%$ \\
\hline Piauí & 164 & $1,0 \%$ & 27 & $16,5 \%$ & 59 & $36,0 \%$ & 98 & $59,8 \%$ \\
\hline Ceará & 392 & $2,4 \%$ & 125 & $31,9 \%$ & 156 & $39,8 \%$ & 272 & $69,4 \%$ \\
\hline Rio Grande do Norte & 189 & $1,2 \%$ & 29 & $15,3 \%$ & 109 & $57,7 \%$ & 126 & $66,7 \%$ \\
\hline Paraíba & 177 & $1,1 \%$ & 32 & $18,1 \%$ & 70 & $39,5 \%$ & 97 & $54,8 \%$ \\
\hline Pernambuco & 446 & $2,8 \%$ & 91 & $20,4 \%$ & 112 & $25,1 \%$ & 230 & $51,6 \%$ \\
\hline Alagoas & 81 & $0,5 \%$ & 28 & $34,6 \%$ & 41 & $50,6 \%$ & 53 & $65,4 \%$ \\
\hline Sergipe & 90 & $0,6 \%$ & 41 & $45,6 \%$ & 73 & $81,1 \%$ & 72 & $80,0 \%$ \\
\hline Bahia & 555 & $3,4 \%$ & 168 & $30,3 \%$ & 364 & $65,6 \%$ & 464 & $83,6 \%$ \\
\hline Sudeste & 8.332 & $51,8 \%$ & 3.502 & $42,0 \%$ & 4.050 & $48,6 \%$ & 6.206 & $74,5 \%$ \\
\hline Minas Gerais & 2.391 & $14,9 \%$ & 950 & $39,7 \%$ & 1.298 & $54,3 \%$ & 2.070 & $86,6 \%$ \\
\hline Espírito Santo & 224 & $1,4 \%$ & 110 & $49,1 \%$ & 151 & $67,4 \%$ & 181 & $80,8 \%$ \\
\hline Rio de Janeiro & 956 & $5,9 \%$ & 358 & $37,4 \%$ & 418 & $43,7 \%$ & 622 & $65,1 \%$ \\
\hline São Paulo & 4.761 & $29,6 \%$ & 2.084 & $43,8 \%$ & 2.183 & $45,9 \%$ & 3.333 & $70,0 \%$ \\
\hline$\overline{\text { Sul }}$ & 3.631 & $22,6 \%$ & 1.575 & $43,4 \%$ & 2.050 & $56,5 \%$ & 2.904 & $80,0 \%$ \\
\hline Paraná & 1.780 & $11,1 \%$ & 793 & $44,6 \%$ & 1.044 & $58,7 \%$ & 1.512 & $84,9 \%$ \\
\hline Santa Catarina & 652 & $4,1 \%$ & 309 & $47,4 \%$ & 432 & $66,3 \%$ & 577 & $88,5 \%$ \\
\hline Rio Grande do Sul & 1.199 & $7,5 \%$ & 473 & $39,4 \%$ & 574 & $47,9 \%$ & 815 & $68,0 \%$ \\
\hline Centro-Oeste & 1.192 & $7,4 \%$ & 438 & $36,7 \%$ & 614 & $51,5 \%$ & 839 & $70,4 \%$ \\
\hline Mato Grosso do Sul & 239 & $1,5 \%$ & 115 & $48,1 \%$ & 175 & $73,2 \%$ & 206 & $86,2 \%$ \\
\hline Mato Grosso & 306 & $1,9 \%$ & 90 & $29,4 \%$ & 148 & $48,4 \%$ & 213 & $69,6 \%$ \\
\hline Goiás & 455 & $2,8 \%$ & 163 & $35,8 \%$ & 226 & $49,7 \%$ & 343 & $75,4 \%$ \\
\hline Distrito Federal & 192 & $1,2 \%$ & 70 & $36,5 \%$ & 65 & $33,9 \%$ & 77 & $40,1 \%$ \\
\hline BRASIL & 16.089 & $100,0 \%$ & 6.283 & $39,1 \%$ & 8.050 & $50,0 \%$ & 11.878 & $73,8 \%$ \\
\hline
\end{tabular}

FONTE: IBGE, 2008a, adaptado pelo autor. 
Anexo 11 - Entidades de Assistência Social Privadas sem Fins Lucrativos, por características dos financiamentos, segundo grandes regiões e unidades da federação - 2006

\begin{tabular}{|c|c|c|c|c|c|c|c|c|c|}
\hline \multirow{3}{*}{$\begin{array}{l}\begin{array}{c}\text { Unidades da } \\
\text { Federação }\end{array} \\
\text { Norte }\end{array}$} & \multirow{3}{*}{$\begin{array}{r}\text { Total } \\
552\end{array}$} & \multicolumn{8}{|c|}{$\begin{array}{c}\text { Fonte de financiamento que disponibiliza a maior quantidade de } \\
\text { recursos }\end{array}$} \\
\hline & & \multicolumn{2}{|c|}{ Privada } & \multicolumn{2}{|c|}{ Pública } & \multicolumn{2}{|c|}{ Internacional } & \multicolumn{2}{|c|}{ Outras } \\
\hline & & 306 & $55,4 \%$ & 182 & $33,0 \%$ & 22 & $4,0 \%$ & 22 & $4,0 \%$ \\
\hline Rondônia & 97 & 57 & $58,8 \%$ & 29 & $29,9 \%$ & 4 & $4,1 \%$ & 6 & $6,2 \%$ \\
\hline Acre & 11 & 3 & $27,3 \%$ & 7 & $63,6 \%$ & 0 & $0,0 \%$ & 0 & $0,0 \%$ \\
\hline Amazonas & 60 & 28 & $46,7 \%$ & 22 & $36,7 \%$ & 5 & $8,3 \%$ & 1 & $1,7 \%$ \\
\hline Roraima & 8 & 7 & $87,5 \%$ & 0 & $0,0 \%$ & 1 & $12,5 \%$ & 0 & $0,0 \%$ \\
\hline Pará & 266 & 174 & $65,4 \%$ & 60 & $22,6 \%$ & 8 & $3,0 \%$ & 13 & $4,9 \%$ \\
\hline Amapá & 15 & 10 & $66,7 \%$ & 4 & $26,7 \%$ & 0 & $0,0 \%$ & 1 & $6,7 \%$ \\
\hline Tocantins & 95 & 27 & $28,4 \%$ & 60 & $63,2 \%$ & 4 & $4,2 \%$ & 1 & $1,1 \%$ \\
\hline Nordeste & 2.382 & 1.357 & $\mathbf{5 7 , 0 \%}$ & 713 & $29,9 \%$ & 154 & $6,5 \%$ & 100 & $4,2 \%$ \\
\hline Maranhão & 288 & 159 & $55,2 \%$ & 83 & $28,8 \%$ & 13 & $4,5 \%$ & 11 & $3,8 \%$ \\
\hline Piauí & 164 & 86 & $52,4 \%$ & 65 & $39,6 \%$ & 9 & $5,5 \%$ & 1 & $0,6 \%$ \\
\hline Ceará & 392 & 221 & $56,4 \%$ & 122 & $31,1 \%$ & 35 & $8,9 \%$ & 10 & $2,6 \%$ \\
\hline Rio Grande do Norte & 189 & 98 & $51,9 \%$ & 61 & $32,3 \%$ & 13 & $6,9 \%$ & 12 & $6,3 \%$ \\
\hline Paraíba & 177 & 132 & $74,6 \%$ & 26 & $14,7 \%$ & 10 & $5,6 \%$ & 9 & $5,1 \%$ \\
\hline Pernambuco & 446 & 255 & $57,2 \%$ & 122 & $27,4 \%$ & 33 & $7,4 \%$ & 20 & $4,5 \%$ \\
\hline Alagoas & 81 & 49 & $60,5 \%$ & 18 & $22,2 \%$ & 2 & $2,5 \%$ & 10 & $12,3 \%$ \\
\hline Sergipe & 90 & 50 & $55,6 \%$ & 35 & $38,9 \%$ & 2 & $2,2 \%$ & 3 & $3,3 \%$ \\
\hline Bahia & 555 & 307 & $55,3 \%$ & 181 & $32,6 \%$ & 37 & $6,7 \%$ & 24 & $4,3 \%$ \\
\hline Sudeste & 8.332 & 5.105 & $61,3 \%$ & 2.536 & $30,4 \%$ & 154 & $1,8 \%$ & 429 & $5,1 \%$ \\
\hline Minas Gerais & 2.391 & 1.451 & $60,7 \%$ & 724 & $30,3 \%$ & 49 & $2,0 \%$ & 136 & $5,7 \%$ \\
\hline Espírito Santo & 224 & 117 & $52,2 \%$ & 87 & $38,8 \%$ & 3 & $1,3 \%$ & 17 & $7,6 \%$ \\
\hline Rio de Janeiro & 956 & 640 & $66,9 \%$ & 231 & $24,2 \%$ & 26 & $2,7 \%$ & 40 & $4,2 \%$ \\
\hline São Paulo & 4.761 & 2.897 & $60,8 \%$ & 1.494 & $31,4 \%$ & 76 & $1,6 \%$ & 236 & $5,0 \%$ \\
\hline Sul & 3.631 & 1.865 & $51,4 \%$ & 1.390 & $38,3 \%$ & 75 & $2,1 \%$ & 201 & $5,5 \%$ \\
\hline Paraná & 1.780 & 837 & $47,0 \%$ & 751 & $42,2 \%$ & 36 & $2,0 \%$ & 101 & $5,7 \%$ \\
\hline Santa Catarina & 652 & 339 & $52,0 \%$ & 270 & $41,4 \%$ & 7 & $1,1 \%$ & 30 & $4,6 \%$ \\
\hline Rio Grande do Sul & 1.199 & 689 & $57,5 \%$ & 369 & $30,8 \%$ & 32 & $2,7 \%$ & 70 & $5,8 \%$ \\
\hline Centro-Oeste & 1.192 & 758 & $63,6 \%$ & 315 & $26,4 \%$ & 29 & $2,4 \%$ & 58 & $4,9 \%$ \\
\hline Mato Grosso do Sul & 239 & 113 & $47,3 \%$ & 101 & $42,3 \%$ & 4 & $1,7 \%$ & 16 & $6,7 \%$ \\
\hline Mato Grosso & 306 & 192 & $62,7 \%$ & 87 & $28,4 \%$ & 13 & $4,2 \%$ & 7 & $2,3 \%$ \\
\hline Goiás & 455 & 313 & $68,8 \%$ & 97 & $21,3 \%$ & 6 & $1,3 \%$ & 21 & $4,6 \%$ \\
\hline Distrito Federal & 192 & 140 & $72,9 \%$ & 30 & $15,6 \%$ & 6 & $3,1 \%$ & 14 & $7,3 \%$ \\
\hline BRASIL & 16.089 & 9.391 & $58,4 \%$ & 5.136 & $31,9 \%$ & 434 & $2,7 \%$ & 810 & $5,0 \%$ \\
\hline
\end{tabular}

FONTE: IBGE, 2008a, adaptado pelo autor. 
Anexo 12 - Entidades de assistência social privadas sem fins lucrativos, por existência de alojamento, segundo grandes regiões e unidades da federação - 2006

\begin{tabular}{|c|c|c|c|c|c|c|}
\hline \multirow{2}{*}{$\begin{array}{l}\text { Unidades da Federação } \\
\text { Norte }\end{array}$} & \multicolumn{2}{|c|}{ Total } & \multicolumn{2}{|c|}{ Com alojamento } & \multicolumn{2}{|c|}{ Sem alojamento } \\
\hline & 552 & $3,4 \%$ & 105 & $19,0 \%$ & 447 & $81,0 \%$ \\
\hline Rondônia & 97 & $0,6 \%$ & 20 & $20,6 \%$ & 77 & $79,4 \%$ \\
\hline Acre & 11 & $0,1 \%$ & 9 & $81,8 \%$ & 2 & $18,2 \%$ \\
\hline Amazonas & 60 & $0,4 \%$ & 16 & $26,7 \%$ & 44 & $73,3 \%$ \\
\hline Roraima & 8 & $0,0 \%$ & 0 & $0,0 \%$ & 8 & $100,0 \%$ \\
\hline Pará & 266 & $1,7 \%$ & 46 & $17,3 \%$ & 220 & $82,7 \%$ \\
\hline Amapá & 15 & $0,1 \%$ & 0 & $0,0 \%$ & 15 & $100,0 \%$ \\
\hline Tocantins & 95 & $0,6 \%$ & 14 & $14,7 \%$ & 81 & $85,3 \%$ \\
\hline Nordeste & 2.382 & $14,8 \%$ & 444 & $18,6 \%$ & 1.937 & $81,3 \%$ \\
\hline Maranhão & 288 & $1,8 \%$ & 23 & $8,0 \%$ & 264 & $91,7 \%$ \\
\hline Piauí & 164 & $1,0 \%$ & 12 & $7,3 \%$ & 152 & $92,7 \%$ \\
\hline Ceará & 392 & $2,4 \%$ & 50 & $12,8 \%$ & 342 & $87,2 \%$ \\
\hline Rio Grande do Norte & 189 & $1,2 \%$ & 38 & $20,1 \%$ & 151 & $79,9 \%$ \\
\hline Paraíba & 177 & $1,1 \%$ & 34 & $19,2 \%$ & 143 & $80,8 \%$ \\
\hline Pernambuco & 446 & $2,8 \%$ & 98 & $22,0 \%$ & 348 & $78,0 \%$ \\
\hline Alagoas & 81 & $0,5 \%$ & 18 & $22,2 \%$ & 63 & $77,8 \%$ \\
\hline Sergipe & 90 & $0,6 \%$ & 24 & $26,7 \%$ & 66 & $73,3 \%$ \\
\hline Bahia & 555 & $3,4 \%$ & 147 & $26,5 \%$ & 408 & $73,5 \%$ \\
\hline Sudeste & 8.332 & $51,8 \%$ & 2.164 & $26,0 \%$ & 6.168 & $74,0 \%$ \\
\hline Minas Gerais & 2.391 & $14,9 \%$ & 672 & $28,1 \%$ & 1.719 & $71,9 \%$ \\
\hline Espírito Santo & 224 & $1,4 \%$ & 66 & $29,5 \%$ & 158 & $70,5 \%$ \\
\hline Rio de Janeiro & 956 & $5,9 \%$ & 241 & $25,2 \%$ & 715 & $74,8 \%$ \\
\hline São Paulo & 4.761 & $29,6 \%$ & 1.185 & $24,9 \%$ & 3.576 & $75,1 \%$ \\
\hline$\overline{\text { Sul }}$ & 3.631 & $22,6 \%$ & 751 & $20,7 \%$ & 2.879 & $79,3 \%$ \\
\hline Paraná & 1.780 & $11,1 \%$ & 353 & $19,8 \%$ & 1.427 & $80,2 \%$ \\
\hline Santa Catarina & 652 & $4,1 \%$ & 126 & $19,3 \%$ & 526 & $80,7 \%$ \\
\hline Rio Grande do Sul & 1.199 & $7,5 \%$ & 272 & $22,7 \%$ & 926 & $77,2 \%$ \\
\hline Centro-Oeste & 1.192 & $7,4 \%$ & 315 & $26,4 \%$ & 876 & $73,5 \%$ \\
\hline Mato Grosso do Sul & 239 & $1,5 \%$ & 65 & $27,2 \%$ & 174 & $72,8 \%$ \\
\hline Mato Grosso & 306 & $1,9 \%$ & 66 & $21,6 \%$ & 240 & $78,4 \%$ \\
\hline Goiás & 455 & $2,8 \%$ & 145 & $31,9 \%$ & 310 & $68,1 \%$ \\
\hline Distrito Federal & 192 & $1,2 \%$ & 39 & $20,3 \%$ & 152 & $79,2 \%$ \\
\hline BRASIL & 16.089 & $100,0 \%$ & 3.779 & $23,5 \%$ & 12.307 & $76,5 \%$ \\
\hline
\end{tabular}

FONTE: IBGE, 2008a, adaptado pelo autor. 
Anexo 13 - Entidades de Assistência Social Privadas sem Fins Lucrativos, com alojamento, por fonte de financiamento que disponibiliza a maior quantidade de recursos, segundo grandes regiões e unidades da federação - 2006

\begin{tabular}{|c|c|c|c|c|c|c|c|c|c|c|}
\hline \multirow{4}{*}{$\begin{array}{l}\text { Unidades da Federação } \\
\text { Norte }\end{array}$} & \multirow{4}{*}{$\begin{array}{r}\text { Total } \\
552\end{array}$} & \multicolumn{9}{|c|}{ Com alojamento } \\
\hline & & \multirow{3}{*}{$\begin{array}{r}\text { Total } \\
105\end{array}$} & \multicolumn{8}{|c|}{$\begin{array}{l}\text { Fonte de financiamento que disponibiliza a maior quantidade de } \\
\text { recursos }\end{array}$} \\
\hline & & & \multicolumn{2}{|c|}{ Privada } & \multicolumn{2}{|c|}{ Pública } & \multicolumn{2}{|c|}{ Internacional } & \multicolumn{2}{|c|}{ Outras } \\
\hline & & & 63 & $60,0 \%$ & 25 & $23,8 \%$ & 9 & $8,6 \%$ & 4 & $3,8 \%$ \\
\hline Rondônia & 97 & 20 & 11 & $55,0 \%$ & 5 & $25,0 \%$ & 2 & $10,0 \%$ & 2 & $10,0 \%$ \\
\hline Acre & 11 & 9 & 3 & $33,3 \%$ & 5 & $55,6 \%$ & 0 & $0,0 \%$ & 0 & $0,0 \%$ \\
\hline Amazonas & 60 & 16 & 8 & $50,0 \%$ & 3 & $18,8 \%$ & 3 & $18,8 \%$ & 1 & $6,3 \%$ \\
\hline Roraima & 8 & 0 & 0 & $0,0 \%$ & 0 & $0,0 \%$ & 0 & $0,0 \%$ & 0 & $0,0 \%$ \\
\hline Pará & 266 & 46 & 33 & $71,7 \%$ & 7 & $15,2 \%$ & 3 & $6,5 \%$ & 1 & $2,2 \%$ \\
\hline Amapá & 15 & 0 & 0 & $0,0 \%$ & 0 & $0,0 \%$ & 0 & $0,0 \%$ & 0 & $0,0 \%$ \\
\hline Tocantins & 95 & 14 & 8 & $57,1 \%$ & 5 & $35,7 \%$ & 1 & $7,1 \%$ & 0 & $0,0 \%$ \\
\hline Nordeste & 2.382 & 444 & 276 & $62,2 \%$ & 82 & $18,5 \%$ & 39 & $\mathbf{8 , 8 \%}$ & 33 & $7,4 \%$ \\
\hline Maranhão & 288 & 23 & 12 & $52,2 \%$ & 3 & $13,0 \%$ & 2 & $8,7 \%$ & 1 & $4,3 \%$ \\
\hline Piauí & 164 & 12 & 7 & $58,3 \%$ & 2 & $16,7 \%$ & 1 & $8,3 \%$ & 0 & $0,0 \%$ \\
\hline Ceará & 392 & 50 & 34 & $68,0 \%$ & 7 & $14,0 \%$ & 5 & $10,0 \%$ & 2 & $4,0 \%$ \\
\hline Rio Grande do Norte & 189 & 38 & 24 & $63,2 \%$ & 6 & $15,8 \%$ & 4 & $10,5 \%$ & 4 & $10,5 \%$ \\
\hline Paraíba & 177 & 34 & 23 & $67,6 \%$ & 5 & $14,7 \%$ & 2 & $5,9 \%$ & 4 & $11,8 \%$ \\
\hline Pernambuco & 446 & 98 & 61 & $62,2 \%$ & 15 & $15,3 \%$ & 10 & $10,2 \%$ & 8 & $8,2 \%$ \\
\hline Alagoas & 81 & 18 & 13 & $72,2 \%$ & 1 & $5,6 \%$ & 2 & $11,1 \%$ & 2 & $11,1 \%$ \\
\hline Sergipe & 90 & 24 & 14 & $58,3 \%$ & 7 & $29,2 \%$ & 1 & $4,2 \%$ & 2 & $8,3 \%$ \\
\hline Bahia & 555 & 147 & 88 & $59,9 \%$ & 36 & $24,5 \%$ & 12 & $8,2 \%$ & 10 & $6,8 \%$ \\
\hline Sudeste & 8.332 & 2164 & 1.407 & $65,0 \%$ & 504 & $23,3 \%$ & 54 & $2,5 \%$ & 161 & $7,4 \%$ \\
\hline Minas Gerais & 2.391 & 672 & 445 & $66,2 \%$ & 122 & $18,2 \%$ & 15 & $2,2 \%$ & 75 & $11,2 \%$ \\
\hline Espírito Santo & 224 & 66 & 37 & $56,1 \%$ & 16 & $24,2 \%$ & 1 & $1,5 \%$ & 12 & $18,2 \%$ \\
\hline Rio de Janeiro & 956 & 241 & 155 & $64,3 \%$ & 55 & $22,8 \%$ & 12 & $5,0 \%$ & 12 & $5,0 \%$ \\
\hline São Paulo & 4.761 & 1185 & 770 & $65,0 \%$ & 311 & $26,2 \%$ & 26 & $2,2 \%$ & 62 & $5,2 \%$ \\
\hline$\overline{\text { Sul }}$ & 3.631 & 751 & 459 & $61,1 \%$ & 190 & $25,3 \%$ & 28 & $3,7 \%$ & 44 & $5,9 \%$ \\
\hline Paraná & 1.780 & 353 & 208 & $58,9 \%$ & 86 & $24,4 \%$ & 13 & $3,7 \%$ & 30 & $8,5 \%$ \\
\hline Santa Catarina & 652 & 126 & 84 & $66,7 \%$ & 37 & $29,4 \%$ & 2 & $1,6 \%$ & 3 & $2,4 \%$ \\
\hline Rio Grande do Sul & 1.199 & 272 & 167 & $61,4 \%$ & 67 & $24,6 \%$ & 13 & $4,8 \%$ & 11 & $4,0 \%$ \\
\hline Centro-Oeste & 1.192 & 315 & 205 & $65,1 \%$ & 75 & $23,8 \%$ & 6 & $1,9 \%$ & 15 & $4,8 \%$ \\
\hline Mato Grosso do Sul & 239 & 65 & 30 & $46,2 \%$ & 24 & $36,9 \%$ & 2 & $3,1 \%$ & 5 & $7,7 \%$ \\
\hline Mato Grosso & 306 & 66 & 47 & $71,2 \%$ & 17 & $25,8 \%$ & 2 & $3,0 \%$ & 0 & $0,0 \%$ \\
\hline Goiás & 455 & 145 & 101 & $69,7 \%$ & 26 & $17,9 \%$ & 1 & $0,7 \%$ & 9 & $6,2 \%$ \\
\hline Distrito Federal & 192 & 39 & 27 & $69,2 \%$ & 8 & $20,5 \%$ & 1 & $2,6 \%$ & 1 & $2,6 \%$ \\
\hline BRASIL & 16.089 & 3779 & 2.410 & $63,8 \%$ & 876 & $23,2 \%$ & 136 & $3,6 \%$ & 257 & $6,8 \%$ \\
\hline
\end{tabular}

FONTE: IBGE, 2008a, adaptado pelo autor. 
Anexo 14 - Estudantes de 5 anos ou mais de idade, por situação do domicílio e sexo, segundo o nível e a série que frequentavam - Brasil - 2006

\begin{tabular}{|c|c|c|c|c|c|c|c|c|c|c|c|c|c|c|c|c|c|c|}
\hline \multirow{4}{*}{$\begin{array}{c}\text { Grau e série que } \\
\text { freqüentavam }\end{array}$} & \multicolumn{18}{|c|}{ Estudantes de 5 anos ou mais de idade (1 000 pessoas) } \\
\hline & \multicolumn{6}{|c|}{ Total } & \multicolumn{6}{|c|}{ Urbana } & \multicolumn{6}{|c|}{ Rural } \\
\hline & \multicolumn{2}{|c|}{ Total } & \multicolumn{2}{|c|}{ Homens } & \multicolumn{2}{|c|}{ Mulheres } & \multicolumn{2}{|c|}{ Total } & \multicolumn{2}{|c|}{ Homens } & \multicolumn{2}{|c|}{ Mulheres } & \multicolumn{2}{|c|}{ Total } & \multicolumn{2}{|c|}{ Homens } & \multicolumn{2}{|c|}{ Mulheres } \\
\hline & 54905 & $100 \%$ & 26937 & $49 \%$ & 27968 & $51 \%$ & 45562 & $83 \%$ & 22224 & $49 \%$ & 23339 & $51 \%$ & 9343 & $17 \%$ & 4714 & $50 \%$ & 4629 & $\mathbf{5 0 \%}$ \\
\hline Pré-escolar & 4910 & $9 \%$ & 2508 & $51 \%$ & 2402 & $49 \%$ & 4090 & $83 \%$ & 2089 & $51 \%$ & 2001 & $49 \%$ & 820 & $17 \%$ & 420 & $51 \%$ & 400 & $49 \%$ \\
\hline Fundamental (1) & 34237 & $62 \%$ & 17430 & $51 \%$ & 16808 & $49 \%$ & 27093 & $79 \%$ & 13719 & $51 \%$ & 13373 & $49 \%$ & 7145 & $21 \%$ & 3710 & $52 \%$ & 3434 & $48 \%$ \\
\hline Regular & 32516 & $59 \%$ & 16706 & $51 \%$ & 15811 & $49 \%$ & 25745 & $79 \%$ & 13183 & $51 \%$ & 12562 & $49 \%$ & 6771 & $21 \%$ & 3523 & $52 \%$ & 3248 & $48 \%$ \\
\hline $1^{\mathrm{a}}$ série & 4805 & $9 \%$ & 2531 & $53 \%$ & 2274 & $47 \%$ & 3641 & $76 \%$ & 1872 & $51 \%$ & 1769 & $49 \%$ & 1164 & $24 \%$ & 659 & $57 \%$ & 505 & $43 \%$ \\
\hline $2^{\mathrm{a}}$ série & 4246 & $8 \%$ & 2256 & $53 \%$ & 1990 & $47 \%$ & 3317 & $78 \%$ & 1749 & $53 \%$ & 1569 & $47 \%$ & 929 & $22 \%$ & 508 & $55 \%$ & 421 & $45 \%$ \\
\hline $3^{\mathrm{a}}$ série & 4120 & $8 \%$ & 2189 & $53 \%$ & 1931 & $47 \%$ & 3234 & $78 \%$ & 1730 & $53 \%$ & 1504 & $47 \%$ & 887 & $22 \%$ & 459 & $52 \%$ & 427 & $48 \%$ \\
\hline $4^{\mathrm{a}}$ série & 4166 & $8 \%$ & 2152 & $52 \%$ & 2014 & $48 \%$ & 3270 & $78 \%$ & 1685 & $52 \%$ & 1585 & $48 \%$ & 896 & $22 \%$ & 467 & $52 \%$ & 429 & $48 \%$ \\
\hline $5^{\text {a }}$ série & 4455 & $8 \%$ & 2351 & $53 \%$ & 2105 & $47 \%$ & 3479 & $78 \%$ & 1836 & $53 \%$ & 1643 & $47 \%$ & 976 & $22 \%$ & 514 & $53 \%$ & 462 & $47 \%$ \\
\hline $6^{\text {a }}$ série & 3906 & $7 \%$ & 1943 & $50 \%$ & 1963 & $50 \%$ & 3151 & $81 \%$ & 1583 & $50 \%$ & 1568 & $50 \%$ & 755 & $19 \%$ & 360 & $48 \%$ & 395 & $52 \%$ \\
\hline $7^{\mathrm{a}}$ série & 3334 & $6 \%$ & 1627 & $49 \%$ & 1707 & $51 \%$ & 2758 & $83 \%$ & 1341 & $49 \%$ & 1417 & $51 \%$ & 576 & $17 \%$ & 286 & $50 \%$ & 290 & $50 \%$ \\
\hline $8^{a}$ série & 3482 & $6 \%$ & 1655 & $48 \%$ & 1827 & $52 \%$ & 2893 & $83 \%$ & 1386 & $48 \%$ & 1507 & $52 \%$ & 589 & $17 \%$ & 269 & $46 \%$ & 319 & $54 \%$ \\
\hline Sem declaração & 2 & $0 \%$ & 1 & $63 \%$ & 1 & $37 \%$ & 2 & $100 \%$ & 1 & $63 \%$ & 1 & $37 \%$ & - & - & - & - & - & - \\
\hline Supletivo (2) & 939 & $2 \%$ & 432 & $46 \%$ & 507 & $54 \%$ & 822 & $88 \%$ & 370 & $45 \%$ & 452 & $55 \%$ & 117 & $12 \%$ & 62 & $53 \%$ & 55 & $47 \%$ \\
\hline Médio (3) & 9884 & $18 \%$ & 4484 & $45 \%$ & 5400 & $55 \%$ & 8690 & $88 \%$ & 3961 & $46 \%$ & 4730 & $54 \%$ & 1194 & $12 \%$ & 523 & $44 \%$ & 671 & $56 \%$ \\
\hline Regular & 8568 & $16 \%$ & 3905 & $46 \%$ & 4663 & $54 \%$ & 7455 & $87 \%$ & 3416 & $46 \%$ & 4040 & $54 \%$ & 1112 & $13 \%$ & 489 & $44 \%$ & 623 & $56 \%$ \\
\hline Supletivo & 838 & $2 \%$ & 377 & $45 \%$ & 461 & $55 \%$ & 771 & $92 \%$ & 350 & $45 \%$ & 421 & $55 \%$ & 68 & $8 \%$ & 27 & $40 \%$ & 41 & $60 \%$ \\
\hline Superior (4) & 5874 & $11 \%$ & 2516 & $43 \%$ & 3358 & $57 \%$ & 5690 & $97 \%$ & 2455 & $43 \%$ & 3234 & $57 \%$ & 185 & $3 \%$ & 61 & $33 \%$ & 124 & $67 \%$ \\
\hline Sem declaração & - & - & - & - & - & - & - & - & - & - & - & - & - & - & - & - & - & - \\
\hline
\end{tabular}

FONTE: IBGE, 2007f, adaptado pelo autor.

(1) Inclusive os estudantes de curso de alfabetização de adultos. (2) Seriado e não-seriado. (3) Inclusive os estudantes de curso pré-vestibular. (4) Inclusive os estudantes de curso de mestrado e doutorado. 
Anexo 15 - Classificação nacional de atividades econômicas - versão 2.0

\begin{tabular}{|c|c|c|}
\hline Seção & Divisões & Descrição CNAE \\
\hline A & $01 \ldots 03$ & Agricultura, pecuária, produção florestal, pesca e aquicultura \\
\hline $\mathrm{B}$ & $05 . .09$ & Indústrias extrativas \\
\hline $\mathrm{C}$ & $10 \ldots 33$ & Indústrias de transformação \\
\hline $\mathrm{D}$ & $35 . .35$ & Eletricidade e gás \\
\hline $\mathrm{E}$ & $36 . .39$ & Água, esgoto, atividades de gestão de resíduos e descontaminação \\
\hline $\mathrm{F}$ & $41 . .43$ & Construção \\
\hline $\mathrm{G}$ & $45 . .47$ & Comércio; reparação de veículos automotores e motocicletas \\
\hline $\mathrm{H}$ & $49 \ldots 53$ & Transporte, armazenagem e correio \\
\hline I & $55 . .56$ & Alojamento e alimentação \\
\hline $\mathrm{J}$ & $58 . .63$ & Informação e comunicação \\
\hline $\mathrm{K}$ & $64 . .66$ & Atividades financeiras, de seguros e serviços relacionados \\
\hline $\mathrm{L}$ & $68 \ldots 68$ & Atividades imobiliárias \\
\hline M & $69 . .75$ & Atividades profissionais, científicas e técnicas \\
\hline $\mathrm{N}$ & $77 . .82$ & Atividades administrativas e serviços complementares \\
\hline $\mathrm{O}$ & $84 \ldots 84$ & Administração pública, defesa e seguridade social \\
\hline $\mathrm{P}$ & $85 . .85$ & Educação \\
\hline \multirow[t]{19}{*}{ Q } & \multicolumn{2}{|c|}{ Saúde humana e serviços sociais } \\
\hline & \multirow[t]{8}{*}{86} & Atividades de atenção à saúde humana \\
\hline & & 861 Atividades de atendimento hospitalar \\
\hline & & 862 Serviços móveis de atendimento a urgências e de remoção de pacientes \\
\hline & & 863 Atividades de atenção ambulatorial executadas por médicos e odontólogos \\
\hline & & 864 Atividades de serviços de complementação diagnóstica e terapêutica \\
\hline & & 865 Atividades de profissionais da área de saúde, exceto médicos e odontólogos \\
\hline & & 866 Atividades de apoio à gestão de saúde \\
\hline & & 869 Atividades de atenção à saúde humana não especificadas anteriormente \\
\hline & \multirow[t]{8}{*}{87} & $\begin{array}{l}\text { Atividades de atenção à saúde humana integradas com assistência social, prestadas em } \\
\text { residências coletivas e particulares }\end{array}$ \\
\hline & & $\begin{array}{l}871 \text { Atividades de assistência a idosos, deficientes físicos, imunodeprimidos e convalescentes, } \\
\text { e de infraestrutura e apoio a pacientes prestadas em residências coletivas e particulares }\end{array}$ \\
\hline & & $\begin{array}{l}\text { 8711-5 Atividades de assistência a idosos, deficientes físicos, imunodeprimidos e } \\
\text { convalescentes prestadas em residências coletivas e particulares }\end{array}$ \\
\hline & & $\begin{array}{l}\text { 8712-3 Atividades de fornecimento de infraestrutura de apoio e assistência a paciente no } \\
\text { domicílio }\end{array}$ \\
\hline & & $\begin{array}{l}872 \text { Atividades de assistência psicossocial e à saúde a portadores de distúrbios psíquicos, } \\
\text { deficiência mental e dependência química }\end{array}$ \\
\hline & & $\begin{array}{l}\text { 8720-4 Atividades de assistência psicossocial e à saúde a portadores de distúrbios } \\
\text { psíquicos, deficiência mental e dependência química }\end{array}$ \\
\hline & & 873 Atividades de assistência social prestadas em residências coletivas e particulares \\
\hline & & 8730-1 Atividades de assistência social prestadas em residências coletivas e particulares \\
\hline & \multirow[t]{2}{*}{88} & Serviços de assistência social sem alojamento \\
\hline & & 880 Serviços de assistência social sem alojamento \\
\hline $\mathrm{R}$ & $90 \ldots 93$ & Artes, cultura, esporte e recreação \\
\hline S & $94 . .96$ & Outras atividades de serviços \\
\hline $\mathrm{T}$ & $97 . .97$ & Serviços domésticos \\
\hline $\mathrm{U}$ & $99 . .99$ & Organismos internacionais e outras instituições extraterritoriais \\
\hline
\end{tabular}

FONTE: IBGE, 2008d. 
Anexo 16 - Critério de classificação econômica Brasil - sistema de pontos

\begin{tabular}{lccccc}
\hline & \multicolumn{5}{c}{ Pontos } \\
\cline { 2 - 6 } & Posse de Itens & Não & \multicolumn{4}{c}{ Quantidade que possui } \\
\cline { 2 - 6 } & tem & $\mathbf{1}$ & $\mathbf{2}$ & $\mathbf{3}$ & $\mathbf{4}+$ \\
\hline Televisão (colorida) & 0 & 2 & 3 & 4 & 5 \\
Rádio & 0 & 1 & 2 & 3 & 4 \\
Automóvel & 0 & 2 & 4 & 5 & 5 \\
Empregada fixa mensalista & 0 & 2 & 4 & 4 & 4 \\
Aspirador de pó & 0 & 1 & 1 & 1 & 1 \\
Máquina de lavar roupa & 0 & 1 & 1 & 1 & 1 \\
Videocassete / DVD & 0 & 2 & 2 & 2 & 2 \\
Banheiro & 0 & 2 & 3 & 4 & 4 \\
Geladeira & 0 & 2 & 2 & 2 & 2 \\
Freezer (aparelho independente ou parte da geladeira duplex) & 0 & 1 & 1 & 1 & 1 \\
\hline
\end{tabular}

\begin{tabular}{ccc}
\hline Grau de Instrução do chefe de família & Pontos \\
\hline Analfabeto/Primário Incompleto & 0 \\
Primário Completo/Ginasial Incompleto & 1 \\
Ginásio Completo/Colegial Incompleto & 2 \\
Colegial Completo/Superior Incompleto & 3 \\
Superior Completo & 5 \\
\hline \multicolumn{3}{c}{} \\
\hline \multicolumn{3}{c}{ Cortes do Critério Brasil } \\
\hline Classe & Pontos & Total Brasil (\%) \\
\hline A1 & $30-34$ & 1 \\
A2 & $25-29$ & 5 \\
B1 & $21-24$ & 9 \\
B2 & $17-20$ & 14 \\
C & $11-16$ & 36 \\
D & $6-10$ & 31 \\
E & $0-5$ & 4 \\
\hline
\end{tabular}

FONTE: ASSOCIAÇÃO BRASILEIRA DE EMPRESAS DE PESQUISA, 2006. 
Anexo 17 - Pesquisa de preço de terrenos em região metropolitana, campo e praia.

\begin{tabular}{|c|c|c|c|c|c|c|}
\hline \multicolumn{7}{|c|}{ TERRENOS } \\
\hline \multirow{2}{*}{$\frac{\text { Bairro }}{\text { Jordanésia }}$} & \multirow[t]{2}{*}{ Cidade } & \multicolumn{2}{|c|}{ Valor (1.000) } & \multirow[t]{2}{*}{$\mathbf{m} 2$} & \multicolumn{2}{|c|}{$\mathbf{R} \$ / \mathbf{m} 2$} \\
\hline & & $\mathrm{R} \$$ & 35 & & $\mathrm{R} \$$ & 39 \\
\hline Capital Ville & Cajamar & $\mathrm{R} \$$ & 59 & 1.084 & $\mathrm{R} \$$ & 54 \\
\hline Serra da Cantareira & Mairipora & $\mathrm{R} \$$ & 54 & 1.250 & $\mathrm{R} \$$ & 43 \\
\hline Serra da Cantareira & Mairipora & $\mathrm{R} \$$ & 66 & 1.300 & $\mathrm{R} \$$ & 51 \\
\hline Pq Delfim Verde & Itapecerica & $\mathrm{R} \$$ & 75 & 550 & $\mathrm{R} \$$ & 136 \\
\hline Serra da Cantareira & Mairipora & $\mathrm{R} \$$ & 77 & 880 & $\mathrm{R} \$$ & 88 \\
\hline Serra da Cantareira & Mairipora & $\mathrm{R} \$$ & 88 & 1.170 & $\mathrm{R} \$$ & 75 \\
\hline Serra da Cantareira & Mairipora & $\mathrm{R} \$$ & 90 & 1.800 & $\mathrm{R} \$$ & 50 \\
\hline Chac das Lavras & Guarulhos & $\mathrm{R} \$$ & 280 & 13.600 & $\mathrm{R} \$$ & 21 \\
\hline Recanto das Rosas & Guarulhos & $\mathrm{R} \$$ & 300 & 3.000 & $\mathrm{R} \$$ & 100 \\
\hline Ponte Grande & Guarulhos & $\mathrm{R} \$$ & 400 & 1.000 & $\mathrm{R} \$$ & 400 \\
\hline Serra da Cantareira & Mairipora & $\mathrm{R} \$$ & 450 & 21.252 & $\mathrm{R} \$$ & 21 \\
\hline Centro & Diadema & $\mathrm{R} \$$ & 550 & 543 & $\mathrm{R} \$$ & 1.013 \\
\hline Jd Sta Maria & Osasco & $\mathrm{R} \$$ & 550 & 4.660 & $\mathrm{R} \$$ & 118 \\
\hline Finco & S B Campo & $\mathrm{R} \$$ & 700 & 11.000 & $\mathrm{R} \$$ & 64 \\
\hline V Alzira & S André & $\mathrm{R} \$$ & 750 & 810 & $\mathrm{R} \$$ & 926 \\
\hline Centro & Diadema & $\mathrm{R} \$$ & 900 & 700 & $\mathrm{R} \$$ & 1.286 \\
\hline Sítio Paredão & F Vasconcelos & $\mathrm{R} \$$ & 1.000 & 4.400 & $\mathrm{R} \$$ & 227 \\
\hline Jd Violeta & Poa & $\mathrm{R} \$$ & 1.200 & 8.000 & $\mathrm{R} \$$ & 150 \\
\hline V Nogueira & Diadema & $\mathrm{R} \$$ & 1.239 & 1.239 & $\mathrm{R} \$$ & 1.000 \\
\hline V Apiai & S André & $\mathrm{R} \$$ & 1.250 & 2.341 & $\mathrm{R} \$$ & 534 \\
\hline Centro & V G Paulista & $\mathrm{R} \$$ & 1.500 & 5.800 & $\mathrm{R} \$$ & 259 \\
\hline V Valparaíso & S André & $\mathrm{R} \$$ & 1.750 & 2.189 & $\mathrm{R} \$$ & 799 \\
\hline Centro & S André & $\mathrm{R} \$$ & 1.800 & 1.485 & $\mathrm{R} \$$ & 1.212 \\
\hline Centro & S André & $\mathrm{R} \$$ & 2.000 & 2.160 & $\mathrm{R} \$$ & 926 \\
\hline Bairro da Usina & Atibaia & $\mathrm{R} \$$ & 75 & 1.047 & $\mathrm{R} \$$ & 72 \\
\hline Indeterminado & Itupeva & $\mathrm{R} \$$ & 85 & 1.660 & $\mathrm{R} \$$ & 51 \\
\hline Jd Paraíso da Usina & Atibaia & $\mathrm{R} \$$ & 150 & 1.795 & $\mathrm{R} \$$ & 84 \\
\hline Centro & Araçoiaba & $\mathrm{R} \$$ & 340 & 3.083 & $\mathrm{R} \$$ & 110 \\
\hline Fazenda Vila Real & Itu & $\mathrm{R} \$$ & 800 & 3.000 & $\mathrm{R} \$$ & 267 \\
\hline Indeterminado & Jarinu & $\mathrm{R} \$$ & 80 & 1.000 & $\mathrm{R} \$$ & 80 \\
\hline Centro & Hortolândia & $\mathrm{R} \$$ & 100 & 3.854 & $\mathrm{R} \$$ & 26 \\
\hline Jd Caxambu & Jundiaí & $\mathrm{R} \$$ & 120 & 1.009 & $\mathrm{R} \$$ & 119 \\
\hline Felix & Ubatuba & $\mathrm{R} \$$ & 80 & 900 & $\mathrm{R} \$$ & 89 \\
\hline Praia Vermelha & Ubatuba & $\mathrm{R} \$$ & 250 & 1.775 & $\mathrm{R} \$$ & 141 \\
\hline Pereque-Açu & Ubatuba & $\mathrm{R} \$$ & 280 & 1.857 & $\mathrm{R} \$$ & 151 \\
\hline Itamambuca & Ubatuba & $\mathrm{R} \$$ & 1.100 & 30.000 & $\mathrm{R} \$$ & 37 \\
\hline Prumirim & Ubatuba & $\mathrm{R} \$$ & 60 & 2.300 & $\mathrm{R} \$$ & 26 \\
\hline Prumirim & Ubatuba & $\mathrm{R} \$$ & 125 & 1.066 & $\mathrm{R} \$$ & 117 \\
\hline Prumirim & Ubatuba & $\mathrm{R} \$$ & 125 & 1.100 & $\mathrm{R} \$$ & 114 \\
\hline Itamambuca & Ubatuba & $\mathrm{R} \$$ & 130 & 1.086 & $\mathrm{R} \$$ & 120 \\
\hline Armação & Ilha Bela & $\mathrm{R} \$$ & 190 & 1.070 & $\mathrm{R} \$$ & 178 \\
\hline Boraceia & Bertioga & $\mathrm{R} \$$ & 442 & 1.758 & $\mathrm{R} \$$ & 251 \\
\hline Boraceia & Bertioga & $\mathrm{R} \$$ & 604 & 2.520 & $\mathrm{R} \$$ & 240 \\
\hline Boraceia & Bertioga & $\mathrm{R} \$$ & 630 & 2.520 & $\mathrm{R} \$$ & 250 \\
\hline
\end{tabular}

FONTE: CLASSIFICADOS, 2008. 